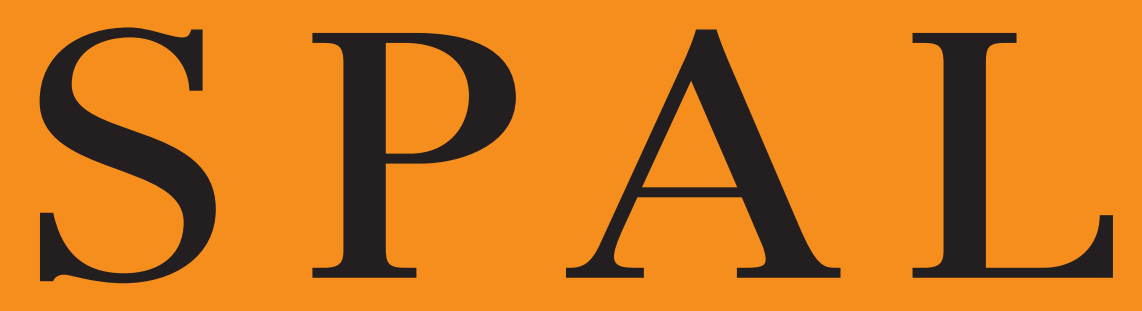

REVISTA DE PREHISTORIA Y ARQUEOLOGÍA

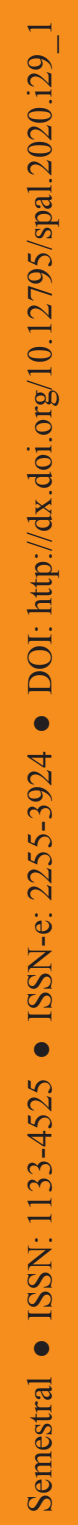

29.1

2020

Editorial Universidad de Sevilla 



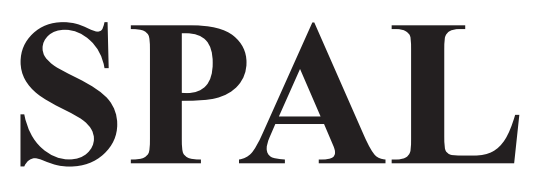

\section{Revista de Prehistoria y Arqueología de la Universidad de Sevilla}
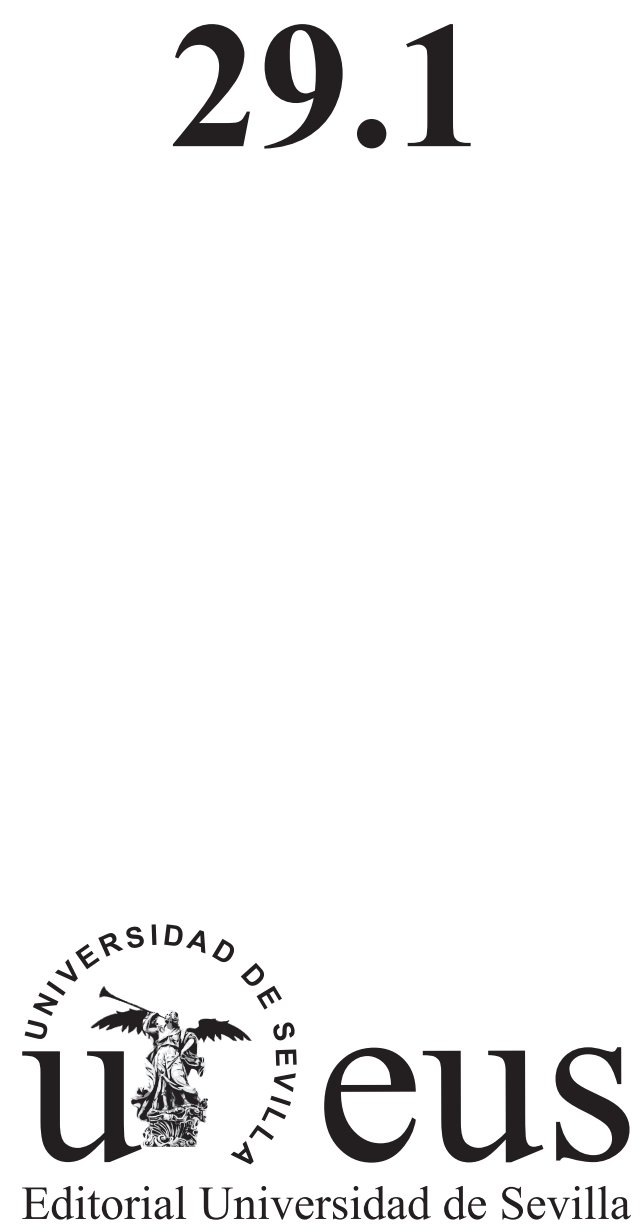

Sevilla (España) 2020 


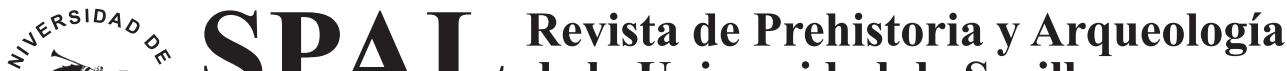 NA」 de la Universidad de Sevilla}

Secretaría: c/ Doña María de Padilla s/n. 41004-Sevilla (España), Tf: 34/954551417; Fax: 34/954 559920; Web: https://editorial.us.es/es/revistas/spal; Correo-e: spal@us.es

\section{EQUIPO EDITORIAL}

\section{Consejo de Redacción}

\section{Director}

Fernando Amores Carredano, Universidad de Sevilla

\section{Secretaría}

Miguel Cortés Sánchez, Universidad de Sevilla Enrique García Vargas, Universidad de Sevilla

Carlos Odriozola Lloret, Universidad de Sevilla Mercedes Oria Segura, Universidad de Sevilla

\section{Vocales}

Gustavo Barrientos, CONICET - División Antropología, Facultad Juan Guillermo Martín, Universidad del Norte-Barranquilla, de Ciencias Naturales y Museo, Universidad Nacional de La

Plata, La Plata, República Argentina, Argentina Martin Bartelheim, Eberhard-Karls-Universität Tübingen, Alemania

José Beltrán Fortes, Universidad de Sevilla Jaume Buxeda i Garrigós, Universidad de Barcelona Beatrice Cacciotti, Università degli Studi di Roma Tor Vergata, Italia José Luis Escacena Carrasco, Universidad de Sevilla Marcella Frangipane, Universidad de Roma Sapienza, Italia Josep Ma Fullola Pericot, Universidad de Barcelona Leonardo García Sanjuán, Universidad de Sevilla

\section{Colombia}

Ricardo González Villaescusa, Université Paris-Nanterre UMR 7041 ArScAn MAE René-Ginouvès. Francia

Francisco Jiménez Espejo, Instituto Andaluz de Ciencias de la Tierra (IACT), CSIC-UGR

Katina T. Lillios, University of lowa, EE.UU.

Dirce Marzoli, Deutsches Archäologisches Institut, Abteilung Madrid

Bartolomé Mora Serrano, Universidad de Málaga

Margarita Sánchez Romero, Universidad de Granada

Félix Teichner, Universität Marburg, Alemania

\section{Consejo Científico}

Ana Margarida Arruda, Universidade de Lisboa, Portugal María Belén Deamos, Universidad de Sevilla Darío Bernal Casasola, Universidad de Cádiz Nuno F. Bicho, Universidade do Algarve, Portugal Massimo Botto, Consiglio Nazionale delle Ricerche, Italia Laurent Callegarin, Université de Pau et des Pays de l'Adour, Francia

João Cardoso, Universidade Aberta, Lisboa, Portugal Carlos Fabião, Universidade de Lisboa, Portugal Eduardo Ferrer Albelda, Universidad de Sevilla Daniel García Rivero, Universidad de Sevilla Beatriz Gavilán Ceballos, Universidad de Huelva Alberto León Muñoz, Universidad de Córdoba
Maria Elisa Micheli, Università degli Studi di Urbino Carlo Bo, Italia

Josephine Quinn, University of Oxford, Reino Unido

Marco de la Rasilla Vives, Universidad de Oviedo

Alonso Rodríguez Díaz, Universidad de Extremadura

Oliva Rodríguez Gutiérrez, Universidad de Sevilla María Luisa Ruiz-Gálvez Priego, Universidad Complutense de Madrid

Thomas Schattner, Deutsches Archäologisches Institut. Abteilung Madrid

María D. Simón Vallejo, Universidad de Sevilla Valentín Villaverde Bonilla, Universidad de Valencia David Wheatley, University of Southampton, Reino Unido

Copyright: Los trabajos publicados en las ediciones impresa y electrónica de Spal son propiedad de la Editorial Universidad de Sevilla. Para cualquier reproducción parcial o total será necesario citar expresamente la procedencia. La Editorial Universidad de Sevilla autoriza a los autores de los trabajos publicados en la revista a ofrecerlos en sus webs (personales o corporativos) o en cualquier repositorio

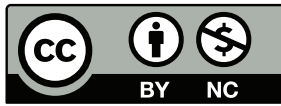
de acceso abierto (Open Access) pero exclusivamente en forma de copia de la versión post-print del manuscrito original una vez revisado y maquetado, que será remitida al autor principal o corresponsal. Es obligatorio hacer mención específica de la publicación en la que ha aparecido el texto, añadiendo además un enlace a la Editorial Universidad de Sevilla (http://www. editorial.us.es/spal).

Dirección y contacto. Postal: c/ Doña María de Padilla, s/n. 41004-Sevilla (España).

Correo-e: spal@us.es, web: https://editorial.us.es/es/revistas/spal | https://revistascientificas.us.es/index.php/spal/index Tf.: (34) 9545514 17, Fax: (34) 954559920

Maquetación. Referencias Cruzadas. Tf.: (34) 657802 595. Correo-e: referencias.maquetacion@gmail.com

Impresión. PodiPrint. C/ Cueva de Viera, 2. Antequera (Málaga).Tf.: (34) 902104 495. Correo-e: podiprint@podiprint.com

Distribución y venta. Spal se intercambia con cualquier publicación sobre Prehistoria, Arqueología e Historia Antigua de cualquier país. Los intercambios, suscripciones y adquisición se realizarán mediante petición a la Secretaría de la revista. La venta de números se hace a través de la Editorial Universidad de Sevilla (http:// www.editorial.us.es).

Identificación. ISSN: 1133-4525. ISSN-electrónico: 2255-3924.

DOI: http://dx.doi.org/10.12795/spal

Depósito legal: SE-915-1993

Título Clave: Spal. Revista de Prehistoria y Arqueología de la Universidad de Sevilla.

Título abreviado: Spal.

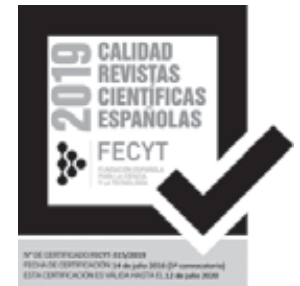


La revista Spal (topónimo más antiguo atribuido a Hispalis, Isbilya o Sevilla) fue fundada en 1992 por el Departamento de Prehistoria y Arqueología de la Universidad de Sevilla con el propósito básico de servir de vehículo para la difusión de las investigaciones realizadas en el campo de la Arqueología desde la Universidad de Sevilla. Aunque nunca se ha perdido ese especial interés por las investigaciones relativas a la Prehistoria y la Arqueología regional andaluza, progresivamente se ha ido abriendo a toda la comunidad científica nacional e internacional y ampliando los objetivos temáticos. En la actualidad se pretende que sea cauce prioritario para la publicación de investigaciones arqueológicas del ámbito Sudoeste de Europa y del Mediterráneo occidental, así como de la Arqueología histórica de América y de estudios sobre la historiografía, las teorías, la metodología y las técnicas aplicadas en Arqueología o sobre el patrimonio arqueológico.

Cobertura: Prehistoria y Arqueología, prioritariamente del ámbito Sudoeste de Europa y del Mediterráneo occidental, así como de la Arqueología histórica de América y de estudios sobre la historiografía, las teorías, la metodología y las técnicas aplicadas en Arqueología o sobre el patrimonio arqueológico.

Números publicados: 28 (1992-2019). Los trabajos publicados podrán consultarse sin restricción editorial en formato PDF desde la página de la Editorial Universidad de Sevilla (https://editorial.us.es/es/revistas/spal).

SPAL está indexada en los siguientes directorios y bases de datos ISOC y Anthropological Literature, clasificada en el grupo A de CIRC y encuadrada en el primer cuartil de las revistas del Área de Humanidades (3 de 88), según los índices IN-RECH y RESH, Ulrich, Dialnet, Proquest, Ebsco, ERIH PLUS, Scimago y SCI.

Frecuencia de publicación: Desde 1992 a 2017 Spal se publicó de forma anual. A partir de 2018 se convierte en publicación semestral. El fascículo 1 se edita en marzo y el fascículo 2 en octubre.

Secciones: Todos los trabajos y textos recibidos deben ser inéditos y no estar pendientes de su publicación total o parcial en otro medio.

a) Cartas al director: extensión máxima de 1.500 palabras. Serán sometidas a revisión.

b) Artículos: trabajos originales de investigación con un máximo en torno a 15.000 palabras (incluidos figuras y tablas). Serán sometidos a la revisión de al menos dos evaluadores. Los trabajos que presentan solo avances de proyectos de investigación y temas novedosos o significativos, dispondrán de un máximo en torno a 7.500 palabras (incluidos figuras y tablas). Serán sometidos a la revisión de al menos dos evaluadores.

c) Recensiones: extensión máxima de 3.000 palabras. Consistirán en evaluaciones críticas de los trabajos reseñados y exposición de principales novedades de eventos científicos.

Sistema de arbitraje. Los originales serán evaluados por dos expertos en la materia. Siempre que sea posible, se incluirán en el proceso revisor a especialistas en el área no pertenecientes a la Universidad de Sevilla. Los autores podrán proponer revisores. La respuesta razonada será comunicada al autor en un plazo no superior a tres meses desde la fecha de recepción del artículo.

Política de acceso abierto. La edición electrónica de Spal se ofrece en acceso abierto desde el primer número publicado en 1992 hasta la actualidad, bajo una licencia de uso y distribución "Creative Commons Reconocimiento-No Comercial 3.0 España" (CC-BY-NC-ND), salvo indicación expresa. Los detalles pueden consultarse en la versión informativa (http://creativecommons.org/licenses/by-nc-nd/3.0/deed.es_ES) y el texto legal de la licencia (http://creativecommons.org/licenses/by-nc-nd/3.0/legalcode).

Ética en la publicación. La revista SPAL sólo publicará artículos originales y de calidad científica contrastada, se velará estrictamente para que no se produzcan malas prácticas en la publicación científica, tales como la deformación o invención de datos, el plagio o la duplicidad. SPAL utiliza el software Turnitin para detectar coincidencias y similitudes entre los textos sometidos a evaluación y los publicados previamente en otras fuentes. Los autores tienen la responsabilidad de garantizar que los trabajos son originales e inéditos, fruto del consenso de todos los autores y cumplen con la legalidad vigente y los permisos necesarios. Los artículos que no cumplan estas normas éticas serán descartados.

Las opiniones y hechos consignados en cada artículo son de exclusiva responsabilidad de sus autores. El Consejo de Redacción de Spal no se hace responsable, en ningún caso, de la credibilidad y autenticidad de los trabajos.

Declaración de privacidad. Los nombres, direcciones de correo-e o cualquier otro dato de índole personal introducidos en esta revista se usarán solo para los fines declarados por esta revista y no estarán disponibles para ningún otro propósito. 

SPAL No 29.1

Sevilla 2020

ISSN: 1133-4525. ISSN-e: 2255-3924. DOI: http://dx.doi.org/10.12795/spal.2020.i29_1

Departamento de Prehistoria y Arqueología

Facultad de Geografía e Historia

Universidad de Sevilla

\section{ÍNDICE}

Editorial

Editorial

\section{Artículos}

Monumentalidad funeraria del Bronce en el sur de la península ibérica: la necrópolis de La OrdenSeminario (Huelva).

Funerary monumentality of the Bronze Age in the south of the Iberian Peninsula: the necropolis of La Orden-El Seminario (Huelva)

José Antonio Linares-Catela (D) https://orcid.org/0000-0002-4773-3645

La cronología fundacional de la Malaka fenicia: investigaciones en el solar del rectorado de la Universidad de Málaga

The founding chronology of the Phoenician Malaka: research on the site of the Rectory of the University of Málaga

José Suárez Padilla (D) https://orcid.org/0000-0001-6795-8668

Joan Ramon Torres (D) https://orcid.org/0000-0003-0646-4423

Bartolomé Mora Serrano D https://orcid.org/0000-0002-0909-9225

Leticia Salvago Soto (D) https://orcid.org/0000-0003-2011-0381

Cristina Chacón Mohedano o https://orcid.org/0000-0002-5638-5312

Uma lucerna grega arcaica da necrópole do Olival do Senhor dos Mártires (Alcácer do Sal, Portugal) ...... An archaic Greek lamp from the necropolis of Olival do Senhor dos Mártires (Alcácer do Sal, Portugal)

Francisco B. Gomes D http://orcid.org/0000-0003-0664-6374

Cerro Macareno (La Rinconada, Sevilla): nuevos datos sobre su secuencia de ocupación y rasgos constructivos

Cerro Macareno (La Rinconada, Sevilla): new data on its occupation sequence and its constructive features

Francisco José García Fernández [D https://orcid.org/0000-0002-4978-8818

Ânforas da Idade do Ferro e de tradição pré-romana do Porto do Sabugueiro (Muge, Portugal)

Iron Age and pre-roman tradition amphorae from Porto do Sabugueiro (Muge, Portugal)

Elisa de Sousa (D) https://orcid.org/0000-0003-3160-108X

João Pimenta (D) https://orcid.org/0000-0001-5149-5566

Inês Silva (D https://orcid.org/0000-0002-8779-7328

Henrique Mendes (D https://orcid.org/0000-0002-3416-8990

Ana Margarida Arruda (D https://orcid.org/0000-0002-7446-1104

Alberto Dorado-Alejos (D https://orcid.org/0000-0003-0351-7550

Hacia una reinterpretación de la secuencia de ocupación del Yacimiento de a Cidadela (A Coruña)

Towards a reinterpretation of the archaeological sequence of the site of A Cidadela (A Coruña, Spain)

José Carlos Sánchez-Pardo D https://orcid.org/0000-0003-2899-4951

Rebeca Blanco-Rotea D https://orcid.org/0000-0003-3975-2149

José Manuel Costa-García (D) https://orcid.org/0000-0002-0819-1361

Jorge Sanjurjo-Sánchez (D https://orcid.org/0000-0002-7559-8647

Victor Barrientos-Rodríguez (D) https://orcid.org/0000-0002-8004-2790

Francisco Alonso-Toucido (D) https://orcid.org/0000-0003-2554-5448

La gestión del agua en la ciudad romana de Lacipo (Casares, Málaga)

The water management in the Roman city of Lacipo (Casares, Málaga)

María del Mar Castro García (D) https://orcid.org/0000-0002-9159-3096 
Arquitectura pública de Santa Criz de Eslava (Navarra, conventvs caesaravgvstanvs) en época altoimperial: el criptopórtico del foro y su almacén anexo.

Public architecture in Santa Criz de Eslava (Navarra, conventus caesaravgvstanvs) in Early Imperial period: the Forum cryptoporticus and the store building

Rosario Cebrián Fernández (D) http://orcid.org/0000-0002-5560-1191

Javier Andreu Pintado (D) https://orcid.org/0000-0003-4662-548X

Luis Romero Novella (D) http://orcid.org/0000-0002-2184-2296

Rosario Mateo Pérez (D) https://orcid.org/0000-0001-6279-5628

Inmaculada Delage González (D) http://orcid.org./0000-0002-2393-1495

Consideraciones sobre la arquitectura doméstica urbana de Hispania en el siglo II d.C.

Considerations on the domestic architecture of hispania in the second century ad

Diego Romero Vera (D) https://orcid.org/0000-0002-4562-2407

Asturica (Astorga, León) y Albocela (Villalazán, Zamora) entre la Antigüedad y la Edad Media: análisis comparativo de sus territorios

Asturica (Astorga, León) and Albocela (Villalazán, Zamora) between Antiquity and the Middle Ages: a comparative analysis of their territories

Pilar Diarte-Blasco D https://orcid.org/0000-0001-7799-593X

Enrique Ariño Gil (D) https://orcid.org/0000-0001-8717-2128

Marta Pérez-Polo D https://orcid.org/0000-0002-3359-7726

Iglesia, cementerio y aldea en Álava durante el siglo XII. ¿Evidencias materiales de la implantación parroquial?

Church, cemetery and village IN 12TH century Álava (Spain). Material evidence of the establishment of the Catholic parish?

Egoitz Alfaro Suescun (D http://orcid.org/0000-0002-7617-0490

Ad comburendum. El uso de la leña en el Castillo de Pambre (Palas de Rei, Lugo) durante los siglos XV-XVII

Ad comburendum. Firewood use in the Pambre Castle (Palas de Rei, Lugo) during the 15th-17th centuries AD

María Martín-Seijo (D https://orcid.org/0000-0003-2924-7763

Santiago Vázquez Collazo (ㄱ https://orcid.org/0000-0002-3941-0731

\section{Recensiones}

Montero, S. y García Cardiel, J. (coords.): Santuarios oraculares, ritos y prácticas adivinatorias en la Hispania Antigua. Serie Investigación 23. Ediciones Complutense, Madrid, 2019. ISBN 978-84-6693604-0. $401 \mathrm{pp}$.

Mercedes Oria Segura (D https://orcid.org/0000-0002-9017-7752,

Victor S. Gonçalves y Ana Catarina Sousa. 2018. Casas Novas, numa curva do Sorraia (no $6^{\circ}$ milénio a.n.e. e a seguir). Estudos \& Memorias 11, Centro de Arqueologia da Universidade de Lisboa.

Faculdade de Letras da Universidade da Lisboa, 279p.

F. Xavier Oms Arias— https://orcid.org/0000-0002-1642-548X

\section{Información editorial}

Normas de publicación

Boletín para suscripción - Pedidos - Intercambios 


\section{EDITORIAL}

\section{EDITORIAL}

El Departamento de Prehistoria y Arqueología de la Universidad de Sevilla creó en 1992 SPAL. Revista de Prehistoria y Arqueología de la Universidad de Sevilla. En las más de dos décadas que han transcurrido desde entonces se han publicado 28 números en los que han aparecido varios centenares de trabajos de gran trascendencia investigadora para nuestra disciplina, realizados por numerosos investigadores y profesionales.

A partir de 2011, el Consejo de Redacción emprendió una serie de modificaciones encaminadas a consolidar SPAL como una publicación de excelencia en Prehistoria, Protohistoria y Arqueología de la península ibérica.

Entre los objetivos prioritarios estaban, en primer lugar, la adopción de criterios de calidad que permitieran consolidar y mejorar el posicionamiento de SPAL en los índices de calidad en las áreas temáticas; otro de los objetivos está relacionado con la internacionalización de la revista, incorporando investigadores extranjeros de conocido prestigio a los consejos editorial y científico y abriendo la revista a trabajos de mayor proyección; y por último, la posibilidad de ofrecer en acceso libre, sin embargo editorial (Creative Commons License), todo el histórico de la revista.

El esfuerzo del Consejo de Redacción, del Consejo Científico, la calidad de los trabajos publicados y la labor altruista de los revisores científicos y de estilo, así como el apoyo del Departamento de Prehistoria y Arqueología de la Universidad de Sevilla y de la Editorial Universidad de Sevilla, han permitido consolidar los estándares de calidad de SPAL. El salto de calidad alcanzado ha sido reconocido con el sello FECYT 2016 a revistas científicas, renovado en 2019, o el posicionamiento dentro de los rankings internacionales, estando en el primer cuartil del Scimago Journal Rank o habiendo sido recientemente indexada en el Web of Science Emerging Science Citation Index.

Entre las iniciativas que emprendió SPAL está la modernización de la gestión de los trabajos. Para ello adoptamos en 2018 el estándar OJS (Open Journal System), incrementado la eficacia en nuestro compromiso en gestionar con la máxima celeridad y rigor los originales que se reciben.

Así mismo y dada la demanda de autores para publicar en nuestra revista, en 2018 ampliamos a dos fascículos por número y año, convirtiendo la publicación de SPAL en semestral, que se edita en versión electrónica en acceso abierto y sin restricciones los días 1 de marzo y 1 de octubre de cada año en la web (https://revistascientificas.us.es/index.php/spal/issue/archive).

Los cambios que hemos acometido en estos últimos años han afectado a algunas de las secciones. Así, la distinción entre artículos de fondo y noticias ha desaparecido.

Por otra parte, la accesibilidad digital a los resúmenes de las actividades científicas que presentan la mayoría de los eventos académicos y la cantidad de medios de divulgación (blogs, twitter, Facebook, Instagram...) han derivado en que las crónicas de eventos hayan quedado desfasadas. De modo que hemos decidido suprimir la sección de crónicas científicas.

En cuanto a la sección dedicada a comentar las novedades editoriales, y en pro de que las reseñas incorporen un apartado crítico, hemos decidido no aceptar recensiones no solicitadas. De tal forma que aquellos autores / editores que quieran contar con una reseña de su trabajo en SPAL deberán enviar dos copias a la revista, una para el reseñador y otra para la biblioteca de la Universidad de Sevilla, siendo el Consejo de Redacción de SPAL el que solicite la recensión de la obra a un especialista. Este podrá ser elegido entre los 
sugeridos por los autores o a discreción del Consejo de Redacción. Excepcionalmente, a criterio del Consejo de Redacción, se publicarán réplicas, y en ningún caso contrarréplicas.

En los últimos tiempos, la comunidad científica en particular y la sociedad en general demandan una defensa y protección de los derechos de autor, que aparece regulado en el ámbito de la Unión Europea por diversas normativas y leyes. En línea con estas preocupaciones,

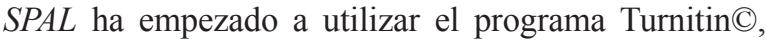
para detectar coincidencias y similitudes entre los textos sometidos a evaluación y los publicados previamente en otras fuentes, al objeto de controlar esta mala praxis.

En este sentido, referido a las imágenes e ilustraciones, SPAL sólo publicará material original. Reproduciendo sólo aquellas imágenes e ilustraciones que tengan autorización expresa por parte de quién ostente los derechos o que hayan sido publicadas mediante licencia Creative Commons.

En otro orden de cosas, el avance imparable del mundo digital, la globalización de la investigación y los sistemas de evaluación de la actividad investigadora aconsejan que los autores sean identificados mediante un identificador digital único. En SPAL hemos adoptado el uso del ORCID (C) y el Researchers ID(C) como sistema de normalización de autorías, por lo que todos los autores deben incluir estos dos identificadores en los artículos que deseen someter a evaluación.

En lo relativo a normas formales, los estándares de calidad nos llevan a adoptar algunos cambios. Así, para homogeneizar los sistemas de cita de las unidades de medida, hemos adoptado el vigente en España (https:/www.boe.es/eli/es/rd/2009/12/30/2032), donde se establecen las definiciones de las unidades, sus nombres y símbolos, así como las reglas para la formación de sus múltiplos y submúltiplos de conformidad con los acuerdos de la CGPM y la normativa de la Unión Europea.

En este sentido, de acuerdo con el compromiso de SPAL con el acceso abierto se implementarán todos los criterios del Plan S` de la Unión Europea, para facilitar que el texto completo sea accesible en un formato legible por máquina (como por ejemplo XML/JATS). 
Artículos 



\title{
MONUMENTALIDAD FUNERARIA DEL BRONCE EN EL SUR DE LA PENÍNSULA IBÉRICA: LA NECRÓPOLIS DE LA ORDEN-SEMINARIO (HUELVA)
}

\section{FUNERARY MONUMENTALITY OF THE BRONZE AGE IN THE SOUTH OF THE IBERIAN PENINSULA: THE NECROPOLIS OF LA ORDEN-EL SEMINARIO (HUELVA)}

\author{
JOSÉ ANTONIO LINARES-CATELA \\ Departamento de Historia, Geografía y Antropología, Facultad de Humanidades \\ Avda. Tres de Marzo s/n, Campus del Carmen, Universidad de Huelva, 21071 Huelva \\ Correo-e: ja.linares@dhga.uhu.es (D) <https://orcid.org/0000-0002-4773-3645> \\ Scopus ID: <https://www.scopus.com/authid/detail.uri?authorld=36348732700> \\ Researcher ID: <https://publons.com/researcher/AAG-2204-2019>
}

\begin{abstract}
Resumen: La permanencia del megalitismo durante la Edad del Bronce en la península ibérica es uno de los elementos destacados en las investigaciones recientes, interpretándose la continuidad de las arquitecturas y de las prácticas funerarias pretéritas de diversas formas. La excavación microespacial, el análisis arquitectónico de las tumbas, el estudio antropológico y el establecimiento de la cronología de la actividad funeraria de las necrópolis de La Orden- Seminario ha posibilitado caracterizar la existencia de un monumentalismo funerario desarrollado durante la Edad del Bronce Antiguo, c 2300-1900 cal BC. Esta monumentalidad funeraria se sustentó en la reapropiación de las necrópolis calcolíticas para la implantación de tumbas individuales en las cámaras de las sepulturas colectivas. Estas tumbas (covachas, fosas, cámaras con suelos nivelados y "cistas" con cubriciones tumulares) se caracterizan por la perpetuación de esquemas conceptuales de la tradición megalítica, presentando elementos arquitectónicos, técnicas constructivas y materiales que propiciaron la perceptibilidad visual, la perdurabilidad y la recreación de una memoria en torno a los espacios mortuorios ancestrales. En su interior se enterraron individuos de diferente sexo y edad, acompañados de diversos ajuares muebles que representan las diferencias sociales introducidas en la esfera de la muerte por la nueva concepción de las sociedades desigualitarias.
\end{abstract}

Palabras clave: Megalitismo, monumentalistimo, Bronce Antiguo, tumbas, prácticas funerarias, cronología

\begin{abstract}
The permanence of megalithic architecture during the Bronze Age in the Iberian Peninsula is one of the elements highlighted in recent research, interpreting the continuity of architectures and funerary practices in various ways. The microspatial excavation, the architectural analysis of the tombs, the anthropological study and the establishment of the chronology of the funerary activity of the necropolis of La Orden-Seminario have made it possible to characterise the existence of a funerary monumentalism developed during the Early Bronze Age, c 2300-1900 cal BC. This funerary monumentality was based on the reappropriation of the Chalcolithic necropolis for the implantation of individual tombs inside the collective burial chambers. These tombs (caves, pits, chambers with level floors and "cists" with tumular coverings) are characterized by the perpetuation of conceptual schemes of the megalithic tradition, presenting architectural elements, constructive techniques and materials that contributed the visual perceptibility, the perdurability and the recreation of a memory around the ancestral mortuary spaces. Inside, individuals of different sexes and ages were buried, accompanied by various grave goods that represent the social differences introduced into the sphere of death by the new conception of unequal societies.
\end{abstract}

Keywords: Megalithism, monumentalism, Early Bronze Age, tombs, funerary practices, chronology. 


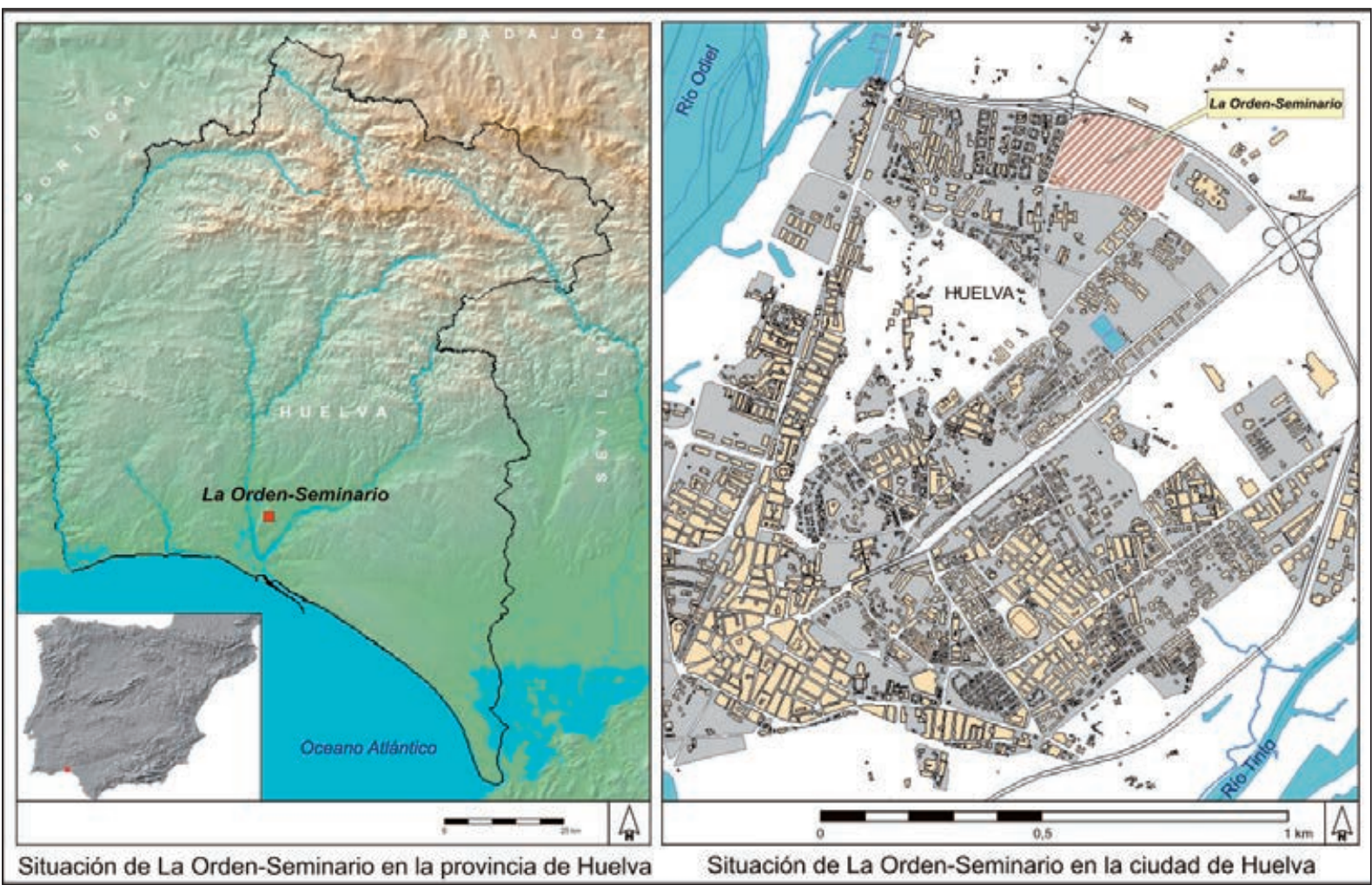

Figura 1. Localización del yacimiento de La Orden-Seminario (Huelva).

\section{INTRODUCCIÓN. EMPLAZAMIENTO Y DATOS BÁSICOS DE LA ORDEN-SEMINARIO}

El yacimiento de La Orden-Seminario se ubica en la periferia norte del casco urbano de la ciudad de Huelva, dentro del sector B3 Santa Marta-La Orden de la Zona Arqueológica de Huelva (fig. 1). Se emplaza en un área amesetada al norte de la península del estuario formado por las desembocaduras de los ríos Tinto y Odiel, una zona intensamente ocupada durante la Prehistoria Reciente en la que el asentamiento de La Orden-Seminario ocupó un sitio estratégico. Entre el 6500-4000 BP esta península dominaba el espacio central del paleoestuario, conformando una gran ensenada abierta al mar delimitada por los esteros de los ríos y desembocaduras de los cauces secundarios del interfluvio, situándose el nivel del agua hasta $2 \mathrm{~m}$ por encima de la cota actual (fig. 2). A partir del $4000 \mathrm{BP}$ el nivel del mar disminuyó drásticamente y se estabilizó la costa, asistiéndose a la progresiva colmatación sedimentaria de los estuarios (Cáceres et al. 2018, Zazo et al. 2005).

El yacimiento comprende una superficie conocida de 23 hectáreas, en la que se presentan estructuras excavadas en el sustrato de arcillas arenosas, limos y arenas finas de la Formación Arenas de Huelva, siendo materiales del Plioceno Inferior de la cuenca del Guadalquivir (Baceta y Pendón 1999: 420, Mayoral y Abad 2008: 23). El sitio arqueológico cuenta con estructuras de distintas fases de ocupación: poblado y necrópolis del IV-III milenios BC, necrópolis de la Edad del Bronce, aldea con fondos de cabaña y otras estructuras del Bronce Final, diversos sistemas de cultivo protohistóricos, estructuras orientalizantes y turdetanas, necrópolis visigoda, necrópolis almohade y área de grandes silos, alcorques y trazas de arboricultura de la Edad Moderna y Edad Contemporánea (Gómez Toscano et al. 2014, González et al. 2008, Vera Rodríguez et al. 2010).

\section{LAS NECRÓPOLIS PREHISTÓRICAS. TUMBAS, PRÁCTICAS FUNERARIAS Y SECUENCIA DIACRÓNICA}

En La Orden-Seminario se han documentado varias necrópolis correspondientes a tres fases: Neolítico Final, Edad del Cobre y Edad del Bronce (fig. 3). 


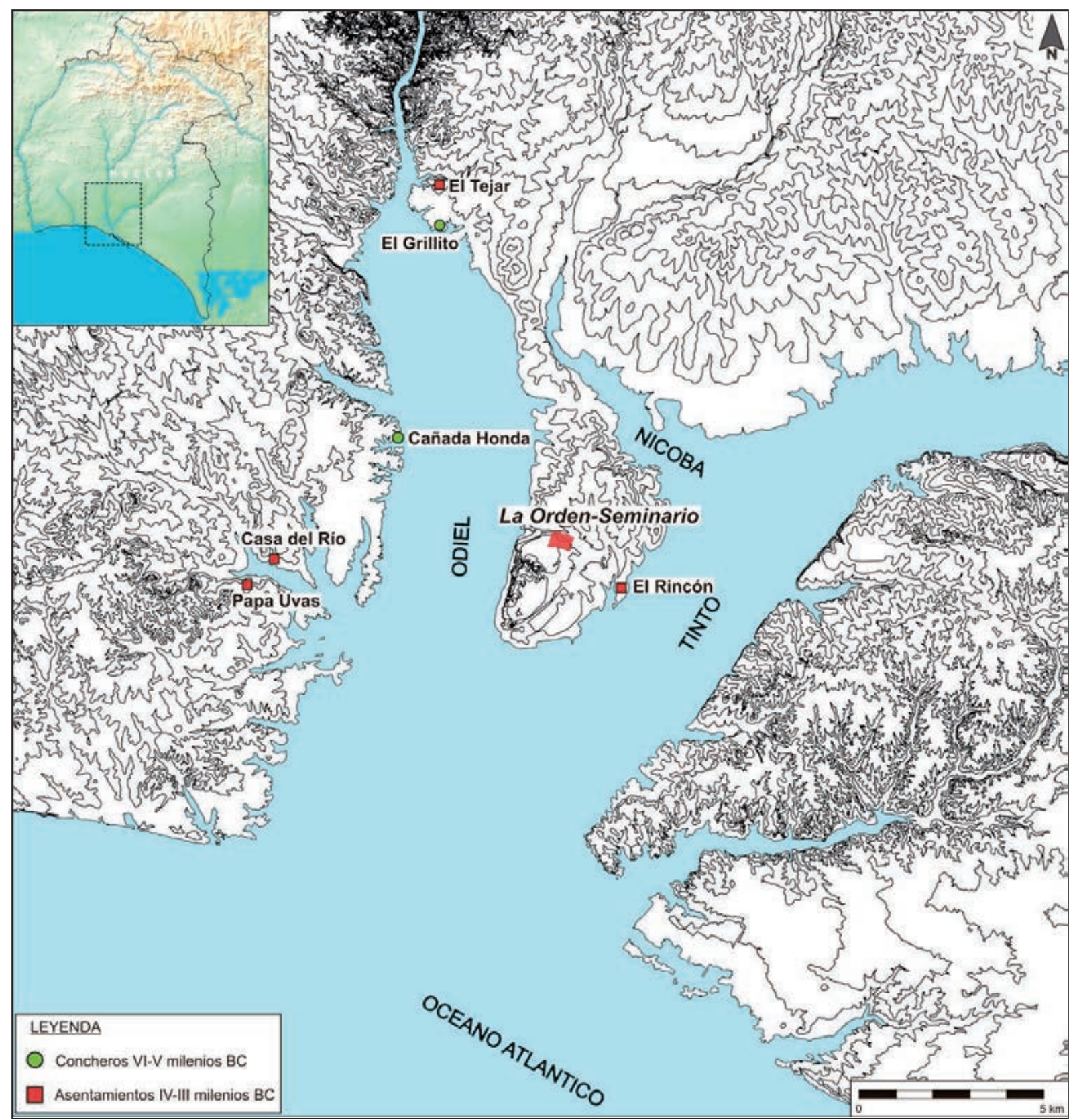

Figura 2. Situación de La Orden-Seminario y otros asentamientos en el paleoestuario del interfluvio de los ríos Tinto y Odiel entre el 6500-4000 BP.

Las necrópolis del IV y III milenios BC se concentraron en las zonas superiores de las dos lomas del asentamiento, siendo espacios reservados de forma preferente al dominio de los muertos. En la necrópolis noroeste se han constatado tres tumbas: dos fosas (estructuras 1307 y 1327) del Neolítico Final y un hipogeo (estructura 1336) de la Edad del Cobre. La necrópolis sureste se concentraba en la franja central de la meseta, estando compuesta por seis tumbas: dos fosas del Neolítico Final (estructuras 279 y 7015) y cuatro tumbas de la Edad del Cobre, siendo dos hipogeos (7005 y 7016) y dos tholoi (7049 y 7055) distribuidos de forma lineal en un eje noroeste-sureste y con orientación preferente de los accesos hacia $65^{\circ} \mathrm{NE}$ (Linares Catela y Vera Rodríguez 2015). 
Las tumbas de la Edad del Bronce se ubicaron en cuatro sitios diferenciados: a) en las necrópolis noroeste y sureste, reutilizándose los espacios colmatados de las cámaras de las sepulturas colectivas calcolíticas para la implantación de tumbas individuales; b) en los alrededores de la necrópolis noroeste, constatándose dos fosas (1305 y 1788); c) en la meseta suroccidental, donde se presentaban una covacha (9240) y dos fosas (2515 y 2668); d) en el extremo suroeste, en donde se formó una nueva necrópolis compuesta por once tumbas, distinguiendo entre cinco fosas simples y seis fosas con cubrición de cantos de cuarcita (Martínez Fernández y Vera Rodríguez 2014).

La metodología de investigación de las necrópolis se ha sustentado en una estrategia de trabajo que ha aunado la excavación arqueológica microespacial, el estudio antropológico, la arqueometría de los materiales y el análisis bayesiano de diecisiete dataciones radiocarbónicas, obtenidas sobre huesos humanos en tres tumbas con una intensa actividad funeraria (1336, 7016 y 7055). Ello ha posibilitado determinar la biografía funeraria de estas sepulturas, reconstruir la secuencia estratigráfica de las estructuras, estudiar sus arquitecturas y técnicas constructivas, identificar los diferentes depósitos (restos óseos y objetos muebles) derivados de las prácticas mortuorias y establecer la temporalidad.

Las necrópolis del Neolítico Final, de mediados del IV milenio BC, presentaban dos fosas en cada sector. Las tumbas eran de plantas circulares y secciones similares a las construcciones doméstico-habitacionales, con dimensiones medias de $2 \mathrm{~m}$ de diámetro y $1 \mathrm{~m}$ de profundidad. Eran accesibles desde el firme externo superior, desde donde se realizaron las operaciones de gestión de los ámbitos mortuorios. Contaban con un espacio sepulcral colectivo formado por la reiteración de deposiciones de individuos diferidas en el tiempo. El número de miembros enterrados fue variable, oscilando entre un individuo en la tumba 1307, tres individuos en la tumba 7015 (dos inhumaciones primarias y un paquete funerario), cuatro individuos inhumados junto a las paredes en la tumba 1327 o hasta doce individuos en la tumba 279, agrupados en paquetes funerarios junto a los objetos muebles. Los individuos, de ambos sexos y diversos rangos de edad, se acompañaban de escasos ajuares, siendo los microlitos geométricos los objetos más comunes.

Las necrópolis de la Edad del Cobre se componían de dos tipos de sepulturas colectivas: hipogeos y sepulcros de falsa cúpula. Ambas arquitecturas poseían tres sectores: atrios abiertos escalonados y pavimentados con puertas y otros dispositivos de cierre/apertura destinados al acceso a las tumbas; corredores cubiertos longitudinales segmentados por jambas, sirviendo como espacios de tránsito y de deposición de ofrendas; y cámaras circulares abovedadas. Los hipogeos eran estructuras subterráneas en su integridad. Por el contrario, los tholoi eran construcciones semisubterráneas con un desarrollo parcial en alzado, con paredes formadas por finas lajas de revestimiento de pizarra azul y cubiertas mixtas, siendo los corredores adintelados y estando las cámaras levantadas mediante aproximación concéntrica de hiladas de mampostería de pizarra trabada con arcilla. En las cámaras sepulcrales se formaron diversos niveles funerarios superpuestos como consecuencia del prolongado uso de estos espacios. Los depósitos identificados, tanto inhumaciones primarias como paquetes funerarios acompañados de ajuares muebles, relatan los diferentes gestos mortuorios y las reiteradas prácticas de manipulación, reorganización y acondicionamiento de los espacios sepulcrales.

La actividad funeraria de las sepulturas colectivas se desarrolló en una cronología c 3000-2400/2300 cal $\mathrm{BC}$, a tenor de las catorce dataciones radiocarbónicas efectuadas en las tumbas 1336, 7016 y 7055. El proceso de colapso estructural, derrumbe y colmatación de las sepulturas colectivas condicionó el abandono y el desuso de las estructuras funerarias c 2500/2400-2300 cal BC, comprendiendo este hiato o lapso temporal una duración de una a dos centurias dependiendo de cada tumba. La actividad funeraria se reanudó en el último cuarto del III milenio BC, asistiéndose a la emergencia y desarrollo de las necrópolis en la Edad del Bronce Antiguo, comprendiendo una cronología c 2300-1900 cal BC, conforme a las tres fechas obtenidas en las tumbas 7016 y 7055 (tab. 1 y 2; fig. 4).

Las necrópolis de la Edad del Bronce Antiguo se caracterizan por la presencia de tumbas individuales de diversas formas arquitectónicas: covachas subterráneas, fosas (con o sin cubrición), suelos nivelados en cámaras bajo tumulaciones y "cista" con cubrición tumular. En una cronología posiblemente posterior, c 1900-1500 BC, a tenor de las arquitecturas y ajuares muebles, pudo surgir la necrópolis suroeste, siendo un nuevo espacio mortuorio.

\section{LAS TUMBAS INDIVIDUALES DEL BRONCE ANTIGUO INTEGRADAS EN LAS SEPULTURAS COLECTIVAS}

\subsection{Sepultura 7016}

En los niveles de colmatación de la cámara del hipogeo 7016 se documentaron dos tumbas individuales 


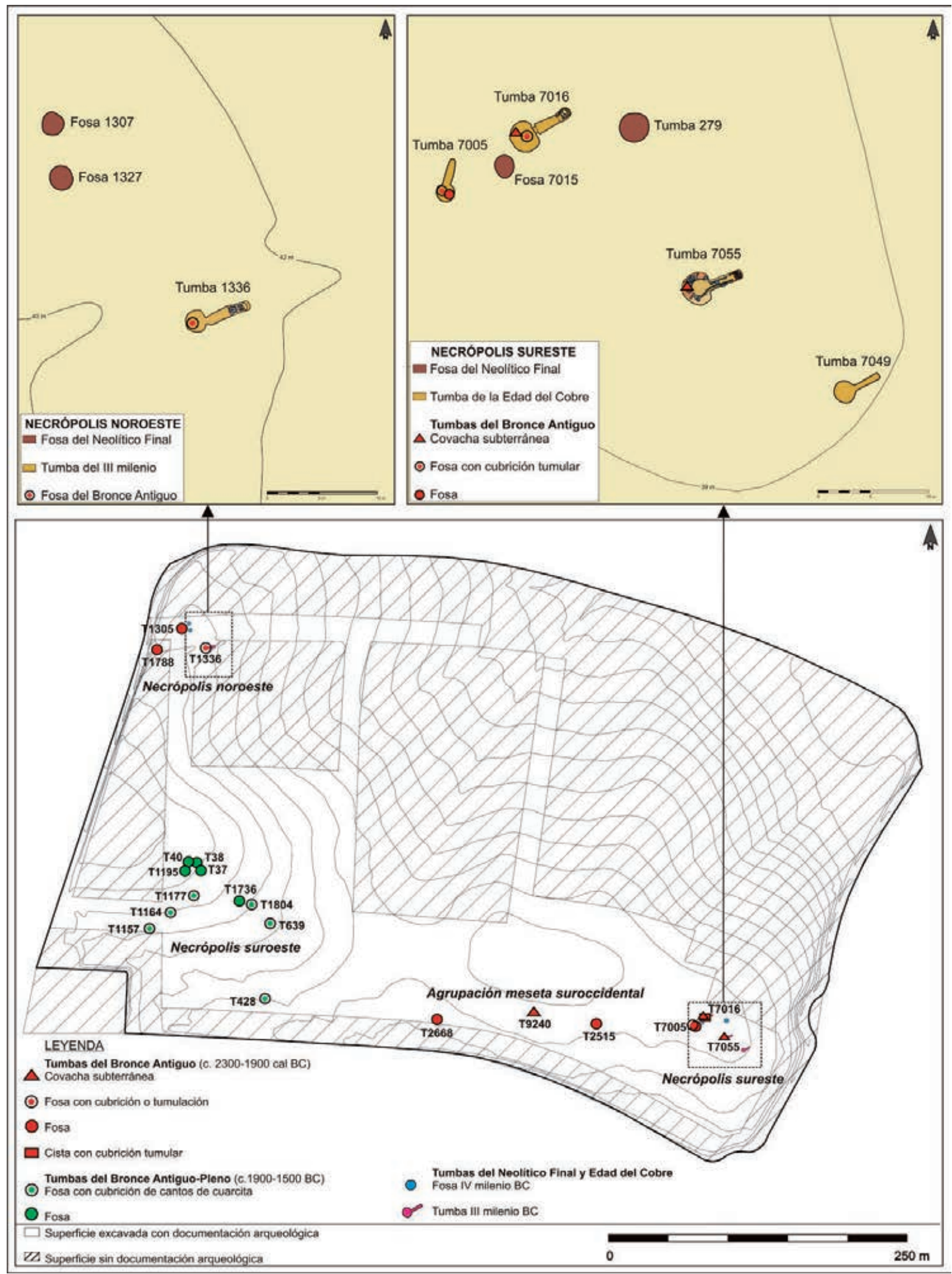

Figura 3. Necrópolis prehistóricas de La Orden-Seminario.

ISSN: $1133-4525$ ISSN-e: $2255-3924$ 
Tabla 1. Dataciones radiocarbónicas de los enterramientos del Bronce Antiguo. Necrópolis sureste de La OrdenSeminario.

\begin{tabular}{|c|c|c|c|c|c|c|c|c|}
\hline $\begin{array}{c}\text { CÓDIGO } \\
\text { LAB. }\end{array}$ & TUMBA & FORMA & $\begin{array}{c}\text { TIPO DE } \\
\text { DEPÓSITO }\end{array}$ & MUESTRA & $\begin{array}{c}\text { FECHA } \\
\text { BP }\end{array}$ & $d^{13} \mathrm{C}(\% o)$ & $\begin{array}{c}\text { FECHA } \\
\text { CAL ANE } \\
1 \sigma(68 \%)\end{array}$ & $\begin{array}{c}\text { FECHA } \\
\text { CALANE } \\
2 \sigma(95 \%)\end{array}$ \\
\hline CNA-327 & $\begin{array}{c}\text { Tumba } \\
7016\end{array}$ & $\begin{array}{c}\text { Covacha } \\
\text { subterránea }\end{array}$ & $\begin{array}{c}\text { Depósito primario } \\
\text { individual (UE 37): } \\
\text { inhumación }\end{array}$ & $\begin{array}{l}\text { Hueso humano } \\
\text { no específico de } \\
\text { adulto masculino }\end{array}$ & $3796 \pm 50$ & $-25.14 \pm 0.30$ & $2300-2140$ & $2460-2040$ \\
\hline CNA-330 & $\begin{array}{l}\text { Tumba } \\
7055\end{array}$ & $\begin{array}{c}\text { Covacha } \\
\text { subterránea }\end{array}$ & $\begin{array}{c}\text { Deposito primario } \\
\text { Individual (UE 87): } \\
\text { inhumación }\end{array}$ & $\begin{array}{l}\text { Hueso humano no } \\
\text { específico de in- } \\
\text { fantil II (6-7 años) }\end{array}$ & $3700 \pm 50$ & $-15.64 \pm 0.72$ & $2200-2020$ & $2280-1940$ \\
\hline CNA-622 & $\begin{array}{c}\text { Tumba } \\
7016\end{array}$ & $\begin{array}{l}\text { "Cista" } \\
\text { con cubri- } \\
\text { ción } \\
\text { tumular }\end{array}$ & $\begin{array}{c}\text { Depósito secundario } \\
\text { individual (UE 15): } \\
\text { inhumación }\end{array}$ & $\begin{array}{l}\text { Hueso humano } \\
\text { (clavícula) de } \\
\text { adulto masculino } \\
\text { maduro }\end{array}$ & $3600 \pm 60$ & $-19.47 \pm 0.68$ & $2120-1880$ & $2140-1770$ \\
\hline
\end{tabular}

con formas y depósitos funerarios diferenciados. Primeramente, se consumó una inhumación en el interior de una covacha subterránea (fig. 5). Esta estructura fue excavada en el lateral noroeste de la cámara, junto a las paredes, llegando hasta el firme del hipogeo. Contaba con dos sectores espaciales conectados: a) un hueco de acceso de perfil escalonado, de $1,20 \mathrm{~m}$ por $0,60 \mathrm{~m}$ de anchura; b) una estructura subterránea de morfología rectangular alargada, con dirección norte-sur $\left(185^{\circ} \mathrm{N}\right)$, de $1,85 \mathrm{~m}$ de longitud por $0,90 \mathrm{~m}$ de achura $\left(1,6 \mathrm{~m}^{2} \mathrm{de}\right.$ superficie) y hasta $0,50 \mathrm{~m}$ de altura. La covacha fue cerrada con un dispositivo de lajas de pizarra y arcilla y cubierta por el nivel de derrumbe removido de la falsa cúpula del hipogeo mixto, conformando un nivel tumular de lajas de pizarra, cantos de cuarcita y arcilla.

En el interior de la covacha se documentaron los restos de un enterramiento primario de un individuo adulto masculino en conexión anatómica parcial y su ajuar (UE 37). Del esqueleto se conservaban las extremidades inferiores y brazos, varios fragmentos del cráneo y huesos del tronco central, determinándose que fue colocado en decúbito lateral izquierdo con las piernas flexionadas y los brazos extendidos y basculados hacia la pared oeste de la covacha, hacia supinación del tórax, con orientación sagital $10^{\circ}$ norte y cara al este. Este difunto se descompuso en un medio aerobio, permanecido la covacha como un espacio hueco de manera previa a su colmatación tras el colapso estructural y entrada de tierras desde el exterior. El estudio antropológico ha revelado que este hombre, de 1,67 $\pm 6,96 \mathrm{~m}$ de estatura, presentaba una patología osteoarticular leve en los pies y diversas afecciones derivadas de hábitos posturales: platicnemia e hiperdesarrollo de la pilastra femoral. Los objetos muebles eran de tradición campaniforme, presentando dos recipientes cerámicos lisos de superficies bruñidas (un cuenco semiesférico y un vaso colocado en su interior), adosados a la pared tras el costado y la cabeza del difunto, y una punta de lanza de cobre tipo Palmela, dispuesta en el extremo superior y que estaría unida al extremo final de un astil de madera. La datación radiocarbónica ha proporcionado una cronología para este enterramiento de 3796 \pm 50 BP: 24602040 cal BC $2 \sigma$ (CNA-327, tab. 1$)$.

Con posterioridad, se construyó sobre y con los materiales reutilizados del nivel de derrumbe del hipogeo mixto una estructura con cubrición tumular, conteniendo en su interior un depósito funerario secundario (fig.6). La estructura era de morfología seudocuadrangular, delimitando un espacio interno de 1,20 $\mathrm{m}$ por 0,80 de lado $\left(0,96 \mathrm{~m}^{2}\right.$ de superficie) a modo de "cista", con orientación dominante noroeste-sureste, perpetuando el eje axial del hipogeo $\left(65^{\circ} \mathrm{NE}\right)$. Estaba formada por dos muretes de mampostería de tres hiladas superpuestas de lajas de pizarra y cantos de cuarcita trabados con arcilla, conformando dos paredes en forma de "L" de 0,30 m de anchura y altura. El firme lo constituía el nivel regularizado de arcilla limo-arenosa del derrumbe de la pared y la cubierta del cuadrante sureste del hipogeo, con marcado buzamiento desde el centro hacia el borde sureste.

En su interior se documentó un depósito secundario compuesto por restos óseos seleccionados de un individuo adulto masculino de edad madura (entre 40-60 años) y un ajuar formado por escasos fragmentos de dos cuencos cerámicos, uno de forma 
Tabla 2. Modelado bayesiano de la actividad funeraria en las necrópolis de La Orden- Seminario. Dataciones radiocarbónicas de las tumbas del Bronce Antiguo.

\begin{tabular}{|c|c|c|c|c|c|c|c|c|}
\hline $\begin{array}{l}\text { ACTIVIDAD } \\
\text { FUNERARIA }\end{array}$ & TUMBA & \multicolumn{4}{|c|}{ DATACIONES CALIBRADAS } & \multicolumn{3}{|c|}{$\begin{array}{c}\text { MODELO BAYESIANO } \\
\text { Amodel }=153.8 \\
\text { Aoverall }=153.6\end{array}$} \\
\hline FASES & & $\begin{array}{l}\text { CÓDIGO } \\
\text { LAB. }\end{array}$ & EDAD BP & $\begin{array}{c}\text { FECHA } \\
\text { CAL BC } \\
1 \sigma \\
68 \%\end{array}$ & $\begin{array}{c}\text { FECHA } \\
\text { CAL BC } \\
2 \sigma \\
95 \%\end{array}$ & & $\begin{array}{c}68 \% \\
\text { probabilidad }\end{array}$ & $\begin{array}{c}95 \% \\
\text { probabilidad }\end{array}$ \\
\hline \multirow{2}{*}{$\begin{array}{c}\text { FASE } 1 \\
\text { TUMBAS } \\
\text { COLECTIVAS }\end{array}$} & - & - & - & - & - & $\begin{array}{l}\text { Boundary } \\
\text { Start } 1\end{array}$ & $2990-2700$ & $3060-2670$ \\
\hline & - & - & - & - & - & $\begin{array}{c}\text { Boundary } \\
\text { End 1 }\end{array}$ & $2460-2330$ & $2480-2250$ \\
\hline \multirow{5}{*}{$\begin{array}{c}\text { FASE } 2 \\
\text { TUMBAS } \\
\text { INDIVIDUALES }\end{array}$} & - & - & - & - & - & $\begin{array}{c}\text { Boundary } \\
\text { Start } 2\end{array}$ & $2330-2150$ & $2400-2060$ \\
\hline & T7016 & CNA-327 & $3796 \pm 50$ & $2300-2140$ & $2460-2040$ & - & $2260-2130$ & $2300-2040$ \\
\hline & T7055 & CNA-330 & $3700 \pm 50$ & $2200-2020$ & $2280-1940$ & - & $2150-2030$ & $2210-1980$ \\
\hline & T7016 & CNA-622 & $3600 \pm 60$ & $2120-1880$ & $2140-1770$ & - & $2140-1930$ & $2200-1870$ \\
\hline & - & - & - & - & - & $\begin{array}{c}\text { Boundary } \\
\text { End } 2\end{array}$ & $2120-1860$ & $2190-1570$ \\
\hline
\end{tabular}

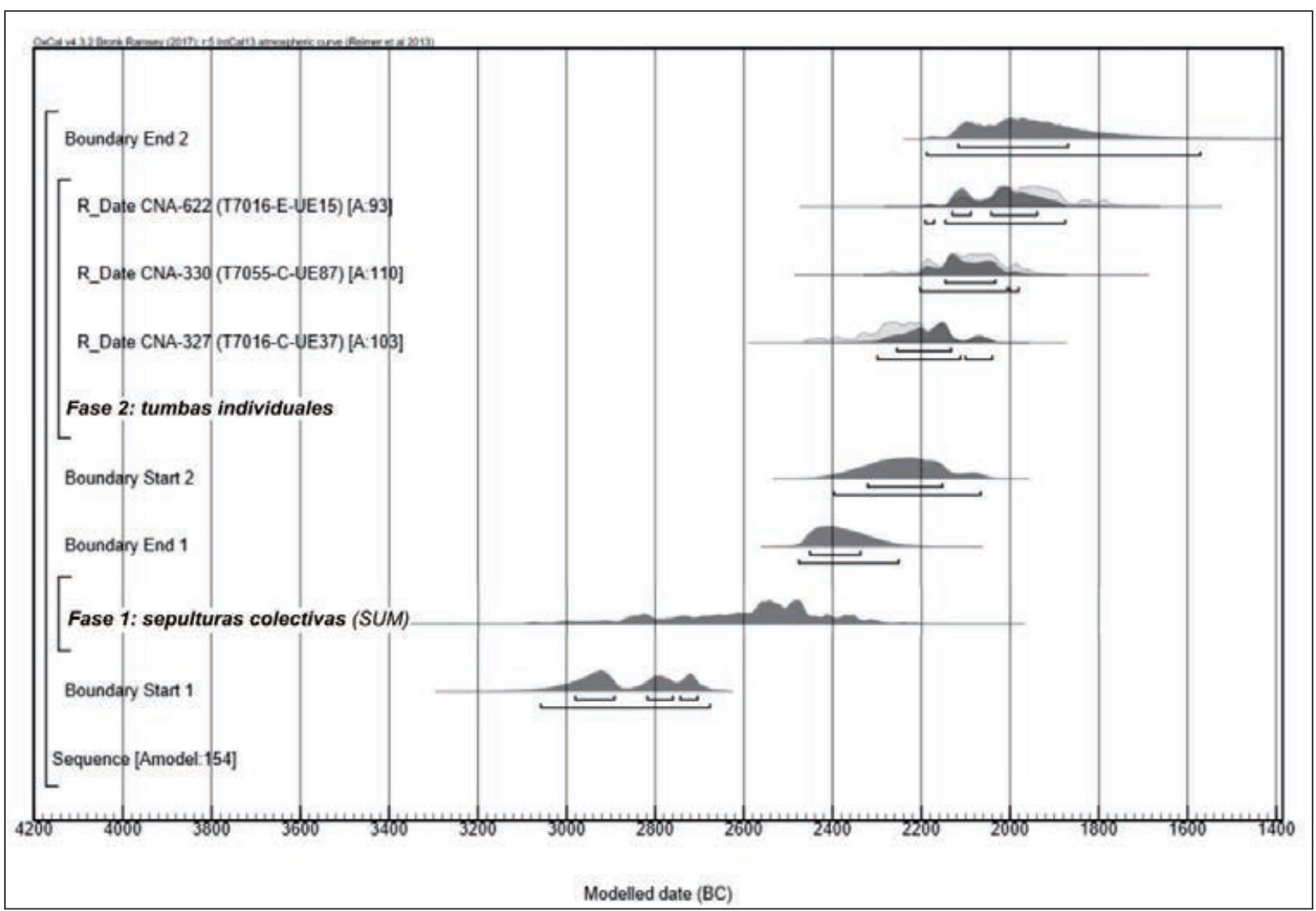

Figura 4. Modelado bayesiano de secuencia en fases de las necrópolis de La Orden-Seminario. Dataciones radiocarbónicas de las tumbas del Bronce Antiguo. OxCal v4.3.3. Brank Ramsey (2017); r:5 IntCal13 atmospheric curve (Reimer et al. 2013). 
hemisférica y otro con mamelón próximo al borde, y dos puntas de flecha de sílex, una de base cóncava y otra con pedúnculo. Los restos óseos se concentraban en la parte central de la estructura, apareciendo algunos fragmentos diseminados en el lateral sureste como consecuencia del soterramiento. Los dieciocho huesos que componían este depósito procedían de distintas partes del esqueleto: cabeza (arco posterior izquierdo del cráneo, molar inferior), tronco central (cuatro costillas, vértebra lumbar L5, dos fragmentos de la rama del pubis, escápula y fragmento de clavícula), extremidades superiores (húmero izquierdo, segunda falange proximal de la mano), extremidades inferiores (fémur, tibia izquierda) y tres fragmentos no específicos. Mediante el estudio antropológico se ha identificado que este hombre padeció artritis, una patología ostearticular degenerativa. La datación radiocarbónica efectuada ha proporcionado una cronología de $3600 \pm 60$ BP: $2140-1770$ cal BC $2 \sigma$ (CNA-622, tab. 1).

Su nivel de cubrición estaba formado por dos capas superpuestas de hasta $25 \mathrm{~cm}$ de espesor, formada por lajas de pizarra, cantos de cuarcita y arcilla, que colmataba al completo el espacio interior de la cámara, de 2,30 $\mathrm{m}$ por 2,10 m. Este elemento de cubrición presentaba un perfil monticular alcanzando la máxima altura y mayor grosor en la parte central de la cámara.

\subsection{Sepultura 7055}

En el tholos 7055 se constató una covacha subterránea construida en el área frontal de la cámara colmatada del sepulcro (fig. 7). Su implantación demandó la ejecución de diversas acciones constructivas: el desmonte parcial del nivel de derrumbe de la falsa cúpula mediante la apertura de una zanja, el arranque y la fracturación de gran parte de las lajas de revestimiento de la pared sureste de la cámara y algunas lajas de las paredes y techumbre del corredor y la excavación de la estructura subterránea. Los materiales extraídos (lajas de pizarra, cantos de cuarcita y arcilla) fueron reutilizados para la construcción de la covacha.

La covacha, con orientación norte-sur, tenía un espacio sepulcral ovalado de reducidas dimensiones $\left(0,76 \mathrm{~m}^{2}\right.$ de superficie), de $0,95 \mathrm{~m}$ en el eje norte-sur por $0,80 \mathrm{~m}$ en el eje este-oeste, alcanzando una altura media en el tramo central de 0,40 m. Se componía de varios elementos arquitectónicos: a) estructura excavada y tallada en el sustrato, con orientación norte-sur, que formaba las paredes norte y trasera y el suelo de la covacha, cuyo firme estaba levemente sobreelevado respecto a la cota de la cámara y con una ligera pendiente ascendente hacia el fondo; b) murete de mampostería lateral y laja de revestimiento; c) techumbre construida mediante dos lajas dispuestas oblicuamente y encastradas en una ranura tallada en el sustrato; d) abertura frontal de forma esférica orientada al este, de 0,80 $\mathrm{m}$ de anchura máxima en el tramo central y 0,50 m de altura. Estos elementos otorgaron a la covacha de una gran consistencia y estabilidad estructural.

En su espacio interno se registró la inhumación primaria de un individuo articulado infantil I-II de 6-7 años de edad, acompañado de un ajuar de tradición campaniforme (UE 87), formado por varios objetos: dos recipientes cerámicos lisos superpuestos componiendo una forma "campaniforme" (un cuenco de carena media que contenía un vaso troncocónico en su interior), colocados detrás de la cabeza, en el espacio existente entre esta y la pared; un pequeño puñal romboidal de cobre, dispuesto con orientación $20^{\circ} \mathrm{N}$ en el antebrazo, de sección longitudinal muy fina, extremo apuntado y bisel doble afilado, enmangado probablemente con madera o hueso; un brazalete de arquero manufacturado en pizarra gris con dos orificios perforados en los extremos, colocado al este del antebrazo.

El individuo fue dispuesto en decúbito lateral izquierdo con brazos flexionados y piernas hiperflexionadas, espalda contra la pared de la covacha, con posición anatómica sagital orientada hacia el norte $\left(20^{\circ} \mathrm{N}\right)$ y con dirección de la cabeza hacia el acceso, mirando la cara hacia el este. La descomposición integral del cuerpo se produjo en un espacio hueco, como consecuencia de la presencia de un dispositivo de cierre que propició la formación de un medio aerobio. Por diversas razones tafonómicas el esqueleto presentaba un bajo estado de conservación, preservándose escasos restos óseos muy deteriorados: un fémur, las dos tibias, los dos peronés, parte de los cúbitos y radios, un húmero, el cráneo y varios fragmentos no específicos. Presentaba diversos rasgos morfológicos dentarios: tubérculos accesorios en el molar $1^{\circ}$ inferior, raíz bífida en premolares superiores y cíngulo marcado en caninos.

Tras el enterramiento del difunto se procedió al cerramiento y sellamiento de la covacha. En primer lugar, se colocó un dispositivo de cierre en la entrada, formado por un murete de mampostería irregular trabada con arcilla de lajas de pizarra y cantos de cuarcita, ejecutado en tres tramos y con progresivo decrecimiento ascendente del grosor de las hiladas y del tamaño de las piedras. En segundo lugar, se construyó un forro de 


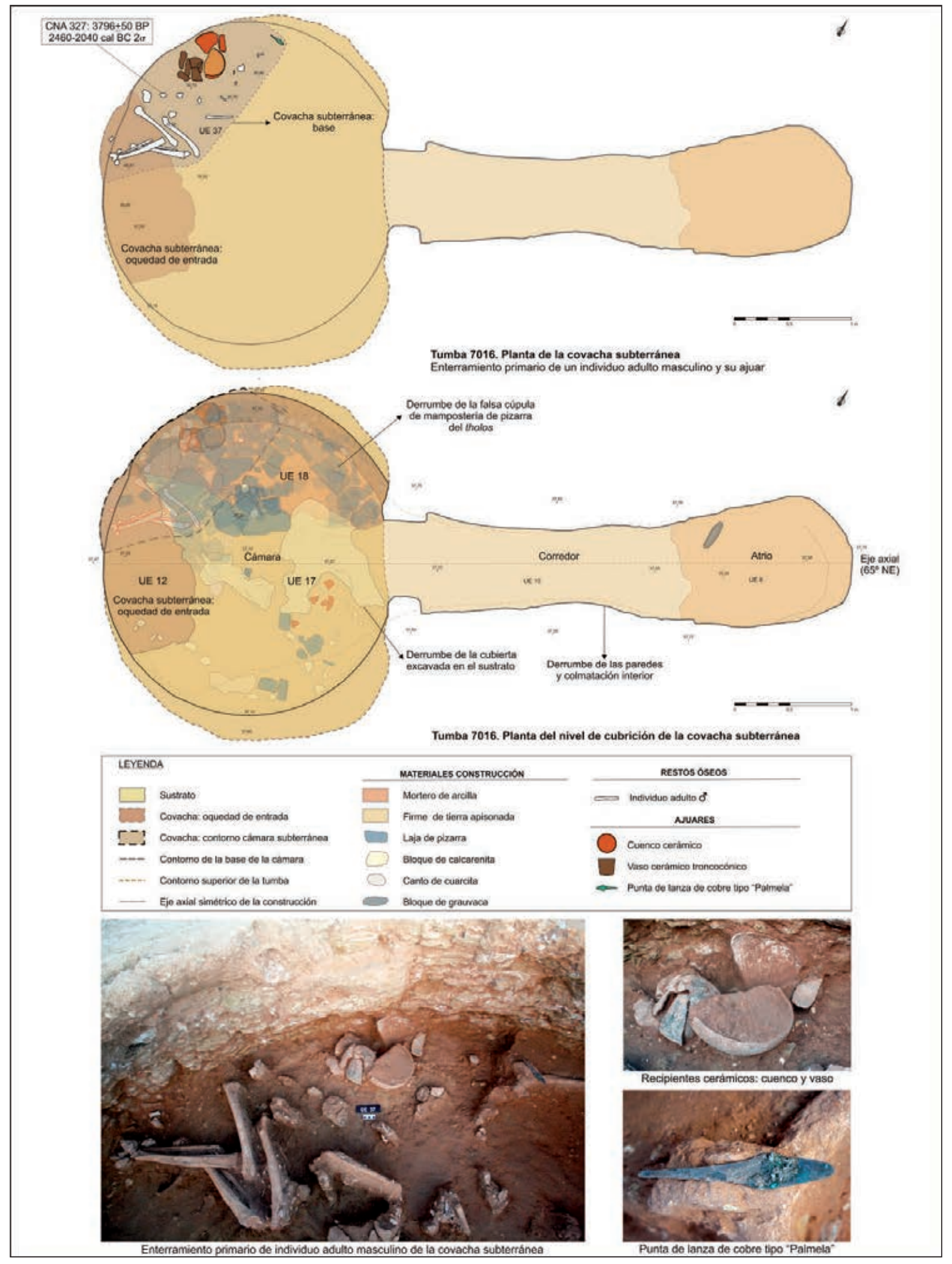

Figura 5. Covacha subterránea de la tumba 7016. Estructura y depósito funerario.

ISSN: $1133-4525 \quad$ ISSN-e: $2255-3924$ 


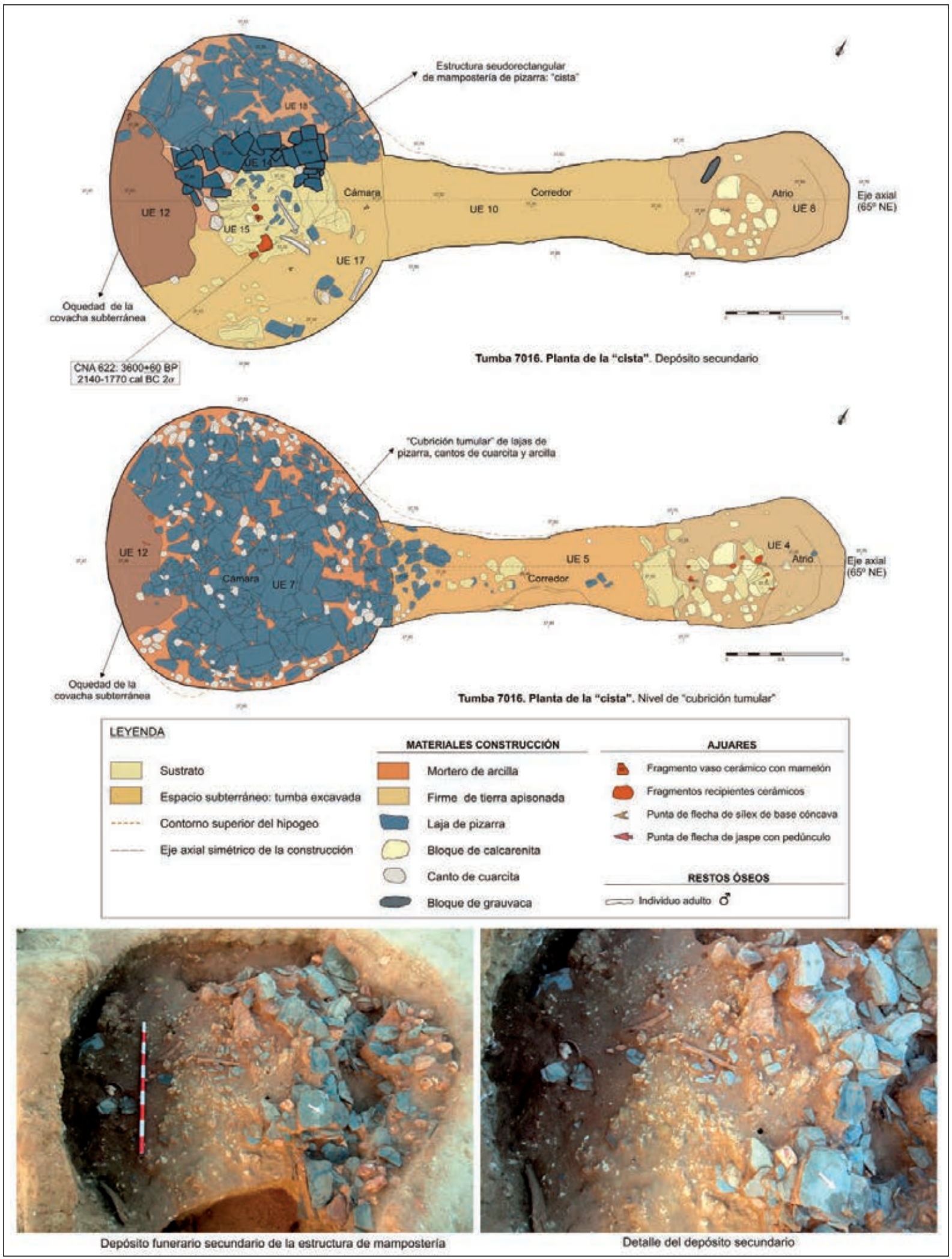

Figura 6. "Cista” con cubrición tumular de la tumba 7016. Elementos arquitectónicos y depósito funerario. 


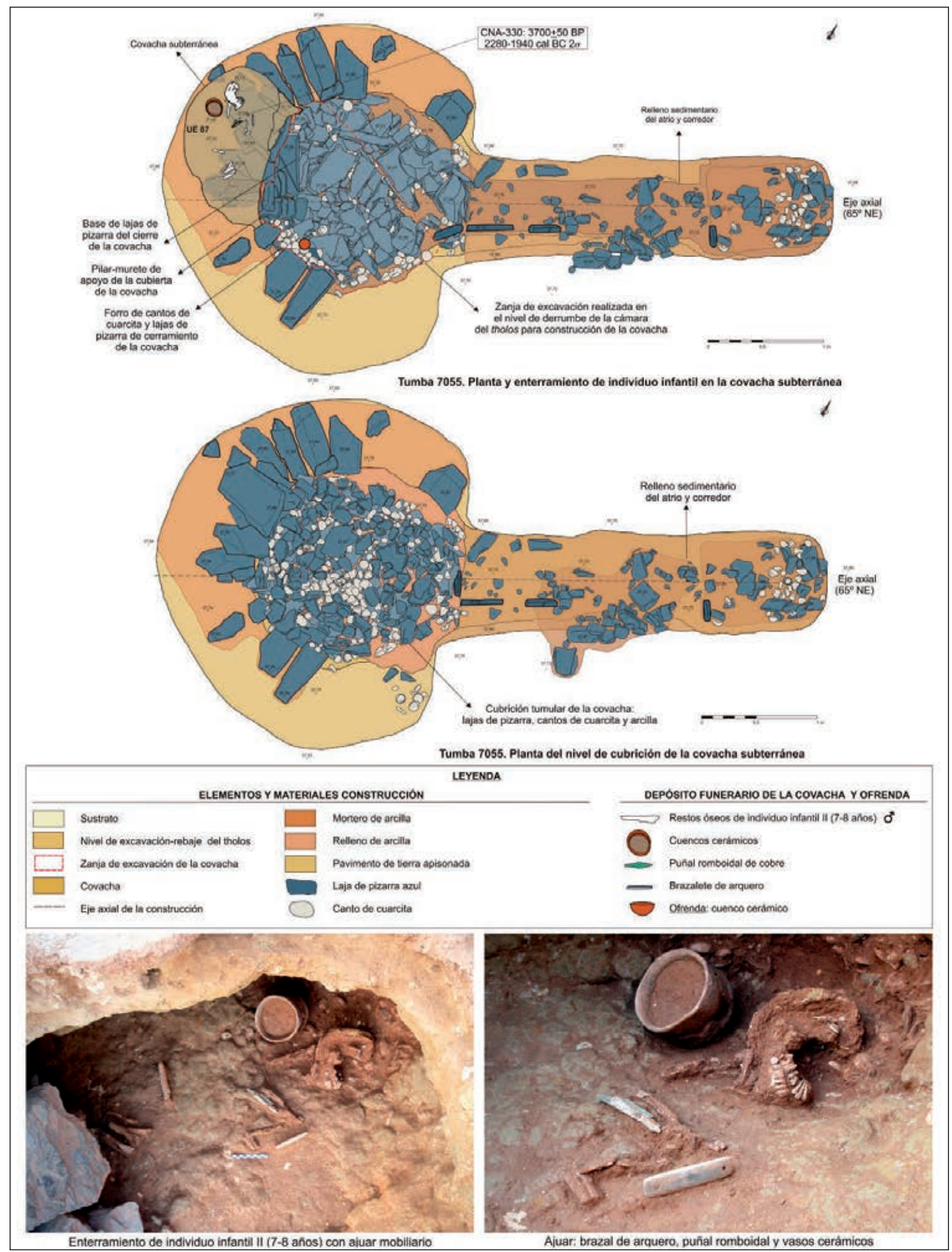

Figura 7. Covacha subterránea de la tumba 7055. Elementos arquitectónicos y depósito funerario.

ISSN: $1133-4525$ ISSN-e: $2255-3924$ 
revestimiento de cantos de cuarcita y pequeñas lajas de pizarra que selló el espacio frontal completo de la cámara, documentándose un cuenco cerámico semiesférico en la base, ofrendado como práctica de clausura de la covacha. Finalmente, se realizó el tapado y la cubrición en dos niveles constructivos. El nivel de base conformaba la colmatación de la zanja, disponiéndose un relleno con cantos de cuarcita, arcilla y algunas lajas de pizarra, que comprendió hasta $0,70 \mathrm{~m}$ de potencia. El nivel superior lo formaba la cubrición tumular circular, compuesta por cantos de cuarcita, pequeñas lajas de pizarra y arcilla, de 1,60 m de diámetro y 0,25 m máximo de espesor, ocupando el espacio completo de la cámara y sobresaliendo por encima de la rasante del firme externo del tholos.

La datación radiocarbónica efectuada sobre este individuo ha arrojado un resultado cronológico de 3700 \pm 50 BP: 2280-1940 cal BC $2 \sigma$ (CNA-330, tab. 1).

\subsection{Sepultura 7005}

En la tumba 7005 se llevaron a cabo varias deposiciones funerarias en el interior de la cámara del hipogeo, de 2,05 m de diámetro, que se encontraba parcialmente colmatada tras su derrumbe. Estas deposiciones se agrupaban en dos niveles estratigráficos, que se corresponden con las fases 2 y 3 de la tumba (fig. 8).

En el nivel funerario 2 (fase 2) se realizaron dos depósitos funerarios. En primer lugar, se efectuó un enterramiento primario (UE 15) en una fosa oblonga excavada en el relleno sedimentario junto al lateral sureste de la cámara, aprovechando las paredes del hipogeo como límite de la estructura. La fosa, con orientación noreste-suroeste, medía $1,30 \mathrm{~m}$ de longitud por $0,65 \mathrm{~m}$ de anchura (1,25 $\mathrm{m}^{2}$ de superficie), alcanzando una altura máxima de $0,40 \mathrm{~m}$. En su interior se inhumó una mujer adulta joven de 20-25 años, con una estatura de 1,54 $\pm 5,96 \mathrm{~m}$, que fue colocada en decúbito lateral derecho con brazos y piernas, plano sagital al noreste $\left(50^{\circ} \mathrm{NE}\right)$ y cara orientada al noroeste. Presentaba una patología dentaria común, caries. Contaba con un cuenco cerámico hemisférico, dispuesto junto a la cabeza y recostado de manera oblicua contra la pared de la fosa. Por el posicionamiento del esqueleto articulado, su buen estado de conservación y por la descomposición del cuerpo en un medio anaerobio, la difunta pudo haber estado ataviada por un sudario o mortaja, siendo soterrada tras su deposición en la fosa.
Posteriormente, se realizó un depósito secundario (UE 12) sobre el suelo nivelado de la cámara, ocupando el espacio central. Formaba un paquete funerario de huesos largos apilados y agrupados con orientación norte-sur en una superficie cuadrangular de $40 \mathrm{~cm}$ de lado $\left(0,16 \mathrm{~m}^{2}\right.$ de superficie), que fue soterrado por una capa de arcilla de $15 \mathrm{~cm}$ en forma de montículo. Los huesos se correspondían con las extremidades inferiores y superiores de una mujer adulta, a la que se asoció una lezna o punzón de cobre y un fragmento de piedra pulida.

En el nivel funerario 3 (fase 3) se documentó un depósito secundario colectivo desarrollado en el tramo central de acceso de la cámara, sobre un firme (UE 7) con buzamiento de las paredes hacia el centro. El paquete funerario (UE 8) estaba formado por cuatro huesos largos de las extremidades inferiores (un fémur derecho, una tibia izquierda) y superiores (un húmero derecho y hueso no específico) de dos individuos adultos (uno masculino y otro femenino), concentrados en un espacio de 55 por $30 \mathrm{~cm}$ de lado $\left(0,16 \mathrm{~m}^{2}\right)$, con dirección este-oeste, acompañado de una lámina tallada de sílex, varios restos de útiles líticos tallados y fragmentos cerámicos. El paquete funerario se delimitó mediante tres bloques de calcarenita colocados en la conexión con el corredor y se cubrió mediante una capa de arcilla rojiza dispuesta en la superficie completa de la cámara, formando un montículo de $25 \mathrm{~cm}$ de espesor que sobresaldría respecto al firme externo. Asociada a este paquete se documentó tumbada una laja de pizarra azul, de forma rectangular alargada, de $70 \mathrm{~cm}$ de longitud por $30 \mathrm{~cm}$ de anchura máxima y $8 \mathrm{~cm}$ de grosor, en conexión espacial con su fosa de cimentación (de 50 por $5 \mathrm{~cm}$ ) y separada $20 \mathrm{~cm}$ al sur de los restos óseos. Esta piedra pudo haber estado colocada en vertical sobresaliendo por encima de la cubrición monticular, funcionando como una estela señalizadora del enterramiento. La laja de pizarra, fracturada en un extremo y retallada en sus aristas laterales, era un soporte reutilizado que pudo haberse extraído del tholos 7055 con anterioridad a la construcción de la covacha subterránea o proceder del tholos 7049, que fue desmantelado integralmente.

\subsection{Sepultura 1336}

El hueco superior de la cámara colmatada del hipogeo 1336 fue reutilizado en el Bronce Antiguo, excavándose una fosa oblonga con orientación norte-sur, 


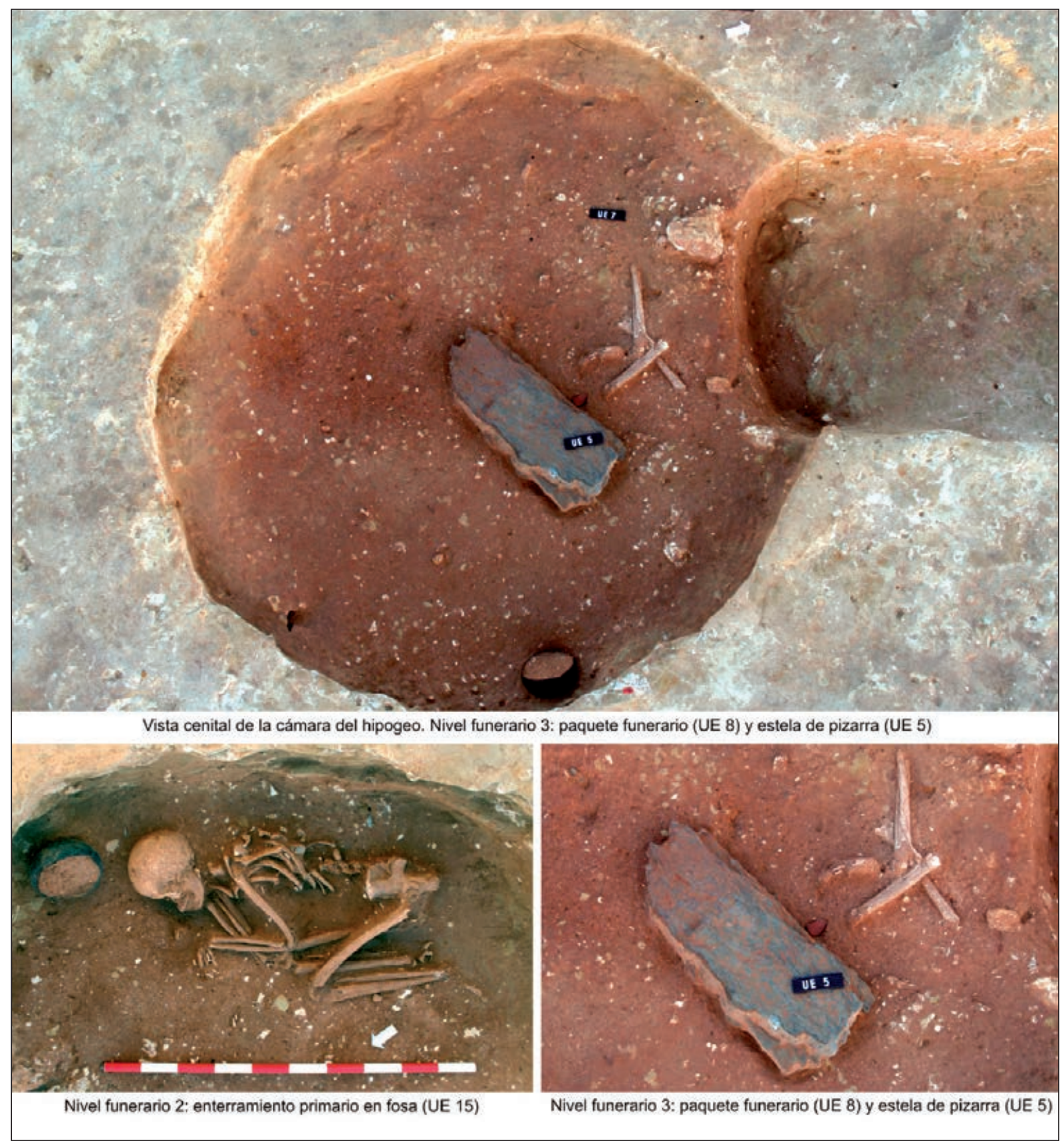

Figura 8. Enterramientos de la tumba 7005: fosa con depósito primario y suelo con paquete funerario y estela asociada.

de $1,25 \mathrm{~m}$ por $1 \mathrm{~m}$ y $0,30 \mathrm{~m}$ de profundidad, destinada a un enterramiento primario de un individuo adulto masculino sin ajuar asociado. El difunto fue colocado en decúbito lateral izquierdo con piernas y brazos flexionados, basculado sobre sí hacia pronación, con la cabeza orientada al sur, con orientación sagital al sur
( $\left.190^{\circ} \mathrm{S}\right)$, habiéndose descompuesto de forma parcial en un medio aerobio. La fosa presentaba una cubrición formada por cantos de cuarcita, bloques de calcarenita y lajas de pizarra, siendo materiales provenientes del atrio del hipogeo y/o del derrumbe del murete de mampostería del nivel estratigráfico inferior. 


\section{ARQUITECTURAS Y PRÁCTICAS FUNERARIAS DE LAS TUMBAS DE LA EDAD DEL BRONCE ANTIGUO}

\subsection{Arquitecturas y técnicas constructivas}

En el conjunto de las necrópolis de La Orden-Seminario se han identificado cuatro formas arquitectónicas del Bronce Antiguo (fig. 9):

- Covachas subterráneas con orientación norte-sur, construidas en el cuadrante noroeste de las cabeceras de las tumbas 7016 y 7055. Cada una de ellas presentaba particularidades constructivas, aunque las dos contaban con cubriciones tumulares formadas por los materiales de derrumbe de las cámaras de las sepulturas colectivas. Otra covacha fue documentada en la agrupación de la meseta suroccidental, la estructura 9240, excavada y modelada en el sustrato con dirección noroeste-sureste, con acceso escalonado y espacio interno ovalado, de $1,50 \mathrm{~m}$ de longitud por $0,65 \mathrm{~m}$ de anchura $\left(1 \mathrm{~m}^{2}\right)$ y hasta 0,75 $\mathrm{m}$ de altura, contando con un murete de cierre de mampostería trabado con arcilla.

- Fosas, de dos tipos: a) fosas sencillas, con orientación noreste-suroeste, sin cubrición tumular, de formas oblonga (tumba 7005) o circular (tumbas 1305 y 1788) y con paredes rectas o curvadas, de 1-1,5 m de longitud, 0,60-0,90 $\mathrm{m}$ de anchura y $0,40-0,65 \mathrm{~m}$ de altura, con un espacio sepulcral de $1 \mathrm{~m}^{2}$, que fueron soterradas tras la deposición de los difuntos en su interior; b) fosas con cubrición tumular o con montículos, de formas y dimensiones análogas, con orientación norte-sur y tapadas por piedras (pizarra, calcarenita y cantos de cuarcita) y tierra, caso de la tumba 1336.

- Depósitos sobre suelos nivelados abiertos con montículos tumulares en la tumba 7005. Los paquetes funerarios fueron depositados en el centro de la cámara, ocupando una superficie de apenas $0,16 \mathrm{~m}^{2}$, siendo soterrados bajo un montículo de tierra y/o piedras de entre $15-25 \mathrm{~cm}$ de espesor, colocándose una estela de pizarra asociada al segundo depósito.

— "Cista" con cubrición tumular, en la tumba 7016. Se trata de una estructura subcuadrangular, construida con mampostería de lajas de pizarra trabadas con mortero de barro que delimitaba un espacio sepulcral de $0,96 \mathrm{~m}^{2}$ y hasta $0,30 \mathrm{~m}$ de altura, con orientación noreste-suroeste. Contenía un depósito funerario secundario que fue soterrado y tapado por un potente nivel de cubrición compuesto por lajas de pizarra, cantos de cuarcita y arcilla, que colmataba la oquedad de la cámara y sobresalía respecto al exterior.

\subsection{Prácticas funerarias y bioantropología}

Las diferentes tumbas estuvieron destinadas a enterramientos individuales de un único episodio, siendo clausuradas o soterradas tras la deposición de los difuntos. La desigual presencia de individuos por sexo y edad en las diferentes arquitecturas, la diversidad de tratamientos y de posicionamiento de los cuerpos (primarios o secundarios) en el interior de las tumbas y las disimetrías en la posesión de objetos funerarios nos lleva a distinguir la realización de cuatro ritos mortuorios (tab. 3).

El ritual mortuorio 1 se corresponde con los enterramientos primarios de individuos masculinos en covachas subterráneas, documentados en las tumbas 7016 y 7055 de la necrópolis sureste así como en la covacha 9240 de la agrupación funeraria de la meseta suroccidental. Los difuntos de estas tumbas fueron colocados en decúbito lateral derecho y en posición flexionada en un medio aerobio, con orientación preferente norte-sur, acompañados generalmente de ajuares de marcada tradición campaniforme, compuestos de uno o dos recipientes cerámicos lisos superpuestos y de armamento metálico (punta de cobre de tipo Palmela, puñal de lengüeta o puñal romboidal). En la covacha de la estructura 7016 se depositó un hombre adulto acompañado de dos recipientes cerámicos (un cuenco y un vaso) colocados tras el costado y la cabeza y de una punta de cobre. En la covacha de la tumba 7055 se inhumó un individuo infantil II, de 6-7 años de edad, tratándose posiblemente de un individuo masculino, al compartir el mismo ritual de enterramiento y ajuares: dos recipientes cerámicos (cuenco de carena media y vaso troncocónico) colocados tras la cabeza y un puñal romboidal de cobre junto al antebrazo y un brazalete de arquero de pizarra al este del antebrazo. En la covacha 9240 se depositó un individuo adulto masculino joven, de entre 20-25 años, envuelto probablemente en sudario o mortaja, siendo colocado en decúbito lateral izquierdo con brazos y piernas hiperflexionados, con posición sagital $340^{\circ} \mathrm{N}$ y cara orientada al este. Su ajuar se componía de dos objetos de raigambre campaniforme: un vaso cerámico troncocónico, colocado verticalmente delante del tórax, y un puñal de lengüeta de cobre cogido por la mano derecha del individuo (Martínez Fernández y Vera Rodríguez 2014: 23-26).

Este ritual funerario se desarrolló a lo largo de las tres últimas centurias del III milenio cal BC. La datación radiocarbónica modelada del individuo de la covacha de la tumba 7016 (CNA-327) ha arrojado una cronometría que sitúa el enterramiento entre las centurias 23 y 22 cal BC, 


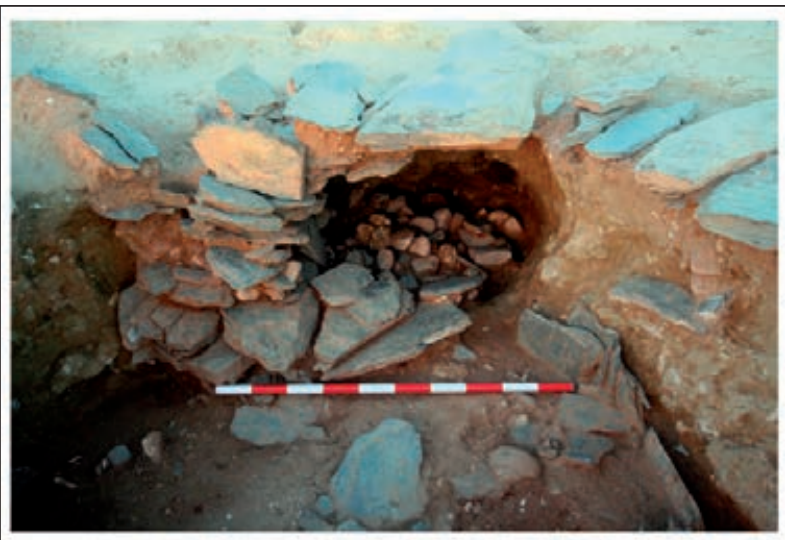

Covacha subterránea integrada en la tumba 7055

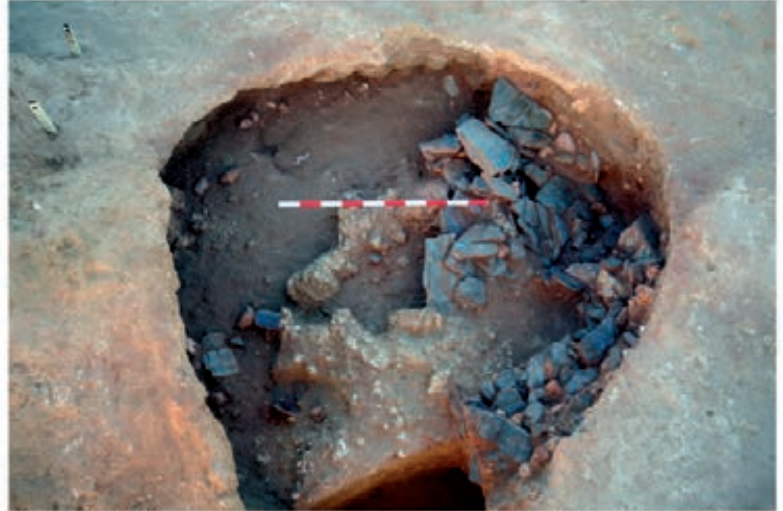

Cubrición de la covacha subterránea de la tumba 7016

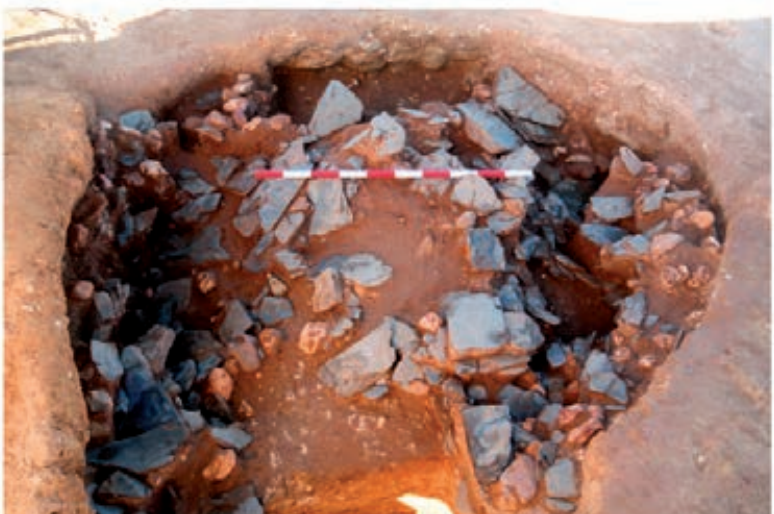

Nivel de soterramiento de la "cista" integrada en la tumba 7016

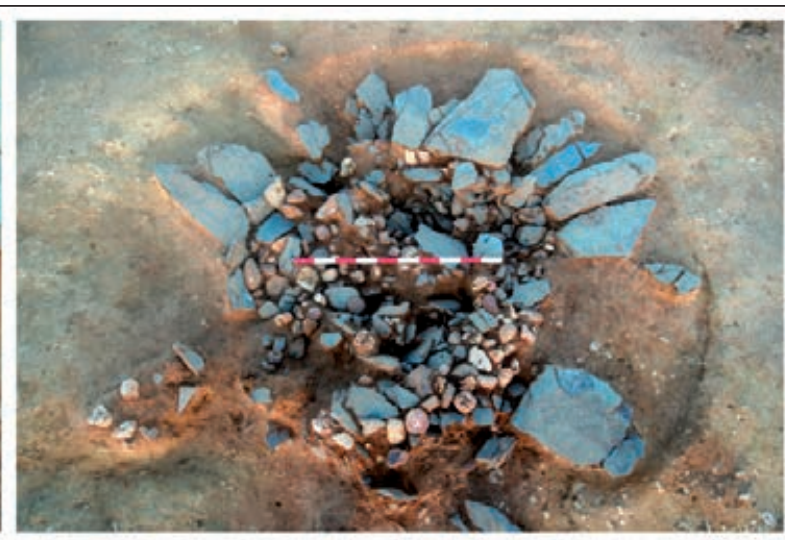

Cubrición tumular de la covacha de la tumba 7055

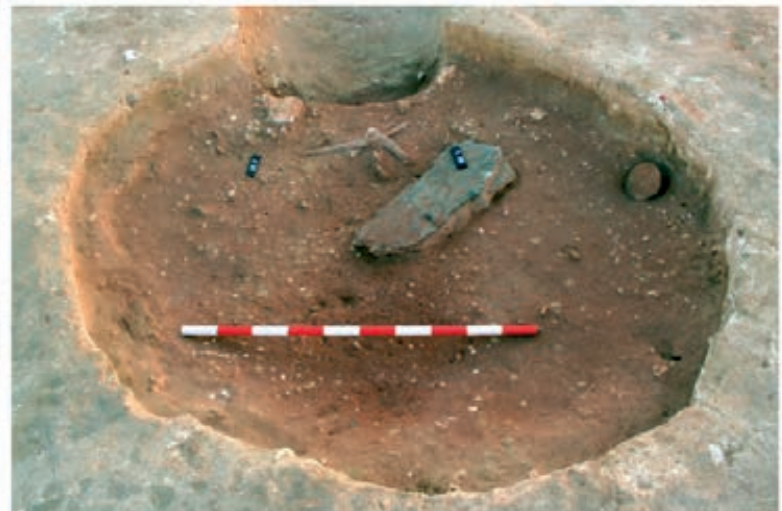

Suelo con paquete funerario y estela de la tumba 7005

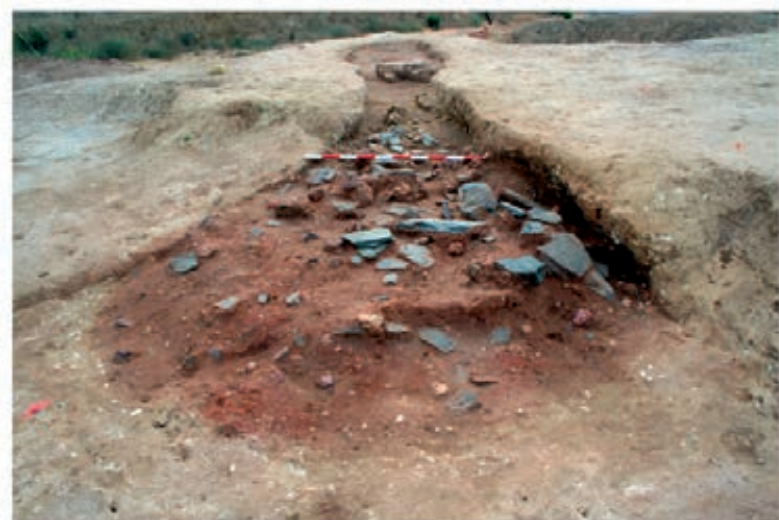

Cubrición tumular de la "cista" de la tumba 7016

Figura 9. Formas arquitectónicas y elementos de cubrición de las tumbas de La Orden-Seminario.

c $2260-2130$ cal BC ( $68 \%$ de probabilidad) o c $300-2040$ cal BC (95\% de probabilidad). La datación modelada del individuo de la covacha 7055 (CNA-330) ha proporcionado una cronología algo posterior, debiendo haberse realizado el entierro un siglo más tarde, entre las centurias 22-21 cal BC, c 2150-2030 cal BC 68\% de probabilidad) o c 2210-1980 cal BC (95\% de probabilidad) (tab. 2).
El ritual mortuorio 2 se atribuye a las inhumaciones primarias de mujeres u hombres adultos con ajuar cerámico reducido o inexistente, depositados en el interior de fosas con o sin montículos de cubrición, como testimonian las tumbas 7005 y 1336. En la sepultura 7005 se documentó una fosa en la que se depositó una mujer adulta de 20-25 años de edad envuelta en un sudario o mortaja, 
siendo colocada en decúbito lateral derecho con brazos y piernas hiperflexionados con cara orientada al noroeste, acompañándose de un cuenco semiesférico liso dispuesto junto a la cabeza y recostado de manera oblicua contra la pared de la fosa. La fosa de la tumba 1336 contenía en su interior un individuo adulto masculino dispuesto en decúbito lateral izquierdo con piernas y brazos flexionados, basculado sobre sí hacia pronación, con la cabeza orientada al sur, sin ajuar asociado.

El ritual mortuorio 3 es representado por la realización de paquetes funerarios de huesos largos de las extremidades inferiores y superiores junto a escasos ajuares muebles, depositados en suelos abiertos nivelados de las cámaras y posteriormente cubiertos por montículos tumulares. En la tumba 7005 se han distinguido dos tipos de depósitos secundarios: a) paquete óseo de mujer adulta, con lezna/punzón de cobre y un fragmento de piedra pulida; b) paquete óseo colectivo de dos individuos adultos (uno masculino y otro femenino), acompañados de fragmentos cerámicos y de productos tallados de sílex (lámina y útiles), soterrados bajo tumulación y con estela de pizarra indicadora.

El ritual mortuorio 4 se concretó en el depósito secundario efectuado en la estructura cuadrangular de mampostería de pizarra soterrada y con posterior cubrición tumular de la tumba 7016. Este depósito se compuso de diversos restos óseos de un individuo masculino adulto y de fragmentos cerámicos dispersos de dos cuencos y tres puntas de flecha de sílex. Según el modelado bayesiano de la datación efectuada (CNA622 ), este ritual mortuorio se desarrolló en una cronología concreta de transición entre el III y II milenios cal BC, c 2140-1930 cal BC (68\% de probabilidad) o c 2200-1870 cal BC (95\% de probabilidad) (tab. 2), una centuria más tarde que los enterramientos en covacha.

El estudio de esos depósitos funerarios y el análisis de las prácticas mortuorias revelan marcadas diferencias respecto al género y edad de los individuos inhumados. El número total de enterrados es reducido, sumando entre las cuatro estructuras la cantidad de ocho individuos. Destaca una mayor predominancia de hombres adultos (cuatro) sobre las mujeres adultas (tres), constatándose solo un infantil de 6-7 años de edad en la covacha de la tumba 7055 (tab. 3).

Todos los difuntos masculinos se inhumaron en una posición común, siendo colocados de forma articulada en decúbito lateral izquierdo con las extremidades flexionadas y/o hiperflexionadas. Las diferencias entre los hombres se presentaban en el contenedor funerario empleado y fundamentalmente en el tipo y grado de acumulación de ajuares muebles. Los hombres enterrados en las covachas subterráneas (7016 y 9240) poseían ajuares de tradición campaniforme, compuestos por uno o dos recipientes cerámicos lisos y una pieza de armamento de cobre (punta de lanza o puñal de lengüeta). Por el contrario, el sujeto inhumado en la fosa de la tumba 1336 no contenía objeto mueble alguno. El individuo infantil II, de 6-7 años, de la covacha 7055 pudo ser de género masculino, dado que presentaba una pieza de armamento metálico en su ajuar, siendo elementos vinculados exclusivamente a los miembros de este sexo enterrados en estas arquitecturas.

Las mujeres evidencian otras prácticas funerarias. La mujer adulta joven enterrada en la fosa de la tumba 7005 fue inhumada con mortaja en una posición contraria, siendo colocada en decúbito lateral derecho con extremidades hiperflexionadas, acompañándose de un cuenco cerámico. El resto de las mujeres formaron parte de paquetes funerarios depositados en suelos bajo tumulaciones en la tumba 7005, caso del paquete individual del nivel inferior, que contenía huesos largos de una mujer adulta y una lezna/punzón de cobre y una piedra pulida o del paquete colectivo del nivel superior, compuesto por restos de dos individuos adultos (mujer y hombre) y varios objetos muebles fragmentados (una lámina tallada, útiles líticos tallados y cerámicas), al que se asoció la estela de pizarra.

\section{DISCUSIÓN}

\subsection{Ruptura con el megalitismo o permanencia de la monumentalidad funeraria en la Edad del Bronce}

Las sociedades de la Edad del Bronce evidencian un profundo cambio respecto a la monumentalidad funeraria de las comunidades de la Edad del Cobre, como consecuencia de las transformaciones de las organizaciones sociales, surgiendo sociedades desigualitarias con unos modelos políticos centralizados (estados) y con marcadas diferencias entre los individuos (clases) en el sur peninsular c 2200-1500 cal BC, tanto en la Cultura de El Argar en el sureste (Lull et al. 2011) como en las comunidades del Bronce del suroeste peninsular (García Sanjuán 2006: 160). Estas transformaciones se iniciaron c 2400-2200 cal BC, experimentándose una crisis generalizada de las sociedades calcolíticas, como atestiguan los procesos de abandono de los poblados y los cambios en los patrones de ocupación (Lull et al. 2010: 90), las rupturas de las secuencias estratigráficas y las discontinuidades diacrónicas de los 


\begin{tabular}{|c|c|c|c|c|c|c|c|c|}
\hline$\stackrel{\frac{\pi}{4}}{3}$ & 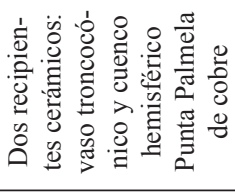 & 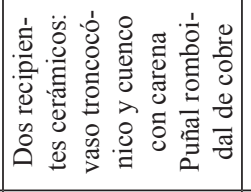 & 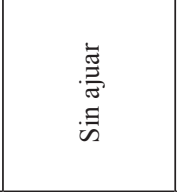 & 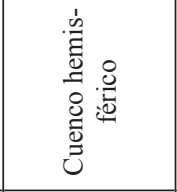 & 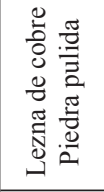 & 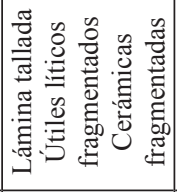 & 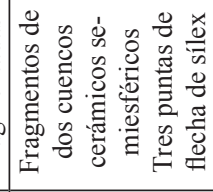 & 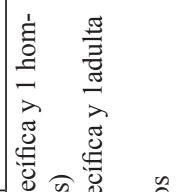 \\
\hline 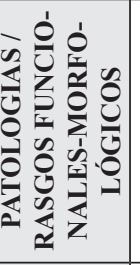 & 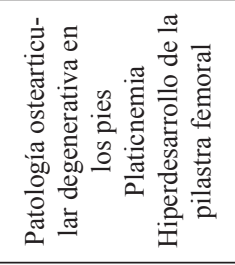 & 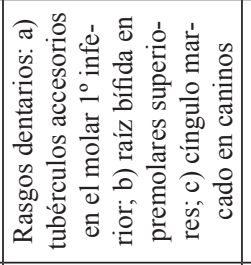 & 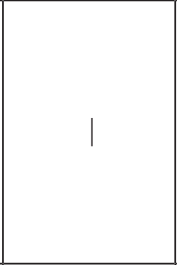 & 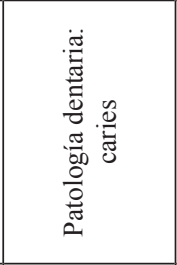 & | & | & 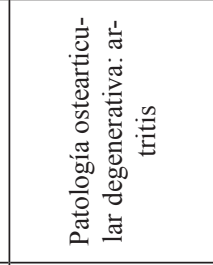 & 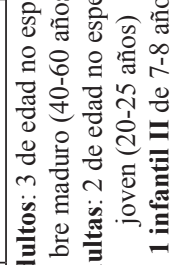 \\
\hline 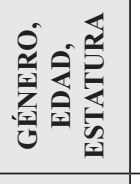 & 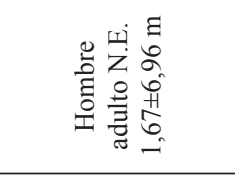 & 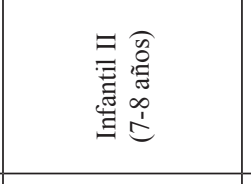 & 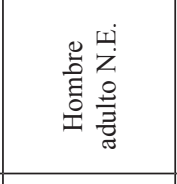 & 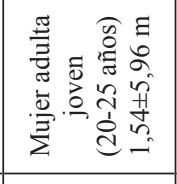 & 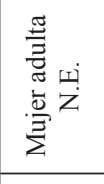 & 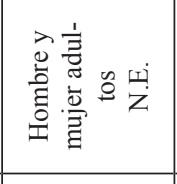 & 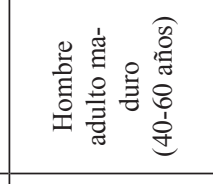 & 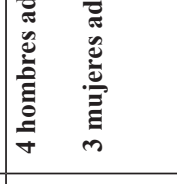 \\
\hline 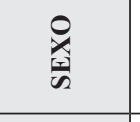 & | & 1 & I & | & 1 & | & 1 & $\infty$ \\
\hline $\begin{array}{l}n \\
0 \\
0 \\
0 \\
0 \\
0\end{array}$ & 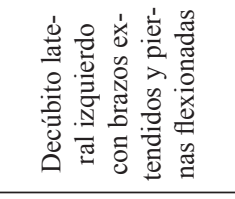 & 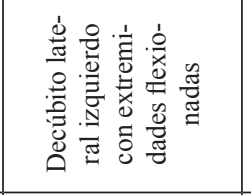 & 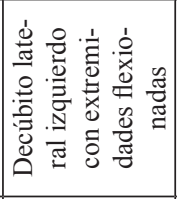 & 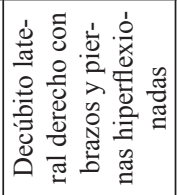 & 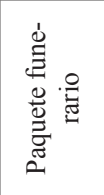 & 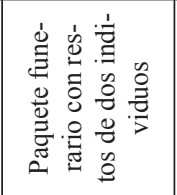 & & \multirow{7}{*}{ 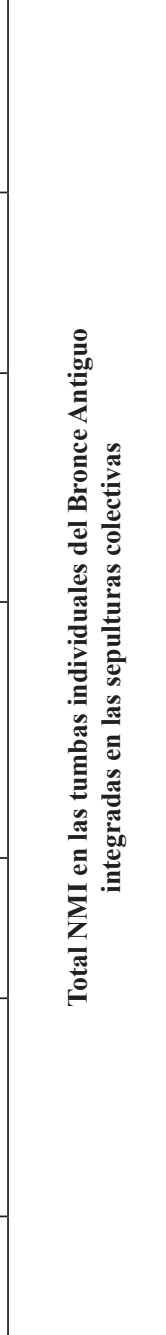 } \\
\hline 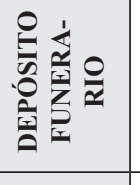 & 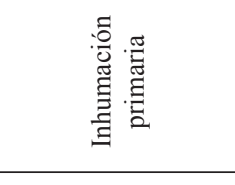 & 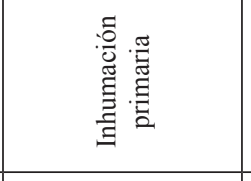 & 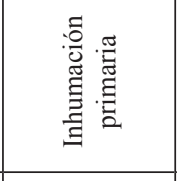 & 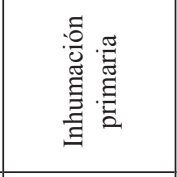 & 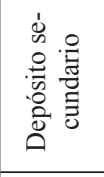 & 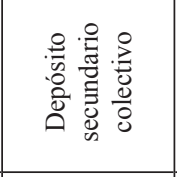 & 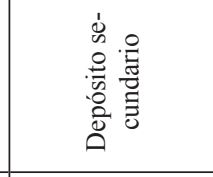 & \\
\hline 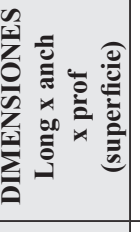 & 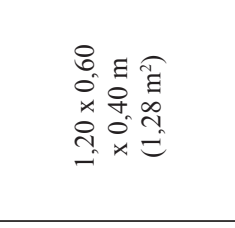 & 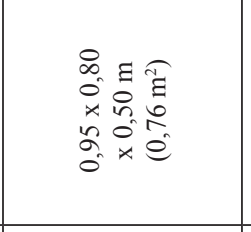 & 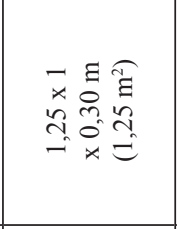 & 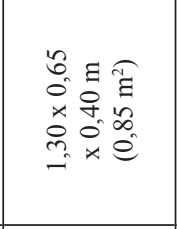 & 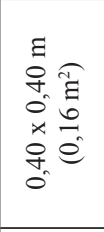 & $\begin{array}{l}\Xi \\
0 \\
0 \\
0 \\
0 \\
x \\
n \\
n \\
n \\
0\end{array}$ & 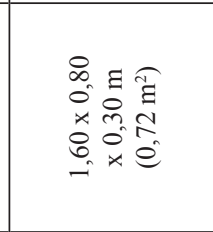 & \\
\hline 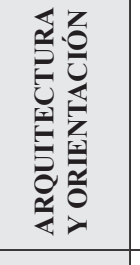 & 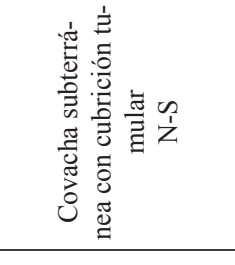 & 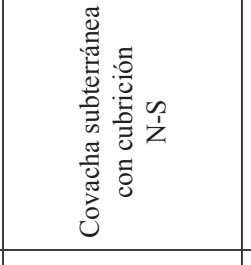 & 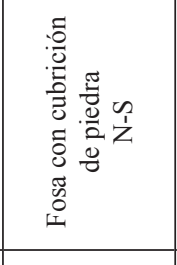 & 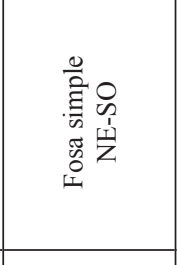 & 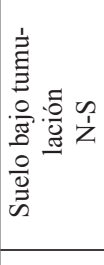 & 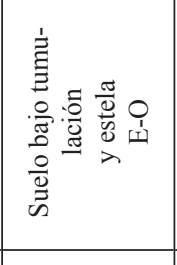 & 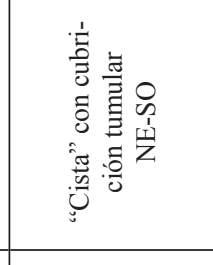 & \\
\hline : & 屬 & $\overline{\underline{\underline{M}}}$ & $\frac{N}{\sqrt[3]{2}}$ & $\frac{\sqrt{\pi}}{\sqrt[3]{2}}$ & $\stackrel{m}{\frac{m}{2}}$ & 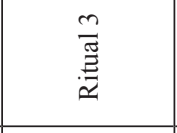 & 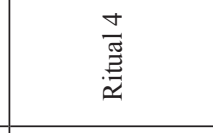 & \\
\hline 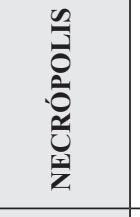 & 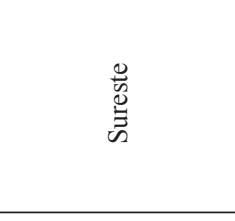 & $\begin{array}{l}\text { 荝 } \\
\stackrel{5}{5}\end{array}$ & 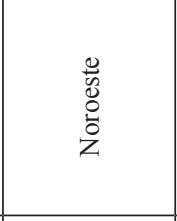 & 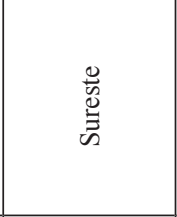 & $\begin{array}{l}\text { 苋 } \\
\stackrel{5}{=} \\
\bar{n}\end{array}$ & $\begin{array}{l}\text { 苋 } \\
\stackrel{5}{5} \\
\bar{n}\end{array}$ & $\begin{array}{l}\text { 苋 } \\
\stackrel{5}{5} \\
\bar{n}\end{array}$ & \\
\hline 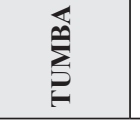 & $\stackrel{0}{\stackrel{0}{0}}$ & $\stackrel{0}{\stackrel{8}{8}}$ & 芯 & $\stackrel{10}{5}$ & 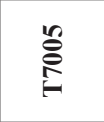 & 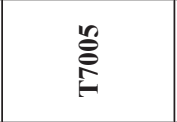 & $\stackrel{0}{\stackrel{0}{0}}$ & \\
\hline
\end{tabular}


poblados (Balsera et al. 2015: 149) y el colapso cultural c 2200 cal BC producido por el drástico cambio climático del evento $4.2 \mathrm{ka} \mathrm{BP}$, significando un repunte de la aridez y una transformación paisajística del sur de la península ibérica (Blanco-González et al. 2018).

Los cambios en la esfera de la muerte se tradujeron en un progresivo proceso de individualización de los enterramientos, constatándose una sustitución progresiva de las sepulturas colectivas por tumbas individuales destinadas a la deposición de un difunto acompañado de un ajuar acorde al grupo o clase social. Al respecto, algunos autores han destacado la desmonumentalización de las arquitecturas funerarias a partir del 2200-2100 cal BC, asistiéndose a una reducción del tamaño de las estructuras y a un descenso en el uso de las tumbas megalíticas (Díaz-Zorita et al. 2012: 61, García Sanjuán 2006: 160161, García Sanjuán et al. 2011: 153).

Esta nueva concepción de la muerte se desarrolló en el suroeste peninsular c 2200-1500 cal BC (García Sanjuán 2006: 160-162, García Sanjuán y Odriozola 2012, García Sanjuán et al. 2011: 149-153), siendo acorde a una cosmovisión social en la que se posicionó al individuo por encima del colectivo. Las necrópolis con tumbas individuales emergieron c 2200-2000 cal BC, constatándose cuatro tipos de contenedores: fosas, cistas, covachas y urnas. Las cronologías más antiguas se sitúan en el último cuarto del III milenio cal BC, como evidencian las dataciones obtenidas de las necrópolis de los grupos SE-K/SE-B y de Jardín de Alá (Salteras, Sevilla), con una diacronía c 2260-1680 cal BC (Hunt 2012, Hunt et al. 2009: 232), situándose la actividad funeraria de las fosas (tumba 12B y tumba 4B) y cistas (tumba 2B) en las centurias 22 y 21 cal BC. Las dataciones de varias tumbas en el casco urbano de Carmona (Sevilla) revelan igualmente que los enterramientos más antiguos se remontan a las dos últimas centurias del III milenio BC, caso de la fosa 2 de la Plaza de Santiago 6-7, con una fecha de 3755 \pm 30 BP: $2290-2040$ cal BC $2 \sigma$ (Belén et al. 2015: 173), generalizándose las covachas y las fosas durante la primera fase de la Edad del Bronce, c 2200/21001600-1500 cal BC (Belén et al. 2000, 2015).

Los monumentos megalíticos sufrieron un proceso de transformación en su consideración y uso como contenedores funerarios durante la Edad del Bronce, pudiendo establecerse tres pautas comunes: el descenso en la actividad, el reúso de las tumbas para enterramientos individuales y colectivos y la permanencia del megalitismo como fenómeno cultural de larga perduración temporal.

El declive del uso y la reducción de la actividad funeraria en los megalitos (dólmenes, tholoi e hipogeos) se inició a partir del 2200-2100 cal BC, decreciendo de forma progresiva hasta el 1600-1500 cal BC (García Sanjuán et al. 2011: 153). No obstante, en el caso de los tholoi se constata un periodo de intensa reutilización funeraria hasta c 1550 cal $\mathrm{BC}$, asistiéndose a una etapa de gran intensidad de uso ritual (Lozano Medina y Aranda Jiménez 2017: 27-28).

En numerosos monumentos megalíticos funerarios se ha puesto de manifiesto la reutilización del espacio sepulcral para la realización de enterramientos y de ofrendas en diversas etapas de la Edad del Bronce (fig.10). En este sentido, se ha destacado el reúso funerario y la reelaboración de las prácticas mortuorias tras el hiatus de mediados del II milenio ANE (c 1550 cal BC), como consecuencia de la crisis de las sociedades de la Edad del Bronce del suroeste (García Sanjuán y Odriozola 2012: 383) y del sureste (Aranda Jiménez 2015, Lozano Medina y Aranda Jiménez 2017: 28). Para algunos autores, el Bronce Tardío fue la fase de reúso más intensa, a tenor de la mayor concentración de las dataciones de los contextos funerarios c 1600/1500-1300 cal BC (García Sanjuán et al. 2011: 151, 153). Para otros, por el contrario, se constata durante el Bronce Tardío y Final una reutilización atenuada de los tholoi que concluyó en los siglos IX-VIII BC, coincidiendo con el inicio de las transformaciones sociales y culturales de la Edad del Hierro (Lozano Medina y Aranda Jiménez 2017: 27-28).

En el sureste peninsular se ha puesto de manifiesto que la reutilización de las sepulturas megalíticas durante el Bronce Final fue una práctica habitual, generalizada y extensiva (Lorrio 2008: 360, 2017: 275, 286, Lorrio y Montero 2004: 102, 113), constatándose una treintena de enterramientos de los siglos X-IX BC en los dólmenes, tholoi y cámaras simples, predominando la deposición de inhumaciones colectivas acompañados de ajuares compuestos por objetos de adorno (brazaletes, anillos, cuentas de collar, y botones de bronce y cuentas de caliza y cornalina) y vasos cerámicos (Lorrio 2017: 278, Lorrio y Montero 2004: 104). Esta práctica perduró hasta los siglos VIII-VII BC, como testimonia la presencia de fíbulas de doble resorte en el grupo de tumbas del Llano de la Sabina 99 de la necrópolis de Gorafe (Lorrio y Montero 2004: 105). El frecuente reúso de las tumbas megalíticas funeraria implicó la consecución de diversas prácticas (Lorrio 2008: 360-368, fig. 198): a) reutilización de los niveles superiores de colmatación de las cámaras, con leves modificaciones estructurales y sin alterar los suelos funerarios precedentes, caso del sepulcro de Domingo 1 de la necrópolis de Fonelas, en el que 


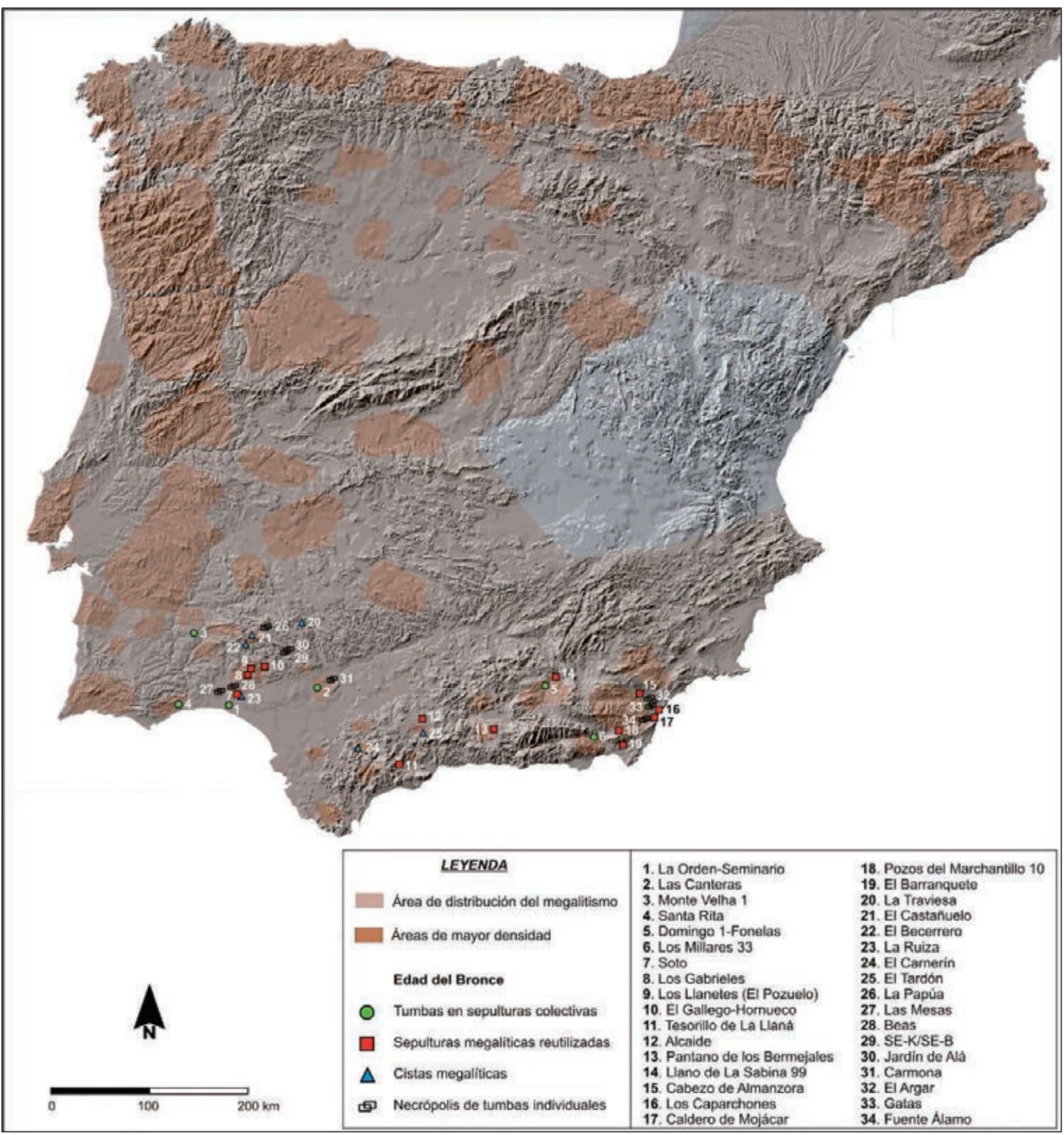

Figura 10. Tumbas y monumentos megalíticos reutilizados en la Edad del Bronce en el sur de la península ibérica. Sitios citados en el trabajo.

se presentaba un depósito colectivo formado por cuatro inhumaciones (Ferrer Palma 1977: 177, 198; Ferrer Palma et al. 1988: 82); b) la limpieza parcial de la cámara, caso de Los Caporchanes o Caldero de Mojácar; c) el vaciado total de la cámara, caso de los Pozos del Marchantillo 10 o Cabezo de Almanzora; d) la construcción de tumbas monumentales de nueva planta "inspiradas" en las sepulturas megalíticas, caso de Los Millares 33. Estas prácticas de reutilización testimonian el valor simbólico de las antiguas sepulturas megalíticas, la vinculación con el pasado y la existencia de una forma de culto a los ancestros que legitimaban la posición social de parte de los individuos de las comunidades en el Bronce Final (Lorrio 2017: 286). 
La pervivencia de la actividad funeraria en las arquitecturas megalíticas durante la Edad del Bronce, c 2200-850 cal BC, ha llevado a plantear la permanencia del megalitismo como fenómeno cultural (García Sanjuán 2005, García Sanjuán et al. 2011: 149), sustentada en la construcción de tumbas con patrones megalíticos y en la continuidad de gestos mortuorios análogos a los depósitos funerarios colectivos. Esta etapa de tradición megalítica tardía (García Sanjuán 2005, 2006: 161) o de permanencia de la ideología megalítica (Costela Muñoz 2017: 53) se ha caracterizado por la construcción de estructuras funerarias que reproducen los diseños arquitectónicos y las formas de las sepulturas megalíticas, la reutilización funeraria de los espacios internos y la adopción de prácticas mortuorias que imitaban las conductas pretéritas, cuya mayor intensidad se evidencia a partir del 1600-1500 cal BC (García Sanjuán y Odriozola 2012: 376, García Sanjuán et al. 2011: 149-153).

Este proceso de emulación de las arquitecturas megalíticas se plasmó en diversos elementos:

- La continuidad en la construcción de arquitecturas megalíticas, en especial de las pequeñas cámaras dolménicas, caso del dolmen de Cortijo de El Tardón (Antequera, Málaga) erigido en el Bronce Antiguo (Fernández Ruiz 2004: 287-288), o del dolmen de El Carnerín (Alcalá del Valle, Cádiz), provisto de un ajuar funerario de la Edad del Bronce (Martínez Rodríguez y Perera 1991: 69-70).

- La construcción de cistas megalíticas (estructuras tumulares con formas, tamaños y técnicas constructivas inspiradas en patrones megalíticos) de manera conjunta en las mismas necrópolis con las cistas de la Edad del Bronce, caso de la tumba 5 de La Traviesa (Almadén de la Plata, Sevilla), fe-

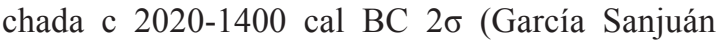
1998: 166-167), o de varias necrópolis en la provincia de Huelva: El Becerrero, El Castañuelo y La Ruiza (Amo 1975).

- La reutilización funeraria y la consecución de enterramientos colectivos a mediados del II milenio cal $\mathrm{BC}$ en dólmenes, hipogeos y sepulcros de falsa cúpula que evidencian prácticas funerarias conectadas con la tradición megalítica, como se ha documentado en el dolmen de Tesorillo de la Llaná (Alozaina, Málaga) durante el Bronce Tardío, c 1610-1450 cal BC $2 \sigma$ (Márquez Romero et al. 2009) y en el hipogeo 14 de la necrópolis de Alcaide (Antequera, Málaga), cuya actividad funeraria se desarrolló en una cronología c 1999/1720-1221/946 cal BC $1 \sigma$ (Tovar et al. 2014: 140).
Para algunos autores, esta permanencia conllevó la continuidad de una memoria cultural y una pervivencia de la ideología funeraria del megalitismo. La consecución de prácticas sociales de imitación y emulación de determinados patrones de tradición megalítica y el desarrollo de cultos a los ancestros realizados en torno a estas arquitecturas milenarias sagradas sirvieron de mecanismos de exhibición del poder de los líderes o elites sociales (jefes y/o guerreros), propiciando la vinculación genealógica con los antepasados y la legitimación de su posición social (García Sanjuán 2005, García Sanjuán 2006: 161).

Para otros autores, la continuidad del uso funerario de sepulturas megalíticas durante la Edad del Bronce, c 2200-1550 cal BC, cabe entenderla como una forma de resistencia a las dinámicas sociales y económicas del Estado Argárico, constatándose enterramientos colectivos con ajuares argáricos (vasos y copas cerámicas, puñales con remaches, punzones, brazaletes, cuentas, anillos y pendientes) en varios sitios, caso del dolmen del Pantano de los Bermejales (Arenas del Rey, Granada) (Aranda Jiménez 2015: 133) o en la necrópolis de tholoi de El Barranquete (Níjar, Almería) (Aranda Jiménez y Lozano Medina 2014, Aranda Jiménez et al. 2017). Estas prácticas funerarias estaban sujetas a dos pautas: la exclusión de los símbolos del poder de la sociedad argárica, siendo minoritarios los materiales que denotaban un alto grado de individualización (alabardas y diademas), y la vinculación con el pasado ancestral, representando a grupos sociales con formas comunitarias de fuerte identidad cultural y de una sólida memoria colectiva (Aranda Jiménez 2015: 136).

En el área de Huelva, se han identificado otras pautas de reapropiación y reutilización de los megalitos durante la Edad del Bronce que amplían la discusión:

1) La ejecución de remodelaciones arquitectónicas de los monumentos funerarios. En el caso del dolmen 1 de Los Gabrieles (Valverde del Camino) se ha constatado la transformación de la galería ortostática preexistente, desmontándose parte de los soportes de las paredes a efectos de construir una estructura cuadrangular de 2,10 m de lado en el área de cabecera, a modo de cista megalítica (Linares Catela 2010: 222, 2011: 143). En su interior se documentó un ajuar mueble compuesto por once recipientes cerámicos característicos del Bronce Antiguo (Cabrero 1978: 84-86), que corrobora la cronología de fines del III milenio y/o inicios del II milenio BC.

2) La destrucción deliberada y la condenación de los monumentos, como se ha atestiguado en varios dólmenes del conjunto de El Gallego-Hornueco 
(Berrocal-El Madroño). En el dolmen de Puerto de los Huertos se produjo el desmantelamiento integral de la galería ortostática (apertura de zanja de expolio, extracción de las losas de cubierta, rotura y extracción de los soportes de las paredes y relleno del interior), el desmonte del túmulo y la ocultación del monumento (Linares Catela 2010, 2011: 154-155). La datación de una muestra de carbón vegetal del relleno de la zanja de expolio proporcionó una fecha de $3680 \pm 50$ BP: $2210-1930$ cal BC $2 \sigma$, situando la destrucción y condenación del monumento entre fines del III milenio e inicios del II milenio cal BC (Linares Catela y García Sanjuán 2010: 140, 142).

3) La aparición de otras formas de monumentalidad arquitectónica, caso de los recintos de terrazas con plataformas circulares en el grupo de Los Llanetes, conjunto de El Pozuelo (Zalamea la Real), siendo una intencional estrategia de reapropiación de los espacios ancestrales con nuevos usos y significados sociales desarrollada en el Bronce Antiguo (Linares Catela 2017). Estos monumentos fueron construidos en los emplazamientos y con los materiales de los viejos dólmenes, estando compuestos por diversas estructuras (muros y rampas, además de una plataforma circular en el monumento 1) dispuestas en niveles escalonados y erigidas mediante varias técnicas de mampostería (ortostática, en seco y con morteros de barro), integrándose los esqueletos megalíticos y los túmulos desmantelados (Linares Catela 2016, 2018: 530).

- La permanencia del uso de los grandes monumentos funerarios hasta el Bronce Final, caso del dolmen de Soto (Trigueros), en el que se ha documentado una estructura de combustión y condenación ritual en el atrio y el grabado de puñales y espadas en los soportes pétreos de la galería megalítica, que testimonian la continuidad del sitio como centro ceremonial c 1230-940 cal BC (Linares Catela y Mora Molina 2018: 110-111, 130).

\subsection{El monumentalismo funerario de La Orden-Seminario}

La investigación de las necrópolis de La Orden-El Seminario ha permitido caracterizar e interpretar la existencia de un monumentalismo funerario específico desarrollado c 2300-1900 cal BC, sustentado en la integración de tumbas individuales en las cámaras de las sepulturas calcolíticas. La reutilización y la continuidad del uso funerario de las dos necrópolis implicaron la reapropiación física de estos espacios, perpetuándose esquemas arquitectónicos, técnicas constructivas y algunos gestos funerarios característicos de los rituales mortuorios colectivos del megalitismo.

El estudio de las necrópolis posibilita plantear la existencia de otras formas de monumentalidad y de permanencia del megalitismo en la Edad del Bronce, coexistiendo elementos y conceptos característicos de las sepulturas colectivas con los nuevos esquemas funerarios de las sociedades desigualitarias. Ello permite introducir otras líneas de discusión (tradición versus ruptura y reformulación versus innovación) y plantear interpretaciones alternativas sobre la secuencia del fenómeno megalítico en el sur peninsular.

Este monumentalismo funerario se sustenta en una serie de elementos: a) la perdurabilidad de las antiguas necrópolis como espacios funerarios, siendo ámbitos usados y reservados de forma exclusiva al dominio de los muertos; b) una variabilidad de tumbas individuales, conteniendo en su mayoría dispositivos que favorecieron la monumentalidad arquitectónica, la delimitación espacial y la alta perceptibilidad visual; c) la diversidad de prácticas funerarias y de ritos mortuorios que podrían representar a los diferentes estatus sociales.

Las tumbas se organizaron en agrupaciones, documentándose tres pautas de emplazamiento: a) tumbas construidas en el interior de las sepulturas colectivas de las necrópolis noroeste y sureste; b) fosas dispuestas en el entorno próximo de la necrópolis noroeste; c) tumbas ubicadas en otras zonas del poblado, conformando nuevos espacios mortuorios, caso de la agrupación de la meseta suroccidental y la necrópolis suroeste.

En las tumbas ubicadas en el interior de las sepulturas calcolíticas y en las áreas circundantes a la necrópolis noroeste se observa una perpetuación de los esquemas de organización dual de los espacios mortuorios de la Edad del Cobre. En cada sector se presentaban tres tumbas con distintas formas arquitectónicas y técnicas constructivas. En la necrópolis noroeste se dispusieron tres fosas, una en la cámara del hipogeo 1336 y dos fosas (1305 y 1788) en el entorno. En la necrópolis sureste se implantaron cuatro modelos de tumbas individuales: a) covachas subterráneas (tumba 7016 y tumba 7055); b) fosa sin tumulación (tumba 7005); c) suelos preparados para la deposición de paquetes funerarios (tumba 7005) soterrados bajo tumulación y con estela asociada; d) "cista" con cubrición tumular (tumba 7016).

La variabilidad formal de las tumbas representa la existencia de técnicas constructivas diferenciadas en las arquitecturas funerarias de la Edad del Bronce Antiguo. Sin embargo, todas las tumbas presentaban 
parámetros, elementos arquitectónicos e intencionalidades comunes:

- Eran estructuras funerarias subterráneas excavadas en el interior de las cámaras de las sepulturas colectivas y construidas con materiales reutilizados.

- Contaban con espacios sepulcrales reducidos, entre 1-1,5 $\mathrm{m}^{2}$ de superficie máxima, con una orientación dominante norte-sur. Estaban destinadas a la deposición de un único individuo, conformando estructuras ocultas e inaccesibles, quedando sus espacios definitivamente sellados por los dispositivos de cierre, montículos de tierra o cubriciones tumulares.

- Presentaban elementos de cubrición (covachas de las tumbas 7016 y 7055; fosa de la tumba 1336; depósitos con montículos en la tumba 7005) e hitos de señalización (estela de la tumba 7005) externos que posibilitaron la preservación, la señalización espacial y la perceptibilidad visual de las estructuras funerarias. Las cubriciones tumulares debían cumplir una cuádruple función arquitectónica: a) estructural, garantizando la protección respecto a las condiciones externas y su ocultación; b) espacial, propiciando la delimitación física de cada tumba como espacio funerario; c) visual, incrementado su grado de perceptibilidad en el espacio circundante; d) simbólica, marcando un espacio funerario sagrado, que se reforzó por la reutilización de materiales de las arquitecturas de los ancestros, conteniendo probablemente determinados valores singulares y propiedades visuales significativas, caso de los cantos de cuarcita blanquecinos que contrastaban con las lajas de pizarra azul y la arcilla rojiza.

Las prácticas funerarias desarrolladas en las tumbas individuales fueron acordes a los nuevos esquemas de la esfera de la muerte de la Edad del Bronce. En los cuatro ritos mortuorios identificados se observan marcadas diferencias en cuanto al género de los individuos enterrados, que pueden expresar los diversos estatus y las desigualdades sociales, siendo un patrón común en las sociedades de la Edad del Bronce Antiguo de Europa (Mittnik et al. 2019).

El ritual funerario 1 se correspondía con hombres adultos enterrados en covachas subterráneas, colocados en decúbito lateral izquierdo con extremidades hiperflexionadas, acompañados de piezas de armamento metálico de cobre (puñal y/o punta de lanza) y uno o dos objetos cerámicos lisos de marcada tradición campaniforme, caso de los individuos de las tumbas 7016 y 9240. Este patrón es común en varias necrópolis de Andalucía occidental de similar cronología, caso de las agrupaciones de cistas y fosas de SE-K/SE-B y Jardín de Alá, (Hunt 2012, Hunt et al. 2009: 232) o de las necrópolis de covachas y fosas del casco urbano de Carmona (Belén et al. 2000, 2015: 173). Los individuos de La Orden-Seminario pudieron contar con un prestigio social relevante, dada su vinculación con los ancestros y la acumulación de objetos metálicos en el mundo de los muertos. No obstante, estos varones no estuvieron exentos de la realización de actividades que implicaron esfuerzos físicos en la vida cotidiana, como denotan las patologías identificadas. El hombre adulto de la covacha 7016 presentaba una patología osteoarticular leve en los pies y diversas patologías, una derivada de hábitos posturales (platicnemia), generadas por actividades continuadas de esfuerzo y tareas repetitivas, y otra por una alteración idiopática de la circulación (hiperdesarrollo de la pilastra femoral) que debió provocarle dolores de cadera y restarle movilidad. El hombre joven de la covacha 9240, de 20-25 años, presentaba igualmente dos rasgos derivados de hábitos funcionales o posturales: lateralidad derecha y posible platimeria y platicnemia (Martínez Fernández y Vera Rodríguez 2014: 23-26), testimoniando igualmente la realización de tareas que implicaron un esfuerzo físico continuado de gran intensidad.

En este grupo puede incluirse el infantil de 6-7 años enterrado en la covacha subterránea integrada en el tholos 7055. A pesar de la corta edad de este individuo (probablemente un niño) debía tener un estatus social elevado adquirido desde su nacimiento, dada la acumulación de diversos objetos funerarios indicadores de su posición y prestigio social (puñal romboidal de cobre, brazalete de arquero de pizarra y dos vasos cerámicos) y la presencia de un cuenco cerámico ofrendado en el forro de clausura de forma previa al ocultamiento definitivo por la cubrición tumular. Este patrón es recurrente en otras áreas de la península ibérica, constatándose desde la fase Campaniforme la presencia de ricos ajuares personales vinculados a determinados individuos infantiles con un elevado estatus social desde el nacimiento (Herrero-Corral et al. 2019).

Posiblemente la elevada posición social del individuo infantil inhumado en la covacha se deba a la posible vinculación genealógica con los antepasados enterrados en el tholos 7055. Este individuo presenta rasgos morfológicos dentarios análogos a los niños inhumados en centurias anteriores en los diversos suelos colectivos. Estos rasgos epigenéticos son diversos: a) tubérculos accesorios en el molar $1^{\circ}$ inferior; b) raíz bífida en premolares superiores, como se evidenció en un premolar de un individuo infantil del suelo funerario 2 depositado 
en la cámara; c) cíngulo marcado en caninos, como se documentó en el individuo 3 (infantil de 7-8 años) del suelo funerario 1 , teniendo también un incisivo lateral superior izquierdo con cíngulo marcado en la cara palatina. Por tanto, es plausible que los rasgos dentarios de estos niños inhumados en esta sepultura pudieran obedecer a una relación genético-hereditaria mantenida durante varias centurias. En este sentido, es revelador el hecho de que en el tholos del NMI, de quince identificados en los tres suelos funerarios colectivos, un total de nueve $(60 \%)$ se corresponden con infantiles.

Las piezas de armamento de cobre solo parecen asociarse a individuos masculinos inhumados conforme al ritual funerario 1, ya fuesen hombres adultos o el niño, enterrados en covachas entre las centurias 23 y 22 cal BC. Estos individuos pudieron pertenecer a grupos familiares dominantes, tratándose probablemente de líderes sociales o de miembros de "clases sociales" privilegiadas.

El ritual funerario 2 englobaba los enterramientos de hombres y mujeres adultos inhumados en fosas con o sin tumulación, poseyendo un ajuar limitado o inexistente. La mujer joven adulta, de 20-25 años, amortajada en el interior de una fosa y acompañada de un cuenco cerámico padeció una patología común, caries. El hombre adulto de la fosa excavada en la tumba 1336 no poseía objeto mueble de ningún tipo. Este ritual mortuorio, por tanto, se aplicó a individuos adultos de ambos sexos que no acumularon objetos de prestigio, enterrándose sin ajuar o con productos cerámicos de la esfera doméstica. Probablemente estas personas, a pesar de ser inhumadas en el espacio de los ancestros, contaron con un rango social más limitado que el grupo anterior.

El ritual funerario 3 se corresponde con depósitos presentes en suelos nivelados bajo tumulaciones de la tumba 7005, representando a hombres y mujeres adultos que recibieron un tratamiento de los cuerpos post-esqueletización. La formación de los paquetes funerarios conllevó la articulación de diversas prácticas de manipulación, reducción y selección de los huesos largos y de deposición de objetos muebles fracturados. Estos paquetes estaban formados por restos de un único individuo o de dos. En el caso del paquete funerario individual se correspondía con los restos de una mujer adulta a la que se asoció un punzón o lezna de cobre y una piedra pulida fragmentada. En el caso del paquete funerario colectivo, combinándose los huesos de un hombre y una mujer adulta, se registraron diversos objetos muebles fracturados (cerámica y útiles tallados de sílex) y una estela de pizarra reciclada colocada verticalmente junto al depósito. Estas prácticas funerarias revelan la continuidad de gestos mortuorios documentados en las sepulturas colectivas calcolíticas, que fueron reformulados y/o reinterpretados durante el Bronce Antiguo, pudiendo estar reservados a grupos de población específicos con un relativo elevado rango social.

El ritual funerario 4 se corresponde con el hombre adulto maduro depositado en la "cista" con cubrición tumular de la tumba 7016. Los restos esqueléticos de este individuo se acopiaron formando un depósito secundario junto a varios fragmentos cerámicos de dos cuencos y dos puntas de flecha de sílex. Este hombre padeció artritis, siendo una patología ostearticular degenerativa acorde a su edad, entre 40-60 años. A pesar de no contar con un ajuar destacado este individuo pudo tener un estatus social relevante, dado que se trataba del último enterramiento efectuado en esta tumba, clausurando la actividad funeraria. Sus restos fueron previamente desarticulados y reducidos en este $\mathrm{u}$ otro espacio y posteriormente soterrados en una estructura con cubrición tumular que la haría visible en el entorno de la necrópolis sureste. De este modo, este ritual mortuorio al igual que el anterior, revela la continuidad de ciertas prácticas funerarias de las sepulturas colectivas durante la transición del III al II milenio cal BC.

Esta amplia variabilidad de rituales mortuorios puede representar los diversos estatus sociales de los individuos, marcando las diferencias de género y edad en la esfera de la muerte las desigualdades sociales existentes en el mundo de los vivos. No obstante, es probable que el conjunto de los individuos enterrados en estructuras integradas en las viejas sepulturas colectivas contase con una consideración social elevada, dado el acceso limitado a estos espacios ancestrales, que pudo estar reservado a familias o grupos sociales de mayor estatus de la comunidad, documentándose tan solo ocho individuos en estos espacios: siete en la necrópolis sureste y uno en la necrópolis noroeste. El resto de los individuos se inhumaron en los restantes espacios mortuorios del asentamiento: dos en las áreas aledañas a las necrópolis noroeste, tres en la agrupación de la meseta suroccidental y once en la necrópolis suroeste, esta última de una cronología posterior, c 1900-1500 BC. Un estudio futuro del conjunto de los espacios funerarios permitirá profundizar en las prácticas funerarias y en los aspectos sociales de la esfera de la muerte de la comunidad de la Edad del Bronce.

Prácticas análogas de reapropiación de espacios ancestrales durante la Edad del Bronce Antiguo han sido documentadas en otros monumentos megalíticos del sur peninsular, presentándose arquitecturas y prácticas funerarias similares en el tholos de Las Canteras (Hurtado y Amores 1984: 156-158, 164-166), tholos de Monte 
Velha 1 (Monge Soares 2008: 47-48) y dolmen de Santa Rita (Inácio et al. 2008: 45-46, 48, 2010: 82-83), testimoniando que esta forma de monumentalidad debió ser una práctica social extensiva.

\section{CONCLUSIONES}

El monumentalismo funerario de la necrópolis de La Orden-Seminairo se sustenta en la reapropiación de los espacios ancestrales para la implantación de tumbas individuales en el interior de las viejas sepulturas colectivas, c 2300-1900 cal BC, siendo testimonio de una de las vías de permanencia de los esquemas del megalitismo en la esfera de la muerte en las sociedades del sur peninsular durante la Edad del Bronce.

La pervivencia funeraria de los espacios mortuorios ancestrales durante 300-400 años conllevó la continuidad de las necrópolis durante el Bronce Antiguo, siendo áreas reservadas de forma exclusiva al dominio de los muertos. Esta forma de monumentalidad revela la continuidad de determinados esquemas constructivos, prácticas funerarias y objetos muebles característicos del megalitismo que coexistieron con los nuevos rituales de la muerte de las sociedades desigualitarias. Los conceptos de la tradición megalítica calcolítica fueron reformulados ante los cambios y códigos sociales introducidos por la nueva ideología funeraria emergente en el último cuarto del III milenio BC.

Las estructuras funerarias fueron de diversas formas arquitectónicas: covachas subterráneas, fosas, depósitos sobre suelos nivelados en las cámaras y "cistas". En ellas destaca la presencia de cubriciones tumulares o tumulaciones que propiciaron la monumentalidad arquitectónica, la perdurabilidad temporal, la delimitación espacial y la perceptibilidad visual de las necrópolis. Del mismo modo, se constata el reciclaje de materiales (lajas de pizarra azul y cantos de cuarcita blanquecinos) de alto valor simbólico en las tumbas de las dos necrópolis, y de una estela de pizarra asociada al paquete funerario bajo tumulación de la tumba 7005 .

Las tumbas estuvieron destinadas a enterramientos individuales, constatándose hasta cuatro rituales funerarios con diferencias en cuanto al tipo de depósito, posicionamiento del difunto y posesión de ajuares muebles en función del género, que pueden corresponderse con los diversos estatus sociales. En cuanto a las prácticas funerarias, se evidencia la continuidad de diversos gestos (reducción y desarticulación de los esqueletos) y de tratamiento de los ajuares muebles (fragmentación de los objetos cerámicos) herederos de la tradición megalítica. El enterramiento en los espacios ancestrales hubo de estar restringido a personas con un estatus social privilegiado, siendo una práctica que justificase la posición de cada grupo o clase social.

Con todo, la reapropiación de los espacios ancestrales posibilitaría la continuidad de las necrópolis como lugares monumentales sagrados, la creación de un discurso genealógico que vinculase a estos miembros con sus ancestros y una nueva memoria colectiva del lugar, a través de los que se regulase el derecho al enterramiento y se legitimase el orden social de la comunidad de La Orden-Seminario en el Bronce Antiguo.

\section{Agradecimientos}

Este trabajo se ha desarrollado en el marco del Proyecto "MEGA-LITHOS. Métodos de estudio geo-arqueológicos para la investigación de los megalitismos de Huelva" (UHU-1263153), financiado por el Programa Operativo FEDER 2014-2020 y la Consejería de Economía y Conocimiento de la Junta de Andalucía, y dentro del Plan General de Investigación de la Zona Arqueológica de Huelva, codirigidos por el profesor titular de Prehistoria de la Universidad de Huelva Juan Carlos Vera Rodríguez, al que agradezco poder disponer de documentación del yacimiento de La Orden-Seminario para su realización. Igualmente quiero agradecer los comentarios y las sugerencias de los revisores, que han favorecido la mejora de diversos aspectos.

\section{BIBLIOGRAFÍA}

Amo, M. del (1975): "Enterramientos en cista de la provincia de Huelva", en M. Almagro Basch et al. (eds.), Huelva. Prehistoria y Antigüedad: 109-182. Madrid, Editora Nacional.

Aranda Jiménez, G. (2015): "Resistencia e involución social en las comunidades de la Edad del Bronce del sureste de la Península Ibérica". Trabajos de Prehistoria 72 (1): 126-144. <https://doi.org/10.3989/ tp.2015.12147>.

Aranda Jiménez, G. y Lozano Medina, A. (2014): “The chronology of megalithic funerary practices: a Bayesian approach to Grave 11 at El Barranquete necropolis (Almería, Spain)". Journal of Archaeological Science 50: 369-382. <https://doi.org/10.1016/j. jas.2014.08.005>.

Aranda Jiménez, G.; Lozano Medina, A.; Díaz-Zorita, M.; Sánchez, M. y Escudero, J. (2017): “Cultural 
continuity and social resistance: the chronology of megalithic funerary practices in southern Iberia”. European Journal of Archaeology 2017: 1-25. $<$ https://doi.org/10.1017/eaa.2017.42>.

Baceta, J.I. y Pendón, J.G. (1999): “Estratigrafía y Arquitectura de facies de la Formación Niebla, Neógeno superior, sector occidental de la Cuenca del Guadalquivir". Revista de la Sociedad Geológica de España 12 (3-4): 419-438.

Balsera, V.; Bernabeu Aubán, J.; Costa Caramé, M.; Díaz del Río, P.; García Sanjuán, L. y Pardo, S. (2015): "The radiocarbon chronology of southern Spain's late Prehistory (5600-1000 cal BC): a comparative review". Oxford Journal of Archaeology 34 (2): 139-156. <https://doi.org/10.1111/ojoa.12053>.

Belén, M.; Anglada, R.; Conlin, E.; Gómez, T. y Jiménez, A. (2000): "Expresiones funerarias de la Prehistoria Reciente de Carmona (Sevilla)". SPAL, Revista de Prehistoria y Arqueología 9: 385-403. $<$ http://dx.doi.org/10.12795/spal.2000.i9.21>.

Belén, M.; Román, J.M. y Vázquez, J. (2015): “Ad aeternum. Enterramiento de la Edad del Bronce en Carmona (Sevilla)". ARPI, Arqueología y Prehistoria del Interior Peninsular 03: 164-179.

Blanco-González, A.; Lillios, K.T.; López-Sáez, J.A. y Drake, B.L. (2018): “Cultural, demographic and environmental dynamics of the Copper and Early Bronze Age in Iberia (3300-1500 BC): towards an interregional multiproxy comparison at the time of the 4.2 ky BP event". Journal of World Prehistory 31: 1-79. <https://doi.org/10.1007/s10963-0189113-3>.

Cabrero, R. (1978): "El conjunto megalítico de los Gabrieles". Huelva Arqueológica IV: 79-143.

Cáceres Puro, L.; Gómez Gutiérrez, P.; Montero, M.L.; Clemente-Pérez, M.J. ; Vidal, J.; Toscano, A.; Monge-Gómez, G.; Abad, M.; Izquierdo, T.; Soares, A.; Muñoz, F.; Campos, J.; Bermejo, J.; Martínez-Aguirre, A. y López, G. (2018): "Modelling the mid-late Holocene evolution of the Huelva Estuary and its human colonization, South-Western Spain". Marine Geology 406: 12-26. <https://doi. org/10.1016/j.margeo.2018.08.008>.

Costela Muñoz, Y. (2017): "La pervivencia de la ideología megalítica durante el II y I milenios a.n.e. Un caso de estudio: el sur de Portugal". Revista Portuguesa de Arqueología 20: 45-60.

Díaz-Zorita, M.; Costa Caramé, M.E. y García Sanjuán, L. (2012): "Funerary practices and demography from Mesolithic to the Copper Age in southern Spain”, en J.F. Gibaja, A.F. Carvalho y P. Chambon (eds.), Funerary Practices in the Iberian Peninsular from the Mesolithic to the Chalcolithic: 51-65. BAR International Series 2417. Oxford, Archaeopress.

Fernández Ruiz, J. (2004): "Uso de estructuras megalíticas por parte de grupos de la Edad del Bronce en el marco de río Grande (Málaga)". Mainake XXVI: 273-292.

Ferrer Palma, J.E. (1977): "La necrópolis megalítica de Fonelas (Granada). El sepulcro "Domingo 1" y sus niveles de enterramiento". Cuadernos de Prehistoria de la Universidad de Granada 2: 173-210.

Ferrer Palma, J.E.; Marqués Merelo, I. y Baldomero Navarro, A. (1988): "La necrópolis megalítica de Fonelas (Granada)". Noticiario Arqueológico Hispánico 30: 21-82.

García Sanjuán, L. (ed.) (1998): La Traviesa. Ritual funerario y jerarquización social de una comunidad de la Edad del Bronce de Sierra Morena occidental. SPAL Monografías 1. Sevilla, Universidad de Sevilla.

García Sanjuán, L. (2005): "Las piedras de la memoria. La permanencia del megalitismo en el Suroeste de la Península Ibérica durante el II y I milenios ANE". Trabajos de Prehistoria 62 (1): 85-109. $<$ https://doi.org/10.3989/tp.2005.v62.i1>.

García Sanjuán, L. (2006): "Funerary ideology and social inequality in the Late Prehistory of the Iberian South-West (c. 3300-850 cal BC)", en P. Díaz del Río y L. García Sanjuán (eds.), Social Inequality in Iberian Late Prehistory: 149-170. BAR International Series S1525. Oxford, Archaeopress.

García Sanjuán, L. y Odriozola, C.P. (2012): "La cronología radiocarbónica de la Edad del Bronce (c. 2200-850 cal ANE) en el Suroeste de la Península Ibérica", en J. Jiménez Ávila (ed.), Sidereum Ana II: El Río Guadiana en el Bronce Final: 363-387. Mérida, CSIC-Junta de Extremadura.

García Sanjuán, L.; Weathley, D.W. y Costa Caramé, M. (2011): "The numerical chronology of the megalithic phenomenon in southern Spain: progress and problems", in L. García Sanjuán, C. Scarre y D. Weathley (eds.), Exploring Time and Matter in Prehistoric Monuments: Absolute Chronology and Rare Rocks in European Megaliths. Proceedings of the 2nd European Megalithic Studies Group Meeting. Menga, Revista de Prehistoria de Andalucia, Monográfico 01: 121-157. Sevilla (2008), Sevilla, Junta de Andalucía.

Gómez Toscano, F.; Beltrán, J.M.; González Batanero, D. y Vera Rodríguez, J.C. (2014): “El Bronce Final en Huelva. Una visión preliminar del poblamiento en su ruedo agrícola a partir del registro 
arqueológico de La Orden-Seminario". Complutum 25 (1): 139-158. < https://doi.org/10.5209/rev_ CMPL.2014.v25.n1.45360>.

González González, B.; Linares Catela, J.A.; González Batanero, D. y Vera Rodríguez, J.C. (2008): “Depotfund zylinderförmiger Idole des 3Jts.v.Chr. aus La Orden-Seminario (Prov. Huelva)". Madrider Mitteilungen 49: 1-28.

Herrero-Corral, A.M.; Garrido Pena, R. y Flores Fernández, R. (2019). "The Inheritors: Bell Beaker Children's Tombs in Iberia and Their Social Context (2500-2000 Cal BC)". Journal of Mediterranean Archaeology 32: 63-87. <http://dx.doi. org/10.1558/jma.39328>.

Hunt, M. (ed.) (2012): Intervenciones Arqueológicas en el Área del Proyecto Minero Cobre Las Cruces (1996-2011): de la Prehistoria a la Época Contemporánea (Provincia de Sevilla, España). Sevilla, Fundación Cobre las Cruces.

Hunt, M.; Vázquez, J.; García Rivero, D. y Pecero, J.C. (2009): "Dataciones radiocarbónicas de las necrópolis de la Edad de Bronce, SE-K, SE-B y Jardín de Alá (Salteras y Gerena, Sevilla)", en S. Rovira, M. García-Heras, M. Gener e I. Montero (eds.), Actas del VII Congreso Ibérico de Arqueometría: 226235. Madrid (2008), Madrid, Quadro.

Hurtado, V. y Amores, F. (1984): "El tholos de Las Canteras y los enterramientos del Bronce en la necrópolis de El Gandul (Alcalá de Guadaira, Sevilla)". Cuadernos de Prehistoria de la Universidad de Granada 9: 147-174.

Inácio, N.; Calado, D.; Nocete, F.; Curate, F.; Oliveira, C.; Peramo, A. y Bayona, M.R. (2008): "Pré-Historia e Megalitismo na região de Cacela. Uma propuesta integrada de investigaçaão, valorizacão e proteccão do patrimonio arqueológico". Actas do $5^{\circ}$ Encontro de Arqueología do Algarve. Xelb 8: 37-49.

Inácio, N.; Nocete, F.; Calado, D.; Curate, F.; Nieto, J.M.; Bayona, M.R. y Oliveira, C. (2010): “O Túmulo Megalítico de Santa Rita (Vila Nova de Cacela). Resultados preliminares de um proceso de investigacão em curso". Actas do $7^{\circ}$ Encontro de Arqueología do Algarve. Xelb 10: 73-86.

Linares Catela, J. A. (2010): “Análisis arquitectónico y territorial de los conjuntos megalíticos de Los Gabrieles (Valverde del Camino) y El GallegoHornueco (Berrocal-El Madroño). El megalitismo en el Andévalo oriental", en J.A. Pérez Macías y E. Romero Bomba (eds.), Actas del IV Encuentro de Arqueología de Suroeste Peninsular: 209-248. Huelva, Universidad de Huelva.
Linares Catela, J.A. (2011): Guía del megalitismo en la provincia de Huelva. Territorios, paisajes y arquitecturas megalíticas. Madrid, Junta de AndalucíaEdiciones SM.

Linares Catela, J.A. (2016): "The megalithic architecture of Huelva (Spain): typology, construction and technical traditions in eastern Andévalo", en L. Laporte y C. Scarre (eds.), The megalithic architectures of Europe: 111-126. Oxford, Oxbow Books. $<$ https://doi.org/10.2307/j.ctvh1dpw8.15>.

Linares Catela, J.A. (2017): El megalitismo en el sur de la Peninsula Ibérica. Arquitectura, construcción y usos de los monumentos del área de Huelva, Andalucía occidental. Tesis Doctoral, Universidad de Huelva / Université de Rennes 1. Inédita.

Linares Catela, J.A. (2018): "Megalitismos del área de Huelva. Investigación y puesta en valor", en J.C. Senna-Martínez, M. Diniz y A.F. Carvalho (eds.), De Gibraltar aus Pirinéus. Megalitismo, vida e norte na Fachada Atlântica Peninsular: 520-538. Lapa do Lobo (2018), Nelas, Fundação Lapa do Lobo.

Linares Catela, J.A y García Sanjuán, L. (2010): “Contribuciones a la cronología absoluta del megalitismo andaluz. Nuevas fechas radiocarbónicas de sitios megalíticos del Andévalo oriental (Huelva)". Menga, Revista de Prehistoria de Andalucía 01: 135-151.

Linares Catela, J.A. y Mora Molina, C. (2018): "El dolmen de Soto 1, Huelva. Arqueología del monumento", en P. Bueno Ramírez, J.A. Linares Catela, R. de Balbín Berhmann y R. Barroso Bermejo (eds.), Símbolos de la muerte en la Prehistoria Reciente del sur de Europa. El dolmen de Soto, Huelva. España: 98-130. Arqueología Monografías. Sevilla, Junta de Andalucía.

Linares Catela, J.A y Vera Rodríguez, J.C. (2015): "La necrópolis del III milenio de El Seminario (Huelva). Organización espacial, contextos y prácticas funerarias", en L. Rocha, P. Bueno Ramírez y G. Branco (eds.), Death as Archaeology of Transition: Thoughts and Materials: 275-290. BAR International Series 2708. Oxford, Archaeopress.

Lorrio, A.J. (2008): Qurénima: El Bronce Final del sureste de la Península Ibérica. Bibliotheca Archaeologica Hispana 27. Madrid, Real Academia de la Historia.

Lorrio, A.J. (2017): “Arquitecturas funerarias y memoria durante el Bronce Final y el periodo orientalizante en el Sureste de la Península Ibérica (ss. X-VI a.C.)", en S. Adroit y R. Graells (eds.), 
Arquitecturas funerarias y memoria. La gestión de las necrópolis e Europa occidental (ss. X-III a.C.). Actas del Coloquio: 275-315. Archeologia Nuova Serie 4. Madrid (2014), Venosa, Osanna Edizioni.

Lorrio, A.J. y Montero, I. (2004): "Reutilización de sepulcros colectivos en el Sureste de la Península Ibérica: la colección Siret". Trabajos de Prehistoria 61 (1): 99-116. <https://doi.org/10.3989/tp.2004.v61.i1>.

Lozano Medina, A. y Aranda Jiménez, G. (2017): “La temporalidad de las sepulturas megalíticas tipo Tholos del sur de la Península Ibérica". SPAL, Revista de Prehistoria y Arqueología 26: 17-31. <http:// dx.doi.org/10.12795/spal.2017i26.01>.

Lull, V.; Micó, R.; Rihuete, C. y Risch, R. (2010): "Límites históricos y limitaciones del conocimiento arqueológico: la transición entre los grupos arqueológicos de Los Millares y El Argar”, en P. Bueno, A. Gilman, C. Martín Morales y F.J. Sánchez-Palencia (eds.), Arqueología, Sociedad, Territorio y Paisaje. Estudios sobre Prehistoria Reciente, Protohistoria y transición al mundo romano en Homenaje a $M^{a}$ Dolores Fernández Posse: 75-94. Biblioteca Praehistórica Hispana 28. Madrid, CSIC.

Lull, V.; Micó, R.; Rihuete, C. y Risch, R. (2011). “El Argar and the beginning of class society in the western Mediterranean", in S. Hansen y J. Müller (eds.), Sozialarchäologische Perspektiven: Cesellschaftlicher Wandel 5000-1500 v. Chr: 381-414. Zwischen Atlantik und Kaukasus (Archäologie in Eurasien 24). Berlin, Philipp von Zabern.

Márquez Romero, J.E.; Fernández Ruiz; J. y Mata Vivar, E. (eds.). (2009): El sepulcro megalítico del Tesorillo de la Llaná, Alozaina (Málaga). Una estructura funeraria singular en la cuenca media del Río Grande. Málaga, Universidad de Málaga.

Martínez Fernández, M.J. y Vera Rodríguez, J.C. (2014): "Los enterramientos de la Edad del Bronce del yacimiento de La Orden-Seminario (Huelva). Rituales funerarios y diferenciación sexual en la transición del Tercer al Segundo Milenios A.C. en Andalucía occidental". Huelva Arqueológica 23: 11-46.
Martínez Rodríguez, F. y Pereda, C (1991): “El dolmen de El Carnerín (Alcalá del Valle, Cádiz): una sepultura "megalítica" de la Edad del Bronce en la sierra gaditana". Anuario Arqueológico de Andalucía 1989 vol. III: 66-70.

Mayoral, E. y Abad, M. (2008): “Geología de la Cuenca del Guadalquivir", en Facultad de Ciencias Experimentales (ed.), Geología de Huelva. Lugares de Interés Geológico: 20-27. Huelva, Universidad de Huelva ( $2^{\mathrm{a}}$ edición).

Mittnik, A.; Massy, K.; Knipper, C; Wittenborn, F.; Friedrich, R.; Pfrengle, S.; Burri, M.; Carlichi-Witje, N.; Deeg, H.; Furtwängler, A.; Harbeck, M.; von Heyking, K.; Kociumaka, C.; Kucukkalipci, I.; Lindauer, S.; Metz, S.; Staskiewicz, A.; Thiel, A.; Wahl, J.; Haak1, W.; Pernicka, E.; Schiffels, S.; Stockhammer, P.W. y Krause1, J. (2019): "Kinship-based social inequality in Bronze Age Europe". Science 10 Oct 2019. < https://doi.org/10.1126/science.aax6219>.

Monge Soares, A. (2008): “O monumento megalítico Monte da Velha 1 (MV1) Vila Verde de Ficalho, Serpa)". Revista Portuguesa de Arqueologia 11 (1): 33-51.

Tovar, E.; Marqués, I.; Jiménez-Brobeil, S. y Aguado, T. (2014): "El hipogeo número 14 de la necrópolis de Alcaide (Antequera, Málaga): un enterramiento colectivo del Bronce". Menga, Revista de Prehistoria de Andalucía 05: 123-149.

Vera Rodríguez, J.C.; Linares Catela, J.A; Armenteros, M.J. y González, D. (2010): "Depósitos de ídolos en el poblado de La Orden-Seminario de Huelva: Espacios rituales en contexto habitacional", en C. Cacho, R. Maicas, E. Galán y J.A. Martos (coord.), Los ojos que nunca se cierran. Ídolos de las primeras sociedades campesinas: 199-242. Madrid, Ministerio de Cultura.

Zazo, C.; Mercier, N.; Silva, P.G.; Dabrio, C.J.; Goy, J.L.; Roquero, E.; Soler, V.; Borja, F.; Lario, J.; Polo, D. y Luque, L. (2005): "Landscape evolution and geodynamic controls in the Gulf of Cadiz (Huelva coast, SW Spain) during the Late Quaternary". Geomorphology 68: 269-290. 

Suárez Padilla, J., Ramon Torres, J., Mora Serrano, B., Salvago Soto, L. y Chacón Mohedano, C. (2020): "La cronología fundacional de la Malaka fenicia: investigaciones en el solar del Rectorado de la Universidad de Málaga", Spal 29.1: 41-77. DOI: http://dx.doi.org/10.12795/spal.2020.i29.02

\title{
LA CRONOLOGÍA FUNDACIONAL DE LA MALAKA FENICIA: INVESTIGACIONES EN EL SOLAR DEL RECTORADO DE LA UNIVERSIDAD DE MÁLAGA
}

\section{THE FOUNDING CHRONOLOGY OF THE PHOENICIAN MALAKA: RESEARCH ON THE SITE OF THE RECTORY OF THE UNIVERSITY OF MÁLAGA}

\author{
JOSÉ SUÁREZ PADILLA \\ Responsable de la correspondencia \\ Departamento de Ciencias Históricas. Facultad de Filosofía y Letras \\ Campus de Teatinos. Universidad de Málaga, E-29010, Málaga \\ Profesor Doctor Interino (Área de Prehistoria) \\ Correo-e: josesuarez@uma.es (D) https://orcid.org/0000-0001-6795-8668 \\ ResearcherID: <https://publons.com/researcher/AAH-1833-2019> \\ JOAN RAMON TORRES \\ Consejo Insular de Ibiza. Departamento de Patrimonio Histórico. Av. España, 49. CP 07800 Ibiza \\ Técnico titular de Patrimonio Histórico \\ Correo-e: jramon@conselldeivissa.es (D) https://orcid.org/0000-0003-0646-4423 \\ ResearcherID: <https://publons.com/researcher/AAH-1763-2019> \\ BARTOLOMÉ MORA SERRANO \\ Departamento de Ciencias Históricas. Facultad de Filosofía y Letras. \\ Campus de Teatinos. Universidad de Málaga, E-29010, Málaga \\ Catedrático de Arqueología. \\ Correo-e: barmora@uma.es (D) https://orcid.org/0000-0002-0909-9225 \\ ResearcherID: <https://publons.com/researcher/D-9866-2014> \\ LETICIA SALVAGO SOTO \\ Proyectos MLK. Apartado de Correos 6094. 29080 Málaga \\ Correo-e: proyectos@mlk.es. D https://orcid.org/0000-0003-2011-0381 \\ ResearcherID: <https://publons.com/researcher/AAH-3841-2019> \\ CRISTINA CHACÓN MOHEDANO \\ Arqueóloga. Avda. Juan Sebastián Elcano № 182. 6으. 29017 Málaga \\ Correo-e: arqueocris@gmail.com. (T) https://orcid.org/0000-0002-5638-5312 \\ ResearcherID: <https://publons.com/researcher/AAG-9955-2019>
}

Resumen: Entre los años 1998 y 2002 se llevó a cabo una actividad arqueológica en el antiguo edificio de la Casa de Correos y Telégrafos de Málaga, como parte de los trabajos de rehabilitación necesarios para su uso como sede del Rectorado de la Universidad. El estudio sistemático de los materiales correspondientes a los niveles más profundos de la secuencia, atribuidos al periodo fenicio arcaico, permiten su datación en momentos anteriores a c 625 a.C., lo que los convierte, al día de hoy, en el contexto de mayor antigüedad de
Abstract: Between the years 1998 and 2002 an archaeological activity was carried out in the old building of the Correos (Post and Telegraph House) of Malaga, as part of the rehabilitation work necessary for its use as the seat of the Rector's Office of the University. The systematic study of the materials corresponding to the deepest levels of the sequence, attributed to the Phoenician archaic period, allows their dating before $c .625 \mathrm{BC}$, which makes them, to this day, the oldest known context associated to ancient Malaka. In addition to 
Malaka. Junto a este dato de valor cronológico destaca la entidad arquitectónica de algunas de las estructuras localizadas, inmediatas a la primera línea de costa de la época. El conjunto resulta de gran interés para estudiar la dinámica del poblamiento fenicio de la bahía de Málaga a partir de la fundación del asentamiento de la Rebanadilla, ubicado en el vecino estuario del río Guadalhorce, datado en la segunda mitad del siglo IX a.C.

Palabras clave: Colonización fenicia; cerámica fenicia; Hierro I; Malaka en el siglo VII a.C.

\section{PRESENTACIÓN}

Junto con otras sugestivas cuestiones, aún no resueltas, como es el mismo origen del topónimo (De Hoz 2010: 432, Martín Ruiz 2010: 78), la ciudad fenicia de Malaka, situada en la margen izquierda del río Guadalmedina, continúa arrastrando el problema de su cronología fundacional. Este aspecto resulta de particular interés, teniendo en cuenta que, hoy en día, la bahía de Málaga (concretamente el entorno de la desembocadura del río Guadalhorce) se configura como uno de los territorios más antiguos, junto con Huelva, de presencia fenicia arcaica en el sur de la península ibérica (fig. 1).

Algunas excavaciones arqueológicas desarrolladas en las últimas décadas en pleno casco histórico malagueño alcanzaron horizontes arcaicos en puntos clave como el palacio de Buenavista o la calle Císter, siendo objeto de publicación de sugerentes avances de resultados (Arancibia y Escalante 2006a y 2006b). No obstante, las secuencias mejores conocidas siguen siendo las procedentes del área del teatro romano (Gran-Aymerich 1991) y del colegio de San Agustín (Recio 1989), publicadas hace algunas décadas, y cuyos niveles más profundos no remontan más allá de la primera mitad del siglo VI a.C. (fig. 2).

Por este motivo, es obvio que la presentación del análisis, con una perspectiva moderna, de dos complejos vasculares hallados entre los años 1998-2002 en el antiguo edificio de Correos y Telégrafos, actual sede del Rectorado de la Universidad de Málaga, puede suplir, al menos provisionalmente, esta grave carencia e, incluso, convertirse en acicate para el estudio de otros contextos arqueológicos que permitan aproximarnos a la temporalidad, naturaleza y dinámica de la implantación colonial en la región. Este es el objetivo principal de esta aportación. this piece of chronological data, the site stands out because of the magnitude of its architecture, located immediately to the first coastline of the time. The assemblage is of great interest to study the dynamics of the Phoenician settlement of the bay of Malaga from the foundation of La Rebanadilla, located in the neighboring estuary of the Guadalhorce River, dated in the second half of the 9th century BC.

Key words: Phoenician colonization; Phoenician ceramics; Early Iron Age; Malaka in the 7th century BC

\section{LA EXCAVACIÓN ARQUEOLÓGICA EN EL EDIFICIO DE CORREOS DE MÁLAGA (1998-2002): EL PERIODO FENICIO ARCAICO}

Entre 1998 y 2002 se llevó a cabo una Actividad Arqueológica de Urgencia vinculada a los trabajos de Rehabilitación del antiguo Edificio de la Casa de Correos y Telégrafos, para su futuro uso como sede del Rectorado de la Universidad de Málaga (Chacón y Salvago 2005). Durante una primera fase (1998-1999) los trabajos se centraron en la excavación en extensión de la parcela. En años sucesivos se realizaron investigaciones puntuales en determinados sectores, en paralelo a la fase de control arqueológico de las obras (2000-2002) (fig. 3).

El solar investigado tenía una superficie de $1461 \mathrm{~m}^{2}$, si bien en más de la tercera parte del sitio emergía directamente el sustrato geológico. Esta circunstancia responde, en particular, a las importantes afecciones que sufrió este sector de la ciudad a partir de finales del siglo XIX, junto a la destrucción del subsuelo que supuso la propia construcción del edificio público. A pesar de estas limitaciones, la actuación arqueológica permitió documentar restos constructivos y deposicionales correspondientes a una secuencia estratigráfica en la cual están representados, de forma desigual, los periodos fenicio arcaico, romano, medieval, moderno y contemporáneo (Chacón y Salvago 2005: 20-25). Para los objetivos de este artículo, nos centraremos en una descripción detallada de la secuencia estratigráfica correspondiente al momento más antiguo (fig. 4).

En términos generales, se trata de una serie de retazos de estructuras en positivo junto a algunas fosas y estratos de relleno, concentrados en un espacio de unos $20 \mathrm{~m}^{2}$ ubicado en la mitad occidental de la parcela. 


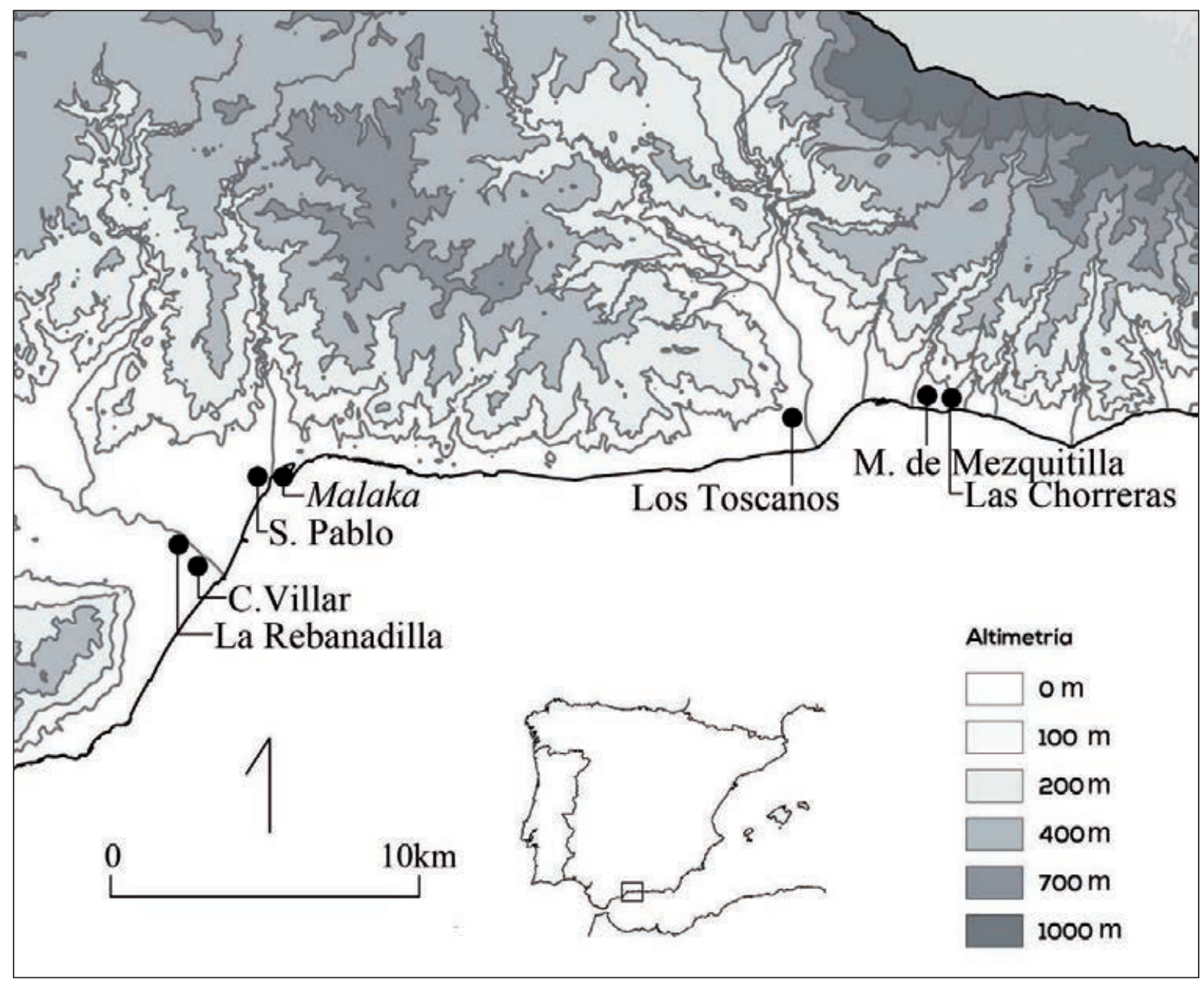

Figura 1. Principales asentamientos fenicios e indígenas en el litoral centro-oriental de Málaga (finales del siglo IX-VII a.C.).

Este ámbito se denominó "sector del muro fenicio". Es necesario señalar que estos restos se encontraban, por lo general, en mal estado de conservación, como resultado de importantes afecciones posteriores entre las que destacan las resultantes de la construcción sobre los mismos de la factoría de salazones de época romana. En particular, esta circunstancia ha limitado en extremo la interpretación de la naturaleza de los restos correspondientes al periodo en estudio (fig. 5).

Previamente a las primeras construcciones del periodo fenicio, la paleotopografía de este sector meridional de la actual colina de la Alcazaba se caracterizó por presentar una ladera de pendiente acusada, que entraba en contacto con el mar.

Los retazos de muros conservados presentan orientación tanto en sentido norte-sur como este-oeste, adaptándose aparentemente a las irregularidades de la topografía del frente marítimo. Concretamente, los denominados como MR02 y MR07 presentan un aparejo de mampuestos de rocas locales careadas (bloques de pizarra y ocasionalmente areniscas), ligadas con barro. Las piedras de MR02 se adaptan al perfil de la roca natural (UE17), posiblemente regularizada de forma artificial (FS16). Al extremo de MR02 se adosa transversalmente un muro denominado MR01. Es una sólida estructura con $80 \mathrm{~cm}$ de ancho, en cuya construcción se emplearon mampuestos pizarrosos, algo regularizados al exterior, dispuestos en hiladas con ripios y ligadas con barro. Para su construcción se llevó a cabo un recorte artificial del frente de roca, que propició espacio suficiente para facilitar la fábrica de su cara interior (FS11). El muro arranca de una hilada a modo de zarpa, que sobresale unos centímetros del resto (UE10) y que apoya directamente sobre el nivel geológico base, a una cota de 2,78 m s.n.m. Este 


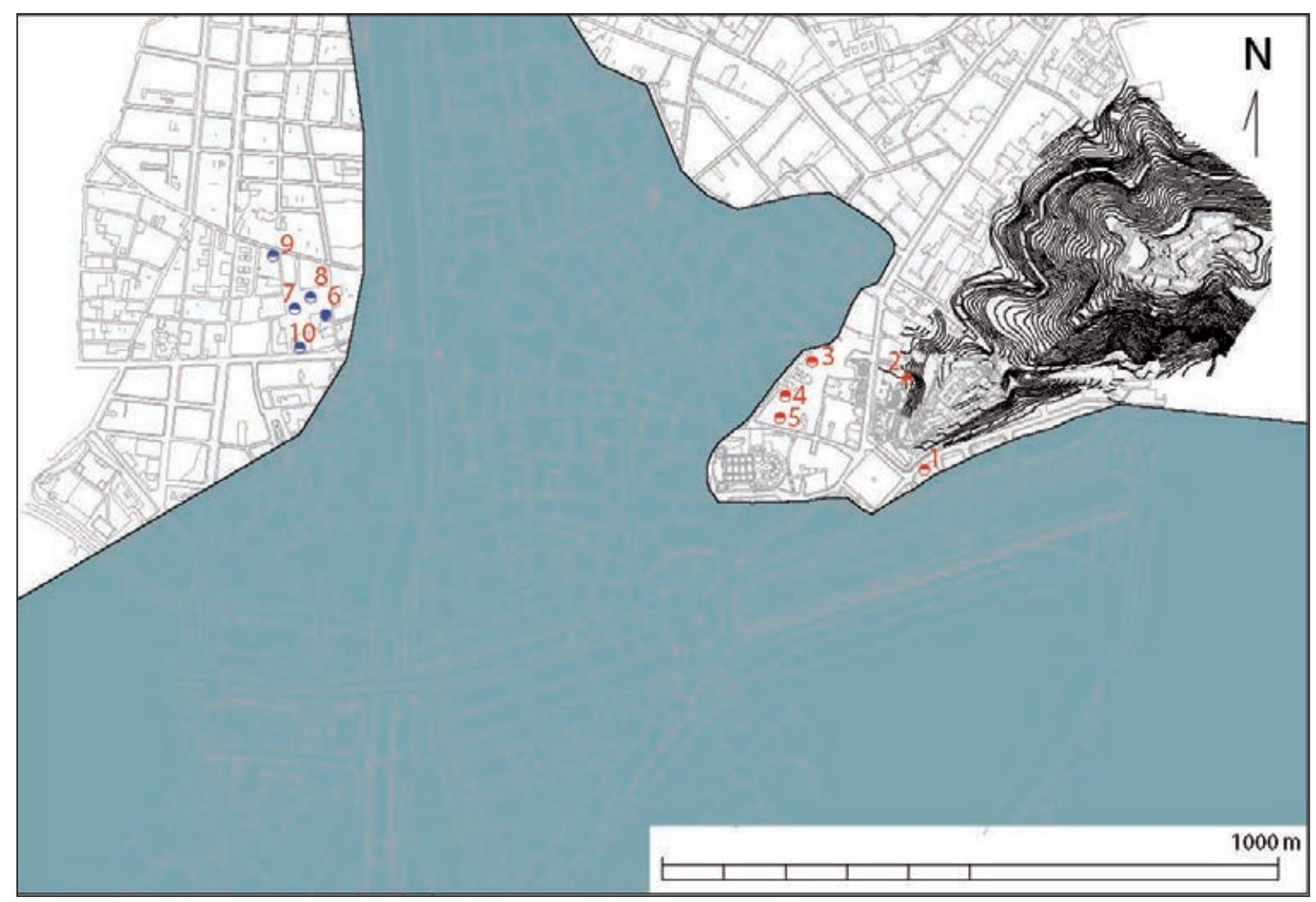

Figura 2. La intervención arqueológica del edificio del Rectorado de la Universidad de Málaga, en el contexto de las principales intervenciones arqueológicas con hallazgos fenicios arcaicos y autóctonos en el marco del paleoestuario del río Guadalmedina (siglos VIII-VI a.C.). 1. Rectorado de la Universidad de Málaga; 2. Ladera de la colina de la Alcazaba-Teatro romano; 3. Museo Picasso-Palacio de Buenavista; 4. Calle San Agustín; 5. Calle Císter-San Agustín; 6. Plaza de San Pablo esquina calle Jara; 7. Entorno de la Plaza de San Pablo; 8. Plaza de San Pablo; 9. Calle San Pablo 19; 10. Calle Tiro esquina a Zamorano.

paramento conserva una altura que varía desde los 1,70 $\mathrm{m}$, a los 2,60 m, alcanzando una cota máxima de 5,43 m s.n.m. Esta diferencia de altura de cerca de un metro es resultante de la afección supuesta por la construcción en época romana de la denominada Pileta IX, que lo destruyó en gran parte. (figs. 6 y 7).

Los grosores de $80 \mathrm{~cm}$ empleados en esta construcción (MR01) remiten al empleo del "codo fenicio" de 52 cm Esta metrología - 1,5 codos en nuestro caso - es frecuente en la arquitectura de tradición oriental (Barresi 2007: 19). Buenos ejemplos de ello son muros empleados como sistema de contención de tierras para posibilitar la disposición de viviendas escalonadas en las laderas de promontorios, caso de las construcciones del periodo fenicio arcaico (siglo VIII a.C.) del Teatro Cómico de Cádiz (Gener et al. 2014: 22, 35-36), en Chorreras (Martín y Recio 2012: 209, 211), así como en Toscanos (Arnold y Marzoli 2009: 444). No obstante, esta metrología convive en ocasiones con la del empleo del codo de 45-46 cm (Barresi 2007: 22, Montanero 2014: 78), identificada en el propio yacimiento de Malaka, aunque para fechas algo posteriores. Es el caso de algunas estructuras localizadas en las excavaciones del Museo Picasso, así como en el santuario excavado en la cercana calle del Císter (Arancibia y Mora 2018: $357-$ 359), luego amortizado por las primeras murallas de la ciudad.

El espacio resultante entre la fosa FS11, practicada para facilitar la construcción de MR01, y la propia cara interior del muro, se rellenó con diversos aportes terrígenos realizados desde el exterior (UEs 09, 08 y 06). El estrato más profundo es UE09, que presenta una acusada pendiente adaptándose al corte practicado en la ladera y que cubre la zarpa (UE10) del muro, apoyando contra él. Este nivel de relleno, de matriz de naturaleza 


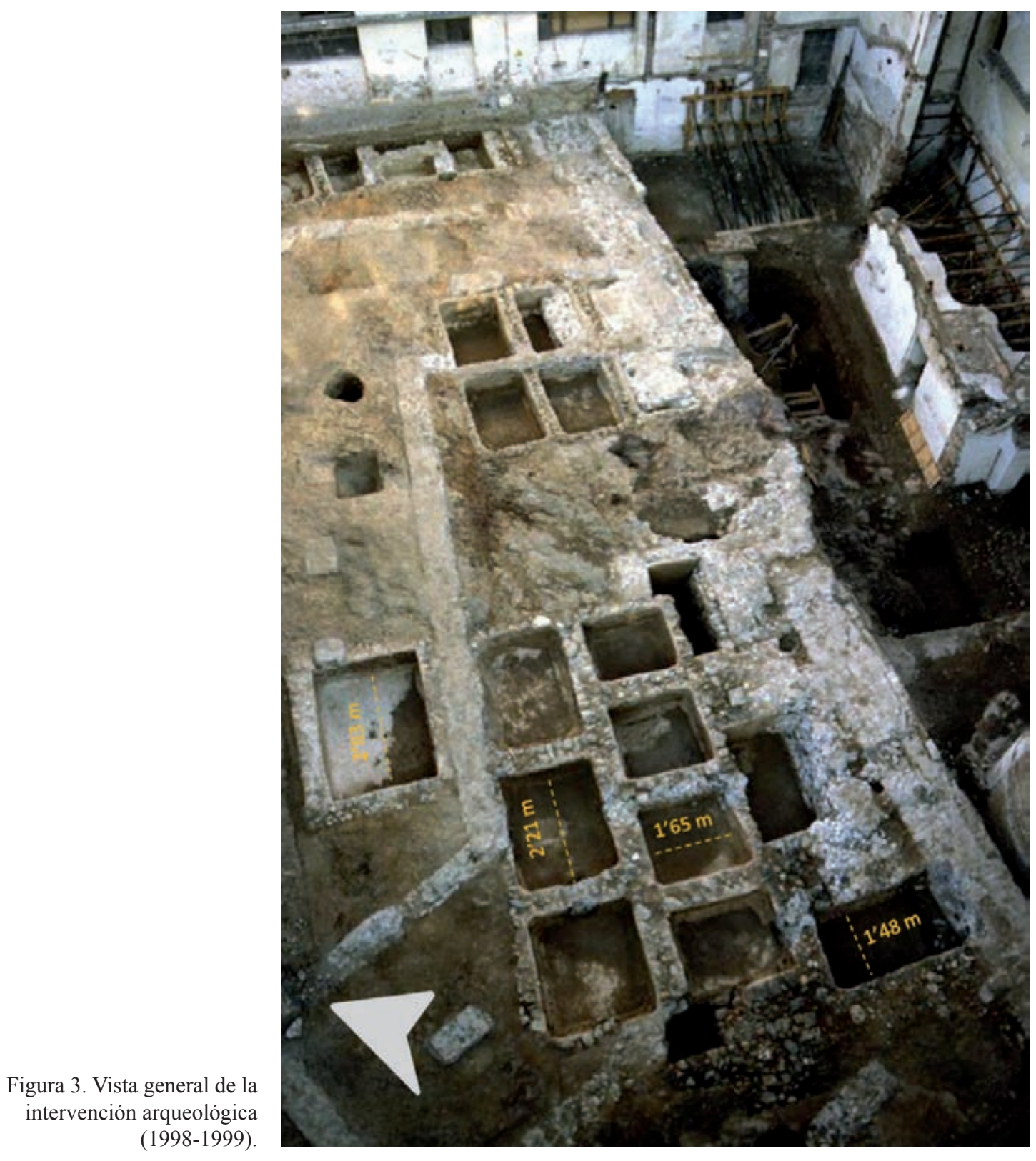

arcillosa y color marrón oscuro, semicompacto, parece ser resultado de un vertido con inclusiones propias de materiales de desecho de actividades domésticas. Contiene una presencia significativa de pequeños nódulos de carbón, junto a un número elevado de fragmentos cerámicos, con escasos indicios de rodamiento, así como restos de malacofauna, con un número mínimo de 18 individuos, que corresponden a un total de 10 especies de moluscos marinos, entre bivalvos y gasterópodos. Todo apunta a que se trata de materiales relacionados con actividades domésticas (fig. 8).
Cabe señalar que se dispone de una datación absoluta para este estrato, obtenida a partir de una muestra de car-

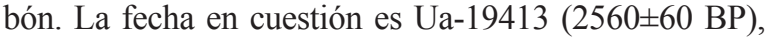
que, calibrada y con un $95,4 \%$ de probabilidad, aporta una horquilla cronológica que resulta excesivamente amplia, entre el 832 y el 488 cal BC, al caer de pleno en la conocida como "meseta de Hallstatt", que corresponde a los primeros siglos de la Edad del Hierro. Es por ello por lo que esta fecha radiocarbónica no resulta una aportación determinante para ajustar con precisión la cronología de este estrato, aunque sí es coherente con 


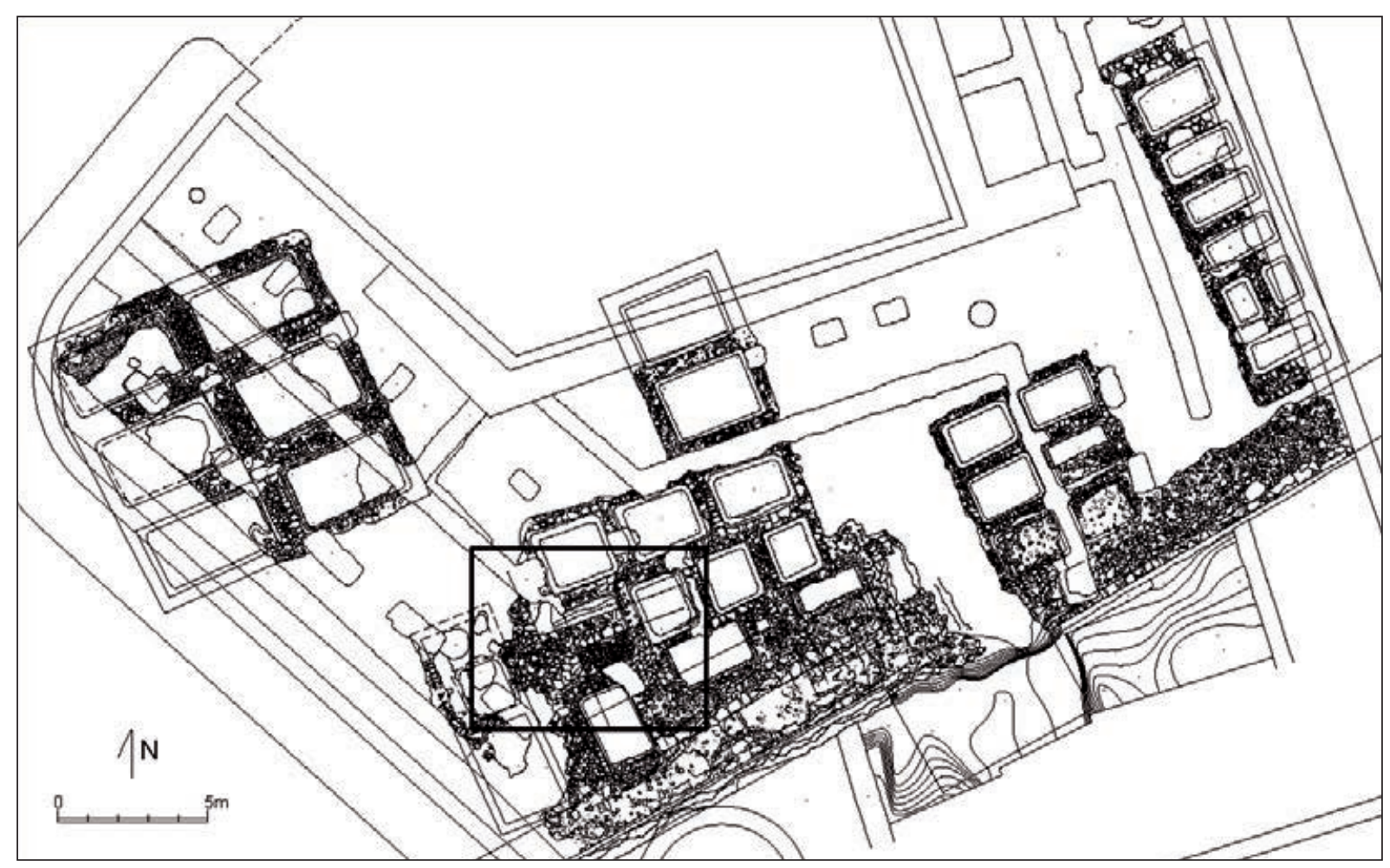

Figura 4. Planta general de las excavaciones del edificio del Rectorado de la Universidad de Málaga (antiguo Correos).

la propuesta de datación convencional resultante del estudio de la cerámica, como se verá más adelante (fig. 9).

UE08 es un estrato que cubre a UE09 y se apoya a su vez en MR01. Presenta matriz algo más arcillosa y compacta, color marrón-amarillento, sin apenas carbones y fragmentos cerámicos, de naturaleza semejante a los subyacentes. El estrato superpuesto a UE08 es UE06, que presenta escasa potencia, una matriz semejante a UE08 y práctica ausencia de material arqueológico. Sobre este último se forma UE03, el relleno superior documentado en la FS11. No presentaba material arqueológico.

Al exterior de MR01 se documentó parcialmente la existencia de un nivel con abundantes piedras (UE14). Tanto estos mampuestos, como el propio muro fueron definitivamente amortizados por un suelo (SL12) localizado al ser destruido parcialmente el suelo de la Pileta IX, y cuya cronología es incierta. A MR01 se adosó otro muro en sentido transversal y paralelo a MR02, denominado MR07, con desarrollo longitudinal en dirección al mar. De este paramento apenas se pudo identificar algo menos de medio metro, al presentarse muy afectado por las construcciones romanas. Pudo cumplir la función de regularización del frente oriental del espigón rocoso que avanzaba hacia el litoral. El espacio resultante entre la roca natural (UE17), previamente recortada (FS16), y MR03 se macizó con piedras (UE04).

Posiblemente a un momento de destrucción de estas estructuras corresponda el estrato UE05, interpretado, a priori, como posible derrumbe situado al exterior de MR07. El espacio conformado por MR03 y las UEs 04 y 05 coincidía con la implantación de un pilar de la cimentación del nuevo edificio del Rectorado, por lo que fue parcialmente destruido y no pudo ser investigado en profundidad.

Con los restos conservados y documentados no deja de resultar arriesgado interpretar con garantías la naturaleza de esta secuencia estratigráfica. Algunos aspectos a destacar serían la entidad de paramentos como MR01, que presenta una orientación adaptada a las curvas de nivel y a la propia línea de costa. Esta última se mantuvo sin grandes variaciones en este sector de la ciudad hasta finales del siglo XIX (figs. 10 y 11), circunstancia que contrasta con otros ámbitos sujetos a la deposición de aluviones procedentes del río Guadalmedina (Mora y Arancibia 2010: 825-826). Es por ello, por lo que en este mismo solar se conservan retazos de lienzos defensivos de época islámica e incluso moderna, que discurren con una orientación semejante a la de este potente muro fenicio. 


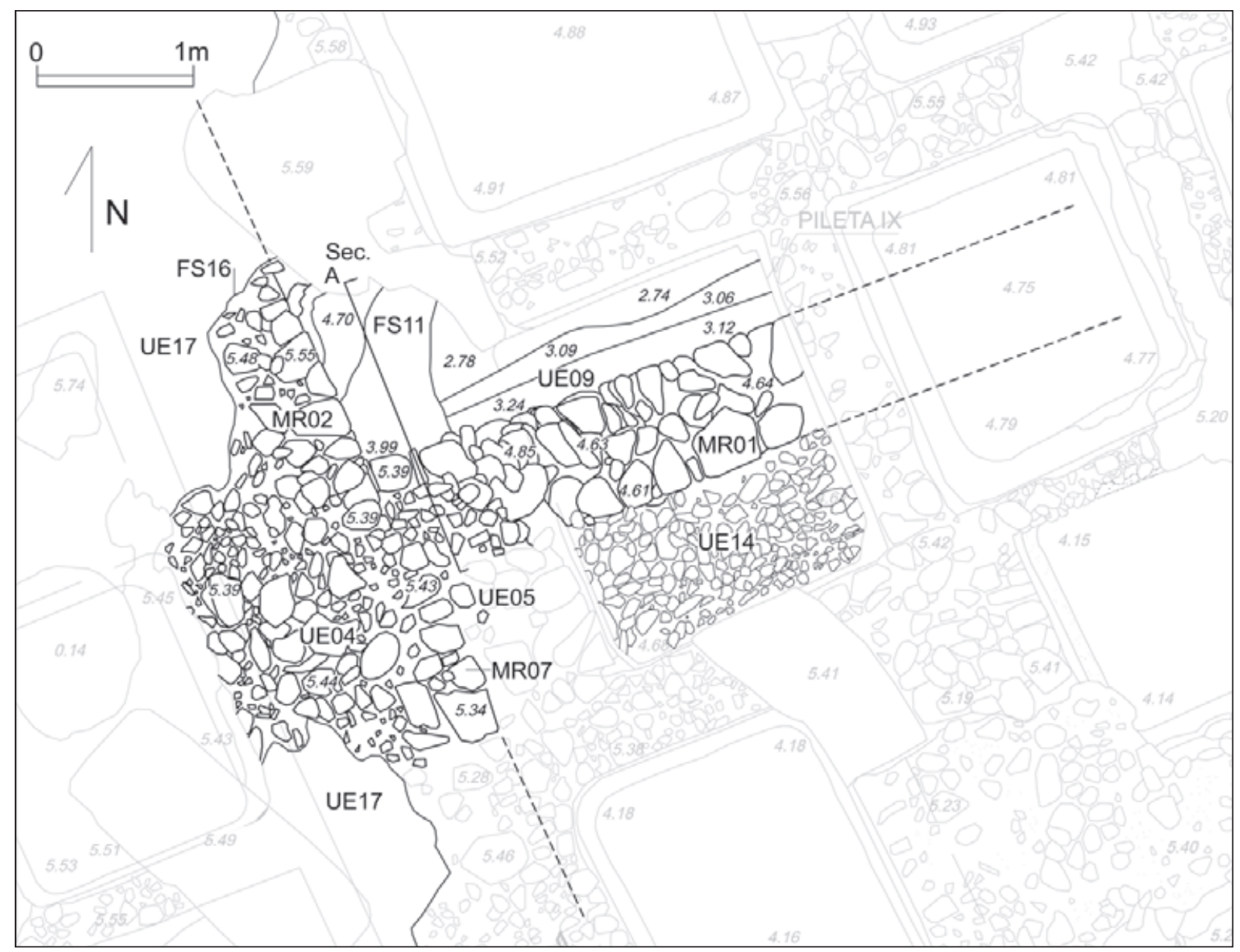

Figura 5. Planta de detallle de las estructuras y depósitos correspondientes al período fenicio.

Todo indica la existencia de construcciones del primer asentamiento de Malaka en primera línea marítima, que se habrían adaptado, con ciertas modificaciones, a la topografía natural preexistente. De hecho, una de las posibles funciones de estas potentes construcciones pudo ser la de acondicionamiento de esta acusada ladera para generar superficies escalonadas sobre las mismas. Si esto fuese así, debemos suponer que buena parte de la ladera sur de la colina de la Alcazaba pudo presentar un hábitat de aspecto "típicamente fenicio", si nos atenemos a la tópica lectura urbanística que le atribuye Estrabón (III. 4. 2) para diferenciarla de la griega Mainake. Este sistema constructivo, empleado allí donde la topografía lo exige, ha sido bien documentado en yacimientos fenicios arcaicos cercanos, como Chorreras (Vélez-Málaga) (Martín y Recio 2012: 209).

En este sentido, las remociones llevadas a cabo en la ladera suroriental de la colina de la Alcazaba a inicios del siglo XX, descritos por Rodríguez de Berlanga
(Berlanga 2001: 145-153), depararon interesantes descubrimientos arqueológicos que permitieron plantear en su momento la ubicación en este punto de una parte de la ciudad antigua (Rodríguez de Berlanga 2001: 217-219). La localización años más tarde, en este mismo sector, de una domus urbana (Serrano y Rodríguez 2009: 49, nota 9), identifica para época imperial romana al menos una terraza artificial situada a una cota de 6,60 m s.n.m.

Es cierto que las recientes excavaciones en el casco urbano antiguo de la ciudad, concretamente en los solares del Museo Picasso y calle Císter, han venido a confirmar la compleja topografía antigua de la ciudad fenicio-púnica, que también se extiende al sector del río Guadalmedina continuando el antiguo poblamiento identificado en el entorno de la iglesia de San Pablo, en el malagueño barrio de la Trinidad (Mora y Arancibia 2010: 821-822). Pero los hallazgos con contexto arqueológico que comentamos de Correos Viejo insisten también en la ocupación urbana de la ladera sur de 


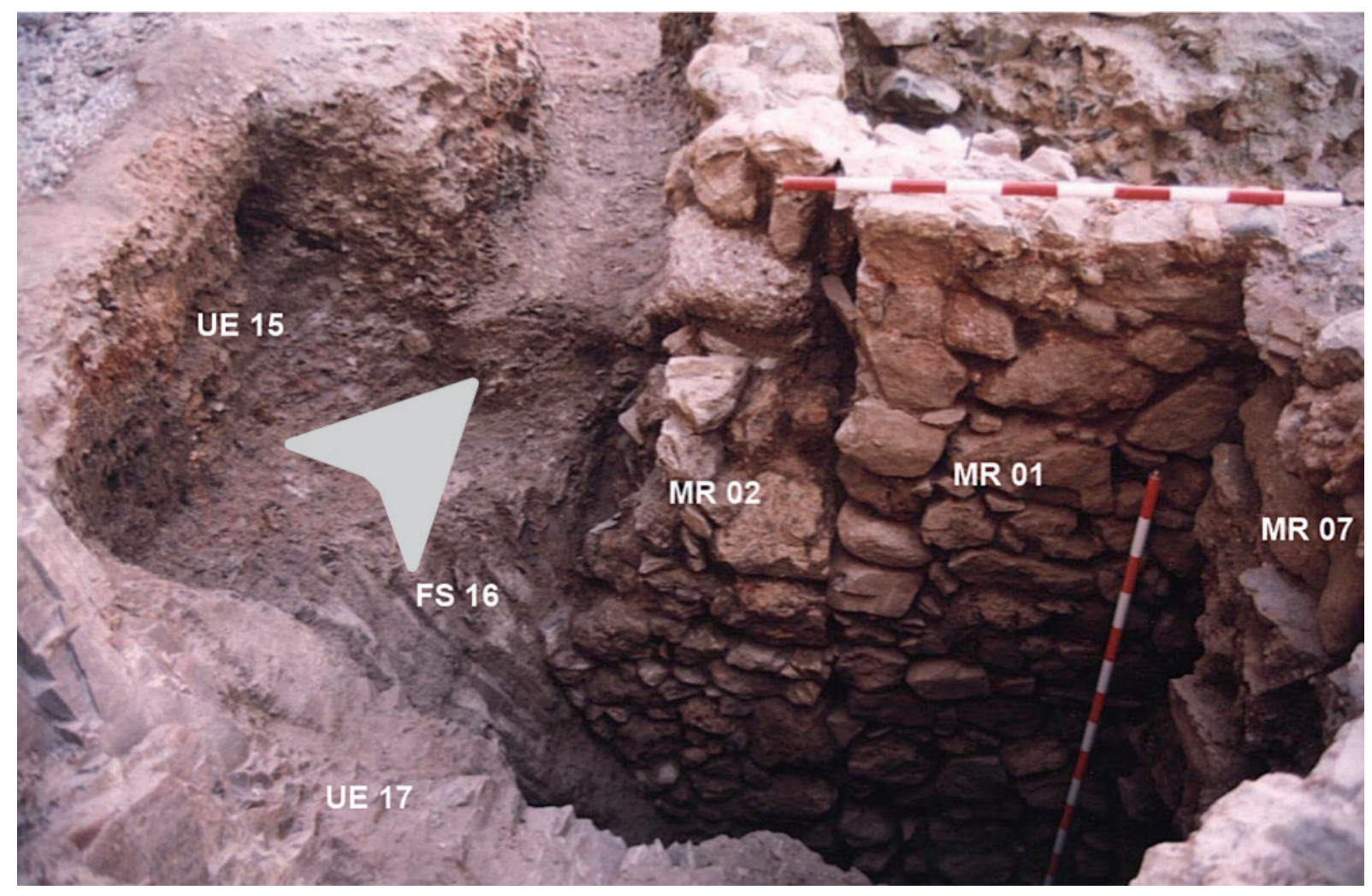

Figura 6. Detalle de la conexión entre los paramentos MR01 y MR02.

la Alcazaba, ampliando el límite de la ciudad hacia el este y dando un mayor sentido a la ubicación de la necrópolis fenicio-púnica de los Campos Elíseos, en uso al menos desde el siglo VI a.C. (Martín 2010: 82, Mora y Arancibia 2010: 820, 827).

\section{LOS MATERIALES ARQUEOLÓGICOS PROCEDENTES DE LAS UES 08 Y 09}

La cerámica contenida en los estratos objetos de estudio se caracteriza, en general, por su buen estado de conservación y por presentar escasos indicios de rodamiento. Se concentran en dos UEs: la UE08 (fig. 12) y la UE09 (figs. 13, 14 y 15). Se presenta una selección de imágenes de piezas representativas del conjunto (fig. 16).

\subsection{La cerámica a torno}

Los tipos que se estudian a continuación, de distribución por lo general amplia, han sido ya debatidos en múltiples ocasiones y ello exime ahora de dar listas exhaustivas de paralelos, que se pueden hallar en diferentes publicaciones harto conocidas. Sin embargo, para la mayoría de ellos, subyacen aún no pocas dudas que afectan de modo particular a su ajuste cronológico.

\subsection{1. Ánforas de almacenaje y transporte}

El conjunto de este tipo de contenedores se enmarca tanto tipológicamente como por sus pastas entre las producciones propias del ámbito fenicio occidental, a las que se suma una pieza de importación de taller ático.

\subsubsection{1. Ánforas fenicias de fabricación occidental.}

Los recipientes de almacenaje occidentales están representados por dos bordes de la UE08 (fig. 12.1 y 12.2) y otros dos de la UE09 (fig. 13.1 y 13.2) que, en todos los casos, se atribuyen al T-10121 (Ramon 1995: 30-231, fig. 109, 196-198), igual que las carenas de la UE08 (fig. 12.3) y de la UE09 (fig. 13.4 a 13.7). Los bordes primeros (fig. 12.1 y 12.2), son más altos (especialmente el núm. 1) y carecen de otros detalles especiales, 


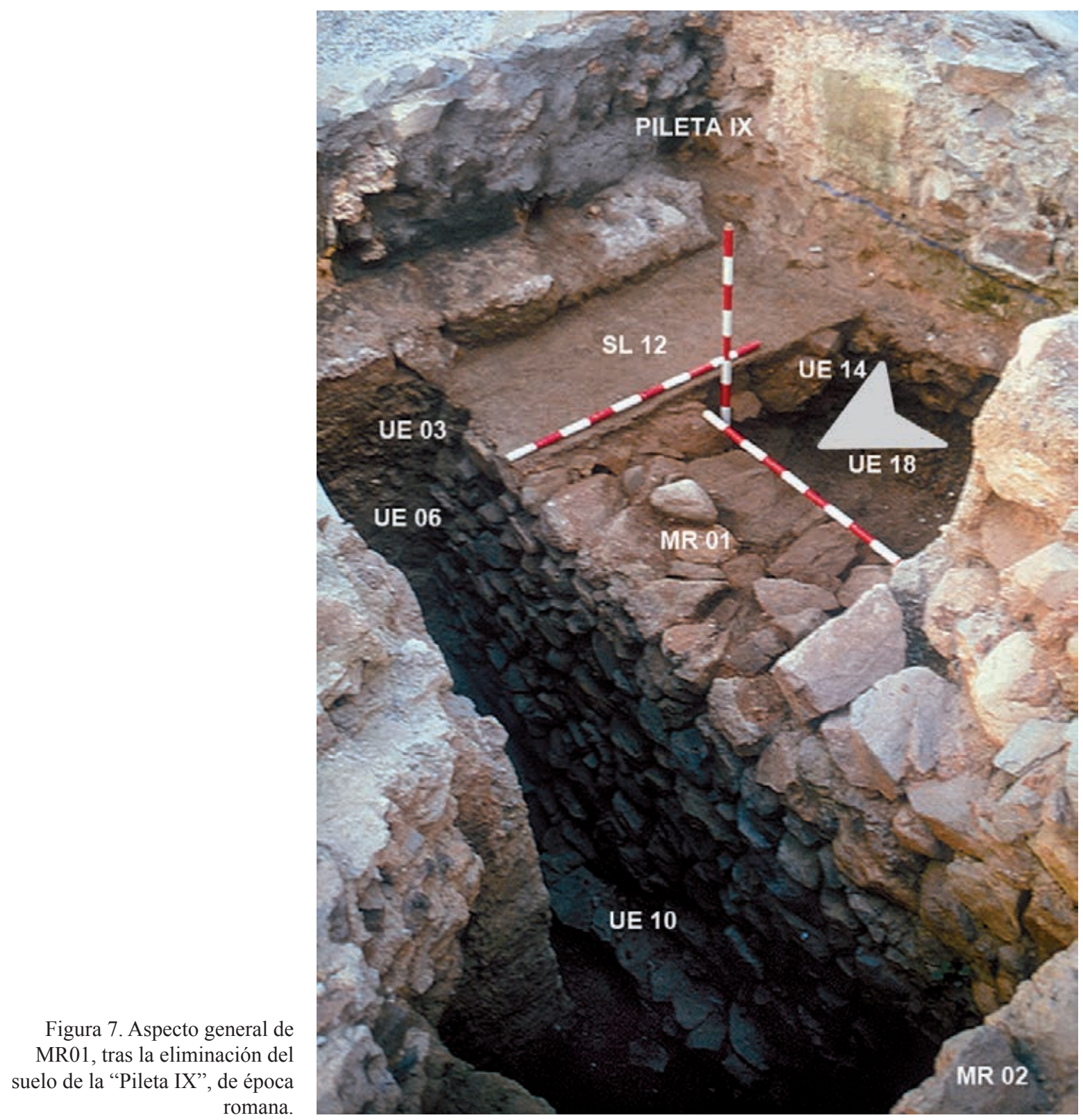

mientras que los de UE09 (figs. 13.1 y 13.2) son más bajos y de sección subtriangular; entre ellos solo el núm. 2 ofrece la típica incisión en la base externa, mientras que el núm. 1 es marcadamente oblicuo-exvasado.

No se aprecian, pues, aspectos que claramente apunten a tipos de ánforas más tardíos, como son las T-10211 (Ramon 1995: 231-232, fig. 110 y 198), sucesoras de las T-10121. Tras la publicación exhaustiva de las excavaciones de la Universidad de Alicante en el asentamiento fenicio de La Fonteta, cuya aportación al conocimiento de los complejos vasculares del siglo VII a.C. actualmente resulta clave, se comprueba que todos los tipos de borde que conforman el corto, pero significativo, repertorio anfórico de Correos encuentran similares estrictos en el numeroso material de la fase II de La Fonteta (González 2011a: 291-295, fig. 3-18), con una cronología ante quem cifrada en 650-640 a.C.

\subsubsection{2. Ánfora griega}

Se han localizado tres fragmentos (fig. 15.40 a 15.42) correspondientes a dos galbos y un trozo de cuello 


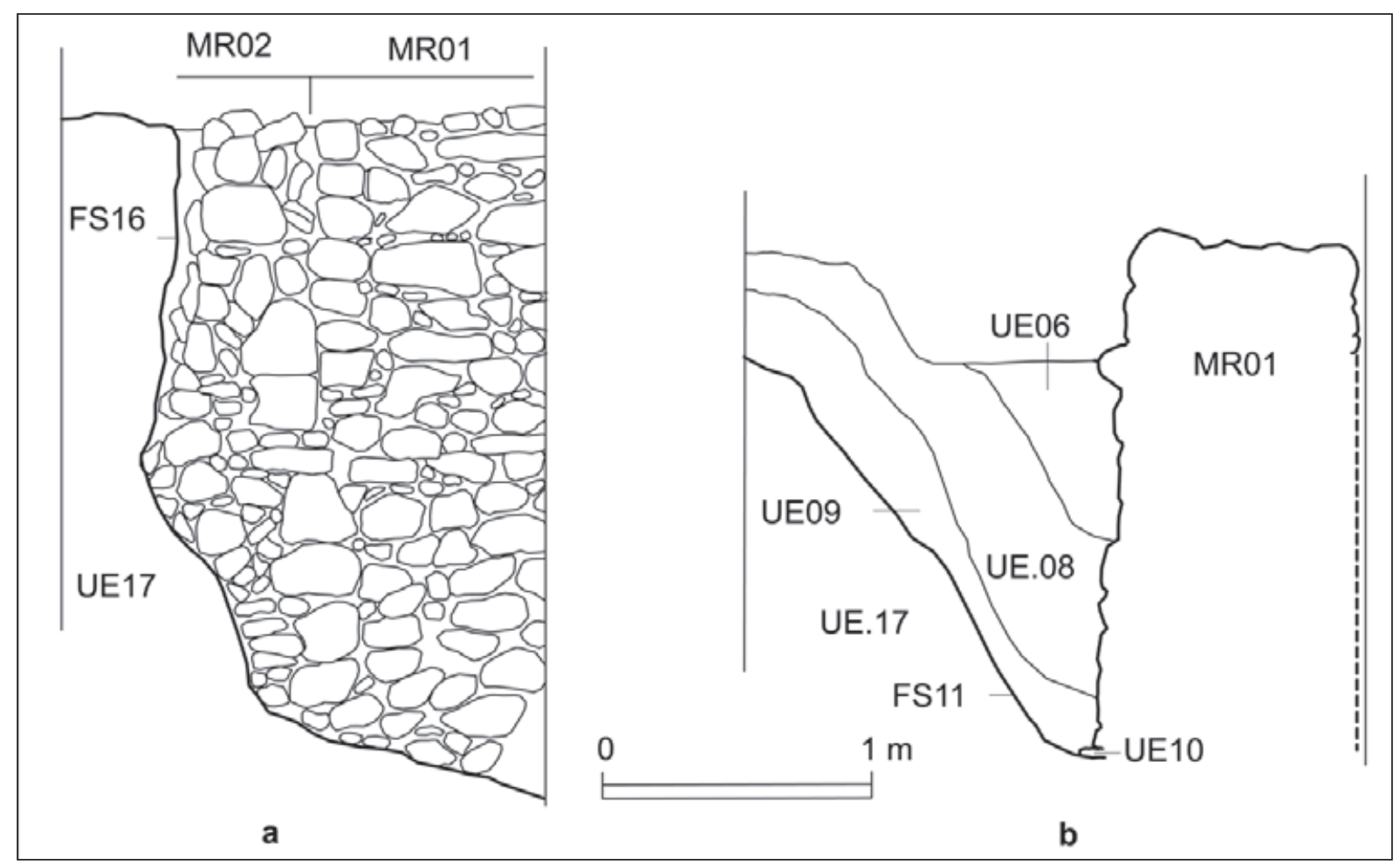

Figura 8. Alzado de la conexión entre MR01 y MR02 y perfil estratigráfico de los rellenos de la fosa de construcción de MR01.

correspondientes a un ánfora griega SOS, concretamente del tipo "ático 2" de Docter, fechable en la segunda mitad del siglo VII a.C.

\subsubsection{Contenedores de tamaño medio y reducido: jarras.}

\subsubsection{Jarras de boca ancha}

La pieza definida por un fragmento de la parte media-alta del cuerpo (fig. 13.11) pertenece a un pythos, así como de cuello y borde, con línea roja interna (¿de la misma pieza?) (fig. 13.9). La primera tiene el interés especial de presentar un motivo estrelliforme de seis radios en la parte alta, en negro, sobre franja roja y, además, cinco franjas rojas anchas y diez líneas negras conservadas.

El motivo estrelliforme tiene paralelos en un pythos de la sepultura 3 del Cortijo de las Sombras (Arribas y Wilkins 1971: 220, fig. 3, ab. izq. y lam. V), en este caso con ocho radios en cada cara, pero de distinto tamaño. En el Cerro del Villar, corte 5, estrato IV (Aubet 1999: fig. 61 f), corte 4, estrato 2 (Curià et al. 1999: fig. 137 k) y IIb (fig. 173 d-e, 184 g), también en la cerámica asociada a los enterramientos de la necrópolis de Jardín, en un caso sobre oenocoe, y en otros dos sobre jarros de un asa sobre el borde y boca ancha, en un claro ambiente de los siglos VI y V a.C., asociada a otros motivos como palmas y espigas (Schubart y Maass-Lindemann 1995: 290, p.e. figs. 19 n. 290, de la tumba 88, fig. 20 n. 336, de la tumba 101 y fig. 29, de la parte baja de la necrópolis; otro jarro de boca ancha con estrelliforme en López 1971-73: fig. 8). En la necrópolis denominada del Faro, en la isla de Rachgoun, uno de los pythoi hallados presenta dos bandas superpuestas de motivos de este tipo (Vuillemot 1965: fig. 17, tipo 2b).

Junto a ello, cabe destacar, por un lado, un fragmento de pythos de gran tamaño con decoración bícroma, que procede de la fase III del Cerro de la Era de Benalmádena (Suárez y Cisneros 1999: 108), fechada entre mediados del siglo VII e inicios del VI a.C. Esta pieza está decorada, al menos, con tres estrelliformes superpuestos de seis radios, que cabe suponer formarían bandas horizontales continuas. Cerca de la Era se localiza el Castillo de Fuengirola, sitio donde se ubicó el asentamiento de Suel, de donde procede un trozo de galbo de una posible jarra carenada decorada con motivo estrelliforme (Martín e Hiraldo 2018: 35). 


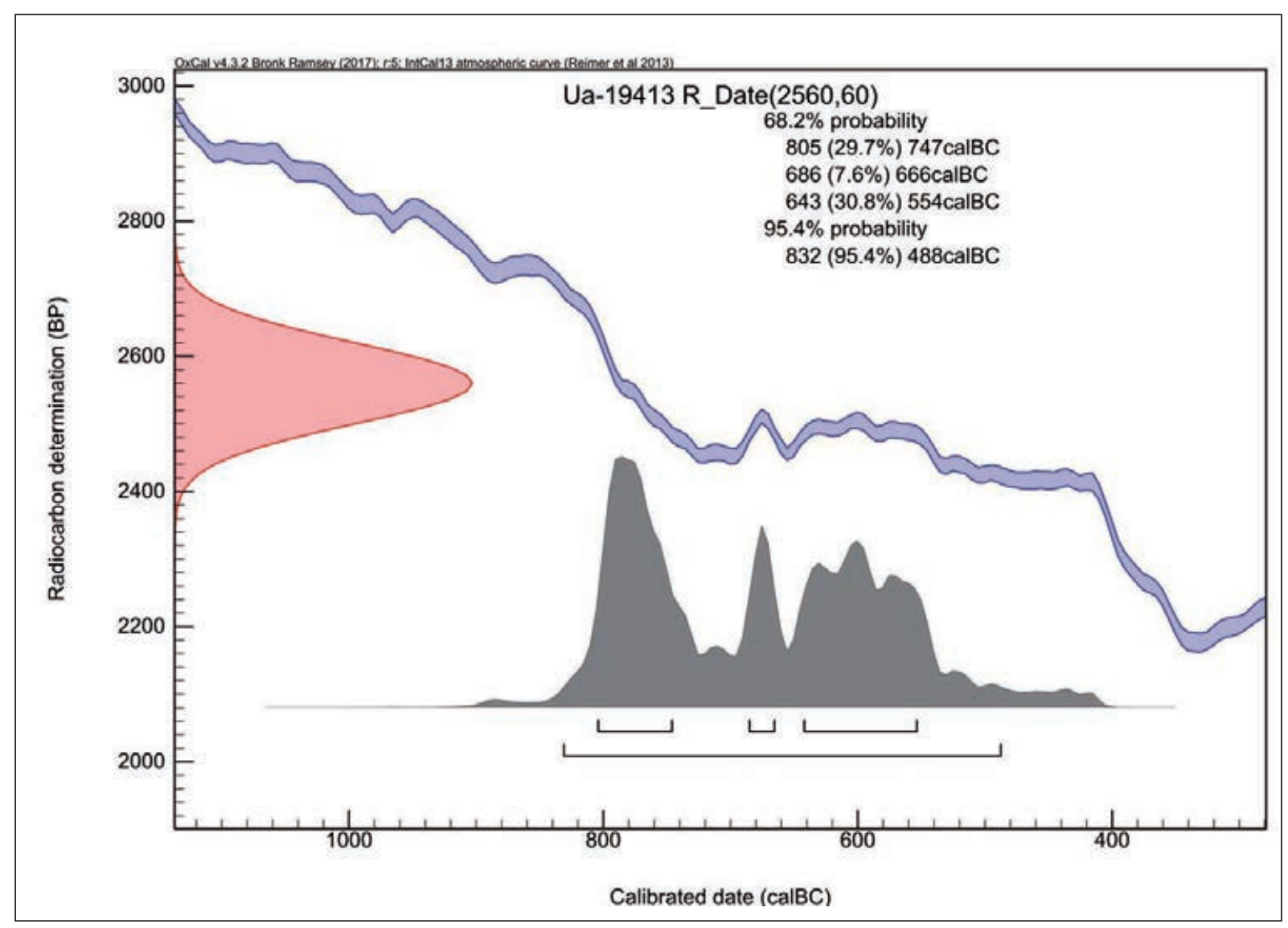

Figura 9. Datación de ${ }^{14} \mathrm{C}(\mathrm{Ua}-19413 \mathrm{R}, 2560 \pm 60$ BP), realizada sobre muestra de carbón, procedente de la UE09.

Por lo que se refiere a este motivo decorativo, cabe apuntar dos cuestiones. La primera, que al menos entre el material publicado, por ahora, se halla invariablemente sobre pythoi y nunca sobre jarras tipo Cruz del Negro; en cambio, en el siglo VI y aún después, aparece sobre oenocoes y sobre jarros de boca ancha. La segunda, que su distribución se circunscribe de modo muy estricto al área de la actual provincia de Málaga, donde se han encontrado hasta la fecha todos los ejemplos, debiéndose considerar, con toda lógica, la pieza de Rachgoun, antes mencionada, una importación malagueña.

Si bien la representación de una estrella es un motivo astral tan antiguo y extendido como sus posibles significados, cabe recordar aquí, en función de los paralelos aducidos, la recurrente presencia de este motivo en las monedas de la ceca de Malaka (Málaga) (Campo y Mora 1995: 107-113, 120-121; CNH 100.1, 102.21 ss.). La lectura iconológica que se ha propuesto para este motivo en la amonedación tardopúnica malacitana se basa en la posible interpretación de conjunto de los reversos de estas amonedaciones y su posible relación con Shamash/
Sol: astro y divinidad del panteón fenicio, pero puede que también referencia genérica al Extremo Occidente, de la que participan otras amonedaciones del entorno del Círculo del Estrecho como Gadir con la representación de Helios/Shamash de frente en sus primeras emisiones (CNH 84.14), y sobre todo la todavía problemática ceca norteafricana de mqm $\check{s} m \check{s}$. La inclusión de este nombre - ̌́mš - en alguno de los cuños de Malaka, en una emisión del siglo I a.C. asociada a un templo tetrástilo, parece insistir en una lectura mítico-geográfica para estas iconografías monetales (Mora 2011: 22), y puede que también para el motivo de la estrella en las cerámicas malacitanas que comentamos.

Al mismo tipo de vaso corresponden, además, un fragmento de la UE08 (fig. 12.5), que se circunscribe a la parte superior del cuello, con un borde fino, exvasado y horizontal, y parte del asa geminada; también un fragmento de cuerpo situado por encima de la zona de máximo diámetro (fig. 12.6) que está decorado con tres líneas negras paralelas enmarcadas por dos franjas anchas de pintura roja. 


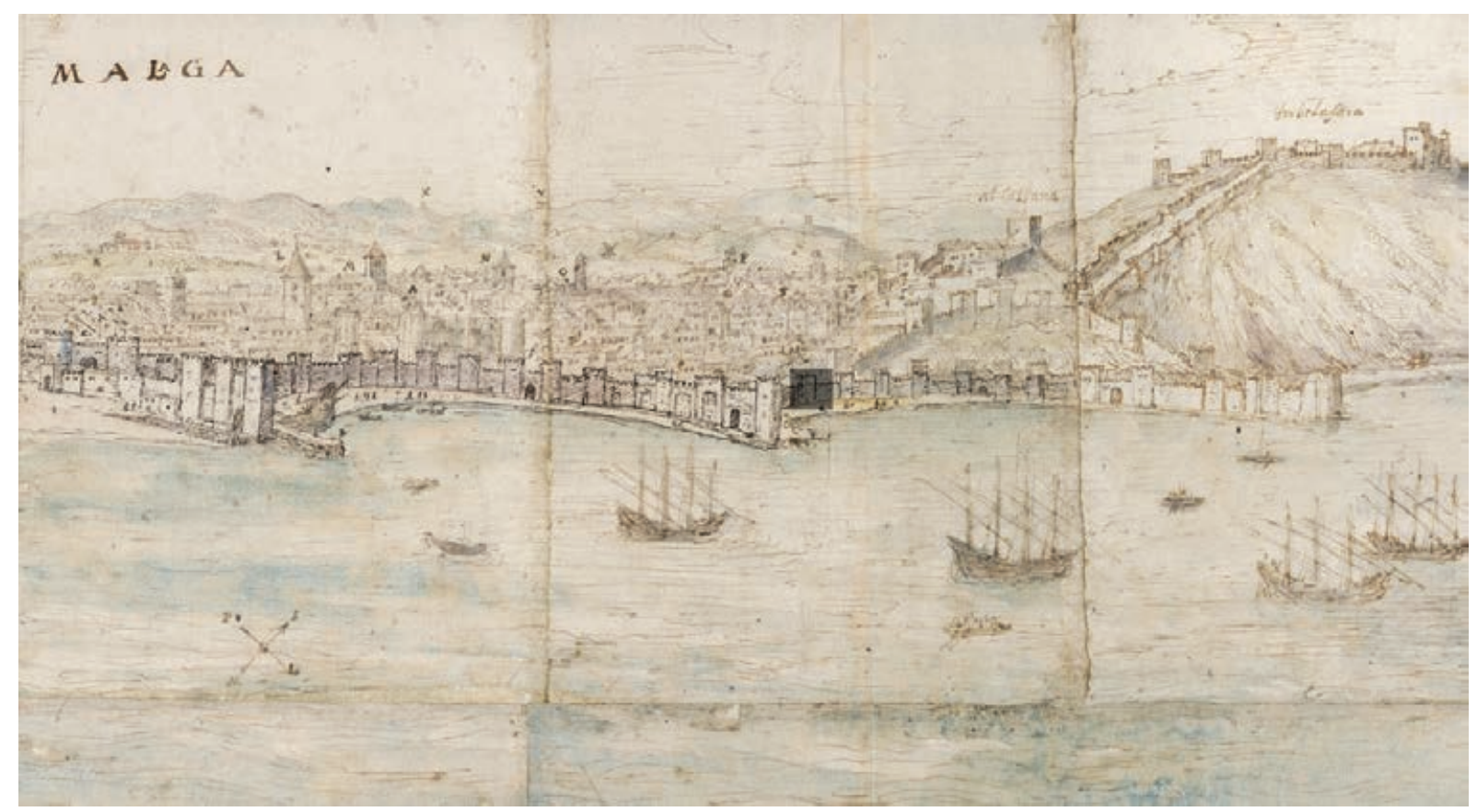

Figura 10. Vista del frente costero de la ladera sur de la colina de la Alcazaba en 1564, según A. van den Wyngaerde. Se observan, en el cuadro sombreado, las defensas medievales del denominado tercer recinto de la Alcazaba derribadas en el siglo XIX, donde se ubica al antiguo Edificio de Correos (C Ashmolean Museum, University of Oxford).

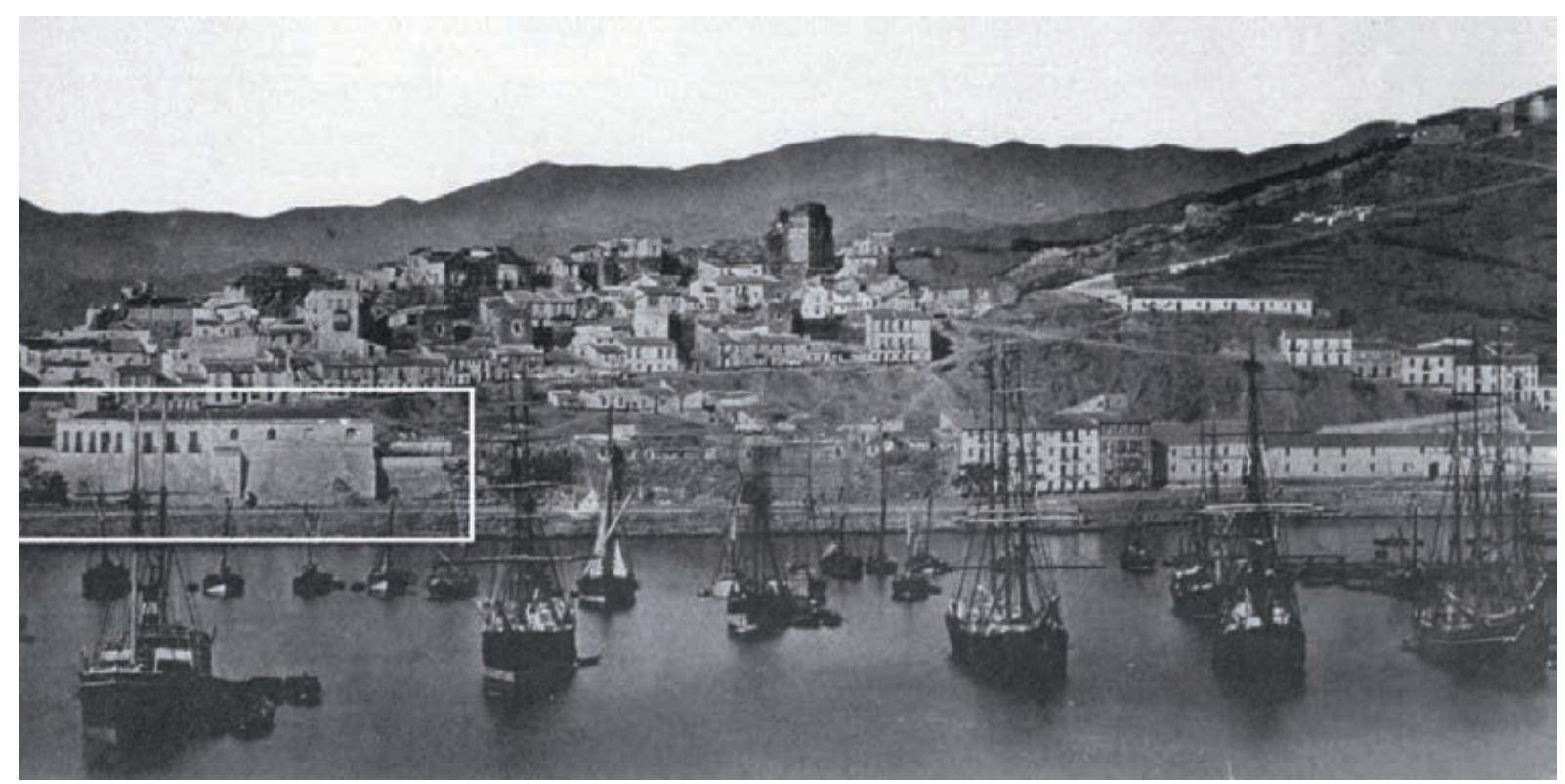

Figura 11. Imagen del sector de la ladera de la colina de la Alcazaba con anterioridad a la construcción del Edificio de Correos (Archivo Temboury. Diputación de Málaga). 


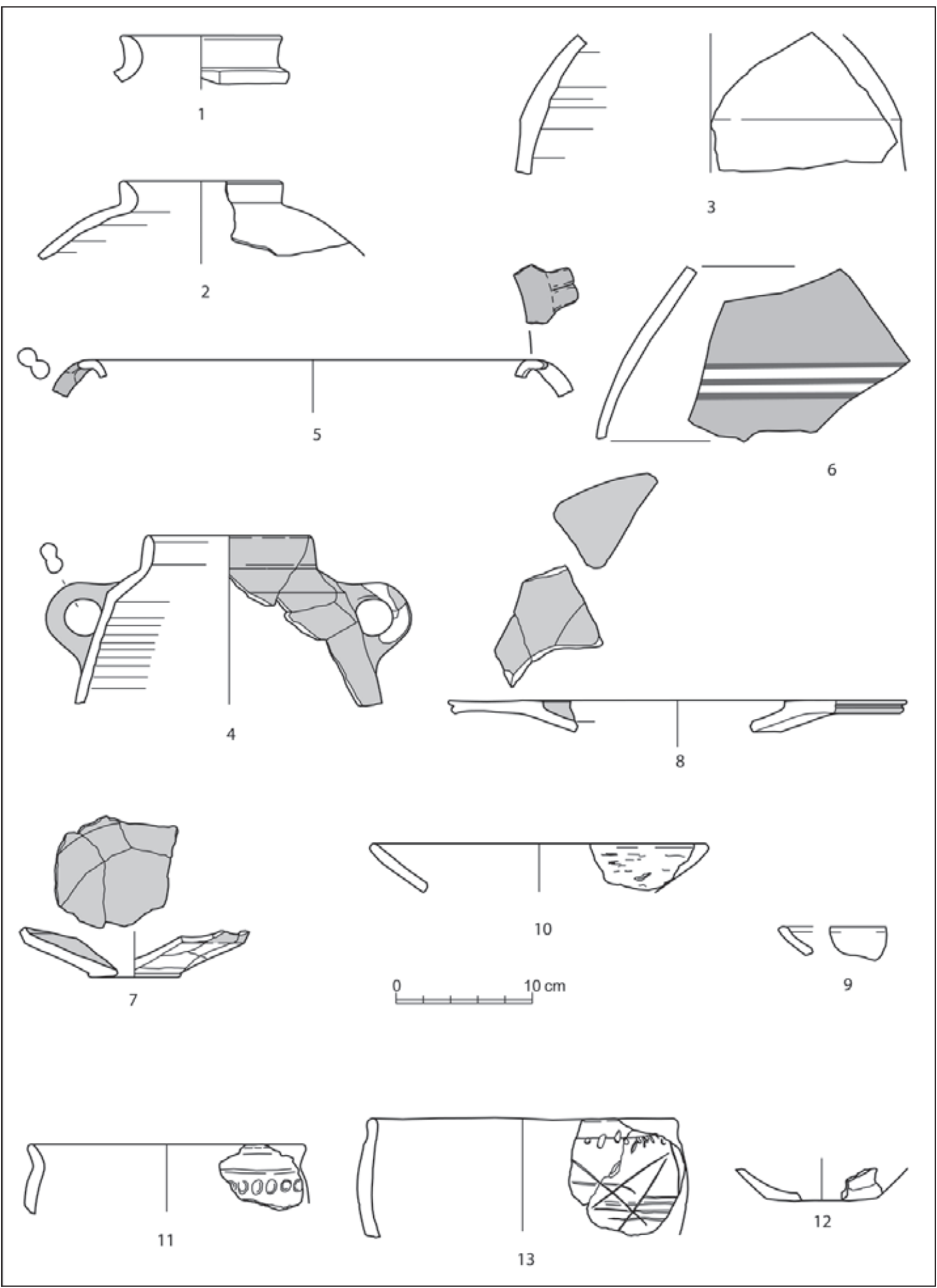

Figura 12. Materiales arqueológicos procedentes de la UE08. Cerámica a torno: ánforas (1 a 3), jarras (4 a 6), plato de engobe rojo (8), cuenco de engobe rojo (7) y cuenco gris (9). Cerámica a mano: cuenco (10) y ollas (11 a 13). 


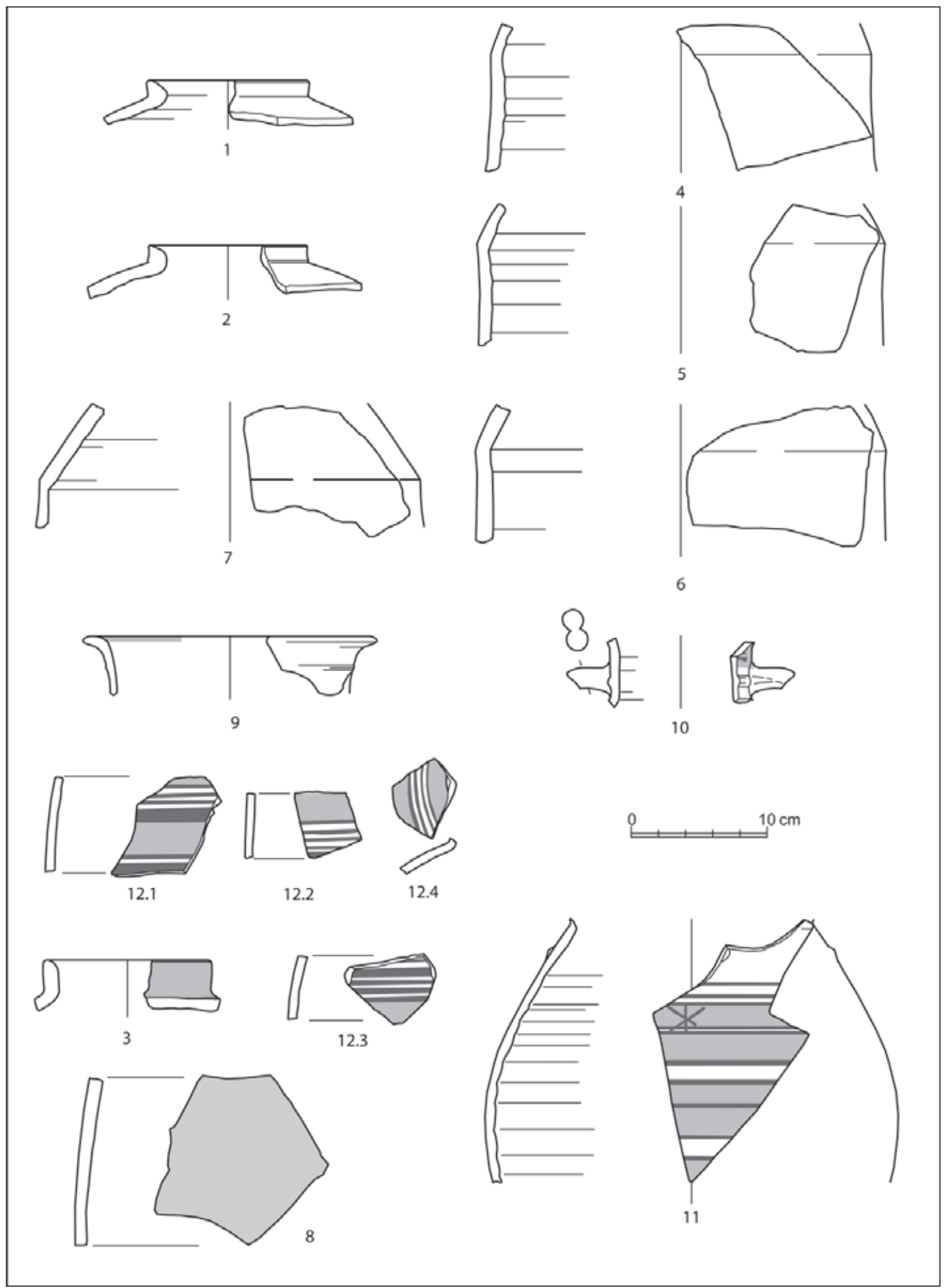

Figura 13. Materiales arqueológicos procedentes de la UE09. Cerámica a torno: ánforas (1, 2, 4 a 7) y jarras (3 y 8 a 12.4). 


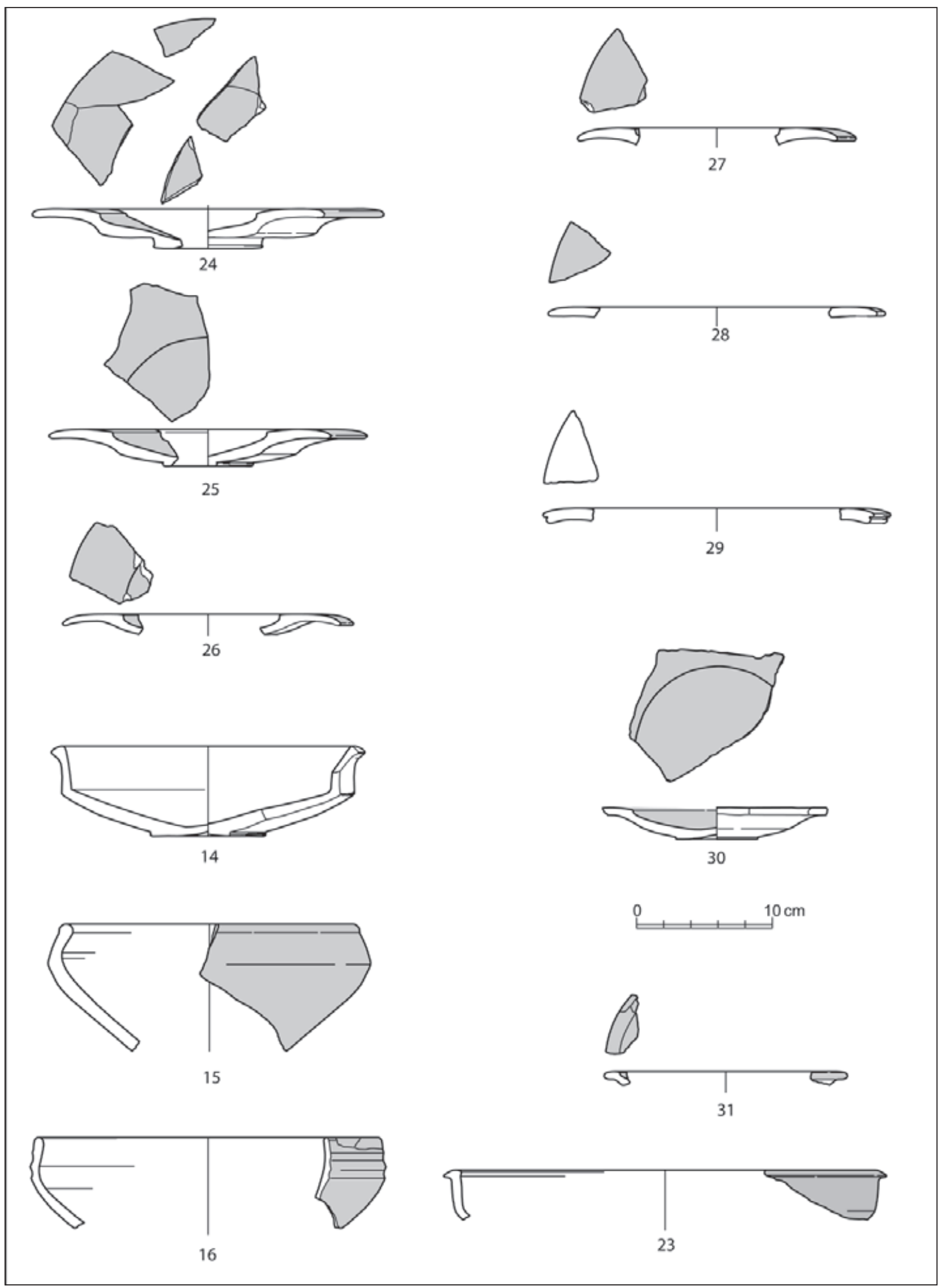

Figura 14. Materiales arqueológicos procedentes de la UE09. Cerámica a torno: platos de engobe rojo (24 a 30), cuencos de engobe rojo (14 a 16 y 23) y lucerna de engobe rojo (31). 


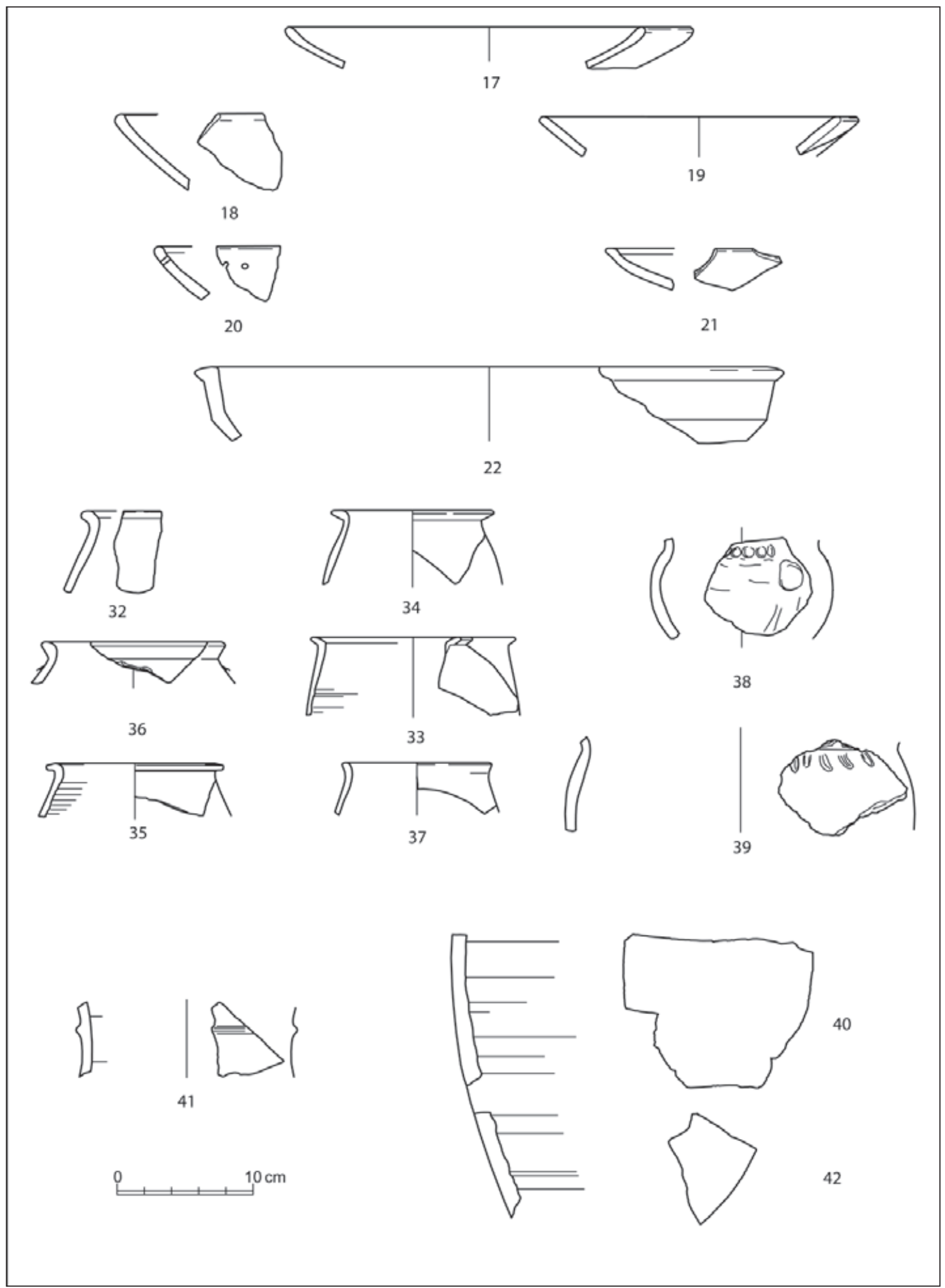

Figura 15. Materiales arqueológicos procedentes de la UE09. Cerámica a torno: cuencos grises (17 a 21), cuenco bizcochado (22), ollas a torno (32 a 37) y ánfora griega (40 a 41). Cerámica a mano: ollas (38 y 39). Varias escalas. 


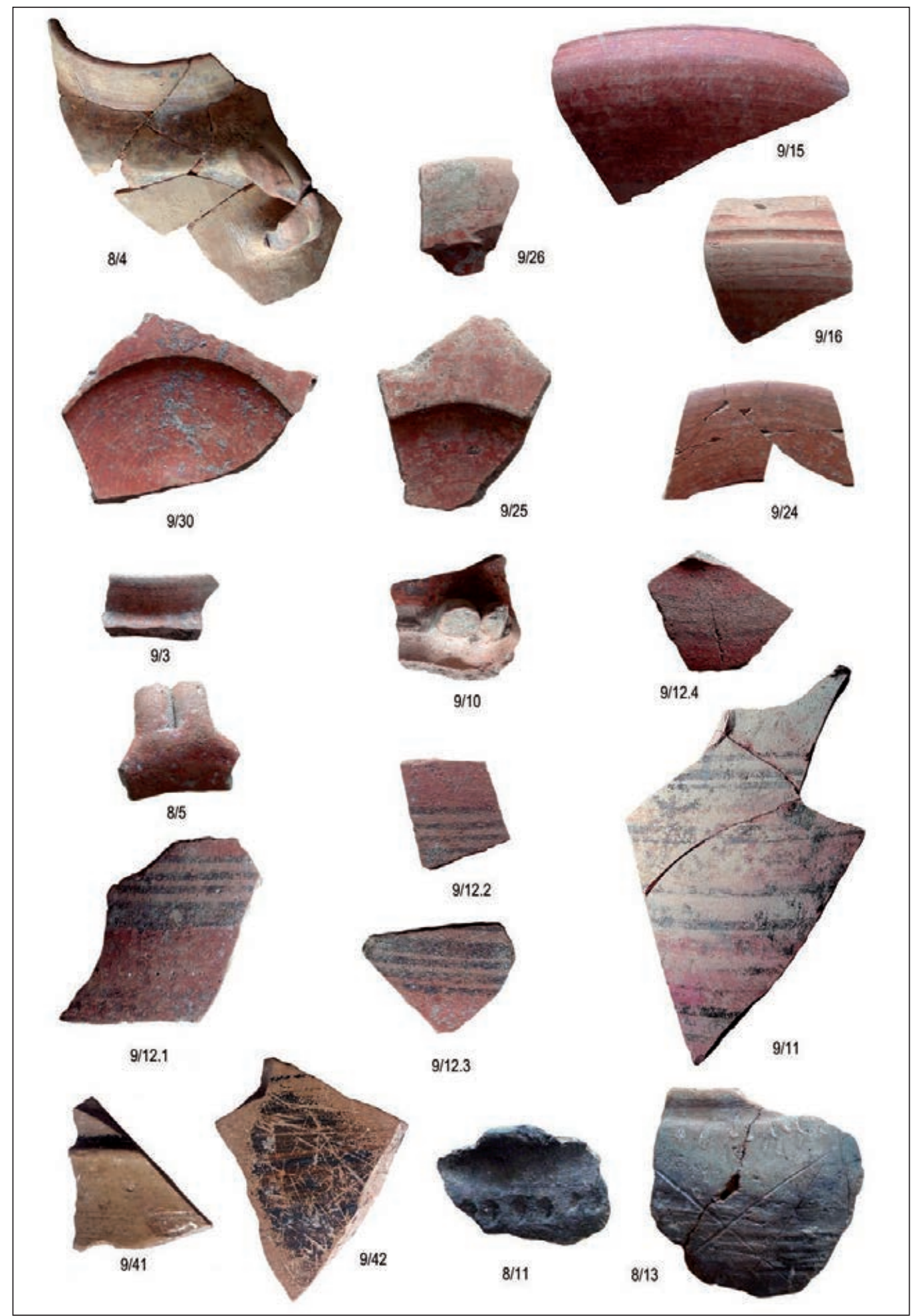

Figura 16. Selección de fragmentos cerámicos procedentes de las UEs 08 y 09 . Vajilla de engobe rojo: cuencos ( $9 / 15$ y $9 / 16)$ y platos $(9 / 24,9 / 25,9 / 26$ y $9 / 30)$; jarras: jarra de engobe rojo $(8 / 4)$ y jarras pintadas $(8 / 5,9 / 3$, 9/10, 9/11, 9/12.1, 9/12.2, 9/12.3, 9/12.4; cerámica a mano: ollas (8/11 y 8/13); ánfora griega (9/41 y 9/42) (varias escalas). 
Otros fragmentos de cuerpo, con decoración bícroma, combinando un diferente número de líneas negras, más finas, con bandas rojas más anchas, son difíciles de atribuir a este tipo de jarra o al que se describe a continuación (fig. 13.12.1 a 13.12.3).

\subsubsection{Jarras de cuello cilíndrico estrecho}

El material clasificable en este tipo vascular, denominado comúnmente "Cruz del Negro", se corresponde, por un lado, a un fragmento perteneciente al cuello y parte superior de una de las asas procedente de UE09 (fig. 13.10). Dicho cuello tiene una proyección muy vertical, con nervio, redondeado y protuberante, en la parte baja. En la zona superior una franja roja, cruzada por dos líneas discontinuas paralelas en negro; el asa es geminada.

Un fragmento corresponde a la espalda del recipiente y su tramo conservado apunta claramente a un cuerpo esférico, decorado con dos franjas anchas de pintura roja que enmarcan cuatro líneas paralelas finas de pintura negra (fig. 13.12.4).

\subsubsection{Jarras de espalda carenada}

De esta clase se documentan tres piezas: la primera (fig.13.3) se reduce a un borde, alargado, de proyección vertical, con pintura roja en su cara externa y, en la base, una raya o banda negra. Jarras de este tipo, con el mismo esquema decorativo, se documentan en Cerro del Villar, corte 4, estrato 2 (Curià et al. 1999: fig. 158 b) y en el horizonte 1a del Cerro del Prado (Ulreich et al. 1990: abb. 21,1 -con labio muy inclinado hacia dentro) y, sin embargo, aparece también ya en el horizonte 2 de la Fonteta (González 2011a: fig. 20 núm. 20167 y 53776 y 21).

La segunda, de la UE08 (fig. 12.4) conserva el perfil de todo el tercio superior, íntegramente cubierto con engobe rojo. A ella puede añadirse un fragmento de cuerpo de gran formato, igualmente con engobe rojo en la cara externa (fig. 13.8).

Sea cual sea su técnica decorativa, se trata también de un tipo vascular bien conocido en el repertorio fenicio del extremo Occidente, a partir de la excavación de las tumbas de Trayamar y, de hecho, estas jarras, al menos las decoradas por el exterior con engobe rojo, suelen denominarse tipo "Trayamar 2" (Schubart y Niemeyer 1976: 212-213, lám. 12 núm. 547, 557, 48 c, 49 c-d y lám. 16. 606, 52 b). También de la campaña de 1971 en Los Toscanos proceden otros individuos fragmentarios (Schubart y Maass-Lindemann 1984: 82-85, fig. 3 núm. 110-113).
Otros hallazgos conocidos se ubican en la sepultura 1 del sector E de Puente Noy (Molina y Huertas 1985: 129, fig. 81, lám. IX) y en las tumbas 12, 16 y 118 de Rachgoun (Vuillemot 1955: 16). En el nivel IV Mogador se señalaron no menos de diez piezas, mayoritariamente con engobe rojo por el exterior, pero algunas con bandas pintadas (Jodin 1966: 91-93, fig. 21 d, 24 c y ¿a?, pl. XXXI).

Cabe mencionar también el estudio de Roald Docter (1997), quien atribuye a su tipo CdE 2B las piezas de Trayamar, Puente Noy y Rachgoun, entre otras. Dicho trabajo tiene como base los materiales de Toscanos y Cartago, pero abarca un radio geográfico más amplio, al cual, en fechas más recientes, se han sumado los también significativos hallazgos de este tipo de sa Caleta (Ramon 2007: fig. 14 núm. I-6, 94 núm. XXXI-35) y la Fonteta (González 2011a: fig. 19 núm. 37013, 20 núm. 34979, 35853 y 11771, fig. 21), confirmando, por otro lado, cronologías anteriores al final del siglo VII a.C.

\subsubsection{Oil bottle}

Solo se ha localizado un fragmento de cuerpo en UE09 que pertenece con claridad a uno de los pequeños contenedores de cerámica común, así denominados, sin decoración o tratamiento especial. De nuevo, y a pesar de su escaso porcentaje, se trata de una de las formas clásicas de época fenicia, puesto que es raro el yacimiento de esta cultura, o de radio de acción comercial fenicia, que no esté afectado por su presencia.

A pesar de que la rotura de la pieza impide algunas precisiones morfológicas, el perfil piriforme de su cuerpo, con diámetro máximo en posición media-baja, parece indicar que se trata de una variante con el fondo de forma ojival, con o sin mamelón, que por su pasta fina y amarillenta, podría pertenecer a un taller oriental. En todo caso, se trata de una variante que, a partir de la segunda mitad del siglo VII a.C, sustituye paulatinamente otros modelos con base anular (Ramon 1982, Orsingher 2010).

\subsubsection{Platos}

Conviene abordar también bajo premisas métricas los materiales de este tipo registrados en los estratos arqueológicos objeto del presente análisis que, por otro lado, constituyen un lote significativo, que se enumera a continuación:

- Borde de proyección horizontal, con ápice simple curvo (fig.14.24). Se caracteriza, además, por una 
fuerte inflexión externa a la altura del límite interior del borde, que le confiere un perfil acentuadamente angular, por debajo de cuyo accidente el perfil es prácticamente horizontal y levemente convexo. Diám. máx. $25,9 \mathrm{~cm}$, anch. del borde $5 \mathrm{~cm}$, cociente diámetro máx. / anch. borde: 5,18.

- Borde de proyección horizontal (fig. 14.25), ligeramente sobreelevado, con ápice simple curvo. Presenta una moderada inflexión externa a media trayectoria del perfil externo. Diám. máx. 23,5, anch. del borde 4,7, cociente diámetro máx. / anch. borde: 5 .

- Borde de proyección horizontal (fig. 14.26), ligeramente colgante, más convexo que en los dos casos anteriores, con ápice simple curvo, sin inflexión externa. Diám. máx. 21,4 cm, anch. del borde 4,5, cociente diámetro máx. / anch. borde: 4,75.

- Borde (fig. 14.27) similar al anterior en sus aspectos generales. Diám. máx. 20,5, anch. del borde 4,3, cociente diámetro máx. / anch. borde: 4,77.

— Borde (fig. 14.28) semejante a los números 24 y 25, incompleto.

- Borde (fig. 14.29) de proyección horizontal, convexo, de ápice bilobulado, incompleto.

- Perfil casi completo de plato (fig. 14.30) a excepción del ápice del borde; más bien bajo.

- Borde de proyección horizontal (fig.12.8), ligeramente sobreelevado, con ápice bilobulado, trayectoria externa levemente convexa, sin aristas ni carenaciones. Diám. máx. 33,7, anch. del borde 7, cociente diámetro máx. / anch. borde: 4,8.

Se registran, además, otros pequeños fragmentos de bordes simples, fragmentos de cazoletas, de perfiles inferiores y de bases, todos ellos con engobe rojo.

Como se ha visto, la mayoría de los fragmentos de este tipo presenta una capa delgada de engobe rojo, por lo general adherente, aunque puede estar muy perdido, con tonalidades que abarcan desde el rojo-marrón castaño $(2.5 \mathrm{YR} 4 / 8)$, al rojo claro $(2.5 \mathrm{YR} 5 / 8)$ y rojo vinoso (10R 4/8), que cubre toda la cara interna y solo la parte del borde en la externa. Al exterior pueden aparecer engalbas blanco-amarillentas (5Y 8/2).

En cinco de los casos puede, con garantías, calcularse el cociente diámetro máximo / ancho del borde, que da valores entre 47 y 52, mientras que los anchos absolutos de los bordes se mueven entre 4,3-4,8 cm tres de ellos, $5 \mathrm{~cm}$ en otro caso y $6,9 \mathrm{~cm}$ en el último. En Toscanos IV, referente no exento de problemas para pleno siglo VII a.C., los anchos de borde oscilan entre 3,6 y $5,8 \mathrm{~cm}$, mientras los cocientes lo hacen entre 45 y 75 , con concentraciones entre 45 y 49 . En realidad, la considerable anchura del borde de uno de los individuos (fig. 12.8) se ve compensada por su gran diámetro, de casi $34 \mathrm{~cm}$, mientras que su arquitectura no ofrece indicios que apunten a una forma manifiestamente tardía.

Otra característica común a los platos descritos es la tendencia de los bordes a la horizontalidad con oscilaciones pequeñas y también el hecho de tratarse, en todos los casos, de piezas visiblemente poco profundas. El plato (fig. 14.24) tiene, incluso en sus detalles, un paralelo estricto en la fase Fonteta II (González 2011c: fig. 10 núm. 823).

Con la excepción de los representados en las figs. 12.8 (UE08) y 13.29 (UE09), los bordes, en todos los casos, son de ápice simple redondeado, detalle también de interés cronológico, puesto que, si bien es cierto que los estriados aparecen ya en un momento muy antiguo, lo es también el hecho que su valor porcentual no es realmente alto hasta un horizonte datable muy a final del siglo VII y en los primeros decenios del VI a.C.

El conjunto de platos estudiado entra plenamente en los parámetros de Toscanos IV y de la fase II de La Fonteta, por citar solo dos horizontes significativos y, por tanto, no es posterior a c 625 a.C., pudiendo, incluso, ser algo más antiguo.

\subsubsection{Cuencos}

\subsubsection{Cuencos carenados de borde triangular exvasado con engobe rojo}

La pieza de la UE09 (fig.14.14) tiene paralelos bastante claros en Toscanos (Schubart y Maass-Lindemann 1984: taf. 5, 152), dónde se clasifica como tipo VI2, concretamente en el estrato 2 de la habitación C de la casa $\mathrm{H}$, fechado a principios del siglo VII a.C.; en Ceuta existen materiales similares (Villada et al. 2010: fig. 66 núm. 051/80). Alfredo González lo clasifica como tipo 17, variante B2b (González 2014a: fig.70 núm. 53948, entre otros) y está bien representado en la fase II del yacimiento.

Por otro lado, y siempre dentro de este tipo, la base y fondo de UE08 (fig. 12.7) tiene paralelos estrictos en sa Caleta (Ramon 2007: fig. 44 núm. a-44). En consecuencia, estas dos piezas, datables a lo largo del siglo VII a.C., podrían ser relativamente antiguas.

Finalmente, un borde de cuenco de la UE09 (fig. 14.23) se diferencia de los anteriores por presentar una carena mucho más atenuada, con borde triangular fino y exvasado y un diámetro máximo en relación a 
la altura, mucho mayor que las piezas descritas de esta serie, en cuya órbita morfológica, y a pesar de ser distinto en detalle, parece entrar. Se conservan solo restos de barniz rojo en el extremo superior del labio.

\subsubsection{Cuenco convexo con acanaladuras exteriores}

De este tipo existe únicamente un individuo en la UE09 (fig. 14.16) que presenta, además de esta característica, engobe rojo (7.5R 5/8) que cubre solo la parte exterior, pero no la interna, como también es típico del modelo.

Se trata de un elemento vascular de perfil abierto, aunque relativamente alto, convexo y borde generalmente entrante, con una o dos acanaladuras de sección redondeada por el exterior.

La pieza de Correos corresponde al tipo C1a de Pilar Rufete (1989: 379 y 386, figs. 3 a y 7 núm. 6 y 7), definido a partir de ejemplares del cabezo de San Pedro y la calle del Puerto, núm. 6, fechados por la autora en la primera mitad del siglo VII a.C. En Toscanos, tratados con engobe rojo, fueron clasificados como tipo VIII 2b (Schubart y Maass-Lindemann 1984: 102-103, fig. 9 núm. 249 y 250). El individuo 249 pertenece al estrato $6 \mathrm{~b}$ del corte 15 , seguramente de avanzado el siglo VII a.C. Se documenta, igualmente, en el Cerro de Alarcón (Maas-Lindemann 1988: 211, lám. 19 núm. 394), pero sin contextualizar.

En el Castillo de Doña Blanca (Ruiz y Pérez 1995: fig. 20 núm. 8 -pieza excepcional por conservar el perfil casi completo-) aparece en horizontes fechados, sin más precisión, en el siglo VII a.C., aunque con posibles precedentes en el siglo VIII a.C. (id. fig. 17 núm. 8). Por otro lado, está bien documentado en el sondeo del colegio de San Agustín de Málaga (Recio 1989: 102-104, fig. 30, núm. 17B, 16, 18C,4 y 21A,4), donde los tres casos claros parecen relacionados con la estratigrafía (niveles 17, 18 y 21) correspondiente a las construcciones anteriores a la muralla, probablemente de los primeros decenios del siglo VI a.C. Existen también en Mogador (López y Habibi 2001: fig. 5 núm. 210-211), aunque con cronología menos precisa.

En Ceuta, todos los ejemplares registrados se sitúan en el techo de la secuencia (fase IIc), es decir, en el último momento estratigráfico conservado, que es próximo al 600 a.C. (Villada et al. 2010: 131, núm. 006/19, 014/139, 020/12).

Sin embargo, este tipo de pieza que, por otro lado, a veces aparece decorada con la técnica black on red, con pintura bícroma y motivos en retícula e incluso en pasta gris, se documenta en la fase II de la Fonteta (González 2014b: fig 72, 1303, f 73, 51011, tipo 40), hecho que, al menos en el área mediterránea, garantiza su presencia en horizontes anteriores a c. 650-640 a.C.

\subsubsection{Cuenco convexo con borde entrante y ligeramente engrosado}

El único individuo de esta clase (fig.14.15) presenta engobe rojo en toda su cara externa, pero no en la interior. Sin paralelos estrictos por el momento, en cierto modo podría estar emparentado con los cuencos de acanaladuras exteriores, pero sin esta característica específica.

\subsubsection{Cuencos de cerámica gris}

El material de este tipo está representado por fragmentos de UE08 (fig. 12.9) y de UE09 (fig. 15.17 a 15.21). Cinco de ellos son cuencos convexos, relativamente abiertos, cuyo borde en ningún caso se halla realmente flexionado hacia el interior y apenas pueden considerarse como engrosados, característica, esta última, común en numerosos cuencos de esta clase, a la cual, y aunque de modo atenuado, pertenece una pieza (fig.15.20).

Piezas similares a las de Correos, de borde no engrosado, se encuentran asociadas al nivel de funcionamiento del horno 1 del sector 9 del Cerro del Villar (Delgado 2011: fig. 10, 2a fila desde abajo) y aparecen en la fase II de la Fonteta, englobados en el tipo 15 de Alfredo González (2014a: fig. 17 núm. 50330, 19 núm. 33844, 20 núm. 38613, 36981, 24 núm. 52172, 26 núm. 37303, 35892, 36867, etc.).

Caso aparte es una pieza de UE09, con una cara superior moderadamente convexa y el ápice ligeramente exvasado (fig. 15.21) que responde a un tipo de borde distinto a los anteriores, no lejano al $16 \mathrm{~A}$ de la Fonteta, también enmarcado en la fase II del yacimiento (González 2014a: fig. 36 núm. 20301).

\subsubsection{Cuencos de cerámica común, carenado y borde triangular exvasado}

Es un modelo en realidad poco conocido, que existe, por ejemplo, en sa Caleta (Ramon 2007: fig. 4, S-97), aunque fuera de contexto. Tal vez pudiera asimilarse al tipo 41 de La Fonteta (González 2014b: 654, fig. 75). Sin duda se trata de un gran cuenco de procesamiento (fig. 15.22).

\subsubsection{Lucernas}

Entre el material de Correos se han documentado dos fragmentos de lucernas fenicias a torno. Uno de ellos 
(fig. 14.31), es un fragmento del borde de la cazoleta y lleva engobe rojo en su cara superior, mientras que el segundo corresponde a la parte del pliegue para formar uno de los picos y no tiene tratamiento.

En realidad, ambos carecen de otra utilidad que no sea testificar la existencia de este tipo en el complejo estudiado, sin aportar nada nuevo en cuanto a morfología o aspectos cronológicos, debido a su grado de fragmentación.

\subsubsection{Ollas de cerámica común}

Corresponden, genéricamente, al tipo Toscanos XVI-1 (Schubart y Maass-Lindemann 1984, taf. 17 y 18), Alarcón V B (Maass- Lindemann 1988: 208-209, lám 17 y 18), González 8A y 8B (borde vuelto) y son abundantes en la fase II de la Fonteta (González 2011b: 395-404, fig. 1-5), con perduraciones más escasas en las fases posteriores (fig. 15.32 a 15.37).

En todo caso, cabe señalar que el tipo, con borde más o menos saliente, se documenta ya en Las Chorreras (Aubet et al. 1979: fig. 9 núm. 119, 11 núm 155), durante la segunda mitad del siglo VIII a.C. En cuanto a su continuidad durante el VII a.C. se documenta en el Cerro del Villar, asociado al nivel constructivo del horno 1 (Delgado 2011: fig. 9).

\subsection{La cerámica a mano}

Junto a la poca representatividad numérica de este conjunto vascular objeto de análisis dentro de este horizonte de la excavación, la cerámica a mano destaca por su escasa variabilidad formal. Se documentan mayoritariamente formas cerradas, correspondientes a vasos de tamaño medio y pequeño del tipo ollas u orzas, y algunos cuencos. Se trata en todo caso de formas propias de repertorios de tradición autóctona, bien caracterizadas en recientes trabajos de síntesis sobre estas producciones en el ámbito malagueño (García 2007: 296).

En general, este tipo de vasijas suele presentar porcentajes poco significativos en los asentamientos coloniales -especialmente a partir del siglo VII a.C.- como ya se observó hace años, por ejemplo, en Toscanos, donde no alcanzaba el $3 \%$ del total del conjunto cerámico documentado en el yacimiento (Schubart et al.1969: 128). En los contextos de la propia Malaka fenicia, como Teatro Romano y San Agustín, su presencia es inferior al $1 \%$ en momentos iniciales del siglo VI a.C. (Recio 1990: 153).

\subsubsection{Las ollas}

Las ollas se caracterizan por presentar cuerpos ovoides o globulares con una suave inflexión en su extremo superior que lo separa del borde y consecuente ausencia de cuello. El borde puede ser ligeramente exvasado (fig. 12.11) o marcadamente saliente (fig. 15.38). Respecto al fondo, del que en realidad solo se conserva un fragmento (fig. 12.12), es simple y plano. Una de las piezas presenta indicios de haber dispuesto de un asa (fig. 15.38), que arrancaría bajo el borde. En el hombro es habitual la presencia de decoraciones consistentes en series de impresiones de aspecto redondeado u ovalado (fig. 12.11 y 12.13 , fig. 15.38 y 15.39), mientras que el cuerpo puede adornarse con trazos incisos (fig. 12.13).

Vasos de estas características fechados en el siglo VIII a.C. se documentan, por ejemplo, en el vecino poblado autóctono de San Pablo, localizado en la margen derecha del río Guadalmedina, donde aparecen masivamente en la UE07 (Fernández et al. 1997: 234, fig. 8.3 a 8.12). En la cuenca del bajo del Guadalhorce están presentes en Taralpe (Alhaurín de la Torre) también en momentos avanzados de la misma centuria, donde cabe señalar la presencia de ejemplares monoansados en la UE03 (Santamaría, Suárez y Ramon 2012: 199: fig. 7, $\left.\mathrm{n}^{\mathrm{o}} 1216\right)$.

En términos generales, esta forma está presente en la mayoría de los yacimientos fenicios coetáneos peninsulares, incluidos los de la propia bahía de Málaga, como el Cerro del Villar, estrato V del Corte 5 (Aubet 1999a: 60, fig. 8, s/n), correspondiente al siglo VII a.C., de donde procede un ejemplar con asa exenta, así como la ciudad de Málaga, en sitios como la ladera opuesta de la colina de la Alcazaba (Gran-Aymerich 1991: 197, n 6) o en el sondeo de San Agustín (Recio 1990: 88), ya en contextos de la primera mitad del siglo VI a.C.

Su representación dentro de los contextos coloniales ha dado pie a analizar el papel desempeñado por estos recipientes de cocina de tradición autóctona en los asentamientos fenicios, habiéndose vinculado a la presencia de poblaciones locales en los mismos, en particular a mujeres (Delgado 2008: 73).

\subsubsection{Los cuencos de casquete esférico}

Junto a las ollas, la forma predominante en los repertorios de la cerámica de tradición del Bronce Final-inicios de la Edad del Hierro son los cuencos de casquete esférico (García 2007: 276). Se trata de vasos con 
superficies poco cuidadas, con tonos grisáceos, resultado de una cocción en atmósfera irregular. Los labios pueden ser simples o ligeramente engrosados al interior (fig. 12.10).

Los mejores paralelos para esta forma se localizan en la propia bahía de Málaga, concretamente en la UE07 del poblado indígena de San Pablo (Fernández et al.1997: 226, fig. 6.9 a 6.11) fechada en momentos del siglo VIII a.C., y aguas arribas del valle del Guadalhorce están presentes en Los Castillejos de Teba (García 1994: fig. 8, a-c), asentamiento de finales de dicha centuria.

En los contextos del siglo VI a.C. de San Agustín se ha documentado un fragmento de escudilla a mano de un total de 6 ejemplares manufacturados, que en conjunto representan el $0,4 \%$ del total de la cerámica de los contextos fenicios (Recio 1990: 155, fig. 55, n 21 ), lo que ejemplifica bien la progresiva pérdida de esta tradición alfarera en los complejos vasculares coloniales entre los siglos VIII al VI a.C.

\subsection{La cronología de los complejos vasculares del horizonte inicial del solar del edificio de Correos}

El Cerro del Villar continúa siendo un referente básico para las cronología del material fenicio occidental entre el último cuarto del siglo VII, momento al cual se atribuye el estrato IV del corte 5 (Aubet 1999b:91), y los primeros decenios del VI a.C., representados por los estratos III y II del mismo corte y, en general, el estrato II del sector 3/4 (Aubet 1999b: 92-93, Curià et al. 1999), pero que otros autores (Torres et al. 2014: 79) circunscriben, aún más, entre 580-560 a.C. Otros puntos de anclaje cronológico válidos, esta vez en la propia ciudad de Málaga, vienen dados por el sondeo de San Agustín (Recio 1990) y los estratos inferiores del Teatro (Gran-Aymerich 1991), con complejos estratigráficos fechados en el primer tercio del siglo VI a.C. Tanto en unos como en otros, la presencia de significativos ejemplos de cerámicas griegas y etruscas constituye una base firme para dichas dataciones.

En el caso del estrato IV del corte 5 del Cerro del Villar, sin cerámicas de esta clase, pero perfectamente estratificado por debajo de los niveles antes citados, es también un indicio que, hasta no se demuestre lo contrario, puede avalar perfectamente la cronología del último cuarto del siglo VII a.C., sugerida por su editora (Aubet 1999b: 91).

Diversas razones, que se argumentan a continuación, inducen a fechar la fase fenicia del antiguo solar de
Correos en un momento anterior al estrato IV del corte 5 del Cerro del Villar y, por tanto, antes de c 625 a.C., siempre y cuando - cabe insistir una vez más- se considere válida la datación de dicho estrato. Del mismo modo también son anteriores, sin lugar a duda, al periodo III del Cine Cómico en Cádiz, que sus editores, con buen criterio, asignan al ventenio 600-580 a.C. (Torres et al. 2014: 79), así como al periodo I del Castillo de San Sebastián, también en Cádiz, e igualmente del 600-580 a.C. (Maya et al. 2014: 177).

El primero de estos argumentos es de carácter técnico. Por ejemplo, en el Cerro del Villar, el engobe rojo, a partir de este momento «adquiere una calidad y una dureza extraordinarias, hasta el punto de confundirse a primera vista con una capa de barniz» (Aubet 1999b: 90). En segundo lugar, destaca la total ausencia de una serie de formas que irrumpen en el escenario vascular en los horizontes citados, como lebrillos, cuencos espuerta, nuevos tipos de platos mucho más evolucionados, igual que sucede con las ánforas, que de hecho corresponden ya al T-10211 o se hallan en el punto de transición de este tipo con el T-10121. Tampoco el material de Correos refleja ningún aumento espectacular de la cerámica gris, $\mathrm{y}$, en cuanto a las pintadas, con decoraciones profusas y diversas a partir del estrato IV del corte 5 del Cerro del Villar (Ramon 2010: 227), cabe señalar que en Correos no parecen aún haber llegado a este estadio.

La mayoría de los platos de Correos refleja arquitecturas de pleno siglo VII a.C., igual que sus tamaños y proporciones. Solo en un caso -un plato, sin embargo, con un diámetro importante- tiene un borde de $6,9 \mathrm{~cm}$ de ancho, medida que se enmarcaría en el muy mal conocido, dicho sea de paso, Toscanos $\mathrm{V}$ y en los materiales contenidos en los rellenos de las tumbas de Trayamar, cuya morfología, en el caso de estos últimos, es distinta a la del plato núm. 11 de Correos. De hecho, en la Fonteta II se documentan platos con bordes incluso sensiblemente más anchos (González 2011c: tabla de la pág. 580) y cocientes aún mucho más bajos, situación que invita claramente a no rebajar excesivamente la cronología de esta pieza.

Por su parte, los cuencos grises, con bordes apenas engrosados, son relativamente abiertos y no tienen la marcada inflexión hacia el interior típica de muchas producciones de esta serie, que sin embargo, como ya se ha visto antes, se compone de modelos que se documentan desde la época de Chorreras y de Fonteta I.

Lo mismo puede decirse de las ollas globulares ansadas, algunas de las cuales, en el caso de Correos, tienen un borde particularmente saliente. A pesar de que 
cabe admitir que una subclasificación de este típico modelo es, por ahora, complicada -no se olvide la elevada proporción del material fragmentario, pero los pocos ejemplares completos-, vasos con este tipo de borde están también presentes en Chorreras y en una fase antigua del Cerro del Villar.

Otro punto de anclaje cronológico a considerar, como en cierto modo ya se ha anticipado, viene dado por la ausencia / presencia o incluso por el porcentaje relativo de determinadas cerámicas griegas. Mientras que el ánfora SOS es una pieza del siglo VII a.C. y, de hecho, un tipo de elemento habitual en un buen número de horizontes estratigráficos de esta centuria, pero siempre en un porcentaje muy pequeño, la afluencia de cerámicas de la Grecia del Este no se produce en los yacimientos del sur peninsular, sino a partir del 600 a.C., o muy poco antes, pero solo con evidencia abrumadora desde el segundo cuarto del VI a.C.

Los estratos de la excavación del Rectorado de la Universidad de Málaga parecen situarse con claridad antes de este momento y, por otra parte, son comparables en todos sus extremos con la fase II de La Fonteta, como se ha ido viendo en el análisis específico de cada una de las piezas. Por todas estas razones, la cronología que, en cifras absolutas se propone, se sitúa en el tercer cuarto del siglo VII a.C. o, más concretamente, en $c$ 650-630 a.C. Así pues, la componenda vascular que forma el complejo cerámico de los dos estratos del solar que nos ocupa, aquí estudiados, se enmarca perfectamente en el "horizonte M4", definido por uno de nosotros (Ramon 2010: 225 -226, figs. 3-4).

\subsection{Procedencia del complejo vascular}

El conjunto cerámico (salvo un par de piezas que pueden atribuirse a importaciones) corresponde a vasijas elaboradas mayoritariamente a torno, con cocciones oxidantes o con núcleo reductor y acabado oxidante. Los colores dominantes son, para la cerámica a torno, rojo claro exterior $(2.5 \mathrm{YR} 7 / 6)$ y al interior gris oliva claro (5Y 6/2). Algunas piezas presentan engalbas blanco-amarillentas ( $5 \mathrm{Y} 8 / 2$ ). El engobe rojo y la pintura empleada en pythoi y jarras abarca desde el rojo marronáceo (2.5YR 4/8) al rojo claro (2.5YR 5/8) y al rojo vinoso (10R 4/8), así como líneas en gris muy oscuro $(2.5 \mathrm{Y} 3 / 1)$, y el tono de la cerámica gris es mayoritariamente el gris claro (5Y 7/1). La cerámica a mano abarca tonos preferentemente marrones anaranjados (5Y 6/4), con manchas color gris muy oscuro (2.5Y $3 / 1)$, propio de cocciones en atmósferas irregulares.
Respecto a las pastas cerámicas, la mayoría son groseras al tacto, duras, con textura irregular en la rotura, con inclusiones abundantes, con ordenación pobre. Tras su visión con lupa digital a 10 aumentos, se observa un predominio de las partículas grises-negruzcas y parduscas, de esfericidad baja, angulosas, con tamaños de fino a grosero y muy grosero, seguidas de nódulos blanco-grises traslúcidos, de esfericidad alta, subangulosos o subredondeados, de tamaño medio a grosero. También es frecuente la presencia de partículas blanco-mate de esfericidad alta y subangulosas, de tamaño fino a grosero (fig.17).

Junto a estas pastas, hay otro grupo que se diferencia del primero por presentar tacto suave al corte, inclusiones con ordenación muy buena y naturaleza semejante a las ya descritas, aunque en este caso el tamaño de las mismas va de fino a muy fino.

A nivel macroscópico, por comparación con la geología local y especialmente por sus semejanzas con los desgrasantes empleados en los vecinos talleres del Cerro del Villar, bien caracterizados petrológicamente (Cardell 1999), se puede proponer la identificación de visu de rocas como los esquistos, arenas con cuarzo, y partículas calizas, propias de los complejos metamórficos y sedimentarios que dominan este entorno. En concreto, destaca la presencia en el conjunto de inclusiones blanco-mate, que podían corresponder a nódulos de cal, una de las señas de identidad de los alfares fenicios localizados en la desembocadura del río Guadalhorce (Cardell 1999: 18).

Respecto a la presencia de dos grupos de pastas tecnológicamente diversos, cabe señalar que aquellas que presentan desgrasantes de tamaño fino o muy fino se asocian mayoritariamente a vajilla de mesa que suele presentar engobe rojo, siendo previsible la fabricación de ambos en los mismos talleres. Esta circunstancia se constata en el propio Cerro del Villar, donde las piezas destinadas al servicio de mesa se han fabricado con escasa presencia de desgrasante y en todo caso de pequeño tamaño (Cardell 1999: 19).

En este punto, ya que es obvio en todos los casos que sus características apuntan con claridad a la actual costa malagueña, la pregunta es ¿de qué talleres exactamente? Aunque en ausencia de análisis complejos del material, como ya apuntamos, una respuesta definitiva es arriesgada, la primera posibilidad, por ahora ni contrastada ni desmentida, es que en la segunda mitad del siglo VII a.C. existieran ya talleres en el propio ámbito urbano o suburbano de la propia Málaga (Mora y Arancibia 2010: 820). La respuesta a esta pregunta deberá esperar a que la investigación 


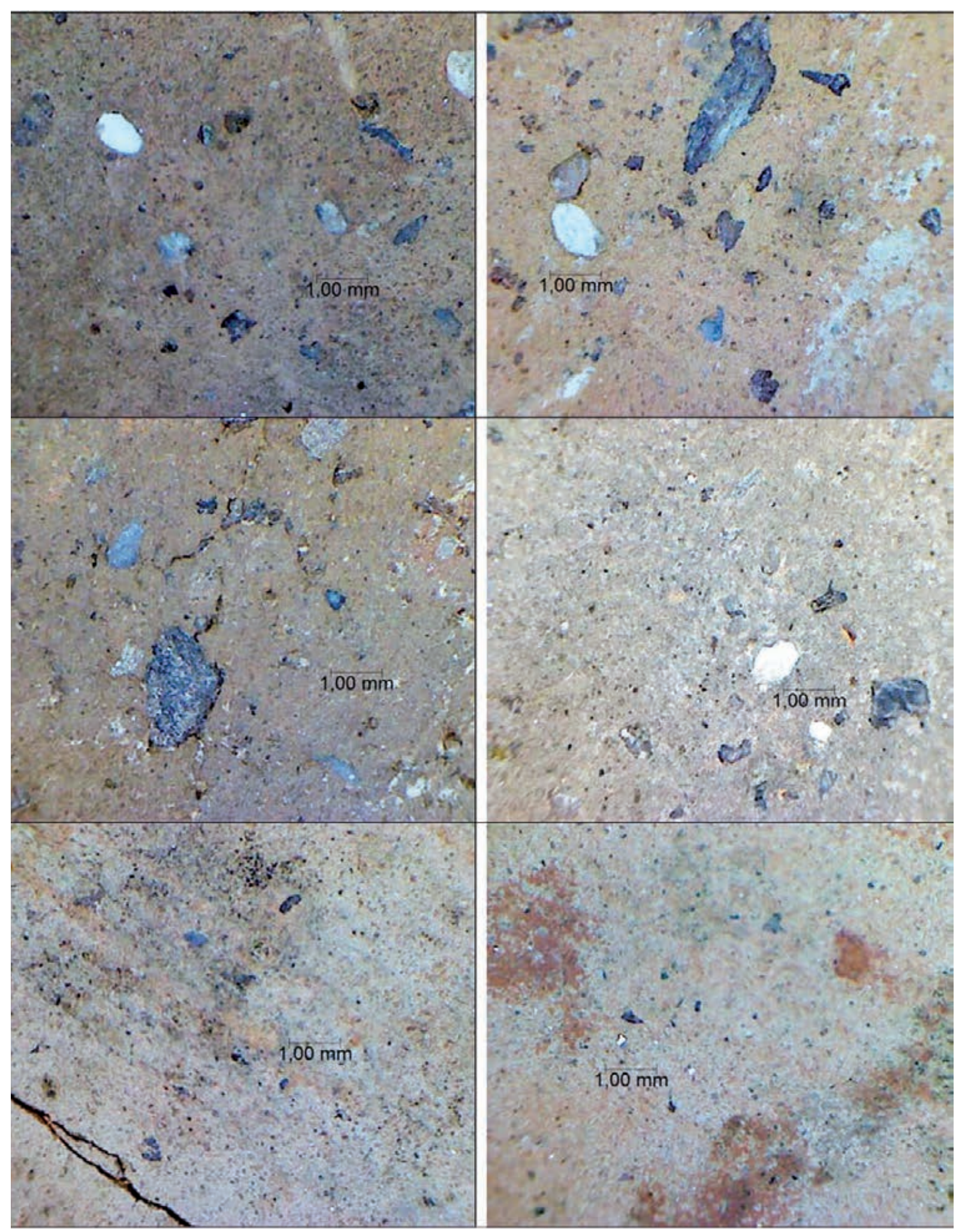

Figura 17. Detalle de pastas (x10 aumentos). Pastas groseras: $n^{\circ} 1(9 / 1)$, ánfora fenicia occidental; $n^{\circ} 2(9 / 12.3)$, jarra; $n^{\circ} 3$ (9/39), olla a mano; $n^{\circ} 4(8 / 9)$, cuenco gris. Pastas finas: $n^{\circ} 5(9 / 24)$, plato de engobe rojo y $n^{\circ} 6(9 / 26)$, plato de engobe rojo. 
avance, tanto en la exploración de nuevos solares como en estudios arqueométricos. La segunda posibilidad, no desdeñable en absoluto, sería que estos talleres se situasen en el área del Guadalhorce, a tan solo $6 \mathrm{~km}$ al oeste de la ciudad de Málaga. En este sentido, cabe no olvidar que en el enclave del Cerro del Villar se han documentado hornos cerámicos ya desde el inicio del siglo VII a.C. o, incluso, finales de la centuria anterior (Delgado 2011). Además, se cuenta con todo un complejo alfarero en el sector 3/4, que funcionó entre el final del siglo VII y el primer tercio del VI a.C. Pero, como se ve, unos por demasiado antiguos y otros por demasiado modernos, ninguno de ellos coincide en el tiempo con los conjuntos de Málaga (650-625 a.C).

La tercera y última posibilidad recurrente es el área productora costera entre los ríos Vélez y Algarrobo, territorio situado a unos 28-35 km al este de Málaga. En efecto, en estos puntos hay razones sobradas para pensar que las producciones vasculares fenicias, que hasta la fecha son las más antiguas occidentales documentadas, se iniciaron antes de mediados del siglo VIII a.C., con plena continuidad en los siglos inmediatamente sucesivos. No obstante, dado que una de las características de las pastas utilizadas en los complejos de Correos es la abundancia de puntos de cal, propia de los talleres del Guadalhorce, todo apuntaría a su probable vínculo con los localizados en la bahía de Málaga.

\subsection{Cuestiones de cuantificación}

En el presente estudio se ha realizado el doble cómputo característico, en un caso, por NR (número total de fragmentos, sin pegar) y, en otro, por NMI (número máximo de individuos, considerados aquí por bordes, con reducción a uno los que pegan entre sí), en cálculo no ponderado.

El NR global, sumando los dos estratos, es de 320 unidades (UE08: 54, UE09: 266), mientras que el NMI es de 46 (UE08: 12, UE09: 34). Se trata, por tanto, de un grupo numéricamente pequeño, pero, sin duda, no exento de significación.

Destaca, por un lado, el tema de las distintas producciones, según tecnología de fabricación (fig. 18), con el resultado, por NR: cerámica a torno 93,7\%, cerámica a mano $6,3 \%$ y por NMI: cerámica a torno $91,3 \%$, cerámica a mano $8,7 \%$.

En el ámbito de la cerámica a torno, los principales resultados obtenidos son los siguientes (fig. 19): por un lado, agrupando los vasos por categorías funcionales, el resultado es: ánforas NR 43,3\% NMI 11,9\%, contenedores medianos y pequeños NR 37,3\% NMI 9,5\%, platos con engobe rojo NR 7,7\% NMI 28,6\%, cuencos con engobe rojo NR 4\% NMI 9,5\%, cuencos grises NR $4 \%$ NMI $16,7 \%$, cerámica de procesamiento NR $0,3 \%$ NMI 2,4\%, cerámica de cocción NR 2,7\% NMI 16,7\%, lucernas NR 0,7\% NMI 4,8\%.

Si esto mismo se evalúa según categorías tecnológicas, el resultado es (fig. 20): cerámica común NR 69,0\% NMI 31,7\%, cerámica con engobe rojo NR 12,3\% NMI $43,9 \%$, cerámica gris NR 4,0\% NMI 17,1\%, cerámica pintada NR 13,7\% NMI 7,3\%, cerámica griega NR $1,0 \%$ NMI $0,0 \%$.

Un último cálculo se ha hecho con base en la procedencia de las piezas, con este resultado: cerámica a torno fenicia occidental NR 92,5\% NMI 91\%, cerámica a torno fenicia oriental NR 0,3\% NMI $0 \%$, cerámica a torno griega NR 0,9\% NMI 0\% y cerámica a mano, de tradición indígena, NR 6,3\% NMI 9\%.

Estos resultados permiten hacer algunas observaciones. La primera es que,en términos cuantitativos, el valor de la cerámica a torno frente a la de producción indígena alude con claridad a un contexto cultural puramente fenicio, semejante a lo observado en el resto de las colonias arcaicas coetáneas del Mediterráneo occidental.

La segunda se refiere a los valores porcentuales de las distintas clases funcionales. Entre estas, como se ve en los datos antes expuestos si se consideran por NR, los vasos contenedores, incluidas obviamente las ánforas, alcanzan un porcentaje de $80,6 \%$ que, en contrapartida, se ve reducido a tan solo el $21,4 \%$ por NMI. En este último terreno, los conjuntos de vajilla, categoría a la que corresponden los platos y cuencos con engobe rojo y los cuencos grises $(54,8 \%)$, superan holgadamente la mitad del conjunto total de cerámica a torno. Otro dato de interés es el porcentaje de elementos relacionados con el procesamiento de alimentos, incluida su cocción, que arroja valores de $19,1 \%$ por NMI y $2,9 \%$ por NR. Finalmente, los elementos de iluminación, como cabría esperar, tienen un porcentaje muy bajo.

De todo ello se infiere, claramente, que se trata de un conjunto vascular relacionado con prácticas de consumo doméstico, sin quedar de manifiesto ningún otro indicio de especialización distinta.

Otro aspecto también analizado aquí es el de las categorías de cerámica a torno, entre ellas la cerámica común, es decir, sin decoraciones, que por NR supera ampliamente al resto, sin embargo por NMI se halla, a su vez, superada por la vajilla con engobe rojo. Las 


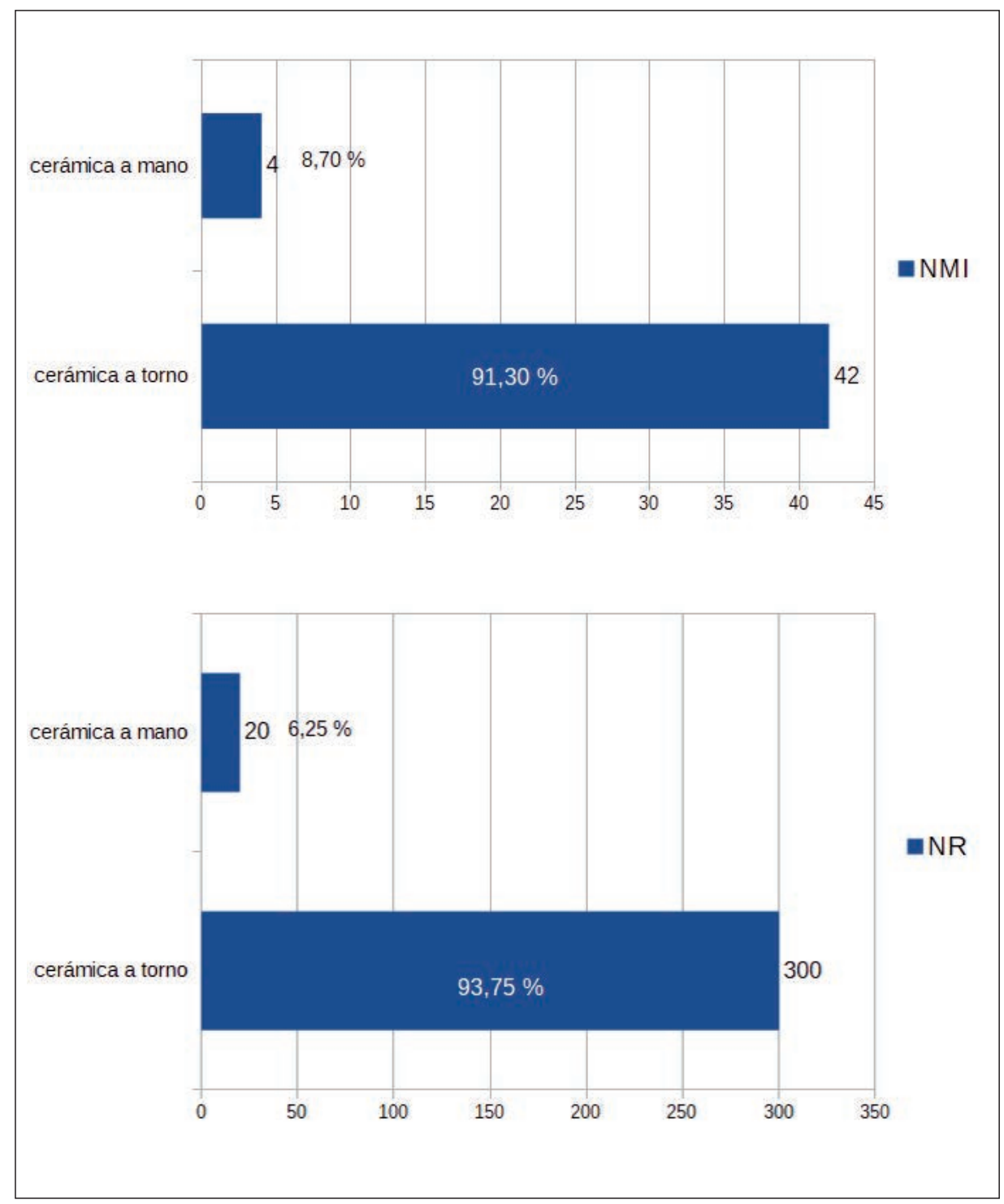

Figura 18. Porcentajes de producciones elaboradas a mano y a torno. UEs 8 y 9.

piezas de cocción reductora, aunque bien presentes, se hallan sensiblemente por debajo de las decoradas con el mencionado engobe. Finalmente, los vasos pintados no alcanzan el $15 \%$ en cualquiera de los dos sistemas de cómputo aplicados, aunque, como se ha indicado otras veces, juegan con una cierta desventaja, ya que no todas las partes del cuerpo están afectadas por la decoración.

Finalmente, queda por comentar el tema de las procedencias de la cerámica a torno, que se hallan absolutamente dominadas (NMI 100\%, NR 98,7 \%) por las producciones fenicias occidentales y en concreto del ámbito malagueño, ofreciendo las (testimoniales) oil bottles y el ánfora ática registradas una presencia normal en el panorama de cualquier asentamiento fenicio extremo occidental del siglo VII a.C.

\section{LOS DATOS DEL SOLAR DE CORREOS EN EL CONTEXTO DE LA BAHÍA DE MÁLAGA A INICIOS DE LA EDAD DEL HIERRO Y LA FASE INICIAL DE MALAKA}

El poblamiento fenicio de la bahía de Málaga destaca en el contexto del sur de la península ibérica por su antigüedad. El santuario de la Rebanadilla, situado sobre un islote localizado en pleno paleoestuario del río Guadalhorce, se remonta a momentos de la segunda mitad 


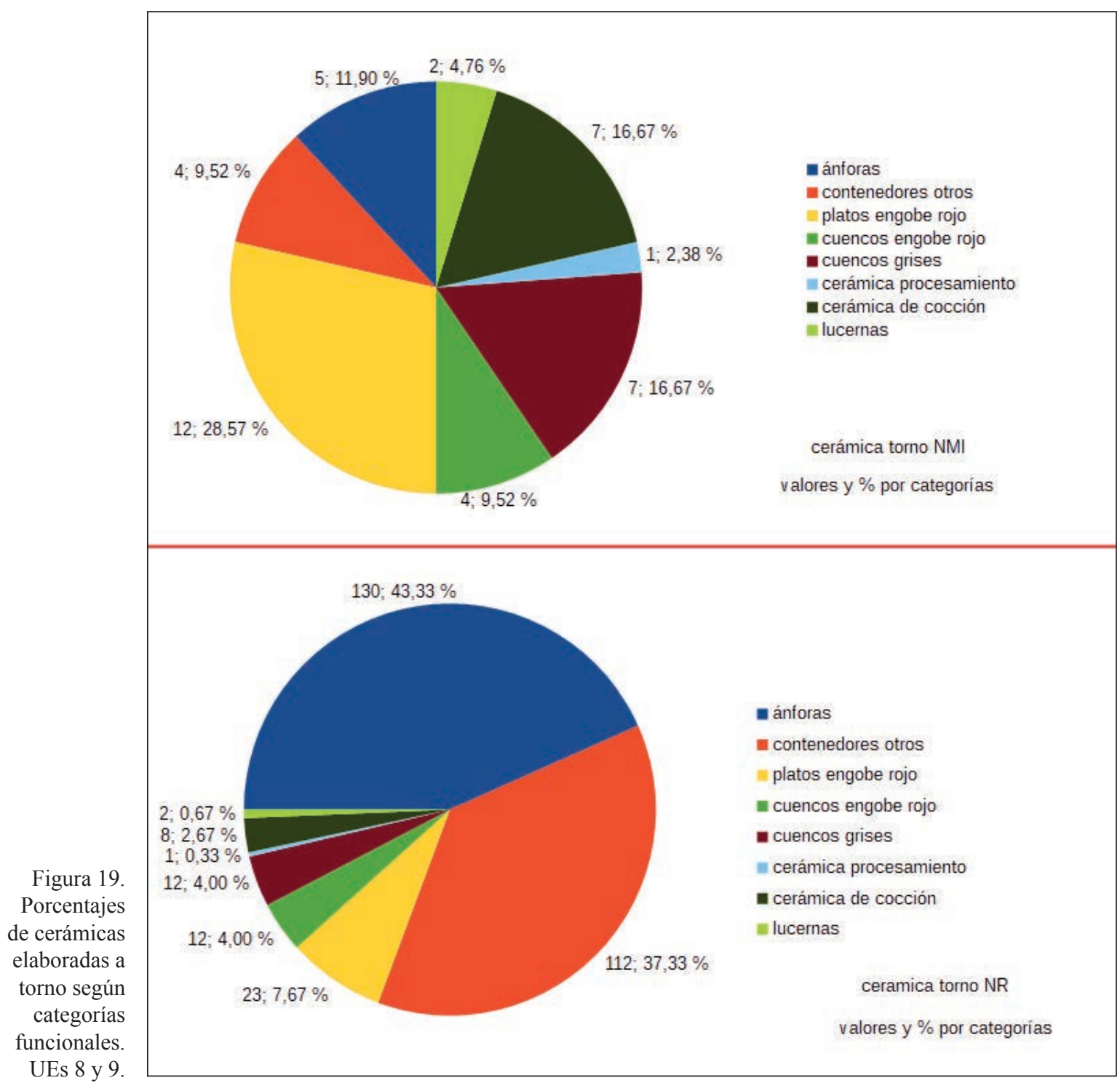

del siglo IX a.C. A finales del siglo VIII a.C. se abandonó este lugar y surgió un importante asentamiento en otra isla localizada a apenas $1,9 \mathrm{~km}$ del primero, en dirección al mar: el Cerro del Villar. Desde sus orígenes, estos sitios convivieron con poblados de origen autóctono de finales de la Edad del Bronce.

Estas circunstancias permiten analizar el ámbito malagueño como un caso concreto de paisaje colonial fenicio y su evolución en el tiempo, hasta que en el último tercio del siglo VII a.C. la propia Malaka se configurase como cabeza de territorio de toda la comarca (fig. 21).

El hallazgo de Rebanadilla fue resultado de los trabajos arqueológicos vinculados a la ampliación de una de las pistas del aeropuerto de la ciudad (Sánchez et al. 2012; Sánchez et al. 2018). Este yacimiento presenta una completa secuencia en la que se pudieron observar hasta cuatro fases bien diferenciadas, asociadas a una necrópolis dispuesta en tierra firme, el Cortijo de San Isidro. Al primer momento de actividad, denominado "Rebanadilla IV", se atribuyen una serie de fosas excavadas en el sustrato natural, donde se arrojaron diversos objetos, destacando algunos relacionados con la práctica de actividades metalúrgicas. Con poca diferencia de años tuvo lugar la fase denominada "Rebanadilla III", que corresponde ya a un asentamiento de algo más de 3 hectáreas delimitado por una cerca, con una serie de edificios construidos con adobes y ordenados por 


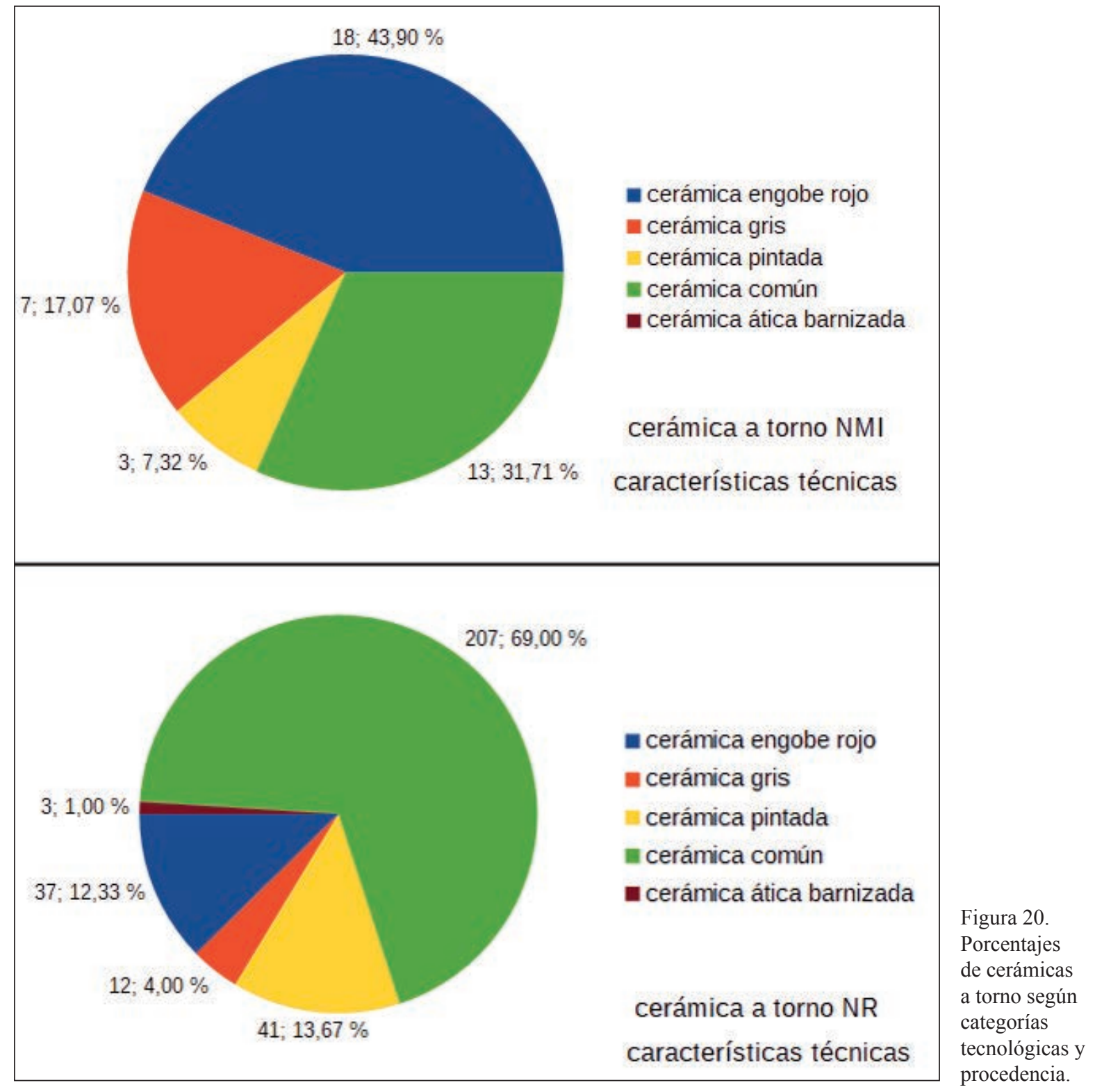

calles, que presentan planta ortogonal y diversas estancias articuladas a partir de zonas abiertas o patios. En alguno de los inmuebles han aparecido objetos que indican prácticas de actividades religiosas. La interpretación del sitio como santuario vendría avalada por el hallazgo de una serie de epígrafes de carácter sacro sobre cerámica (Sánchez et al. 2018). "Rebanadilla II" es una fase peor conocida, que se caracteriza por la presencia de edificios con zócalos de piedra y en algún caso, pavimentos de conchas marinas. Sobre los restos del antiguo poblado de Rebanadilla II se dispusieron cabañas elaboradas con materiales perecederos ("Rebanadilla I").
Respecto a la cronología propuesta para el asentamiento, sus orígenes se centran en momentos de la segunda mitad del siglo IX a.C., siguiendo tanto dataciones convencionales (basadas en la cronología aportada por un par de escifos del Geométrico Medio II) como radiocarbónicas (García 2016: 124).

El abandono de Rebanadilla se produciría en momentos de la segunda mitad del siglo VIII a.C. (Arancibia et al. 2011: 130). Por esas fechas, el asentamiento de mayor importancia en la bahía es el Cerro del Villar (Aubet et al. 1999: 47, Aubet 2018). Esta nueva colonia se fundó sobre un amplio islote con unas dimensiones cercanas a 


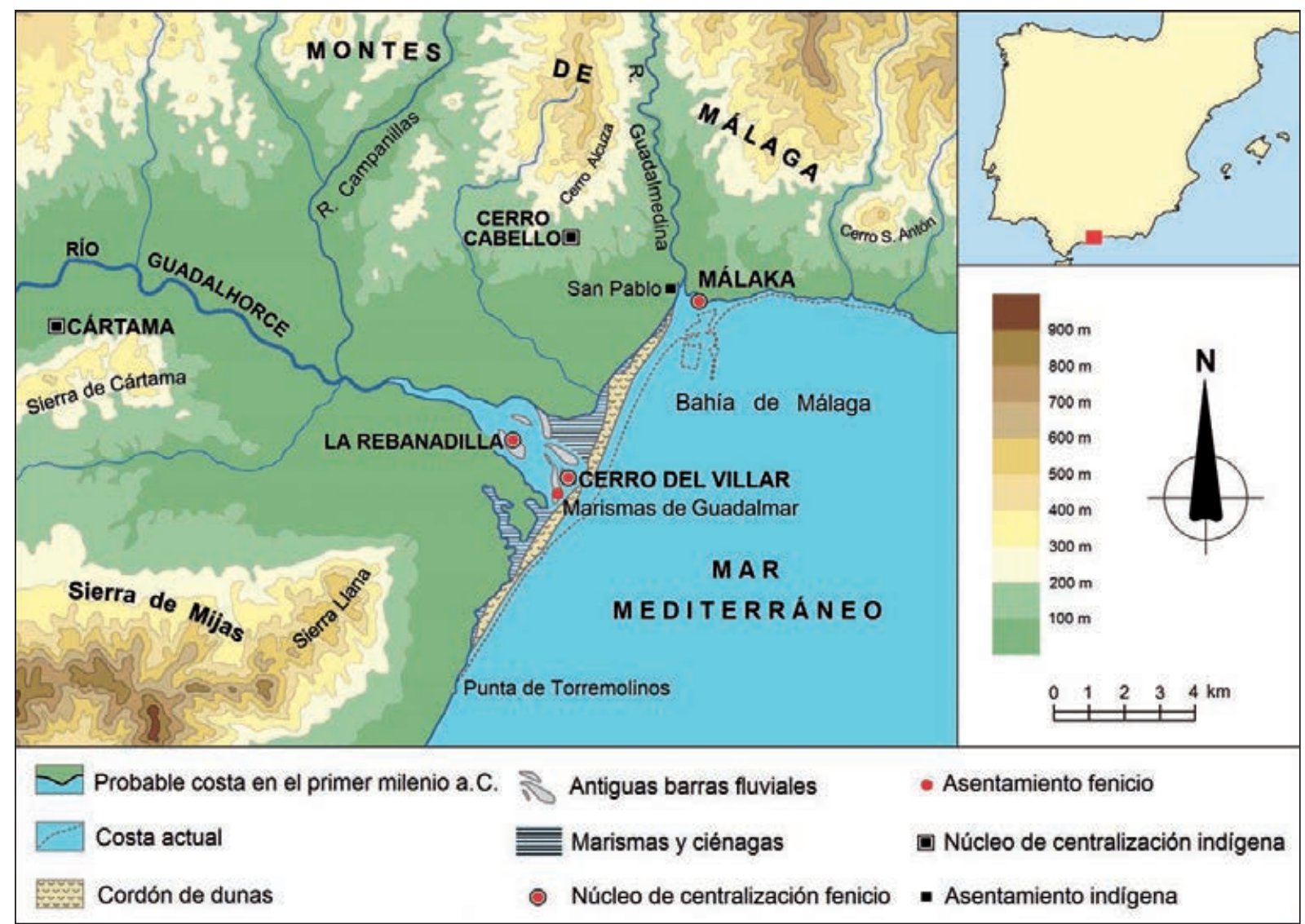

Figura 21. Poblamiento de la bahía de Málaga entre los siglos IX al VII a.C. (cortesía de E. García Alfonso).

las 10 hectáreas. En momentos avanzados del siglo VIII a.C. presentaba un urbanismo ortogonal planificado a partir de calles, algunas con $5 \mathrm{~m}$ de ancho, desde las que se accedía a grandes casas, fabricadas con zócalos de mampostería local recrecidos con adobe. Algunos de los inmuebles contaban con soportales, bajo los cuales se ha propuesto que se practicaron actividades de intercambio con la población local. También se ha constatado la presencia de talleres alfareros dedicados tanto a la fabricación de contenedores como de vajilla de mesa, así como otros destinados a actividades metalúrgicas. A partir de mediados del siglo VII a.C. y durante el primer cuarto del siglo VI a.C., el asentamiento parece orientarse específicamente a la producción cerámica (Aubet 1999b: 93).

En los primeros siglos del I milenio a.C. el segundo cauce fluvial en importancia de la bahía de Málaga, el Guadalmedina, conformaba a su vez un amplio estuario (Hoffmann 1988). En su margen derecha, sobre una suave colina de unas 5 hectáreas de superficie, entre las cotas 4 y 6 m s.n.m., se ubicó un poblado autóctono con orígenes en el siglo IX a.C., conocido como
San Pablo (Peral 2006: 213). De los primeros momentos del poblado se conocen restos de una cabaña elaborada con materiales perecederos, localizada en un solar ubicado entre las calles Tiro-Zamorano (Melero 2011: 2431). Se trata de una estructura de hábitat de planta oval, ligeramente rehundida en el sustrato geológico, con suelo de tierra apisonada y un hogar consistente en una torta de barro. Entre los niveles de colmatación se localizaron exclusivamente fragmentos de cerámica a mano, consistentes en vasos de almacenamiento de cuello corto y exvasado, junto a fuentes y copas de perfil cónico, profundo, con carenas angulosas y bordes cortos, formas presentes a su vez en los contextos más antiguos de Rebanadilla (Sánchez et al. 2012: 71, ilus. 6; 72, ilus. 8; 74, ilus. 11). También a estas primeras fases correspondería una de las fosas excavadas en la plaza de San Pablo, que aportó una fecha radiocarbónica de una muestra de carbón, la Ua-23136 (2785 \pm 45 BP), que calibrada, y con un $68 \%$ de probabilidad, se sitúa entre el 1.000 y el 840 cal BC (Arancibia y Fernández 2012: 57). Resulta 
de interés observar cómo esta datación viene a coincidir significativamente con las procedentes del santuario fenicio ubicado en el estuario del Guadalhorce (Sánchez et al. 2012: 69, fig. 2).

El poblado presenta un nuevo horizonte de ocupación, que con dataciones convencionales se sitúa en el siglo VIII a.C., detectado en la Fase II del propio solar de calle Tiro-Zamorano (UE29) y en el relleno (UE07) de otra fosa de grandes dimensiones de la plaza de San Pablo. En el primer contexto los materiales arqueológicos asociados presentan ya cerámicas fenicio-occidentales, limitadas a unas pocas categorías, entre las cuales están presentes las ánforas, alguna del tipo T-10121, junto a pythoi, cuencos y platos de borde estrecho de engobe rojo (Melero 2011: 2435, fig. 4). Respecto al segundo de los casos, la plaza de San Pablo (Fernández et al. 1997: 234, fig. 5), el conjunto cerámico asociado a este momento presenta más de un $90 \%$ de vasos realizados a mano de tradición del Bronce Final local, junto a escasas piezas torneadas fenicias, entre las que se encuentran varios fragmentos de pythoi, bordes de platos estrechos de engobe rojo y un trozo de dipper jug.

En momentos avanzados del siglo VIII a.C. se constata la creación de aldeas en el entorno del paleoestuario del Guadalhorce. Uno de los mejores ejemplos es el sitio de Taralpe (Alhaurín de la Torre) (Santamaría, Suárez y Ramon 2012), situado sobre la ladera de un arroyo subsidiario del río principal de la bahía, y próximo a las minas polimetálicas del Llano de la Plata. En este lugar se ha documentado parcialmente una amplia fosa, interpretada a priori como cabaña, donde se ha localizado un número significativo de cerámicas, entre las cuales las fabricadas a mano de tradición local siguen siendo dominantes, aunque se amplía el repertorio de producciones torneadas tanto cuantitativa como cualitativamente.

La organización del territorio durante el siglo VII a.C. es peor conocida en la comarca. En la margen derecha del Guadalmedina, el poblado de San Pablo presenta nuevas fases de ocupación, mal caracterizadas. En los solares de calle San Pablo 19 (Ferrando e Íñiguez 2011) y en el entorno de la plaza de San Pablo (Díaz 2011) se han documentado retazos de muros inconexos de edificios y espacios abiertos, en algún caso con presencia de pavimentos de conchas marinas.

En la margen izquierda del río Guadalmedina se localiza históricamente la ciudad de Málaga. En los primeros siglos del I milenio a.C. la paleotopografía de este ámbito se caracterizó por la existencia de dos promontorios: uno de mayor entidad, la colina de la Alcazaba, que funcionaría a modo de península, descendiendo suavemente hacia el mar; y otro menos pronunciado en dirección al paleoestuario del río, separados ambos por una vaguada coincidente con el trazado de la actual calle Alcazabilla (Recio 1989). En su día, se propuso una ocupación de la colina de la Alcazaba en el siglo VIII a.C., a partir del hallazgo en superficie de fragmentos de platos de engobe rojo de borde estrecho (Arteaga 1987: 213-214). Esta cronología, aportada a partir de un número mínimo de fragmentos, debe ser tomada con la correspondiente cautela (Ramon 2013: 29). Entre 1980 y 1985 se llevaron a cabo cuatro campañas de intervenciones arqueológicas en la ladera oeste de este promontorio, colindantes al extremo septentrional del graderío del teatro romano. Se constató una secuencia estratigráfica de ladera, sin evidencias constructivas, cuyos niveles más antiguos se fecharon entre el 600-580 a.C. (Gran-Aymerich 1991).

Respecto a las investigaciones realizadas en la más baja de estas dos elevaciones, hay que destacar los trabajos de excavación arqueológica llevados a cabo en el triángulo formado por los solares ubicados entre el Palacio de Buenavista, calle San Agustín y calle Císter. En el primero de los casos, las investigaciones fueron resultado de los trabajos de rehabilitación de este inmueble del siglo XVI para su actual uso como sede del Museo Picasso (Corrales 2006). La estratigrafía prerromana estaba muy alterada por la presencia de varios complejos destinados a la producción de salazones de época romana tardía (Mayorga 2006). No obstante, en determinados sectores se documentó una importante secuencia con más de $5 \mathrm{~m}$ de potencia desde el sustrato geológico. En los estratos más profundos se constató la presencia de varios momentos constructivos superpuestos identificados por tramos de muros rectos de mampostería (Fase I) e indicios de actividades metalúrgicas, que remontarían, según los investigadores, a momentos finales del siglo VII a.C. (Arancibia y Escalante 2006a: 48-50, fig. 9). Los materiales arqueológicos correspondientes a esta fase se han descrito de forma genérica. Se trata de cerámicas fenicias occidentales: vajilla de engobe rojo, formas abiertas y cerradas, junto a ánforas T-10121, así como un fragmento de un vaso griego que fue atribuido al Wild goat style -la única pieza publicada con ilustración correspondiente a los contextos más antiguos- (Arancibia y Escalante 2006a: 48, fig. 7) e interpretado recientemente como parte de un dino de taller de Quíos vinculado al Grand Style, fechado sobre el 600 a.C. (García 2018: 32-33). A esta misma fase se asoció un tramo de un potente muro, identificado parcialmente en los trabajos de seguimiento del proceso de cimentación, 
y que se ha propuesto que pudo formar parte de una primera cerca de la ciudad fenicia (Arancibia y Escalante 2006b: 356). Precisamente en este solar se han detectado restos de una vivienda fechada en la primera mitad del siglo VI a.C. (Escalante y Aguilar 2006a: 50- 51, fig. 10), amortizada por una compleja muralla con diversas fases constructivas, inmediatamente posterior (Suárez et al. 2007: 219-221).

En un solar contiguo, calle Císter 3 y San Agustín 4, una excavación con una amplia secuencia arqueológica ha proporcionado interesantes datos correspondientes al periodo fenicio-púnico. Se ha propuesto que el inicio de la secuencia arrancaría en momentos avanzados del siglo VII a.C. A una primera fase corresponden una serie de hoyos y estructuras, mal conservadas, que se han asociado con posibles indicios de actividades artesanales (Arancibia y Escalante 2006b: 344). Junto estos restos de construcciones, mal conocidas, se dispuso un inmueble con una estancia con suelo de arcilla coloreada en rojo en la que se instaló un altar del tipo del "piel de toro", y otra sala paralela con acceso pavimentado de conchas, a las que se accedía desde un pequeño patio o espacio abierto rodeado de una tapia. Estas construcciones, identificadas con el primer santuario fenicio de Malaka (Arancibia y Mora 2018: 356363), fueron amortizadas por la mencionada muralla del siglo VI a.C.

El sondeo del colegio de San Agustín fue realizado en 1986 (Recio 1989: 36) y su aportación básica fue la constatación, por primera vez, de la existencia de restos arquitectónicos fenicios en la ciudad. Dentro de la secuencia prerromana se pudieron distinguir dos fases, ambas del siglo VI a.C. La primera corresponde a una serie de estructuras que apoyaban sobre el firme de esquisto, colmatadas por depósitos con abundantes cerámicas fenicias y algunas importaciones griegas y etruscas. El conjunto se fechó en la primera mitad de dicha centuria y las estructuras se interpretaron como de carácter doméstico. La práctica antigua de actividades metalúrgicas en la zona se hizo evidente por la presencia de escorias y toberas. Estos restos aparecían a su vez amortizados por la muralla conocida en el Palacio de Buenavista y en el vecino solar de Císter.

\section{CONCLUSIONES}

Si atendemos al poblamiento de inicios de la Edad del Hierro en la bahía de Málaga, no puede desligarse la fundación fenicia de Malaka de un contexto colonial, preexistente y cercano, localizado en la desembocadura del río Guadalhorce, que queda tan solo a una distancia de poco más de $6 \mathrm{~km}$ en línea recta al oeste de la ciudad. En este ámbito, la excavación parcial de la Rebanadilla ha modificado bastante nuestra visión de la ocupación fenicia en el territorio, cuyo inicio podría retrotraerse a momentos de la segunda mitad del siglo IX a.C. (García 2016: 125). Por otro lado, el vecino establecimiento del Cerro del Villar precisa de más excavaciones y de la publicación de una serie de áreas investigadas, a los efectos de establecer no solo la caracterización de sus diversos sectores, sino también su secuencia cronológica, junto con la verificación de posibles hiatos planteados en ocasiones -según se desprende del estudio del corte 5 (Aubet 2018: 339-342)- y un tanto diluidos en otros casos (Delgado 2011). El tema de la secuencia cronoestratigráfica entre los enclaves del Cerro del Villar y de Malaka ha sido objeto de discusión, planteándose la posibilidad de una sustitución, a partir de los inicios del siglo VI a.C., del primero por el segundo (Aubet 1994: 295, entre otros trabajos).

Los datos aportados por el estudio de los niveles más profundos de la secuencia estratigráfica obtenida en la excavación del antiguo edificio de Correos, objeto de este trabajo, y su encaje en la cronología del poblamiento fenicio de la margen izquierda del río Guadalmedina, cuentan con un problema de partida: como se ha avanzado, el grueso de los materiales cerámicos recuperados en las recientes intervenciones arqueológicas de referencia, que deben sustentar el anclaje temporal con las estratigrafías antes descritas y su comparación con la que nos ocupa, está pendiente de su publicación definitiva. En este sentido, resulta fundamental ajustar las cronologías de contextos singulares previsiblemente coetáneos o poco posteriores, como el santuario de calle Císter, amortizado por la muralla púnica en momentos avanzados de la primera mitad del siglo VI a.C. Esto permitirá afinar su relación con el sitio objeto de estudio en estas páginas y ahondar en el conocimiento de esta primera fase de ocupación de Malaka.

De este modo, si se admite que Malaka ya existía, al menos, antes del 625 a.C., como se ha intentado demostrar en el presente trabajo, habría que insistir en la caracterización del poblamiento fenicio en la bahía de Málaga alrededor del tercer cuarto del siglo VII a.C., haciendo hincapié en el papel desempañado por el Cerro del Villar en estos momentos. En el estado actual de la investigación, la necesidad de nuevas excavaciones $\mathrm{y}$, desde luego, de la publicación detallada de contextos todavía inéditos, hace sumamente arriesgado cualquier tipo de hipótesis en este sentido. 
Junto a sus valiosas indicaciones cronológicas, la excavación del antiguo edificio de Correos ha aportado datos de interés topográfico para el conocimiento del primer asentamiento fenicio en la ciudad. La evidencia de muros de cierta entidad confirma la existencia de construcciones arcaicas inmediatas a la primera línea de costa. Sin embargo, cabe observar que se trata de la costa exterior, desprotegida frente a vientos y oleaje, hecho que obliga a excluir este punto como lugar portuario, más aún contándose en esta época con el amplio estuario del Guadalmedina, mucho menos sedimentado $\mathrm{y}$, evidentemente, mucho más protegido (Mora y Arancibia 2010: 821,García 2017). Esta circunstancia no es contraria, sin embargo, a su potencial uso como sitio de amarre ocasional para embarcaciones menores.

Por ello, la naturaleza de las construcciones identificadas en Correos, máxime considerando la escasez de restos documentados, resulta difícil de interpretar. Una posibilidad es que formaran parte de un sistema de hábitat escalonado y en este caso, se podría barajar la extensión del primer asentamiento fenicio a la parte baja de la ladera meridional de la Alcazaba. Cabe también recordar que, de haber existido una cerca fenicia del siglo VII a.C., como se ha propuesto en las excavaciones del Palacio de Buenavista (Arancibia y Escalante 2006b: 356), tendría que haber contado con un cierre por el extremo sureste del asentamiento desde un punto de vista estratégico, por lo que la posibilidad de vincular estas construcciones a parte de un sistema defensivo tampoco puede ser totalmente descartada, aunque supone otros problemas a la hora de interpretar el urbanismo del primer asentamiento.

En suma, puede afirmarse que el futuro de la investigación sobre la arqueología fenicia malacitana pasa por un estudio sistemático y contextualizado de todos los datos disponibles, potenciando su estudio y publicación de excavaciones antiguas, como necesario contrapeso a los desarrollos teóricos propuestos.

\section{Agradecimientos}

Agradecemos a José Luis Vera y María del Carmen Lozano las referencias básicas de la clasificación de los restos malacológicos, así como a Eduardo García Alfonso (jefe del Departamento de Difusión del Museo de Málaga, Junta de Andalucía) el estudio de los fragmentos de ánfora griega, objeto de una futura publicación específica por parte de este investigador.

Esta publicación forma parte de los resultados del proyecto de investigación I+D (HAR2015-68669-P), financiado por el Gobierno de España.

\section{BIBLIOGRAFÍA}

Almagro-Gorbea, M. (2013): "La 'Tumba de Melqart' del Herákleion de Gadir". Madrider Mitteilungen 54: 159-202.

Arancibia, A.; Escalante, M. M. (2006a): "La Málaga fenicio-púnica a la luz de los últimos hallazgos". Mainake XXVIII: 333-360.

Arancibia, A.; Escalante, M. M. (2006b): “Génesis y consolidación de la ciudad de Malaka". Memoria Arqueológica del Museo Picasso Málaga: desde los orígenes hasta el siglo V d.C.: 41-78. Málaga, Museo Picasso-Málaga.

Arancibia, A.; Galindo, L.; Juzgado, M.; Dumas, M.; Sánchez, V. M. (2011): "Aportaciones de las últimas intervenciones a la arqueología fenicia de la Bahía de Málaga”, en M. Álvarez (ed.), Fenicios en Tartesos: nuevas perspectivas. BAR International Series 2245: 129-149. Oxford, Archaeopress.

Arancibia, A.; Fernández, L.E. (2012): "El periodo fenicio arcaico en la Bahía de Málaga”, en E. García (ed.), Diez años de arqueología fenicia en la provincia de Málaga (2001-2010). Monografías-Arqueología: 49-66. Sevilla, Junta de Andalucía.

Arancibia, A.; Mora, B. (2018): "Malaka before the Polis: a Colonial Emporium of the 7thC. BC Inheritor of the Archaic Phoenician Settlement on the Guadalhorce River Mouth", en M. Botto (ed.), De Huelva a Malaka. Los fenicios en Andalucía a la luz de los descubrimientos más recientes. Collezioni di Studi Fenici 47: 351369. Roma, Consiglio Nazionale delle Ricerche.

Arnold, F.; Marzoli, D. (2009): "Toscanos, Morro de Mezquitilla und Las Chorreras im 8. Und 7. Jh. v. Chr: Siedlungsstruktur und Wohnhaustypologie", en S. Helas, D. Marzoli (eds.), Phönizisches und punisches Städtewesen. Iberia Archaeologica 13: 437-460. Mainz, P. von Zabern.

Arribas, A.; Wilkins, J. (1971): "La necrópolis fenicia del Cortijo de Las Sombras (Frigiliana, Málaga)". Pyrenae 5: 185-244.

Arteaga, O. (1978): "Problemática general sobre la iberización en Andalucía Oriental y en el Sudeste de la Península", en Simposi Internacional: El origens del món ibèric (Barcelona, Empúries, 1977). Ampurias 38-40: 23-60.

Aubet, M. E. (1994): Tiro y las colonias fenicias de Occidente, Edición ampliada y puesta al día. Barcelona, Crítica.

Aubet, M. E. (1997): “Un lugar de mercado en el Cerro del Villar", en M. E. Aubet (coord.), Los fenicios en Málaga: 197-221. Málaga, Universidad de Málaga. 
Aubet, M. E. (1999a): "La secuencia arqueo-ecológica del Cerro del Villar", en A. González (ed.), La cerámica fenicia de occidente. Centros de producción $y$ áreas de comercio. Actas del I Seminario Internacional sobre temas fenicios: 41-68. Guardamar del Segura (1997), Alicante, Instituto de Cultura Juan Gil-Albert.

Aubet, M. E. (1999b): "La estratigrafía del corte 5", en M. E. Aubet, P. Carmona, E. Curià, A. Delgado, A. Ferrnández Cantos y M. Párraga, Cerro del Villar I. El asentamiento fenicio en la desembocadura del río Guadalhorce y su interacción con el hinterland, Arqueología. Monografías: 76-127. Sevilla, Junta de Andalucía.

Aubet, M. E. (2018): "La colonia fenicia del Cerro del Villar", en M. Botto (ed.), De Huelva a Malaka. Los fenicios en Andalucía a la luz de los descubrimientos más recientes, Collezioni di Studi Fenici 48: 325-349. Roma, Consiglio Nazionale delle Ricerche.

Aubet, M. E.; Maass-Lindemann, G.; Schubart, H. (1979): "Chorreras. Un establecimiento fenicio al este de la desembocadura del río Algarrobo". Noticiario Arqueológico Hispánico 6: 89-138.

Aubet, M. E.; Carmona, P.; Curià, E.; Delgado, A.; Fernández, A.; Párraga, M. (1999): Cerro del Villar - I. El asentamiento fenicio en la desembocadura del rio Guadalhorce y su interacción con el hinterland, Arqueología. Monografías. Sevilla, Junta de Andalucía.

Barresi, P. (2007): Metrologia púnica. Lugano, Athenaion.

Cabrera, P. (1994): “Importaciones arcaicas del Cerro del Villar (Guadalhorce, Málaga)", en P. Cabrera, E. Sanmartí, R. Olmos Romera (eds.), Iberos y griegos: Lecturas desde la diversidad. Simposio Internacional. Ampurias (1991). Huelva Arqueológica XIII: 97-121.

Chacón, C.; Salvago, L. (2005): “Actividad arqueológica en la antigua Casa de Correos y Telégrafos. Integración de los restos excavados en la sede de la Universidad de Málaga (1998-2002)". Anuario Arqueológico de Andalucía 2002, III, 2: 18-28. Sevilla, Junta de Andalucía.

Campo, M.; Mora, B. (1995): Las monedas de Malaca. Madrid, Fábrica Nacional de Moneda y TimbreMuseo Casa de la Moneda.

Cardell, C. 1999: “Anexo V. Arqueometría de las cerámicas fenicias”, en M. E. Aubet, P. Carmona, E. Curià, A. Delgado, A. Ferrnández Cantos y M. Párraga, Cerro del Villar - I. El asentamiento fenicio en la desembocadura del río Guadalhorce y su interacción con el hinterland. Arqueología-Monografías: 1-23. Sevilla, Junta de Andalucía.

Cisneros, M. I.; Suárez, J.; Mayorga, J.; Escalante, M. M. (2001): "Cerámicas griegas arcaicas en la Bahía de Málaga”, en P. Cabrera, M. Santos (coords.), Ceràmiques jònies d'època arcaica: centres de producció i comercialització al Mediterrani occidental: actes de la Taula Rodona:189-206. Empúries (1999), Empúries, Museu d‘Arqueologia de Catalunya.

$\mathrm{CNH}=$ Villaronga, L. (1994): Corpus Nummum Hispaniae ante Augustiaetatem. Madrid, J. A. Herrero.

Corrales, M. (2006): "Introducción”, Memoria Arqueológica del Museo Picasso Málaga: desde los orígenes hasta el siglo V d.C.: 14-18. Málaga, Museo Picasso-Málaga.

Corrales, M.; Corrales, M. P. (2012): "Malaca: de los textos literarios a la evidencia arqueológica", en J. Beltrán Fortes, O. Rodríguez Gutiérrez (coords.), Hispaniae urbes. Investigaciones arqueológicas en ciudades históricas. Serie Historia y Geografía 203: 363-402. Sevilla, Universidad de Sevilla.

Curià, E.; Delgado, A.; Fernández, A.; Párraga, M. (1999): "El taller alfarero de principios del siglo VI a.C. 2. Estudio de los materiales cerámicos”, en M. E. Aubet, P. Carmona, E. Curià, A. Delgado, A. Ferrnández Cantos y M. Párraga, Cerro del Villar - I. El asentamiento fenicio en la desembocadura del rio Guadalhorce y su interacción con el hinterland: 157-277 Arqueología- Monografías. Sevilla, Junta de Andalucía.

Delgado, A. (2005): "Multiculturalidad y género en las colonias fenicias de la Andalucía mediterránea: un análisis contextual de las cerámicas a mano del Cerro del Villar (Málaga)", en V Congresso Internazionale di Studi Fenici e Punici III: 1249-1260. Marsala - Palermo (2000), Palermo, Università degli Studi.

Delgado, A. (2011): "La producción de cerámica fenicia en el extremo Occidente: hornos de alfar, talleres e industrias domésticas en los enclaves coloniales de la Andalucía mediterránea (siglos VIII-VI a.C.)", en Yoserim: la producción alfarera feniciopúnica en Occidente. Treballs del Museu Arqueològic d'Eivissa i Formentera 66: 9-48. Eivissa. Museo Arqueológico de Ibiza y Formentera.

Díaz, M.J. (2011): “Intervención arqueológica preventiva en la parcela UE 3, 4.31 del PERI TrinidadPerchel (Málaga, Barrio de la Trinidad)". Anuario Arqueológico de Andalucía 2004, III.2: 3498-3508. Sevilla, Junta de Andalucía. 
Docter, R. F. (1997): Archaische Amphoren aus Karthago und Toscanos. Fundspektrum und Formentwicklung ein Beitrag zur phönizischen Wirtschaftsgeschichte. Amsterdam, Proefschrift Universiteit van Amsterdam.

Fernández, L. E.; Suárez, J.; Navarro, I.; Cisneros, M. I.; Mayorga, J.; Rambla, A.; Arancibia, A.; Escalante, M. M. (1997): "Un poblado indígena del siglo VIII a.C. en la bahía de Málaga. La intervención de urgencia en la plaza de San Pablo", en M.E. Aubet (coord.), Los fenicios en Málaga: 215-251. Málaga, Universidad de Málaga.

Ferrando, M.; Íñiguez, M.C. (2011): “Resultados de la intervención efectuada en la calle de San Pablo $\mathrm{n}^{\circ}$ 19, en Málaga". Anuario Arqueológico de Andalucía 2004, III.2: 3449-3457. Sevilla, Junta de Andalucía.

Florido, D.D.; Navarrete, V.; Ramírez, J.D.; Ruiz, N.; Sabastro, M.A. (2012): "Un hipogeo con forma de piel de toro a orillas del Guadalmedina. Málaga", en E. García (ed.), Diez años de arqueología fenicia en la provincia de Málaga (2001-2010): 121-136. Monografías Arqueología. Sevilla, Junta de Andalucía.

García, A.; Prados, F. (2014): "La presencia fenicia en la Península Ibérica: el Cabezo Pequeño del Estaño (Guardamar del Segura, Alicante)". Trabajos de Prehistoria 71.1: 113-133. doi: <https://doi. org/10.3989/tp.2014.12127>.

García, E. (1994): “Los Castillejos de Teba (Málaga). Campaña de 1993. Estratigrafía de los siglos VIIIVII a.C.". Mainake XV-XVI: 45-83.

García, E. (2007): En la orilla de Tartessos. Indígenas y fenicios en las tierras malagueñas. Siglos XI-VI a. C. Málaga, Fundación Málaga.

García, E. (2016): “Las primeras importaciones griegas en Occidente y la cronología de la cerámica geométrica hacia un nuevo paradigma (I)". Menga. Revista de Prehistoria de Andalucía: 101-132.

García, E. (2017): “Aproximación a los fondeaderos fenicios de la bahía de Málaga y su evolución: paleografía y arqueología”, en M. Martínez, J.M. García, J. Blánquez, A. Iniesta (eds.), Mazarrón II. Contacto, viabilidad y perspectivas del barco $B-2$ de la bahía de Mazarrón. Homenaje a Julio Mas García: 341384. Mazarrón, Universidad Autónoma de Madrid.

García, A. (2018): "Málaka en los siglos VII-VI a.C. Los orígenes de una ciudad-estado fenicia occidental", en D. García, S. López, E. García (eds.), La tumba del guerrero. Un enterramiento excepcional en la Málaga fenicia del siglo VI a.C.: 2474. Arqueología Monografías. Sevilla, Junta de Andalucía.
Gener, J. Ma; Navarro M.-Á.; Pajuelo, J.-M.; Torres, M.; López, E. (2014): "Arquitectura y urbanismo de la Gadir fenicia: el yacimiento del "Teatro Cómico" de Cádiz", en M. Botto (ed.), Los fenicios en la Bahía de Cádiz. Nuevas investigaciones, Collezione di Studi Fenici 46: 14-50. Pisa - Roma, Fabrizio Serra.

González, A. (2011a): "Las ánforas (Tipos 1 a 6)", en A. González (coord. y ed.), La Fonteta. Excavaciones de 1996-2002 en la colonia fenicia de la actual desembocadura del río Segura (Guardamar del Segura, Alicante) 1. Seminarios Internacionales sobre Temas Fenicios: 291-374. Alicante, Universidad de Alicante.

González, A. (2011b): “Ollas monoansadas (Tipo 8)", en A. González (coord. y ed.), La Fonteta. Excavaciones de 1996-2002 en la colonia fenicia de la actual desembocadura del río Segura (Guardamar del Segura, Alicante) 1. Seminarios Internacionales sobre Temas Fenicios: 395-416. Alicante, Universidad de Alicante.

González, A. (2011c): "Platos de ala (Tipo 18)", en González, A. (coord. y ed.) La Fonteta. Excavaciones de 1996-2002 en la colonia fenicia de la actual desembocadura del río Segura (Guardamar del Segura, Alicante) 1. Seminarios Internacionales sobre Temas Fenicios: 573-657. Alicante, Universidad de Alicante.

González, A. (2014 a): "La cerámica a torno: Tipos 12 a 21 ", en A. González (coord. y ed.), La Fonteta-2. Estudio de los materiales arqueológicos hallados en la colonia fenicia de la actual desembocadura del río Segura (Guardamar, Alicante) 2, 1. Seminarios Internacionales Sobre Temas Fenicios: 426552. Alicante, Universidad de Alicante.

González, A. (2014 b): "La cerámica a torno: Tipos 2332, 35-42 y 44-48”, en A. González (coord. y ed.), La Fonteta-2. Estudio de los materiales arqueológicos hallados en la colonia fenicia de la actual desembocadura del río Segura (Guardamar, Alicante) 2, 2. Seminarios Internacionales Sobre Temas Fenicios: 573-671. Alicante, Universidad de Alicante.

Gran-Aymerich, J. M. J. (1991): Málaga phénicienne et punique. Recherches franco-espagnoles 19811988. Paris, Recherche sur les Civilisations.

Hoffmann, G. (1988): Holozänstratigraphie und Küstenlinienver-lagerung an der andalusischen Mittelmeerküste. Fachbereich Geowissenschaften der Universität Bremen 2. Bremen, Universität Bremen.

Jodin, A. (1966): Mogador, comptoir phénicien du Maroc atlantique. Tanger, Éditions marocaines et internationales. 
López, F.; Habibi, M. (2001): “Le comptoir phénicien de Mogador: Approche chronologique et céramique à engobe rouge", en Actes des lères Journées Nationales d'Archéologie et du Patrimoine: 53-63. Rabat (1998), Rabat, Société Marocaine d'Archéologie et du Patrimoine.

Maass-Lindemann, G. (1982): Toscanos. Die Westpönikische Niederlassung an der Mündung des Rio de Vélez. Lieferung 3. Grabunpskampagne 1971 und die impordatierte Westphönikische Grabkeramik des 7/6 J.H.S V. CHR. Madrider Forschungen 6. Berlin, P. von Zabern.

Maass-Lindemann, G. (1988): "Alarcon. Vorbericht über die Funde aus der Grabungskampagne 1984", en O. Arteaga Matute, C. Briese, R. Bahnemann (eds.), Forschungen zur Archäologie und Geologie im Raum von Torre del Mar, 1983/84. Madrider Beitrage 14: 189-197. Mainz, P. von Zabern.

Martín, E.; Recio, A. (2012): "Yacimientos fenicios en la costa de Vélez-Málaga. Nuevas intervenciones arqueológicas", en E. García (ed.), Diez años de arqueología fenicia en la provincia de Málaga (20012010): 207-245. Monografías Arqueología. Sevilla, Junta de Andalucía.

Martín, E.; Ramírez, J. de D.; Recio, A. (2006): “Producción alfarera fenicio-púnica en la costa de Vélez-Málaga (siglos VIII-V a.C.)". Mainake XXVIII: 257-287.

Martín, E.; Ramírez, J. de D.; Ruescas, V.; Recio, Á. (2006): "Necrópolis fenicias de los siglos VIII-VII a.C. en la desembocadura del río de Vélez". Mainake XXVIII: 303-331.

Martín, J.A. (2010): "El urbanismo en la colonia fenicia de Malaca". Byrsa 17-18: 73-90.

Martín, J.A.; Hirado, R. (2018): La colonia fenicia de Suel (Fuengirola, Málaga). Análisis histórico y arqueológico. Fuengirola, Ayuntamiento de Fuengirola.

Maya, R.; Jurado, G.; Gener, J. Mª; López, E.; Torres, M.; Zamora, A. (2014): "Nuevos datos sobre la ubicación del Kronion de Gadir: las evidencias de época fenicia arcaica", en M. Botto, M. (ed.), Los fenicios en la Bahía de Cádiz. Nuevas investigaciones. Collezione di Studi Fenici 46: 156-180 Pisa Roma, Fabrizio Serra.

Mayorga, J. (2006): "El periodo romano en el Museo de Málaga", en Memoria Arqueológica del Museo Picasso Málaga: desde los orígenes hasta el siglo $\mathrm{V}$ d.C.: 93-116. Málaga, Museo Picasso-Málaga.

Melero, F. (2008): "Nuevas aportaciones para el estudio del Bronce Final de San Pablo (Málaga). La secuencia de C/ Tiro 9-11, esquina Zamorano". Mainake XXX: 355-377.

Melero, F. (2009): "Descubrimiento de una nueva secuencia fenicia completa en los solares $\mathrm{n}^{\circ} 9$ y 11 de la C/Tiro, esq. Zamorano (Barrio de la Trinidad, Málaga)". Anuario Arqueológico de Andalucía 2004, 1: 2430-2440. Sevilla, Junta de Andalucía.

Molina, F.; Huertas, C. (1985): Almuñecar en la antigüedad. La necrópolis fenicio-púnica de Puente de Noy II. Granada, Caja Provincial de Ahorros de Granada.

Molina, F.; Rodríguez, A.; Buendía, A. (1984): “Excavaciones en el casco antiguo de Almuñecar", en F. Molina Fajardo (ed.), Almuñecar Arqueología e Historia II: 121-183. Granada, Caja de Ahorros Provincial de Granada.

Montanero, D. (2014): "Arquitectura doméstica fenicio-púnica en Sicilia y Cerdeña (siglos VIII-III a.C.)", en Arquitectura urbana y espacio doméstico en las sociedades fenicio-púnicas. XXVIII Jornadas de arqueología fenicio-púnica: 41-110. Eivissa (2013), Eivissa, Museu Arqueològic d'Eivissa i Formentera.

Mora, B.; Arancibia, A. (2010): “La bahía de Málaga en los períodos púnico y romano-republicano: viejos problemas y nuevos datos". Mainake XXXII: 813-836.

Mora, B.; Arancibia, A. (2018): "Malaka en los siglos VI-V a.C.: la consolidación de una polis fenicio-púnica en el sur de la Península Ibérica". Archivo de Prehistoria Levantina 32: 117-134. IRI <http://mupreva.org/pub/1019/es>.

Mora, B. (2011): "The Imaginary Far West and South Iberian and North African Punic Coins", en A. Dowler, E.R. Galvin (eds.), Money, Trade and Trade Routes in Pre-Islamic North Africa: 21-32. Londres, The British Museum.

Olmedo, M. (2006): “Los orígenes del Parque de Málaga”. Péndulo. Revista de Humanidades 7: 174-184.

Orsingher, A. (2010): "Le oil bottles fenicie: analisi dei contesti e considerazioni crono-tipologiche". DOI: $<$ https://doi.org/10.1400/157169>. Sardinia, Corsica et Baleares Antiquae 8: 37-69.

Ramon, J. (1982): "Cuestiones de comercio arcaico: frascos de aceite perfumado en el Mediterráneo central y occidental". Ampurias 44: 17-41.

Ramon, J. (1992): "La colonización arcaica de Ibiza. Mecánica y proceso”, en G. Roselló Bordoy (coord.), La Prehistòria de les Illes de la Mediterrània Occidental. X Jornades d'Estudis Històrics 
Locals: 453-478. Palma de Mallorca (1991), Palma de Mallorca, Institut d'Estudis Baleàrics.

Ramon, J. (1994): "El nacimiento de la ciudad fenicia de la bahía de Ibiza", en A. González Blanco et al. (coords.), El Mundo Púnico. Historia, Sociedad y Cultura. Coloquios de Cartagena. Cartagena, nov. 1990). Biblioteca Básica Murciana, Extra 4: 325 368. Murcia, Editorial Regional de Murcia.

Ramon, J. (1995): Las ánforas fenicio-púnicas del Mediterráneo Central y Occidental. Instrumenta 2. Barcelona, Universidad de Barcelona.

Ramon, J. (1999): "La cerámica fenicia a torno de sa Caleta", en A. González Prats (ed.), La cerámica fenicia de occidente. Centros de producción y áreas de comercio. Actas del I Seminario Internacional sobre temas fenicios: 149-214. Guardamar del Segura (1997), Alicante, Instituto de Cultura Juan GilAlbert.

Ramon, J. (2007): Excavaciones arqueológicas en el asentamiento fenicio de sa Caleta, Cuadernos de Arqueología Mediterránea 16. Barcelona, Publicaciones del Laboratorio de Arqueología.

Ramon, J. (2010): “La cerámica fenicia del Mediterráneo extremo-occidental y del Atlántico (s. VIII - 1r 1/3 del VI aC). Problemas y perspectivas actuales", en L. Nigro (ed.), Motya and the Phoenician ceramic repertoire between the Levant and the West 9th6th century BC: Proceedings of the International Conference: 211-253. Roma (2010), Roma, Missione Archeologica a Mozia.

Ramon, J. (2013): "Les villes phéniciennes puniques de l'extrême occident méditerranéen et atlantique", en Urbanisme et architecture en Méditerranée antique et médiévale à travers les sources archéologiques et littéraires. Actes du 2ème Colloque International: 15-49. Túnez (2011), Túnez, Institut Supérieur des Sciences Humaines.

Recio, A. (1989): "Consideraciones acerca del urbanismo de Málaga fenicio-púnica”. Mainake X: 75-82.

Recio, A. (1989): La cerámica fenicio-púnica, griega y etrusca del sondeo de San Agustín. Monografías 3. Málaga, Diputación Provincial.

Rodríguez de Berlanga, M. (2001): “Conjeturas topográficas”. Malaca VI: 217-237. Málaga, Ayuntamiento de Málaga (reed.).

Rufete, P. (1989): “Las cerámicas con engobe rojo de Huelva”. Huelva Arqueológica X-XI, 3: 9-40.

Rufete, P. (1989): "La cerámica con barniz rojo de Huelva", en Ma . E. Aubet (ed.), Tartessos. Arqueología protohistórica del bajo Guadalquivir: 375 394. Sabadell, Ausa.
Ruiz, D.; Pérez, C. (1995): El poblado fenicio del Castillo de Doña Blanca (El Puerto de Santa María, Cádiz). Biblioteca de Temas Portuenses 5. El Puerto de Santa María, Ayuntamiento de El Puerto de Santa María.

Sánchez, V. M.; Galindo, L.; Juzgado, M.; Dumas M. (2011): "La desembocadura del Guadalhorce en los siglos IX y VIII a. C. y su relación con el Mediterráneo", en J. C. Domínguez (ed.), Gadir y el Círculo del Estrecho revisados. Propuestas de la arqueología desde un enfoque social: 185-200. Cádiz, Universidad de Cádiz.

Sánchez V. M.; Galindo, L.; Juzgado, M.; Dumas, M. (2012): "El asentamiento fenicio de la Rebanadilla a finales del siglo IX a.C.”, en E. García (ed.), Diez años de Arqueología Fenicia en la provincia de Málaga (2001-2010): 67-85. Monografías Arqueología. Sevilla, Junta de Andalucía.

Sánchez, V.M.; Galindo, J.L.; Juzgado, M.; Belmonte, J.A. (2018): "La Rebanadilla, santuario litoral fenicio en el sur de la Península Ibérica", en M. Botto (ed.), De Huelva a Malaka. Los fenicios en Andalucía a la luz de los descubrimientos más reciente. Collezione di Studi Fenici 48: 305-324. Roma, Consiglio Nazionale delle Ricerche.

Santamaría, J. A.; Suárez, J.; Ramon, J. (2012): “Taralpe Alto (Alhaurín de La Torre, Málaga). Un nuevo asentamiento de la Edad del Hierro en el entorno de la cuenca baja del río Guadalhorce", en E. García (ed.), Diez años de arqueología fenicia en la provincia de Málaga (2001-2010): 193206. Monografías Arqueología. Sevilla, Junta de Andalucía.

Schubart, H. (1976): "Westphönizische Teller". Rivista di Studi Fenici IV. 2:179-196.

Schubart, H.; Maass-Lindemann, G. (1984): “Toscanos: el asentamiento fenicio occidental en la desembocadura del río de Vélez (excavaciones de 1971)". Noticiario Arqueológico Hispánico 18: 41-205.

Schubart, H.; Maass-Lindemann, G. (1995): "Las excavaciones en la Necrópolis de Jardín (Vélez-Málaga, Málaga)".Cuadernos de Arqueología Mediterránea 1: 57-64.

Schubart, H.; Niemeyer, H. G. (1976): Trayamar. Los hipogeos fenicios y el asentamiento en la desembocadura del río Algarrobo. Excavaciones Arqueológicas en España 90. Madrid, Ministerio de Educación y Ciencia.

Schubart, H.; Niemeyer, H. G.; Pellicer, M. (1969): Toscanos. La factoría paleopúnica en la desembocadura del río Vélez, Excavaciones de 1964. 
Excavaciones Arqueológicas en España 66. Madrid, Ministerio de Educación y Ciencia.

Serrano, E.; Rodríguez, P. (2009): "El mosaico de Bellerofonte de la villa de Puerta Oscura". Jábega 100: 48-54.

Suárez, J.; Cisneros, M. I. (1999): "La entrada de los territorios de Benalmádena en la Historia", en A. Palomo Laburu et al. (eds.), Una historia de Benalmádena: 99-126. Benalmádena, Delegación de Cultura.

Suárez, J.; Escalante, M. del M.; Cisneros, M. I.; Mayorga, J.; Fernández, L. E. (2007): “Territorio y urbanismo fenicio-púnico en la bahía de Málaga. Siglos VIII-V a.C.”, en J. L. López Castro (ed.), Las ciudades fenicio-púnicas en el Mediterráneo occidental: 209-232. Almería, Universidad de Almería.

Torres, M.; López, E.; Gener, J. Ma; Navarro, M. Á.; Pajuelo, J. M.; Maya, R.; Jurado, G. (2014): "El material cerámico de los contextos fenicios del "Teatro
Cómico" de Cádiz: un análisis preliminar", en M. Botto (ed.), Los Fenicios en La Bahía de Cádiz. Nuevas investigaciones. Collezione di Studi Fenici 46: 51-82. Pisa - Roma, Fabrizio Serra.

Ulreich, H.; Negrete, M. A.; Puch, E.; Perdigones, L. (1990): “Cerro del Prado. Die ausgrabungen 1989 im schutthang der phönizischen ansiedlung an der Guadarranque-mundung". Madrider Mitteilungen 31: 194-250.

Villada, F.; Ramon, J.; Suárez, J. (2010): El asentamiento protohistórico de Ceuta. Indígenas y fenicios en la orilla norteafricana del Estrecho de Gibraltar. Ceuta, Archivo General de Ceuta.

Vuillemot, G. (1955): "La nécropole punique du Phare dans l'île de Rachgoun (Oran)". Libyca (Arch. Ep.) III: 7-76.

Vuillemot, G. (1965): Reconnaissances aux échelles puniques d'Oranie. Autun, Musée Rolin. 

B. Gomes (2020): “Uma lucerna grega arcaica da necrópole do Olival do Senhor dos Mártires (Alcácer do Sal, Portugal)", Spal 29.1: 79-91. DOI: http://dx.doi.org/10.12795/spal.2020.i29.03

\title{
UMA LUCERNA GREGA ARCAICA DA NECRÓPOLE DO OLIVAL DO SENHOR DOS MÁRTIRES (ALCÁCER DO SAL, PORTUGAL)
}

\section{AN ARCHAIC GREEK LAMP FROM THE NECROPOLIS OF OLIVAL DO SENHOR DOS MÁRTIRES (ALCÁCER DO SAL, PORTUGAL)}

\author{
FRANCISCO B. GOMES \\ Uniarq. Faculdade de Letras. Universidade de Lisboa. \\ Alameda da Universidade, 1600-214 Lisboa, Portugal. \\ Correo-e: franciscojbgomes@gmail.com (D) http://orcid.org/0000-0003-0664-6374. \\ Research ID: <https://publons.com/researcher/AAE-7217-2019>
}

\begin{abstract}
Resumo: Entre os materiais exumados por Vergílio Correia na necrópole do Olival do Senhor dos Mártires (Alcácer do Sal) durante a década de 1920 conta-se uma lucerna ainda inédita. Pelas suas características morfológicas e produtivas esta peça inscreve-se no âmbito do repertório lychnológico grego arcaico, podendo identificar-se como uma produção coríntia. O contexto desta peça, exumada na Sepultura 98 da necrópole, confirma esta adscrição crono-tipológica, permitindo atribuir-lhe uma datação do primeiro quartel do século $\mathrm{V}$ a.n.e.. Este exemplar pode assim enquadrar-se no contexto do comércio de produtos gregos tardo-arcaicos no actual território peninsular.
\end{abstract}

Palavras-chave: cerâmica grega; iluminação; Corinto; práticas funerárias; I Idade do Ferro.

\section{CONSIDERAÇÕES PRÉVIAS: A PEÇA E A SUA DESCOBERTA}

Apesar da sua precoce identificação, ocorrida ainda nos finais do século XIX (Silva 1875), a necrópole do Olival do Senhor dos Mártires (OSM), utilizada como espaço funerário pela comunidade de Alcácer do Sal
Abstract: Among the material exhumed by Vergílio Correia in the necropolis of Olival do Senhor dos Mártires (Alcácer do Sal) during the 1920's there is an unpublished lamp which by its morphological and productive characteristics can be considered an archaic Greek production, specifically from Corinth. The context of this piece, retrieved in the necropolis's Tomb 98, confirms this chrono-typological attribution and indicates this piece must be dated to the first quarter of the fifth century B.C.E.. This lamp can therefore be analysed in the framework of the trade of late archaic Greek products to the Iberian Peninsula.

Key words: Greek pottery; illumination; Corinth; funerary practices; Early Iron Age.

entre os inícios da Idade do Ferro e a Época Romana Republicana (fig. 1), não foi objecto de uma exploração sistemática até bastante mais tarde.

Com efeito, as primeiras intervenções arqueológicas realizadas no sítio datam já da década de 1920, durante a qual Vergílio Correia conduziu quatro extensas campanhas de escavação no OSM que permitiram pela 


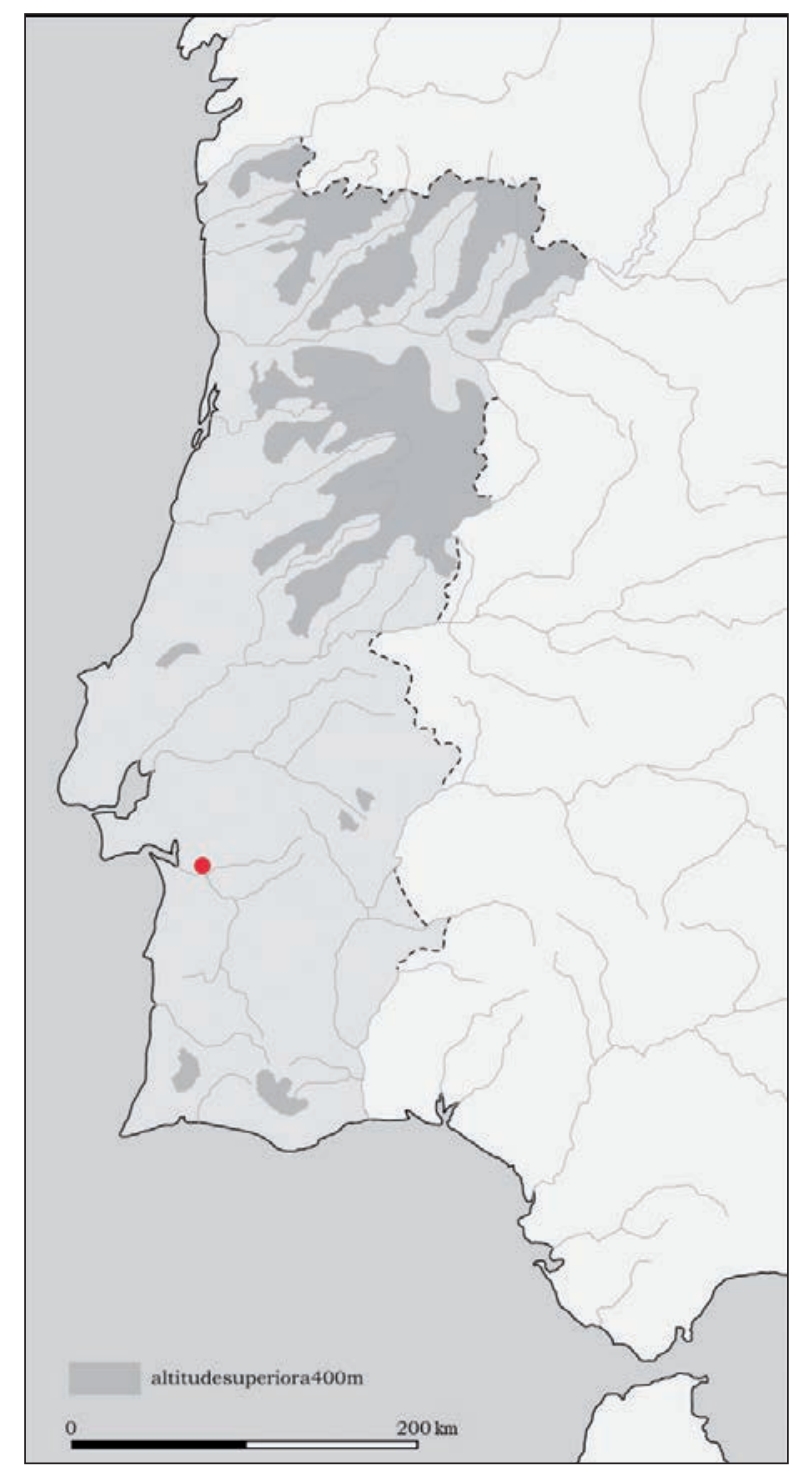

Figura 1. Localização do OSM no actual território português (base cartográfica: Professor Victor S. Gonçalves).

primeira vez caracterizar de forma relativamente detalhada as diversas modalidades funerárias ali representadas (Correia 1972 [1925]; Correia 1972 [1928]).

Infelizmente, os resultados destas intervenções pioneiras nunca chegaram a ser sistematicamente publicados. Os trabalhos dados à estampa por Vergílio Correia (ibidem), apesar do seu carácter preliminar, constituem ainda assim um dos elementos chave para a compreensão da diversa e complexa sequência funerária da necrópole (Gomes 2016; no prelo).

Além desses fundamentais contributos, os trabalhos do Professor da Universidade de Coimbra legaram-nos um extenso conjunto de materiais arqueológicos hoje distribuídos entre o Museu Nacional de Arqueologia, em Lisboa, e o Museu Didáctico do Instituto de Arqueologia da Universidade de Coimbra (MDIA). Esta última instituição conserva um conjunto de elementos particularmente expressivos (cf. Vilaça 2016) que foram já objecto de estudo, parcial ou total, em múltiplas ocasiões (Brito 1968, Schüle 1969, Paixão 1970, Ponte 1985, Rouillard et al. 1989, Frankenstein 1997, Gomes 2016).

Entre este lote de materiais levado por Vergílio Correia para Coimbra e hoje custodiado pelo MDIA conta-se uma lucerna em bastante bom estado de conservação (fig. 2) que, apesar do interesse dedicado ao resto do conjunto do OSM ali depositado, escapou até ao momento à atenção da investigação.

Esta peça, recolhida na última campanha conduzida por aquele investigador no OSM em 1927, apresenta uma morfologia particular, muito invulgar no território peninsular, o que poderá ter dificultado o seu correcto enquadramento crono-cultural, justificando assim de alguma forma a sua sistemática não inclusão nos estudos antes citados.

Atendendo à sua morfologia e às suas características produtivas, esta peça pode integrar-se no quadro da produção lychnológica grega arcaica, constituindo assim um elemento a somar aos raros exemplares de cerâmicas gregas documentados no Ocidente Peninsular anteriores à fase clássica (Arruda 2019). Parece portanto importante dar a conhecer esta lucerna, insistindo nas suas características formais e produtivas, bem como discutir a sua posição dentro do diverso e complexo panorama tipológico das mais antigas lucernas gregas.

O estudo exaustivo dos materiais exumados por Vergílio Correia no OSM, recentemente concluído (Gomes 2016), permite igualmente reconstruir de forma muito aproximada o contexto primário desta peça, delimitando o seu enquadramento histórico e permitindo uma breve discussão da sua posição no quadro do comércio de produtos gregos arcaicos na Península Ibérica.

\section{A LUCERNA GREGA ARCAICA DO OSM: MORFOLOGIA, CLASSIFICAÇÃO E CARACTERÍSTICAS PRODUTIVAS}

Ao tratar-se de um elemento raro nos repertórios ceramológicos da Península Ibérica em geral, e do Extremo Ocidente em particular, a correcta interpretação da lucerna aqui estudada implica antes de mais uma exposição detalhada das suas características formais e produtivas que permita cotejá-la com os dados de 


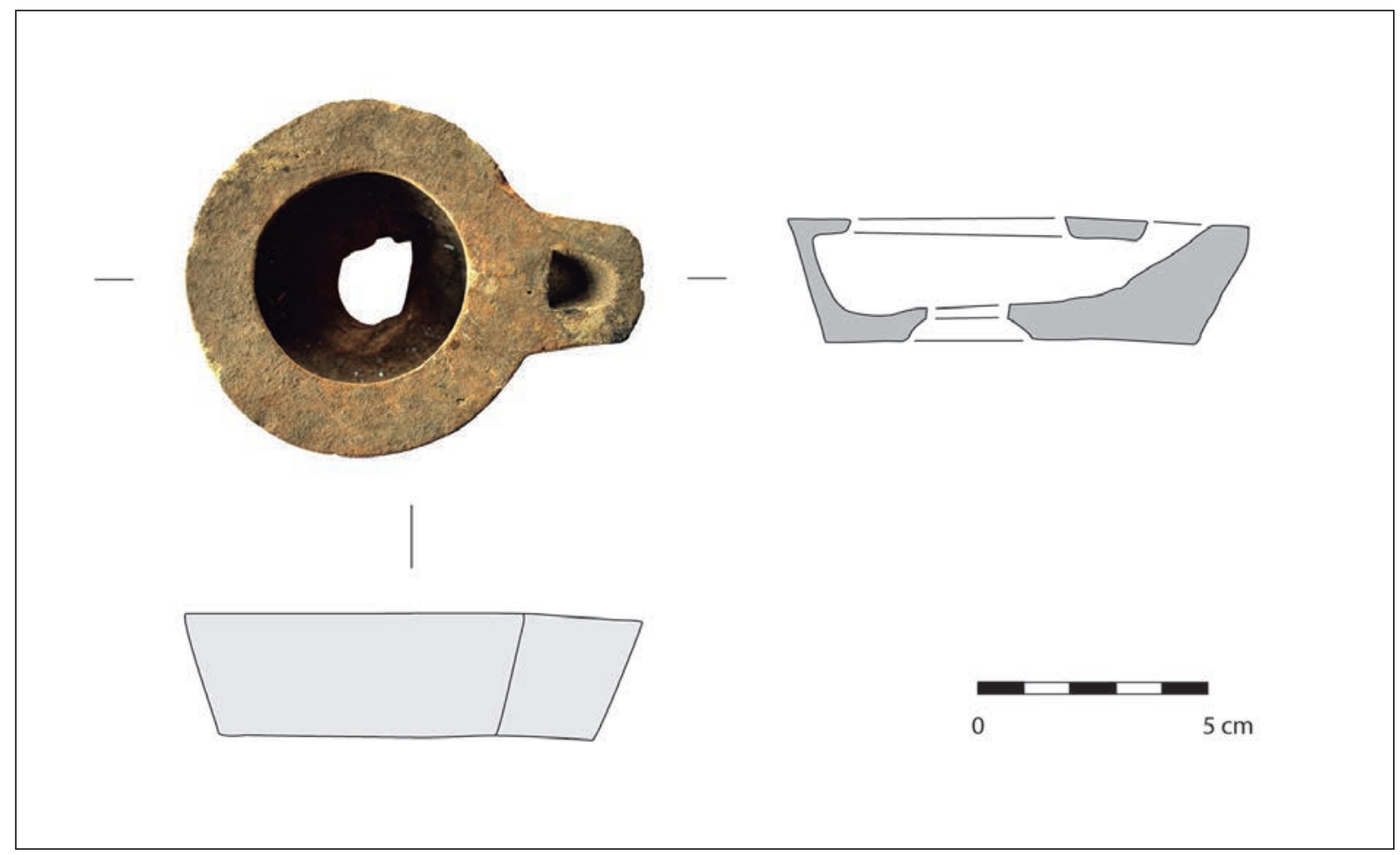

Figura 2. Lucerna grega arcaica do Olival do Senhor dos Mártires.

outras áreas do Mediterrâneo onde as lucernas de tipos afins à da que aqui nos ocupa são mais frequentes e se encontram mais bem estudadas.

Do ponto de vista morfológico, esta peça corresponde a um modelo de lucerna com depósito aberto, sem disco (fig. 2). O seu comprimento máximo é de $10 \mathrm{~cm}$ e o diâmetro do seu depósito é de $7,8 \mathrm{~cm}$; a sua altura máxima é de $2,7 \mathrm{~cm}$.

A base desta peça é plana, sem pé, contando não obstante com uma concavidade central hoje fracturada, o que impede a restituição exacta da forma como a mesma se desenvolveria. As paredes, separadas da base por um marcado ângulo obtuso, são perfeitamente rectas e divergentes, configurando um depósito de secção trapezoidal com uma morfologia muito regular e marcadamente geométrica.

O bordo desta peça, plano e recto, encontra-se igualmente separado do corpo por uma inflexão muito marcada e angulosa, ainda que não assinalada exteriormente. A sua largura é relativamente regular, oscilando entre 1,3 e $1,6 \mathrm{~cm}$.

Esta lucerna conta ainda com um pico pouco desenvolvido (c 2,6 cm), de tendência trapezoidal e esquinas arredondadas, dotado de um orifício para a mecha de configuração igualmente trapezoidal que não chega a invadir a área do bordo. Este pico desenvolve-se grosso modo em linha com o bordo da lucerna, contribuíndo também ele para o aspecto linear e fortemente geométrico que caracteriza este exemplar em geral. A peça não conta com qualquer elemento de preensão.

As características morfológicas gerais desta peça indiciam, como já se avançou, a sua integração num ambiente produtivo grego arcaico. Os modelos de lucerna com depósito aberto, sem disco, são particularmente característicos do âmbito grego em geral, ao passo que certos aspectos formais, como o bordo comparativamente estreito, o pico pouco desenvolvido ou a ausência de elementos de preensão indiciam claramente a relativa antiguidade do exemplar do OSM.

Deve no entanto salientar-se que durante as suas etapas inicias, e apesar da existência de uma série de características gerais comuns como as que acabam de se enunciar, a produção lychnológica grega se caracteriza por uma considerável diversidade e falta de normalização. Torna-se por isso difícil estabelecer uma classificação operativa do material, particularmente quando este apresenta características formais mais raras ou peculiares como no caso que aqui nos ocupa. 


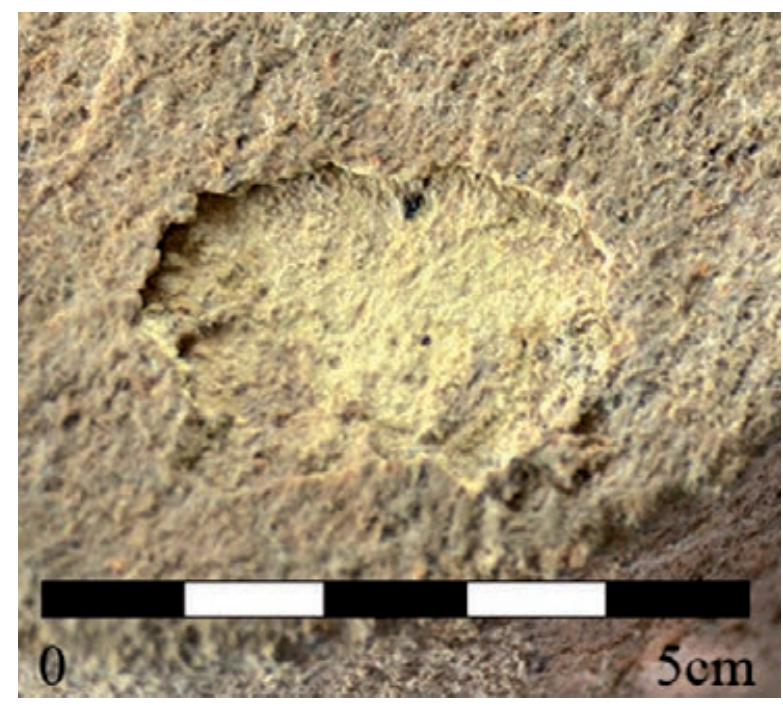

Figura 3. Detalhe da pasta da lucerna do OSM.

A integração da lucerna do OSM nos principais quadros tipológicos em uso para a classificação das lucernas gregas arcaicas e/ou clássicas (Broneer 1930, Howland 1958, Galli 2004) constitui, portanto, uma tarefa complexa, mas parece ainda assim possível estabelecer algumas comparações úteis para a correcta valorização desta peça.

Assim, e de forma tentativa, o exemplar alcacerense pode aproximar-se do Tipo III de Broneer (1930: 38-39) com o qual partilha alguns traços morfológicos, nomeadamente o reservatório muito aberto, o bordo tendencialmente plano ou a forma geral do pico. Com efeito, a morfologia da lucerna em apreço aproxima-se significativamente do perfil 14 definido por aquele autor (ibd.: fig. 14).

Peças de perfil similar encontram-se também documentadas na Ágora de Atenas, tendo sido classificadas por R. H. Howland como variantes do seu Tipo 12 (Howland 1958: 27, especialmente o n. 81). Este tipo considera-se contudo comparável ao Tipo II de Broneer (1930: 35-38), equivalência que no caso do perfil que aqui nos ocupa não parece totalmente evidente. Algumas peças de origem siciliana conservadas nos acervos do Museu Britânico e classificadas também elas no referido Tipo 12 de Howland apresentam igualmente similitudes com a peça em análise (Bailey 1975: 301, n. Q 639; 303-4, n. Q 645).

A peça do OSM pode, por outro lado, aproximar-se do Tipo 6, variante b de V. Galli (2004: 48-49), considerado equivalente ao já referido exemplar n. 81 da Ágora de Atenas. Segundo esta autora, esta variante tem origem na Grécia de Leste, tendo-se difundido na Grécia Continental e nas colónias ocidentais, onde o modelo terá sido localmente imitado (ibd: 48; v. tb. Bailey 1975: 300, 303-304).

Finalmente, caberia assinalar a presença nas colecções do Museo Civico Archeologico de Bologna estudadas por M. C. Gualandi Genito (1977) de uma peça com um perfil muito similar à que aqui nos ocupa (ibd: 34 , n. 10), classificada neste caso como pertencendo ao Tipo IV de Broneer (1930: 39-42).

A peça do OSM apresenta, contudo, algumas diferenças com respeito aos exemplares reunidos nestes grupos tipológicos, nomeadamente um aspecto mais marcadamente geométrico e uma total ausência de pé. De igual modo, a porção conservada da concavidade central da base não sugere a priori a existência de um cone central desenvolvido, característica geralmente presente nos tipos antes citados.

O ângulo externo do bordo não é, por outro lado, proeminente, característica que poderia aproximar esta peça do Tipo II de Broneer (1930: 35-38), sugerindo assim uma posição de certa forma intermédia entre este e o já citado Tipo III. Os Tipos I a IV de Broneer formam, de resto, uma família tipológica estreitamente interrelacionada entre si, o que nem sempre facilita a diferenciação entre os vários tipos concretos.

Assim, e apesar das ligeiras discrepâncias morfológicas antes comentadas - que, como referido, se podem justificar pela escassa estandardização da produção lychnológica grega arcaica - a adscrição da peça em apreço a este âmbito tipológico global parece clara. As características produtivas e, até certo ponto, decorativas, parecem igualmente suportar essa atribuição.

A lucerna em estudo apresenta, do ponto de vista da estrutura física, uma pasta calcária, relativamente compacta e bem depurada (fig. 3). Apesar de contar com escassos elementos não-plásticos - em particular nódulos de calcite e areias quartzíticas, de dimensões reduzidas - apresenta uma superfície de aspecto relativamente áspero. A cozedura, perfeitamente regular, parece ter-se realizado em ambiente oxidante, resultando em superfícies com uma tonalidade beige amarelada muito homogénea.

As superfícies não apresentam, no geral, marcas evidentes de nenhum tratamento particular. Não obstante, e apesar da existência de concreções que dificultam a observação da superfície, parece observar-se algum tipo de revestimento de tonalidade alaranjada aplicado sobre o bordo (fig. 2). O estado de conservação muito deficiente deste revestimento não permite 
assegurar se se trataria de uma aguada/ engobe ou mais propriamente de um verniz.

As características produtivas desta peça parecem assim compatíveis com as das lucernas de produção local coríntia, cujas pastas se descrevem como «...of a pale yellow colour (...) fine and well worked, with almost no sand and gritty substance, and (...) absolutely free from mica» (ibd: 34). Essas características aproximam-se também das da já citada peça n. 81 da Ágora de Atenas, considerada uma possível importação de Corinto (Howland 1958: 27).

As peças de Gravisca, em contrapartida, apresentam pastas com características muito distintas, atribuídas a centros produtores da Grécia de Leste (Galli 2004: 48), aos quais se poderia também adscrever a peça do Museu de Bolonha antes comentada (Genito 1977: 34).

Do ponto de vista decorativo, e como já houve oportunidade de comentar, a peça em estudo não conserva restos particularmente expressivos do revestimento que outrora terá possuído. Os vestígios preservados parecem contudo, também eles, compatíveis com o tipo de verniz alaranjado/ acastanhado considerado característico das produções coríntias (Broneer 1930: 38, Howland 1958: 27), situando-se além do mais sobre o bordo, zona onde tipicamente se aplica o verniz nas lucernas dos tipos antes comentados (Broneer 1930: 38, Howland 1958: 27; v. tb. Galli 2004: 48).

Assim, e com todas as devidas reservas resultantes das suas peculiaridades, a lucerna do OSM pode considerar-se uma produção grega arcaica, muito provavelmente coríntia. Morfológicamente, deve integrar-se na mais antiga família tipológica dentro do repertório lychnológico grego, formado pelos Tipos I a IV de Broneer (1930), aproximando-se em particular do Tipo II e especialmente do Tipo III (ibd: 35-39). Os paralelos mais específicos anteriormente enunciados permitem contudo estabelecer uma aproximação mais exacta ao seu enquadramento cronológico.

Com efeito, e independentemente das ligeiras discrepâncias ao nível da suas respectivas equivalências, já comentadas, o Tipo III de Broneer, as variantes do Tipo 12 de Howland e a variante $6 \mathrm{~b}$ de Galli compartem grosso modo as mesmas balizas cronológicas, produzindo-se entre o último terço do século VI e os inícios do V a.n.e. (Broneer 1930: 39, Howland 1958: 27 , Galli 2004: 48). A peça do OSM deverá também atribuir-se a esse mesmo intervalo de tempo, facto aliás confirmado pelo seu contexto primário, que seguidamente se procurará reconstruir.

\section{O CONTEXTO: A SEPULTURA 98 DO OSM}

Como já foi mencionado, a lucerna que temos vindo a analisar foi exumada por Vergílio Correia durante a última campanha de escavação por si conduzida no OSM em 1927. Mais concretamente, esta peça provém de um contexto sepulcral designado por aquele investigador como Sepultura 98.

Ao contrário de outros raros contextos, esta sepultura não mereceu qualquer menção na importante síntese publicada pelo Professor da Universidade de Coimbra no ano seguinte (Correia 1972 [1928]), pelo que a priori desconhecemos as suas características específicas. Não obstante, o estudo exaustivo da cultura material do OSM recentemente levado a cabo (Gomes 2016) permitiu identificar um conjunto significativo de materiais atribuídos a esta sepultura (fig. 4), repartidos pelo MDIA (cerâmicas) e pelo Museu Nacional de Arqueologia (metais), o que possibilita uma aproximação ao seu enquadramento cronológico e à sua posição na sequência global da necrópole.

Além da lucerna objecto do presente estudo, o espólio votivo da Sepultura 98 incluía também uma jarra de cerâmica cinzenta polida (fig. 4, n.1). Esta peça, enquadrada na Forma VI.1 da cerâmica cinzenta do OSM (Gomes 2016: 164 e est. XXXII, n. 434), apresenta um corpo globular separado do colo, alto e côncavo, por um ressalto bem marcado. Esse colo culmina num bordo triangular extroverso, ao passo que o fundo se encontra destacado por um pé de anel incipiente.

Esta peça pode comparar-se, até certo ponto, com a pequena jarra de Medellín recolhida na forma D7C da cerâmica cinzenta daquela necrópole, datada do último quartel do século VI a.n.e. (Lorrio 2008: 706). A peça alcacerense apresenta contudo algumas características morfológicas mais evolucionadas, como um incipiente pé de anel ou um colo com um perfil de aspecto moldurado, que a diferenciam deste exemplar extremenho.

Esta jarra não conta, com efeito, com paralelos próximos nos repertórios da cerâmica cinzenta do $\mathrm{Su}-$ doeste Peninsular, podendo contudo aproximar-se de algumas peças de cerâmica comum fina provenientes da área Ibérica, nomeadamente de El Cigarralejo (Cuadrado 1987: fig. 8) e de Los Villares (Blánquez 1990: fig. 38).

Estes paralelos, somados aos detalhes morfológicos tendencialmente tardios antes comentados parece sugerir uma cronologia relativamente avançada para esta peça do OSM, que pode datar-se já do século $\mathrm{V}$ a.n.e..

Entre o material da sepultura 98 contam-se igualmente alguns elementos relacionados com a 


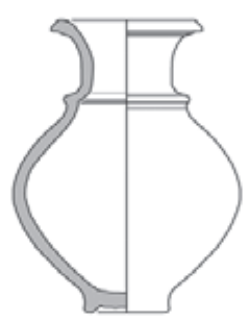

1

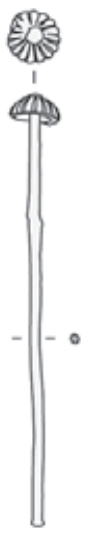

4
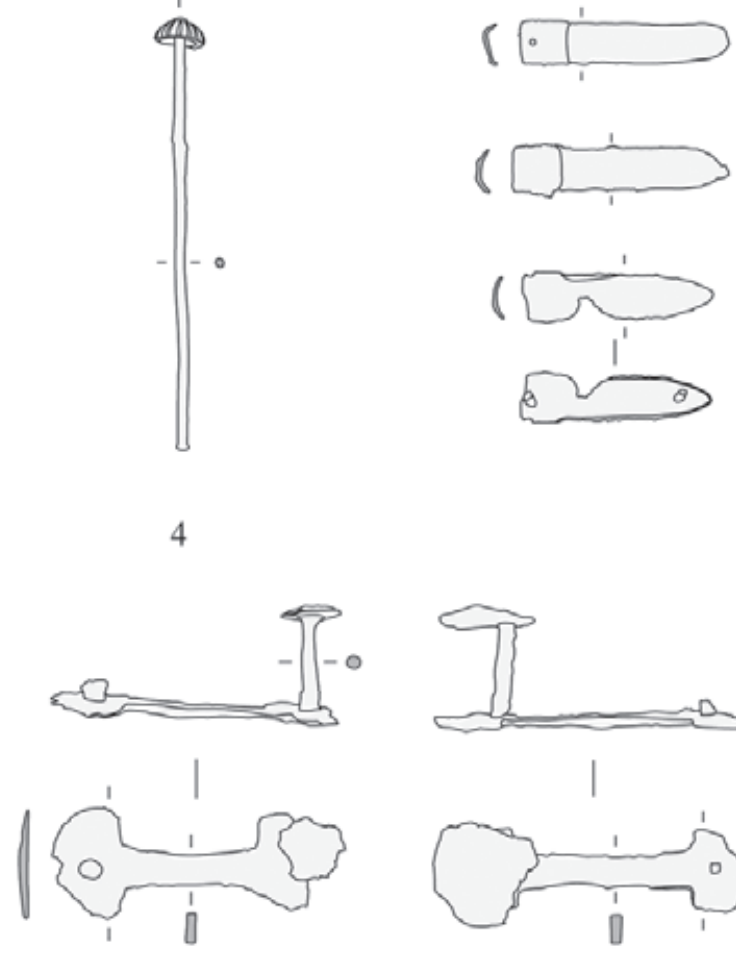

5

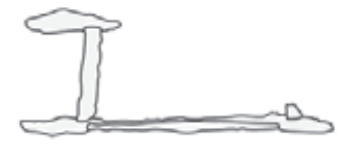

1
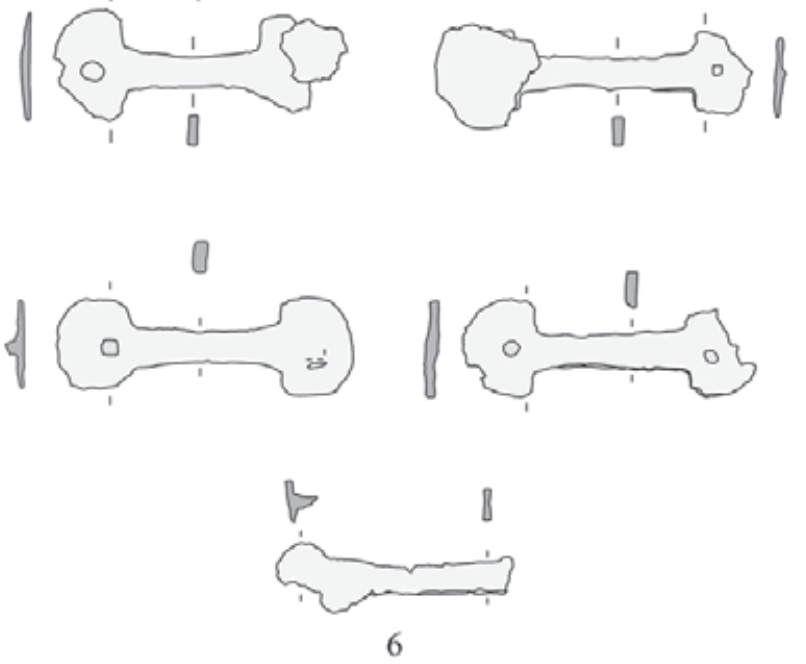

Figura 4. Materiais da Sepultura 98 do OSM.

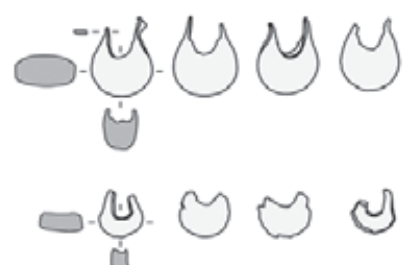

3
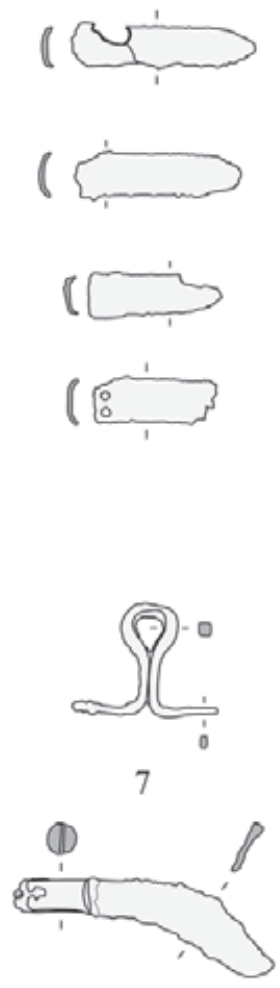

8

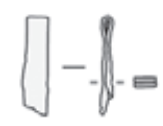

9

$0=5 \mathrm{~cm}$ 
indumentária e o adorno. Entre estes merece destaque um fragmento da peça activa de um fecho de cinturão de tipo dito "céltico" (fig. 4, n. 2). Apesar de muito incompleta, esta peça parece ter contado originalmente com chanfraduras fechadas e três garfos, ostentando ainda uma decoração incisa junto ao rebordo. Enquadra-se portanto no tipo DIII3 de Cerdeño (1978: 283), no tipo B3B3 de Lorrio (1997: 217) ou ainda, segundo a mais recente notação proposta por R. Graells e A. Lorrio (2017), no tipo 3.3.2?.?.?.?.2/3a.B.

Originalmente, as peças deste grupo foram datadas de um intervalo entre o final do século VI e o final do V a.n.e. (Cerdeño 1978: 283). Esta cronologia foi contudo objecto de uma revisão posterior, elevando-se a datação dos primeiros exemplares a meados do século VI a.n.e (Torres Ortiz 2002: 212-213), tal como sugerido pelos dados de Medellín (Badajoz) onde estes fechos, integrados no Tipo B2 daquela necrópole, se documentam entre os meados do século VI e os meados do V a.n.e. (López Ambite 2008: 521-523).

$\mathrm{Na}$ sepultura 98 recolheram-se igualmente vários fragmentos de um bracelete de tipo "xorca" ("ajorca"), destacando-se um conjunto de pendentes em forma de sanguessuga parcialmente ocos, englobáveis no Tipo B estabelecido para os exemplares do OSM (Gomes 2016: 255) (fig. 4, n. 3). Este tipo de bracelete, que conheceu uma ampla difusão geográfica, é particularmente frequente nos contextos da fachada atlântica peninsular (Maluquer 1957: 251-256, Schüle 1969: 214-215, Gomes e Domingos 1983, Abásolo et al. 2004: 136), ocorrendo sobretudo em contextos datados dos séculos VI e V a.n.e. (Piñel 1971), com eventuais perdurações na centúria seguinte.

Esta sepultura continha ainda, ao que tudo indica, um (ou mais) elemento(s) complexo(s) de mobiliário de que se conservam diversas componentes metálicas de distinta natureza. Porventura a mais característica entre estas é uma charneira de ferro com remate discóide decorado com uma roseta (fig. 4, n. 4), seguramente parte de uma banqueta funerária de tipo diphros. Esta peça integra-se na variante $4 \mathrm{~b}$ definida para as dobradiças recolhidas na já citada necrópole de Medellín, na qual se documenta em contextos datados entre os meados do século VI e os inícios do V a.n.e. (Jiménez Ávila 2008: 550).

Outros elementos poderão classificar-se como braçadeiras (grapas, na terminologia espanhola). Estas peças oblongas de ferro, de tendência rectangular com uma extremidade arredondada ou em ponta e de secção convexa (fig. 4, n. 5), enquadram-se no Grupo 3 da tipologia avançada para as peças do OSM
(Gomes 2016: 304). Os elementos deste grupo parecem especialmente adequados para a aplicação nas extremidades de elementos perecíveis, podendo além de elementos de fixação ter servido como remates.

Nesta sepultura recolheu-se ainda um conjunto de peças de ferro formadas por barras estreitas de secção rectangular com extremidades semicirculares largas e aplanadas, agrupadas em pares unidos entre si por hastes de secção circular (fig. 4, n. 6). Estes elementos, de difícil interpretação, poderão ter também formado parte deste(s) mesmo(s) elemento(s) de mobiliário. Idêntica interpretação se poderia avançar para um grampo (fig. 4, n. 7) e um prego de ferro igualmente exumados neste contexto.

Uma outra peça distintiva proveniente da Sepultura 98 corresponde a uma pequena faca afalcatada de uma tipologia relativamente invulgar (fig. 4, n. 8), individualizada como Tipo 3 b na seriação estabelecida para os exemplares do OSM (Gomes 2016: 276). Os paralelos disponíveis sugerem que as facas afalcatadas deste tipo se desenvolveram fundamentalmente durante os séculos VI e V a.n.e. (ibd, com bibliografia).

Finalmente, caberia ainda assinalar a presença entre o conjunto artefactual procedente deste sepulcro de uma pequena pinça de bronze de morfologia muito simples e algo tosca (fig. 4, n. 9), que remete com toda a probabilidade para o domínio dos cuidados corporais.

Como se pode apreciar pela enunciação realizada nas páginas precedentes, os vários elementos atribuídos à Sepultura 98 do OSM configuram um conjunto bastante coerente, nomeadamente do ponto de vista da sua datação. As balizas cronológicas dos elementos antes citados são genericamente coincidentes, e uma ponderação combinada das mesmas permite afirmar que a Sepultura 98 datará muito provavelmente do primeiro quartel do século $\mathrm{V}$ a.n.e.

Esta cronologia, como facilmente se apreciará, coincide perfeitamente com a datação intrínseca avançada para a lucerna aqui estudada, confirmando assim de forma cabal o enquadramento cronológico e, em certa medida, cultural acima proposto para esta peça.

Por outro lado, estas balizas cronológicas permitem situar a sepultura em apreço num momento avançado da Sub-fase Ib da sequência de utilização da necrópole (c 550 - 475/450 a.n.e.) (Gomes 2016: 346-347, Gomes no prelo), o que permite tecer algumas considerações adicionais sobre a tipologia específica deste conjunto sepulcral.

Com efeito, a Sub-fase Ib caracteriza-se precisamente pela simplificação e aparente homogeneização do panorama funerário do OSM, que passa a ser 
dominado de forma virtualmente exclusiva durante esta etapa pelas sepulturas de incineração in situ em fossa simples, de tipo busta, enquadráveis no $3^{\circ}$ Tipo estabelecido por Vergílio Correia (1972 [1928]).

Assim, e ainda que não contemos com uma descrição específica desta estrutura sepulcral em particular, parece verosímil que a sepultura que aqui nos ocupa corresponda a uma deposição integrável neste mesmo tipo, embora de características ao que tudo indica um tanto destacadas dada a comparativa riqueza dos espólios associados.

Essa riqueza encontra-se materializada, entre outros aspectos, na capacidade de aceder a circuitos comerciais supra-regionais e de adquirir um elemento como a lucerna aqui estudada que, apesar da sua simplicidade, deverá ter constituído um elemento exótico e putativamente prestigioso num contexto local/regional onde as importações gregas estão ainda longe de ser comuns (Arruda 2019; v. tb. Gomes 2017: fig. 3).

A inclusão deste elemento no espólio funerário desta sepultura pode entender-se como uma substituição das típicas "saucer lamps" fenício-púnicas, que parecem ter constituído parte integrante do pacote ritual próprio das sepulturas do $3^{\circ}$ Tipo (Correia 1972 [1928]: 176, v. tb. Gomes 2016: 330), por um elemento mais exótico e, portanto, mais prestigioso; o contexto de utilização desta peça não deixa, portanto, de se pautar pelas práticas e crenças funerárias locais. A sua singularidade deve no entanto interpretar-se como um símbolo mais do elevado estatuto do defunto ali depositado.

Os dados actualmente disponíveis não permitem tecer muito mais considerações sobre a identidade desse defunto e, por extensão, sobre a biografia da lucerna que o acompanhou na sua última morada. Com efeito, faltam-nos por completo os dados antropológicos que permitiriam estabelecer uma aproximação à sua idade ou mesmo ao seu género.

O espólio da sepultura poderá contudo oferecer-nos algumas pistas em relação a este último aspecto, na medida em que os fechos de cinturão de tipo "céltico" e as banquetas funerárias (diphros) surgem tendencialmente associados em várias necrópoles da I Idade do Ferro do Sudoeste a indivíduos masculinos (Almagro-Gorbea 2008, Arruda et al. 2017: 219-221, Graells e Lorrio 2017: 133-140).

Assim, e com todas as reservas decorrentes das limitações informativas já mencionadas, a lucerna em estudo parece ter acompanhado um indivíduo, possivelmente masculino, de elevado estatuto social. Este indivíduo - ou o seu grupo familiar - deteria, ao que tudo indica, os recursos necessários para aceder a circuitos comerciais de larga distância através dos quais obter um elemento tão exótico como aquele que nos ocupa. Esta lucerna materializa assim, no cenário da morte, a sua preeminência social, que contudo se expressa no quadro de umas práticas funerárias perfeitamente enraizadas e consagradas na tradição local.

\section{A LUCERNA DO OSM NO CONTEXTO DO COMÉRCIO GREGO ARCAICO COM O EXTREMO OCIDENTE: ALGUMAS OBSERVAÇÕES FINAIS}

O carácter excepcional da lucerna do OSM, enfatizado pelas considerações sobre a sua proveniência e o seu contexto cronológico tecidas nas páginas anteriores, impõe a necessidade de abordar, mesmo que de forma esquemática, a posição desta peça no âmbito do comércio grego arcaico com o Extremo Ocidente e o contexto no qual a mesma poderá ter chegado a Alcácer do Sal.

Com efeito, a presença desta peça em Alcácer do Sal não deixa de causar alguma estranheza já que as importações gregas arcaicas são sumamente raras no actual território português (Arruda 2019), resumindo-se na prática a um fragmento atribuído ao Coríntio Médio, do Castelo de Castro Marim (Arruda 2006: 135-136, n. 69), a dois fragmentos, também do Coríntio Médio, da Quinta do Almaraz (Almada) (Cardoso 2004: fig. 173), e a uma possível vicup ática de Lisboa (Arruda 1997: 86-7).

Mais interessante para o caso vertente é, contudo, a presença no próprio OSM de um recipiente ático de figuras negras, concretamente uma taça do tipo $\mathrm{C}$ de H. Bloesch (1940, apud Arruda, 2019) enquadrável no grupo das floral band-cups de J. Beazley (1978: 197, apud Arruda, 2019) e datável do primeiro quartel do século V a.n.e. (Arruda 2006: 136; Arruda 2019).

Esta peça, virtualmente contemporânea portanto da lucerna aqui estudada, confirma não apenas a capacidade da comunidade de Alcácer do Sal de aceder aos circuitos comerciais mediterrâneos através dos quais circularia a cerâmica grega arcaica, bem documentada noutros âmbitos do Ocidente Peninsular (v. Domínguez e Sánchez 2000, com bibliografia anterior; Cabrera e Santos 2001), como também as peculiaridades das suas pautas de consumo.

Tal como a lucerna que agora se apresenta, esta taça constitui com efeito um caso isolado no panorama das importações gregas arcaicas do Ocidente peninsular. A presença em Alcácer do Sal da peça que aqui nos ocupa não se encontra, portanto, totalmente desenquadrada, 


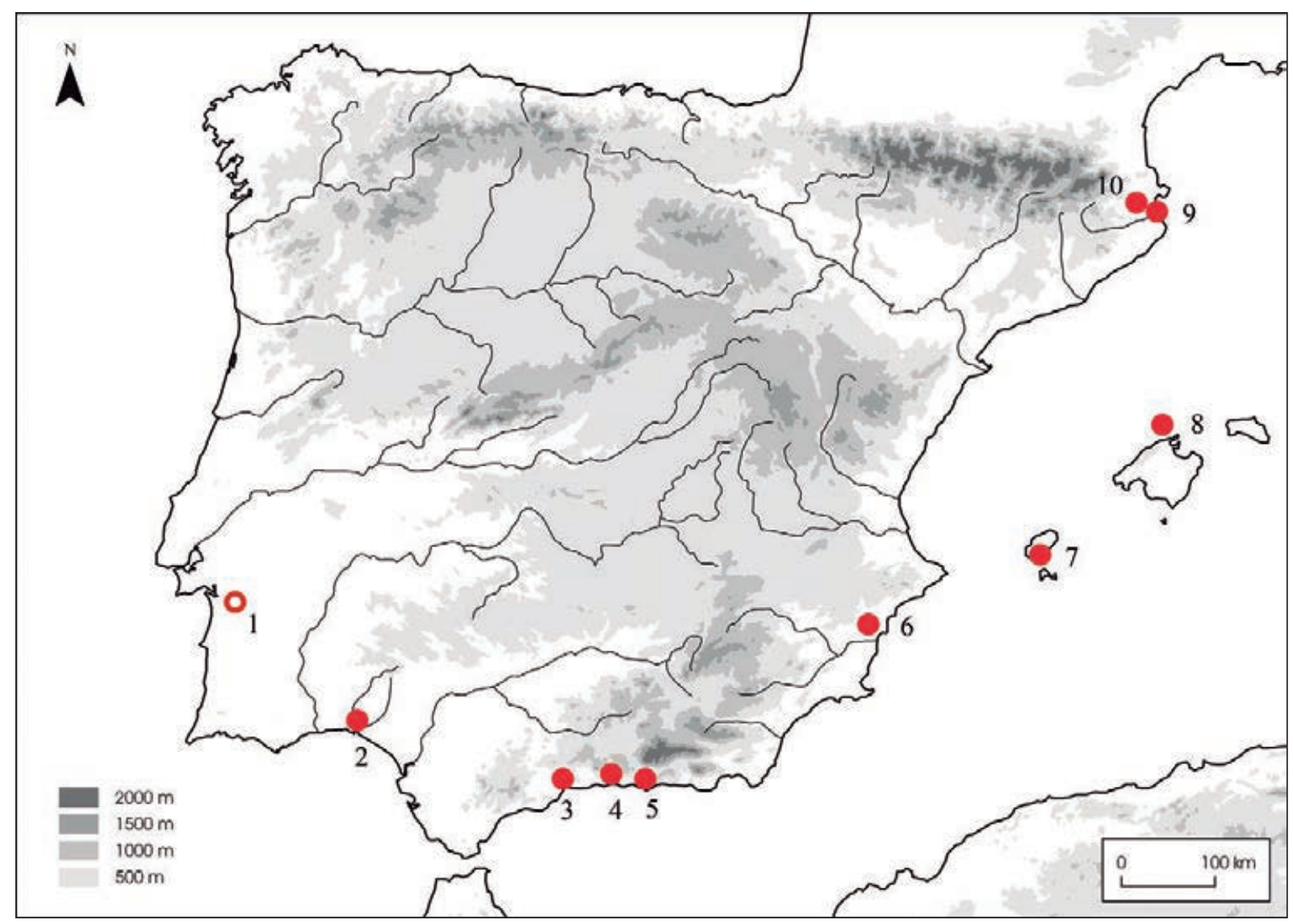

Figura 5. Distribuição geográfica das lucernas gregas arcaicas peninsulares mencionadas no texto: 1 - Olival do Senhor dos Mártires (Alcácer do Sal); 2 - Huelva; 3 - Málaga; 4 - Jardín (Vélez-Málaga); 5 - Puente de Noy (Almuñécar); 6 - Peña Negra (Crevillente); 7 - Puig des Molins (Ibiza); 8 - Cala Sant Vicenç (Mallorca); 9 - Empúries; 10 - Mas Castellar de Pontós (Alt Empordà).

posto que já anteriormente se documentou no sítio não apenas um recipiente de produção grega com uma datação similar mas, sobretudo, de natureza igualmente única (cf. Arruda 2019).

No entanto, o enquadramento desta lucerna no contexto do comércio grego arcaico peninsular merece algumas considerações adicionais. Desde logo, deve assinalar-se que a presença de lucernas entre os repertórios das mais antigas importações gregas na Península Ibérica não é particularmente comum.

Ainda assim, essa presença não é desconhecida (fig. 5), mesmo na área atlântica, conhecendo-se um lote significativo de lucernas arcaicas provenientes de escavações no Centro Histórico de Huelva (fig. 5, n. 2), geralmente atribuídas a produções da Grécia de Leste datáveis entre o século VI e os inícios do V a.n.e. (Cabrera 1989: fig. 9 nn. 159-162, fig. 13 nn. 254-261; Fernández Jurado1989: lám. CXXXIV n. 4, lám. CXXXIX n. 1; Garrido e Orta 1994: fig. 3, Cabrera e Sánchez
2000: 257 n. 31). Recentemente, a realização de análises arqueométricas permitiu também documentar uma produção local de lucernas de tipo grego arcaico, presumivelmente datável da primeira metade/ meados do século VI a.n.e. (González de Canales e Llompart 2017: n. 21).

A presença de lucernas gregas (e de tipo grego) arcaicas está também bem documentada no Centro Histórico de Málaga (Gran-Aymerich 1991: fig. 49, 5 - produção da Grécia de Leste) (fig. 5 n. 3), na necrópole de Jardín (Vélez-Málaga) (Schubart e Maass-Lindemann 1995: 126 - possíveis produções locais) (fig. 5 n. 4), na de Puente de Noy (Almuñécar) (Molina e Huertas 1986: fig. 4 n. 2 - possível produção local) (fig. 5 n. 5), bem como na Fase II do povoado da Peña Negra (Crevillente) (González Prats 1982: 95-96, fig. 1 nn. 3-4 - possíveis produções da Grécia de Leste) (fig. 5 n. 6).

Outro conjunto significativo de lucernas arcaicas foi ainda recolhido em Ibiza, na necrópole de Puig des Molins (fig. 5 n. 7), incluíndo sobretudo 
lucernas áticas de verniz negro (Sánchez 1981: 292 296, figs. 6-7; Fernández et al. 1987: 20-29) mas também uma possível lucerna coríntia do Tipo IV de Broneer (Domínguez e Sánchez 2000: 83), e próxima portanto da família tipológica da peça que aqui nos ocupa. Ainda no âmbito do arquipélago balear cabe assinalar o exemplar recuperado no naufrágio de Cala Sant Vicenç, ao largo de Maiorca (fig. 5 n. 8), considerado neste caso uma produção da Magna Grécia (Nieto e Santos 2009: 89-92).

Finalmente, e como seria de esperar, na colónia grega de Emporion e na sua área de influência as peças deste tipo estão também relativamente bem representadas. Em Ampúrias (fig. 5 n. 9), com efeito, estão documentadas tanto produções áticas como gregas ocidentais (Domínguez e Sánchez 2000: 68-70), a que podem somar-se - sem pretensões de exaustividade - um exemplar da Grécia de Leste e outro grego ocidental de Ullastret (Ugolini 1993: 286) e um exemplar de Mas Castellar de Pontós (Asensio et al. 2017: fig. 2 n.17) (fig. 5 n. 10).

Caberia por outro lado salientar que a escassez de lucernas gregas arcaicas parece extensível ao território meridional francês (Ugolini 1993), excepção feita, como é natural, aos núcleos propriamente gregos ou com uma forte presença grega, como Marselha (Villard 1960: 45) ou Arles (Ugolini 1993: 284). Saliente-se, contudo, a presença de um lote de lucernas áticas ou da Grécia de Leste no naufrágio grego arcaico de Pont Lequin 1 (Long et al. 1992: 217-218 e fig. 37), associado a um conjunto de floral band cups muito similares à do OSM, antes comentada (ibd: 209).

Apesar destas ocorrências, não deve obviar-se o facto de até ao momento não se terem documentado na Península Ibérica nem nos territórios adjacentes lucernas morfologicamente comparáveis à do OSM. Igualmente problemática é a ausência de referências claras a lucernas de produção coríntia ou assimilável, excepção feita ao possível exemplar ebusitano (Domínguez e Sánchez 2000: 83). Com efeito, e como ficou patente na enunciação antes realizada, as produções da Grécia de Leste (e, em menor medida, as produções áticas) são totalmente predominantes entre as lucernas gregas arcaicas peninsulares, o que reforça o carácter isolado e excepcional da peça aqui apresentada.

No entanto, e apesar da extrema raridade das lucernas coríntias no Ocidente, não pode deixar de se assinalar que as produções coríntias em geral não são de modo algum desconhecidas na Península Ibérica, sendo relativamente frequentes os pequenos recipientes de perfume (Rouillard 1991, Domínguez e
Sánchez 2000: 86), mas também produtos de outra natureza, nomeadamente anfórica (Domínguez e Sánchez 2000: 88).

Como ficou referido, a presença de cerâmicas coríntias de figuras negras encontra-se também documentada em Portugal, mesmo que de forma residual (Cardoso 2004: fig. 173, Arruda 2006: 135-6 n. 69, Arruda 2019). Estes elementos, datados do Coríntio Médio, são contudo significativamente mais antigos do que a lucerna aqui apresentada e pertencem a fluxos comerciais de natureza sem dúvida muito distinta.

No período que aqui nos ocupa, em contrapartida, os produtos coríntios são de uma forma geral bastante residuais no território peninsular, reduzindo-se a alguns exemplares de ânforas Coríntias A e B recolhidos em contextos de finais do século VI ou de inícios do V a.n.e. (Pellicer et al. 1983: 89, Fernández Izquierdo et al. 1989: 608-609, Abad e Sala 1993: 203, Cabrera 1995: 391, Aquilué et al. 2001: 329; see also Muñoz 1996: 82) e a um vaso plástico exumado no centro histórico de Huelva, datado também ele desses momentos (Cabrera e Sánchez 2000: 251 n. 25).

Assim, e ainda que desconheçamos o modo ou as vias específicas pelos quais a lucerna aqui estudada (ou, por sinal, a floral band cup ática antes comentada) alcançou Alcácer do Sal, a presença desta invulgar peça parece poder enquadrar-se no quadro mais amplo da circulação de produtos gregos tardo-arcaicos em geral, e coríntios em particular, que, apesar de residual, se encontra ainda assim bem atestada.

Não é por outro lado impossível que a futura publicação dos abundantes materiais ainda inéditos provenientes de escavações em vários pontos do povoado de Alcácer do Sal venham permitir uma melhor contextualização das importações gregas arcaicas do OSM.

Em todo caso, a presença desta peça neste contexto do Extremo Ocidente afigura-se em si mesma como um dado do maior interesse em face da escassez de lucernas gregas arcaicas na Península Ibérica e do absoluto desconhecimento das mesmas no território português, onde a cerâmica grega arcaica é, como vimos, francamente rara (Arruda 2019).

Por outro lado, o estudo desta peça vem reforçar a imagem de Alcácer do Sal como um enclave que deteve, ao longo de toda a sua diacronia sidérica, uma considerável conexão com as redes que unem o território actualmente português à bacia do Mediterrâneo. A lucerna aqui estudada representa portanto um importante dado adicional para a restituição dos processos históricos da comunidade que durante o I milénio a.n.e. ocupou este núcleo do Baixo Sado. 


\section{Agradecimentos}

Gostaria de expressar o meu agradecimento ao Instituto de Arqueologia da Faculdade de Letras da Universidade de Coimbra, na pessoa da Professora Doutora Raquel Vilaça, por todas as facilidades concedidas no acesso a esta e às demais peças de Alcácer do Sal ali depositadas. Agradeço também à Professora Doutora Ana Margarida Arruda e ao Doutor Carlos Pereira pelos seus úteis comentários a uma versão prévia deste trabalho.

O presente artigo foi realizado no contexto do Projecto de Pós-Doutoramento "Made in the Mediterranean: consumo, identidade e economia política no Bronze Final e na I Idade do Ferro do Sul de Portugal" financiado pela Fundação para a Ciência e Tecnologia (Portugal) através da Bolsa de Pós-Doutoramento SFRH/BPD/115343/2016.

\section{BIBLIOGRAFIA}

Abad, L. e Sala, F. (1993): El poblado ibérico de El Oral (San Fulgencio, Alicante). Valencia, Universidad de Valencia.

Abásolo, J.-A.; Ruiz Vélez, I. e Rodríguez, A. (2004): "El conjunto arqueológico de Alto de Rodilla (Monasterio de Rodilla, Burgos)". Boletín del Seminario de Estudios de Arte y Arqueología 69-70: $115-$ 146.

Aquilué, X.; Castanyer, P.; Santos, M. e Tremoleda, J. (2001): "Les ceràmiques gregues arcaiques de la Palaià Polis d'Empòrion", em P. Cabrera e M. Santos (eds.), Ceràmiques jònies d'època arcaica: centres de producció i comercialització al Mediterrani Occidental. Actes de la Taula Rodona celebrada a Empúries, els dies 26 al 28 de maig de 1999: 285 346. Empúries (1999), Barcelona, Museu d'Arqueologia de Catalunya.

Arruda, A. M. (2006): "Cerâmicas gregas encontradas em Portugal”, em Vasos Gregos em Portugal. Aquém das Colunas de Hércules: 135-149. Lisboa, Museu Nacional de Arqueologia.

Arruda, A. M. (2019): "A cerâmica grega arcaica do território actualmente português". Archivo Español de Arqueología 92: 19-25. DOI: <http://doi. org/10.3989/aespa.092.019.002>.

Asensio, D.; Pons, E.; Jornet, R. e Morer, J. (2017): "Aportación de la cerámica griega fina y sus contextos cerámicos a la caracterización de la secuencia de asentamientos superpuestos entre el siglo VI y el siglo IV a. C. en el Mas Castellar de Pontós
(Alt Empordà, Girona)", em X. Aquilué, P. Cabrera e M. Orfila (eds.), Homenaje a Glòria Trias Rubiés. Cerámicas griegas de la Península Ibérica: cincuenta años después (1967-2017): 124-139. Empúries, Centro Iberia Graeca. URL: <https://www.iberiagraeca.net/otros/Libro_Homenaje_Gloria.pdf> [consultado a 20/07/2018].

Bailey, D. M. (1975): A Catalogue of the lamps in the British Museum. 1. Greek, Hellenistic and early Roman pottery lamps. Londres, British Museum.

Beazley, J. (1978): Attic Black-Figure Vase-Painters. Oxford, Oxford University Press.

Blánquez, J. (1990): La formación del mundo ibérico en el Sureste de la Meseta. Estudio arqueológico de las necrópolis ibéricas de la provincia de Albacete. Albacete, Diputación Provincial de Albacete.

Bloesch, H. (1940): Formen attischer Schalen. Berna, Benteli.

Brito, M. A. de A. e (1968): Contributo para a classificação de alguns achados de Alcácer do Sal (Época Pré-Romana). Tese de Licenciatura, Universidade de Coimbra. Inédita.

Broneer, O. (1930): Corinth. Volume IV, Part II, Terracotta Lamps. Cambridge, Harvard University Press.

Cabrera, P. (1989): "El comercio foceo en Huelva: cronología y fisionomía". Huelva Arqueológica 10-11: 41-100.

Cabrera, P. (1995): “Cerámicas griegas en Tartessos: su significado en la costa meridional de la Península desde Málaga a Huelva", em Tartessos: 25 años después, 1968-1993. Actas del Congreso Conmemorativo del V Symposium Internacional de Prehistoria Peninsular: 387-399. Cádiz (1993), Jerez de la Frontera, Ayuntamiento de Jerez de la Frontera.

Cabrera, P. e Sánchez, C. (2000): "El comercio griego con el mundo ibérico durante la época clásica", em Los Griegos en España: tras las huellas de Heracles: 133-148. Madrid, Museo Arqueológico Nacional.

Cabrera, P. e Santos, M. (2001) (eds.): Ceràmiques jònies d'època arcaica: centres de producció $i$ comercialització al Mediterrani occidental. Barcelona, Museu d'Arqueologia de Catalunya.

Cardoso, J. L. (2004): A Baixa Estremadura, dos finais do IV milénio a.C. até à chegada dos Romanos: um ensaio de História Regional. Oeiras, Centro de Estudos Arqueológicos de Oeiras.

Cerdeño, Mª L. (1978): "Los broches de cinturón peninsulares de tipo céltico". Trabajos de Prehistoria 35: 279-307.

Correia, V. (1972 [1925]): "Uma conferência sobre a Necrópole de Alcácer do Sal", em Obras. Volume 
IV, Estudos Arqueológicos: 151-168. Coimbra, Universidade de Coimbra.

Correia, V. (1972 [1928]): “Escavações realizadas na Necrópole Pré-Romana de Alcácer do Sal em 1926 e 1927”, em Obras. Volume IV, Estudos Arqueológicos: 169-179. Coimbra, Universidade de Coimbra.

Cuadrado, E. (1987): La necrópolis ibérica de El Cigarralejo (Mula, Murcia). Madrid, Real Academia de la Historia.

Domínguez, A. e Sánchez, C. (2000): Greek Pottery in the Iberian Peninsula. Leiden, Brill.

Fernández, J. H.; Maluquer, J. e Picazo, M. (1987): Corpus Vasorum Antiquorum. Espagne, Fascicule 6. Musée d'Eivissa. Barcelona, Institut d'Estudis Catalans.

Fernández Jurado, J. (1989): Tartessos y Huelva. Huelva, Diputación Provincial de Huelva.

Fernández Izquierdo, A.; Gómez, C. e Ribera, A. (1989): “Ánforas griegas, etruscas y fenicias del yacimiento submarino de Cabanyal-Malvarrosa (Valencia)", em Crónica del XIX Congreso Nacional de Arqueología: 607-617. Valencia (1987), Zaragoza, Universidad de Zaragoza.

Frankenstein, S. (1997): Arqueología del colonialismo. El impacto fenicio y griego en el sur de la Península Ibérica y el suroeste de Alemania. Barcelona, Editorial Crítica.

Galli, V. (2004): Gravisca. Scavi nel Santuario Greco. Le lucerne greche e locali. Bari, Edipuglia.

Garrido, J. P. e Orta, E. M. (1994): El habitat antíguo de Huelva (Periodos Orientalizante y Arcaico). La primera excavación en la Calle del Puerto. Madrid, Instituto de Conservación y Restauración de Bienes Culturales.

Genito, M. C. G. (1977): Lucerne fittili delle collezioni del Museo civico archeologico di Bologna. Bologna, Istituto per la Storia di Bologna.

Gomes, F. B. (2016): Contactos culturais e discursos identitários na I Idade do Ferro do Sul de Portugal (séculos VIII - V a.n.e.): leituras a partir do registo funerário. Tese de Doutoramento. Universidade de Lisboa. Inédita. URL: <http://hdl.handle. net/10451/25042> [consultado a 20/07/2018].

Gomes, F. B. (2017): “Un conjunto de cerámicas áticas inéditas de la necrópolis de Olival do Senhor dos Mártires". Onoba 5: 45-58. URL: <http://www. uhu.es/publicaciones/ojs/index.php/onoba/article/ view/3122/2874> [consultado a 20/07/2018].

Gomes, F. B. (no prelo): "A evolução dos rituais funerários da Idade do Ferro no Ocidente Peninsular: uma nova proposta de faseamento para a necrópole do Olival do Senhor dos Mártires (Alcácer do Sal)". O Arqueólogo Português S.5:6.

Gomes, J. J. F. e Domingos, J. B. B. (1983): “A 'xorca' da Serra das Ripas (Alenquer)". O Arqueólogo Português S.4:1: 287-300.

González de Canales, F. e Llompart, J. (2017): "Producción de cerámicas griegas arcaicas en Huelva". Archivo Español de Arqueología 90: 125-145. DOI: $<$ http://doi.org/10.3989/aespa.090.017.006>.

González Prats, A. (1982): "El componente tipológico griego en el ambiente cerámico de Peña Negra II (675-650 A.C.)". Lucentum I: 93-113.

Graells, R. e Lorrio, A. (2017): Problemas de cultura material: Broches de cinturón decorados a molde de la Península Ibérica (s. VII-VI A.C.). Alicante, Universidad d'Alacant.

Gran-Aymerich, J. (1991): Málaga Phénicienne et Punique: Recherches franco-espagnoles 1981-1988. Paris, Éditions Recherches sur les Civilisations.

Howland, R. H. (1958): Athenian Agora. Volume IV, Greek Lamps and their survivals. Princeton, The American School of Classical Studies at Athens.

Jiménez Ávila, J. (2008): "Grapas y charnelas de diphroi”, em M. Almagro-Gorbea (dir.), La necrópolis de Medellín. II. Estudio de los hallazgos: 542552. Madrid, Real Academía de la Historia.

Long, L.; Miro, J. e Volpe, G. (1992): "Les épaves archaïques du Point Lequin (Porquerolles, Hyères, Var). Des donnés nouvelles sur le commerce de Marseille à la fin du VIe et dans la première moitié du Ve s. av. J.C.", em M. Bats, G. Bertucchi, G. Congès e H. Tréziny (eds.), Marseille Grecque et la Gaule. Actes du colloque international, Marseille, 18-23 novembre 1990: 199-234. Marselha (1990), Lattes/ Aix-en-Provence, ADAM éditions/ Université de Provence.

López Ambite, F. (2008): "Broches de cinturón", em M. Almagro-Gorbea (dir.), La necrópolis de Medellín. II. Estudio de los hallazgos: 514-528. Madrid, Real Academía de la Historia.

Lorrio, A. (1997): Los Celtiberos. Madrid, Universidad Complutense de Madrid.

Lorrio, A. (2008): “Cerámica gris”, em M. Almagro-Gorbea (dir.), La necrópolis de Medellín. II. Estudio de los hallazgos: 673-723. Madrid, Real Academía de la Historia.

Maluquer, J. (1957): "Un interesante lote de bronces, hallado en el castro de Sanchorreja (Avila)". Zephyrus VIII: 241-256.

Molina, F. e Huertas, C. (1986): Almuñécar en la Antiguedad. La necrópolis fenicio-púnica de Puente de Noy II. Granada, Caja Provincial de Granada. 
Muñoz, Á. (1996): "Secuencia histórica del asentamiento fenicio-púnico de Cádiz: un análisis crono-espacial tras quince años de investigación arqueológica". Boletín del Museo de Cádiz 7: 77-105.

Nieto, X. e Santos, M. (2009): El vaixell grec arcaic del pecio de Cala Sant Vicenç. Barcelona: Museu d'Arqueologia de Catalunya.

Pellicer Catalán, M.; Escacena Carrasco, J. L. e Bendala Galán, M. (1983): El Cerro Macareno. Madrid, Ministerio de Cultura.

Paixão, A. C. (1970): A necrópole do Senhor dos Mártires, Alcácer do Sal. Novos elementos para o seu estudo. Tese de Licenciatura, Universidade de Lisboa. Inédita.

Piñel, C. (1976): "Materiales del poblado de Las Paredejas, en el Cerro del Berrueco. Una nueva arracada". Zephyrus XXVI-XXVII: 351-368.

Ponte, S. da (1985): "Algumas fíbulas de Alcácer do Sal”. O Arqueólogo Português S.4:3: 137-154.

Rouillard, P. (1991): Les Grecs et la Péninsule Ibérique: du VIIIe au IVe siècle avant Jésus-Christ. Paris, Diffusion du Boccard.

Rouillard, P.; Paixão, A. C.; Villanueva-Puig, M.-C. e Durand, J.-L. (1989): "Les vases grecques d'Alcácer do Sal”. O Arqueólogo Português S.4:6-7: 43-108.
Sánchez, C. (1981): "La cerámica ática de Ibiza en el Museo Arqueológico Nacional”. Trabajos de Prehistoria 38: 281-311.

Schubart, H. e Maass-Lindemann, G. (1995): "Informe de las excavaciones en la necrópolis de Jardín (Vélez-Málaga, Málaga)". Cuadernos de Arqueología Mediterránea 1: 57-213.

Schüle, W. (1969): Die Meseta-kulturen der Iberischen Halbinsel: Mediterrane und Eurasische elemente in früheisen zeitlichen kulturen südwesteuropas. Berlim, Walter de Gruyter \& Co.

Torres Ortiz, M. (2002): Tartessos. Madrid, Real Academia de la Historia.

Ugolini, D. (1993): "Lampes grecques et de type grec de Béziers. Utilisation et diffusion de la lampe grecque dans le Midi entre le VIe et le IVe siècle avant J.-C.". Documents d'Archéologie Méridionale 16: 279-293.

Vilaça, R. (ed.) (2016): O Instituto de Arqueologia: fragmentos da sua colecção. Coimbra, Imprensa da Universidade de Coimbra. DOI: <http://dx.doi. org/10.14195/978-989-26-1124-2>

Villard, F. (1960): La céramique grecque de Marseille (VIe - IVe s.). Essai d'histoire économique. Paris, Éditions du Boccard. 



\title{
CERRO MACARENO (LA RINCONADA, SEVILLA): NUEVOS DATOS SOBRE SU SECUENCIA DE OCUPACIÓN Y RASGOS CONSTRUCTIVOS
}

\author{
CERRO MACARENO (LA RINCONADA, SEVILLA): NEW DATA ON ITS \\ OCCUPATION SEQUENCE AND ITS CONSTRUCTIVE FEATURES
}

\author{
FRANCISCO JOSÉ GARCÍA FERNÁNDEZ \\ Profesor Titular de Universidad, Departamento de Prehistoria y Arqueología, Facultad de Geografía e Historia, \\ Universidad de Sevilla. Dirección postal: c/ María de Padilla s/n, 41004, Sevilla \\ Telf.: 954551414. Correo-e: fjgf@us.es. D https://orcid.org/0000-0002-4978-8818 \\ Researcher ID: https://publons.com/researcher/K-3364-2014
}

\begin{abstract}
Resumen: La intervención arqueológica llevada a cabo en 2017 en Cerro Macareno ha proporcionado un ingente caudal de información que corrobora, pero también matiza, los datos aportados por las excavaciones de urgencia realizadas en este yacimiento a mediados de la década de los setenta. La metodología aplicada se ha basado en todo momento en técnicas no destructivas o de bajo impacto sobre los restos. Entre las tareas desarrolladas destaca la limpieza de perfiles y el estudio de las secciones estratigráficas resultantes en diferentes puntos del yacimiento, que han permitido llevar a cabo un análisis comparado de las distintas secuencias obtenidas. Estas se han cotejado posteriormente con las plantas y secciones de las antiguas excavaciones publicadas, una vez que han sido digitalizadas y georreferenciadas, especialmente el sondeo estratigráfico efectuado por M. Pellicer y su equipo en 1976. Como resultado, contamos con una sistematización de la documentación existente y una actualización del conocimiento sobre los niveles de ocupación conservados y su cronología. Asimismo, se han podido recopilar nuevos datos sobre las formas arquitectónicas, los materiales y técnicas constructivas, así como sobre las pautas de edificación-reparación-reconstrucción de los edificios.

Palabras clave: Protohistoria, Bajo Guadalquivir, estratigrafía, cronología, urbanismo, arquitectura, técnicas constructivas.
\end{abstract}

\begin{abstract}
The archaeological intervention carried out in 2017 in Cerro Macareno has provided an enormous amount of information that corroborates and qualifies the data provided by the emergency excavations carried out in this site in the mid-seventies. The methodology applied has always been based on non-destructive techniques or low impact on the remains. Among the tasks developed, the cleaning of slopes and the study of the resulting stratigraphic sections in different points of the site stand out, which have allowed a comparative analysis of the different sequences obtained. Then, they have been compared with the plants and sections of the old excavations published, once they had been digitalised and georeferenced, especially the stratigraphic sounding carried out by M. Pellicer and his team in 1976. As a result, we have a systematization of the existing documentation and an update of the knowledge about the levels of occupation conserved and their chronology. Likewise, it has been possible to collect new data on architectural forms, materials and construction techniques, as well as on the building-repair-reconstruction guidelines of the buildings.
\end{abstract}

Key words: Protohistory, Lower Guadalquivir valley, stratigraphy, chronology, urbanism, architecture, construction techniques. 
Cerro Macareno es un gran tell protohistórico ubicado en el municipio de La Rinconada (Sevilla), junto a la barriada de San José. Se situaba originalmente sobre un suave promontorio formado por las terrazas bajas del Guadalquivir, en su margen izquierda y junto a un canal navegable del mismo, ocupado actualmente por el arroyo Almonázar. Ello le proporcionaba una posición privilegiada en relación con el sistema poblacional introducido por los fenicios a inicios de la Edad del Hierro y que se mantuvo con pocos cambios a lo largo del I milenio a.C. (Escacena 1983 y 1987; véase también Ferrer et al. 2008, Ferrer 2017, García Fernández 2017). El yacimiento pasó inadvertido para la arqueología hasta el inicio de su destrucción a principios de la década de los setenta, cuando su explotación como gravera levantó la voz de alarma entre aficionados e investigadores, que pusieron los primeros medios para su conservación y estudio, como se verá más adelante. A pesar de la paralización de las labores extractivas en 1975, su perímetro acabó reducido a menos de un tercio de su superficie original, que se llegó a estimar en $50000 \mathrm{~m}^{2}$ (Pellicer et al. 1983: 18). Hoy en día el yacimiento está constituido por dos cerros testigo separados por una lengua de tierra, correspondiente al antiguo frente de extracción de la gravera, con diferente nivel de conservación. La elevación oriental, la menos afectada por la acción de las máquinas, conforma una meseta regular de forma romboidal de aproximadamente $9000 \mathrm{~m}^{2}$ y $8 \mathrm{~m}$ de potencia máxima, conservando la superficie original del cerro y, por tanto, la mayor parte de los depósitos arqueológicos. Por el contrario, la elevación occidental, de unos $6500 \mathrm{~m}^{2} \mathrm{y}$ con una superficie más irregular, ya había sido parcialmente desmontada a mediados de los años setenta, por lo que solo conserva unos $2 \mathrm{~m}$ de potencia arqueológica, correspondientes a los estratos inferiores (fig. 1).

Paradójicamente, el cierre de la cantera no supuso un avance en las investigaciones, que carecieron de continuidad más allá del estudio de los resultados de las ya realizadas o la revisión de algunos materiales procedentes de las mismas. Solo cuarenta años después de las últimas excavaciones, dirigidas por M. Pellicer (Pellicer et al. 1983), se han retomado las investigaciones en Cerro Macareno a partir de un convenio suscrito entre el Departamento de Prehistoria y Arqueología de la Universidad de Sevilla y el Ayuntamiento de La Rinconada, con un triple objetivo: avanzar en el conocimiento científico del yacimiento y su entorno, garantizar su adecuada protección y conservación y explorar las estrategias más adecuadas de integración urbanística y puesta en valor de este espacio. Para ello se planteó una primera intervención arqueológica puntual en 2017 destinada a realizar un diagnóstico previo mediante técnicas no invasivas (prospección superficial, prospección geofísica, limpieza de perfiles y registro de estructuras emergentes), que permitiera valorar el estado de los restos conservados y su potencial científico, así como aportar nuevos datos sobre la secuencia de ocupación y la organización urbana del primitivo asentamiento con objeto de orientar actuaciones futuras en el marco de proyectos de investigación sistemáticos. Los resultados obtenidos son coherentes con los proporcionados por las excavaciones anteriores, pero introducen también interesantes matices en lo que se refiere a la evolución del hábitat y su distribución espacial, la entidad o función de las estructuras y sus características arquitectónicas y constructivas (v. García Fernández et al. e.p.).

\section{ANTECEDENTES}

Las primeras noticias que se tienen de Cerro Macareno se remontan a inicios de la década de los setenta, cuando unos vecinos de la cercana localidad de Brenes dan a conocer la existencia de restos arqueológicos en la zona, comunicándoselo al Departamento de Prehistoria y Arqueología de la Universidad de Sevilla. Las visitas de algunos de sus miembros y de M. Ponsich, que por aquel entonces estaba elaborando el primer volumen de su obra Implantation rurale Antique sur le Bas-Guadalquivir (Ponsich 1974), dieron lugar a las primeras noticias científicas que se tienen del mismo. Durante esos mismos años se había producido también el depósito, en el Museo Arqueológico de Sevilla, de algunos materiales de esa procedencia, lo que incrementó el interés por este lugar (Fernández-Chicarro 1974).

No obstante, fue la sistemática destrucción del yacimiento con motivo de su puesta en explotación como cantera de áridos la que despertó la atención de la comunidad científica y la que determinó el inicio de su estudio y las primeras tentativas de protección. Así pues, a finales de 1973 los terrenos ocupados por el yacimiento fueron incluidos en el Decreto 3383/1973, de 21 de diciembre, por el que se declaran de utilidad pública, a efectos de expropiación forzosa, diversos yacimientos arqueológicos de excepcional importancia para el conocimiento del reino de Tartessos, en el Bajo Guadalquivir (García y Del Espino 2019). Al año siguiente, tras una visita de J. Maluquer de Motes, por aquel entonces Comisario General de Excavaciones Arqueológicas, se organizó la primera campaña de excavaciones 

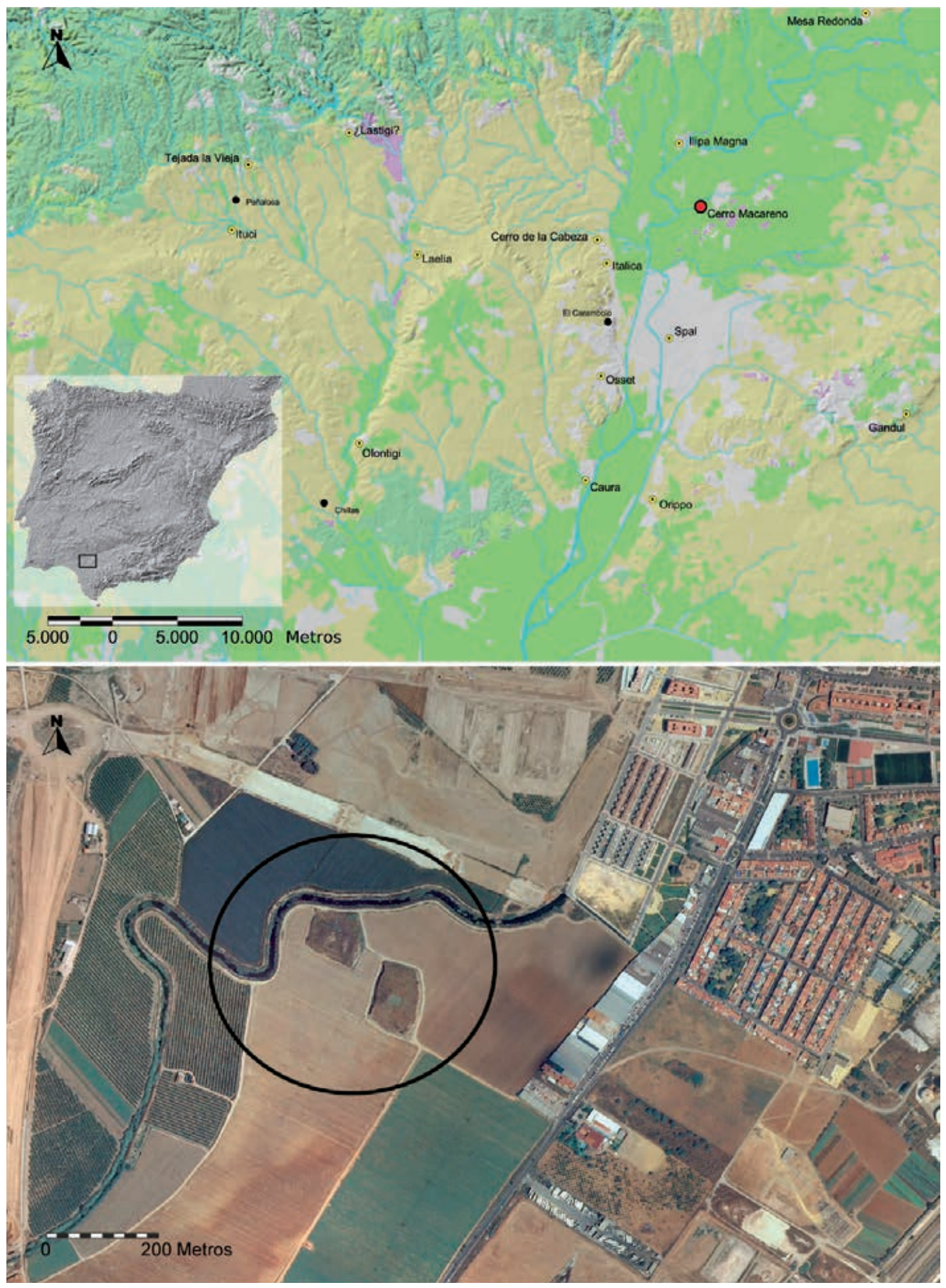

Figura 1. Ubicación de Cerro Macareno en el contexto del poblamiento protohistórico del Bajo Guadalquivir (arriba) e imagen aérea del yacimiento (abajo), a partir de la Ortofotografia Básica Color de Andalucía 2010-2011 (<http://www. ideandalucia.es/wms/ortofoto2010>).

ISSN: $1133-4525$ ISSN-e: $2255-3924$ 


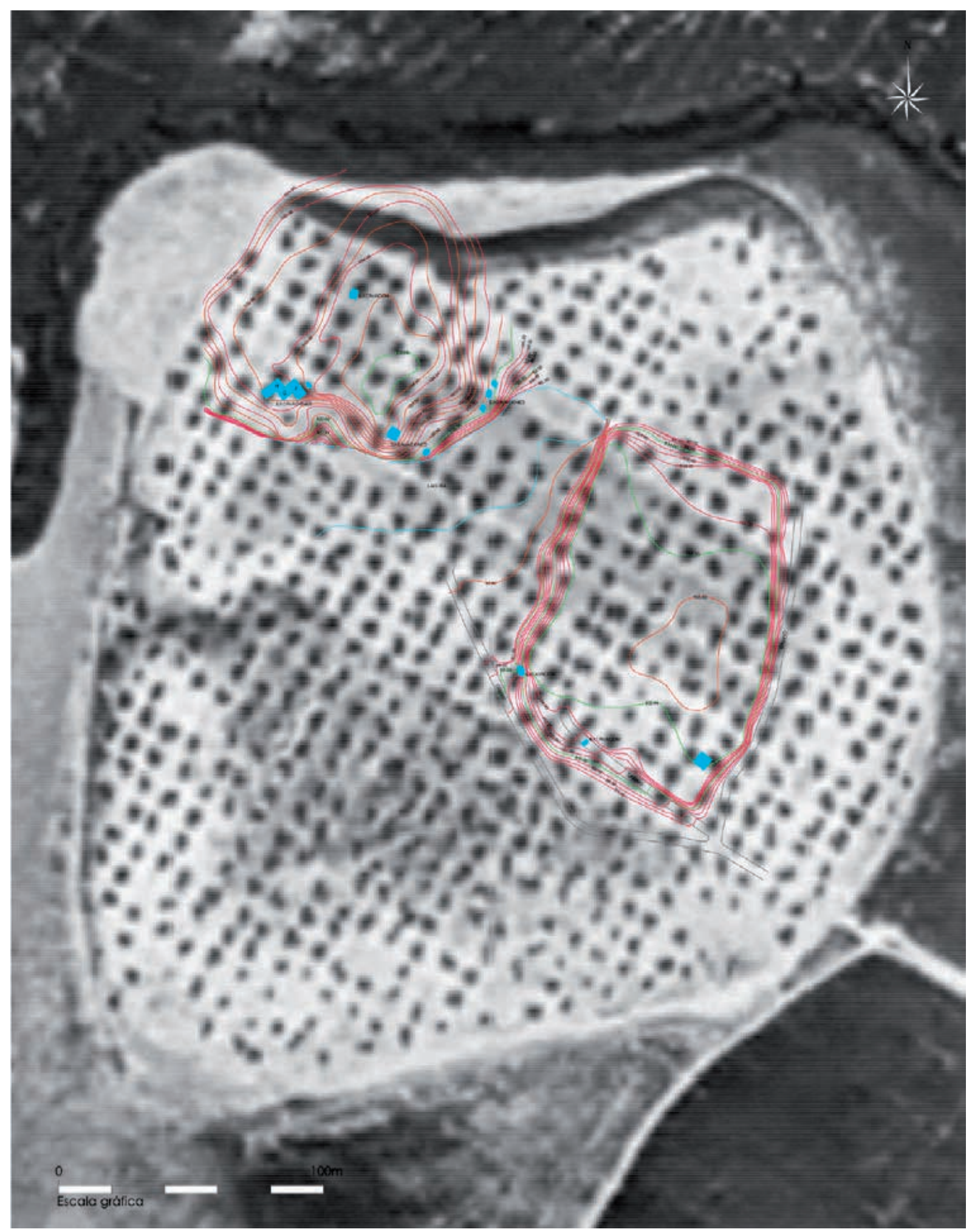

Figura 2. Levantamiento topográfico realizado en 1974, con indicación de los cortes practicados entre 1974 y 1976 (a partir de Fernández Gómez et al. 1979), superpuesto a la imagen del yacimiento previa a su destrucción obtenida de la Ortofoto de Andalucía 1956-57 (Vuelo General de España de 1956). 


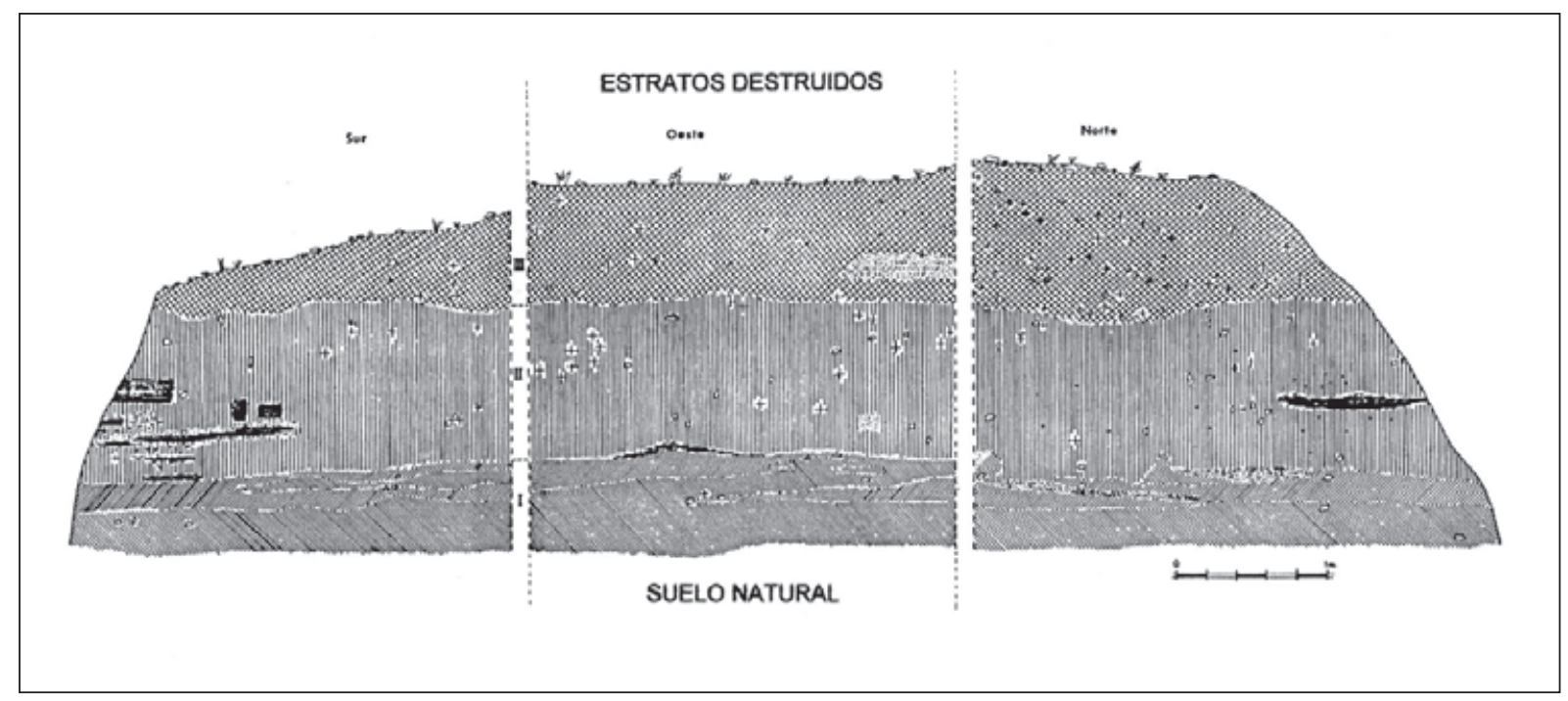

Figura 3. Secciones estratigráficas obtenidas en el corte C (elevación occidental) de 1974 (Ruiz Mata y Vallejo 2002: fig. 2).

a cargo de un equipo de arqueólogos de la Universidad Autónoma de Madrid, el Museo Arqueológico de Sevilla y la Universidad de Sevilla (Fernández Gómez et al. 1979: 11).

La intervención se inició con la excavación, durante el verano de 1974, de los cortes A, B, C, D y E, localizados en distintos puntos de la elevación occidental, así como con una limpieza de perfiles en la elevación oriental (corte F), con el fin de poder correlacionar estratigráficamente ambos sectores (fig. 2). A principios de noviembre del mismo año se reanudaron las excavaciones en la elevación occidental, en un sector cuya destrucción era inminente, pues aún no se habían paralizado las labores extractivas de la cantera. Aquí se abrieron otros tres cortes ( $\mathrm{F}, \mathrm{G}$ y $\mathrm{H})$, de los que finalmente se encargó el equipo del Museo Arqueológico de Sevilla (fig. 2). Esta segunda fase se interrumpió a finales del mismo mes a causa de las lluvias y no se pudieron retomar debido a la negativa de los propietarios y del contratista hasta que no se resolviera el expediente de expropiación incoado (Fernández Gómez et al. 1979: 11).

$\mathrm{Al}$ año siguiente, en 1975, se programó una segunda campaña, aunque nunca llegó a emprenderse debido a las mismas razones. Finalmente, en 1976 y con el beneplácito del contratista, M. Pellicer obtuvo el permiso para la realización de una nueva intervención con el fin de recabar la información necesaria para agilizar los trámites iniciados. En este caso la excavación se llevó a cabo en el talud SE de la elevación oriental, una zona que aparentemente ofrecía una secuencia completa e inalterada de las distintas fases de ocupación del cerro (fig. 2). El corte V-20, que recibió ese nombre a partir de la nueva organización del yacimiento en un sistema cartesiano de cuadrículas planteada por el equipo de Pellicer (Pellicer et al. 1983: 18), constituye la última excavación realizada hasta la fecha.

Lamentablemente, la publicación de los resultados de estas intervenciones fue muy irregular. Los cortes A, B y D quedaron inéditos; por el contrario, el estudio de los cortes E, F y G, a cargo del equipo del Museo Arqueológico de Sevilla, vio rápidamente la luz (Fernández Gómez et al. 1979). La limpieza de perfiles realizada en la elevación oriental constituyó la Memoria de Licenciatura de J.C. Martín de la Cruz, publicándose también de forma inmediata (Martín de la Cruz 1976), mientras que el sondeo estratigráfico efectuado en 1976 en el mismo sector por el equipo de M. Pellicer dio lugar algunos años después a una monografía que se convertiría en un referente para el estudio de la secuencia cultural protohistórica del Bajo Guadalquivir (Pellicer et al. 1983). A partir de ahí habría que esperar dos décadas para que D. Ruiz Mata emprendiera la publicación de los restantes cortes, el H.I y H.II (Ruiz Mata y Córdoba 1999) y el corte C (Ruiz Mata y Vallejo 2002).

Este último, ofreció una estratigrafía de $2,5 \mathrm{~m}$ de potencia máxima (fig. 3), donde pudieron distinguirse tres estratos bastante homogéneos, sin restos constructivos y con una cronología que puede situarse en torno al s. VI a.C. a partir del material exhumado en los mismos, exclusivamente cerámico (Ruiz Mata y Vallejo 2002: 199). Paralelamente, el corte E se excavó hasta 


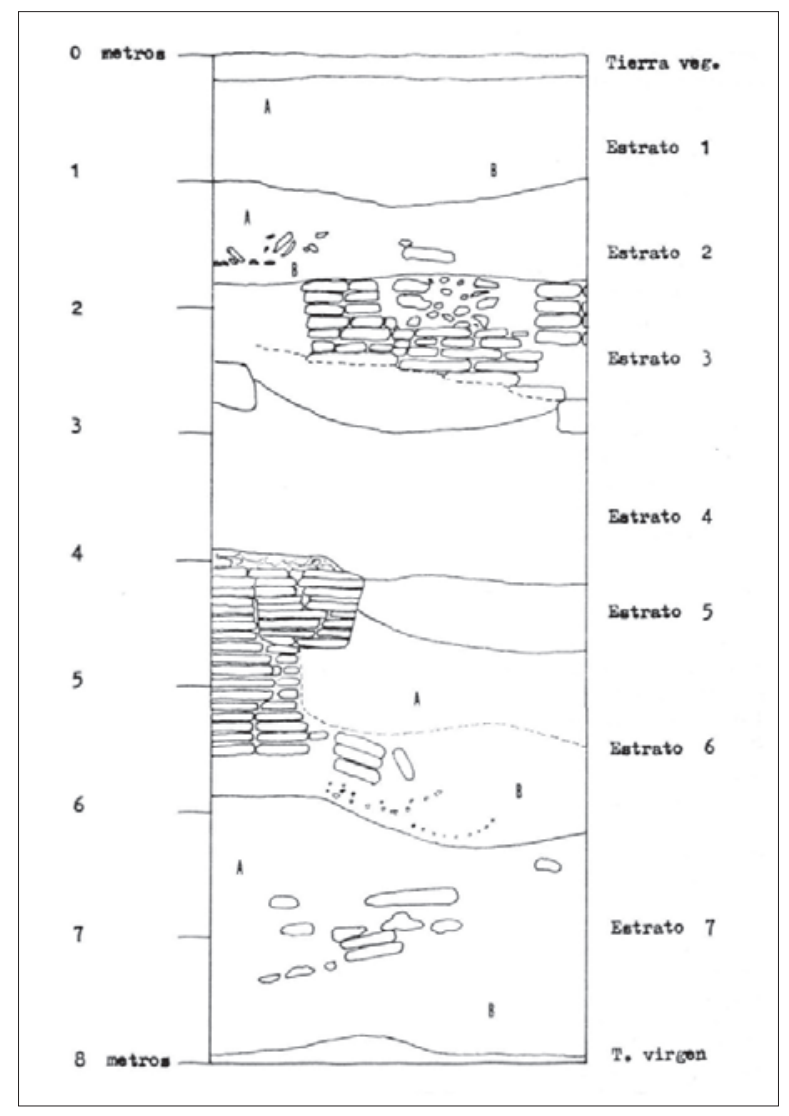

Figura 4. Sección estratigráfica obtenida en el corte F (elevación oriental) de 1974 (Martín de la Cruz 1976: fig. 2).

una profundidad de 1,45 m. En ese punto apareció un potente suelo de habitación que abarcaba prácticamente toda la cuadrícula, asociado a restos de muros de adobe y a un hogar sobre el que se superponía un depósito de abandono y derrumbe formado por escombros, tierra y ceniza (Fernández Gómez et al. 1979: 14-23).

Por su parte, los cortes F, G y H dieron con una amplia área artesanal asociada a un posible espacio de hábitat anejo (fig. 5). Este se pudo registrar únicamente en el corte $\mathrm{F}$, dividido en dos por un potente muro que lo atravesaba en sentido NE-SO y al cual se unía otro perpendicular en el centro de la cuadrícula, conformando dos ámbitos perfectamente delimitados: uno exterior, relacionado con las estructuras de producción de los cortes $\mathrm{G}$ y $\mathrm{H}$, y otro interior, separado a su vez en dos estancias distintas y bien pavimentadas (Fernández Gómez et al. 1979: 23-26). Sin embargo, es la presencia de un conjunto de hornos de cerámica lo que determina la función de este sector. En el corte G se documentó la cámara de combustión de un horno de planta ovalada y pilar central, con la boca abierta al este (Fernández
Gómez et al. 1979: 26-28); mientras que en los cortes H.I y H.II se excavaron otras dos estructuras de similares características aunque de distinto tamaño (Ruiz Mata y Córdoba 1999). Tanto uno como los otros estaban asociados a dos hoyos que se extendían hacia la cuadrícula $F$, rellenos de capas de ceniza, tierra, adobe y restos de cerámica procedentes de la limpieza de los hornos (Fernández Gómez et al. 1979: 25). Estos materiales y otros vinculados a sus niveles de construcción y uso, permitieron fechar este complejo alfarero entre mediados/finales del s. V y mediados del IV a.C. (García Fernández y García Vargas 2012: 21).

Por último, el corte V-20 de Pellicer, con 4 x $4 \mathrm{~m}$ de lado y 7,50 m de potencia máxima (fig. 6), ofreció una secuencia completa de la ocupación del cerro que se inicia a mediados del s. VIII y se prolonga ininterrumpidamente hasta principios del I a.C. (Pellicer et al. 1983). Aquí se pudieron registrar hasta siete episodios constructivos, representados por una sucesión de muros, pavimentos, hogares, etc., algunos de ellos con varias fases de refacción, asociados siempre a niveles domésticos, que contribuyeron a reconstruir la evolución del poblado, tanto en lo que se refiere a su cultura material como sus las formas de vida. No en vano, el estudio sistemático de los contextos cerámicos exhumados en las distintas fases sentó las bases para la clasificación de las producciones regionales de la Edad del Hierro (Pellicer 1982, Pellicer et al. 1983) y, sobre todo, para la primera seriación tipológica de las ánforas prerromanas del valle del Guadalquivir (Pellicer 1978). Asimismo, se examinaron los restos faunísticos (Amberger 1985) y se emprendieron las primeras analíticas de pastas, con el fin de determinar el origen y las características de estas producciones (González García et al. 1985, González Vilches et al. 1985a, b, 1988).

Desde entonces y hasta el inicio del actual proyecto no se han llevado a cabo nuevas intervenciones sobre el yacimiento, a excepción de la prospección arqueológica superficial realizada en 2007 con motivo de la redacción del PGOU de La Rinconada (Jiménez 2010). Este estudio se centró en los sectores recientemente calificados como Suelo Urbanizable, que afectaban tanto a los terrenos ocupados por el Cerro Macareno como a su entorno más inmediato, y tuvo entre sus principales objetivos establecer la delimitación original del primitivo oppidum de cara a garantizar su protección futura. Combinando el trabajo de campo con el análisis de las fotografias aéreas, desde el Vuelo Americano de 1956 hasta las más recientes, se pudo reconstruir cartográficamente el perímetro del montículo antes de su destrucción y avanzar en la determinación de posibles áreas y fases de ocupación, 


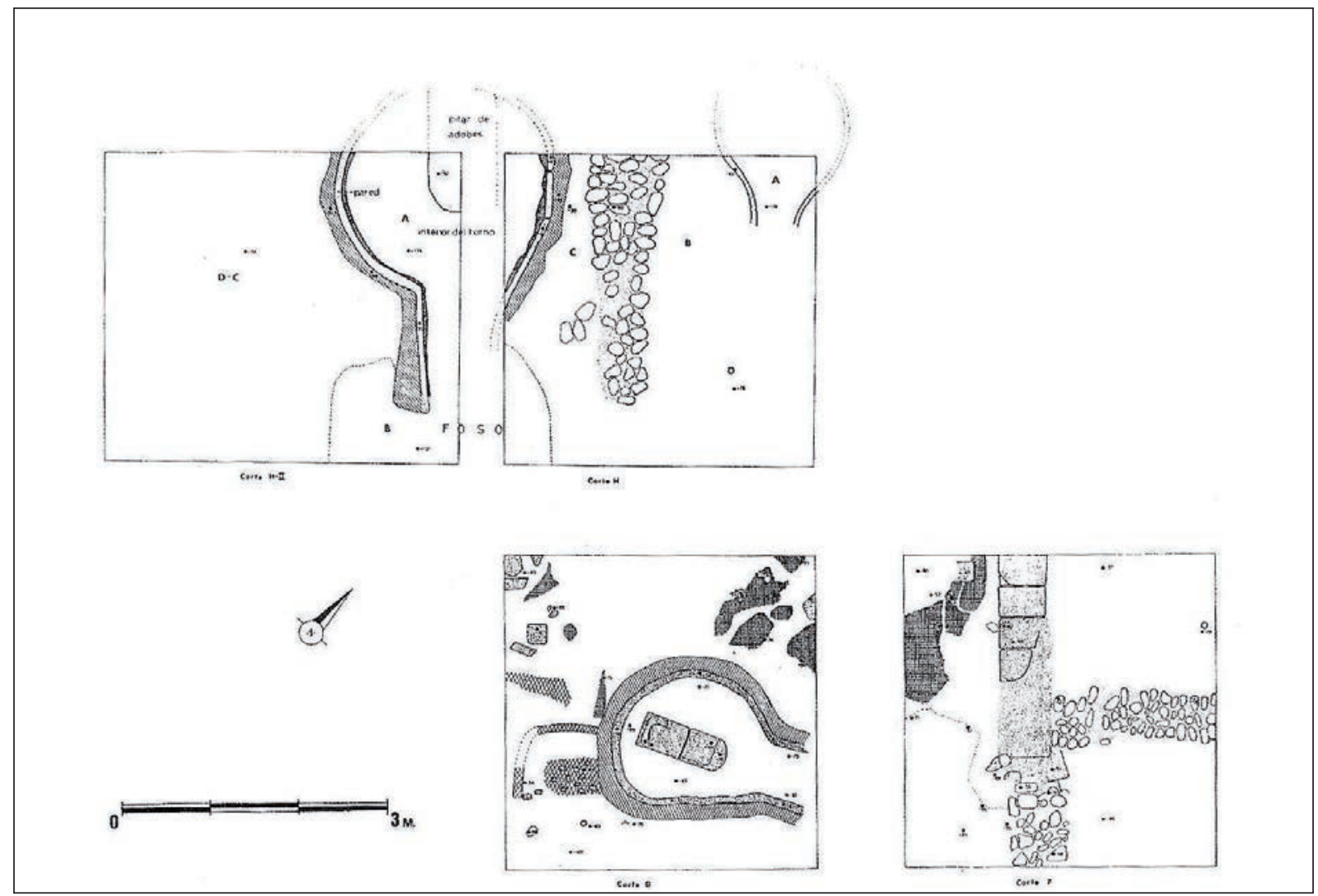

Figura 5. Planta de las estructuras documentadas en los cortes F, G y H (elevación occidental) de 1974 (Ruiz Mata y Córdoba 1999: fig. 3).

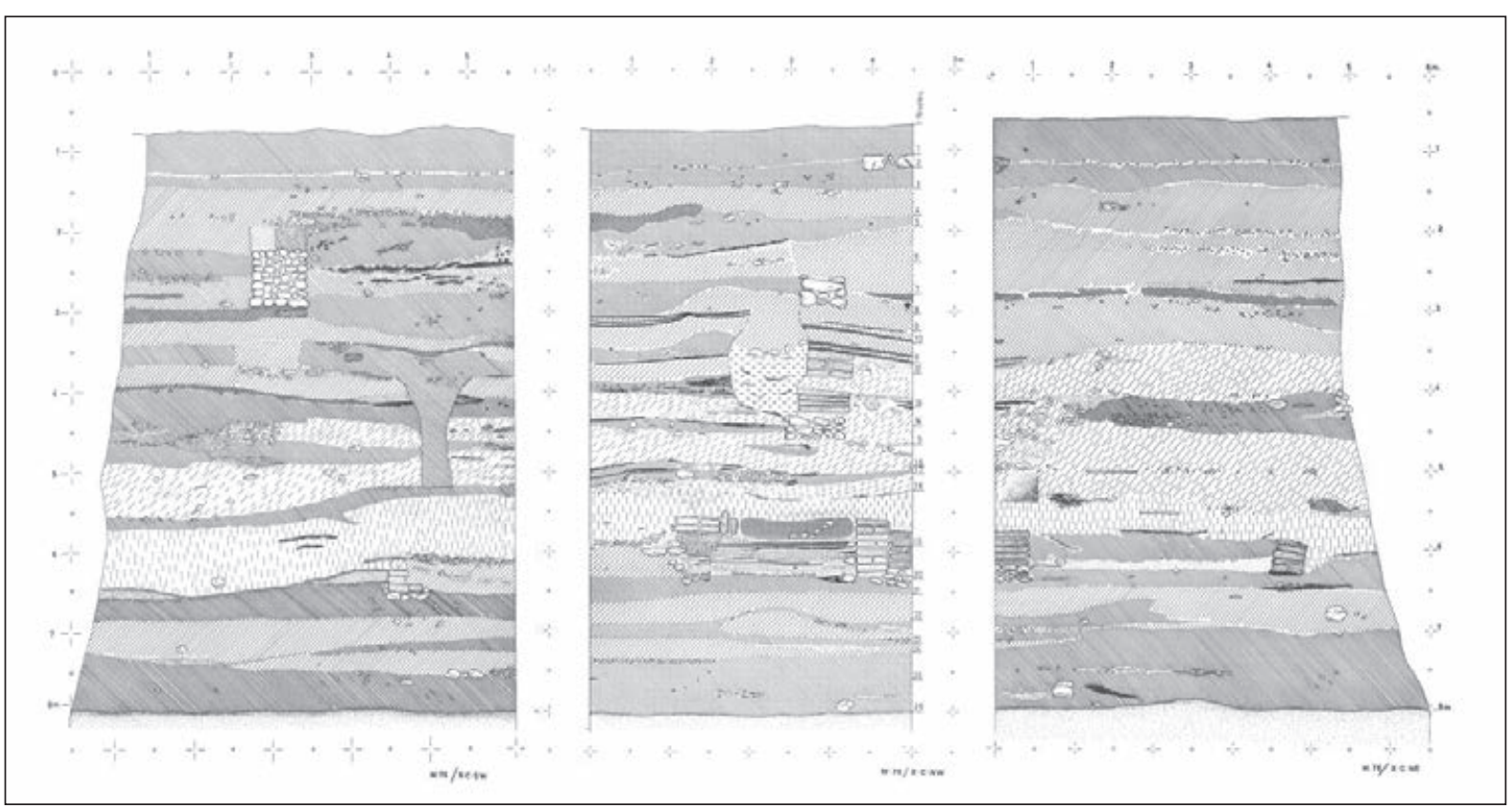

Figura 6. Sección estratigráfica obtenida en el corte V-20 (elevación oriental) de 1976 (Pellicer et al. 1983: figs. 5-7).

ISSN: 1133-4525 ISSN-e: 2255-3924 
lo que ha servido de base indispensable para el actual proyecto (Jiménez 2010: 3801-3802). A lo largo de estas últimas décadas sí han sido frecuentes, en cambio, los estudios sobre los materiales procedentes de las antiguas campañas, especialmente los cerámicos, lo que es indicativo del interés que sigue despertando este yacimiento entre los investigadores y las expectativas sobre el potencial científico de los restos conservados.

\section{LA CAMPAÑA DE 2017: METODOLOGÍA Y DESARROLLO DE LOS TRABAJOS}

Como se ha dicho más arriba, en esta intervención de diagnóstico se han priorizado las actividades menos invasivas con objeto de extraer la máxima información sobre el yacimiento con el mínimo impacto sobre los restos.

\subsection{Prospección superficial}

La primera actividad fue la inspección visual del yacimiento y su entorno, utilizando como base la información procedente de trabajos anteriores, especialmente los resultados de la prospección llevada a cabo en 2007 (Jiménez 2010). Además de la revisión de los límites del bien y de los sectores conservados, se pudo comprobar la potencia estratigráfica de las dos elevaciones principales, el estado de conservación de sus perfiles, la regularidad de su superficie, accesibilidad, tipo y densidad de vegetación, etc.

\subsection{Levantamiento planimétrico}

Paralelamente se realizó un nuevo levantamiento de todo el yacimiento y sus accesos a partir de las bases cartográficas existentes (fig. 7). Ello permitía disponer de un soporte digital de referencia más preciso donde integrar y gestionar la información generada por el proyecto y los recursos cartográficos utilizados. Asimismo, a este soporte se ha ido incorporando el registro gráfico procedente de las intervenciones arqueológicas anteriores mediante la digitalización de las planimetrías y su transformación en capas vectoriales.

\subsection{Prospección geofísica}

Una de las actividades principales fue la realización de una prospección magnética de la superficie de las dos elevaciones, con el fin de contar con una primera lectura de la tipología, función y distribución de las estructuras subsuperficiales, así como poder valorar su potencia, complejidad y estado de conservación. Asimismo, se realizaron también tomas de datos con el georradar para corroborar la información proporcionada por el magnetómetro y afinar la lectura de las irregularidades detectadas en superficie. A pesar de ello los resultados fueron muy desiguales entre una elevación y otra, debido en parte a la naturaleza de los materiales subyacentes y su complejidad estratigráfica, lo que exige explorar y aplicar en el futuro otras técnicas geofísicas sobre los mismos sectores.

\subsection{Limpieza de perfiles y registro de estructuras}

Con objeto de sacar el máximo provecho a los cortes dejados por las máquinas excavadoras en el contorno de los dos cerros testigo conservados, se planteó la limpieza y documentación de una serie de perfiles previamente seleccionados y delimitados. Para evitar el deterioro de los mismos y garantizar un registro más amplio no se llevaron a cabo rectificaciones manuales de su superficie, mientras que el rebaje de los taludes se redujo a lo estrictamente necesario para trabajar sobre ellos. Asimismo, la altura de los cortes limitaba el trabajo en los niveles superiores de la estratigrafía dentro de los márgenes de seguridad establecidos, por lo que finalmente se sacrificó la obtención de secuencias verticales continuas y homogéneas por la documentación de secciones extensas y horizontales.

Antes fue preciso dividir el perímetro de los dos cerros en sectores que facilitaran la organización de las tareas y la localización de las unidades de intervención. Para ello se siguieron los siguientes criterios: respetar la propia geometría de los cerros, definir tramos cuyos perfiles presentasen características y condiciones de conservación parecidas, y tratar de mantener sectores más o menos homogéneos en tamaño. En la elevación oriental se delimitaron un total de 8 sectores de entre 35 y 55 m de longitud, numerados siguiendo el sentido contrario a las agujas del reloj, mientras que en la elevación occidental se establecieron 5 , correspondientes a los lados del polígono que lo conforma. Ante la imposibilidad de abarcar todos los sectores en una misma campaña se decidió dar prioridad a la elevación oriental debido al mejor estado de conservación de sus depósitos, con perfiles más potentes, mayor cantidad de estructuras visibles y la práctica ausencia de vegetación, en comparación con la elevación occidental. Finalmente se seleccionaron cuatro sectores situados en puntos opuestos del cerro (sectores 1, 4, 5 y 7), buscando tener 


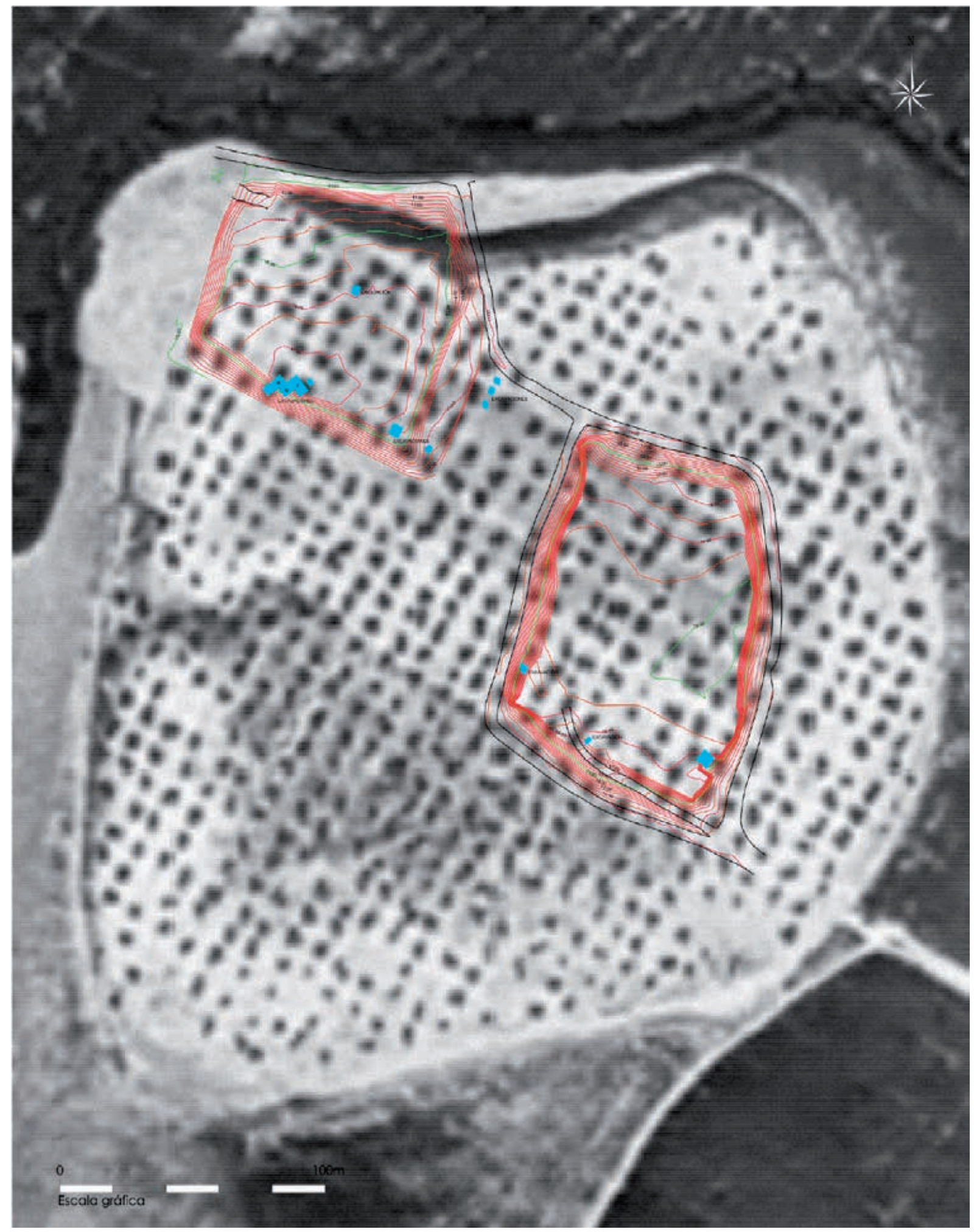

Figura 7. Nuevo levantamiento topográfico realizado en 2017, con indicación de los cortes practicados entre 1974 y 1976 , superpuesto a la imagen del yacimiento previa a su destrucción obtenida de la Ortofoto de Andalucía 1956-57 (Vuelo General de España de 1956).

ISSN: $1133-4525$ ISSN-e: $2255-3924$ 


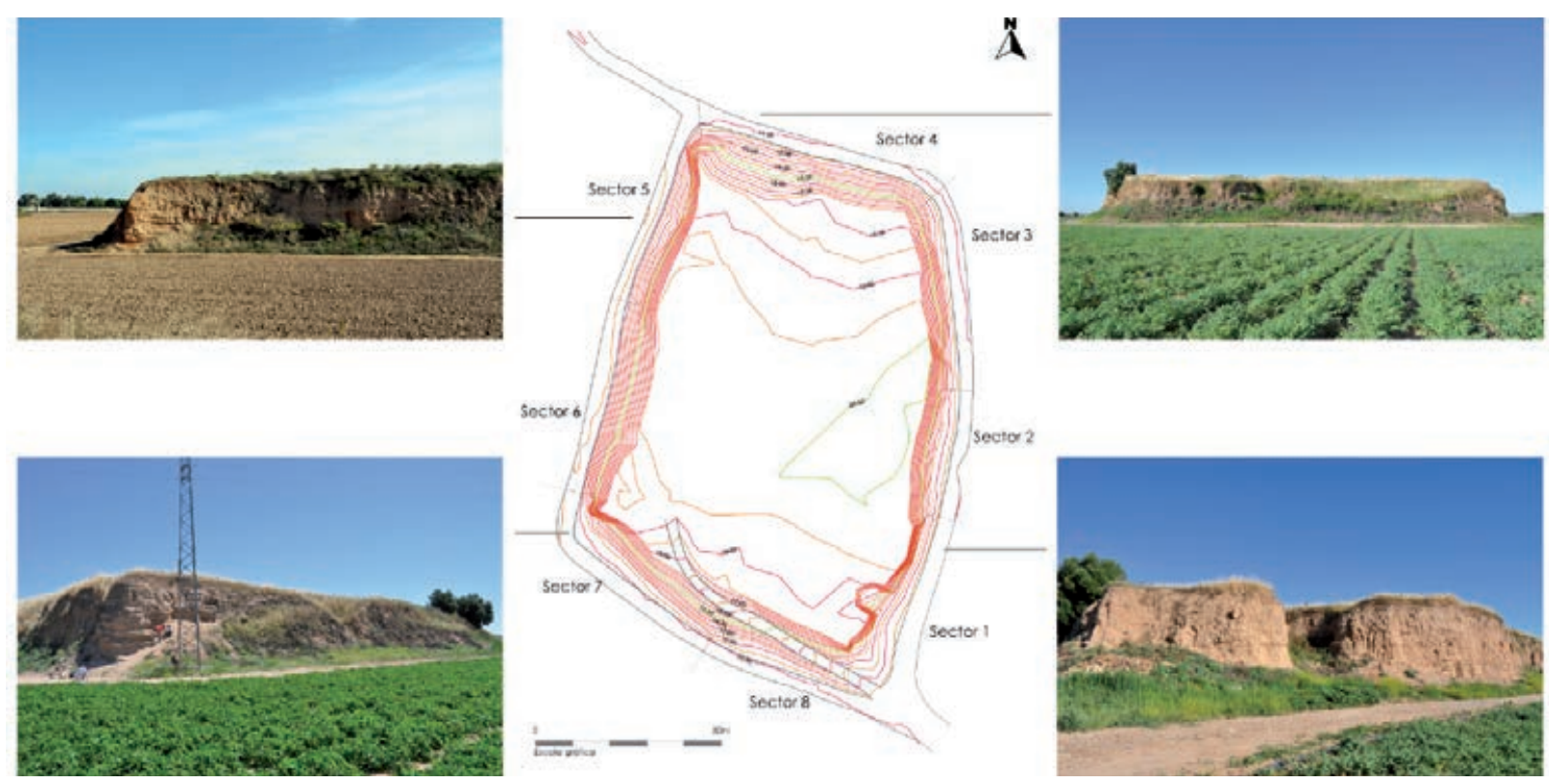

Figura 8. Detalle del nuevo levantamiento topográfico realizado en 2017 con indicación de los sectores en los que fueron divididos los perfiles de la elevación oriental y panorámica general de los sectores intervenidos $(1,4,5$ y 7$)$.

una muestra representativa de todo su perímetro para su comparación. Las unidades de intervención se establecieron en aquellos lugares que cumplían estos mismos criterios y ofrecían mejores posibilidades de establecer secciones amplias con el menor esfuerzo (fig. 8).

El procedimiento seguido en todas las unidades de intervención fue el mismo: delimitación del área de trabajo, limpieza superficial de los perfiles, identificación y delimitación de los elementos de interés (muros, pavimentos, instalaciones) y de las unidades deposicionales asociadas, documentación y registro gráfico (dibujo y fotografía), recogida de materiales, diagnóstico del estado de conservación y georreferenciación. Posteriormente se llevaron a cabo levantamientos tridimensionales en cada una de las unidades de intervención utilizando la técnica de la fotogrametría digital convergente, lo que permitió disponer de un registro más exhaustivo y preciso de los perfiles.

\section{ESTUDIO DE LAS SECCIONES ESTRATIGRÁFICAS}

Una síntesis de los resultados de esta intervención se presentó en el IX Congreso Internacional de Estudios Fenicios y Púnicos (García Fernández et al. e.p.), por lo que nos centraremos aquí en el estudio pormenorizado de las secciones estratigráficas obtenidas en las limpiezas de perfiles y su correlación con los datos aportados por las excavaciones realizadas en los años setenta, anteriormente descritas.

\subsection{Sector 1}

La sección obtenida en este sector fue la más amplia en extensión, tanto por las óptimas condiciones de trabajo que ofrecía el perfil como por los elementos constructivos que a priori se vislumbraban en el mismo. Se alcanzó una longitud total de $10,70 \mathrm{~m}$ y una potencia máxima de $3,80 \mathrm{~m}$, desde la cota 12,87 a la 16,66 m s.n.m. (fig. 9). Sin embargo, también ha sido la unidad de intervención más compleja, tanto por la intensa y prolongada dinámica de construcción/reparación/ amortización, como por la destrucción a la que fue sometido el perfil, dejando importantes lagunas estratigráficas en algunos puntos.

El nivel más antiguo detectado, a una cota de 13 m s.n.m. aproximadamente, es un relleno de arcilla y ceniza, de color grisáceo y poco compacto (UE-143), que parece amortizar a una estructura anterior, probablemente un muro de adobe color rojizo, que no se llegó a excavar, ya que se proyectaba en planta fuera del perfil (UE-153). Asociados a este aparecieron materiales relativamente antiguos, en concreto dos fragmentos de cerámica modelada a mano de acabado tosco, 


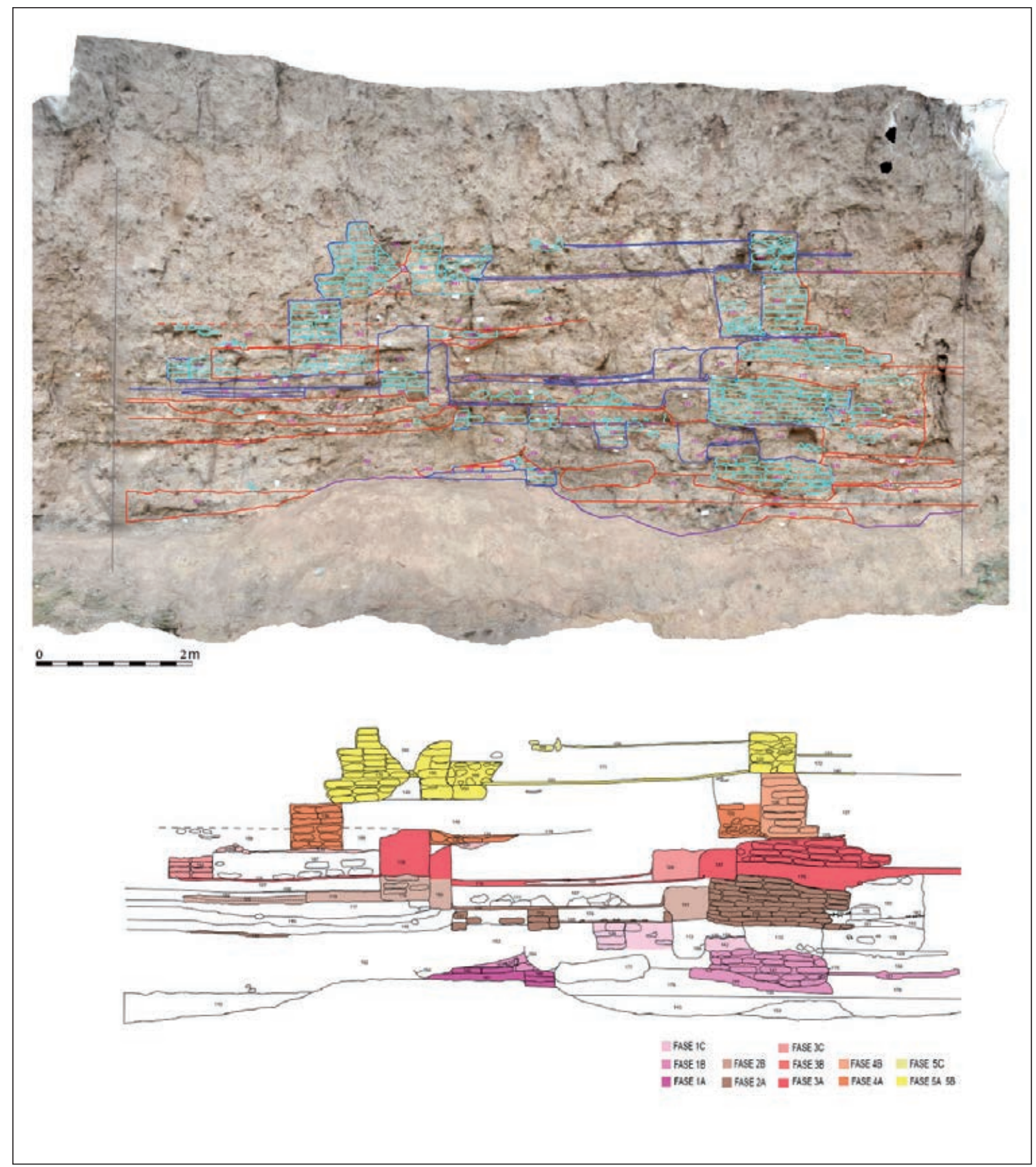

Figura 9. Ortofotografía y dibujo interpretativo del perfil obtenido en el sector 1.

correspondientes a un recipiente de cocina y otro de almacenamiento; tres paredes de ánfora de producción local/regional y tipología indeterminada; y un fragmento también atípico de cerámica a torno común perteneciente a un recipiente de gran tamaño (urna o tinaja).
A partir de aquí se suceden una serie de estructuras constructivas que corresponden a lo que hemos denominado Fase 1 (13,36-13,99 m s.n.m.). La primera de ellas (Fase 1A) comprende dos muros que parecen trabarse en ángulo recto, uno en sentido E-O (UE-166) 
y otro con una orientación aproximada N-S (UE160/161). Están construidos con ladrillos de adobe colocados aparentemente a tizón, al menos en el caso del muro UE-166, con una anchura de unos $37 \mathrm{~cm}$ y una altura documentada de $21 \mathrm{~cm}$ Ninguno se llegó a limpiar por completo ya que ambos se proyectaban también fuera del perfil. El abandono de esta estructura coincide con un depósito compuesto por limos y arcillas que se forma junto al muro UE-166 y se extiende hacia el norte del perfil (UE-176). Sobre él se levanta una segunda estructura (Fase 1B). Se trata de un muro de adobes (UE-141) de unos $40 \mathrm{~cm}$ de longitud y sentido $\mathrm{N}-\mathrm{S}$ sobre un relleno de cimentación de arcilla compactada (UE-155/144), donde se pudo registrar el borde de una olla de cocina modelada a torno y tres fragmentos atípicos a mano, probablemente de almacenamiento (fig. 10). El muro presenta unas dimensiones de 1,50 m de largo por $50 \mathrm{~cm}$ de altura y estaría asociado a un pavimento de guijarros y pequeños cantos (UE-121) de unos $10 \mathrm{~cm}$ de espesor y una longitud de 1,66 m. Al mismo tiempo, parece mantenerse un uso secundario al otro lado de esta estructura, directamente sobre los restos de la fase anterior, donde encontramos un nivel de ceniza muy parcialmente conservado con restos de fauna y cerámica (UE-162). Se trata del fondo de otra olla de cocina a torno de base plana y dos fragmentos de cerámica a torno común, uno de ellos con las características líneas o filetes rojizos y negros de las producciones más antiguas (fig. 10). La amortización de estos niveles se realiza mediante una serie de vertidos de arcillas de similar composición y textura difíciles de diferenciar (UE-152), que sirvieron de base a las estructuras de la Fase 2. No obstante, en la parte norte del perfil aún encontramos un expediente constructivo intermedio que hemos definido como Fase 1C. Consiste en una serie de elementos sin conexión aparente que pudieron corresponder a una estructura muy alterada por los niveles posteriores. Está formada por un posible muro o banco de ladrillos de adobe sin disposición aparente y sentido N-S, de $1 \mathrm{~m}$ de longitud y $35 \mathrm{~cm}$ de alzado conservado (UE-129), y un pavimento de arcilla roja compactada y cal (UE-130) de 1 a $2 \mathrm{~cm}$ de espesor, sobre el que se sitúa una fina capa de ceniza y restos de carbón (UE-158). El pavimento presenta una superficie muy irregular y solo conserva $50 \mathrm{~cm}$ de longitud, ya que está muy afectado por la interfaz negativa UE-186, que pudo servir de zanja de cimentación de la siguiente estructura. Por último, al otro lado del muro UE-141 y sobre su depósito de amortización UE156 , se sitúa un nuevo nivel de gravas y cantos rodados (UE-120), de sección lenticular y algo más potente que el anterior, alcanzando los $10 \mathrm{~cm}$ de espesor en su parte central. Parece conformar un nivel de circulación exterior o un espacio abierto, que hemos vinculado por cota a esta Fase $1 \mathrm{C}$, aunque no tiene conexión aparente con ninguna estructura.

La Fase 2 (14,17-14,39 m s.n.m.) está relacionada con una remodelación general del sector a partir de una serie de unidades negativas y deposicionales que sirvieron para nivelar el terreno y cimentar las siguientes estructuras. La inaugura una primera construcción (Fase 2A) formada por un muro masivo de ladrillos de adobe de entre 35 y $40 \mathrm{~cm}$ de largo, dispuestos casi todos a soga y con llagas horizontales de 2-2,5 cm de ancho aproximado (UE-118). Su conservación es excepcional si lo comparamos con los documentados en este y otros sectores del yacimiento, con hasta 8 hiladas de alzado $(65 \mathrm{~cm})$ y un recorrido de $1,80 \mathrm{~m}$ de longitud. Sigue una orientación N-S, paralela a la del muro UE144/141, sobre el cual se sitúa. Estaría asociado a un nivel de uso UE-182, que aparece dividido en dos por un banco o poyo de $37 \mathrm{~cm}$ de ancho y 19 de altura, formado por dos hiladas de ladrillos de adobe dispuestos a tizón y una pieza de menores dimensiones y forma planoconvexa situada en su parte superior (UE-180). Este muro parece relacionarse también con otra estructura formada por las UUEE-131, 112 y 128, de las que está separado por un banco correspondiente a una refacción posterior (UE-151). La primera parece ser un muro o banco, de $1,37 \mathrm{~m}$ de longitud y $27 \mathrm{~cm}$ de alzado conservado, construido con ladrillos de adobe dispuestos aparentemente a soga y llagas de 1,5 cm de ancho. La segunda es un nivel de uso sin pavimento alguno formado por una acumulación de ceniza, carbones, cantos y cerámica, de unos $2 \mathrm{~cm}$ de espesor y 1,45 m de longitud. Estas estructuras sufren una refacción marcada por la anulación de este último ámbito y la construcción de dos estancias anejas a la formada por el muro UE118, que aún se mantiene en uso (Fase 2B). Se inician con los rellenos UUEE-148, 145, 117 y 174, que elevan y homogeneizan la cota de ocupación. Sobre ellos se dispone una primera estancia que se asocia al muro UE-118 mediante un banco de adobe o tapial dispuesto perpendicularmente a este con una orientación E-O (UE-151). Cuenta con unas dimensiones de $58 \mathrm{~cm}$ de ancho y $42 \mathrm{~cm}$ de alzado, incluyendo su cimentación, ya que en realidad solo sobresale unos $22 \mathrm{~cm}$ de la cota de uso. Se cierra con un tabique de $27 \mathrm{~cm}$ de ancho y 82 $\mathrm{cm}$ de alzado conservado construido probablemente en tapial, ya que no se aprecian los ladrillos de adobe en su sección. Entre ambos se coloca un pavimento de arcilla apisonada y cal, de $4 \mathrm{~cm}$ de espesor y una longitud de 


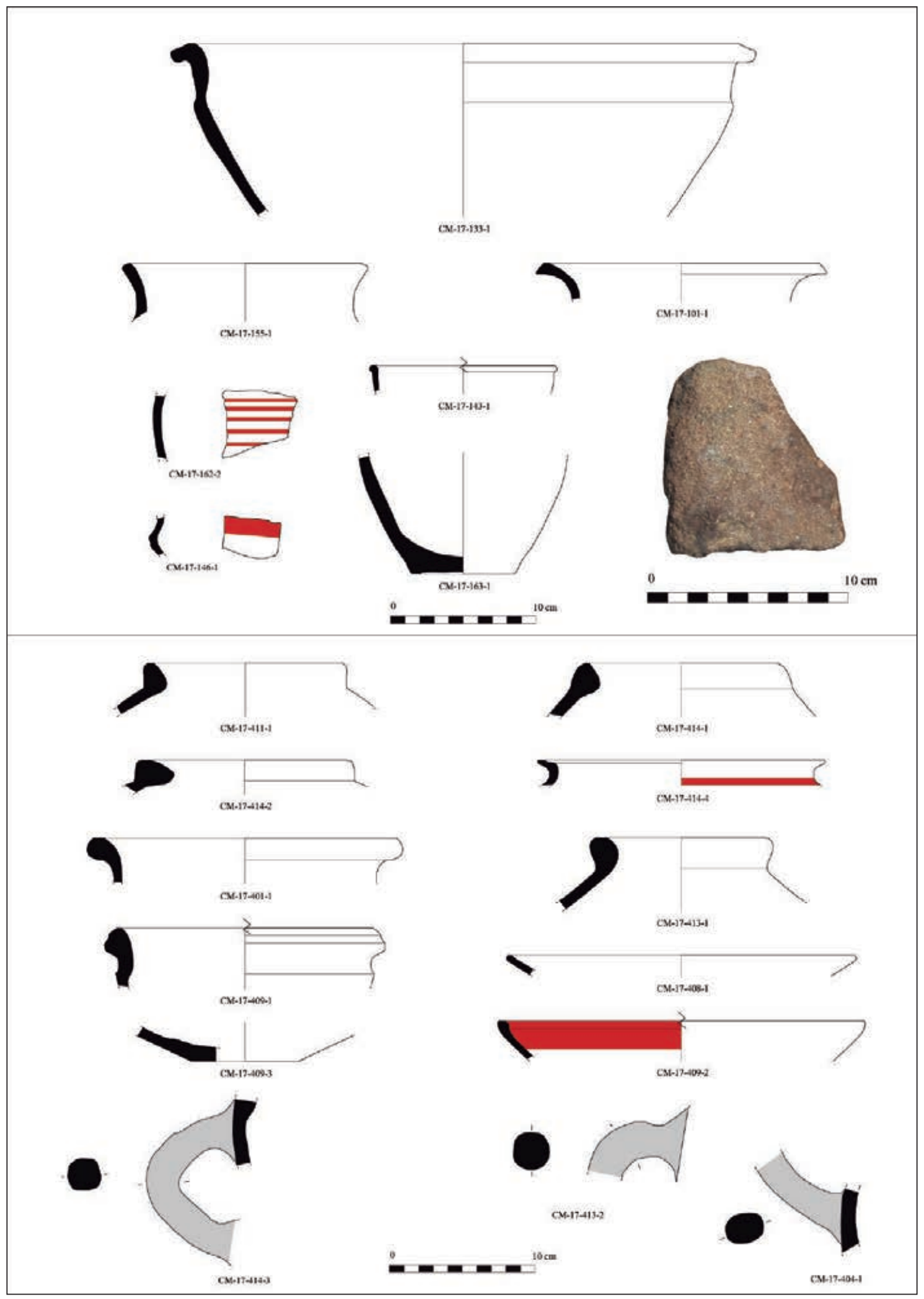

Figura 10. Materiales procedentes de las secuencias obtenidas en los sectores 1 y 4. 
2,70 m, adosándose a los mismos mediante un revoco cóncavo de media caña (UE-109). Al S encontramos una segunda estancia que se adosa al tabique UE-185. Está formada por un muro de ladrillos de adobe dispuestos aparentemente a soga y tizón, de $65 \mathrm{~cm}$ de ancho y un alzado de $35 \mathrm{~cm}$, con llagas de $1,5 \mathrm{~cm}$ y una orientación aproximada E-O. A él se asocia un pavimento de arcilla roja apisonada y cal de unos $5 \mathrm{~cm}$ de espesor (UE-105). Sin embargo, este fue anulado posteriormente por una plataforma o zócalo de adobe, de $1 \mathrm{~m}$ de largo por $13 \mathrm{~cm}$ de anchura (UE-119/192), que se adosa al muro UE-114 y sirve de asiento a un nuevo pavimento de arcilla roja apisonada y cal: la UE-106. $\mathrm{Su}$ espesor, apenas medio centímetro, indica que este último nivel de ocupación debió ser breve en relación con el anterior. En ambos casos, la extensión de los pavimentos $(2,80 \mathrm{~m}$ de longitud, continuando más allá de los límites del perfil) sugiere que nos encontramos ante una estancia de grandes dimensiones, como mínimo del mismo tamaño que la que se le adosa hacia el S.

A esta fase se superpone una nueva serie de estructuras con la misma disposición y orientación general, la Fase 3 (14,64-15,20 m s.n.m.). Previamente, las tres unidades de habitación documentadas fueron anuladas por sendos depósitos de nivelación que contribuyeron de nuevo a homogenizar la cota de uso: UUEE-184, 111/167 y 107. La primera estructura documentada (Fase 3A) está formada por un muro que se superpone directamente sobre el paramento UE-118, constituido por un zócalo de arcilla muy compacto de unos $28 \mathrm{~cm}$ de espesor (UE-175) y un alzado de ladrillos de adobe dispuestos a soga, con llagas de 1,5 cm (UE-150). Al igual que el anterior, mantiene una orientación N-S, con una altura de $35 \mathrm{~cm}$ y una longitud conservada de $1,94 \mathrm{~m}$. Al S se le adosa de nuevo un banco de adobe o tapial (UE-157). Presenta orientación y dimensiones similares a la UE-151 (47 cm de ancho por $39 \mathrm{~cm}$ de altura) y conforma también una unidad de habitación con el muro UE-185, que aún continúa en uso. Entre ambos se dispone otro pavimento de arcilla apisonada y cal de entre 8 y $10 \mathrm{~cm}$ de espesor y 2,57 m de longitud, con los extremos en media caña (UE-110). Esta estructura coincide al otro lado del muro UE-185 con una refacción de la habitación anterior mediante el recrecido del muro UE-114, probablemente en tapial, y un nuevo suelo de arcilla apisonada y cal (UE-108), de 2-3 cm de espesor y una longitud conservada de $2,57 \mathrm{~m}$. Del interior del tapial se pudo extraer un fragmento de ánfora y otro de cerámica a torno común de tipología indeterminada, pero encuadrables en el Hierro II. Hacia el S de esta estancia se levanta un nuevo muro (UE-154) que parece pertenecer a un segundo momento de ocupación (Fase 3B) y que amortiza parcialmente el pavimento UE-108. Esta construido con ladrillos de adobe aparejados a soga, con $56 \mathrm{~cm}$ de ancho por casi $30 \mathrm{~cm}$ de altura conservada y una orientación E-O, que reduce el tamaño de la habitación a 2,15 m de longitud. Esta subfase la marca realmente la reparación de la estancia contigua mediante la construcción de otro banco, paralelo al UE-157 y levantado directamente sobre el pavimento UE-110. Este nuevo banco (UE-124), de materiales y dimensiones parecidas al anterior $(60 \mathrm{~cm}$ de ancho por 40 de altura), sigue manteniendo una relación funcional con el muro UE-185. Entre uno y otro se instala un segundo pavimento de similares características que viene a recrecer el nivel de uso de la estancia entre 4 y $10 \mathrm{~cm}$ (UE-159), adosándose de nuevo mediante un revoco de media caña al banco UE-124. La amortización de esta estructura se realiza, una vez más, con rellenos de arcilla compacta y ladrillos sueltos de adobe procedentes del desmantelamiento de los muros (UE-167). No obstante, aún se detecta un tercer episodio de ocupación sobre estos rellenos (Fase 3C): dos niveles de ceniza, aparentemente coetáneos, situados a ambos lados del muro UE-116 (UUEE-137 y 139). Pudo tratarse de un nivel de uso, de función y duración indeterminada, aunque no aparece asociado a estructura alguna.

La Fase 4 (15,23-15,38 m s.n.m.) es quizá la peor documentada, tanto por la escasa entidad de las construcciones como por las lagunas existentes en la parte central del perfil. No obstante, las estructuras registradas parecen mantener con pocas variaciones la disposición de las precedentes. Es el caso del muro UE-133, que se sitúa justo sobre el muro UE-150 y el banco UE157 , con una orientación análoga a la de este último. Se trata de un paramento de ladrillos de adobe muy mal conservado, de $55 \mathrm{~cm}$ de ancho y unos $78 \mathrm{~cm}$ de alzado, construido sobre una base de dos o tres hiladas de cantos de río de mediano tamaño. De su parte superior, y procedente probablemente de su amortización, se desprendieron dos paredes de ánfora de tipología indeterminada y un borde de lebrillo, una forma muy común que podemos fechar entre los ss. IV y III a.C. (fig. 10). El muro UE-133 se encuentra asociado a un pavimento de arcilla apisonada y cal de $2-3 \mathrm{~cm}$ de ancho y poco más $1 \mathrm{~m}$ de longitud, que se pierde en el límite de la unidad de intervención (UE-125), mientras que en el centro del perfil hallamos otro nivel de uso, relacionado probablemente con la misma estructura, ya que parece reproducir la disposición de las estancias de la Fase 3. Consiste de nuevo en un pavimento de arcilla roja y 
cal parcialmente conservado, del que apenas se ha registrado $1 \mathrm{~m}$ de recorrido (UE-178), asociado a un paquete de ceniza y restos cerámicos de forma lenticular que pudo corresponder a un hogar (UE-134). Al otro lado de estos muros, un nuevo paramento parece cumplir la misma función de reconstrucción de las estructuras precedentes (UE-136), aunque en este caso no se ha podido determinar su nivel de uso. Se asienta directamente sobre el depósito de ceniza UE-139 mediante una zanja de cimentación (UE-115) que atraviesa el relleno de la ocupación anterior (UE-188). Está construido sobre una primera capa de piedras, en este caso de caliza o calcarenita, con un alzado de ladrillos de adobe dispuestos a soga de $65 \mathrm{~cm}$ de ancho, un alzado conservado de $55 \mathrm{~cm}$ y una orientación E-O. En un segundo momento (Fase 4B), se construye directamente sobre el suelo de la estructura anterior (UE-125) un segundo muro bastante potente de ladrillos de adobe aparejados indistintamente a tizón o a soga y tizón, con anchas llagas de arcilla (UE-126). Presenta unos $54 \mathrm{~cm}$ de ancho y una altura conservada de $75 \mathrm{~cm}$, mientras que parece mantener la orientación habitual E-O. Después de esta refacción se produce una nueva reforma general del sector que implica, una vez más, el desmoche de los muros y el relleno de las estructuras con tierra y escombros (UUEE-127 y 146). Entre los materiales registrados se pudieron identificar una pared de ánfora de producción local/regional y dos fragmentos de cerámica a torno común, uno de los cuales parece corresponder a un cuenco tulipiforme (fig. 10), una forma relativamente habitual en el s. III a.C. (Ferrer y García 2008: 208).

La Fase 5 (15,93-16,49 m s.n.m.) es la última registrada en este perfil y está marcada por la introducción de algunas novedades constructivas, como es la aparición del cimiento-zócalo de mampuestos careados, que viene a sustituir a la hilada de cantos de río que solía utilizarse en las fases anteriores, aunque estos no llegarán a desaparecer por completo. El muro que mejor ejemplifica este proceso es el UE-122. Está construido con bloques de piedra caliza de mediano tamaño, careados al exterior y unidos con argamasa de barro y grava. Presenta un alzado conservado de $52 \mathrm{~cm}$ y una anchura de $58 \mathrm{~cm}$, por lo que mantiene las dimensiones medias del resto de las estructuras domésticas documentadas, aunque en este caso parece adoptar una orientación SONE. Al muro se adosan dos pavimentos de similares características, realizados con lechadas de arcilla roja y cal de entre 2 y 3,5 cm de espesor: uno al N (UE-140), cuyo recorrido se pierde en los límites del perfil, y otro al S (UE-123), conformando una estancia de 3,30 m de longitud cerrada por un segundo muro (UE-189), conservado únicamente a nivel de cimiento (UE-191). En ella apareció un fragmento de pared de ánfora de producción local/regional de tipo indeterminado y el extremo de un molino barquiforme realizado en granito, que se encontraba apoyado justo en el contacto entre el pavimento UE-123 y el muro UE-122 (fig. 10). Llama la atención cómo esta estructura (Fase 5B) reproduce a grandes rasgos la disposición y casi el tamaño de las habitaciones que se superponen entre las fases 2B y $3 \mathrm{~B}$. En efecto, al otro lado del muro UE-189 se había construido previamente una estructura que se asentaba directamente sobre el muro UE-136 y el relleno UE-146 (Fase 5A). De ella conservamos la sección de un muro de adobe o tapial (UE-190), al que se adosa el anterior mediante la interfaz UE-191, y el alzado de un segundo paramento que parece cerrar en ángulo recto con aquel (UE-170). De este último solo se conservan escasos centímetros de su espesor original, prácticamente desmantelado por las excavadoras, por lo que a través de las partes más deterioradas se pueden apreciar los niveles de preparación, uso y amortización de una estancia que se extiende hacia el interior del perfil, entre los que destaca un pavimento ancho de arcilla roja y cal (UE-147), del que únicamente han podido documentarse $10 \mathrm{~cm}$ de longitud. El muro UE-190 es una construcción muy compacta de arcilla de unos $40 \mathrm{~cm}$ de ancho por $75 \mathrm{~cm}$ de alzado y orientación E-O o, más probablemente, E-NE. El muro UE-170, por su parte, está realizado con ladrillos de adobe de dimensiones indeterminadas, dispuestos a soga y trabados con arcilla. Conserva una altura máxima de $92 \mathrm{~cm}$ y una orientación aproximada S-N o NNO-SSE. Por último, fue detectado un tercer nivel de ocupación en relación con el muro UE-122 (Fase 5C). Se trata de dos pavimentos de arcilla y cal de apenas $2 \mathrm{~cm}$ de espesor dispuestos respectivamente al $\mathrm{N}$ y al $\mathrm{S}$ del mismo, sobre los depósitos que anularon las estancias anteriores: UUEE-172 y 171. El situado más al N (UE-173) se encuentra a una cota inferior (20 cm aproximadamente) y desconocemos sus dimensiones totales, ya que continúa fuera del área de intervención. El otro pavimento (UE-138) conforma una nueva habitación, más pequeña que la anterior (2,40 $\mathrm{m}$ de longitud), al adosarse a un murete de mampostería caliza de $40 \mathrm{~cm}$ de ancho del que solo se conservan las dos primeras hiladas de piedra (UE-169).

A pesar de la escasez de materiales datantes podemos, a modo de hipótesis, proponer una cronología aproximada para las diferentes fases de ocupación identificadas. La Fase 1, con sus distintos episodios, correspondería al Hierro I, desarrollándose probablemente entre el último cuarto 
del s. VII y finales del VI a.C. La reforma que inaugura la Fase 2 tendría lugar a principios del s. V a.C., mientras su uso se extendería a lo largo de esta centuria. Las construcciones pertenecientes a la Fase 3 podría fecharse grosso modo de finales del s. V a la primera mitad del IV a.C. y la Fase 4 en su segunda mitad, aunque los límites cronológicos son poco claros. En todo caso, los materiales correspondientes a la amortización de la estructura formada por las UUEE-136, 133 y 134, son compatibles con una fase avanzada de esta centuria. Por último, la Fase V se extendería a lo largo del s. III a.C. hasta su último tercio, coincidiendo con la introducción de los zócalos de mampuestos en los muros de tierra, que se produce en un momento avanzado de esta centuria.

\subsection{Sector 4}

Este sector es el que ha ofrecido resultados más limitados debido tanto a las condiciones de trabajo del lugar, con la cota superficial del cerro más baja, taludes más potentes y perfiles peor conservados, como a la complejidad de la secuencia, con elementos poco elocuentes y de escasa continuidad, muy alterados por la acción de las excavadoras y del arado, en la superficie. Debido a ello actuación se tuvo que centrar en los niveles superiores, a una cota inferior de 14,50 y una cota superior de $16,51 \mathrm{~m}$ s.n.m., alcanzando una potencia de 2,01 m y una longitud máxima de 4,70 m (fig. 11).

El primer nivel de ocupación registrado, que denominamos Fase 1 (14,49-14,85 m s.n.m.), corresponde a un depósito de ceniza de forma lenticular, de apenas $58 \mathrm{~cm}$ de diámetro (UE-412), relleno con caracoles con evidencias de haber sido manipulados para su consumo, ya que presentan orificios en sus caparazones, de forma muy similar a los documentados en los niveles iniciales de las excavaciones en Pajar de Arti1lo, Itálica (Luzón 1973: 13, lám. XXVIII-A). Parece tratarse de un hogar o cocina asociado a un posible pavimento (UE-404), solo parcialmente conservado en la parte central del perfil, compuesto por arcilla suelta, ceniza y abundantes restos cerámicos. Entre ellos se pudieron registrar un asa y varias paredes de ánforas de producción local/regional, así como otros fragmentos de recipientes a torno, especialmente algunos pertenecientes a grandes vasos globulares pintados (fig. 10). A partir de aquí se sucede una serie de depósitos de relleno y niveles de uso más propios de un espacio abierto que del interior de una vivienda, ya que las superficies están formadas simplemente por una acumulación de cantos rodados y tierra apisonada mezclada con cerámicas, ceniza y detritus (UUEE-419 y 420). En sus respectivos preparados (UUEE-407 y 411) se registró un fragmento de cerámica gris orientalizante, probablemente un cuenco o plato, y el borde de un ánfora arcaica T.10.1.2.1 (fig. 10), tratándose posiblemente de materiales residuales.

La Fase 2 (14,85-15,24 m s.n.m.) se inaugura con un muro de adobe que solo se conserva, muy alterado, en la parte central del perfil (UE-406). Está aparejado con ladrillos de unos $40 \mathrm{~cm}$ de longitud dispuestos aparentemente a soga. La parte superior forma una línea continua y más homogénea de arcilla color rojizo que pudo corresponder a un alzado de tapial posteriormente desmantelado para la siguiente construcción. El muro presenta una altura de $20-25 \mathrm{~cm}$ en la parte mejor conservada, donde se pudieron registrar hasta tres hiladas de adobe, y un recorrido mínimo de $3 \mathrm{~m}$ en dirección SE-NO. Resulta difícil precisar los límites orientales del muro y las relaciones estratigráficas con el resto de las unidades. No obstante, es posible que el depósito que encontramos a la misma cota al este del corte (UE-408) funcionara como un nivel de amortización/nivelación destinado a servir de base a la siguiente fase. Se trata de un relleno de arcilla compactada y restos de adobe, procedentes probablemente del mismo muro, con algunos materiales cerámicos: un borde de cuenco realizado a torno y varios fragmentos de ánfora pertenecientes a un mismo individuo (fig. 10). El resultado es una superficie horizontal donde se dispone el siguiente expediente constructivo (Fase 2B), un nivel de cantos rodados de mediano/gran tamaño y algunos fragmentos cerámicos (UE-402) que se extiende a lo largo de 3,5 m en sentido E-O o SE-NO, apoyándose directamente sobre el muro UE-406. Por el tamaño y disposición de los cantos podría interpretarse como la cimentación de otro muro de adobe, si no fuera porque sobre el mismo se sitúa un nivel de uso (UE-403) constituido simplemente por una capa de tierra arcillosa, endurecida en su superficie y con restos de ceniza. Contenía restos muy fragmentados de cerámica, especialmente ánforas (una de ellas de producción arcaica) y recipientes de almacenamiento realizados a torno. Sobre este se deposita una capa de tierra suelta limosa, con abundantes materiales, que podría corresponder al nivel de abandono de esta fase, previo a su amortización (UE-409). Entre ellos destacan los bordes de un cuenco y de un lebrillo, decorados ambos con pintura roja, y abundantes fragmentos de ánforas y grandes vasos de almacenamiento a torno pintados (fig. 10). La amortización de esta subfase se llevó a cabo mediante una serie de depósitos yuxtapuestos de 25 a 45 $\mathrm{cm}$ de espesor, cuyos límites y relaciones estratigráficas 


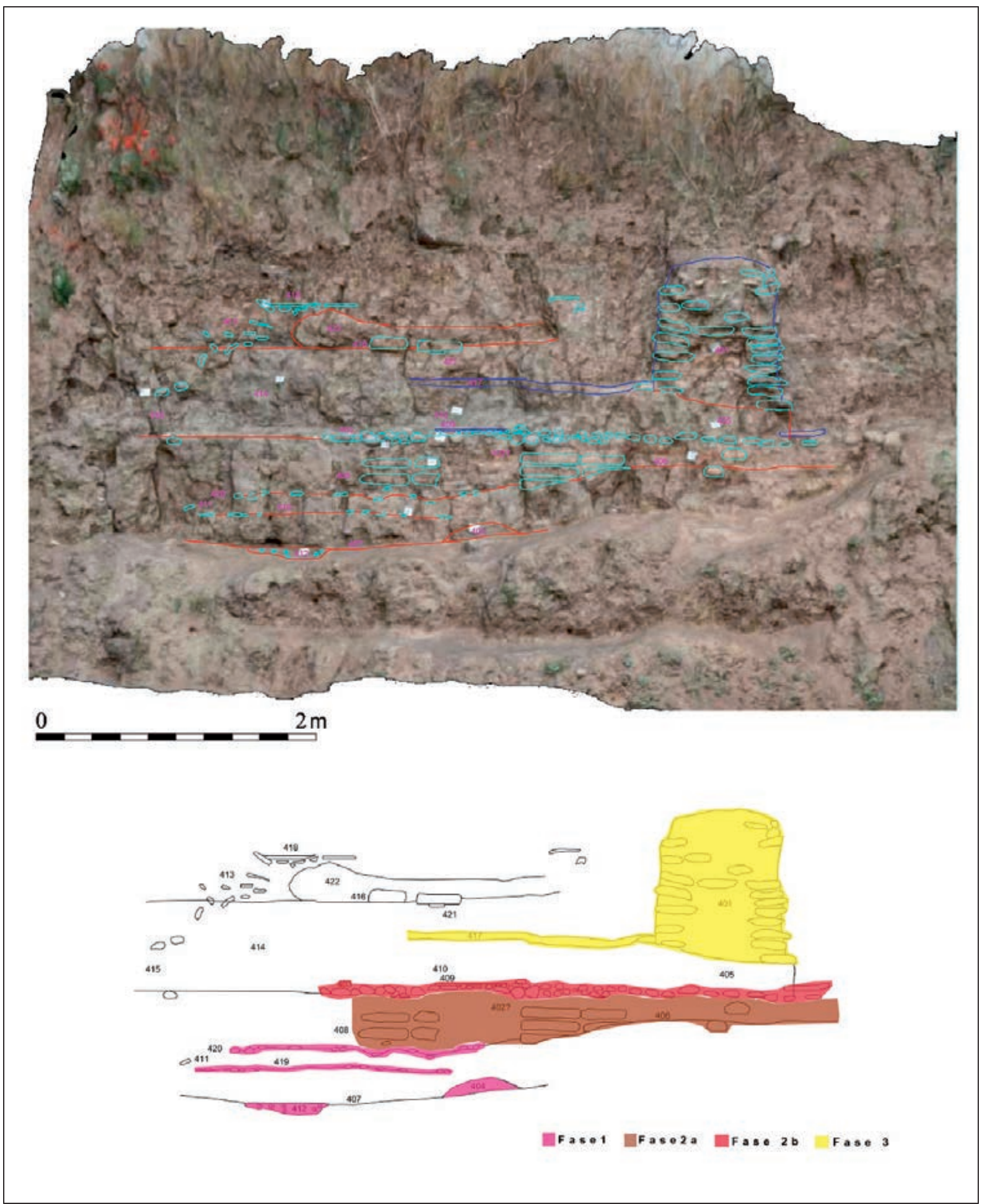

Figura 11. Ortofotografía y dibujo interpretativo del perfil obtenido en el sector 4.

ISSN: 1133-4525 ISSN-e: 2255-3924 
no son suficientemente claros (UUEE-405, 410, 414 y 415), aunque pueden diferenciarse grosso modo a partir de la matriz y el material contenido, un elenco abundante y variado de cerámicas de cronología turdetana. De la UE-410 se extrajeron varias paredes de ánforas de distintas procedencias correspondientes, al menos, a 11 individuos, mientras que la UE-414 ofreció un asa y dos bordes de ánfora, una indeterminada y otra perteneciente a una variante antigua del tipo Mañá-Pascual A4, un borde de urna pintada de pequeño tamaño, además de fragmentos atípicos de ánforas y de grandes recipientes a torno de almacenamiento, algunos con decoración pintada (fig. 10).

Sobre estos depósitos se cimentó la siguiente estructura, correspondiente a la Fase 3 (15,59-15,79 m s.n.m.). Se trata de un zócalo de mampostería careada realizado con lajas de caliza de mediano tamaño, dispuestas horizontalmente y trabadas con tierra (UE401), donde aparecen algunos restos cerámicos, entre ellos un borde de recipiente de cocina a torno (fig. 10). Presenta unos $90 \mathrm{~cm}$ de ancho por poco más de $1 \mathrm{~m}$ de alzado conservado, con una orientación N-S, y se encuentra asociado a un nivel de uso de similares características que la UE-403: una superficie de tierra arcillosa endurecida, con restos de ceniza y cerámica incrustada (UE-417). No ha sido posible calcular sus dimensiones, ya que solo aparece adosada al muro y en algunos puntos del centro del perfil, perdiéndose hacia el E, quizá alterada por el siguiente nivel de ocupación. Este se sitúa en la mitad oriental como una capa de ceniza de 1,7 $\mathrm{m}$ de longitud mínima y entre 4-5 cm de espesor (UE416), dispuesta sobre un pequeño depósito de arcilla y cal bastante compactado (UE-421), aunque no parece guardar relación estratigráfica con el muro UE-401. Con todo, el final de esta fase, la última con estructuras conservadas, viene marcado por un nivel de derrumbe sobre la UE-416, donde encontramos ladrillos de adobe procedentes de algún muro próximo, así como abundantes restos cerámicos y algunos cantos, mezclados con arcilla rojiza (UE-422). Asociadas a este nivel se pueden individualizar, además, dos concentraciones significativas: la UE-418 y la UE-413, que proporcionó el borde y un asa de ánfora de producción local/regional perteneciente al tipo Pellicer B/C (fig. 10).

Este sector sí ofreció suficientes materiales como para establecer una secuencia cronológica aproximada, aunque teniendo en cuenta la cota a la que se sitúa la unidad de intervención, solo se han podido registrar muy parcialmente algunas fases de ocupación correspondientes a momentos avanzados de la Edad del Hierro. Si nos atenemos a la posición relativa de la Fase 1 con respecto a las secuencias obtenidas en otros puntos del yacimiento, podríamos fechar esta ocupación en la primera mitad del s. IV a.C., lo que no desentona con los materiales hallados en la UE-404. La Fase 2 se centraría entre mediados de esta centuria e inicios de la siguiente. Aunque los abundantes restos anfóricos son poco elocuentes, tanto la posición estratigráfica de estos niveles como las producciones comunes identificadas en los mismos apuntan a esta cronología. Por último, la Fase 3 correspondería grosso modo al s. III a.C. Hay pocos materiales asociados al uso y amortización de esta estructura, aunque la entidad del muro UE-401 y las técnicas constructivas empleadas en el mismo solo suelen documentarse, como se verá, a esta cota y a partir de esta fecha.

\subsection{Sector 5}

Este sector ofrecía a priori una sucesión bastante elocuente y regular de pavimentos y algunas estructuras de adobe. La unidad de intervención se estableció al $\mathrm{S}$ del mismo, entre las cotas 12,78 y 15,53 m s.n.m. (2,80 m de potencia), abarcando una longitud máxima de 8,80 m (fig. 12). No obstante, a pesar de la claridad que presenta gran parte de la secuencia, la escasez de materiales recuperados -la mayor parte en el talud-y su poca entidad ha dificultado la adscripción cronológica de los distintos niveles.

La Fase 1 (13,05-13,60 m s.n.m.) está formada por dos posibles construcciones. La primera (Fase 1A) se asienta sobre una serie de depósitos de relleno (UUEE530 y 551), el último de los cuales pudo servir de primer nivel de uso de esta estructura. Está constituida por un muro de adobe o tapial (UE-536) y posible orientación N-S, al que se asocia un segundo nivel de uso, un posible pavimento de arcilla roja y cal (UE-535), que a su vez se asienta sobre un nivel de recrecimiento formado por las UUEE-529 y 532. No obstante, la conservación de estos niveles es muy deficiente para poder avanzar sobre el carácter de esta estructura. El único material recuperado de esta fase es un fragmento de pared de ánfora de procedencia malagueña hallado en la UE-529 y fechable de forma imprecisa en el Hierro I. La segunda (Fase 1B) está formada por un muro de ladrillos de adobe aparejados a tizón de unos $45 \mathrm{~cm}$ de longitud y una altura conservada de $55 \mathrm{~cm}$ (UE-534), que se dispone de forma perpendicular sobre el primero (UE-536). Se encuentra asociado a un depósito (UE520) que, además de amortizar la estructura anterior, pudo haber servido de preparación para un suelo hoy perdido, así como a una compleja serie de vertidos que 


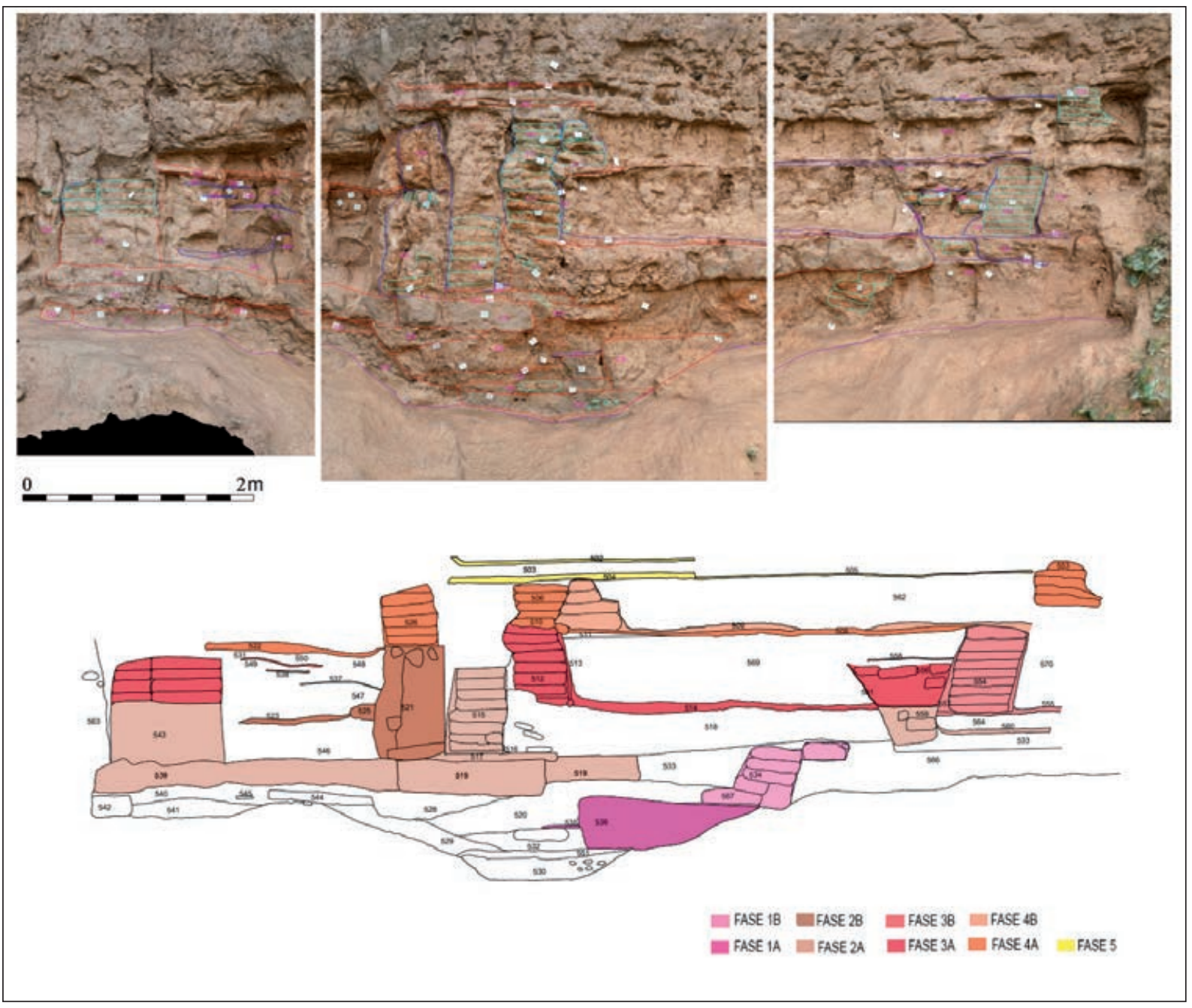

Figura 12. Ortofotografía y dibujo interpretativo del perfil obtenido en el sector 5.

se extienden hacia el N. La conforman varios niveles de arcilla compacta muy irregulares (UUEE-541, 542, 545) sobre los que se superponen capas de cantos rodados de forma lenticular (UUEE-540 y 528), que pudieron haber servido de superficie de circulación de un espacio abierto o una calle. En ellos, y especialmente en la UE-540, se documentaron abundantes restos cerámicos, sobre todo fragmentos atípicos de ánforas y recipientes de almacenamiento realizados a torno, algunos pintados. Los niveles de destrucción de esta segunda estructura se limitan al relleno formado por la posible caída del muro UE-534 hacia el S (UE-566), ya que el resto está muy alterado por la preparación de la siguiente fase constructiva.

En efecto, la Fase 2 (13,88-14,19 m s.n.m.) está precedida por una profunda remodelación que implicó la nivelación del terreno mediante depósitos de arcilla y tierra (UE-533) y potentes dados de cimentación de adobe (UUEE-539 y 519) de unos $30 \mathrm{~cm}$ de espesor medio, que sirvieron de base a las nuevas estructuras. La cronología aproximada de esta reforma vendría marcada por los materiales registrados en los rellenos, en su mayoría restos muy fragmentados de ánforas y recipientes de almacenamiento realizados a torno, cuyas pastas y decoraciones se encuadran ya en el Hierro II. La primera serie de estas estructuras (Fase 2A) está formada por el muro UE-517/515, asociado al pavimento UE-516; el muro UE-559, asociado al pavimento UE-560; y el muro UE-543, que no aparece relacionado con ningún nivel de uso. En todos los casos se trata de muros de ladrillos de adobe de $40-50 \mathrm{~cm}$ de módulo, unidos con argamasa del mismo material, 
dejando llagas de unos $2 \mathrm{~cm}$. Los dos primeros fueron aparejados a tizón, mientras que el muro UE-543 presenta dos filas de ladrillos, una a soga y otra a tizón, lo que le otorga un ancho $90 \mathrm{~cm}$ aprox. Los pavimentos (UUEE-516 y 560), por su parte, son de arcilla roja apisonada y cal, de unos 2-3 cm de espesor. El muro UE$517 / 515$, de $70 \mathrm{~cm}$ de alzado conservado, y el UE-559, de apenas $32 \mathrm{~cm}$, parecen conformar una amplia habitación de 3,30 m aproximados de ancho o largo, mientras que a partir de este último se abre otra en dirección $\mathrm{S}$, cuyo cierre no sido documentado. Adosado al muro UE-517/515 se levantó un segundo paramento de similares materiales, técnicas y dimensiones (UE-521/525), aunque mucho más deteriorado por la acción de las palas mecánicas (Fase 2B), como se observa en la profunda mordida del perfil. Arranca del mismo nivel de cimentación UE-519, aunque parece estar asociado al pavimento UE-523, algo más ancho y a una cota superior con respecto a los anteriores, descansando sobre el relleno UE-546. Observamos que la distancia de aquel con respecto al muro UE-543 es muy reducida $(1,30 \mathrm{~m})$, por lo que no podemos descartar la posibilidad de que se trate de una calle, o más probablemente un espacio de circulación interior, si tenemos en cuenta la secuencia de depósitos y pavimentos que se suceden regularmente en la siguiente fase. El final de la Fase 2 viene marcado por un desmantelamiento parcial e intencionado de los muros precedentes para la posterior reconstrucción de estas mismas estructuras. Los espacios delimitados por ellos fueron rellenados con depósitos de amortización/nivelación compuestos por limo, arcilla, y ceniza (UUEE-546 y 564), así como restos de ladrillos de adobe (UE-518), que se concentran sobre todo al pie del muro UE-517/515.

La Fase 3 (14,24-14,68 m s.n.m.) la conforman una serie de estructuras que suceden claramente a las anteriores, ya que no solo mantienen la misma orientación y dimensiones, sino que se superponen y adosan a los muros previos. También reproducen las mismas técnicas constructivas: ladrillos de adobe de unos $50 \mathrm{~cm}$ de módulo dispuestos a tizón, unidos con argamasa de arcilla de $2 \mathrm{~cm}$ de ancho, y pavimentos de arcilla roja apisonada y cal que, en este caso, suelen superar los $5 \mathrm{~cm}$ de espesor. La primera (Fase 3A) está constituida por los muros UUEE-512 y 556, de 70 y $35 \mathrm{~cm}$ de alzado conservado respectivamente, y revestidos en ambos casos con un espeso enlucido de cal. Entre ellos encontramos un potente pavimento de 2,60 m de ancho o largo y unos $10 \mathrm{~cm}$ de espesor (UE-514), fruto de constantes reparaciones, ya que esta habitación parece haberse mantenido en uso durante toda la fase ocupacional. Hacia el S, otro pavimento de $6 \mathrm{~cm}$ de espesor (UE-555) se adosa al muro UE-556, delimitando una estancia que se pierde en el perfil. Por su parte, en el extremo N, el muro UE-543 parece recrecerse con los mismos materiales y técnicas, conservando en esta fase un alzado de $40 \mathrm{~cm}$ (UE-524). Sin embargo, no han podido registrarse niveles de uso asociados más allá de una secuencia de pavimentos de escaso espesor (UUEE-537, 538 y 531) y sus respectivos niveles de amortización/preparación (UUEE-548, 549, 550), que quedan aislados entre este y el muro UE-521/525 debido al deterioro de esta parte del perfil. Ellos pueden pertenecer, como se ha dicho arriba, a un espacio de circulación interior reparado en sucesivas ocasiones, al menos tres en esta fase, hasta su posterior amortización. La siguiente estructura (Fase 3B) corresponde a reparaciones realizadas sobre las estancias formadas por los muros UUEE-512 y 556. En un momento determinado, el muro UE-556 se queda obsoleto y se construye un nuevo paramento (UE-554) de similares características y orientación, aunque un poco más ancho, asentándose directamente sobre el pavimento UE-555. De él se conservan unos 75 $\mathrm{cm}$ de alzado, al igual que del muro UE 512, que continúa en funcionamiento durante esta subfase. La base del muro UE-557 parece mantenerse, no obstante, como un banco adosado revestido de capas de arcilla roja apisonada y cal similares a los suelos conservados, aunque más estrechos (UE-558). Al otro lado del muro UE-554, el pavimento UE-555 se recrece para adosarse al mismo mediante la habitual solución de media caña, continuando igualmente en dirección $\mathrm{S}$ hasta perderse en el perfil. La amortización de esta estructura viene dada por los depósitos de relleno UUEE-569 y 556, mientras que en el extremo $\mathrm{N}$ del perfil el final de esta fase de ocupación corresponde probablemente al depósito UE-550, que sirve de preparación al siguiente nivel de uso. Los primeros están formados por restos constructivos procedentes del desmantelamiento de las estructuras previas, que se concentran sobre todo al pie de los muros y van disminuyendo en el centro de la habitación, como puede apreciarse en las líneas de enlucido que aún se mantienen adheridas a los ladrillos de adobe, sobre los que se vierten tongadas de tierra compactada.

Sobre estos rellenos se dispone la Fase 4 (14,7214,98 m s.n.m.), constituida de nuevo por dos estructuras, una al $\mathrm{S}$ más completa y otra al $\mathrm{N}$ del perfil, solo conservada muy parcialmente. La primera (Fase 4A) conforma una habitación que se superpone directamente sobre la anterior, previa nivelación (UE-511), aunque presenta mayores dimensiones, alcanzando prácticamente los $4 \mathrm{~m}$ de longitud. Está delimitada por 
el muro UE-510/506, de unos $40 \mathrm{~cm}$ de alzado conservado, que se asienta justo sobre el muro UE-512, y por el muro UE-553, de unos $38 \mathrm{~cm}$ de alzado. El pavimento (UE-508) es similar al de las estructuras previas, aunque no se adosa al muro UE-553, sino que continúa por debajo, lo que lleva a pensar que este funcionara más bien como un tabique de compartimentación interna y no como un muro de cierre. Sobre el pavimento, y relacionado con su última fase de uso, aparecieron algunos fragmentos cerámicos de cronología turdetana: dos paredes de ánforas, una de probable procedencia malagueña y otra de producción local/regional, varios fragmentos de cerámica a torno pintada y restos de escoria de cobre. Posteriormente, al muro UE-510/506 se adosa un banco del mismo material (Fase 4B), de unos $50 \mathrm{~cm}$ de ancho y altura indeterminada, pues fue descabezado en la Fase 5 (UE-507). Este banco se instala también directamente sobre el pavimento UE-508, aunque en esta ocasión se repara para adosarse a aquel formando un bocel de media caña (UE-509). Sobre él también se documentaron algunos restos cerámicos, aunque más escasos, representados sobre todo por un borde de cuenco común a torno (fig. 13). La segunda estructura (Fase 4A) se sitúa al $\mathrm{N}$ del perfil y está compuesta de nuevo por un muro y un pavimento adosado. El muro está construido con una primera hilada de cantos rodados de medio tamaño (UE-527) y un alzado de ladrillos de adobe (UE-526) de $46 \mathrm{~cm}$ de módulo dispuestos a tizón, con una altura de $51 \mathrm{~cm}$ en la parte mejor conservada. Se sitúa sobre el muro UE-521/525 de la Fase 2, ya completamente amortizado, siguiendo la misma orientación. El suelo, por su parte, presenta las mismas características que los anteriores: capas alternas de arcilla roja apisonada y cal, alcanzando un espesor de unos $9 \mathrm{~cm}$. Aunque solo conserva una longitud de 1,55 m, ambos parecen conformar una habitación que se superpone al posible espacio de tránsito formado entre los muros UE-521 y UE-543/524. En todo caso, el deterioro de esta parte del perfil y las dificultades del trabajo por encima de esa cota desaconsejaron continuar la limpieza y registro en este punto.

Debido a ello, la siguiente fase solo se pudo documentar en la parte central y sur del perfil. La amortización de las estructuras precedentes se realizó siguiendo el mismo procedimiento de desmantelamiento parcial de los muros y el vertido de sus escombros, tierra y otros materiales como relleno (UE-562). No obstante, el muro UE-553 parece haberse mantenido aún visible o incluso en uso, aunque no se ha podido precisar con exactitud su relación con los niveles posteriores. La Fase 5 (15,32-15,53 m s.n.m.) corresponde a una sucesión pavimentos de arcilla de distinta factura y espesor variable (UUEE-505 y 503) y niveles de uso o abandono compuestos por cenizas, carbones y abundante detritus (UUEE-504 y 502). Sobre ellos se sitúa un potente nivel de relleno de tierra arenosa, restos constructivos y cerámicos que se extiende por encima del área de intervención prevista. Este último pudo servir de base a la siguiente fase, correspondiente a un muro de mampostería y cantos rodados que se observa al $\mathrm{N}$ de perfil, fuera del corte, sobre una cota de 16 m s.n.m. y que por motivos de seguridad no llegó a ser registrada.

Aunque el repertorio material aportado por esta unidad de intervención ha sido con diferencia el más reducido de todos los sectores estudiados, tanto la coherencia de la secuencia como sus similitudes con la obtenida en el sector 1 permiten a grandes rasgos proponer una cronología aproximada a las distintas fases. En este sentido, la Fase 1 podría fecharse en el s. VI a.C., como parecen apuntar los materiales asociados a su amortización, que evidencian la transición al Hierro II. La gran remodelación que antecede a la Fase 2 correspondería, como en el sector 1 , a inicios del s. V a.C. y sus distintos episodios constructivos a esta centuria. La Fase 3, por su parte, iría desde finales del s. V a inicios del IV a.C., mientras que la Fase 4 ocuparía el tramo central de este siglo. Los pocos materiales asociados a sus dos niveles de uso sucesivos (UUEE-508 y 509) no desentonan con esta cronología. A partir de aquí se sucederían los niveles pertenecientes a la Fase 5 , que podemos fechar con poca precisión entre finales del s. IV e inicios del III a.C.

\subsection{Sector 7}

En este caso la unidad de intervención se ubicó en el vértice suroccidental de la elevación oriental, en un punto donde la pendiente del talud descendía suavemente facilitando la limpieza del perfil a varios niveles de altura y permitiendo de este modo contar con una lectura más completa de la secuencia. El perfil se dividió, por tanto, en tres tramos dispuestos a distinta cota, entre los 12,53 y los 17,43 m s.n.m (fig. 14), abarcando una potencia acumulada de $4,90 \mathrm{~m}$ y una longitud total de $8,90 \mathrm{~m}$. Sin embargo, aunque el repertorio material aportado por este sector es un poco más amplio, adolece en cambio de niveles constructivos elocuentes, a excepción de la parte superior de la estratigrafía. En su mayoría está formado por una sucesión de superficies de uso, depósitos de ceniza y suelos de tierra apisonada, 


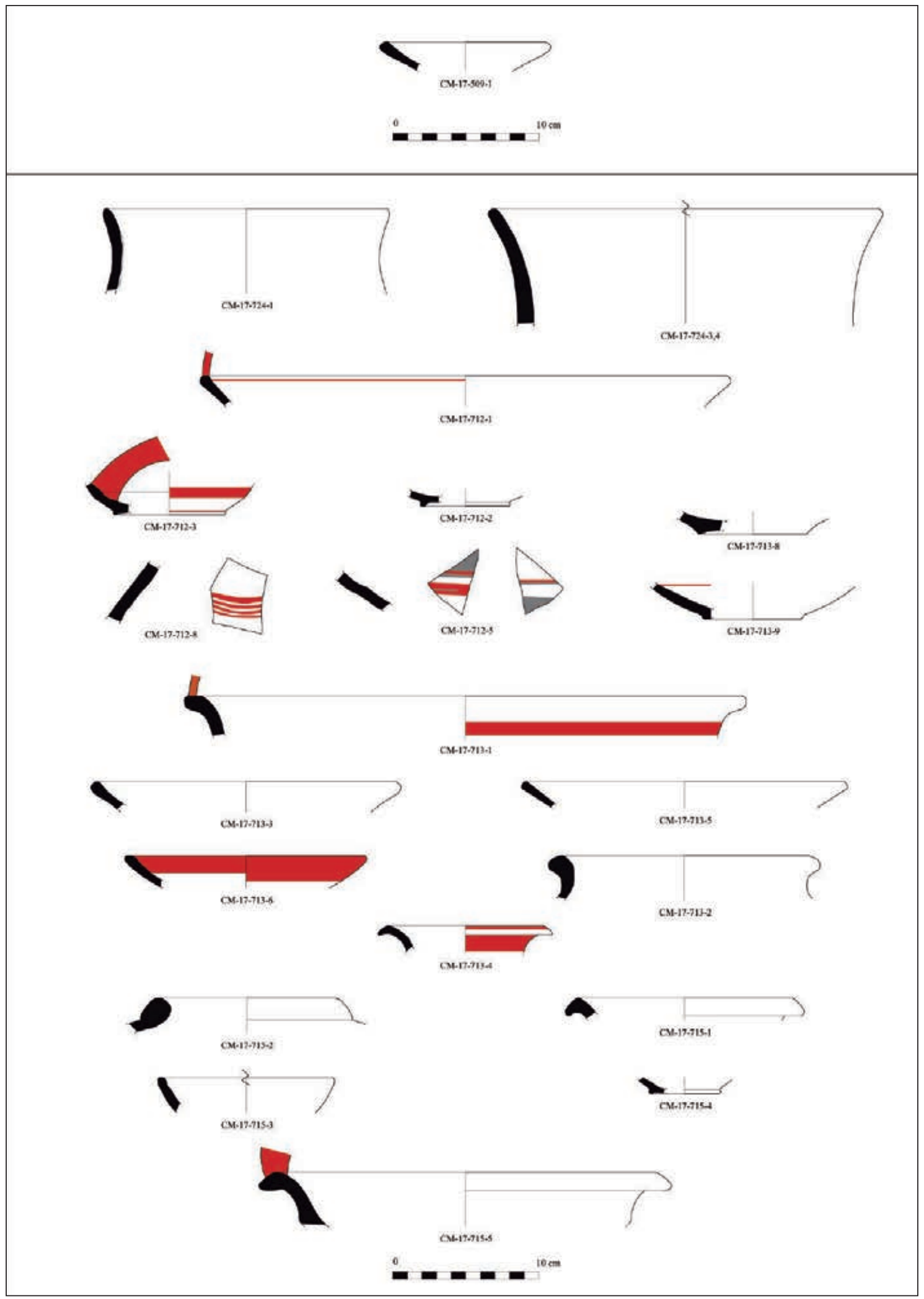

Figura 13: Materiales procedentes de las secuencias obtenidas en los sectores 5 y 7 . 


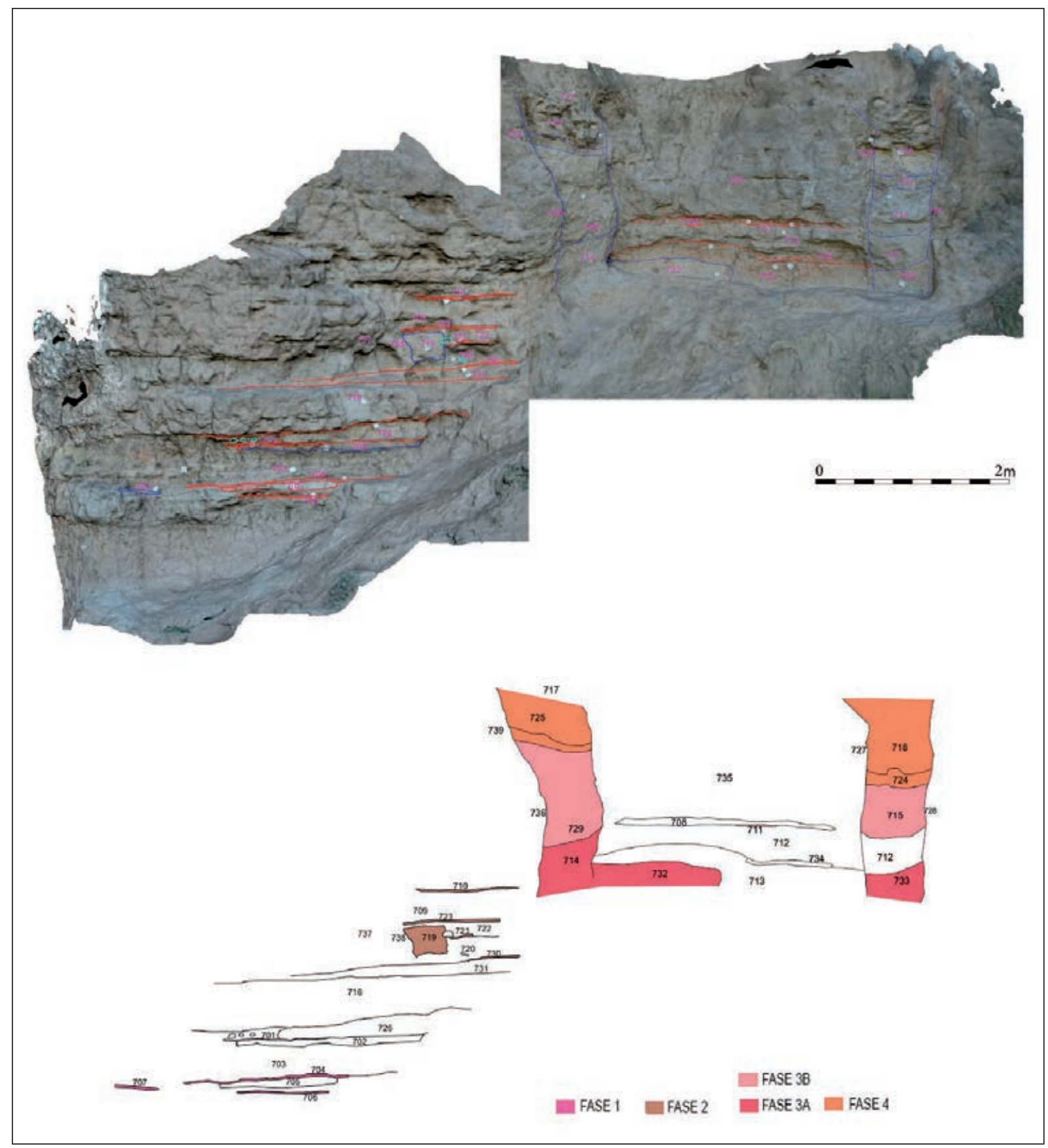

Figura 14. Ortofotografía y dibujo interpretativo del perfil obtenido en el sector 7.

con sus correspondientes niveles de anulación, que podrían responder en algunos casos a espacios abiertos o zonas de circulación. Debido a ello, y al carácter fragmentario de algunas unidades, resulta difícil realizar una lectura continua de la secuencia y establecer las relaciones entre las diferentes fases ocupacionales.
La parte inferior de la estratigrafía está definida por un potente nivel muy heterogéneo de tierra arcillosa con carbones, nódulos de cal y algunos restos cerámicos que arranca prácticamente de la base del cerro, oculto por 1,50 $\mathrm{m}$ de talud aproximadamente (UE724). De él proceden varios fragmentos de cerámica 
modelados a mano correspondientes a recipientes de almacenamiento, dos de ellos clasificables como vasos "à chardón" (fig. 13).

Este relleno sirve de base al primer nivel de ocupación (Fase 1), inaugurando una serie de superficies de uso o tránsito que se extiende entre la cota 13,20 y la cota 13,80 m s.n.m. Arranca con un nivel de ceniza de 1 a $2 \mathrm{~cm}$ de espesor y una longitud de $98 \mathrm{~cm}$ (UE-706), cubierto a su vez por un depósito de unos 5-10 cm de potencia compuesto por arcillas y cal (UE-705). Sobre él se sitúa un nuevo nivel de ceniza del mismo grosor (UE-704), aunque un poco más extenso (2,60 m documentados), y una superficie de arcilla roja y cal de 3 $\mathrm{cm}$ de espesor, que solo ha podido registrarse parcialmente en su extremo O (UE-707). De nuevo un relleno arcilloso compacto, en este caso con una superficie más regular y un espesor de unos $40 \mathrm{~cm}$, viene a anular a la ocupación anterior (UE-703). De él proceden varios fragmentos atípicos de cerámica común pintada, así como un fragmento de cerámica a mano con tratamiento superficial espatulado. Sobre este depósito se construye una plataforma de ladrillos de adobe de 10 $\mathrm{cm}$ de grosor y $2 \mathrm{~m}$ de longitud (UE-702) relacionada probablemente con la preparación de alimentos o el trabajo artesanal, ya que está cubierta en su totalidad por una capa homogénea de ceniza de 1,2 cm de espesor, que acaba rebasando los bordes de la misma para depositarse a sus pies (UE-701). La amortización de esta fase se realiza mediante dos potentes vertidos de arcilla y restos de adobe que pudieron servir para anular las estructuras precedentes y asentar el siguiente nivel de ocupación (UUEE-726 y 716). De hecho, estos depósitos presentan una cota análoga a los que separan las fases 1 y 2 de la secuencia obtenida en el sector 1 (entre 13,80 y 14,47 m s.n.m.) y podrían relacionarse también con la reforma general que se observa en el sector 5 .

A partir de aquí encontramos una sucesión de niveles de relleno y uso asociados a la Fase $2(14,47-$ 15,38 m s.n.m.). Comienza con un último depósito de nivelación de arcilla, carbones y cal (UE-731), de 15 cm de espesor máximo, donde pudieron documentarse dos paredes de ánforas de producción local/regional indeterminadas y varios fragmentos atípicos de cerámica común a torno. Sobre este se dispone un nivel de uso de $2 \mathrm{~cm}$ de grosor y más de $2 \mathrm{~m}$ de longitud (UE-730), amortizado por un nuevo paquete de arcilla y restos cerámicos de 20-30 $\mathrm{cm}$ de potencia (UE-720). La única estructura clara se desarrolla a continuación. Consiste en un muro de adobe o más probablemente tapial que se asienta en la UE-720 mediante una pequeña fosa de cimentación de unos $15 \mathrm{~cm}$ de profundidad (UE-738).
El muro UE-719 conserva $32 \mathrm{~cm}$ de altura, una anchura de $44 \mathrm{~cm}$ y parece estar asociado a un nivel de uso que se adosa a la cara oriental (UE-721). Se trata en realidad de una capa de ceniza muy localizada que se sitúa sobre el relleno UE-720, extendiéndose levemente hacia el E. Al otro lado del muro este nivel de uso es imperceptible, aunque sí se aprecia un cambio en la composición de los sedimentos a esa misma cota, marcando el siguiente nivel de amortización (UE-722/737) que encontramos a ambos lados del muro UE-719. Sobre este vertido se asienta otro nivel de ceniza de similares características que el anterior (UE-723), aunque mucho más limitado en el espacio, pudiendo tratarse de una fogata o un hogar. Una vez más, un potente relleno compuesto por restos de adobe, arcilla compactada y algunos fragmentos muy rodados de cerámica (ánforas y cerámica común) anula esta actividad (UE709). La horizontalidad de su superficie facilita la instalación de un nuevo nivel de uso (UE-710), en este caso más extenso, con 2-3 cm de grosor y una longitud que supera el metro. Podría estar asociado al muro UE-714 de la Fase 3, aunque la atonía de los depósitos y la dificultad para trabajar a esta cota limitaron la lectura de la secuencia.

Ello obligó a trasladar el área de intervención hacia el E, donde era posible registrar los niveles más altos de los perfiles. Aquí se pudieron identificar hasta 3 episodios constructivos, el primero de los cuales (Fase 3A: 15,38 m s.n.m.) estaría formado por dos muros de adobe o tapial, uno al E (UE-714) y otro al O (UE-733). Ambos tienen una anchura de unos $75 \mathrm{~cm}$ y están construidos con arcilla gris muy compactada, aunque solo se ha podido documentar su extremo superior, ya que la mayor parte de la estructura se encuentra bajo el talud que cubre esta parte del perfil. Al primero parece adosársele un muro o banco del mismo material (UE-732), del que se ha documentado una altura de $30 \mathrm{~cm}$ y una longitud de 1,56 m. Esta estructura se encuentra amortizada por un relleno de restos de adobe y cal procedente probablemente del desmantelamiento de sus propios alzados (UE-713). Este depósito ofreció un repertorio cerámico abundante, destacando las ánforas de producción local/ regional y la cerámica común a torno, representada por cuencos, lebrillos y vasos de distintos formatos, la mayoría decorados con las características bandas y líneas color rojizo. A ellos se suman el borde de un recipiente de cocina y algunos restos residuales de cerámica modelada a mano de cocina y almacenamiento (fig. 13). La UE-713 está cubierta, a su vez, por un segundo relleno de matriz arcillosa (UE-712) que sirve de base para el nivel de uso de la siguiente estructura. Aquí se registró 
de nuevo una amplia nómina de restos cerámicos, principalmente anfóricos (hasta 11 individuos diferentes si tenemos en cuenta las paredes identificadas), seguidos por las producciones comunes a torno, especialmente los cuencos y los vasos globulares, algunos de cronología avanzada dentro del Hierro II (fig. 13). Entre ambos rellenos se identificó, además, una superficie rojiza más endurecida de 4 a $6 \mathrm{~cm}$ de grosor y poco más de $1 \mathrm{~m}$ de longitud (UE-734), que pudo ser resultado de un uso puntual (¿hoguera?) o una alteración superficial del estrato subyacente. El segundo episodio (Fase 3B: 15,9016,30 m s.n.m.) lo conforman de nuevo dos muros de tapial (UUEE-715 y 729) que se asientan directamente sobre los anteriores mediante zanjas de cimentación (UUEE-728 y 736). Ambos presentan la misma anchura (75-80 $\mathrm{cm}$ aproximadamente) y un alzado variable, oscilando entre los $65 \mathrm{~cm}$ del muro E (UE-715) y los $100 \mathrm{~cm}$ del muro O (UE-729). Su orientación es respectivamente $\mathrm{NE}$ y N-NO, lo que invita a pensar que pudieron encontrarse formando una esquina varios metros hacia el S, en la parte hoy desaparecida. En el espacio entre los dos muros (que alcanza en el perfil los 3,20 m) se documentó una capa de ceniza de 2,5 cm de espesor que podemos interpretar como el nivel de uso de la estancia (UE-711). Sobre ella se registraron algunos restos cerámicos, en especial un borde de ánfora Pellicer D al que podemos atribuir cronología del s. III a.C. (Ferrer y García 2008: 211-212) y que se mantuvo en el perfil. Aparte de estos, los únicos materiales recuperados de esta fase proceden de la base del muro UE-715, donde se extrajo otro borde de ánfora de producción local, en este caso una variante evolucionada del tipo Pellicer $\mathrm{B} / \mathrm{C}$, y varios fragmentos de cerámica común: bordes y paredes de cuencos, lebrillos y vasos de almacenamiento, algunos con decoración pintada, además de restos residuales de recipientes a mano de gran formato (fig. 13). Esta estructura fue amortizada por una serie de depósitos de arcilla poco compacta y cantos (UUEE-708 y 735) que terminan colmatando el espacio entre los dos muros hasta alcanzar su cresta.

De la última fase constructiva, la Fase 4 (16,40 m s.n.m.), solo han podido documentarse dos muros de similar anchura y orientación (UUEE-718 y 717) realizados en mampostería. Se trata en realidad de cimientos/ zócalos de entre 60 y $80 \mathrm{~cm}$ de alzado insertos parcialmente en los niveles de amortización previos a través de zanjas de cimentación (UUEE-727 y 739). Están construidos con bloques irregulares de piedra caliza de mediano tamaño (en torno a $15 \times 20 \mathrm{~cm}$ ), toscamente careados al exterior, formando dos hiladas rellenas al interior con ripio, cantos de río y barro, sobre los que se situaría un alzado de adobe o tapial. Lamentablemente, la altura del perfil en este punto ha impedido intervenir en condiciones de seguridad en la parte superior de los muros, así como en los depósitos que se disponen entre ellos, por lo que no se han podido identificar los niveles de uso asociados. Estos parecen ser, no obstante, contemporáneos a las estructuras de similares características documentadas en los sectores anteriores y correspondientes a las últimas fases de ocupación del yacimiento.

No resulta fácil, dada la escasez de elementos constructivos, otorgar una cronología relativa a la secuencia obtenida en este sector. Parece evidente, por su posición y por los materiales registrados, compuestos en su totalidad por cerámicas a mano, que los depósitos más profundos corresponden a un momento pleno del Hierro I (s. VII a.C.), mientras que los niveles de ocupación que se superponen a ellos (Fase 1) podrían fecharse a lo largo del s. VI a.C. La Fase 2, separada de los niveles previos por potentes depósitos de amortización y preparación similares a los de los sectores 1 y 5 , pertenecería por tanto al s. V a.C. A partir de aquí observamos una laguna en la parte central de la secuencia que parece abarcar el final de este siglo y el inicio del siguiente. La Fase 3 supone tanto la amortización de las estructuras precedentes como una nueva construcción, cuya vida se extendería durante el s. IV a.C. La reforma de la Fase 3B se situaría con mayor precisión entre fines del s. IV e inicios del III a.C. En consecuencia, la estructura documentada en la Fase 4 debe corresponder a mediados del s. III a.C., coincidiendo con el proceso de petrificación de la arquitectura en tierra que afecta por igual en esta cota a los distintos sectores del yacimiento.

\section{SÍNTESIS DE LAS FASES DE OCUPACIÓN}

Hemos tratado de establecer una correspondencia entre los distintos niveles y fases de ocupación identificados en estos sectores del yacimiento y los registrados por las excavaciones realizadas en los años setenta (fig. 15). En el caso de la elevación oriental, hemos referenciado los perfiles resultantes del corte F de 1974 y V-20 de 1976, una vez escalados, situándolos a cota con la superficie actual del cerro con el fin de compararlos con las secuencias obtenidas en la campaña de 2017. Para ello nos hemos apoyado en el nuevo levantamiento planimétrico, usando como base las curvas de nivel correspondientes a los bordes del tell que, grosso modo, se han mantenido estables desde el cierre 


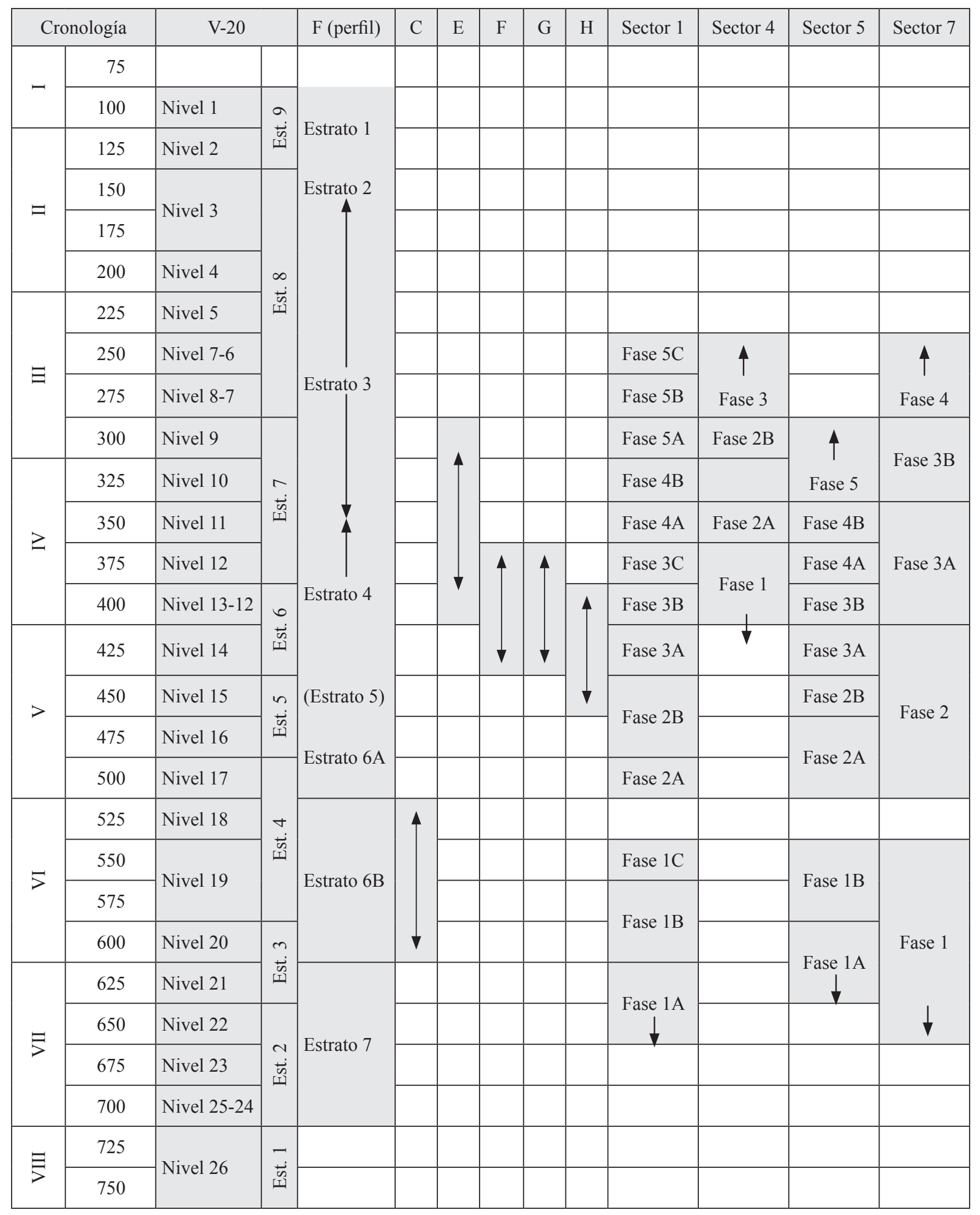

Figura 15. Propuesta de correspondencia estratigráfica y cronológica entre los niveles y fases de ocupación registrados en las excavaciones de 1974-1976 y en los perfiles intervenidos en 2017. En los cortes C, F, G y H de la elevación occidental no se describe más de una fase de ocupación. En los otros casos las flechas corresponden a fases cuyos límites inferiores o superiores no son nítidos, por lo que pueden tener su origen o prolongarse en niveles no registrados. 
de la cantera en torno a los 19 m s.n.m. La única excepción la constituye el sector 4 , cuyos estratos superiores han sido parcialmente destruidos por la acción de las máquinas. A ello hay que sumar, además, el cambio de cota que se produce en esta parte del cerro, descendiendo ligeramente hacia el norte en dirección al arroyo Almonázar, lo que explica que los niveles de ocupación documentados aparezcan sensiblemente más bajos, 1 $\mathrm{m}$ aprox. con respecto a los demás sectores estudiados (fig. 7). Por lo que respecta a la elevación occidental, la desaparición de buena parte de la secuencia arqueológica y la ausencia de referencias absolutas nos impide adaptar con fiabilidad las cotas recogidas en las planimetrías publicadas. Ni siquiera es posible situar las cuadrículas en la superficie del cerro, ya que los sectores excavados fueron posteriormente desmantelados y no han quedado huellas evidentes de las mismas en los perfiles (fig. 7). Aun así, la cronología ofrecida por los contextos exhumados, pertenecientes posiblemente al sector industrial del primitivo asentamiento, permite correlacionarlos con las fases registradas en la elevación oriental. Cabe advertir, no obstante, que no se ha llevado a cabo una revisión crítica de estas excavaciones antiguas, ya que excedería los límites y propósito de este trabajo, por lo que se acepta, con algunos matices que al cabo señalaremos, la datación y la interpretación ofrecida por sus excavadores.

Los niveles antrópicos más antiguos solo se han registrado, hasta el momento, en el corte V-20, donde se plantea como hipótesis la existencia en el nivel 26 (Estructura I) de una primera fase de ocupación compuesta por cabañas de planta oval y adobe fechada en la segunda mitad del s. VIII a.C. (Pellicer et al. 1983: 57). Lo mismo puede decirse de la siguiente fase, que abarca la mayor parte del s. VII a.C. (Estructura II). Aquí las evidencias se limitan a la presencia en el nivel 25 de cantos rodados de gran tamaño que podrían pertenecer a la base de un muro (fig. 6), así como otros cantos de menor tamaño interpretados por los excavadores como restos de un pavimento (Pellicer et al. 1983: 57). La ausencia de estructuras claras es extensiva al resto de las secuencias que han alcanzado estas cotas, como el Estrato VII del corte F (fig. 4) y los niveles de base del sector 7 (UE-724). Solo en el sector 1 se observaron unos restos de adobe que podrían pertenecer a un muro (UE-153) aunque, como se ha advertido, no llegó a excavarse por motivos de conservación.

A partir de este momento (último cuarto del s. VII a.C.) se inaugura una serie de episodios constructivos que se suceden a lo largo del último tramo del Hierro I, siendo especialmente elocuentes en la Fase 1 de los sectores 1 y 5 , mientras que en el sector 7 la ausencia de estructuras nos ha llevado a interpretar los niveles de uso documentados como un espacio abierto. A esta fase pertenecen también las construcciones registradas en los niveles 21-20 y 19 del corte V-20 (fig. 6), así como en el Estrato 6B del corte F (fig. 4). La primera, fechada en torno al 600 a.C. (Estructura III), está formada por un muro de ladrillos de adobe dispuestos en horizontal y vertical sobre una base de cantos de gran tamaño, con un ancho medio de $55 \mathrm{~cm}$ y una orientación aproximada N-S. La segunda, que mantiene prácticamente las mismas técnicas constructivas, medidas y orientación, parece corresponder a una refacción del anterior (Estructura IV), la cual pudo haber tenido lugar en la primera mitad del s. VI a.C. Ambos casos parecen estar asociados además a varios pavimentos de arcilla y cal o superficies de uso de tierra apisonada, como puede apreciarse en las secciones y fotografías publicadas (Pellicer et al. 1983: 57, fig. 13-15, lám. IV). Por lo que respecta al corte F, se identificó en el lado norte del perfil un muro de ladrillos de adobe de casi $1,10 \mathrm{~m}$ de altura, parcialmente amortizado por un nivel de derrumbe donde se aprecian ladrillos procedentes probablemente de su destrucción. Su excavador dató este estrato, a partir de los escasos materiales recogidos, en torno al s. VI a.C. (Martín de la Cruz 1976: 15, 25). Ello es coherente con los rasgos constructivos de la estructura y su cota (aproximadamente 13,4 m s.n.m. en su base), si la comparamos con el resto de las secuencias obtenidas en esta elevación. Es también en este momento cuando parece extenderse la ocupación hacia la parte oeste del cerro, más próxima al antiguo cauce del Guadalquivir, como se desprende de los depósitos excavados en el corte C, que se sitúan directamente sobre los niveles naturales de la terraza aluvial (Ruiz Mata y Vallejo 2002: 199). A falta de un estudio más profundo de este sector del yacimiento, podemos plantear a modo de hipótesis que el barrio industrial que se ha identificado en la elevación occidental tuviera su origen a finales del s. VII o inicios del VI a.C.

El final de este horizonte está asociado, como se ha venido advirtiendo más arriba, a una serie de depósitos de relleno, que acaban amortizando las construcciones del Hierro I, y unos potentes niveles de cimentación que las separan netamente de las estructuras que se suceden a lo largo de los siglos siguientes. Estos episodios, detectados en los sectores 1 y 7 prácticamente a la misma cota y con una diferencia de $40 \mathrm{~cm}$ con respecto al 5, se han interpretado como una interrupción temporal de la ocupación -al menos en esta zona-, que se extendería durante las últimas décadas del s. VI, y una 
posterior remodelación general del hábitat en los primeros compases del s. V a.C. La propia composición heterogénea de los depósitos, con algunas evidencias de actividades antrópicas puntuales (hogueras, vertidos de detritus), y la clara discontinuidad -tanto estratigráfica como arquitectónica- de las estructuras con respecto a las siguientes fases, nos llevan a pensar que estas quedaron abandonadas y a la vista antes de la instalación de los nuevos edificios. Es lo que se observa también en los niveles 18 y 17 del corte V-20 (fig. 6), aunque en este caso el reinicio de la actividad antrópica -cuyos niveles de uso pueden verse en el perfil- no está asociado a episodios constructivos, y en el Estrato 3A del corte F (fig. 4), que colmata definitivamente el muro identificado en el estrato anterior (Martín de la Cruz 1976: 15), si bien se ha puesto en duda que ello significara un hiato poblacional (Escacena 1993: 193).

El nuevo horizonte constructivo que se establece a inicios del s. V a.C. es muy evidente en la Fase 2 de los sectores 1,5 y 7 , sobre los que se desarrolla, como se ha visto, una secuencia de estructuras que se extiende de forma prácticamente ininterrumpida a lo largo del Hierro II. Esta fase tiene también su correspondencia en el corte V-20, quizá en un momento ligeramente posterior, en el segundo cuarto del s. V a.C. Esa es la fecha que sus excavadores asignan a los niveles 16 y 15 (Estructura V), donde se registró la cimentación de dos muros realizados con una base de piedras sin escuadrar y un segundo nivel de cantos rodados que se encuentran en ángulo recto (fig. 6). Mantienen una orientación casi cardinal, aunque aparecen desplazados $30 \mathrm{~cm}$ al E en relación con los muros de las Estructuras III y IV, por lo que incide en la discontinuidad que se observa entre finales del Hierro I y del Hierro II. En el interior de la estancia, adosado al muro E-O (el más ancho, con $70 \mathrm{~cm}$ ), se dispuso un hogar de piedras semicircular, mientras que el muro N-S presenta indicios de destrucción tanto al interior como al exterior de la vivienda que pudo haber tenido lugar a mediados de la misma centuria (Pellicer et al. 1983: 57-58, fig. 12). Es posible atribuir también a este momento el Estrato 5 del corte F, en el que se documenta un muro de adobes que «rompe, se apoya y superpone» parcialmente al muro del Estrato 6B (fig. 4), y cuyo límite superior está formado por un conglomerado de restos de adobe procedentes de la destrucción del muro, caídos probablemente en su nivel de habitación (Martín de la Cruz 1976: 15-16).

Parece que la estructura erigida en el corte V-20 fue reconstruida posteriormente en los niveles 14 y 13 (Estructura VI), en este caso con una simple base de cantos rodados y un alzado de adobe (fig. 6) fechados entre finales del s. V e inicios del IV a.C. (Pellicer et al. 1983: 58). Esta nueva construcción podría ser contemporánea a las estructuras de la Fase 3 en los sectores 1 y 5, al tránsito entre las Fases 2 y 3 en el sector 7, a los primeros niveles de la Fase 1 en el sector 4, así como al Estrato 4 del corte F (fig. 4). En este último se observa un potente relleno de 1,10 m de espesor que debió corresponder con un hiato en la ocupación este sector, que pudo prolongarse a lo largo de casi todo el s. IV a.C. a juzgar por el material extraído del perfil (Martín de la Cruz 1976: 19-20, 26-27, figs. 6-8). No obstante, la tónica general que se extrae de los distintos cortes es la de un hábitat extenso, denso y dinámico que abarca en este momento la totalidad del yacimiento, al menos en su parte conservada. Ello es extensivo a la elevación occidental, donde se documentó un conjunto de estructuras de producción pertenecientes a un posible barrio industrial vinculado al puerto fluvial (fig. 5). Las más antiguas (corte $\mathrm{H}$ ) se dataron entre mediados del s. V y el primer cuarto del IV a.C. (Ruiz Mata y Córdoba 1999: 97), mientras que el resto (cortes F y G) parecen ser ligeramente posteriores, entre finales del s. V y un momento avanzado del IV a.C. (Fernández Gómez et al. 1979: 75). Lamentablemente, como se vio al inicio, los estratos superiores ya habían sido desmantelados a mediados de los años setenta, por lo que resulta imposible conocer la evolución de este sector productivo en los siglos posteriores. La única excepción parece ser la estancia excavada en el corte E, ubicado en el extremo suroriental de la elevación, cuyos rellenos ofrecieron un abundante repertorio material que puede fecharse a lo largo del s. IV e incluso inicios del III a.C. (Fernández Gómez et al. 1979: passim).

Este es el arco cronológico de la siguiente etapa, que comprende las Fases 3C, 4 y 5A del sector 1, las Fases 1 y 2 del sector 4, las Fases 4 y 5 del sector 5, y la Fase 3 del sector 7. En todos los casos las estructuras reflejan una clara continuidad con respecto a las fases precedentes, tanto por su posición estratigráfica, orientación, materiales y técnicas, como por los rasgos formales y funcionales de los espacios resultantes, reproduciendo la misma dinámica constructiva. En algunas ocasiones los muros se apoyan o adosan a los anteriores y los pavimentos se implantan directamente sobre los rellenos que amortizan las estancias previas, elevando la cota de uso casi $1 \mathrm{~m}$. Ello se aprecia también en el corte V-20, donde se instala una nueva estructura que abarca los niveles 12 al 9 (Estructura VII). Se trata de un muro de 65 $\mathrm{cm}$ de ancho y orientación N-S, construido con una cimentación de cantos rodados y alzado de adobe, perpendicular a una línea de cantos rodados en sentido E-O 
con el que parece formar también una esquina en ángulo recto, aunque desplazada unos $30 \mathrm{~cm}$ al sur con respecto a la anterior (Pellicer et al. 1983: 58, fig. 11). Estas estructuras se encuentran asociadas en su base a un pavimento de arcilla apisonada que se reconstruye sucesivamente en los niveles superiores, al menos hasta el 9 (fig. 6). En el corte F, por su parte, una bolsada de relleno, que rompe aparentemente los restos de una estructura de tapial, sirve de base a una nueva fase constructiva (Estrato 3 ) constituida por dos muros sucesivos (fig. 4). El primero es el típico paramento de ladrillos de adobe, similar a los documentados en los demás sectores, que presenta una altura conservada de $60 \mathrm{~cm}$. El segundo, en cambio, es un zócalo de piedras unidas entre sí con mortero de barro de unos $40 \mathrm{~cm}$ de altura, que rompe y se encaja en la anterior en su zona central superior (Martín de la Cruz 1976: 20-21).

Este último muro, perteneciente ya a una fase posterior, inaugura un nuevo horizonte constructivo que puede observarse en prácticamente todos los sectores de la elevación oriental. Se caracteriza por la introducción de potentes cimientos-zócalos de mampostería careada sobre los que se colocaría un alzado de adobe o tapial. La coetaneidad de este proceso de petrificación de la arquitectura doméstica en la primera mitad del s. III a.C. queda demostrada por las cotas de base de los muros de piedra documentados en los sectores 1 (Fase 5B y 5C), 4 (Fase 3), 5 (fuera del corte) y 7 (Fase 4), que se sitúa en torno a los 16 m s.n.m. a excepción del sector 4, que como se ha visto mantiene una altura absoluta ligeramente inferior. A ellos debemos sumar los registrados en corte V-20, que arrancan también a esta cota (fig. 6). Nos referimos a los cimientos de bloques sin escuadrar del nivel 8, que prosiguen en los niveles 7 y 6 (Estructura VIII) y estarían asociados a niveles de habitación de pequeños cantos rodados y tierra apisonada (Pellicer et al. 1983: 58, Lám. II,1). Muros de estas características son perceptibles, además, en otros sectores del cerro, generalmente anchos y potentes, continuando hasta los niveles superiores de la secuencia.

Las últimas fases de ocupación del oppidum protohistórico solo son reconocibles en el corte V-20 (fig. 6), ya que en el $\mathrm{F}$ únicamente se describió un posible nivel de habitación aislado en el extremo norte del Estrato II, restos de adobe, tapial y diversas bolsadas de material de relleno que se extienden hasta el nivel superficial (Estrato I) (Martín de la Cruz 1976: 21-22), mientras que la limpieza de perfiles llevada a cabo en 2017 no llegó en ningún caso a esa cota por motivos de seguridad. En el nivel 5 se localizó una nueva estructura, esta vez de cantos rodados, con alzado de adobes y un grosor de $58 \mathrm{~cm}$. Mantiene prácticamente la misma orientación que las anteriores, aunque ligeramente girada hacia el $\mathrm{N}$, lo que provoca un claro desplazamiento, sobre todo del muro orientado N-S. El interior de la habitación era de tierra rojiza con abundantes cenizas y en su límite $\mathrm{E}$ aparecieron dos recipientes de cocina intactos, situados en el interior de un hogar. Este hecho se interpretó como un abandono precipitado que sus excavadores situaron en el contexto de la II Guerra Púnica, a finales del s. III a.C., aunque a continuación señalaban la presencia de un nuevo pavimento de tierra apisonada en el nivel inmediatamente posterior, lo que estaría indicando la continuidad de la Estructura VIII hasta los inicios del s. II a.C. (Pellicer et al. 1983: 58, fig. 10, Lám. I,3). Un último nivel constructivo fue identificado en el nivel 2 (Estructura IX). Consistía en un muro de mampuestos y cantos rodados muy destruido, atravesando el ángulo $\mathrm{N}$ del corte en sentido E-O y asociado a restos de un encachado de grava, que podría fecharse ya en la segunda mitad del s. II a.C. (Pellicer et al. 1983: 58, fig. 10, Lám. I,2). Por último, el nivel 1, muy removido por las labores agrícolas, cerraría la secuencia con unos materiales que permiten situar el final del hábitat en torno al cambio de siglo (Pellicer et al. 1983: 55).

\section{NUEVOS APUNTES SOBRE LAS TÉCNICAS CONSTRUCTIVAS}

Una de las principales aportaciones de la intervención realizada en 2017 ha sido la posibilidad de profundizar sobre las técnicas constructivas empleadas en el yacimiento y su evolución a lo largo de la Edad del Hierro.

Desde el punto de vista arquitectónico nos encontramos ante estructuras de planta rectangular y tamaño medio, entre $2 \mathrm{~m}$ las más pequeñas y 3,5 $\mathrm{m}$ las de mayores dimensiones (cf. Díes Cusí 2001: 92). Aunque en los perfiles es difícil determinar si se trata del ancho o la longitud de la habitación, en ambos casos sugieren espacios amplios, presumiblemente de un solo piso. Los muros siguen una orientación predominante N-S/E-O, ligeramente desviada hacia el N-NE en casi todas las fases definidas, si bien tampoco son infrecuentes otras orientaciones, especialmente la SO-NE, que encontramos en las estructuras más recientes, coincidiendo con la aparición de los zócalos pétreos. Parece tratarse en su mayoría de estructuras domésticas, o bien de espacios asociados a las mismas, a juzgar por su forma y tamaño, acabados e instalaciones, así como por los materiales registrados en sus niveles de construcción y amortización, generalmente cerámicas comunes y ánforas. 
Los muros están realizados con ladrillos de adobe y, en ocasiones, con tapial. Pueden construirse sobre los depósitos de nivelación previos o encajarse en ellos mediante una pequeña zanja de cimentación, cuando no se asientan directamente sobre los restos de las estructuras anteriores para ganar mayor estabilidad. A veces suelen llevar una cama de cantos rodados, de una o dos hiladas, que además de aportar solidez pudo servir como elemento de aislamiento y drenaje de la humedad (fig. 16, B), pero también son frecuentes los muros construidos completamente en tierra desde su propia base (fig. 16, A). Solo en las últimas fases de ocupación (s. III a.C.) se generaliza, como hemos visto, el zócalo de mampuestos careados, relleno con ripio y tierra (fig. 16, C). Resulta muy llamativa la tardía incorporación de esta solución constructiva, muy común en el ámbito fenicio-púnico (Prados 2003: 159-160), que encontramos en el sur de la península ibérica desde los inicios de la colonización fenicia (ibd: 47-48, Díes Cusí 2001: 81) y que es habitual en otros yacimientos turdetanos, como Niebla, Tejada la Vieja o Carmona (Serrano 2015: 327-328). Ello podría deberse, probablemente, a la escasez de piedra en la vega del Guadalquivir frente a la abundancia de cantos de río, que habrían perpetuado el uso de ese tipo de cimentaciones sencillas hasta finales de la Edad del Hierro, conformando un rasgo característico de la tradición constructiva de las poblaciones ribereñas, como puede observarse también en Sevilla (García y González 2007) o Alcalá del Río (Ferrer y García 2007).

Los muros de adobe están construidos, por lo general, con ladrillos rectangulares de entre $40-50 \mathrm{~cm}$ de largo por 25-30 de ancho y $10 \mathrm{~cm}$ de grosor, o bien con ladrillos cuadrangulares de unos $35 \mathrm{~cm}$ de lado, aunque se aprecia una relativa variabilidad entre unas fases y otras (cf. Pellicer et al. 1983: 57-58). Suelen estar realizados con arcilla rojiza o marrón, y unidos con una argamasa de barro fino más claro que deja unas llagas de 1-2 cm, por lo que resulta fácil diferenciarlos de los depósitos de amortización y nivelación, en los que se utiliza mayoritariamente arcilla grisácea. A veces están recubiertos de un enlucido de cal que puede alcanzar con el tiempo un espesor considerable. Se usa indistintamente el aparejo a soga, a tizón, y muy raramente a soga y tizón, pudiendo responder a la propia entidad o función del paramento (muro de cierre, tabique de compartimentación, etc.). Solo en una ocasión, en los niveles 21-19 del corte V-20, se ha registrado un aparejo singular, formado por una hilada de ladrillos en horizontal y otra en vertical junto a los anteriores, «como refuerzo del muro» (Pellicer et al. 1983: 57, fig. 13-14), pero ignoramos si se trata de un hecho aislado o una solución común, al menos en las fases constructivas más antiguas. Por lo que respecta a sus medidas, los ejemplos conservados van desde los 45 hasta los $70 \mathrm{~cm}$ de ancho, dependiendo de la función desempeñada (muros maestros o tabiques), siendo la medida más frecuente entre 50 y 60 , salvo los zócalos pétreos más tardíos, que oscilan ya entre 60 y $80 \mathrm{~cm}$ de ancho, en la línea de otros yacimientos protohistóricos de la región (Díes Cusí 2001: 81, Serrano 2015: 337-338). Metrológicamente, estas estructuras se mantienen dentro de los estándares introducidos por los fenicios en la península ibérica a inicios de la Edad del Hierro, tanto en sus asentamientos costeros como en las comunidades establecidas en el interior (Belén et al. 1993: 223-226, cf. Díes Cusí 2001: passim), correspondiendo a las distintas unidades de codo $(50-55 \mathrm{~cm})$ que se mantuvieron posteriormente en la arquitectura púnica (Prados 2003: 196, Barresi 2007: 2021) y que se adoptarán también en la ibérica (Prados 2007: 31) y en la turdetana (Serrano 2015: 375-376).

Las estancias documentadas suelen estar pavimentadas con lechadas alternas de arcilla y cal (fig. 16, D). Esta técnica la encontramos desde los niveles más antiguos (s. VI a.C.) hasta los más recientes, conviviendo con la introducción de los zócalos de piedra. Se trata de una forma de pavimentar bien conocida y atestiguada en los yacimientos protohistóricos del sur de la península ibérica (Díes Cusí 2001) y el Mediterráneo (Braemer 1982). Lo que singulariza a los suelos de Cerro Macareno es su potencia, alcanzando en ocasiones los $10 \mathrm{~cm}$ de espesor. Ello revela la larga vida de estas estructuras, que fueron reparadas periódicamente con las mismas técnicas, conservando probablemente también la misma función. No obstante, lo normal es que su grosor oscile entre 2 y $5 \mathrm{~cm}$, manteniendo generalmente su superficie limpia de residuos, lo que indica que su anulación no se debió a un abandono sino a una amortización intencionada para reparar o reconstruir la estructura. Volveremos sobre este tema más adelante. Un detalle interesante es la forma en la que los pavimentos se adosan a los muros (fig. 16, E). Suelen tener un acabado en media caña, a modo de rodapié, que se eleva sobre su superficie adosándose al enlucido del muro y garantizando así el aislamiento de la estancia. En ocasiones, utilizan para ello cantos rodados que se colocan entre el muro y el nivel sobre el que se asienta el pavimento, ayudando de este modo a generar la curvatura. Esta solución constructiva -con o sin cantos rodadosse utiliza tanto en el contacto entre los pavimentos y los muros, como en su relación con otras instalaciones domésticas como bancos o poyos, y es habitual en los niveles medios y superiores de la estratigrafía (desde la 


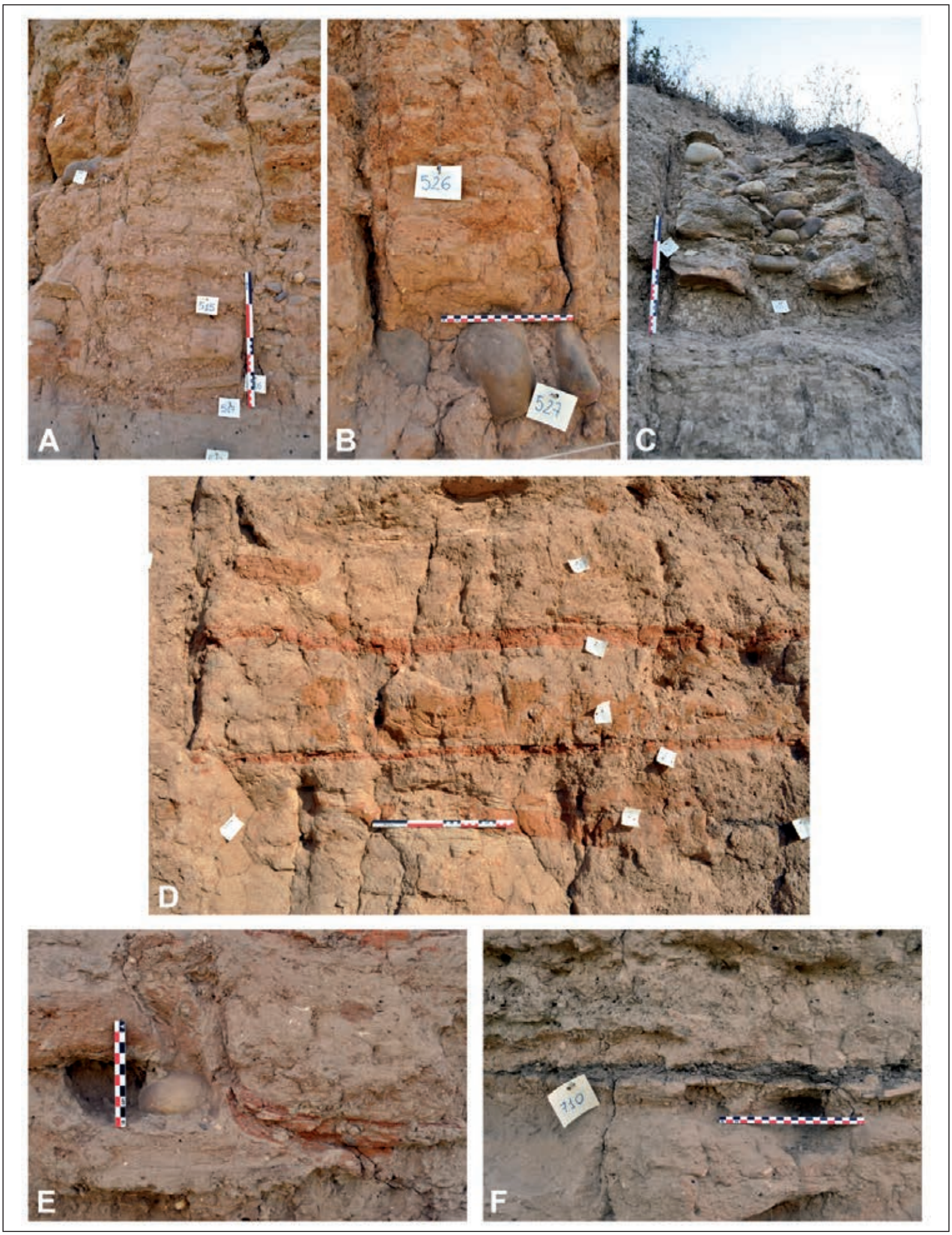

Figura 16. Imágenes de las soluciones constructivas de muros, pavimentos y niveles de relleno más frecuentes empleadas en el yacimiento durante el Hierro II.

ISSN: $1133-4525 \quad$ ISSN-e: $2255-3924$ 
Fase 2 de los sectores 1, 5 y 7), por lo que podemos deducir que constituye un rasgo característico de la arquitectura de Cerro Macareno, al menos desde mediados del I milenio a.C.

También se documentan otros tipos de niveles de uso, generalmente superficies no pavimentadas endurecidas por su uso o por la acción del fuego, en ocasiones cubiertas por tierra suelta, ceniza y detritus, o bien depósitos de ceniza relacionados con hogares (fig. 16, F). En el primer caso resulta difícil determinar si se trata de espacios abiertos o cerrados, o incluso de niveles de circulación exterior (calles, explanadas) salvo que estén relacionados claramente con elementos constructivos. Lo mismo se puede decir de los depósitos de grava y encachados, que pudieron corresponder tanto a rellenos de compactación como a espacios de tránsito, dada la extensión y horizontalidad que suelen presentar. Tanto en unos como en otros aparecen instalaciones de distinto tipo: bancos, poyos, hogares, o incluso plataformas de adobe, como la documentada en el sector 7. Los primeros pueden tener pavimentos adosados o estar revestidos de capas de arcilla y cal, mientras que los hogares y plataformas están asociados a restos de carbón, ceniza y basura derivados de su uso.

Como se ha visto, salvo cuando se produce un abandono más o menos dilatado en el tiempo, en cuyo caso las estructuras están sepultadas por depósitos irregulares de tierra y residuos domésticos, el ciclo vital de las construcciones turdetanas (las fases más antiguas no han sido completamente documentadas y presentan además una peor conservación) parece seguir siempre el mismo patrón (fig. 16, D). Durante el uso del edificio, este se mantiene y repara periódicamente mediante el enlucido de las paredes y el enlechado del suelo, o incluso se refuerza para garantizar su estabilidad cuando uno de los muros anuncia ruina, construyendo un nuevo paramento directamente sobre el propio piso. Eventualmente se disponen también elementos como hogares, bancos o poyos, que obligan a recrecer el pavimento o a revocar su contacto con estas instalaciones. Sin embargo, cuando el edificio está totalmente obsoleto se procede a destruirlo para construir otro justo encima, aprovechando la base de sus muros como cimentación de los nuevos. Las estructuras suelen desmocharse hasta una altura comprendida entre los 30 y los $70 \mathrm{~cm}$, vertiendo los escombros dentro de la habitación, sobre un pavimento limpio casi siempre de enseres o restos de basura. Sobre este depósito, que presenta una superficie irregular, generalmente inclinada desde la base de los muros hacia el centro de la habitación, se dispone un segundo nivel de arcilla compacta color grisáceo que sirve de nivelación para la siguiente fase constructiva. Será sobre su superficie donde se construya el nuevo pavimento, con o sin ayuda de un preparado de regularización realizado también en arcilla. Estos depósitos ofrecen a menudo cerámicas, restos faunísticos, carbón, etc. procedentes de los aportes de tierra utilizados en los rellenos, o que han sido vertidos como basura en los mismos, si bien su cantidad varía mucho entre unos sectores y otros o incluso entre unas fases constructivas y otras.

Con todo, a pesar de la abundante presencia de material residual en estos niveles secundarios y la aparición de restos in situ sobre algunos pavimentos, hogares o instalaciones, los contextos exhumados -compuestos principalmente por cerámicas comunes de cocina y mesa, ánforas y, en menor medida, vajilla fina importada- se muestran insuficientes a día de hoy para determinar la función exacta de estas estructuras, más allá de la doméstica. Resulta imprescindible, por tanto, la realización de nuevas intervenciones en los sectores conservados que saquen a la luz contextos amplios de las principales fases de ocupación de Cerro Macareno, o al menos de las más representativas de las etapas de transición, con objeto de estudiar en extensión sus rasgos arquitectónicos, constructivos y urbanísticos, así como las actividades desarrolladas por sus habitantes.

\section{CONCLUSIONES}

Con todo, el estudio de diagnóstico llevado a cabo recientemente ha permitido confirmar gran parte de las propuestas realizadas por sus primeros excavadores a mediados de los años setenta y avanzar en algunas de ellas, aportando un gran caudal de información sobre la extensión del yacimiento, su potencia estratigráfica, las fases de ocupación presentes, la organización espacial del hábitat y su evolución, sus rasgos arquitectónicos y constructivos, así como sobre la entidad y estado de conservación de los restos subyacentes.

Para empezar, se ha podido calcular la extensión actual de los restos conservados en las dos elevaciones, que suman poco más de $20000 \mathrm{~m}^{2}$, incluyendo los taludes, con respecto al tamaño original del cerro, que alcanzaba los $90000 \mathrm{~m}^{2}$. Ello supone una destrucción de más de tres cuartas partes de su superficie, o lo que es lo mismo, ha llegado hasta nosotros poco más del $20 \%$ del yacimiento para su investigación. En cuanto a su potencia estratigráfica, la elevación oriental mantiene aún su cota primitiva (19-18 m s.n.m.), lo que da lugar a perfiles profundos, de más de $7 \mathrm{~m}$ desde su base $(11 \mathrm{~m}$ s.n.m.) en la mayor parte de su perímetro, a excepción 
del $\mathrm{N}$, donde apenas supera los $5 \mathrm{~m}$. En cambio, la elevación occidental, que ya había perdido los niveles superiores de su estratigrafía, presenta perfiles más alterados, con una potencia de entre 4 y $5 \mathrm{~m}$ desde la base de la terraza (12,5 m s.n.m.) en la parte más alta (17 m s.n.m.), descendiendo hasta los $3 \mathrm{~m}$ en la cara $\mathrm{N}$ (14 m s.n.m.).

Asimismo, se ha confirmado la secuencia de ocupación establecida por las primeras intervenciones, aunque con algunos matices. A juzgar tanto por los materiales recogidos en superficie como, sobre todo, por el estudio comparado de las estratigrafías obtenidas en la elevación oriental, todo apunta a que el hábitat debió iniciarse en un momento indeterminado del s. VIII para terminar a finales del II a.C., mientras que, en la elevación occidental, ni la potencia de los depósitos conservados ni los materiales asociados permiten pensar en niveles anteriores al VI a.C. No obstante, sí se constatan evidencias de ocupaciones posteriores, aunque de poca entidad, que podrían haberse situado sobre el cerro, en sus laderas o en sus alrededores, en los sectores ya desaparecidos, aunque también es probable que una parte de los restos de época romana y medieval documentados llegaran desplazados por movimientos de tierra relacionados con la explotación de la cantera.

Por otro lado, se mantiene la distribución de las áreas funcionales propuesta en los años setenta, ya que el hábitat parece concentrarse principalmente en la elevación oriental, mientras que las estructuras de carácter industrial se disponen en la elevación occidental, más próxima al antiguo cauce del Guadalquivir, que se transforma a mediados del I milenio a.C. en un auténtico barrio industrial. En este sentido, a pesar de la tendencia horizontal que se aprecia en la mayor parte de los perfiles, las cotas absolutas obtenidas en los distintos sectores estudiados permiten adivinar los pequeños cambios topográficos que debieron existir durante su fase de actividad, y que habrían condicionado su desarrollo espacial, como el leve escalón que se observa en el extremo $\mathrm{N}$ de la elevación oriental, o el aumento de cota de la base del cerro en la elevación occidental, que pudo contribuir también a la separación física de las actividades artesanales con respecto al hábitat.

Las estratigrafías obtenidas en la elevación oriental demuestran también que la función de hábitat se extendió de forma prácticamente ininterrumpida a lo largo de todo el periodo de ocupación del yacimiento. Se advierte además una gran coherencia entre estas y las antiguas secuencias publicadas, especialmente el corte $\mathrm{V}-20$, cuyas fases coinciden grosso modo con las registradas en los perfiles estudiados en 2017. Aun así, se ha podido identificar una remodelación extensa en tres de los cuatro sectores intervenidos que parece suceder a un abandono temporal del hábitat, probablemente a finales del Hierro I. Está constituida por rellenos potentes y heterogéneos que amortizan las estructuras anteriores, por lo general muros de adobe muy precariamente conservados, en algunos casos sellados por niveles de uso puntuales, como hogueras o depósitos de ceniza. Sobre ellos se disponen -en ocasiones encajados por medio de zanjas- rellenos masivos de arcilla gris muy compactada destinados a nivelar el terreno y cimentar la siguiente fase constructiva. Esta inaugura en realidad una secuencia de estructuras, reparaciones, amortizaciones y reconstrucciones que se suceden en el tiempo sin aparente solución de continuidad hasta el final de la vida del antiguo oppidum. El mantenimiento de las mismas tipologías arquitectónicas, materiales, técnicas, medidas, orientaciones y funciones da fe no solo de la estabilidad del hábitat, sino también de la persistencia de las mismas tradiciones y formas de vida.

En este sentido, cabe destacar la continuidad de las formas constructivas a lo largo de las distintas fases identificadas y su enorme personalidad, que es extensiva al resto de los grandes establecimientos portuarios del Guadalquivir, como Ilipa (Alcalá del Río), Italica (Santiponce), Spal (Sevilla) o Caura (Coria del Río). Se aprecia obviamente una gran sintonía con la tradición arquitectónica fenicio-púnica, que se refleja no solo en la tipología edilicia y las técnicas constructivas, sino también en perduración de los patrones metrológicos de origen oriental, ya sea en las proporciones generales de los espacios como, sobre todo, en la modulación de las estructuras. No obstante, se desarrollan por otro lado soluciones particulares que solo pueden entenderse en clave local. Estas son el resultado de una larga evolución en la que los modelos orientales se van adaptando a las condiciones ecológicas del entorno y a las coyunturas económicas, sociales y culturales de sus pobladores.

Finalmente, cuarenta años después de las últimas excavaciones, hemos podido valorar el potencial científico y patrimonial que aún alberga Cerro Macareno. La profundidad y extensión de los depósitos arqueológicos subsistentes, el estado de conservación de los niveles de ocupación, su continuidad cronológica y su coherencia en relación con la secuencia cultural del Bajo Guadalquivir protohistórico, aportando nuevos datos sobre los momentos poco conocidos, como el tránsito entre el Hierro I y el Hierro II o el inicio de la presencia romana, así como la excelente legibilidad de las estructuras los contextos asociados, suponen un estímulo para el estudio sistemático de este yacimiento y el desarrollo de las estrategias de conservación y puesta en valor 
adecuadas con el fin de avanzar en el conocimiento y la difusión de este periodo histórico en la región.

\section{Agradecimientos}

Este trabajo es fruto en gran medida de una estancia de movilidad de profesores e investigadores sénior en centros extranjeros (Programa "Salvador de Madariaga") realizada en el Istituto di Studi sul Mediterraneo Antico de Roma en el verano de 2018 (PRX18/00285). Agradecemos al responsable de la estancia en el centro de destino, el Dr. Massimo Botto, su generosa acogida y el estímulo para llevar a término esta síntesis. Se enmarca en los proyectos de investigación "Tarteso Olvidado (en los Museos)" (PGC2018-097131-B-I00) y “La Construcción en el Valle del Guadalquivir en Época Romana. Tradición e Innovación en las Soluciones Arquitectónicas y los Procesos Tecnológicos, Económicos y Productivos" (HAR2015-64392-C4-4-P). Por su parte, las labores de campo fueron financiadas por el Departamento de Prehistoria y Arqueología de la Universidad de Sevilla y el Área de Cultura del Ayuntamiento de La Rinconada, a cuyos responsables agradecemos su inestimable apoyo. Asimismo, ha sido fundamental la ayuda prestada por los miembros del equipo de investigación del proyecto arqueológico, especialmente P. Albuquerque y L. Guillén Rodríguez, la colaboración de A. Mateos Orozco, N. Conejero Redondo e I. Romero Mata en el registro y documentación gráfica, y de J. García Cerezo, encargado de la realización de los levantamientos topográficos. Agradecemos a los profesores O. Rodríguez Gutiérrez y A.M. Sáez Romero, de la Universidad de Sevilla, sus sugerencias sobre distintos aspectos del proyecto y al personal del Museo Arqueológico y Paleontológico de La Rinconada (M.I. Rodríguez Achútegui, J. Navarro Perza y M. Garrido Martín) su apoyo logístico. Por último, es preciso mencionar la ayuda de los alumnos del Grado de Arqueología, que realizaron sus prácticas en el marco del proyecto.

\section{BIBLIOGRAFÍA}

Amberger, G. (1985): "Tierknochenfunde vom Cerro Macareno/Sevilla". Studien über frühe Tierknochenfunde von der Iberischen Halbinsel 9: 76-105.

Barresi, P. (2007): Metrología púnica. Milano, Athenaion.

Belén, M.; Escacena, J.L.; Anglada, R.; Jiménez, A.; Pardo, Ma ${ }^{\mathrm{a}}$. y y
(1993): "Arquitectura de tradición fenicia en Carmona (Sevilla)". Spal 2: 219-242. <http://dx.doi. org/10.12795/spal.1993.i2.09>.

Braemer, F. (1982): L'Architecture domestique du Levant à l'Âge de Fer. Paris, Recherche sur les Civilisations.

Díes Cusí, E. (2001): "La influencia de la arquitectura fenicia en las arquitecturas indígenas de la Península Ibérica (s. VIII-VI)", en D. Ruiz Mata y S. Celestino Pérez (eds.), Arquitectura oriental y orientalizante en la Península Ibérica: 69-121. Madrid, CSIC.

Escacena Carrasco, J.L. (1983): "Problemas en torno a los orígenes del urbanismo a orillas del Guadalquivir". Gades 11: 39-83.

Escacena Carrasco, J.L. (1987): "El poblamiento ibérico en el Bajo Guadalquivir”, en A. Ruiz y M. Molinos (eds.), Actas de las Primeras Jornadas sobre Mundo Ibérico: 273-297. Jaén, Ayuntamiento de Jaén-Junta de Andalucía.

Escacena Carrasco, J.L. (1993): "De la muerte de Tartesos. Evidencias en el registro poblacional". Spal 2: 183-218. doi: <http://dx.doi.org/10.12795/ spal.1993.i2.08>.

Fernández-Chicarro y de Dios, C. (1974): “Adquisiciones del Museo Arqueológico de Sevilla”. Bellas Artes 33: 31-34.

Fernández Gómez, F.; Chasco Vila, R. y Oliva Alonso, D. (1979): "Excavaciones en 'El Cerro Macareno'. La Rinconada. Sevilla (Cortes E-F-G. Campaña 1974)". Noticiario Arqueológico Hispánico 7: 7-93.

Ferrer Albelda, E. (2017): "La colonización fenicia en la Tartéside: estrategias y fases", en S. Celestino y E. Rodríguez (eds.), Territorios comparados: los valles del Guadalquivir, el Guadiana y el Tajo en época tartésica: 11-46. Mérida, IAM-CSIC.

Ferrer Albelda, E. y García Fernández, F.J. (2007): "Primeros datos sobre la Ilipa turdetana”, en E. Ferrer, A. Fernández, J.L. Escacena y A. Rodríguez (eds.), I Congreso de Historia de Alcalá del Río: Ilipa Antiqua. De la Prehistoria a la Época Romana: 103130. Alcalá del Río (2006), Sevilla, Ayuntamiento de Alcalá del Río.

Ferrer Albelda, E. y García Fernández, F.J. (2008): "Cerámica turdetana", en D. Bernal y A. Ribera (eds.), Cerámicas hispanorromanas. Un estado de la cuestión: 201-220. Cádiz, Universidad de Cádiz.

Ferrer Albelda, E.; García Vargas, E. y García Fernández, F.J. (2008): “Inter Aestuaria Baetis. Espacios naturales y territorios ciudadanos prerromanos en el Bajo Guadalquivir". Mainake XXX: 217-246. 
García Fernández, F.J. (2017): "La herencia de Argantonio: cambios y estrategias en el Tarteso postcolonial", en S. Celestino y E. Rodríguez (eds.), Territorios comparados: los valles del Guadalquivir, el Guadiana y el Tajo en época tartésica: 147-173. Mérida, IAM-CSIC.

García Fernández, F.J. y Del Espino Hidalgo, B. (2019): "Doce yacimientos para el conocimiento del 'Reino de Tartessos'. El Decreto 3833/1973: biografía de una declaración no consumada". Lvcentvm 38: 89-110. doi:<http://dx.doi.org/10.14198/LVCENTVM2019.38.04>

García Fernández, F.J. y García Vargas, E. (2012): “Los hornos alfareros de tradición fenicia en el valle del Guadalquivir y su perduración en época romana: aspectos tecnológicos y sociales". Spal 21: 9-38. doi:<http://dx.doi.org/10.12795/spal.2012.i21.01>.

García Fernández, F.J. y González Acuña, D. (2007): "Secuencias estratigráficas y contextos culturales de la Sevilla prerromana", en M. Bendala y M. Belén (eds.), Actas del V Congreso de Historia de Carmona. El nacimiento de la ciudad: la Carmona protohistórica: 525-566. Carmona (2005), Carmona, Universidad de Sevilla-Ayuntamiento de Carmona.

García Fernández, F.J.; Albuquerque, P. y Guillén Rodríguez, L. (e.p.): “Cerro Macareno (La Rinconada, Sevilla): nuevas investigaciones en un yacimiento paradigmático del Guadalquivir protohistórico", en Actas del IX Congreso Internacional de Estudios Fenicios y Púnicos. Mérida (2018), Mérida.

González García, F.; González Vilches, M.C. y García Ramos, G. (1985): "Productos de alfarería de Cerro Macareno (Sevilla): naturaleza y procedencia de las ánforas y otros objetos cerámicos. Siglos VIII a III a.J.C.”. Noticiario Arqueológico Hispánico 21: 157-174.

González Vilches, M.C.; González García, F. y García Ramos, G. (1985a): "Materias primas y datos tecnológicos de piezas cerámicas antiguas del yacimiento arqueológico de Cerro Macareno (Sevilla) (I)". Boletín de la Sociedad Española de Cerámica y Vidrio 24 (3): 173-186.

González Vilches, M.C.; García Ramos, G. y González García, F. (1985b): "Materias primas y datos tecnológicos de piezas cerámicas antiguas del yacimiento arqueológico de Cerro Macareno (Sevilla) (II)". Boletín de la Sociedad Española de Cerámica y Vidrio 24 (4): 219-232.

González Vilches, M.C.; González García, F.; García Ramos, G. y González Rodríguez, M. (1988):
"Estudio arqueométrico de pigmentos de algunas piezas cerámicas de Cerro Macareno (Sevilla)". Boletín de la Sociedad Española de Cerámica y Vidrio 27 (2): 73-80.

Jiménez Sancho, A. (2010): “Prospección Arqueológica Superficial en sectores urbanizables. P.G.O.U. de La Rinconada (Sevilla)". Anuario Arqueológico de Andalucía 2006: 3797-3809.

Luzón Nogué, J.Mª (1973): Excavaciones en Itálica. Estratigrafía en el Pajar de Artillo (Campaña 1970). Madrid, Ministerio de Educación y Ciencia.

Martín de la Cruz, J.C. (1976): "El corte F del Cerro Macareno. La Rinconada (Sevilla)". Cuadernos de Prehistoria y Arqueología de la Universidad Autónoma de Madrid 3: 9-31.

Pellicer Catalán, M. (1978): “Tipología y cronología de las ánforas prerromanas del Guadalquivir, según el Cerro Macareno (Sevilla)". Habis 9: 365-400.

Pellicer Catalán, M. (1982): “Las cerámicas del mundo fenicio en el Bajo Guadalquivir: evolución y cronología según el Cerro Macareno (Sevilla)", en Phöinizier im Westen: 371-406. Mainz am Rhein, Philipp Von Zabern.

Pellicer Catalán, M.; Bendala Galán, M. y Escacena Carrasco, J.L. (1983): El Cerro Macareno. Madrid, Ministerio de Educación y Ciencia.

Ponsich, M. (1974): Implantation rurale antique sur le Bas-Guadalquivir, vol. 1. París, E. de Boccard.

Prados Martínez, F. (2003): Introducción al estudio de la arquitectura púnica. Madrid, Universidad Autónoma de Madrid.

Prados Martínez, F. (2007): "La edilicia púnica y su reflejo en la arquitectura ibérica: materiales, aparejos y técnicas constructivas". Pallas 75: 9-36.

Ruiz Mata, D. y Córdoba Alonso, I. (1999): “Los hornos turdetanos del Cerro Macareno. Cortes H.I y H.II", en XXIV Congreso Nacional de Arqueologia: 95-105. Cartagena (1997), Cartagena, Gobierno de la Región de Murcia-Instituto de Patrimonio Histórico.

Ruiz Mata, D. y Vallejo Sánchez, J.I. (2002): “Continuidad y cambio durante el siglo VI a.C. Las cerámicas del Corte $\mathrm{C}$ del Cerro Macareno (La Rinconada, Sevilla)". Spal 11: 197-218. doi: $<$ http:// dx.doi.org/10.12795/spal.2002.i11.10>.

Serrano Martín, T. (2015): La arquitectura doméstica de época turdetana en el Bajo Guadalquivir. Tesis Doctoral, Universidad de Sevilla. <http://hdl. handle.net/11441/34619> [08/10/2019]. 

De Sousa, E., Pimenta, E., Silva, E., Mendes, H., Arruda, A.M., Dorado-Alejos, A. (2020):

"Ânforas da Idade do Ferro e de tradição pré-romana do Porto do Sabugueiro (Muge, Portugal)", Spal 29.1: 129-156. DOI: http://dx.doi.org/10.12795/spal.2020.i29.05

\title{
ÂNFORAS DA IDADE DO FERRO E DE TRADIÇÃO PRÉ-ROMANA DO PORTO DO SABUGUEIRO (MUGE, PORTUGAL)
}

\section{IRON AGE AND PRE-ROMAN TRADITION AMPHORAE FROM PORTO DO SABUGUEIRO (MUGE, PORTUGAL)}

\author{
ELISA DE SOUSA \\ Responsable de la correspondencia \\ Universidade de Lisboa - Faculdade de Letras - Uniarq (Centro de Arqueologia) \\ Correo-e: e.sousa@campus.ul.pt. (D) https://orcid.org/0000-0003-3160-108X \\ Researcher ID: <https://publons.com/researcher/AAG-6086-2019> \\ JOÃO PIMENTA \\ Centro de Estudos Arqueológicos Vila Franca de Xira - CEAX \\ Correo-e: joao.marques@cm-vfxira.pt. (D) https://orcid.org/0000-0001-5149-5566 \\ Researcher ID: <https://publons.com/researcher/AAG-6215-2019> \\ INÊS SILVA \\ Mestranda em Arqueologia pela Faculdade de Letras da Universidade de Lisboa \\ Correo-e: inesdomingos1@campus.ul.pt. (D) https://orcid.org/0000-0002-8779-7328 \\ Researcher ID: <https://publons.com/researcher/AAG-6469-2019> \\ HENRIQUE MENDES \\ Centro de Estudos Arqueológicos Vila Franca de Xira - CEAX. \\ Correo-e: henriquecale@sapo.pt. (D https://orcid.org/0000-0002-3416-8990 \\ Researcher ID: <https://publons.com/researcher/AAG-6988-2019> \\ ANA MARGARIDA ARRUDA \\ Universidade de Lisboa - Faculdade de Letras - Uniarq (Centro de Arqueologia). \\ Correo-e: a.m.arruda@letras.ulisboa.pt. (D) https://orcid.org/0000-0002-7446-1104 \\ Researcher ID: <https://publons.com/researcher/F-3570-2016> \\ ALBERTO DORADO-ALEJOS \\ Laboratorio de Arqueometría - Departamento de Prehistoria y Arqueología - Universidad de Granada (Espanha) \\ Correo-e: doradoalejos@ugr.es. D https://orcid.org/0000-0003-0351-7550 \\ Researcher ID: <https://publons.com/researcher/AAG-8112-2019>
}

Resumo: Durante as várias intervenções efectuadas no sítio do Porto do Sabugueiro foram recolhidas mais de duas centenas de fragmentos de ânforas da Idade do Ferro ou de tradição pré-romana. Trata-se de um conjunto importante no quadro regional, não só pela variedade tipológica das produções locais/regionais (tipos 1, 3, 4, 5, 6 e 7 do estuário do Tejo), mas também pela diversidade de fabricos identificados, revelando a complexidade das redes de produção e circulação dos recipientes anfóricos nesta área específica do território ocidental. A importância deste conjunto recai também na presença de um grupo considerável de materiais importados do sul da
Abstract: During the various interventions carried out on the site of Porto do Sabugueiro, more than two hundred amphora fragments of the Iron Age or pre-Roman tradition were collected. This is an important assemblage in the regional context, not only because of the typological variety of local / regional productions (Types 1, 3, 4, 5, 6 and 7 of the Tagus estuary) but also by the diversity of fabrics we were able to identify, revealing the complexity of the networks of production and circulation of amphorae containers inside the Tagus estuary. The importance of this set also lies in the presence of a considerable group of imported fragments from the south of 
Península Ibérica (ânforas dos tipos 10.1.1.1 de Ramon Torres, Pellicer B/C, Pellicer D e 8.1.1.2 de Ramon Torres), uma situação que não é frequente no contexto regional, e que é discutida com detalhe.

Palavras-chave: Atlântico, Tejo, $1^{\circ}$ milénio, comércio, produção, arqueometria.

\section{INTRODUÇÃO}

O Porto do Sabugueiro é um importante sítio arqueológico localizado no estuário do Tejo, mais especificamente no concelho de Salvaterra de Magos (fig. 1 e 2), freguesia de Muge (CNS - 2693), tendo sido identificado na década de 30 século passado, por Mendes Correa (Pimenta et al. 2014a).

Implanta-se na margem esquerda do rio Tejo, nas proximidades da vala de Alpiarça, numa área de baixa altitude que oscila entre os 5 e os 8 metros, tendo a zona um potencial agrícola considerável. Infelizmente, esta última característica foi também um dos factores que mais prejudicou a sua conservação. A presença de artefactos à superfície estende-se por uma área ampla, com cerca de 25 hectares, sendo muito difícil determinar se esta extensão está directamente relacionada com as suas dinâmicas de ocupação na Antiguidade (sobretudo desde a Idade do Ferro até ao período romano imperial), ou se é resultante da dispersão de materiais devido às intensas práticas agrícolas aí desde há muito realizadas (Pimenta et al. 2014a).

As intervenções arqueológicas que foram realizadas no Porto do Sabugueiro, efectuadas inicialmente por dois dos signatários (Pimenta e Mendes 2008, 2013) e posteriormente desenvolvidas no quadro do projecto de investigação FETE - Fenícios no Estuário do Tejo (PTDC/EPH-ARQ/4901/2012), financiado pela Fundação para a Ciência e a Tecnologia, permitiram constatar que o local foi, efectivamente, muito afectado pelas práticas agrícolas a que foi, e continua a ser, sujeito. Com efeito, os dados obtidos indicam que o potencial estratigráfico do sítio foi, quase na sua totalidade, irremediavelmente destruído (Pimenta et al. 2014a).

Ainda assim, os materiais recuperados quer em prospecção quer durante as várias campanhas de escavação, permitiram compreender que o espaço terá estado intensamente ocupado durante o $1^{\circ}$ milénio a.n.e. e as primeiras centúrias da nossa era, tendo revelado uma quantidade verdadeiramente extraordinária de the Iberian Peninsula (Ramon Torres type 10.1.1.1, type Pellicer B/C, type Pellicer D and Ramon Torres 8.1.1.2), which are not frequent in the regional context, and is discussed in detail.

Keywords: Atlantic, Tagus, $1^{\text {st }}$ millennium, trade, production, archaeometry.

artefactos dos diferentes períodos cronológicos, alguns dos quais já publicados (Pereira 1975, Pimenta e Mendes 2008, 2013, Pimenta et al. 2014a, Arruda et al. 2016, Pereira 2017, García Fernández 2019, Rodrigues et al. no prelo). Estes estudos indicam ainda que a sua ocupação proto-histórica se terá iniciado em torno ao século VII a.n.e., e que se prolongou, sem aparentes descontinuidades, até ao período romano imperial (Pimenta et al. 2014a).

Entre os vários materiais recuperados, cabe destacar a presença abundante de fragmentos de ânforas da Idade do Ferro e de tradição pré-romana que, apesar de não permitirem qualquer leitura contextual, apresentam particularidades que justificam um estudo mais detalhado, que será apresentado nas páginas seguintes. Cabe, porém, referir que neste estudo não se incluíram os recipientes que se enquadram claramente na época romana (republicana e imperial), ainda que várias das formas documentadas, que se relacionam com as tradições oleiras da Idade do Ferro da área do Tejo, tenham atingido também estes momentos mais tardios, concretamente do período romano-republicano (Sousa e Pimenta 2014), daí a utilização da expressão "de tradição pré-romana".

A importância do estudo que agora se apresenta reside sobretudo no facto de se terem identificado, entre os vários materiais, um conjunto muito significativo de contentores anfóricos que exibem características macroscópicas que indicam que se trata de produções locais, situação que parece ser agora corroborada com as análises radiométricas realizadas.

A identificação e compreensão da verdadeira complexidade e dimensão da produção de ânforas no estuário do Tejo é uma realidade que só recentemente tem sido valorizada (Sousa 2014, Sousa e Pimenta 2014), mas a verdade é que ainda nos faltam dados para compreendermos de forma mais detalhada os seus circuitos de fabrico e distribuição. O conjunto que agora se apresenta, ainda que não disponha de dados contextuais, é o terceiro mais numeroso conhecido em todo o estuário 


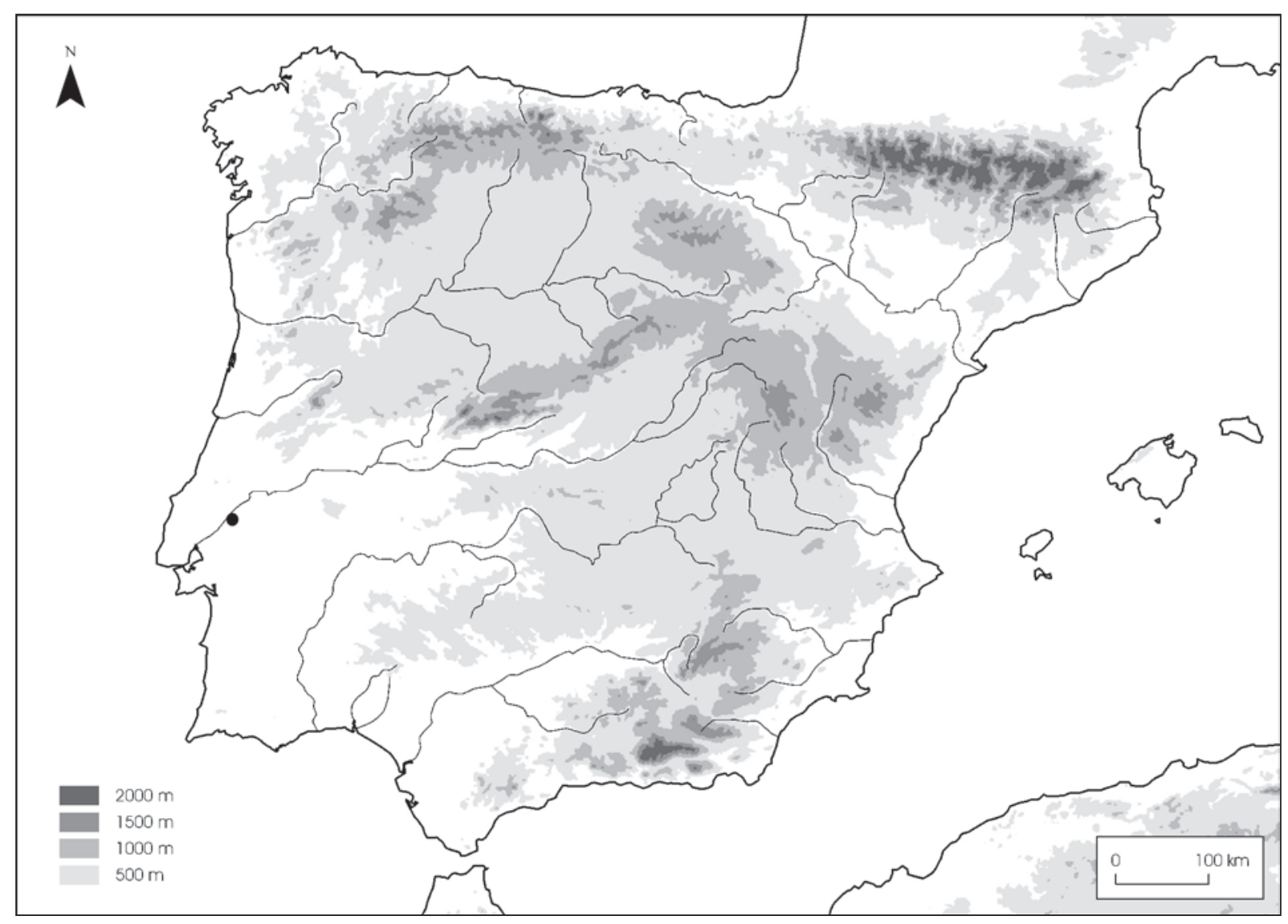

Figura 1. Localização do Porto do Sabugueiro no território peninsular.

do Tejo, depois do da Rua dos Correeiros, em Lisboa (Sousa 2014), e do da Quinta do Almaraz, Almada (Olaio 2018). Estes últimos, integrados na zona terminal da foz do Tejo, estão, muito provavelmente, nas proximidades dos respectivos centros produtores. A circulação destas produções anfóricas da área de Lisboa/ Almaraz chega também, e com muita expressividade, à região mais interior do curso do Tejo, como se verifica não só no Porto do Sabugueiro, mas também em outros sítios próximos como o Cabeço Guião (Arruda et al. 2017), Alto dos Cacos (Sousa et al. 2017), Alto do Castelo (Arruda et al. 2014) e Eira da Alorna (Pimenta et al. 2018). Contudo, a existência de uma outra área produtora de contentores anfóricos nesta zona mais interior, localizada muito provavelmente na própria zona do Porto do Sabugueiro (Sousa e Pimenta 2014), fornece contributos inestimáveis para a compreensão da complexidade destas redes distributivas. Desta forma, justifica-se a necessidade de procurar caracterizar, quer a nível formal, quer macroscópico e arqueométrico, estas produções mais interiores.
Um último aspecto que deve ser enfatizado é a identificação de um grupo bastante significativo de contentores anfóricos importados no conjunto do Porto de Sabugueiro, especialmente no contexto das realidades centro-atlânticas conhecidas até à data (Sousa 2017), e que mostram que este local, consideravelmente interior, esteve ligado, de certa forma, às redes comerciais das áreas mais meridionais da Península Ibérica ao longo de todo o $1^{\circ}$ milénio a.C.

\section{O CONJUNTO ANFÓRICO DO PORTO DO SABUGUEIRO}

Neste trabalho, incluem-se, portanto, os fragmentos de ânforas do Porto do Sabugueiro que estão relacionados, directa ou indirectamente, com o horizonte pré-romano. Como já foi anteriormente referido, a ausência de dados contextuais dificulta a atribuição de balizas cronológicas específicas para uma parte significativa destes materiais, não se podendo excluir a possibilidade 
de alguns (ou vários) poderem ter integrado a componente artefactual da fase romano-republicana. Contudo, apenas com a publicação mais detalhada de contextos desta cronologia no estuário do Tejo, e particularmente de materiais de tradição regional que acompanharam as importações itálicas e da Hispânia Ulterior que chegaram à região a partir do último terço do século II a.n.e., será possível determinar, com mais precisão, este tipo de pervivências e coexistências.

As várias intervenções efectuadas no Porto de Sabugueiro permitiram recuperar um total de 240 fragmentos de bordo de ânforas de cronologia ou tradição pré-romana, que foram sub-divididos em dois grandes grupos: os materiais de produção local e regional (231 exemplares), ou seja, da área do Estuário do Tejo, e os que parecem corresponder a importações das zonas mais meridionais do território peninsular (nove exemplares), alguns dos quais já publicados (García Fernández 2019: 137). A estes somam-se ainda dezenas de fragmentos de asas e alguns fundos, ainda que a informação que estes elementos proporcionem seja bastante limitada.

\subsection{As produções locais/regionais}

\subsubsection{Os grupos de fabrico}

Dentro dos exemplares que considerámos serem de origem local e regional, foi possível distinguir quatro grandes grupos de fabrico, um dos quais com características que justificaram uma ulterior subdivisão. Estes correspondem, grosso modo, a distinções e critérios já utilizados em estudos anteriores (Sousa e Pimenta 2014), ainda que a análise mais detalhada dos fragmentos recolhidos no Porto do Sabugueiro tenha permitido distinguir agora dois grupos distintos no quadro das produções da área mais interior do estuário do Tejo (grupos II e III), e um outro que parece ter origem numa zona mais próxima da foz (grupo IV). Dois fragmentos apresentavam ainda especificidades que justificaram a identificação do que definimos, dada a sua escassa representatividade, como fabricos raros A e B.

\subsubsection{Grupo I}

O primeiro grupo caracteriza-se por apresentar pastas compactas e com fractura regular, sendo o seu grau de depuração variável (entre 5\% e 20\%). Neste grupo, a análise macroscópica permitiu identificar a presença de moscovites, biotites, quartzos, plagióclase e calcites, sendo estas últimas particularmente abundantes. A coloração das pastas varia entre o castanho e o laranja, podendo por vezes mostrar também tonalidades acinzentadas, possivelmente devido aos processos de cozedura. Trata-se, muito provavelmente, de produções originárias da foz do estuário do Tejo, mais concretamente da zona de Lisboa/Almaraz.

Um elemento caracterizador deste grupo é a presença de microfósseis que, contudo, têm uma representatividade bastante variável que justificou a sub-divisão em dois fabricos distintos. O grupo I-A caracteriza-se pela presença frequente destes elementos; no grupo I-B os microfósseis são bastante mais raros.

Nas ânforas do Porto de Sabugueiro, o grupo I engloba 49 exemplares (distribuídos pelo fabrico I-A, com 26 fragmentos, e I-B, com 23 fragmentos), que corresponde a $21 \%$ do conjunto presentemente analisado.

\subsubsection{Grupo II}

O segundo grupo de fabrico reúne exemplares de pastas compactas e escassamente depuradas (superior a 20\%). A análise macroscópica permitiu identificar a presença frequente de partículas de quartzo, elementos carbonatados e também de desengordurantes de cerâmica moída em vários dos exemplares. Em termos de coloração, estes recipientes apresentam tons mais escuros, que variam entre o castanho e o cinzento. A considerável representatividade deste fabrico no Porto de Sabugueiro (61 exemplares - $26 \%$ do conjunto), assim como a sua escassez em outras áreas do estuário do Tejo, são elementos que poderão indicar uma origem local para estes recipientes.

\subsubsection{Grupo III}

O grupo III inclui fragmentos de pastas mediamente compactas e pouco depuradas (20\%). A observação macroscópica permitiu a identificação de elementos de quartzos, por vezes de grande dimensão, e algumas moscovites. As suas tonalidade são geralmente acastanhadas, podendo por vezes apresentar tons mais acinzentados. Estas características são semelhantes às do grupo anterior (grupo II), ainda que se note um maior cuidado na produção e preparação das pastas. Ainda assim, é muito provável que corresponda também a uma produção local ou das proximidades, devendo, neste aspecto, assinalar-se a grande semelhança revelada nos dados arqueométricos (ver 2.1.2).

No conjunto aqui analisado, este grupo inclui 65 exemplares, correspondendo a $28 \%$. 


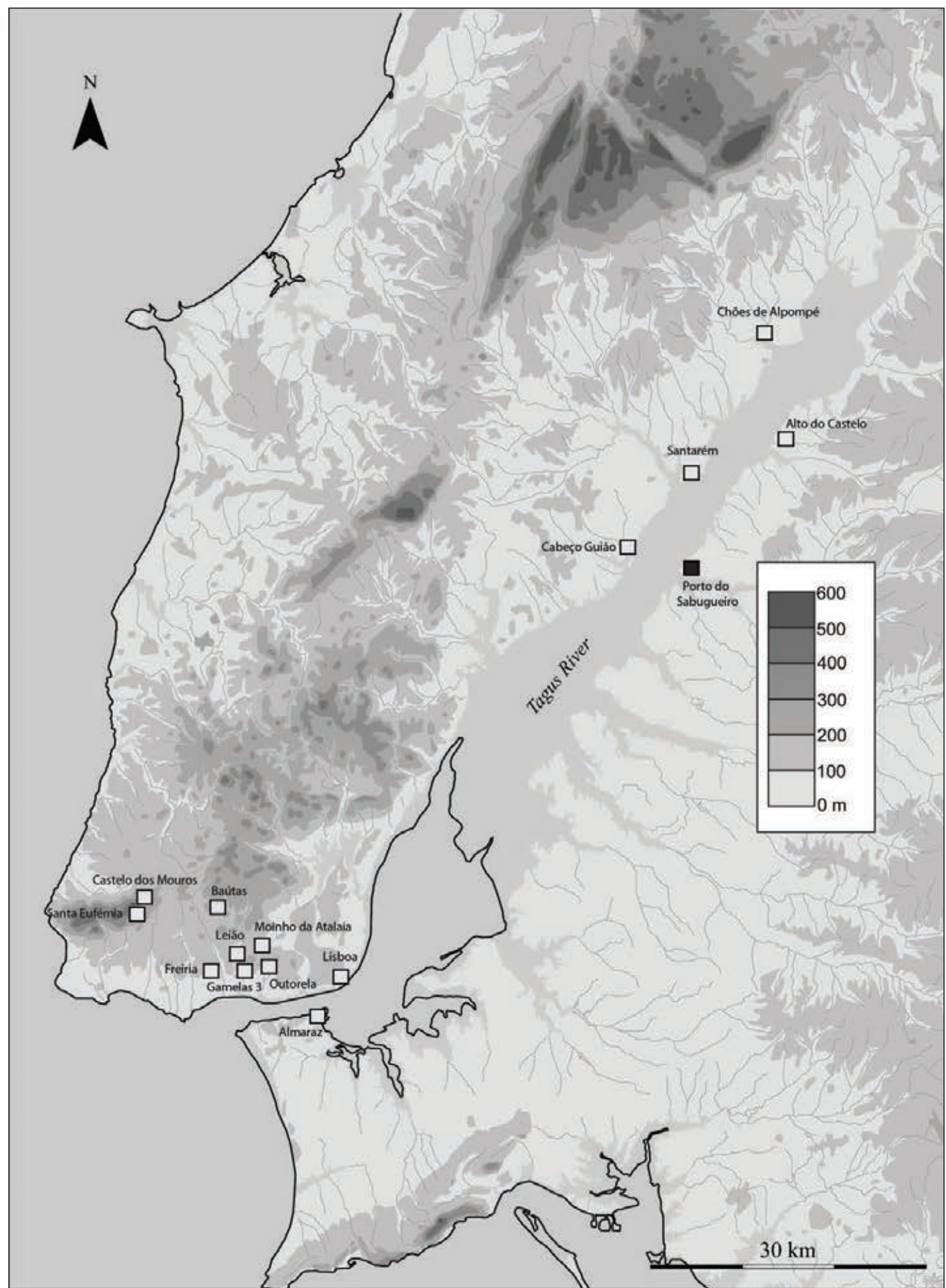

Figura 2. Localização do Porto do Sabugueiro (a negro) e dos principais núcleos de povoamento do Estuário do Tejo durante a Idade do Ferro (séculos V a III a.n.e.).

ISSN: $1133-4525$ ISSN-e: $2255-3924$ 


\subsubsection{Grupo IV}

O grupo IV integra peças de pastas bastante compactas e relativamente depuradas (entre 10 e $20 \%$ ). A observação macroscópica permitiu a identificação de abundantes elementos de quartzos, calcites, moscovites e desengordurantes avermelhados, possivelmente de cerâmica moída, mas também de óxidos de ferro. Cabe ainda indicar a presença de microfósseis, identificáveis macroscopicamente. As suas tonalidades são tendencialmente alaranjadas, ainda que por vezes apresentem um núcleo acinzentado. Estas características parecem quase representar uma produção "intermédia" entre os dois grupos anteriormente definidos (II e III) e os fabricos típicos da zona de Lisboa/Almaraz (Grupo I-A e I-B). Ainda que não se possa excluir completamente a possibilidade de ser uma produção um pouco mais interior, a macroscopia e as análises arqueométricas parecem indicar uma proveniência próxima da proposta para o Grupo I, quiçá ligeiramente mais interior, considerando que os materiais do Grupo IV são, efectivamente, menos depurados. Contudo, esta questão só poderá ser definitivamente resolvida através da identificação dos respectivos centros produtores.

Os fragmentos integrados no grupo IV totalizam 50 peças, correspondendo a $23 \%$.

\subsubsection{Fabrico raro A}

Neste grupo integra-se apenas um exemplar (1\% do conjunto), cujas características são bastante semelhantes às do grupo III, mas que exibe uma pasta bastante mais depurada e uma tonalidade cinzenta acastanhada, ainda que esta se deva, quase seguramente, a variações no quadro do processo de cozedura do recipiente.

\subsubsection{Fabrico raro B}

Também neste caso contamos com apenas um fragmento ( $1 \%$ do conjunto), que se distingue por apresentar uma pasta de tonalidade castanha amarelada, com presença frequente de micas, ainda que seja, em termos gerais, semelhante aos exemplares do grupo III.

\subsubsection{Análises arqueométricas}

A definição de grupos de fabrico com base na mera análise macroscópica tem, naturalmente, fortes limitações sobretudo ao nível da caracterização das inclusões e desengordurantes que fazem parte das pastas cerâmicas
(De la Fuente e Vera 2015: 265, nota 3). Por essa razão, os elementos definidos macroscopicamente terão de ser confirmados por futuros estudos mineralógicos e petrográficos. Ainda assim, e com o objectivo de complementar as divisões anteriormente esboçadas, foi realizada uma primeira aproximação da composição química de alguns dos exemplares, sobretudo daqueles que foram considerados como possíveis produções das áreas mais interiores do estuário do Tejo (grupos macroscópicos II e III), assim como de outros aparentemente mais próximos da foz (grupo IV). Assim, foram recolhidas 16 amostras do conjunto anfórico recolhido no Porto do Sabugueiro (tab. 1). Para determinar ou corroborar as origens propostas para estas produções foram incluídas no espectro de análise outras sete amostras recolhidas em outros sítios localizados na região do Tejo, concretamente do Cabeço Guião (Arruda et al. 2017), Lisboa (Sousa e Guerra 2018) e da Alcáçova de Santarém (Arruda 2000, Sousa e Arruda 2018), alguns dos quais provenientes de zonas mais interiores, e outros provavelmente originários da área da foz (Lisboa/Almaraz).

A metodologia utilizada recorreu a um analisador pXRF Niton XL3t de PANATEC com tubo de raio-x 50 $\mathrm{kV}$ e 100 microamperes. O filtro usado foi o Soils, de dois feixes, a 60 " por feixe para um total de 120". Cada modo opera com uma voltagem diferente, que aperfeiçoa a fluorescência de um conjunto de elementos e seleciona diferentes filtros para otimizar as relações de pico/fundo. Essa técnica permitiu-nos quantificar os seguintes elementos: Mo, Zr, Sr, U, Rb, Th, Pb, As, Zn, $\mathrm{Cu}, \mathrm{Fe}_{2} \mathrm{O}_{3}, \mathrm{MnO}, \mathrm{Cr}, \mathrm{V}, \mathrm{TiO}_{2}, \mathrm{CaO}$ e $\mathrm{K}_{2} \mathrm{O}$. Estes resultados foram tratados estatisticamente pela Análise de Componentes Principais (ACP) (Aitchison 1983, 1984, Whallon 1990, Glasckoc 1992, Baxter 1994, 2003), uma análise estatística muito útil para interpretar a relação entre diferentes produções cerâmicas (Gómez Siurana 1987, Galván Martínez 1995, Carmona et al. 2008, Aldazábal et al. 2010, entre outros).

Os resultados obtidos permitiram confirmar a relativa homogeneidade já verificada na análise macroscópica das produções anfóricas deste importante núcleo de povoamento no interior do estuário do Tejo (fig. 3).

No grupo composto pelas amostras 1703, 1681, $1545,1608,1623,1561$ e 1711, todas fazendo parte dos grupos macroscópicos previamente estabelecidos como II e III, observa-se uma certa homogeneidade relativa (fig. 4). Este primeiro grupo apresenta os menores valores dos elementos maioritários, sendo estes $\mathrm{Fe}_{2} \mathrm{O}_{3}$ (33349 ppm), $\mathrm{TiO}_{2}$ (4420 ppm), $\mathrm{CaO}$ (9232 ppm) e $\mathrm{K}_{2} \mathrm{O}$ (23336 ppm), em relação aos demais agrupamentos, 


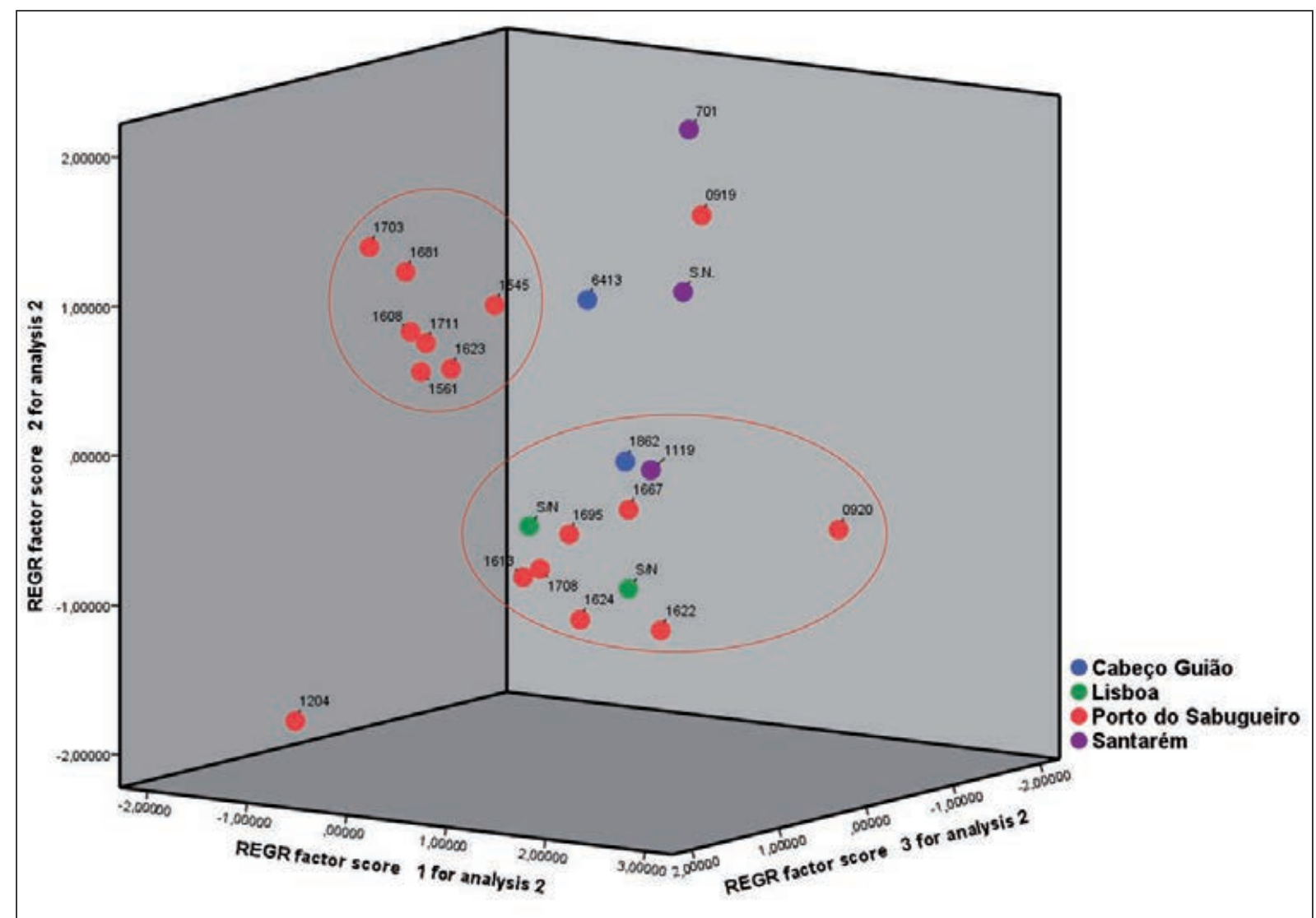

Figura 3. Representação no diagrama de dispersão 3D dos três factores extraídos da Análise de Componentes Principais.

sendo $\mathrm{MnO}$ (388) o mais elevado do conjunto. Os restantes elementos são ordenados, de acordo com a sua presença, como segue: $\mathrm{Sr}$ (191 ppm), Zr (184 ppm), Rb (157 ppm), V (123 ppm), Zn (115.07 ppm), Cr (72 ppm), Pb (23 ppm), Cu (15ppm), Th (14 ppm), As (12 ppm), U (4 ppm) e Mo (3 ppm). Os dados permitem propor que tanto a extração como o tratamento das matérias-primas realizado pelos oleiros locais são similares. Estas produções apresentam, com frequência, tons acinzentados na zona do núcleo, de caráter redutor, enquanto suas zonas externas são de tons bege e alaranjado, de eminente cozedura redutiva. A falta de uma preparação ideal de matérias-primas levou à presença de desengordurantes de pequena dimensão, que foram identificados como quartzo, micas e restos de matéria vegetal, em quantidades que variam entre 10 e $30 \%$ do total das argilas. Além disso, sua morfologia é sub-arredondada, ou seja, apresentam uma alta taxa de erosão que pode estar ligada a contribuições aluviais e de desengordurantes que são orientadas de forma paralela/ oblíqua em relação às paredes, como consequência de sua modelagem a torno. Finalmente, queremos realçar a presença de pequenos poros que estão relacionados com a fase de secagem, que às vezes se transformam em estrias que correm na mesma direção das paredes.

Um segundo grupo incorpora as amostras 920, $1622,1624,1708,1613,1695$ e 1667 que foram englobadas no grupo macroscópico IV (fig. 5). Este conjunto apresenta certas variações nas quantidades dos elementos maioritários, de modo que tem uma maior presença de $\mathrm{Fe}_{2} \mathrm{O}_{3}$ (37852), $\mathrm{TiO}_{2}$ (5211.04) e $\mathrm{K}_{2} \mathrm{O}$ (28912), sendo inferior em MnO (131). Também observamos certas variações nos restantes elementos, que são ordenados, de acordo com sua presença, conforme segue: $\mathrm{Zr}$ (163), Rb (160), V (151), Sr (128), Cr (118), $\mathrm{Zn}$ (109), Pb (21), Cu (15), Th (13), As (8), U (6) e Mo (3). Ainda que relativamente próximas das anteriores, estas amostram formam um agrupamento bastante homogéneo, estando muito próximas de outros fragmentos recolhidos em Lisboa, Santarém e Cabeço Guião, e cujas características macroscópicas indiciam uma produção originária na foz do estuário (zona de Lisboa/ 


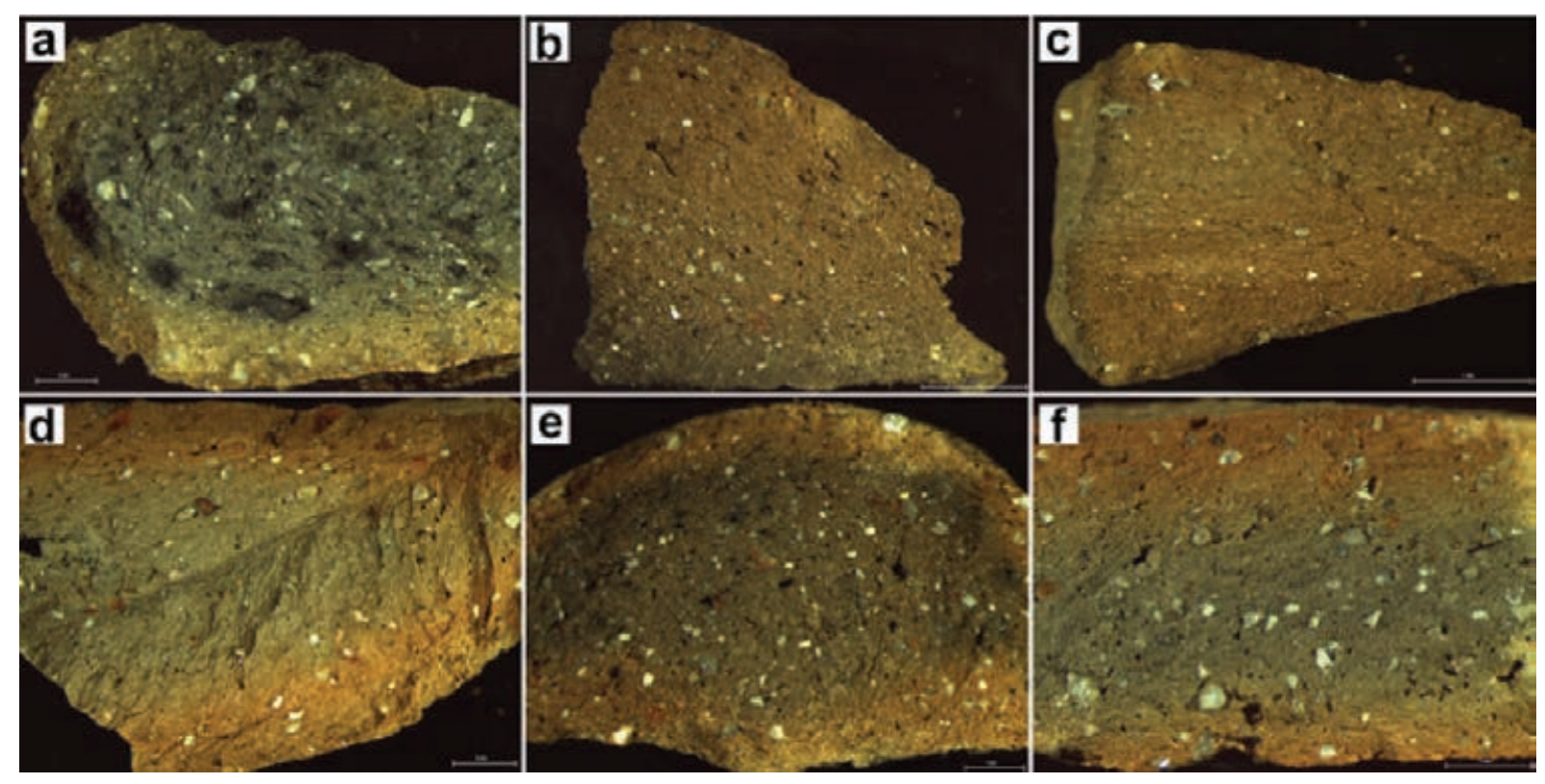

Figura 4. Conjunto de amostras correspondentes às produções consideradas originárias do interior do estuário identificadas pelo pFRX: a) 1703 (grupo II); b) 1681 (grupo II); c) 1545 (grupo II); d) 1608 (grupo III); e) 1711 (grupo II); f) 1623 (grupo III).

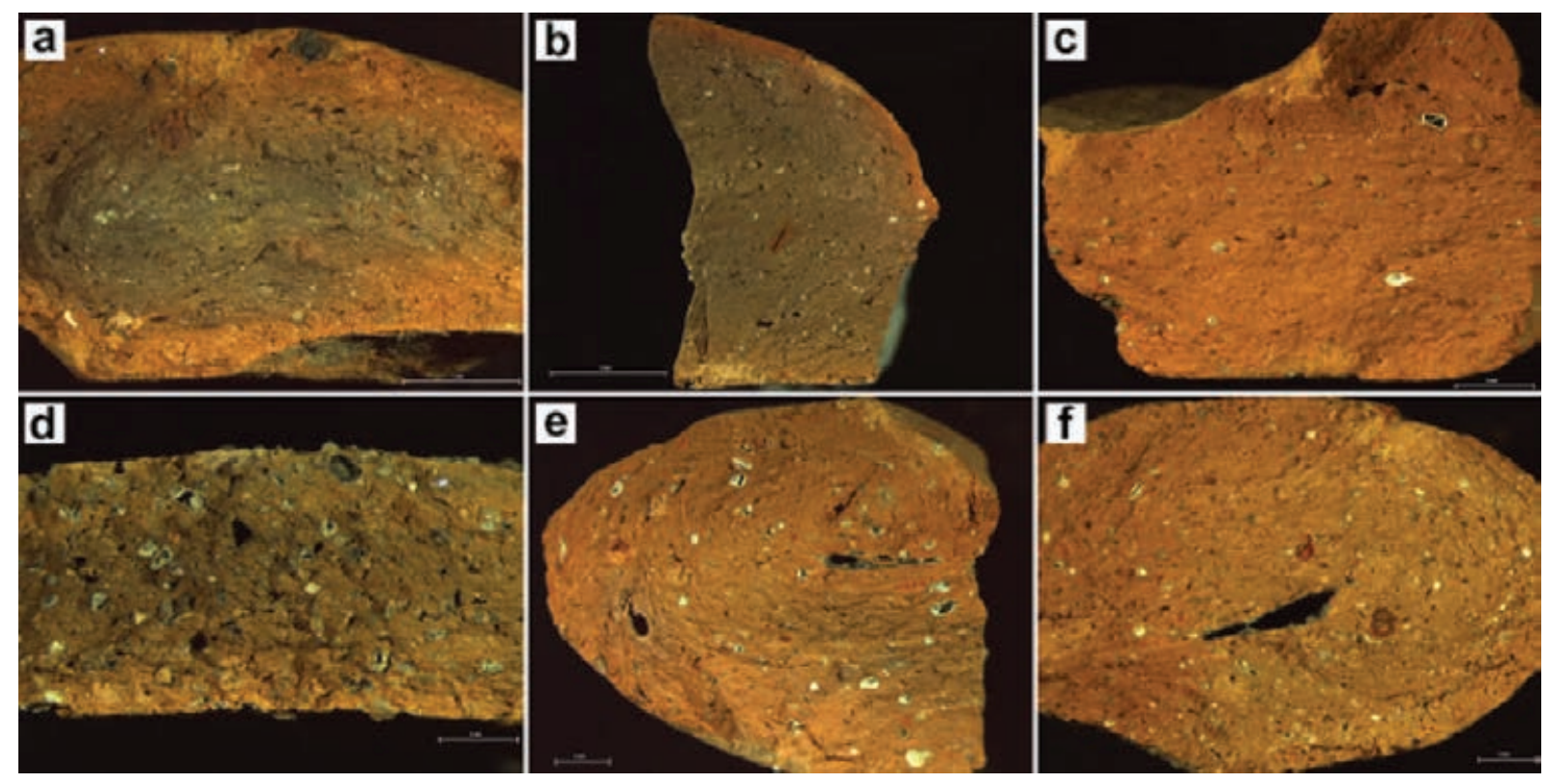

Figura 5. Conjunto de correspondentes às produções consideradas originárias junto à foz do estuário (grupo IV) identificadas pelo pFRX: a) 920; b) 1622; c) 1624; d) 1708; e) 1613; f) 1695.

Almaraz). A aproximação macroscópica feita neste conjunto permite apontar certas variações de tonalidade em relação aos grupos anteriores (II e III), que são agora mais alaranjadas e com tonalidades mais regulares na matriz cerâmica. Em termos gerais, trata-se de produções mais refinadas, com menor presença de desengordurantes, localizadas em torno de 10 a $15 \%$ do total de matérias-primas, de modo que determinados processos de tratamento pudessem ser deduzidos (Coll Conesa 2000). Esse conjunto apresenta, portanto, um 
cozimento geralmente oxidante e no qual se observa uma certa regularidade no desenvolvimento das estratégias de cozedura. As inclusões identificadas foram o quartzo, micas e alguns foraminíferos, que devem ser encontrados nas matérias-primas. Além disso, destacam-se pequenos nódulos de argila que deveriam ter sido adicionados ao grupo de matérias-primas durante os diversos processos de tratamento prévio à cozedura. Os desengordurantes, como no caso anterior, apresentam uma alta esfericidade e, portanto, devem ser entendidos como elementos de matérias-primas do contexto aluvial, em que a erosão teria definido a sua morfologia final. Da mesma forma, e como consequência do uso do torno no processo de modelagem, esses desengordurantes foram orientados preferencialmente de maneira oblíqua/paralela em relação às paredes. Por fim, percebe-se que os possuem uma morfologia vesicular e, em casos raros, possuem sulcos que são orientados no mesmo sentido que as paredes dos contentores como consequência da contração de argilas durante a secagem/cozedura.

Estes resultados permitem, assim, confirmar ou corroborar a existência de intensas relações comerciais entre diferentes núcleos de povoamento no interior do estuário do Tejo. No entanto, é necessário, no futuro, aumentar o universo de amostras dos vários sítios, quer do próprio Porto de Sabugueiro, como dos restantes locais situados nos seus arredores.

Um outro resultado interessante é demonstrado pela amostra 1204, que está claramente individualizada do resto das produções que se presumem serem originárias do estuário do Tejo (fig. 6). Esta produção é caracterizada por conter os maiores valores de $\mathrm{Fe}_{2} \mathrm{O}_{3}$ (38256) e $\mathrm{CaO}$ (66759) e valores médios de $\mathrm{K}_{2} \mathrm{O}$ (24071) e $\mathrm{MnO}$ (199), contendo os menores de $\mathrm{TiO}_{2}$ (4330). Por outro lado, essas diferenças observadas nos componentes maioritários também foram observadas nas razões composicionais minoritárias, sendo sua ordem: $\mathrm{Sr}$ (193), V (124), Zn (119), Rb (116), Cr (89), Zr (85.05), $\mathrm{Cu}$ (23), As (11), Th (10), Pb (9) e Mo (7). Finalmente, esta amostra não contém urânio. Cabe, contudo, adiantar desde já que esta peça foi classificada de acordo com o tipo 10.1.1.1 de Ramon Torres (1995), e que as suas características macroscópicas indicam uma origem alóctone, muito provavelmente da região mais meridional da Península Ibérica. Este elemento permite, por um lado, corroborar as propostas de definição dos fabricos anteriormente esboçada, uma vez que mostra uma clara diferenciação na composição das produções taganas e outras que parecem ser claramente oriundas do sul peninsular. A superfície desta ânfora não teria nenhum

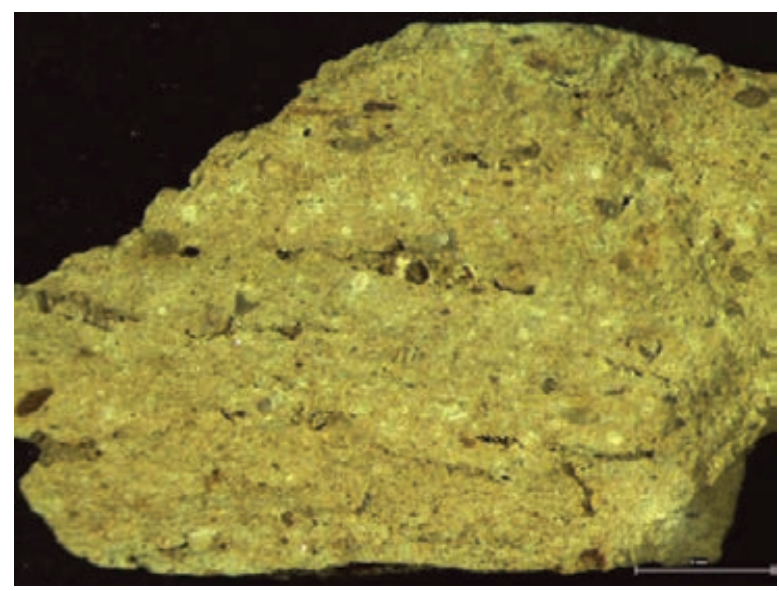

Figura 6. Ânfora n. ${ }^{0} 1204$ do Porto de Sabugueiro, classificada como uma provável produção da área de Málaga atribuída ao tipo 10.1.1.1. de Ramon Torres.

tratamento específico, ou pelo menos este não pôde ser identificado; a existir, tratar-se-ia de uma aguada feita com base ao recurso das mesmas matérias-primas. As tonalidades de sua matriz são caracterizadas por seu tom bege que, além disso, denota uma grande homogeneidade durante a cozedura oxidante. Os desengordurantes identificados variam substancialmente em relação aos identificados nos grupos anteriores, sendo o quartzo e os foraminíferos, que ocorrem em valores próximos a $20 \%$ do total das matérias-primas utilizadas. Por outro lado, os desengordurantes possuem uma morfologia arredondada como consequência de factores erosivos, estando orientados paralelamente às paredes. Finalmente, as porosidades identificadas são estrias e poros, que se formam durante a secagem e a cozedura.

\subsubsection{As formas}

Entre os fragmentos que foram integrados no grupo das produções locais/regionais, foi possível reconhecer seis morfologias distintas (tipos 1, 3, 4, 5, 6 e 7), tendo sido utilizada a tabela tipológica proposta para as ânforas do estuário do Tejo (Sousa e Pimenta 2014). A este conjunto somam-se ainda 24 fragmentos de bordo que não foram passíveis de classificação devido ao seu mau estado de conservação.

\subsubsection{Tipo 1}

As ânforas do tipo 1 do estuário do Tejo correspondem a produções regionais inspiradas nos protótipos do Sul 


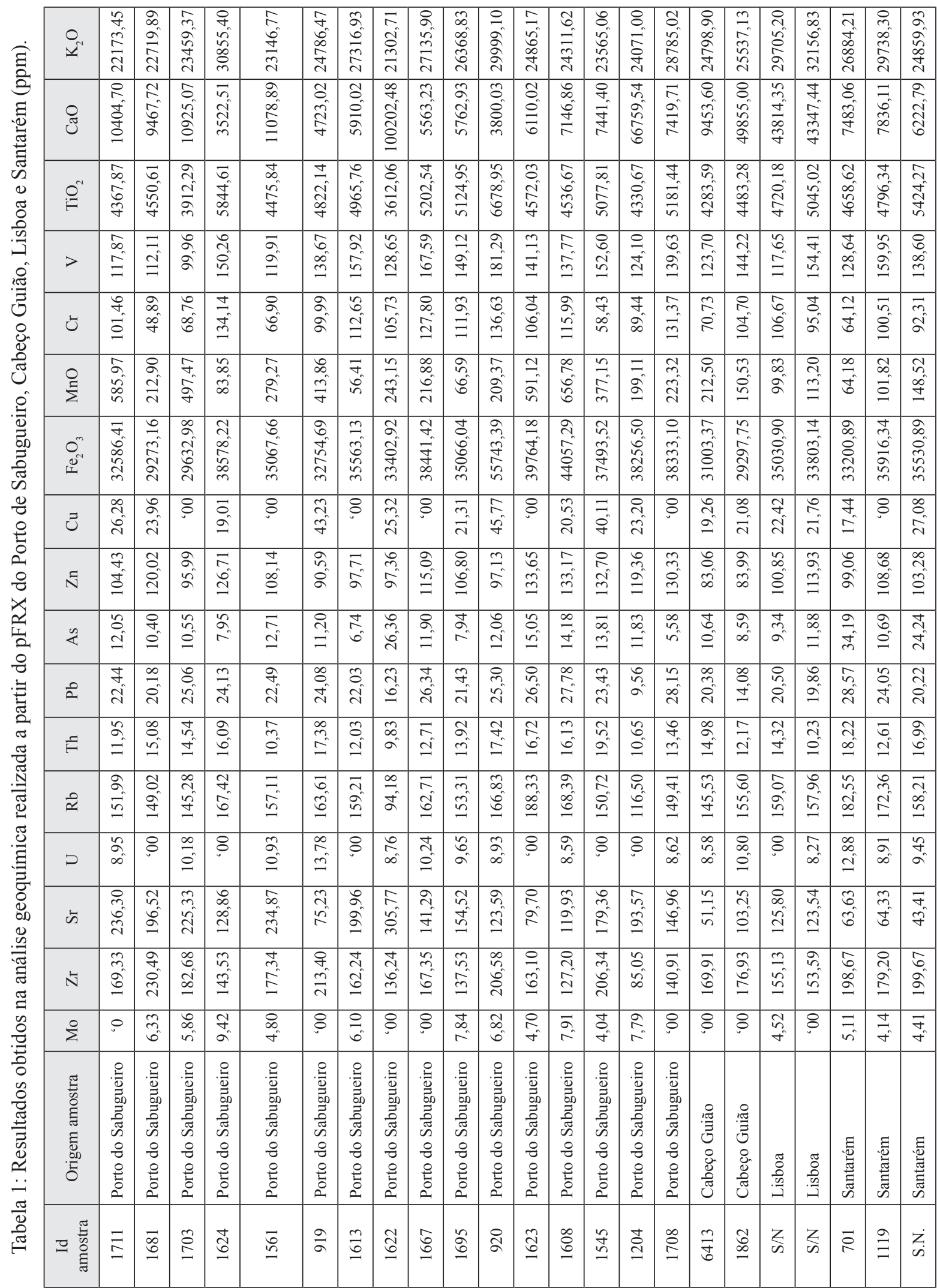


Peninsular integrados, grosso modo, nos tipos 10.1.1.1 e 10.1.2.1 da tipologia elaborada por J. Ramon Torres (1995).

A origem desta produção deverá relacionar-se directamente com a instalação, no estuário do Tejo, de oleiros provenientes do sul da Península Ibérica durante os finais do século VIII / inícios do século VII a.n.e., em cronologia tradicional, e que reproduziram os modelos em uso nas áreas mais meridionais. Os centros produtores fundados por esses oleiros que se estabelecem na área centro atlântica irão desenvolver certas especificidades regionais no quadro dos contentores anfóricos, que devem ser entendidas como evoluções paralelas a outras documentadas nos restantes espaços peninsulares. No caso concreto das produções taganas, o aspecto que mais se destaca é a maior amplitude de bordo (geralmente entre os 16 e os $19 \mathrm{~cm}$ ), quando comparadas com as morfologias mais meridionais, ainda que outras alterações ao nível dos bordos sejam também identificáveis. No que diz respeito às características gerais destes recipientes, e apesar da semelhança de alguns exemplares com os protótipos 10.1.1.1 e 10.1.2.1 de Ramon Torres, pensamos ser mais adequado estabelecer a sua classificação com base na tipologia estabelecida para a região. Ainda assim, é necessário indicar que recentes publicações (Olaio 2018, Sousa e Guerra 2018) têm vindo a evidenciar uma acentuada variabilidade morfológica no âmbito deste tipo 1 do estuário do Tejo, que justifica uma futura reelaboração e sub-divisão das tabelas tipológicas existentes. Esta tarefa terá de ser, contudo, suportada por dados contextuais concretos que permitam identificar momentos mais exactos do aparecimento de algumas destas variantes, condições que que até à data ainda não se verificaram.

No que diz respeito à cronologia deste tipo 1 do estuário do Tejo, o início da produção parece situar-se em momentos relativamente antigos, de acordo com os vestígios recolhidos nos contextos inferiores da Rua de São Mamede ao Caldas, datados em torno a finais do séc. VIII / inícios do séc. VII a.n.e. (Pimenta et al. 2014b, Sousa e Pimenta 2014). Contudo, os dados existentes parecem indicar uma longa diacronia da sua utilização. Na Rua dos Correeiros, estas ânforas surgem em contextos datados entre o século $\mathrm{V}$ a.n.e. e os inícios da centúria seguinte, o que indicava já uma utilização recorrente durante os meados do $1^{\circ}$ milénio (Sousa 2014). Estudos mais recentes, concretamente os efectuados sobre os conjuntos artefactuais do Cabeço Guião, na zona do Cartaxo, evidenciaram ainda a utilização desta morfologia em momentos mais avançados do século IV e III a.n.e. (Arruda et al. 2017).
Sobre os centros de produção, desconhecem-se, até ao momento, dados concretos que permitam discriminar origens mais específicas dentro da escala regional, uma situação que é estendível a todos os tipos taganos. Contudo, e para o caso específico do tipo 1, cabe referir a identificação de alguns destes fragmentos deformados no sítio da Quinta da Marquesa, em Vila Franca de Xira, estando associados a prismas cerâmicos, o que pode indiciar uma área de produção neste local (Pimenta e Mendes 2011: 603-607).

Dentro do conjunto anfórico do Porto do Sabugueiro, foram identificados 17 fragmentos de bordo integráveis no tipo 1 do estuário do Tejo, distribuídos pelos grupos de fabrico I-A (oito exemplares), I-B (sete exemplares), III (um exemplar) e IV (um exemplar). Os recipientes desta morfologia correspondem a 7\% do conjunto (fig. 7).

Em termos formais, e como já foi referido anteriormente, trata-se de um grupo bastante heterogéneo. Exemplares com diâmetros reduzidos e perfis muito aproximados do tipo 10.1.2.1 de Ramon Torres (n. ${ }^{\circ} 1207$ e 1206) convivem com fragmentos de diâmetro consideravelmente mais amplo, que por vezes apresentam o bordo mais evertido e arredondado (n. ${ }^{\circ} 1721,1720,1715$ e 1205,1523$)$, características que devem ser associadas ao desenvolvimento interno destas produções regionais. Infelizmente, a inexistência de dados contextuais no Porto do Sabugueiro impossibilita esboçar qualquer leitura sobre a evolução destas especificidades.

Cabe ainda referir a presença de cinco exemplares pertencentes aos grupos de fabrico I-A (n. ${ }^{\circ} 839$ e 775), I-B (n. $\left.{ }^{\circ} 1215\right)$ e IV (n. ${ }^{\circ} 1520$ e S.N.a) que parecem corresponder a formas já de transição entre o tipo 1 e o 3 (fig. 7), cujas morfologias surgem, nas sequências estratigráficas de Lisboa, a partir do séc. VI a.n.e. (Sousa e Guerra 2018: 69 e 73). Estas formas de transição correspondem a $2 \%$ da totalidade do conjunto.

\subsubsection{Tipo 3}

O tipo 3 do estuário do Tejo caracteriza-se por apresentar um corpo mais ovalado, um colo curto e um bordo claramente diferenciado externamente, sendo a sua secção variável (Sousa e Pimenta 2014).

Trata-se de uma morfologia que surge, em Lisboa, em contextos da segunda metade do século VI a.n.e. (Sousa e Pimenta 2014), o que foi recentemente corroborado pela estratigrafia do Largo de Santa Cruz do Castelo (Sousa e Guerra 2018). Sobre a sua origem, cabe referir que as semelhanças que este tipo apresenta 
com outras morfologias contemporâneas meridionais (tipo Pellicer B/C - Pellicer Catalán 1978) e das zonas mais interiores do território peninsular (tipos Cancho Roano I e II - Guerrero Ayuso 1991), poderá efectivamente indicar algumas influências exógenas nas produções regionais do estuário do Tejo. Contudo, o peso da própria evolução interna dos recipientes anfóricos terá sido, em nossa opinião, o factor determinante na emergência deste tipo 3, considerando, sobretudo, que as características que o definem parecem surgir ainda durante a primeira metade do século VI a.n.e. (Sousa e Guerra 2018: 69), sendo, portanto, anteriores às dos casos referidos.

A utilização destes recipientes durante as fases mais tardias da Idade do Ferro foi recorrente, mas os dados existentes indicam que este tipo desaparece dos repertórios artefactuais num momento anterior à segunda metade do século II a.n.e. (Sousa e Pimenta 2014: 308).

A forma está bem documentada não só em Lisboa, mas também nos sítios da Idade do Ferro identificados nos concelhos de Almada (Olaio 2018), Amadora, Sintra (Sousa 2014), Oeiras (Cardoso et al. 2014, Cardoso e Silva 2013), Cascais (Cardoso 1991, Cardoso e Encarnação 2013), Almeirim (Sousa et al. 2017, Pimenta et al. 2018), Alpiarça (Arruda et al. 2014), Cartaxo (Arruda et al. 2017) e Santarém (Arruda 2000, Diogo 1993).

No Porto do Sabugueiro, o tipo 3 do estuário do Tejo está representado por 16 exemplares, integráveis nos grupos de fabrico I-A (cinco exemplares), I-B (quatro exemplares), II (quatro exemplares), III (um exemplar) e IV (dois exemplares). Correspondem a 7\% da totalidade do conjunto (fig. 7 e 8 ).

Em termos morfológicos, deve referir-se que dois exemplares $\left(n .^{\circ} 1203,1525\right)$ apresentam a parte superior do bordo muito evertida, o que poderia talvez indicar alguma antiguidade, uma vez que parece estar em linha de continuidade com as produções do tipo 1 do estuário do Tejo. Os restantes fragmentos enquadram-se já nas morfologias mais clássicas definidas para este tipo (Sousa e Pimenta 2014).

\subsubsection{Tipo 4}

O tipo 4 do estuário do Tejo é distinguível sobretudo pelas características do bordo, que é alto e vertical, externamente, e engrossado internamente.

Trata-se de uma morfologia que surge nos repertórios artefactuais regionais a partir do século $\mathrm{V}$ a.n.e., não parecendo, tal como no caso anterior, atingir a época romana (Sousa e Pimenta 2014).
O tipo está relativamente bem representado em todo o estuário do Tejo, concretamente em Lisboa (Sousa 2014), Almada (Barros e Soares 2004, Olaio 2018). Amadora, Sintra (Sousa 2014), Oeiras (Cardoso e Silva 2013, Cardoso et al. 2014), Cascais (Cardoso e Encarnação 2013), Almeirim (Sousa et al. 2017, Pimenta et al. 2018), Alpiarça (Arruda et al. 2014) e Cartaxo (Arruda et al. 2017).

Entre o conjunto anfórico recolhido no Porto do Sabugueiro, este tipo está documentado através de apenas seis exemplares (n. ${ }^{\circ} 1725,1281,1212,1727,1623$ e S.N. b), que correspondem a $3 \%$ do conjunto (fig. 8), e que se integram nos grupos de fabrico I-A (três exemplares), III (dois exemplares) e IV (um exemplar). Esta escassez quantitativa é, aliás, comum à maioria dos sítios localizados nas áreas mais próximas, com a excepção do Cabeço Guião (Arruda et al. 2017).

Deve, contudo, referir-se que um dos exemplares é um pouco atípico no que diz respeito à forma (n. $\left.{ }^{\circ} 1623\right)$, situação que se pode explicar pelo facto de pertencer ao grupo de fabrico III, para o qual se assume uma origem mais interior, sendo os exemplares que serviram para a seriação tipológica produções da área de Lisboa/Almaraz. Poderá, assim, corresponder apenas a uma pequena variação dos centros de produção do curso superior do estuário.

\subsubsection{Tipo 5}

O tipo 5 incorpora recipientes de corpo mais ovoide, sendo o bordo reentrante e espessado, com secção geralmente ovalada. $\mathrm{Na}$ tipologia estabelecida para as produções anfóricas taganas, esta forma foi definida exclusivamente com base nos fragmentos do Porto do Sabugueiro (Sousa e Pimenta 2014: 308) e, até ao momento, não se encontra documentada em nenhum outro local.

Os materiais recuperados no sítio de Muge permitiram (fig. 8 a 10), inclusivamente, apresentar uma proposta de reconstituição mais completa desta morfologia, tendo sido possível associar asas de secção oval com sulcos na área externa e fundos de perfil cónico (n. ${ }^{\circ} 1800$ - Pimenta e Mendes 2008, Sousa e Pimenta 2014).

Com efeito, grande parte dos exemplares classificados como tipo 5 apresentam fabricos que indicam uma possível origem local (grupos de fabrico II - 34 fragmentos; III - 31 fragmentos; fabrico raro A - um fragmento), sendo estes fabricos muito raros na própria zona estuarina. Pastas semelhantes foram apenas documentadas na margem oposta, no Cabeço 


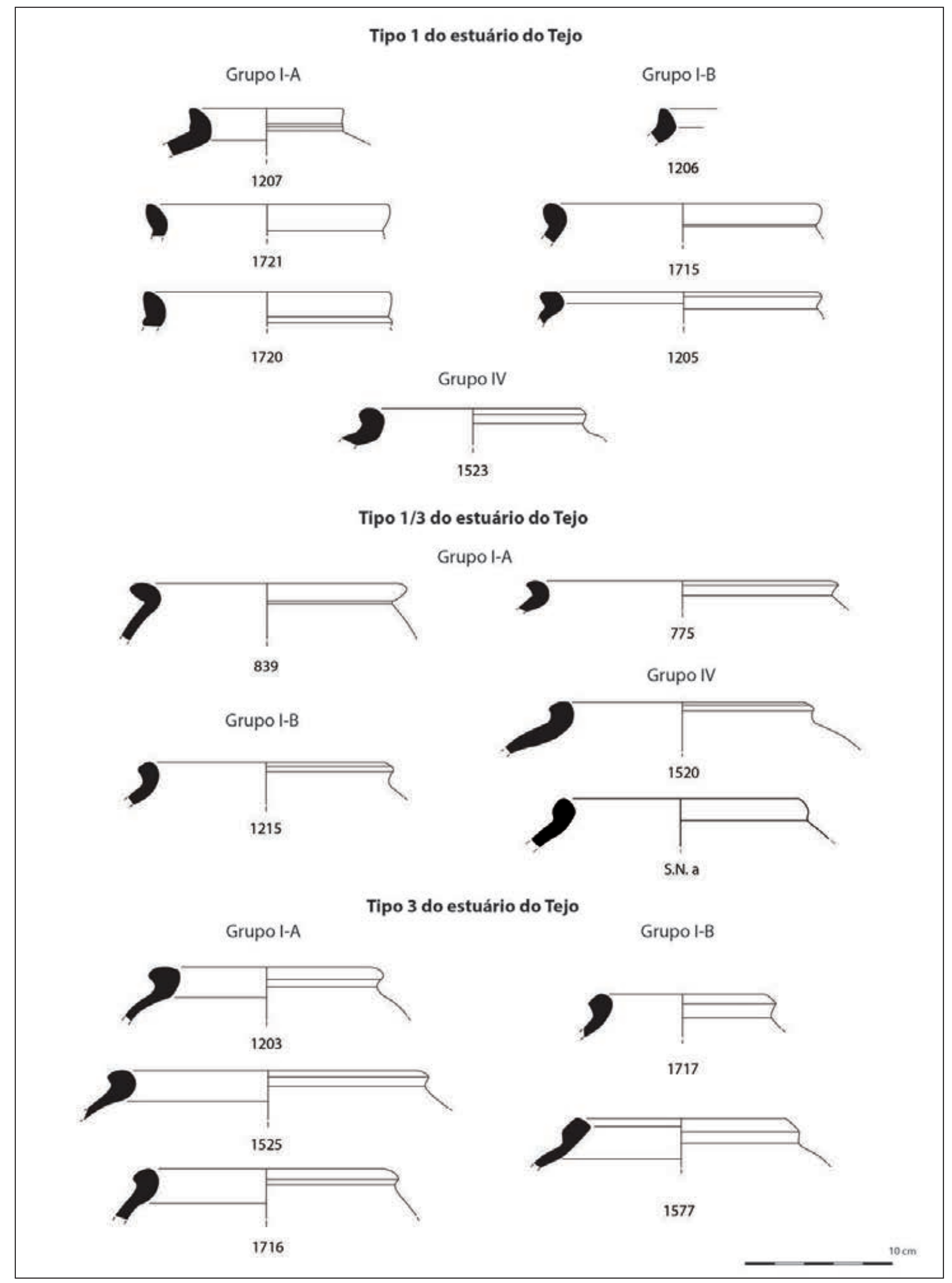

Figura 7. Ânforas dos tipos 1, 1/3 e 3 do estuário do Tejo. 
Guião, mas correspondem a escassos fragmentos (Arruda et al. 2017: 352). Contudo, deve ainda salientar-se a representatividade de recipientes que se incluem no grupo de fabrico IV (22 fragmentos), para o qual se assume uma proveniência um pouco mais meridional dentro da zona estuarina. Este é um dado importante considerando que até ao momento não se equacionava a possibilidade de este tipo formal poder ser também fabricado em zonas mais meridionais.

Considerando a escassez de dados contextuais, é muito difícil estabelecer parâmetros cronológicos para esta forma, ainda que se admita poder ser bastante tardia no quadro da Idade do Ferro (Sousa e Pimenta 2014: 308), e de poder eventualmente transitar para o período seguinte, ainda que tal proposta careça de dados concretos que a corroborem.

Como já foi indicado, esta morfologia é abundante no conjunto de ânforas recolhido no Porto do Sabugueiro, contando com 88 exemplares, que correspondem a $38 \%$ do conjunto.

Os bordos são muito variáveis no que diz respeito à sua secção, podendo apresentar sulcos pouco acentuados na parede externa (n. ${ }^{\circ} 1658,1586,1552,1675$, $1619,1553)$, apesar de genericamente todos apresentarem formato ovalado. Os diâmetros são também bastante diversos, podendo oscilar entre os oito e os quinze centímetros.

\subsubsection{Tipo 6}

O tipo 6 do estuário do Tejo foi individualizado, essencialmente, por apresentar bordos curtos, reentrantes e espessados, e ombros de tendência horizontal (Sousa e Pimenta 2014).

Trata-se de um tipo relativamente tardio no quadro das produções taganas. Ainda que os exemplares mais antigos tenham sido documentados na Rua dos Correeiros, cuja cronologia está centrada entre o século V e os inícios do século IV a.n.e. (Sousa 2014, Sousa e Pimenta 2014), estes parecem corresponder a protótipos antigos desta morfologia, que se desenvolveram posteriormente para formas com ombros mais horizontais. De qualquer forma, o tipo permanece seguramente nos quadros artefactuais até aos inícios do período romano-republicano (Pimenta et al. 2005, Sousa e Pimenta 2014). Encontra-se bem documentado em Lisboa, Almada (Cardoso e Carreira 1997-1998), Amadora (Sousa 2014), Cascais (Cardoso e Encarnação 2013) e, mais no interior do estuário, também em Castanheira do Ribatejo (Pimenta et al. 2010), Quinta do Bulhaco II (Pimenta e Mendes 2015), Cabeço Guião (Arruda et al 2017), Eira da Alorna (Pimenta et al. 2018), Alto dos Cacos (Sousa et al. 2017), Alto do Castelo (Arruda et al. 2014) e na Alcáçova de Santarém (Arruda 2000).

Tal como a forma anterior, é um dos tipos mais bem representados no conjunto do Porto do Sabugueiro, contando com 57 exemplares (fig. 10 e 11), que se distribuem pelos fabricos I-B (um fragmento), II (17 fragmentos), III (21 fragmentos) e IV (18 fragmentos).

No conjunto, este tipo 6 corresponde a $25 \%$ do conjunto analisado.

Os bordos apresentam perfis bastante variáveis, uma diversidade que poderá justificar, futuramente, uma ulterior subdivisão desta morfologia, ainda que tal processo só possa ser estabelecido com base em dados contextuais precisos e em perfis mais completos, que não estão ainda disponíveis. Mesmo assim, torna-se clara a existência de bordos com um acentuado espessamento interno, espessamento que em outros casos é também externo.

\subsubsection{Tipo 7}

O tipo 7 do estuário do Tejo engloba recipientes cuja parte superior é troncocónica, sendo as paredes de tendência rectilínea e o bordo espessado interiormente.

A sua cronologia é difícil de estabelecer com precisão devido à escassez de dados contextuais. Ainda assim, cabe referir a identificação deste tipo no Cabeço Guião, ocupado entre o século IV e III a.n.e. (Arruda et al. 2017), no Castelo de São Jorge, em níveis do século III a.n.e., e nos níveis pré-romanos de Chibanes (Silva e Soares 2012), o que indica tratar-se de uma forma tardia no quadro das produções anfóricas taganas, que se mantém contudo em utilização até ao período romano-republicano (Sousa e Pimenta 2014). Com efeito, a sua presença em contextos do último terço do século II a.n.e. está bem documentada na área urbana de Lisboa (Pimenta 2005, Pimenta et al. 2014c). Esta forma foi ainda identificada nos concelhos de Cascais (Nieuwendam e Santos 2008), Almada (Olaio 2018) e Vila Franca de Xira (Pimenta e Mendes 2011, 2015).

No Porto do Sabugueiro, foram recolhidos 14 exemplares integráveis nesta forma, que correspondem a $6 \%$ do conjunto (fig. 11). Distribuem-se pelos grupos de fabrico I-A (dois fragmentos), I-B (quatro fragmentos), II (dois fragmentos), III (dois fragmentos) e IV (três fragmentos). A secção interna do bordo é geralmente sub-triangular, apresentando por vezes um pequeno sulco na zona interna do bordo (n. ${ }^{\circ} 1644,1729$, 1723, 1531), mais ou menos acentuado, e que recorda, 


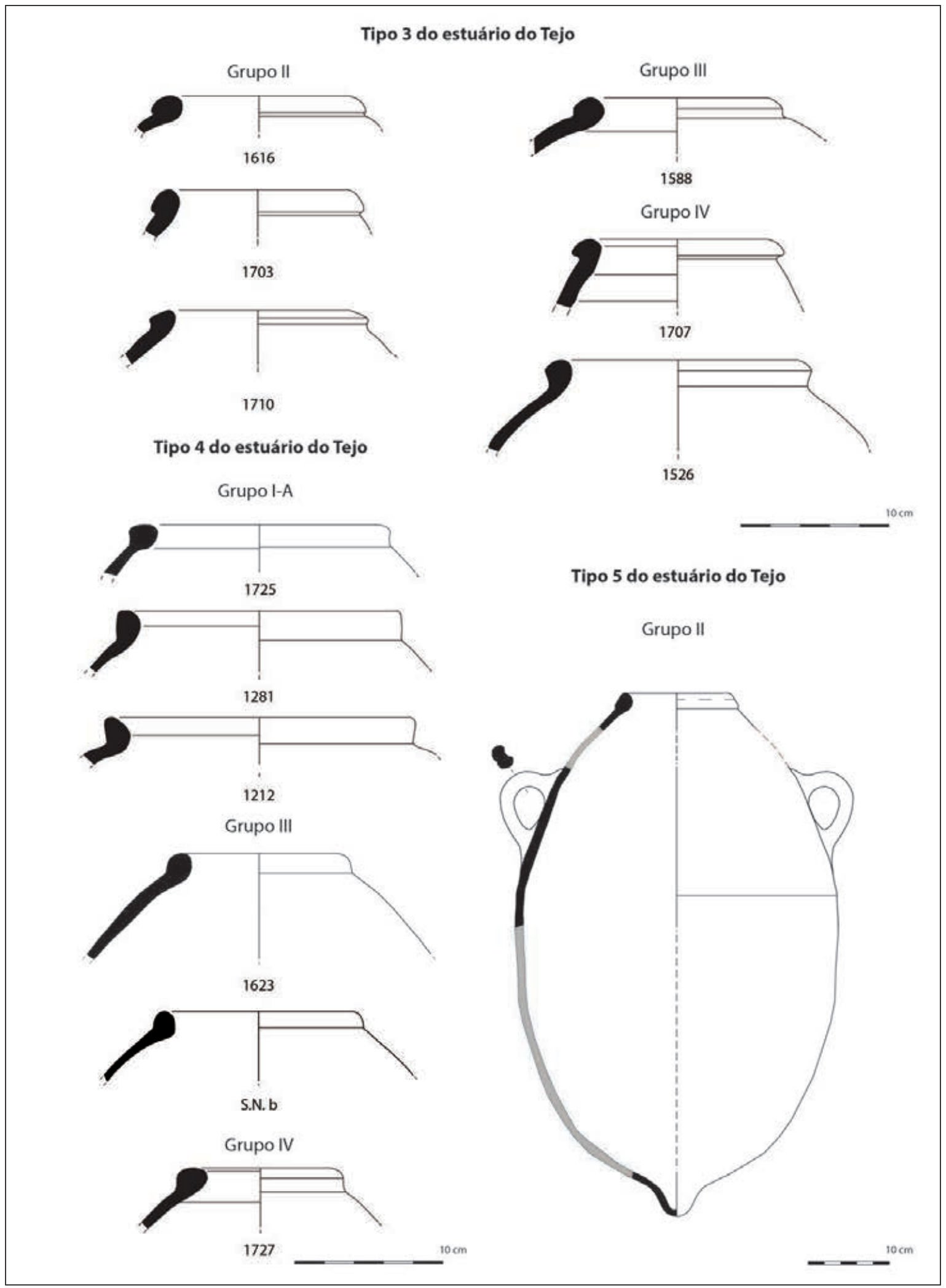

Figura 8. Ânforas dos tipos 3, 4 e 5 do estuário do Tejo. 
de certa forma, as características de algumas ânforas da área da Campina Gaditana do tipo 8.1.1.2. (Ramon Torres 1995; Carretero Poblete 2004).

\subsubsection{Formas de difícil classificação}

Dentro das produções locais/regionais, cabe ainda referir quatro fragmentos de bordo que não permitiram uma classificação precisa (fig. 12). Todos eles se integram nos fabricos que consideramos serem originários das áreas mais interiores do estuário (grupo II - um fragmento; III - um fragmento), e de outra zona mais difícil de determinar (grupo IV - dois fragmentos), situação que pode justificar algumas das particularidades morfológicas.

Um destes fragmentos (n. ${ }^{\circ} 1672$ ) poderia eventualmente aproximar-se do tipo 1 do estuário do Tejo, ainda que tenha uma secção mais circular e um bordo de tendência mais vertical do que os exemplares que normalmente são integrados neste tipo.

Dois fragmentos (n. ${ }^{\circ} 1612$ e 1713) aproximam-se, por sua vez, tanto do tipo 3 , pelas características do bordo, como do tipo 6, pela horizontalidade do ombro, sendo, portanto, difícil atribuir-lhes uma classificação específica.

O último fragmento de bordo, muito mal conservado, parece exibir um bordo de tendência vertical, que poderia aparentar-se, ainda que com reservas, com o tipo 7 (n. $\left.{ }^{\circ} 1646\right)$.

Resta referir ainda a recolha de dezenas de fragmentos de asas pertencentes aos vários fabricos definidos, que exibem secções circulares e, em alguns casos, ovais com sulco na zona exterior, e alguns fundos de perfil cónico (fig. 13).

\subsection{Os materiais importados}

Dentro do conjunto recolhido no Porto do Sabugueiro foi ainda possível identificar nove fragmentos de ânforas (fig. 12) que, pelas suas características de fabrico, parecem corresponder a importações das regiões meridionais da Península Ibérica, concretamente da Andaluzia.

Dois destes exemplares (n. ${ }^{\circ} 1211$ e 1204) apresentam fabricos que são geralmente associados à área de Málaga. A morfologia do bordo e o ressalto que apresenta no lábio, na junção à parede, permitem uma classificação no tipo 10.1.1.1 de Ramon Torres, ainda que se deva assumir que a distinção entre este e a forma que lhe sucede (tipo 10.1.2.1) nem sempre seja fácil de estabelecer com precisão.
No conjunto do Porto do Sabugueiro, surgem também cinco fragmentos que parecem corresponder a ânforas do tipo Pellicer B/C (n. ${ }^{\circ} 1736,1730,1734$, 1735, 1733), algumas das quais já publicadas (García Fernández 2019: 137 - P.SAB-08-3185 = n. ${ }^{\circ}$ 1733; P. SAB-08-0989 = n. ${ }^{\circ}$ 1734; P.SAB-08-0301 = n. ${ }^{\circ} 1736$; P.SAB-08-3211 = n. ${ }^{\circ}$ 1735), ainda que um destes (n. ${ }^{\circ}$ 1734) apresente a zona interna mais engrossada, o que poderia permitir uma aproximação ao tipo Pellicer D. As suas pastas alaranjadas (por vezes com núcleos acinzentados), compactas e relativamente bem depuradas, indicam uma origem no Baixo Guadalquivir. Deve ainda referir-se que as duas outras ânforas consideradas como possíveis importações (García Fernández 2019) foram, após a análise integral do conjunto, consideradas como pertencentes aos grupos II e IV (2019: 137 - P.SAB-08-0161 = n. ${ }^{0} 1703$ do tipo 3 do estuário do Tejo; P.SAB-08-0046 = n. ${ }^{\circ} 1622$ do tipo 5 do estuário do Tejo).

Um outro fragmento, cujo bordo é pouco diferenciado e de tendência mais horizontal, sendo ainda espessado internamente, poderá eventualmente corresponder a uma ânfora do tipo Pellicer D (n. ${ }^{\circ}$ 1651). As características da sua pasta são muito semelhantes às anteriores, sugerindo, igualmente, uma origem do Baixo Guadalquivir, ainda que esta proposta seja feita com algumas reservas, sendo necessário corroborá-la com análises arqueométricas futuras.

Uma situação muito similar aplica-se também ao último fragmento que consideramos ser de importação (n. ${ }^{\circ}$ 1647). As características da sua pasta e mesmo a sua morfologia permitem uma aproximação às produções da Campiña Gaditana do tipo 8.1.1.2 de Ramon Torres (Ramon Torres 1995; Carretero Poblete 2004), ainda que esta associação tenha sido feita também com reservas.

\section{DISCUSSÃO E CONCLUSÃO}

O conjunto de ânforas da Idade do Ferro e de tradição pré-romana recuperado no Porto do Sabugueiro é um dos mais representativos do estuário do Tejo, contando com mais de duas centenas de fragmentos de bordo (tab. 2). A diversidade morfológica e a variedade de fabricos documentados estão seguramente relacionadas com a longa diacronia de ocupação do sítio durante o $1^{\mathrm{o}}$ milénio a.n.e., sendo de lamentar que as prolongadas e intensivas práticas agrícolas tenham impossibilitado conjugar este estudo com dados estratigráficos e contextuais mais precisos. 


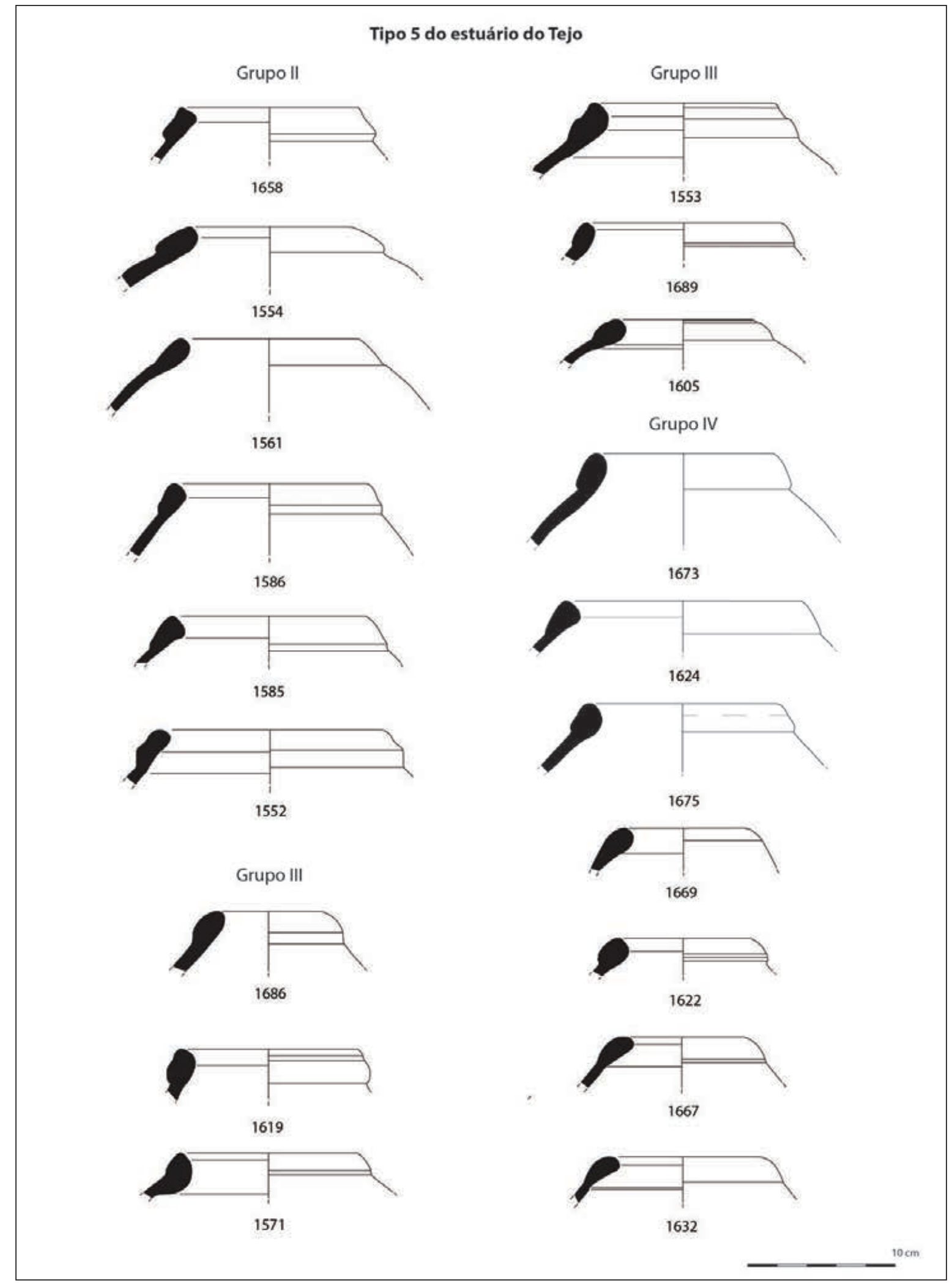

Figura 9. Ânforas do tipo 5 do estuário do Tejo. 


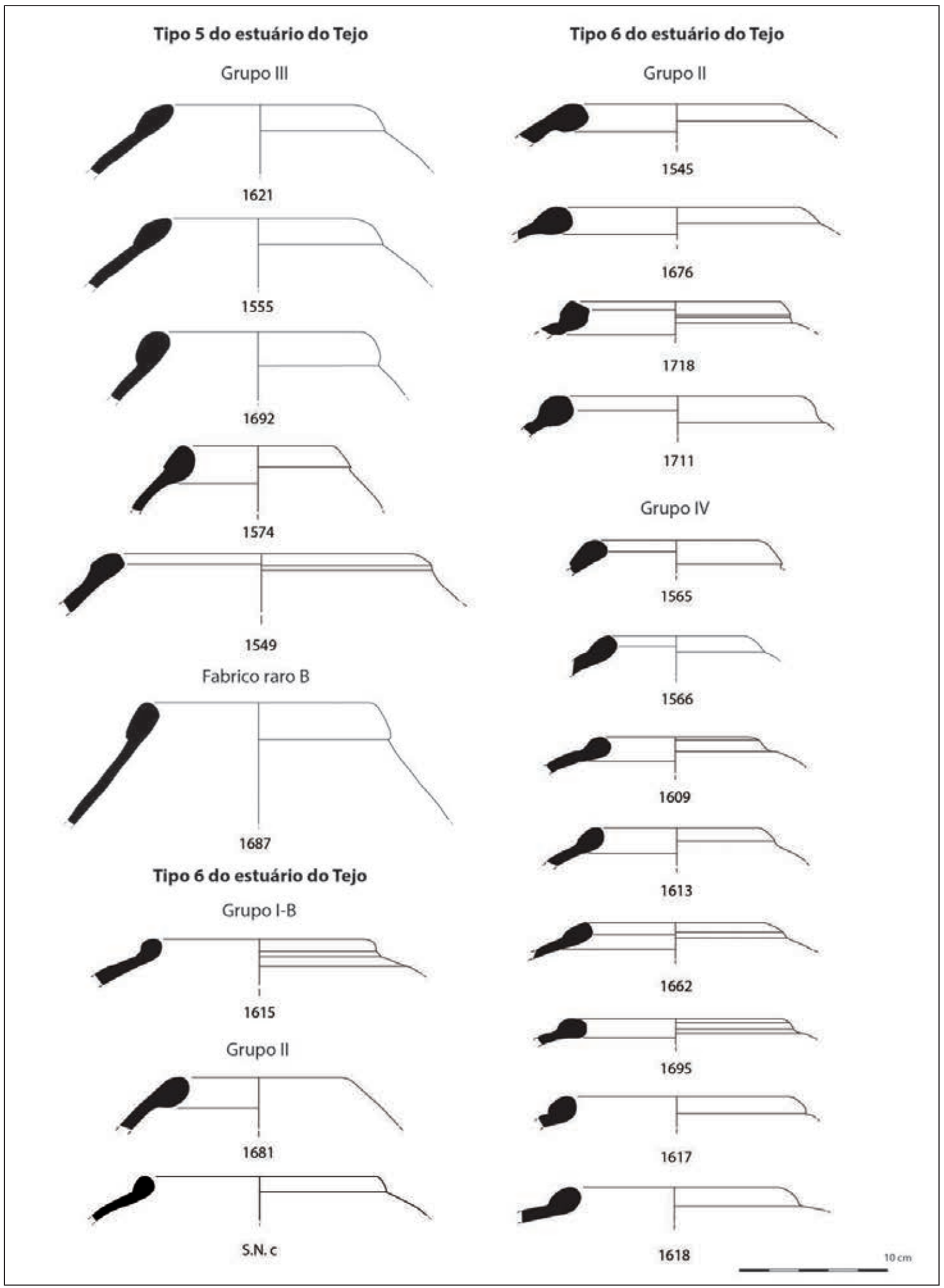

Figura 10. Ânforas dos tipos 5 e 6 do estuário do Tejo. 
O grupo das produções locais e regionais (grupos de fabrico I, II, III, IV e fabrico raro A e B) é, sem qualquer dúvida, o mais representativo, correspondendo a $96 \%$ do conjunto, enquanto que os materiais de provável importação correspondem a apenas $4 \%$, sendo esta escassa expressão recorrente no quadro dos conjuntos artefactuais regionais (Sousa 2014, 2017).

Dentro ainda das produções taganas (fig. 14 e 15), a única morfologia ausente é o tipo 2 do estuário do Tejo (Sousa e Pimenta 2014), sendo, contudo, de referir que a forma é também rara em outros sítios localizados nas áreas mais interiores do estuário. Os restantes tipos estão todos relativamente bem representados.

O tipo 1, cronologicamente mais antigo, mas que se prolonga até momentos bem avançados do $1^{\circ} \mathrm{mi}-$ lénio a.n.e., como já foi anteriormente referido, constitui $7 \%$ do conjunto (17 fragmentos), podendo acrescentar-se ainda as formas de transição $1 / 3$, que correspondem a outros $2 \%$ (cinco fragmentos). Estas morfologias englobam recipientes produzidos, sobretudo, na foz do estuário, mais especificamente na área de Lisboa/Almaraz, integrados no grupo de fabrico I (18 fragmentos). O grupo de fabrico IV, que poderá localizar-se nas suas proximidades, conta com três fragmentos, e as pastas mais típicas do curso interior do estuário (grupo III) contam com apenas um exemplar.

O tipo 3, recorrente nas produções regionais a partir da segunda metade do século VI a.n.e., conta com 7\% do conjunto total (16 fragmentos). Neste caso, encontramos um maior equilíbrio entre as produções da foz (nove exemplares), "intermédias" (dois exemplares) e as do interior (cinco exemplares), o que poderá talvez indicar que o início do fabrico de ânforas nas áreas mais interiores do estuário poderá ter ocorrido apenas a partir da segunda metade do século a.n.e..

A forma menos bem representada é o tipo 4, característico da segunda metade do $1^{\circ}$ milénio a.n.e., com apenas 3\% (seis exemplares), notando-se uma maioria dos fabricos da foz (três exemplares) e uma certa simetria entre os fabricos "intermédios" (um exemplar) e da zona interior (um exemplar).

A mesma situação verifica-se no tipo 7, mais tardio, que conta com $6 \%$ (14 exemplares - dos quais seis terão sido produzidos na zona da foz e cinco na área mais interior, sendo três da zona "intermédia").

As formas dominantes são, sem qualquer dúvida, os tipos 5 e 6 , que constituem, respectivamente, $38 \%$ (88 exemplares) e $25 \%$ (57 exemplares) do conjunto. A grande maioria destas peças são pertencentes aos fabricos que assumimos serem do próprio Porto do
Sabugueiro ou de uma área muito próxima (103 fragmentos dos grupos II e III). Apenas um, da forma 6, é passível de ser integrado nas produções típicas da zona de Lisboa/Almaraz (grupo I), sendo os restantes do grupo IV, para o qual se assume uma origem próxima da anterior (40 fragmentos).

A expressividade destas produções locais no Porto do Sabugueiro foi já associada à possibilidade de o local ter constituído, durante os momentos mais tardios do $1^{\circ}$ milénio, um centro de produção de contentores anfóricos (Sousa e Pimenta 2014), provavelmente relacionado com a proximidade de locais vocacionados para a exploração agrícola, como é o caso do Cabeço Guião, ocupado durante o século IV e III a.n.e. (Arruda et al. 2017), e localizado exactamente em frente do Porto do Sabugueiro, na margem oposta do Tejo (Sousa 2017). Contudo, não podemos deixar de estranhar a escassez, nesse mesmo local, de fragmentos que partilhem as características de fabrico desta zona mais interior, assim como a ausência de ânforas que sejam claramente integráveis no tipo 5 (Arruda et al. 2017), que são tão abundantes no Porto do Sabugueiro.

Esta estranha situação poderia eventualmente explicar-se de duas formas.

Por um lado, poderia equacionar-se que o Porto do Sabugueiro fosse, durante a Idade do Ferro, um núcleo de primeira importância, capaz de reunir e concentrar os excedentes agrícolas do território imediato, envazando-os directamente em contentores de produção local que seriam depois distribuídos para outras áreas. Esta relação de tipo unidirecional poderia, assim, justificar a escassez desses mesmos recipientes nos sítios de vocação agrícola das proximidades, que seriam, por sua vez, abastecidos sobretudo por outros produtos com origem na zona mais meridional do estuário. Esta hipótese enfrenta, contudo, um sério obstáculo, que é justamente a escassez destes fabricos anfóricos mais interiores em outras áreas do estuário do Tejo, apesar dessa carência poder ser imputada a problemas de identificação dos mesmos. Contudo, a verdade é que entre os vários conjuntos artefactuais que temos vindo a publicar (Arruda et al. 2014, 2017, 2018, Cardoso et al. 2014, Sousa 2014, Sousa e Arruda 2018, Sousa e Guerra 2018, Sousa et al. 2017, Pimenta et al. 2018) as produções da área da foz, Lisboa/Almaraz, parecem ser sempre largamente maioritárias. Ainda assim, parece importante referir que os estudos sobre os fabricos do estuário do Tejo se encontram ainda numa fase preliminar, sendo necessário corroborar estas propostas de proveniência com a 


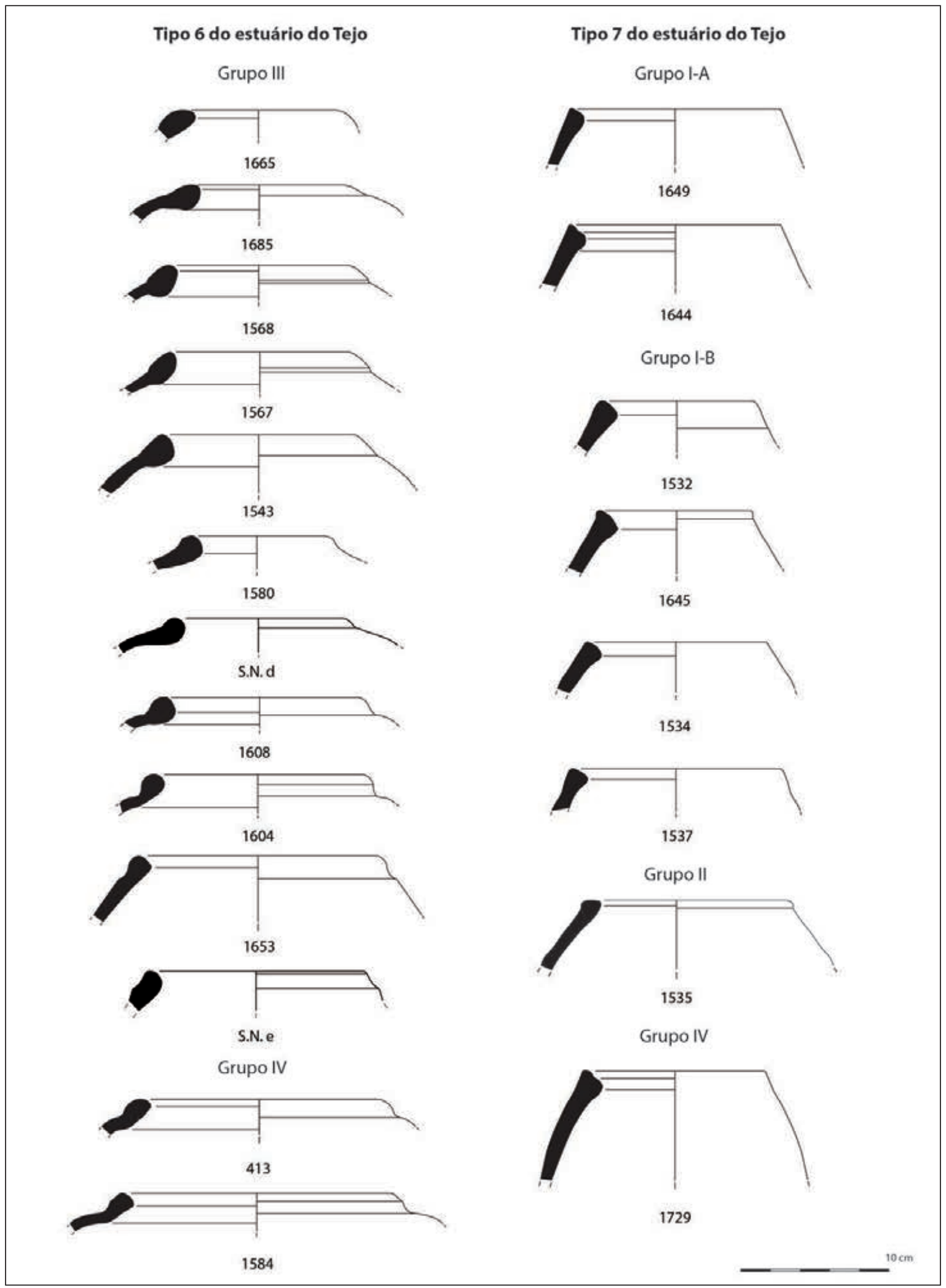

Figura 11. Ânforas dos tipos 6 e 7 do estuário do Tejo. 


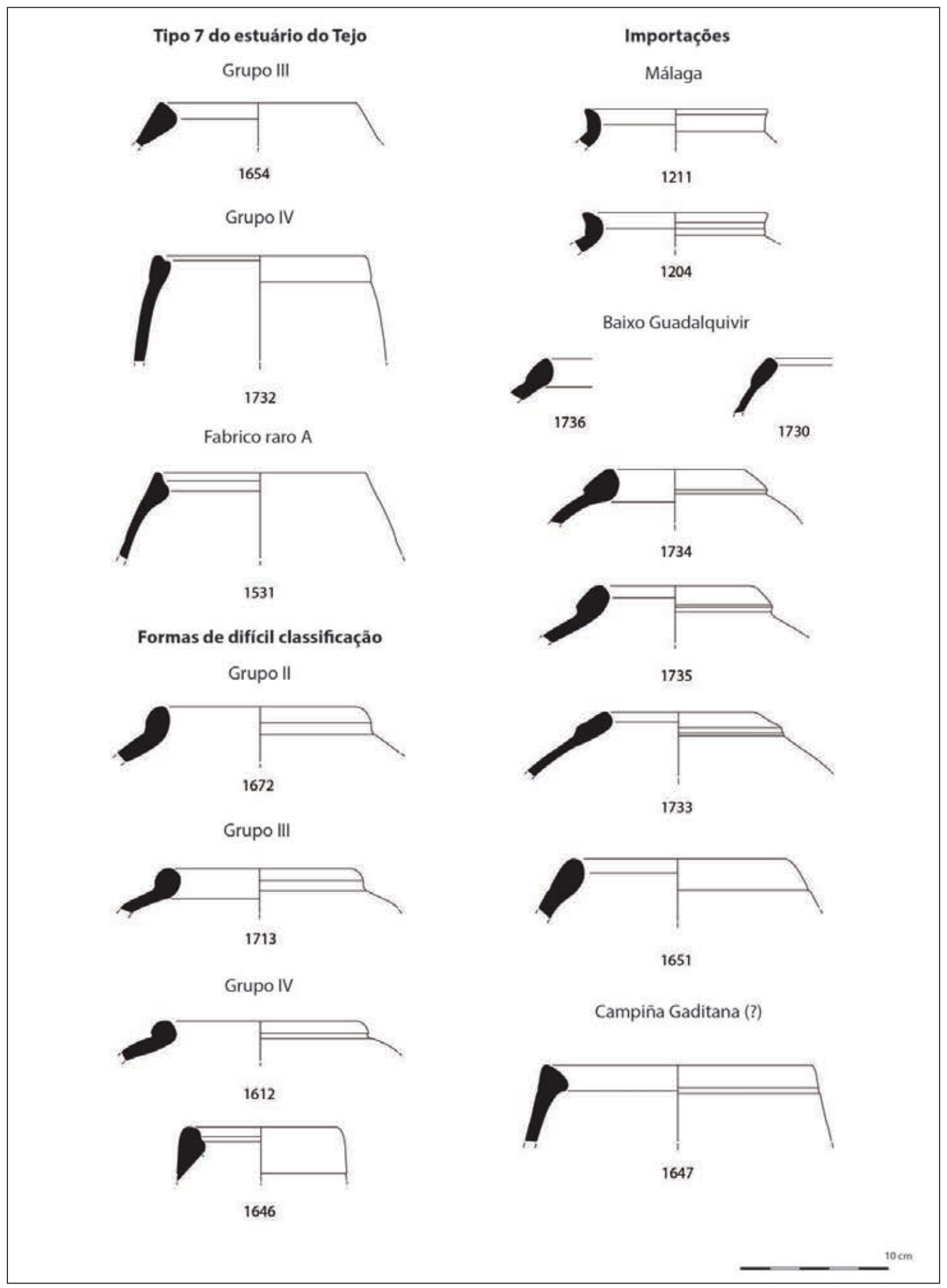

Figura 12. Ânforas dos tipos 7 do estuário do Tejo, formas de difícil classificação e importações. 
Tabela 2: Quantificação das produções locais e regionais do Porto do Sabugueiro de acordo com o grupo de fabrico e forma.

\begin{tabular}{|l|c|c|r|r|r|r|r|c|r|r|}
\hline Fabrico/forma & 1 & \multicolumn{1}{|c|}{$1 / 3$} & \multicolumn{1}{|c|}{3} & 4 & 5 & 6 & 7 & Difícil classificação & Indeterminada & Total \\
\hline Grupo I-A & 8 & 2 & 5 & 3 & - & - & 2 & - & 6 & $\mathbf{2 6}$ \\
\hline Grupo I-B & 7 & 1 & 4 & - & - & 1 & 4 & - & 6 & $\mathbf{2 3}$ \\
\hline Grupo II & - & - & 4 & - & 34 & 17 & 2 & 1 & 3 & $\mathbf{6 1}$ \\
\hline Grupo III & 1 & - & 1 & 2 & 31 & 21 & 2 & 1 & 6 & $\mathbf{6 5}$ \\
\hline Grupo IV & 1 & 2 & 2 & 1 & 22 & 18 & 3 & 2 & 3 & $\mathbf{5 4}$ \\
\hline Fabrico raro A & - & - & - & - & 1 & - & - & - & - & $\mathbf{1}$ \\
\hline Fabrico raro B & - & - & - & - & - & - & 1 & - & - & $\mathbf{1}$ \\
\hline Total & $\mathbf{1 7}$ & $\mathbf{5}$ & $\mathbf{1 6}$ & $\mathbf{6}$ & $\mathbf{8 8}$ & $\mathbf{5 7}$ & $\mathbf{1 4}$ & $\mathbf{4}$ & $\mathbf{2 4}$ & $\mathbf{2 3 1}$ \\
\hline
\end{tabular}

futura identificação de centros de produção e com dados arqueométricos.

Uma segunda possibilidade deve ser, porém, também equacionada. Mesmo não dispondo de informação precisa sobre as cronologias exactas destas produções, alguns dados, sobretudo os tipológicos, permitem admitir que elas poderão corresponder a uma etapa tardia no quadro das produções anfóricas taganas, iniciada num momento muito avançado da Idade do Ferro (talvez a partir do século III a.n.e.) ou mesmo já dentro da fase romano-republicana. Esta cronologia tardia poderia assim justificar a extrema escassez de ânforas produzidas em Porto do Sabugueiro na grande maioria dos sítios pré-romanos do estuário, ocupados sobretudo entre o século V e IV a.C. (Sousa 2017), e a ausência, até ao momento, de ânforas do tipo 5 em todos eles, com a excepção do próprio Porto do Sabugueiro. Só o estudo detalhado de conjuntos artefactuais de fase romano-republicana, que estão ainda por concretizar, poderá responder a esta questão.

Uma outra referência deve ser feita ao número de materiais importados identificados no Porto do Sabugueiro, que, apesar de tudo, é bastante apreciável quando comparado com outros da mesma área geográfica (Sousa 2017), totalizando nove fragmentos.

Destes, dois integram-se seguramente no horizonte cronológico da chamada I Idade do Ferro, concretamente as duas ânforas de provável produção malaguenha do tipo 10.1.1.1 de Ramon Torres (1995), que terão chegado ao Porto do Sabugueiro durante o século VII a.n.e.. Estas importações antigas da Andaluzia não constituem uma novidade no cenário regional, como ficou demonstrado, por exemplo, em Santarém e em Lisboa (Arruda 2000; Pimenta et al. 2014b, Sousa e Guerra 2018).

As ânforas do tipo Pellicer B/C, muito provavelmente produzidas no Baixo Guadalquivir, estão representadas por cinco exemplares. Trata-se de contentores produzidos entre momentos avançados do século VI e o século III a.n.e. (Pellicer Catalán 1978), tendo chegado ao território ocidental atlântico durante este período. Com efeito, e no que diz respeito à importação de produtos alimentares da actual Andaluzia, esta morfologia é, apesar dos reduzidos números que apresenta, a mais frequente na área do Tejo, estando representada, até ao momento, em Lisboa (um exemplar, recolhido em contextos do século V/inícios do IV a.n.e. na Rua dos Correeiros e outros dois na Travessa do Chafariz d'el Rei - Sousa 2014 e García Fernandez 2019) e no Cabeço Guião (um exemplar - Arruda et al. 2017), somando-se agora os cinco do Porto do Sabugueiro. Cabe, contudo, realçar, uma vez mais, esta representatividade do tipo do Guadalquivir neste sítio do curso superior do estuário, que constitui o conjunto mais numeroso destas importações em toda a região.

Deve, contudo, referir-se que, numa publicação recente, F. J. García Fernández (2019) propõe, com base na análise morfológica de algumas peças publicadas, outras possíveis importações destes produtos turdetanos na área do Tejo. Apesar de esta possibilidade ser perfeitamente válida, a grande semelhança que as ânforas do tipo Pellicer B/C apresentam com as produções locais do estuário levam-nos a ter alguma cautela em considerar esses exemplares como importações, até se poder realizar uma análise mais detalhada das respectivas pastas. 


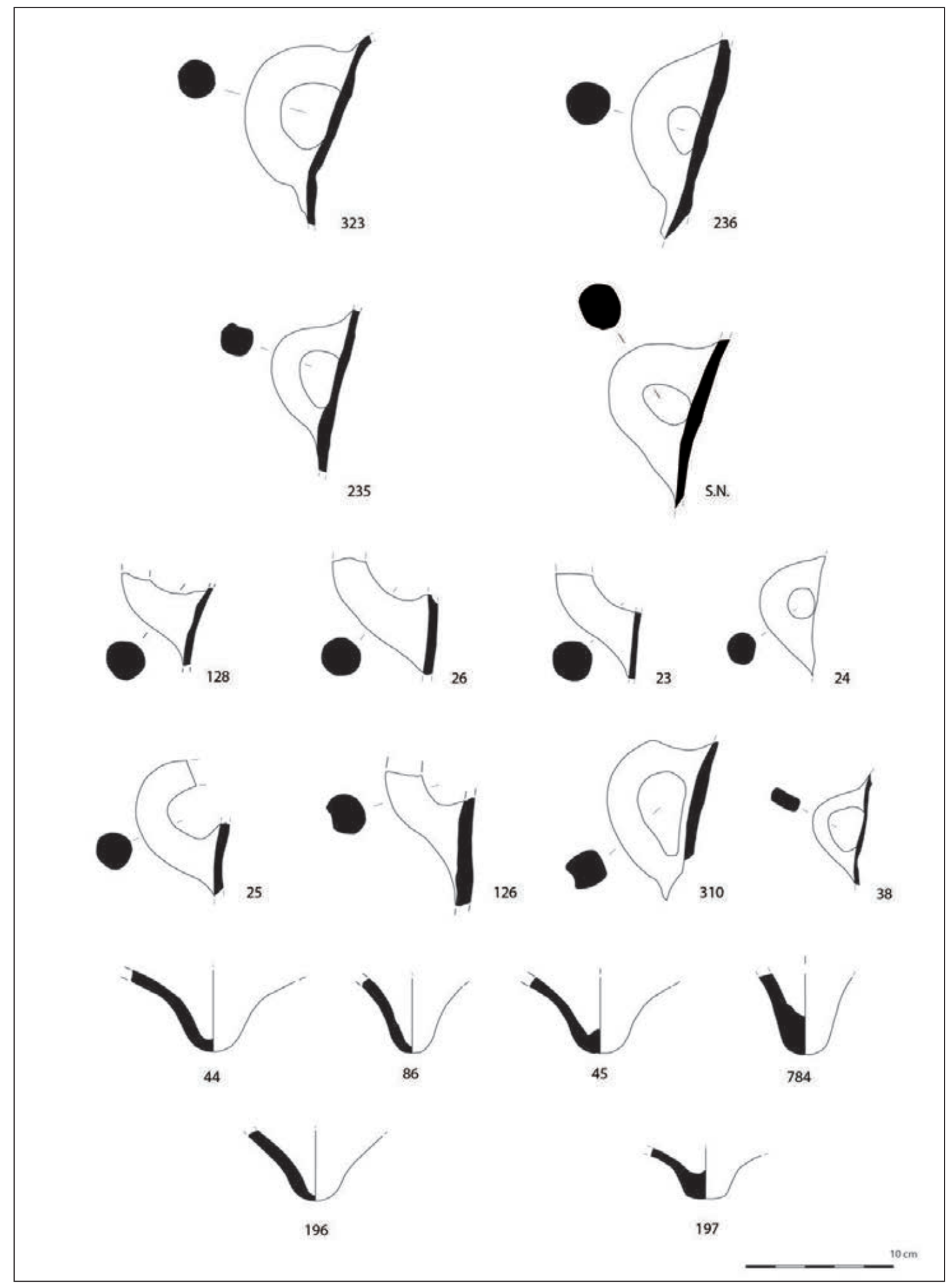

Figura 13. Fragmentos de asas e fundos de ânforas recolhidos no Porto do Sabugueiro. 


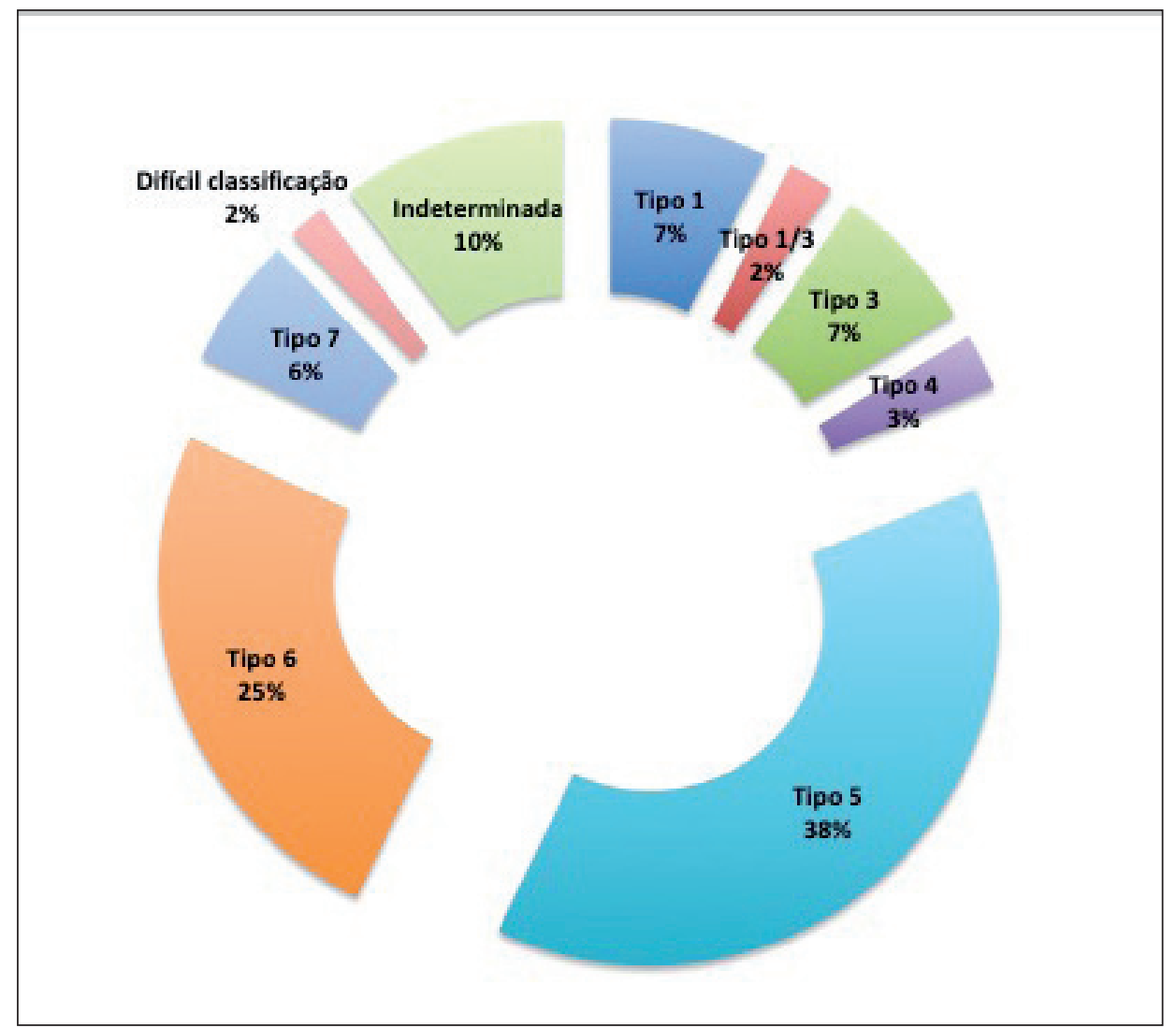

Figura 14. Gráfico de distribuição das produções locais/ regionais de acordo com os tipos morfológicos

As restantes importações são um pouco mais problemáticas de analisar. O fragmento que classificámos, ainda que com algumas reservas, como tipo Pellicer D, e que é, muito possivelmente também, originário do Baixo Guadalquivir, tem uma cronologia que se inicia em momentos avançados do século IV a.n.e., mas permanece nos inventários até momentos avançados do período romano-republicano. Assim, é muito difícil determinar se esta ânfora terá chegado ao Porto de Sabugueiro durante a Idade do Ferro ou já durante o século II ou inícios do I a.n.e.. Deve, contudo, referir-se que as ânforas do tipo Pellicer D produzidas na Andaluzia são muito raras na região, conhecendo-se, até ao momento, apenas o caso da Quinta do Almaraz (Olaio 2018), infelizmente, e também neste caso, sem dados contextuais.

Uma situação similar aplica-se ao fragmento que classificámos como 8.1.1.2, aparentemente produzido na Campiña Gaditana, e que seria um dos primeiros exemplares desta morfologia a ser reconhecido no estuário do Tejo. Trata-se de uma forma que começa a ser produzida a partir do século IV a.n.e., tendo-se assumido que não ultrapassaria o final da centúria seguinte (Carretero Poblete 2004). Contudo, o estudo de conjuntos artefactuais recuperados no ocidente do Algarve tem vindo a revelar quantidades consideráveis de ânforas do tipo 8.1.1.2 em contextos de finais do século II / inícios do século I a.n.e., o que tem levantado algumas questões sobre a cronologia do final da sua produção (Arruda e Sousa 2013; Sousa et al. 2016).

Assim, e apesar de estes dois últimos tipos (tipo Pellicer D e 8.1.1.2) serem tradicionalmente agregados às fases finais da Idade do Ferro, não devemos associar, inequivocamente, estas evidências ao período pré-romano, devendo ter-se em consideração a possibilidade de estas terem chegado à região já no quadro da integração da área do Tejo nos circuitos comerciais de época romano-republicana. Mais uma vez, só dados contextuais mais seguros poderão dar resposta a esta questão.

De qualquer forma, o conjunto de ânforas da Idade do Ferro e de tradição pré-romana do Porto do Sabugueiro fornece dados importantes sobre a produção e distribuição destes contentores nas áreas do curso médio e superior do estuário do Tejo. Ainda que não 


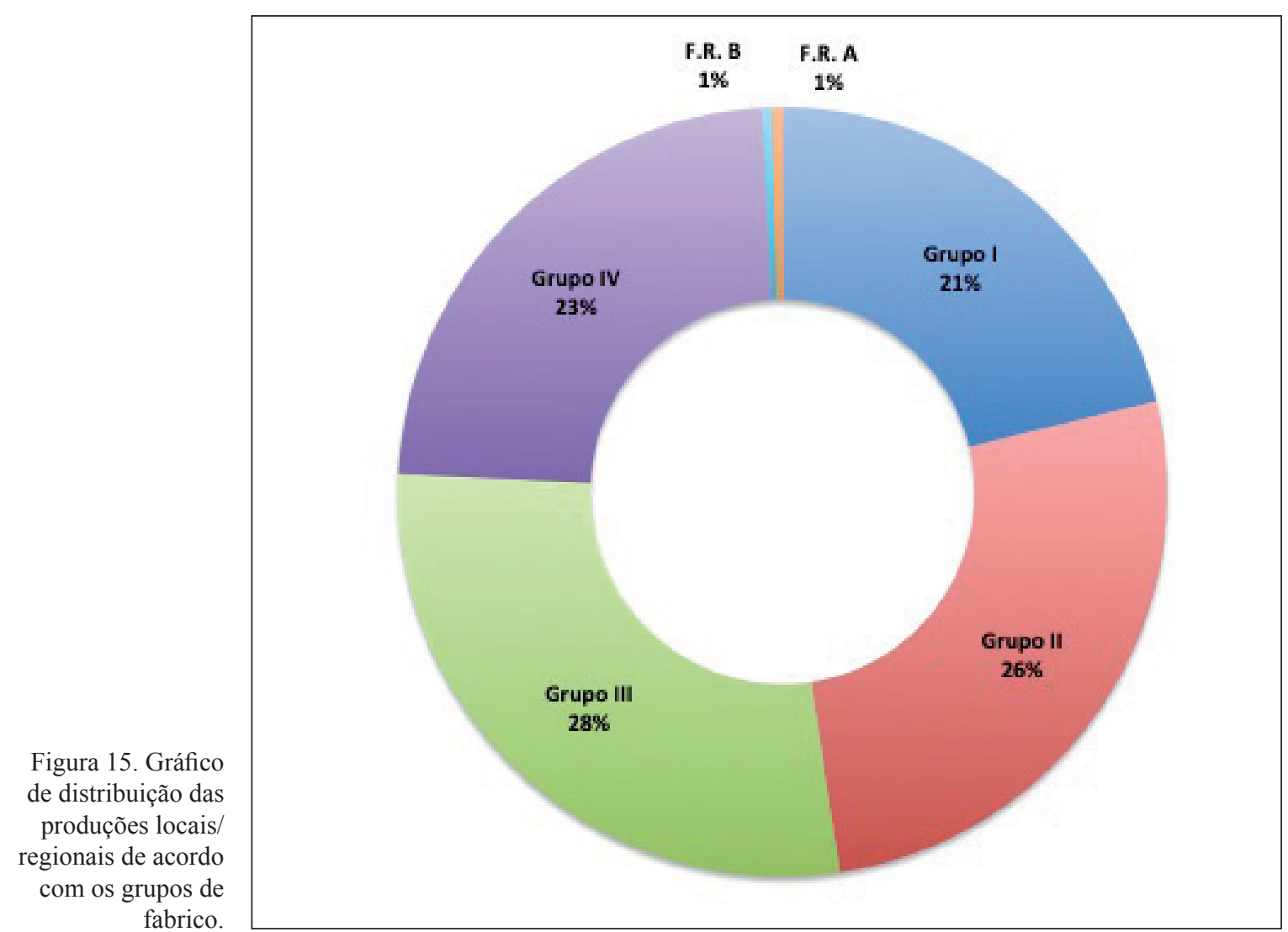

possamos deixar de lamentar a inexistência de dados contextuais, estes materiais mostram, sem qualquer dúvida, a importância que este sítio terá desempenhado ao longo do primeiro milénio no quadro da rede de povoamento deste território.

O estudo da complexidade das redes de produção e distribuição de contentores anfóricos no estuário do Tejo, ainda que tendo uma extensão essencialmente regional, podendo definir-se como uma espécie de circuito fechado, encontra-se ainda numa fase preliminar. Como já foi referido anteriormente, a importância e a dimensão deste fenómeno foram reconhecidas apenas durante os últimos cinco anos, sendo absolutamente necessário desenvolver os estudos tipológicos e arqueométricos que permitam conhecer, com mais detalhe, as suas especificidades. O trabalho que foi aqui apresentado é, assim, de primeira importância na correcta definição destas realidades: as características do conjunto, a sua representatividade quantitativa e a diversidade de produções identificadas é um contributo essencial para entender a grande complexidade que a produção e comercialização de contentores anfóricos atingiu, no estuário do Tejo, durante o $1^{\circ}$ milénio a.n.e.

\section{Agradecimentos}

Este trabalho foi realizado no âmbito do Projecto FETE - Fenícios no Estuário do Tejo (PTDC/EPH-ARQ/4901/2012), financiado pela Fundação para a Ciência e a Tecnologia.

\section{BIBLIOGRAFIA}

Aitchison, J. (1983): "Principal Component Analysis of Compositional Data”. Biometrika 70-1: 57-65.

Aitchison, J. (1984): "Reducing the dimensionality of compositional data sets". Mathematical Geology 16-6: 617-635.

Aldazábal, V.; Plá, R. e Ivernizzi, R. (2010): “Determinación de elementos traza en cerámicas arqueológicas del Lago Traful. Áreas de aprovisionamiento y circulación", in S. Bertolino, R. Cattáneo e A. D. Izeta (eds.), Arqueometría en Argentina y Latinoamérica: 29-34. Córdoba, Universidad Nacional de Córdoba.

Arruda, A. M. (2000): Los Fenicios en Portugal. Fenicios y mundo indígena en el centro y sur de 
Portugal (siglos VIII-VI a.C.). Barcelona, Universitat Pompeu Fabra.

Arruda, A. M.; Pereira, C.; Pimenta, J.; Sousa, E.; Mendes, H. e Soares, R. (2016): “As contas de vidro do Porto do Sabugueiro (Muge, Salvaterra de Magos, Portugal)". Cuadernos de Prehistoria y Arqueología de la Universidad Autónoma de Madrid 42: 79-101. <http://dx.doi.org/10.15366/ cupauam2016.42.002>.

Arruda, A. M.; Pereira, C.; Sousa, E.; Pimenta, J.; Detry, C. e Gomes, J. (2018): “Chões de Alpompé (Vale de Figueira, Santarém): Lendas e Narrativas”. Spal 27-2: 201-227. <http://dx.doi.org/10.12795/ spal.2018i27.20>.

Arruda, A. M. e Sousa, E. (2013): “Ânforas Republicanas de Monte Molião (Lagos, Algarve, Portugal)". Spal 22: 101-141. <https://doi.org/10.12795/ spal.2013.i22.05>.

Arruda, A. M.; Sousa, E.; Pimenta, J.; Mendes, H. e Soares, R. (2014): "Alto do Castelo's Iron Age occupation (Alpiarça, Portugal)". Zephyrus 74: 143-155 <http://dx.doi.org/10.14201/zephyrus201474143155>

Arruda, A. M.; Sousa, E.; Barradas, E.; Batata, C.; Detry, C. e Soares, R. (2017): “O Cabeço Guião (Cartaxo - Portugal): um sítio da Idade do Ferro do Vale do Tejo", in S. Celestino Pérez e E. Rodríguez González (eds.), Territorios comparados: los valles del Guadalquivir, el Guadiana y el Tajo en época tartesica: 319-361. Mérida, CSIC.

Barros, L. e Soares, A. M. (2004): “Cronologia absoluta para a ocupação orientalizante da Quinta do Almaraz, no estuário do Tejo (Almada, Portugal)". $O$ Arqueólogo Português série IV 22: 333-352.

Baxter, M. J. (1994): Exploratory Multivariate Análisis in Archaeology. Edinburgh, Edinburgh University Press.

Baxter, M. J. (2003): Statistics in Archaeology. London, Arnold Publishers.

Cardoso, J. L.; Arruda, A. M.; Sousa, E. e Rego, M. (2014): “Outorela I e Outorela II, dois pequenos sítios da Idade do Ferro a norte do Estuário do Tejo (concelho de Oeiras)". Estudos Arqueológicos de Oeiras 21: 393-428.

Cardoso, J. L. e Carreira, J. R. (1997-1998): “A ocupação de época púnica da Quinta da Torre (Almada)". Estudos Arqueológicos de Oeiras 7: 189-217.

Cardoso, J. L. e Silva, C. T. (2013): “O casal agrícola da Idade do Ferro de Gamelas 3 (Oeiras)". O Arqueólogo Português série V 2: 353-398.

Cardoso, G. (1991): Carta Arqueológica do Concelho de Cascais. Cascais, Câmara Municipal.
Cardoso, G. e Encarnação, J. (2013): “O povoamento pré-romano de Freiria - Cascais". Cira-Arqueologia 2: 133-180.

Carmona, N.; García-Heras, M.; Villegas, M. A.; Fernández-Posse, M.D. e Sánchez-Palencia, F. J. (2008): "Producción cerámica en Las Médulas (León). Una comparación diacrónica a través de métodos arqueométricos", in S. Rovira Llorens, M. García-Heras, M. Gener Moret e I. Montero Ruiz (eds.), Actas VII Congreso Ibérico de Arqueometría: 277-287. Madrid (2007), Madrid, Quadro.

Carretero Poblete, P. A. (2004): Las ánforas tipo "Tiñosa" y la explotación agrícola de la CampiñaGaditana entre los siglos Vy III a.C. Tese de doutoramento, Universidad Complutense de Madrid. Inédita.

Coll Conesa, J. (2000): "Aspectos de tecnolocía de producción de la cerámica ibérica”, in C. Mata Parreño e G. Pérez Jordá (eds.), IBERS. Agricultors, artesans i comerciants. III Reunió sobre Economia en el Món lbèric (Saguntvm-PLAV Extra-3): 191-209. Valencia, Universitat de Valencia.

De la Fuente, G. A. e Vera S. D. (2013): "Evidencias de sobrecocción y vitrificación en las estructuras de combustión (hornos de cerámica) y en cerámica arqueológica procedentes del sitio Costa de Reyes $\mathrm{N}^{\mathrm{o}}$ 5: Una aproximación a través de la petrología cerámica, MEB-EDS y difracción de rayos x (Dpto. Tinogasta, Provincia de Catamarca, Noroeste, Argentina)", in E. F. Irassar e E. Aglietti (coords.), Actas del XI Congreso y Exposición Internacional de la Industria Cerámica, del Vidrio, Refractarios y Suministros (Olavarria 2013): ATACER 2013: 351356. Tandil, Universidad Nacional del Centro de la Provincia de Buenos Aires.

Diogo, A. M. D. (1993): “Ânforas pré-romanas dos Chões de Alpompé (Santarém)". Estudos Orientais IV: 215-227.

Galván Martínez, V. (1995): “Almizaraque: correlación entre geoquímica y tipos cerámicos". Complutum 6 : 319-327.

García Fernández, F. (2019): "Rumbo a poniente: el comercio de ánforas turdetanas en la costa atlántica de la península ibérica (siglos V-I a.C.). Archivo Español de Arqueología 92: 119-153<https://doi. org/10.3989/aespa.092.019.007>.

Glasckoc, M. D. (1992): "Neutron Activation Analysis", in H. Neff (ed.), Chemical characterization of ceramic pastes in archaeology: 11-26. Madison, Prehistory Press.

Gómez Siurana, M. D. (1987): Caracterización de cerámicas arqueológicas de la provincia de Alicante 
por aplicación de análisis estadístico multivariable a los datos de composición química. Tese de doutoramento, Universidad de Alicante. Inédita.

Guerrero Ayuso, V. M. (1991): "El palacio-santuario de Cancho Roano (Badajoz) y la comercializacion de ánforas fenicias indígenas". Rivista di Studi Fenici 19-1: 49-81.

Nieuwendam, L. e Santos, R. (2008): "Villa romana de Vilares, Cascais. Trabalhos arqueológicos em 20072008". Al-madan online adenda electrónica. II série: 16 (http://www.almadan.publ.pt/16Adenda. htm, consultada a 27 de Junho de 2019).

Olaio, A. (2018): "O povoado da Quinta do Almaraz (Almada, Portugal) no âmbito da ocupação no Baixo Tejo durante o $1^{\circ}$ milénio a.n.e.: os dados do conjunto anfórico". Spal 27-2: 125-163 <http://dx. doi.org/10.12795/spal.2018i27.18>.

Pellicer Catalán, M. (1978): “Tipología y cronología de las ánforas prerromanas del Guadalquivir según el Cerro Macareno (Sevilla)". Habis 9: 365-400.

Pereira, M. A. H. (1975): "Objectos Egípcios do Porto do Sabugueiro (Muge)". Conímbriga XIV: 173-176.

Pereira, M. (2017): "Os cossoiros de Porto de Sabugueiro (Muge, Salvaterra de Magos)". Cira - Arqueologia 5: 55-75.

Pimenta, J. (2005): As ânforas romanas do Castelo de São Jorge (Lisboa). Trabalhos de Arqueologia 41. Lisboa, Instituto Português de Arqueologia.

Pimenta, J.; Calado, M. e Leitão, M. (2005): "Novos dados sobre a ocupação pré-romana da cidade de Lisboa: as ânforas da sondagem n. ${ }^{\circ} 2$ da Rua de São João da Praça". Revista Portuguesa de Arqueologia 8-2: 313-334.

Pimenta, J. e Mendes, H. (2008): "Descoberta do povoado pré-romano de Porto do Sabugueiro (Muge)". Revista Portuguesa de Arqueologia 11-2: 171-194.

Pimenta, J. e Mendes, H. (2011): "Novos dados sobre a presença fenícia no vale do Tejo. As recentes descobertas na área de Vila Franca de Xira". Estudos Arqueológicos de Oeiras 18: 591-618.

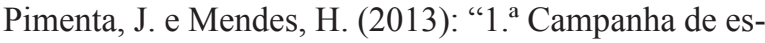
cavações arqueológicas no povoado pré-romano de Porto do Sabugueiro - Muge - Salvaterra de Magos". Cira Arqueologia 2: 195-219.

Pimenta, J. e Mendes, H. (2015): "Casal dos Pegos I e o Povoamento Orientalizante do Rio da Silveira Vila Franca de Xira". Cira-Arqueologia 4: 19-54.

Pimenta, J.; Mendes, H. e Madeira, F. (2010): "O povoado pré-romano de Castanheira do Ribatejo, Vila Franca de Xira". Revista Portuguesa de Arqueologia 13: 25-56.
Pimenta, J.; Mendes, H.; Arruda, A. M.; Sousa, E. e Soares, R. (2014a): "Do pré-romano ao Império: a ocupação humana do Porto do Sabugueiro (Muge, Salvaterra de Magos)". Magos. Revista Cultural do Concelho de Salvaterra de Magos 1: 39-58.

Pimenta, J.; Silva, R. e Calado, M. (2014b): "Sobre a ocupação pré-romana de Olisipo. A intervenção arqueológica urbana da Rua de São Mamede ao Caldas n. ${ }^{\circ} 15$ ", in A. M. Arruda (ed.), Fenícios e Púnicos, por terra e mar. Actas do VI Congresso Internacional de Estudos Fenícios e Púnicos (Lisboa 2005): vol. 2 712-723. Lisboa, Centro de Arqueologia da Universidade de Lisboa.

Pimenta, J.; Gaspar, A.; Gomes, A.; Mota, N. e Miranda, P. (2014c): "O estabelecimento romano-republicano de Olisipo: estrutura e contextos do Beco do Forno do Castelo, Lote 40 - Lisboa". Cira Arqueologia 3: 122-148.

Pimenta, J.; Sousa, E.; Mendes, H.; Henriques, E. e Arruda, A. M. (2018): "A Eira da Alorna (Almeirim): as ocupações pré e proto-históricas". Cira Arqueologia 9: 9-49.

Ramon Torres, J. (1995): Las Ánforas Fenicio-Púnicas del Mediterráneo Central y Occidental. Barcelona, Publicacions Universitat de Barcelona.

Rodrigues, M.; Pimenta, J.; Sousa, E.; Mendes, H. e Arruda, A. M. (no prelo): "A cerâmica cinzenta de Porto do Sabugueiro (Muge, Portugal)". Cira-Arqueologia.

Silva, C. T. e Soares, J. (2012): "Castro de Chibanes (Palmela). Do III milénio ao século I a.C.", in Palmela Arqueológica no Contexto da Região Interestuarina Sado-Tejo: 67-87. Palmela, Câmara Municipal.

Sousa, E. (2014): A ocupação pré-romana da foz do Estuário do Tejo. Lisboa, Centro de Arqueologia da Universidade de Lisboa.

Sousa, E. (2017): "Percorrendo o Baixo Tejo: Regionalização e Identidades Culturais na $2^{\mathrm{a}}$ metade do $1^{\circ}$ milénio a.C.”, in S. Celestino Pérez e E. Rodríguez González (eds.), Territorios comparados: los valles del Guadalquivir, el Guadiana y el Tajo en época tartesica: 295-318. Mérida, CSIC.

Sousa, E.; Alves, C. e Pereira, T. (2016): "O conjunto anfórico da urbanização do Moleão, Lagos (Portugal)", in R. Járrega e P. Berni (eds.), Amphorae ex Hispania: paisajes de producción y consumo: 464478. Tarragona, ICAC.

Sousa, E. e Arruda, A. M. (2018): “A I Idade do Ferro na Alcáçova de Santarém (Portugal): os resultados da campanha de 2001". Onuba 6: 57-95. 
Sousa, E. e Guerra, S. (2018): “A presença fenícia em Lisboa: novos vestígios descobertos no alto da colina do Castelo de São Jorge". Saguntum 50: 57-88. DOI: $10.7203 /$ SAGVNTVM.50.10636

Sousa, E. e Pimenta, J. (2014): "A produção de ânforas no Estuário do Tejo durante a Idade do Ferro", in R. Morais, A. Fernández e M. J. Sousa (eds.), As Produções Cerâmicas de Imitação na Hispânia. Monografias Ex Officina Hispana II: vol. 1 303-316. Porto, Faculdade de Letras da Universidade do Porto.
Sousa, E.; Pimenta, J.; Mendes, H. e Arruda, A. M. (2017): "A ocupação Proto-Histórica do Alto dos Cacos (Almeirim, Portugal)". Cira - Arqueologia 5: 9-32.

Whallon, R. (1990): "Defining structure in clustering dendrograms with multilevel clustering", in A. Voorips e B. Ottaway (eds.), New tools for mathematical Archaeology: 1-13. Cracow, Polish Academy of Sciences. 
Sánchez-Pardo, J. C., Blanco-Rotea, R., Costa-García, J.M., Sanjurjo-Sánchez, J., Barrientos-Rodríguez, V. y Alonso-Toucido, V. (2020): "Hacia una reinterpretación de la secuencia de ocupación del Yacimiento de a Cidadela (A Coruña)", Spal 29.1: 157-188. DOI: http://dx.doi.org/10.12795/spal.2020.i29.06

\title{
HACIA UNA REINTERPRETACIÓN DE LA SECUENCIA DE OCUPACIÓN DEL YACIMIENTO DE A CIDADELA (A CORUÑA)
}

\author{
TOWARDS A REINTERPRETATION OF THE ARCHAEOLOGICAL \\ SEQUENCE OF THE SITE OF A CIDADELA (A CORUÑA, SPAIN)
}

Dedicado a la memoria de nuestro maestro y amigo, José Manuel Caamaño Gesto

\author{
JOSÉ CARLOS SÁNCHEZ-PARDO
}

Responsable de la correspondencia

Investigador Ramón y Cajal. Departamento de Historia, Universidade de Santiago de Compostela

Laboratorio de Patrimonio, Paleoambiente e Paisaxe. Ed. Monte da Condesa s/n, 15782, Santiago de Compostela Correo-e: josecarlos.sanchez@usc.es. (1) https://orcid.org/0000-0003-2899-4951

Researcher ID: <https://publons.com/researcher/AAH-1559-2019>

\section{REBECA BLANCO-ROTEA}

Investigadora Posdoutoral da Xunta de Galicia. Departamento de Historia

Universidade de Santiago de Compostela. Laboratorio de Patrimonio, Paleoambiente e Paisaxe.

Ed. Monte da Condesa s/n, 15782, Santiago de Compostela. Investigadora visitante. Unidade de Arqueologia

Universidade do Minho. Edifício dos Congregados. Avda. Central, 100, 4710-229, Braga (Portugal)

Correo-e: rebeca.blanco.rotea@usc.es. (1) https://orcid.org/0000-0003-3975-2149

Researcher ID: <https://publons.com/researcher/B-2499-2018>

JOSÉ MANUEL COSTA-GARCÍA

Investigador Posdoutoral da Xunta de Galicia

Departamento de Historia, Universidade de Santiago de Compostela. Laboratorio de Patrimonio, Paleoambiente e Paisaxe Ed. Monte da Condesa s/n, 15782, Santiago de Compostela. Visiting Scholar. School of History, Classics and Archaeology

Faculty of Humanities and Social Sciences. Newcastle University, NE1 7RU (United Kingdom) Correo-e: josemanuel.costa@usc.es D https://orcid.org/0000-0002-0819-1361

Researcher ID: <https://publons.com/researcher/H-5584-2015>

\section{JORGE SANJURJO-SÁNCHEZ}

Profesor Contratado Doctor. Instituto Universitario de Geología - Grupo de investigación CULXEO, Universidade da Coruña Edificio de Servicios Centrales de Investigación. Campus de Elviña, 15071, A Coruña Correo-e: jsanjurjo@udc.es. (D https://orcid.org/0000-0002-7559-8647 Researcher ID: <https://publons.com/researcher/E-4404-2011>

VICTOR BARRIENTOS-RODRÍGUEZ

Profesor Contratado Doctor. Departamento de Ingeniería Civil - Grupo de investigación CULXEO, Universidade da Coruña Edificio de Servicios Centrales de Investigación. Campus de Elviña, 15071, A Coruña Correo-e: victor.barrientos@udc.es. D https://orcid.org/0000-0002-8004-2790 Researcher ID: <https://publons.com/researcher/AAH-2012-2019>

FRANCISCO ALONSO-TOUCIDO

Arqueólogo e investigador predoctoral. Departamento de Historia, Universidade de Santiago de Compostela Laboratorio de Patrimonio, Paleoambiente e Paisaxe. Ed. Monte da Condesa s/n, 15782, Santiago de Compostela Correo-e: franalonsotoucido@hotmail.com. (D) https://orcid.org/0000-0003-2554-5448 Researcher ID: <https://publons.com/researcher/K-2841-2018> 
Resumen: Se presentan los resultados de un amplio trabajo interdisciplinar de revisión, análisis, datación y excavación del conocido yacimiento de A Cidadela (A Coruña). Tradicionalmente los esfuerzos investigadores en este yacimiento se habían centrado en la presencia de un fuerte romano (siglos II-III d.C), dejando de lado una serie de fases posteriores denominadas "germánicas". Con el objetivo de profundizar en el conocimiento de la secuencia completa del yacimiento publicamos en 2015 una lectura de paramentos de dos sectores del mismo. Continuando con ese trabajo, en este artículo se presentan los resultados de la revisión de materiales tardoantiguos y medievales, análisis de composición y procedencia del material pétreo, datación absoluta de un total de 21 muestras de morteros, carbones y sedimentos por radiocarbono y luminiscencia ópticamente estimulada y dos sondeos arqueológicos realizados en 2016. La combinación de toda esta nueva información cambia radicalmente nuestra visión y comprensión de las fases "posromanas" de A Cidadela con la detección de al menos cuatro horizontes arqueológicos posteriores al fuerte romano: tardoantiguo (ss. IV-VI/VII), altomedieval (ss. IX-XI), plenomedieval (s. XIII) y bajomedieval-moderno. A Cidadela se convierte así en un enclave privilegiado para analizar arqueológicamente la ocupación del interior de Galicia en los últimos 2000 años.

Palabras clave: Tardoantigüedad, fuerte romano, iglesia altomedieval, OSL, Geoarqueología, materiales de importación.

\section{INTRODUCCIÓN}

A Cidadela (Sobrado dos Monxes, A Coruña) es uno de los yacimientos más conocidos e intervenidos de la arqueología gallega. Se sitúa sobre un altozano entre los ríos Cabalar y Pequeño (fig. 1), lugar donde la existencia de restos arqueológicos es públicamente conocida desde al menos principios del siglo XX (Costa-García 2014). Aunque en la década de 1930 se desarrollaron las primeras intervenciones arqueológicas en el yacimiento (Del Castillo López 1934, 1935), no fue hasta 1981 cuando, bajo la dirección de J. M. Caamaño Gesto (1984), se iniciaron las excavaciones sistemáticas que supondrían un importante avance en el conocimiento del sitio.

Gracias a estos trabajos, prolongados hasta la década de 2000, sabemos que en época romana se construyó un fuerte auxiliar ocupado por la cohors I Celtiberorum (Caamaño Gesto 1989). Las excavaciones han permitido exhumar casi el 20\% del asentamiento, habiéndose prestado especial atención a las edificaciones situadas en el centro del recinto militar -los denominados latera praetorii- $\mathrm{y}$ al sector oeste de su sistema defensivo
Abstract: This paper presents the results of an extensive interdisciplinary work of revision, analysis, dating and excavation of the well known site of A Cidadela (A Coruna). Research on this site has traditionally focused on the presence of a Roman fort (2nd-3rd centuries AD), leaving aside a series of later phases known as "Germanic". In order to deepen our knowledge of the whole sequence of the site, we published in 2015 an stratigraphical analysis of two sectors. Continuing this work, this article presents the results of the review of the late antique and medieval material record, petrological analysis of rocks, absolute dating of 21 samples of mortars, charcoal and sediments by means of radiocarbon and optically stimulated luminescence and two archaeological surveys conducted in 2016. The combination of all this new information radically changes our vision and understanding of the "post-Roman" phases of A Cidadela with the detection of at least four archaeological horizons after the Roman fort: late antique $\left(4^{\text {th }}-6^{\text {th }} / 7^{\text {th }}\right.$ centuries $\left.A D\right)$, late medieval $\left(9^{\text {th }}-11^{\text {th }}\right.$ centuries AD), Central Middle Ages ( $13^{\text {th }}$ century AD) and Late Medieval-Modern times. A Cidadela thus became a privileged place for the archaeological analysis of the occupation of inland Galicia in the last 2000 years.

Keywords: Late Antiquity, roman camp, early medieval church, OSL, Geoarchaeology, imported materials.

(Caamaño Gesto 1997, Caamaño Gesto y Fernández Rodríguez 2002, Ramil González et al. 2013) (fig. 2). Asimismo, diversas publicaciones han abordado aspectos relativos a la arquitectura y organización interna del asentamiento militar romano, su cultura material, o la relación de éste con su entorno (Caamaño Gesto et al. 2000, Caamaño Gesto y Fernández Rodríguez 2006, Costa-García 2010, López Pérez 2006).

Sin embargo, ya desde las primeras excavaciones fueron identificados determinados elementos materiales y estructurales que excedían el marco cronológico habitualmente barajado para esta ocupación militar -entre los siglos II y IV d.C. -. Estas evidencias nunca se estudiaron de forma detallada, pero a lo largo de los últimos 30 años se fueron integrando en una secuencia general explicativa para el yacimiento (Caamaño Gesto y Fernández Rodríguez 2006, Costa-García y Varela Gómez 2011). Dicha secuencia considera que tras el abandono del recinto militar se habría producido una ocupación puntual en época tardoantigua (siglos IV-VI d.C.). Después de un breve hiato, un nuevo grupo humano se habría asentado aquí en el siglo VII d.C. Esta ocupación, 


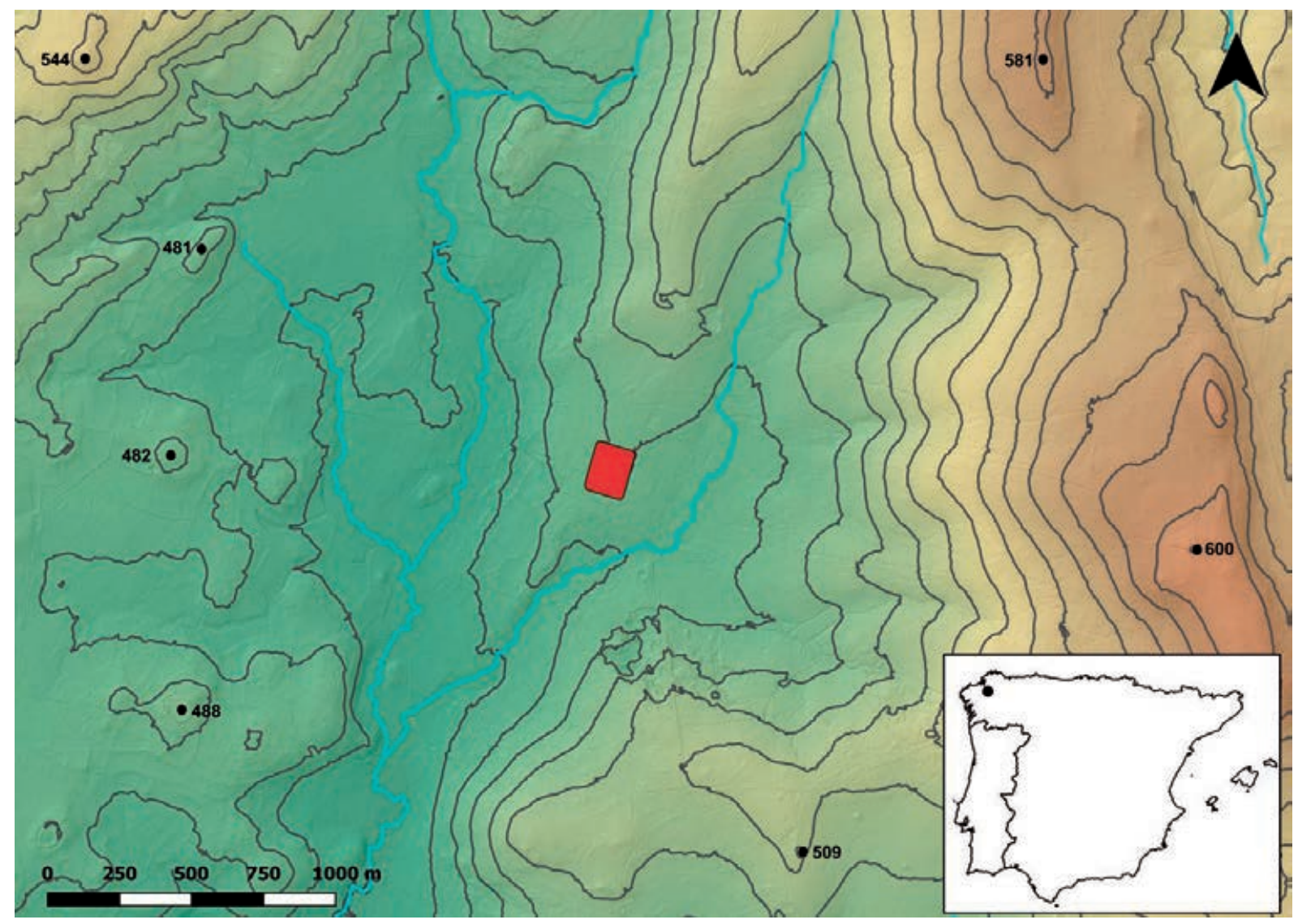

Figura 1. Localización de yacimiento sobre modelo digital del terreno LiDAR 1m. Curvas de nivel cada 10 m. (Base cartográfica del Instituto Geográfico Nacional)..

denominada "germánica", se caracterizaría por la fuerte reorganización del espacio y la construcción de una iglesia, posiblemente monástica y con dependencias a su alrededor, en el sector central del antiguo recinto militar. Finalmente, algunas estructuras dispersas en el yacimiento pertenecerían a una fase "medieval" poco definida (Fernández Rodríguez 1997). En relación con ella, una mención en un documento del cercano monasterio de Sobrado (Loscertales 1976: doc. 137) avalaría la existencia de una iglesia en A Cidadela en el año 995, tradicionalmente identificada con el templo parroquial hoy sito extramuros.

Con el objetivo de profundizar en el conocimiento de las llamadas fases "germánica" y "medieval" del yacimiento, entre los años 2014 y 2017 se llevaron a cabo diversas iniciativas en el marco del proyecto EMCHAHE (Sánchez-Pardo y Blanco-Rotea 2014). En una primera fase, se procedió a la revisión de toda la información documental disponible sobre el yacimiento con el fin de reconstruir la secuencia de ocupación del mismo. La complejidad de este proceso, agudizada por la heterogeneidad y carácter parcial de los datos disponibles, nos llevó a centrarnos en el estudio de dos sectores de especial interés en los que se habían documentado actividades "posromanas": el espacio situado al noroeste de la antigua via principalis del fuerte romano, y el área correspondiente a la supuesta iglesia "germánica" (fig. 2). En ellos se llevó a cabo una lectura de paramentos que nos permitió establecer una nueva secuencia y cronología relativa de ocupación del yacimiento (Blanco-Rotea et al. 2015).

Tras la publicación de este primer trabajo, en los dos últimos años hemos centrado nuestros esfuerzos en caracterizar y datar con precisión cada una de las fases identificadas. Para ello, se tomaron muestras de morteros, carbones y sedimentos de tierra para su datación mediante radiocarbono y luminiscencia óptimamente estimulada (OSL). También se procedió a revisar la cultura material asociada a las fases "posromanas". Con el fin de contrastar los datos obtenidos, se abrieron dos 
pequeños sondeos en diferentes zonas del yacimiento, en los cuales se tomaron nuevas muestras para datar por radiocarbono. Asimismo, se realizó un estudio geológico de los distintos materiales pétreos utilizados en los muros. Como complemento a estas iniciativas, se realizaron prospecciones geofísicas puntuales mediante georradar y espectrometría de rayos gamma in situ en dos zonas del yacimiento así como un levantamiento fotogramétrico a cargo de Juan Ortiz Sanz (USCAN3D - USC). Para dicho levantamiento se combinaron fotografías tomadas con pértiga y otras desde un dron Phantom III con altura media de vuelo de $60 \mathrm{~m}$, y procesadas con software Agisoft Photoscan ${ }^{\circledR}$.

La información proporcionada por estos recientes trabajos permite cambiar radicalmente nuestra visión acerca de las fases "posromanas" del yacimiento. En este artículo pretendemos mostrar de forma sintética los resultados de dichas investigaciones para posteriormente realizar, con base en los mismos, una revisión de la secuencia de ocupación del yacimiento y apuntar una serie de reflexiones respecto a la misma. No incidiremos en explicar en detalle las cuestiones relacionadas con la lectura de paramentos ya que están publicadas en Blanco-Rotea et al. (2015), aunque sí revisaremos la cronología propuesta entonces.

\section{REVISIÓN DE LA CULTURA MATERIAL RECUPERADA EN ANTERIORES INTERVENCIONES}

Durante las excavaciones desarrolladas en los años 1981-2010 se recuperaron algunos materiales (cerámicos, vítreos y metálicos) que excedían la periodización tradicionalmente propuesta para el asentamiento militar romano (Caamaño Gesto et al. 2000, Caamaño Gesto y Fernández Rodríguez 2006). En una primera fase de trabajo decidimos llevar a cabo una aproximación al estudio de estos materiales adscritos a los periodos tardoantiguo y medieval, analizando los contextos arqueológicos en los que aparecieron y revisando la cronología propuesta en trabajos anteriores en relación con nuevos estudios peninsulares en esta materia. $\mathrm{Al}$ igual que en los restos de los análisis llevados a cabo, nuestro objetivo era intentar ordenar la información relativa a estos contextos y datarla de forma absoluta.

\subsection{Aproximación a la cerámica y vidrios posromanos}

Como complemento al anterior estudio de López Pérez (2006), se examinaron las cerámicas de importación correspondientes a las campañas de 2006-2009, depositadas en el Museo Arqueolóxico e Histórico da Coruña. Tal y como establecía esta última autora, parece que ninguna de las formas de terra sigillata hispánica transicional (TSHT) documentadas hasta la fecha en el yacimiento (8T, 35T, 37a, $15 / 17 \mathrm{~T}$ y 50 ) supera la primera mitad del siglo IV d.C., con excepción de dos individuos procedentes de los talleres del valle del Duero y fechables a partir de la segunda mitad de esta centuria (CID06-21-23, CID09-99). Más amplia es la cronología ofrecida por las piezas de terra sigillata africana D (TSAD, formas Hayes 59, 61 A, 91, 103B) y focense tardía (TSFT), que se enmarcan entre este último momento y mediados del siglo VI d.C. A este mismo horizonte parecen pertenecer los escasos fragmentos documentados de ánforas estriadas del Mediterráneo Oriental.

Resulta llamativo también que la mayor parte de los vidrios tipológicamente identificados (Isings 67, 96, 101, 106c, 118) se encuadren en un momento cronológico avanzado (siglos IV-VI d.C.), siendo muy probablemente producidos en talleres locales o regionales fundados en el periodo inmediatamente anterior (Caamaño Gesto 1990, Vázquez Martínez 2000).

Desgraciadamente, carecemos de datos estratigráficos que nos permitan analizar la evolución de la cerámica común durante los periodos tardoantiguo y altomedieval. Sabemos que las producciones de época romana son muy semejantes a las de la cercana Lucus Augusti (Lugo) (Barbazán Domínguez et al. 2015, Caamaño Gesto y Fernández Rodríguez 2006: 172-173, Bartolomé Abraira 2015, Fernández Fernández y Bartolomé Abraira 2016). Una breve inspección de los materiales exhumados en 2006, que será necesario ampliar en futuras ocasiones, nos permitió distinguir posibles cerámicas lucenses tardías -alcanzarían en algunos casos la segunda mitad del siglo V d.C.-, así como otras piezas cuya producción se enmarcaría quizá en los siglos VI-VII d.C. (CID06-186).

Asimismo, varias memorias de excavación recogen piezas genéricamente clasificadas como cerámica "postcampamental" (Caamaño Gesto 1987, 1992a), siendo frecuentemente asociadas a supuestas estructuras "germánicas". Se trataría de ollas, botellas, jarras, cuencos y vasijas de almacenamiento de factura muy tosca, pastas poco cuidadas y presencia en algunos casos de fragmentos de otras cerámicas o vidrios a 


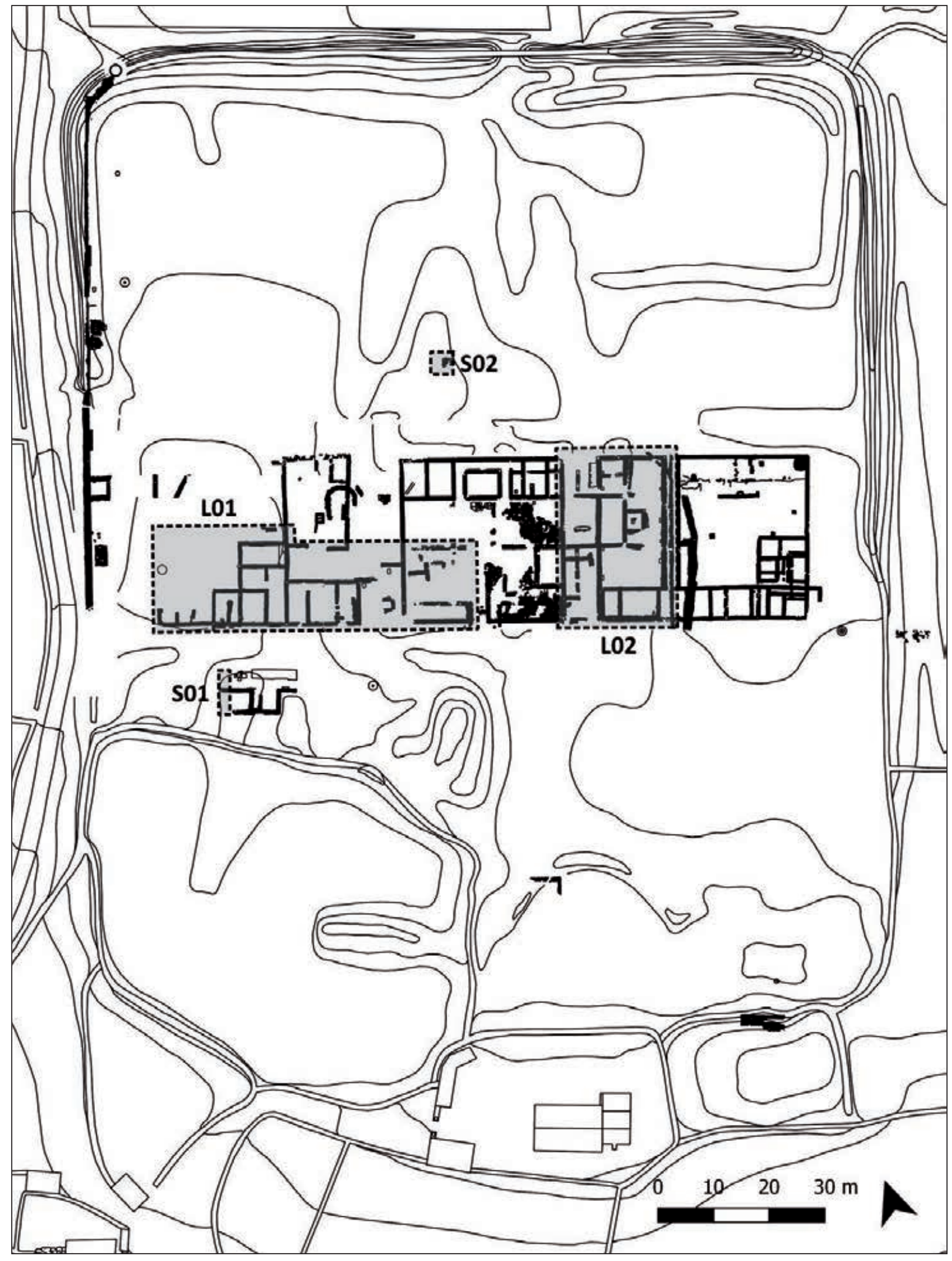

Figura 2. A Cidadela, planimetría tras la intervención de 2016 con indicación de los sectores donde se realizó la lectura de paramentos (L01 y L02) y los sondeos excavados (S01 y S02). 
modo de desgrasante, aunque este hecho no ha podido ser corroborado. De igual modo, la memoria técnica de la campaña de 2006 menciona el hallazgo de dos fragmentos de un recipiente globular con esmalte vidriado en su interior que habría sido identificado como una "producción califal", así como el borde de una olla de "cronología altomedieval” (Ramil González 2007). El mal estado de conservación de ese fragmento cerámico vidriado, así como su escasa representatividad, genera dudas sobre su verdadero origen y cronología. Una revisión premilinar de estos conjuntos ha permitido como novedad identificar material cerámico claramente plenomedieval (siglos XI-XIII), principalmente en la campaña de 1991. Se trata de bordes oblicuos biselados y de protopestaña de pastas gris perla (figs. 3 y 4), similares a los localizados en otros puntos de Galicia (Cid 91/208), como Santiago de Compostela, pero también de pastas marrones como los localizados en A Coruña (Cid 91/1174, Cid 91/314, Cid 09/700, Cid 91/555) (Alonso et al. 2013, Bello et al. 2008). A su vez, esta revisión ha permitido identificar cerámica común, no coincidente tipológicamente con las formas plenomedievales ni con formas romanas, con bordes facetados hechos a mano o bordes apuntados verticales con cepillado vertical u oblicuo (Cid 91/311), que nos pueden estar remitiendo a momentos altomedievales. Así lo indica su similitud con producciones localizadas en la ciudad de Vigo, en concreto con las producciones micáceas de tradición indígena y su olla de borde vertical, encuadrable entre los siglos V y VIII (Fernández Fernández y Bartolomé Abraira 2016).

\subsection{Metales}

Tampoco los objetos metálicos del yacimiento han sido publicados de forma monográfica en anteriores trabajos, pero existe un conjunto de piezas de notable interés que se ha asociado a sus fases más tardías, sobre el que haremos una breve revisión, aun siendo conscientes de que no han sido hallados en contextos arqueológicos estratigráficamente bien datados.

Entre los elementos de adorno personal, destaca en primer lugar una fíbula de bronce de tipo Vyškov con goterón y asiento de la aguja en hierro (fig. 5.5.; Caamaño Gesto 1984). Solo conocemos un paralelo en la península ibérica, en el Castillón de Tábara (Zamora), que puede datarse en el siglo V d.C. (Sastre Blanco y Catalán Ramos 2012: 203-204, Sastre Blanco et al. 2015: 68-71), pudiendo encuadrarse nuestro ejemplar en el subtipo Bratei. Igualmente llamativa es otra fíbula de hierro de arco simple recuperada en 1996, cuya cronología sería de la segunda mitad del siglo V d.C. (fig. 5.4 = CID96-M57; Fernández Rodríguez 1997).

También han aparecido varios elementos correspondientes a hebillas de cinturón. Así, se recuperó en 1983 una aguja o hebijón de base escutiforme (fig. 5.2; Caamaño Gesto 1987, López Quiroga y Martínez Tejera 2017: 260), un modelo antiguo que podría datarse a partir del primer tercio del VI d.C. (Azkarate Garai-Olaun 2006: 409-410, Ripoll 1991: 113). En este mismo contexto se documentó un fragmento del broche decorado de una hebilla de bronce con mucha aleación de plomo (fig. 5.3) que sin embargo no se relaciona tipológicamente con la mencionada aguja.

En 1991 se halló una placa articulada de bronce con su hebijón (fig. 5.1, Caamaño Gesto 1992a). De acuerdo con su morfología y decoración incisa, estamos ante una pieza de procedencia aquitana producida entre finales del siglo VI d.C. y mediados del VII d.C. -Merovingio Reciente I- (Azkarate GaraiOlaun 1993, 2007). Más complicado resulta clasificar otras tres hebillas de hierro documentadas durante las campañas de 1996 (CID96-M189A y B) y 2007 (CID07-153, CID07-182) en los llamados "niveles germánicos" (Fernández Rodríguez 1997, Ramil González 2007). El primer elemento es una sencilla pieza de forma elíptica y sección cuadrangular que conservaba in situ una aguja de sección circular. Las otras dos piezas parecen ser broches de hebillas de cinturón, pero se encuentran en un avanzado estado de oxidación que las hace casi irreconocibles.

Por último, consideramos que la datación en los siglos IV-V d.C. de dos puntas de lanza halladas en 1983 y 1996 a partir de ciertos paralelos en las necrópolis del Duero (Caamaño Gesto et al. 2000: 285) resulta arriesgada. Esta clase de armamento se resiste aún hoy día a cualquier intento de sistematización crono-tipológica, existiendo formas similares a las de Cidadela en contextos de época romana (Bishop y Coulston 2006, Feugère 2002: 169-171).

\subsection{Discusión}

Uno de los grandes problemas que, en su conjunto, presentan todos los materiales referidos es la relativa indefinición de los contextos arqueológicos en los que fueron hallados. Como ya comentamos en otra ocasión, las intervenciones en las que muchas de estas piezas fueron recogidas datan de varias décadas atrás, en las que se empleaban otras metodologías de 


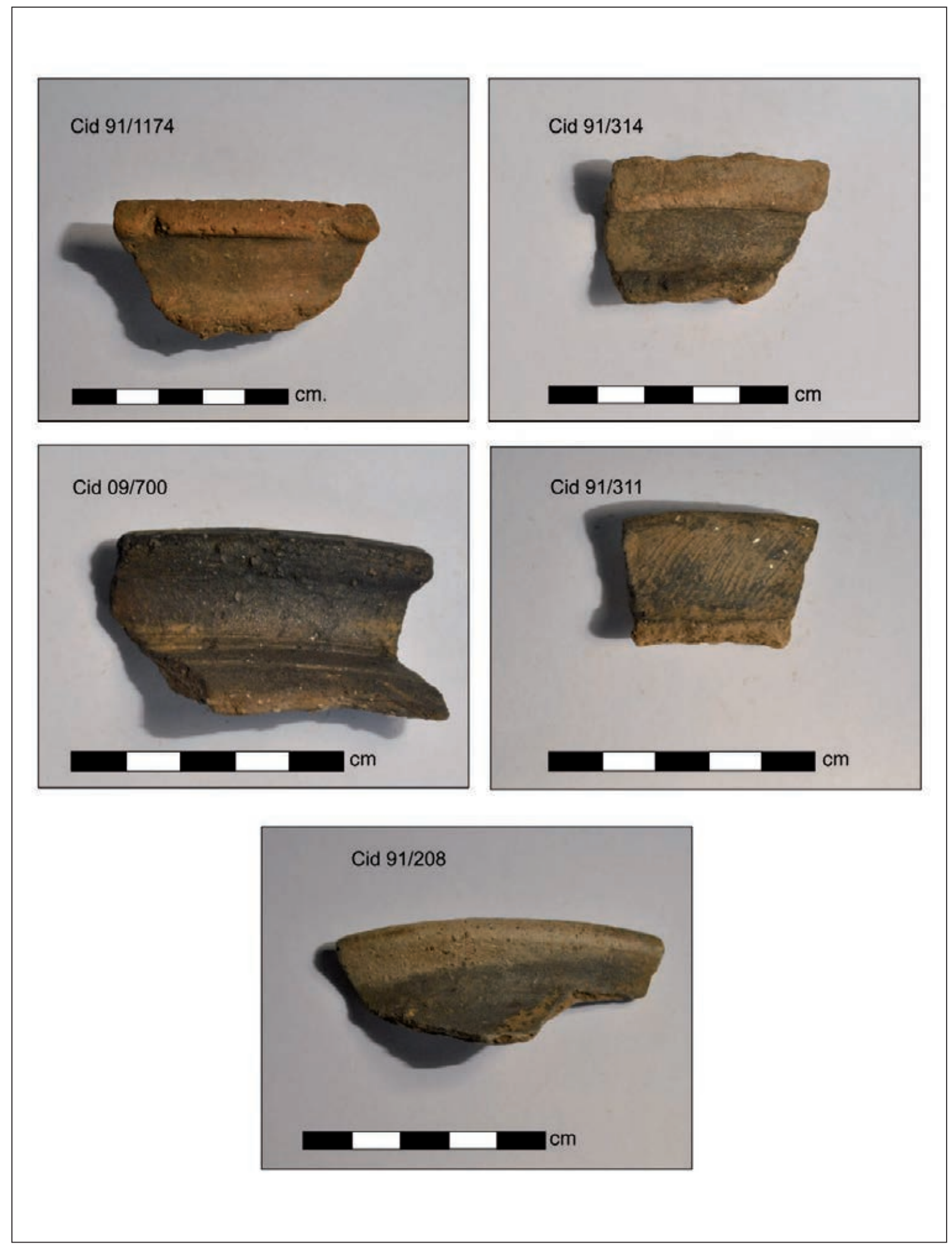

Figura 3. Cerámica de época plenomedieval de la campaña de 1991. Fotografías de algunos bordes representativos. 


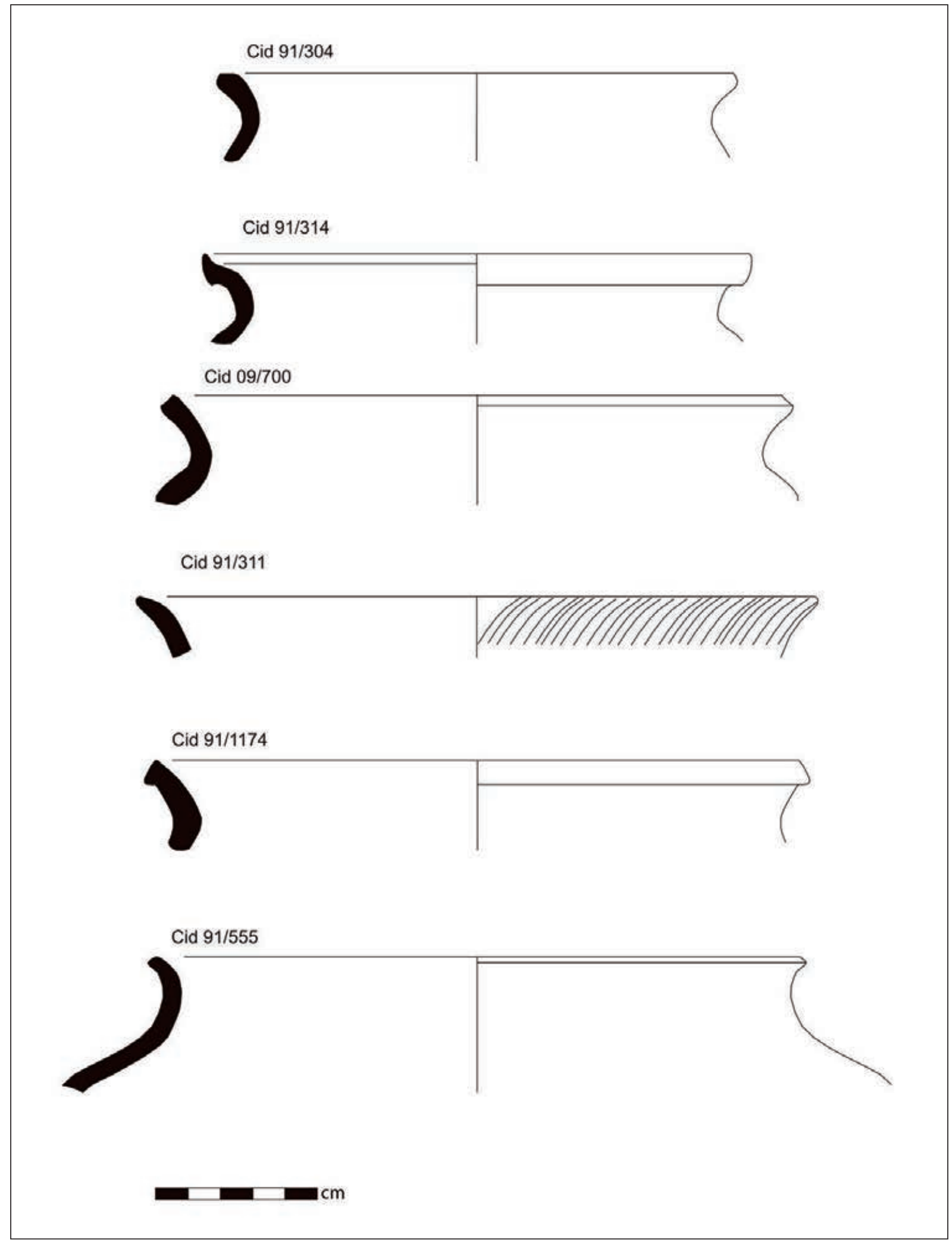

Figura 4. Dibujos de perfiles de cerámica de época plenomedieval de la campaña de 1991. 


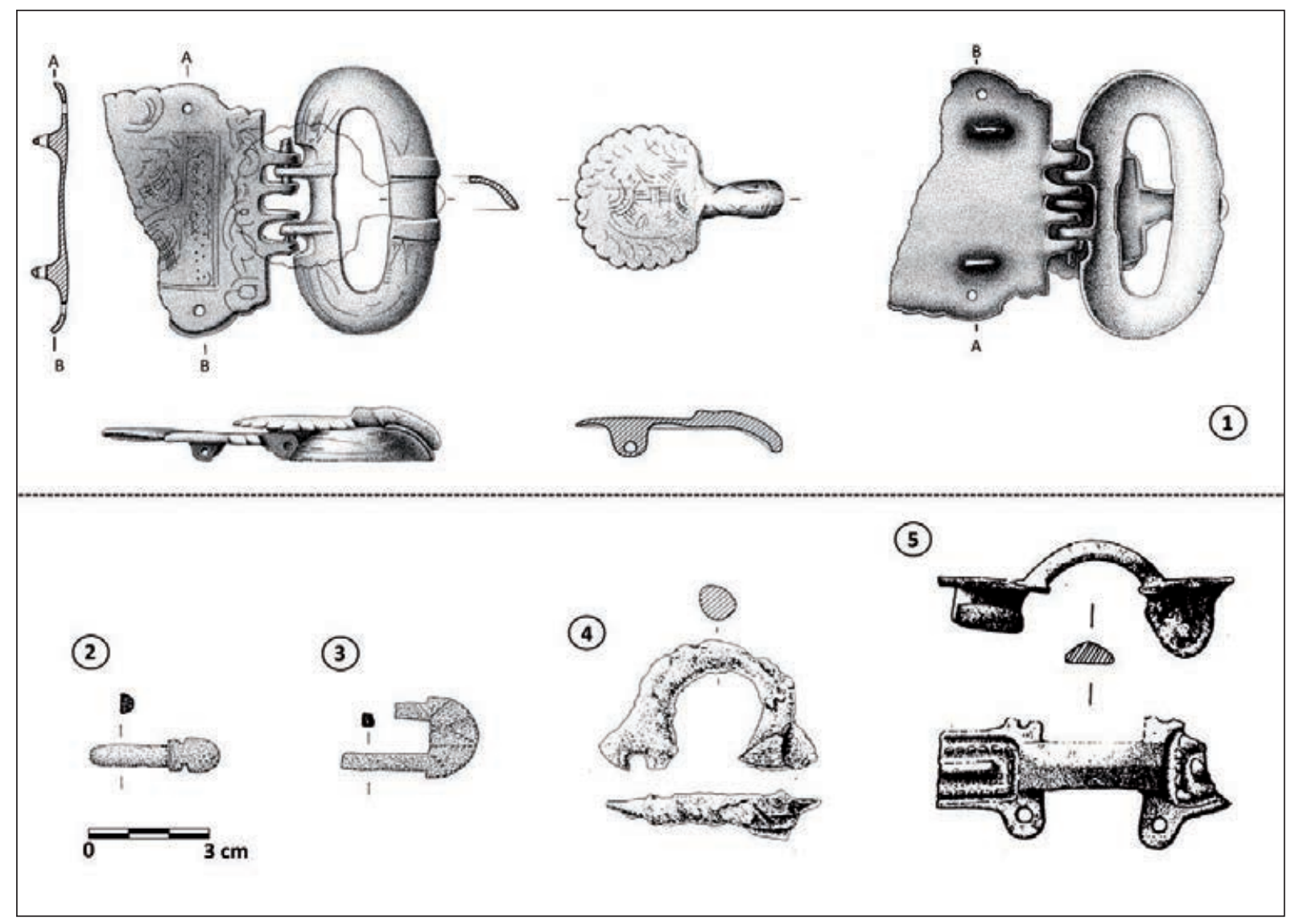

Figura 5. Elementos metálicos de adorno. Placa articulada de bronce con hebijón (1) hallada en 1991 (Anxo R. Paz en Caamaño 1992). Aguja de base escutiforme (2) y placa de cinturón (3) recuperadas en 1983 (Xosé Lomba en Caamaño Gesto 1987). Fíbula de hierro (4) documentada en 1996 (Anxo R. Paz en Fernández Rodríguez 1997). Fíbula tipo Vyškov (5) registrada en 1981 (Xosé Lomba en Caamaño Gesto 1984).

excavación en ocasiones pre-estratigráficas (BlancoRotea et al. 2015: 70-71). Las memorias de excavación reflejan una excesiva simplificación estratigráfica, tendiendo a agrupar los distintos depósitos -nunca descritos- en tres niveles estandarizados: romano (III), abandono y ocupación "germánica" (II), alteraciones posteriores (I). En su mayoría, las piezas referidas se han adscrito al segundo nivel, que se ha considerado un paquete revuelto dentro del cual es posible encontrar elementos de cultura material claramente romanos -p. ej. sigilatas altoimperiales- junto con piezas como las descritas con anterioridad, datadas en momentos posteriores situados entre los siglos IV y VII (datación que, como veremos, coincide con algunos de los horizontes datados en la estratigrafía muraria). Tan solo la documentación del sector excavado en 2006, especialmente rico en evidencias materiales y constructivas, permite definir la procedencia de casi todas las piezas "posromanas" en su contexto estratigráfico, razón por la que, como veremos, ha sido escogido como una de las áreas prioritarias en nuestro estudio.

En todo caso, la revisión de materiales muestra claramente la presencia de un nutrido grupo de piezas datables entre los siglos IV y VII d.C., así como otro grupo de cerámicas de cronología plenomedieval que hasta la fecha habían pasado inadvertidas. Y sobre todo, esta revisión nos ha permitido poner de relieve la existencia de una compleja secuencia estratigráfica más allá de los niveles preconcebidos, algo ya apuntado pero no manifiestamente expresado en 1996 (Fernández Rodríguez 1997). Sin embargo, como ya señalamos, todos estos materiales posromanos requieren un estudio más detallado y exhaustivo que los realizados hasta la fecha, por lo que los datos aquí expuestos solo pueden emplearse como hipótesis para apuntalar o no la información obtenida mediante 
el estudio de la estratigrafía muraria, de los pocos materiales hallados en su contexto, y de las dataciones absolutas. Como veremos, aunque fueron realizados dos sondeos arqueológicos con la intención de obtener una secuencia horizontal limpia y datada de forma absoluta, los materiales documentados fueron muy escasos y no permiten ampliar la información derivada de intervenciones anteriores.

\section{DATACIÓN ABSOLUTA DE LAS ESTRUCTURAS EXCAVADAS EN ANTERIORES CAMPAÑAS}

El cometido de realizar la lectura estratigráfica de las estructuras excavadas con anterioridad a 2016 fue establecer una nueva secuencia relativa de ocupación del yacimiento. Por motivos operativos, se optó por limitar esta actuación a dos aéreas que presentaban un particular interés para los objetivos del proyecto. El Sector 1 se situó en el espacio occidental de los llamados latera praetorii (fig. 1, L01), comprendiendo fundamentalmente la mitad sur del Edificio 1 y el cuadrante sudoeste del Edificio 3. Esta área comprende el espacio excavado en 2006, donde se había documentado una interesante acumulación de evidencias posromanas. Por su parte, el Sector 2 se emplazó más al este, comprendiendo principalmente el Edificio 4 y el espacio situado entre este y el Edificio 3 (fig. 1, L02). En esta zona se habían documentado los restos de la posible iglesia de "época germánica” (Fernández Rodríguez 1997, Caamaño Gesto y Fernández Rodríguez 2002).

Como ya hemos señalado, una primera versión de la secuencia constructiva obtenida como resultado de este estudio ya ha sido publicada (Blanco-Rotea et al. 2015). Sin embargo, la hipótesis barajada en aquel momento para la datación de dicha secuencia se basaba únicamente en la información aportada por los restos de cultura material identificados hasta entonces y las propuestas de otros autores. Con el fin de ofrecer una seriación cronológica más estricta, fueron tomadas un total de 15 muestras de mortero y sedimentos, de las que 9 se dataron por luminiscencia y 6 por radiocarbono. En las siguientes líneas se ofrecen los resultados de esas dataciones, que presentan un sustancial impacto en la mencionada secuencia.

\subsection{Metodología}

La datación por luminiscencia se realizó por medio de luminiscencia ópticamente estimulada (Optically Stimulated Luminescence u OSL), que permite estimar la edad de morteros como el cociente entre la dosis de radiación absorbida total medida (estimada como dosis equivalente o $D_{e}$ ) por luminiscencia y la tasa de dosis de radiación ionizante de las muestras estudiadas $\left(D_{r}\right)$ y los materiales circundantes. La edad estimada corresponderá al tiempo transcurrido desde la última exposición a la luz de los materiales datados (Aitken 1988), lo que en morteros se produce durante la producción y colocación del mortero como diversos estudios han demostrado (Goedicke 2011, Urbanova et al. 2015, Sánchez Pardo et al. 2017). Las medidas de OSL se realizan en granos de cuarzo extraídos del mortero (Sanjurjo-Sánchez 2016).

Se tomaron 9 muestras de morteros de tierra para su datación por OSL. Las dataciones fueron realizadas en el laboratorio de Luminiscencia de la Universidad de A Coruña. Los detalles de la preparación de las muestras para la datación por OSL así como la metodología utilizada se encuentran detalladas en un trabajo previo al que remitimos (Sánchez-Pardo et al. 2017a).

Se tomaron 6 muestras de mortero de tierra para datación por radiocarbono. En dos de estas la datación se obtuvo a partir de carbones contenidos en ellas, mientras que en las otras se utilizó la materia orgánica que contenían. Las muestras fueron analizadas mediante Espectrometría de Masas acoplada a un Acelerador (Accelerator Mass Spectrometry, AMS) en el laboratorio de Beta Analytic (Florida, USA). Se calibraron las edades con el paquete de software Oxcal 4.1 (Bronk Ramsey 2011) en base a la curva de calibración de Reimer et al. (2013).

\subsection{Resultados}

La edad obtenida por luminiscencia corresponde a la razón entre la radiación absorbida por el cuarzo de una muestra (estimada como De) y la tasa de radiación recibida (estimada como dosis anual). Para estimar la dosis anual se midió la humedad de las muestras y su saturación en agua, dado que el agua atenúa la radiación ionizante (Atitken 1985). El contenido en agua estimado resultó similar para todas las muestras estudiadas (tab. 1). Los análisis elementales de las muestras permitieron obtener las concentraciones de $\mathrm{K}, \mathrm{U}$ y Th en ellas y los materiales de su entorno (roca y sedimento) de modo que se pudo estimar la dosis beta y la gamma (tab. 2). La segunda de estas se estimó 
Tabla 1. Contenido en radionúclidos y en agua estimado para las muestras datadas por OSL. Nota: W, contenido en agua.

\begin{tabular}{|l|c|c|c|c|}
\hline \multicolumn{1}{|c|}{ Muestra } & W (\%) & U (ppm) & Th (ppm) & K (\%) \\
\hline MU141003U01 & $6 \pm 0,6$ & $1,36 \pm 0,07$ & $6,72 \pm 0,34$ & $0,82 \pm 0,01$ \\
\hline MU141003U02 & $6 \pm 0,6$ & $1,60 \pm 0,08$ & $6,82 \pm 0,34$ & $0,98 \pm 0,01$ \\
\hline MU141003U07 & $6 \pm 0,6$ & $1,25 \pm 0,06$ & $3,94 \pm 0,20$ & $0,49 \pm 0,01$ \\
\hline MU141003U11 & $6 \pm 0,6$ & $1,19 \pm 0,06$ & $6,20 \pm 0,31$ & $0,87 \pm 0,01$ \\
\hline MU141003U12 & $5 \pm 0,5$ & $1,86 \pm 0,08$ & $6,37 \pm 0,32$ & $1,20 \pm 0,01$ \\
\hline MU141003U13 & $5 \pm 0,5$ & $1,52 \pm 0,08$ & $4,09 \pm 0,20$ & $1,04 \pm 0,01$ \\
\hline MU141003U14 & $4 \pm 0,4$ & $2,44 \pm 0,12$ & $6,41 \pm 0,32$ & $2,42 \pm 0,02$ \\
\hline MU141003U15 & $6 \pm 0,6$ & $2,46 \pm 0,12$ & $8,39 \pm 0,42$ & $1,21 \pm 0,01$ \\
\hline MU141003U16 & $5 \pm 0,5$ & $2,03 \pm 0,10$ & $3,73 \pm 0,19$ & $0,88 \pm 0,01$ \\
\hline
\end{tabular}

Tabla 2. Tasas de dosis de radiación estimadas para las muestras datadas por OSL.

\begin{tabular}{|l|c|c|c|c|}
\hline \multicolumn{1}{|c|}{ Muestra } & Dr beta (mGy/a) & Dr gamma (mGy/a) & Dr cósmica (mGy/a) & Dr total (mGy/a) \\
\hline MU141003U01 & $0,91 \pm 0,10$ & $0,63 \pm 0,03$ & $0,22 \pm 0,01$ & $1,75 \pm 0,13$ \\
\hline MU141003U02 & $1,04 \pm 0,12$ & $0,55 \pm 0,14$ & $0,23 \pm 0,01$ & $1,82 \pm 0,13$ \\
\hline MU141003U07 & $0,61 \pm 0,07$ & $0,30 \pm 0,01$ & $0,23 \pm 0,01$ & $1,14 \pm 0,13$ \\
\hline MU141003U11 & $0,91 \pm 0,10$ & $0,70 \pm 0,02$ & $0,24 \pm 0,01$ & $1,84 \pm 0,13$ \\
\hline MU141003U12 & $1,22 \pm 0,14$ & $0,73 \pm 0,02$ & $0,21 \pm 0,01$ & $2,16 \pm 0,13$ \\
\hline MU141003U13 & $1,02 \pm 0,11$ & $0,69 \pm 0,02$ & $0,22 \pm 0,01$ & $1,92 \pm 0,13$ \\
\hline MU141003U14 & $2,11 \pm 0,24$ & $0,55 \pm 0,02$ & $0,22 \pm 0,01$ & $2,88 \pm 0,13$ \\
\hline MU141003U15 & $1,33 \pm 0,15$ & $0,91 \pm 0,03$ & $0,26 \pm 0,01$ & $2,50 \pm 0,13$ \\
\hline MU141003U16 & $0,97 \pm 0,11$ & $1,46 \pm 0,04$ & $0,22 \pm 0,01$ & $2,64 \pm 0,13$ \\
\hline
\end{tabular}

tanto a partir de un modelo geométrico como por espectrometría gamma portátil, obteniéndose una relación siempre cercana a 1 entre ambas (entre 0,8 y 1,2). En todas las muestras, salvo en bloques de granito, se observó una baja concentración de $\mathrm{K}$ y U y relativamente baja en Th, lo que repercute en bajas dosis anuales. En los morteros la variación observada es de entre $1,19 \pm 0,06$ y $2,46 \pm 0,10 \mathrm{ppm}$ para el $\mathrm{U}$, siendo de entre $3,94 \pm 0,20$ y $8,39 \pm 0,42 \mathrm{ppm}$ para el Th $\mathrm{y}$ de entre $0,82 \pm 0,01$ a $2,42 \pm 0,02 \%$ para el $\mathrm{K}$ en morteros (tab. 1). Esto indica una relación Th: $U$ cercana al rango de ratios $3: 1$ y $5: 1$, que estarían dentro de lo esperable en condiciones de equilibrio secular de las series de desintegración del ${ }^{238} \mathrm{U}$ y del ${ }^{232} \mathrm{Th}$ para materiales derivados de rocas graníticas y magmáticas ultrabásicas (peridotitas, incluso serpentinizadas), respectivamente (Aitken 1985, Boyle 1982). A pesar de estas similitudes, las dosis anuales estimadas oscilan relativamente entre muestras, siendo de entre $1,14 \pm 0,13$ y $2,88 \pm 0,13 \mathrm{mGy} / \mathrm{a}$ (tab. 2), principalmente debido a las variaciones estimadas en las dosis gamma y cósmica.

A pesar de que, teniendo en cuenta el rango de edad abarcado por la OSL, las muestras se pueden considerar recientes, la señal obtenida para algunas de las muestras fue relativamente elevada, siendo notablemente baja para las muestras U11, U02, U12, U14 y U15 (tab. 3), aunque dentro de lo esperado. Esto implica una relación señal/fondo relativamente elevada. Sin embargo, estas diferencias de señal no se pueden 
Tabla 3. Estimación de De obtenidas para las muestras. Nota: N: número de alícuotas; Error rel.: error relativo; Sobredis.: sobredispersión.

\begin{tabular}{|l|c|c|c|c|c|c|}
\hline \multicolumn{1}{|c|}{ Muestra } & Rango aprox. señal (cts) & $\mathrm{N}$ & $D_{e}(\mathrm{~Gy})$ & Error rel. $D_{e}(\%)$ & Sobredis. (\%) & Modelo \\
\hline MU141003U01 & $1000-14000$ & 42 & $4,12 \pm 0,17$ & 4,2 & $55 \pm 6$ & MAM \\
\hline MU141003U02 & $120-3000$ & 46 & $3,51 \pm 0,43$ & 12,2 & $43 \pm 7$ & MAM \\
\hline MU141003U07 & $300-13000$ & 34 & $0,94 \pm 0,06$ & 6,6 & $54 \pm 8$ & MAM \\
\hline MU141003U11 & $80-1300$ & 41 & $1,50 \pm 0,12$ & 8,3 & $37 \pm 7$ & CAM \\
\hline MU141003U12 & $200-2000$ & 40 & $3,52 \pm 0,17$ & 4,9 & $59 \pm 7$ & MAM \\
\hline MU141003U13 & $500-31000$ & 35 & $1,62 \pm 0,13$ & 7,9 & $38 \pm 6$ & CAM \\
\hline MU141003U14 & $150-2500$ & 34 & $2,33 \pm 0,18$ & 7,6 & $36 \pm 6$ & CAM \\
\hline MU141003U15 & $100-3000$ & 32 & $2,57 \pm 0,23$ & 9,9 & $43 \pm 8$ & CAM \\
\hline MU141003U16 & $150-17000$ & 34 & $2,57 \pm 0,14$ & 5,5 & $16 \pm 5$ & CAM \\
\hline
\end{tabular}

relacionar con las $D$ obtenidas ni con los errores estimados para la $D_{e}$, dado que el coeficiente de relación de Pearson entre señal natural y ambos parámetros apenas alcanza el 0,6. Menos clara entre la $D$ y su error, cuyo coeficiente de correlación es muy bajo. Esto se debe también al uso de diferentes modelos de edad para obtener las $D_{e}$. La señal OSL observada varía además respecto a la velocidad de caída, oscilando entre un blanqueado del $80 \%$ tras estimular la señal natural en algunas muestras durante 2-3 segundos (U01, U02, U11, U12 y U15) y en 1-1,5 segundos (U07, U13, U14 y U16), alcanzándose entre 10 y 15 segundos en las señales más lentas y en 5-10 segundos en las más rápidas.

Se han estimado las $D_{e}$ a partir de un número significativo de alícuotas aceptadas (entre 32 y 46) según los requisitos del SAR. Las distribuciones obtenidas de las $D_{e}$ de las alícuotas medidas han proporcionado distribuciones muy diversas en cuanto a asimetría, dispersión y curtosis. Algunas muestras presentaron distribuciones simétricas con baja curtosis, es decir, elevada dispersión alrededor de la media de la distribución (U11, U13, U14 y 15), o elevada curtosis, lo que implica baja dispersión (U16), siendo las que menor sobredispersión mostraban (ver tab. 4). En otras muestras se observa una mayor asimetría, como en U07 y U12, pero sobre todo en U01 y U02 (con valores de sobredispersión cercanos al 50\%). En función de estas distribuciones y los valores de sobredispersión (tab. 4), se utilizó el Modelo de Edad Central o CAM para aquellas con menor sobredispersión y simetría y el Modelo de Edad Mínima o MAM para aquellas con valores de sobredispersión más elevados y asimetría, según la propuesta de por Galbraith et al. (1999). Los tests de recuperación de la dosis mostraron un buen cociente de recuperación, alrededor de $\sim 1.0$, pero con desviaciones grandes, cercanas al $\pm \sim 0.1$ lo que indica una sensibilidad variable en las muestras. Las $D_{e}$ obtenidas se exponen en la tabla 4.

Las edades resultantes de la datación por OSL indican un amplio rango cronológico para las estructuras estudiadas. En el caso de la muestra MU141003U01 se observa que la edad obtenida es excesivamente antigua. Esto es coherente con la asimetría y sobredispersión de la $D_{e}$ de dicha muestra, que indica un evidente blanqueado parcial de la señal residual del cuarzo en el momento de preparación del mortero, por lo que consideramos que esta edad no debe tenerse en cuenta dentro de la interpretación cronológica del yacimiento. Un comportamiento similar de la señal y las alícuotas analizadas se observa en las muestras MU141003U02, MU141003U07 y MU141003U12, aunque en estos casos, la edad obtenida entra en el rango de las edades esperadas y es coincidente con los resultados de la datación por ${ }^{14} \mathrm{C}$ de otras muestras obtenidas en estructuras vinculadas a las mismas fases constructivas, pero debemos actuar igualmente con cautela.

Las edades de radiocarbono obtenidas también proporcionan dataciones diversas (tab. 5). La datación por medio de carbones proporciona edades para las UEs 15 y 17 que coinciden en una parte del rango obtenido, por lo que podrían ser contemporáneas entre sí. Sin embargo, el resto de dataciones en materia orgánica proporcionan edades más dispares y tardías. Los valores 
Tabla 4. De, DR (dosis anual) y edades obtenidas para las muestras datadas por OSL

\begin{tabular}{|l|c|c|c|r|c|}
\hline \multicolumn{1}{|c|}{ Muestra } & $D_{e}(\mathrm{~Gy})$ & $D_{r}(\%)$ & \multicolumn{1}{c|}{ Edad (a) } & \multicolumn{1}{c|}{ Edad d.C. } & Rango \\
\hline MU141003U01 & $4,12 \pm 0,17$ & $1,75 \pm 0,13$ & $2354 \pm 201$ & $339 \pm 201 \mathrm{AC}$ & $540-138 \mathrm{AC}$ \\
\hline MU141003U02 & $3,51 \pm 0,43$ & $1,82 \pm 0,13$ & $1926 \pm 270$ & $89 \pm 270$ & $182 \mathrm{AC}-359$ d.C. \\
\hline MU141003U07 & $0,94 \pm 0,06$ & $1,14 \pm 0,13$ & $825 \pm 110$ & $1187 \pm 110$ & $1077-1297$ \\
\hline MU141003U11 & $1,50 \pm 0,12$ & $1,84 \pm 0,13$ & $807 \pm 87$ & $1205 \pm 87$ & $1118-1292$ \\
\hline MU141003U12 & $3,52 \pm 0,17$ & $2,16 \pm 0,13$ & $1631 \pm 125$ & $381 \pm 125$ & $256-506$ \\
\hline MU141003U13 & $1,62 \pm 0,13$ & $1,92 \pm 0,13$ & $841 \pm 86$ & $1171 \pm 86$ & $1085-1258$ \\
\hline MU141003U14 & $2,33 \pm 0,18$ & $2,88 \pm 0,13$ & $808 \pm 71$ & $1204 \pm 71$ & $1133-1275$ \\
\hline MU141003U15 & $2,57 \pm 0,23$ & $2,50 \pm 0,13$ & $1028 \pm 114$ & $984 \pm 114$ & $869-1098$ \\
\hline MU141003U16 & $2,57 \pm 0,14$ & $2,64 \pm 0,13$ & $974 \pm 71$ & $1038 \pm 71$ & $967-1109$ \\
\hline
\end{tabular}

Tabla 5. Edades de radiocarbono obtenidas por AMS.

\begin{tabular}{|l|r|r|l|c|l|c|}
\hline \multicolumn{1}{|c|}{ Muestra } & UEb & \multicolumn{1}{c|}{ Edad 14C } & \multicolumn{1}{c|}{ Material } & \multicolumn{1}{c|}{ 13C (\%) } & \multicolumn{1}{c|}{ Código lab. } & Edad cal. d.C. \\
\hline MU150601U01 & 22 & $1590 \pm 30$ & MO & -24.5 & Beta-436841 & $400-545$ \\
\hline MU150601U02 & 17 & $1670 \pm 30$ & Carbones & -24.4 & Beta-412615 & $265-275330-420$ \\
\hline MU150601U03 & 15 & $1660 \pm 30$ & Carbones & -25 & Beta-422616 & $335-425$ \\
\hline MU150601U07 & 108 & $210 \pm 30$ & MO & -25.9 & Beta-412618 & $\begin{array}{c}1645-16851735-1805 \\
1950-\text { post }\end{array}$ \\
\hline MU150601U05 & 114 & $750 \pm 30$ & MO & -25.8 & Beta-412617 & $1225-1285$ \\
\hline MU150601U04 & 115 & $330 \pm 30$ & MO & 25.7 & Beta-436842 & $1465-1645$ \\
\hline
\end{tabular}

obtenidos de $\delta^{13} \mathrm{C}(\%)$ de la materia orgánica utilizada en la datación entran en el rango considerado para restos vegetales del suelo, lo que indicaría que no se han producido transformaciones posdeposicionales en ese material debido a la actividad de organismos o que estas han sido leves, no habiendo incorporación de ${ }^{14} \mathrm{C}$ postdeposicional en proporciones significativas, dado que eso cambiaría la relación $\delta^{13} \mathrm{C}$. Por ello, la edad radiocarbono no debería corresponder a alteraciones posteriores a la colocación de los morteros, y la edad obtenida puede corresponder en realidad al suelo de donde procedían las materias primas, lo que no se corresponde necesariamente con la edad de construcción de las estructuras en donde el mortero fue utilizado o de formación de los derrumbes datados (para el caso de las UEs 15 y 17), en los que posteriormente crecería vegetación aportando el carbono orgánico que habría sido datado en esos casos.

\subsection{Discusión}

A continuación cotejaremos los resultados de todas estas dataciones con la secuencia constructiva previamente publicada (Blanco-Rotea et al. 2015) (figs. 6-7).

Dentro del primer horizonte romano se identificaron cuatro fases en aquel trabajo que, en lo sustancial, no se ven afectadas por las dataciones obtenidas: Fase 0: planificación del fuerte. Fase I: planta original de la fortificación romana. Fase II: ocupación efectiva del fuerte durante la que se realizarían algunas reformas parciales. Fase III: intensa reestructuración del fuerte que altera su planta original.

Desde un punto de vista constructivo, los muros se alinean en sentido norte-sur y este-oeste, la modulación es ordenada, se usa una mampostería irregular-opus incertum- con piezas de tamaño medio, $\mathrm{y}$ en los esquinales e intersecciones de los muros de 


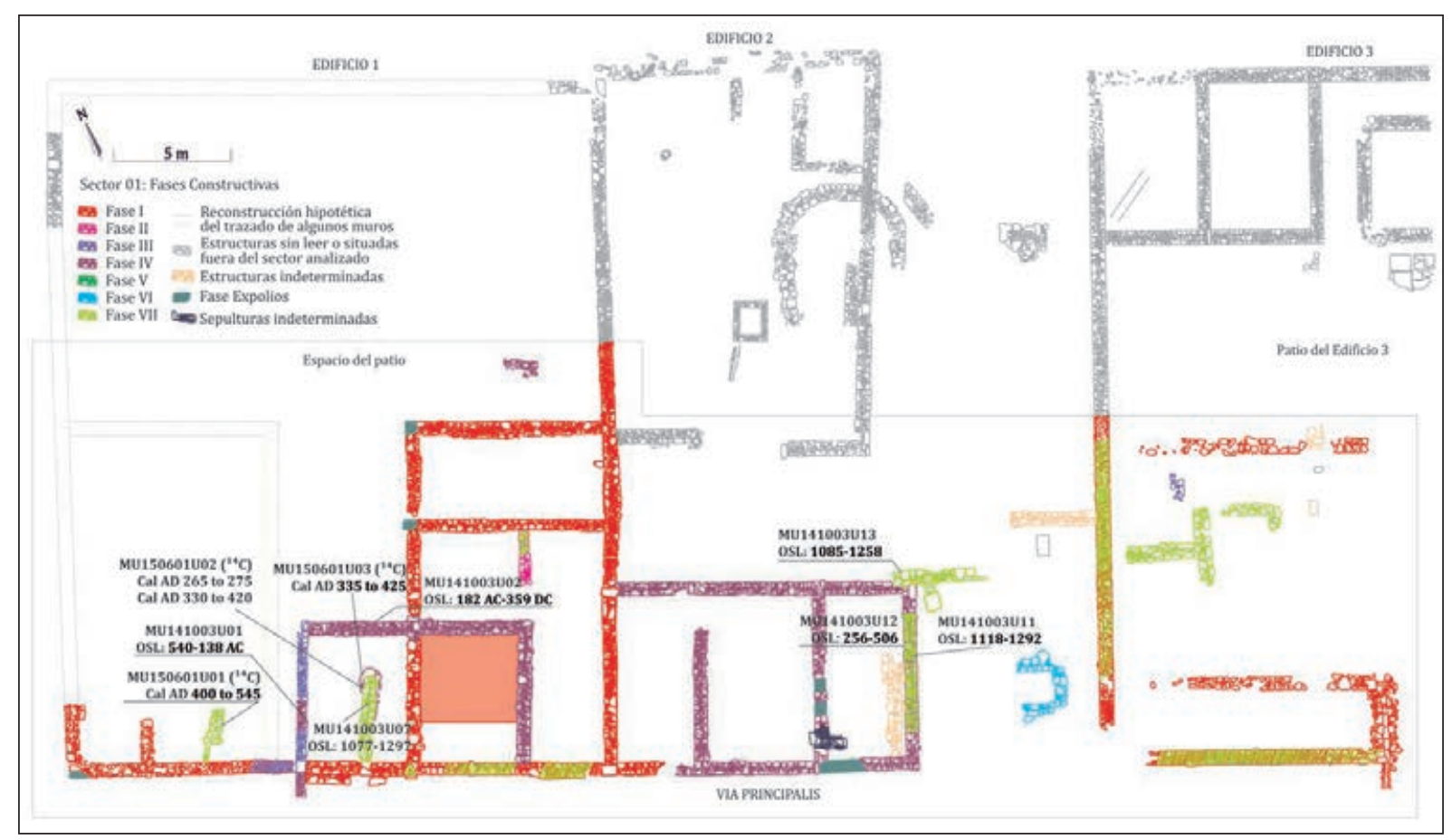

Figura 6. Secuencia constructiva en el Sector 1 con indicación de las dataciones obtenidas.

sillares aparecen piezas molduradas de granito. Además, los materiales se disponen en pseudohiladas, las juntas están enripiadas y presentan mortero de tierra, y se documentan dos caras y núcleo sin tizones. Únicamente en la fase III se emplea teja como ripio y se reutilizan sillares de granito. Las cimentaciones de los muros perimetrales se asientan sobre una capa de gravas, mientras que los muros tabiqueros se disponen a una cota superior. Los pavimentos son de tierra apisonada sobre varias capas de drenaje de grava y piedra, documentándose puntualmente el uso de opus signinum.

Dado que el objetivo de la intervención fue la datación de las fases posromanas, las escasas muestras tomadas en las estructuras de este horizonte no fueron procesadas. La datación más antigua obtenida por OSL (MU141003U01) corresponde al mortero del muro UEM123 perteneciente a la fase $\mathrm{V}$, una reforma del muro UEM011 de la fase III. Sin embargo, el arco obtenido, 540-138 a.C., es una edad excesivamente antigua para este yacimiento. La asimetría y sobredispersión de la $D_{e}$ en dicha muestra indica un blanqueado parcial de la señal residual del cuarzo en el momento de preparación del mortero, por lo que esta edad está claramente sobreestimada y no debe tenerse en cuenta dentro de la interpretación cronológica del fuerte.
Un segundo horizonte tardorromano se relacionó con el abandono del fuerte y su posterior reconstrucción y reocupación parcial. A este periodo pertenece la fase IV, cuyas estructuras se asientan sobre derrumbes de teja terraplenados o pavimentos romanos. Los muros son de mampostería irregular, de dos hojas, con piezas de diversos materiales (peridotitas serpentinizadas, granodioritas y granito), sin tizones y de factura menos cuidada y más irregular que los muros romanos. Inicialmente se dató esta fase en los siglos IV-VI d.C. a partir del conjunto de materiales identificados en los derrumbes excavados en 2006, siendo difícil adscribir con seguridad estructuras a la misma (Blanco-Rotea et al. 2015: 83).

Con la intención de datar de forma absoluta esta fase, se tomaron varias muestras procedentes de depósitos relacionados con los derrumbes de pizarra. Así, el depósito situado bajo este derrumbe, con abundante teja (UEM015, MU150601U03/ Beta-422616), arrojó una datación por ${ }^{14} \mathrm{C}$ de $335-425$ d.C. considerando un intervalo $2 s$ (98\% de probabilidad). El depósito de tierra ubicado sobre este, que sirve de asiento al muro UEM018, ofreció una datación $(2 s)$ de 265-275 y 330-420 d.C. (UEM017, MU150601U02/ Beta-412615). Por su parte, un depósito similar a este, localizado bajo el muro UEM024, ha sido datado en 400-545 d.C. (UEM022, MU150601U01/ Beta-436841) (fig. 6). Es decir, nos 


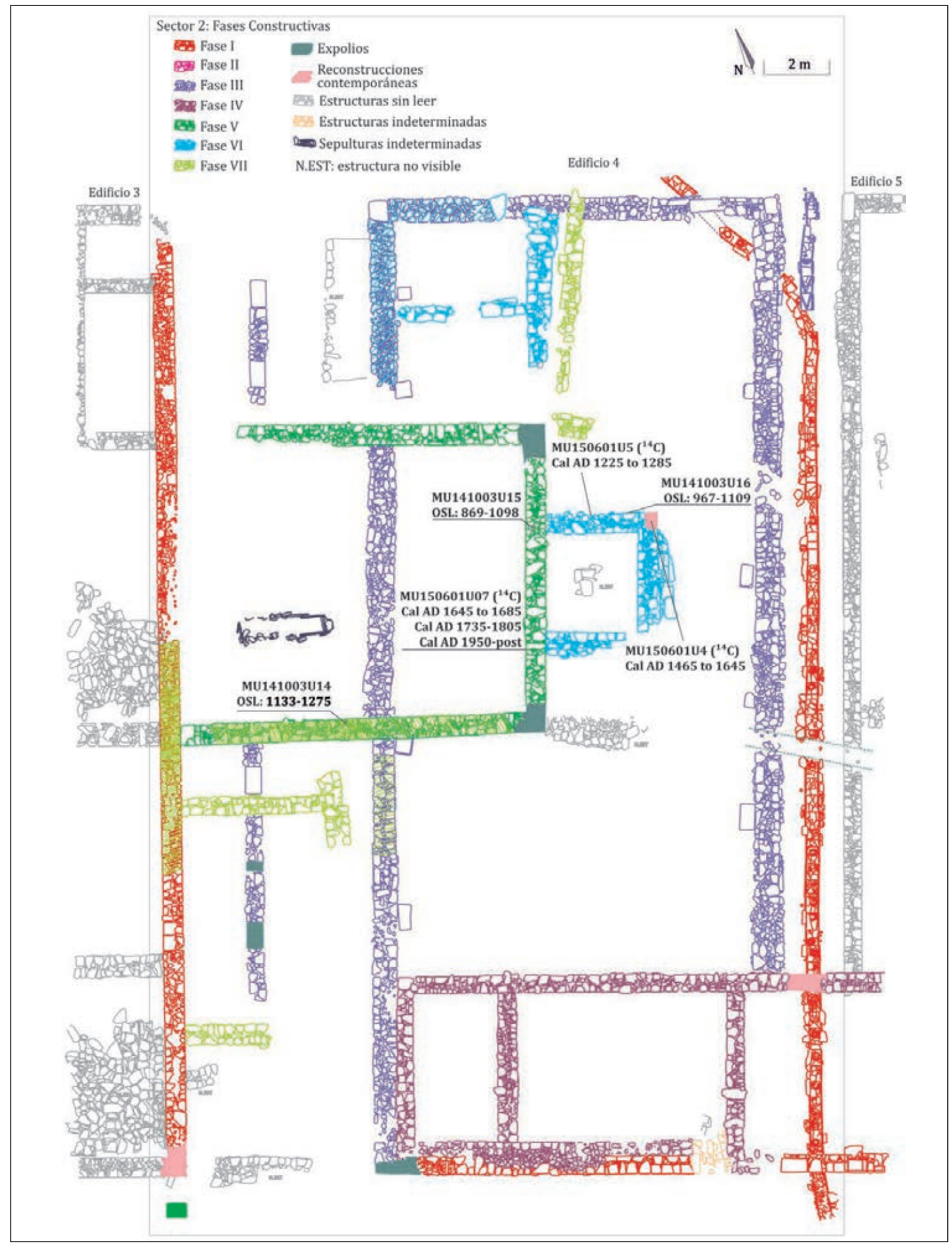

Figura 7. Secuencia constructiva en el Sector 2 con indicación de las dataciones obtenidas.

ISSN: $1133-4525$ ISSN-e: 2255-3924 
encontramos en un horizonte entre los siglos IV-V y primera mitad del VI, espectro también cubierto por la cultura material.

Significativos son los resultados de la datación por OSL del mortero de la UEM051 (MU141003U12), que la encuadran en 256-506. Esta estructura se consideró inicialmente parte de la fase 1 del horizonte romano, pero podría ahora enmarcarse en el proceso general de reforma de la fase III o bien tratarse de una ampliación del Edificio 1 vinculada a la fase IV. Puesto que la estructura se recreció en momentos posteriores, no es posible determinar con exactitud este punto.

Al horizonte tardoantiguo se vincularon dos fases que ahora podemos encuadrar mejor desde un punto de vista cronológico. Durante la fase V se habrían rehabilitado y recrecido muchos de los muros romanos, manteniendo su orientación y doblándose en casos puntuales. Las estructuras presentarían dos caras y relleno, empleándose los mismos materiales que en las estructuras de la fase IV y fragmentos de teja como material de relleno de los muros. Con todo, el módulo de las piezas sería de mayor tamaño y las hiladas más irregulares. La identificación de tizones nos permitió diferenciar definitivamente estos muros de los encuadrados en la fase IV, aparentemente desprovistos de ellos. Estas reformas se extenderían a la práctica totalidad de los edificios excavados.

Se documentaron también muros de nueva planta que, aunque seguían la modulación y orientación romanas, eran más estrechos, no respetaban la división interna de los edificios previos y presentaban su cimentación a una cota más elevada. En concreto, se vinculó a esta fase uno de los edificios de nueva planta que ocupa parte de los Edificios 3 y 4 . Se orientaría en sentido oeste-este y habría sido identificado como posible iglesia.

Hasta la fecha, esta fase se había encuadrado en el siglo VII d.C. de acuerdo con la datación genérica de las piezas metálicas documentadas en anteriores excavaciones arqueológicas. Sin embargo, los resultados de las nuevas dataciones permiten replantear dicha cronología. Por un lado, todas las muestras recogidas en los morteros de junta de los recrecimientos arrojan dataciones similares en las dos técnicas empleadas $\left({ }^{14} \mathrm{C}\right.$ y OSL), moviéndonos entre los siglos XII y XIII (UEM052, MU141003U11: 1118-1292 d.C.; UEM107, MU14100314: 1133-1275 d.C.; UEM114, MU150601U05/ Beta-412617: 1225$1285 \mathrm{dC}$.). Por su parte, la muestra tomada en el edificio de nueva planta (UEM108, MU141003U15) lo sitúa entre 869-1098 d.C. Esto, unido a los resultados de los elementos datados en las siguientes fases, nos permite encuadrar los recrecimientos en un horizonte plenomedieval, mientras que la construcción de este y otros edificios de nueva planta de similares características se situarían en un horizonte altomedieval.

La fase VI también se incluyó en el horizonte tardoantiguo propuesto inicialmente. Se corresponde con varias acciones constructivas (Blanco-Rotea et al. 2015: 86) de las que destacaremos ahora una de ellas por su carácter representativo: la pequeña estancia cuadrangular adosada al muro este del edificio de nueva planta, identificada como ábside. Situada a una cota superior, sus muros tienen una mayor anchura y presentan en las caras internas un aparejo de sillarejo dispuesto en hiladas horizontales. Es destacable el abundante uso de tizones y aunque los muros exteriores están muy arrasados, se observa todavía en su cara este un forrado de sillares de granito en las hiladas inferiores y esquinales, así como de peridotitas y granodioritas en el resto del muro. Las dos hiladas inferiores se apoyan sobre un zócalo también sobresaliente. A diferencia de la fase anterior, los muros se asentaban sobre tierra y presentan dos caras con relleno de tierra y mampuestos. Dado que el ábside no se imbrica con el muro de la posible nave, sino que se apoya en ella, consideramos que no pertenecen a la misma fase constructiva. Su datación mediante OSL (UE114, MU141003U16) lo sitúa en 967-1109 d.C., fecha ligeramente posterior a la de la nave. Por estos motivos, se confirma que esta fase no sería tardoantigua, sino altomedieval.

Todo esto genera un conflicto con el encuadre cronológico de la fase VII, originariamente fechada en época altomedieval de acuerdo con algunos materiales. A ella pertenecen una serie de muros construidos sobre los derrumbes de cubiertas (en los depósitos se observan tanto fragmentos de teja como de lajas de pizarra), pavimentos y estructuras de las fases anteriores. Los muros presentan una anchura irregular, son ondulantes, no guardan un orden estético y carecen de cimentación, rompiendo con la articulación ortogonal de las fases previas. Sin embargo, ahora nos replanteamos esta ruptura, puesto que las dos muestras tomadas en muros de esta fase en el sector 1 han arrojado dataciones que se mueven entre los siglos XI y XIII (UEM018, MU141003U07: 1077-1297 d.C.; UEM053, MU141003U13: 1085-1258 d.C.). Estas fechas coinciden con las reconstrucciones en altura efectuadas en los muros romanos y tardorromanos, por lo que se encuadrarían en el nuevo horizonte plenomedieval. O bien en este momento se llevan a cabo dos tipos de acciones (construcción de estancias de nueva planta y recrecimiento de muros preexistentes) o bien dentro de este horizonte podrían existir diversas fases que aún no somos capaces de diferenciar. 
Dos fases se identificaron en un horizonte posmedieval. La fase VIII se vinculó a una serie de parcelaciones y expolios que afectaron a diferentes zonas del yacimiento, también documentados en los sondeos (vid. infra). Hoy sabemos que la actividad de expolio debió producirse ya en plena Edad Media. De hecho, muchos de los materiales usados en la iglesia parroquial románica (c 1200) situada extramuros del fuerte son romanos (sillares de granito con marcas de diferentes sistemas de elevación, sillares que presentan la misma modulación que los documentados en el fuerte, etc.). Igualmente, en la serie de enlosados que hoy podemos datar en el siglo XIII también se reutilizan materiales anteriores. Estas actividades se habrían extendido hasta prácticamente la actualidad. Una de las muestras recogida en una de la zona de los expolios (UEM115) ha ofrecido una datación de 1465 - 1645 d.C. (MU150601U04/Beta-436842). Cabe señalar que a esta fase se había vinculado también un ancho muro hoy desaparecido por encontrarse a una cota superior a la del Edificio 4. Como veremos, se trata de una estructura muy similar a la documentada en el sondeo 2 (UE107), fechada por ${ }^{14} \mathrm{C}$ en el $895-925$ y $940-$ 1020 d.C. (MU160624U04/Beta-448170).

Finalmente, la fase IX se corresponde a distintas acciones llevadas a cabo en el yacimiento en época contemporánea, que incluyen actividades agrícolas y de pastoreo, reparcelaciones, las propias intervenciones arqueológicas, la construcción de la cubierta y caseta, etc.

\section{ANÁLISIS GEOLÓGICO Y PETROLÓGICO}

Tras la reformulación de las distintas fases constructivas a partir de las nuevas dataciones absolutas, nos planteamos realizar la identificación de los distintos materiales pétreos empleados en cada fase y la determinación de su origen. La identificación mediante análisis petrológico nos permitirá comprobar si algún tipo de roca fue utilizado de forma prioritaria en alguna etapa concreta o por si el contrario, todos se utilizaban indistintamente a lo largo de la historia de la ocupación del lugar. Por su parte, la determinación de la procedencia (local o alóctona) del material pétreo utilizado en la construcción también nos puede ofrecer interesante información sobre la organización, aprovisionamiento y grado de inversión económica de las tareas constructivas en cada una de las etapas de ocupación del yacimiento. Por todo ello se procedió en 2016 a la identificación de las distintas litologías que aquí pasamos a describir.

\subsection{Contexto geológico}

El yacimiento de A Cidadela está incluido en la Hoja 71 de la cartografía geológica nacional del IGME. El contexto geológico es el propio del Dominio de GaliciaTras os Montes, dentro de la Zona Centroibérica del Macizo Ibérico, caracterizado por la presencia de rocas graníticas y complejos metamórficos de distinto tipo asociados a la sutura oceánica durante la Orogenia Hercínica (Arenas et al. 1995). Localmente la estructura más importante es el antiforme de Sobrado, una ventana tectónica en la que afloran rocas metamórficas de grado medio y alto y rocas ultramáficas de origen profundo. En su parte más oriental, este antiforme limita con unos afloramientos graníticos de dos litologías distintas que discurren de forma paralela entre sí en una banda con dirección NNO-SSE. En ambos casos son rocas muy deformadas y que petrológicamente corresponden a granitos de dos micas y, más al $\mathrm{E}$, granodioritas (fig. 8). El yacimiento se localiza entre las peridotitas serpentinizadas del centro del complejo polimetamórfico de Sobrado y las rocas metabásicas que las rodean, compuestas fundamentalmente por granulitas máficas y anfibolitas. Estas serpentinitas aparecen en numerosos afloramientos en la zona. Su aspecto suele corresponder a una roca bandeada, aunque se pueden encontrar muestras homogéneas.

\subsection{Metodología}

En una primera fase de determinación, se observaron varias litologías en los muros del yacimiento: esquistos, pizarras, serpentinitas y granitoides, siendo estas dos últimas las más abundantes. Tras este proceso de identificación en los muros objetos de estudio y su disposición en el entorno, se tomaron 5 muestras de las litologías dominantes en los muros del yacimiento (M-1, M-2, M-3, M-4 y M-5). Así, las rocas más comunes corresponden a dos tipos distinguibles por su aspecto macroscópico:

1) Rocas de aspecto masivo, homogéneo, de grano fino y con coloraciones verdosas, con alguna banda de colores más claros (M-1, M-2 y M-3).

2) Rocas de aspecto granítico de grano grueso a medio con abundancia de feldespatos, aparición de megacristales y presencia de máficos (M-4 y M-5).

A continuación se realizaron análisis químicos y mineralógicos para determinar su composición y mineralogía. La composición química se determinó mediante Fluorescencia de Rayos X (XRF) usando 
un equipo MALDI-TOF, Voyager STR-DE de AB. La mineralogía se determinó mediante difracción de Rayos X (XRD), utilizándose un equipo D5000 SIEMENS. Ambos análisis se realizaron en las instalaciones de los Servicios Xerais de Investigación (SAI) de la Universidade da Coruña (UDC). De cada una de las muestras se realizó una lámina delgada para su análisis mediante microscopio óptico de polarización (Nikon 512005). Asimismo se empleó una lupa Nikon H550S para observar detalles macroscópicos de la textura de las rocas.

\subsection{Resultados}

Para las muestras M-1, M-2 y M-3, los resultados obtenidos en los análisis XRF (tab. 6) muestran valores típicos de rocas básicas en un sentido amplio, serpentinitas con un origen en rocas ultrabásicas (Krauskopf y Bird 1995). La composición mineralógica es rica en antigorita y magnetita y presenta minerales accesorios como el talco o piroxenos ricos en $\mathrm{Mg}$. El estudio visual macro y microscópico permite identificar texturas metamórficas que las categorizan como peridotitas serpentinizadas. Estas rocas son las más habituales en el conjunto del yacimiento (fig. 9).

Las muestras M-4 y M-5 (fig. 9.5 y 9.6) corresponden a rocas graníticas muy deformadas, encontrándose ambas dentro del rango composicional de una granodiorita (Krauskopf y Bird 1995). Debe senalarse asimismo que al interior del propio yacimiento se observó la existencia de afloramientos sucesivos que aparecen como una banda en el sector centro-oriental, al E de la teórica iglesia (vid. infra). La presencia de grandes cristales de feldespatos y, en menor cantidad, de cuarzo, parece indicar el origen de la misma en alguno de los dos tipos de granodiorita (precoz y de dos micas) que afloran en este emplazamiento. Por su parte, la muestra M-5 (fig. 9.6), con grano más fino, posiblemente se relacione con los granitos poco deformados que aparecen al E de la parroquia y que corresponden al denominado granito de Friol (IGME 1981).

\subsection{Discusión}

No se ha constatado un uso diferencial de materiales pétreos en las distintas fases constructivas. Tanto las serpentinitas como los granitos se combinan y se reutilizan indistintamente y en proporciones similares en los muros de las diferentes etapas identificadas. Además en ambos casos hemos podido determinar que se trata de materiales locales, procedentes del área del propio yacimiento o su entorno inmediato.

Diferente es, en cambio, la situación de las pizarras identificadas en el yacimiento, cuya litología es distinta a la de las pizarras propias del Complejo de Órdenes que afloran en la zona y son, por tanto, claramente importadas desde un ámbito supralocal-regional. Estas pizarras aparecen en niveles relacionados con el horizonte "post-campamental" y muchas de ellas se encuentran agujereadas. En ocasiones se relacionan directamente con clavos de hierro y en algunos casos aparecen formando niveles uniformes de derrumbe (Ramil González 2007), motivos por los que se ha considerado que serían usadas principalmente como elementos de cubrición. Puesto que en época romana las construcciones cuentan con cubiertas de teja e ímbrice, se dedujo que estas piezas fueron empleadas con tal finalidad en un momento posterior (Caamaño Gesto y Fernández Rodríguez 2006: 171-172). Sin embargo, como se vio durante la campaña de 1996, la pizarra habría sido usada también como material constructivo en los llamados muros “germánicos” (Fernández Rodríguez 1997:84), sin descartar que fuese parte del generalizado proceso de extracción y reutilización de elementos pétreos procedentes de fases anteriores. De hecho, durante esta misma intervención habrían aparecido fragmentos de pizarra en contextos teóricamente "romanos". Cabe la posibilidad, entonces, de que la introducción de la pizarra sea un fenómeno que debamos ubicar en un momento entre la fase de ocupación militar romana y la construcción de las denominadas estructuras "germánicas", no asociándose, por tanto, de manera directa con estas últimas.

\section{SONDEOS DE LA CAMPAÑA 2016}

Los distintos análisis que hemos presentado en los apartados anteriores (dataciones absolutas, revisión de materiales, análisis geológico y lectura estratigráfica de muros) suponen un importante avance en nuestro conocimiento de las estructuras excavadas a lo largo de varias décadas en el yacimiento de A Cidadela. Sin embargo, seguía siendo necesario la obtención, registro y datación de nuevas secuencias estratigráficas limpias, que sirviesen de contrapunto a los resultados obtenidos con anterioridad, y que permitiesen calibrar la naturaleza, el alcance y la extensión espacial de las ocupaciones posromanas del yacimiento. Por tanto, 


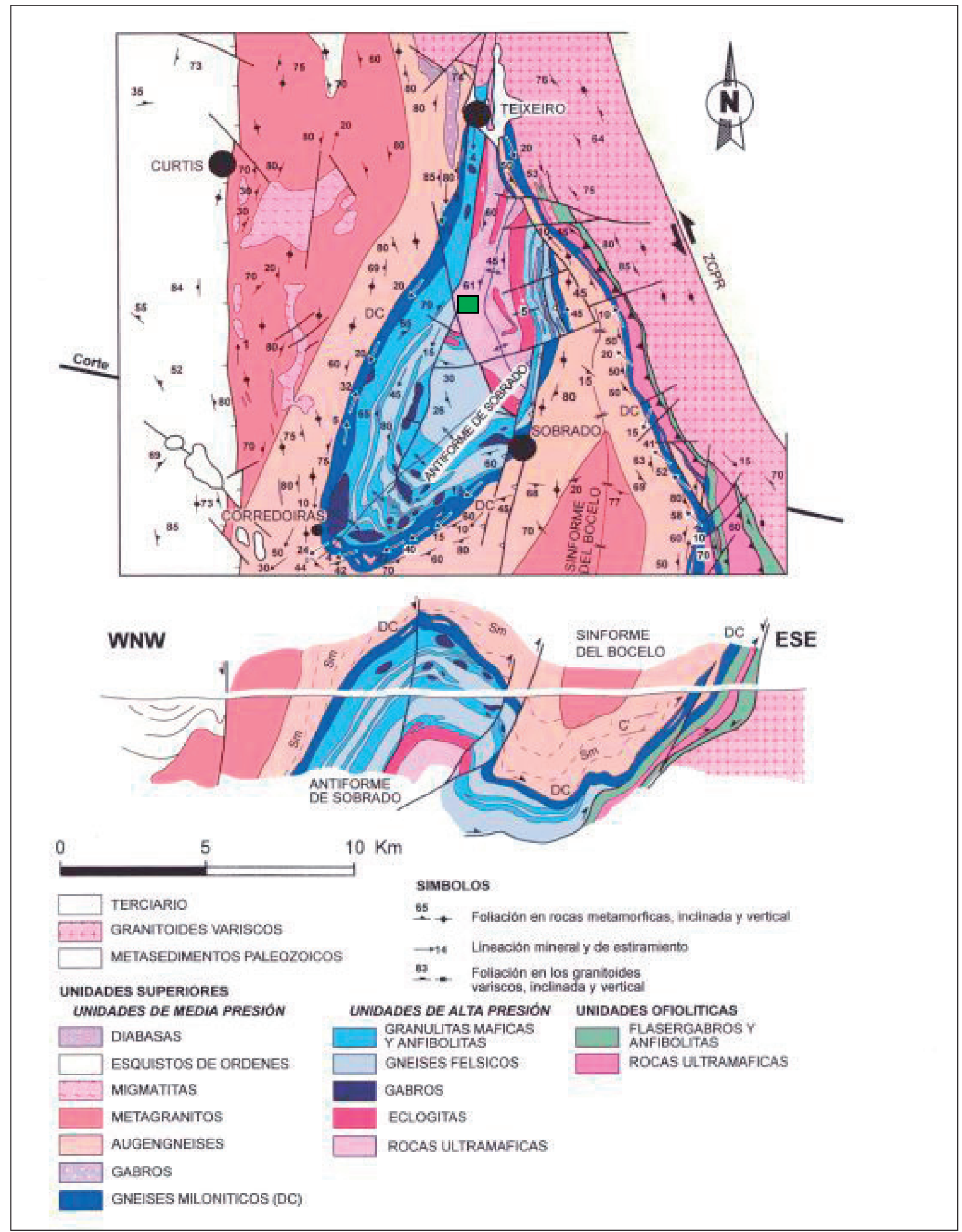

Figura 8. Situación del yacimiento en el mapa geológico del IGME (tomado de Arenas et al. 2016). El yacimiento está representado con un rectángulo verde en el mapa. 
Tabla 6. Composición química por XRF de las muestras recogidas.

\begin{tabular}{|c|c|c|c|c|c|}
\hline & Cidadela M-1 & Cidadela M-2 & Cidadela M-3 & Cidadela M-4 & Cidadela M-5 \\
\hline $\mathrm{SiO} 2$ & 44,000 & 45,000 & 44,500 & 64,900 & 69,200 \\
\hline $\mathrm{A} 12 \mathrm{O} 3$ & 3,700 & 2,800 & 2,600 & 19,000 & 17,300 \\
\hline $\mathrm{K} 2 \mathrm{O}$ & 0,022 & - & - & 8,200 & 5,900 \\
\hline $\mathrm{Na} 2 \mathrm{O}$ & - & - & - & 4,700 & 4,900 \\
\hline $\mathrm{Fe} 2 \mathrm{O} 3$ & 9,900 & 9,700 & 9,400 & 1,400 & 1,200 \\
\hline $\mathrm{CaO}$ & 0,026 & - & 0,014 & 0,580 & 0,460 \\
\hline $\mathrm{MgO}$ & 41,200 & 41,100 & 42,300 & 0,510 & 0,320 \\
\hline $\mathrm{TiO} 2$ & 0,061 & 0,048 & 0,036 & 0,220 & 0,130 \\
\hline $\mathrm{P} 2 \mathrm{O} 5$ & - & - & - & 0,340 & 0,430 \\
\hline $\mathrm{BaO}$ & - & - & - & 0,150 & - \\
\hline $\mathrm{MnO}$ & 0,140 & 0,110 & 0,150 & 0,019 & 0,014 \\
\hline $\mathrm{ZrO} 2$ & - & - & - & 0,011 & 0,009 \\
\hline $\mathrm{SrO}$ & - & - & - & 0,023 & 0,007 \\
\hline $\mathrm{ZnO}$ & 0,013 & 0,015 & 0,012 & - & 0,010 \\
\hline $\mathrm{Rb} 2 \mathrm{O}$ & - & - & - & 0,043 & 0,036 \\
\hline $\mathrm{CuO}$ & 0,010 & 0,008 & 0,009 & 0,007 & 0,008 \\
\hline $\mathrm{SO} 3$ & - & - & - & - & - \\
\hline $\mathrm{Cr} 2 \mathrm{O} 3$ & 0,340 & 0,500 & 0,410 & - & - \\
\hline $\mathrm{NiO}$ & 0,300 & 0,330 & - & - & 0,300 \\
\hline
\end{tabular}

decidimos realizar dos sondeos en el yacimiento en junio de 2016. Teniendo en cuenta estos objetivos, la extensión de ambos sondeos no podía ser excesiva, a fin de no comprometer la calidad del registro. Por otro lado, debían seleccionarse áreas donde se pudiese garantizar la existencia de dichas fases de ocupación, aun teniendo en cuenta lo complicado que ello podía resultar a priori.

En este apartado describiremos los resultados de estos dos sondeos y las dataciones radiocarbónicas realizadas en ellos. Debemos indicar que en ellos apenas se detectaron materiales, que fundamentalmente eran fragmentos de tégula, por lo que desde este punto de vista no aportan apenas información que permita avanzar en la interpretación de la cultura material del yacimiento, aunque sí, en cambio, complementan y refuerzan las secuencias de ocupación del yacimiento previamente identificadas.

\subsection{Sondeo 1}

Se localizó a continuación del sector abierto en 2010 al sur de la antigua via principalis (fig. 1, S01). No solo se habían documentado aquí niveles estratigráficos y estructuras relacionadas con las fases de ocupación posromanas, sino que la apertura de un sondeo en esta área nos permitiría ahondar en la comprensión general de los sectores que se ordenaban alrededor de un gran espacio de tránsito. De este modo, se planteó la apertura de un sondeo de $2 \times 8 \mathrm{~m}\left(16 \mathrm{~m}^{2}\right)$ que, siguiendo los planteamientos y la retícula planimétrica establecida en anteriores intervenciones, integraba parcialmente las cuadrículas K31, K32 y K33.

Pese a lo reducido de su extensión, este sondeo presenta una estratigrafía bastante compleja en la que es posible identificar la existencia de hasta nueve fases (fig. 10): 


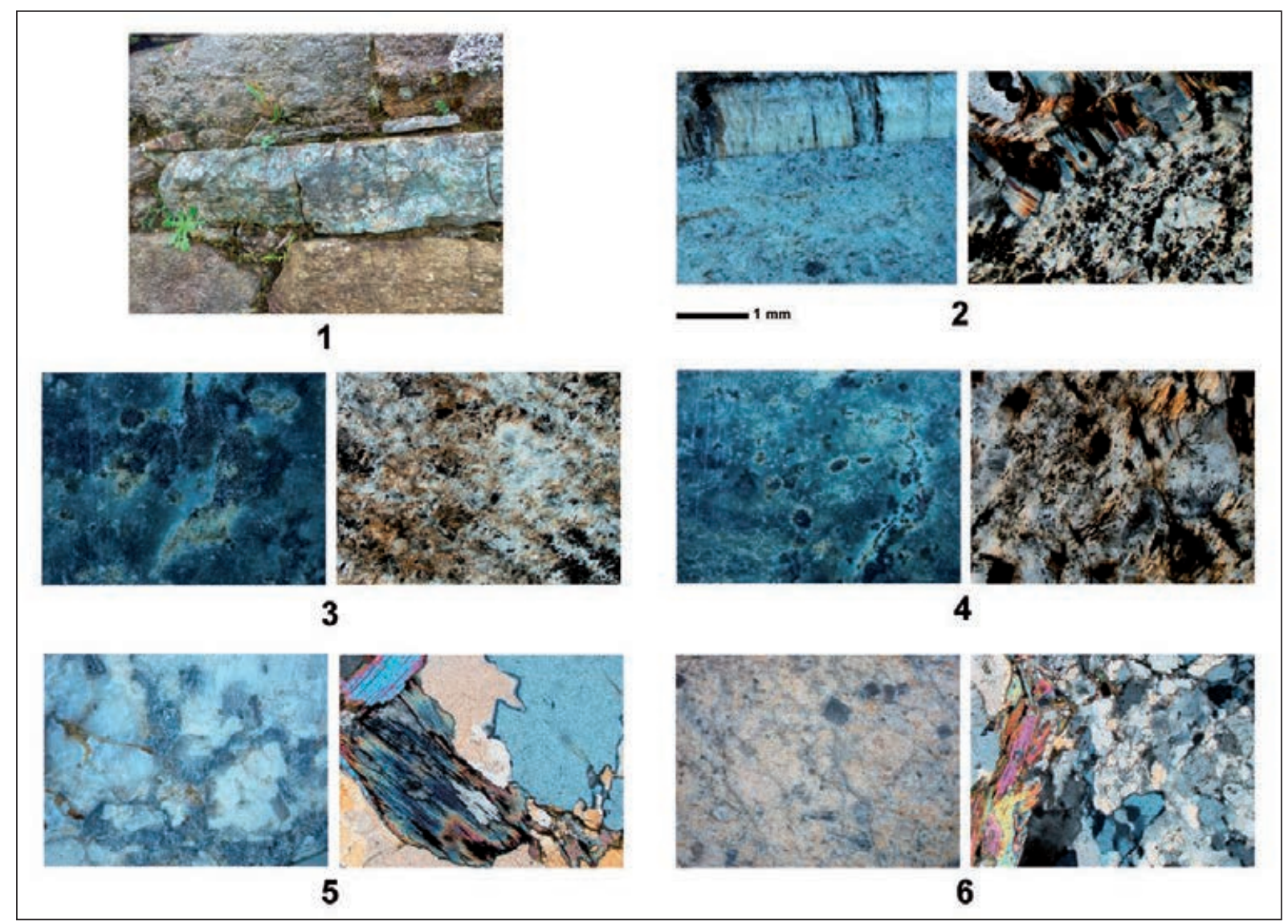

Figura 9. Petrología del yacimiento. 1: detalle de un muro con los dos tipos litológicos principales (serpentinitas y granitoides). 2: muestra 1 (M1), serpentinita. A la izquierda, en lupa, a la derecha al microscopio, en la que se aprecia antigorita, opacos y relictos de piroxeno. 3: muestra 2 (M2), serpentinita, bajo la lupa (izquierda) y al microscopio (derecha). 4: muestra 3 (M3) serpentinita, bajo la lupa (izquierda) y al microscopio (derecha). 5: muestra 4 (M4), granodiorita. En lupa, a la izquierda, se observa cuarzo y feldespatos. Al microscopio, a la derecha, se aprecia cuarzo y micas. 6: muestra 5 (M5), granodiorita. En lupa, a la izquierda, se observa plagioclasa y cuarzo. Al microscopio, a la derecha, se aprecia cuarzo, plagioclasa, microclina y micas.

a) Primera fase constructiva. Está representada por un muro de doble cara (UE019) cuya factura, orientación y dimensiones $(63-65 \mathrm{~cm})$ permiten identificarlo como un muro de carga romano (Blanco-Rotea et al. 2015, Costa-García 2010), que parte de una construcción ya documentada durante la intervención de 2010 (Ramil González et al. 2013).

La estructura divide el sondeo en dos sectores bien diferenciados. Hacia el norte, sobre la zapata del muro (UE026) nos encontramos con un depósito de tierra, gravilla y tejas meteorizadas (UE022) que habría servido de cama para un estrato de matriz arcillosa identificado como pavimento de época romana (UE018). Este suelo parece pertenecer a una reforma dentro del propio periodo romano. Desgraciadamente, la datación radiocarbónica de la muestra de sedimento orgánico MUCID160623U05/Beta448173 obtenida no fue concluyente.

Al sur del sondeo se documenta un panorama completamente diferente, sobre la zapata de cimentación (UE029) se identificó un pavimento arcilloso, amarillo y apisonado (UE025) sellado por un potente derrumbe de teja (UE020). Se trata de una secuencia ya detectada en los años 2006-2010 en las edificaciones situadas a ambas márgenes de la via principalis.

b) Abandono y colapso de la primera fase constructiva. Esta fase se documenta solo en el sector meridional del sondeo y viene representada por el mencionado derrumbe (UE020) y por la disgregación del muro, que atestiguan dos depósitos arcillosos con pequeñas piedras (UE016 y UE027). 
c) Primer expolio. También al sur del sondeo se documenta un corte en los estratos más antiguos (UE024), cuyo relleno (UE023) es un depósito revuelto con materiales muy fragmentados y tierra suelta.

d) Segunda fase constructiva. Esta fase replica la división de espacios ya vista con anterioridad, con el desarrollo de un espacio cubierto hacia el sur y un ámbito de tránsito hacia el norte. Sirve como divisor un muro (UE015) que recrece la antigua estructura romana, un fenómeno ya evidenciado previamente en otros puntos del yacimiento (Blanco-Rotea et al. 2015, Costa-García y Varela Gómez 2011) y que había sido definido tradicionalmente como el epítome de "lo germánico". Sin embargo, la muestra de sedimento MUCID160624U01/Beta-448174 nos remite con claridad a la segunda mitad del siglo XIII (Cal AD 1225 to 1285), en la línea de lo ya visto en el apartado anterior.

Al interior de la construcción se identificó un depósito uniforme de tierra arcillosa y compactada (UE011) que sellaba el derrumbe y el expolio de los estratos romanos, actuando posiblemente como pavimento. Al exterior se detectó otro pavimento que usa mampuestos graníticos romanos en su construcción (UE017), fenómeno ya documentado en 2010 (Ramil González et al. 2013) y que posiblemente se relaciona con una repavimentación posterior de la antigua vía romana.

e) Segundo expolio. A continuación se produjo la extracción de algunas de las piezas graníticas que conformaban este pavimento, pues se localizaron buzadas y desplazadas de su posición original. Rellena la interfaz extractiva (UE028) un depósito de materiales revueltos (UE014) en el que se halló un ladrillo romano que, como otros documentados en 2010 (Carlsson-Brandt Fontán 2011), habrían servido para parchear la vía romana.

f) Colapso del segundo horizonte constructivo. Aunque no sabemos exactamente cuándo tuvo lugar el expolio, todo parece indicar que habría sucedido con anterioridad al derrumbe de la estructura recrecida en el siglo XIII. Este fenómeno se atestigua mediante un pequeño depósito de tierra (UE013) cuya coloración, textura y materiales se corresponderían con el núcleo del muro y un potente derrumbe de piedras y tejas (UE012) que en su caída hacia el sur habrían destruido parcialmente el pavimento interior (UE011).

Con el fin de determinar el momento en que se habría producido el colapso de la mencionada estructura, se dató por radiocarbono una muestra de carbones de la UE013 (MUCID160623U04/Beta448175), cuyos resultados nos remiten con mayor probabilidad a un momento avanzado del siglo IV d.C. (Cal AD 255 to 295; Cal AD 320 to 415). No es la primera vez que se obtienen dataciones de este tipo en contextos teóricamente posteriores y este fenómeno puede relacionarse con el abundante contenido de material reutilizado que presentaba el depósito.

g) Tercer horizonte constructivo. Dos estratos indican la existencia de una última fase constructiva en este sondeo. En el sector norte nos encontramos con un revuelto compactado de tierra, piedras y material latericio que podría haber sido empleado como suelo de uso (UE009). Al sur, otro depósito (UE007) parchea, cubre y nivela los estratos anteriores. Muestra una elevada compactación y plasticidad, así como una casi total ausencia de piedra y teja.

h) Colapso del tercer horizonte constructivo. Dos derrumbes (UE008 y UE010) cubren este nivel de relleno interior. Presentan un buzamiento diferenciado pero idéntica composición, indicio de su coetaneidad. La muestra de sedimento (MUCID160621U01/Beta-448172), tomada en uno de los derrumbes, arrojó un resultado de 1695-1735, 1815-1920, y post 1950, aunque cabe la posibilidad de que esté datando en realidad alteraciones sobre el propio derrumbe.

i) Actividades antrópicas recientes. Sobre estos estratos se hallaron varios depósitos que cubren uniformemente el sondeo (UE006, UE004 y UE003). Son niveles de tierra oscura compactada, con presencia de material latericio muy rodado y piedras. Las bolsadas informes de arcilla roja en los estratos inferiores revelan tal vez los efectos de rozas o quemas controladas, también documentadas en el sondeo 2. Un corte en los mismos (UE005), cuyo relleno (UE002) está compuesto por arena y presenta abundante tornillería, se relaciona con la instalación de la cubierta metálica en el yacimiento en 2000 .

\subsection{Sondeo 2}

En el segundo sondeo se planteó la exploración de un área inédita del yacimiento con el objetivo de comprobar la extensión real de las referidas fases de ocupación posromanas. Su localización exacta en el área de la retentura (fig. 1, S02) se fio al uso combinado 


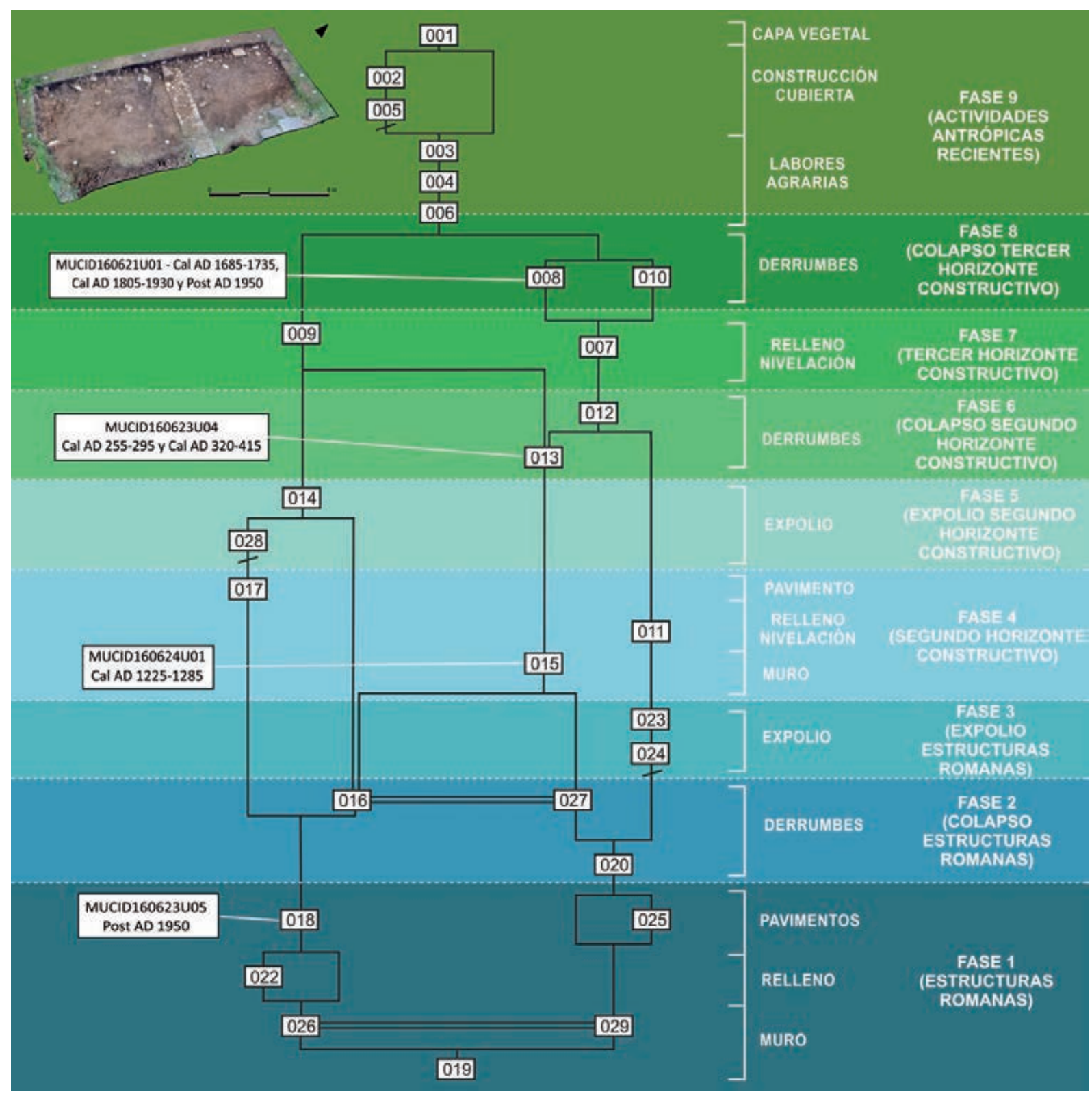

Figura 10. Matrix del sondeo 01 con indicación de las dataciones obtenidas.

de algunos cálculos relativos al ordenamiento del yacimiento en época romana (Costa-García 2011) y a los resultados de la prospección geofísica desarrollada con carácter experimental. Dicha prospección fue realizada por los técnicos del Sistema de Información Territorial de la Universidade de Santiago de Compostela en colaboración con el ingeniero Manuel Pereira. Para esta actividad se utilizó un georradar MALÅ GPR ProEx System con antenas apantalladas de $250 \mathrm{MHz}$ y $500 \mathrm{MHz}$. Ante la imposibilidad de cubrir en su totalidad el área norte del yacimiento en la jornada de trabajo prevista $(0,86$ ha), se optó por definir una serie de transectos (10 longitudinales y 7 transversales) que, en forma de retícula, ofrecerían un muestreo representativo del sector

Un sondeo de $4 \times 4 \mathrm{~m}\left(16 \mathrm{~m}^{2}\right)$ se abrió a caballo entre las cuadrículas T17 y T18 de la retícula original donde las anomalías mostradas por los radargramas nos habían hecho pensar en la existencia de derrumbes $\mathrm{y} / \mathrm{o}$ estructuras a una cota prácticamente 


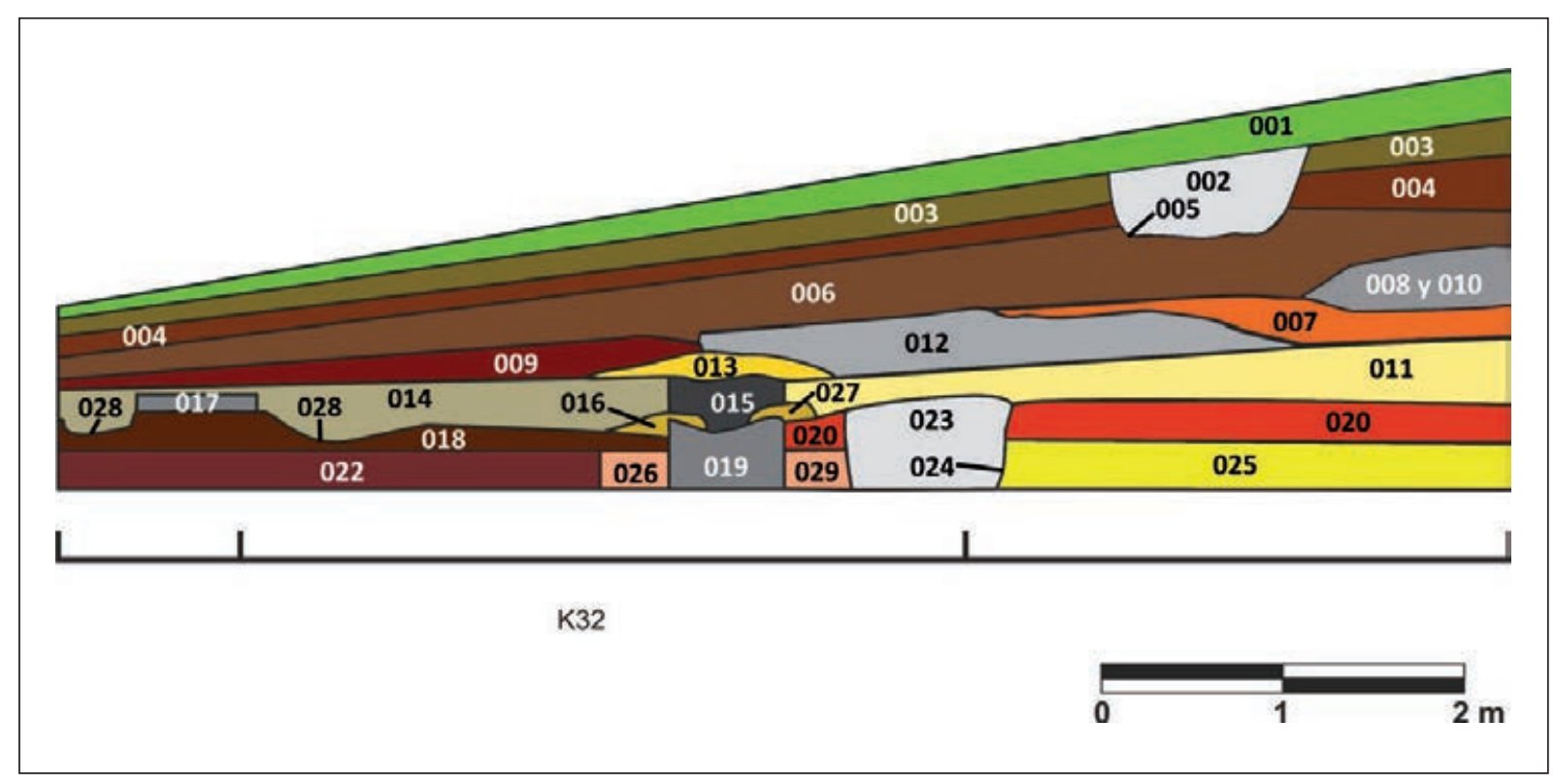

Figura 11. Corte estratigráfico simplificado del sondeo 001.

superficial. Al confirmarse este punto nada más retirarse la cubierta vegetal, se optó por reducir el área de excavación hasta los $4 \times 2 \mathrm{~m}$. Así y todo, no fue posible agotar la potencia arqueológica, de modo que el sondeo hubo de cubrirse tras excavarse unos 50-60 $\mathrm{cm}$ en el extremo sur por $35-40 \mathrm{~cm}$ en el norte, documentándose las estructuras más recientes del mismo (figs. 11-13).

a) Horizonte constructivo anterior al siglo $\mathrm{X} \mathrm{d}$. C. Por los motivos señalados, el horizonte más antiguo no se ha podido definir aquí, de modo que esta fase está únicamente integrada por el derrumbe de una estructura muraria que se desarrolla en sentido este-oeste y que tendría una anchura de aproximadamente $1,5 \mathrm{~m}$.

b) Abandono de estructuras anteriores al siglo $\mathrm{X}$. $\mathrm{Cu}$ briendo esta y extendiéndose de forma uniforme por todo el sondeo se detectó un depósito de tierra (UE109-113), que creemos que se genera como consecuencia de un abandono de esta parte del yacimiento. La muestra de sedimento aquí recogida (MUCID160624U09/Beta-448171) ofreció una datación de 905-920 y 965-1025 d.C.

c) Horizonte constructivo del siglo $X$. Sobre este depósito se identificó una nueva estructura, muy deteriorada, un muro de 1,7-1,8 $\mathrm{m}$ de anchura, construido a seco y con piedra de tamaño pequeño-medio. La datación de la tierra extraída entre las piedras (MUCID160624U04/Beta-448170) ofreció una cronología de 895-925 y 940-1020 d.C. La coincidencia con el depósito anterior nos hace pensar que ambas forman parte de una misma acción constructiva, mediante la cual se terraplenan los niveles de abandono anteriores y se construye sobre ellos un muro sin cimentación y de escasa altura.

Como ya indicábamos anteriormente, este muro es similar a una estructura curvada documentada durante las campañas de 1992 y 1993 (Caamaño Gesto 1992b, 1993) y eliminada a fin de poder registrar y dejar a la vista muros más antiguos. Se localizaría al este de la estructura interpretada como posible iglesia y al exterior de su ábside. Hoy pensamos que ambos elementos se relacionan entre sí y con la posible iglesia, que podemos situar precisamente en un horizonte del siglo $\mathrm{X}$ gracias a las dataciones por OSL. Esto coincide con la referencia documental más antigua existente sobre una iglesia de Santa María de Ciadella (Costa-García y Varela Gómez 2011) y quizá la estructura que ahora nos ocupa fuese parte de una cerca o vallado que delimitaría el espacio de la misma.

d) Horizontes de uso post-altomedievales. A ambos lados de la estructura muraria se registraron depósitos de tierra de composición muy similar (UE105, 110, 111) interpretados como un posible suelo formado tras el abandono del yacimiento en un momento 


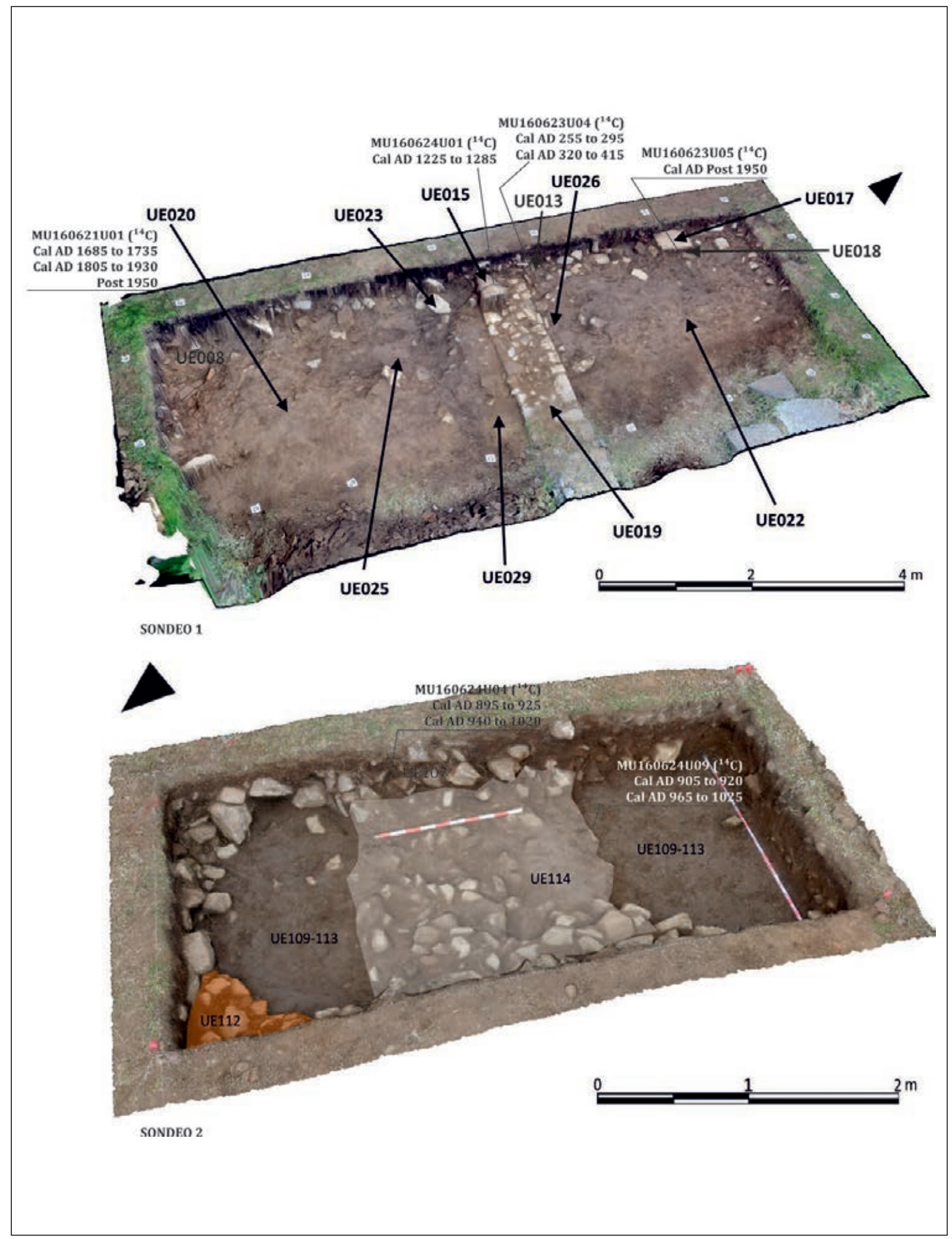

Figura 12. Matrix del sondeo 02 con indicación de las dataciones obtenidas.

ISSN: $1133-4525$ ISSN-e: $2255-3924$ 
posterior a finales del siglo X-inicios del XI, tal vez en época plenomedieval.

Asimismo, en la zona norte del sector se documentó un nuevo derrumbe (UE108) perteneciente a un posible muro que debía tener una orientación Este-Oeste pero que, por encontrarse fuera del área excavada, no fue posible documentar y caracterizar. Sobre este derrumbe se localizó un depósito con abundantes manchas anaranjadas (UE106) que podría ser resultado de rozas, tal vez relacionadas con el laboreo agrícola.

En las capas más superficiales del sondeo se localizarían dos depósitos de piedras (UE104 y UE102) que, por su disposición y buzamiento, creemos se habrían generado como consecuencia del uso del arado. Igualmente, un suelo de tierra orgánica originado por el abandono de las estructuras arqueológicas (UE103) se documentó uniformemente en el sondeo.

\section{REINTERPRETACIÓN DE LA SECUENCIA DE OCUPACIÓN DEL YACIMIENTO}

Con base en todos estos resultados, y a su cotejo con la información previamente disponible sobre el yacimiento, podemos proponer la siguiente secuencia cronológica para el mismo (figs. 8-9):

\subsection{Horizonte romano (siglos I-III d.C.)}

Aunque tradicionalmente se venía ofreciendo una visión del fuerte romano caracterizada por la sincronía de sus diferentes elementos constructivos, el trabajo desarrollado en el seno del proyecto EMCHAHE confirma la hipótesis de un horizonte de ocupación bastante más complejo. Como se recordará, esta hipótesis, apuntada en distinto grado en trabajos anteriores (Caamaño Gesto y Fernández Rodríguez 2002, Costa-García 2010), cristalizó en la caracterización de cuatro fases en la primera propuesta de secuencia constructiva del yacimiento (Blanco-Rotea et al. 2015).

Esta clasificación no se ha visto sustancialmente afectada por los resultados de las dataciones. La excepción la constituye el apéndice sudoriental del Edificio 1, cuya factura se correspondería con la fase III o IV en lugar de la I, teniendo en cuenta los resultados de las dataciones. Es muy posible, sin embargo, que se trate de una reforma sobre una estructura ya contemplada en el planeamiento original del Edificio 1. Aunque el estudio de estas fases no fue un objetivo prioritario de este proyecto, este caso particular subraya la necesidad de ahondar en la caracterización crono-morfológica de las mismas en un futuro próximo.

\subsection{Horizonte tardoantiguo (siglos IV-VI/VII)}

La mayor parte de las evidencias relacionadas con este horizonte se concentran en el sector 1 . Desde el punto de vista de la secuencia edilicia, no solo se constata aquí el levantamiento de determinadas estructuras murarias que implican un reordenamiento de los antiguos espacios construidos, sino también su posterior colapso y derrumbe. Ello nos permite caracterizar con seguridad dos momentos dentro de lo que anteriormente denominábamos Fase IV, y que ahora podríamos definir como fases IVa y IVb. Asimismo, la datación de los depósitos que se encuentran bajo y sobre los derrumbes de pizarra nos permiten apuntar que este lítico probablemente se estuviese usando como material de cubierta ya desde mediados-finales del siglo IV.

Cabe la posibilidad de que estas dos fases no fuesen las únicas dentro de un horizonte que se caracteriza por su amplia cronología. Tanto dataciones como restos materiales apuntan hacia una intensa ocupación de estos espacios entre mediados del siglo IV y al menos inicios del VI. Sin embargo, se trata por el momento de datos demasiado fragmentarios como para proponer una secuencia precisa de la misma, con varias subfases. Desconocemos las motivaciones detrás de esta ocupación, pero la llegada de materiales de importación permite plantear la hipótesis de un grupo humano con cierta capacidad económica, máxime teniendo en cuenta que A Cidadela, por lo que sabemos hasta la fecha, es uno de los escasos yacimientos del interior de Galicia que continúa recibiendo materiales importados hasta el siglo VI.

Resulta también difícil definir en qué momento esta ocupación concluye o se produce una transformación en su función. Carecemos de dataciones que vayan más allá de mediados del siglo VI y a partir de este momento desaparecen también los materiales de importación que nos permitían caracterizar las fases anteriores. La presencia descontextualizada de un diverso conjunto de elementos de atuendo personal -que en algunos casos podrían datarse en el siglo VII- y la existencia de sepulturas que, o bien cortan estructuras de las fases anteriores (una tumba de lajas, UEM044, cortando la UEM047, de la fase IVa) o bien son reutilizadas en otras de momentos posteriores (un sarcófago pétreo infantil en la UEM053), podría ser 


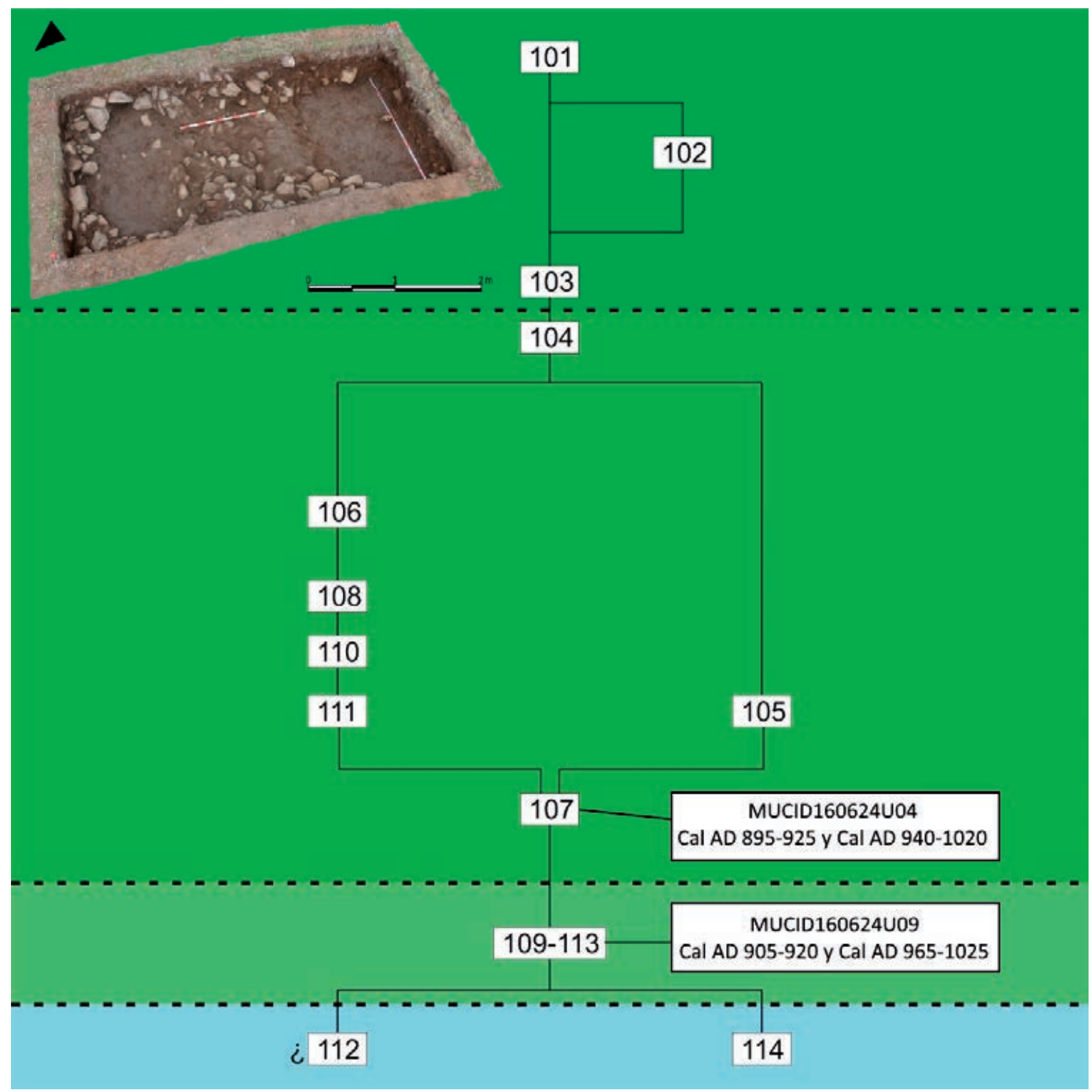

Figura 13. Imagen de los modelos fotogramétricos de los dos sondeos con indicación de las UEs documentadas y las dataciones radiocarbónicas obtenidas en cada uno.

indicativo quizá de la existencia de una necrópolis que se habría visto severamente afectada por las subsiguientes ocupaciones del yacimiento y a la que, tal vez, podrían pertenecer estos materiales.

Por lo que respecta al sector 2 , inicialmente se consideró que el conjunto de estructuras localizadas en el área meridional de los edificios 4 y 5 se correspondería con la fase $\mathrm{V}$, entonces datada en época tardoantigua (vid. supra). Estos muros en ocasiones doblan las estructuras romanas e incluso rebasan la línea de fachada de las edificaciones romanas. Sin embargo, indudablemente conservan el alineamiento ortogonal de las fases anteriores y parecen organizarse respetando la antigua via principalis como espacio de tránsito. Como acabamos de ver, este fenómeno es idéntico al documentado en el sector sur del edificio 1, por lo que cabe la posibilidad de que esta intensa fase de reestructuración se relacione con la Fase IVa y no con la V como 
proponíamos anteriormente. Con todo, por el momento carecemos de dataciones para reforzar esta hipótesis.

\subsection{Horizonte altomedieval (siglos IX-XI d.C.)}

Es fundamentalmente en el sector 2 donde mejor podemos caracterizar la existencia de dos fases que, sin embargo, parecen muy próximas en el tiempo. La mayoría de las muestras tomadas en esta área tuvieron como finalidad el encuadre cronológico de la edificación identificada como posible iglesia, compuesta por una nave rectangular y un pequeño ábside que se adosaba a esta. De este modo, la Fase V se relacionaría con la erección del primer espacio, mientras que la VI lo haría con el segundo. Aunque la secuencia relativa es clara a este respecto, las dataciones obtenidas en uno y otro elemento se solapan en buena medida (869-1098 d.C., MU141003U15 y 967-1109 d.C., MU141003U16, respectivamente), por lo que es posible que los dos procesos constructivos no se separasen en exceso en el tiempo.

Pertenece también a este horizonte el derrumbe de un muro hallado en el sondeo 2, fechado entre el siglo X e inicios del XI. Este posible muro semeja haber sido parte de una estructura mayor cuya disposición en planta parece indicar su función como elemento de delimitación alrededor de la teórica iglesia, quizá marcando físicamente la extensión de la sacraria. Desafortunadamente, resulta imposible relacionar estratigráfica o secuencialmente este muro con las estructuras pertenecientes a nave y ábside. Aunque las dataciones obtenidas nos permitirían un encuadre cronológico en cualquiera de las dos fases señaladas, cabe pensar en una secuencia constructiva general en la que el proceso de reforma y delimitación del espacio sagrado -si se quiere, incluso monumentalización- (Fase VI) sucedería a la erección de la iglesia misma (Fase V).

Una problemática similar presentan las restantes UEM relacionadas con este horizonte, ya que no han sido datadas ni existen adecuados registros del contexto estratigráfico en el que se hallaron. En el sector 2 , ya nos hemos referido a las estructuras documentadas al sur del edificio IV, que hallarían un mejor encuadre en la Fase IV. Por su parte, las situadas al norte de este mismo espacio muestran similitudes formales con el mencionado ábside y se podrían relacionar con el proceso de reforma vivido durante la Fase VI en esta área. Tampoco es posible relacionar estratigráficamente la tumba de lajas situada al interior de la iglesia con los muros de esta, por lo que podría pertenecer tanto a este horizonte como al anterior.

En el sector 1, destaca la presencia de una pequeña estructura cuadrangular que podría identificarse con un ábside (Blanco-Rotea et al. 2015: 86), de ahí su adscripción a la Fase VI. Sin embargo, se trata de un elemento totalmente aislado en un espacio especialmente afectado por alteraciones posteriores y cubierto por vegetación en el momento de la lectura, por lo que sin un trabajo arqueológico más detallado no es posible adscribirla con seguridad a una de las fases del yacimiento.

\subsection{Horizonte plenomedieval (siglos XII-XIII d.C.)}

Este horizonte integra un numeroso conjunto de estructuras que, o bien recrecen muros de fases anteriores, o bien corresponden a muros de tosca factura y nueva construcción asentados sobre antiguos derrumbes y suelos de uso. Hasta seis muros datados tanto en los sectores 1 y 2 como en el sondeo 1 se enmarcan en un rango cronológico que abarca desde finales del siglo XI hasta finales del XIII, solapándose todas las dataciones en el arco 1225-1259. Se evidencia, por tanto, que el sector central del yacimiento vivió en su conjunto una intensa reforma durante el periodo plenomedieval, dando lugar a nuevos espacios que cuentan con su propia organicidad. La cerámica plenomedieval detectada en la revisión de material refuerza esta interpretación. No obstante, como ocurría en el caso del horizonte tardoantiguo, es posible que este fenómeno no se produjese en una sola fase, y tal vez los recrecimientos correspondan a un momento y los muros de nueva planta a otro.

Esta batería de dataciones tiene dos consecuencias inmediatas desde el punto de vista historiográfico e histórico. En primer lugar, se pone de relieve que el conjunto de estructuras genéricamente identificadas como "germánicas" corresponden en realidad a diferentes fases, desde la Tardoantigüedad hasta momentos avanzados del Medievo. Por otro lado, esta intensa reforma de los espacios construidos al interior del recinto coincide con el levantamiento extramuros de un templo románico que, reformado, subsiste hoy en día como iglesia parroquial de Santa María de Ciadella. Cabe pensar entonces en un desmantelamiento y "desacralización" de las anteriores estructuras sitas intramuros para su reutilización con otra finalidad, quizá en relación con la fundación aquí de un asentamiento campesino. 
Tabla 7. listado del total de dataciones absolutas obtenidas para el yacimiento de Cidadela en esta investigación.

\begin{tabular}{|c|c|c|c|c|}
\hline Muestra & Código Laboratorio & Método datación & Material & Rango de fechas d.C. \\
\hline MU141003U01 & & OSL & Mortero de tierra & 540-138 a.C. \\
\hline MU141003U02 & & OSL & Mortero de tierra & 182 a.C.-359 d.C. \\
\hline MU141003U07 & & OSL & Mortero de tierra & $1077-1297$ \\
\hline MU141003U11 & & OSL & Mortero de tierra & $1118-1292$ \\
\hline MU141003U12 & & OSL & Mortero de tierra & $256-506$ \\
\hline MU141003U13 & & OSL & Mortero de tierra & $1085-1258$ \\
\hline MU141003U14 & & OSL & Mortero de tierra & $1133-1275$ \\
\hline MU141003U15 & & OSL & Mortero de tierra & $869-1098$ \\
\hline MU141003U16 & & OSL & Mortero de tierra & $967-1109$ \\
\hline MU150601U01 & Beta-436841 & Radiocarbono & Materia orgánica & $400-545$ \\
\hline MU150601U02 & Beta-412615 & Radiocarbono & Carbones & $\begin{array}{l}265-275 \\
330-420\end{array}$ \\
\hline MU150601U03 & Beta-422616 & Radiocarbono & Carbones & $335-425$ \\
\hline MU150601U07 & Beta-412618 & Radiocarbono & Materia orgánica & $\begin{array}{c}1645-1685 \\
1735-1805 \\
1950-\text { post }\end{array}$ \\
\hline MU150601U05 & Beta-412617 & Radiocarbono & Materia orgánica & $1225-1285$ \\
\hline MU150601U04 & Beta-436842 & Radiocarbono & Materia orgánica & $1465-1645$ \\
\hline MUCID160624U04 & Beta-448170 & Radiocarbono & Materia orgánica & $\begin{array}{c}895-925 \\
940-1020\end{array}$ \\
\hline MUCID160624U09 & Beta-448171 & Radiocarbono & Materia orgánica & $\begin{array}{c}905-920 \\
965-1025\end{array}$ \\
\hline MUCID160621U01 & Beta-448172 & Radiocarbono & Materia orgánica & $\begin{array}{l}1685-1735 \\
1805-1930 \\
\text { Post } 1950\end{array}$ \\
\hline MUCID160623U05 & Beta-448173 & Radiocarbono & Materia orgánica & Post 1950 \\
\hline MUCID160624U01 & Beta-448174 & Radiocarbono & Materia orgánica & $1225-1285$ \\
\hline MUCID160623U04 & Beta-448175 & Radiocarbono & Carbones & $\begin{array}{l}255-295 \\
320-415\end{array}$ \\
\hline
\end{tabular}

\subsection{Horizonte bajomedieval y moderno (posterior al siglo XIV)}

A partir de la plena Edad Media es más difícil secuenciar la ocupación humana en el yacimiento. Por un lado, las labores agrícolas y ganaderas o expolios de material afectaron sistemáticamente a muchas de las estructuras más recientes; por otro, con frecuencia estos mismos muros habrían sido desmantelados durante las anteriores intervenciones arqueológicas. Aquellos que sobrevivieron a estas acciones no se encuentran tampoco en buen estado de conservación, al haberse priorizado la consolidación de aquellas estructuras consideradas romanas.

Así y todo, en términos generales no se detectan fases constructivas de entidad semejante a las anteriores. 
Los resultados del sondeo 1 evidencian que sobre las ruinas de las estructuras de época plenomedieval se habrían levantado nuevas construcciones de tosca factura y en otros puntos se han documentado restos de parcelas y muros divisorios. De forma genérica, dichos elementos fueron definidos como Fase VIII, aunque perfectamente podrían pertenecer a distintos momentos históricos.

De idéntico modo, los resultados de las distintas intervenciones contemporáneas en el yacimiento, desde las propias excavaciones hasta las consolidaciones de los muros, pasando por la construcción de la carpa y caseta que hoy se hallan en el yacimiento, se han agrupado bajo la Fase IX.

\section{CONCLUSIONES}

Gracias a las acciones desarrolladas en el marco del proyecto EMCHAHE, hoy sabemos que la secuencia de ocupación del yacimiento de Cidadela a partir del siglo IV es bastante más compleja de lo que inicialmente se había barajado. Frente a la idea tradicional de una importante fase "germánica" del siglo VII caracterizada por la construcción de una iglesia monástica, profundas reformas en las estructuras del antiguo fuerte romano y la utilización de un característico techo en pizarra, hemos podido definir al menos cuatro horizontes de ocupación posteriores al romano que se extienden hasta la actualidad: tardoantiguo, altomedieval, plenomedieval y bajomedieval-moderno. A nivel metodológico, cabe destacar el potencial de la combinación de distintos métodos de datación absoluta (OSL y radiocarbono) que en líneas generales, con un total de 21 dataciones realizadas para esta investigación (tab. 7), han mostrado una fuerte coherencia en sus resultados, reforzando la propuesta cronológica aquí ofrecida.

Aunque los resultados de la intervención han permitido responder algunos de los interrogantes que planteaba el yacimiento, todavía son muchas las cuestiones abiertas e incluso se formulan ahora nuevas preguntas como consecuencia de estas acciones. Este es el reto de futuro que plantea la investigación de este interesante yacimiento arqueológico.

\section{Agradecimientos}

Este trabajo es resultado de los proyectos "EMCHAHE: Early Medieval Churches: History, Archaeology and Heritage", financiado por una ayuda Marie Curie CIG de la Unión Europea (PCIG12-GA-2012-334068);
"TERPOMED: Territorio y poder monástico en la Alta Edad Media", financiado por un proyecto de excelencia de la Consellería de Cultura, Educación e Ordenación Universitaria de la Xunta de Galicia (PG-065, convocatoria Consolidación e Estructuración 2016), y "CONSILIENCIA II", financiado por una ayuda para la creación de Redes de Grupos de Investigación de la Consellería de Cultura, Educación e Ordenación Universitaria de la Xunta de Galicia. Así mismo, la revisión de la cerámica medieval del presente trabajo se ha realizado en el marco del proyecto "Tecnología y producción de la cerámica medieval de Galicia" -MC-PTG-. HAR2015-64441-P -Plan Nacional: Ministerio de Economía y Competitividad, Convocatorias 2015, Proyectos EXCELENCIA y Proyectos RETOS, Dirección General de Investigación Científica y Técnica, Subdirección General de Proyectos de Investigación-2016-2019.

Los autores desean expresar su sincero agradecimiento a Ana Martínez, Adolfo Fernández, Agustín Azkarate y Raúl Catalán, por su ayuda en la identificación de materiales, y a Oria Ferreiro Diz, Celtia Rodríguez González, Tania Rial Figueiras, Mario Fernández Pereiro, Martín Domínguez y Carlos Otero Vilariño, por su fundamental colaboración en la campaña de excavación del yacimiento en 2016.

\section{BIBLIOGRAFÍA}

Aitken, M. J. (1998): An introduction to optical dating. Oxford, Oxford Science Publications.

Alonso Toucido, F.; Prieto Martínez M. P. y Rodríguez Resino A. (2013): “Cerámica en silos. Contextos medievales e modernos na rúa do Franco n ${ }^{\circ} 31$. Santiago de Compostela”. Gallaecia 32: 215-248.

Arenas, R.; Martínez, J.R. y Díaz, F. (2004): “Zona de Galicia-Tras-os-Montes”, en J. A. Vera (ed.), Geología de España: 133-165. Madrid, Sociedad Geológica Española - IGME.

Azkarate Garai-Olaun, A. (1993): "Francos, aquitanos y vascones. Testimonios arqueológicos al sur de los Pirineos". Archivo Español de Arqueología 66 (167-168): 140-176.

Azkarate Garai-Olaun, A. (2006): "Sobre los orígenes cronológicos de los cementerios cispirenaicos de época tardoantigua". Munibe Antropologia - Arkeologia 57: 405-417.

Azkarate Garai-Olaun, A. (2007): "Necrópolis de Buzaga (Elortz)", en VV.AA., La tierra te sea leve: Arqueología de la muerte en Navarra: 195-198. Pamplona, Gobierno de Navarra. 
Barbazán Domínguez, S.; Caamaño Gesto, J. M.; Lozano Hermida, H. y Ramil Rego, E. (2015): "La cerámica común del campamento romano de Cidadela (Sobrado dos Monxes, A Coruña). Campaña 2007”. Gallaecia 33: 189-214.

Bartolomé Abraira, R. (2015): “Cerámica gris fina tardía. Los fondos resaltados de copas y cuencos carenados de Lvcvs Avgvsti”. Férvedes 8: 371-380.

Bello Diéguez, J.M.; Sanjurjo Sánchez, J. y Fernández Mosquera, D. (2008): "Los niveles medievales de la Torre de Hércules: caracterización arqueológica y datación mediante TL y OSL". Férvedes 5: 453464.

Bishop, M. C. y Coulston, J. C. (2006): Roman military equipment from the Punic Wars to the fall of Rome. Oxford, Oxbow Books.

Blanco-Rotea, R.; Costa-García, J. M. y Sánchez-Pardo, J. C. (2015): "Análisis de la evolución constructiva de las estructuras excavadas en el yacimiento de A Cidadela (Sobrado dos Monxes, A Coruña) y propuestas interpretativas sobre sus "fases tardoantiguas"". Estudos do Quaternário 12: 69-93.

Boyle, R. W. (1982): Geochemical Prospecting for Thorium and Uranium Deposits. Amsterdam, Elsevier.

Bronk Ramsey, C. y Lee, S. (2013): "Recent and Planned Developments of the Program OxCal", $R a$ diocarbon 55 (2-3): 720-730. <doi:https://doi. org/10.1017/s0033822200057878>.

Caamaño Gesto, J. M. (1984): “Excavaciones en el campamento romano de Cidadela (Sobrado dos Monxes. Coruña). Memoria preliminar de la campaña de 1981". Noticiario Arqueológico Hispánico 18: 233-254.

Caamaño Gesto, J. M. (1987): Excavaciones en el campamento romano de Cidadela. Campaña de 1983. Santiago de Compostela, Xunta de Galicia.

Caamaño Gesto, J. M. (1989): "Estampillas de la Cohors I Celtiberorum halladas en el campamento romano de Cidadela". Gallaecia 11: 209-229.

Caamaño Gesto, J. M. (1990): "Vidrios hallados en el campamento de Cidadela (Sobrado dos Monxes - A Coruña)". Gallaecia 12: 177-190.

Caamaño Gesto, J. M. (1992a): Excavaciones en el campamento romano de Cidadela. Campaña de 1991. Santiago de Compostela, Xunta de Galicia.

Caamaño Gesto, J. M. (1992b): Excavaciones en el campamento romano de Cidadela. Campaña de 1992. Santiago de Compostela, Xunta de Galicia. Caamaño Gesto, J. M. (1993): Memoria Técnica de Excavación en el campamento romano de Cidadela.
Año 1992. Santiago de Compostela, Xunta de Galicia.

Caamaño Gesto, J. M. (1997): “Sondeos arqueológicos en la muralla del campamento romano de Cidadela". Gallaecia 16: 265-284.

Caamaño Gesto, J. M.; Castro, I.; Ínsua, Ma J.; López Pérez, M ${ }^{\mathrm{a}}$ C.; Vázquez Martínez, $\mathrm{M}^{\mathrm{a}}$ A. y Fernández Rodríguez, C. (2000): "Evidencias materiales en el campamento romano de Cidadela -Sobrado dos Monxes, A Coruña-", en V. Oliveira (Ed.), Arqueología da Antigüedade na Península Ibérica, Vol. VI: 281-292. Porto, ADECAP. Caamaño Gesto, J. M. y Fernández Rodríguez, C. (2002): "Novedades sobre el campamento romano de Cidadela (Sobrado dos Monxes, A Coruña)", en A. Morillo (Ed.), Arqueología Militar Romana en Hispania: 213-226 Madrid, CSIC. Caamaño Gesto, J. M. y Fernández Rodríguez, C. (2006): "Producción y comercialización en el campamento romano de Cidadela", en A. Morillo (Ed.), Arqueología militar romana en Hispania II: Producción y abastecimiento en el ámbito militar: 167-184. León, Universidad de León.CarlssonBrandt Fontán, E. (2011): "El material constructivo latericio en el campamento de Cidadela (Sobrado dos Monxes, A Coruña)". Gallaecia 30: 67-180.

Costa-García, J. M. (2010): "Estudo de paramentos e análise das estruturas exhumadas na "pars nobilis" do campamento romano de A Cidadela (Sobrado dos Monxes, A Coruña)". Gallaecia 29: 191-201.

Costa-García, J. M. (2011): "La castrametación romana en el Noroeste Peninsular: Algunos apuntes para su estudio". Férvedes. Revista de investigación 7: 215-223.

Costa-García, J. M. (2014): "Las primeras intervenciones arqueológicas en A Cidadela (Sobrado dos Monxes, A Coruña". Gallaecia 32: 109-127.

Costa-García, J. M. y Varela Gómez, D. (2011): “A Cidadela después de Roma. Introducción al estudio del yacimiento y su entorno durante el período medieval". Gallaecia 30: 181-194.

Del Castillo, Á. (1934): "El campamento romano de Ciudadela". La Voz de Galicia 24/6/1934 (num. 16924): 1.

Del Castillo, Á. (1935): "El campamento romano de Ciudadela". La Voz de Galicia 4/1/1935 (num. 17085): 1 .

Fernández Fernández, A. y Bartolomé Abraira, R. (2016). “Cerámicas tardoantiguas en el Noroeste de la Península (Galicia y norte de Portugal): entre la importación y el artesanado local/regional (ss.V-VII)", en: A. Vigil-Escalera y J. A. Quirós (eds.). La cerámica de la Alta Edad Media en el cuadrante noroeste 
de la Península Ibérica (siglos V-X). Sistemas de producción, mecanismos de distribución y patrones de consumo: 69-111 Bilbao, Universidad del País Vasco. Fernández Rodríguez, C. (1997): Excavación arqueológica del campamento romano de Cidadela (Sobrado dos Monxes, Coruña). Campaña de 1996. Informe preliminar. Santiago de Compostela, Xunta de Galicia.

Feugère, M. (2002): Les armes des romains de la République à l'Antiquité tardive. Collection des Hespérides. Paris, Errance.

Galbraith, R. F.; Roberts, R. G.; Laslett, G. M.: Yoshida, H. Y y Olley, H. (1999): “Optical dating of single and multiple grains of quartz from Jinmium Rock Sherlter, Northern Australia: Part 1". Archaeometry 41: 339-364, doi: <https://doi. org/10.1111/j.1475-4754.1999.tb00987.x>.

Goedicke, C. (2011): "Dating mortar by optically stimulated luminescence: a feasibility study". Geochronometria 38: 42-49, dói: <https://doi.org/10.2478/ s13386-011-0002-0>.

Krauskopf, K.B y Bird, D. (1995): Introduction to geochemistry. New York, McGraw Hill.

López Pérez, Ma C. (2006): "La importación de terra sigillata en el campamento de Cidadela (Sobrado dos Monxes, A Coruña)", en: A. Morillo (Ed.), Arqueología militar romana en Hispania II: Producción y abastecimiento en el ámbito militar: 432-437 León, Servicio de Publicaciones de la Universidad de León. López Quiroga, J. y Martínez Tejera, A. M. (Eds.) (2017): In tempore Sueborum. El tiempo de los suevos en la Gallaecia (411-485). Ourense, Deputación de Ourense.

Loscertales De García, P. (1976): Tumbos del monasterio de Sobrado de los Monjes (2 Vol.). Madrid, Dirección General del Patrimonio Artístico y Cultural.

Ramil González, E. (2007): Escavación arqueolóxica e limpeza no campamento romano de Cidadela Sobrado dos Monxes. Memoria técnica 2006. Santiago de Compostela, Xunta de Galicia.

Ramil González, E. y Caamaño Gesto, J. M. (2009): "Escavación e consolidación arqueolóxica no campamento romano de Cidadela", en M. P. García (Ed.), Actuacións Arqueolóxicas, Ano 2007: 81-82. Santiago de Compostela: Xunta de Galicia.

Ramil González, E. y Caamaño Gesto, J. M. (2010): "Escavación, consolidación e limpeza no campamento romano de Cidadela”, en M. P. García (Ed.), Actuacións Arqueolóxicas, Ano 2008: 65-66 Santiago de Compostela, Xunta de Galicia.
Ramil González, E.; Costa-García, J. M. y Caamaño Gesto, J. M. (2013): "Hornos hallados en el campamento romano de Cidadela (Sobrado dos Monxes, A Coruña)". Boletín del Seminario de Arte y Arqueología. Sección Arqueología 77-78: 269-290.

Reimer, P. J., (2013): "IntCal13 and Marine13 Radiocarbon Age Calibration Curves 0-50,000 Years cal BP”. Radiocarbon 55 (4): 1869-1887, doi: <https:// doi.org/10.2458/azu_js_rc.55.16947>.

Ripoll, G. (1991): "Materiales funerarios de la Hispania visigoda : problemas de cronología y tipología”, en P. Perin (Ed.), Gallo-Romains, Wisigoths et Francs en Aquitanie, Septimanie et Espagne: 111132 Rouen, Association française d'archéologie mérovingienne.

Sánchez-Pardo, J. C. y Blanco-Rotea, R. (2014): "Early Medieval Churches. History, Archaeology and Heritage (2013-2017). Marie Curie EMCHAHE project”. The European Archaeologist 42: 83-85.

Sánchez-Pardo, J. C.; Blanco-Rotea, R. y SanjurjoSánchez, J. (2017): "The church of Santa Comba de Bande and early medieval Iberian architecture: new chronological results". Antiquity 357: 1011-1026, doi: <https://doi.org/10.15184/aqy.2017.83>.

Sanjurjo-Sánchez, J. (2016): "Dating historical buildings: an update on the possibilities of absolute dating methods". International Journal of Architectural Heritage 10: 620-635, doi: <https://doi.org/10.1 080/15583058.2015.1055384>.

Sastre Blanco, J. C. y Catalán Ramos, R. (2012): “Un asentamiento fortificado en la tardoantigüedad el castro de El Castillón (Santa Eulalia de Tábara, Zamora)", en J. A. Quirós y J. M. Tejado (eds.), Los castillos altomedievales en el noroeste de la Península Ibérica: 193-211 Bilbao, UPV.Sastre Blanco, J. C.; Fuentes Melgar, P.; Rodríguez Monterrubio, Ó. y Vázquez Fadón, M. (2015): El yacimiento arqueológico de El Castillón (Santa Eulalia de Tábara, Zamora). Un enclave tardoantiguo a orillas del Esla. Valladolid, Glyphos.

Urbanova, P.; Hourcade, D.; Ney, C. Y. y Guibert, P. (2015): "Sources of uncertainties in OSL dating of archaeological mortars: The case study of the Roman amphitheatre "Palais-Gallien" in Bordeaux". $R a$ diation Measurements 72: 100-110, doi: <https:// doi.org/10.1016/j.radmeas.2014.11.014>.

Vázquez Martínez, Ma A. (2000): Los vidrios de Cidadela (Sobrado dos Monxes, A Coruña). Santiago de Compostela, USC. 


\title{
LA GESTIÓN DEL AGUA EN LA CIUDAD ROMANA DE LACIPO (CASARES, MÁLAGA)
}

\section{THE WATER MANAGEMENT IN THE ROMAN CITY OF LACIPO (CASARES, MÁLAGA)}

\author{
MARÍA DEL MAR CASTRO GARCÍA \\ Investigadora posdoctoral Marie Curie european individual fellow. Dipartimento di Scienze Storiche e dei Beni Culturali \\ Università di Siena (Italia). Via Roma 65 (Sede dei Servi). 53100 Siena (SI) Italia \\ Correo-e: mariadel.castro@unisi.it. (D) https://orcid.org/0000-0002-9159-3096 \\ Researcher ID: <https://publons.com/researcher/AAG-6975-2019>
}

\begin{abstract}
Resumen: Lacipo es una ciudad romana de modestas dimensiones que se extiende sobre un cerro que controla el valle del río Genal-Guadiaro, próximo al litoral mediterráneo, en la provincia Baetica. Entre los restos arqueológicos que se conservan, destaca un conjunto de estructuras hidráulicas diseminadas por el propio cerro y por el territorio circundante. El examen detallado de estas construcciones permite conocer los métodos de gestión del agua empleados en este centro urbano, reconstruyendo el sistema de abastecimiento de aguas desde su captación, conducción, distribución, almacenaje y sus posteriores usos. Este análisis demuestra cómo el agua era un recurso necesario y valioso para la ciudad, y que para garantizar su abundancia los habitantes de Lacipo no dudaron en captar manantiales de calidad en las proximidades y conducirlos diversos kilómetros para poder desarrollar las actividades públicas y privadas propias de una civitas romana.
\end{abstract}

Palabras clave: Baetica, ciclo del agua, hidráulica, cisterna, acueducto, civitas.

\section{INTRODUCCIÓN}

Lacipo (cerro Alechipe o cerro Pellizcoso, Casares, Málaga) es una civitas stipendiaria del conventus
Abstract: Lacipo is a small Roman town situated on a hill that overlooks the fluvial valley of Genal-Guadiaro, next to the Mediterranean coast, in the province of Baetica. In amongst the archaeological remains that are conserved on the site, a group of hydraulic structures are particularly notable. They are scattered around the hill and the surrounding countryside. Examination of these constructions has allowed us to study the urban water resources management, through the reconstruction of the water supply system: collecting, carrying, storing, distributing, and the subsequent usage. The analysis shows that water was a necessary and valuable resource for the city in order to guarantee it. The inhabitants of Lacipo did not hesitate to collect quality spring water from the surrounding area and transport it over several kilometres to be able to develop the public and private activities of a Roman civitas.

Key words: Baetica, water cycle, hidraulic, cisterns, aqueduct, civitas.

Gaditanus, en la provincia Baetica (Plin. Nat. 3.15.; otros autores que citan Lacipo: Mela 2.93.; Ptol. Geog. 2.4.11.). Se ubica en un cerro amesetado sobre una de las laderas meridionales de la sierra de Crestellina, una 


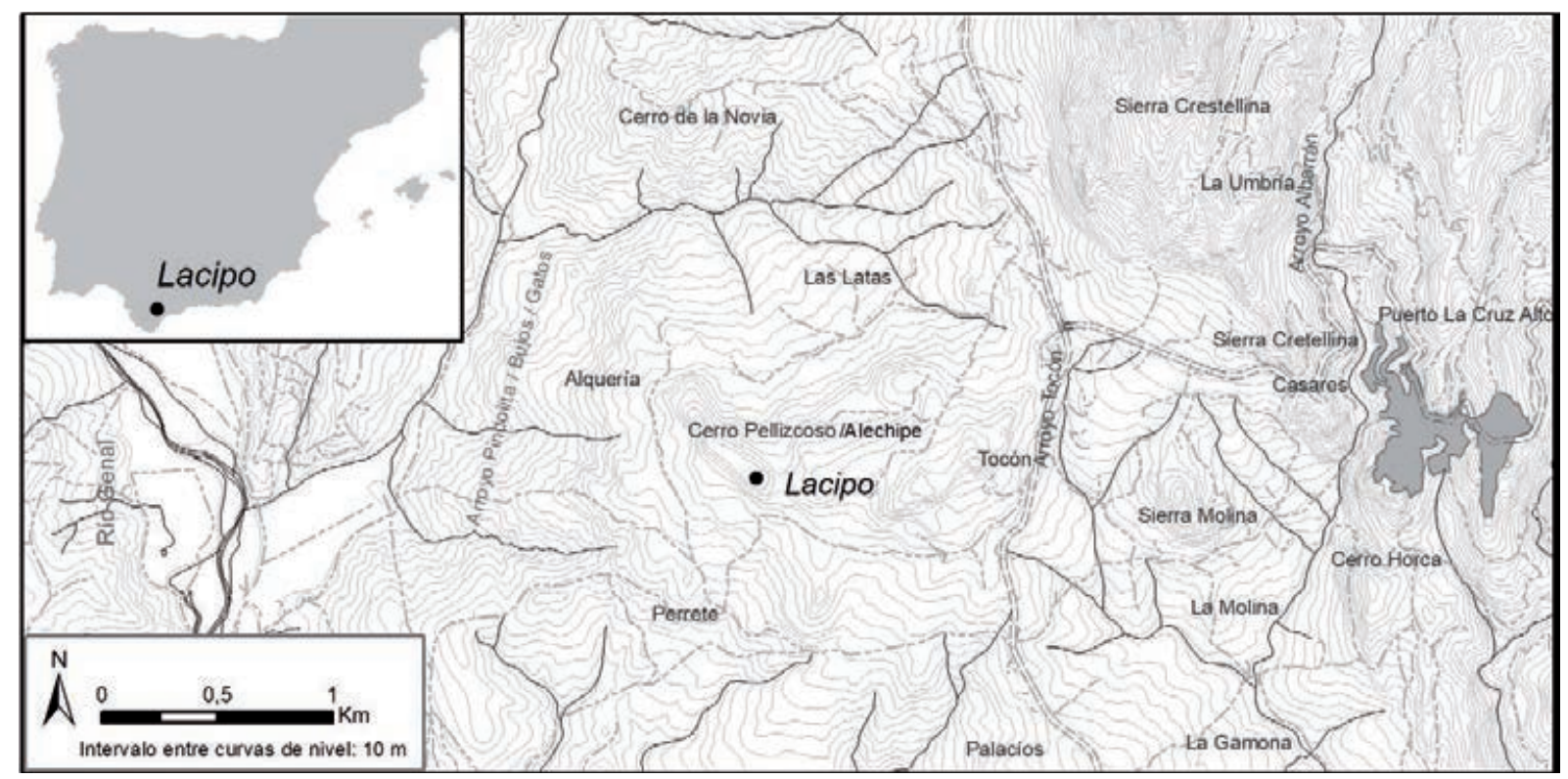

Figura 1. Situación geográfica de la ciudad romana de Lacipo.

de las últimas estribaciones de la serranía de Ronda. Próxima a la costa mediterránea y al estrecho de Gibraltar, desde su emplazamiento controla el valle del río Genal en su confluencia con el Guadiaro, el cual constituiría una vía de comunicación entre la costa y el interior. El topónimo porta el sufijo ipo/-ippo, interpretado como indicador de "ciudad", "lugar habitado" (Villar 2000: 118). Esta particularidad ha sido tomada como prueba de la existencia de una ciudad indígena que toma contacto con Roma a fines del siglo III a.C. (Rodríguez Oliva 2017: 54-55). También se ha propuesto su inclusión en un ámbito de influencia cultural púnicocartaginés por su proximidad a los asentamientos costeros del Estrecho (Bravo 2010: 171).

Lacipo tuvo una temprana importancia, como evidenciaría su ceca tardorrepublicana (Mora 1990: 8, Corzo 2005). Igualmente, se apuntan posibles vínculos de sus habitantes con los primeros colonos de Carteia (171 a.C.) (Rodríguez Oliva 2006). La ciudad contó con instituciones político-administrativas, constatadas por los testimonios epigráficos que hacen referencia a un ordo decuriorum y una res publica (CIL II 1934 y 1936), y religiosas, con referencias a libertos desempeñando cargos de sacerdocio dedicado al culto imperial (CIL II 1934-1935). El contenido de estas inscripciones no permite una datación precisa, pero esta práctica religiosa remite a los siglos I-III d.C. (Fishwick 1993). Posiblemente, la ciudad deba su existencia al control territorial que ejerce desde su posición: por un lado, en el acceso del litoral al interior, a través del valle fluvial, y por otro, como centro cívico de la población dispersa que se extiende en su territorium.

Las únicas investigaciones arqueológicas sistemáticas en el asentamiento se remiten a los años setenta del siglo pasado (Puertas 1982). Durante varias campañas, dos sectores del cerro (norte y sur) fueron excavados. En el sector sur se documentó un gran edificio, posiblemente de carácter público, y en el norte restos de construcciones de carácter defensivo. Todo el conjunto fue datado en los siglos I-II d.C. Testimonios epigráficos parecen confirmar la existencia de edificios religiosos (AE 1981 504; CIL II 1934, 1935, 1936; CIL II²/7 259). Sin embargo, la parte habitacional no se ha constatado arqueológicamente.

\section{EL ABASTECIMIENTO DE AGUA: LA CAPTACIÓN Y CONDUCCIÓN DEL AGUA CORRIENTE, EL ACUEDUCTO}

El agua es un recurso esencial para una ciudad romana, siendo fundamental no solo para las necesidades humanas básicas, sino también para el desarrollo de las distintas funciones cívicas, religiosas, higiénicas o lúdicas (véase Malissard 1994). Lacipo, al estar situada en altura, no dispone de fuentes susceptibles de ser explotadas. Los pequeños arroyos que la circundan son limitados y muy estacionales. Además, se encuentra 
alejada y a una diferencia de altura importante del río Genal. Por ello debe buscar otras alternativas. Por un lado recurre a la captación y almacenamiento de agua de lluvia, en una zona donde las precipitaciones se concentran en determinadas épocas del año. Posteriormente busca manantiales de calidad susceptibles de ser captados y conducidos hasta el núcleo urbano. Para ello emplea diversas soluciones constructivas propias de la ingeniería hidráulica romana. Una vez en la ciudad, el agua debía ser convenientemente distribuida a los edificios y fuentes públicas, y destinada a los diversos usos públicos o privados. Finalmente, el agua usada debía ser evacuada (sobre el ciclo de agua en la ciudad romana consúltese: Front. Aq., Eschebach 1977, Bruun 1991, Hodge 1992, Ricciardi y Scrinari 1996, Dessales 2013).

Los testimonios materiales conservados en el yacimiento, visibles en la actualidad, nos permiten reconstruir en parte el ciclo urbano del agua. El objetivo inicial de esta investigación fue el estudio del empleo de prácticas de gestión a través de una planificación ejercida por un municipio romano de modestas dimensiones y relevancia local. Para ello, realizamos una serie de visitas al yacimiento con el fin de documentar las construcciones hidráulicas. Estos resultados, junto con la información aportada por las excavaciones practicadas en el sitio y por algún estudio previo relativo a la ciudad romana en general, y a su abastecimiento de agua en particular (Soto Jiménez 1979, Navarro 2006, Tomassetti et al. 2016, Sánchez y Martínez 2016), nos han permitido plantear las hipótesis expuestas en este trabajo.

La primera descripción del acueducto de Lacipo la aporta L. Soto Jiménez (1979). Posteriormente, la conducción ha sido mencionada en diversos trabajos (Navarro 2006, Sánchez y Martínez 2016: 208, Tomassetti et al. 2016). Sin embargo, hasta el momento no se ha llevado a cabo un análisis en profundidad de su trazado.

En cuanto al caput aquae, L. Soto Jiménez (1979) señala la Fuente Grande como posible lugar de captación. La localización del manantial es problemática, ya que no aparece en la cartografía actual. Tampoco se incluye en los inventarios de fuentes y manantiales oficiales (Proyecto Conoce tus Fuentes, <http://www. conocetusfuentes.com>). En cambio, en 1967 fue derivada para abastecer al municipio de Casares (Saborido 2006: 96). Otro manantial, la fuente de la Arquita, localizado más al sur, en el "camino de las Viñas", también ha sido empleado en el suministro hídrico de la actual localidad (Saborido 2006: 96). Asimismo, la tradición oral del lugar habla sobre la abundancia y riqueza de la
Fuente Grande, pudiendo ser este el motivo de su atribución como cabecera del acueducto. Lo cierto es que toda esta zona es rica en agua, tal y como demuestra la presencia de otros manantiales y de abundantes pozos. Además, es el área desde la que se condujo el agua para el primer abastecimiento a Casares en el siglo XVIII (Saborido 2006: 96).

La ubicación aproximada de la Fuente Grande se ha establecido siguiendo la información aportada por un bosquejo planimétrico de 1875 (Casares, Planimetría 1875). En él aparece el topónimo "Cortijo Fuente Grande", situado en la ribera izquierda del arroyo de la Albarrada o Albarrá, en la ladera del macizo Matagallar. Entendemos que este cortijo tuvo que ser la propiedad que albergaba la fuente. El topónimo se emplaza a una cota aproximada de entre 495 y 500 m s.n.m., es decir, a una altura superior al yacimiento de Lacipo (328 m s.n.m.). Del mismo modo, los primeros vestigios de specus sobre substructio documentados, situados en la ladera opuesta de la Sierra Crestellina, se encuentran a una cota de 430 m s.n.m.

El manantial desapareció como consecuencia de alteraciones sufridas en época contemporánea, sin poder comprobar la existencia de restos que ratifiquen su vinculación como cabeza de captación del acueducto. Sin embargo, la fuente de la Arquita continúa manando agua de calidad. Por ello, la hemos considerado otro posible punto de captación de aguas para el acueducto. Aunque se encuentra un poco más alejada de la Fuente Grande $(1.500 \mathrm{~m})$, se sitúa en una cota susceptible de ser conducida (450 m s.n.m.). Para enlazar con la substructio documentada en la ladera opuesta debe mantener una pendiente constante.

En función de la topografía y de los escasos restos documentados in situ, presentamos un trazado hipotético del acueducto. Este recorrido propuesto es limitado, ya que falta información necesaria para poder precisar y determinar las soluciones constructivas empleadas en los distintos tramos. El principio de un acueducto es conducir agua entre dos puntos, el de captación y el de destino. El caput aquae debe situarse a una altura superior que el lugar de llegada, ya que a través de un canal, el agua circula por gravedad. Así, el $l i-$ brator debía nivelar el recorrido con mucha precisión, consiguiendo una pendiente suficiente para que el agua llegase a su destino, sin mucha velocidad para que no dañase la obra. El canal o specus, empleando diversas soluciones constructivas según fuera más conveniente (subterráneo, semienterrado, elevado sobre muro o substructio, elevado sobre arcuationes o pilares, a presión mediante sifón, etc.), avanzaba adaptándose a la 
topografía del terreno (Fabre et al. 1991, Hodge 1992, Sánchez y Martínez 2016: 37-38).

En el caso concreto del acueducto de Lacipo, los primeros restos documentados se sitúan en la ribera derecha del arroyo la Albarrada. La conducción, desde el caput aquae, debía atravesar el curso de agua en algún punto. Para ello emplearía alguna solución constructiva para salvar el obstáculo, probablemente arcuationes (Hodge 1992: 129-147). El arroyo normalmente lleva agua durante todo el año, con importantes crecidas en invierno. Sin embargo, su lecho no es ancho, lo que demuestra el ojo del pequeño puente erigido para su cruce, denominado popularmente "puente romano". En cambio, la técnica empleada en su construcción no pertenece a esta cronología. Tras la inspección del lugar no detectamos restos del acueducto.

Como hemos comentado, encontramos los primeros restos de la conducción en la ladera opuesta al emplazamiento del caput, tras cruzar el arroyo. La técnica constructiva empleada es el canal sobre substructio. Esta es una de las soluciones constructivas más empleada en los acueductos romanos (Hodge 1992: 129). Se traduce en un specus elevado sobre murete, en este caso adosado a la pared de la ladera por la que discurre. Situado aproximadamente a $430 \mathrm{~m}$ s.n.m., presenta unas dimensiones de $1 \mathrm{~m}$ de altura y $0,55 \mathrm{~m}$ de ancho. Está realizado en conglomerado de piedras y mortero de cal (fig. 3). En su parte superior sustentaría el specus, que no se ha conservado. Habitualmente el canal está protegido por una cubierta realizada en diversos materiales, sin embargo no hemos hallado indicios que prueben su existencia.

El acueducto continúa su trazado en dirección sur. Debido al desnivel que adquiere el terreno a modo de barranco, el specus discurre sobre un paredón. Está realizado con el mismo aparejo que la substructio, empleando sillarejos pequeños bien careados trabados con mortero y escuadrados, formando una pared lisa. Alterna una serie de pilares adosados a modo de contrafuertes para reforzarlo (fig. 4). Esta solución se utiliza debido al relieve accidentado por el que discurre la obra, con el objeto de mantener la pendiente del canal. La conducción prosigue adosada a esta vertiente de la sierra de Crestellina, discurriendo en dirección a Casares y más concretamente a Lacipo.

Avanzando en su recorrido fueron detectados restos del specus in situ. Se encontraba fracturado, lo que impidió tomar sus medidas. Revestido con opus signinum, conserva el cuarto de bocel en sus ángulos (fig. 5). En esa pared, que sirve de sustento del canal y de contención del barranco de la montaña, localizamos una rotura. Esta nos permitió observar con detalle el adosamiento del muro de contención a la pendiente natural, con un grosor de 1,30 m aproximadamente (fig. 6C). En algunas de sus partes, la obra conserva un enlucido exterior alisado a modo de revestimiento final que sirve para darle consistencia al sillarejo y mejorar su apariencia (fig. 6A).

Más adelante el muro continúa. No obstante, los pilares se encuentran exentos en este tramo, separados unos $4 \mathrm{~m}$ de la pared (fig. 7). En algunos de ellos se conservan restos de signinum en la parte superior. Estos pilares podrían sustentar el canal, según indicaría el mortero hidráulico. El muro de contención evitaría desprendimientos de la ladera superior, que dañasen la fila paralela de pilares exentos. Otra posibilidad es que hubieran sido pilares para arcos que sirvieran de contrafuertes a la pared construida, que sostendría el canal. Así se aliviaría el empuje de la ladera. Por otra parte, el muro, realizado a base de sillarejos, se adosa a la montaña. Las rocas calizas que sobresalen se tallan para formar ángulos rectos y permitir el acoplamiento de la construcción (fig. 6B).

Otro detalle constructivo del acueducto es la inserción de aliviaderos o desagües en la pared de mampuestos para canalizar escorrentías, evitando así el deterioro de la obra por las aguas procedentes de cotas superiores. Estos aliviaderos son triangulares, en forma de cubierta a dos aguas, y se sitúan en la parte inferior del muro (fig. 6D).

En el avance de la conducción por la vertiente este de la sierra Crestellina hacia el sur, a una altura de 418-420 m s.n.m., observamos el empleo de otra técnica constructiva. Debido a la naturaleza caliza del terreno y sus afloramientos rocosos, los salientes de la pendiente son utilizados para tallar el canal. El specus presenta unas dimensiones de $0,35 \mathrm{~m}$ de ancho y $0,65 \mathrm{~m}$ de alto, conservando huellas de talla (fig. 8). El canal excavado en la roca es una técnica minoritaria empleada en los acueductos romanos (Hodge 1992: 105-106). En general se utiliza en zonas montañosas o poco pobladas, incluso es muy usual encontrarla en conducciones destinadas a usos agrícolas e industriales. En cambio, en Hispania sí que contamos claros ejemplos de canales excavados en la roca destinados a abastecer ciudades: particularmente en la Tarraconensis, en el acueducto de Albarracín-Cella (Teruel) (Almagro 2002), en el acueducto de los Bañales (Uncastillo, Zaragoza), que incluso alberga una tubería cerámica o metálica en su interior (Beltrán 1977: 95-101), o en el acueducto de Peña Cortada (Tuéjar, Valencia) (Jiménez 1995). En Baetica, este tipo de canales se ha documentado en lugares como 


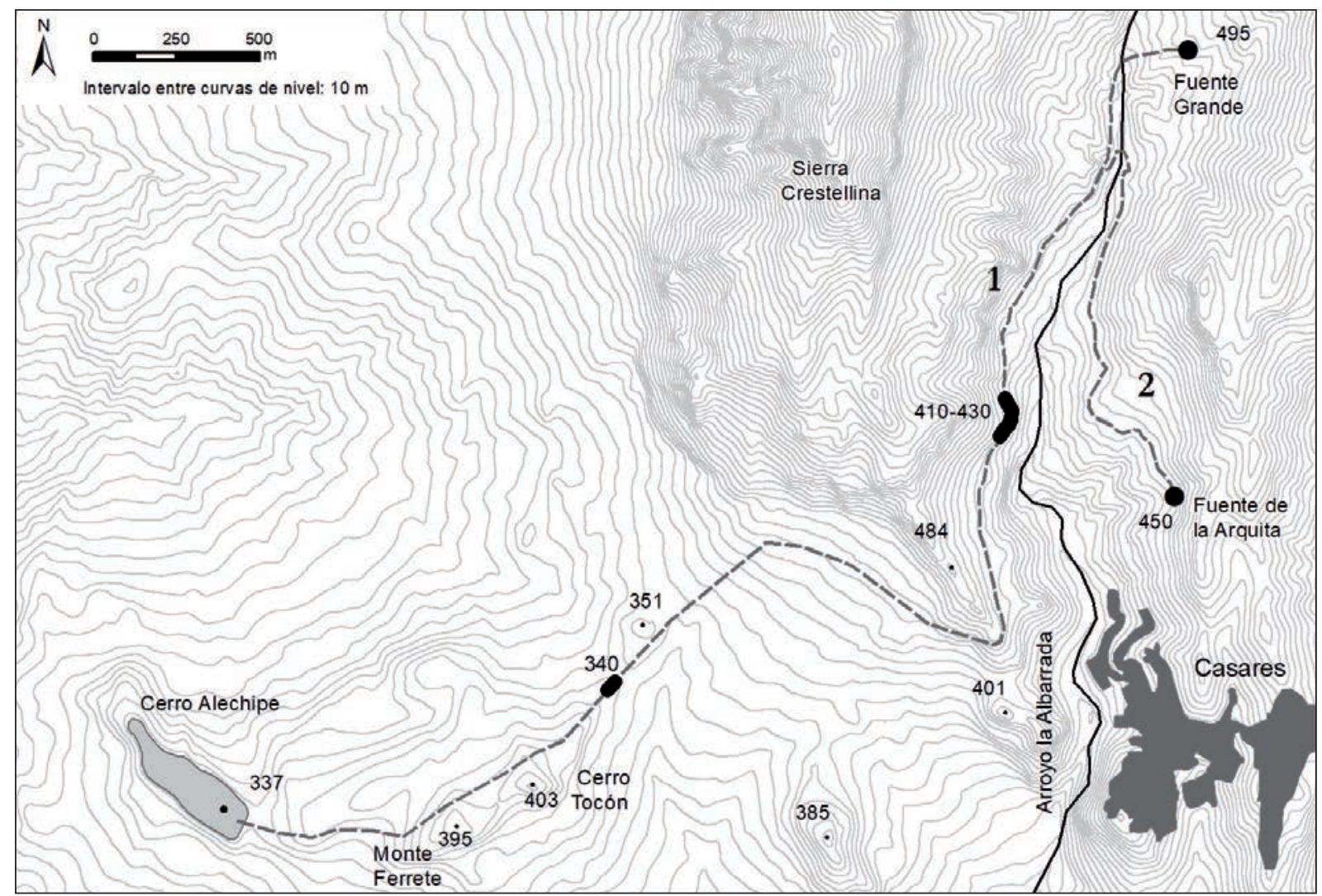

Figura 2. Trazado hipotético del acueducto romano de Lacipo con indicación de los restos localizados.

sierra Aznar (Arcos de la Frontera, Cádiz). Este asentamiento, localizado sobre un cerro, presenta importantes infraestructuras destinadas a la captación, conducción y almacenamiento de agua, pero cuya función no está clara (Guerrero 2001, Gener 2001). En cambio, el yacimiento no parece tratarse de un núcleo urbano, sino más bien de algún tipo de explotación de carácter minero o industrial (Mata et al. 2010).

Tras estos vestigios no detectamos más huellas de la conducción hasta llegar al llano. Suponemos que continúa alternando diversas soluciones constructivas adaptándose al relieve y a la pendiente por la ladera sureste de la sierra Crestellina, hasta su extremo sur. De forma gradual va descendiendo y bordeando la sierra para dirigirse al cerro Alechipe, donde se asienta la ciudad. En este recorrido, el acueducto debe discurrir entre las cotas 420 y $410 \mathrm{~m}$ s.n.m., bordeando la montaña en su punto más bajo.

Posteriormente, la conducción avanza por un terreno menos accidentado, a través de una sucesión de cerros de alturas suaves. Esta transición de la zona montañosa a la llanura conlleva un problema. Los constructores romanos debieron emplear alguna solución constructiva que permitiera el descenso drástico del nivel de cota. Una alternativa podrían haber sido los pozos de resalto o estructuras que permiten el frenado de la fuerza del agua, la ruptura de la pendiente y los cambios de dirección (Chanson 2000). Es una técnica utilizada en otros lugares con características similares, como en Córdoba. El acueducto romano de Valdepuentes o Aqua Vetus debía superar la acusada pendiente de Sierra Morena para alcanzar el llano. Para ello emplearon casi una cuarentena de pozos de resalto o spiramina, en los cuales el agua llenaba la parte más profunda y, una vez frenada la fuerza de la caída, salía remansada por otro canal a $5 \mathrm{~m}$ de profundidad respecto al primero. En algunos casos, el canal sucesivo se situaba en ángulo de $90^{\circ}$ respecto al siguiente, permitiendo la variación del trazado (Ventura 1996: 30-40, Ventura y Pizarro 2010: 190-191). Esta técnica también la encontramos en otros acueductos béticos, como en los de Baelo Claudia (Bolonia, Cádiz), donde los pozos ayudan a reducir la velocidad adquirida por el agua como consecuencia de una fuerte pendiente media (Jiménez 1973: 277, Sillières 1997: 145, Borau 2015: 155 y 157) 


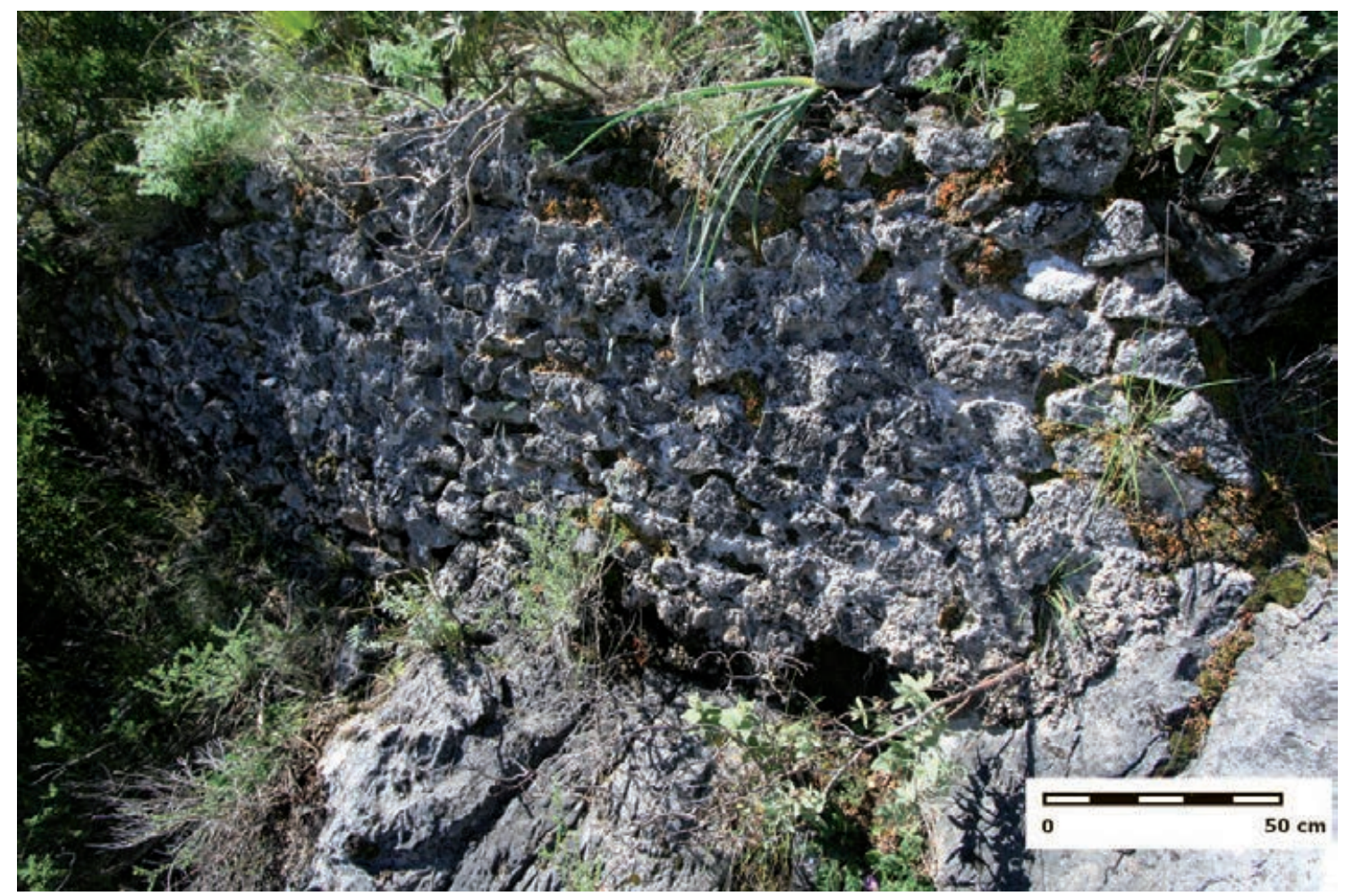

Figura 3. Substructio del acueducto en la ribera derecha del arroyo la Albarrada.

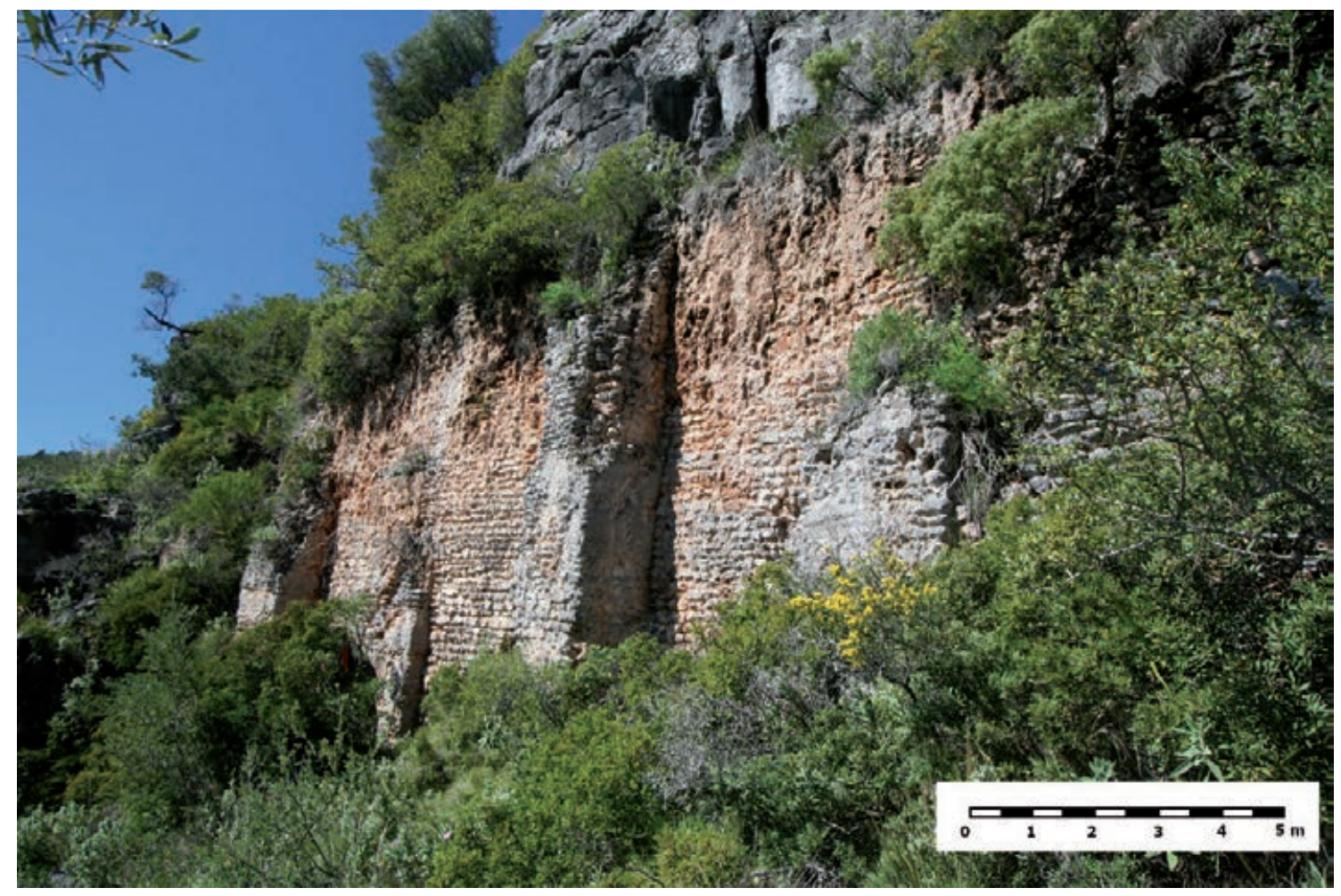

Figura 4. Paredón de sillarejo con contrafuertes para el sustento del specus adosado a la ladera. 


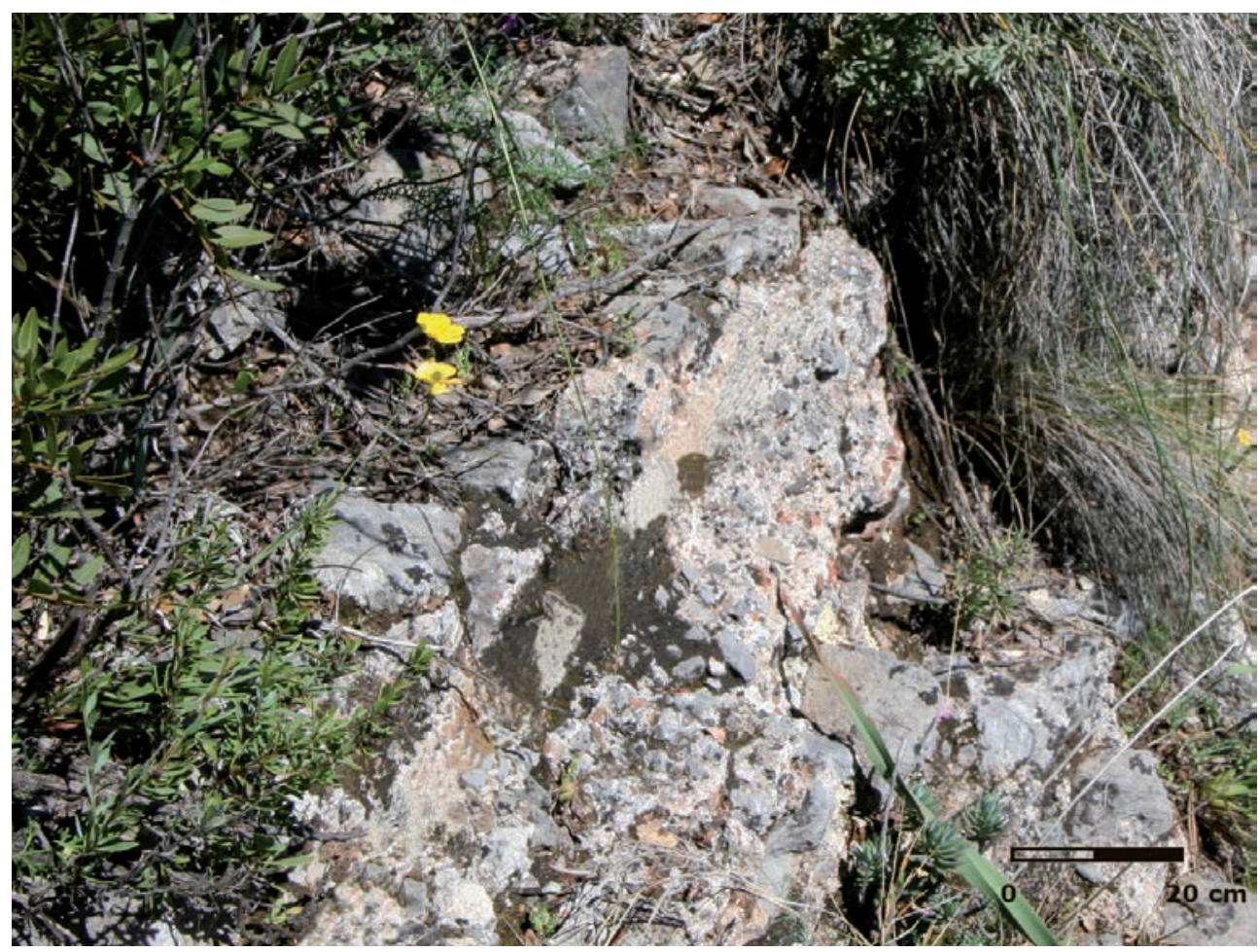

Figura 5. Restos de specus del acueducto.

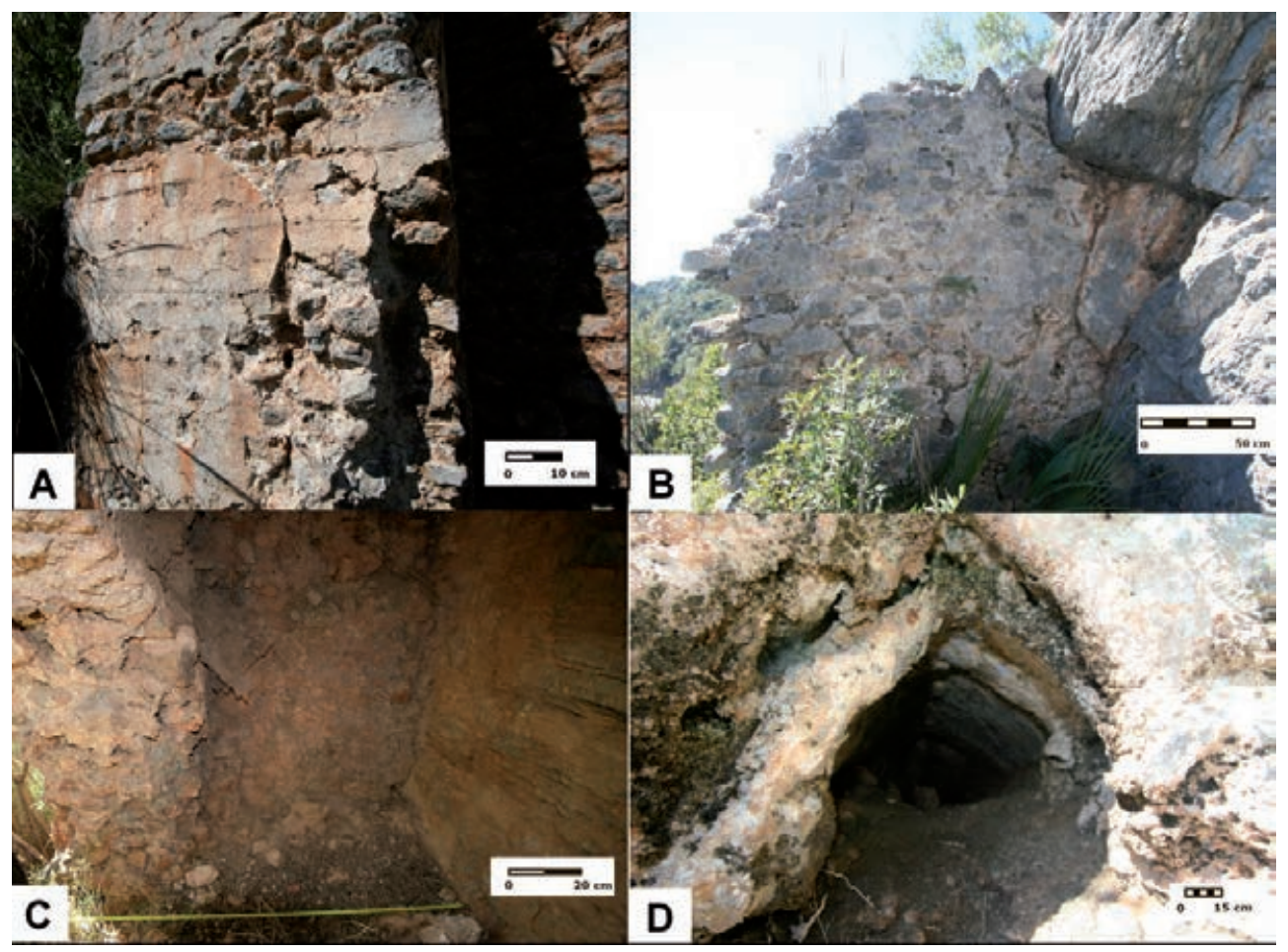

Figura 6. Detalles constructivos del acueducto. A. Enlucido exterior alisado a modo de revestimiento final en el muro de contención. B. Adosamiento del muro de contención a las rocas calizas de la ladera. C. Fractura en el muro de sillarejos que permite observar el adosamiento a la pared de la ladera. D. Aliviadero. 


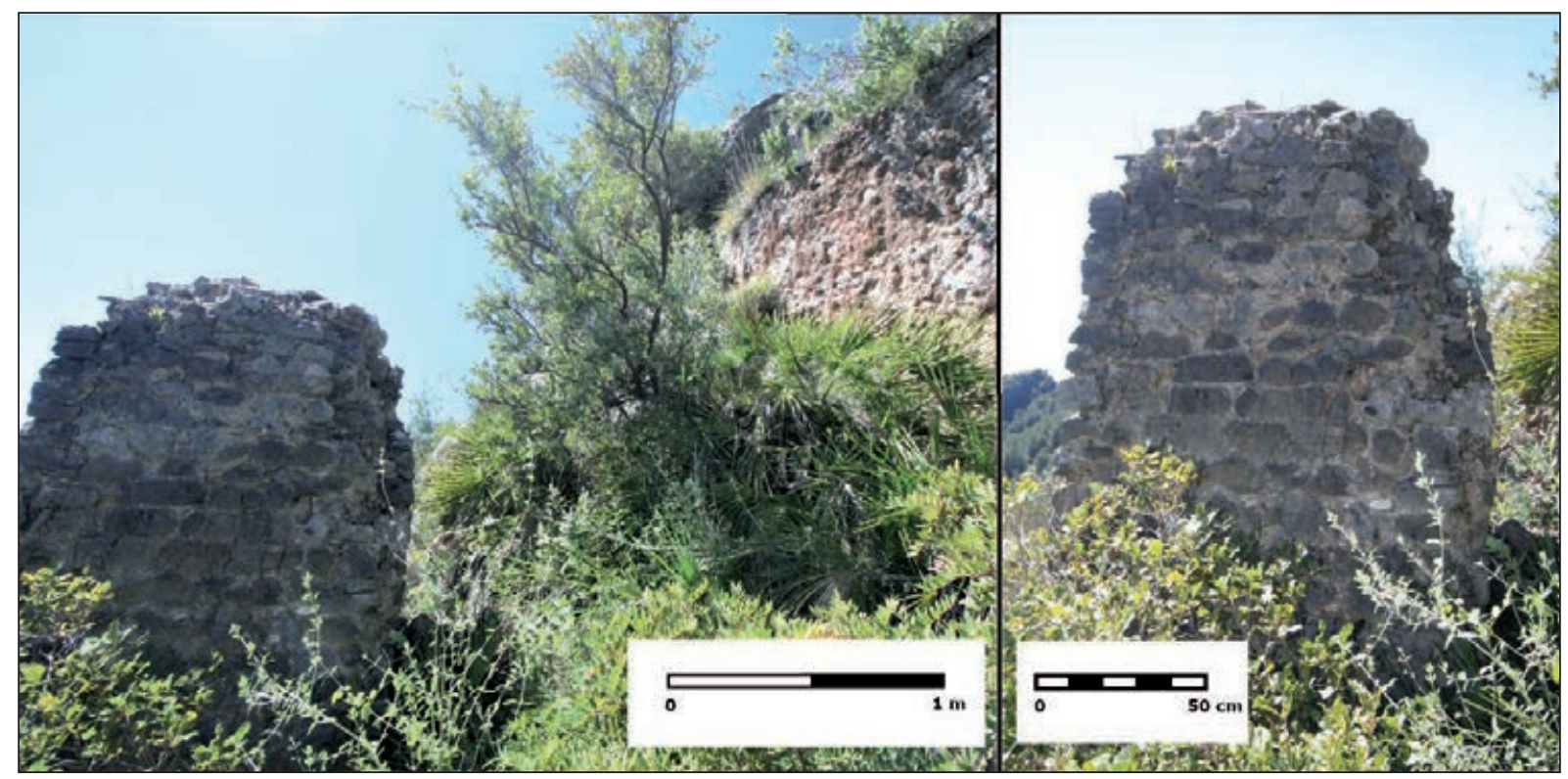

Figura 7. Izquierda: Pilar exento del acueducto en relación al muro de contención de la ladera. Derecha: Detalle del pilar.

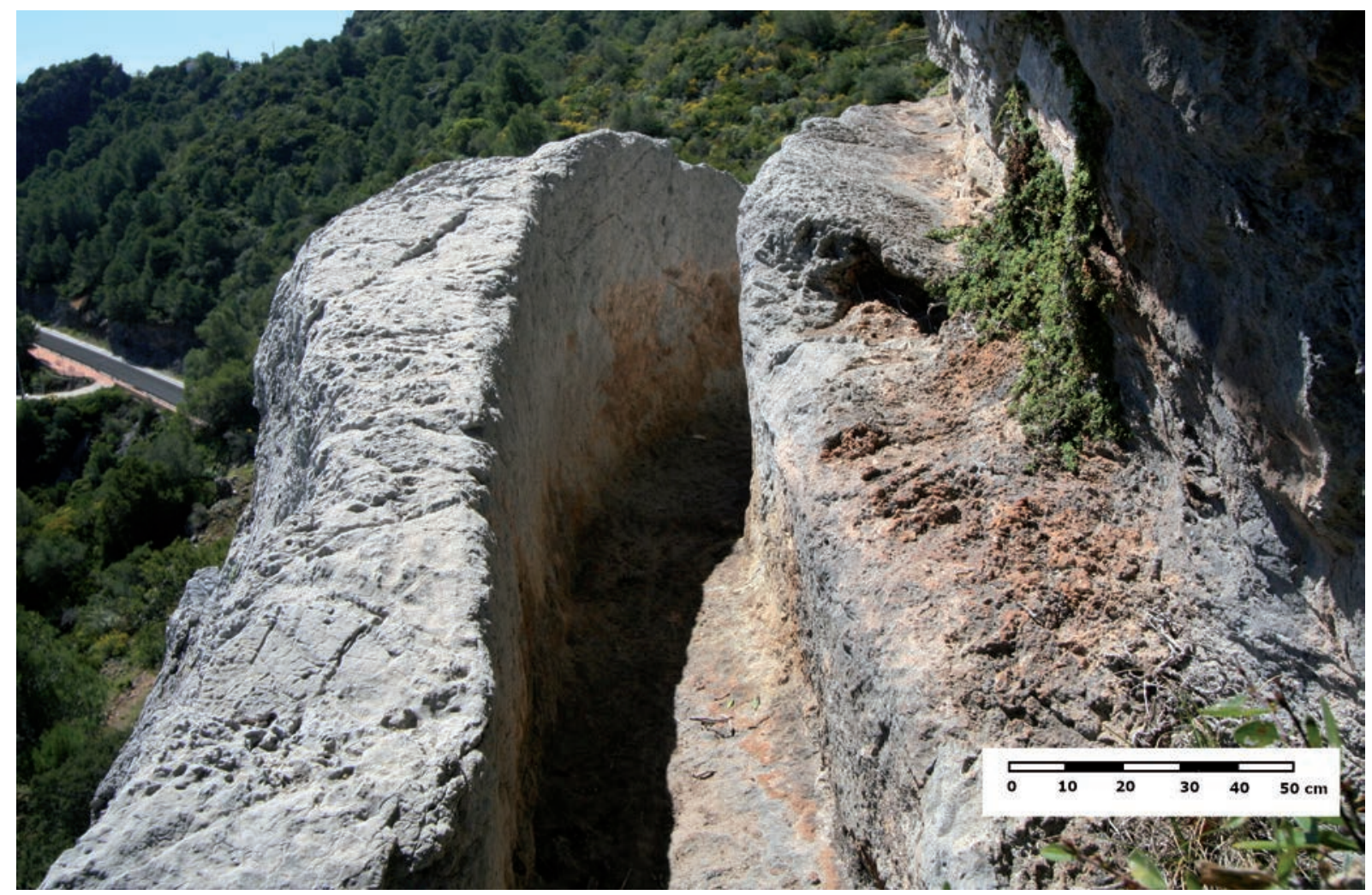

Figura 8. Specus tallado en la roca. 


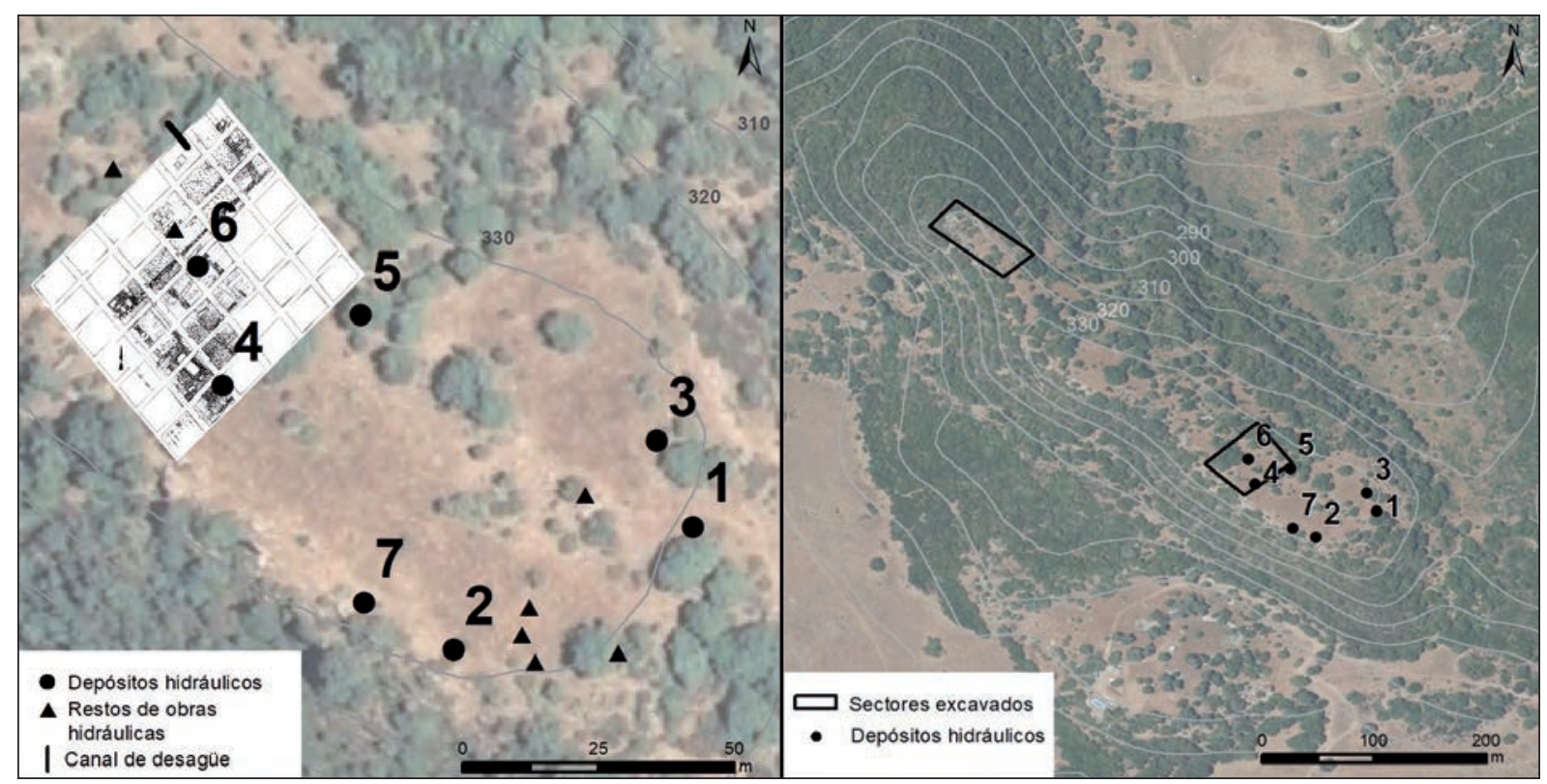

Figura 9. Izquierda: Ubicación de los depósitos hidráulicos documentados en cerro Alechipe. Derecha: Detalle del sector de concentración de los vestigios hidráulicos con la georreferenciación de la planta de la excavación realizada por Puertas (1982) en el sector sur.

Una vez que deja atrás Crestellina, una de las soluciones que emplea para atravesar la llanura y sus suaves cerros es mantener la altura del specus sobre pilares o arcuationes. Unas bases de pilares fueron localizadas al pie del cerro Tocón, en dirección este-oeste, a 340 m s.n.m. Los pilares están realizados en mampostería, coincidiendo con la misma fábrica que los detectados en la ladera de la sierra. Su función sería sustentar el specus, que probablemente fuese de mampostería. La altura del pilar nivelaría la diferencia de cota desde su procedencia, desde el final de la ladera de la sierra. El cerro Tocón alcanza los $400 \mathrm{~m}$ s.n.m., por lo que debería bordearlo entre las cotas 340 y 350 en su lado izquierdo o derecho, al igual que ocurre con el monte Ferrete, situado a continuación. Tras salvar ambas elevaciones, el acueducto debe discurrir por el llano que limita los cerros y el Alechipe, a una cota de $311 \mathrm{~m}$ s.n.m. En este último tramo el acueducto emplearía la técnica de specus sobre arcuationes, siendo los pilares las bases de los mismos. Esta técnica fue muy utilizada en la construcción de acueductos en el mundo romano (Hodge 1992: 129-147). De la misma contamos con numerosos ejemplos en Hispania (Sánchez y Martínez 2016: 50-52).

Finalmente, sobre pilares o sobre substructio, la canalización alcanzaría la cota de 328-330 m s.n.m., accediendo por la ladera sureste del cerro Alechipe. En el final de la ladera, en su sentido ascendente, hemos detectado restos de un murete a modo de substructio que podría pertenecer a la conducción. Además, la concentración de depósitos hidráulicos en esta parte del cerro induce a pensar en una entrada del acueducto por esta vertiente, como ya apuntó Soto Jiménez (1979: 6-7). No podemos asegurar qué cisterna es la que recoge las aguas de la conducción a su llegada, a modo de castellum aquae, ya que no encontramos vestigios de su conexión. El depósito debería encontrarse en la cota más alta del cerro, para posteriormente proceder a la distribución del agua por gravedad.

La longitud que discurre entre la fuente de captación y las construcciones hidráulicas del yacimiento es de 3,7 km en línea recta. En cambio la conducción, en su adaptación al terreno y ante la necesidad de mantener la cota, alcanzaría los $5 \mathrm{~km}$, teniendo en cuenta el obstáculo que supone la estribación sur de la sierra Crestellina.

\section{EL ABASTECIMIENTO DE AGUA: EL AGUA EN LA CIUDAD, LOS DEPÓSITOS HIDRÁULICOS Y LAS CISTERNAE}

Una serie de depósitos hidráulicos y cisternas constituyen los vestigios más llamativos del yacimiento. 
Los encontramos concentrados en la parte sur, suroeste y sureste del cerro Alechipe. Esta agrupación se sitúa en el posible punto de acceso del acueducto a la ciudad. El terreno donde se asientan está aterrazado, para así aliviar la pendiente de la zona alta del cerro. Las construcciones de la parte más baja se sitúan en torno a los 328 m s.n.m., mientras que aquellas emplazadas en la parte más alta, lo hacen sobre una cota de 337 m s.n.m.

Los depósitos han sido documentados en las visitas arqueológicas realizadas al yacimiento, a excepción del número 6, que fue localizado en las excavaciones practicadas en el año 1975 (Puertas 1982) y que no es visible en la actualidad.

- Depósito 1: Se encuentra en el borde de la planicie del cerro sobre la que se extiende el yacimiento, en la ladera sureste. Está situado en la cota más baja con respecto a las siguientes construcciones, a 329 m s.n.m. El depósito se encuentra exento, sin estar relacionado con otra estructura ni integrado en ella. El estado de conservación no es bueno, pues está fracturado por la mitad, quedando una de sus partes desplazada hacia la ladera. La planta es rectangular, con dos cámaras abovedadas comunicadas por medio de un arco de medio punto. Presenta restos de cubierta abovedada. Su orientación es oeste-este y sus dimensiones aproximadas, teniendo en cuenta el desplazamiento y fractura, son 3,5 m de largo y $2,88 \mathrm{~m}$ de ancho. La altura hasta la cubierta es de 2,32 $\mathrm{m}$, siendo 1,71 $\mathrm{m}$ hasta el arranque de la bóveda y $0,55 \mathrm{~m}$ el arco, con una altura total de 2,26 $\mathrm{m}$. El grosor de los muros es 0,60 m. Su cubicaje aproximado calculado a partir de estas medidas es $22,78 \mathrm{~m}^{3}$. Está construido en sillarejo, compuesto por piedras de pequeño tamaño trabadas con mortero de cal. El arco de comunicación entre las dos cámaras está reforzado con ladrillos. Posee revestimiento en opus signinum con varias capas, presentando una final más lisa preparada a modo de superficie. También podría ser fruto de una obra posterior de restauración. Las esquinas se hacen cóncavas, otorgando una forma ovalada a los bordes con el propio signinum para asegurar la estanqueidad en las juntas, aprovechando el revoco que aporta el mortero. No sabemos si el fondo estaría dispuesto a dos niveles con el objeto de depurar las aguas o decantarlas, tal y como aconseja Vitrubio (8.6.15.). El desplazamiento de parte del depósito hacia la ladera nos impidió conocer el nivel de cota. Los orificios de entrada y salida del agua no pudieron ser detectados.
- Depósito 2: Corresponde a los restos de una gran estructura abovedada de la que solo se conserva una parte, con unas dimensiones de al menos $2 \mathrm{~m}$ de ancho. Ocupa uno de los laterales de la parte suroeste del cerro, situado junto a los restos de la muralla que lo circunda. Se emplaza en una cota más alta que el anterior depósito, a 331 m s.n.m. Conserva el arranque y parte de la bóveda de cañón que poseía a modo de cubierta. No conocemos si disponía de una sola cámara o dos. La estructura presenta unos potentes muros realizados en sillarejo, aunque con piedras de mayor tamaño que la anterior construcción. Igualmente está revestido en opus signinum, con el detalle de un cordón hidráulico en las juntas. Puede existir relación con los restos de una substructio de sillarejo, argamasa y signinum a modo de canal, que se localiza en la parte final de la ladera del cerro y apunta en dirección a este depósito. Esta posible conducción podría pertenecer a parte del acueducto. Por otro lado, entre el reservorio y la substructio encontramos restos de lo que podría haber sido un pequeño lacus, o la pavimentación de una fuente ornamental de modesto tamaño de algún edificio.

- Depósito 3: La siguiente estructura se sitúa en la parte este del cerro, en el lado contrario al depósito 2. El estado de conservación es malo, ya que mantiene solo uno de sus ángulos, que parece corresponder con el fondo. La orientación es oeste-este, dirigiéndose hacia el lugar donde se dispondría la parte habitacional del yacimiento. Situado entre la cota 328 y 331 m s.n.m., constituye otro depósito de tamaño considerable, presentando una longitud conservada de al menos $3,5 \mathrm{~m}$. En sus proximidades se encuentran restos de lo que sería su cubierta, abovedada. La técnica constructiva es muy parecida a la empleada en el depósito 2. Gruesos muros están realizados en sillarejo trabado con mortero, formado por piedras de mayor tamaño que el primer depósito. La capa de revestimiento en signinum está formada por fragmentos cerámicos de gran tamaño, aportándole un color ocre muy marcado. Está en correlación y en la misma dirección que otros vestigios de estructuras hidráulicas. Estos restos se encuentran en una altura un poco más elevada, entre los 332 y 333 m s.n.m., y se corresponden con aparentes depósitos, atanores y fragmentos de signinum.

- Depósito 4: Esta construcción hidráulica fue hallada en la campaña de excavación del año 1975, en el extremo sur del cerro (Puertas 1982: 25 y 32-33). 


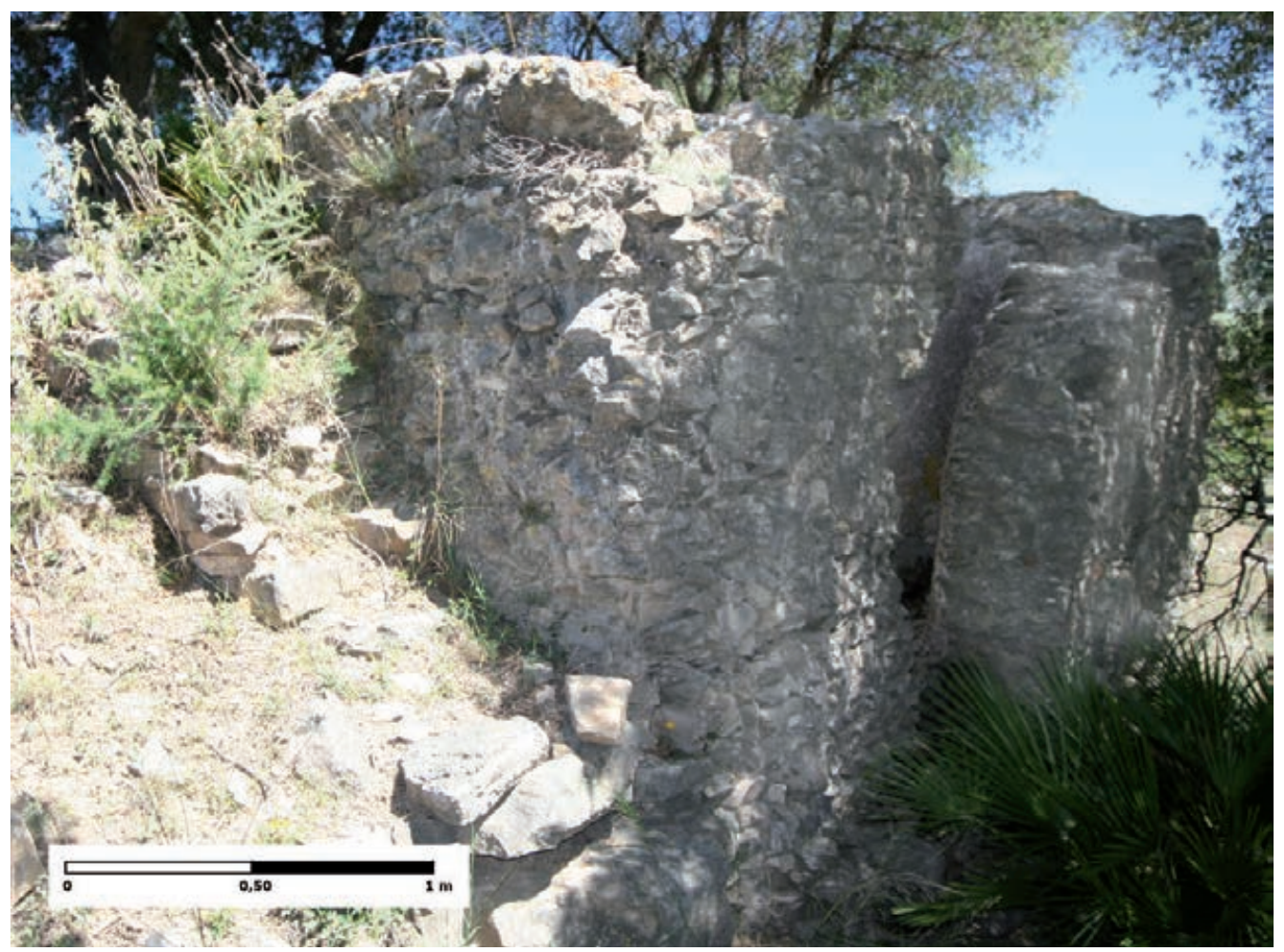

Figura 10. Exterior del depósito hidráulico 1.

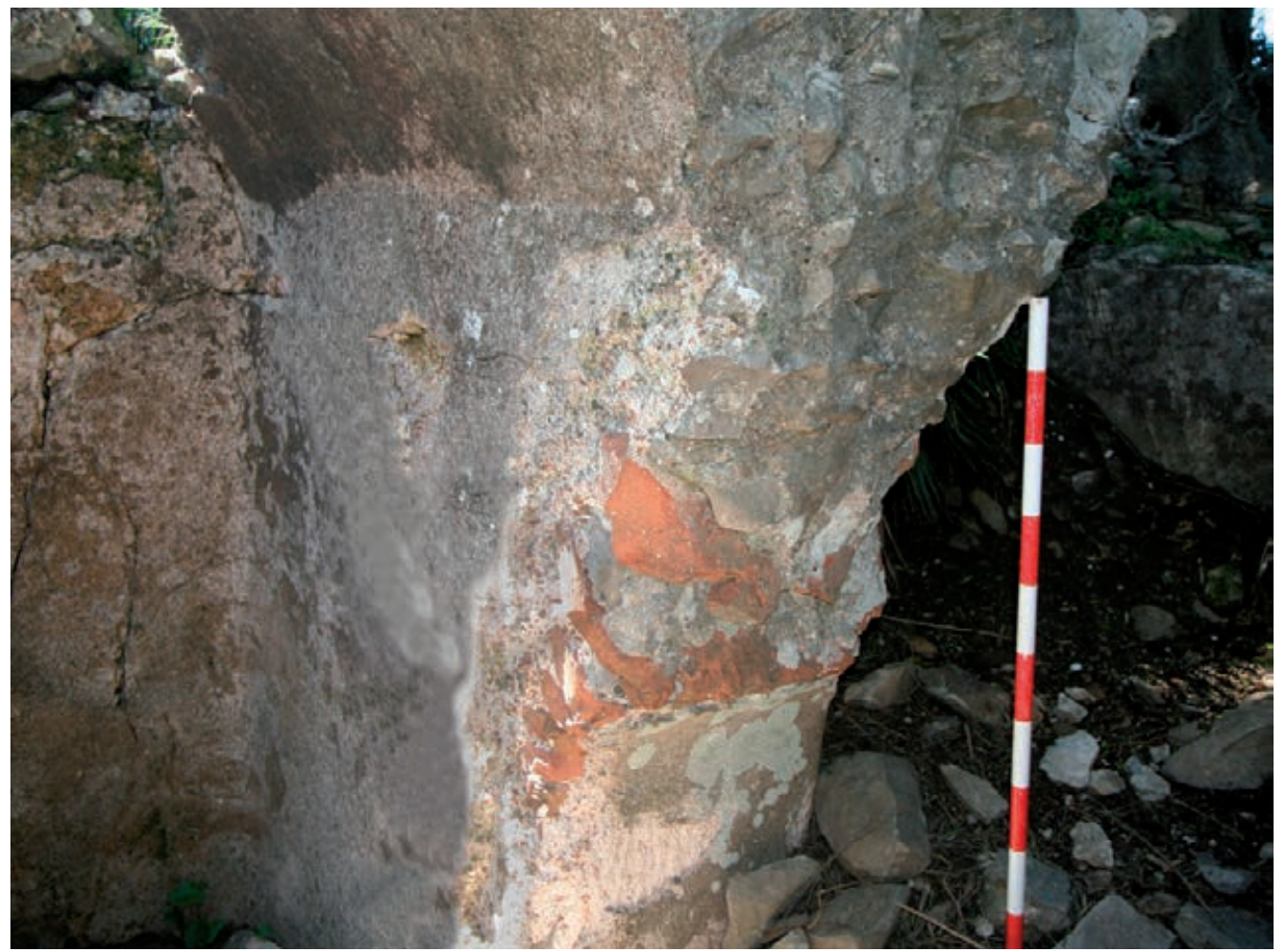

Figura 11. Detalle del arco de comunicación de las dos cámaras del depósito hidráulico 1.

ISSN: 1133-4525 ISSN-e: 2255-3924 
Está asociada a una de las estructuras documentadas en el nivel cronológico romano, interpretada como gran edificio público. Se encuentra sobre la cota de 337,5 m s.n.m. En la actualidad continúa siendo visible, lo que nos permitió documentarla. La planta del aljibe es rectangular y sus extremos redondeados. Está excavado en el subsuelo y sus lados reforzados con sillarejos previamente labrados, redondeados en las esquinas. Finalmente se impermeabiliza con mortero hidráulico u opus signinum. En función de sus características morfológicas podemos calificarlo como cisterna a bagnarola. Las dimensiones son 4,7 $\mathrm{m}$ de largo y 2,4 $\mathrm{m}$ de ancho, junto con una profundidad máxima de $2,7 \mathrm{~m}$. La pared oeste y el fondo presentan una marcada curvatura debido al empuje de la tierra.

De su técnica constructiva podemos señalar el uso de dos aparejos diferentes a la hora de revestir los muros. Por una parte se utilizan lajas de piedra escuadradas en los laterales, mientras que por otra se emplea sillería caliza y arenisca labrada en redondo en los ángulos. Localizamos dos lugares por donde se produciría la entrada de los tubuli cerámicos que conducen el agua hacia ella. Además, en la excavación se registraron canalillos que llegaban al compartimento donde se localiza la cisterna (Puertas 1982: 25). El signinum del revestimiento parece diferir en composición al de los demás depósitos, siendo la capa más fina. De la cubierta no tenemos constancia. Según la tipología del aljibe, su relación con el nivel de suelo y las estructuras murarias asociadas, dispondría de una cubierta adintelada, con una abertura a modo de brocal para la extracción del agua, todo ello integrado en una estancia del edificio (Puertas 1982: 34). Como consecuencia del abandono, en la excavación, el interior se encontró colmatado por material constructivo, cerámico y metálico.

- Depósito 5: Se corresponde con restos ubicados en el extremo de la ladera este del cerro. El depósito, de una cámara, está construido siguiendo la misma técnica que los anteriores. Gruesos muros realizados en sillarejo están revestidos en su interior con signinum, con signos de haber sido reparado en diversas ocasiones. No pudimos tomar medidas de la estructura ya que el interior se encontraba colmatado con grandes piedras.

- Depósito 6: Hallado en la campaña de excavación de 1975. No ha sido posible localizarlo, por lo que la información aportada está extraída del informe arqueológico (Puertas 1982: 28). Emplazado sobre la cota 337 m s.n.m., se encuentra inserto en un conjunto constructivo y asociado a estructuras murarias. Presenta un brocal formado por piedras en alineación semicircular. El revestimiento de la cisterna es de opus signinum, alisado en su superficie. Una conducción cerámica compuesta por piezas abocinadas ensambladas era su método de alimentación. En su interior se hallaron fragmentos de cerámica y de tejas. La profundidad del aljibe alcanza los $3 \mathrm{~m}$. En la información contenida en la memoria de excavación no se detalla la morfología de su planta, sin embargo, atendiendo a sus características constructivas, su ubicación y su cercanía a la anterior cisterna documentada, podría tratarse de otra cisterna a bagnarola.

- Depósito 7: Encontramos vestigios de otro depósito hidráulico en la vertiente oeste del cerro. Está emplazado a 332 m s.n.m., en el inicio de la ladera, cerca de los restos interpretados como muralla. Emplea la misma técnica constructiva que los reservorios de grandes dimensiones. Al estar desprendido en una pendiente escarpada y oculto por densa vegetación, no pudimos documentar más detalles constructivos.

En cuanto a la función de los depósitos hidráulicos presentes en Lacipo, a partir de los datos con los que contamos planteamos algunas ideas de cómo se integran en el ciclo del agua de la ciudad.

En una ciudad romana, el ciclo urbano del agua se inicia con la captación y conducción. Posteriormente se distribuye en el interior de la propia urbe y en algunos casos se almacena. El punto de llegada del acueducto al asentamiento generalmente se corresponde con un depósito o castellum aquae. Esta construcción sirve o únicamente para distribuir el agua, tal y como indica de manera teórica e ideal Vitrubio (8.6.), o para distribuirla y almacenarla (Peleg 2000, Wilson 2001, Bukowieki et al. 2008). Otra de sus funciones principales es la decantación y eliminación de las impurezas de las aguas portadas por el acueducto (Bukowieki et al. 2008). Asimismo, estos castella pueden ser de grandes dimensiones, como el gran depósito de Italica (Santiponce, Sevilla) (Pellicer 1982) y el documentado en Sevilla (García García 2007), o ser más modestos, como el presente en Baelo Claudia (Borau 2015: 162-164).

En el caso de Lacipo, la relación de alguno de estos depósitos con el acueducto parece clara. El aqua ducta alcanzaría la ciudad por la ladera sureste del cerro, siendo el punto de más fácil acceso y donde 


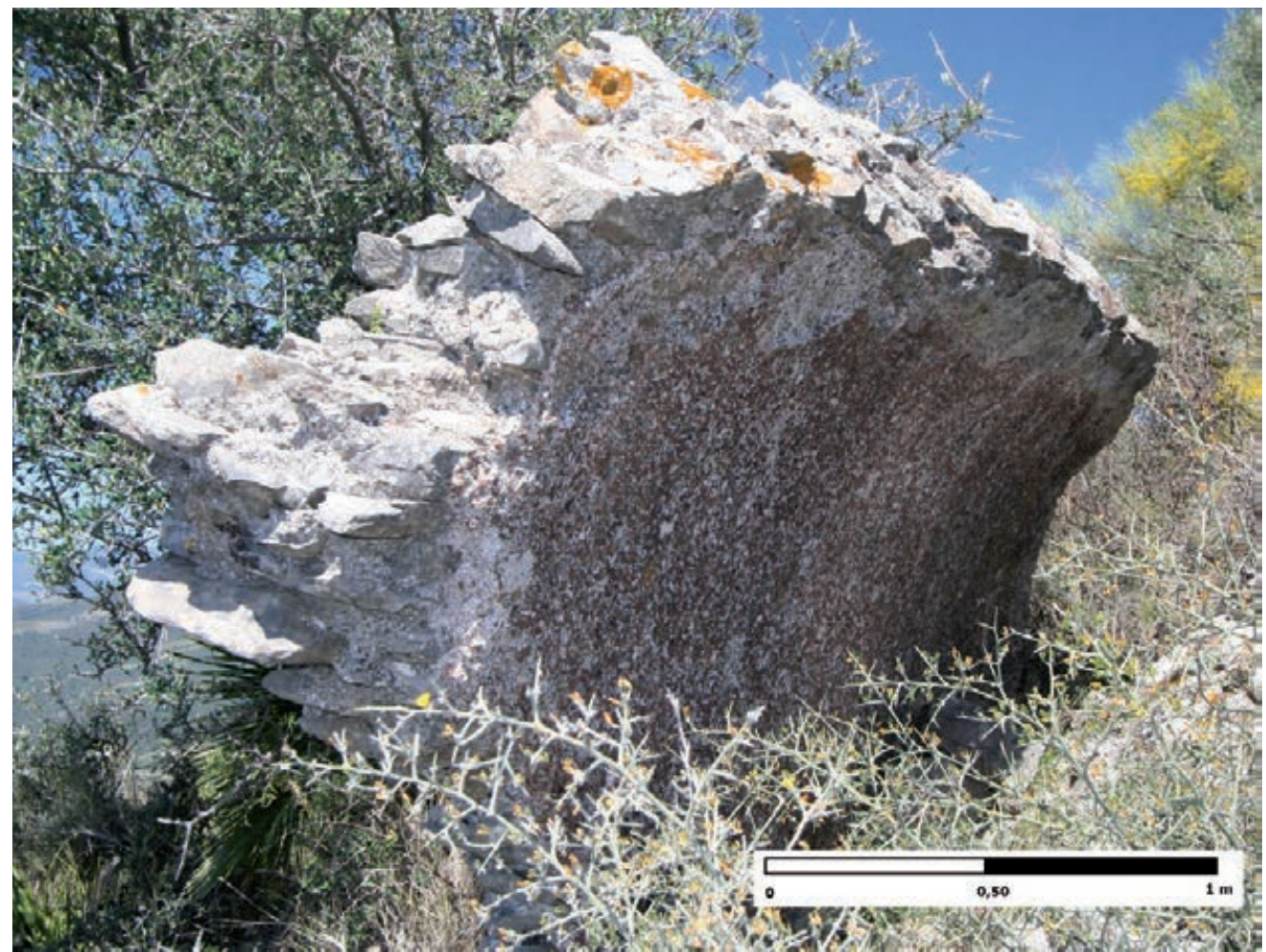

Figura 12. Restos conservados del depósito hidráulico 2.

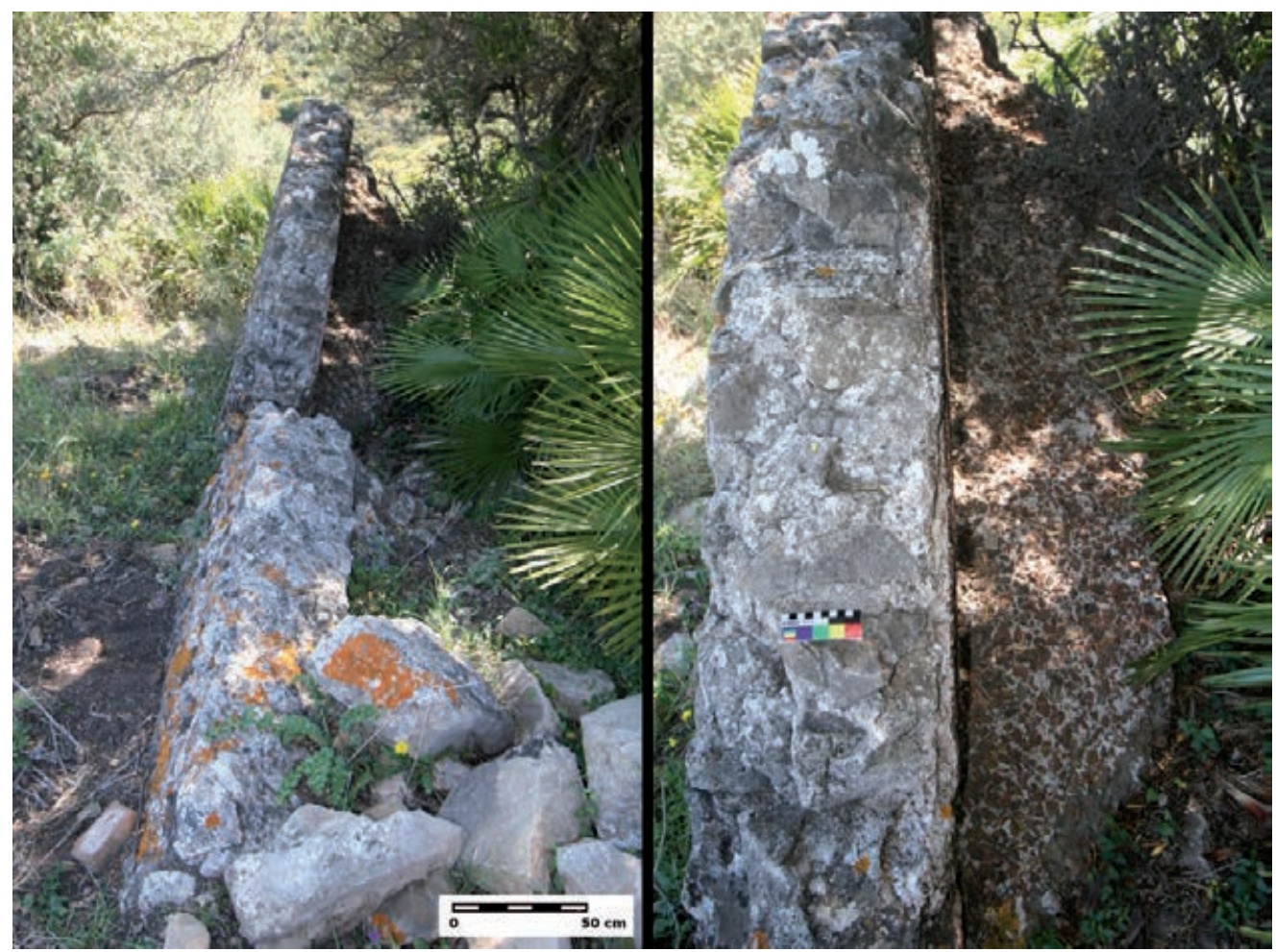

Figura 13. Restos conservados del depósito hidráulico 3.

ISSN: $1133-4525$ ISSN-e: 2255-3924

SPAL 29.1 (2020): 189-212

http://dx.doi.org/10.12795/spal.2020.i29.07 


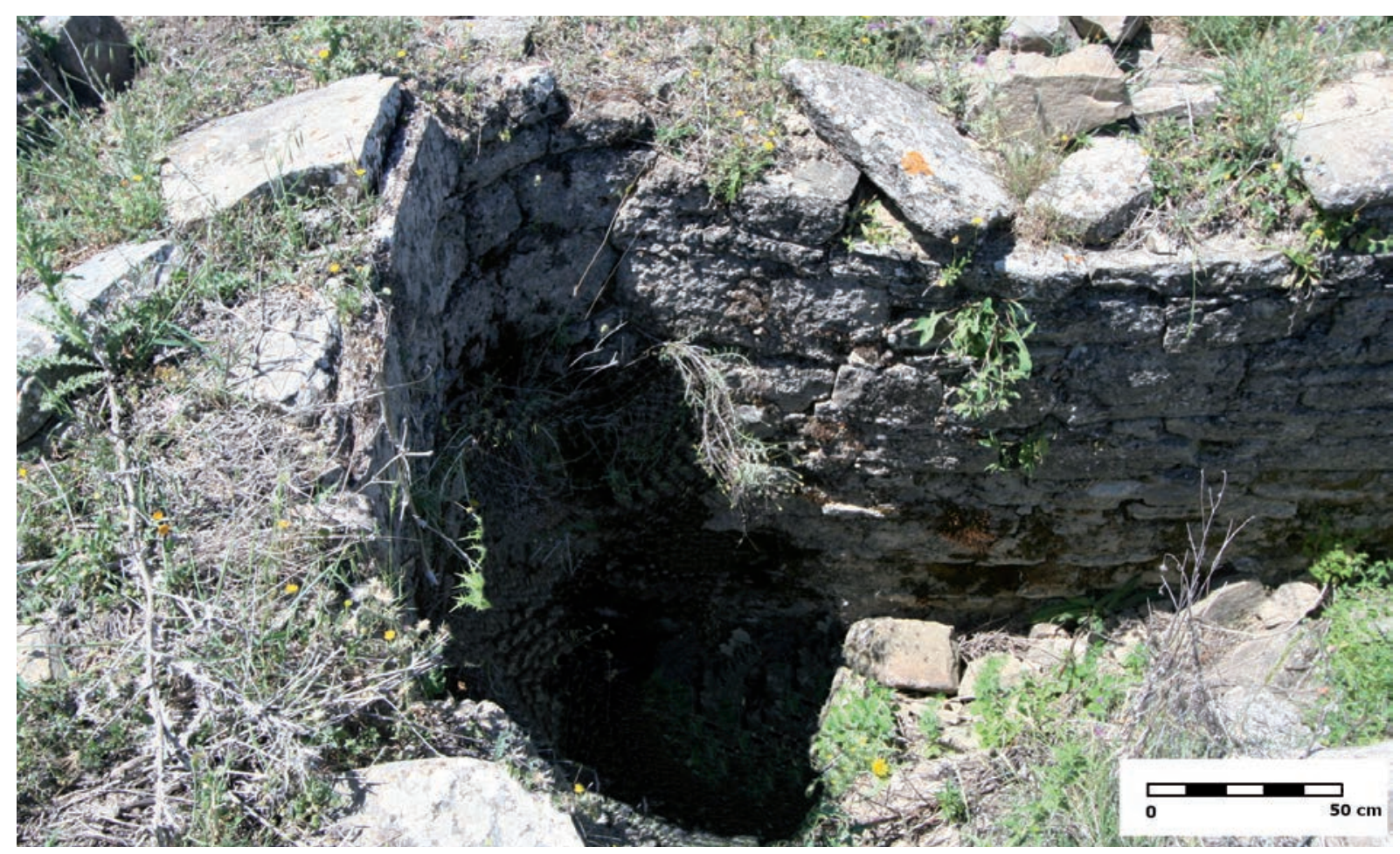

Figura 14. Uno de los extremos del depósito hidráulico 4 o cisterna a bagnarola.

probablemente se situara la puerta principal. Los reservorios de grandes dimensiones documentados se emplazan en esta parte. Al igual sucede con otros castella aquae que se ubican en la entrada de las urbes romanas. Uno de los más representativos es el de Pompeya, en la Puerta del Vesubio (Adams y Varène 2008), o el de Ostia en la Puerta Romana (Bukowieki et al. 2008). Por otro lado, los depósitos están exentos aparentemente, sin edificios que sirvan de impluvia para su llenado, sugiriendo una alimentación mediante el agua del acueducto.

Según la topografía de Lacipo, el depósito situado a mayor altura debería ser el castellum aquae del acueducto. Excluimos las dos cisternas a bagnarola que por su situación, insertas en un edificio, y su tipología no son propias de un castellum. Los reservorios situados en las cotas más altas son el depósito 2 y 3 . Del número 2 no conocemos su solución de cubierta, aunque sí sus grandes dimensiones. Al estar fracturado no podemos establecerlas con exactitud, pero al menos posee más de $3 \mathrm{~m}$ de largo. Se encuentra a la misma cota que el depósito 3. Uno y otro están emplazados a ambos lados del límite de la parte amesetada del cerro, donde se asienta la ciudad. Del reservorio 3 solo se conserva el arranque de la bóveda. Sin embargo, la potencia de los muros sugiere que debió disponer de una importante capacidad. Los siguientes depósitos también se encuentran en los límites de la meseta del cerro. En concreto, el número 7 parece desplazado hacia abajo, también fracturado. El depósito 5 es el más cercano a la zona excavada y al edificio de grandes dimensiones documentado.

El modo de conexión entre los depósitos es desconocido. No se conservan restos de tubuli o fistulae en el lugar. Tampoco se ha excavado la zona circundante para localizar canalizaciones. En cambio, sí que detectamos una conducción sobre murete junto al depósito 2 que podría funcionar como canal de conexión. Asimismo, localizamos un atanor en piedra procedente de un conducto que podemos poner en relación con la redistribución interna del agua en el yacimiento.

Las construcciones hidráulicas se distribuyen siguiendo una lógica topográfica, encuadrados entre los 329 y 334 m s.n.m., siempre en los límites de la zona donde se asienta la ciudad. La separación entre las mismas es regular, alternando $50 \mathrm{~m}$ entre las que se encuentran más alejadas, y casi $20 \mathrm{~m}$ aquellas más cercanas entre sí. Por tanto, el agua se concentra en un área determinada del yacimiento. Este detalle puede estar indicando el lugar donde se encontraban los edificios y 


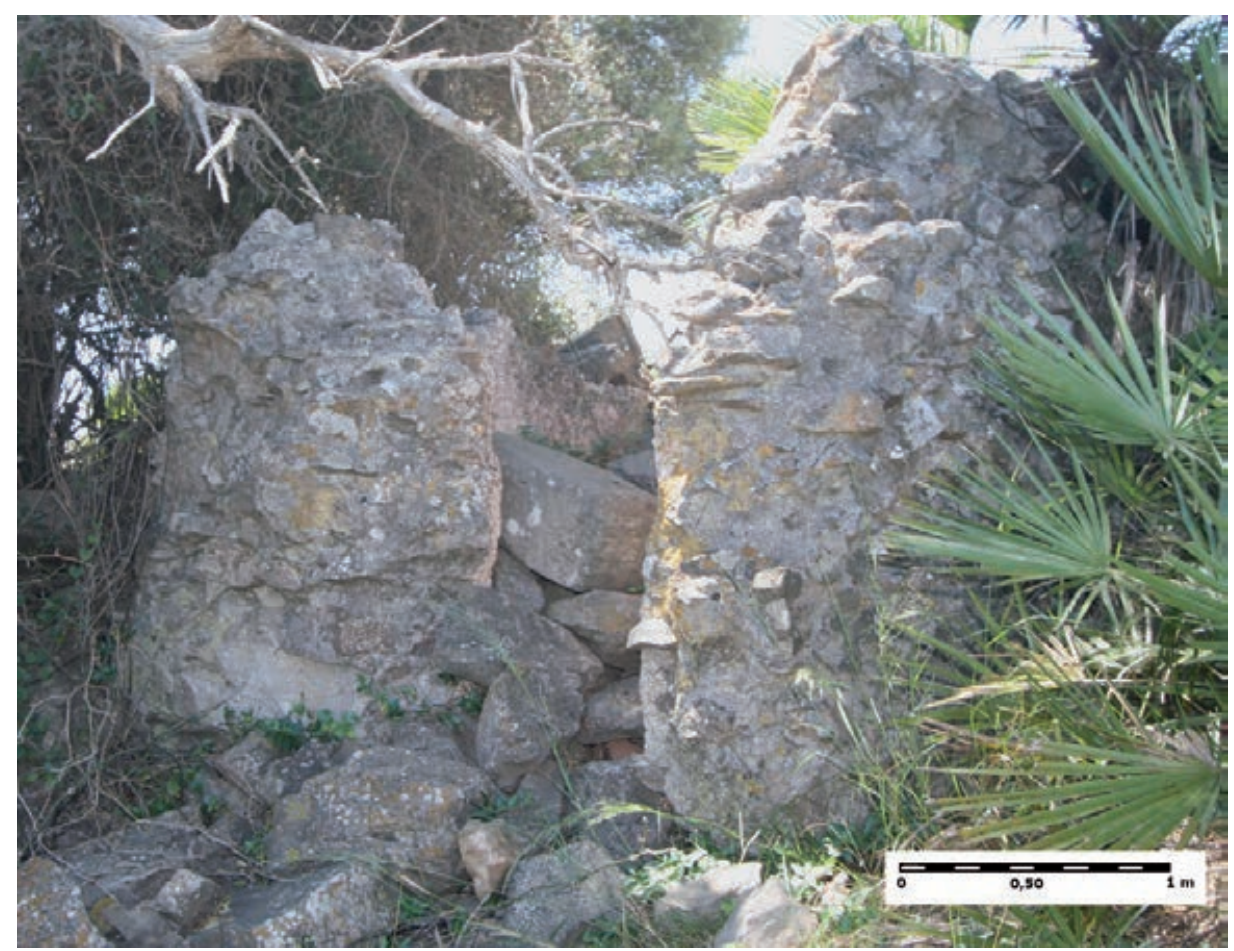

Figura 15. Restos conservados del depósito hidráulico 5.

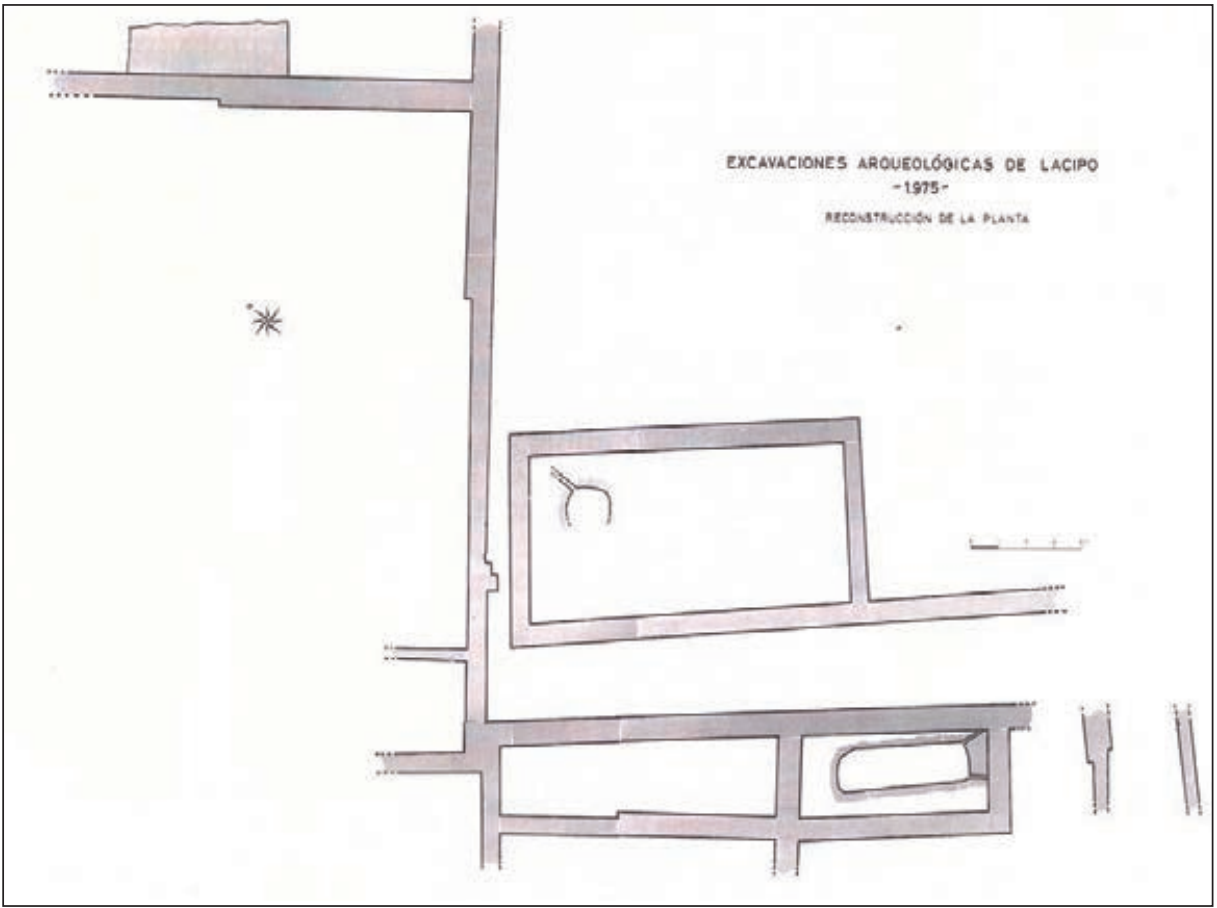

Figura 16. Reconstrucción de la planta del edificio donde se documentan las cisternas halladas en las excavaciones de 1975 (Puertas 1982: 34). 
construcciones a los cuales iba destinada el agua. También podría ser el punto desde donde se distribuía al resto del asentamiento, mediante pequeñas canalizaciones y fistulae.

El yacimiento tiene una extensión aproximada de $45.300 \mathrm{~m}^{2}$, abarcando la totalidad de la zona amesetada del cerro. Una distancia de $450 \mathrm{~m}$ separa los depósitos hidráulicos del espacio más al norte, ocupado por construcciones de carácter defensivo a modo de bastión, sin estructuras habitacionales ni edificios de carácter público (Puertas 1982: 102-105). En cambio, en la parte sur del asentamiento, donde se concentran los reservorios, se documenta un edificio al que por su magnitud y características estructurales, se ha otorgado una función pública (Puertas 1982: 35).

Los testimonios existentes en Hispania de redistribución de agua por medio de cisternae o depósitos hidráulicos los encontramos en la Tarraconensis bien estudiados, concretamente en Bilbilis (Huérmeda, Zaragoza) o Uxama (Osma, Soria). En el municipium Bilbilis, los depósitos están dispuestos en coherencia topográfica para su posterior repartición por gravedad (Martín Bueno 1975). En cambio en Uxama el sistema de alimentación de aguas es más complejo. Al igual que en Bibilis y a diferencia de las presentes en Lacipo, las cisternas están realizadas en caementicium, revestidas con paramento de opus vittatum (García Merino 2006: 185-186). Un gran depósito subterráneo semicircular de decantación era alimentado por un acueducto mediante un artilugio para la elevación de aguas, ya que se encontraban a diferente altura (García Merino 2010: 288-291). Un conjunto de reservorios, casi una veintena, repartidos por toda la superficie urbana de forma escalonada sobre una serie de curvas de nivel, redistribuyen el agua. Se encuentran semiencastrados en las laderas y separados entre sí por distancias regulares. Su capacidad oscila entre los 30 y $40 \mathrm{~m}^{3}$ (García Merino 2006: 185-186, García Merino 2010: 293).

En el presente caso de estudio cabe señalar que dos de los depósitos descritos tienen una tipología y unas características constructivas diferentes. Nos referimos a las dos cisternas a bagnarola que se hallaron en las excavaciones del sector sur (depósitos 4 y 6). Una de ellas se documentó completa. La tipología a bagnarola es de tradición helenística (en la península ibérica: Burés 1998; en el Mediterráneo: Mezzolani 1997, Bonetto et al. 2012). En la provincia Baetica, en la mitad sur occidental, encontramos una concentración de cisternas adscritas a esta tipología. Este fenómeno es consecuencia de la cercanía a las colonias púnicas costeras y de su importancia como influencia cultural en la zona (Bravo 2010). Un ejemplo de ello se encuentra en la cercana $O b a$, actual Jimena de la Frontera (Cádiz). El oppidum guarda con Lacipo una estrecha relación, tanto visual como funcional, debido a su situación en la ribera opuesta del río Guadiaro. Ambos controlan el valle fluvial, que supondría una vía de acceso hacia el interior desde el estrecho de Gibraltar, en su parte más oriental. En esta localidad, durante las excavaciones practicadas en el castillo medieval, se localizó una cisterna a bagnarola asociada a unas estancias de carácter público pertenecientes a la antigua ciudad romana (Tabales et al. 2005: 144). Así pues, encontramos otro aljibe correspondiente a la misma tipología en otra localidad próxima, en la comarca de la Janda, concretamente en Alcalá de los Gazules (Cádiz). Se encuentra asociado a dos grandes depósitos hidráulicos de época romana (Montañés y Montañés 2010).

En función de sus dimensiones, las cisternas $a$ bagnarola laciponenses parecen ser privadas, de uso doméstico. Aunque se encuentren en un edificio de tipo público, podrían cumplir la función de abastecimiento de los usos privados del establecimiento. Por otro lado, el agua destinada a los lacus y fuentes ornamentales, que podrían estar relacionados con los pavimentos de signinum documentados en el edificio (Puertas 1982: 35), sería provista por el acueducto. En la mayor parte de las ciudades romanas, el abastecimiento urbano alterna diversas fuentes de aprovisionamiento: por un lado el aqua ducta, por otro el agua almacenada en cisternas, de procedencia pluvial, y si es posible la captación de las aguas subterráneas mediante pozos (Oleson 2010: 285 ss.). Este sistema se documenta en una de las ciudades donde el abastecimiento hídrico ha sido mejor estudiado. Nos referimos a Pompeya, en la que se ha demostrado que el agua para usos domésticos y cotidianos proviene de las cisternas privadas. Estos aljibes eran domésticos, se encontraban ubicados en el subsuelo de los inmuebles y el agua contenida era recogida mediante impluvia. Por otro lado, el agua proveniente de los acueductos, a la que tienen acceso solo algunos particulares, se emplea para usos ornamentales. Así, el aqua publica es símbolo de poder y ostentación del que la posee, junto con su destinación pública para el embellecimiento y disfrute de la ciudad. Otra de las finalidades del agua corriente es el abastecimiento público mediante lacus o surtidores ubicados en los espacios públicos, de carácter utilitario (Dessales 2008). Existen excepciones a este modelo, lo cual podría demostrar que también se utiliza el agua de los acueductos para aprovisionar cisternas domésticas, 
como parece ser el caso de las cisternas tardías en $\mathrm{Ta}$ rraco (Martínez Jiménez 2012: 35).

\section{PROMOCIÓN Y CRONOLOGÍA DEL CONJUNTO HIDRÁULICO}

El promotor, o promotores, del sistema hidráulico destinado a abastecer a la ciudad nos es desconocido. Hasta el momento no contamos con datos que aporten información sobre su autoría. A ello debemos sumarle el escaso conocimiento existente sobre la propia ciudad y la sociedad que la habitaba. Sin embargo, el registro epigráfico, aunque limitado, menciona a algunos personajes importantes de la civitas. El promotor del complejo hidráulico podría haberse correspondido con un evergeta, una persona adinerada que invierte sus recursos en el beneficio de la comunidad, con el fin de ostentar cargos municipales y adquirir prestigio (sobre el "evergetismo del agua", Corbier 1984: 251, Melchor 1994: 25, Belfaida 2000: 1597). En Hispania contamos con numerosos testimonios epigráficos que rememoran la financiación de obras hidráulicas por parte de particulares (Rodríguez Neila 1988, Mayer 1996).

En este sentido, en Lacipo tenemos constancia de personajes con tal poder que los vemos actuando como promotores de obras y edificios. Uno de ellos es Quinto Fabio Varo, pontífice y quinquevir, que dona un complejo monumental destinado al culto imperial, concretamente una cripta y un hypaetrum ( $A E$ 1981, 504). Asimismo, encontramos libertos ejerciendo cargos relacionados con este mismo culto, como el sevirato, o incluso el flaminato provincial en la capital de la Bética (CIL II 1934, 1935, 1936; CIL II²/7 259). Todos ellos son representantes de un cierto dinamismo económico de la zona, que posiblemente provenga de la exportación de productos del interior hacia los puertos que se sitúan en el ámbito del estrecho de Gibraltar. Además, se ha apuntado una relación de los pobladores de $\mathrm{La}$ cipo con la familia Canuleia, un gentilicio poco común y que debido a la proximidad de Carteia, cuyo deductor fue Lucio Canuleyo, sugiere una relación de sus colonos con Lacipo y su habitantes (Rodríguez Oliva 2006).

Otra posibilidad es la financiación municipal de las obras de infraestructura hidráulica. Tenemos constancia de la existencia de un ordo decurionum, ya que lo encontramos eximiendo el pago de la summa honoraria a un sevir (CIL II 1934).

En algunos casos, el emperador se presenta como promotor de las infraestructuras hidráulicas urbanas. En la península itálica existen ejemplos de intervención imperial en la construcción de acueductos en época altoimperial (De Rosa 2009). Tras un análisis de los casos conocidos, se observa cómo esta intervención y financiación ocurre en lugares en los que el emperador tiene un determinado interés por promocionar; concretamente, en colonias de veteranos, ciudades con importancia militar y comercial, principalmente portuarias, y en aquellas a las que le une algún tipo de vínculo familiar, clientelar o personal. En Hispania, la intervención imperial en la construcción de acueductos se intuye en las capitales de provincia como Augusta Emerita ( $A E$ 1984, 493; Hiernard y Álvarez 1982) o Corduba (CIL II ${ }^{2} / 7218$, Ventura y Pizarro 2010). Por otro lado, la actuación de la autoridad provincial en la ejecución de infraestructuras hidráulicas es poco conocida. Encontramos algún ejemplo de su intervención cuando acontece un problema técnico o financiero en la ejecución de la obra, como en el caso del acueducto de Nicomedia (Plin. Ep. 10.37-38, 90-91).

Por todo ello, en función de la importancia y categoría de Lacipo, parece más probable una promoción de sus construcciones hidráulicas procedente de la propia civitas, ya fuese de carácter público o privado.

En cuanto a la cronología del conjunto, no disponemos de datos para poder establecerla. El acueducto y los depósitos parecen corresponder a un mismo momento constructivo, empleándose materiales y técnicas similares, tanto en el opus incertum como en el signinum del revestimiento. Para proponer una cronología relativa, relacionamos el acueducto con el abastecimiento del presunto espacio público documentado en las excavaciones (Puertas 1982), en torno al cual se concentran las evidencias de hidráulica en la ciudad. Por tanto, cabría relacionar la construcción del acueducto con la urbanística de este lugar, datándose conjuntamente. En este sentido, se sugieren los siglos I-II d.C. como marco cronológico. Igualmente, el momento de abandono puede relacionarse con el ocaso de esta área, a la que iría destinada el agua. Una necrópolis datada en época tardoantigua se superpone a los niveles romanos, rompiendo y alterando los muros de la fase anterior (Puertas 1982: 26 y 35). Por ello, el momento de abandono de las estructuras hidráulicas debe datarse a partir de finales del siglo II o en el III d.C., en consonancia con el resto del urbanismo altoimperial. No debemos descartar un posible uso residual de estas estructuras en época tardoantigua, tal y como se ocurre con otros acueductos hispanos (Martínez 2012). Sin embargo parece poco probable, debido a la escasa entidad del asentamiento y la poca relevancia de la ocupación tardía de Lacipo. 
En general, la datación de los acueductos romanos es una cuestión compleja. Esto se debe a la escasez de excavaciones arqueológicas y a la falta de hallazgos de elementos que aporten una cronología absoluta. Por ello, como método de datación relativa, se ha establecido una relación entre momentos de construcción de los acueductos y de fundación o promoción cívica (Sánchez y Martínez 2010: 68-69). La correspondencia entre el cambio estatuario y la monumentalización es un fenómeno estudiado en las ciudades hispanas (Fear 1996: 220, Le Roux 1997: 335, Roddaz 1996, Keay 1998). Sin embargo, existen casos que contradicen esta generalidad. El acueducto de Conimbriga fue construido en época augustea (Etienne y Alarcão 1974, Dos Santos et al. 1994, Reis 2013, Sánchez y Martínez 2016: 69), mientras que la municipalización de la ciudad es de época flavia. Ocurre lo mismo en Igabrum (Cabra, Córdoba) (Goffaux 2013) y en otros casos en los que el momento de datación del aqua ducta no está tan claro, pero que apuntan a una ejecución anterior a la fecha de concesión de su estatuto cívico. Así sucedería en Ilipla (Niebla, Huelva), municipio flavio con acueducto julio-claudio (Campos et al. 2006: 347). Por tanto, no es posible generalizar la asociación entre monumentalización y concesión del estatuto urbano. Aunque en muchos casos fueran coetáneas, se ha confirmado que también pueden ser independientes, como sucedió en Cartima (Cártama, Málaga) (Gouffaux 2003: 146).

En cuanto a las cisternas a bagnarola, parecen corresponder, según su tipología, ubicación y función, a un momento cronológico previo (hipótesis ya apuntada por Rodríguez Oliva 2017: 60). Pueden indicar el tipo de aprovisionamiento que posee la ciudad con anterioridad a la construcción del acueducto. La situación topográfica del asentamiento, en altura, conlleva la falta de fuentes de captación. Esta práctica puede estar fosilizando un método de abastecimiento de época prerromana. Las cisternas, tanto comunitarias como privadas, son frecuentes en poblados de esta cronología (Mata 2009). Contamos con algunos ejemplos de cisternas a bagnarola en este tipo de asentamientos, como en el Cerro de la Cruz (Almedinilla, Córdoba), ubicadas en ámbito doméstico (Quesada et al. 2010). Más cercano geográficamente se encuentra el yacimiento de Cerro de las Naranjas (Jerez de la Frontera, Cádiz), donde la cisterna presenta un sistema constructivo muy parecido al que encontramos en Lacipo (Mata 2009).

Por tanto en esta ciudad, tras la introducción del acueducto, el método de recogida de aguas pluviales y almacenamiento en cisternas se habría mantenido.
En Pompeya, cuyo sistema de gestión de agua urbana es uno de los mejor conocidos del Imperio, se ha demostrado cómo el antiguo abastecimiento mediante cisternas domésticas sigue en funcionamiento tras la introducción del agua corriente (Dessales 2008).

\section{USOS DEL AGUA EN LA CIUDAD DE LACIPO}

En Lacipo encontramos un sistema de alimentación hídrica mixto. De una parte el agua es traída desde un manantial por el acueducto, que constituiría el aqua publica. Recordemos la preferencia en la Antigüedad por el agua proveniente de fuentes naturales para el abastecimiento urbano (Vitr. 8.6.12.) y la destinación a diferentes usos según la calidad de las aguas (Front. Aq. 2.92.; sobre el debate generado en torno al aqua ducta destinada al consumo humano véase Feijoo 2005). Sin embargo, no debemos desdeñar el valor simbólico de los acueductos como obra que representa una categoría y una posición de la urbe que la posee. Constituyen uno de los elementos que da forma a la ciudad romana, símbolo de romanización y poder (Leveau y Paillet 1976: 419-442, Sánchez y Martínez 2016: 59). Por otra parte, parece coexistir un sistema de recogida y almacenamiento de agua pluvial por medio de cisternae insertas en las edificaciones (depósitos 4 y 6). Aunque no podemos afirmar su función doméstica por la falta de datos arqueológicos, el agua recogida y contenida podría responder al modelo presente en otras ciudades romanas, en las que el aqua privata era la contenida en las cisternas pluviales (Dessales 2008).

Esto nos hace cuestionarnos sus distintas destinaciones y por tanto funciones. El aqua ducta parece tratarse más de un agua para usos concretos, relacionados con la vida pública de la ciudad, con el embellecimiento de la misma a través de sus fuentes ornamentales. También puede tener una función cultual, como demuestra el ejercicio del culto imperial y de la existencia de construcciones destinadas a ello. La relación del agua y este tipo de culto desarrollado en los principales ámbitos cívicos como el foro, ha sido estudiada en las ciudades hispanas (Reis 2010: 285-314). En estos espacios se ubican estructuras hidráulicas destinadas a la realización de ritos y ceremonias. En el caso que venimos analizando, la concentración de depósitos en un sector específico relacionado con la posible zona de acceso, puede estar indicando la presencia de un ámbito público y principal, posible foro. En esta área se situaría algún tipo de edificio donde se ejercería el culto al 
emperador y su familia, tal y como nos atestiguan las fuentes epigráficas ( $A E$ 1981, 504).

Asimismo, podemos relacionarlo con el uso simbólico y ornamental de los acueductos, en el espacio principal de la ciudad, o incluso con la existencia en esta zona de unos baños o termas. Este tipo de instalaciones requieren una gran cantidad de agua, por lo que algunos investigadores las han relacionado con el motivo de construcción de los acueductos (Leveau y Paillet 1976: 419-442). La existencia de fuentes decorativas para las que podía estar destinada el aqua ducta, nos la confirma el hallazgo de una estatua-fuente en bronce (Rodríguez Oliva 1976: 44). Se conservan dos fragmentos, uno correspondiente a la pierna derecha de una escultura y la segunda pieza, a un pedestal prismático, carente de zócalo y rematado por un friso. Sobre él tiene un jarrón en cuya parte superior, a ambos lados de un asa, se apoyan los dedos de una mano. Una perforación de sección circular, por donde discurría el agua que manaría de su boca, demuestra su funcionalidad. Esta estatua-fuente podría corresponder con una representación de Dyonisos, divinidad relacionada con las aguas superficiales (Rodríguez Oliva 1976).

En lo que respecta a la parte habitacional del asentamiento, no disponemos de datos y en consecuencia, tampoco de su disponibilidad de agua. En función del tamaño del asentamiento, las unidades habitacionales no debían ser numerosas, solo las propias de las principales familias que ostentan los cargos de administración del municipio. Aun así, la excavación completa del cerro corroboraría la hipótesis, con el conocimiento completo del patrón de asentamiento de la ciudad. Sin embargo la ciudad, por su fisonomía, parece acercarse más a entidades cívicas erigidas como centros políticos, administrativos y religioso, núcleos dinamizadores del territorio, aglutinadores de una población diseminada, asimilándose al modelo civitas sine urbem o civitas dispersa (Detlefsen 1873, Oller 2011, Houten 2017). Una de las principales características de este tipo de entidad cívica es contar con un centro monumental basado en uno o diversos edificios de carácter público de diferente tipo y funciones, sin evidencias materiales de una zona de hábitat en consonancia con la entidad monumental de dicho centro. Uno de estos ejemplos es la ciudad bética de Munigua (Villanueva del Río y Minas, Sevilla) (Oller 2011: 194). Era el centro cívico, político y administrativo de una comarca amplia, en la que la población se encontraba dispersa. En Baetica, el modelo urbano iniciado por César y culminado por los Flavios responde a colonias y municipios cuya función no era tanto la de lugares de hábitat de la población rural, sino más bien la de centros de reorganización administrativa del territorio (Rodríguez Neila 1994: 469470). En el caso de Munigua, constituía el lugar de representación de la comunidad, de control por parte del aparato administrativo aportado por la provincialización y el sistema de civitates romanas que lo integran. El agua aquí jugaba un papel importante desde el punto de vista ritual, religioso, cultual, ornamental y placentero, materializado en el santuario y en las termas (Schattner 2003, 2007).

\section{EVACUACIÓN DE LAS AGUAS RESIDUALES}

El ciclo del agua en Lacipo finalizaría con la evacuación de las aguas usadas y excedentarias. Las ciudades romanas contaban con métodos de saneamiento en función de la complejidad y extensión del entramado urbanístico que poseyeran. En aquellas abastecidas por acueductos, el aqua caduca de los lacus y salientes publici era empleada en la limpieza de las calles, cloacas y conducciones de desagüe, contribuyendo a mantener la salubritas (Front. Aq. 2.111.). Contamos con ejemplos de ciudades hispanas con un complejo sistema de canales de desagüe jerarquizado, situado bajo el entramado viario. Entre ellas destaca Corduba (Sánchez 2011), Italica (Jiménez 2011) o Emerita Augusta (Acero 2018). Ciudades más modestas también presentan sistemas de drenaje y evacuación de residuos. Es el caso de Baelo, donde se combinan colectores situados bajo los cardines con el aprovechamiento de la pendiente natural de la ladera sobre la que se emplaza la ciudad, para así desaguar las aguas por gravedad (Bernal et al. 2010).

En la civitas objeto de nuestro estudio, este proceso está testimoniado mediante el hallazgo de restos de canalizaciones destinadas a la evacuación de las aguas. Estos vestigios pueden estar indicando la existencia de una planificación urbana o incluso de un verdadero sistema de alcantarillado. En la excavación del edificio del sector sur, se constataron canalillos que conducían las aguas hacia los límites del cerro (Puertas 1982: 35). En los márgenes del mismo, localizamos una canalización más amplia, cubierta con grandes lajas de piedra a modo de cloaca (fig. 17). De la misma no se conserva su trazado completo, ni tampoco se conoce el lugar por donde evacúa el agua. Solo disponemos de un pequeño tramo cuya orientación es paralela al límite del cerro y por tanto del asentamiento (fig. 9). Esta canalización podría circundar la ciudad para verter las 


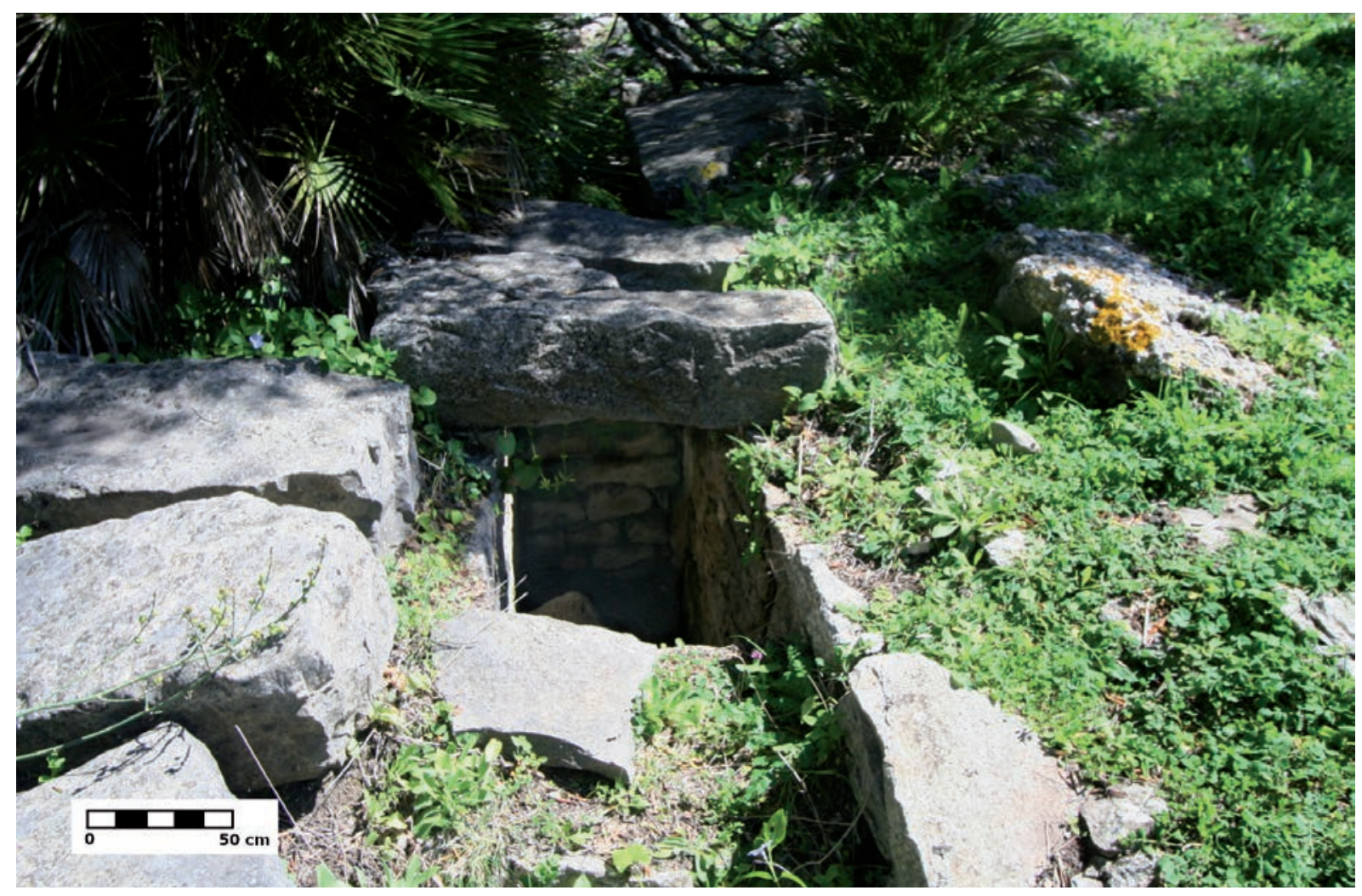

Figura 17. Restos conservados de la existencia de un alcantarillado o sistema de evacuación de aguas residuales.

aguas por alguna de sus laderas, quizás la norte, en donde se encuentra el arroyo Albarrán. Estas estructuras señalan la presencia de un sistema de regulación de las aguas usadas y de los excedentes pluviales. La ley municipal de Irni nos indica cómo los ediles eran los encargados del mantenimiento de las cloacas públicas (Lex Irn. 19.82., Liebeschuetz 2000: 57-59, Rodríguez Neila 2011: 38-44). Así en Lacipo, los representantes de la res publica serían los encargados del mantenimiento y la limpieza de las estructuras para el buen cumplimiento de su función.

\section{CONCLUSIONES}

El ciclo del agua en Lacipo se muestra completo: captación, conducción, distribución, uso y evacuación. Sin embargo, hasta el momento son escasos los testimonios de cada una de sus etapas. A través de este estudio observamos cómo la ciudad planifica, desde un ente superior, ya sea público o privado, un proyecto de captación, conducción y distribución de agua, que posteriormente hay que administrar y mantener para asegurar su correcto funcionamiento. Además, vemos cómo existió un interés por almacenar agua, tal y como sugiere la concentración de depósitos hidráulicos en una parte determinada del cerro. En cambio, el destino de esta agua nos es desconocido. Por un lado sería el consumo humano, que podría estar garantizado a través de la captación y almacenamiento pluvial. Por otro, estaría destinada al ejercicio de las diversas actividades cívicas y lúdicas propias de una ciudad romana, ya sean cultuales, ornamentales, higiénicas o placenteras. Sin embargo, el estudio de caso se encuentra incompleto, debido a la falta de investigaciones arqueológicas en el yacimiento. Su realización aportaría un conocimiento más detallado de la fisonomía urbana y de su trayectoria cronológica. Aun así, el asentamiento muestra las características de un núcleo urbano de pequeñas dimensiones e importancia limitada. Mediante el análisis de los vestigios visibles hemos comprobado cómo se ponen en práctica los conocimientos hidráulicos romanos en los núcleos poblacionales más modestos, y cómo se dotan de los elementos propios de una civitas, adoptando una verdadera cultura del agua romana. 


\section{Agradecimientos}

Este trabajo se ha realizado en el marco del proyecto Riparia 2. La Interacción histórica sociedad-medio ambiente: humedales y espacios lacustres en la Bética romana. HAR2016-77724-P, Ministerio de Economía y Competitividad, Gobierno de España.

Mis más sinceros agradecimientos van dirigidos al profesor Dr. D. Lázaro Lagóstena por su participación en la visita realizada al yacimiento arqueológico, cuyos resultados son expuestos en este artículo, y por las ideas aportadas. Igualmente, quiero reconocer el apoyo del investigador D. Pedro Trapero a los trabajos realizados en el yacimiento y a D. Javier Martos, gran conocedor de la zona, por la aportación desinteresada de datos geográficos, históricos y arqueológicos, y por su disposición a acompañarnos y mostrarnos los restos arqueológicos durante las visitas realizadas.

\section{BIBLIOGRAFÍA}

Acero, J. (2018): La gestión de los residuos en Augusta Emerita. Siglos I a.C.-VII d.C. Anejos de Archivo Español de Arqueología LXXXII. Madrid, Consejo Superior de Investigaciones Científicas.

Adams, J.P. y Varène, P. (2008): "Le castellum aquae de Pompéi, étude architecturale". Revue Archéologique 45-1: 37-72.

Almagro, A. (2002): "El acueducto de Albarracín a Cella (Teruel)", en Artifex. Ingeniería romana en España: 212-240. Madrid, Ministerio de Fomento, Fundación Juanelo Turriano.

Belfaida, A. (2000): "Eau et évergétisme en Afrique romaine: témoignages épigraphiques", en M. Khanoussi, P. Ruggeri y C. Vismara (eds.), L'Africa romana. Geografia, viaggiatori, militari nel Maghreb: alle origini dell'archeologia nel Nord Africa, vol. II: 1589-1601. Dejerba (1998), Roma, Carocci.

Beltrán, A. (1977): "Las obras hidráulicas de los Bañales", en Symposium de arqueología romana, Bimilenario de Segovia: 91-129. Segovia (1974), Barcelona, Universidad de Barcelona, Instituto de Prehistoria y Arqueología.

Bernal D.; Arévalo, A.; Muñoz, A.; García, I.; Bustamante, M. y Sáez, A. (2011): "Baelo Claudia”, en J.A. Remolà y J. Acero (eds.), La gestión de los residuos urbanos en Hispania. Xavier Dupré Raventós (1956-2006). In memoriam. Anejos de Archivo Español de Arqueología LXXXII: 65-92. Mérida, Consejo Superior de Investigaciones Científicas.
Bonetto, J.; Cespa, S. y Erdas S.V. (2012): “Approvvigionamento idrico a Nora: nuovi dati sulle cisterne", en M.B. Cocco, A. Gavini y A. Ibba (eds.), L'Africa romana. Trasformazione dei paesaggi del potere nell'Africa settentrionale fino alla fine del mondo antico, vol. III: 2591-2624. Sassari (2010), Roma, Carocci.

Borau, L. (2015): "Difusión de modelos romanos: particularidades técnicas del sistema de abastecimiento de agua a Baelo Claudia”. Archivo Español de Arqueología 88: 149-169. DOI: <http://dx.doi. org/10.3989/aespa.088.015.008>.

Bravo, S. (2010): Dinámicas de control ideológico y territorial en el Estrecho de Gibraltar en épocas fenicia, púnica y romana. Tesis doctoral, UNED, Facultad de Geografía e Historia, disponible en línea: <http://e-spacio.uned.es/fez/ view/tesisuned:GeoHis-Sbravo> (12 de febrero de 2019).

Bruun, C. (1991): Water Supply of Ancient World. A Study of Roman Imperial Administration. Helsinki, Societas Scientiarum Fennica.

Bukowiecki, E.; Dessales, H. y Dubouloz, J. (2008): Ostie, l'eau dans la ville: chateaux d'eau et réseau d'adduction. Roma, École Française de Rome.

Burés, L. (1998): Les estructures hydràuliques a la ciutat antiga: l'exemple d'Empúries. Barcelona, $\mathrm{Mu}-$ seu d'Arqueologia de Catalunya-Empúries.

Campos, J.M.; Gómez, F. y Pérez, J.A. (2006): Ilipla. Niebla. Evolución urbana y ocupación del territorio. Huelva, Universidad de Huelva.

Casares, Planimetría 1875. Ayuntamiento de Casares, provincia de Málaga, $12^{\mathrm{a}}$ Brigada, bosquejos planimétricos, Instituto Geográfico y Estadístico, colocado, dibujado y construido por el topógrafo Darío Varela-Escala 1:25.000. Instituto Geográfico Nacional, Madrid, IECA1989004108. Digitalizado por Catálogo digital de Cartografía Histórica de Andalucía, Instituto de Estadística y Cartografía de Andalucía. Consejería de Economía, Innovación, Ciencia y Empleo. <http://www.juntadeandalucia. es/institutodeestadisticaycartografia/cartoteca/buscar/getisbn/query/casares/autor/titulo/lugargeo/materias/fechadesde/fechahasta/buscar/Buscar/startid/10/id/3982> (29 de marzo de 2019).

Chanson, H. (2000): “A Hydraulic Study of Roman Aqueduct and Water Supply". Australian Journal of Water Resources 4, n 2: 111-120.

Corbier, M. (1984): "De Volsinii a Sestinum: Cura aquae et évergétisme municipal de 1'eau en Italie". Revue des Études Latines 62: 236-274. 
Corzo, S. (2005): "La ceca romana de Lacipo: análisis y nuevo hallazgo", en C. Alfaro, C. Marcos y P. Otero (eds.), XIII Congreso Internacional de Numismática, vol. 1: 499-502. Madrid (2002), Madrid, Ministerio de Cultura, Subdirección General de Publicaciones, Información y Documentación.

Dessales, H. (2008): “Des usages de l'eau aux évaluations démographiques: l'exemple de Pompéi”. Histoire Urbaine 22: 25-39.

Dessales, H. (2013): Le partage de l'eau. Fontaines et distribution hydraulique dans l'habitat urbain de l'Italie romaine. Roma, École Française de Rome.

Detlefsen, D. (1873): “Die Geographie der tarraconensiscen Provinz bei Plinius (Plin. nat. Hist. 3, 18-30/ 76-79; 4, 110-112)". Philologus 32: 600-668.

Dos Santos, C.J.; Pessoa, M.; Madeira, J.L.; Tröger, U. y Dos Santos, M.M. (1994): “Os pólos de captaçao de agua de Conimbriga”. Conimbriga 32-33: 171179.

Eschebach, H. (1977): "Die Gebrauchwasserer sorgung des Pompeii". Antike Welt 10: 3-24.

Étienne, R. y Alarcão, J. (1974): “O aqueduto romano de Conímbriga”, en Actas do III Congreso Nacional de Arqueología, vol. 1: 283-292. Oporto (1973), Oporto, Junta Nacional de Educação.

Fabre, G.; Fiches, J.L.; Paillet, J.L. (eds.) (2000 [1991]): L'Aqueduc de Nimes et le Pont de Gard, archaeolgie, geosysteme et histoire. París, CNRS éditions ( $2^{\mathrm{a}}$ ed. rev.).

Fear, A.T. (1996): Rome and Baetica. Urbanization in Southern Spain, c. 50 B.C.-A.D. 150. Oxford, Clarendon Press.

Feijoo, S. (2005): "Las presas y los acueductos de agua potable una asociación incompatible en la antigüedad. El abastecimiento en Augusta Emerita", en T. Nogales (ed.), Augusta Emerita. Territorios, Espacios, Imágenes y Gentes en Lusitania Romana: 173205. Mérida, Museo Nacional de Arte Romano.

Fishwick, D. (1993): The Imperial Cult in the Latin West: Studies in the Ruler Cult of the Western Provinces of the Roman Empire I, 1 y 2, II, 1 y 2. Leiden, Brill.

García Merino, C. (2006): “Avance al estudio del acueducto de Uxama”, en I. Moreno (ed.), Nuevos elementos de ingeniería romana. III Congreso de las Obras Públicas Romanas: 167-194. Valladolid, Consejería de Cultura y Turismo.

García Merino, C. (2010): "Las cisternas y la elevación de agua del acueducto en Uxama", en I. Moreno (ed.), Las técnicas y las construcciones en la ingeniería romana. V Congreso de las obras públicas romanas: 283-298. Córdoba (2010), Madrid, Fundación de la Ingeniería Técnica de Obras Públicas.

García García, M.A. (2007): “Aqua Hispalensis: Primer avance sobre la excavación de la cisterna romana de Plaza de la Pescadería (Sevilla)". Romvla 6: 125-142.

Gener, J.M. (2001): "Puesta en valor del yacimiento arqueológico de Sierra Aznar (Arcos de la Frontera). Limpieza, consolidación y documentación". Anuario Arqueológico de Andalucía 1997, III: 44-52.

Goffaux, B. (2003): "Promotions juridiques et monumentalisation des cités hispano-romaines". Saldvie 3: $143-161$.

Goffaux, B. (2013): “CIL II2/5, 316 (Igabrum) y la cronología de los primeros flamines provinciales de la Bética". Archivo Español de Arqueología 86: 261-278. $<$ https://doi.org/10.3989/aespa.086.013.015>.

Guerrero, L. (2001): “Intervención arqueológica de urgencia en la ciudad romana de Sierra Aznar, Arcos de la Frontera (Cádiz)". Anuario Arqueológico de Andalucía 1998, I: 32-37.

Hiernard, J. y Álvarez, J.M. (1982): “Aqua Augusta, una inscripción de letras de bronce en Mérida”. Sautuola 3: 221-229.

Hodge, A.T. (2002 [1992]): Roman Aqueducts and Water Supply. London, Duckworth.

Houten, P. (2017): "El papel de las aglomeraciones secundarias en las civitates dispersas", en S. Panzram (ed.), Oppidum-civitas-urbs. Städteforschung auf der Iberischen Halbinsel zwischen Rom und al-Andalus. Geschichte und Kultur der Iberischen Welt 12: 681-708. Münster, LIT-Verlag.

Jiménez, A. (1973): "Los acueductos de Baelo Claudia (Bolonia, Cádiz)". Habis 4: 273-293. <https:// doi.org/10.12795/Habis.1973.i04.15>.

Jiménez, A. (2011): "Italica. La red de alcantarillado", en J.A. Remolà y J. Acero (eds.), La gestión de los residuos urbanos en Hispania. Xavier Dupré Raventós (1956-2006). In memoriam. Anejos de AEspA LX: 145-154. Mérida, Consejo Superior de Investigaciones Científicas.

Jiménez, J.L. (1995): “Referencias historiográficas sobre el Acueducto de Peña Cortada (Los Serranos, Valencia)". Arse 28-29: 217-234.

Keay, S. (1998): "The development of towns in Early Roman Baetica", en S. Keay (ed.), The archaeology of early Roman Baetica. Journal of Roman Archeology, suppl. 29: 55-85. Rhode Island-Portsmouth, Editorial Committee of the Roman of Roman Archaeology. 
Le Roux, P. (1997): Le Haut-Empire romain en Occident d'Auguste: aux Sévères 31 av. J.-C.-235 apr. $J .-C$. París, Éditions du Seuil.

Leveau, P y Paillet, J.L. (1976): L'alimentation en eau de Caesarea de Mauritania et l'aqueduc de Cherchell: 419-442. París, L'Harmattan.

Liebeschuetz, W. (2000): "Rubbish Disponsal in Greek and Roman Cities", en X. Duprés y J.A. Remolà (eds.), Sordes Urbis. La eliminación de residuos en la ciudad romana. Actas de la reunión de Roma: 5161. Roma (1996), Roma, L'Erma di Bretschneider.

Malissard, A. (1994): Les Romains et l'eau: fontaines, salles de bains, thermes, égouts, aqueducs. París: Les Belles Lettres.

Martín Bueno, M.A. (1975): "El abastecimiento y distribución de agua al Municipium Augusta Bilbilis". Hispania Antiqua 5: 205-222.

Martínez, J. (2012): "Reuse, Repair and Reconstruction. Functioning aqueducts in post-Roman Spain", en B. Jervis y A. Kyle (eds.), Make-do and Mend: Arquaeologies of Compromise, Repair and Reuse. British Archaeological Report International Series 2408: 27-42. Oxford, Archaeopress.

Mata, E. (2009): "Precedentes de los aprovechamientos hídricos en la antigüedad gaditana. El mundo turdetano", en L.G. Lagóstena y F.B. Zuleta (eds.), La captación, los usos y la administración del agua en Baetica: estudios sobre el abastecimiento hídrico en comunidades cívicas del Conventus Gaditanus: 115-170. Cádiz, Universidad de Cádiz, Seminario Agustín de Horozco.

Mata, E.; Zuleta, F. B.; Lagóstena L.G. y Cobos. L.M. (2010): "Sierra Aznar ¿Castellum aquae o caput aquae?”, en L.G. Lagóstena, J.L. Cañizar y L. Pons (eds.), Aquam perducendam curavit: captación, uso y administración del agua en las ciudades de la Bética y el occidente romano: 261-270. Cádiz, Universidad de Cádiz, Seminario Agustín de Horozco.

Mayer, M. (1996): "El evergetismo referente a las aguas en Hispania”, en M. Mayer y M. Miró (ed.), Homenatge a F. Giunta: committenza e committenti tra antichità e alto medievo: actes del XVIe workshop. Erice (1994), Barcelona, Promociones y Publicaciones Universitarias.

Melchor, E. (1994): El mecenazgo cívico en la Bética: la contribución de los evergetas al desarrollo de la vida municipal. Córdoba, Instituto de Historia de Andalucía.

Mezzolani, A. (1997): “L'approvvigionamento idrico a Tharros: note preliminari”, en E. Acquaro, G.M. Francisi, G.M. Ingo y L.I. Manfredi (eds.), Progetto
Tharros: 121-130. Roma, Consiglio Nazionale delle Ricerche.

Montañés, S. y Montañés, M. (2010): “Actuación arqueológica de urgencia. C/ San Juan de Ribera y Alfonso el Sabio. Alcalá de los Gazules (Cádiz)". Аnuario Arqueológico de Andalucía 2006, Cádiz: 504-509.

Mora, B. (1990): "Malaca, Acinipo y Lacipo: tres cecas monetales en los territorios malacitanos". Jábega $67: 3-12$.

Navarro, I. (2006): "El abastecimiento de agua a una ciudad romana: Lacipo (Casares)", en A. Serrano, F. López y F.A. López (coords.), Aqua Nostra, Agua de todos. El agua en la Costa Occidental Malagueña: 99-103. Marbella, Cilniana.

Oleson, J.P (2010): The Oxford Handbook of Engineering and Technology in the Classical World. Oxford, Oxford University Press.

Oller, J. (2011): "La ciudad sin ciudad: la civitas sine urbe como elemento de control territorial". Estrat Critic 5/1: 190-203.

Peleg, Y. (2000): "The characteristics of water distribution in Roman towns", en Cura Aquarum in Sicilia. Proceeding of the Tenth International Congress on the History of Water Management and Hydraulic Engineering in the Mediterranean Region: 241-246. Siracusa (1998), Leiden, Stichting Babesch.

Pellicer, M. (1982): "Excavaciones en Itálica (19781979). Murallas, cloacas y cisterna”, en Itálica (Santiponce, Sevilla). Actas de las Primeras Jornadas sobre Excavaciones Arqueológicas en Itálica. Excavaciones Arqueológicas en España 121: $205-$ 224. Sevilla (1980), Madrid, Subdirección General de Arqueología y Etnografía.

Proyecto "Conoce tus Fuentes, Fuentes y Manantiales de Andalucía". Instituto Universitario de Investigación del Agua de la Universidad de Granada. $<$ http://www.conocetusfuentes.com/home.php>, [8 de marzo de 2019].

Puertas, R. (1979): "Nuevo epígrafe monumental de Lacipo". Mainake 1: 99-104.

Puertas, R. (1982): Excavaciones arqueológicas en Lacipo (Casares, Málaga). Campañas de 1975 y 1976. Madrid, Ministerio de Cultura, Dirección General de Bellas Artes y Archivos. Subdirección General de Arqueología y Etnografía.

Puertas, R. y Rodríguez Oliva, P. (1979): “La ciudad de Lacipo y sus monedas". Mainake 1: 105-127.

Quesada, F.; Kavanagh E. y Moralejo, J. (2010): “El asentamiento de época ibérica en el Cerro de la Cruz". Oikos 2: 75-97. 
Reis, M.P. (2010): “Tanques, fontes e espelhos de água nos foro lusitanos", en T. Nogales (ed.), Ciudad y foro en Lusitania Romana: 285-363. Mérida, Museo Nacional de Arte Romano.

Reis, M.P. (2013): “Gestão e Rede Hidráulica de Conimbriga. A domus de Tancinus e construções anexas", en J. López (ed.), Conimbriga tardo-antigua y medieval. Excavaciones arqueológicas en la domus tancinus (2004-2008) (Condeixa-a-Velha, Portugal). British Archaeological Report 2466: 25-36. Oxford, Archeopress.

Ricciardi, M.A. y Scrinari, V.S.M. (1996): La civiltà dell'acqua in Ostia antica, 2 vol. Roma, Fratelli Palombi.

Roddaz, J.M. (1996): "Pouvoir et provinces: remarques sur la politique de colonisation et de municipalisation de Rome dans la Penínsule Ibérique entre César et Auguste", en E. Ortiz de Urbina y J. Santos (eds.), Teoría y práctica del ordenamiento municipal en Hispania. Actas del Simposium. Veleia. Anejos, Series, Acta III: 13-25. Vitoria-Gasteiz (1993), Vitoria-Gasteiz, Instituto de Ciencias de la Antigüedad, Universidad del País Vasco.

Rodríguez Neila, J.F. (1988): “Aqua publica y política municipal romana”. Gerión 6: 223-252.

Rodríguez Neila, J.F. (1994): “Ciudad y territorio de la provincia romana de la Bética". Florentia Iliberritana 4-5: 445-485.

Rodríguez Neila, J.F. (2011): "Problemas medioambientales urbanos en el mundo romano", en J.A. Remolá, J. Acero (eds.), La gestión de los residuos urbanos en Hispania. Xavier Dupré Raventós (1956-2006). In memoriam. Anejos de AEspA LX: 27-49. Mérida, Consejo Superior de Investigaciones Científicas.

Rodríguez Oliva, P. (1976): "Una estatua fuente de Lacipo”. Jábega 13: 43-46.

Rodríguez Oliva, P. (2006): "Unas inscripciones funerarias de Lacipo (Casares, Málaga) que evocan el establecimiento en Carteia (San Roque, Cádiz) de la Colonia Latina Libertinorum". Baetica 28-2: 123-158.

Rodríguez Oliva, P. (2017): "El yacimiento arqueológico de Lacipo (Casares, Málaga)". Revista PH 92: 52-61.

Saborido, S. (2006): "El agua en Casares", en A. Serrano, F. López y F.A. López (coords.), Aqua Nostra,
Agua de todos. El agua en la Costa Occidental Malagueña: 96-98. Marbella, Asociación Cilniana.

Sánchez, E. y Martínez, J. (2016): Los acueductos de Hispania, construcción y abandono. Madrid, Fundación Juanelo Turriano.

Schattner, T.G. (2003): Munigua, cuarenta años de investigaciones. Sevilla-Madrid, Consejería de Cultura, Instituto Arqueológico Alemán.

Schattner, T.G. y Ovejero, G. (2007): “Agua en Munigua”, en J. Mangas y S. Martínez Caballero (eds.), El agua y las ciudades romanas: 99-132. Móstoles, Ediciones 2007.

Sillières, P. (1997): Baelo Claudia. Una ciudad romana de la Bética. Madrid, Casa de Velázquez.

Soto Jiménez, L. (1979): “Lacipo. Ciudad turdetana y romana". Jábega 28: 3-7.

Tabales, M.A.; Oliva, P.; Mora, G.; Huarte, R.; Graciani, A.; Calama, J.M. y Pérez A. (2005): "Investigaciones arqueológicas en el Castillo de Jimena de la Frontera. Cádiz. Fase I (2002)". Anuario Arqueológico de Andalucía 2002, III, tomo I: 131-155.

Tomassetti, J.M.; Suárez, J. y Martos J. (e.p.): “Prospección arqueológica superficial del término municipal de Casares (Málaga)". Anuario Arqueológico de Andalucía 2010.

Ventura, A. (1996): El abastecimiento de agua a la Córdoba romana II: acueductos, ciclo de distribución y urbanismo. Córdoba, Servicio de Publicaciones, Universidad de Córdoba.

Ventura, A. y Pizarro, G. (2010): "El Aqua Augusta (Acueducto de Valdepuentes) y el abastecimiento de agua a Colonia Patricia Corduba: Investigaciones Recientes (2000-2010)", en I. Moreno (ed.), Las técnicas y las construcciones en la ingeniería romana: V Congreso de las Obras Públicas Romanas: 177-203. Córdoba (2010), Madrid, Fundación de la Ingeniería Técnica de Obras Públicas.

Villar, F. (2000): Indoeuropeos y no indoeuropeos en la Hispania prerromana. Salamanca, Universidad de Salamanca.

Wilson, A. (2001): "Urban water storage, distribution and usage in Roman North Africa", en A.O. Koloski-Ostrow (ed.), Water use and hydraulics in the Roman city: 83-96. Dubuque-Iowa, Kendall / Hunt Publishing Compani. 
Cebrián Fernández, R., Andreu Pintado, J., Romero Novella, L., Mateo Pérez, R.y Delage González, I. (2020): “Arquitectura pública de Santa Criz de Eslava (Navarra, conventus

Caesaraugustanus) en época altoimperial: el criptopórtico del foro y su almacén anexo", Spal 29.1: 213-242. DOI: http://dx.doi.org/10.12795/spal.2020.i29.08

\title{
ARQUITECTURA PÚBLICA DE SANTA CRIZ DE ESLAVA (NAVARRA, CONVENTVS CAESARAVGVSTANVS) EN ÉPOCA ALTOIMPERIAL: EL CRIPTOPÓRTICO DEL FORO Y SU ALMACÉN ANEXO

\author{
PUBLIC ARCHITECTURE IN SANTA CRIZ DE ESLAVA (NAVARRA, CONVENTUS \\ CAESARAVGVSTANVS) IN EARLY IMPERIAL PERIOD: THE FORUM \\ CRYPTOPORTICUS AND THE STORE BUILDING
}

\author{
ROSARIO CEBRIÁN FERNÁNDEZ. \\ Dpto. de Prehistoria, Historia Antigua y Arqueología. Fac. de Geografía e Historia \\ Universidad Complutense de Madrid. C/ Profesor Aranguren, s/no, 28040 Madrid \\ Correo-e: marcebri@ucm.es. (D) http://orcid.org/0000-0002-5560-1191 \\ Researcher ID: <https://publons.com/researcher/AAG-9091-2019> \\ JAVIER ANDREU PINTADO \\ Responsable de la correspondencia \\ Dpto. de Historia, Historia de Arte y Geografía, Fac. de Filosofía y Letras \\ Universidad de Navarra. Crtra. Río Sadar s/n, 31900 Pamplona (Navarra) \\ Correo-e: jandreup@unav.es. D https://orcid.org/0000-0003-4662-548X \\ Researcher ID: <https://publons.com/researcher/AAG-8246-2019> \\ LUIS ROMERO NOVELLA \\ Dpto. de Historia, Historia de Arte y Geografía, Fac. de Filosofía y Letras \\ Universidad de Navarra. Crtra. Río Sadar s/n, 31900 Pamplona (Navarra) \\ Correo-e: Iromero@alumni.unav.es. (D) http://orcid.org/0000-0002-2184-2296 \\ Researcher ID: <https://publons.com/researcher/AAG-9507-2019> \\ ROSARIO MATEO PÉREZ \\ Olcairum Estudios Arqueológicos S. L. Bulevar Anelier, 18, 1응. 31014 Pamplona (Navarra) \\ Correo-e: olcairum@gmail.com. (D) https://orcid.org/0000-0001-6279-5628 \\ Researcher ID: <https://publons.com/researcher/AA-8913-2019> \\ INMACULADA DELAGE GONZÁLEZ \\ Dpto. de Historia, Historia de Arte y Geografía, Fac. de Filosofía y Letras \\ Universidad de Navarra. Crtra. Río Sadar s/n, 31900 Pamplona (Navarra) \\ Correo-e: idelage@alumni.unav.es. (D) http://orcid.org./0000-0002-2393-1495 \\ Researcher ID: <https://publons.com/researcher/AAG-9403-2019>
}

Resumen: A partir de un castrum de la Edad del Hierro surgió en Santa Criz de Eslava una civitas en territorio vascón, cuya base económica fue la agricultura. La ampliación de la muralla en época tardorrepublicana explica el papel territorial que alcanzó en el valle medio del Ebro y la buena situación respecto a la red de comunicaciones terrestres. Alcanzó 13 ha de extensión. Integrada en el conventus Caesaraugustanus, en época augustea inició importantes trabajos de urbanización a la manera romana con la construcción de un conjunto
Abstract: With origin as an Iron Age II settlement, Santa Criz de Eslava was a Roman civitas in the Vascones' territory with an economy based in agriculture. The ampliation of the city walls during the Late Republic shows the territorial importance that the city reached in the center of the Ebro Valley and its well-connected position concerning the roadsystem. During that Roman period the city covered 13 Has. Integrated in the conventus Caesaraugustanus, in the Augustan times the city began to undertake important public works 
público de carácter monumental. Las excavaciones recientes (2007-2016) han puesto al descubierto el criptopórtico, que sostenía el porticado sur de la plaza forense, y un almacén contiguo. El estudio completo de su estructura arquitectónica y decoración permite ahora el análisis de su interpretación funcional, el establecimiento de la fase constructiva inicial y reformas y una propuesta de restitución de su espacio público.

Palabras clave: Vascones, ciudades romanas, urbanismo hispanorromano, monumentalización urbana, arquitectura pública, foros romanos.

En septiembre de 1944, los arqueólogos B. Taracena y L. Vázquez de Parga llevaron a cabo la primera excavación en el cerro de Santa Criz de Eslava (Navarra), cuyo informe no fue publicado, pero una sucinta referencia a los hallazgos en uno de sus trabajos advertía de la riqueza arqueológica del subsuelo de este enclave, rodeado de cierta mitología en la arqueología de Navarra (Andreu et al. 2019b: 14-21). Del terreno asomaban dos capiteles toscanos, otro de orden corintio, un fragmento de fuste decorado con hojas imbricadas y varios fustes acanalados de los que ya había hablado, algo antes, el jesuita del castillo de Javier, F. Escalada (1943: 119). En las excavaciones practicadas se descubrieron, a poca profundidad, algunos lienzos murarios correspondientes a viviendas, una de las cuales presentaba un atrio con impluvium. Se localizó también un paramento de grandes sillares, que identificaron con la cimentación de un templo, y recogieron un gran número de fragmentos cerámicos de terra sigillata (Taracena y Vázquez de Parga 1946: 427).

En la década de los años 90 del siglo XX comenzó la investigación arqueológica reciente en el lugar -la única, hasta la fecha, continuada y sistemática- con la realización de varios sondeos en la muralla del castro de la Edad del Hierro, criptopórtico del foro y área cementerial de cronología altoimperial situada a los pies del cerro por su lado meridional (Arméndariz et al. 1996: 322-326). Durante el período 2007-2016 los esfuerzos se centraron en la exhumación del conjunto forense, que concluyeron con la puesta en valor del área excavada.

El resultado de estos trabajos se publicó en un artículo en el que se describían las estructuras excavadas y se establecía la secuencia evolutiva del conjunto a partir del análisis de las fábricas murarias y de los materiales cerámicos recuperados (Armendáriz et al. 2016). Una nueva lectura e interpretación de los datos leading to its urban development. Recent archaeological excavations (2007-2016) has discovered the cryptoporticus, which sustained the porticoes of the south side of the forum, and its adjacent depot. A complete study of the architectonic structure and its decoration allow us now to the whole analysis of both its function and its final aspect, the fixing of its early stage, its reforms and a proposal of reconstruction to the whole public area.

Keywords: Vascones, Roman cities, Hispanoroman urbanism, Public architecture, Roman forums.

arqueológicos, que aquí presentamos, permite abordar el estudio arquitectónico del conjunto, el establecimiento de la fase constructiva inicial y reformas, el análisis de los elementos decorativos y una propuesta de restitución del complejo monumental. Sin embargo, es necesario advertir que los trabajos arqueológicos no han concluido, por lo que nuestra aportación es necesariamente susceptible de ser modificada en el futuro a partir de los nuevos hallazgos que puedan sucederse.

\section{EL CONTEXTO TOPOGRÁFICO E HISTÓRICO}

El cerro de Santa Criz tiene planta trapezoidal y está constituido por dos cimas amesetadas de forma triangular, una en su extremo oeste elevada 545 m s.n.m. y otra al este de 542 m s.n.m, entre las que se sitúa una zona llana que discurre a la cota de $530 \mathrm{~m}$. Los flancos del cerro descienden pronunciadamente hasta alcanzar la cota de 515-510 m. Está situado a orillas del barranco de Pisaldea en el curso medio del Indusi, afluente del río Aragón, que discurre por su lado septentrional. Dos arroyos de este barranco recorren los costados del cerro, uno por el lado occidental de $1.400 \mathrm{~m}$ y otro por el oriental de $1.860 \mathrm{~m}$.

Los yacimientos agrarios de época romana en torno al fértil valle de la Val de Aibar son numerosos. De hecho, los trabajos de prospección arqueológica han documentado cerca de medio centenar en el posible territorio adscrito a la civitas ignota de Santa Criz (Armendáriz et al. 1997: 154). A partir del siglo I d.C. se instalarán, en torno a Santa Criz de Eslava, villae dedicadas a la explotación agrícola, entre las que se encuentra la villa de Valuriáin ocupando una pequeña elevación al noroeste de la civitas, que conserva restos de una prensa de viga y materiales cerámicos adscritos a época flavia. Algunos de esos enclaves alcanzaron 
notable protagonismo en la vertebración territorial sobreviviendo, incluso, a la propia ciudad romana, caso del ubicado en La Venta, entre el núcleo urbano actual de Eslava y Santa Criz, que aparece, incluso, citado en la documentación medieval y del que procede un representativo repertorio epigráfico (Andreu et al. 2019b: 54-55, además de Andreu et al. 2019a, para toda la cultura material de la civitas).

Pese a su aparente situación excéntrica, Santa Criz de Eslava ocupó un lugar importante y nada desdeñable, desde el punto de vista estratégico, en la red de comunicaciones que vertebró el norte del distrito jurídico de Caesar Augusta al que el enclave pertenecía, precisamente a partir de la fundación de la colonia por Augusto en el 15-14 a.C. (Beltrán Lloris 2017). Por un lado, a los pies del cerro, por el centro de la Val de Aibar, pasó la vía Iacca-Vareia que ha concentrado el catálogo de miliarios descubiertos en el territorio actualmente navarro y que desde el Pirineo central, tras pasar por el importante nudo viario de Campo Real/ Fillera se dirigía por Santa Criz, Andelo (Mendigorría, Navarra) y Curnonium (Los Arcos, Navarra) hacia Vareia (Varea, Logroño), último puerto navegable en la vía del Ebro (Andreu y Armendáriz 2018). A esa vía pertenecieron, de hecho, los dos miliarios que, publicado el primero en 1917 por J. Castrillo y el segundo poco después por F. Fita (CIL XVII-1, 188 y 189), darían a conocer Santa Criz de Eslava a la comunidad científica en las primeras décadas del siglo XX (Andreu et al. 2019b: 15-16). No lejos del enclave discurriría además la denominada "vía romana de las Cinco Villas", en realidad la Caesar Augusta-Beneharnum (Moreno 2008), con un ramal por Los Bañales de Uncastillo, Cabezo Ladrero de Sofuentes y Campo Real/ Fillera de Sos del Rey Católico, que alcanzaría la Jacetania atravesando la Canal de Berdún y, a partir de época de Tiberio, con otro por el valle del río Aragón que prestaría importancia a la ciudad de los Carenses (Santacara, Navarra) y que correspondería con la denominada "vía del Ravenate" (Castiella 2003: 71-73).

Con ese panorama en términos de conectividad, el territorio circundante a la ciudad romana de Santa Criz de Eslava exhibe uno de los más intensos grados de urbanización del área septentrional del citado conventus. Así, además de las civitates mencionadas -algunas de ellas reducidas, como se ha visto, a topónimos citados en los textos antiguos (Andreu 2006)-, las fuentes ubican a apenas 30 kilómetros de Santa Criz, hacia el norte y al otro lado de la Sierra de Izco, que cierra por el norte la Val de Aibar, la civitas de los Iluberitani. Citada por Plinio entre los oppida stipendiaria del distrito cesaraugustano (Plin. Nat. 3. 24), se identifica con la actual localidad navarra de Lumbier. Iluberis conoció también, en su posición en altura, un notable proceso de monumentalización con foro aterrazado sobre estructuras de opus caementicium prácticamente inédito hasta la fecha (Romero 2014: 207-209). Esa intensidad de la urbanización complica la adscripción del yacimiento que nos ocupa a alguna de las comunidades citadas bien en la lista de la Naturalis Historia de Plinio bien en la de las póleis de los Vascones ofrecida por Ptolomeo (Ptol. 2.6.67). Cierto éxito han tenido en la investigación las propuestas de R. Armendáriz, P. Sáez y R. Mateo, de identificar el lugar con la Nemanturissa de dichos listados o la que, argumentada por J. L. Ramírez Sádaba, ha buscado en Santa Criz la Bituris del propio Ptolomeo (Andreu et al. 2019b: 11, con toda la bibliografía). Sin embargo, ninguna de esas propuestas, a día de hoy y a falta de prueba epigráfica, puede confirmarse (fig. 1).

Sí es cierto que Santa Criz de Eslava - como demuestran las inscripciones de Lerga (IRMN 50) y de Ujué (IRMN 34)- se encuentra en una zona que el propio J. L. Ramírez Sádaba (2009) caracterizó como de predominio lingüístico vascónico en, al menos, la toponimia -aunque también en la onomástica y en la teonimia (Velaza 1995)- y que por tanto un nombre como Nemanturissa encajaría bien en dicho contexto vasconizado. Sin embargo, la ausencia de confirmación epigráfica y, especialmente, la mezcla cultural -con evidentes rasgos indoeuropeos- que puede inferirse de la onomástica atestiguada en sus inscripciones (Andreu 2018) deja el tema abierto todavía. Sí parece claro que, como se ha subrayado recientemente (Andreu et al. 2019b: 1011), fue una civitas stipendiaria -uno de esos parva oppida citados por Mela (3.4)- que conoció una intensa monumentalización desde la época del emperador $\mathrm{Au}-$ gusto -como, por otra parte, el resto de enclaves de su entorno, arriba citados (Andreu 2017 y Larrañaga 2007: 143-144)-, y que -como la mayor parte de las comunidades de su entorno- debió promocionar al estatuto de municipio de derecho latino en época flavia. Pese a que, todavía, carezcamos de mención epigráfica expresa de esa evolución institucional, esta resulta acorde, en cualquier caso, con la evolución urbanística que describe el enclave (Romero 2018: 201-206) y el que, sin duda, constituye, a día de hoy, su conjunto arquitectónico más representativo: el área meridional de su espacio forense.

En este contexto, el origen y desarrollo de Santa Criz como ciudad romana resulta incierto. Un pequeño castro de la Edad del Hierro ocupó el extremo noroeste del cerro del mismo nombre en las estribaciones de la sierra de San Pedro en territorio vascón 


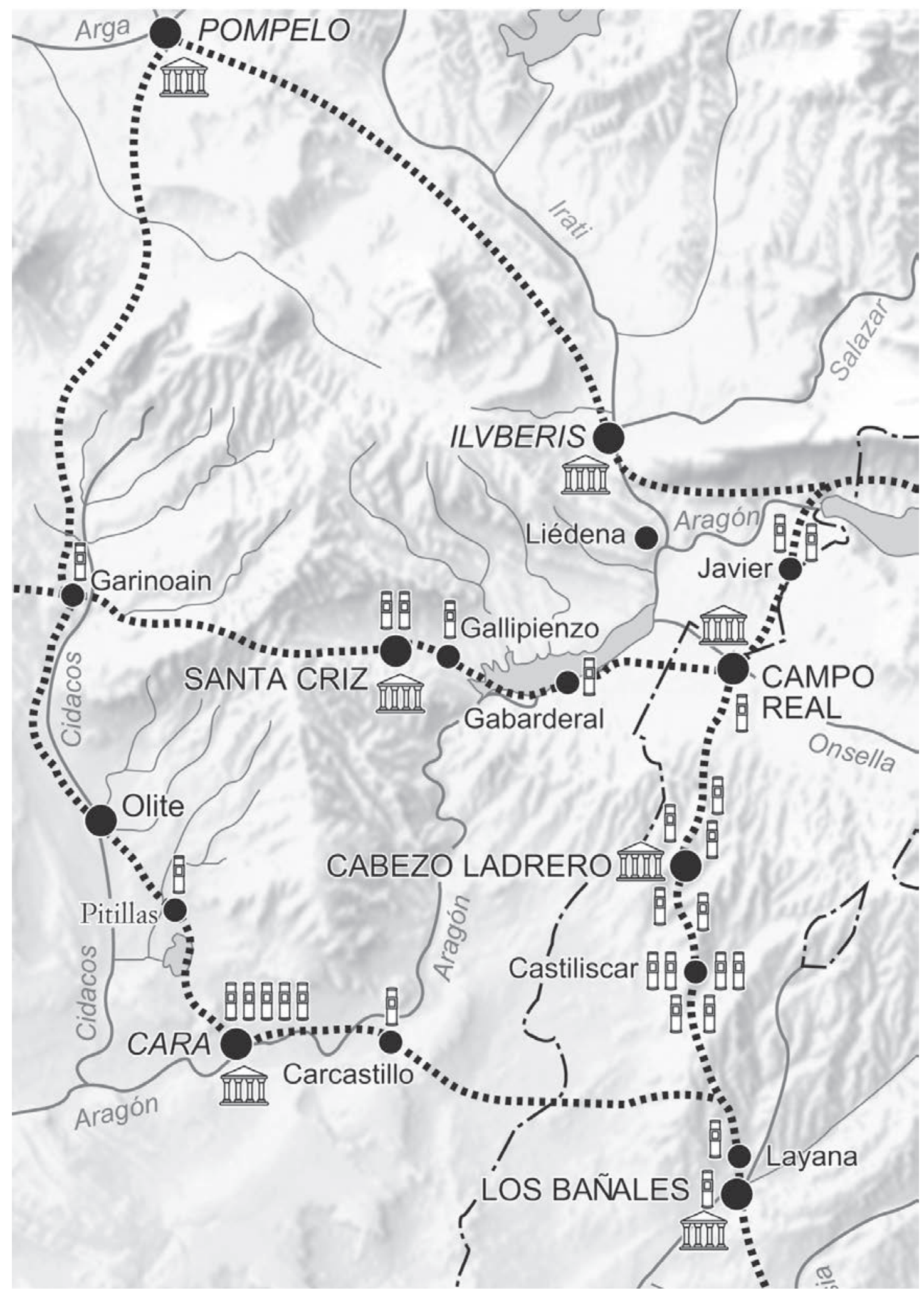

Figura 1. Situación de Santa Criz de Eslava en el entramado viario de época romana y ubicación de los centros urbanos de su entorno (mapa: Óscar Ribote a partir del topográfico nacional 1:50.000. Hoja Sangüesa). 


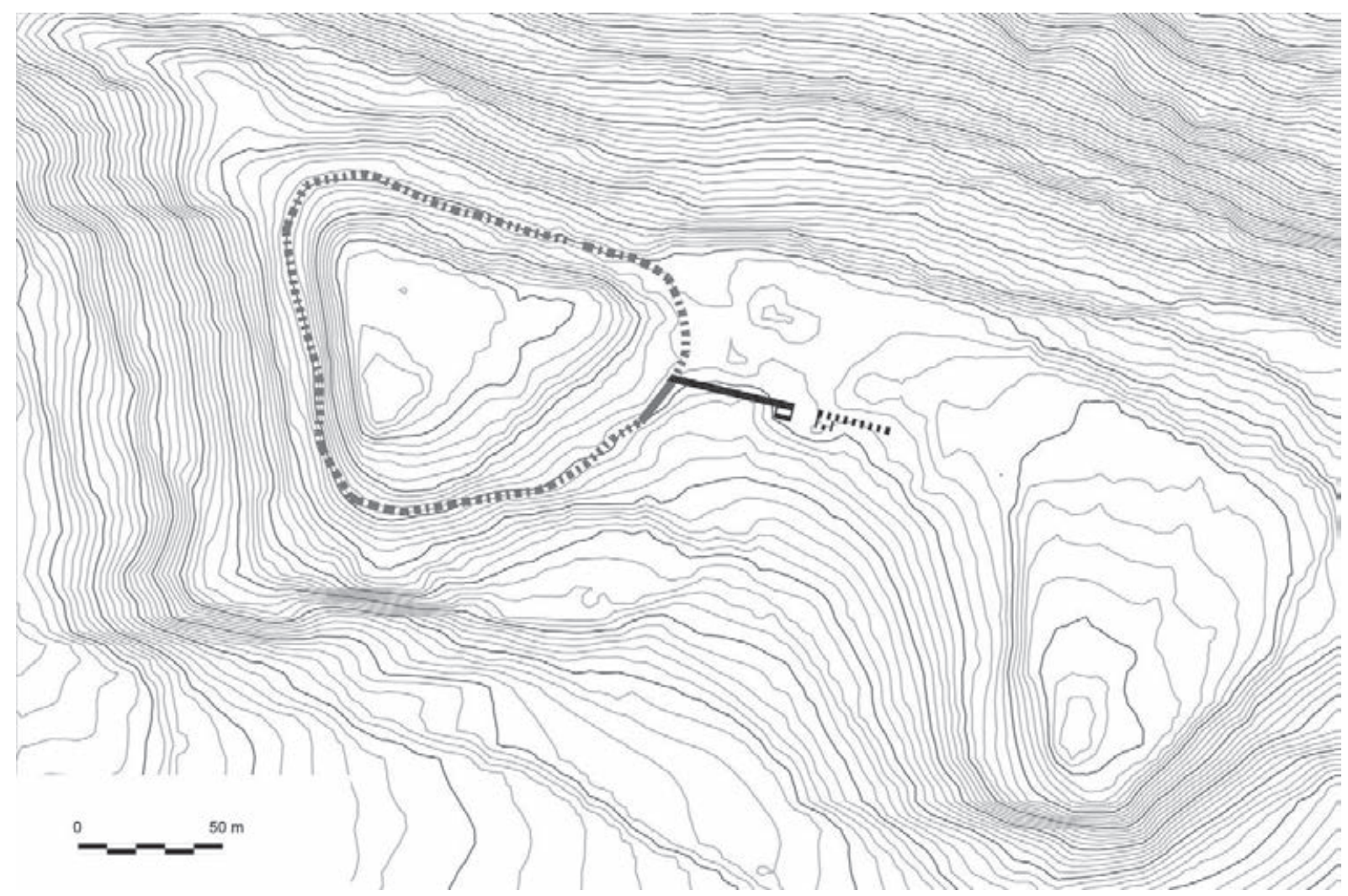

Figura 2. Fases previas a la monumentalización de la ciudad de Santa Criz de Eslava. En gris, la fase inicial correspondiente al castro de la Edad del Hierro; en negro, la fase de ampliación de la muralla en época tardorrepublicana (imagen: R. Cebrián sobre datos obtenidos de LIDAR IGN, hoja 0174 del PNOA MDT_05).

(Armendáriz 2008). Este primer asentamiento tuvo una extensión de 1,5 ha y contó con una muralla dispuesta a la cota 530 m s.n.m, que alcanzó una longitud de 400 $\mathrm{m}$. Se ha supuesto que el acceso a este recinto se realizó a través de una rampa, que recorre la muralla desde su flanco sur hasta llegar a la puerta situada en el lado noreste (Armendáriz 2008: 454-455). El lienzo de muralla oriental del castrum corresponde a la estructura identificada como GEM1 en las excavaciones desarrolladas entre 1995 y 2015 (Armendáriz et al. 2016: 3-4). Presenta una anchura de $3 \mathrm{~m}$ y se extiende a lo largo de 21,75 m. Cimentada sobre la roca natural, se construyó con grandes bloques trabados con barro y relleno interno de piedras de menor tamaño sin amalgamar.

La evolución urbana que hemos establecido a partir de la información reunida de los trabajos arqueológicos realizados revela nueve fases constructivas, que pueden agruparse en cinco grandes etapas. La primera etapa correspondería al castrum de la Edad del Hierro y la segunda a la ampliación del recinto murario cuando, previsiblemente, Santa Criz debió convertirse en un importante establecimiento urbano, vertebrador del fértil territorio del valle del río Indusi (Armendáriz 2008: 456) y en ese contexto de dignificación y monumentalización temprana que constituye una constante de los centros urbanos del entorno y aun de gran parte del Valle del Ebro (fig. 2).

Se edificó entonces un tramo rectilíneo de al menos 40,70 m de longitud, de dirección oeste-este adosado al ángulo sureste de la muralla anterior, que amplió notablemente las dimensiones de la población al ocupar la parte central del cerro de Santa Criz. En los trabajos arqueológicos recientes se equiparó este lienzo con una estructura de contención denominada GEM2 del espacio forense (Armendáriz et al. 2016: 248-249), aunque el análisis de sus características permite plantear la hipótesis de su adscripción al sistema defensivo. $\mathrm{Su}$ técnica constructiva, que ofrece una anchura variable entre 3 y 2,20 m, presenta un aparejo de piedra escuadrada en hileras regulares sin presencia de morteros. Para su construcción se realizaron dos muros paralelos, cuyo interior se rellenó con piedras de mediano y 


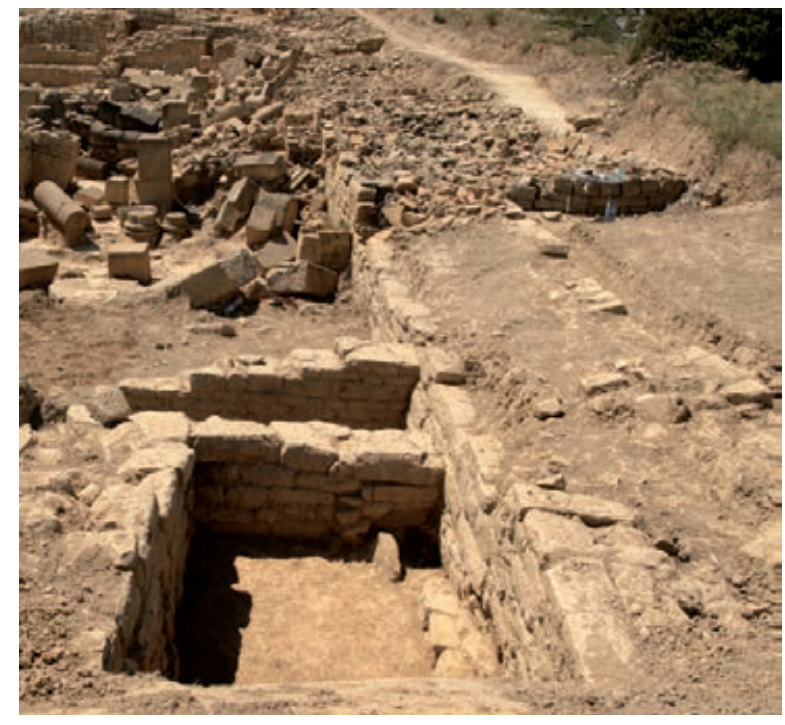

Figura 3. Vista general del tramo de muralla correspondiente a la ampliación del pomerium y torre (imagen: R. M $\mathrm{M}^{\mathrm{a}}$. Armendáriz y P. Sáez de Albéniz).

pequeño tamaño trabadas con tierra de textura arcillosa. Dispuso de una banqueta de cimentación sobre la roca natural reconocida en el extremo oriental de la muralla. En esta zona se ha documentado una torre de 6,14 $\mathrm{m}$ de longitud y 3,66 m de anchura, cuyos muros traban con el lienzo exterior de la muralla y presentan la misma fábrica. La excavación de los rellenos interiores de la torre solo aportó un nivel de amortización (UE 56) fechado en la segunda mitad del siglo I d.C. (fig. 3).

La construcción de la nueva muralla pudo conllevar el trazado de una vía de acceso a la población por el lado meridional del cerro, por la zona por la que discurrió el Camino Viejo de Gallipienzo paralelo a las viae sepulcrales detectadas en las excavaciones del área funeraria (Armendáriz et al. 2007). Sus restos parecen coincidir con la calle enlosada (UEC 1145) documentada delante de la torre, que asciende desde el oeste hasta alcanzar presumiblemente una puerta que, tal vez, estuvo flanqueada por dos torres iguales. Esta puerta quedaría anulada en la fase de monumentalización de la ciudad al construirse dos escaleras, una junto a este acceso, que permitirían la circulación directa a la plaza del foro.

La época augustea, clave en la puesta en relación de estas comunidades con el modo de vida romano (Andreu 2017), supuso el inicio de un proceso de transformación urbana y la construcción de su espacio público donde el forum reunió las funciones administrativojurídicas y un gran almacén aglutinó la actividad comercial (tercera etapa). La civitas alcanzaría entonces unas 13 ha de extensión. Este programa arquitectónico debió ser concebido en esa fecha tomando en consideración los materiales cerámicos contenidos en la estratigrafía del interior del criptopórtico, datados en el primer cuarto del siglo I d.C. (Armendáriz et al. 2016: 254), y la cronología aportada por el repertorio de piezas de decoración arquitectónica y escultórica exhumadas en los niveles de derrumbe del pórtico meridional y edificio circundante de la plaza por su costado occidental. Una reforma posterior condujo a la demolición del almacén público, que acabaría provocando en las décadas siguientes la realización de importantes obras de refuerzo y restauración del criptopórtico sur del foro para solucionar los problemas estructurales derivados de aquel desmontaje. Su abandono definitivo ha sido fechado en el siglo III con un antoniniano de Claudio II acuñado en Roma entre los años 268-270 d.C., que proporciona la fecha ante quem para el desplome del foro (Armendáriz et al. 2016: 255-256), quedando en su posición de caída un total de 149 piezas de decoración arquitectónica en el interior del criptopórtico y área occidental del almacén tras el colapso del foro. La aparición in situ durante el proceso de excavación de los fragmentos decorados constituye una de las imágenes más impactantes de la arqueología reciente en conjuntos forenses de Hispania.

La reocupación del espacio a partir del siglo IV se manifiesta en la construcción de varias estructuras murarias, que reutilizan sillares anteriores en sus fábricas, sobre los niveles de derrumbe del criptopórtico (cuarta etapa). Una torre bajomedieval situada en el área central del cerro constituye la última evidencia de su ocupación (quinta etapa).

\section{EL PROYECTO CONSTRUCTIVO. ACONDICIONAMIENTOS PREVIOS. LA FECHA DE CONSTRUCCIÓN}

Sin ninguna duda, las estructuras excavadas en Santa Criz corresponden al espacio público de la ciudad romana. El área urbanizada exhumada por los trabajos arqueológicos alcanzó los $1.150 \mathrm{~m}^{2}$ en el costado septentrional del espacio central del cerro y al exterior de la muralla. La posición topográfica de un lienzo de esta muralla sirvió como muro de contención delimitador de la plataforma ocupada por el foro, al que se adosó el criptopórtico excavado en la pendiente del cerro. Yuxtapuesto a él se construyó un gran almacén de carácter público. Ambas construcciones conformaron la fachada exterior del conjunto forense (fig. 4). 


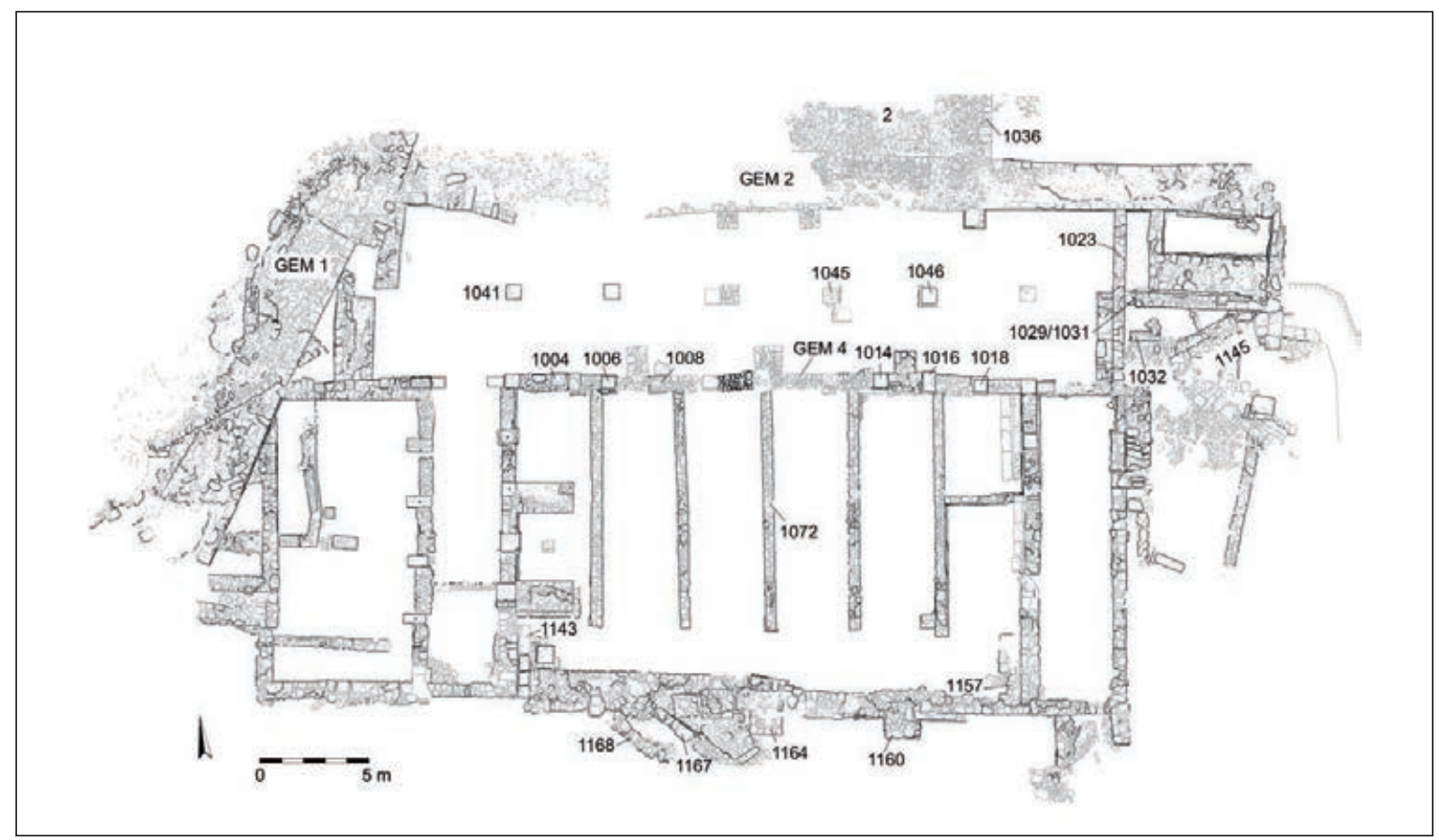

Figura 4. Planimetría general del conjunto excavado en Santa Criz de Eslava con la denominación de las UUEE mencionadas en el texto (I. Diéguez para Gobierno de Navarra).

La primera fase de la obra obligó a tallar la roca natural hasta la cota de 526,31 m s.n.m. Sobre esta superficie retallada se diseñó el nuevo espacio público que iba a quedar por debajo del nivel de la plaza forense. Se trazó un eje de simetría N-S coincidente con el centro de uno de los muros de las habitaciones del almacén (UEC 1072) y el intercolumnio central de los pilares del interior del criptopórtico. El módulo empleado fue de 81 pies de lado -aproximadamente $24 \mathrm{~m}$ - desde el eje, reservándose dos terceras partes para el almacén y una para el criptopórtico. Así, el conjunto construido al exterior de la muralla alcanzó los 162 pies de longitud y 81 pies de anchura, siendo el módulo de 27 pies aproximadamente $8 \mathrm{~m}$-del criptopórtico el que permite plantear una propuesta modular del foro.

En los trabajos arqueológicos llevados a cabo en el lugar no se alcanzó la cota de cimentación del criptopórtico en toda su extensión, pero los sondeos realizados evidencian que sobre la superficie nivelada se levantaron las estructuras murarias y se colocaron las zapatas de cimentación de los pilares centrales, vertiéndose sucesivas capas de áridos arcillosos, arenosos y paquetes de gravas (UE 66 y 75) a modo de rellenos constructivos. Estos paquetes están sellados por un nivel horizontal en el que se entremezclan manchas de cal y hogueras vinculadas a la actividad constructiva. Tampoco se documentaron zanjas de cimentación en los muros del almacén, aunque todos ellos presentan una banqueta en su base (fig. 5).

La disposición urbanística que adoptó el foro ganó superficie útil con la edificación del criptopórtico, destinado a elevar hasta la cota de la plaza una doble galería porticada por su costado meridional. Entre los trabajos de acondicionamiento previos se encontraba también la nivelación de la plaza consistente en un relleno de piedras (UEC 12) localizado junto al lienzo interior de la muralla. Este vertido constructivo colmató un retalle natural del terreno, que se extendía en una franja de $2 \mathrm{~m}$ de ancho y 17,5 $\mathrm{m}$ de longitud (Armendáriz et al. 2016: 248). Amortizó, al menos, una estructura adosada a la muralla (UEC 1036).

Todo el conjunto fue diseñado formando parte de un único programa arquitectónico realizado en los años de la monumentalización de la comunidad que habitaba Santa Criz. El establecimiento de la cronología debe abordarse con prudencia. Los materiales cerámicos obtenidos en la excavación son escasos y aportan una datación entre los siglos I a.C. y V d.C. El nivel previo a la construcción del criptopórtico ha sido fechado por las formas de terra sigillata itálica, barniz negro y 


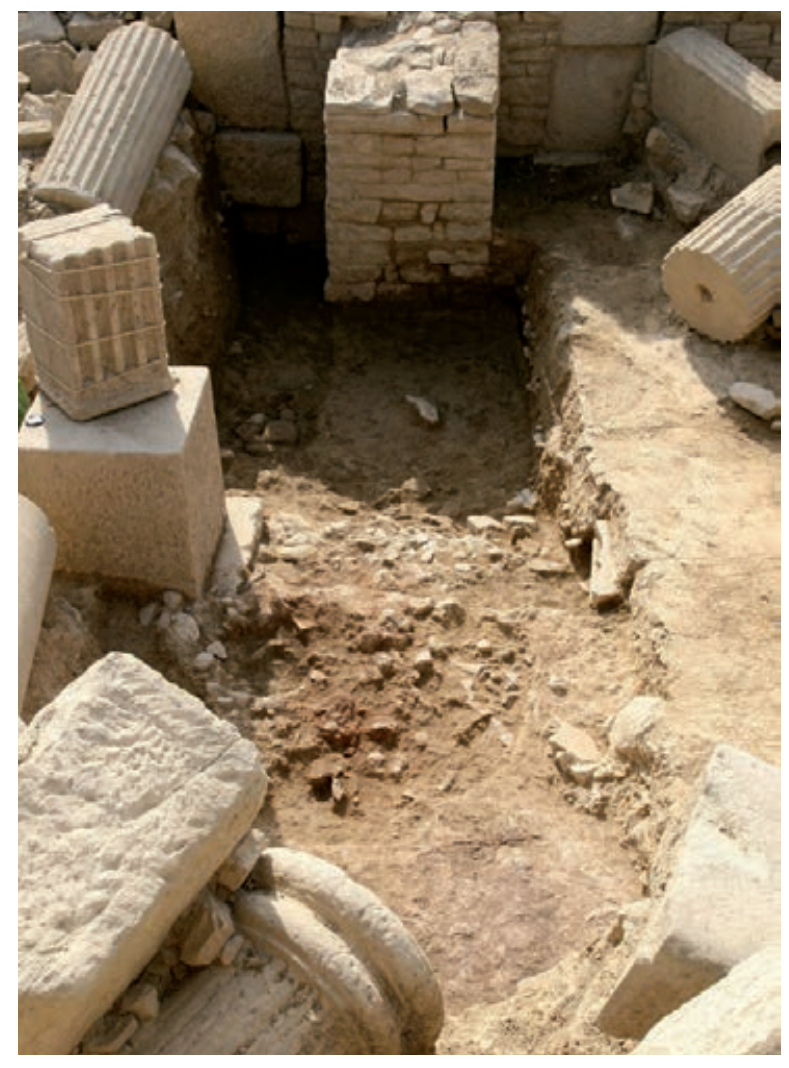

Figura 5. Relleno constructivo del criptopórtico y cimentación de uno de los pilares del interior del criptopórtico (imagen: R. $\mathrm{M}^{\mathrm{a}}$. Armendáriz y P. Sáez de Albéniz).

cerámica de tradición celtibérica en la segunda mitad del siglo I a.C. (Armendáriz et al. 2016: 253-254), constituyendo el terminus post quem para la construcción del foro. La nivelación de criptopórtico y almacén en la fase de reforma se realizó con un vertido muy homogéneo con abundante pintura mural y presencia de cerámicas residuales celtibéricas y producciones locales de cerámica común, junto a algunos fragmentos de terra sigillata hispánica lisa (Armendáriz et al. 2016: 263), de amplio marco temporal, que no ayudan a la hora de fijar la cronología del abandono. En el relleno de nivelación de la denominada taberna 1 (UE 101) se documentaron varios fragmentos de cerámica estampillada gris, de producción gala, junto a producciones del valle del Ebro de cerámica de paredes finas y vidrio. Su presencia obligaría a adelantar la fecha de amortización de esta habitación hacia el 350 d.C., entrando en contradicción con la datación flavia defendida hasta ahora. De manera que parece prioritario acometer el estudio ceramológico exhaustivo de los estratos excavados, que ayude en el establecimiento de la cronología de las fases arqueológicas identificadas. Esta tarea será abordada en el marco del proyecto de investigación en curso.

Hay que asumir además que las reformas posteriores enmascararon la planta original, de manera que muros que ahora están adscritos a la modificación del área excavada pueden estar cimentados sobre la fase original, tal y como se ha podido documentar en la UEM 4, que cerró el criptopórtico por el sur.

De manera que para determinar la datación del centro cívico monumental contamos con la identificación de la técnica constructiva empleada-opus vittatum, formado por piedras de tendencia rectangular y mediano tamaño dispuestas en hiladas regulares y bien aparejadas- y las características particulares de los elementos arquitectónicos utilizados en su decoración.

La nueva decoración arquitectónica -como toda la obra del conjunto- fue ejecutada en arenisca local -de la que se consignan afloramientos con marcas de extracción de probable filiación romana en toda el área de Artamaleta, al oeste del cerro de Santa Criz-y, por tanto, elaborada por un taller local en el que tal vez intervinieron artesanos itinerantes (Mar y Pensabene 2013: 2730). El origen de los elementos decorados no es único, reconociéndose distintos órdenes arquitectónicos, así como abundantes marcas del proceso constructivo. El estilo de algunos capiteles de orden corintio procede de los modelos estilísticos del Segundo Triunvirato, que perduró en Hispania durante el reinado de Augusto (Heilmeyer 1970: 39, Trunk 2008: 21-24). Los capiteles del orden dórico/toscano de la porticus duplex del foro presentan el perfil del equino en arco de círculo, seguido de un caveto y sumoscapo liso con ejemplos en el período augusteo en Ampurias (Aquilué et al. 1984: 85) e Italica (Rodríguez Gutiérrez 2004: 450-451).

Aépoca de Augusto remite también el material escultórico recuperado de los estratos de derrumbe hallados en el interior del criptopórtico. La estatua más completa se adscribe al tipo Ba de H. R. Goette (1990: 113-129), definido por la toga en forma de U característica de los inicios del siglo I d.C. (Romero 2018: 208-209 y Andreu et al. 2019a: 38-54).

\section{LA ARQUITECTURA DE LAS ESTRUCTURAS EXHUMADAS}

\subsection{El criptopórtico del foro y el almacén público}

El complejo excavado corresponde a un criptopórtico que sirvió de cimiento de la porticus duplex delimitadora de la plaza del foro por su costado meridional. 


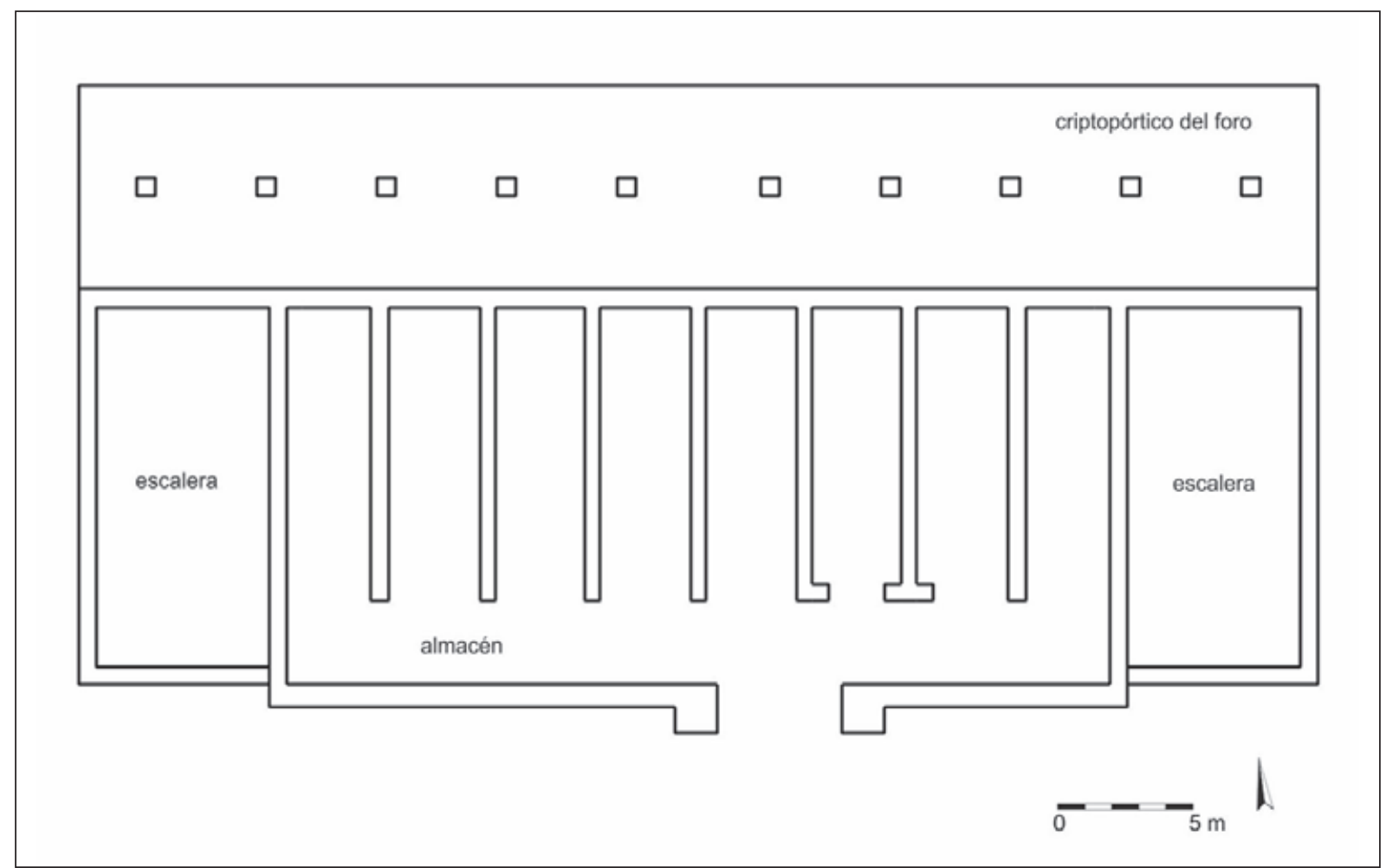

Figura 6. Restitución de la planta del criptopórtico sur del foro y el almacén de Santa Criz de Eslava, a partir de la documentación publicada de los resultados de la investigación arqueológica de Arméndariz et al. 2006.

Dentro de la tipología establecida por E. M. Luschin (2002: 32-33), el criptopórtico de Santa Criz se adscribe al modelo con subestructuras en forma de corredor en complejos aterrazados. En la trasera del muro sur del criptopórtico se adosó un edificio conformado por grandes naves rectangulares, organizadas en hilera y abiertas a un corredor longitudinal de acceso, interpretado como almacén. Esta disposición conforma un espacio arquitectónico público en dos terrazas: la superior, al norte, con la plaza y edificios del foro de la ciudad, aun por excavar, y la inferior, al sur, con un establecimiento destinado al almacenamiento de productos y centralizador de las tasas agrícolas que debieron constituir la base económica de la civitas (fig. 6).

Quedan inciertas las estructuras exhumadas en el costado oriental de este conjunto, donde se disponen dos paramentos de opus vittatum con orientación E-O (UEC 1029/1031 y 1032). Ambos están cortados por el muro UEC 1023, que acotó el criptopórtico por su lado oriental, dejando abierta la posibilidad de que en su fase inicial la subestructura presentase una longitud mayor, tomando en consideración por un lado la disposición de la UEC 1029 en el eje de los pilares centrales y por otro, la técnica constructiva de la UEC 1023 idéntica a la empleada en los muros adscritos a la reforma posterior.

El criptopórtico en su estado actual presenta planta rectangular y está orientado E-O. Ocupa un espacio de unos $300 \mathrm{~m}^{2}$. La longitud máxima es de 38,40 m y 8,19 m de anchura. Su altura alcanzó los 3,30 m. Los límites $\mathrm{N}$ y $\mathrm{O}$ del criptopórtico corresponden al tramo de muralla GEM 2 y al lienzo murario del castrum GEM 1, respectivamente. Por el este, cierra el recinto un paramento con obra de mampostería careada trabada con tierra arcillosa (UEC 1023), de 0,55 m de anchura. Por el sur, la pared está realizada en aparejo mixto que combina cadenas de opus quadratum con paños de opus vittatum, también amalgamados con barro (GEM 4). Las cuatro hiladas verticales de sillería en seco sirvieron para proporcionar la solidez necesaria a la estructura, diseñada como muro de cierre por el lado sur del foro. Los sillares presentan almohadillado por ambas caras y miden $0,68 \times 0,68 \mathrm{~m}$, trabando con los lienzos de sillarejo, de $0,55 \mathrm{~m}$ de anchura. La distancia entre ejes de los pilares 1-2 y 3-4 es de 9,13 m y de 7,77 m entre los pilares 2-3. 
En el interior del criptopórtico se sitúa una línea de seis basamentos cuadrados, que apoya en sillares de cimentación de $0,95 \mathrm{~m}$ de lado, a los que se llegó en excavación en dos de los pilares (UUEE 1045-1046). Están conformados con bloques escuadrados de diferentes alturas y sección ligeramente troncopiramidal. La superficie de cada una de las caras presenta huellas muy marcadas del trabajo de la piedra y aristas cinceladas. En el lado occidental, siguiendo el ritmo de los pilares centrales deben situarse otros dos, uno debajo la UEC 1041 y otro bajo el derrumbe de los elementos arquitectónicos, que no ha sido excavado.

Los pilares interiores del criptopórtico presentan una disposición irregular respecto a su eje de colocación y tampoco la distancia entre ejes guarda un ritmo regular. Por término medio, distan aproximadamente 4,50-4,65 m, con la excepción de los basamentos centrales conservados donde se separan 5,45 m. Sirvieron para sostener las vigas del forjado del piso superior y para la cimentación de las columnas del porticado interior del foro.

La subestructura se construyó con la finalidad de disponer de más terreno en plano horizontal del espacio destinado a la plaza pública, que se desarrolló en la terraza superior. La solución adoptada fue frecuente en la arquitectura romana para nivelar y ampliar el espacio disponible, tomada de la experiencia helenística (Gros 1996: 95-99). Sobre el criptopórtico de Santa Criz se situó una doble galería porticada, de 3,80 m de anchura cada una, a la que pueden adscribirse algunos de los elementos arquitectónicos recuperados en los niveles de derrumbe (UUEE 4 y 6), atribuibles al orden dórico/toscano.

El criptopórtico presenta defectos constructivos de origen, tales como las irregularidades de la puesta en obra de los pilares interiores, la estrechez del muro de cierre oriental y sobre todo el meridional, que pudo ser corregida con la inserción de un número mayor de cadena de sillares. Estas deficiencias estructurales abocarían a la edificación a su colapso, tal y como se produjo a inicios del siglo III d.C. a pesar de las obras de refuerzo llevadas a cabo a finales del siglo I, cuando se desmanteló el almacén debilitando su estructura. No hay evidencias de una cubierta con bóveda a modo de los criptopórticos de las ciudades itálicas del Lacio (Giuliani 1973), Campania (Johannowsky 1973) o de la Galia, como el de Arles (Amy 1973), fechados en época tardorrepublicana y augustea. En cambio, se ha podido atestiguar la existencia de una techumbre plana conformada por vigas de madera a partir de las entalladuras conservadas en algunos de los sillares aparecidos en el derrumbe, que sirvieron para el asiento de los soportes del forjado.
Formando parte del mismo proyecto constructivo que el foro de la ciudad, se levantó un edificio de planta rectangular, que recorrió su frente meridional. Este edificio fue identificado con un horreum (Armendáriz et al. 2016: 263-265). La tipología de los espacios de almacenaje destinados a la conservación de variadas mercancías antes de su distribución y/o comercialización fue establecida por G. Rickman (1971). En líneas generales, diferenció dos tipos: aquellos que presentan grandes naves alineadas en fila simple o doble y edificios de patio central. A la primera categoría puede adscribirse el almacén de Santa Criz. Junto a la arquitectura del edificio, el hallazgo en excavación de fragmentos de dolia y recipientes anfóricos, entre los que se han identificado ánforas del área bética destinadas al suministro de salazones y ánforas vinarias de origen tarraconense, determina su función. Respecto del carácter público de este espacio, puede recordarse aquí -como se ha hecho recientemente (Armendáriz et al. 2016: 264) - la presencia de un dispensator publicus en la ciudad, encargado entre otras funciones de la gestión de préstamos y cobros de una caja pública (Andreu 2010), si bien la complejidad de la vida municipal no excluye que este Athenio -al que conocemos por el homenaje de su compañera, Ant(onia) Crysaeis sobre una placa de circunstancias y lugar de hallazgos poco claros (Andreu et al. 2019b: 29$32, n^{\circ} 3$ )- desempeñase en la comunidad otras tareas ajenas -o complementarias- a la gestión del almacén. En cualquier caso, Ahtenio debió estar bajo las órdenes de los cuestores municipales (Rodríguez Neila 1997: 226). $\mathrm{Su}$ presencia manifiesta, por un lado, la existencia de un ordo decurionum en Santa Criz a partir del siglo I d.C. fecha que se propone para la inscripción, a pesar de que el repertorio epigráfico procedente del lugar no ha documentado hasta el momento mención alguna al cursus honorum de las magistraturas civiles- y, por otro, el control público de las mercancías depositadas en el almacén.

Ese almacén presenta unas dimensiones máximas conservadas de $32,15 \mathrm{~m}$ de longitud y $15,70 \mathrm{~m}$ de anchura (fig. 7). Su espacio interior está compartimentado en ocho naves paralelas orientadas N-S, que miden 11,25 $\mathrm{m}$ de longitud y aproximadamente 3,50 $\mathrm{m}$ de anchura. Por el lado occidental presenta un cuerpo anexo, de 7,50 $\mathrm{m}$ de anchura, subdividido por muros transversales, que interpretamos como una caja de escaleras de acceso directo a la plaza del foro desde la calle situada al sur.

La entrada al almacén se realizó desde el lado meridional a través de un corredor de 2,70 m de anchura, que comunicaba con todos los compartimentos. La entrada a las cellae de los extremos oriental y occidental debió realizarse a través de puertas ubicadas en los 


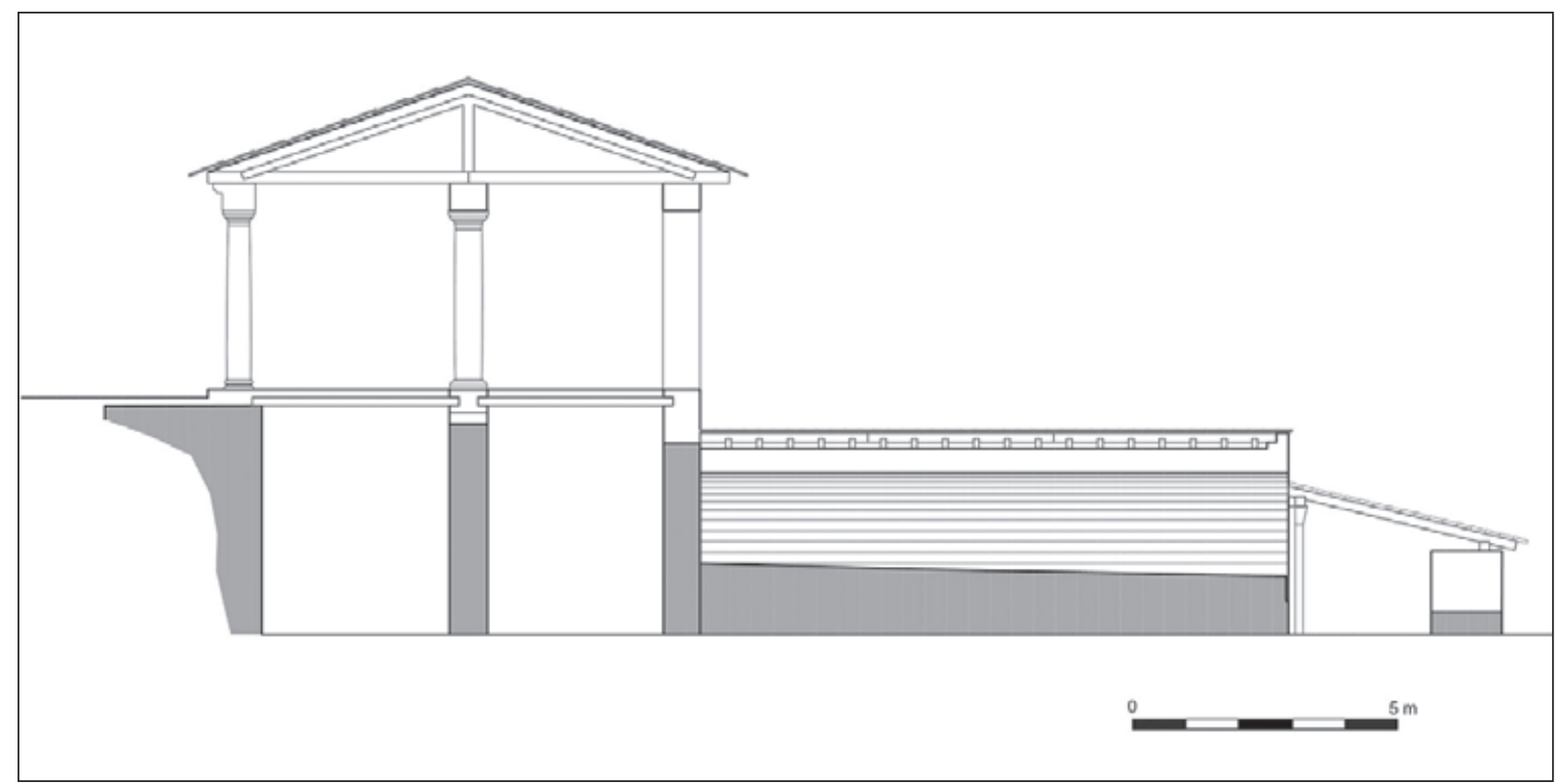

Figura 7. Propuesta interpretativa de la sección del pórtico meridional del foro y almacén público de Santa Criz de Eslava (imagen: I. Hortelano).

muros N-S. Ciertos restos podrían corresponder a la cimentación de varios peldaños (UUEE 1143 y 1157), que hacen pensar que se situaban a un nivel más elevado que el corredor.

A este corredor se accedía desde una única puerta que parece reconocerse en el muro de cierre del edificio. La puerta tiene un vano de 4,65 m y está flanqueada por dos machones de obra (UUEE 1160 y 1164). Su jamba izquierda coincide con el eje axial del proyecto constructivo. Por debajo de este muro atraviesa un canal de desagüe en dirección noroeste-sureste siguiendo la pendiente del cerro. Debió formar parte del sistema de drenaje del almacén y está construido con dos muros de mampostería careada (UUEE 1167-1168), de 0,55 m de anchura, que delimitan un canal de $1,10 \mathrm{~m}$ de anchura. Los muros perimetrales del edificio presentan paramentos de opus vittatum sin argamasas. La anchura del muro oriental y occidental es de $0,65 \mathrm{~m}$ y de $1,30 \mathrm{~m}$ en el muro meridional. Esta diferencia de grosores debe relacionarse con la necesidad de robustecer la fábrica del muro sur, dada la longitud de su traza y el hecho de que esté construido en la ladera sin contar con el refuerzo de ninguna otra estructura, mientras los muros este y oeste soportarían los esfuerzos laterales del posible sistema de bóvedas.

Las paredes de las naves se adosaron al muro de cierre del criptopórtico por su costado sur (GEM 4). Se trata de muros de sillarejo, de 0,45-0,50 m de anchura, que conservan una pequeña zapata de cimentación.
Las habitaciones situadas en el lado meridional presentan la entrada enmarcada por dos salientes de sillarejo, de 0,60 $\mathrm{m}$ de anchura, definiendo un acceso de aproximadamente $2 \mathrm{~m}$. En cuanto a su decoración, el hallazgo de dos fragmentos de fustes de semicolumnas lisas (UUEE 790 y 791), de 0,42 y 0,43 m de anchura respectivamente, en una de las naves y en el nivel de amortización del edificio (UE 787) permite restituir su ubicación, adosados al extremo de los muros de la nave, flanqueando la puerta de acceso. En el mismo estrato se halló un conjunto de lajas de piedra en posición vertical (UE 788), que evidencia el uso de tejas de piedra de las naves del almacén (fig. 8).

Aunque el área interior del edificio no ha sido excavada completamente, en algunos de los departamentos (UE 792) se documentó un nivel muy disgregado con presencia de cantos de río, de $0,10 \mathrm{~m}$ de potencia, que podría interpretarse como los restos de un pavimento de mortero de cal.

\subsection{Evidencias de la estructura portante sobre vigas del criptopórtico y tejado del pórtico sur del foro}

Entre el material arquitectónico recuperado en la excavación del derrumbe del pórtico y edificio circundante de la plaza del foro por su costado occidental, se encuentra 


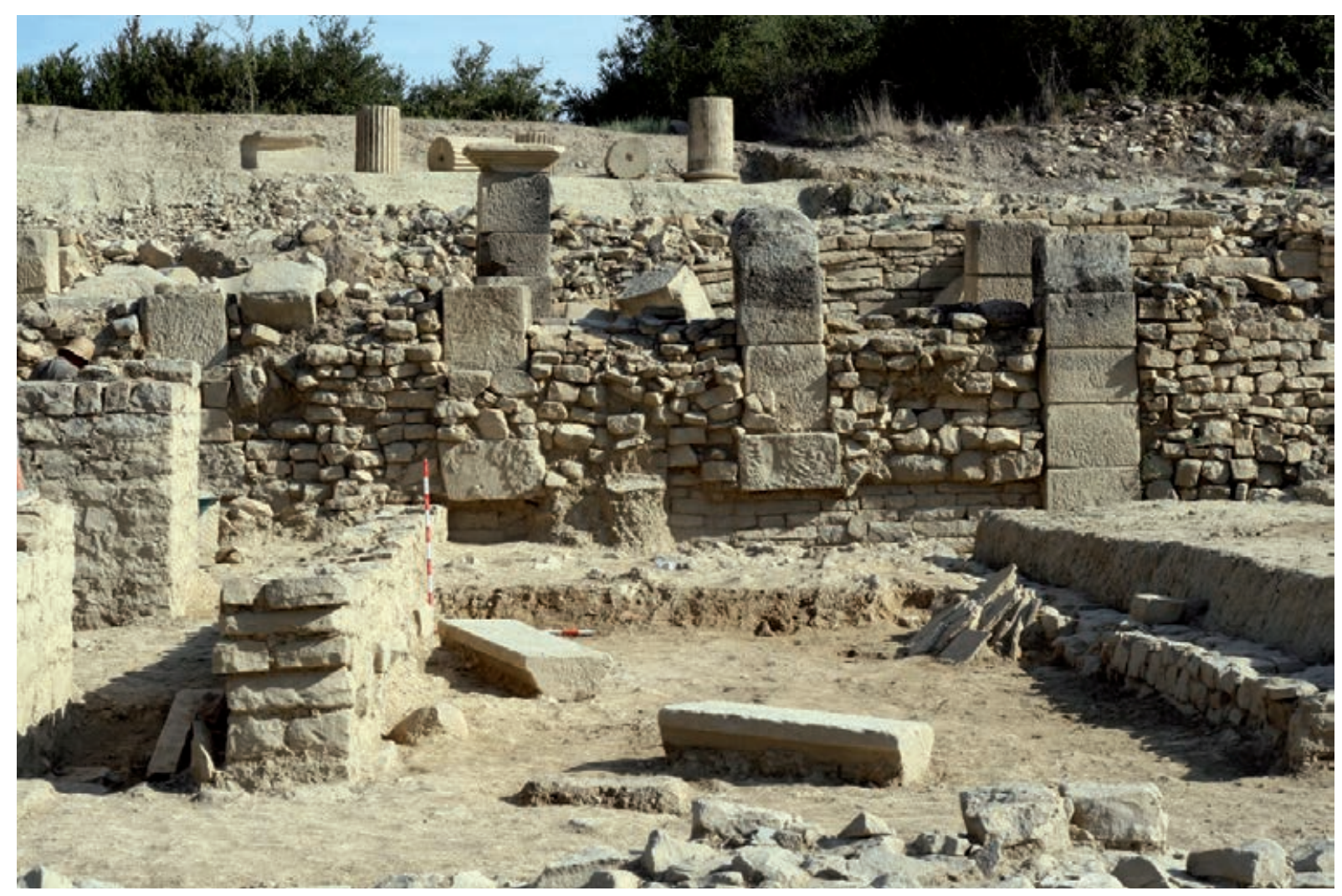

Figura 8. Vista desde el sur de una de las naves del almacén con la posición en la que se encontraron las semicolumnas que flanquearon la puerta de acceso y las lajas de piedra del tejado. Al fondo, el muro de cierre del criptopórtico GEM 4 (imagen: R. Mateo).

un conjunto de dieciocho piezas que define el sistema de forjado de la subestructura y las particularidades del tejado del pórtico situado en el piso superior. Algunas de ellas conservan además muescas en la cara superior y laterales para el izado con grúa en la puesta en obra.

Sobre los sillares superiores de los pilares del interior del criptopórtico corrían pares de vigas que los unían axialmente en sentido longitudinal. Arrancaban desde los muros de cierre este y oeste de la subestructura. Una de las piezas halladas es un sillar cuadrangular, de $0,55 \mathrm{~m}$ de lado y $0,47 \mathrm{~m}$ de altura, que presenta dos entalladuras en la misma dirección en la parte inferior de una de sus caras laterales. Miden 0,27 x 0,35 x 0,14 m y sirvieron para el encaje de estas jácenas del forjado estructural del criptopórtico. Esta pieza resulta muy significativa, pues permite restituir el orden del pórtico meridional del foro al tener tallada en su cara superior una basa toscana sin plinto, de $0,43 \mathrm{~m}$ de diámetro del fuste (fig. 9.1).

Sobre las jácenas y los muros norte y sur de la estructura, apoyaron sucesivas vigas transversales separadas entre sí $0,46 \mathrm{~m}$. La evidencia arqueológica se encuentra en cuatro sillares pertenecientes a los pilares del interior del criptopórtico, que disponen de dos entalladuras enfrentadas en sus caras laterales, de 0,16 m de profundidad (fig. 9.2, 9.3 y 9.4). En ellas se encajarían vigas de $0,13 \mathrm{~m}$ de canto. Tres de los sillares presentan planta cuadrangular, de $0,65 \mathrm{~m}$ de lado, mientras el cuarto mide $0,70 \times 0,64 \mathrm{~m}$. La separación entre ellas se deduce del hallazgo de un sillar de $1,11 \mathrm{~m}$ de longitud, 0,50 $\mathrm{m}$ de anchura y 0,39 $\mathrm{m}$ de altura, que debió situarse en uno de los dos muros largos al nivel del forjado, posiblemente en el meridional atendiendo a la posición de caída de la pieza en el momento del derrumbe (fig. 9.5). Presenta dos muescas separadas $0,46 \mathrm{~m}$, medida que corresponde al entrevigado. Con esta función, se ha documentado otro fragmento de sillar que conserva una entalladura de las mismas dimensiones. Finalmente, estas vigas servirían para el apoyo de los travesaños a los que se fijaría el tablero del encofrado del suelo del piso superior.

Al mismo sistema de entrevigado se adscriben otros dos sillares cuadrangulares, de $0,55 \mathrm{~m}$ de lado, que también presentan un rebaje para el asiento de vigas de 0,13 


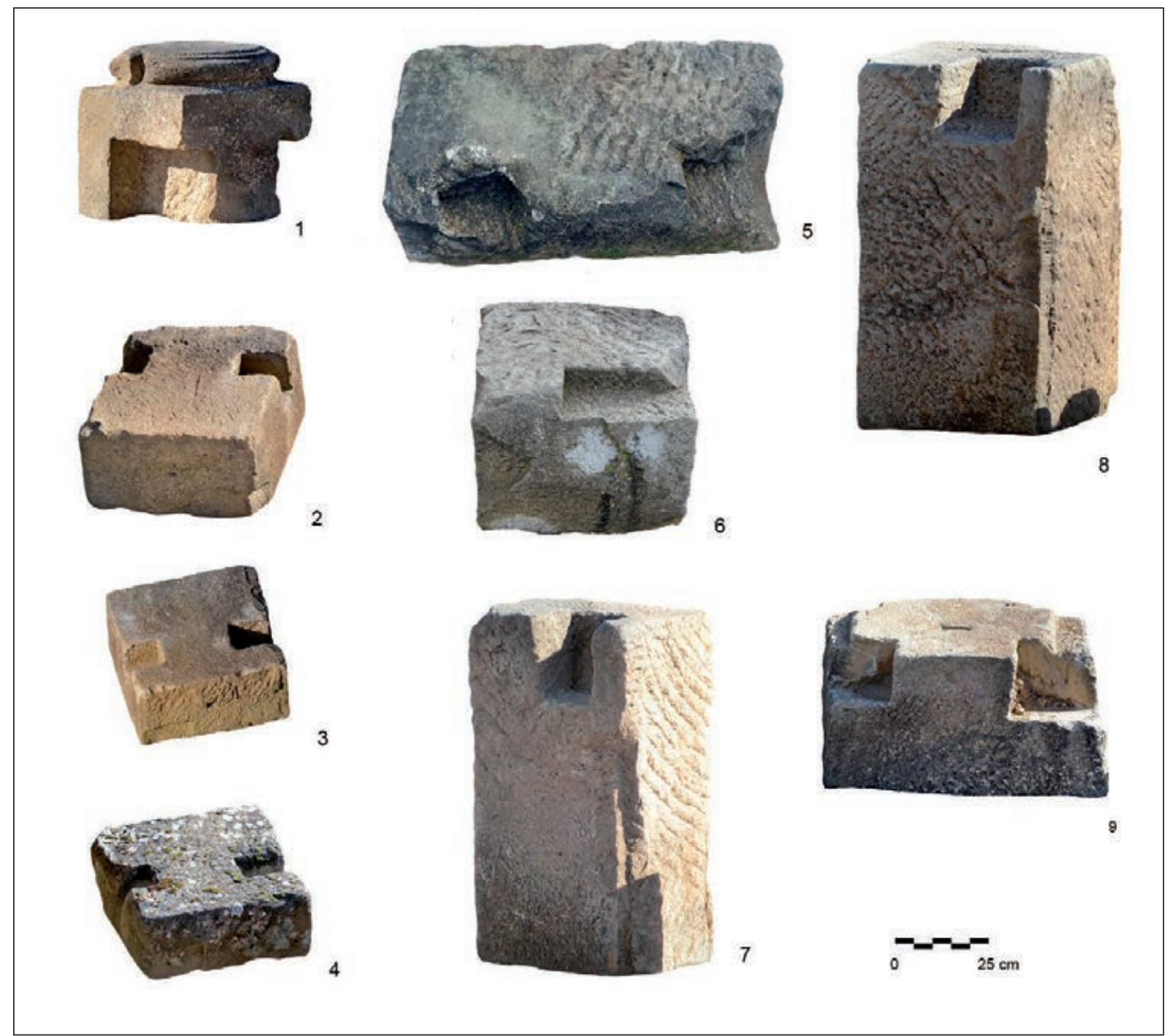

Figura 9. Vistas fotogramétricas de los elementos arquitectónicos atribuibles a la estructura portante sobre vigas del criptopórtico meridional del foro de Santa Criz. Advertimos de que las piezas n ${ }^{\circ} .2,3$ y 4 no muestran su altura original debido a la ubicación en la que se encuentran actualmente (imagen: R. Cebrián).

$m$ de canto. El tamaño de las piezas aconseja considerar su disposición en el lienzo meridional de cierre del criptopórtico (fig. 9.6).

La remodelación del espacio acaecida a finales del siglo I conllevó inmediatamente después el refuerzo de la estructura del criptopórtico. Entre las acciones realizadas, se encontraba la instalación de seis machones o pilares de sillería en su muro meridional con el fin de robustecerlo en los puntos en que la construcción soportaba mayor empuje (UEC 1004, 1006, 1008, 1014, 1016 y 1018). Se trataba de colocar cadenas de sillares dispuestos verticalmente, asentados sobre otros bloques a modo de banquetas de cimentación. Dos de ellos conservan una entalladura idéntica en la cara superior, de $0,25 \times 0,22 \times 0,20-0,26 \mathrm{~m}$, para el apoyo de las vigas transversales. La talla de los sillares con un desbastado tosco y huellas del instrumental empleado muy marcadas permite su atribución a esta fase de reforma (fig. 9.7 y 9.8). A este periodo adscribimos también un sillar que presenta dos muescas realizadas en la misma cara lateral para el cobijo de jácenas de $0,24-0,20 \mathrm{~m}$ de canto. La pieza mide $0,48 \times 0,74 \times 0,54 \mathrm{~m}$ y presenta en la cara superior dos rebajes, de $0,8-0,10 \mathrm{~m}$ de profundidad, quizás para el apoyo de las siguientes vigas (fig. 9.9). 


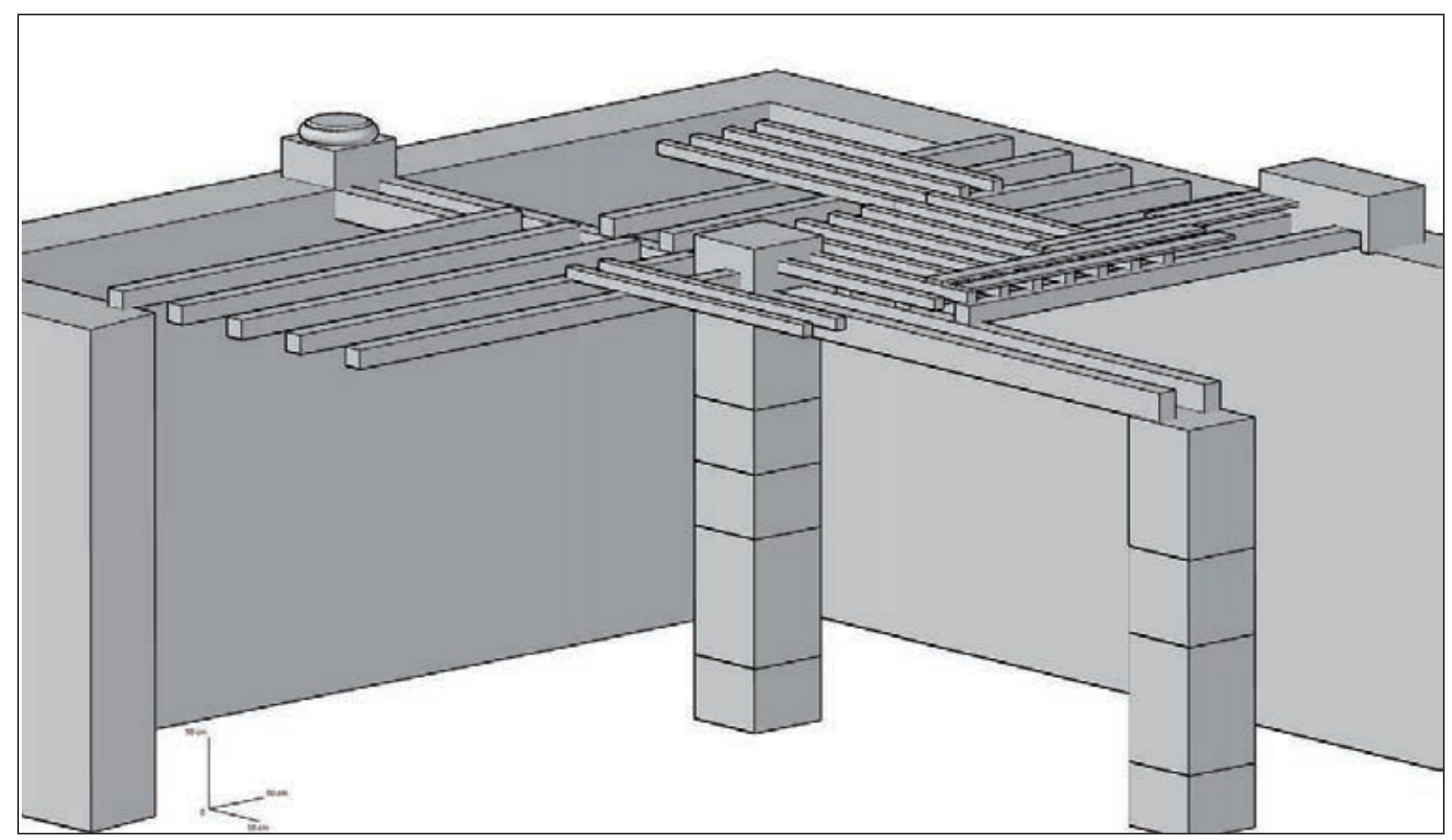

Figura 10. Propuesta de reconstrucción del forjado del piso del pórtico meridional del foro de Santa Criz (imagen: I. Hortelano).

Es posible que el refuerzo del criptopórtico incluyese la instalación de traviesas que atasen los nuevos pilares levantados en el muro meridional con los centrales.

De esta manera, el piso del pórtico meridional del foro se asentaba en un forjado cuyo espesor total superaría los 0,50 $\mathrm{m}$, conformado con vigas de madera colocadas longitudinalmente de pilar a pilar que corrían por la parte central del criptopórtico. Sobre ellas apoyaban otras vigas transversales, que partían desde el muro norte -muralla- hasta los pilares centrales y desde estos al muro meridional. Esta estructura servía para el apoyo de las latas y tablero sobre los que se construiría el suelo del pórtico (fig. 10). Un sistema idéntico lo encontramos en el forjado del criptopórtico de Conimbriga, reformado en época flavia y restituido a partir del texto de Vitruvio (Alarcão y Etienne 1973: 403, fig. 11).

Del mismo derrumbe proceden cuatro piezas, cuyas posiciones de caída y características formales sugieren su ubicación en el tejado del pórtico del foro (ESL1/71, 106, 122 y $\sin \mathrm{n}^{\circ}$ inv.). Se trata de lastras, de $0,22 \mathrm{~m}$ de altura, que presentan secciones en su cara superior talladas en bisel, conformando un ángulo de $20^{\circ} / 21^{\circ}$. La distancia entre la sección rebajada y la que no lo está es de 0,49 m. El espesor es de 0,62 m.

La cubierta del pórtico del foro debió realizarse con tejas de piedra, tomando en consideración la inexistencia en el nivel de derrumbe de material latericio asignable a tegulae e imbrices y la descripción de la composición de este derribo, donde se identifican «pequeñas piedras y lajitas que se estiman producto de la degradación de posibles lajas de cubierta» (Armendáriz et al. 2016: 255). Sin duda, constituye una particularidad constructiva del foro, que puede responder a una tradición indígena. No hemos encontrado ningún paralelo para este tipo de pieza, que consideramos una singularidad relacionada con el material pétreo empleado en el tejado (fig. 11).

Los sistemas de cubierta de la carpintería de madera del tejado pudieron realizarse con tejas de arcilla, en piedra utilizando losas o placas y, excepcionalmente, en opus caementicium (Ginouvès 1992: 182-183). En el mundo griego, las tejas en piedra en forma de losanges o triangulares fueron empleadas en la cubierta de edificios circulares como el tholos del Ágora de Atenas (Hellmann 2002: 320-326). Fueron frecuentes las tejas de mármol en los edificios religiosos, encontrando ejemplos en Grecia, Magna Grecia, Anatolia e incluso en la península ibérica en el templo ampuritano de Asclepios (Aquilué et al. 2001: 37) o en el Traianeum de Italica (Vargas 2018: 215-222). Esta tradición de cubierta en piedra fue asimilada por Roma, difundiéndose principalmente en la arquitectura funeraria (Adam 1989: 232). El 


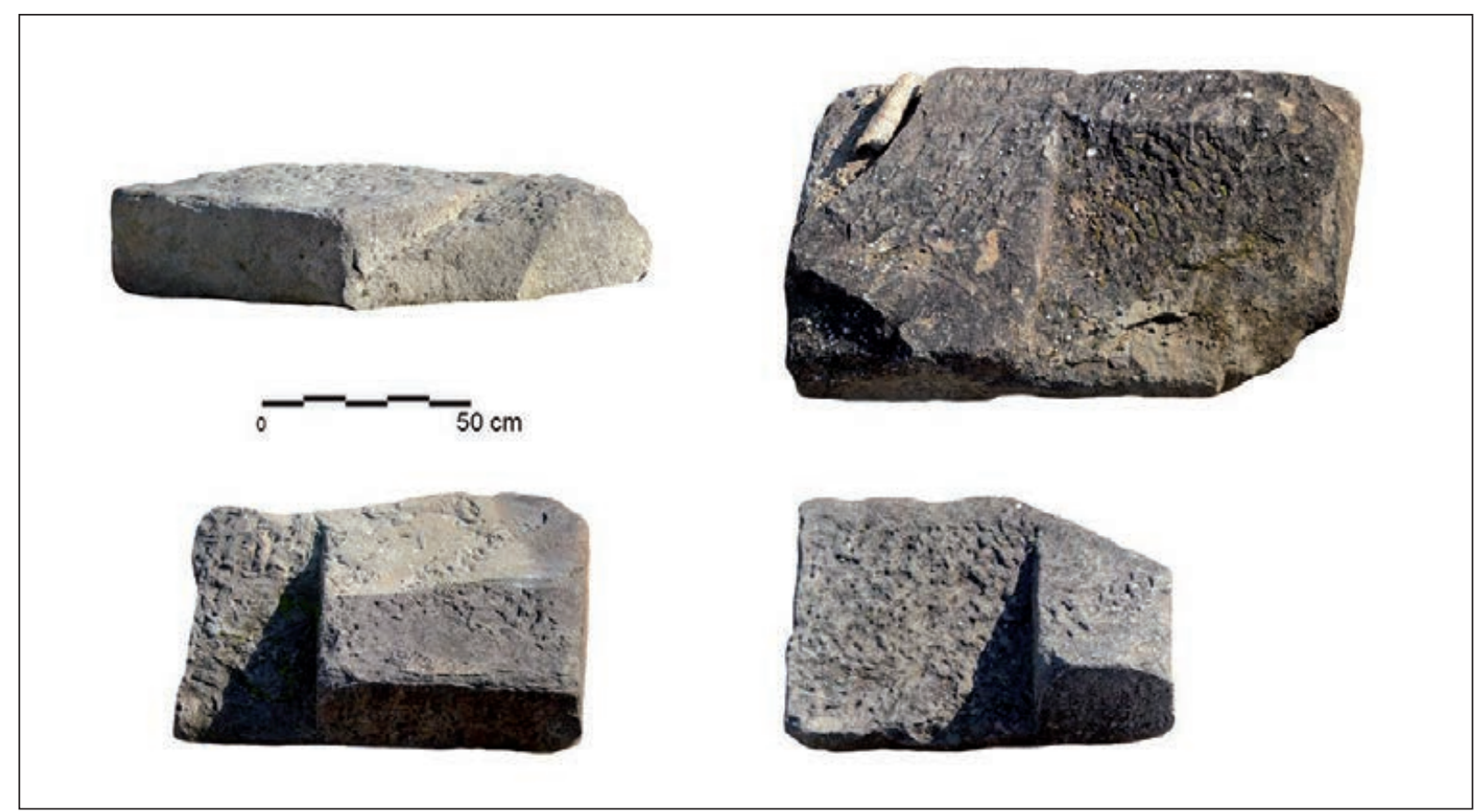

Figura 11. Losas de piedra de apoyo de la cubierta y del soporte del alero del tejado del pórtico sur del foro halladas en el derrumbe del interior del criptopórtico (imagen: R. Cebrián).

sistema de tejas conformadas con losas cortadas con sierra fue muy utilizado en Galia. Están presentes en numerosos oppida del área marsellesa (Excoffon 2009: 265). En Glanum el tipo de cubierta en piedra se ha reconocido en un templo próstilo de tipo toscano datado en el siglo II a.C. y ubicado en el foro (Roth-Congès 1992: 356, fig. 2, XVII), que fue identificado, estudiado y restituido por A. Olivier (1982). Y en Olbia, tejas de piedra de un tejado tipo corintio se vinculan a un posible santuario fechado a inicios del siglo II a.C. (Excoffon 2009). Los hallazgos más tardíos se fechan en el siglo II d.C., aunque se trata del reempleo de tejas de piedra (Poguet y Pelletier 2004: 111). A escala regional, esta praxis para las cubiertas también se ha anotado como plausible en el vecino yacimiento de Campo Real/Fillera, en Sos del Rey Católico, conectado con la civitas de Santa Criz de Eslava. En él, y en prospecciones superficiales, la ausencia de tegulae e imbrices y la presencia constante de lajas de arenisca permite pensar en un sistema de cubiertas semejante (Andreu et al. 2008: 99).

Las piezas de Santa Criz se situaron sobre la cornisa de tipo dórico del pórtico meridional de la plaza, que presenta la cara superior horizontal de $0,77 \mathrm{~m}$ de profundidad. Sirvieron de borde exterior al tejado al disponerse en la parte externa de la cornisa, dejando una franja de apoyo al interior de al menos $0,15 \mathrm{~m}$ para la colocación de la estructura horizontal del tejado. La cara biselada determinó la inclinación de la cubierta a dos aguas y sobre ella corrieron los cabrios de madera, existiendo espacio suficiente para alojar en cada ranura un par de vigas. La explicación podría encontrarse en la necesidad de disponer de una estructura lo suficientemente robusta como para soportar un tejado de piedra, cuyo peso podría llegar a suponer prácticamente el doble que el de uno de terracota (fig. 12).

\subsection{La interpretación funcional del conjunto excavado. Modelo arquitectónico}

La construcción de espacios públicos en lugares elevados creó un problema urbanístico ante la necesidad de mantener una cota regular suficientemente extensa para dotar a la ciudad de una plaza porticada convertida en su centro religioso, político y administrativo. La experiencia del helenismo romano aportó el sistema de terrazas, que se difundió a partir de época tardorrepublicana por las ciudades de la costa tirrénica de Italia y Magna Grecia para la configuración en altura de los nuevos espacios públicos (Etxebarria 2008: 82-85).

El sistema de tabernae o criptopórticos, a modo de galerías abovedadas, se desarrolló como solución 
habitual, repitiéndose en la disposición de los espacios públicos a partir del siglo II a.C. y hasta época augustea según el modelo forum-basilica-templum (Ward-Perkins 1970, Gros 1990).

En Santa Criz, la pared trasera del criptopórtico destinado a sostener el pórtico meridional del foro quedó limitada por un almacén de unos $500 \mathrm{~m}^{2}$ de superficie destinado al acopio de mercancías de distinta procedencia. De esta manera el diseño del espacio público de la civitas dejó fuera del foro la actividad comercial. La difusión, a partir de época tardorrepublicana, de un edificio de tipología reconocible y específico para la venta de productos alimentarios (De Ruyt 1973) acabaría sacando del foro a las tabernae, que habían ocupado hasta entonces, al menos, uno de los lados de la plaza.

La disposición del almacén siguió el modelo de las alineaciones de habitaciones regulares organizadas en hileras con una sola fachada -tabernae tabulatae-, cuyo antecedente se encuentra en la construcción de las grandes terrazas de los santuarios republicanos del Lacio (Mar 2005: 131); aunque su función no puede vincularse con negocios abiertos a una vía comercial sino con un establecimiento cerrado y con acceso controlado.

La riqueza agrícola del territorio administrado por la ciudad consiente un papel destacado en la recepción de productos alimentarios, principalmente cereal, que se guardaron en el almacén junto a otros productos importados, como evidencian los envases de vino tarraconense y salazones béticas hallados en su excavación.

Desde época tardorrepublicana conocemos horrea en el valle del Ebro para el acopio del grano, que reflejan el potencial económico agrícola de la zona. Emplazado en el centro del espacio urbano de Contrebia Belaisca (Botorrita, Zaragoza), un edificio de adobe sirvió como almacén. Con una superficie construida de $225 \mathrm{~m}^{2}$, presenta cinco naves alargadas abiertas a un pórtico (Medrano et al. 1991). A partir de época imperial, Caesar Augusta canalizaría, a través de su puerto, la salida de cereal de las ricas tierras de este valle y otros productos manufacturados hacia las áreas portuarias de Dertosa y Tarraco (Erice 2011: 152). Aunque desconocida la ubicación concreta de los horrea caesaraugustanos, las menciones al genius tutelae horreorum (CIL II 2991) y a un horrearius (Beltrán Lloris 1982: 56) en sendas inscripciones halladas en el casco urbano testimonian su existencia. De igual modo, la investigación ha querido ver estructuras horrearias próximas en Los Bañales de Uncastillo y en Campo Real/Fillera (Andreu 2011: 77-78), así como en la vecina villa de Liédena, ya en el territorio de los Iluberitani plinianos, aunque no lejos de Santa Criz de Eslava (Zuza 2013).

La estructura arquitectónica del edificio adosado al criptopórtico del foro de Santa Criz, con amplias naves alargadas, se asemeja a otros almacenes documentados en áreas portuarias de Roma y las provincias. Las formas reconocidas de los edificios destinados a almacenes son muy variadas, aunque la tipología más repetida presenta un cierto número de naves alineadas en fila o en torno a un patio central. En Roma proliferaron junto a los muelles fluviales, principalmente en el Emporium del Testaccio al pie de la colina Aventina (Sebastiani y Serlorenzi 2011), en Ostia y en Portus. Grandes puertos como Aquileia, Leptis Magna o Patara dispusieron también de almacenes donde agrupar las mercancías antes de su distribución. Los edificios destinados a tal fin presentaban naves estrechas y alargadas que, en ocasiones, se abrían a áreas porticadas (Rickman 1971: 132-138).

Construcciones similares se localizaron en el interior de las ciudades desde época tardorrepublicana. En ocasiones, se construyeron cerca de las puertas de la ciudad y, por tanto, bien comunicadas con las principales vías urbanas, como en la colonia latina de Cosa (Brown 1979) o en el municipium de Volsinii Novi (Gros 1981: 54-57), tal vez destinados a la conservación de alimentos para su venta en mercados locales.

En las inmediaciones de los fora se situaron algunos almacenes. Tal es el caso de los horrea Agrippiana en Roma, ubicados desde época augustea en el límite del foro republicano al sur de la basilica Iulia y destinados al depósito de bienes pero también a su venta (Astolfi 1996). De planta cuadrada y con una superficie ocupada de $3.600 \mathrm{~m}^{2}$, las habitaciones de planta alargada se organizaban en torno a un patio central (Rickman 1971: 91, fig. 20). Por su parte, en Tibur hacia mediados del siglo I a.C. se llevaron a cabo obras de ampliación en el foro, que incluyeron la construcción en el límite suroeste de la plaza de potentes subestructuras para ampliar el espacio público y que debieron funcionar como un gran almacén (Coarelli 1982: 86-90). La misma disposición se reconoce en otros núcleos urbanos del Lacio, donde en el municipium de Cora un edificio, de planta rectangular con varias naves cubiertas por bóvedas y con acceso a través de un corredor, sirvió de cimentación a la plaza del foro (v. Ribera 2011: 209-215).

En Hispania, estructuras de almacenamiento se han identificado en ciudades donde una gran parte de su actividad económica estuvo vinculada al comercio. Tarraco, Carthago Nova o Hispalis dispusieron de edificios destinados al almacén de mercancías importadas 


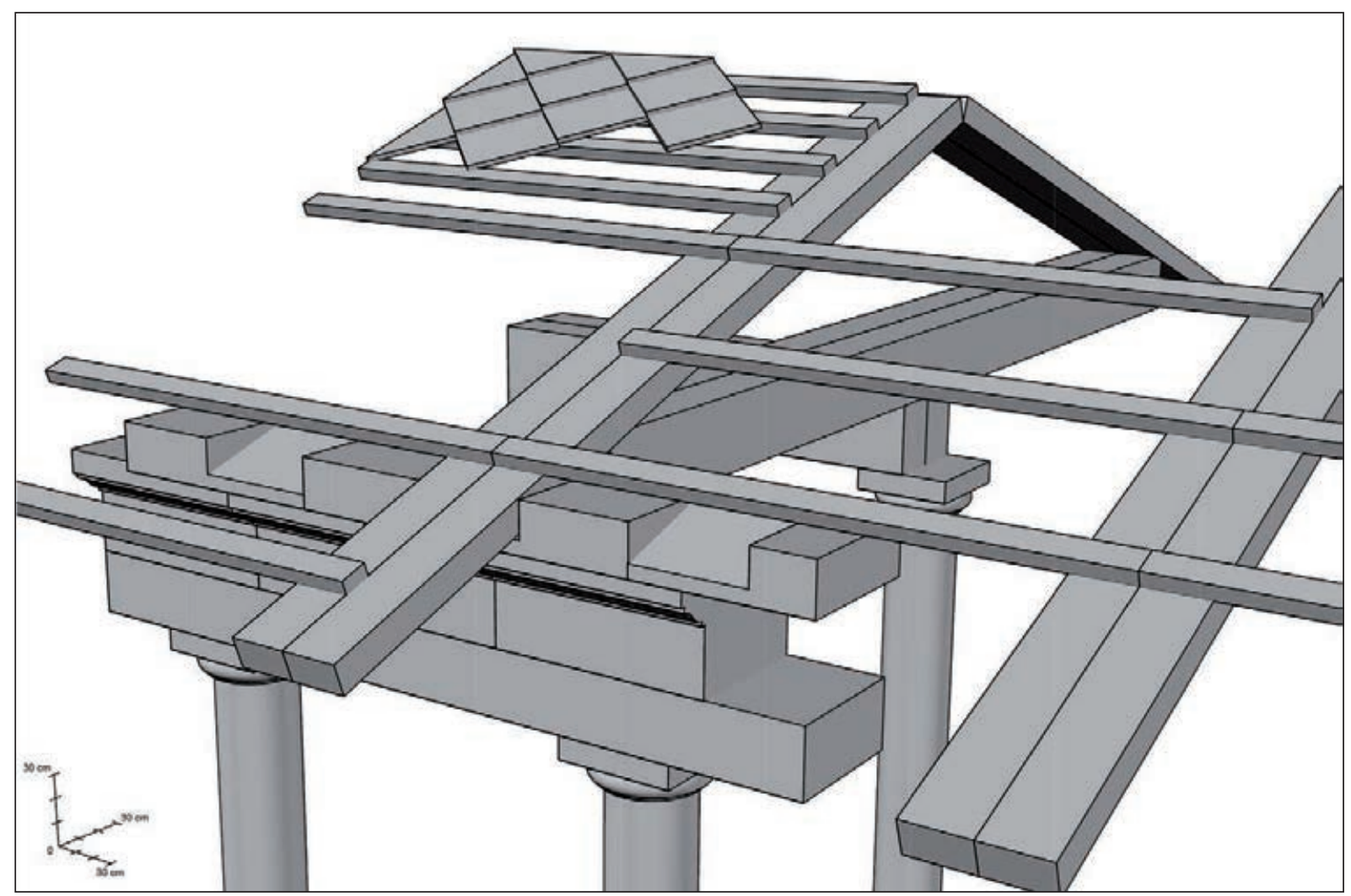

Figura 12. Propuesta interpretativa del sistema de cubierta del pórtico meridional del foro de Santa Criz (imagen: I. Hortelano).

y productos para exportación en las áreas portuarias. Este mismo carácter pudo tener el horreum construido a finales del siglo I o principios del II en Valentia, sobre el solar del antiguo almacén edificado al este de la plaza del foro en torno al 100 a.C. (Ribera 2011). Y quizás también las tabernae construidas en la primera mitad del siglo I a.C. en el costado suroriental de la terraza del foro de Baetulo, que ocuparon una superficie de 300 m² (Guitart y Padrós 1990: 173).

Las diferencias formales entre los edificios identificados como almacén en el mundo romano son consecuencia de la inexistencia de un modelo estandarizado (Andreau 2007: 263), que impidió la difusión de una forma arquitectónica concreta por el resto de las provincias. El tipo arquitectónico de almacén conformado por una serie de largas y estrechas naves caracterizó a los edificios de almacenamiento construidos en ciudades de Asia Menor (Rickman 1971: 153). Mientras, el corredor de acceso que presentan algunos de ellos sirvió para proteger el grano de la entrada de agua desde la calle (Rickman 1971: 142).

El almacén de Santa Criz encuentra su precedente más cercano en la arquitectura de las naves del horreum de Contrebia Belaisca, mientras el modelo de habitaciones alargadas y corredor de acceso aparece en los grandes horrea de época adrianea de Myra y Patara en Licia (Rickman 1971: 137-140), de propiedad imperial (CIL III 6738 y 12129), o en el de Cuicul en Numidia (Papi y Martorella 2009: 178-182) construido en la primera mitad del siglo II d.C. (fig. 13).

La localización de tabernae en torno a los foros fue habitual en el mundo romano (v. Mar et al. 2015: 283287). Los establecimientos comerciales aparecen limitando uno de los costados de la plaza o al exterior de la misma, disposición más propia de época imperial cuando el forum desplazó la función comercial. Edificios comerciales adosados a los criptopórticos del foro se localizan en algunos conjuntos monumentales hispanos, como en Tarraco, donde aparecerán a una altura inferior a la plaza durante la reforma augustea del foro colonial (Mar et al. 2015: 258), en Valeria a partir de época tiberiana (Fuentes et al. 2007: 466-467) y en Los Bañales recorriendo el flanco sur de la plaza desde época augustea (Romero e.p.).

En el caso de Santa Criz el almacén se construyó fuera de la unidad arquitectónica del foro. Situado en la 


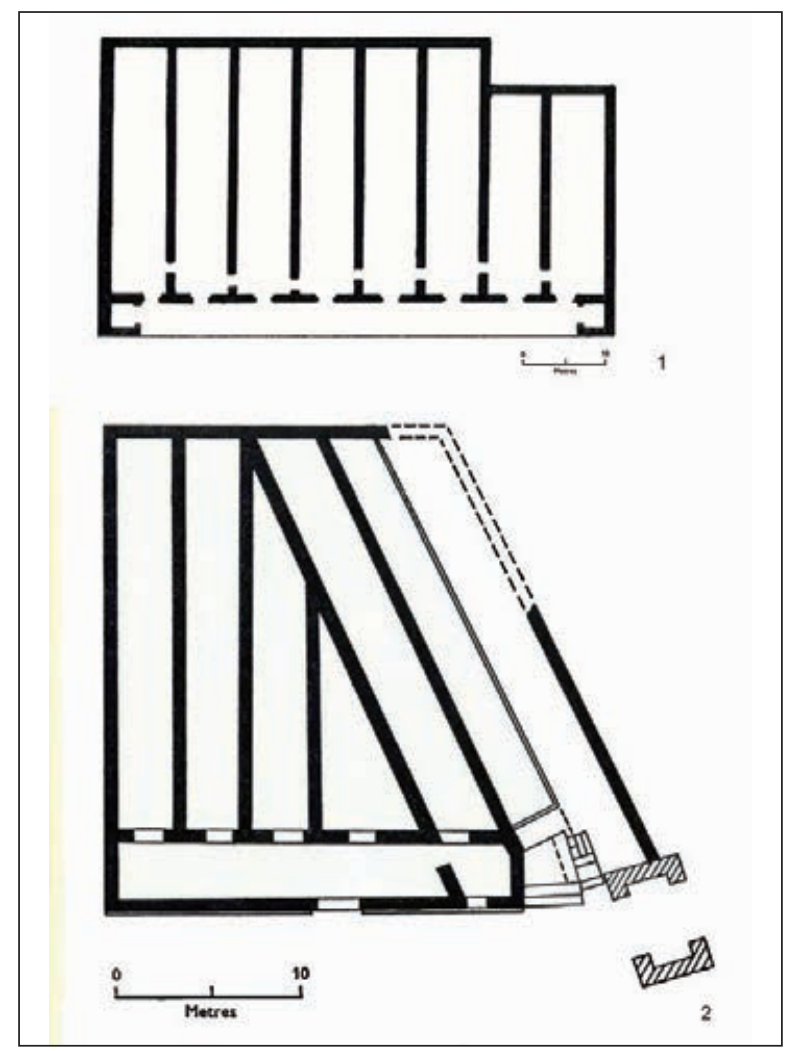

Figura 13. Planta de los almacenes de Myra (1) y Cuicul (2) con el mismo esquema arquitectónico del de Santa Criz de Eslava (imagen tomada de Rickman 1971: Figuras 31 y 32).

trasera del porticado de la plaza, que se elevaba sobre el criptopórtico, fue un edificio público relacionado con la actividad comercial de la ciudad pero alejado de la funcionalidad político-administrativa y religiosa del forum. Abierto a una calle E-O, que comunicaba con una de las puertas de la ciudad, la única vinculación con el centro cívico fue quizás la ubicación de los accesos a la plaza a través de sendas escaleras situada en el lado occidental y oriental del edificio. Esta disposición junto a la entrada de la ciudad facilitaría el transporte y el comercio de los productos alimentarios custodiados a corto y medio plazo en el almacén y destinados al aprovisionamiento de la ciudad.

\section{LA DECORACIÓN ARQUITECTÓNICA DEL FORO. ESTILO Y CRONOLOGÍA}

Durante los trabajos arqueológicos se encontraron caídos y amontonados en el interior del criptopórtico y en la nave más occidental del almacén numerosas basas, fustes, capiteles, cornisas y sillares, junto a algunos fragmentos de estatuaria, zócalos y coronamientos de pedestales de estatua, altares votivos y varias inscripciones. Aparecieron en la posición de caída en la que quedaron tras el colapso y derrumbe del pórtico meridional del foro y del edificio situado en el costado occidental de la plaza (fig. 14). La atribución de todos los fragmentos de decoración arquitectónica a edificios públicos queda confirmada por las proporciones, riqueza decorativa y buena ejecución. La mayoría de las piezas se conservan completas y pertenecen a distintos órdenes arquitectónicos, sobre todo corintio y dórico/toscano, al que se une un capitel de orden compuesto (tab. 1).

Un primer grupo de piezas lo constituyen elementos en orden corintio, que incluyen tanto capiteles de columna como de pilastras (Romero 2018: 206-207, Andreu et al. 2019a). La altura de todos ellos es idéntica, aproximadamente $70 \mathrm{~cm}$, y presentan igual desarrollo de kalathos y ábaco. Asociados al orden de columnas, hay fustes estriados y basas áticas. Asimismo, del orden de pilastras se conservan fustes estriados y basas pertenecientes a este orden arquitectónico. Por su posición de caída en el criptopórtico y uniformidad en cuanto a dimensiones y estilo, debieron de formar parte de la decoración arquitectónica de un edificio ubicado en la zona occidental del foro de Santa Criz de Eslava. Este edificio sería arrastrado total o parcialmente en el momento del colapso del ángulo suroccidental del foro. En cuanto a la cronología de este grupo, los capiteles son de los denominados corintios normales de finales de época republicana y comienzos del Imperio (Romero 2018: 206-207, Andreu et al. 2019a). Las piezas de columna y de pilastra son idénticas estilísticamente. Se caracterizan por la utilización de un acanto simétrico, con sombras de aspecto geométrico en la zona de unión de los lóbulos de hojitas lanceoladas. Los caulículos son rígidos, inclinados y con acanaladuras verticales. Ambas folias de acanto presentan casi idéntica altura, de aproximadamente $16 \mathrm{~cm}$. Las hojas de acanto se encuentran divididas en cinco lóbulos de hojitas que presentan un corte de hoja de época medioaugustea, idéntico al que poseen otros capiteles hispanos, como los de la basílica de Segobriga (Abascal et al. 2004: 250-253, Trunk 2008: 13-21). Su rasgo estilístico más significativo es la presencia de sendas rosetas en las enjutas, como las que se dan en los capiteles corintios del denominado estilo del Segundo Triunvirato (Heilmeyer 1970: 36-42, Pensabene 1973: 207-208, Roth-Congès 1983: 106, Mar et al. 2015: 313-315). Esta tipología con rosetas está presente en Roma entre los años 30-20 a.C., 


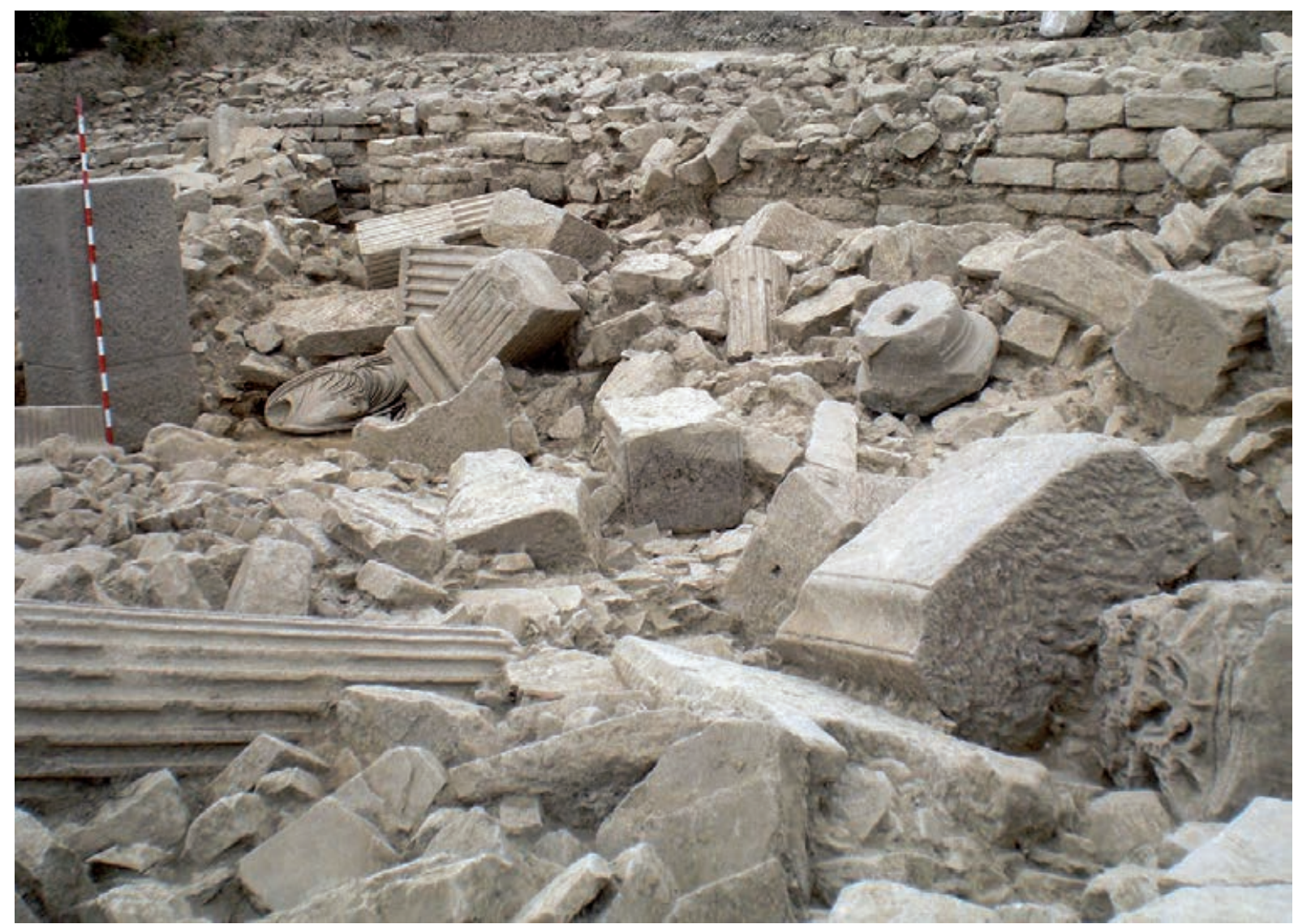

Figura 14. Nivel de derrumbe en el interior del criptopórtico con los restos de una estatua togada y elementos arquitectónicos de la decoración del foro (imagen: R. Mateo).

sobreviviendo en algunos casos hasta el cambio de era. Los ejemplares metropolitanos más cercanos son los del templo de Apolo Capitolino (Heilmeyer 1970: 37). En la Galia, aparecen a partir del 20 a.C. y se convierten casi en exclusivos en la parte occidental del Imperio a partir del 10 a.C., donde sobreviven hasta bien entrado el s. I d.C. (Roth-Congès 1983: 103-134). Este tipo de capiteles son muy frecuentes en Hispania (Gutiérrez Behemerid 1992: 70-72) y en especial en la Tarraconense. Dentro de su ámbito geográfico más cercano, en el conventus Caesaraugustanus, se dan en la propia capital conventual Caesar Augusta (Beltrán Lloris y Paz Peralta 2014: 105), en Osca (Asensio y Justes 2014: 29-42) o en Cara (Gutiérrez Behemerid 1992: 79, $\mathrm{n}^{\mathrm{o}}$ 206-209). Entre las piezas hispanas con rosetas en las enjutas, destacan los citados de la basílica segobrigense, los del teatro de Tarraco o los del templo de Barcino (Domingo et al. 2011: 852-856). En los ejemplares de columna, es significativo el delicado trabajo en tres lados y ausencia de trabajo en la cara posterior, donde la arenisca apenas está desbastada y sin presencia de alisado. La explicación es que el capitel no debía verse en esta zona o su visión debió de ser parcial. Idéntico tratamiento presenta un capitel corintio del pórtico del foro provincial de Tarraco, aunque datado en época adrianea (Mar et al. 2015: 148-149).

Los elementos arquitectónicos se encontraban estucados en tonos ocre. Los restos de estuco se conservan en los capiteles de columna, en los de pilastra y en uno de los fustes de pilastra. En los capiteles de pilastra, el estuco se ha preservado en casi toda la superficie, a excepción de la parte superior derecha de uno de ellos y la parte inferior izquierda del otro ejemplar, al haberse hallado fragmentados. El empleo de estuco en decoración arquitectónica es bastante habitual y se encuentra con bastante profusión en Hispania, sobre todo cuando las piezas están realizadas en piedra arenisca. Buen ejemplo de ello son los capiteles del denominado templo de Diana de Augusta Emerita (De la Barrera 1984: 33-34, no 20, De la Barrera 2000: 23-24) 
Tabla 1. Inventario y ordenación de las piezas de decoración arquitectónica procedentes de las excavaciones realizadas en Santa

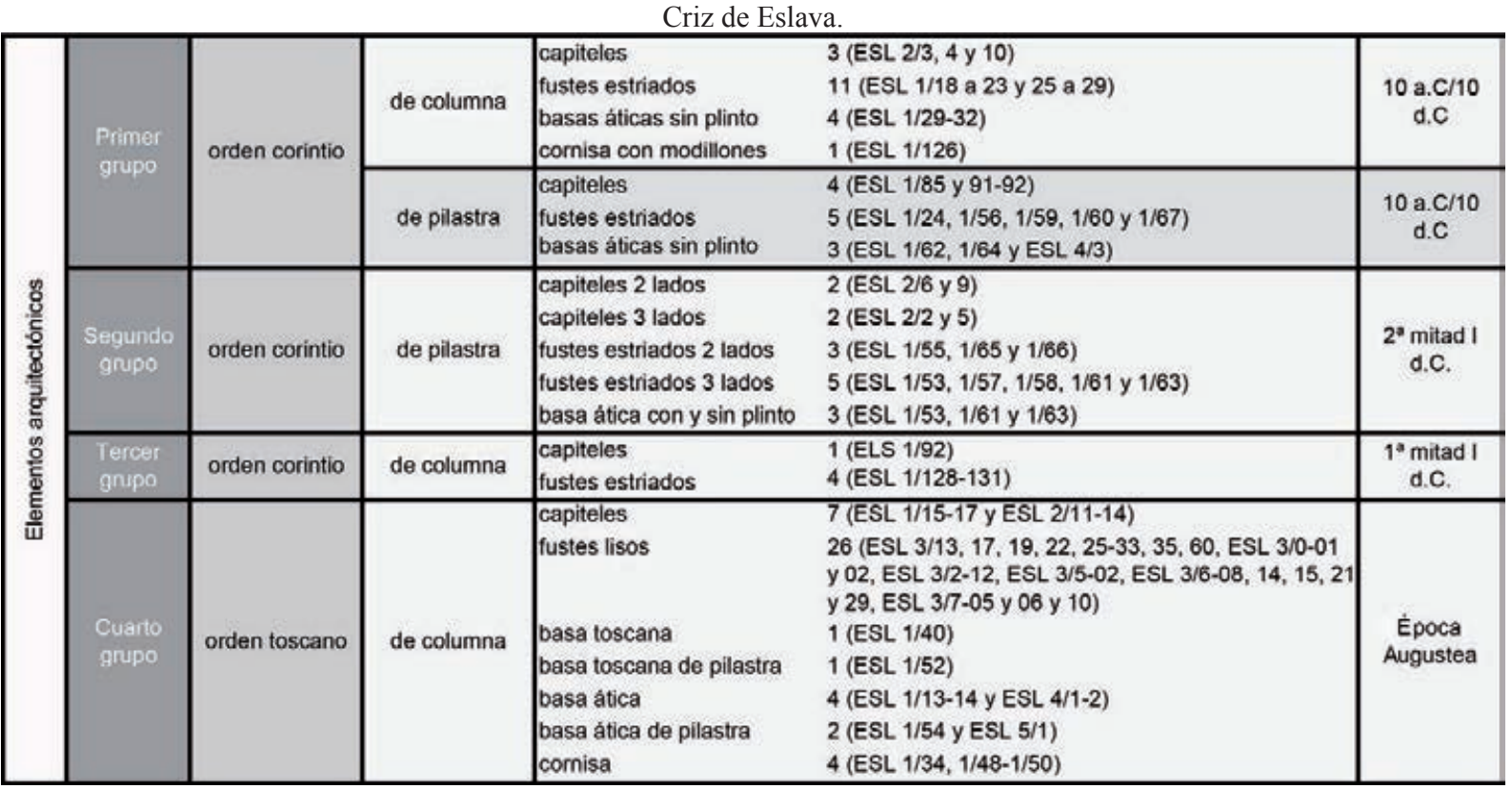

o los del templo de Barcino (Domingo et al. 2011: 851854). El color ocre se empleó para simular el color oro -ya que el pan de oro era costosísimo- y estaba reservado para unas edificaciones muy concretas. Habitualmente, se utilizó para los capiteles de edificios religiosos, como se ha constatado en Hispania en el templo de culto imperial del forum novum de Corduba (Portillo 2016: 28-33) o en algunos edificios forenses, como es el caso de la basílica del cercano foro de Los Bañales de Uncastillo (Romero 2017: 126-127). En los capiteles de columna, la presencia de estuco es mucho más escasa, conservándose sobre todo en las zonas de las hojas de acanto. La idéntica altura que las piezas anteriores, unida al citado tratamiento de estucado en tonos amarillentos, parece apuntar a que los cinco capiteles y los fustes de columna y basas asociables a ellos pertenecieron a un mismo edificio, datado en época augustea (fig. 15).

El segundo grupo lo constituye un orden arquitectónico corintio de pilastra trabajados por dos y tres lados. Se han conservado dos capiteles del orden corintio de pilastra con labra por dos lados y otros dos trabajados por tres caras. Asociados al orden de pilastra con labra por dos lados existe una serie de fustes estriados, con esquema idéntico de cuatro acanaladuras y cinco listeles, de $43 \mathrm{~cm}$ de anchura.

Al orden trabajado por tres lados puede vincularse una serie de fustes, que miden entre 45 y $53 \mathrm{~cm}$, algunos de ellos con basa ática sin plinto en la misma pieza. Su desarrollo es también igual, con cuatro acanaladuras y cinco listeles. Los capiteles presentan características estilísticas similares, aunque con algunas diferencias. Además, poseen dimensiones diversas que oscilan entre alturas de $49 \mathrm{~cm}$ y $69 \mathrm{~cm}$. Las hojas de acanto son bastante extendidas, cortas y muy pegadas al cuerpo del capitel excepto el borde superior de cada una de ellas. Estas hojas poseen lóbulos de cuatro y cinco hojitas lanceoladas que acaban con un perfil redondeado y con zonas de sombra en forma triangular. Las volutas y las hélices, presentan forma de cinta y están recorridas por una incisión. Los caulículos son casi rectos, aunque con una ligera inclinación hacia los lados, a diferencia de los ejemplares del estilo del Segundo Triunvirato, cuya inclinación es más acusada. Presentan diferencias en los calículos en función del ejemplar, con estrías verticales -la gran mayoría de ellas- y algunas oblicuas. La tendencia vertical de los caulículos, empieza a darse a partir de época julioclaudia, aunque en algunas ciudades se mantiene la inclinación hacia los lados del periodo augusteo. En la Tarraconense se conservan bastantes ejemplos, entre los que sobresalen los casos de las termas públicas de Tarraco o algunas piezas de Barcino (Domingo 2005: 51-56). Presentan una altura de las coronas de aproximadamente la mitad de altura del capitel, aspecto este observado desde 


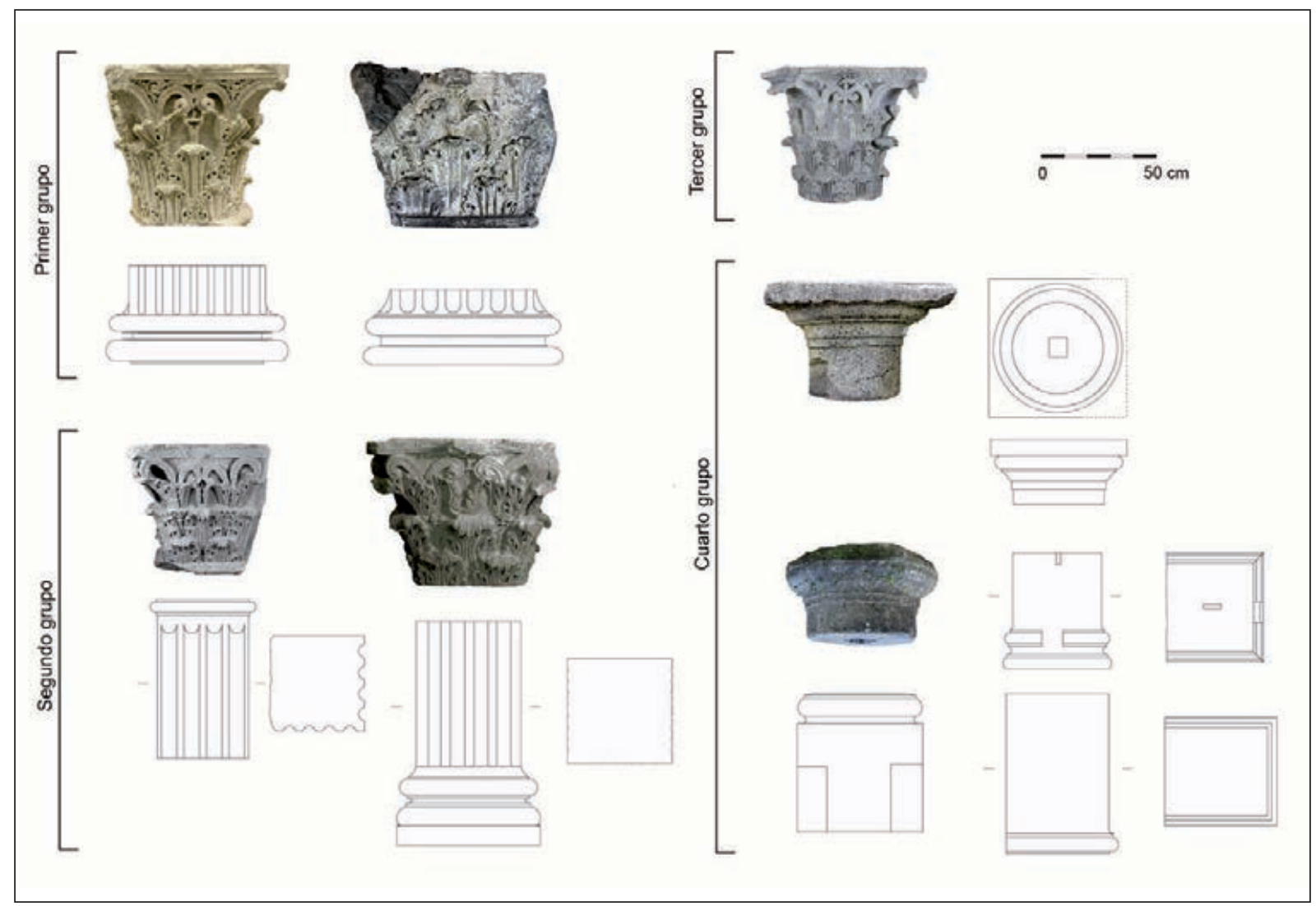

Figura 15. Conjunto de elementos arquitectónicos y dimensiones hallados en la excavación de Santa Criz de Eslava (fotografías: L. Romero, dibujos: I. Diéguez, montaje: R. Cebrián).

época julioclaudia hasta finales del s. I d.C. (Gutiérrez Behemerid: 1992, 132). Se advierte sobrecarga ornamental de las piezas que lleva a decorar casi toda la superficie disponible, a excepción de una pequeña zona entre el cáliz de la flor del ábaco y los calículos y cálices. Sin embargo, no llega al barroquismo de ciertos ejemplares datados en época flavia (Gutiérrez Behemerid 2004: 281 y 286). Este ciclo de capiteles se caracteriza por la enorme tosquedad en la ejecución, la presencia de asimetrías e importantes errores de cálculo a la hora de ejecutar el modelo en el que se inspiraron. Este aspecto parece indicar que fueron elaborados por un taller claramente provincial entre finales de época julioclaudia y flavia.

La ausencia de excavaciones en la plataforma superior al criptopórtico, donde previsiblemente se situó la plaza del foro rodeada de pórticos y de los edificios religiosos y administrativos de la ciudad, impide conocer con certeza la ubicación concreta de las piezas de decoración arquitectónica de estos dos grupos. La posición de caída y, sobre todo, la combinación de un orden corintio idéntico, de columnas exentas y pilastras ambas estucadas, de la serie asignada al primer grupo permite plantear la hipótesis de su adscripción a la basílica jurídica, edificada en época augustea en el costado occidental de la plaza forense. Los elementos exentos formarían parte de la peristasis columnada y las piezas de pilastra pudieron decorar la pared del fondo de la basílica. Para el segundo grupo es posible sugerir una ubicación en la fachada de la basílica, donde no existiría un pórtico hacia la plaza sino un sistema de puertas en arco decoradas por pilastras.

Un tercer grupo lo constituye un orden corintio de columna de fuste mucho más pequeño que el atestiguado en el primer conjunto de elementos arquitectónicos, para el que de momento no contamos con una propuesta de situación. Está compuesto por un capitel de columna, con un diámetro de sumoscapo de 34 $\mathrm{cm}$ y fustes estriados vinculables conservados en el derrumbe ubicado en la nave más occidental del almacén. El capitel de columna se encuentra trabajado por todos sus lados -a diferencia de los del estilo del Segundo 
Triunvirato- y se ha preservado en muy buen estado de conservación. Ha sido limpiado y restaurado durante el año 2018. Su característica técnica más llamativa es la tendencia vertical del caulículo a diferencia de los otros capiteles corintios que presentan inclinación hacia los lados. Este aspecto se da desde época julioclaudia, aunque hay piezas que mantienen la tendencia hacia los lados del mismo. En las hojas de acanto, las hojitas siguen la tradición de los capiteles del estilo del Segundo Triunvirato, sin presentar formas más redondeadas, típicas de cronología julioclaudia, como ocurre en los capiteles del segundo grupo. Destaca la gran profundidad de los surcos de las nervaduras centrales de los acantos, aspecto también propio de ejemplares vinculables a época julioclaudia. Por tanto, el capitel puede datarse en época de Tiberio-Claudio, en con base a en la continuación de ciertos rasgos estilísticos de los capiteles del estilo del Segundo Triunvirato y en la presencia de elementos propios de época julioclaudia, como la tendencia más vertical del caulículo o los profundos surcos presentes en las nervaduras centrales de las hojas de acanto. También hacia esta cronología apunta la proporción de las folias de acanto, aún muy inferior a la mitad de la altura del capitel, y solo superada a partir de finales del s. I d.C.

El cuarto grupo lo compone una serie de elementos en orden dórico/toscano con abundantes piezas. Los capiteles toscanos forman un conjunto de siete ejemplares en el que se pueden distinguir dos grupos teniendo en cuenta su diámetro. Todos ellos se caracterizan por la misma secuencia de elementos decorativos. Las medidas del ábaco oscilan entre 60 y $70 \mathrm{~cm}$ de lado y un espesor de $10 \mathrm{~cm}$. El diámetro de sumoscapo es de 40 y $49 \mathrm{~cm}$. Los fustes de estos capiteles son lisos, habiéndose documentado una serie de veintiséis con diámetros que oscilan entre los 40 y los $55 \mathrm{~cm}$. Al mismo grupo se vincula una basa toscana con diámetro en el imoscapo de $46 \mathrm{~cm}$ y quizás cuatro basas áticas.

Por la enorme cantidad de piezas y la existencia de abundantes fustes lisos, parece lógico plantear que ambas hileras del pórtico meridional del foro emplearon este tipo de columna. Más problemático es el tipo de orden utilizado en la primera galería del pórtico. Por los elementos conservados es posible plantear que se realizó en orden toscano provincial a partir del hallazgo de cuatro basas áticas -de 46-47 cm de diámetro- con fustes lisos, en la excavación del criptopórtico. Se asocian al orden toscano provincial al no presentar plinto, un toro inferior más grande que el superior y escocias de tamaño medio, con perfiles de sección cóncava semicircular entre dos listeles. La singularidad del orden toscano en la zona vascona era ya conocida por otro capitel de desarrollo muy alejado de los cánones, localizado en el criptopórtico del foro de Los Bañales de Uncastillo (Romero 2017: 117-118, n 1). El orden toscano provincial con basas áticas sin plinto nos proporciona una cronología en la segunda mitad del s. I a.C e inicios del Principado, a partir de los ejemplos en otras ciudades hispanas, como en Carthago Nova (Noguera y Madrid 2013: 237) o en la basílica del foro de Los Bañales en un programa datado en época augustea temprana (Romero 2017: 127-128). Sin embargo, también es plausible plantear que la galería exterior se realizó en orden dórico y que las basas áticas corresponden a otro edificio sin identificar del foro de Santa Criz de Eslava. A este mismo grupo se adscribe una basa de pilastra toscana y, al menos, otras dos basas de pilastras áticas, cuya posición original queda incierta.

El empleo del orden toscano en los pórticos es muy habitual desde épocas tempranas en la península itálica, como en el foro de Cosa (Brown et al. 1993: 122, Etxebarria 2008: 138) o ya en época imperial en los de Rusellae (Dell'Acqua 2012: 21-34), Sassina (Ortalli 1995: 278-279) o Scolacium (Donzelli 1991: 489). Los capiteles no siguen ninguno de los tipos propuestos por P. Broise (1969: 17-20), aunque su desarrollo es parecido al modelo AC, si bien en el caso de los capiteles de Santa Criz el sumoscapo tiene un tratamiento diferente. Tienen por tanto una estructura de ábaco + equino en arco de círculo + caveto + collarino liso. Los ejemplares del tipo AC se atestiguan frecuentemente en la Galia, como por ejemplo en el gran pórtico de la Villasse de Vaison-la-Romaine, la casa des Antes y la casa d'Atys de Glanum (Broise 1969: 20). En Hispania, hay ejemplares del tipo AC en $T a-$ rraco (Gimeno 1989: 117-118) o Saguntum (Chiner 1990: 77-78). Idéntico desarrollo, con sumoscapo similar al de los capiteles de Santa Criz de Eslava, se da en una pieza en orden toscano de Barcino que ha sido interpretada como una basa (Gimeno 1991: 62-63, $\mathrm{n}^{\circ}$ 9; Escrivà 2005: 17-18, n ${ }^{\circ} 7$ ). Las piezas también son parecidas al tipo BC de P. Broise (1969: 17-20), aunque en esta tipología el equino no es de arco de círculo.

El empleo del orden dórico en los pórticos forenses es también muy frecuente en la arquitectura romana desde fechas muy tempranas, con ejemplos en los foros de Minturnae, Praeneste o Pompeya (Etxebarria 2008: 136-138). En época imperial se continuó usando con bastante frecuencia en los foros itálicos, caso de Luni (Rossignani 1995: 464) o de Assisi (Sisani 2006: 100-101). Su uso en los fora hispanos es también muy 
habitual y se encuentra desde época tardorrepublicana en los pórticos del foro de Emporiae (Gimeno 1989: 107-112) e inicios de época augustea en Segobriga (Abascal et al. 2007: 387).

La serie de piezas de cornisas que puede asociarse al pórtico meridional del foro de Santa Criz presenta un estilo arcaico, en ellas se ha tallado una faja seguida de una cyma recta entre dos listeles en la parte alta de un paralelepípedo. Una de ellas corresponde a una pieza angular, que pudo situarse en la esquina occidental del pórtico.

\section{LA AMORTIZACIÓN DEL ALMACÉN PÚBLICO Y EL REFUERZO DEL CRIPTOPÓRTICO}

La interpretación del conjunto excavado en Santa Criz determinó dos fases de reformas consecutivas entre la segunda mitad del siglo I d.C. (fase II) y primera mitad del siglo II d.C. (fase III). Los lienzos de la fase original (fase I) se distinguen por estar construidos en opus vittatum, de hiladas horizontales y bien aparejadas, mientras los de la fase II y III presentan tongadas de diferentes alturas, en ocasiones inclinadas, y la inserción de lajas en casi todas las filas. La fase II quedó individualizada por la elevación de nuevos pilares de refuerzo en el muro sur del criptopórtico y en los muros de las naves longitudinales situadas en los extremos del almacén. La fase III, por la construcción de entrepaños entre aquellos pilares y el apuntalamiento del lienzo de la muralla republicana, y el cierre meridional del criptopórtico resuelto por contrafuertes (Armendáriz et al. 2016: 250-251).

Esta explicación partía de la transformación del almacén en una plaza rodeada de un pórtico en forma de $\mathrm{U}$ abierta hacia el sur y el consiguiente uso del criptopórtico, que conllevó el desmontaje de los muros de las naves y la sobreelevación de la cota de circulación tanto en el almacén como en el interior del criptopórtico (fase II). En la fase III se produciría la amortización de este pórtico, que no impediría la continuidad del uso del espacio como plaza limitada ahora por un deambulacro perimetral.

En realidad, esta lectura plantea serias dudas difíciles de aceptar desde el punto de vista constructivo, relativas, sobre todo, a la situación en la que quedaría el pórtico meridional del foro. La propuesta es incompatible con la permanencia de este pórtico al desaparecer el elemento estructural GEM 4, que permitiría el apoyo del forjado.
A partir de aquí la búsqueda de una explicación más verosímil nos lleva a plantear la siguiente hipótesis. La reestructuración del espacio supuso la demolición del almacén público. Su desaparición en el marco de una reforma es segura por la ausencia de derrumbes, el desmontaje de los muros hasta alcanzar una misma cota y la existencia de un vertido de nivelación (UE 786=787), cuya finalidad fue sobreelevar la cota de circulación por encima de estos muros. Esta sobreelevación también afectó al interior del criptopórtico (UE 65), ahora transitable con la apertura en el muro meridional de dos puertas en los extremos este y oeste.

La demolición del almacén generó un problema estructural grave en el criptopórtico al perder la construcción que le servía de apoyo. Así es posible imaginar que el muro meridional comenzó a vencerse hacia el exterior, obligando a acometer obras de refuerzo. Los trabajos de saneado de este muro debieron obligar a su desmontaje hasta el nivel donde se encontrara sin afecciones, lo que queda evidenciado en las diferentes alturas mantenidas a lo largo de su traza. A partir de aquí se reconstruyó con los mismos sillarejos empleando una fábrica similar pero de peor factura, en la que se introdujeron elementos verticales de refuerzo semejantes a los originales. Estos nuevos pilares se cimentaron sobre el degollado muro original GEM 4. Algunos de los sillares que conformaron estos pilares presentan entalladuras para el encaje de las vigas del forjado, que ya hemos descrito. Ello demostraría que aun cuando parte de este forjado pudo desmantelarse durante las obras, fue repuesto simultáneamente (fig. 16).

También se instalaron nuevos pilares sobre los muros de las naves situadas en el extremo oriental y occidental del almacén, convertidas ahora en los pasillos de acceso al interior del criptopórtico. Los cuatro sillares conservados en uno de los machones del lado oeste presentan marcas epigráficas en la parte superior e inferior de la misma cara, que sirvieron para indicar a los operarios la colocación exacta de las piezas. La coincidencia entre el numeral tallado en la parte superior del sillar y el de la parte inferior del siguiente sugiere esta idea (Andreu et al. 2019b: 32-35, n 4). A pesar de la ejecución de los trabajos de refuerzo, los problemas estructurales persistieron. La solución adoptada pasó por la construcción de contrafuertes en el interior del criptopórtico, que aseguraron su muro meridional, uno de los pilares internos y la muralla.

El foro acabaría derrumbándose a lo largo del siglo III d.C. debido a un fallo estructural perceptible en el costado noroccidental del criptopórtico, donde se observa que el lienzo exterior de la muralla se encuentra 


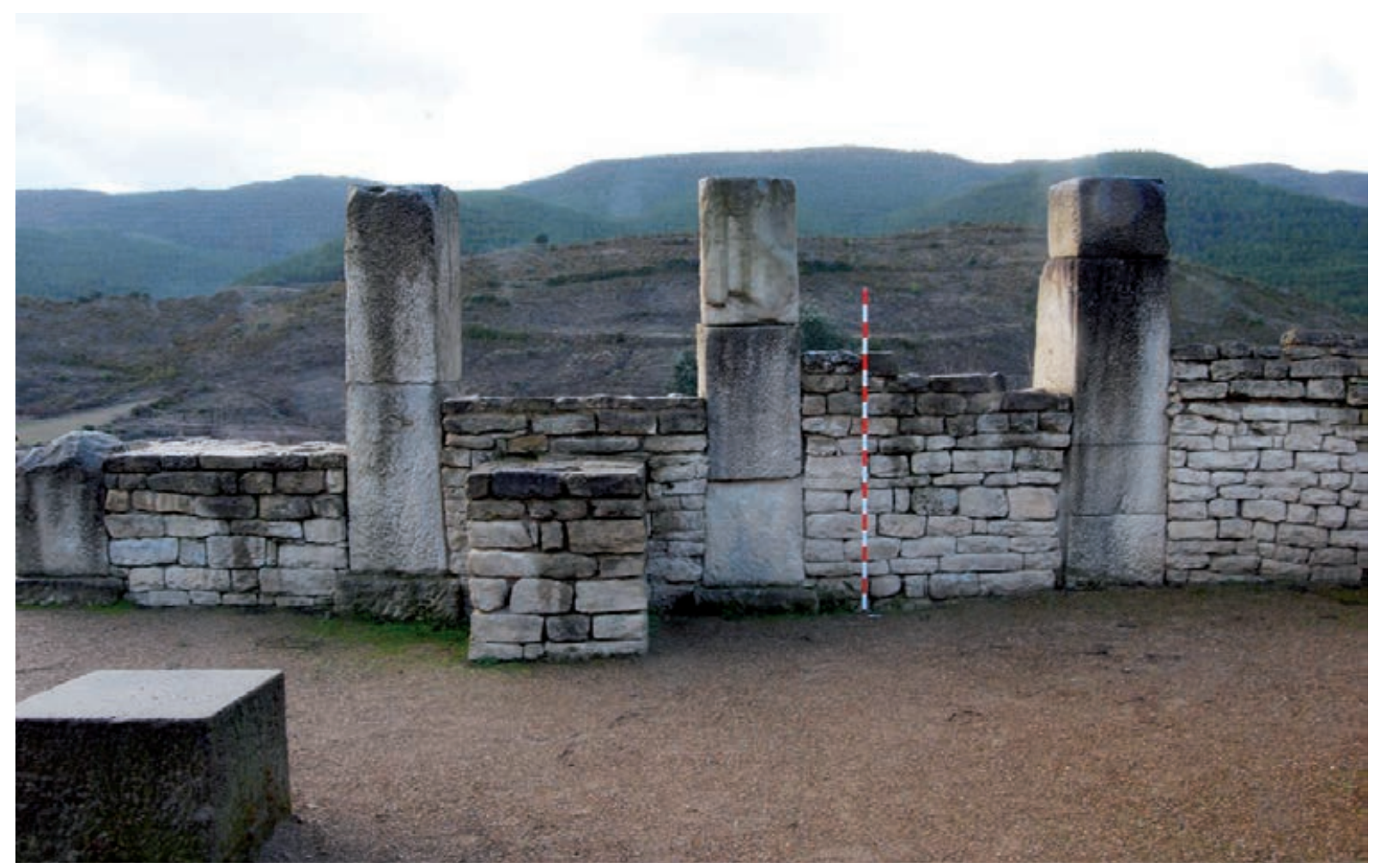

Figura 16. Estado en el que quedó el muro GEM 4 tras la reforma, visto desde el interior del criptopórtico (imagen: R. Cebrián).

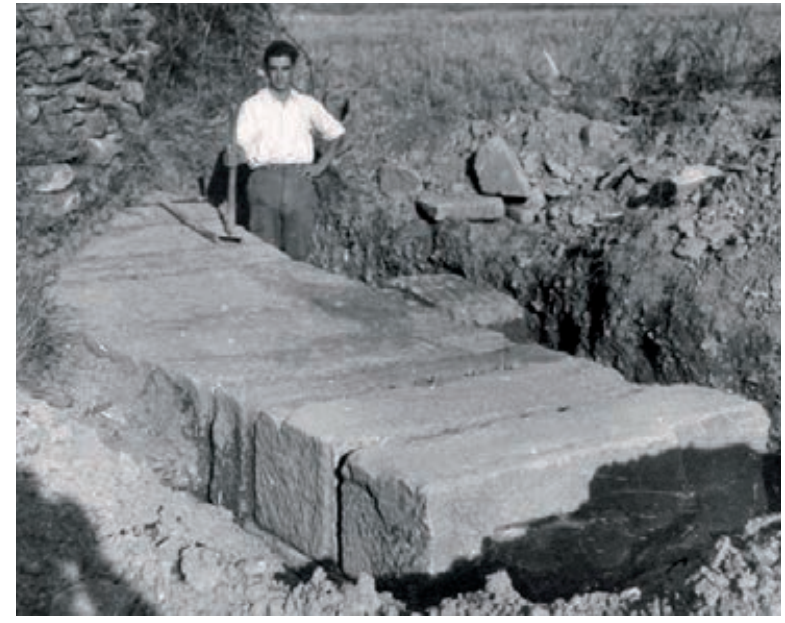

Figura 17. Fotografía del basamento de sillares hallado por B. Taracena y L. Vázquez de Parga en 1944 (imagen: Archivo de la Institución Príncipe de Viana, Gobierno de Navarra).

desplomado hacia el interior de la subestructura. Posiblemente cedió por empujes del terreno, afectando al edificio situado en el lado occidental de la plaza y al pórtico meridional, que provocarían su destrucción.

\section{A MODO DE RECAPITULACIÓN. PROPUESTA INTERPRETATIVA DEL CENTRO CÍVICO DE SANTA CRIZ}

Los hallazgos arqueológicos en Santa Criz corresponden a una pequeña parte de su centro monumental. El proyecto de investigación actualmente en marcha prevé la excavación sistemática del conjunto forense en los próximos años, que determinará su arquitectura y fases constructivas, por lo que plantear una hipótesis reconstructiva parece de momento aventurado aun cuando se puede esbozar una propuesta interpretativa inicial.

El descubrimiento en 1944 de un basamento con sillares dispuestos a tizón al norte del espacio excavado confirma la existencia de edificios públicos situados en torno a la plaza del foro (fig. 17). Aunque desconocemos el lugar exacto donde se encontró, a unos $22 \mathrm{~m}$ del límite septentrional del criptopórtico y en su franja oriental se localiza semienterrado un sillar de 1,54 m de longitud, que podría formar parte de este podium. Esta obra de sillería podría identificarse con el basamento de un templo que presidiría la plaza por su lado oriental.

En el límite sur del foro se sitúa el criptopórtico destinado a sostener uno de los pórticos de la plaza. 


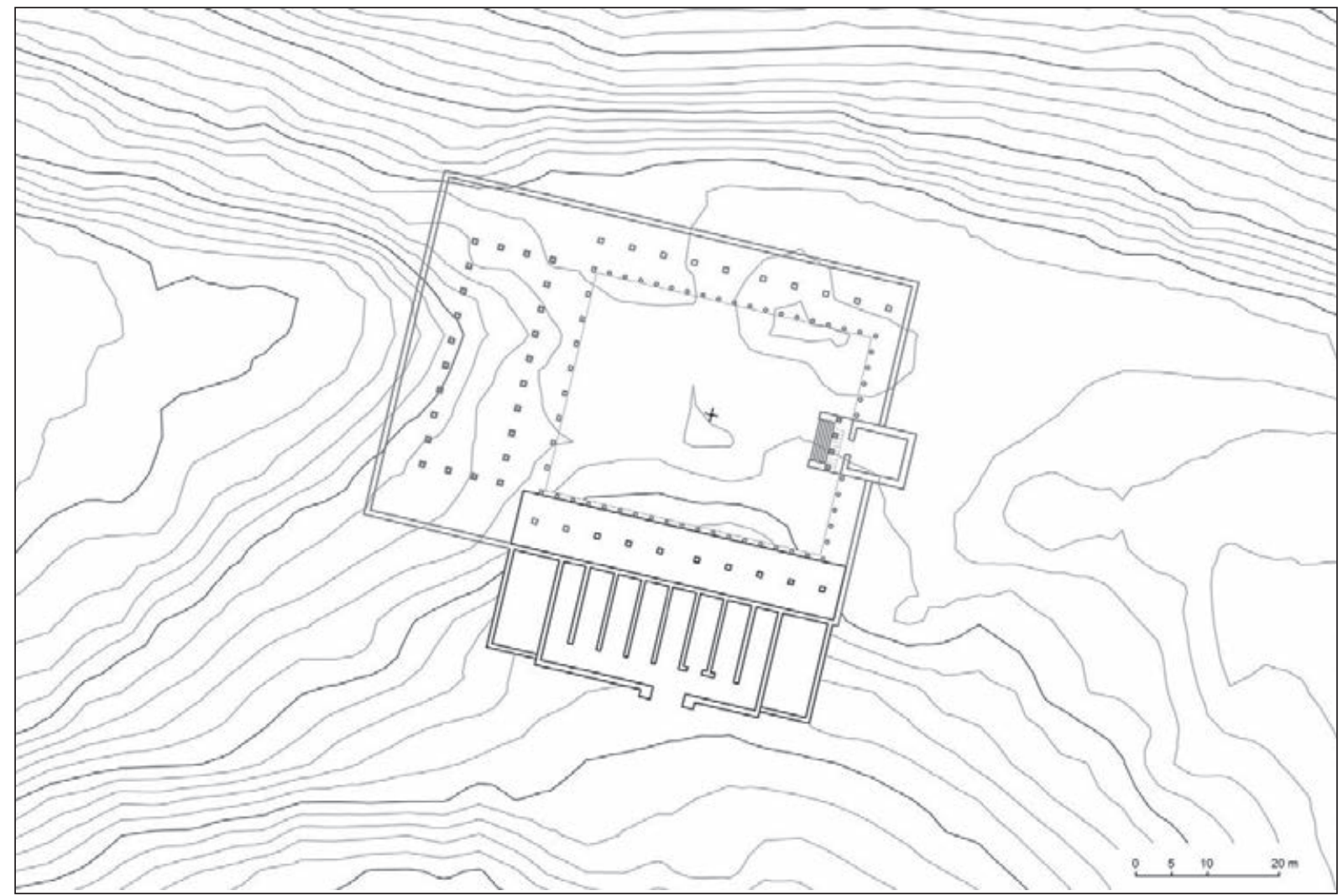

Figura 18. Propuesta interpretativa de la implantación del foro de Santa Criz en la orografía del cerro de Santa Criz (imagen: R. Cebrián).

Con una longitud máxima de 47,90 m -aproximadamente 161 pies-y una anchura de $8,19 \mathrm{~m}$, configuró una doble galería porticada al nivel de la plaza con columnas de orden dórico/toscano de aproximadamente 3,35 $\mathrm{m}$ de alto. La longitud del criptopórtico nos ofrece la extensión de uno de los lados de la plaza forense, que alcanzaría los 40,50 $\mathrm{m}$ al restar la anchura equivalente a los posibles pórticos este y oeste, que conjeturamos serían de una única nave. La presencia de una cornisa de esquina del orden dórico/toscano en el derrumbe del interior del criptopórtico asegura la presencia de un pórtico al menos por su lado occidental.

Frente a la ubicación teórica del templo se situaría la basilica forensis ocupando todo el costado occidental de la plaza, lo que explicaría que los elementos de su decoración aparecieran caídos y amontonados no solo en el extremo oeste del criptopórtico sino también en la posible caja de escalera de acceso a la plaza y en la nave más occidental del almacén. A su decoración arquitectónica se adscriben las basas, fustes y capiteles pertenecientes al orden corintio hallados en la excavación de los niveles de derrumbe. La mayor parte de las piezas constituye un conjunto homogéneo que corresponde a columnas de 5,90 m de altura. Al mismo sistema decorativo pertenecen las basas áticas, fustes y capiteles corintios de pilastra (primer grupo) y quizás también un fragmento moldurado, que permanece semienterrado en el nivel de derrumbe en el interior del criptopórtico, que podría corresponder a una cornisa con modillones.

El proyecto arquitectónico del foro debió seguir el módulo detectado en la construcción del criptopórtico y almacén. La porticus duplex que rodeó la plaza por el sur midió 27 pies de anchura, que equivaldría a 1 módulo de aproximadamente $8 \mathrm{~m}$. A partir de esta medida, y tomando en consideración la posible posición del templo, resulta una plaza de 5 x 4 módulos (en torno a $40 \times 48 \mathrm{~m}$ ), en cuyo eje central se situaría un templum, con fachada de 1 módulo, en el lado este y la basilica al oeste, de 6 x 3 módulos (aproximadamente 48 x $24 \mathrm{~m}$ ). Otra porticus duplex cerraría el conjunto por el lado septentrional. Su construcción tuvo que ceñirse al espacio disponible en la parte media del cerro, cuya longitud no supera los $75 \mathrm{~m}$ en dirección $\mathrm{N}-\mathrm{S}$, de manera que al situar el diseño propuesto sobre 
la planimetría y los restos excavados comprobamos que queda englobado en el terreno llano (fig. 18).

El esquema adoptado en el foro de Santa Criz respondería así a un modelo arquitectónico muy difundido por todas las regiones del Imperio a partir de época augustea, donde un templo se alzaría en uno de los lados cortos de la plaza y en el opuesto se situaría la basílica (Ward-Perkins 1970, Gros 1996: 207-234). Los restos de estatuas y pedestales (Andreu et al. 2019b: 24-27, n 1 y $27-28, n^{\circ} 2$, probable) procedentes del estrato de derrumbe confirman que a lo largo de la vida del forum se fueron erigiendo estatuas para honrar a los nuevos magistrados o miembros de la familia imperial. El número de zócalos y coronamientos moldurados recuperados es de siete, dos de los cuales corresponden a estatuas ecuestres (Andreu et al. 2019b: 35-37, nº 5-6). Del mismo derrumbe proceden algunas inscripciones, una de ellas es el dado de un pedestal en el que se menciona al evergeta L. Aurelius Ursinus (Andreu et al. 2019b: 24-27, n 1), el cual por legado testamentario levantó acaso una estatua en honor a una divinidad. Una estatua togada, otra tipo Hüftmantel y algunas hojas de laurel de estatuas broncíneas atestiguan el programa estatuario erigido en honor de un emperador o miembros relevantes de la familia julioclaudia y las vincula al culto imperial (Andreu et al. 2019a: 47-49 y Romero 2018: 209). Por último, dos fragmentos de pulvini prueban la existencia de altares dedicados a diversas divinidades embelleciendo el conjunto forense (Andreu et al. 2019b: 37-40, $\mathrm{n}^{\circ}$ 6, 7 y 8).

Las hipótesis de ubicación de los edificios en torno a la plaza pública se solucionarán con las futuras excavaciones, que ayudarán a resolver los problemas históricos del origen, la temprana monumentalización, la promoción jurídica y el declive de este enclave del ámbito vascón. No obstante las excavaciones arqueológicas realizadas hasta la fecha permiten incluir a la civitas en la lista de enclaves hispanorromanos que construyeron su centro cívico en época augustea. A pesar de ello todavía en Santa Criz queda un forum por descubrir.

\section{Agradecimientos}

Apoyos recibidos para la realización del estudio: Proyecto de investigación financiado en el marco del Convenio de Colaboración entre la UNED de Pamplona, La Fundación Caja Navarra y la Obra Social La Caixa en el marco de las “Ayudas a la Investigación de 2018”. Convenio de colaboración suscrito entre el Ayuntamiento de Eslava y la Universidad de Navarra de cara a la dinamización cultural e investigadora del yacimiento.

\section{BIBLIOGRAFÍA}

Abascal, J. M.; Almagro-Gorbea, M. y Cebrián, R. (2007): "Parque Arqueológico de Segobriga. Últimos descubrimientos", en J. M. Millán y C. Rodríguez (coord.), Arqueología de Castilla-La Mancha: Actas de las I Jornadas: 385-398. Cuenca (2005), Cuenca, Universidad de Castilla-La Mancha.

Abascal, J. M.; Cebrián, R. y Trunk, M. (2004): “Epigrafía, arquitectura y decoración arquitectónica del foro de Segobriga", en S. F. Ramallo (ed.), La decoración arquitectónica en las ciudades romanas de Occidente: 219-256. Cartagena (2003), Murcia, Universidad de Murcia.

Adam, J.-P. (1989): La construction romaine. Matériaux et techniques. París, Picard.

Alarcão, J. de y Etienne, R. (1973): “L'architecture des cryptoportiques de Conimbriga (Portugal)", en Les cryptoportiques dans l'architecture romaine. Actes du Colloque de Roma: 371-405. Roma (1972), París, École Française de Rome.

Amy, R. (1973): “Les cryptoportiques d'Arles", en Les cryptoportiques dans l'architecture romaine. Actes du Colloque de Roma: 275-291. Roma (1972), París, École Française de Rome.

Andreau, J. (2007): "Conclusions du dossier. Pour l'étude des entrepôts antiques". Antiquités africaines 43: 261-264. <https://doi.org/10.3406/antaf.2007.1429>.

Andreu, J. (2006): "Ciudad y territorio en el solar de los vascones en época romana”, en J. Andreu (ed.), Navarra en la Antigüedad. Propuesta de actualización: 179-228. Pamplona, Gobierno de Navarra.

Andreu, J. (2010): "Un dispensator publicus en territorio vascón. A propósito de AE, 1971, 199 de Eslava (Navarra)", en Classica boliviana. Actas del IV Encuentro Boliviano de Estudios Clásicos: 177-190. La Paz (2010), Cochabamba, Sociedad Boliviana de Estudios Clásicos.

Andreu, J. (2011): "La ciudad romana de Los Bañales (Uncastillo, Zaragoza) en las fuentes históricas". Caesaraugusta 82: 19-100.

Andreu, J. (2017): "El territorio vascón y sus ciudades en la era de Augusto". Gerión 35: 551-569. <https:// doi.org/10.5209/GERI.56163>.

Andreu, J. (2018): "El hábito epigráfico entre los Vascones antiguos: Santa Criz de Eslava como paradigma". Príncipe de Viana 272: 1007-1027.

Andreu, J.; Armendáriz, J.; Ozcáriz, P.; García-Barberena, M. y Jordán, Á. A. (2008): "Una ciudad de los Vascones en el yacimiento de Campo Real/ 
Fillera (Sos del Rey Católico-Sangüesa)". Archivo Español de Arqueología 81: 71-100. <https://doi. org/10.3989/aespa.2008.v81.41>.

Andreu, J. y Armendáriz, J. (2018): “La vía romana de la Navarra Media entre las ciuitates de Campo Real/ Fillera de Sos del Rey Católico (Zaragoza) y Santa Criz de Eslava (Navarra): a propósito de un nuevo miliario procedente de Gabarderal", en R. Torres (ed.), Studium, magisterium et amicitia. Homenaje al profesor Agustín González Enciso: 41-48. Pamplona, Eunate Ediciones.

Andreu, J.; Delage, I.; Romero, L. y Mateo, Tx. (2019a): Santa Criz de Eslava, reflejos de Roma en territorio vascón. Pamplona, Servicio de Patrimonio Histórico del Gobierno de Navarra.

Andreu, J.; Ozcáriz, P. y Mateo, Tx. (2019b): Epigrafía romana de Santa Criz de Eslava (Eslava, Navarra). Faenza, Fratelli Lega Editori.

Aquilué, X.; Mar, R.; Nolla, J. M.; Ruiz de Arbulo, J. y Sanmartí, E. (1984): El Fòrum romà d'Empúries: (excavacions de l'any 1982): una aproximació arqueològica al procés històric de la romanització al nord-est de la Península Ibèrica. Barcelona, Diputació de Barcelona, Institut de Prehistòria i Arqueologia.

Aquilué, X.; Castanyer, P.; Santos, M. y Tremoleda, J. (2001): Empúries. Guides du Museu d'Arqueologia de Catalunya. Barcelona. Museu d'Arqueologia de Catalunya.

Armendáriz, J. (2008): De aldeas a ciudades. El poblamiento durante el primer milenio a. C. Navarra, Gobierno de Navarra.

Armendáriz, R. M ; Mateo, Mª R. y Sáez de Albéniz, $M^{a}$ P. (1996): "Primera campaña de excavación en el yacimiento de Santa Criz (Eslava, Navarra)". Trabajos de Arqueología de Navarra 12: 322-326.

Armendáriz, R. M ${ }^{\mathrm{a}}$; Sáez de Albéniz, $\mathrm{M}^{\mathrm{a}}$ P. y Mateo, $\mathrm{M}^{\mathrm{a}}$ R. (1997): "Prospección del término municipal de Eslava". Isturitz 7: 145-163.

Armendáriz, R. M M $^{\mathrm{a}}$ Mateo, M ${ }^{\mathrm{a}}$ R. y Sáez de Albéniz, $M^{a}$ P. (2007): "La necrópolis de Santa Criz (Eslava)", en La tierra te sea leve. Arqueología de la muerte en Navarra: 149-155. Pamplona, Gobierno de Navarra.

Armendáriz, R. Mª Sáez de Albéniz, Mª P. y Diéguez, I. (2016): "Aproximación al paisaje urbano del yacimiento arqueológico de Santa Criz (Eslava)". Trabajos de Arqueología Navarra 28: 245-285.

Asensio, J. A. y Justes, J. (2014): "Nuevos datos acerca de la arquitectura y el urbanismo en el Municipium Osca. Arquitectura pública y privada en el sector sureste de la ciudad. El entorno del teatro". Bolskan 25: $15-50$.

Astolfi, F. (1996): "Horrea Agrippiana", en E.M. Steinby (dir.), Lexicon topographicum urbis Romae, III: 37-38. Roma, Quasar.

Beltrán Lloris, F. (2017): “Augusto y el valle medio del Ebro". Gerión 35: 525-540. <https://doi. org/10.5209/GERI.56160>.

Beltrán Lloris, M. (1982): La arqueología de Zaragoza. Últimas investigaciones. Zaragoza, Ministerio de Cultura-Excmo. Ayuntamiento de Zaragoza.

Beltrán Lloris, M. y Paz Peralta, J. A. (2014): Augustus: annus Augusti MMXIV. Zaragoza, Museo de Zaragoza.

Broise, P. (1969): “Éléments d'un ordre toscan provincial en Haute-Savoie". Gallia 27: 15-22. <https:// doi.org/10.3406/galia.1969.2516>.

Brown, F. E. (1979): Cosa. The Making of a Roman Town. Ann Arbor, University of Michigan Press.

Brown, F. E.; Richardson, E. H. y Richardson Jr. L. (1993): Cosa III: the buildings of the forum. Colony, municipium and village. Roma, American Academy in Rome.

Castiella, A. (2003): Por los caminos romanos de $\mathrm{Na}$ varra. Pamplona, Fundación Caja Navarra.

Chiner, P. (1990): La decoración arquitectónica en Saguntum. Valencia, Generalitat Valenciana.

Coarelli, F. (1982): Lazio. Guide archeologiche Laterza. Roma-Bari, Gius. Laterza\&Figli Spa.

De la Barrera, J. L. (1984): Los capiteles romanos de Mérida. Mérida, Museo Nacional de Arte Romano.

De la Barrera, J. L. (2000): La decoración arquitectónica de los foros de Augusta Emerita. Roma, L'Erma di Bretschneider.

Dell'Acqua, A. (2012): "Un capitello tuscanico da Ruselle”. LANX. Rivista della Scuola di Specializzazione in Archeologia - Università degli Studi di Milano 11: 21-34 <https://doi.org/10.13130/20354797/2411>.

Domingo, J. A. (2005): Capitells corintis a la provincia Tarraconense (s. I-III d.C.). Tarragona, Arola Editors y Ajuntament de Tarragona.

Domingo, J. A.; Garrido, A. y Mar, R. (2011): "Talleres y modelos decorativos en la arquitectura pública del noreste de la tarraconense en torno al cambio de era", en T. Nogales e I. Rodà (eds), Roma y las provincias: modelo y difusión. XI coloquio internacional de arte romano provincial: 851-862. Mérida (2009), Roma, L'Erma di Bretschneider.

Donzelli C. (1991): "Le strutture tardoantiche di Scolacium". Mélanges de l'Ecole Française de 
Rome. Moyen Age 103-2: 485-503 <https://doi. org/10.3406/mefr.1991.3185>.

Erice, R. (2011): "El puerto fluvial de Caesaraugusta", en J. Arce y B. Goffaux (coord.), Horrea d'Hispanie et de la méditerranée romaine: 143-157. Madrid, Casa de Velázquez.

Escalada, F. (1943): La Arqueología en la villa y castillo de Javier y sus contornos. Pamplona, Leyre.

Escrivá, M. ${ }^{a}$ I. (2005): Basas romanas de la provincia Tarraconensis. Valencia, Institució Alfons El Magnànim.

Etxebarria, A. (2008): Los foros romanos republicanos en la Italia centro-meridional tirrena. Origen y evolución formal. Madrid, Consejo Superior de Investigaciones Científicas.

Excoffon, P. (2009): "Eléments de couverture en tuiles sciées de type corinthien à Olbia de Provence (Hyères, Var)". Documents d'Archéologie Méridionale 32: 255-267.

Fuentes, Á.; Escobar, R. y García, J. (2007): "Precisiones cronológicas sobre el origen del Foro de Valeria, Cuenca. (Resumen de los trabajos llevados a cabo durante las campañas del 2003-2005)", en $A r$ queología de Castilla-La Mancha, I Jornadas: 445468. Cuenca (2005), Cuenca, Universidad de Castilla-La Mancha - Junta de Comunidades de Castilla la Mancha.

Gimeno, J. (1989): “Tipología y aplicaciones de elementos dóricos y toscanos en Hispania. El modelo del Nordeste". Archivo Español de Arqueología 62: 101-139.

Gimeno, J. (1991): Estudios de arquitectura y urbanismo en las ciudades romanas del Nordeste de Hispania. Madrid, Universidad Complutense de Madrid.

Ginouvès, R. (1992): Dictionnaire méthodique de l'architecture grecque et romaine. II. Eléments constructifs: supports, couvertures, aménagements intérieurs. Rome, École Française de Rome.

Giuliani, C. F. (1973): "Contributi allo studio della tipologia dei cryptoportici”, en Les cryptoportiques dans l'architecture romaine. Actes du Colloque de Roma: 79-115. Roma (1972), París, École Française de Rome.

Guitart, J. y Padrós, P. (1990): "Baetulo. Cronología y significación de sus monumentos", en W. Trillmich y P. Zanker (eds), Stadtbild und Ideologie die Monumentalisierung hispanischer Städte zwischen Republik und Kaiserzeit: 165-178. Madrid (1987), München, Verlag der Bayerischen Akademie der Wissenschaften.

Goette, H. R. (1990): Studien zu römischen Togadarstellungen. Mainz, Verlag Ph. von Zabern.
Gros, P. (1981): Bolsena I. Scavi della scuola francese di Roma a Bolsena (Poggio Moscini). Guida agli scavi. Roma, École Française de Rome.

Gros, P. (1990): "Les étapes de l'aménagement monumental du forum: observations comparatives (Italie, Gaule, Narbonnaise, Tarraconaise)", en La Città nell'Italia settentrionale in étà romana. Morfologia, strutture e funcionamento dei centri urbani delle Regiones X e XI, Atti del convegno: 29-68. Trieste (1984), Rome, École Française de Rome.

Gros, P. (1996): L'architecture romaine. 1. Les monuments publics. París, Picard.

Gutiérrez Behemerid, M. A. (1992): Capiteles romanos de la Península Ibérica. Valladolid, Universidad de Valladolid.

Gutiérrez Behemerid, M. A. (2004): “Los programas arquitectónicos de época imperial en el conventus Cluniensis", en S.F. Ramallo (ed.), La decoración arquitectónica en las ciudades romanas de Occidente: 275-292. Cartagena (2003), Murcia, Universidad de Murcia.

Heilmeyer, W.-D. (1970): Korinthische Normalkapitelle: Studien zur Geschichte der römischen Architekturdekoration. Heidelberg, F. H. Kerle.

Hellmann, M.-C. (2002): L'architecture grecque. 1. Les principes de la construction. París, Picard.

Johannowsky, W. (1973): "Note sui cryptoportici pubblici in Campania", en Les cryptoportiques dans l'architecture romaine. Actes du Colloque de Roma: 143-165. Rome (1972), París, École française de Rome.

Larrañaga, K. (2007): El hecho colonial romano en el área circumpirenaica occidental. Vitoria, Universidad del País Vasco.

Luschin E. M. (2002): Cryptoporticus. Zur Entwicklungsgeschichte eines multifunktionalen Baukörpers. Viena, Österreichisches Archäologisches Institut.

Mar, R. (2005): El Palatí. La formación dels palaus imperials a Roma. Tarragona, Universitat Rovira $\mathrm{i}$ Virgili - Institut Català d'Arqueologia Clàssica.

Mar, R. y Pensabene, P. (2013): “El Foro de Segobriga y la formación de la arquitectura imperial en la Hispania romana: entre innovación y continuidades", en A. Sousa y M. do Carmo (coord.), História da Construçâo. Arquiteturas e Tecnicas construtivas, Centro de Investigaçâo Transdisciplinar Cultura, Espaço e Memória: 15-40. Braga, Centro de Investigação Transdisciplinar Cultura, Espaço e Memória - Laboratoire de Médiévistique Occidentale de Paris (Université de Paris 1 et CNRS). 
Mar, R.; Ruiz de Arbulo, J.; Vivó, D.; Beltrán-Caballero, J. A. y Gris, F (2015): Tarraco. Arquitectura y urbanismo de una capital provincial romana. vol. II. La ciudad imperial. Tarragona, Universitat Rovira i Virgili - Institut Català d'Arqueologia Clàssica.

Medrano, M.; Díaz Sanz, Ma A. y Tramullas, J. (1991): "Reconstrucción del edificio monumental de Contrebia Belaisca (Botorrita, Zaragoza)". Complutum 1: 281-292.

Moreno, I. (2008): Item a Caesarea Augusta Beneharnum. La carretera romana de Zaragoza al Bearn. Ejea de los Caballeros, Centro de Estudios Cinco Villas.

Noguera, J. M. y Madrid, Mª J. (2013): “Mármoles y marmorización arquitectónica en Nova Carthago: nuevas evidencias del Molinete", en V. García-Entero (ed.), El marmor en Hispania. Explotación, uso y difusión en época romana: 229-252. Madrid, UNED Editorial.

Olivier, A. (1982): "Dalles de toiture en pierre sciée à Glanum: opus pavonaceum?". Revue Archéologique de Narbonnaise 15: 69-101. <https://doi. org/10.3406/ran.1982.1199>.

Ortalli, J. (1995): “Complessi forensi e architetture civiche nelle città romane dell'Emilia Romagna: Ariminum, Sassina, Mevaniola, Veleia, Bononia", en M. Mirabella Roberti (coord.), Forum et basilica in Aquileia e nella cisalpina romana: 273-328. Udine, Arti Grafiche Friulane.

Papi, E. y Martorella, F. (2007): "I granai della Numidia". Antiquités africaines 43: 171-186. <https:// doi.org/10.3406/antaf.2007.1424>.

Pensabene, P. (1973): Scavi di Ostia VII. I Capitelli. Roma, Libreria dello Stato.

Poguet, M. y Pelletier, J.-P. (2004): "Eyguières. SaintPierre de Vence 1", en Bilan scientifique 2003 de la région Provence-Alpes-Côte d'Azur: 111-112. Aixen-Provence, Service Régional de l'ArchéologieDRAC.

Portillo, A. (2016): "La importancia del color en la arquitectura pública romana. Testimonios del empleo de marmora y pintura en algunos templos de la Bética". Cuadernos de Arqueología de la Universidad de Navarra 24: 21-48 <https://doi. org/10.15581/012.24.004>.

Ramírez Sádaba, J. L. (2009): "La toponimia de las ciudades vasconas", en J. Andreu (ed.), Los Vascones de las fuentes antiguas. En torno a una etnia de la Antigüedad peninsular: 127-146. Barcelona, Publicacions i edicions de la Universitat de Barcelona.
Ribera, A. (2011): "Los horrea de Valentia. De la Republica al Imperio", en J.Arcey y B. Goffaux (coord.), Horrea d'Hispanie et de la méditerranée romaine: 201-223. Madrid, Casa de Velázquez.

Rickman, G. (1971): Roman granaries and store buildings. Cambridge, Cambridge University Press.

Roth-Congès, A. (1992): "Le centre monumental de Glanon, ou les derniers feux de la civilisation salyenne". Marseille Grecque et la Gaule 3: 351-367.

Rodríguez Gutiérrez, O. (2004): El teatro romano de Itálica: estudio arqueoarquitectónico. Madrid, Universidad Autónoma de Madrid.

Rodríguez Neila, J. F. (1997): “Apparitores y personal servil en la administración local de la Bética”. Studia Historica. Historia Antigua 1: 197-228.

Romero, L. (2014): "Novedades en los fora del conuentus Caesaraugustanus". Bolskan 25: 195-218.

Romero, L. (2017): "La basílica del foro de Los Bañales (Uncastillo, Zaragoza). Habis 48: 113-131.

Romero, L. (2018): “Fora vasconiae. Centros cívicos en los límites del conventus Caesaraugustanus: el caso de Santa Criz de Eslava (Eslava, Navarra)". Trabajos de Arqueología Navarra 30: 197-214.

Romero, L. (en prensa): "The roman forum of Los Bañales (Uncastillo, Zaragoza): Building, remodelling and reutilisation of a forum from the conuentus Caesaraugustanus", en 19th International Congress of Classical Archaeology: s. pp. Colonia-Bonn (2018), Colonia/Bonn, Oxford, Oxbow Books, e.p.

Roth-Congès, A. (1983): "L'acanthe dans le décor architectonique protoaugustéen en Provence". Revue Archéologique de Narbonnaise 16: 103-134. $<$ https://doi.org/10.3406/ran.1983.1226>.

Rossignani, M. P. (1995): "Foro e basilica a Luni", en M. Mirabella Roberti (coord.), Forum et basilica in Aquileia e nella cisalpina romana: 443-466. Udine, Arti Grafiche Friulane.

Ruyt, C. de (1983): Macellum. Marché alimentaire des Romains. Lovaina-la-Nueva, Dubois-Pèlerin.

Sebastiani, R. y Serlorenzi, M. (2011): "Nuove scoperte dall'area di Testaccio (Roma): tecniche costruttive, riuso e smaltimento dei contenitori anforici pertinenti ad horrea e strutture utilitarie di età imperiale", en J. Arce y B. Goffaux (coord.), Horrea d'Hispanie et de la méditerranée romaine: 67-95. Madrid, Casa de Velázquez.

Sisani, S. (2006): Umbria. Marche. Guide Archeologiche Laterza 7. Roma, Laterza.

Taracena, B. y Vázquez de Parga, L. (1946): "Excavaciones en Navarra. V. La Romanización”. Príncipe de Viana 24: 413-470. 
Trunk, M. (2008): Los capiteles del foro de Segóbriga. Evaluación tipológica y estilística. Cuenca, Consorcio del Parque Arqueológico de Segóbriga.

Ward-Perkins, J.B. (1970): "From Republic to Empire: Reflections on the Early provincial Architecture of the Roman West". The Journal of Roman Studies 60: 1-19.

Vargas, S. (2018): "La techumbre marmórea del Traianeum de Italica", en J. Beltrán, M. L. Loza y E. Ontiveros (coord.), Marmora Baeticae: Usos de materiales pétreos en la Bética romana. Estudios arqueológicos y análisis arqueométricos: 215-222. Sevilla, Editorial Universidad de Sevilla.

Velaza, J. (1995): "Epigrafía y dominios lingüísticos en territorio de Vascones", en F. Beltrán Lloris (ed), Roma y el nacimiento de la cultura epigráfica en Occidente: 209-218. Zaragoza, Institución Fernando el Católico.

Zuza, C. (2013): "El patio oriental de la villa romana de Liédena (Navarra) en el Bajo Imperio y la annona militaris: una propuesta”. Cuadernos de Arqueología de la Universidad de Navarra 21: 291-308. 
Romero Vera, D., (2020): “Consideraciones sobre la arquitectura doméstica urbana de Hispania en el siglo II d.C.", Spal 29.1: 243-270.

DOI: http://dx.doi.org/10.12795/spal.2020.i29.09

\title{
CONSIDERACIONES SOBRE LA ARQUITECTURA DOMÉSTICA URBANA DE HISPANIA EN EL SIGLO II D.C.
}

\section{CONSIDERATIONS ON THE DOMESTIC ARCHITECTURE OF HISPANIA IN THE SECOND CENTURY AD}

\author{
DIEGO ROMERO VERA \\ Departamento de Prehistoria y Arqueología \\ Facultad de Geografía e Historia. Universidad de Sevilla. C/ Doña María de Padilla, S/N, 41004 - Sevilla \\ Correo-e: drvera@us.es. (D) https://orcid.org/0000-0002-4562-2407 \\ Researcher ID: <https://publons.com/researcher/AAE-9894-2019
}

Resumen: En este trabajo ofrecemos una revisión sintética de las evidencias arqueológicas pertenecientes a domus del siglo II d.C. que han ofrecido una veintena de núcleos urbanos de Hispania. Partiendo de esta documentación, pretendemos establecer un primer acercamiento a los rasgos característicos de la arquitectura doméstica hispanorromana en esta época.

Palabras clave: Domus, época antonina, ciudades hispanorromanas, balnea, monumentalización, crisis urbana.

\section{INTRODUCCIÓN}

En el presente artículo abordamos una aproximación a las principales dinámicas y características que rigen la arquitectura residencial de un nutrido grupo de ciudades hispanorromanas en el siglo II d.C. Somos conscientes de la dificultad que entraña ofrecer una visión integradora sobre este tema en un marco temporal tan amplio y del que, además, existe una enorme (y muy
Abstract: In this work we will review briefly the domestic archeological evidence dated in the second century belonging to a score of Hispania's urban centres. On the basis of this documentation, we would like to offer, in general terms, the characteristic features of the hispanorroman domestic architecture in this period.

Keywords: Domus, Antonine epoch, Hispano-Roman cities, balnea, monumentalization, urban crisis

dispar en cuanto a su calidad) documentación. Como vemos, el objetivo planteado no resulta nada sencillo.

Asimismo, creemos que se trata de una investigación pertinente y necesaria por varias razones: por un lado, pese a la gran cantidad de evidencias aportada por el registro arqueológico y al impulso que ha recibido el estudio de la vivienda hispanorromana en las últimas décadas, todavía existen importantes lagunas en este campo de investigación. 
En efecto, la atención de los investigadores se ha centrado preferentemente en la decoración y los modelos arquitectónicos. Tampoco hay que pasar por alto que la gran mayoría de las intervenciones realizadas en yacimientos no superpuestos se concentran en los espacios públicos de la ciudad, quedando sin excavar la mayor parte del núcleo urbano, compuesto justo por aquellas áreas que fueron ocupadas previsiblemente por viviendas. Por su parte, en las llamadas ciudades superpuestas o históricas, las casas no siempre son excavadas en extensión debido a la complicada naturaleza de las intervenciones arqueológicas en contexto urbano. Todos estos factores determinan el estado actual de conocimiento sobre la vivienda hispanorromana.

En general, los estudios de conjunto sobre la vivienda romana en la península ibérica son muy escasos (Balil 1972, A.A.V.V. 1991, Beltrán y Mostalac 1996, Gros 2001: 137 y ss., Beltrán 2003). Concretamente, no existe una obra actualizada que arroje una visión global sobre el tema propuesto; sin embargo, sí se han publicado ciertos estados de la cuestión sobre la casa hispanorromana que presentan una somera evolución de la edilicia doméstica desde época tardorrepublicana hasta el final de la Antigüedad (Beltrán y Mostalac 1996, Beltrán 2003). Por lo común, los estudios de este género se han centrado en unidades residenciales concretas o en análisis de la arquitectura doméstica de determinados núcleos urbanos. Con todo, en fecha reciente se han realizado estudios que dejan atrás la perspectiva local para analizar esta materia en áreas precisas de la península ibérica (Rodríguez Gómez 2010, Bermejo 2014, Cortés 2014b, Uribe 2015).

En lo que respecta al análisis de las diferentes etapas evolutivas de la casa hispanorromana, se echa en falta, especialmente, un estudio sincrónico sobre la edilicia doméstica en época antonina, periodo que con toda seguridad (y especialmente en lo que respecta a la decoración) fue uno de los de mayor esplendor de la vivienda hispanorromana (Ramallo 1990: 141-160, Pérez Olmedo 1996: 42-49, Beltrán y Mostalac 1996: 68, Beltrán 2003: 50-51, López Monteagudo 2003: 301333, Garriguet 2013: 266 y ss., Fernández Díaz 2014: 209-216). En efecto, el registro arqueológico revela que muchas casas adquirieron su configuración definitiva (al menos desde el punto de vista ornamental) o fueron construidas en este periodo. Este aspecto resulta especialmente llamativo si tenemos en cuenta que en Hispania las construcciones públicas disminuyen a partir de la segunda mitad del siglo II d.C. Todo indica que las ciudades hispanorromanas vivieron en época antonina una fase de cierto estatismo, tras haberse dotado de las infraestructuras y los edificios públicos necesarios en las etapas precedentes. En efecto, en los espacios públicos, la dedicación de epígrafes se fue reduciendo $\mathrm{y}$, aunque se detectan algunas intervenciones decorativas y constructivas, su volumen decae abruptamente con respecto al periodo anterior (Romero Vera 2016: 374-383). Esto contrasta con la marcada luxuria privata que parece proyectarse en el ámbito doméstico, lo que induce a especular con un probable traslado de la inversión pública a la esfera privada en la Hispania del siglo II d.C. A esto cabría añadir que, desde finales de la segunda centuria, algunas poblaciones -no todasexperimentan un declive material que las llevará, en un breve periodo de tiempo, al colapso urbano. Nos estamos refiriendo, entre otras, a: Bilbilis (García Villalba y Sáenz 2015), Carthago Nova (Quevedo y Ramallo 2015), Emporiae (Castanyer et al. 1993), Labitolosa (Sillieres et al. 1995: 112), Lucentum (Guilabert et al. 2015); Iulia Lybica (Olesti et al. 2014), Dertosa (Járrega et al. 2014) Cartima (Berlanga y Melero 2009), Arucci/Turobriga (Bermejo 2011), Lesera (Arasa 2009: 81 y ss.), Torreparedones (Morena et al. 2011: 150 y ss.), Tiermes (Pérez González et al. 2015: 250-251) y Los Bañales (Andreu et al. 2014).Precisamente, el análisis de la vivienda constituye un registro fiable para tasar el grado de vitalidad de las comunidades cívicas de época antonina y para evaluar, al mismo tiempo, la situación económica de sus habitantes.

En nuestro estudio hemos empleado el método comparativo a fin de establecer un primer acercamiento a los patrones o modelos que imperan en la arquitectura doméstica del citado marco cronológico-espacial. Con este objetivo, hemos analizado las evidencias correspondientes a un buen número de ciudades hispanorromanas, precisamente aquellas que ofrecen mayor cantidad de información arqueológica e histórica, en concreto: Astigi, Asturica Augusta, Augusta Emerita, Baelo Claudia, Baetulo, Barcino, Bilbilis, Bracara Augusta, Caesar Augusta, Carthago Nova, Clunia, Conimbriga, Corduba, Emporiae, Italica, Lucentum, Mirobriga Celticorum, Munigua, Saguntum, Segobriga, Tarraco y Valentia (fig. 1).

El catálogo está ordenado por provincias, disponiendo en primer término las capitales provinciales, después las capitales conventuales y, finalmente, el resto de ciudades. De esta forma, se tiene un acceso más razonable a la realidad de cada demarcación territorial de época romana, facilitando una valoración de conjunto de cada realidad provincial.

Somos conscientes de que este muestrario es limitado y no recoge todos los núcleos urbanos hispanos susceptibles de ofrecer información sobre arquitectura 


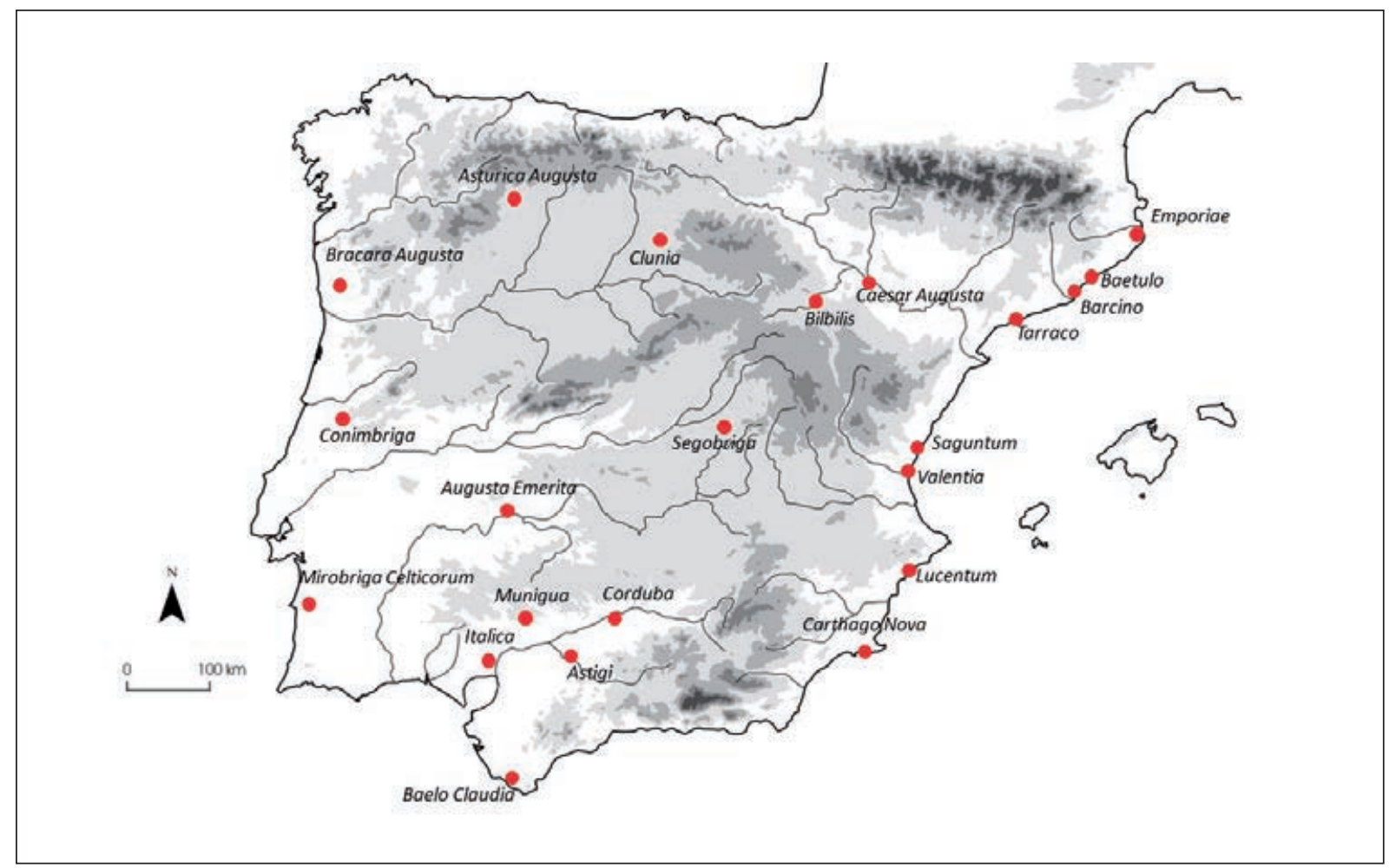

Figura 1. Situación de las ciudades hispanas analizadas en este trabajo.

doméstica. Sin embargo, estimamos que todas las ciudades analizadas son representativas y poseen un peso específico en este campo de estudio. Asimismo, el número de yacimientos que integran el catálogo, 22 en concreto, es suficientemente amplio como para poder establecer hipótesis de partida y tendencias al respecto. Por último, cabría reiterar que no pretendemos en absoluto realizar un estudio integral y exhaustivo de la vivienda urbana en el siglo II d.C., algo que excede con mucho el fin de este trabajo, sino analizar de forma amplia y, a la vez, obligatoriamente sintética, los principales rasgos de los espacios domésticos de las ciudades citadas en el marco temporal propuesto.

\section{ESTUDIO DE CASOS}

\subsection{Bética}

Colonia Patricia

La evolución de la arquitectura privada en Colonia Patricia durante la segunda centuria de nuestra era ha de trazarse con base en testimonios arqueológicos indirectos, debido, entre otros factores, a la falta de viviendas excavadas en extensión y a su carácter de ciudad superpuesta, esto es, habitada desde su fundación (Carrillo 1999: 77-80, Vaquerizo 2004: 81-94, Márquez 2005: 54-56). Estos vestigios revelan que las viviendas gozaban de un gran nivel decorativo y que sus comitentes estaban al tanto de las novedades estilísticas de moda en Roma, lo que sirve para definir al periodo antonino como una época de esplendor para la arquitectura residencial local. En esta línea, las estatuas-fuente, hermas-retrato, hermas báquicas y monopodia decoradas constituyen la decoración escultórica de carácter doméstico predominante durante el siglo II (Peña 2011: 54). Del elenco de pavimentos musivos documentados, destacan una mayoría que pueden ser estilísticamente datados en dicha centuria, lo que hay que poner en relación con reformas decorativas de domus preexistentes (Secilla y Márquez 1991: 341, Moreno 1996: 81 y 84). Del mismo modo, una parte importante de los capiteles reutilizados en la Mezquita Aljama fueron labrados en el siglo II y pudieron pertenecer a viviendas (Márquez 1993, Peña 2010). Aun así, existen evidencias de la ampliación de domus, cuya planta no se ha podido documentar completamente, y que ocuparon, en parte, el viario público, 
como es el caso de la documentada en plaza Pineda 2 (Ruiz Bueno 2014: 46-47, 2015: 102).

Este dinamismo también se detecta en las áreas suburbanas. Los suburbia occidental y oriental se colmaron de inmuebles y se expandieron más allá de sus límites tradicionales, al mismo tiempo que se operó en ellos un retroceso de la función funeraria frente a la habitativa y comercial (Ruiz Bueno 2018: 265-266). El mejor ejemplo de vivienda suburbana lo constituye la domus del Sátiro, que sobresale por la calidad de sus revestimientos pictóricos, fruto de una intervención decorativa de época antonina. Esta fase no llegó a ser concluida y la casa se abandonó por motivos que ignoramos a finales del siglo II (Cánovas 2010: 427-438).

\section{Astigi}

Las diversas intervenciones arqueológicas que se han sucedido en el solar de la Écija romana han sacado a la luz no pocos testimonios de viviendas. Sin embargo, hasta el momento ninguna ha podido ser analizada en toda su extensión. La cantidad de unidades domésticas que se reformaron o construyeron en la segunda centuria es amplísima y solo su descripción ocuparía largo espacio (un compendio actualizado sobre las estructuras que se adscriben a espacios domésticos en García-Dils 2015: 287-443). Normalmente, las domus excavadas presentan dos fases constructivas: la primera se fecha entre época fundacional y la primera mitad del siglo I d.C., mientras que la segunda ocupa todo el siglo II d.C., especialmente su segunda mitad (Sáez et al. 2004: 58, García-Dils et al. 2009: 524). Entre las últimas estructuras habitacionales excavadas hay que destacar las documentadas en la plaza de España: las llamadas casa de las Hermae y casa del $O s-$ cillum. Ambas fueron reformadas en el siglo II. En el caso de la domus del Oscillum, la segunda centuria trajo consigo un cambio de envergadura: el vestibulum que daba acceso a la vivienda desde el kardo maximus y que, por ende, constituía su entrada principal, se amortiza para construir una estructura sobre grandes basamentos interpretada como una porticus (García-Dils et al. 2009: 533, García-Dils et al. 2011: 268-269). En cuanto a la casa de las Hermae, su estructura fue modificada en las postrimerías del siglo II para acoger unas tabernae. Igualmente, se reformó el atrio-peristilo y se renovó su aparato decorativo con tres retratos de los que sólo conocemos sus pedestales (García-Dils et al. 2006: 353 y 363) (AE 2006, 647; $A E$ 2006, 648; $A E$ 2006, 649).
La casa excavada en el solar de plaza de Santo Domingo 5 y 7 , en el sector nororiental de la colonia, constituye un caso particularmente interesante. Se trata de una vivienda construida a finales del siglo I o en los primeros años de la centuria siguiente. Resulta realmente llamativo que esta fuese la primera edificación que albergó la parcela; es decir, la casa fue erigida sobre un solar baldío situado intramuros y que, además, estaba perfectamente delimitado por el viario. La excavación no detectó una fase edilicia previa, únicamente los rellenos de tierra propios de los trabajos de urbanización datados, gracias a la presencia de fragmentos de cerámica, en época fundacional (Romero Paredes et al. 2006: 58-59). Por lo tanto, estamos ante una insula intraurbana que no acoge ninguna construcción hasta un siglo después de la fundación de la colonia (Romero Vera 2014: 937-940).

El cúmulo de información sobre el área suburbana occidental es mayor, ya que allí se han desarrollado más procesos de sustitución inmobiliaria en los últimos años. Así, las intervenciones han revelado que, desde época augustea, el suburbium occidental poseyó funciones diversas. Se han documentado tumbas, vertederos e instalaciones vinculadas con la producción de aceite. A partir de época julio-claudia, comenzaron a erigirse algunas viviendas, pero desde finales del siglo I y durante todo el II se desarrolló una transformación de envergadura: el espacio cambia de uso y adquiere, casi en exclusiva, una función residencial. En efecto, la práctica totalidad de este sector fue ocupado por viviendas de notables dimensiones, propias de una clase pudiente (Rodríguez Termiño 1991: 346-352, Vera et al. 2005: 494, García-Dils et al. 2006: 359).

En el suburbio oriental, justo en la lengua de terreno situado entre las murallas y el cauce del río Singilis, parece que se dio una situación análoga. Allí se han desarrollado menos intervenciones, pero todo apunta a que, igualmente, esta área tuvo una función netamente residencial en la segunda centuria y que las viviendas situadas allí comenzaron a edificarse a partir de dicho siglo. Por tanto, este constituye el primer episodio de ocupación doméstica del suburbio oriental (Carrasco y Romero Paredes 2001: 576-579).

\section{Baelo Claudia}

Hasta la actualidad, tan solo se han identificado dos viviendas altoimperiales en Baelo Claudia, ya que, como es frecuente en este tipo de yacimiento, los esfuerzos se han centrado en estudiar el foro y los edificios 
públicos. Tanto la casa del Cuadrante como la casa del Oeste se encuentran situadas en el barrio industrial pesquero-conservero que ocupa el sector meridional de la ciudad (Arévalo y Bernal 2007). Ambas fueron excavadas por Pierre Paris y su equipo a principios del siglo pasado, hecho que dificulta tanto su interpretación como la datación de las fases que presentan (Sillières 1991: 321-324). Para el caso de la domus del Cuadrante se han analizado unos grafitos repartidos por varias estancias en el estrato preparatorio de sus pinturas murales. Su análisis paleográfico ha ofrecido un terminus ante quem para, al menos, datar las pinturas a mediados del siglo II (Bonneville et al. 1988: 94 y 96). Posiblemente, pertenezca a esta misma fase la reforma de la sala 51, interpretada como triclinio, puesto que se detecta en sus muros el empleo de incertum o pseudo vittatum de caliza y arenisca, cuyo uso se atestigua en la ciudad en época trajanea (Sillières 1991: 324-326, Diderjean et al. 1986: 128). Por su parte, la casa del Oeste fue ampliada en época antonina. Corresponden a este horizonte constructivo las habitaciones número 32 y 33 , estancias de aparato con las que se amplía la casa en detrimento de una cetaria vecina (Sillières 1991: 324-326, Sillières 1997: 173).

El uso residencial de ambas casas no supera el siglo II. Se plantea que fueron abandonadas a mediados de esta centuria, ya que se ha comprobado que algunas de sus estancias fueron ocupadas por piletas $\mathrm{y}$, por tanto, pasaron a tener una función productiva (Bernal et al. 2007a: 129-130 y 187). Por último, hay que citar el llamado Edificio Meridional III, construcción de difícil interpretación de la que no está clara ni su función residencial ni su identificación con una factoría de salazón. En cualquier caso, se ha comprobado que dicho edificio se amortiza a finales del siglo II (Bernal et al. 2007a: 194-200). Hecho que no determina su definitivo abandono, puesto que a partir de esa fecha adquiere un uso incierto, posiblemente marginal, y se convierte en un lugar de deposición de desechos que elevaron la cota de hábitat dos metros. En dichos estratos se han hallado materiales relacionados con actividades pesquero-conserveras que llegan hasta el siglo IV (Bernal et al. 2007a: 198-199, 2007b: 389-395).

\section{Italica}

La falta de registro estratigráfico con la que se efectuó la excavación de la mayor parte de las viviendas documentadas en Italica obliga a tomar en consideración otro tipo de información (Mañas 2010: 82). En este sentido, el estudio de los pavimentos musivos ha servido para trazar una evolución general de la arquitectura doméstica italicense. Así, de los ochenta y dos mosaicos y opera sectilia que ha aportado el yacimiento, la mayor parte pertenece a la segunda mitad del siglo II (Mañas 2011: 91). Esta datación, ciertamente tardía, nos ilustra sobre el proceso de urbanización de la Nova Urbs. En primer lugar, se desarrolló la planificación y construcción del trazado viario, cloacas y acueducto, para proceder después a la erección de los edificios públicos y espacios monumentales (Traianeum, Termas Mayores, anfiteatro, etc.). En última instancia, ya durante el reinado de Antonino Pío, se construyó y decoró el grueso de las viviendas (Mañas 2009: 197). Esta secuencia deja patente que existió un cierto desfase temporal entre la arquitectura de iniciativa imperial o pública y la edilicia privada.

En otro orden de cosas, la única vivienda cuyo abandono se constata dentro del siglo II corresponde a la casa de las Columnas, cuya amortización se fecha a finales de dicha centuria (aunque volvería a ser reocupada a finales del siglo III) (Abad 1982: 146-148). Con todo, las intervenciones decorativas en ámbito doméstico no se circunscriben a la etapa tardoantonina, ya que en época severa se han detectado ciertas actuaciones puntuales (Mañas 2009: 194-196). En efecto, cuatro pavimentos de la casa del Nacimiento de Venus y el opus sectile de la casa de la Exedra (fruto de la repavimentación de una estancia) pertenecen a esta fase (Canto 1976: 293-318, Roldán 1991: 303-311).

\section{Munigua}

El aspecto más destacable sobre la arquitectura doméstica en Munigua es el escaso número de viviendas que formaban parte del tejido urbano. En efecto, se piensa que la mayor parte de la población local se encontraba dispersa por el territorium adscrito a la ciudad y que solo unas pocas familias habitaron el núcleo urbano (Hauschild y Haussmann 1991: 329-335, Schattner 2003: 223). La principal fase de la edilicia doméstica local se desarrolla entre finales del siglo I y principios del II. La casa 1 adquirió su articulación arquitectónica definitiva en esta etapa. Dicha vivienda tiene forma trapezoidal y estaba formada por 22 estancias, entre las que destacan el triclinio y el peristilo que articula todo el edificio (Hauschild 1985: 235-267, Meyer et al. 2001: 50-65). Igualmente, la casa 2 fue reformada a finales del siglo I o principios del siglo II, después 
de que una parte de su solar se desgajara para la construcción de la basílica forense (fig. 2). Para paliar esta pérdida de espacio, la residencia fue ampliada hacia el sur, construyéndose dos estancias dedicadas al comercio (habitaciones 3 y 4) y otra empleada como almacén de ánforas (Meyer et al. 2001: 260-261). Por último, también la casa 6 , con una distribución muy parecida a la casa 1, se edificó dentro de la misma fase constructiva (Vegas 1985: 269-289, Meyer et al. 2001: 65-76).

\subsection{Lusitania}

\section{Augusta Emerita}

Además de por sus espacios públicos, la Mérida romana destaca por la gran cantidad de estructuras habitacionales y elementos decorativos domésticos que se han hallado en su subsuelo. De hecho, es la capital provincial hispana que más volumen de información referente a la vivienda ha aportado, de forma que resulta complicado citar cada uno de elementos relativos a la arquitectura doméstica emeritense adscritos a la época de nuestro estudio (Corrales 2016).

Parece que en esta colonia preponderaron las casas con un único espacio de distribución abierto, fundamentalmente un peristilo (Alba 2004: 67 y ss., Corrales 2016: 139-143). Asimismo, buena parte de las viviendas documentadas presenta un horizonte constructivo en el siglo II d.C. (Palma 1997: 367-386). Sin embargo, se ignora en gran medida el estado que presentaban en dicho periodo, ya que sufrieron profundos cambios en el siglo IV que enmascararon el aspecto de las viviendas altoimperiales (Palma 1997: 362). Con todo, dentro del lenguaje decorativo del siglo II hay que destacar el predominio de los mosaicos bícromos en la primera mitad de siglo, momento a partir del cual se imponen los polícromos. En cuanto a la producción pictórica, los dos primeros siglos del Imperio están marcados por la abundancia de composiciones clásicas de clara raigambre itálica, dotadas de rodapié y zócalo, en las que predominan las texturas pulidas (Corrales 2016: 262-263). No obstante, la incorporación de balnea supone el rasgo más sobresaliente de la edilicia doméstica emeritense de época antonina. En relación con ello, cabría destacar dos ejemplos: por un lado, la suntuosa vivienda documentada en la c/ Félix Valverde Lillo 7, cuyas dependencias destinadas al baño ocuparon una extensión de $90 \mathrm{~m}^{2} \mathrm{y}$, por otra parte, la casa 5 del área arqueológica de Morería, la cual contó con todos los espacios propios de unas termas públicas, es decir, apodyterium/frigidarium, tepidarum y caldarium. Dicho balneum se ubicó en un costado de la vivienda y se accedía a él a través del peristilo (Corrales 2016: 264).

Por lo que respecta a las áreas suburbanas, las excavaciones arqueológicas han atestiguado la existencia de un gran foso que defendía el flanco este de la colonia. Se trataba de un corte realizado en el estrato geológico que corría en paralelo a la muralla, a unos $25 \mathrm{~m}$ de ésta. Así, el espacio suburbano oriental más inmediato a la ciudad estuvo caracterizado desde época fundacional por la presencia de este elemento defensivo (Pérez Maestro 2005: 238). Entre finales del siglo I y principios del II, esta zanja fue amortizada con vertidos de desechos domésticos y constructivos. Una vez colmatada, esta área suburbana se aprovechó para la edificación de construcciones domésticas. Sobre los propios estratos de colmatación del foso se han documentado las cimentaciones de las domus que se erigieron allí desde inicios del siglo II. Esta dinámica parece estar relacionada con la demanda de nuevos espacios extramuros para la instalación de viviendas (Pérez Maestro 2005: 239).

Dentro de esta misma línea, se tiene noticia de varias estructuras domésticas suburbanas emeritenses (entre las que cabría citar las que se han documentado en el llamado "solar de Resti") datadas por su decoración pictórica en el transcurso del siglo I al II (Márquez 2010: 146). De esta misma cronología es la conocida como casa del Albarregas, situada junto al río, al noroeste de la ciudad, cuyos restos se corresponden con tres habitaciones y un conjunto termal privado (Márquez 2010: 147). Por su parte, la casa del Mitreo, aunque erigida a finales de siglo I, también presenta una interesante fase fechada a inicios del siglo II, cronología que cabría dar tanto a los pavimentos como las pinturas de las diversas estancias. A una fase posterior, entre la segunda mitad de siglo II e inicios del III, pertenece el conocido mosaico cosmogónico (Álvarez y Nogales 2011: 484).

\section{Conimbriga}

El estudio de la arquitectura doméstica de esta ciudad no es una cuestión sencilla. A pesar de que Conimbriga ha ofrecido numerosos ejemplos de viviendas, la mayor parte de estas fueron excavadas en una época en la que no existía una metodología muy depurada, lo que implica, en última instancia, que haya problemas para datar con fiabilidad sus diferentes fases constructivas. 


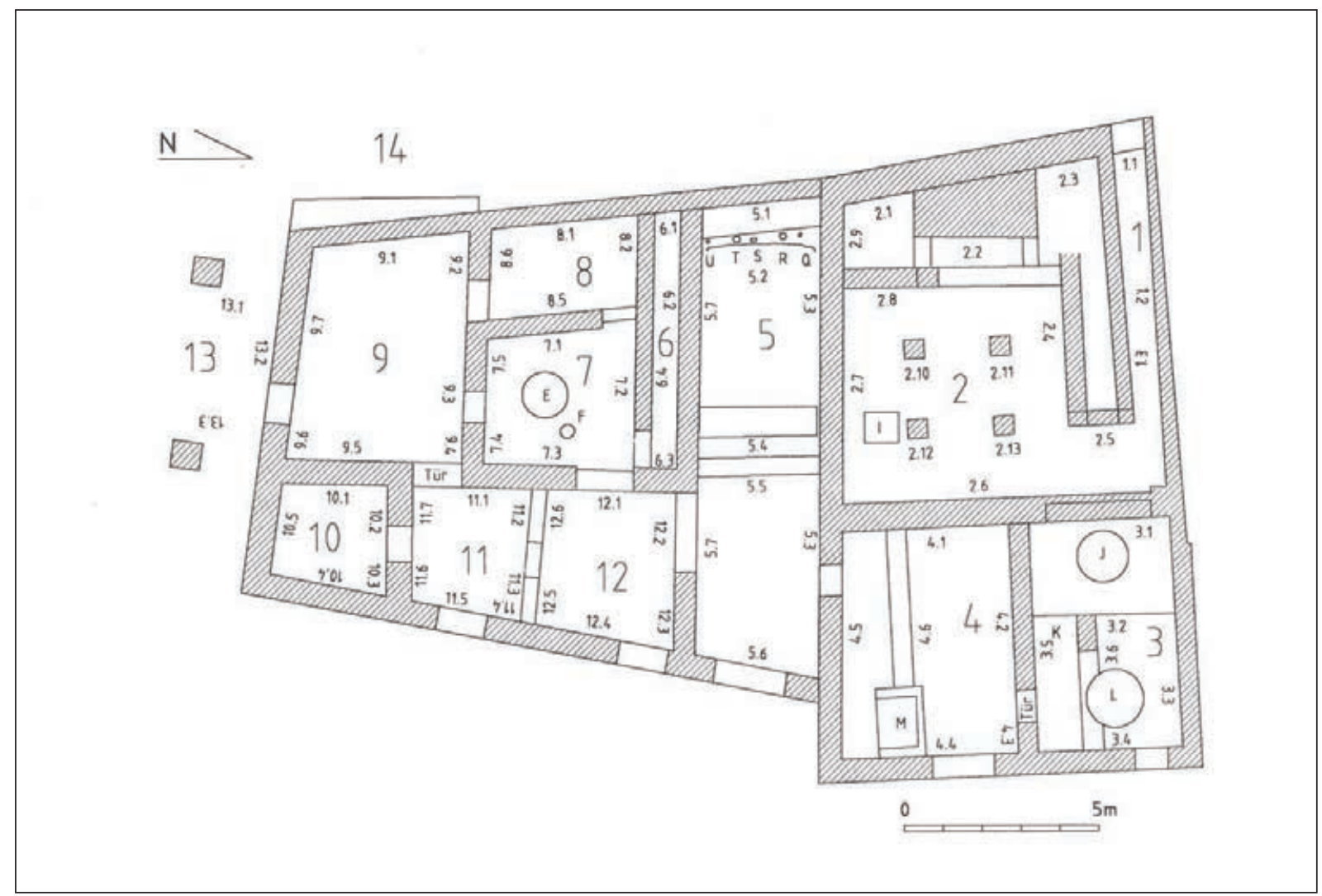

Figura 2. Planta de la segunda fase de la casa 2 (a partir de Meyer et al. 2001: 222, fig. 7).

A pesar de todo, en general, se observa que en la época de nuestro estudio casi todas las intervenciones arquitectónicas son de pequeña escala o de orden decorativo (Correia 2010b: 8-9). Un fenómeno propio del siglo II es el equipamiento de baños privados en las casas, detalle indicativo de la riqueza de los propietarios (Correia y Reis 2000: 279).

Una de las domus más sobresalientes del municipio es la casa dos Repuxos (Morand 2005, Correia 2013: 149-156). La segunda fase de la misma supuso la construcción del gran impluvium ajardinado (y decorado con un sistema de 521 surtidores) del que deriva su moderna denominación (fig. 3) (Correia 2004: 5455, Reis y Correia 2006: 296-298). El acceso original al edificio fue amortizado y se edificó en su lugar una entrada monumental (Correia 2013: 155). También corresponde a esta fase la construcción de unas pequeñas letrinas (Reis et al. 2011: 195-196). Por su parte, a finales del siglo II, la casa atribuida a Cantaber se dotó de unos baños privados en los que no falta ninguno de los espacios propios de las termas públicas (fig. 4) (Correia y Reis 2000: 276-277, Correia 2001: 83-140). También la casa de los Esqueletos, en su aspecto final, se data en la segunda centuria. Esta suntuosa domus se articula en torno a un peristilo central porticado y con estanque (Reis y Correia 2006: 304-305, Alarcão 2010: 46-63, Correia 2013: 169-174).

\section{Mirobriga Celticorum}

A pesar de que se han excavado varias estructuras domésticas, tan solo dos casas revisten interés para nuestro estudio (Barata 1999: 51-68, 1998: 59-62). Junto a la actual capilla de San Blas se excavó una gran domus (de cerca de $300 \mathrm{~m}^{2}$ ) organizada en torno a un atrio. Con toda seguridad, la casa formaba parte del paisaje doméstico de Mirobriga en la segunda centuria, puesto que presenta una larga e ininterrumpida ocupación que va del siglo I al V d.C. (Barata 1999: 55-59). Igualmente, se ha podido determinar que la casa 1 , situada junto a las termas, fue ampliada en época flavia y estuvo en uso hasta finales del siglo III (Teichner et al. 2014: 1121-1124). 


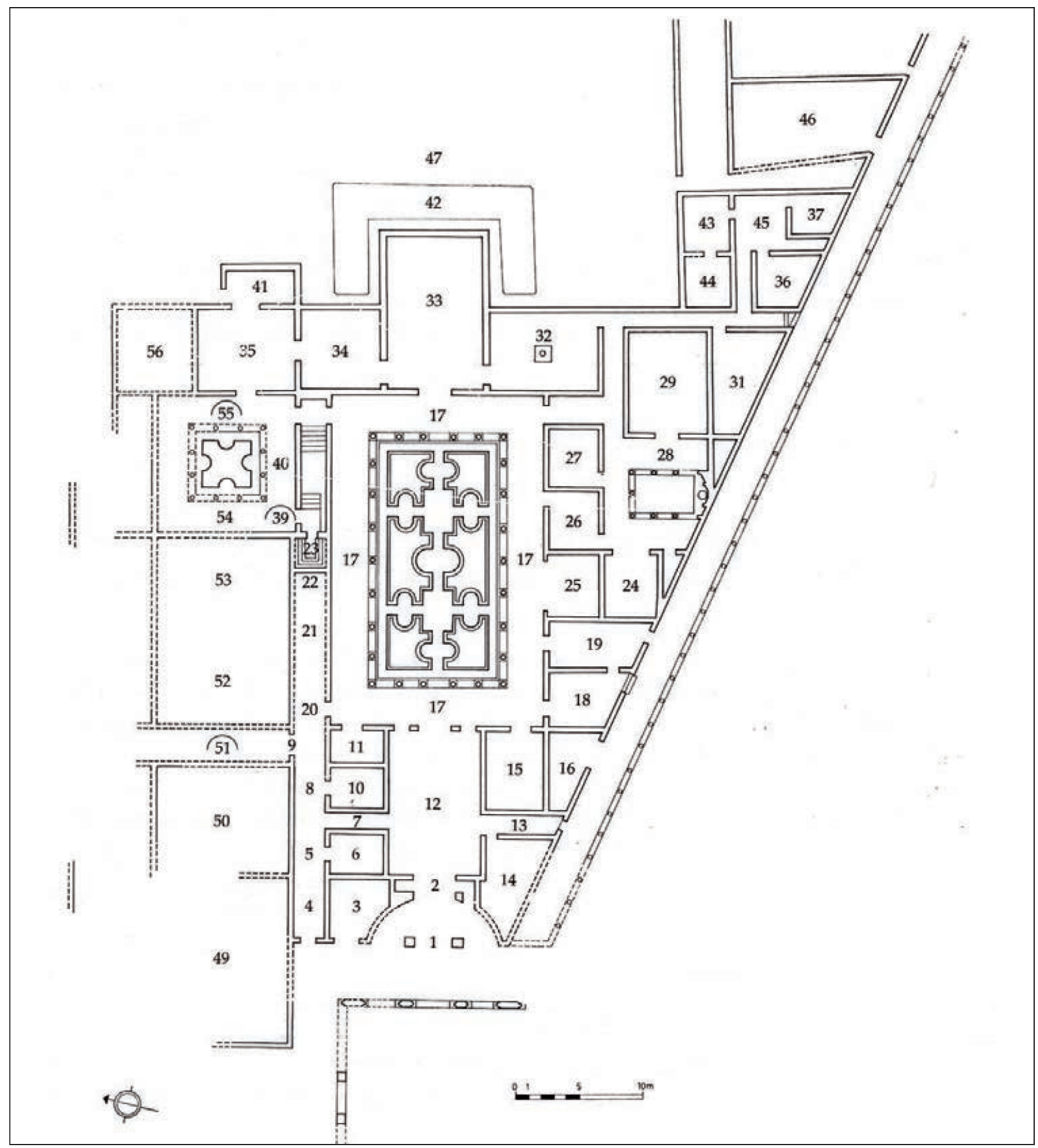

Figura 3. Planta de la segunda fase de la casa dos Repuxos (a partir de Morand 2005: 21, fig. 4).

\subsection{Hispania Citerior}

\section{Tarraco}

Existe un cierto desfase entre el nivel de conocimiento de los conjuntos públicos de Tarraco y el de su arquitectura doméstica. La información arqueológica sobre la vivienda, principalmente la de la zona intramuros, es escasa y fragmentaria debido a las dificultades con las que ha contado su estudio. En especial, la apertura de ensanches en el siglo XIX y XX, que eliminaron gran parte del registro arqueológico 


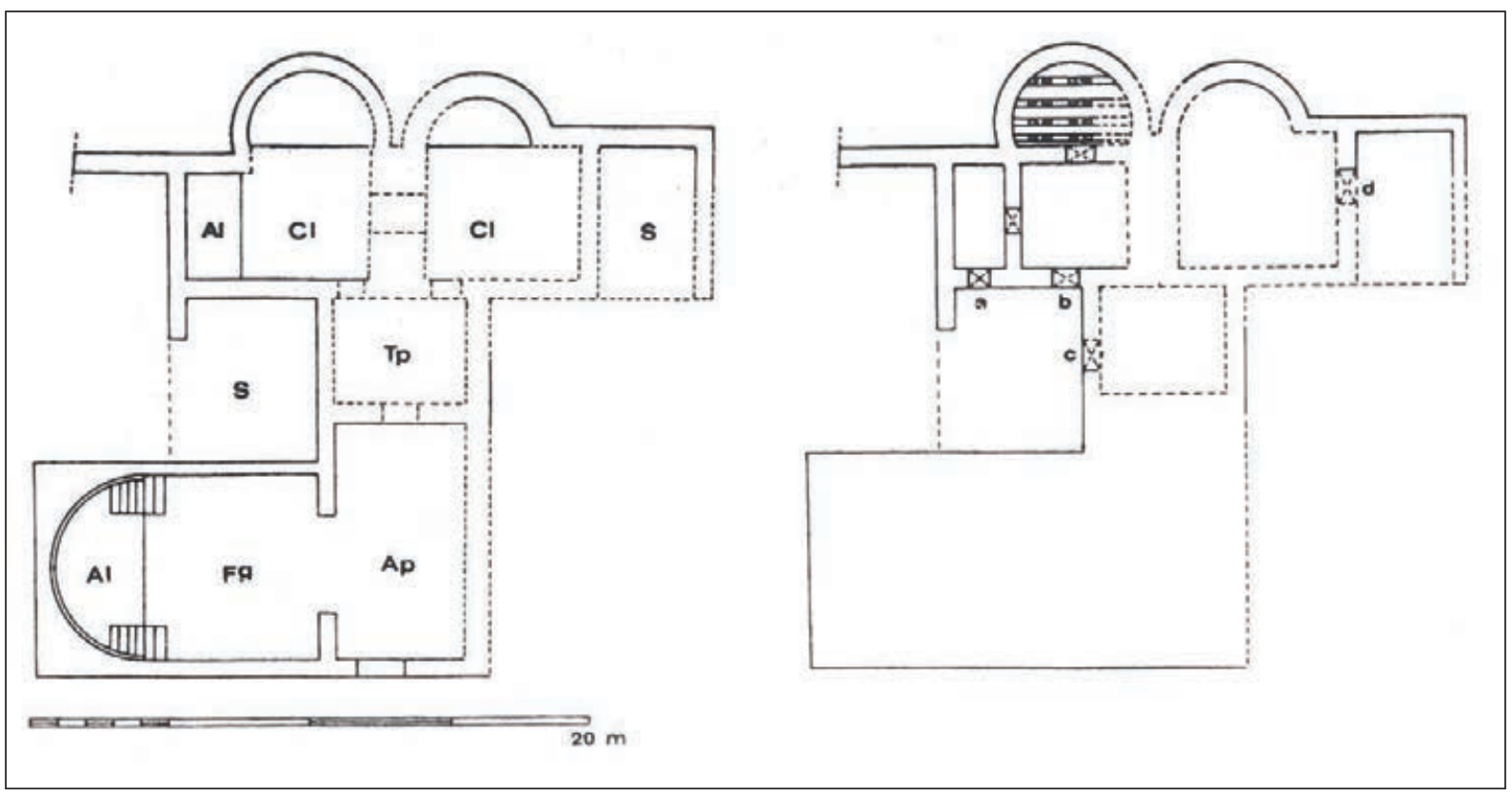

Figura 4. Planta del balneum de la casa de Cantaber (a partir de Correia y Reis 2000: 276, fig. 4).

de una zona ocupada, esencialmente, por residencias (Perich 2014: 119-122). Con todo, el registro arqueológico revela que el siglo II fue una etapa de esplendor en lo que respecta a la edilicia doméstica (Cortés 2009: 517). De hecho, existe un buen número de esculturas de carácter ideal adscritas a casas y jardines que fueron elaboradas en época antonina (Koppel 1985: 69 ss. y 100 ss.).

Por lo que respecta a ejemplos domésticos intraurbanos, debemos citar la domus descubierta en c/ Gobernador González 17, cuyo aparato ornamental, mosaicos y revestimientos pictóricos fueron renovados en época antonina (Mar et al. 2012: 143). La periferia urbana más cercana a la muralla, sobre todo en el costado suroeste, adquirió desde época augustea una apariencia prácticamente urbana, debido al elevado número de viviendas que ocuparon ese espacio (Macias 2004: 76). Dentro del siglo II, se reconstruyen y reforman algunas de estas viviendas. Es el caso de una domus de cronología augustea hallada en la excavación de la c/ Alguer 9, situada a pocos metros de la muralla occidental. En época antonina fue reformada, constituyéndose en una casa articulada en torno a un peristilo porticado de planta irregular, ornamentado con una fuente central. La casa destaca por su profusa decoración: pavimentos que combinan el sectile y el signinum (este último para las zonas cubiertas de lechos), zócalos decorados con pinturas, así como un triclinio enlosado con un opus sectile de mármoles locales y de importación que forman motivos geométricos (Macias y Puche 1997: 153-154, Perich 2014: 133). Otro ejemplo se encuentra en el suburbio portuario. Se trata de la domus de c/ Eivissa 9, conocida solo parcialmente, que presenta un triclinio decorado con pinturas y un larario, así como una galería cubierta de pinturas que representan una venatio (fig. 5) (Adserías et al. 2000: 140, Macias et al. 2007: 144-145). Finalmente, la vivienda documentada en avda. Prat de la Riba 9 incorporó en este siglo un triclinium aestivum (Cortes 2009: 517). Al margen, en época antonina también se reconoce este mismo proceso de embellecimiento y reformas en viviendas situadas en el extrarradio urbano y en las villae diseminadas por el ager Tarraconensis (Macias 2001: 40-50, Keay 2004: 102).

\section{Caesar Augusta}

Aunque parcial, la información disponible sobre las viviendas de Caesar Augusta es abundante y, pese a sus limitaciones, posibilita un conocimiento general del estado de la arquitectura doméstica en el siglo II (Beltrán y Mostalac 2007: 78-81). Por un lado, es necesario señalar que entre los materiales de construcción empleados en este periodo no figura, curiosamente, el ladrillo. Eso sí, muchas domus fueron pavimentadas con mosaicos como es el caso de las estructuras domésticas 


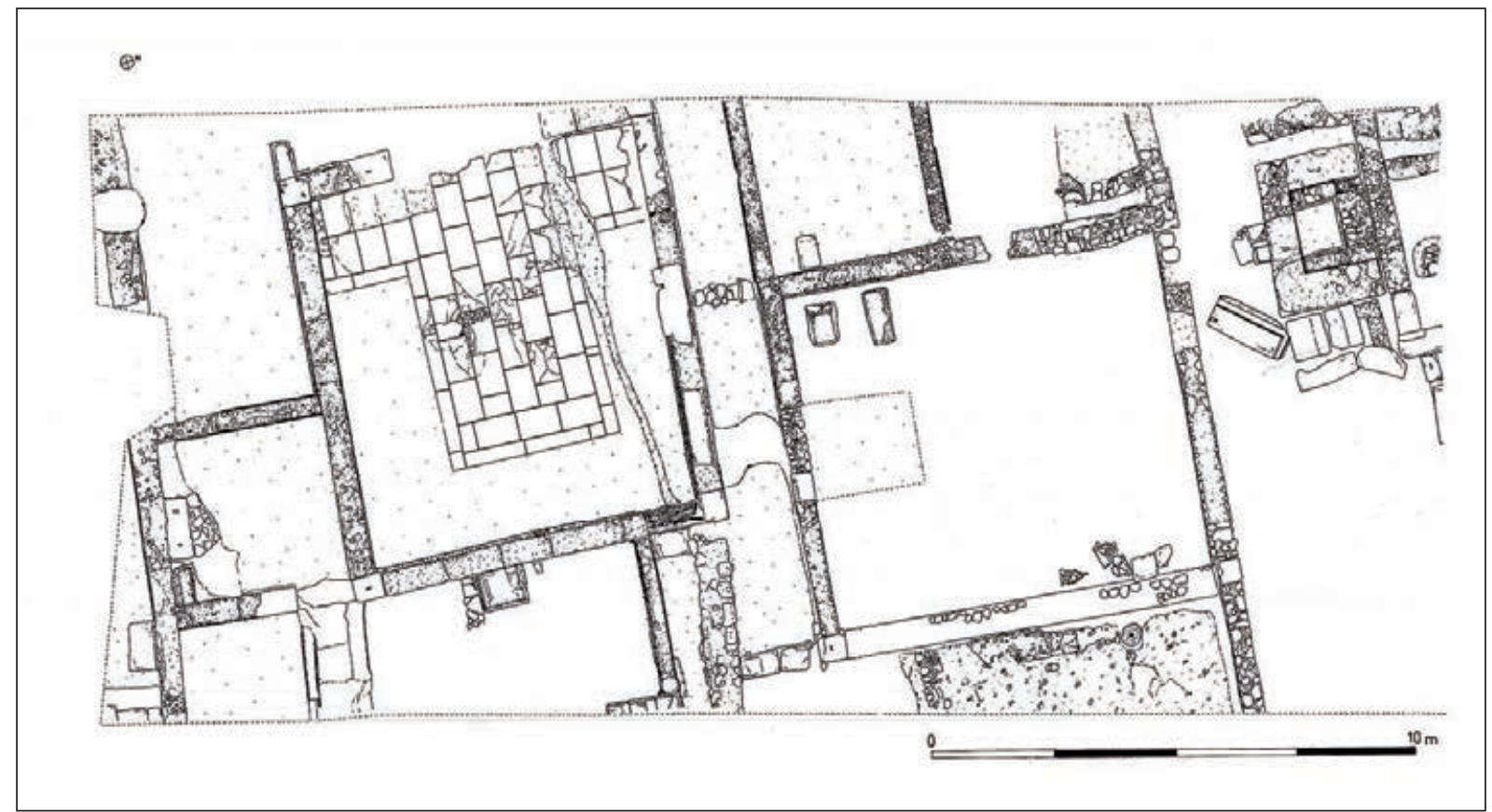

Figura 5. Planta de los restos exhumados de la domus de c/ Eivissa 9 (a partir de Adserías et al. 2000: 148, fig. 12).

exhumadas en c/ Torrenueva 6 y c/ don Jaime (Beltrán et al. 1985, Paz 1991: 21). Por otro lado, algunas excavaciones han sacado a la luz evidencias de balnea como los hallados en la plaza de Santa Marta. En el ángulo noroeste de la ciudad se encuentra la llamada casa de Orfeo, una domus de grandes dimensiones que ha ofrecido notables mosaicos fechados entre finales del s. II y principios del III (Beltrán y Mostalac 2007: 80-81). Para cerrar este apartado, recordemos en último lugar el soberbio ejemplar de escultura de ambiente doméstico cuyo emplazamiento original fue, probablemente, un peristilo. Se trata del llamado "grupo Ena", una escena de ninfas en acto musical datada en época trajanoadrianea (fue hallado en el número 15 de la c/ del Coso) (Koppel y Rodà 2007: 119-120).

En la periferia urbana también han salido a la luz estructuras domésticas. Es el caso de la villa suburbana de la calle Alonso V-Rebolería, de la que solo se ha podido documentar un ambiente porticado en el que apareció una estatua-fuente que representa a un fauno ebrio recostado sobre un lecho (fig. 6) (Beltrán 1952: 439-445). Esta magnífica escultura, elaborada en mármol de Tasos, estuvo destinada a ornar el peristilo de la villa. Se ha datado entre los reinados de Adriano y Antonino Pío (Koppel y Rodá 2007: 120). Una cabeza de sátiro constituye otra singular pieza de ambiente doméstico. Fue hallada en la inmediata periferia, en la calle Teniente
Coronel Valenzuela 6. En este caso, la escultura se data en la segunda mitad del siglo II (Koppel y Rodá 2007: 121-122). La excavación del solar situado en la calle Palomar 4 ha deparado el hallazgo de dos conjuntos pictóricos y cinco fragmentos de cornisas de estuco fechados en el siglo II, que pertenecieron a la reforma decorativa de una vivienda (Guiral 2015: 125-130). Un gran número de viviendas suburbanas, incluida las dos citadas anteriormente, se abandonan en el transcurso de la segunda centuria. Es el caso de las domus de calles Predicadores 24-26, plaza de España, Palomeque 12 y plaza de San Miguel. Esta dinámica de abandonos se ha querido relacionar con una posible restauración o reforma de la cercana línea de muralla, teoría para la que, de momento, no existe refrendo arqueológico (Beltrán y Fatás 1998: 62-64, Beltrán y Mostalac 2007: 78).

\section{Carthago Nova}

En lo que concierne a la arquitectura doméstica de Carthago Nova, durante toda la primera mitad del siglo II d.C. se aprecia cierta ebullición centrada, especialmente, en la actualización de los programas decorativos de antiguos inmuebles (Fernández Díaz y Quevedo 2008: 283). Así lo atestigua la aparición de toda una serie de elementos: piezas arquitectónicas de 
carácter ornamental, pavimentos marmóreos de importación, pinturas murales del IV estilo y un buen conjunto de esculturas domésticas y de jardín (Noguera 2002a: 85-86, Soler 2005: 52, Soler 2017: 85, Fernández Díaz 2017: 79-82). Entre las domus que presentan un horizonte constructivo datado en la primera mitad de la segunda centuria se encuentra la situada en la c/ Gisbert 14, donde se han hallado unos capiteles corintizantes de mármol blanco de esta época. O bien, la llamada domus de la c/ Saura, situada en la ladera septentrional del Monte Sacro, cuyo triclinium fue ornamentado con un opus sectile datado también en este periodo (fig. 7) (Soler 2003: 161, Fernández Díaz y Quevedo 2008: 286-287). Dicho inmueble sufrió varias remodelaciones hasta su amortización definitiva. Entre las pinturas más interesantes del conjunto se encuentran las de la habitación V (datada a mediados del siglo II) y las de la estancia VI (de inicios de la segunda centuria) (Martín et al. 2001: 41 y ss.). Igualmente, la domus de la Gorgona presenta un pavimento de opus tessellatum de similar cronología (Fernández Díaz y Suárez 2006: 96-100).

Este panorama contrasta abruptamente con el que se registra en la segunda mitad del siglo II. De todos los cambios que experimentó la ciudad en este marco temporal, el más llamativo es, sin duda, el abandono del sector centro-oriental, área con una marcada función residencial. De este modo, a finales de siglo se produce un abandono en cadena de muchas domus, construidas a inicios de la época imperial, algunas de las cuales habían sido rehabilitadas a principios del siglo II. Las intervenciones arqueológicas llevadas a cabo en los últimos años demuestran que el espacio habitado se redujo al extremo más cercano al puerto y que la población se replegó en la lengua de terreno existente entre el cerro del Molinete y el de la Concepción (Vizcaíno 1999: 93-95).

Por tanto, la retracción de Carthago Nova se hace patente en la reducción de la extensión habitada a prácticamente la mitad del espacio delimitado por sus antiguas murallas (Noguera 2002b: 85, Ramallo 2006: 453). Pero no solo se registran abandonos en aquel sector, también fueron deshabitadas algunas casas de la parte occidental (Ramallo y Vizcaíno 2007: 495). Los inmuebles situados en c/ Duque 33, Beatas, Caballero 7 y 8, plaza de la Merced 1, Cuatro Santos 40, Serreta 3 y 9, así como las domus de Fortuna, de la Gorgona, del Peristilo Pintado, del Sectile y del Barrio universitario, presentan una fase de abandono homogénea, situada cronológicamente en la segunda mitad de siglo II d.C. (Vizcaíno 1999: 93, Ruiz 1996: 503-514,

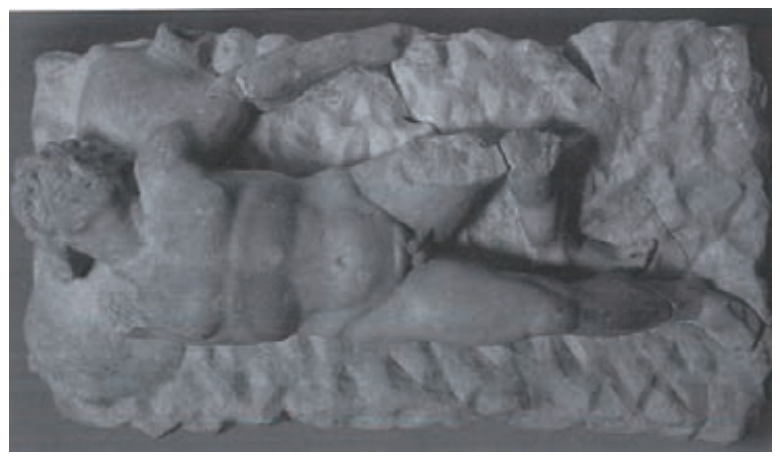

Figura 6. Fauno (a partir de Koppel y Rodá 2007: 121, fig. 11).

Martín et al. 2001: 47-48, Soler 2003: 168, Madrid 2004: 69, Fernández Díaz et al. 2005: 143-144, Fernández y Quevedo 2008: 291, Fernández Díaz 2017: 79-82, Madrid 2017: 74-75).

No obstante, tal vez sería incorrecto indicar que estas viviendas fueron completamente abandonadas. Más bien se transformaron, pues de forma previa a su definitiva ruina acogieron nuevos usos artesanales y habitacionales. Las antiguas residencias fueron convertidas en improvisados talleres, mientras que algunas casas fueron compartimentadas. Por consiguiente, bajo el denominador común de la reutilización y la precariedad que trajeron consigo los nuevos tiempos, más que de "abandono" cabría hablar de cambio en el uso de las nobles domus altoimperiales (Soler 2003: 176, Fernández Díaz y Quevedo 2008: 300-301). A la vez, este sector se convierte en un lugar de expolio de materiales constructivos y de vertidos de residuos (Martín et al. 2001: 47, Fernández Díaz et al. 2005: 143, Egea et al. 2011: 292). Incluso en el hinterland de la ciudad se detectan niveles de abandono que revelan la severa regresión urbana que vivió Carthago Nova en esta etapa (Murcia 1999: 231-236).

\section{Clunia}

Casi todas las intervenciones acometidas hasta la fecha se han centrado en los espacios públicos de la ciudad, quedando aún por excavar la mayor parte del núcleo urbano, justamente aquellos sectores que fueron ocupados, previsiblemente, por viviendas. Aun así, existen algunos ejemplos de arquitectura doméstica en Clunia. Para el espacio cronológico que nos ocupa, hay que citar una intervención en la casa 1 (o de Taracena). Se trata, en concreto, de la ornamentación de dicha domus 


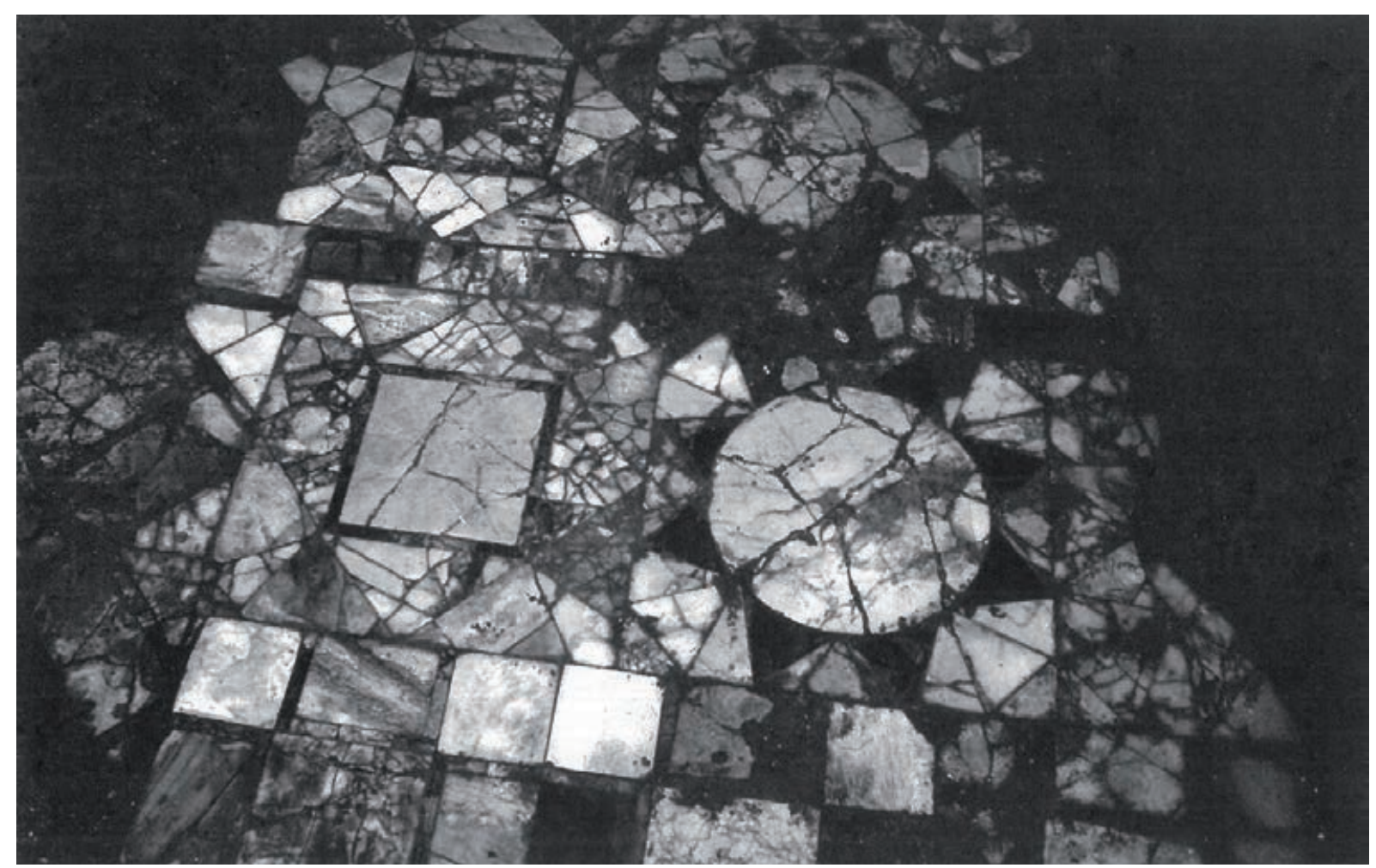

Figura 7. Opus sectile de la domus de la c/ Saura (a partir de Fernández Díaz y Quevedo, 2007-2008: 289, fig. 7).

con pinturas consistentes en plafones con temas florales geométricos propios de un momento avanzado de la segunda centuria (De Palol 1994: 46-48). Por otro lado, la habitación 8 de la casa 3 (o de la Ermita) presenta un mosaico geométrico y vegetal, con círculos en los que se representan cráteras, que ha sido fechado en un momento impreciso del siglo que nos ocupa ( $\mathrm{De} \mathrm{Pa}-$ lol 1994: 61-64). A este repertorio cabría sumar algunos elementos de decoración arquitectónica, basas y capiteles, procedentes de construcciones domésticas que apuntan una cronología de la segunda mitad del siglo II (Gutiérrez Behemerid 2002: 225-227).

\section{Asturica Augusta}

Posiblemente, la vivienda sea el aspecto mejor conocido de la Asturica del siglo II. Efectivamente, se han documentado, al menos, una decena de viviendas, de las cuales la mayoría presenta una fase constructiva o decorativa coincidente con nuestra etapa de estudio. A pesar de esto, debido a la naturaleza de las intervenciones arqueológicas en contexto urbano, ninguna de las domus ha podido ser excavada al completo.
A finales del siglo II o principios del III, la conocida como casa del Pavimento de Opus Signinum, situada en los aledaños del foro, incrementó su ya notable equipamiento con la construcción de un área termal de la que se han conservado una estancia calefactada y el praefurnium (fig. 8) (Burón 1997: 61-63, 2002: 265-266). Esta fase se completa con la pavimentación de dos corredores cercanos al peristilo con mosaicos polícromos de tema geométrico (Burón 1997: 63-64). La domus del Mosaico del Oso y los Pájaros se encuentra, también, muy cerca del foro. Se trata de una vivienda noble, fruto de varias fases, que incluye unas termas privadas (García y Vidal 1993: 23-28). A inicios de época severiana, el oecus o triclinium fue decorado con un mosaico de unos $70 \mathrm{~m}^{2}$ con figuraciones animalísticas y vegetales que da nombre a la casa (Regueras 1991: 140-154). Por su parte, la llamada domus de las Pinturas Pompeyanas destaca por la calidad de sus revestimientos pictóricos, fechados en el segundo cuarto del siglo II, calificados como uno de los mejores ejemplos de decoración pictórica de Hispania (Abad 1982: 293-295). Asimismo, la casa de las Columnas Pintadas ha ofrecido varios fragmentos de decoración pictórica compuestos por columnas estriadas que separan paneles datables a finales del 


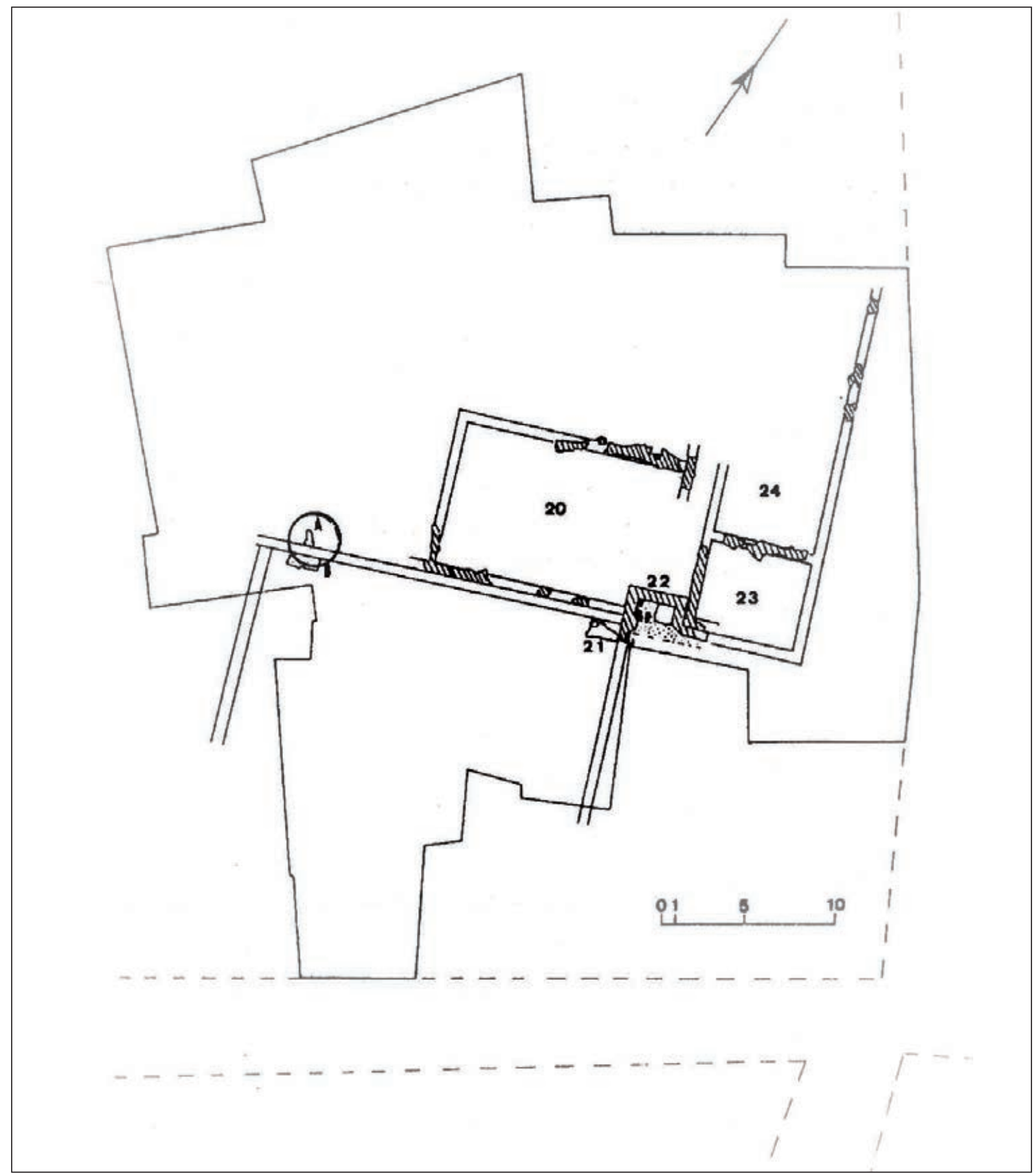

Fig. 8. Planta del balneum construido a finales del siglo II o principios del III, casa del Pavimento de Opus Signinum (a partir de Burón 1997: 63).

siglo I o principios del siglo II (García Marcos y Vidal 1999: 929-930).

La casa de la Muralla se emplazaba en el límite oriental de la ciudad. Fue derribada entre finales del siglo I d.C. e inicios de época antonina. Ya en pleno siglo II fue reedificada respetando su distribución anterior. De esta fase datan un área termal, varias estancias decoradas con pinturas murales del tercer estilo y 
zonas de servicio (García Marcos y Vidal 1999: 928929). El fenómeno del arrasamiento de las estructuras precedentes vuelve a darse en el caso de la domus del Gran Peristilo, situada en las inmediaciones de las Termas Mayores. En efecto, tras su derribo, en el siglo II, se construyó un peristilo porticado dotado de una gran fuente, alrededor del cual se establecieron las distintas habitaciones (García Marcos y Vidal 1999: 928).

\section{Bracara Augusta}

Las excavaciones desarrolladas en el antiguo solar de Bracara han sacado a la luz bastantes testimonios de estructuras domésticas. Sin embargo, la única vivienda excavada de forma íntegra es la llamada domus das Carvalheiras, una casa de atrio y peristilo construida en época flavia que ha sido tomada como paradigma de la casa bracaragustana (Martins 2009: 198). Con todo, V.H. Correia (2017: 33) interpreta la construcción como macellum. La vivienda, situada en el cuadrante noroeste de la ciudad, ocupaba en origen una extensión de $1.150 \mathrm{~m}^{2}$. En la primera mitad del siglo II, el sector al este del peristilo fue amortizado para la construcción de las termas homónimas. Hasta ese momento, dicho sector estaba ocupado por cubicula, así como por unas tabernae que abrían a una calle porticada (Martins 1997-1998: 32, Ribeiro y Martins 2013: 77). Otra estancia reestructurada en esta fase fue la sala situada al sur del peristilo, en cuyo espacio se crearon dos estancias interpretadas como cubicula (Magalhães 2010: 43). Finalmente, en la rua Santo António das Travessas se documentó una domus con restos de decoración pictórica cuya cronología se remonta a la segunda mitad del siglo I d.C. Esta vivienda fue destruida entre mediados y finales del siglo II para construir en su solar un edificio público de naturaleza desconocida (Magalhães 2010: 58-67).

\section{Emporiae}

El hecho de que solo se haya excavado una mínima parte de este municipio, sobre todo espacios públicos, limita bastante el nivel de conocimiento que tenemos sobre la arquitectura doméstica en Emporiae. No obstante, se han documentado varias domus de enorme extensión (casa 1 y casa 2B) no exentas de transformaciones en el periodo que nos ocupa. En este sentido, las viviendas acogieron una última reforma a inicios de siglo, antes de su abandono, momento en que la crisis ya era patente en la ciudad (Santos 1991: 34, Santos 2012: 69-70). En concreto, ambas casas incorporan estancias de uso convivial, conectadas con jardines interiores para ser usadas en verano. En la casa 1 la sala se construye a uno de los lados del peristilo. Además de pavimentarse determinados ambientes con mosaicos, entre los intercolumnios de dicho jardín se añadieron plutei decorados con imitaciones de crustae de mármol. En la casa $2 \mathrm{~B}$ se erigió un gran salón con antecámara abierto al hortus oriental (Santos 2012: 81-82).

Todo indica que estas grandes mansiones (cuya extensión total superó los $3.000 \mathrm{~m}^{2}$ tras su última reforma) serían muy difíciles de mantener y fueron presa de la dinámica de ruina que vive Emporiae en época antonina. Los materiales arqueológicos fechan el abandono final de las viviendas en la segunda mitad del siglo II (Mar y Ruiz de Arbulo 1993: 418, Santos 2012: 83).

\section{Baetulo}

Uno de los mejores ejemplos domésticos baetulonenses es la casa de Quinto Licinio, datada a finales del siglo I o principios del II. Se trata de un gran edificio que ocupa una extensión de $3.000 \mathrm{~m}^{2}$, enclavado junto a la puerta oriental de la ciudad. De hecho, curiosamente, la domus se asienta sobre la muralla fundacional, amortizando parte de su trazado. De entre sus múltiples espacios, destaca un gran peristilo decorado en su centro con un estanque absidiado de $13 \mathrm{~m}$ de longitud ( $\mathrm{Cu}-$ yás 1977: 139-142, Padrós y Sánchez 2014: 103). El nombre de la casa deriva del hallazgo en su interior de la tabula hospitalis de Q. Licinius Silvanus Granianus (AE 1936, 66). La datación de la vivienda, así como el hallazgo in situ de la tabula invitan a pensar que esta fastuosa vivienda pudo pertenecer al patrono de Baetulo (Guitart 1976: 139-142).

Además, hemos podido analizar algunas intervenciones de carácter menor en contextos domésticos. Es el caso de la casa 2, situada en el kardo minor II. A esta construcción pertenece una taberna que fue ampliada a inicios de la segunda centuria a costa de reducir las fauces de la propia vivienda (Padrós y Sánchez 2014: 111). En el patio de la casa documentada en la c/ Fluviá 23 se documentó una reforma datable en el primer cuarto del siglo II. Al parecer, el cerramiento de la boca de un pozo, así como la creación de un nivel de suelo que amortiza la huella de los dolia documentados en la fase previa, demostrarían que dicho espacio dejó de usarse como almacén (Guitart et al. 1991: 42). Por último, probablemente a inicios del siglo II, una de las 
de la casa del patio de la Rectoría de Santa María, edificada a finales del siglo I a.C., fue adornada con un mosaico polícromo con decoración geométrica (Guitart et al. 1991: 42).

A finales del siglo II y en época severiana el panorama cambió radicalmente. Se evidencia un proceso de abandono que repercute especialmente en la parte baja de la ciudad y en los aledaños del foro (Padrós y Sánchez 2014: 112). Efectivamente, las domus del Dofins y de l'Heura, ambas construidas en época augustea y situadas junto al foro, fueron amortizadas a finales del siglo II. También se han detectado niveles de abandono en el patio de la Casa 1 (Padrós y Sánchez 2014: 111). Este proceso afecta igualmente a un gran número de $t a$ bernae. Concretamente, en un solar adyacente a la Torre Vella se excavó una insula ocupada por cinco de estos espacios comerciales que se amortizó a mediados de la segunda centuria (Guitart et al. 1991: 45). Asimismo, en la calle Templo se efectuó un sondeo que sacó a la luz dos tabernae con planta superior cuyo derrumbe aconteció a mitad del siglo II. Por su parte, las tabernae pertenecientes a las casas 3 y 6 presentan unos niveles de abandono que se datan a finales del siglo que nos ocupa (Padrós y Sánchez 2014: 111-112).

\section{Barcino}

Las domus de la colonia suelen presentar dos características comunes: por un lado, se trata de casas nobles con estancias articuladas en torno a un atrio o peristilo; y, por otra parte, la mayoría data de finales del siglo I y principios del II (Beltrán de Heredia 2010: 35, Cortés 2011: 61). La domus de Sant Miquel, que, sin embargo, se remonta a época fundacional, sufrió una reforma entre finales del siglo I y principios del II, consistente en la instalación de un balneum que ocupó parcialmente una vía pública (Cortés 2011: 21 y 25, Miró 2011: 71-72). En la domus de la plaza de Sant Iu se ha documentado una habitación pavimentada con mosaicos y abierta a un viridiarium dotado de estanques. Esta nueva estancia se adscribe a una remodelación de la casa operada en el siglo II (Cortés 2011: 28, 2014: 123). Por otro lado, aunque solo se conoce una pequeña parte de la domus de la calle Avinyó, su decoración musivaria y parietal (encuadrada dentro del IV estilo) se ha fechado entre la segunda mitad del s. I y el s. II d.C. (Cortés 2011: 36, Beltrán de Heredia y Cortés 2018: 137-156). El opus tessellatum de la habitación 2 se ha datado, justamente, en la fecha de nuestro estudio (Beltrán de Heredia y Cortés 2018: 142-143).

\section{Saguntum}

Tan solo una domus de las excavadas en el antiguo solar de Saguntum entra dentro de nuestros límites cronológicos. Se trata de una vivienda situada en los terrenos del cine Marvi y de la que se han documentado varias estancias (Antoni et al. 2002: 99-116). La construcción de la domus se ha datado en el siglo II, si bien fue ampliamente reformada en una fase posterior, durante el siglo III. Por lo que respecta a su decoración original, destaca el revestimiento pictórico del tablinum, compuesto por imitaciones de crustae de giallo antico (Antoni et al. 2002: 110-111).

\section{Valentia}

La arquitectura doméstica sigue siendo uno de los aspectos menos conocidos del pasado romano de Valentia a pesar de los notables avances que se han dado recientemente (Ribera y Jiménez 2012: 101). Para el periodo que nos ocupa, el mejor ejemplo de vivienda es la llamada casa de Terpsícore, conocida a raíz de las intervenciones desarrolladas en el Palau de les Corts (no obstante, se han planteado otra funciones distintas a la doméstica para esta construcción vid. Escrivá et al. 2016: 428-434). Se trata de un lujosa domus articulada en torno a un atrio y un peristilo. Su construcción se desarrolló en época flavia y, posteriormente, fue reformada en la segunda mitad del siglo II. Especial interés reviste la decoración que presenta la vivienda, en concreto, una exedra cuyo pavimento fue decorado con un gran mosaico, en el que se representó la musa que da nombre a la casa (Jiménez 2006: 479480). Las paredes de la exedra fueron revestidas con un ciclo pictórico de alegorías provinciales, es decir, una serie de figuras femeninas ataviadas con los símbolos más característicos de cada provincia, acompañadas de su nombre en griego dentro de una cartela (fig. 9) (De Hoz 2007: 131-146). Recientemente, se ha excavado una vivienda suburbana en la c/ Purísima. La casa, datada a inicios del siglo II, se sitúa al SO del núcleo urbano, a menos de un kilómetro de las murallas. Estructuralmente está compuesta por una serie de habitaciones, decoradas con mosaicos bícromos con motivos vegetales y geométricos, dispuestas en torno a peristilo trapezoidal (Machancoses y Peñalver 2017: 139-164). Finalmente, cabría indicar que la domus documentada en la plaza de la Almoina quedó amortizada a finales del s. II o inicios del III d.C. (Roselló y Soriano 1998: 43). 


\section{Lucentum}

Solo una de las viviendas conocidas, la domus de la Puerta Oriental, ha arrojado evidencias que se pueden encuadrar dentro del marco temporal de nuestro estudio. La casa se sitúa junto a la torre III del lienzo murario, justo en el sector este de la ciudad (Olcina y Pérez Jiménez 1998: 81). Tras su excavación se comprobó que la residencia presentaba dos fases, a la segunda de las cuales se debe la decoración pictórica de la habitación norte, consistente en una imitación de mármol cipollino y pavonazzetto que cabría datar en época trajano-adrianea (Fernández Díaz 2000-2001: 8-11). Finalmente, la domus fue abandonada en el último cuarto del siglo II (Olcina 2009: 108).

Por otra parte, todo el terreno que delimitaba el núcleo urbano de Lucentum ha sido invadido por construcciones recientes, otorgándonos una visión del yacimiento muy diferente a la que presentaba en época romana. Lógicamente, la construcción de estas edificaciones, llevada a cabo sin control arqueológico alguno, supuso una gran pérdida de información sobre los $s u$ burbia de la ciudad. A pesar de todo, en el hinterland de Lucentum se han podido excavar algunas villae, tanto rurales como suburbanas. La mayor parte de ellas surgieron a inicios de época imperial y su abandono coincide con el momento de declive de la ciudad: el siglo II (Ortega 1999: 471, Olcina 2009: 119-122). Es el caso de la villae de Balsa Finca Castillo y de Casa Ferrer II (Ortega 1999: 471).

\section{Bilbilis}

Los trabajos arqueológicos desarrollados en el yacimiento se han centrado, principalmente, en el estudio del centro monumental. Sin embargo, también se han analizado de forma paralela algunas domus que tuvieron que acomodarse a la abrupta orografía del terreno donde se asienta la ciudad (Martín-Bueno 1991). La información disponible es limitada para el periodo que nos interesa. En la zona meridional del cerro de San Paterno se excavó una vivienda adaptada al sistema de aterrazamiento, puesto que se construyó en dos niveles, uno superior de carácter habitativo y una bodega inferior. La casa, cuya construcción se fecha a inicios del siglo I o principios del II, estuvo decorada con pinturas y presenta una cronología de abandono temprana, siendo deshabitada a finales del siglo II (Martín-Bueno 1991: 174, Guiral y Martín-Bueno 1996: 287-289). En la falda suroriental del cerro de
Bámbola se documentó otra vivienda cuyo aparato decorativo se fecha en el siglo I d.C. y que fue abandonada en la primera mitad de la segunda centuria (Martín-Bueno 1991: 171).

\section{Segobriga}

Las excavaciones y prospecciones desarrolladas en el interior del núcleo urbano no han arrojado testimonios de viviendas en Segobriga. Es decir, todo el área circundada por las murallas estuvo ocupada por edificios públicos y no existen evidencias de construcciones privadas hasta época tardía (Abascal y Cebrián 2007: 543, Abascal y Almagro 2012: 320). Por tanto, habría que pensar que los vecinos residirían en las afueras de la ciudad, ya fuese en viviendas suburbanas o en villae agrícolas. Por otro lado, una gran parte de la población dependió económicamente de la explotación del lapis specularis y, en consecuencia, habitaría en las proximidades de las minas (Abascal y Almagro Gorbea 2012: 320). La única excepción es la domus atribuida al procurador imperial C. Iulius Silvanus. Esta vinculación se deriva del hallazgo en los aledaños de la casa de un altar dedicado por Silvanus a Zeus Theos Megistos. La vivienda se situaba en la zona alta de la ciudad, junto a las termas. De entre las diversas estancias que la componían llama la atención la número 1, espacio consagrado a la citada divinidad de origen griego como santuario particular (Cebrián 2002-2003: 131). En paralelo, destaca la estancia 2, decorada con un rico mosaico y pinturas murales (Abascal y Cebrián 1999: 299, Cebrián y Fernández 2004). Las evidencias arqueológicas coinciden con la cronología propuesta para la inscripción, de forma que esta suntuosa casa debió de erigirse a principios de época severiana (Abascal y Cebrián 1999: 301).

\section{DISCUSIÓN Y CONCLUSIONES}

Como es sabido, la arquitectura doméstica nos brinda información sobre infinidad de aspectos de la vida en las ciudades. Desde el punto de vista de la urbanística, permite analizar el tejido doméstico y el trazado viario; es decir, la distribución planimétrica de una ciudad. Asimismo, el examen de los repertorios ornamentales y de los diferentes ambientes domésticos posibilita evaluar el avance de las modas y determinar el nivel socioeconómico y cultural de los habitantes de 
una determinada comunidad urbana. Igualmente, hay que tener en cuenta que cada casa constituye un microcosmos singular e irrepetible; es decir, un conjunto arquitectónico sujeto a procesos de construcción, transformación, abandono y reutilización (Fernández Vega 1999, Gros 2007: 392-395).

Desde un punto de vista general, el siglo II supuso una época de gran dinamismo para la arquitectura doméstica. Como hemos visto, buena parte de las domus de las ciudades examinadas vivieron en esta etapa intervenciones de distinto signo relacionadas, en su mayor parte, con un aumento del lujo y el bienestar (bien es verdad que nuestro conocimiento es relativo, ya que apenas se conocen las moradas de las capas más bajas de la población hispanorromana). Atendiendo a la documentación arqueológica, podemos concluir que más que un auge de la edificación de nuevas viviendas (que, no obstante y como es natural, se seguirán construyendo), las principales intervenciones en ámbito doméstico se limitaron a ligeras modificaciones en la distribución espacial y actuaciones de orden decorativo.

En efecto, muchas domus de esta época fueron remodeladas arquitectónicamente, lo que conllevó que cambiaran su distribución y asumieran nuevos espacios. En estos casos, es común que la reforma concluya con el embellecimiento de la vivienda. En época antonina, los nuevos ámbitos creados en los domicilios fueron, fundamentalmente, baños domésticos (balnea) y estancias de uso convivial conectadas con jardines para su uso en verano (triclinia aestiva). Del mismo modo, el registro arqueológico revela que una gran proporción de las domus preexistentes se dotaron de nuevos repertorios decorativos en época antonina, especialmente, en la primera mitad de siglo. Entre tales elementos ornamentales destacan: piezas de decoración arquitectónica, pinturas murales del IV estilo, pavimentos marmóreos, así como esculturas domésticas y de jardín (Ramallo 1990: 141-160, Pérez Olmedo 1996: 4249, López Monteagudo 2003: 301-333, Garriguet 2013: 266 y ss., Fernández Díaz 2014: 209-216); elementos y composiciones que demuestran la permeabilidad de las provincias hispanas en lo que respecta a modas estilísticas. En este sentido, los espacios en los que se enfocó la atención fueron perystila-viridiaria, triclinia y, en menor proporción, tablina y oeci; todos ellos ambientes domésticos abiertos a amigos y clientes en los que se proyectaba la riqueza y estatus del dominus (Ellis 1991, Hales 2003: 135 y ss.).

Como se ha dicho, y a pesar de no ser el rasgo distintivo de la arquitectura doméstica, no faltan ejemplos

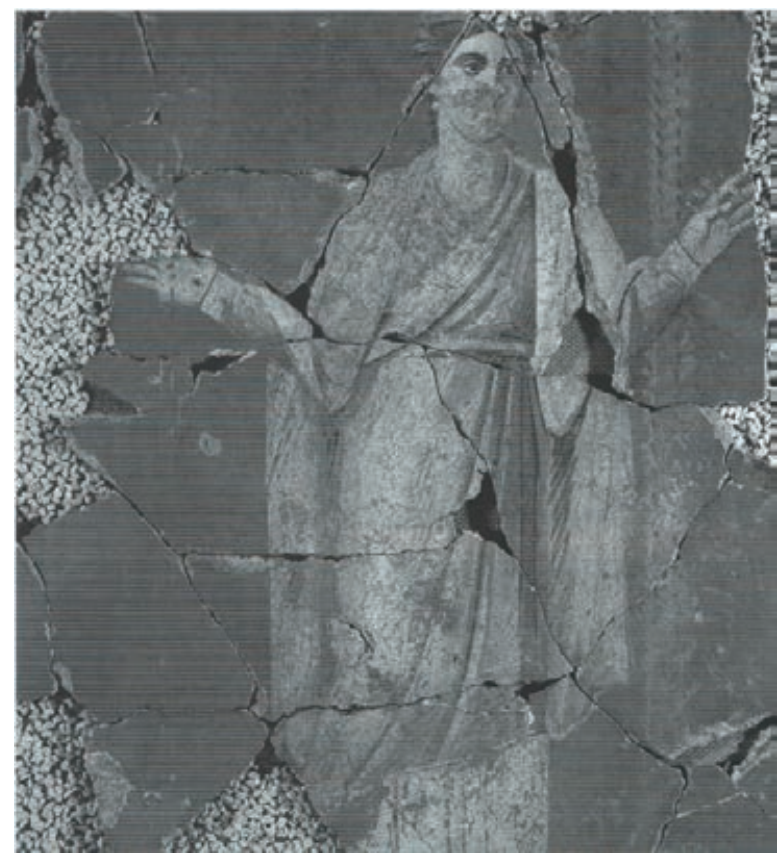

Figura 9. Probable representación de África (a partir de De Hoz 2007: 144, fig. 4).

de casas edificadas en la segunda centuria. Así, la edilicia doméstica de urbes especialmente dinámicas como Astigi, Augusta Emerita, Barcino, Carthago Nova y Munigua comparte un horizonte constructivo común en la primera mitad del siglo II. El modelo de casa imperante en época antonina es la domus de peristilo. $\mathrm{Si}$ bien es cierto que este esquema de vivienda surge en la Hispania de época augustea, será en la segunda centuria cuando desplace definitivamente al modelo de atrio, y continuará siendo predominante durante los siglos III y IV d.C. (Beltrán 2003: 32 y 52, Gros 2001: 148-150, Cortés y Guitart 2011: 45-46, Cortés 2014a: 77-80). Bajo este esquema se articulan diferentes variantes: peristilo porticado concebido como un espacio ajardinado, o bien como espacio abierto sin vegetación; igualmente, también existieron viviendas de peristilo con patios secundarios y viviendas en las que este espacio distribuidor fue el único del hogar (Beltrán 2003: 31). Esta dinámica se registra no solo en Hispania, sino también en la gran mayoría del resto de provincias durante esta etapa (Gros 2001: 148-195, Beltrán 2003: 51 y not. 190). Encontramos excelentes modelos de casas de peristilo de esta cronología en Augusta Emerita, Baetulo, Conimbriga, Valentia y, sobre todo, en Italica. En efecto, la ampliación de esta última ciudad contó con unas domus que representan el mejor y más lujoso ejemplo de vivienda de peristilo de las documentadas 
en Hispania (Gros 2001: 179-184). Se trata de unidades habitacionales de hasta $2.000 \mathrm{~m}^{2}$ de superficie con una fachada porticada en la que, normalmente, se disponen varias tabernas. La distribución interior queda jerarquizada por medio del peristilo, en cuyo eje se abre un triclinium (García y Bellido 1960: 81-102, Luzón 1983: 79 y ss., Mañas 2010: 81-97).

Por otro lado, el siglo II es el momento en el que se difunde el termalismo privado. Por tanto, no extraña que un buen número de domus de esta etapa incorporaran pequeños establecimientos termales; fenómeno que, por otro lado, hay que relacionar con un incremento del grado de confort doméstico (García-Entero 2006: 741744 y 868). De hecho, los baños privados constituyeron un signo de refinamiento y posición económica; ya que, en efecto, mientras que el grueso de la población debía contentarse con acudir a las termas públicas, ciertos privilegiados contaron con balnea en sus propios hogares (Fernández Vega 1999: 218-225). La luxuria que implicaba la posesión de un balneum fue reseñada por varios autores, como es el caso de Séneca (Ep. 86. 7.) y Petronio (Satyr. 73. 2.). Ciertamente, existieron viviendas con ambientes termales desde época republicana, pero no será hasta finales del siglo I d.C. y, sobre todo, durante el siglo II cuando los baños domésticos se conviertan en tendencia en Hispania (García-Entero 2007 2008: 251-254). En el marco cronológico de nuestro estudio, la mayor parte de los balnea se construyeron en residencias preexistentes, por lo que fue necesario amortizar espacios y estancias secundarias de las domus. Generalmente, se ubicaron junto a uno de los pasillos del peristilo de la vivienda y, en menor proporción, en jardines o patios interiores, en una posición menos central (García-Entero 2008: 251-263). Así pues, a la luz del hallazgo de numerosos balnea en ciudades como Augusta Emerita, Barcino, Bracara, Caesar Augusta, Conimbriga y Asturica Augusta, podemos afirmar que la construcción de baños privados constituye uno de los rasgos característicos de las viviendas del siglo II (Fernández Ochoa y García-Entero 2000).

La ampliación de muchas unidades habitacionales se hace a costa de edificar la totalidad de la parcela, amortizando para ello jardines o estancias de servicio. Otras veces, la expansión de la vivienda se lleva a cabo a partir de la compra de terrenos o espacios edificados privados. Hasta aquí nada nuevo; sin embargo, desde el siglo II se registran los primeros casos de extensión de viviendas a costa de espacios públicos. Este fenómeno se ha venido fechando tradicionalmente a partir del siglo III d.C., pero su génesis se encuentra en esta etapa. El ejemplo más evidente se documenta en Augusta Emerita, donde los pórticos de las calles pasaron gradualmente a ser absorbidos por viviendas (Alba 2004: 75). Un caso similar se desarrolló en Barcino, en concreto, la domus localizada en la plaza de Sant Miquel incorporó en el siglo II un conjunto termal, construido, en parte, sobre un kardo minor (Miró 2011: 71-72). Esta dinámica también se detecta en la capital de la Bética, valga como ejemplo la domus de época augustea localizada en plaza Pineda 2. Dicha vivienda fue ampliada en la segunda mitad del siglo II a costa de ocupar la mitad de la extensión de un decumanus minor. Otras veces, como se ha documentado en la intervención de c/ Tomás Conde 8, la invasión por parte de los edificios colindantes provocó, a mediados del siglo II, la reducción de la anchura de una vía (Ruiz Bueno 2014: 46-47, 2015: 102). Esta merma del espacio público, rara antes del siglo II, parece que se relaciona tanto con la falta de superficie edificable en el interior del entramado urbano, como con la relajación de las autoridades en dicha materia. Tal abuso edilicio quedó expresamente prohibido en la legislación y revela, en cierta medida, la prevalencia de la esfera privada sobre la pública, tendencia que no hará más que aumentar con el paso del tiempo (Zaccaria 1995: 260263). Dicha práctica se penaliza de forma expresa en el Edictum perpetuum praetoris urbani, III. De locis et itineribus publicis. Igualmente, en el capítulo XIX de la lex Irnitana se especifica, entre otros aspectos, que era potestad de los ediles la supervisión, limpieza y conservación de las calles, así como la vigilancia de que no hubiera obstáculos que dificultaran el tráfico (cura viarum). En CIL X, 1018 y CIL VI, 266 encontramos dos casos de apropiación de terreno público en época altoimperial por parte de privados recogidos en la epigrafía.

Por último, otro fenómeno que afecta a la arquitectura residencial es el abandono o cambio de uso original. La edilicia doméstica no es ajena a las dificultades que vivieron determinadas comunidades urbanas desde finales del siglo II (Ramallo y Quevedo 2014, Brassous y Quevedo 2015; Andreu 2017). Las huellas materiales de este declive están reflejando un cambio de orden demográfico, económico y político en estas localidades. Esta "decadencia" no solo afectó a las viviendas, puesto que en estas comunidades se detecta no solo falta de intervenciones arquitectónicas, sino también la ausencia de mantenimiento del equipamiento urbano y monumental. Así, el caserío de ciudades como Baetulo, Bilbilis, Carthago Nova y Emporiae, sujeto a los rigores de la crisis económica y demográfica, quedó en buena 
medida abandonado entre la segunda mitad del siglo II y principios del III d.C. (Padrós y Sánchez 2014: 112, Martín-Bueno 2000: 21-22, Vizcaíno 1999: 93, Santos 2012: 83). En estos casos, el tejido urbano fue perdiendo su uniformidad arquitectónica, adquiriendo un estado semirruinoso, de forma que las ciudades acabaron contrayéndose sobre sí mismas (Macías 2012: 72; 2015: 43). La caída de la demografía es difícil de cuantificar con base en registro arqueológico, si bien la amortización de viviendas o su readaptación funcional es un rasgo propio de las ciudades afectadas por la crisis urbana. Hay que subrayar que unos decenios antes de ser abandonados, muchos de estos inmuebles fueron foco de inversión por parte de sus dueños, circunstancia que hace más sorprendente si cabe este fenómeno. No obstante, dicha dinámica no se puede analizar de forma aislada, sino en conjunto con el urbanismo y con las causas y los síntomas de regresión urbana, que pueden ser distintos en función de cada ciudad.

El abandono de viviendas y de sectores urbanos es síntoma de despoblación, como se ha indicado en Emporiae (Nieto 1981: 34-51, Nolla 1993: 212-214, 1998 : 437-439). Sin embargo, no está claro si la caída de la demografía en las ciudades es una consecuencia de la crisis urbana o una causa de la misma. Asimismo, también sería aclarador analizar la evolución del territorio de las ciudades. En este sentido, no existe un patrón común. Por otra parte, la despoblación de las ciudades podría relacionarse con el efecto de la peste antonina (DuncanJones, 1996: 108-136, Scheidel, 2002: 97-114, 2003: 158-176, Bruun, 2003: 426-434). No obstante, no existe en la actualidad ningún tipo de evidencia que autorice a pensar que la enfermedad llegó a las provincias hispanas, si bien sus trazas, en el caso de existir, serían difíciles de reconocer desde el punto de vista arqueológico. Continuando con este asunto, en Carthago Nova y Lucentum el abandono de muchos establecimientos rurales es paralelo a la crisis de la ciudad (Murcia 1999: 231-236, Ortega 1999: 471, Olcina 2009: 119-122). En otras poblaciones, como Iulia Lybica, se ha atestiguado una continuidad en el territorio con respecto a periodos anteriores (Olesti et al. 2014: 72-74). En Baetulo, por su parte, un buen número de villae acogieron remodelaciones arquitectónicas en el siglo II y pasaron a tener una función habitativa (Prevosti 1981: 32). Esto se ha relacionado con un desplazamiento de población del núcleo urbano al territorio (Comas et al. 1999: 4344). También en las villae de la Bética se detectan cambios de tipo arquitectónico y productivo en esta época, transformaciones que están en sintonía con la situación descrita (Fornell 2005).
Todos los fenómenos que venimos comentando se desarrollan, a grandes rasgos, en las tres provincias hispanas. Por tanto, desde el punto de vista territorial, no se observan diferencias notables en las dinámicas globales que afectan a la arquitectura doméstica del siglo II.

Para acabar, cabría hacer una reflexión: en ocasiones se ha hablado de que en época antonina existió un traslado de la inversión a la esfera privada. La naturaleza de nuestro estudio posibilita formular una respuesta al interrogante propuesto. No hace falta que aludamos de nuevo a la traba que supone para ello que las investigaciones se hayan centrado, principalmente, en los espacios y edificios públicos. Por tanto, solo podemos hablar con fundamento de aquellos casos en los que exista un conocimiento firme tanto de la edilicia pública como privada. De esta forma, partiendo de la información arqueológica, es posible afirmar que, en determinados casos, el gasto se concentró de forma preferente en el ámbito doméstico. El caso más evidente lo encontramos en Conimbriga. En efecto, después de la fase de transformación urbana que arranca en época flavia y concluye en época de Trajano, no se ha documentado en el municipio ningún programa constructivo de carácter público. En este sentido, existe más bien un periodo de continuidad y mantenimiento del equipamiento urbano y los espacios monumentales (Correia 2010: 102). Sin embargo, como reflejan las intervenciones efectuadas en las domus de Cantaber, de los Repuxos y de los Esqueletos, los propietarios emplean su patrimonio en la reforma y ampliación de sus suntuosos inmuebles. Otro caso análogo lo encontramos en Emporiae, donde el pulso de la edilicia pública -dejando al margen las termas- es mínimo. Esta comunidad se encuentra en franca regresión desde época flavia y su foro se halla en estado ruinoso desde el inicio del siglo II (Castanyer et al. 1993, Nolla 1993: 1998). No obstante, en esta misma época las casas 1 y $2 \mathrm{~B}$ fueron ampliamente reformadas e incorporaron nuevos espacios, conformando, de esta forma, viviendas con una extensión de $3.000 \mathrm{~m}^{2}$. Aunque existen menos evidencias, esta misma dinámica parece imperar en Barcino y Caesar Augusta. En la segunda se han constatado solo algunas actividades constructivas y decorativas en espacios públicos, pero en el campo de la arquitectura doméstica se advierte, en cambio, un verdadero dinamismo (Casabona y Pérez Casas 1991: 22, Beltrán 1993: 104-106). Muestra de ello son los numerosos pavimentos musivos fechados en este siglo y las refinadas esculturas domésticas encuadradas dentro del clasicismo adrianeo. Por su parte, las intervenciones en la próspera Barcino 
de época antonina también se encauzaron mayoritariamente en el ámbito privado (Rodà 2001: 22-33, Beltrán de Heredia 2010: 31-41).

En síntesis, la arquitectura doméstica es un campo especialmente activo en la segunda centuria. Atendiendo al registro arqueológico de las ciudades analizadas, la mayor parte de las actuaciones consisten en cambios en la distribución espacial, así como en la renovación del aparato decorativo de viviendas de cronología anterior al siglo II, aunque no faltan ejemplos de construcción de nuevas domus. En relación con esto, la atención se focalizó, especialmente, en peristilos y triclinios, como demuestra la gran cantidad de pavimentos musivos fechados en época antonina que decoraban estos espacios de representación. Otro de los rasgos característicos de la edilicia doméstica de este siglo es la construcción de baños privados en los inmuebles, en línea con la luxuria privata y con el interés por las termas públicas que caracteriza este periodo. Ello estaría manifestando, en buena medida, que durante la segunda centuria la inversión de los particulares se trasladó al ámbito doméstico. En efecto, esta es la tónica que impera en Barcino, Caesar Augusta, Conimbriga o Emporiae, ciudades en las cuales el gasto se concentró, preferentemente, en la reforma y ampliación de suntuosas domus frente al mantenimiento del cuadro monumental público heredado del siglo anterior.

\section{Agradecimientos}

El resultado de nuestra investigación se ha beneficiado del apoyo financiero del Programa Estatal de Promoción del Talento y su Empleabilidad, en el marco del Plan Estatal de Investigación Científica y Técnica y de Innovación 2013-2016, entre las que se encuentran las ayudas Juan de la Cierva-formación 2016 (FJCI-201629310).

\section{BIBLIOGRAFÍA}

A.A.V.V. (1991): La casa urbana hispanorromana. Ponencias y comunicaciones. Zaragoza, Institución Fernando el Católico.

Abad, L. (1982): La pintura romana en España. Alicante, Universidad de Alicante.

Abascal, J.M. y Almagro Gorbea, M. (2012): "Segobriga, la ciudad hispano-romana del sur de la Celtiberia", en G. Carrasco (coord.), La ciudad romana en Castilla-La Mancha: 287-370. Cuenca, Universidad de Castilla-La Mancha.

Abascal, J.M. y Cebrián, R. (1999): "Mosaico romano de Segobriga". Archivo Español de Arqueología 72: 299-301, doi: <http://dx.doi.org/10.7203/SAGVNTVM..1861>.

Abascal, J.M. y Cebrián, R. (2007): "Las murallas romanas de Segobriga", en A. Rodríguez Colmenero e I. Rodá (eds.), Murallas de ciudades romanas en el occidente del Imperio: Lucus Augusti como paradigma: 527-546. Lugo, Diputación Provincial de Lugo.

Adserias, A.; Pociña, C.A. y Remolà, J.A. (2000): "L'habitat suburbá al sector afectat pel PERI-2 (Jaume I, Tabacalera)". en J. Ruiz de Arbulo (ed.), Tarraco 99: arqueologia d'una capital provincial romana: 137-154. Tarragona, Universitat Rovira i Virgili.

Alarcão, J. (2010): As casas da zona B de Conimbriga. Coimbra, Centro de Estudos Arqueológicos das Universidades de Coimbra e Porto.

Alba, M. (2004): "Arquitectura doméstica", en X. Dupré (ed.), Las capitales provinciales de Hispania, Mérida, Colonia Augusta Emerita: 67-83. Roma, L'Erma di Bretschneider.

Álvarez Martínez, J.M. y Nogales, T. (2011): "Las producciones pictóricas y musivas emeritenses", en J.M. Álvarez Martínez y P. Mateos (eds.), 19102010, el yacimiento emeritense: 463-490. Mérida, Museo Nacional de Arte Romano.

Andreu, J. (2014): "Rationes rei publicae uexatae y oppida labentia: la crisis urbana de los siglos II y III d. C. a la luz del caso del municipio de Los Bañales de Uncastillo (Zaragoza, España)", en D. Vaquerizo, J.A. Garriguet y A. León (eds.), Ciudad $y$ territorio: transformaciones materiales e ideológicas entre la época clásica y el Altomedioevo: 251-264. Córdoba, Universidad de Córdoba.

Andreu, J. (ed.) (2015): Oppida labentia. transformaciones, cambios y alteración en las ciudades hispanas entre el siglo II y la tardoantigüedad. Uncastillo, Fundación Uncastillo.

Antoni, C.; Hernández, F.J. y De Antonio, J.M. (2002): "Noticia preliminar de las excavaciones de la domus romana del solar del cinema Marvi (Sagunt)". Arse 36: 99-116.

Arasa, F. (2009): La ciutat romana de Lesera. Forcall, Ajuntament de Forcall, disponible en $<$ http://roderic.uv.es/handle/10550/34623>.

Arévalo, A. y Bernal, D. (2007): "Síntesis y perspectivas de investigación”, en A. Arévalo y D. Bernal 
(coords.), Las cetariae de Baelo Claudia. Avance de las investigaciones arqueológicas en el barrio meridional (2000-2004): 547-556. Sevilla, Junta de Andalucía.

Balil, A. (1972): Casa y urbanismo en España antigua. Valladolid, Universidad de Valladolid.

Barata, M.F. (1998): Mirobriga: urbanismo e arquitectura. Lisboa, Ministério da Cultura.

Barata, M.F. (1999): “As habitaçoes de Mirobriga e os ritos domésticos romanos". Revista Portuguesa de Arqueologia 2, 2: 51-68.

Beltrán de Heredia, J. (2010): "Barcino de colonia augustea a sede regia en época visigoda. Las transformaciones urbanas a la luz de las nuevas aportaciones de la arqueología", en Arqueología, patrimonio y desarrollo urbano. Problemática y soluciones: 31-49. Girona, Ajuntament de Girona.

Beltrán, A. (1952): "Una casa romana en Zaragoza", en Actas del II Congreso Nacional de Arqueología: 439-50. Zaragoza, Institución Fernando el Católico.

Beltrán, M. (1993): "El teatro de Caesaragusta. Estado actual del conocimiento". Cuadernos de arquitectura romana 2: 93-118.

Beltrán, M. (2003): "La casa hispanorromana. Modelos". Bolskan 20: 13-63, disponible en <http://revistas.iea.es/index.php/BLK/article/view/451>.

Beltrán, M. y Fatás, G. (1998): Historia de Zaragoza. Cesar Augusta ciudad romana. Zaragoza, Ayuntamiento de Zaragoza.

Beltrán, M. y Mostalac, A. (1996): “La casa romana en Hispania. Estado de la cuestión", en La maison urbaine d'epoque romaine en Gaule narbonnaise et dans les provinces voisines: 61-71. Vaucluse, Service d'Archéologie du Conseil Général de Vauclus.

Beltrán, M. y Mostalac, A. (2007): “Arquitectura doméstica”, en F. Beltrán (ed.), Las capitales provinciales de Hispania, Zaragoza, Colonia Caesar Augusta: 71-84. Roma, L'Erma di Bretschneider.

Beltrán, M.; Mostalac A., Paz J. y Aguarod M.C. (1985): "La Arqueología urbana en Zaragoza", en Arqueología de las ciudades modernas superpuestas a las antiguas: 73-116. Madrid, Ministerio de Cultura.

Berlanga, M. y Melero, F. (2009): “Cartima a través de las fuentes arqueológicas y epigráficas”, en J. González y P. Pavón (eds.), Andalucía romana y visigoda. Ordenación y vertebración del territorio: 167-190. Roma, L'Erma di Bretschneider.

Bermejo Meléndez, J. (2011): "El fin del modelo urbano y municipal en Arucci Turobriga: la transformación hacia la antigüedad tardía (ss. III-VII d.C.)".
Arqueología y territorio medieval 18: 55-70, doi: $<$ https://dx.doi.org/10.17561/aytm.v18i0.1467>.

Bermejo Tirado, J. (2014): Arqueología de los espacios domésticos romanos: Condiciones de vida y sociedad en la Meseta nordeste durante el período imperial. Soria, Diputación Provincial de Soria.

Bernal D., Arévalo, A.; Aguilera, L.; Lorenzo, L.; Díaz, J. J. y Expósito J.A. (2007a): "La topografía del barrio industrial. Baelo Claudia, paradigma de la industria conservera urbana hispanorromana", en A. Arévalo y D. Bernal (coords.). Las cetariae de Baelo Claudia. Avance de las investigaciones arqueológicas en el barrio meridional (2000-2004): 91-212. Sevilla, Junta de Andalucía.

Bernal D.; Arévalo, A.; Lorenzo L. y A. Cánovas (2007b): "Abandonos en algunas insulae del barrio industrial a finales del siglo II d.C.”, en A. Arévalo y D. Bernal (coords.), Las cetariae de Baelo Claudia. Avance de las investigaciones arqueológicas en el barrio meridional (2000-2004): 383-451. Sevilla, Junta de Andalucía.

Betrán de Heredia, J. y Cortés, A. (2018): “La domus de la calle Avinyó de Barcelona: un ejemplo de la arquitectura doméstica de las elites barcinonenses en los siglos I-II". Anales de Arqueología Cordobesa 29: 137-156, disponible en $<$ http://hdl.handle. net/10396/17735>

Bonneville, J.N.; Dardaine, S. y Le Roux, P. (1988): L'epigraphie: les incriptions romaines de Baelo Claudia. Paris, Diffusion De Boccard.

Brassous, L. y Quevedo, A. (eds.) (2015): Urbanisme civique en temps de crise. Les espaces publics d'Hispanie et de l'Occident romain entre le IIe et le IVe siècle. Madrid, Casa de Velázquez.

Bruun, C. (2003): "The Antonine Plague in Rome and Ostia". Journal of Roman Archeology 16: 426-434, doi: <https://doi.org/10.1017/ S1047759400013234>.

Burón, M. (1997): El trazado urbano en las proximidades del foro en Asturica Augusta: la Casa del pavimento de Opus Signinum. Valladolid, Junta de Castilla y León.

Burón, M. (2002): "El proceso urbanizador en Asturica Augusta: las primeras construcciones domésticas”, en L. Hernández Buena; L. Sagredo y J.M. Solana (eds.), Actas del I Congreso Internacional de Historia Antigua "La Península Ibérica hace 2000 años”: 263-268. Valladolid, Universidad de Valladolid.

Canovas, A. (2010): "La arquitectura doméstica de la zona occidental de Colonia Patricia Corduba", en 
D. Vaquerizo y J.F. Murillo (eds.), El anfiteatro romano de Córdoba y su entorno urbano. Análisis arqueológico (ss. I-III d.C.): 415-427. Córdoba, Universidad de Córdoba.

Canto, A. (1976): "El mosaico del Nacimiento de Venus de Itálica”. Habis 7: 293-338, disponible en $<$ http://hdl.handle.net/11441/29145>.

Carrasco, I. y Romero Paredes, C. (2001): "Intervención arqueológica de urgencia en la plaza de Giles y Rubio $n^{\circ} 9$ esquina a C/ bodegas, a C/ Berbisa y a plaza de Giles y Rubio n ${ }^{\circ} 19$ de Écija, Sevilla”. Anuario Arqueológico de Andalucía 1997, 3: 576-579.

Carrillo, J.R. (1999): "Evolución de la arquitectura doméstica en Colonia Patricia Corduba", en F.R. García Verdugo y F. Acosta (coords.), Córdoba en la Historia. La construcción de la Urbe: 75-86. Córdoba, Ayuntamiento de Córdoba.

Casabona, J.I. y Pérez Casas, J.A. (1991): “El fórum de Caesaragusta", en Zaragoza, prehistoria y arqueología: pp. 17-26. Zaragoza, Ayuntamiento de Zaragoza.

Castanyer, P.; Sanmartí, E.; Santos, M.; Tremoleda, J.; Benet, C.; Carreté, J.M.; Fàbrega, X.; Remolá, J.A. y Rocas, X. (1993): “L'excavació del kardo B. Noves aportacions sobre l'abandonement de la ciutat romana d'Empuries". Cypsela 10: 159-194, disponible en <https:/www.raco.cat/index.php/Cypsela/ article/view/119175>.

Cebrián, R. (2002-2003): "Surtidor de fuente procedente de la vivienda de C. Iulius Silvanus en Segóbriga (Saélices, Cuenca, Conventus Carthaginesis)". Lucentum 21-22: 131-134, doi: <https://doi. org/10.14198/LVCENTVM2002-2003.21-22.08>.

Cebrián, R. y Fernández, A. (2004): “Un techo pintado en la domus de G. lulius Siluanus en Segobriga (Saelices, Cuenca. Conventus Carthaginensis)", en Plafonds et voutes a l'époque antique, Actes du Vllle. Colloque International de l'Association Internationale pour la Peinture Múrale Antique: pp. 137-146. Budapest, Pytheas Kft.

Comas, M.; Guitart, J. y Padrós, J. (1999): "Prehistòria i Història Antiga", en J. Villarroya (dir.). Història de Badalona: 21-52. Badalona, Editorial Base.

Corrales, A. (2016): La arquitectura doméstica de Augusta Emerita. Madrid, CSIC.

Correia, V.H. (2001): "Conimbriga, casa atribuida a Cantaber. Trabalhos arqueológicos 1995-1998”. Conimbriga 40: 83-140.

Correia, V.H. (2004): “Coexistência e revoluçao. Urbanismo e arquitectura em Conimbriga (séc. I
a.C.-III d.C.)", en M.C. Lopes y R. Vilaça (coords.), O passado em cena: narrativas e fragmentos. Miscelânea oferecida a Jorge de Alarçao: 261-298. Coimbra, Centro de Estudos Arqueológicos.

Correia, V.H. (2010a): “O fórum de Conimbriga e a evoluçao do centro urbano”, en T. Nogales (coord.), Ciudad y foro en Lusitania romana: 89-106. Mérida, Museo Nacional de Arte Romano.

Correia, V.H. (2010b): Arquitectura domestica de Conimbriga e as estructuras económicas e sociais da cidade romana. Tesis Doctoral, Universidade de Coimbra. Inédita, disponible en $<$ http://hdl.handle. net/10316/18134>.

Correia, V.H. (2013): A arquitectura doméstica de Conimbriga e as estructuras económica e sociais da cidade romana. Coimbra, Centro de Estudos Arqueológicos das Universidades de Coimbra e Porto.

Correia, V.H. (2017): A arquitetura do ocidente da Lusitânia romana: entre o público e o privado. Lisboa, Academia das Ciências de Lisboa, disponible en $<$ https://comum.rcaap.pt/handle/10400.26/19489>.

Correia, V.H. y Reis, M.P. (2000): “As termas de Conimbriga: tipologías arquitectónicas e integraçao urbana", en C. Fernández Ochoa y V. García-Entero (eds.), Termas romanas en el Occidente del Imperio: 271-280. Gijón, VTP.

Cortés, A. (2009): "L'arquitectura domèstica a Tarraco. Epoca tardorepublicana i altimperial". Butlletí Arqueolòic 31: 511-534, disponible en $<$ https://www.raco.cat/index.php/ButlletiArq/article/view/314883>.

Cortés, A. (2011): "L'arquitectura doméstica de la ciutat romana de Barcino". Quaderns d'Arqueologia $i$ Història de la Ciutat de Barcelona 7: 16-66.

Cortés, A. (2014a): “Clasificación tipológica de la arquitectura doméstica romana. Reflexiones a partir de las ciudades del NE peninsular". Pyrenae 45, 2: 59-93, disponible en $<$ https://www.raco.cat/index. php/Pyrenae/article/view/286121>.

Cortés, A. (2014b): L'arquitectura domèstica d'època tardorepublicana $i$ altimperial a les ciutats romanes de Catalunya. Barcelona, Institut d'Estudis Catalans.

Cortés, A. y Guitart, J. (2011): "La Arqueología de la casa romana en Cataluña". Bollettino di Archeologia on line. Proceedings of the XVII International Congress of Classical Archaeology, vol. esp.: 34-49.

Cuyàs, J.M. (1977): Historia de Badalona. Badalona Romana i visigòtica. Badalona, Arts Grafiques Duran. 
De Hoz, M.P. (2007): “A new set of simulacra gentium indenified by greek inscriptions in the so called house of Terpsichore in Valentia (Spain)". Zeitschrift für Papyrologie und Epigraphik 163: 131-146.

De Palol, P. (1994): Clunia. Historia de la ciudad y guía de las excavaciones. Burgos, Diputación Provincial de Burgos.

Didierjean, F.; Ney, C. y Paillet, J.L. (1986): Le macellum. Paris, Diffusion De Boccard.

Duncan-Jones, R. (1996): "The impact of the Antonine plague". Journal of Roman Archeology 9: 108-136, doi: <https://doi.org/10.1017/ S1047759400016524>.

Egea, A.; Ruiz, E. y Vizcaíno, J. (2011): "Carthago Nova”, en J.A. Remolá y J. Acero (eds.), La gestión de los residuos urbanos en Hispania: 281-296. Mérida, CSIC.

Ellis, S.P. (1991): "Power, architecture and decor: how the Late Roman aristocrat appeared to his guest", en E.K. Gazda (ed.), Roman Art in private sphere: $117-$ 134. Michigan, The University of Michigan Press.

Escrivá, M.J.; Jiménez, J.L.; Machancoses, M. y Ribera, A. (2016): "Domus de Terpsicore, Valentia (Valencia)", en O. Rodríguez Gutiérrez; N. Tran y B. Soler Huertas (coords.), Los espacios de reunión de las asociaciones romanas: 428-434. Sevilla, Universidad de Sevilla.

Fernández Díaz, A. (2000-2001): “Algunos restos pictóricos de la ciudad de Lucentum (Tossal de Manises-Alicante)". Lucentum 1920: 215-236, doi: <https://doi.org/10.14198/ LVCENTVM2000-2001.19-20.14>.

Fernández Díaz, A. (2014): "La evolución de los centros urbanos en Hispania a través de su pintura mural (s. II-IV d.C.)", en S.F. Ramallo y A. Quevedo (eds.), Las ciudades de la Tarraconense oriental entre los s. II-IV d.C. Evolución urbanistica y contextos materiales: 207-244. Murcia, Universidad de Murcia.

Fernández Díaz, A. y Quevedo, A. (2008): "La configuración de la arquitectura doméstica en Carthago Nova desde la época tardo-republicana hasta los inicios del Bajoimperio". Anales de prehistoria y arqueología 23-24: 273-309, disponible en $<$ https:// revistas.um.es/apa/article/view/178131>.

Fernández Díaz, A. y Suárez, L. (2006): "La Gorgona/Medusa en el pavimento de una domus de la ciudad de Carthago Nova: un unicum en un conjunto de mosaicos geométricos y bícromos". Anales de prehistoria y arqueología 22: 73-108, disponible en $<$ https://revistas.um.es/apa/article/ view/93171/125371>.

Fernández Díaz, A. (2017): "La pintura mural romana en los ambientes domésticos", en E. Ruiz Valderas (coord.), Cartagena, Colonia Urbs Julia Nova Carthago: 79-82. Roma, L'Erma di Bretschneider.

Fernández Díaz, A.; Murcia, A. y García, C. (2005): “Actuación arqueológica en C/ Beatas (Cartagena): constatación de una nueva técnica decorativa en ámbito doméstico". Anales de prehistoria y arqueología 21: 127-146, disponible en <https://revistas. um.es/apa/article/view/93071/0>.

Fernández Ochoa, C. y García-Entero, V. (eds.) (2000): Termas romanas en el Occidente del Imperio. Gijón, VTP.

Fernández Vega, P.A. (1999): La casa romana. Madrid, Akal.

Fornell, A. (2005): "Evolución de las villae béticas durante la dinastía Antonina”, en L. Hernández (ed.), La Hispania de los Antoninos (98-180): 587-596. Valladolid, Universidad de Valladolid.

García Marcos, V. y Vidal, J.M. (1993): Astorga. Excavaciones y restos arqueológicos. León, La Crónica 16.

García Marcos, V. y Vidal, J.M. (1996): “Asturica Augusta: recientes investigaciones sobre su implantación y desarrollo urbano", en C. Fernández Ochoa (coord.), Los finisterres atlánticos en la Antigüedad: 135-145. Madrid, Electa.

García Marcos, V. y Vidal, J.M. (1999): “Asturica Augusta: de asentamiento militar a urbs magnifica”, en A. Rodríguez Colmenero (coord.), Los orígenes de la ciudad en el noreste hispánico, vol. II: 911-944. Lugo, Diputación Provincial de Lugo.

García Villalba, C. y Sáenz Preciado, J. (2015): “Municipium Augusta Bilbilis ¿paradigma de la crisis de la ciudad julio-claudia?", en L. Brassous y A. Quevedo (eds.), Urbanisme civique en temps de crise. Les espaces publics d'Hispanie et de l'Occident romain entre le IIe et le IVe siècle: 221-235. Madrid, Casa de Velázquez.

García-Dils, S. (2015): Colonia Augusta Firma Astigi. El urbanismo de la Écija romana y tardoantigua. Sevilla, Universidad de Sevilla.

García-Dils, S.; Ordóñez, S. y Rodríguez Gutiérrez, O. (2009): "La casa del Oscillum en Astigi: Aspectos edilicios", en R. Cruz-Auñón y E. Ferrer (coords.), Estudios de Prehistoria y Arqueología en homenaje a Pilar Acosta Martínez: 521-544. Sevilla, Universidad de Sevilla.

García-Dils, S.; Ordóñez, S.; Conlin, E.; Saquete, J.C. y Sáez, P. (2006): "La casa de las Hermae de Astigi”. 
Habis 37: 349-364, disponible en <https://hdl. handle.net/11441/72378>.

García-Dils, S.; Ordóñez, S.; Sánchez Velasco, J.; Vázquez, J. y Fournier, J. (2011): "La conversión de una porticus monumental de colonia Augusta Firma en recinto funerario cristiano". Habis 42: 263-291, disponible en $<\mathrm{http}$ :/hdl.handle.net/11441/12170>.

García-Entero, V. (2006): Los balnea domésticos -ámbito rural y urbano- en la Hispania romana. Madrid, CSIC.

García-Entero, V. (2008): “El ocio en el ámbito doméstico de la arquitectura hispanorromana: las termas". Anales de prehistoria y arqueología 23-24: 253272, disponible en $<$ https://revistas.um.es/apa/article/view/178121>.

Garriguet, J.A. (2013): “La ornamentación escultórica de la Bética entre Trajano y Antonino Pío. Breves reflexiones sobre su producción e importación”, en R. Hidalgo y P. León (eds.), Roma, Tibur, Baetica. Investigaciones adrianeas: 251-269. Sevilla, Universidad de Sevilla.

Gros, P. (2001): L'Architecture romaine. Maisons, palais, villas et tombeaux. Paris, Diffusion De Boccard.

Gros, P. (2007): Storia dell'urbanistica. Il mondo romano. Roma, Laterza.

Guilabert, A.; Olcina, M. y Tendero, E. (2015): “Lucentum (Tossal de Manises, Alicante). Estudio de caso de un municipium de la Tarraconense sur", en L. Brassous y A. Quevedo (eds.), Urbanisme civique en temps de crise. Les espaces publics d'Hispanie et de l'Occident romain entre le IIe et le IVe siècle: 145-160. Madrid, Casa de Velázquez.

Guiral, C. (2015): "Un conjunto de estucos de la Colonia Caesar Augusta", en M. Salvadori; A. Didonè y G. Salvo (eds.), TECT 2: la pittura frammentaria di età romana, metodi di catalogazione e studio dei reperti: 123-137. Padova, Padova University Press.

Guiral, C. y Martín-Bueno, M. (1996): Bilbilis I: decoración pictórica y estucos ornamentales. Zaragoza, Institución Fernando El Católico.

Guitart, J. (1976): Baetulo: topografía arqueológica, urbanismo e historia. Badalona, Ayuntamiento de Badalona.

Guitart, J.; Padrós, P. y Puerta, C. (1991): "La casa urbana en Baetulo", en La casa urbana hispanorromana. Ponencias y comunicaciones: 35-47. Zaragoza, Institución Fernando el Católico.

Gutiérrez Behemerid, M.A. (2002): La decoración arquitectónica en la Colonia Clunia Sulpicia. Valladolid, Universidad de Valladolid.
Hales, S. (2003): The roman house and social identity. Cambridge, Cambridge University Press.

Hauschild T. (1985): "Munigua. Informe preliminar sobre las excavaciones en casa 1 y casa 6 (Campaña de 1982)". Noticiario Arqueológico Hispánico 23: 235-267.

Hauschild T. y Haussmann E. (1991): “Casas romanas de Munigua", en La casa urbana hispanorromana. Ponencias y comunicaciones: 329-335. Zaragoza, Institución Fernando el Católico.

Járrega, R.; Diloli, J.; Ferré, R. y Vilà, J. (2014): “Elementos urbanísticos de abandono y una posible crisis estructural en la ciudad de Dertosa (Hispania Citerior) en el siglo II d.C.", en S.F. Ramallo y A. Quevedo (eds.), Las ciudades de la Tarraconense oriental entre los s. II-IV d.C. Evolución urbanistica y contextos materiales: 149-174. Murcia, Universidad de Murcia.

Jiménez, J.L. (2006): “Consideraciones sobre la evolución de las corrientes decorativas en la ciudad romana de Valentia", en D. Vaquerizo y J.F. Murillo (coords.), El concepto de lo provincial en el mundo antiguo: 471-484. Córdoba, Universidad de Córdoba.

Keay, S. (2004): "El territorio", en X. Dupré (ed.), Tarragona: Colonia Iulia Urbs Triumphalis Tarraco. Las capitales provinciales de Hispania 3: 97-109. Roma, L'Erma di Bretschneider.

Koppel, E.M. (1985): Die römischen Skulpturen von Tarraco. Berlin, Walter de Gruyter.

Koppel, E.M. y Rodá, I. (2007): "La escultura”, en F. Beltrán (ed.), Las capitales provinciales de Hispania 4, Zaragoza, Colonia Caesar Augusta: 109-122. Roma, L'Erma di Bretschneider.

López Monteagudo, G. (2003): "Mosaicos hispanos de época de Trajano", en J. Alvar y M. Blázquez (eds.), El Imperio de Trajano: 301-333. Madrid, Universidad Complutense.

Machancoses, M. y T. Peñalver (2017): “Purísima 3: un ambiente doméstico periurbano en Valentia”. Cuadernos de Arqueología de la Universidad de Navarra 25: 139-164, disponible en <http://hdl.handle. net/10171/45803>.

Macias, J.M. (2001): "La villa romana de la Llosa en el marc de l'ocupació agricola del territorium de Tàrraco", en M. García; J.M. Macias; J. Menchon; J.M. Puche; E. Ramón y J.A. Remolà (eds.), La villa romana de la LLosa. Deus anys d'investigació arqueológica: 40-50. Cambrils, Ajuntament de Cambrils.

Macias, J.M. (2004): "Arquitectura doméstica", en X. Dupré (ed.). Tarragona: Colonia Iulia Urbs 
Triumphalis Tarraco. Las capitales provinciales de Hispania 3: 73-95. Roma, L'Erma di Bretschneider.

Macias, J.M.; Fiz, I.; Piñol, L.; Miró, M.T. y Guitart, J. (2007): Planimetria arqueolòica de Tàrraco. Tarragona, Institut Català d'Arqueologia Clàssica.

Macias, J.M. y Puche, J.M. (1997): "Noves excavacions a la part baixa de Tarragona. Dades per a l'evolució urbanística de la ciutat romana". Tribuna d'Arqueologia 1995-1996: 149-163, disponible en $<$ http://hdl.handle.net/10687/91603>.

Madrid, M.J. (2004): "Primeros avances sobre la evolución urbana del sector oriental de Carthago Nova. PERI CA-4/ Barrio universitario". Mastia 3: 31-70.

Madrid, M.J. (2017): "La arquitectura doméstica", en E. Ruiz Valderas (coord.), Cartagena, Colonia Urbs Julia Nova Carthago: 69-78. Roma, L'Erma di Bretschneider.

Magalhães, F. (2010): Arquitectura doméstica em Bracara Augusta. Tesis Doctoral, Universidade do Minho. Inédita disponible en $<$ http://hdl.handle. net/1822/13619>.

Mañas, I. (2009): "Pavimentos decorativos de Itálica. Una fuente para el estudio de la ampliación adrianea". Romula 8: 179-199, disponible en <https://www.upo. es/revistas/index.php/romula/article/view/209>.

Mañas, I. (2010): “Arquitectura doméstica", en A. Caballos (ed.), Itálica-Santiponce, Municipium y Colonia Aelia Augusta Italicensium: 81-97. Roma, L'Erma di Bretschneider.

Mañas, I. (2011): Mosaicos romanos de Itálica (II): mosaicos contextualizados y apéndice. Madrid, CSIC.

Mar, R. y Ruiz de Arbulo, J. (1993): Ampurias romana. Historia, arquitectura y arqueología. Sabadell, AUSA.

Mar, R.; Ruiz de Arbulo, J.; Vivó, D. y Beltrán-Caballero, J.A. (2012): Tarraco. Arquitectura y urbanismo de una capital provincial romana. De la Tarragona ibérica a la construcción del templo de Augusto. Tarragona, Universitat Rovira i Virgili.

Márquez, C. (1993): Capiteles romanos de Corduba Colonia Patricia. Córdoba, Monte de Piedad y Caja de Ahorros de Córdoba.

Márquez, C. (2005): "Córdoba romana: dos décadas de investigación arqueológica", Mainake 27: 33-60.

Márquez, J. (2010): "Los suburbios de Augusta Emerita en perspectiva diacrónica", en D. Vaquerizo (ed.), Las áreas suburbanas en la ciudad histórica. Topografía, usos, función: 135-152. Córdoba, Universidad de Córdoba.

Martín, M.; Ortiz, D.; Portí, M. y Vidal, M. (2001): “La domus de la Fortuna: un conjunto arquitectónico doméstico de época romana en la calle del Duque", en E. Ruiz y M. Martínez Andreu (coords.), La casa romana en Carthago Nova. Arquitectura privada y programas decorativos: 19-52. Murcia, Tabularium.

Martín-Bueno, M. (1991): "Bilbilis: arquitectura doméstica", en La casa urbana hispanorromana. Ponencias y comunicaciones: 165-180. Zaragoza, Institución Fernándo el Católico.

Martín-Bueno, M. (2000): Bilbilis Augusta. Zaragoza, Caja de Ahorros de la Inmaculada de Aragón.

Martins, M. (1997-1998): “A zona arqueológica das Carvalheiras. Balanço das escavações e interpretação do conjunto". Cadernos de Arqueologia 14-15: 23-46, disponible en <http://hdl.handle. net/1822/10409>.

Martins, M. (2009): "Bracara Augusta: panorama e estado da questao sobre o seu urbanismo", en M. Dopico; M. Villanueva y P. Rodríguez (eds.), Do castro a cidade: a romanización na Gallaecia e na Hispania indoeuropea: 181-212. Lugo, Diputación Provincial de Lugo.

Meyer, K.; Basas, C. y Teichner, F. (2001): Mulva IV: die Hauser 1 und 6, la cerámica de la casa n. 6, das Haus 2. Mainz am Rhein, Von Zabern.

Miró, C. (2011): "Els balnea de les domus de Barcino". Quaderns d'Arqueologia i Història de la Ciutat de Barcelona 7: 68-83.

Morand, I. (2005): La maison aux Jets d'eau de Conimbriga (Portugal). Programmes architectural et décoratif. Paris, Diffusion De Boccard.

Morena, J.A.; Ventura, A.; Márquez, C. y Moreno, A. (2011): "El foro de la ciudad romana de Torreparedones (Baena, Córdoba): primeros resultados de la investigación arqueológica (Campaña 20092010)", Itálica 1: 145-169.

Moreno González, M.F. (1996): Aproximación al estudio de la decoración musivaria en Colonia Patricia Corduba. Córdoba, Universidad de Córdoba.

Murcia, A.J. (1999): "Poblamiento rural romano en el Campo de Cartagena: el tránsito de los siglos II al III d.C. ", en Actas del XXIV Congreso Nacional de Arqueología, vol. IV: 231-236. Cartagena, Instituto de Patrimonio Histórico.

Nieto Prieto, J. (1981): “Acerca del progresivo despoblamiento de Ampurias". Rivista di Studi Liguri 47: 34-51.

Noguera, J.M. (2002a): "Carthago Nova: una metrópoli hispana del Mediterráneo occidental”, en J.M. Abascal; J.M. Noguera y F. González (eds.), Cartagena romana. Historia y epigrafía. Edición facsímil 
y estudio de Inscripciones de carthago Nova, hoy Cartagena, en el reyno de Murcia, ilustradas por el excelentísimo señor Conde Lumiares, individuo de la Academia de Ciencias y Artes de Padua: 49-87. Murcia, Tabularium.

Noguera, J.M. (2002b): "Un edificio del centro monumental de Carthago Nova: análisis arquitectónicodecorativo e hipótesis interpretativas". Journal of Roman Archaeology 15: 63-96, doi: <https://doi. org/10.1017/S1047759400013842>.

Nolla, J.M. (1993): “Ampurias en la Antigüedad tardía. Una nueva perspectiva”. Archivo Español de Arqueología 66: 207-224, doi: <https://doi. org/10.3989/aespa.1993.v66.470>.

Nolla, J.M. (1998): "Empuries. Creiximent, crisis i adaptació. Algunes consideracions", en M. Mayer; J.M. Nolla y J. Pardo (eds.), De les estructures indigenes a l'organització provincial romana de la Hispania citerior: 429-439. Barcelona, Institut d'Estudis Catalans.

Olcina, M. (ed.) (2009): Lucentum (Tossal de Manises, Alicante): arqueología e historia. Alicante, Museo Arqueológico de Alicante.

Olcina, M. y Pérez Jiménez, R. (1998): La ciudad ibero-romana de Lucentum (El Tossal de Manises, Alicante). Introducción a la investigación del yacimiento arqueológico y su recuperación como espacio público. Alicante, Museo Arqueológico de Alicante.

Olesti, O.; Guàrdia, J. y Mercadal, O. (2014): “El fin del sueño urbano en Iulia Livica (Llívia, Cerdaña)", en S.F. Ramallo y A. Quevedo (eds.), Las ciudades de la Tarraconense oriental entre los s. II-IV d.C. Evolución urbanística y contextos materiales: 6188. Murcia, Editum.

Ortega, J.R. (1999): “Aportaciones al estudio del poblamiento romano en el entorno de Lucentum (Alicante)", en XXIV Congreso Nacional de Arqueología, vol. IV: 467-474. Murcia, Instituto de Patrimonio Histórico.

Padrós, P. y Sánchez, J. (2014): “Transformaciones en los espacios urbanos en Baetulo. Siglos II al IV d.C.", en S.F. Ramallo y A. Quevedo (eds.), Las ciudades de la Tarraconense oriental entre los siglos II-IV d.C.: 89-118. Murcia, Editum.

Palma, F. (1997): "Las casas romanas intramuros en Mérida. Estado de la cuestión". Mérida excavaciones arqueológicas, 3: 347-365.

Paz, J.A. (1991): Cerámica de mesa romana de los siglos III al VI d.C. en la provincia de Zaragoza. Zaragoza, Institución Fernando el Católico.
Peña, A. (2010): Estudio de la decoración arquitectónica romana y análisis del reaprovechamiento del material en la Mezquita Aljama de Córdoba. Córdoba, Universidad de Córdoba.

Peña, A. (2011): "La escultura doméstica", en M.D. Baena; C. Márquez y D. Vaquerizo (comis.), Córdoba reflejo de Roma: 146-155. Córdoba, Ayuntamiento de Córdoba.

Pérez González, C.; Illarregui, E. y Arribas, P. (2015): "Tiermes en los siglos II-IV. Evolución del poblamiento y del urbanismo de una ciudad de la cuenca del Duero", en S.F. Ramallo y A. Quevedo (eds.), Las ciudades de la Tarraconense oriental entre los s. II-IV d.C. Evolución urbanística y contextos materiales: 237-251. Murcia, Editum.

Pérez Maestro, C. (2005): "Nuevas aportaciones para el conocimiento de la secuencia ocupacional del área periurbana de Mérida". Mérida excavaciones arqueológicas 8: 227-246.

Pérez Olmedo, E. (1996): Revestimientos de opus sectile en la Península Ibérica. Valladolid, Universidad de Valladolid.

Perich, A. (2014): "Las transformaciones urbanas en Tarraco. El ámbito doméstico a finales del altoimperio", en S.F. Ramallo y A. Quevedo (eds.), Las ciudades de la Tarraconense oriental entre los s. IIIV d.C. Evolución urbanística y contextos materiales: 119-147. Murcia, Editum.

Prevosti, M. (1981): Cronologia i poblament a l'area rural de Baetulo. Badalona, Museu de Badalona.

Quevedo, A. y Ramallo, S.F. (2015): “La dinámica evolutiva de Carthago Nova entre los siglos II y III", en L. Brassous y A. Quevedo (eds.), Urbanisme civique en temps de crise. Les espaces publics d'Hispanie et de l'Occident romain entre le IIe et le IVe siècle: 161-177. Madrid, Casa de Velázquez.

Ramallo, S.F. (1990): “Talleres y escuelas musivas en la Península Ibérica", en Mosaicos romanos. Estudios sobre iconografia: 135-180. Guadalajara, Asociación Española del Mosaico.

Ramallo, S.F. (2006): “Talleres urbanos y talleres locales en los capiteles corintios de Cartagena" en D. Vaquerizo y J.F. Murillo (eds.), El concepto de lo provincial en el mundo antiguo, vol. I: 451-470. Córdoba, Universidad de Córdoba.

Ramallo, S.F. y Quevedo, A. (eds.) (2014): Las ciudades de la Tarraconense oriental entre los s. IIIV d.C. Evolución urbanística y contextos materiales. Murcia, Editum.

Ramallo, S.F. y Vizcaíno, J. (2007): "Evolución del sistema defensivo de Cartagena durante la Antigüedad", 
en A. Rodríguez Colmenero e I. Rodà (coords.), $M u$ rallas de Ciudades Romanas en el Occidente del Impero. Lucus Augusti como paradigma: 483-522. Lugo, Diputación Provincial de Lugo.

Regueras, F. (1991): "Mosaicos romanos de Asturica Augusta". Boletín del Seminario de estudios de arte y arqueología 57: 131-162.

Reis, M.P. y Correia, V.H. (2006): "Jardins de Conimbriga: arquitetura e gestao hidrulica”, en J.P. Morel; J. Tressera y J.C. Matamala (eds.), The archeology of cropfields and gardens: 293-312. Bari, Edipuglia.

Reis, M.P.; De Man, A. y Correia, V.H. (2011): “Conimbriga", en J. Acero y J.A. Remolá, (eds.), $L a$ gestión de los residuos urbanos en Hispania: 181202. Mérida, CSIC.

Ribeiro, J. y Martins, M. (2013): “Os procesos constructivos da edilicia privada em Bracara Augusta: o caso da Domus das Carvalheiras", en A. Sousa y M. Carmo (coords.), Historia da construçao, arquitecturas e tecnicas construtivas: 75-98. Braga, CITCEM.

Ribera, A. y Jiménez, J.C. (2012): "Valentia, ciudad romana: su evidencia arqueológica", en J. Beltrán y O. Rodríguez Gutiérrez (coords.), Hispaniae Urbes. Investigaciones arqueológicas en ciudades históricas: 77-120. Sevilla, Universidad de Sevilla.

Rodá, I. (2001): "Barcelona. Desde su fundación hasta el siglo IV d.C.”, en J. Beltrán de Heredia (dir.), De Barcino a Barcinona (siglos I-VII). Los restos arqueológicos de la plaza del Rey de Barcelona: 2231. Barcelona, Ajuntament de Barcelona.

Rodríguez Gómez, A. (2010): La arquitectura doméstica urbana en época romana en la provincia Baetica. Tesis Doctoral, Universidad de Huelva. Inédita, disponible en $<$ http://hdl.handle.net/10272/2870>.

Rodríguez Termiño, I. (1991): "La casa urbana hispanorromana en Augusta Firma Astigi, Écija, Sevilla", en La casa urbana hispanorromana. Ponencias y comunicaciones: 345-354". Zaragoza, Institución Fernando el Católico.

Roldán, L. (1991): "La casa de la Exedra de Itálica (Santiponce, Sevilla). Un intento de valoración espacial a través de las técnicas constructivas", en $L a$ casa urbana hispanorromana. Ponencias y comunicaciones: 303-311. Zaragoza, Institución Fernando el Católico.

Romero Vera, D. (2014): "Dinámicas urbanas en el siglo II d.C.: el caso de Colonia Augusta Firma Astigi (Écija, Sevilla)". en D. Vaquerizo, J.A. Garriguet y A. León (eds.), Ciudad y territorio: transformaciones materiales e ideológicas entre la época clásica y el Altomedioevo: 217-234. Córdoba, Universidad de Córdoba.

Romero Vera, D. (2016): La ciudad hispanorromana en el s. II d.C. Consolidación y transformación de un modelo urbano. Tesis Doctoral, Universidad de Córdoba. Inédita, disponible en $<$ http://hdl.handle. net/10396/14222>.

Rosselló, M. y Soriano, R. (1998): "Los restos arqueológicos exhibidos", en Cripta arqueológica de la Cárcel de San Vicente: 41-56. Valencia, Ajuntament de València.

Ruiz Bueno, M.D. (2014): "El entorno del decumanus maximus de Colonia Patricia: ¿evidencia de una remodelación urbanística hacia época severiana?", en D. Vaquerizo, J.A. Garriguet y A. León (eds.), Ciudad y territorio: transformaciones materiales e ideológicas entre la época clásica y el Altomedioevo: 41-54. Córdoba, Universidad de Córdoba.

Ruiz Bueno, M.D. (2015): "El kardo maximus de Córdoba en la Antigüedad Tardía". Anales de Arqueología Cordobesa 25-26: 83-114, doi: <https://doi. org/10.21071/aac.v0i25-26.6416>.

Ruiz Bueno, M.D. (2018): Dinámicas topográficas urbanas en Hispania. El espacio intramuros entre los siglos II y VII d.C. Bari, Edipuglia.

Ruiz Valderas, E. (1996): "Los niveles de abandono del siglo II d. C. en Cartagena: los contextos de la calle Jara n ${ }^{\circ} 12$ ", en Actas del XXIII Congreso Nacional de Arqueología, vol. I: 503-514. Elche, Ayuntamiento de Elche.

Sáez, P.; Ordóñez, S.; García Vargas, E. y García-Dils, S. (2004): Carta Arqueológica Municipal de Écija. 1. La ciudad. Sevilla, Junta de Andalucía.

Santos, M. (1991): "Distribución y evolución de la vivienda urbana tardorrepublicana y altoimperial en Ampurias", en La casa urbana hispanorromana. Ponencias y comunicaciones: 19-34. Zaragoza, Institución Fernando el Católico.

Santos, M. (2012): “Arquitectura doméstica", en X. Aquilué (ed.). Empuries, Municipium Emporiae: 69-84. Roma, L'Erma di Bretschneider.

Schattner, T.G. (2003): Munigua: cuarenta años de investigaciones. Sevilla, Junta de Andalucía.

Scheidel, W. (2002): "A model for demographic and economic change in Roman Egypt after the Antonine plague". Journal of Roman Archeology 15: 97-114, doi: <https://doi.org/10.1017/ S1047759400013854>.

Scheidel, W. (2003): "Germs for Rome", en C. Edwards and G. Woolf (eds.), Rome the cosmopolis: 158-176. Cambridge, Cambridge University Press. 
Secilla, R. y Márquez, C. (1991): “Una casa romana en el S.E. de Colonia Patricia Corduba: un ejemplo a seguir". en La casa urbana hispanorromana. Ponencias y comunicaciones: 337-342. Zaragoza, Institución Fernando el Católico.

Sillières, P. (1991): "La maison romaine a Baelo Claudia. Essai de révision de donnes anciennnes", en $L a$ casa urbana hispanorromana. Ponencias y comunicaciones: 321-326. Zaragoza, Institución Fernando el Católico.

Sillières, P. (1997): Baelo Claudia: una ciudad romana de la Bética. Madrid, Casa de Velázquez.

Sillières, P.; Magallón, M.A. y Navarro, M. (1995): “El municipium Labitolosanum y sus notables: novedades arqueológicas y epigráficas". Archivo Español de Arqueología 68: 107-130, doi: <https://doi. org/10.3989/aespa.1995.v68.400>.

Soler, B. (2003): "Algunas consideraciones sobre el empleo privado del mármol en Carthago Nova". Mastia 2: 149-187.

Soler, B. (2005): "Hacia una sistematización cronológica sobre el empleo del marmor y su comercialización en Carthago Nova". Mastia 4: 29-64.

Soler, B. (2017): "Pavimentos en opus sectile y otros revestimientos marmóreos en la arquitectura doméstica", en E. Ruiz Valderas (coord.), Cartagena, Colonia Urbs Julia Nova Carthago: 83-85. Roma, L'Erma di Bretschneider.
Teichner, F.; Oberhofer, K. y Kopf, J. (2014): "Miróbriga (Santiago do Cacém, Portogallo): nuovi dati archeologici sul modello lusitano della residenza privata in età romana", en J.M. Álvarez; T. Nogales y I. Rodà (eds.), XVIII CIAC: Centro y periferia en el mundo clásico: 1121-1124. Mérida, Museo Nacional de Arte Romano.

Uribe, P. (2015): La arquitectura doméstica urbana romana en el Valle Medio del Ebro (Siglos II a.C.III d.C.). Bordeaux, Aquitania Supplément.

Vaquerizo, D. (2004): “Arquitectura doméstica y funeraria”, en X. Dupré, (ed.), Las capitales provinciales de Hispania. Córdoba. Colonia Patricia Corduba: 81-94. Roma, L'Erma di Bretschneider.

Vegas, M. (1985): "Munigua. Casa 6. Estudio de los materiales para fechar las habitaciones y el pozo". Noticiario Arqueológico Hispánico 23: 269-289.

Vera, E.; Romero Paredes, C. y Carrasco, I. (2005): “Intervención arqueológica de urgencia realizada en un solar sito en la calle Avendaño número 7. Écija. Sevilla". Anuario Arqueológico de Andalucía 2002, 3: 487-498.

Vizcaíno, J. (1999): “Transformaciones del urbanismo tardoantiguo en Cartagena. El caso de los vertederos". Anales de prehistoria y arqueología 14: 8798, disponible en $<\mathrm{https}$ ://revistas.um.es/apa/article/view/62351>.

Zaccaria, A. (1995): Spazio privato e spazio pubblico nella città romana. Roma, Ecole française de Rome. 
Diarte-Blasco, P., Ariño Gil, E., Pérez-Polo, M. (2020): “Asturica (Astorga, León) y Albocela (Villalazán, Zamora) entre la Antigüedad y la Edad Media: análisis comparativo de sus territorios", Spal 29.1: 271-299. DOI: http://dx.doi.org/10.12795/spal.2020.i29.10

\title{
ASTURICA (ASTORGA, LEÓN) Y ALBOCELA (VILLALAZÁN, ZAMORA) ENTRE LA ANTIGÜEDAD Y LA EDAD MEDIA: ANÁLISIS COMPARATIVO DE SUS TERRITORIOS
}

\author{
ASTURICA (ASTORGA, LEÓN) AND ALBOCELA (VILLALAZÁN, ZAMORA) BETWEEN \\ ANTIQUITY AND THE MIDDLE AGES: A COMPARATIVE ANALYSIS OF THEIR TERRITORIES
}

\author{
PILAR DIARTE-BLASCO \\ Responsable de la correspondencia \\ Investigadora Juan de la Cierva-Incorporación. Universidad de Alcalá \\ Correo-e: pilar.diarte@uah.es. D https://orcid.org/0000-0001-7799-593X \\ Researcher ID: <https://publons.com/researcher/R-7288-2018> \\ ENRIQUE ARIÑO GIL \\ Catedrático de Arqueología. Universidad de Salamanca \\ Correo-e: argil@usal.es. D https://orcid.org/0000-0001-8717-2128 \\ Researcher ID: <https://publons.com/researcher/B-6726-2017> \\ MARTA PÉREZ-POLO \\ Investigadora predoctoral. Universidad de Navarra \\ Correo-e: marta.perez.polo@gmail.com. (D https://orcid.org/0000-0002-3359-7726 \\ Researcher ID: <https://publons.com/researcher/AAH-1690-2019>
}

\begin{abstract}
Resumen: Entre el siglo IV y el VI, se observan importantes transformaciones tanto en el espacio urbano como en el rural en la península ibérica. En algunos aspectos, los fenómenos que se detectan tienen su origen en fechas anteriores a la formación de los reinos suevo y visigodo. Otros cambios parecen derivar de procesos puestos en marcha por la creación de nuevos estados en el espacio peninsular. La investigación arqueológica revela importantes transformaciones tanto en el ámbito urbano como en el rural en este periodo. Sin embargo, el espacio urbano y el rural se analizan con frecuencia de forma independiente, sin abordar las diferencias que a veces experimentan en su evolución. En este estudio se aborda el análisis de los cambios en dos ciudades que viven evoluciones urbanas diferentes, Asturica y Albocela, prestando especial atención a la evolución de los espacios de hábitat rural respectivos y confrontándolos con la evolución de los centros urbanos de los que dependen.
\end{abstract}

Palabras clave: Arqueología del Paisaje, Prospección arqueológica, Antigüedad Tardía, Alta Edad Media, Hábitat rural, Valle del Duero.
Abstract: From the fourth century until the sixth, coinciding with the last centuries of the Roman Empire and the consolidation of the Suevic and Visigothic Kingdoms in the Iberian Peninsula, important transformations in both the urban and rural contexts took place. In some cases, the phenomena could probably have their origin in dates before the formation of the Suevi and Visigoth kingdoms, but other changes seem to derive from processes set in motion by the creation of new states in the Iberian Peninsula. Archaeological research reveals important transformations in both urban and rural areas in this period. However, the urban and rural spaces have often been analyzed independently, without addressing the differences they experience in their evolution. In this study we seek to assess changes in both contexts, through close analysis of two cities with different urban evolutions, namely Asturica and Albocela. For each we will evaluate the varied impacts on their respective territories, especially in terms of the types of rural habitat and exploitation.

Keywords: Landscape Archaeology, Archaeological survey, Late Antiquity, Early Medieval Ages, Rural habitat, Duero Valley. 


\section{INTRODUCCIÓN}

Cada vez es más evidente, a juzgar por los datos arqueológicos, que algunas ciudades hispanas que tienen su origen en el principado de Augusto o en la época julio-claudia experimentaron procesos de crisis y abandono en fechas tan tempranas como el siglo II, crisis que parece vinculada a la imposibilidad de mantener a largo plazo el impulso constructivo desarrollado por Augusto y sus sucesores (Martín-Bueno 1999; Andreu Pintado 2017). Este fenómeno matiza en gran medida la crisis urbana de la Antigüedad Tardía, si bien es cierto que el periodo que sigue a la entrada de, primero, suevos, vándalos y alanos, con la posterior llegada de los visigodos, fue acompañado en la península ibérica de la contracción de algunos espacios habitados o, incluso, del colapso urbano de un buen número de ciudades.

La ciudad hispana, en el periodo que incluye el final del imperio romano y los primeros siglos medievales, es un espacio sometido a drásticos cambios. Uno de los fenómenos que la caracterizan es la reconversión de los antiguos edificios públicos (teatros, termas, foros, etc.) hacia nuevos usos, especialmente domésticos o productivos. Al mismo tiempo, el solar urbano experimenta procesos de abandono de algunas zonas, acompañados de expolios y vertidos de basura (Gurt i Esparraguera 2001, Diarte-Blasco 2012, Diarte-Blasco y Gurt i Esparraguera 2015). Sin embargo estos fenómenos no tienen su origen en el siglo V, pues están bien documentados, al menos, ya en el siglo IV. Paralelamente a estos cambios se asiste a la gradual cristianización de la topografía urbana, con la instalación de complejos episcopales, iglesias y monasterios, fenómeno que se produce a partir del siglo $\mathrm{V}$ y que se incrementa, sobre todo, a partir del siglo VI (Gurt i Esparraguera y Sánchez Ramos 2011, Diarte-Blasco 2018: 112-127).

En el contexto rural, lo que se observa es el abandono de la villa como residencia aristocrática, si bien el edificio -o el solar que ocupaba- continúa en uso bajo una amplia diversidad de formas: espacio de hábitat degradado, necrópolis, lugar de culto, área productiva o simple cantera de expolio (Chavarría Arnau 2007). Sin embargo, el final de la villa como lugar de vivienda y representación de las aristocracias bajoimperiales es un fenómeno menos gradual que la mutación que se observa en la ciudad. En Hispania, los fenómenos de cambio en el entorno rural se datan en el marco de la primera mitad del siglo $\mathrm{V}$ y es posible incluso que haya que fecharlos en las dos primeras décadas del siglo $\mathrm{V}$ (aunque respetando las lógicas excepciones tanto antes como después de estas fechas). Desde el mismo momento en que colapsa la villa aristocrática se asiste a la reformulación del espacio agrícola con nuevas formas de hábitat, en un proceso de lenta maduración en el que el siglo VI se revela como un momento de especial relevancia (Ariño Gil 2013).

Pese a que los ritmos del proceso difieren de una zona a otra, la mayor parte de los investigadores que se han ocupado del periodo reconocen evoluciones similares a las que someramente acabamos de detallar. Sin embargo, es probablemente la cuestión relacionada con el abandono total de algunos centros urbanos la que más dudas sigue generando: ¿Por qué ciudades (en principio) similares evolucionan de forma diferente? ¿Por qué unas comienzan una lenta degeneración hasta su olvido, mientras que otras sobreviven o, incluso, mejoran su situación durante estos siglos? ¿Por qué encontramos ambas situaciones a pocos kilómetros de distancia? Son preguntas de difícil respuesta que, sin embargo, provocan un creciente interés entre los investigadores.

En el marco de estas cuestiones presentamos la investigación que llevamos a cabo durante los años 2016 y 2017 en los territorios de Albocela (Villalazán, Zamora) y Asturica (Astorga, León), precisamente por tratarse de dos ciudades con una evolución urbana diferente (fracasando la primera y perviviendo la segunda) y pertenecientes a un mismo paisaje, el del valle medio del Duero, donde la tasa de colapso urbano es considerablemente más alta que en otras zonas peninsulares (Núñez Hernández y Curchin 2007). La investigación, cuyos resultados mostramos aquí, fue diseñada con el propósito de comparar los procesos de evolución de dos ciudades con destinos finales diferentes a partir del examen de sus territorios. Después de todo, en la época romana, el vínculo con el campo fue constante: la riqueza derivada de los territoria de las ciudades fue capital en el desarrollo de estas. Así, más allá del debate de la ciudad vista como consumidor/parásito del campo o de su relación simbiótica o, incluso, de la necesidad de un centro urbano que organiza y redistribuye los excedentes rurales (un análisis de las diferentes posiciones sobre esta relación en Whittaker 1990), de lo que no cabe duda es de que la relación entre el espacio urbano y el territorio que administra es tan intensa que no se puede concebir de forma separada.

En realidad, nada hace pensar que entre el siglo $\mathrm{V}$ y el VI se hubiera producido un cambio en la dinámica entre centro urbano y territorio (Arce 2005: 213-217). La ciudad no se limitaba a sus murallas -por cierto, en muchos casos restauradas en este periodo-, sino que seguía incluyendo su territorium, como se desprende 
de la Chronica de Hidacio. Este autor deja constancia del saqueo de los territoria de Caesar Augusta (en el año 449), Lucus (en el 460) y, precisamente, Asturica (en el año 468), expediciones que, sin alcanzar los centros urbanos, produjeron grandes botines (Hidacio, Chron. 250, 199 y 186; Arce 2005: 216). Del mismo modo, la relación entre ciudad y territorio se hace patente, un siglo más tarde, en la donación y el testamento de Vicente de Asán (de los años 551 y 576 respectivamente). Estos documentos consignan las propiedades de las que Vicente hace entrega al monasterio de Asán situándolas en el marco de los territorios de las ciudades romanas (Ariño Gil y Díaz 2003, Corcoran 2003). La aparición reciente de nuevos documentos relacionados con las donaciones y las gestiones del predio del monasterio de Asán (Tomás-Faci y Martín-Iglesias 2017) han incrementado la nómina de ciudades en las que el cenobio de Asán tenía sus propiedades, confirmando la imagen que se desprendía de la donación y testamento de Vicente. Algunas ciudades, como por ejemplo Labitolosa (La Puebla de Castro, Huesca), están, con toda probabilidad, completamente abandonadas en el periodo en el que se redacta la documentación de Asán (Magallón Botaya y Sillières 2013, Asensio Esteban et al. 2016). Sin embargo, el vínculo ciudad-territorio es tan importante que las propiedades del monasterio se identifican siempre previa alusión al territorio urbano de pertenencia.

Nuestro objetivo en la investigación proyectada en los territorios de Asturica y Albocela era el de comprobar si una evolución urbana diferente tenía también incidencia en el desarrollo de sus respectivos territorios, especialmente en lo referente a los tipos de hábitat rural y a los niveles de pervivencia, discontinuidad y mutación de los mismos. El proyecto fue concebido como un muestreo sobre yacimientos arqueológicos preseleccionados en las dos áreas de actuación. La hipótesis de partida, que el proyecto diseñado aspiraba a comprobar, era que, dado que Albocela, en la secuencia estudiada, es una ciudad en fase de abandono, en tanto que Asturica sobrevive a las crisis del periodo, asumiendo el papel de sede episcopal y convirtiéndose en una de las ciudades más relevantes del reino de León (Cabero Domínguez 1995, Sánchez Badiola 2004), cabía la posibilidad de que esta diferencia repercutiera también en el espacio agrario. El proyecto diseñado contemplaba también valorar en qué medida los recursos del territorio de ambas ciudades podían haber influido en su diferente evolución, teniendo en cuenta que Asturica fue centro, desde época altoimperial, de una importante zona de explotación minera (Domergue 1986: 38-42,
García Marcos y Vidal Encinas 1995: 389-390, Orejas Saco del Valle y Morillo Cerdán 2013).

\section{EL CONTEXTO GEOGRÁFICO E HISTÓRICO}

A inicios del siglo II, en Hispania había más de $300 \mathrm{mu}$ nicipia y alrededor de 30 coloniae (Kulikowski 2005: 34), distribuidos fundamentalmente entre la Bética, las costas y las riberas de los grandes ríos, lugares con una sólida tradición urbana, anterior a la llegada de los romanos. En este sentido, los procesos urbanizadores en la Meseta central y sus estribaciones dieron lugar, en muchos casos, a fundaciones ex nihilo que, en no pocos ejemplos, tras un breve recorrido histórico, fracasaron. Como ya hemos señalado, el área de la Meseta norte es probablemente una de las zonas en las que se observa una mayor incidencia de fracaso urbano desde la secuencia romana hasta la altomedieval (Núñez Hernández y Curchin 2007). Sin embargo algunas ciudades mantienen un rol determinante durante todo este periodo y se configuran como centros determinantes en la topografía urbana medieval. Tal es el caso, por ejemplo, de Asturica. La ciudad nace como campamento romano en el contexto de las Guerras Cántabras (Morillo Cerdán 1991: 163-164), probablemente como base para la Legio X Gemina, pero Augusto la convierte en ciudad y en capital del Conuentus Asturum. Su conversión en asentamiento urbano y la gestión de los metalla publica tuvieron que llevar aparejados cambios sustanciales (Sastre et al. 2017: 542-544). Uno de los más importantes tuvo que ser la constitución de un territorio (Orejas Saco del Valle y Morillo Cerdán 2013: 107-109). Además, los pobladores, entre los cuales se encontrarían probablemente ex legionarios, tuvieron que recibir no solo casa, sino también tierras para su sustento.

No existen argumentos que permitan suponer que Asturica Augusta tuviera un estatuto especial en su momento fundacional (Orejas Saco del Valle y Morillo Cerdán 2013: 93-94, Sastre et al. 2017: 543). Sin embargo, es cierto que Asturica presenta unos rasgos especiales que le dan un carácter singular si se la compara con otras ciudades peregrinas. En primer lugar su sobrenombre de Augusta, que avala una intervención imperial directa en su constitución. En segundo lugar su planta urbana, regular y con dos tramas ortogonales imbricadas, creadas ex novo y con un foro destinado al culto imperial (Le Roux 2009, Sevillano Fuertes 2013, Vidal Encinas y González Fernández 2018). En tercer lugar su función como capital de conuentus, papel para el que siempre se 
eligen colonias o ciudades de rango privilegiado, aunque existan excepciones conocidas como Bracara $\mathrm{Au}$ gusta y Lucus Augusti, las cuales además presentan muchos paralelismos con Asturica. En cuarto lugar el hecho de que en su fundación intervengan militares o individuos de origen militar (Mañanes Pérez 1982: 21-52, Vidal Encinas y González Fernández 2004, v. también Rabanal Alonso y García Martínez 2001). Por último, el término urbs magnifica que utiliza Plinio (Nat. 3.28), nos indica que Asturica no era un asentamiento cualquiera, sino una ciudad que respondía a los modelos de organización más puramente romanos. Independientemente de cuál fuera su estatuto jurídico, el hecho es que se trataba de una auténtica ciudad para el naturalista latino, equiparable, al menos en sus aspectos formales, a otras de las consideradas como de rango privilegiado.

Entre el reinado de Tiberio y el de Claudio, coincidiendo con la construcción de los primeros edificios de carácter civil -como el foro, que ocupó un espacio de 3 ha y era de planta cuadrangular, con tres de sus lados porticados (Sevillano Fuertes 2013: 118)-, se erigió la muralla altoimperial de la ciudad (con una anchura de 2,5 m), de la que, a día de hoy, se conocen pocos tramos (Vidal Encinas y González Fernández 2018: 277 y 280-281). No sabemos si coincidiría con la bien conocida muralla tardoantigua, construida entre finales del siglo III o inicios del siglo IV y que, con una longitud de unos $2,2 \mathrm{~km}$, encerraba un recinto de c 26 ha de superficie. Similar a las murallas de León o Lugo, esta construcción llegó a duplicar el espesor del amurallamiento original, entre 4 y $5 \mathrm{~m}$, destacando además la altura de las torres que lo jalonaban (Sevillano Fuertes 2007, Vidal Encinas y González Fernández 2018: 277 y 280-281).

El auge constructivo de la ciudad, no obstante, tuvo lugar en el periodo flavio (García Marcos y Vidal Encinas 1996: 135, Orejas Saco del Valle y Morillo Cerdán 2013: 96-97), siendo en este momento cuando la ciudad se dota de complejos termales (destacando las Termas Mayores y las Menores: Sevillano Fuertes y Vidal Encinas 2000, García Marcos y Burón 2000, Vidal Encinas y González Fernández 2018: 282-284). Sin embargo, esta explosión constructiva no durará demasiado, ya que en el siglo III, probablemente en relación con el decaimiento de la actividad minera en la región, la ciudad experimentará un cierto estancamiento (Orejas Saco del Valle y Morillo Cerdán 2013: 98).

En el siglo IV, Asturica se convertirá en sede episcopal, información que conocemos a través de una carta del obispo de Cartago, Cipriano (Epístola LXVII, Teja Caruso 1990: 117). Pese a ello, los restos constructivos pertenecientes a los siglos IV y V son muy escasos, algo que contrasta con la gran cantidad de material cerámico de la misma época hallado en la ciudad, el cual está compuesto sobre todo por recipientes de origen peninsular, aunque no faltan producciones procedentes de territorios galos y africanos (Morillo Cerdán y Amaré Tafalla 2003, Paz Peralta 2013). El abundante material cerámico recuperado estaría señalando un dinamismo comercial de la ciudad como principal núcleo de redistribución y consumo de la zona hasta, por lo menos, mediados del siglo $\mathrm{V}$ d.C.

La falta de documentación sobre las estructuras arquitectónicas bajoimperiales se prolonga en el periodo suevo/visigodo, en contraste con la información proporcionada por las fuentes escritas, relativamente abundante (Fernández Ochoa et al. 2005: 100-102). No obstante, cabe destacar el hallazgo de un modesto edificio cristiano, datado entre finales del siglo VI y el siglo VII, en la zona de la actual iglesia de santa Marta, junto a la catedral medieval (Sevillano Fuertes y Vidal Encinas 2002). El edificio, que aprovecha como cimentación el hypocaustum de unas termas romanas, es de nave única y conservaba in situ el pavimento de opus signinum y el pie de una mensa, siendo posible identificar en él el sanctuarium, el coro y el espacio que ocuparía la congregación. Dentro de la nave, además, se pudo documentar una estructura que se ha identificado como un posible baptisterio (Martín López y Sevillano Fuertes e.p.).

Es necesario señalar que la organización del entorno de la ciudad responde, desde el inicio, a la cercanía a los principales yacimientos auríferos del territorio astur, siendo quizá por ese motivo la cabeza visible de la administración regional hasta que, tras la reorganización dioclecianea -en la que los conventus Bracarense, Lucense y Asturicense se desgajan de la antigua provincia Tarraconense y se integran en la nueva provincia Gallaecia-, la capitalidad fue asumida por Bracara Augusta. Se ha sugerido, de hecho, que este traslado podría haber estado relacionado, además de con otros factores, con el abandono en el primer tercio del siglo III de la explotación estatal del oro en la zona de Asturica y su desplazamiento hacia el sector galaico (Sánchez-Palencia 1995: 148, Morillo Cerdán y Amaré Tafalla 2003: 122-123). En cualquier caso, no cabe duda de que la implantación del control romano en el territorio de Asturica estuvo desde el inicio íntimamente relacionada con la actividad económica apenas referida, que creó una nueva organización del territorio. El castro pre-romano autosuficiente dejó de ser la unidad territorial fundamental (aunque algunos de ellos subsistieron y otros nuevos se crearon, sobre todo 
donde la morfología del terreno no permitía otro tipo de asentamiento). Es probable, además, que la utilización de los castros pudiese ser intermitente, respondiendo a las necesidades de la explotación aurífera, y con una alta movilidad de los trabajadores que, a partir de labores de prospección en las que desde las zonas bajas se remontaban los valles, buscaban las zonas con mayor potencial mineral para establecer la explotación (Sánchez-Palencia et al. 2000). Por otro lado, más allá de los espacios castreños, surgieron también nuevos asentamientos, de diferente forma y configuración, que solo tuvieron sentido como parte de una red de poblamiento y explotación minera regional, así como villas, mucho más conectadas con el poblamiento tradicional romano que, con un evidente carácter aristocrático, fueron claves en la jerarquización del territorio.

El caso de Albocela es bastante diferente del de Asturica (las ciudades distan c $115 \mathrm{~km}$ ), tanto en el desarrollo urbano, como en la organización de su paisaje, mucho más similar a la forma tradicional de ocupación rural romana. Albocela es un núcleo urbano ubicado a orillas del Duero, a medio camino entre Zamora y Toro, al oeste de la actual población de Villalazán y dentro de su término municipal. El asentamiento mide unos $1.000 \mathrm{~m}$ en sentido $\mathrm{E}-\mathrm{W}$ por $500 \mathrm{~m}$ en sentido N-S. Las dimensiones totales del espacio urbano rondan las 50 ha, lo que supone una ciudad de tamaño medio para la península ibérica. La ciudad romana nace sobre el precedente de un establecimiento de la Edad del Hierro identificado en los trabajos de prospección en la zona conocida como Valcuevo. Al occidente del espacio urbano, que es de trama regular, la prospección aérea reveló trazas de un campamento romano. A juzgar por el hallazgo de terra sigillata itálica y gálica en el muestreo superficial, la trama urbana regular podría datar del principado de Augusto o Tiberio (Ariño Gil et al. 2007). Apenas se han practicado excavaciones en la ciudad, si bien en 1987 se intervino en un edificio que fue interpretado como unas termas (González Serrano 1990, Martín Arija et al. 1994a y 1994b, García Rozas 1995). Los trabajos de prospección en Albocela indican que el espacio urbano está ocupado (no sabemos en qué forma) al menos hasta el siglo $\mathrm{V}$, momento a partir del cual se asistiría al abandono de la ocupación (Ariño Gil et al. 2007: 192).

\section{BASES CIENTÍFICAS Y DISEÑO DEL PROYECTO}

La investigación que hemos llevado a cabo partía de una división del espacio de trabajo en dos zonas diferentes, cada una de ellas jerarquizada en torno a las ciudades romanas de Albocela y Asturica. Su objetivo era llevar a cabo un muestreo superficial en distintos tipos de asentamientos en el territorio de cada uno de los dos centros urbanos elegidos como modelos. Los asentamientos del periodo comprendido entre el c 400 y c 800 presentan una gran diversidad morfológica, por lo que la preselección de puntos de muestreo aspiraba a incluir al menos las categorías que se consideran más significativas del periodo: 1) el castro prerromano con ocupación tardía, así como otros poblados en altura; 2) la villa romana con evidencias de ocupación posteriores al año 400; 3) otros asentamientos romanos en llano, en el caso de Asturica, especialmente, puntos de hábitat asociados a la explotación minera; 4) asentamientos suevo/visigodos o altomedievales en llano; 5) necrópolis tardías, con posibles puntos de hábitat asociado; 6) despoblados o aldeas plenomedievales que pudieran albergar una secuencia de ocupación de periodos anteriores.

La selección de yacimientos para el muestreo se enfrenta, desde su principio, al problema de que los territorios urbanos objeto de estudio no tienen límites geográficos precisos, siendo posible solamente una definición aproximada de los mismos partiendo de su relación con las ciudades vecinas. Por ello, se seleccionaron para la base de datos inicial aquellos yacimientos que quedaran incluidos en un polígono que tuviera a cada una de las ciudades en su punto central y que, por su proximidad al centro urbano, pudieran considerarse con cierta seguridad como dependientes de este. Si bien se trata de una solución pragmática, puede considerarse que todos los yacimientos sobre los que se ha actuado estarían efectivamente dentro de los territorios urbanos analizados.

La base de datos utilizada como documentación de partida fue el Inventario Arqueológico de Castilla y León (IACyL), complementado o refrendado con la literatura científica disponible sobre cada uno de los yacimientos. Con frecuencia, la adscripción cultural de un yacimiento en el IACyL es poco fiable (Ariño Gil y de Soto García 2016). Este problema deriva de varios factores, entre los que cabe destacar especialmente que la clasificación cultural del yacimiento - a partir del material de prospección- es en gran medida intuitiva y se basa sobre todo en criterios cualitativos, basados en ocasiones en la identificación de unos pocos fragmentos cerámicos en superficie (en menor medida, también de otros materiales arqueológicos, como epigrafía, monedas u otros hallazgos). En el caso del territorio asturicense, el problema de la clasificación cultural del yacimiento 


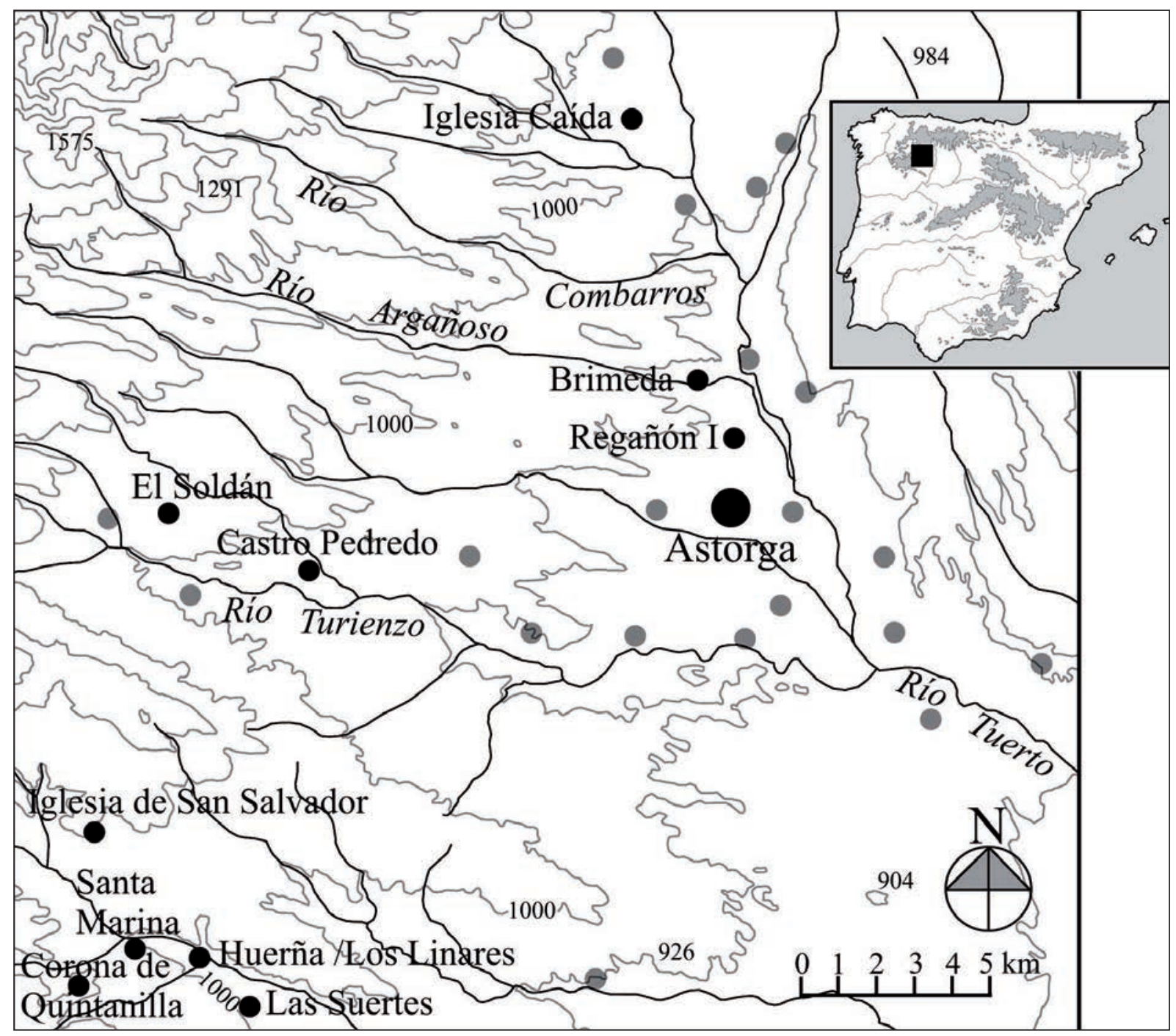

Figura 1. Mapa del territorio de Asturica, en el que se señalan los yacimientos que poseen indicadores en superficie de ocupación en época romana o de la secuencia tardoantigua (se valora la presencia de tegula, terra sigillata, itálica, gálica, hispánica o hispánica tardía, cerámica común de cocina o cerámica común de cocina decorada con líneas bruñidas). Se destacan los yacimientos prospectados. Imagen elaborada sobre base cartográfica de Iberpix 4, Instituto Geográfico Nacional.

se complica por el hecho de que muchos asentamientos del periodo romano se definen por la morfología de su planta a partir del análisis de la fotografía aérea o de satélite (por la presencia de fosos de circunvalación) y por sus localizaciones características junto a explotaciones mineras, sin que el examen superficial (por circunstancias asociadas a una muy deficiente visibilidad) permitan recuperar material cerámico (Orejas Saco del Valle 1996). Por ello, la preselección de puntos de visita se hizo privilegiando aquellos yacimientos en los que el IACyL y la literatura científica informaban de la observación de material cerámico en superficie.
En el territorio de Asturica se preseleccionaron para el estudio 30 yacimientos (fig. 1) que se juzgaron como susceptibles de aportar información positiva en un muestreo superficial. Trece de ellos fueron objeto de prospección (por estimarse que eran los que mejor definían las categorías objeto de análisis), pero solo cinco revelaron material cerámico en superficie y pudieron ser objeto de muestreo (tab. 1). Estos cinco yacimientos se juzgaron representativos de distintos modelos de hábitat con secuencias de los periodos de interés. Castro Pedredo (Santa Colomba de Somoza) estaba catalogado como un castro prerromano y romano asociado a 
Tabla 1. Yacimientos prospectados en el territorio de Asturica. Se señala el topónimo, municipio, material registrado en los informes del IACyL y resultado de la prospección.

\begin{tabular}{|l|l|l|l|}
\hline \multicolumn{1}{|c|}{ Yacimiento } & \multicolumn{1}{|c|}{ Municipio } & \multicolumn{1}{c|}{ Indicadores } & \multicolumn{1}{c|}{ Prospección } \\
\hline Santa Marina & Luyego & tegula & negativa \\
\hline Huerña/Los Linares & Luyego & excavado: asentamiento romano altoimperial & $\begin{array}{l}\text { superficie muestreada: } \\
8.330 \mathrm{~m}^{2}\end{array}$ \\
\hline Las Suertes & Luyego & $\begin{array}{l}\text { terra sigillata hispánica, cerámica de paredes } \\
\text { finas, tegula }\end{array}$ & negativa \\
\hline Corona de Quintanilla & Luyego & excavado: asentamiento romano altoimperial & negativa \\
\hline Iglesia de San Salvador & Luyego & tegula & negativa \\
\hline Iglesia Caída & Magaz de Cepeda & terra sigillata hispánica & $\begin{array}{l}\text { superficie muestreada: } \\
8.131 \mathrm{~m}^{2}\end{array}$ \\
\hline Castro Pedredo & Santa Colomba de Somoza & terra sigillata hispánica, tegula & $\begin{array}{l}\text { superficie muestreada: } \\
14.139 \mathrm{~m}^{2}\end{array}$ \\
\hline El Soldán & Santa Colomba de Somoza & excavado: villa romana altoimperial & negativa \\
\hline Regañón I & Villaobispo de Otero & terra sigillata hispánica & $\begin{array}{l}\text { superficie muestreada: } \\
37.357 \mathrm{~m}^{2}\end{array}$ \\
\hline Brimeda & Villaobispo de Otero & Sin datos & $\begin{array}{l}\text { superficie muestreada: } \\
386.854 \mathrm{~m}^{2}\end{array}$ \\
\hline
\end{tabular}

los frentes de explotación de minería antigua conocida como Los Fuellos (Orejas Saco del Valle 1996: 74-78, 117 y 194). Huerña/Los Linares (Luyego) se identificaba como un hábitat minero no castreño con secuencia de ocupación altoimperial, asociado a las explotaciones de Los Castellones-Río Llamas (Orejas Saco del Valle 1996: 154 y 192). En este yacimiento se habían practicado excavaciones que habían puesto al descubierto estructuras de vivienda datadas en los siglos I-II (Domergue y Martin 1977). Iglesia Caída (Magaz de Cepeda) presentaba una morfología que permitía proponerlo como un castro con secuencia de habitación en el periodo romano y altomedieval. Como materiales significativos de la secuencia más antigua en este asentamiento se registraban dos fíbulas zoomorfas y una figura de un gallo, todas en bronce, que en la actualidad se hallan en el Museo de León ( $\mathrm{n}^{\mathrm{o}}$ de inventario 398, 399 y 671), si bien, en el desarrollo del trabajo de campo, la atribución de estos materiales al yacimiento de Iglesia Caída resultó ser dudosa ${ }^{1}$. Regañón I (Villaobispo de Otero) se definía como hábitat rural en llano con secuencias del periodo romano altoimperial y

1. Información personal de Luis Grau Lobo, Museo de León, 26 de enero de 2017. tardío. El quinto espacio de prospección se situó en el entorno de Brimeda (Villaobispo de Otero). Brimeda no es propiamente un yacimiento, ya que es una aldea fundada en el siglo IX que continúa habitada en la actualidad. Un importante documento datado en el año 878 atestigua labores de colonización agrícola basadas en la construcción de un parcelario regular asociado a la fundación de la aldea, denominada como Villa Vimineta (Floriano Cumbreño 1951: 127-130 -doc. 120, Ariño Gil et al. 2004: 203-209). Brimeda era un caso de especial interés para los objetivos de nuestro estudio, ya que debía permitir abordar la cuestión de si se trataba de una fundación ex novo -como al parecer permite suponer el documento que, además, de forma expresa menciona la organización de su parcelario, la puesta en cultivo y su edificación (...et fecit ibidem suas signas et aedificauit ibidem casas, cortes, arauit, seminauit in ipsa uilla...)- o si la aldea se estableció sobre el precedente de una ocupación anterior.

Por último, pese a que no pudo ser objeto de muestreo superficial a causa de la mala visibilidad que el yacimiento presenta en la actualidad, se ha incluido en el estudio el yacimiento de El Soldán (Santa Colomba de Somoza). El Soldán es sin duda la villa romana mejor documentada del territorio de Asturica. (Mañanes 


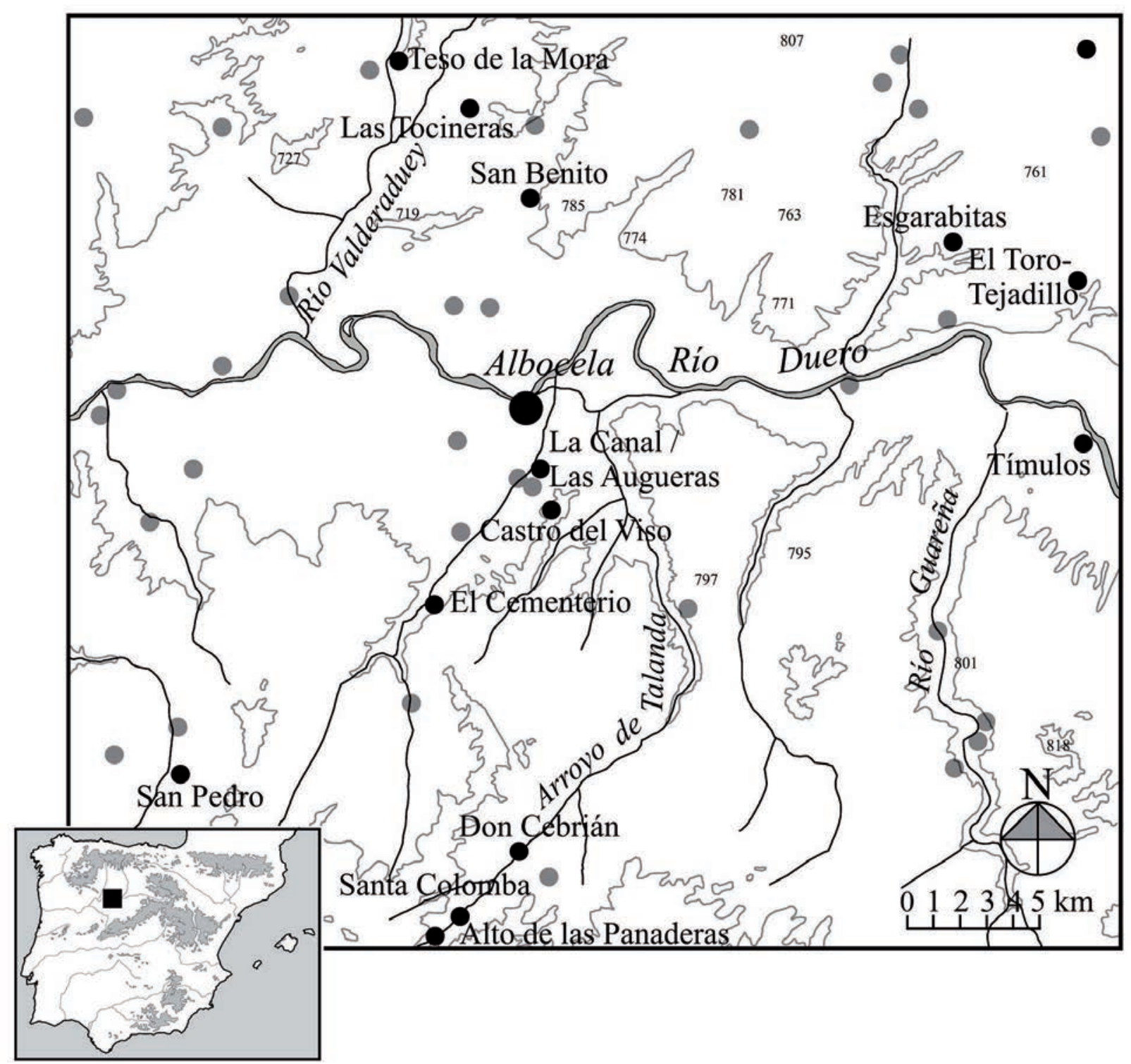

Figura 2. Mapa del territorio de Albocela, en el que se señalan los yacimientos que poseen indicadores en superficie de ocupación en época romana o de la secuencia tardoantigua (se valora la presencia de tegula, terra sigillata, itálica, gálica, hispánica o hispánica tardía, cerámica común de cocina o cerámica común de cocina decorada con líneas bruñidas). Se destacan los yacimientos prospectados. Imagen elaborada sobre base cartográfica de Iberpix 4, Instituto Geográfico Nacional.

Pérez 1977, Gorges 1979: 276-277, García-Entero 2001: 141-147). Ante la imposibilidad de obtener un contexto superficial, el análisis de los contextos cerámicos de la villa de El Soldán se llevó a cabo sobre el material cerámico recuperado en las excavaciones llevadas a cabo por Carro en los inicios del siglo XX (Carro 1934). Este material está depositado en el Instituto Leonés de Cultura y fue tratado como conjunto, ya que no existe constancia de su registro estratigráfico. Sin embargo, puede juzgarse representativo de la secuencia de ocupación del asentamiento, ya que su examen reveló que no había sido objeto de selección por parte de su excavador. Así, los contextos de excavación incluyeron, junto a piezas de cerámica de mesa, numerosos fragmentos de cerámicas comunes y de cocina.

En el territorio de Albocela se preseleccionaron 47 yacimientos en total (fig. 2). De ellos, 13 fueron objeto de prospección superficial con el fin de valorar 
Tabla 2. Yacimientos prospectados en el territorio de Albocela. Se señala el topónimo, municipio, material registrado en los informes del IACyL y resultado de la prospección.

\begin{tabular}{|c|c|c|c|}
\hline Yacimiento & Municipio & Indicadores & Prospección \\
\hline San Benito & Algodre & terra sigillata hispánica, tegula & negativa \\
\hline San Pedro & Casaseca del Campeán & $\begin{array}{l}\text { terra sigillata hispánica, cerámica común de } \\
\text { cocina }\end{array}$ & negativa \\
\hline Alto de las Panaderas & Cuelgamures & terra sigillata hispánica, tegula & negativa \\
\hline Santa Colomba & Fuentespreadas & excavado: necrópolis romana tardía & negativa \\
\hline Don Cebrián & Fuentespreadas & $\begin{array}{l}\text { cerámica estampillada, cerámica común de } \\
\text { cocina, tegula }\end{array}$ & negativa \\
\hline El Cementerio & Gema & $\begin{array}{l}\text { terra sigillata hispánica, terra sigillata } \\
\text { hispánica tardía, cerámica pintada, cerámica de } \\
\text { paredes finas, lucerna, tegula }\end{array}$ & $\begin{array}{l}\text { superficie muestreada: } \\
2.368 \mathrm{~m}^{2}\end{array}$ \\
\hline Castro del Viso & Madridanos & cerámica pintada celtibérica & $\begin{array}{l}\text { superficie muestreada: } \\
3.212 \mathrm{~m}^{2}\end{array}$ \\
\hline La Canal/Las Augueras & Madridanos & $\begin{array}{l}\text { terra sigillata hispánica, terra sigillata } \\
\text { hispánica tardía cerámica pintada, tegula }\end{array}$ & negativa \\
\hline Teso la Mora & Molacillos & excavado: cisternas romanas & $\begin{array}{l}\text { superficie muestreada: } \\
1.107 \mathrm{~m}^{2}\end{array}$ \\
\hline Las Tocineras & Molacillos & terra sigillata hispánica, tegula & negativa \\
\hline El Toro-Tejadillo & Toro & $\begin{array}{l}\text { cerámica pintada celtibérica, terra sigillata } \\
\text { hispánica, tegula }\end{array}$ & $\begin{array}{l}\text { superficie muestreada: } \\
4.047 \mathrm{~m}^{2}\end{array}$ \\
\hline Esgarabitas & Toro & cerámica común de cocina & negativa \\
\hline Tímulos & Toro & cerámica común de cocina & $\begin{array}{l}\text { superficie muestreada: } \\
4.445 \mathrm{~m}^{2}\end{array}$ \\
\hline
\end{tabular}

su idoneidad para llevar a cabo un muestreo (tab. 2), pero solo en cinco se pudo recuperar un contexto cerámico superficial significativo. El Castro del Viso (Madridanos) estaba definido como un importante castro de la II Edad del Hierro (Martín Valls 1973: 403405, 1995: 154-157 y 172), pero con posibles indicios de ocupación en el periodo medieval (Larrén Izquierdo 1994: 336). A la misma categoría de castro prerromano, pero con una ocupación romana al parecer significativa, correspondía el Teso de la Mora (Molacillos), donde se habían excavado dos importantes cisternas romanas de opus signinum en cuyos niveles de amortización se había recuperado terra sigillata itálica, la cual fechaba el final de uso de las cisternas hacia los últimos años del reinado de Augusto o en los primeros años del de Tiberio (Martín Valls y Delibes de Castro 1976: 427-429, Balado Pachón y Martínez García 2008). El Cementerio (Gema) (Martín Valls 1973: 405, Pérez
Centeno 1990: 447) y El Toro-Tejadillo (Toro) (Martín Valls y Delibes de Castro 1977: 309-311) estaban definidos por la investigación previa como villas romanas, con indicios de ocupación tardía. En el Cementerio se había practicado una excavación de urgencia, aunque con escasos resultados (Larrén Izquierdo 1994: 338-339). Por último, el yacimiento de Tímulos (Toro) podía catalogarse, a juzgar por el material obtenido en las investigaciones previas anotadas en el IACyL, como un asentamiento en llano del periodo suevo/visigodo y altomedieval. En este caso existía además el interés adicional de que el topónimo Tímulos estaba registrado como lugar poblado en el año 1208 (Pascual Sánchez 1991: 198-199).

Resulta de interés destacar los resultados negativos del muestreo en la necrópolis de Santa Colomba (Fuentespreadas). Santa Colomba (Caballero Zoreda 1974) es uno de los yacimientos más representativos de lo que en 
su día fue caracterizado como "necrópolis del Duero" (Palol 1958) y que hoy se prefiere considerar como necrópolis tardorromanas o post-imperiales (Fuentes Domínguez 1989, Vigil-Escalera 2015: 71-78 y 155-162). La prospección no proporcionó material cerámico en superficie en la zona en la que se localiza el yacimiento ni en el Alto de las Panaderas, un sitio en el que el IACyL localizaba restos compatibles con la cronología de las necrópolis, lo cual deja abierta la contextualización y lectura de las inhumaciones documentadas. En el yacimiento de San Pedro (Casaseca del Campeán), considerado por el IACyL como despoblado medieval, se desestimó el muestreo porque la prospección superficial previa no ofreció fragmentos cerámicos a la vista, aunque sí un abundante número de fragmentos de teja.

\section{MÉTODOS Y TÉCNICAS}

Como paso previo al muestreo se realizó, en todos los yacimientos preseleccionados (trece para cada uno de los territorios), una inspección previa. Esta inspección previa no incluyó la recogida de material arqueológico. Su finalidad era, por un lado, chequear la información contenida en el IACyL y comprobar la presencia de restos cerámicos en superficie en el área marcada en los registros cartográficos del IACyL y, por otro, seleccionar el espacio de intervención en el yacimiento, atendiendo especialmente a las condiciones de visibilidad superficial en el momento de la actuación. Los datos obtenidos en esta inspección ocular previa, como hemos señalado antes, obligaron a modificar el plan de trabajo original ya que solo una parte de los yacimientos preseleccionados (un 41,6\% del conjunto del entorno de Albocela y un $30,7 \%$ en el de Asturica) exhibía restos cerámicos en esta inspección superficial. No siempre fue posible determinar la causa de esta discordancia entre los datos del IACyL y los obtenidos en nuestra visita, la cual en algunos casos pudiera deberse a problemas de visibilidad superficial en el momento de la inspección, pero también a deficiencias de actuación en los registros previos, deficiencias derivadas de dos posibles fenómenos: a) sobrevaloración de material off-site como indicativo de la existencia de un yacimiento y; b) error en la localización geográfica del yacimiento, a causa de un registro cartográfico incorrecto, derivado en ocasiones de la coincidencia de topónimos en dos áreas distintas o debido a otras causas y factores imposibles de determinar. Por otro lado, incluso en varios de aquellos sitios en los que la inspección previa revelaba la presencia de material cerámico en superficie, las condiciones de visibilidad no eran las óptimas para, como inicialmente habíamos previsto, realizar un muestreo mediante cuadrículas de $10 \mathrm{~m}$ de lado (sistema ensayado satisfactoriamente en la provincia de Salamanca y que se había revelado como eficaz para definir las secuencias de ocupación de los yacimientos basada en la cuantificación del material cerámico, vid. Ariño et al. 2015, Ariño Gil y Soto García 2016), ya que solo pequeños espacios discontinuos presentaban las condiciones de visibilidad adecuadas. En este sentido, se concluyó que la solución óptima para las características de los territorios en estudio era la de una estrategia de muestreo basada en la recolección integra de todo el material observado en superficie en la zona marcada, siendo cada pieza o fragmento registrada como way-point en coordenadas GPS.

Como ya se ha expuesto, la clasificación cultural que registra el IACyL se basa en la observación del material cerámico superficial atendiendo a valores cualitativos. Sin embargo, como ya hemos argumentado en otras ocasiones (Ariño Gil y Rodríguez Hernández 1997, Ariño Gil et al. 2002), la secuencia altomedieval es subestimada en este tipo de examen, ya que el material de este periodo (que incluye la secuencia suevo/visigoda) se caracteriza por la asociación tegula/cerámica común de cocina, siendo el material característico del periodo (cerámica estampillada o TSHip, cerámica común de cocina decorada con líneas bruñidas) muy escaso (Ariño Gil y Dahí Elena 2012, Dahí Elena 2012). En el registro estratificado, la cerámica de cocina es el material más abundante, a partir de mediados o finales del siglo $\mathrm{V}$ y hasta una época no bien determinada, que en nuestra zona de trabajo al menos alcanza los inicios del siglo IX (Ariño Gil y Dahí Elena 2012, Dahí Elena 2012, Vigil-Escalera 2013, Sastre Blanco et. al. 2018: 392-396). En el registro superficial no es fácil poder reconstruir tipologías (por otro lado no determinantes para elaborar cronologías, ya que el repertorio formal de esta producción es muy sencillo). Sin embargo altos valores del número de fragmentos de cerámica común de cocina, asociados a la presencia minoritaria de terra sigillata hispánica tardía o de cerámica de cocina decorada con líneas bruñidas, se juzgan indicadores suficientes para proponer una ocupación en el periodo tardoantiguo o altomedieval.

El registro del material en coordenadas GPS favorece la cuantificación, permite abordar un análisis del yacimiento en el nivel del microespacio, facilitando la detección de variaciones en la intensidad de ocupación zonal, y sirve para definir los límites exactos de la superficie muestreada al registrar el recorrido de cada uno de los prospectores mediante tracks. Los datos fueron registrados sobre la base cartográfica del Instituto Geográfico 


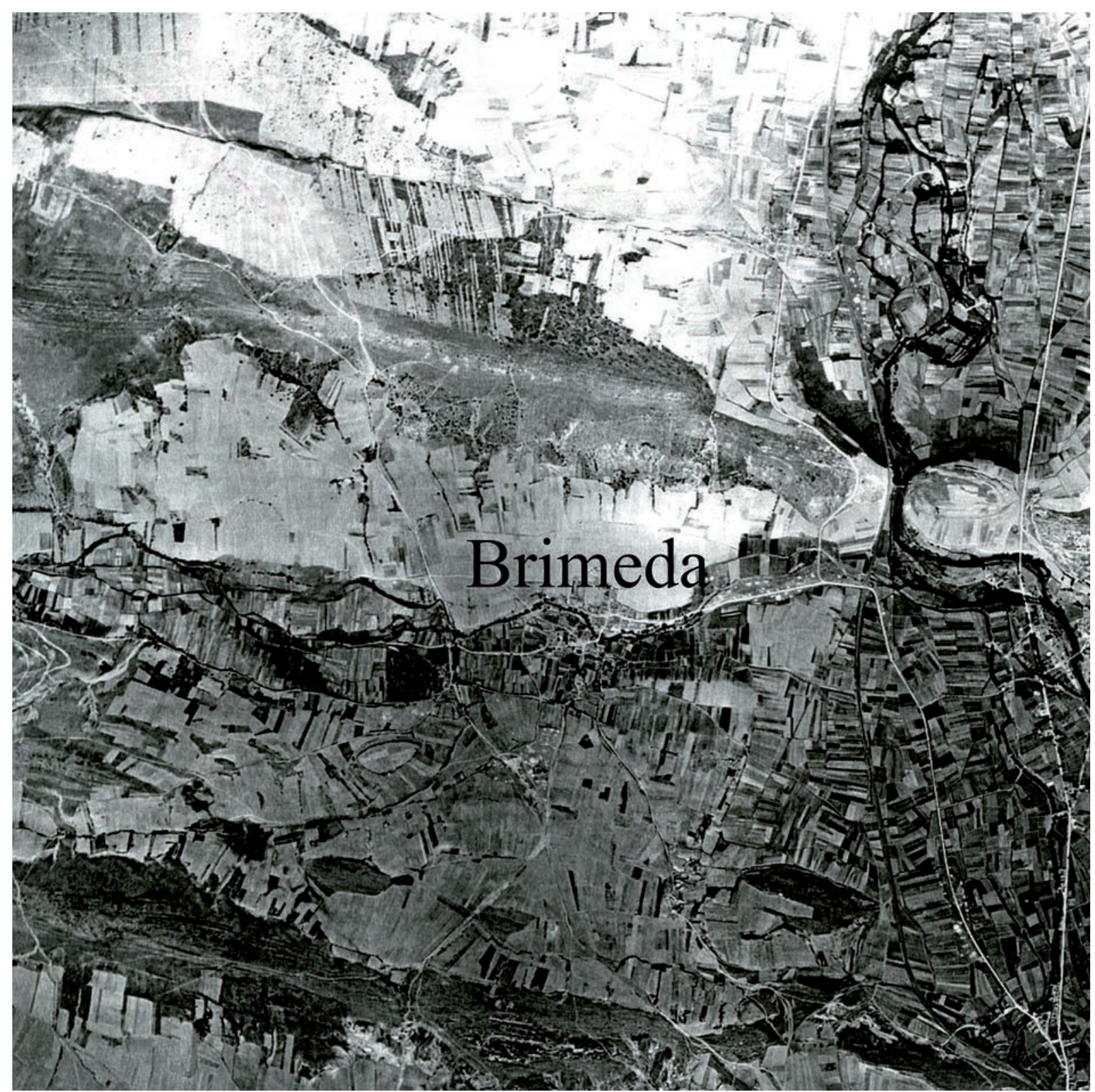

Figura 3. Fotografía aérea del año 1956 en que se aprecia el parcelario regular en torno a Brimeda (Servicio Geográfico del Ejército, fot. 14931-R. 160-27 de julio de 1956). Escala original del vuelo 1: 33.000 aprox.

Nacional (portal $<$ http://pnoa.ign.es/productos $>$ ) en una herramienta SIG (sistema de código libre QGIS, 2.18 Las Palmas: <https://qgis.org/es/site/about/index.html>.).

El estudio de Brimeda, villa fundada en el año 878, parte de la interpretación del fotograma aéreo del Servicio Geográfico del Ejército (fot. 14931, R. 160, 27 de junio de 1956), el cual permite apreciar un parcelario regular jerarquizado en tono a la aldea que es con toda probabilidad aquel al que hace referencia el documento (fig. 3). Partiendo de esta información, se diseñó un muestreo del entorno agrícola de Brimeda con el fin de recuperar material cerámico off-site en las tierras de cultivo, partiendo de la hipótesis de que las labores de abonado realizadas con basura doméstica podrían albergar un registro de toda la secuencia de actuación humana sobre un paisaje histórico y, de ser así, el registro cerámico podría incluir materiales de la secuencia altomedieval. 


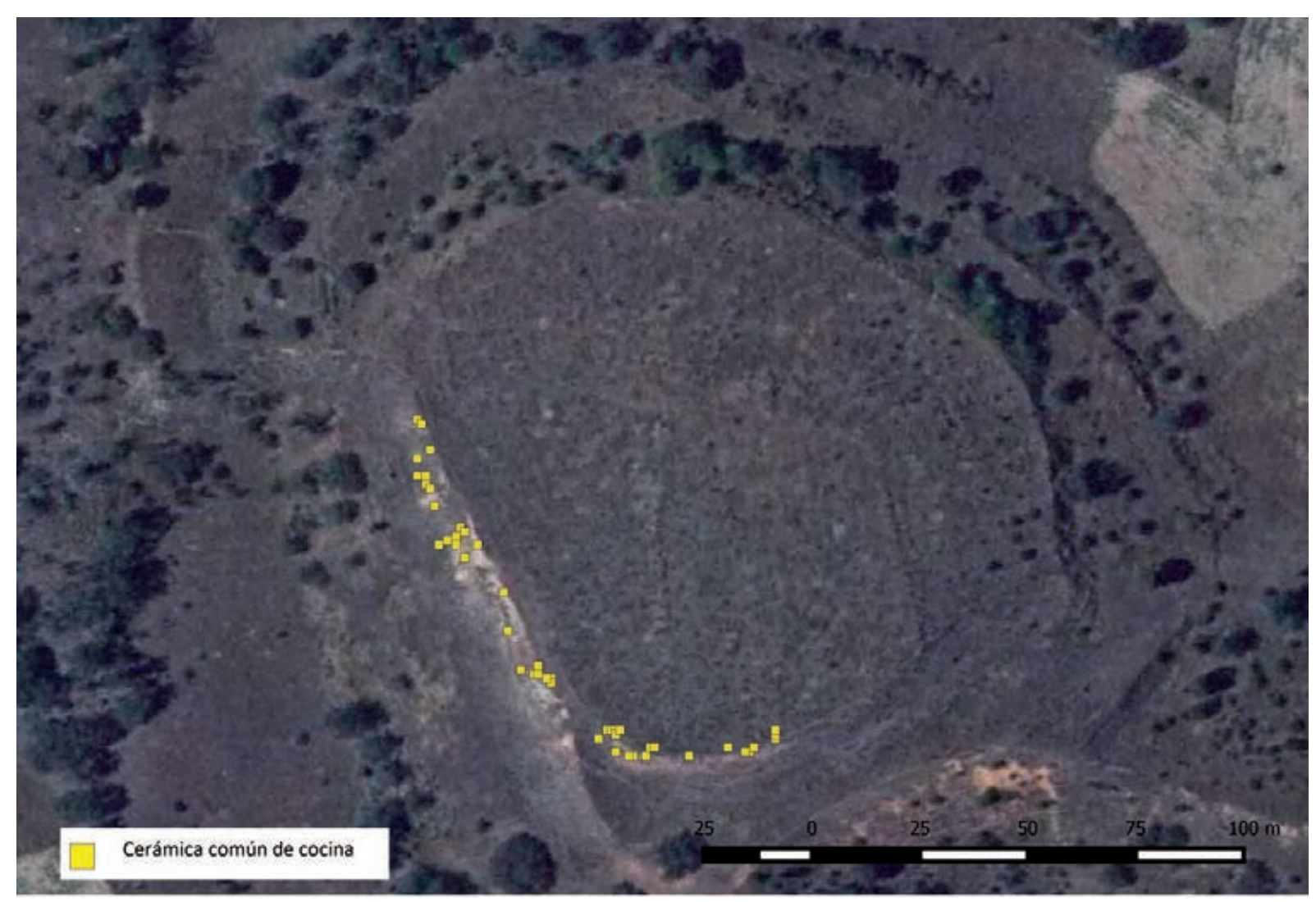

Figura 4. Castro de Pedredo (Santa Colomba de Somoza). Planta del asentamiento y dispersión de la cerámica común de cocina en el área prospectada. Base cartográfica del Instituto Geográfico Nacional (portal <http://pnoa.ign.es/>.).

\section{RESULTADOS DE LA PROSPECCIÓN. REGISTRO DEL MATERIAL CERÁMICO SUPERFICIAL}

\subsection{En el territorio de Asturica}

De los yacimientos seleccionados en territorio asturicense, hay dos que se pueden relacionar directamente con la explotación minera de la zona en época romana: la Corona del Castro y el yacimiento de Huerña-Los Linares. La Corona del Castro, también denominada como Castro de Pedredo-Alto de la Corona, es un lugar bien reconocible, pues destaca sobre el terreno y se localiza a unos $200 \mathrm{~m}$, al sureste de Pedredo (Orejas Saco del Valle 1996: 74-78, 117 y 194). La fotografía aérea permite apreciar la forma de la planta del asentamiento, sensiblemente circular, de unos $75 \mathrm{~m}$ de diámetro, con un recinto bien delimitado que cuenta, al parecer, con al menos un foso. El castro minero de época romana altoimperial se asentó sobre un espacio que ya había contado con una ocupación anterior, en la Edad del Hierro.
El contexto cerámico, aunque escaso, parece descartar una ocupación en época bajoimperial, ya que no se registra terra sigillata hispánica tardía. Sin embargo el hecho de que la producción más representada sea la cerámica común de cocina obliga a considerar la posibilidad de que exista una ocupación del asentamiento en el periodo suevo y visigodo (fig. 4, tab. 3).

En Huerña-Los Linares se identificó un poblado en llano de época altoimperial (siglos I-II), a partir de las excavaciones realizadas por Domergue y Martin (1977), que pusieron al descubierto estructuras de vivienda y un conjunto significativo de materiales. Se localiza al sur del Duerna y al oeste del río Llamas, en un espacio de minería intensamente explotado en la antigüedad (Orejas Saco del Valle 1996: 154 y 192). En el contexto cerámico superficial se obtienen, sin embargo, indicadores (terra sigillata hispánica tardía en cantidades significativas) que apuntan a una ocupación en fases más avanzadas. La ocupación del periodo suevo/ visigodo, queda marcada por un importante número de fragmentos de cerámica común de cocina asociada a la 
Tabla 3. Números totales y porcentajes (en gris) de las producciones cerámicas recuperadas en la prospección de Asturica. Cam: cerámica fabricada a mano, Cpint: cerámica pintada, Tsi: terra sigillata itálica, Tsg: terra sigillata gálica, Tsh: terra sigillata hispánica, Tsh avan: terra sigillata hispánica avanzada, Tsht lisa: terra sigillata hispánica tardía lisa, Tsh mold: terra sigillata hispánica tardía a molde, ARSW: African Red Slip Ware, CCCafr: cerámica común de cocina africana, Cpf: cerámica de paredes finas, Ceng: cerámica engobada, Cerp: cerámica de engobe rojo pompeyano, Cierp: imitación de la cerámica de engobe rojo pompeyano, CC: cerámica común, CCC: cerámica común de cocina, Cgn: cerámica de color gris o negro con superficies bruñidas, CCCb: cerámica común de cocina decorada con líneas bruñidas, CCb: cerámica común decorada con líneas bruñidas, Lu: lucernas, Mo: morteros, Lo: loza tradicional, lo ind: loza industrial y porcelana.

\begin{tabular}{|l|c|c|c|c|c|c|c|c|}
\hline \multicolumn{1}{|c|}{ Yacimiento } & Cam & Cpint & Tsi & Tsg & Tsh & $\begin{array}{c}\text { Tsh } \\
\text { avan }\end{array}$ & $\begin{array}{c}\text { Tsht } \\
\text { lisa }\end{array}$ & $\begin{array}{c}\text { Tsht } \\
\text { mold }\end{array}$ \\
\hline \multirow{3}{*}{ Iglesia Caída } & 0,00 & 0,00 & 0,00 & 0,00 & 0,00 & 0,00 & 0,00 & 0,00 \\
\cline { 2 - 10 } & 0,00 & 0,00 & 0,00 & 0,00 & 0,00 & 0,00 & 0,00 & 0,00 \\
\hline \multirow{2}{*}{ Regañón I } & 0,00 & 0,00 & 0,00 & 0,00 & 1,00 & 0,00 & 50,00 & 5,00 \\
\cline { 2 - 10 } & 0,00 & 0,00 & 0,00 & 0,00 & 0,81 & 0,00 & 40,32 & 4,03 \\
\hline \multirow{2}{*}{ La Corona del Castro } & 1,00 & 0,00 & 0,00 & 0,00 & 10,00 & 0,00 & 0,00 & 0,00 \\
\cline { 2 - 10 } & 1,15 & 0,00 & 0,00 & 0,00 & 11,49 & 0,00 & 0,00 & 0,00 \\
\hline \multirow{2}{*}{ Luerña- } & 0,00 & 0,00 & 0,00 & 0,00 & 36,00 & 1,00 & 13,00 & 1,00 \\
\cline { 2 - 10 } & 0,00 & 0,00 & 0,00 & 0,00 & 22,09 & 0,61 & 7,98 & 0,61 \\
\hline \multirow{2}{*}{ Brimeda } & 2,00 & 1,00 & 0,00 & 0,00 & 0,00 & 0,00 & 0,00 & 0,00 \\
\hline \multirow{2}{*}{ El Soldán } & 0,22 & 0,11 & 0,00 & 0,00 & 0,00 & 0,00 & 0,00 & 0,00 \\
\hline
\end{tabular}

\begin{tabular}{|l|c|c|c|c|c|c|c|c|}
\hline \multirow{2}{*}{ Yacimiento } & ARSW & $\begin{array}{c}\text { CCC } \\
\text { afr }\end{array}$ & Cpf & Ceng & Cerp & Cierp & CC & CCC \\
\hline \multirow{3}{*}{ Iglesia Caída } & 0,00 & 0,00 & 0,00 & 0,00 & 0,00 & 0,00 & 15,00 & 7,00 \\
\cline { 2 - 9 } & 0,00 & 0,00 & 0,00 & 0,00 & 0,00 & 0,00 & 65,22 & 30,43 \\
\hline \multirow{2}{*}{ Regañón I } & 0,00 & 0,00 & 0,00 & 0,00 & 2,00 & 1,00 & 31,00 & 17,00 \\
\cline { 2 - 9 } & 0,00 & 0,00 & 0,00 & 0,00 & 1,61 & 0,81 & 25,00 & 13,71 \\
\hline \multirow{2}{*}{ La Corona del Castro } & 0,00 & 0,00 & 1,00 & 0,00 & 0,00 & 0,00 & 24,00 & 48,00 \\
\cline { 2 - 9 } & 0,00 & 0,00 & 1,15 & 0,00 & 0,00 & 0,00 & 27,59 & 55,17 \\
\hline \multirow{2}{*}{ Huerña- } & 0,00 & 0,00 & 0,00 & 0,00 & 1,00 & 0,00 & 57,00 & 24,00 \\
\cline { 2 - 9 } & 0,00 & 0,00 & 0,00 & 0,00 & 0,61 & 0,00 & 34,97 & 14,72 \\
\hline \multirow{2}{*}{ Brimeda } & 0,00 & 0,00 & 0,00 & 0,00 & 0,00 & 0,00 & 215,00 & 10,00 \\
\cline { 2 - 9 } & 0,00 & 0,00 & 0,00 & 0,00 & 0,00 & 0,00 & 23,97 & 1,11 \\
\hline \multirow{2}{*}{ El Soldán } & 0,00 & 0,00 & 83,00 & 2,00 & 57,00 & 0,00 & $2.405,00$ & 1.670 \\
\cline { 2 - 9 } & 0,00 & 0,00 & 1,65 & 0,04 & 1,14 & 0,00 & 47,93 & 33,28 \\
\hline
\end{tabular}




\begin{tabular}{|l|c|c|c|c|c|c|c|c|}
\hline \multicolumn{1}{|c|}{ Yacimiento } & $\mathrm{Cgn}$ & $\mathrm{CCCb}$ & $\mathrm{CCb}$ & $\mathrm{Lu}$ & $\mathrm{Mo}$ & Lo & Lo ind & Total \\
\hline \multirow{3}{*}{ Iglesia Caída } & 0,00 & 0,00 & 0,00 & 0,00 & 0,00 & 1,00 & 0,00 & 23 \\
\cline { 2 - 10 } & 0,00 & 0,00 & 0,00 & 0,00 & 0,00 & 11,11 & 0,00 & 100 \\
\hline \multirow{2}{*}{ Regañón I } & 2,00 & 0,00 & 2,00 & 0,00 & 0,00 & 11,00 & 2,00 & 124 \\
\cline { 2 - 11 } & 1,61 & 0,00 & 1,61 & 0,00 & 0,00 & 8,87 & 1,61 & 100 \\
\hline \multirow{2}{*}{ La Corona del Castro } & 0,00 & 0,00 & 0,00 & 0,00 & 0,00 & 3,00 & 0,00 & 87 \\
\cline { 2 - 10 } & 0,00 & 0,00 & 0,00 & 0,00 & 0,00 & 3,45 & 0,00 & 100 \\
\hline \multirow{2}{*}{$\begin{array}{l}\text { Huerña- } \\
\text { Los Linares }\end{array}$} & 0,00 & 0,00 & 0,00 & 0,00 & 0,00 & 30,00 & 0,00 & 163 \\
\hline \multirow{2}{*}{ Brimeda } & 0,00 & 0,00 & 0,00 & 0,00 & 0,00 & 18,40 & 0,00 & 100 \\
\hline \multirow{2}{*}{ El Soldán } & 0,00 & 0,00 & 50,00 & 0,00 & 0,00 & 345,00 & 274,00 & 897 \\
\hline
\end{tabular}

presencia de terra sigillata hispánica tardía a molde, ya que esta producción empieza a fabricarse en las últimas décadas del siglo IV (López Rodríguez 1985: 140 y 245-46, Paz Peralta 1991: 104, 117-19 y 228; 2008: 506-7; Dahí Elena 2007 y 2012) (fig. 5, tab. 3).

Sin aparente relación con la actividad minera, el yacimiento de Iglesia Caída destaca como un pequeño espacio elevado de forma aproximadamente circular, de c $75 \mathrm{~m}$ de diámetro, localizado a un kilómetro al oeste de Vega de Magaz. De hecho, es la morfología del asentamiento lo que justifica la catalogación del sitio como castro. Los materiales obtenidos en el muestreo, en condiciones de mala visibilidad, son suficientes para postular la existencia de poblamiento en Iglesia Caída, pero no permiten definir una secuencia cultural precisa, aunque la asociación de cerámica común de cocina y cerámica común, como únicas producciones significativas recuperadas, apunta a una ocupación alto y plenomedieval, que podría ser continuadora de la secuencia romana, en gran medida dudosa, definida tan solo por la morfología del asentamiento (fig. 6, tab. 3).

Prospectamos también un yacimiento, Regañón I, cuya tipología por el momento está por determinar, ya que la superficie de dispersión de material es muy reducida e incompatible con la lectura del yacimiento como villa romana. El contexto cerámico obtenido define una secuencia de ocupación en el Bajo Imperio (con seguridad en el siglo IV, aunque podría remontar a un momento impreciso del siglo III), a juzgar por el importante número de fragmentos de terra sigillata hispánica tardía. El hallazgo de cinco fragmentos de la variante a molde de esta producción junto a la presencia de dos fragmentos de cerámica de color gris o negro con superficie bruñida son argumentos para proponer una ocupación del lugar en la primera mitad del siglo V (Ariño Gil y Dahí Elena 2012, Dahí Elena 2012: 224). Un fragmento de cerámica a molde con barniz rojo-pompeyano podría ser indicativo de una fase más avanzada (Ariño Gil y Dahí Elena 2012, Dahí Elena 2012: 225), pero el escaso número recuperado de fragmentos de cerámica común de cocina es una evidencia que argumenta en contra de una secuencia de ocupación en el periodo visigodo avanzado (fig. 7, tab. 3).

Como hemos señalado antes, el hábitat tipo villa está representado por el yacimiento de El Soldán, de hecho, la única villa bien documentada en el territorio asturicense. La clasificación y cuantificación del material cerámico procedente de las excavaciones practicada a principios del siglo XX documenta un periodo de ocupación del asentamiento bastante reducido, entre la época flavia y los inicios del siglo III. Entre las producciones de mesa domina de forma casi exclusiva la terra sigillata hispánica lisa y a molde. Aunque la bibliografía recoge la presencia de dos fragmentos de terra sigillata gálica (Mañanes Pérez 1977: 228, Gorges 1979: 276-277) estas piezas no se encontraban entre los materiales que pudimos examinar. La terra sigillata hispánica tardía está prácticamente ausente (tan solo se contabilizan tres fragmentos de la variedad lisa). La producción más representada es la cerámica común, 


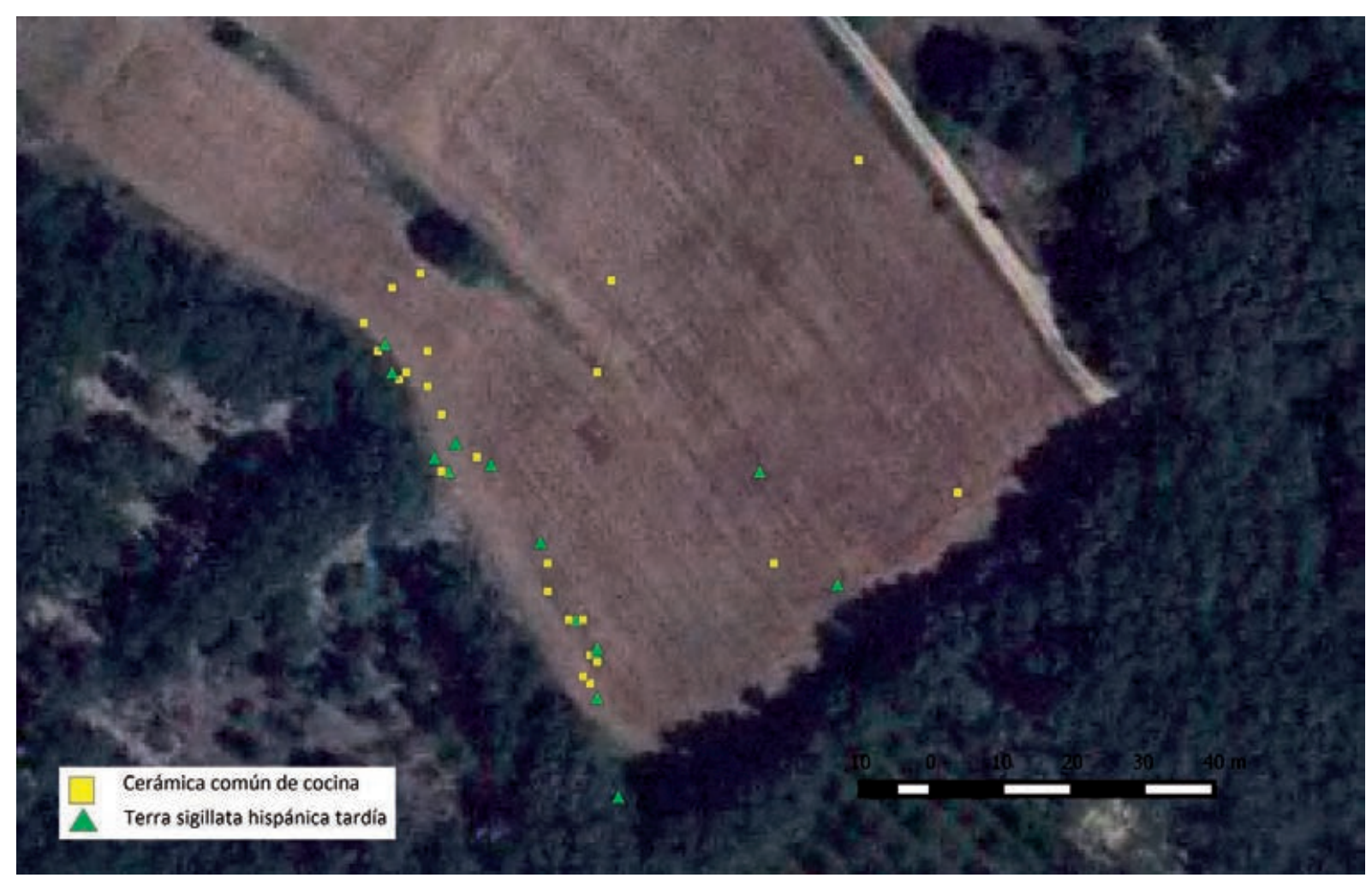

Figura 5. Huerña-Los Linares (Luyego). Dispersión de la terra sigillata hispánica tardía y de la cerámica común de cocina en el área prospectada. Base cartográfica del Instituto Geográfico Nacional (portal http://pnoa.ign.es/).

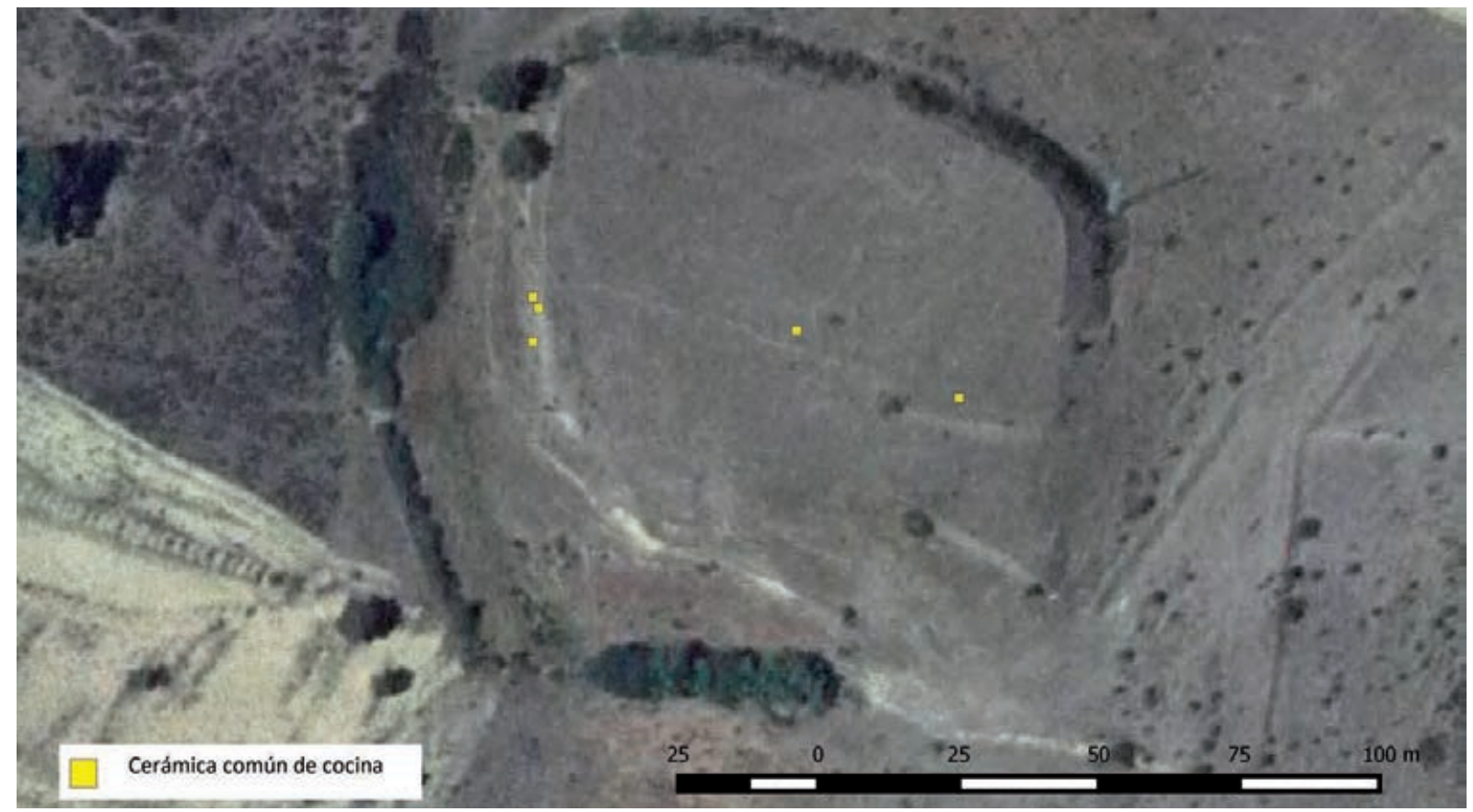

Figura 6. Iglesia Caída (Magaz de Cepeda). Planta del asentamiento y dispersión de la cerámica común de cocina en el área prospectada. Base cartográfica del Instituto Geográfico Nacional (portal http://pnoa.ign.es/).el área prospectada. Base cartográfica del Instituto Geográfico Nacional (portal http://pnoa.ign.es/). 


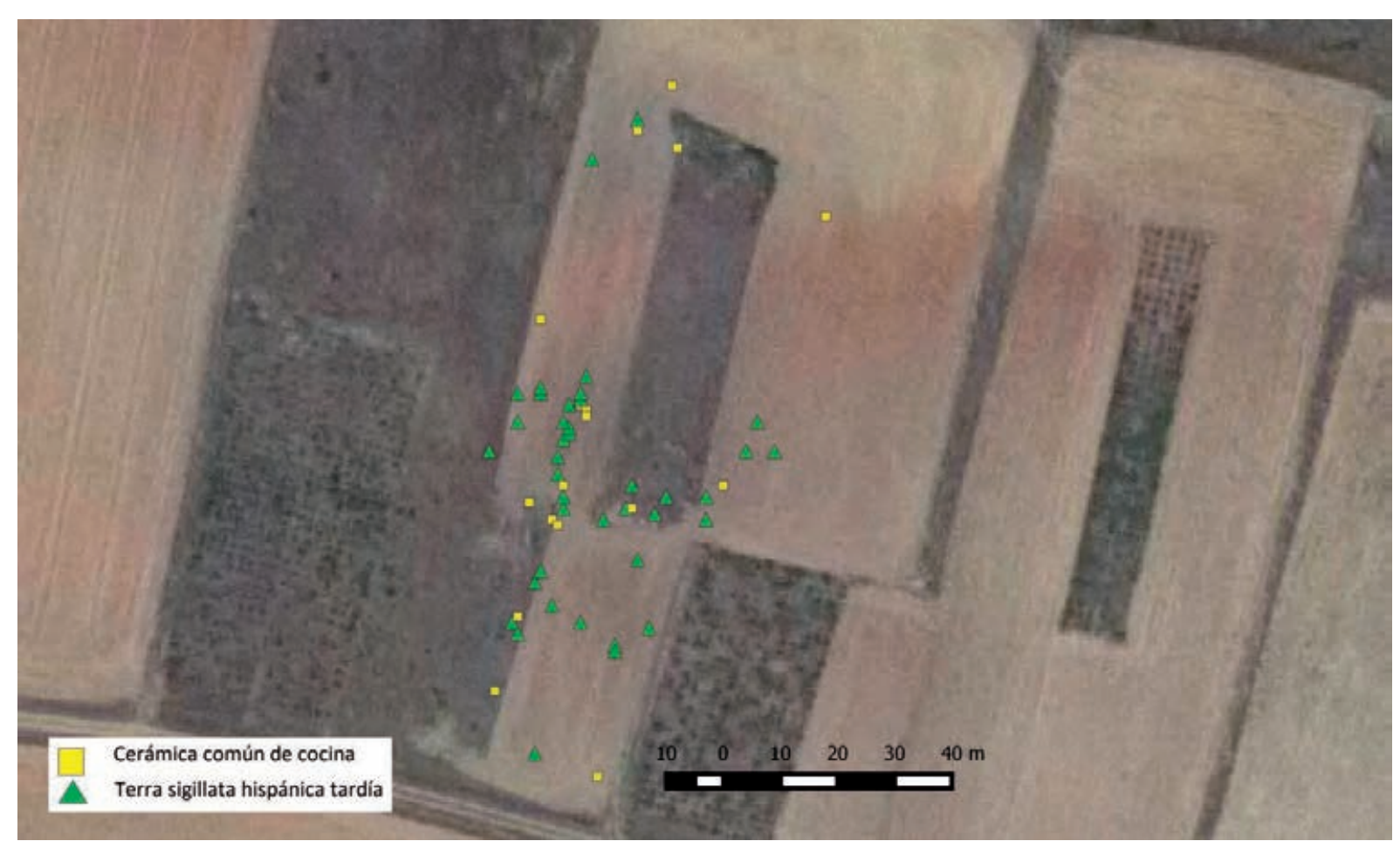

Figura 7. Regañón I (Villaobispo de Otero). Dispersión de la cerámica común de cocina y de terra sigillata hispánica tardía en el área prospectada. Base cartográfica del Instituto Geográfico Nacional (portal http://pnoa.ign.es/).

tanto con cocciones reductoras como oxidantes. La cerámica común de cocina presenta valores muy altos, pero dado que es el único indicio que podría apuntar a una ocupación tardía, lo más probable es que esta producción haya que situarla también en el periodo romano altoimperial. El examen del conjunto cerámico revela que no existen indicadores seguros que avalen la ocupación del asentamiento en la secuencia sueva, visigoda o altomedieval (tab. 3).

El muestreo del material off-site en el parcelario regular del entorno de Brimeda aporta importante información sobre el proceso de colonización del espacio agrícola en época altomedieval. Los indicios de ocupación del suelo antes del periodo en que se funda la villa son casi inexistentes y concuerdan con el hecho de que la colonización se hiciera sobre tierras prácticamente vírgenes, tal como describe el documento. En todo el espacio muestreado no se detectó ni un solo enclave previo e incluso el material registrado que podría datar de una fase anterior a la colonización emprendida por el obispo de Asturica se reduce a dos fragmentos de tegulae. Algunos de los fragmentos de cerámica común de cocina (diez en total) presentan fábricas características de las producciones del periodo suevo y visigodo, aunque no son incompatibles con contextos del siglo IX. Sin embargo el dato más importante lo aporta el hallazgo de 50 fragmentos de cerámica común decorada con líneas bruñidas, entre las que cabe destacar que existe una variación en esta técnica decorativa más cercana al espatulado con un instrumento de poca anchura (figs. 8 y 9, tab. 3). Estas cerámicas suelen considerarse como propias del periodo plenomedieval, asociándose a la segunda mitad del siglo XII, basándose para ello, fundamentalmente, en el registro del alfar de La Morterona (Saldaña) donde se asocian a una moneda de Sancho III (Peñil Mínguez 1987). No obstante la exacta cronología de esta producción cerámica está por establecer. Se sabe que se prolonga más allá de esta fecha-pues aparece por ejemplo en un contexto datado en el siglo XIII en el alfar de la calle Duque de la Victoria de Valladolid (Villanueva Zubizarreta 2011: 98-100)-, pero también se han propuesto dataciones en fases anteriores, en torno a los siglos IX-XI (Martínez Peñín 2007: 173-174). Por otro lado, su relación con la cerámica común de cocina decorada con líneas bruñidas, característica de la secuencia final del periodo visigodo (Dahí Elena 2012: 224-225) es un asunto pendiente de determinar, dado que la técnica decorativa es la misma en ambas producciones. 


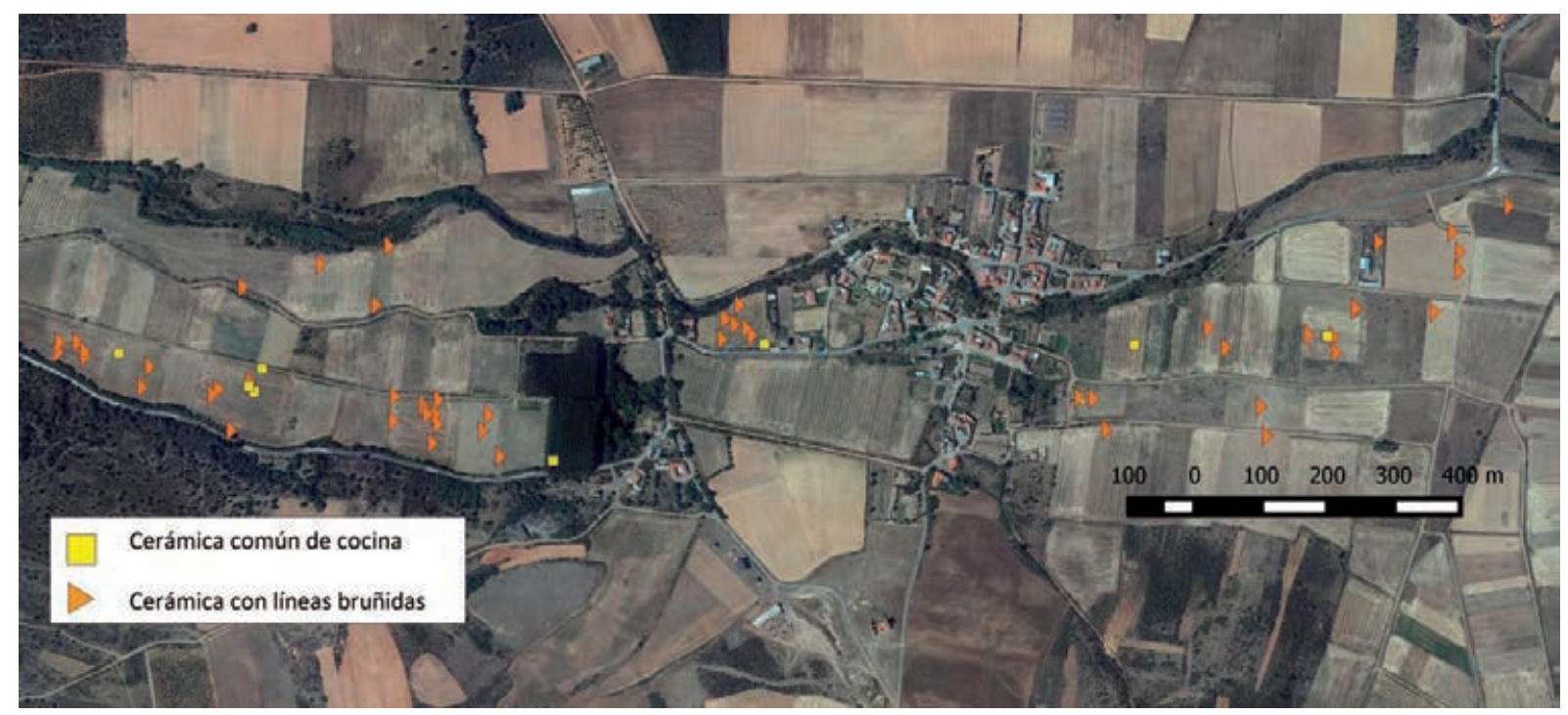

Figura 8. Brimeda (Villaobispo de Otero). Dispersión de la cerámica común decorada con líneas bruñidas en el área prospectada. Base cartográfica del Instituto Geográfico Nacional (portal http://pnoa.ign.es/).

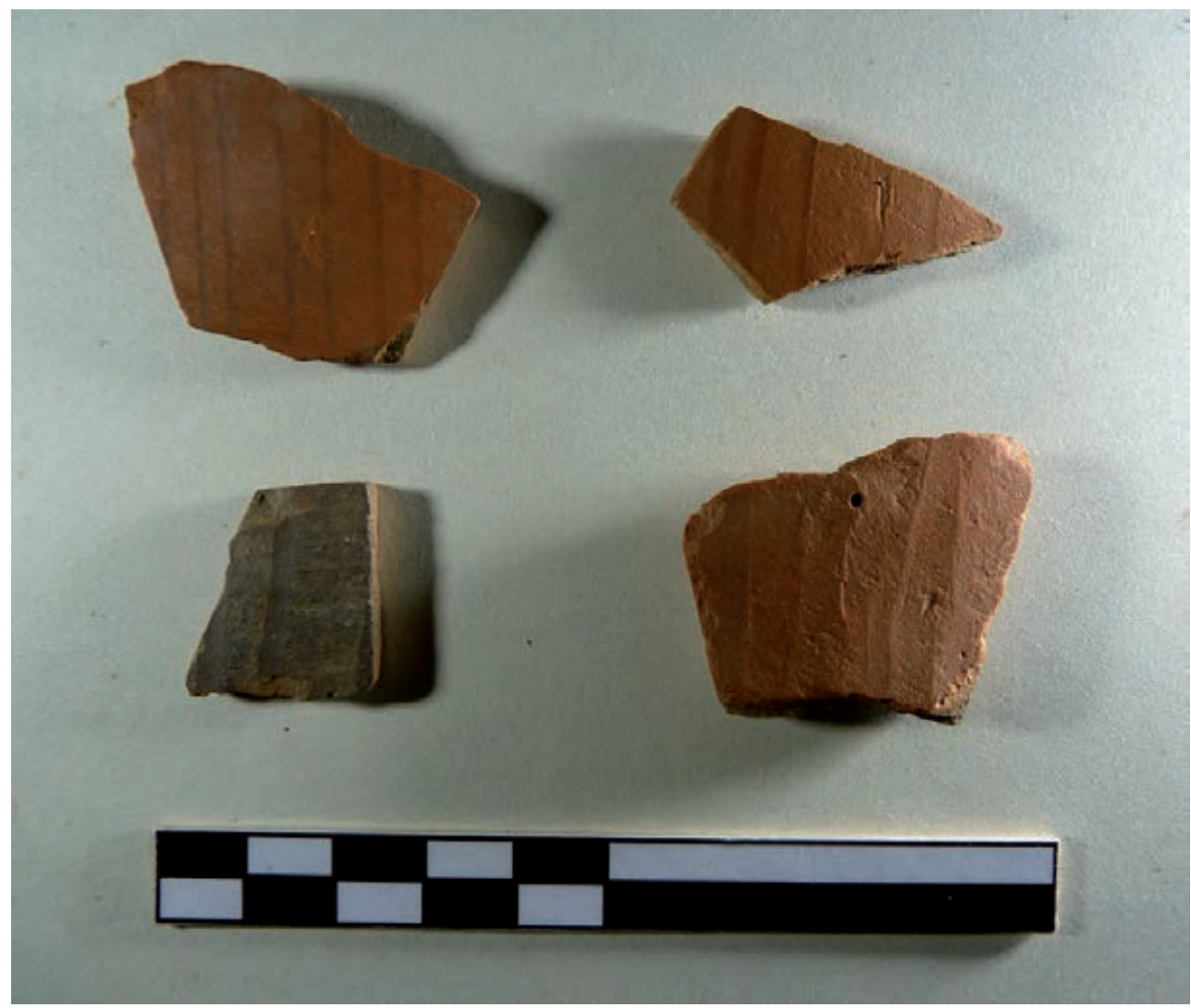

Figura 9. Brimeda (Villaobispo de Otero). Producciones de cerámica común decoradas con líneas bruñidas recuperadas en el muestreo.

ISSN: $1133-4525 \quad$ ISSN-e: $2255-3924$ 


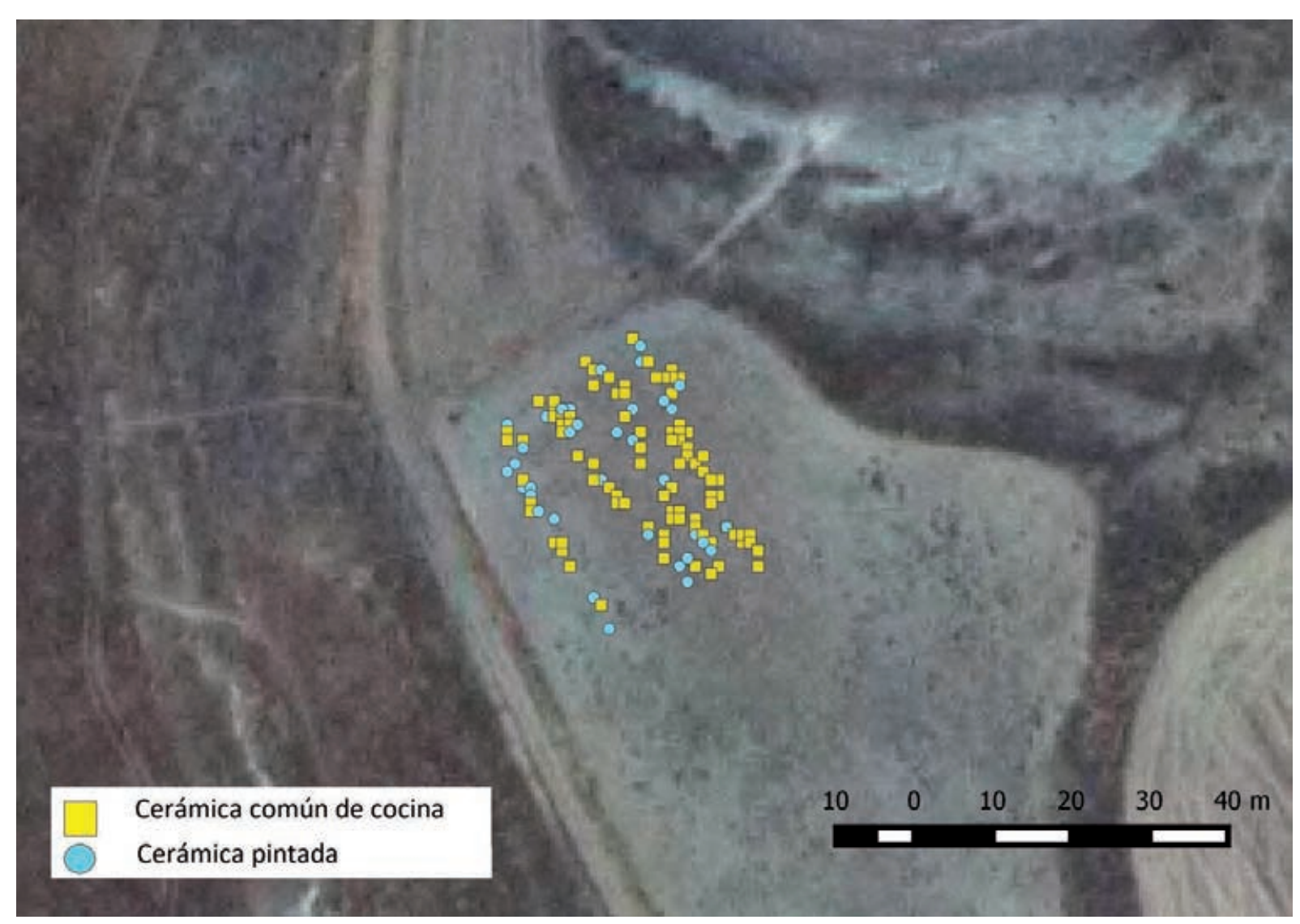

Figura 10. Teso de la Mora (Molacillos). Dispersión de la cerámica pintada de tipo celtibérico y de la cerámica común de cocina en el área prospectada. Base cartográfica del Instituto Geográfico Nacional (portal http://pnoa.ign.es/).

\subsection{En el territorio de Albocela.}

En el territorio de Albocela se prospectaron dos asentamientos en altura, uno de ellos (el Teso de la Mora) con una posible continuación del hábitat entre el periodo prerromano y romano y otro (el Castro del Viso) que parecía haber estado deshabitado durante el periodo romano y ocupado, de nuevo, en el periodo altomedieval. El primero de ellos, el Teso de la Mora, pese a la evidencia de las cisternas romanas, a los resultados positivos obtenidos en las excavaciones practicadas por Balado Pachón y Martínez García (2008) y a que la inspección fue realizada con la superficie con buenas condiciones de visibilidad, no presentaba material cerámico en la parte alta y plana del cerro, donde presumiblemente se habría establecido el hábitat. No obstante en la ladera meridional del teso, al este del camino de acceso al conjunto arqueológico, se detectó un espacio que presentaba un significativo conjunto de cerámica en superficie y fue en esta zona donde se practicó el muestreo (fig. 10, tab. 4).
En el muestreo se recuperaron fragmentos de cerámica a mano, asociados quizá a una secuencia de la I Edad del Hierro. También un número significativo de fragmentos de cerámica pintada con motivos de líneas en arcos trazados a compás, de tipo celtibérico. El hallazgo de estas dos producciones aparentemente confirma la interpretación del Teso de la Mora como un castro con ocupación en la Edad del Hierro. Esta lectura debe enfrentarse, sin embargo, al hecho de que no se hayan documentado restos de muralla ni restos cerámicos en la zona alta del cerro y, sobre todo, a que las excavaciones practicadas en la parte alta del teso hayan revelado niveles de la Edad del Hierro de muy escasa potencia y asociados sobre todo al conjunto donde se localizan las cisternas romanas. La exacta tipología del asentamiento queda por definir, pero es posible que el hábitat romano al que abastecerían las cisternas haya que localizarlo a los pies del cerro. Por lo que respecta a la ocupación tardía, el importante conjunto de cerámica común de cocina recogido en la zona del muestreo 
Tabla 4. Números totales y porcentajes (en gris) de las producciones cerámicas recuperadas en la prospección de Albocela. Cam: cerámica fabricada a mano, Cpint: cerámica pintada, Tsi: terra sigillata itálica, Tsg: terra sigillata gálica, Tsh: terra sigillata hispánica, Tsh avan: terra sigillata hispánica avanzada, Tsht lisa: terra sigillata hispánica tardía lisa, Tsh mold: terra sigillata hispánica tardía a molde, ARSW: African Red Slip Ware, CCCafr: cerámica común de cocina africana, Cpf: cerámica de paredes finas, Ceng: cerámica engobada, Cerp: cerámica de engobe rojo pompeyano, Cierp: imitación de la cerámica de engobe rojo pompeyano, $\mathrm{CC}$ : cerámica común, CCC: cerámica común de cocina, Cgn: cerámica de color gris o negro con superficies bruñidas, CCCb: cerámica común de cocina decorada con líneas bruñidas, CCb: cerámica común decorada con líneas bruñidas, Lu: lucernas, Mo: morteros, Lo: loza tradicional, lo ind: loza industrial y porcelana.

\begin{tabular}{|c|c|c|c|c|c|c|c|c|}
\hline Yacimiento & Cam & Cpint & Tsi & Tsg & Tsh & Tsh avan & Tsht & Tsht mold \\
\hline \multirow{2}{*}{ Teso de la Mora } & 25,00 & 39,00 & 1,00 & 0,00 & 0,00 & 0,00 & 0,00 & 0,00 \\
\hline & 6,94 & 10,83 & 0,28 & 0,00 & 0,00 & 0,00 & 0,00 & 0,00 \\
\hline \multirow{2}{*}{ Castro del Viso } & 19,00 & 12,00 & 0,00 & 0,00 & 0,00 & 0,00 & 0,00 & 0,00 \\
\hline & 4,36 & 2,75 & 0,00 & 0,00 & 0,00 & 0,00 & 0,00 & 0,00 \\
\hline \multirow{2}{*}{ EI Toro-Tejadillo } & 0,00 & 0,00 & 0,00 & 0,00 & 19,00 & 0,00 & 53,00 & 8,00 \\
\hline & 0,00 & 0,00 & 0,00 & 0,00 & 5,72 & 0,00 & 15,96 & 2,41 \\
\hline \multirow{2}{*}{ Tímulos } & 66 & 0,00 & 0,00 & 0,00 & 0,00 & 0,00 & 0,00 & 0,00 \\
\hline & 27,27 & 0,00 & 0,00 & 0,00 & 0,00 & 0,00 & 0,00 & 0,00 \\
\hline \multirow{2}{*}{ EI Cementerio } & 0,00 & 0,00 & 0,00 & 0,00 & 27,00 & 0,00 & 52,00 & 12,00 \\
\hline & 0,00 & 0,00 & 0,00 & 0,00 & 5,49 & 0,00 & 10,57 & 2,44 \\
\hline
\end{tabular}

\begin{tabular}{|l|c|c|c|c|c|c|c|c|}
\hline \multicolumn{1}{|c|}{ Zona } & ARSW & CCC afr & Cpf & Ceng & Cerp & Cierp & CC & CCC \\
\hline \multirow{3}{*}{ Teso de la Mora } & 0,00 & 0,00 & 1,00 & 0,00 & 1,00 & 0,00 & 193,00 & 100,00 \\
\cline { 2 - 10 } & 0,00 & 0,00 & 0,28 & 0,00 & 0,28 & 0,00 & 53,61 & 27,78 \\
\hline \multirow{2}{*}{ Castro del Viso } & 0,00 & 1,00 & 0,00 & 1,00 & 0,00 & 0,00 & 152,00 & 239,00 \\
\cline { 2 - 10 } & 0,00 & 0,23 & 0,00 & 0,23 & 0,00 & 0,00 & 34,86 & 54,82 \\
\hline \multirow{3}{*}{ El Toro-Tejadillo } & 0,00 & 1,00 & 8,00 & 1,00 & 1,00 & 0,00 & 81,00 & 119,00 \\
\cline { 2 - 10 } & 0,00 & 0,30 & 2,41 & 0,30 & 0,30 & 0,00 & 24,40 & 35,84 \\
\hline \multirow{2}{*}{ El Cemulos } & 0,00 & 0,00 & 0,00 & 0,00 & 0,00 & 0,00 & 112,00 & 44,00 \\
\cline { 2 - 10 } & 0,00 & 0,00 & 0,00 & 0,00 & 0,00 & 0,00 & 46,28 & 18,18 \\
\hline
\end{tabular}




\begin{tabular}{|l|c|c|c|c|c|c|c|c|}
\hline \multirow{2}{*}{ Zona } & $\mathrm{Cgn}$ & $\mathrm{CCCb}$ & $\mathrm{CCb}$ & $\mathrm{Lu}$ & $\mathrm{Mo}$ & Lo & Lo ind/ & Total \\
\hline \multirow{3}{*}{ Teso de la Mora } & 0,00 & 0,00 & 0,00 & 0,00 & 0,00 & 0,00 & 0,00 & 360 \\
\cline { 2 - 11 } & 0,00 & 0,00 & 0,00 & 0,00 & 0,00 & 0,00 & 0,00 & 100 \\
\hline \multirow{2}{*}{ Castro del Viso 2 } & 0,00 & 0,00 & 1,00 & 0,00 & 0,00 & 11,00 & 0,00 & 436 \\
\cline { 2 - 11 } & 0,00 & 0,00 & 0,23 & 0,00 & 0,00 & 2,52 & 0,00 & 100 \\
\hline \multirow{2}{*}{ El Toro-Tejadillo } & 0,00 & 0,00 & 5,00 & 0,00 & 0,00 & 34,00 & 2,00 & 332 \\
\cline { 2 - 11 } & 0,00 & 0,00 & 1,51 & 0,00 & 0,00 & 10,24 & 0,60 & 100 \\
\hline \multirow{2}{*}{ Tímulos } & 0,00 & 5,00 & 11,00 & 0,00 & 0,00 & 3,00 & 1,00 & 242 \\
\cline { 2 - 10 } & 0,00 & 2,07 & 4,55 & 0,00 & 0,00 & 1,24 & 0,41 & 100 \\
\hline \multirow{2}{*}{ El Cementerio } & 0,00 & 1,00 & 0,00 & 0,00 & 0,00 & 17,00 & 0,00 & 492 \\
\cline { 2 - 10 } & 0,00 & 0,20 & 0,00 & 0,00 & 0,00 & 3,46 & 0,00 & 100 \\
\hline
\end{tabular}

se interpreta como un indicio de ocupación fechada en el periodo suevo/visigodo, si bien no aparece ninguna de las otras producciones significativas de este periodo, siendo llamativa la ausencia de terra sigillata hispánica tardía a molde, habitual en los contextos del siglo V, lo que apunta a una datación del conjunto de la cerámica común de cocina en una fase avanzada del periodo visigodo, algo que se refuerza por la ausencia de tegulae en la zona del muestreo, la cual se limita a un único fragmento. La ocupación tardía, a juzgar por los datos obtenidos, no es general y no afecta a la parte alta del cerro.

El segundo ejemplo, el Castro del Viso, es un cerro testigo que se eleva de forma significativa sobre el terreno circundante. La cima amesetada, donde las intervenciones anteriores habían detectado restos arqueológicos atribuibles a la Edad del Hierro (Martín Valls 1973: 403-405, 1995: 154-157 y 172), se encontraba cubierta de vegetación en el momento de la prospección. No obstante, pudo recuperarse un conjunto cerámico -que juzgamos representativo de la ocupación- muestreando en espacios reducidos con buena visibilidad. El yacimiento responde por su tipología a un asentamiento tipo castro, algo que también está respaldado por la significativa presencia de fragmentos de cerámica a mano y de cerámicas pintadas de tipo celtibérico, repartidas en toda la superficie muestreada. La ocupación del periodo suevo/visigodo está argumentada por el importante número de fragmentos recuperados de la producción de cerámica común de cocina, con fábricas características de este periodo. Aunque no se recupera terra sigillata hispánica tardía, sí aparecen en la proporción habitual, casi testimonial, algunas de las producciones de tradición romana que habitualmente se recuperan en los contextos cerámicos del periodo suevo/visigodo, en este caso la cerámica engobada y la cerámica de cocina africana, ambas representadas por un único fragmento (fig. 10, tab. 4).

Las dos villae que pudimos muestrear en el territorio de Albocela dieron resultados interesantes. Por un lado, El Toro-Tejadillo ofreció un perfil cerámico -con terra sigillata hispánica, cerámica de paredes finas, cerámica engobada y cerámica de engobe rojo pompeyano-, que es sin duda el característico de una villa romana con ocupación desde el Alto Imperio (quizá en torno a finales del siglo I o principios del II) hasta el periodo suevo/visigodo (a juzgar por el número importante de fragmentos de cerámica común de cocina y la significativa presencia de terra sigillata hispánica tardía a molde, que remite al menos a la primera mitad del siglo V). No existen indicadores cualitativos que aporten más información, aunque la recuperación de un fragmento de tegula mammata (que apunta a la existencia de un espacio termal) es concordante con la interpretación del yacimiento como una villa romana que prolonga su ocupación a lo largo de los periodos suevo y visigodo (tab. 4).

Como en el caso de El Toro-Tejadillo, los restos superficiales detectados en El Cementerio ocupaban una amplia extensión y se encontraban en buenas condiciones de visibilidad. El contexto cerámico de El Cementerio es, de hecho, muy similar al de El Toro-Tejadillo - con terra sigillata hispánica, cerámica de paredes finas, cerámica engobada y cerámica de engobe rojo pompeyano- y señala del mismo modo una ocupación 


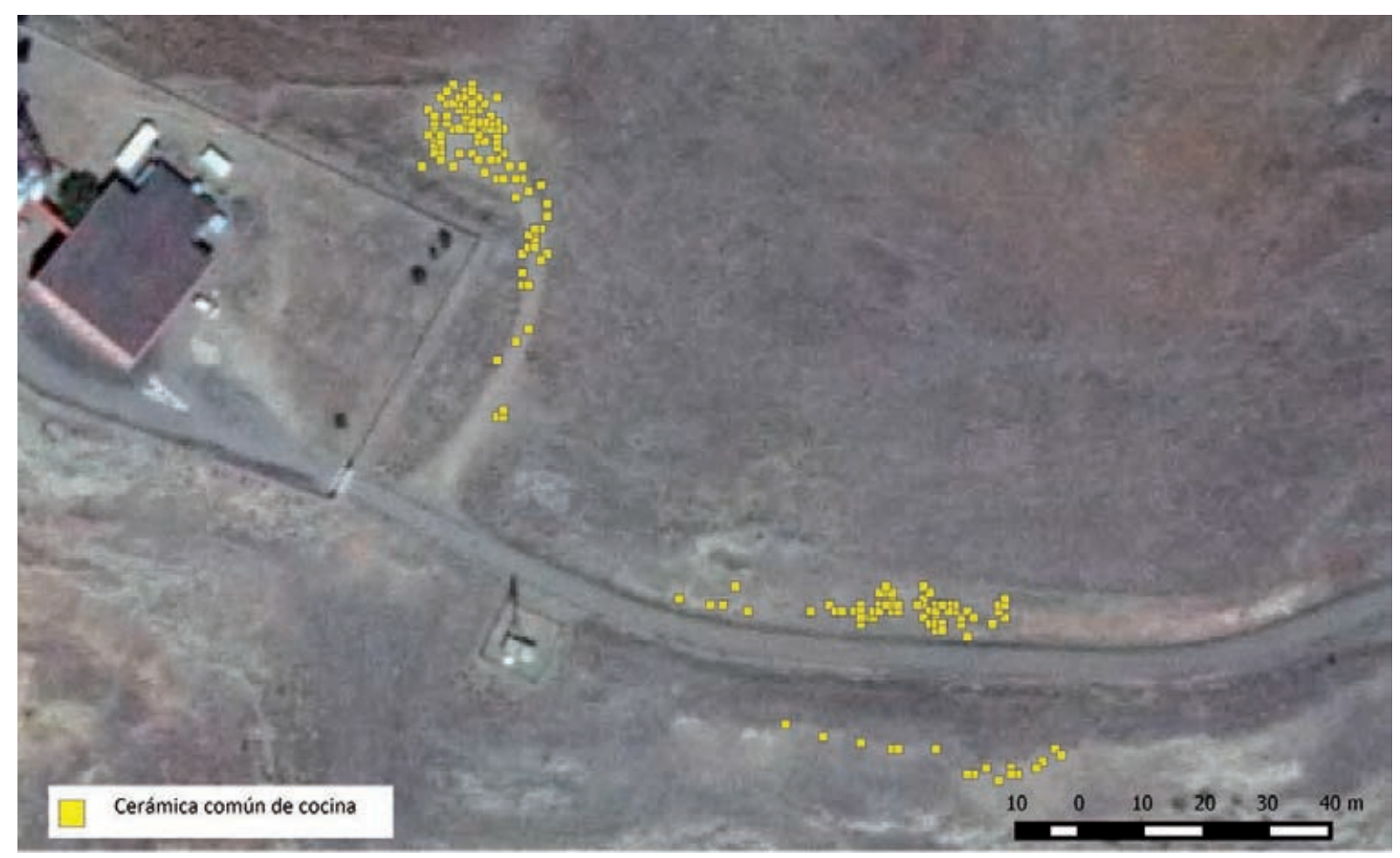

Figura 11. Castro del Viso (Madridanos). Dispersión de la cerámica común de cocina en el área prospectada. Base cartográfica del Instituto Geográfico Nacional (portal http://pnoa.ign.es/).

que se inicia en torno a finales del siglo I o principios del II, hasta el periodo suevo/visigodo, con al menos un fragmento de cerámica común de cocina decorada con líneas bruñidas que remite a fechas posteriores a mediados del siglo VI (Dahí Elena 2012: 224-225) (tab. 4).

Por último hay que referirse al yacimiento de Tímulos, asentamiento que fue seleccionado como representativo del hábitat tardío y altomedieval en llano. El topónimo remite a un caserío localizado en la margen izquierda del río Duero, al sur de Toro. A unos $150 \mathrm{~m}$ al sur del caserío se detectó una estructura que, aunque transformada en palomar, responde sin ninguna duda a la tipología de un monumento funerario romano en un apreciable estado de conservación, con muros de opus caementicium y sillares angulares en piedra formando un cuerpo inferior prismático (fig. 11). La prospección previa no detectó, sin embargo, restos cerámicos asociados a esta construcción. En cambio sí se obtuvo un contexto cerámico superficial importante en la zona de huertas y viñas inmediatas a los edificios más meridionales del caserío y fue allí donde se practicó el muestreo.

En Tímulos existen argumentos para considerar la existencia de una ocupación en el Bronce Medio, a juzgar por el significativo número de piezas cerámicas a mano, algunas de ellas con decoraciones características de ese periodo (se reconocen rasgos de las culturas de Proto-Cogotas y Cogotas I). No se documentan materiales del periodo romano, pese a que según nuestra lectura, los restos arquitectónicos detectados a unos $150 \mathrm{~m}$ de la zona del muestreo se identifican con un monumento funerario romano. Sí hay indicios, aunque débiles, para proponer una ocupación del espacio en el periodo visigodo avanzado, a juzgar por la cerámica común de cocina (con fábricas características de esta fase) junto a cinco fragmentos de la variante de esta misma producción decorada con líneas bruñidas, la cual no aparece en los registros antes de mediados del siglo VI (Dahí Elena 2012: 224-225) (fig. 12, tab. 4). Más clara es aún la secuencia medieval plena, representada por la cerámica común decorada con líneas bruñidas. Suele admitirse que esta producción marca niveles plenomedievales, en torno a la segunda mitad del siglo XII (Peñil Mínguez 1987, Bohígas Roldán 1990), si bien no se ha establecido una fecha para el origen de esta producción, que podría ser más temprana (Martínez Peñín 2007). La presencia de esta producción es concordante con la documentación que recoge el lugar en la toponimia del año 1208 (Pascual Sánchez 1991: 198-199). Tímulos es 


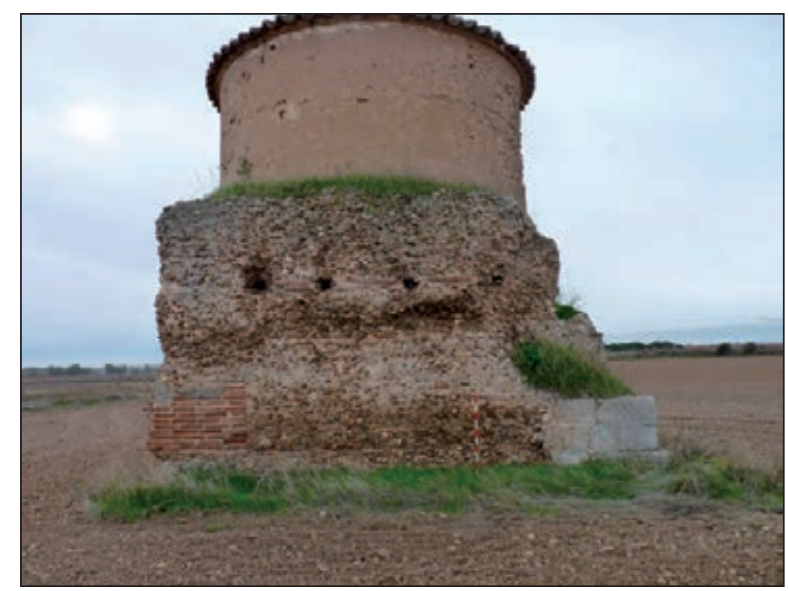

Figura 12. Tímulos (Toro). Edificación interpretada como un monumento funerario de época romana.

un caso único en el que el hábitat del periodo suevo y visigodo se prolonga hasta el periodo medieval, perviviendo como espacio ocupado hasta hoy.

\section{INTERPRETACIÓN FINAL Y CONCLUSIONES}

La investigación que hemos llevado a cabo pretendía analizar el comportamiento y evolución de los asentamientos rurales en el periodo entre la Antigüedad Tardía y la Alta Edad Media en dos ciudades con trayectorias diferentes. Los resultados obtenidos (bien es cierto que sobre el número limitado de yacimientos que han sido objeto de muestreo) parecen indicar que el hábitat rural del periodo post-romano y altomedieval responde a su propia dinámica y esta es independiente de la supervivencia o no del núcleo urbano del que depende.

En ambos casos de estudio ha podido observarse la reactivación de los lugares en altura con ocupación en fases precedentes. En el territorio de Albocela, ciudad completamente abandonada en el siglo V, este fenómeno se aprecia tanto en el Teso de la Mora como en el Castro del Viso, pese a que las secuencias de ocupación de ambos son algo diferentes. Mientras que en el Teso de la Mora la ocupación previa al periodo suevo/visigodo está marcada sobre todo por la presencia de dos cisternas romanas (y quizá por una ocasional ocupación en la Edad del Hierro mal documentada), el Castro del Viso puede considerarse un castro de la Edad del Hierro prototípico. En el territorio asturicense, este fenómeno aparece en el Castro de Pedredo, el cual presenta secuencias de ocupación en la Edad del Hierro y en el periodo romano, perviviendo en el periodo suevo/visigodo. El yacimiento de Iglesia Caída podría entrar en la misma categoría, si bien en este asentamiento solo la secuencia altomedieval está atestiguada en el muestreo.

Con la información disponible no es posible establecer si la ocupación de estos asentamientos en altura es continuista con las fases anteriores o responde a fenómenos de reocupación, si bien hay que señalar que en tres de los casos analizados (la excepción la constituye Castro de Pedredo) se aprecia un hiato en la secuencia, faltando en los contextos la terra sigillata hispánica altoimperial. El fenómeno documentado en estos asentamientos es, aparentemente, algo diferente al de los asentamientos en altura de nueva creación que la arqueología está identificando en todo el paisaje rural hispano en los periodos suevo y visigodo (Ariño Gil 2013, Martín Viso 2006, Diarte-Blasco 2018: 70-75), siendo especialmente característico del noroeste hispánico (Quirós Castillo 2011: 291-293) y quizá relacionado con la gestión del espacio de frontera entre los reinos suevo y visigodo (Ariño Gil y Díaz 2014), así como con la ausencia de un número significativo de centros urbanos que ejerzan el rol de lugares centrales en el territorio.

Otro fenómeno característico de las secuencias sueva y visigoda es el de la creación de asentamientos rurales en llano (Vigil-Escalera 2007 y 2009, Quirós Castillo 2013), lo que también se documenta en los dos territorios de estudio. En Albocela aparece en el yacimiento de Tímulos, el cual parece tener como referencia no un espacio de hábitat previo, sino un monumento funerario romano, algo que pone de manifiesto la gran complejidad que reviste el análisis de los fenómenos de continuidad/discontinuidad entre el hábitat del periodo suevo/visigodo y el precedente romano (Ariño Gil 2013: 94-95). Tímulos es un asentamiento altamente singular ya que, de todos los casos analizados, es el único centro rural habitado en los periodos suevo y visigodo que sobrevive a lo largo de la Edad Media y continúa poblado hasta hoy, si bien como caserío y no como municipio. En Asturica los pequeños asentamientos en llano están representados por el yacimiento de Regañón I, un hábitat rural de pequeña entidad con origen en el periodo romano tardío (en torno a los siglos III o IV), pero también en un asentamiento de tipo minero como es Huerña-Los Linares, característico del hábitat altoimperial vinculado a la extracción de oro. La pervivencia de ocupación de la villa en la secuencia sueva y visigoda (pero sin prolongación en los siglos siguientes) aparece bien atestiguada en el caso de Albocela, con los casos emblemáticos de 


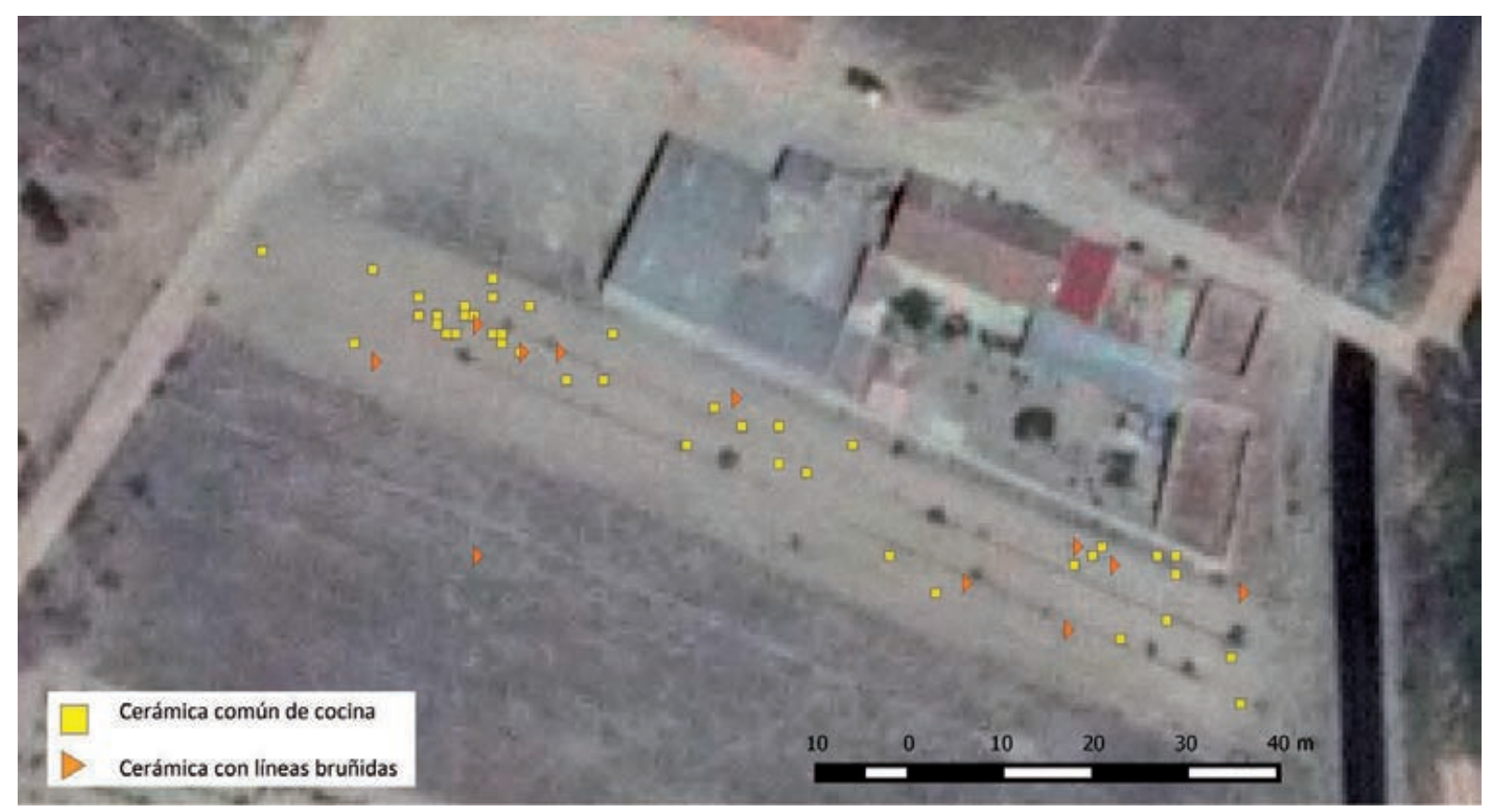

Figura 13: Tímulos (Toro). Dispersión de la cerámica común de cocina y de la cerámica común decorada con líneas bruñidas en el área prospectada. Base cartográfica del Instituto Geográfico Nacional (portal http://pnoa.ign.es/).

El Toro-Tejadillo y El Cementerio. Definir la composición social de las poblaciones que ocupan el espacio de la villa una vez que los indicadores aristocráticos desaparecen es un reto interpretativo. No puede descartarse, sin embargo, que pese al carácter humilde de la ocupación de la villa en el periodo suevo y visigodo, las aristocracias (nuevas o descendentes de las viejas familias romanas) continúen ejerciendo un cierto dominio sobre el espacio de la villa (Ariño 2013: 103-106, DiarteBlasco 2018: 62-67). Solo la villa romana de El Soldán, en el espacio agrario de Asturica, colapsa antes de alcanzar la secuencia bajoimperial, algo que en el caso de estudio se asocia a la dinámica de la explotación minera $\mathrm{y}$ sus peculiares formas de organización del espacio y de los patrones de asentamiento. Es probable, de hecho, que la más evidente reorganización del territorio asturicense se hubiese gestado a partir de mediados del siglo III, cuando muchas de sus minas estaban ya completamente abandonadas.

Por último, es especialmente relevante el caso de Brimeda, ya que plantea directamente el tema de la continuidad (o no) de la aldea medieval con respecto a espacios de hábitat preexistentes. Los resultados de la prospección parecen respaldar la información proporcionada por el documento del año 878 , en el que se presenta el origen de la aldea como un acto fundacional que incluye roturaciones, parcelación del espacio agrícola y construcción de espacios de vivienda. La prospección del territorio de Brimeda ha permitido recuperar materiales que pueden atribuirse a la secuencia visigoda, pero tan dispersos y en cantidad tan escasa que es difícil establecer con seguridad la existencia de un asentamiento humano previo al del siglo IX, si bien hay que tener en cuenta que la prospección no ha cubierto la totalidad del espacio en torno a Brimeda ni, por razones obvias, ha podido actuar sobre el solar de la villa. La recuperación de 50 fragmentos de cerámica común decorada con líneas bruñidas, fechada en el periodo plenomedieval, sería un refrendo de naturaleza arqueológica a la fuente documental que fecha el origen de la villa en el año 878. Este material está disperso en el espacio parcelado en torno a la villa, sin formar concentraciones que puedan interpretarse como puntos de hábitat. Suele considerarse que este material off-site es consecuencia del vertido de basura doméstica, al ser esta usada como abono y siendo la cerámica un aporte casual o secundario (Foley 1981, Wilkinson 1982 y 1989, Alcock et al. 1994).

A modo de conclusión puede decirse que los resultados de la investigación llevada a cabo nos sitúan ante una realidad distinta de la que había sido nuestra hipótesis de partida. Así, mientras que los centros 
urbanos no pueden subsistir sin un territorio dinámico que les suministre (gran) parte de los bienes que necesitan, los asentamientos rurales fechados entre c $400 \mathrm{y}$ c 800 , continúan desarrollando su actividad (y respondiendo a nuevas dinámicas) pese a que el núcleo del que fueron dependientes se encuentre en fase de abandono. Esta situación nos abre un nuevo horizonte de estudio en el que las preguntas se multiplican: ¿Hasta qué punto la relación entre ciudad y territorio fue tan estrecha y constante durante todo el Imperio Romano? ¿Es posible que esta se hubiese empezado a diluir a partir de los siglos IV y V y que algunos centros rurales hubiesen emprendido la vía hacia la autosuficiencia? Y, sobre todo, cuando en un determinado territorio una ciudad se abandona, ¿cuál o cuáles de los centros rurales tomaron el rol central (de control, de coerción, etc.) y de qué forma podemos identificarlo en el paisaje? Solo el análisis en profundidad de estas cuestiones y la implementación de los métodos y técnicas utilizados permitirá, esperemos que un plazo no demasiado dilatado, comprender cómo se desarticuló la organización rural romana y se gestó el inicio de una nueva organización del territorio que, junto a las ciudades, pueblos y aldeas, fueron fundamentales en la ordenación y jerarquización del incipiente paisaje medieval.

\section{Agradecimientos}

Este artículo ha sido escrito como parte del proyecto MED-FARWEST (University of Leicester, Reino Unido) financiado por el programa de investigación e innovación Horizon 2020 de la Unión Europea y, más concretamente, de un contrato Marie Sklodowska-Curie $n^{\circ} 658045$. No obstante, los resultados han sido elaborados en el periodo de disfrute de un contrato Juan de la Cierva-Incorporación (MINECO, JCI-2015-24930), ya en la Universidad de Alcalá.

Estamos en deuda con el equipo del Museo de León, Luis Grau Lobo, Manuel Antonio García Garrido, Miryam Hernández Valverde y Ana Álvarez Martínez, por todas las facilidades que nos dieron para acceder a los fondos del museo, así como por la información que nos proporcionaron sobre aspectos que concernían a nuestra investigación. También queremos agradecer a Jesús Celis Sánchez, arqueólogo a cargo de la sección de Patrimonio Cultural en la Diputación de León, el que nos facilitara el acceso a los materiales arqueológicos de la villa romana de El Soldán. Agradecemos a Javier González-Tablas y Antonio Blanco el asesoramiento que nos han prestado en la catalogación de la cerámica prehistórica recuperada en el yacimiento de Tímulos. Estamos en deuda con Inés Centeno Cea por la información que nos proporcionó sobre la cerámica del periodo medieval en el valle del Duero, así como por compartir con nosotros sus opiniones personales sobre esta producción.

\section{BIBLIOGRAFÍA}

Alcock, S.E.; Cherry, J.F. y Davis, J.L. (1994): “Intensive Survey, agricultural practice and the classical landscape of Greece", en I. Morris (ed.), Classical Greece: Ancient Histories and Modern Archaeologies: 137-170. Cambridge, Cambridge University Press.

Andreu Pintado, J. (ed.) (2017): Oppida Labentia, transformaciones, cambios y alteración en las ciudades hispanas entre el siglo II y la tardoantigüedad. Serie Monografías "Los Bañales". Uncastillo, Fundación Uncastillo.

Arce, J. (2005): Bárbaros y romanos en Hispania (400507 A.D.). Madrid, Marcial Pons.

Ariño Gil, E. (2013): "El hábitat rural en la Península Ibérica entre finales del siglo IV y principios del VIII: un ensayo interpretativo". Antiquité Tardive 21: 93-123. <https://doi.org/10.1484/J. AT.5.101406>.

Ariño Gil, E.; Gurt i Esparraguera, J. M. y Palet i Martínez, J. M. (2004): El pasado presente. Arqueología de los paisajes en la Hispania romana. Salamanca, Barcelona, Ediciones Universidad de Salamanca, Ediciones Universidad de Barcelona.

Ariño Gil, E. y Dahí Elena, S. (2012): "La cerámica de los yacimientos rurales de la provincia de $\mathrm{Sa}$ lamanca (España) entre la Antigüedad Tardía y la alta Edad Media (350-700)". Archeologia Medievale 39: 371-383.

Ariño Gil, E. y Díaz, P. C. (2003): "Poblamiento y organización del espacio. La Tarraconense pirenaica en el siglo VI". Antiquité Tardive 11: 223-237<https:// doi.org/10.1484/J.AT.2.300260>.

Ariño Gil, E. y Díaz, P. C. (2014): "La frontera suevovisigoda: ensayo de lectura de un territorio en disputa”, en R. Catalán, P. Fuentes y J.C. Sastre (eds.), Las fortificaciones en la Tardoantigüedad. Élites y articulación del territorio (siglos V-VIII d.C.): 179190. Madrid, La Ergástula.

Ariño Gil, E.; Didierjean, F.; Liz Guiral, J. y Sillières, P. (2007): “Albocela (Villalazán, Zamora). Interpretación de la ciudad romana a partir de la fotografía 
aérea y la prospección intensiva", en M. Navarro Caballero y J. J. Palao Vicente (eds.), Villes et territoires dans le Bassin du Douro à l'époque romaine: Actes de la table-ronde internationale. Études 17: 171-193. Burdeos (2004), Burdeos, Ausonius Éditions.

Ariño Gil, E.; Riera i Mora, S. y Rodríguez Hernández, J. (2002): "De Roma al Medievo. Estructuras de hábitat y evolución del paisaje vegetal en el territorio de Salamanca". Zephyrus 55: 283-309.

Ariño Gil, E. y Rodríguez Hernández, J. (1997): “El poblamiento romano y visigodo en el territorio de Salamanca. Datos de una prospección intensiva". Zephyrus 50: 225-245.

Ariño Gil, E. y De Soto García, R. (2016): “Técnicas de muestreo en la prospección arqueológica: la experiencia del Ager Salmanticensis (Salamanca, España)". Anales de Arqueología Cordobesa 27: 35-58. < https://doi.org/10.21071/aac. v0i27.6288>.

Asensio esteban, J. Á.; Magallón Botaya, M. Á. y Sillières P. (2016): La ciudad romana de Labitolosa. El conjunto arqueológico de cerro Calvario (la Puebla de Castro, Huesca) en la Antigüedad y la Edad Media. Huesca, Instituto de Estudios Altoaragoneses.

Balado Pachón, A. y Martínez García, A. B. (2008): "Sobre el temprano asentamiento militar romano de El Teso de la Mora en Molacillos (Zamora) y la ubicación de la mansio de Vico Aquario". Boletín del Seminario de Arte y Arqueología 74: 149-195.

Bohígas Roldán, R. (1990): “El alfar medieval de 'Cuernos Pequeños', Alto de la Morterona (Saldaña, Palencia)", en M. A. Calleja González (coord.), II Congreso de Historia de Palencia Tomo 1, Prehistoria, arqueología e Historia Antigua: 221-241. Palencia, Diputación Provincial de Palencia, Departamento de Cultura.

Caballero Zoreda, L. (1974): La necrópolis tardorromana de Fuentespreadas (Zamora). Un asentamiento en el valle del Duero. Excavaciones Arqueológicas en España 80. Madrid, Ministerio de Educación y Ciencia.

Cabero Domínguez, M. C. (1995): Astorga y su territorio en la edad media (s. IX-XIV): evolución demográfica, económica, social, político-administrativa y cultural de la sociedad astorgana medieval. León, Universidad de León, Universidad de Oviedo.

Carro, J. (1934): En la enigmática Maragatería. Importantes descubrimientos arqueológicos. Madrid, Imprenta de Juan Pueyo.
Chavarría Arnau, A. (2007): El final de las villae en Hispania (siglos IV-VIII). Turnhout, Brepols.

Corcoran, S. (2003): "The donation and will of Vincent of Huesca: Latin text and English translation". Antiquité Tardive 11: 215-221. <https://doi.org/doi. org/10.1484/J.AT.2.300259>.

Dahí Elena, S. (2007): "Un contexto cerámico de la Antigüedad tardía: el yacimiento de San Pelayo (Aldealengua, Salamanca). Nuevos datos sobre la cronología de las pizarras visigodas". Pyrenae 38 (1): 57-77.

Dahí Elena, S. (2012): Contextos cerámicos de la Antigüedad Tardia y Alta Edad Media (siglos IV-VIII) en los asentamientos rurales de la Lusitania Septentrional (provincia de Salamanca, España). British Archaeological Reports, International Series 2401. Oxford, Archaeopress.

Diarte-Blasco, P. (2012): La configuración urbana de la Hispania tardoantigua. Transformaciones y pervivencias de los espacios públicos romanos (s. III$V I$ d. C.). British Archaeological Reports, International Series 2429. Oxford, Archaeopress.

Diarte-Blasco, P. (2018): Late Antique and Early Medieval Hispania: Landscapes without Strategy? Oxford, Oxbow Books.

Diarte-Blasco, P. y Gurt i Esparraguera, J.M. (2015): "La percepción del espacio en el urbanismo tardoantiguo: características evolutivas en el ejemplo hispano". Antiquité Tardive (Isidore de Séville et son temps) 23: 307-328<https://doi.org/10.1484/J. AT.5.109386>.

Domergue, C. (1986): "Dix-huit ans de recherche (1968-1986) sur les mines d'or romaines du nordouest de la Péninsule Ibérique", en Actas del I Congreso Internacional de Astorga Romana II: 7-101. Astorga (1986), Astorga, Ayuntamiento de Astorga.

Domergue, C. y Martin, T. (1977): Minas de oro romanas de la provincia de León. II, Huerña: excavaciones 1972-1973. Excavaciones Arqueológicas en España 94. Madrid, Servicio de publicaciones del Ministerio de Educación y Ciencia.

Fernández Ochoa, C.; Morillo Cerdán, Á. y López Quiroga, J. (2005): "La dinámica urbana de las ciudades de la fachada noratlántica y del cuadrante noroeste de 'Hispania' durante el bajo imperio y la antigüedad tardía (siglos III-VII d. C.)”, en J. M. Gurt i Esparraguera y A. Ribera i Lacomba (eds.), VI Reunió Cristiana Hispánica: les ciudats tardoantigues d'Hispania: cristianització i topografia: 95-120. Valencia (2003), Barcelona, Institut d'Estudis Catalans. 
Floriano Cumbreño, A. C. (1951): Diplomática española del periodo astur (718-910), II. Oviedo, Diputación Provincial de Oviedo, Instituto de Estudios Asturianos.

Foley, R. (1981): “Off-site archaeology: an alternative approach for the short-sited", en G. Isaac y N. Hammond (eds.), Pattern of the past: studies in the honour of David Clarke: 157-183. Cambridge, Cambridge University Press.

Fuentes Domínguez, Á. (1989): La necrópolis tardorromana de Albalate de las Nogueras (Cuenca) y el problema de las denominadas "necrópolis del Duero”. Serie Arqueológica Conquense. Cuenca, Diputación de Cuenca.

García-Entero, V. (2001): Los "balnea" de las "villae" hispanorromanas. Provincia Tarraconense. Monografías de Arquitectura Romana 5, Serie Termas 1. Madrid, Universidad Autónoma de Madrid.

García Marcos, V. y Burón, M. (2000): "Las termas menores de Asturica Augusta”, en C. Fernández Ochoa y V. García Entero (eds.), Termas romanas en el Occidente del Imperio: II Coloquio Internacional de Arqueología en Gijón: 207-214. Gijón (1999), Gijón Ayuntamiento de Gijón.

García Marcos, V. y Vidal Encinas, J. M. (1995): "Recent Archeological Research at Asturica Augusta". Proceedings of the British Academy 86: 371-394.

García Marcos, V. y Vidal Encinas, J. M. (1996): “Asturica Augusta: Recientes investigaciones sobre su implantación y desarrollo urbano”, en C. Fernández Ochoa (coord.), Los Finisterres Atlánticos en la Antigüedad. Época prerromana y romana. Coloquio Internacional, Homenaje a Manuel Fernández-Miranda: 135-145. Gijón (1995), Gijón, Ayuntamiento de Gijón.

García Rozas, M. R. (1995): “Arqueología romana en la provincia de Zamora", Historia de Zamora, Tomo. I. De los orígenes al final del Medievo: $267-$ 337. Zamora, Diputación de Zamora, Instituto de Estudios Zamoranos "Florián de Ocampo", Caja España.

González Serrano, C. (1990): “Avance de la excavación realizada en el Pago del Alba, Villalazán, Zamora", en Congreso de Historia de Zamora, Tomo II: Prehistoria, Mundo Antiguo: 497-513. Zamora, Diputación de Zamora, Instituto de Estudios Zamoranos "Florián de Ocampo".

Gorges J.-G. (1979): Les villas hispano-romaines. Inventaire et Problématique archéologiques. Publications du Centre Pierre Paris (E.R.A. 522), 4. París, De Boccard.
Gurt i Esparraguera, J. M. (2001): "Transformaciones en el tejido de las ciudades hispanas durante la Antigüedad Tardía: dinámicas urbanas". Zephyrus 5354: 443-471.

Gurt i Esparraguera, J. M. y Sánchez, I. (2011): “Episcopal Groups in Hispania". Oxford Journal of Archaeology 30 (3): 273-298. <https://doi.org/10.111 1/j.1468-0092.2011.00369.x>.

Kulikowski, M. (2005): “Cities and government in late antique Hispania: recent advances and future research", en K. Bowes y M. Kulikowski (eds.), Hispania in Late Antiquity: Current Perspectives: 3170. Leiden, Boston, Colonia, Brill.

Larrén Izquierdo, H. (1994): “Arqueología Preventiva y de Gestión. Zamora, Arqueología en Castilla y León 1991/1992". Numantia 5: 335-351.

Le Roux, P. (2009): “Cultos y religión en el Noroeste de la Península Ibérica en el Alto Imperio Romano: nuevas perspectivas". Veleia 26: 265-285.

López Rodríguez, J. R. (1985): Terra sigillata hispánica tardía decorada a molde de la Península Ibérica. Valladolid, Universidad de Valladolid, Junta de Castilla y León, Universidad de Salamanca.

Magallón Botaya, M. Á. y Sillères, P. (2013): Labitolosa (La Puebla de Castro, province de Huesca, Espagne). Une cité romaine de l'Hispanie citérieure. Mémoires 33. Burdeos, Ausonius Éditions.

Mañanes Pérez, T. (1977): "Materiales cerámicos de la villa romana de El Soldán, Santa Colomba de Somoza (León)". Sautuola II: 227-261.

Mañanes Pérez, T. (1982): Epigrafía y numismática de Astorga romana. Salamanca, Museo de los Caminos de Astorga, Ediciones Universidad de Salamanca.

Martín Arija, A. M.; Iglesias del Castillo, L.; Salvador Velasco, M. y Viñé Escartín, A. I. (1994a): "Nueva intervención arqueológica en el yacimiento El Alba, Villalazán (Zamora)". Anuario del Instituto de Estudios Zamoranos Florián de Ocampo 11: 19-41.

Martín Arija, A M.; Iglesias del Castillo, L.; Salvador Velasco, M. y Viñé Escartín, A. I. (1994b): "El Alba, (Villalazán): un importante yacimiento romano en la provincia de Zamora". Numantia 6: 61-79.

Martín-Bueno, M. (1999b): "La ciudad julio-claudia: ¿una estrella fugaz?", en R. de Balbín Behrmann y P. Bueno Ramírez (eds.), II Congreso de Arqueología Peninsular, Tomo IV, Arqueología Romana y Medieval: 117-122. Zamora (1996), Alcalá de Henares, Universidad de Alcalá, Fundación Rei Alfonso Henriques. 
Martín López, A. y Sevillano Fuertes, M. Á. (e.p.): “The role of Christianity in transforming the conventus of Asturica Augusta. New archaeological perspectives", en $V$ International Colloquium New Perspectives on Late Antiquity: The loss of Hispania. Ideology, power and conflict. Madrid (2016), e.p.

Martín Valls, R. (1973): "Hallazgos arqueológicos en la provincia de Zamora". Boletín del Seminario de Arte y Arqueología XXXIX: 403-414.

Martín Valls, R. (1995): "La Segunda Edad del Hierro", Historia de Zamora, Tomo I. De los orígenes al final del Medievo: 151-189. Zamora, Diputación de Zamora, Instituto de Estudios Zamoranos "Florián de Ocampo", Caja España.

Martín Valls, R. y Delibes de Castro, G. (1976): "Hallazgos arqueológicos en la provincia de Zamora (III)". Boletín del Seminario de Arte y Arqueología XLII: 411-440.

Martín Valls, R. y Delibes de Castro, G. (1977): “Hallazgos arqueológicos en la provincia de Zamora (IV)". Boletín del Seminario de Arte y Arqueología XLIII: 291-319.

Martín Viso, I. (2006): “Central places and territorial organization of communities: the occupation of hilltop sites in Northern Castile ( $6^{\text {th }}-11^{\text {th }}$ centuries)", en W. Davies; G. Halsall y A. Reynolds (eds.), People and Space in the Middle Ages, 300-1300: 167-185. Turnhout, Brepols.

Martínez Penín, R. (2007): "La producción cerámica medieval de Castrum Iudeorum (Puente Castro, León): análisis de los materiales de la campaña de 1999”. Arqueología y Territorio Medieval 14: 163 $207<$ https://doi.org/10.17561/aytm.v14i0.1508>.

Morillo Cerdán, Á. (1991): "Fortificaciones campamentales de época romana en España". Archivo Español de Arqueología 64: 135-190 <https://doi. org/10.3989/aespa.1991.v64>.

Morillo Cerdán, Á. y Amaré Tafalla, M. T. (2003): “Asturica Augusta como centro de producción y consumo cerámico", en P. García Díaz y C. Fernández Ochoa (coord.), Unidad y diversidad en el arco atlántico en época romana: 121-143. Oxford, Archaeopress.

Núñez Hernández, S. y Curchin, L. A. (2007): “Corpus des villes / Corpus de ciudades romanas en el valle del Duero", en M. Navarro Caballero y J. J Palao, Vicente (eds.), Villes et territoires dans le Bassin du Douro à l'époque romaine, Actes de la tableronde internationale. Études 17: 429-612. Burdeos (2004), Burdeos, Ausonius Éditions.

Orejas Saco del Valle, A. (1996): Estructura social y territorio. El impacto romano en la cuenca noroccidental del Duero. Anejos de Archivo Español de Arqueología XV. Madrid, Consejo Superior de Investigaciones Científicas.

Orejas Saco del Valle, A. y Morillo Cerdán, Á. (2013): "Asturica Augusta. Reflexiones sobre su estatuto y su papel territorial (finales del siglo I a.C. -principios del siglo III d.C.)", en R. M. Cid López y E. B. García Fernández (eds.), Debita verba: estudios en homenaje al profesor Julio Mangas Manjarrés, vol. 2: 93-119. Oviedo, Servicio de Publicaciones de la Universidad de Oviedo.

Palol, P. de (1958): "Las excavaciones de San Miguel del Arroyo. Un conjunto de necrópolis tardorromanos del valle del Duero". Boletín del Seminario de Estudios de Arte y Arqueología XXIV: 209-217.

Pascual Sánchez, M. (1991): “Aportaciones al estudio de la Historia de la población medieval de la provincia de Zamora", Primer Congreso de Historia de Zamora, Tomo 3. Medieval y Moderna: 183-202. Zamora, Instituto de Estudios Zamoranos "Florián de Ocampo", Diputación de Zamora.

Paz Peralta, J. Á. (1991): Cerámica de mesa romana de los siglos III al VI d.C. en la provincia de Zaragoza. (Terra sigillata hispánica tardía, African red slip ware, sigillata gálica tardía y Phocaean red slip ware). Zaragoza, Institución Fernando el Católico.

Paz Peralta, J. Á. (2008): "Las producciones de terra sigillata hispánica tardía," en D. Bernal y A. Ribera (eds.), Cerámicas hispanorromanas. Un estado de la cuestión: 497-539. Cádiz, Servicio de Publicaciones de la Universidad de Cádiz.

Paz Peralta, J. Á (2013): "La vajilla de cerámica hispánica tardía gris y naranja en Asturica Augusta (Astorga, León). Conjunto C". Ex Officina Hispana: cuadernos de la SECAH 1: 217-255.

Peñil Mínguez, J. (1987): "El Testar Medieval de Saldaña (Palencia): Camino de la Morterona", en Actas del II Congreso de Arqueología Medieval Española, vol. 3: 613-620. Madrid, Dirección General de Cultura.

Pérez Centeno, M. del R. (1990): "El poblamiento romano en Zamora durante el s. III d.C.", en Primer Congreso de Historia de Zamora, Tomo 2. Prehistoria e Historia Antigua: 445-454. Zamora, Instituto de Estudios Zamoranos "Florián de Ocampo", Diputación de Zamora.

Quirós Castillo, J. A. (2011): "Early medieval landscapes in north-wet Spain: local power and communities, fifth-centuries". Early Medieval Europe 19 (3): 285-311 <https://doi.org/10.111 1/j.1468-0254.2011.00321.x>. 
Quirós Castillo, J. A. (ed.) (2013): El poblamiento rural de época visigoda en Hispania. Arqueología del campesinado en el interior peninsular. Documentos de Arqueología Medieval 6. Bilbao, Universidad del País Vasco.

Rabanal Alonso, M. A. y García Martínez, S. M. (2001): Epigrafía romana de la provincia de León: revisión y actualización. León, Universidad de León.

Sánchez Badiola, J. J. (2004): El territorio de León en la Edad Media: poblamiento, organización del espacio y estructura social (siglos IX-XIII). León, Universidad de León.

Sánchez-Palencia, F. J. (1995): “Minería y metalurgia de la región astur en la Antigüedad" en Astures. Pueblos y culturas en la frontera del Imperio Romano. Catálogo de la Exposición: 141-157. Gijón, Gran Enciclopedia Asturiana, Ayuntamiento de Gijón

Sánchez-Palencia, F J.; Orejas, A.; Sastre, I. y Ruíz del Árbol, M. (2000): "Minería y organización del territorio en Hispania romana. Las zonas mineras de $A s$ turia Augustana", en Primer Simposio sobre la Minería y la Metalurgia Antigua en el SW Europeo, Serós 2000: 247-262. Serós, Centre d'Arqueologia d'Avinganya.

Sastre, I.; Orejas, A.; Currás, B. y Zubiaurre, E. (2017): "La formación de la sociedad provincial del Noroeste hispano y su evolución: civitates y mundo rural”. Gerión 35(2): 537-552<https://doi.org/http:// dx.doi.org/10.5209/GERI.59923>.

Sastre Blanco, J. C.; Catalán Ramos, R.; Fuentes Melgar, P.; Vázquez Fadón, M.; Rodríguez Monterrubio, Ó. y Álvarez Rodríguez, A. (2018): "Producciones cerámicas en el poblado de El Castillón entre los siglos V-VI d.C.”, en I. Marín Viso, P. Fuentes Melgar, J.C. Sastre Blanco y R. Catalán Ramos (coords.), Cerámicas altomedievales en Hispania y su entorno (siglos V-VIII d.C.): 379-400. Valladolid, Arbotante Patrimonio e Innovación S.L, Glyphos Publicaciones.

Sevillano Fuertes, M. Á. (2007): "La muralla romana de Astorga (León)", en A. Rodríguez e I. Rodà (coord.), Murallas de ciudades romanas en el occidente del Imperio: Lucus Augusti como paradigma, Actas Congreso Internacional: 345-357. Lugo (2005), Lugo, Diputación Provincial de Lugo.

Sevillano Fuertes, M. Á. (2013): "Un espacio público singular: la porticus del ara conventual o el foro de Asturica Augusta (Astorga, León)”, en B. Soler Huertas, P. Mateos Cruz, J.M. Noguera Celdrán y J. Ruiz de Arbulo Bayona (coords.), Las sedes de los "Ordines decurionum" en Hispania: análisis arquitectónico y modelo tipológico: 111-134. Anejos de Archivo Español de Arqueología 77. Mérida, Consejo Superior de Investigaciones Científicas.

Sevillano Fuertes, M. Á. y Vidal Encinas, J.M. (2000): "Las termas mayores de Astorga", en C. Fernández Ochoa y V. García Entero (eds.), Termas romanas en el Occidente del Imperio. II Coloquio Internacional de Arqueología en Gijón: 199-205. Gijón (1999), Gijón, Ayuntamiento de Gijón.

Sevillano Fuertes, M. Á. y Vidal Encinas, J.M. (2002): Urbs Magnifica. Una aproximación a la arqueología de Astúrica Augusta (Astorga, León). León, Museo Romano.

Teja Casuso, R. (1990): "La carta 67 de S. Cipriano a las comunidades cristianas de León-Astorga y Mérida: algunos problemas y soluciones", en A. González Blanco y J. M. Blázquez Martínez (eds.), Cristianismo y aculturación en tiempos del Imperio Romano, Antigüedad y Cristianismo VII: 115-124. Murcia, Universidad de Murcia.

Tomás Faci, G. y Martín Iglesias, J. C. (2017): “Cuatro documentos inéditos del monasterio visigodo de San Martín de Asán (522-586)". Mittellateinisches Jahrbuch 52: 261-286.

Vidal Encinas, J. M. y González Fernández, M. L. (2004): "La Legio X Gemina y Astúrica Augusta (Astorga, León)". Astorica 23: 35-63.

Vidal Encinas, J. M. y González Fernández, M. L. (2018): "Asturica Augusta: actualización de su urbanismo a la luz de las excavaciones recientes", en S. Martín Caballero, J. Santos Yanguas y L.J. Municio González (eds.), El urbanismo de las ciudades romanas del valle del Duero, Actas de la I Reunión de Ciudades Romanas del Valle del Duero: 273-298. Segovia (2016), Segovia, Junta de Castilla y León.

Vigil-Escalera Guirado, A. (2007): “Granjas y aldeas tardoantiguas y altomedievales de la Meseta. Configuración espacial, socioeconómica y política de un territorio rural al norte de Toledo (ss. V-X d. C.)". Archivo Español de Arqueología 80: 239-284 $<$ https://doi.org/10.3989/aespa.2007.v80>.

Vigil-Escalera Guirado, A. (2009): "Las aldeas altomedievales madrileñas y su proceso formativo", en J. A. Quirós Castillo (ed.), The Archaeology of Early Medieval Villages in Europe: 315-339. Bilbao, Universidad del País Vasco <https://doi.org/10.13140/ RG.2.1.4036.4000>.

Vigil-Escalera Guirado, A. (2013): "El registro arqueológico del campesinado del interior peninsular en época altomedieval", en J. A. Quirós Castillo (ed.): El poblamiento rural de época visigoda en 
Hispania. Arqueología del campesinado en el interior peninsular: 65-258. Documentos de Arqueología Medieval 6. Bilbao, Universidad del País Vasco.

Vigil-Escalera Guirado, A. (2015): Los primeros paisajes altomedievales en el interior de Hispania. Registros campesinos del siglo quinto d.C. Documentos de Arqueología Medieval 7. Bilbao, Universidad del País Vasco.

Villanueva Zubizarreta, O. (2011): “La ollería alcallería en la cuenca del Duero a lo largo de la Edad Media y Moderna", en J. Coll Conesa (coord.), Manual de Cerámica Medieval y Moderna: 87-115. Madrid, Museo Arqueológico Regional de la Comunidad de Madrid.
Whittaker, C.R. (1990): “The Consumer City revisited: the vicus and the City". Journal of Roman Archaeology 3: 110-118 <https://doi.org/10.1017/ S1047759400010862>.

Wilkinson, T.J. (1982): “The definition of ancient manured zones by means of extensive sherd-sampling techniques". Journal of Field Archaeology 9 (3): 323-333<https://doi.org/10.1179/0093469827915 $04616>$.

Wilkinson, T.J. (1989): "Extensive Sherd Scatters and Land-Use Intensity: Some Recent Results". Journal of Field Archaeology 16 (1): 31-46<https://doi. org/10.1179/jfa.1989.16.1.31>. 

Alfaro Suescun, E. (2020): “Iglesia, cementerio y aldea en Álava durante el siglo XII.

¿Evidencias materiales de la implantación parroquial?",

Spal 29.1: 301-320. DOI: http://dx.doi.org/10.12795/spal.2020.i29.11

\title{
IGLESIA, CEMENTERIO Y ALDEA EN ÁLAVA DURANTE EL SIGLO XII ¿EVIDENCIAS MATERIALES DE LA IMPLANTACIÓN PARROQUIAL?
}

\section{CHURCH, CEMETERY AND VILLAGE IN 12TH CENTURY ÁLAVA (SPAIN). MATERIAL EVIDENCE OF THE ESTABLISHMENT OF THE CATHOLIC PARISH?}

\author{
EGOITZ ALFARO SUESCUN \\ Universidad del País Vasco / Euskal Herriko Unibertsitatea \\ Centro de Investigación Micaela Portilla. c/ Justo Vélez de Elorriaga, 1. 01006 Vitoria-Gasteiz (Álava) \\ Correo-e: egoitz.alfaro@gmail.com. (D http://orcid.org/0000-0002-7617-0490 \\ Researcher ID: <https://publons.com/researcher/H-9320-2017>
}

\begin{abstract}
Resumen: En el presente artículo se analizan los registros arqueológicos plenomedievales (siglos XI-XIII) de seis aldeas de Álava (Armentia y los despoblados de Zornoztegi, Zaballa, Aistra, Torrentejo y Dulantzi), poniendo el acento en las iglesias, sus estructuras asociadas y su relación con las unidades domésticas del entorno. El objetivo es doble. Por un lado, determinar si se produjeron transformaciones generalizadas y coincidentes en el tiempo. Por otro, y en el caso de identificarlas, establecer si tuvieron relación con la implantación de la red parroquial, proceso casi exclusivamente estudiado desde las fuentes escritas. Se confirmarán ambas cuestiones, subrayando la heterogeneidad del proceso. Así, en la discusión se definirán los diversos escenarios sobre los que se estableció la parroquia y se evaluarán los variados marcadores materiales empleados para su reconocimiento.
\end{abstract}

Palabras clave: Plena Edad Media; marcadores materiales; rentas eclesiásticas; iglesias propias; poderes episcopales; comunidades aldeanas.
Summary: This paper analyses the archaeological record of six villages of Álava, north-central Iberia, in the High Middle Ages (11-13th centuries AD): Armentia and the deserted villages of Zornoztegi, Zaballa, Aistra, Torrentejo and Dulantzi. The approach focuses on their churches, their associated structures and the relationship with the surrounding domestic households, with a double aim. First, to establish if these elements were subject to widespread and synchronic transformations. Second, to assess whether these changes, if identified, had any connections with the implementation of the Catholic parish network, a process that so far has been almost exclusively studied after the written sources. The results come to confirm both issues, showing the notable heterogeneity of the process in the territory. The discussion serves here to define a set of diverse scenarios for the establishment of the parish and to evaluate the different material markers used for their identification.

Keywords: High Middle Ages; material markers; ecclesiastical rents; proprietary churches; episcopal powers; peasant communities. 


\section{INTRODUCCIÓN}

En el estudio de las iglesias, tanto desde una perspectiva monumental como del paisaje, la arqueología del centro-norte peninsular ha puesto el acento principalmente en las cronologías altomedievales (p. ej. Caballero 2001, Caballero y Utrero 2005, Utrero 2006, Sánchez Zufiaurre 2007, Quirós 2011). Los templos construidos o reformados a partir del siglo XI apenas han recibido la atención de los arqueólogos, proviniendo las principales aportaciones desde la historia del arte. Su coincidencia cronológica con el estilo románico ha generado una abundante bibliografía sobre estos edificios de culto desde hace tres décadas (p. ej. los diversos volúmenes de la Enciclopedia del Románico editados por la Fundación Santa María la Real).

Los escasos trabajos que desde la arqueología se han ocupado de estas cuestiones han hecho referencia a algunas de las transformaciones asociadas a estas iglesias, pero sin buscar una comprensión integral. En una reciente publicación señalábamos los cambios que se produjeron en las funciones, significados, promotores y actores de las iglesias de Álava y Treviño durante y a partir del siglo XII. Tanto la oferta como la demanda se modificaron de manera profunda, mostrándonos un escenario en el siglo XIII radicalmente diferente al que había existido hasta el siglo XI (Alfaro 2017). No obstante, dicho estudio, que se desarrolló en el ámbito de la arqueología de la arquitectura, se limitaba a los caracteres constructivos de los templos, sin tener en cuenta otras transformaciones que ocurrieron en sus estructuras asociadas, así como en el propio caserío circundante.

Del mismo modo, hay otras publicaciones que se han centrado en cómo cambiaron las necrópolis durante estos siglos, documentando la transición de las «altomedievales» a las «parroquiales» (García Camino 2002, Gutiérrez Cuenca 2015). De nuevo, faltaría un enfoque holístico que integre y explique todas las transformaciones que se visibilizan durante estos siglos en el registro arqueológico.

Esta desatención ha provocado que la arqueología medieval del norte peninsular apenas haya hecho hincapié en la red parroquial como instrumento de análisis social, más allá de considerarlo un fenómeno tardío en el marco de la feudalización. Ello contrasta con la amplia producción científica desarrollada desde las fuentes escritas sobre la parroquia pleno y bajomedieval.

Aludimos a este tipo de parroquia porque este es un término polisémico que no hace referencia a una única realidad inmutable o intrínseca a la organización de la sociedad cristiana. Por ejemplo, y sin querer ser exhaustivos, G. Ripoll e I. Velázquez diferencian hasta tres acepciones de parrochia en las actas conciliares de los siglos VI y VII (Ripoll y Velázquez 1999: 113-121, 142-144, 156). Asimismo, y para la diferenciación de estas parroquias de los albores de la Edad Media con las que nos atañen, remitimos a los trabajos de F. López Alsina (antigua-clásica) y de J. Á. García de Cortázar (gentilicia-de aldea) (López Alsina 1999: 264-265, 277 , 284-285; García de Cortázar 1988: 90-92).

En relación con las parroquias pleno y bajomedievales, los historiadores coinciden en que durante este periodo se fijó en Europa occidental una red con diversos rasgos comunes: un templo, un territorio delimitado, una comunidad que paga rentas a cambio de enterrarse y recibir sus sacramentos, y un presbítero que se encarga de administrarlos. Estas características son casi unánimemente mencionadas por los autores que se han ocupado de la temática, aunque casi siempre destacando unas sobre otras (Le Bras 1975: 227, García de Cortázar 1988: 90, Etxezarraga 2011: 89, Curiel 2009: 35, López Alsina 1999: 264, Ruiz de la Peña 2008: 199). Enrique de Segusio, eclesiástico que vivió a mediados del siglo XIII, incluyó ya esta triple dimensión templo-territorio-comunidad de la parroquia en su obra Summa aurea (Lauwers 2005: 29).

En el proceso de implantación parroquial se asumen ritmos y procesos variados condicionados por los diferentes puntos de partida (López Alsina 2006: 421422 , 425). A modo de ejemplo para la península ibérica baste mencionar las tempranas cronologías que la historiografía baraja para la extensión de la red parroquial en Cataluña, siglo XI o anterior (Villaginés 1988, To Figueras 1991, Martí 2006), en comparación con la de otras regiones del centro-norte peninsular, como Vizcaya (García Camino 2002), Asturias (Ruiz de la Peña 1993: 108, Calleja 2000) o Soria (Asenjo 1999: 393-396), donde se proponen los siglos XII-XIII o, incluso, el siglo XIV para el caso de Guipúzcoa (Etxezarraga 2011).

Sin embargo, los aspectos definitorios de la institución comentados, especialmente la territorialidad y la administración de sacramentos, no son fácilmente aprehensibles desde el registro material, hasta el punto de que podríamos cuestionarnos si la praxis arqueológica es un método válido para reconocer un proceso como el de la formación parroquial, con grandes variaciones en sus rasgos y cronologías a diferentes escalas.

El objetivo del presente trabajo es, en este sentido, analizar las secuencias ocupacionales de diversos yacimientos del Territorio Histórico de Álava, 


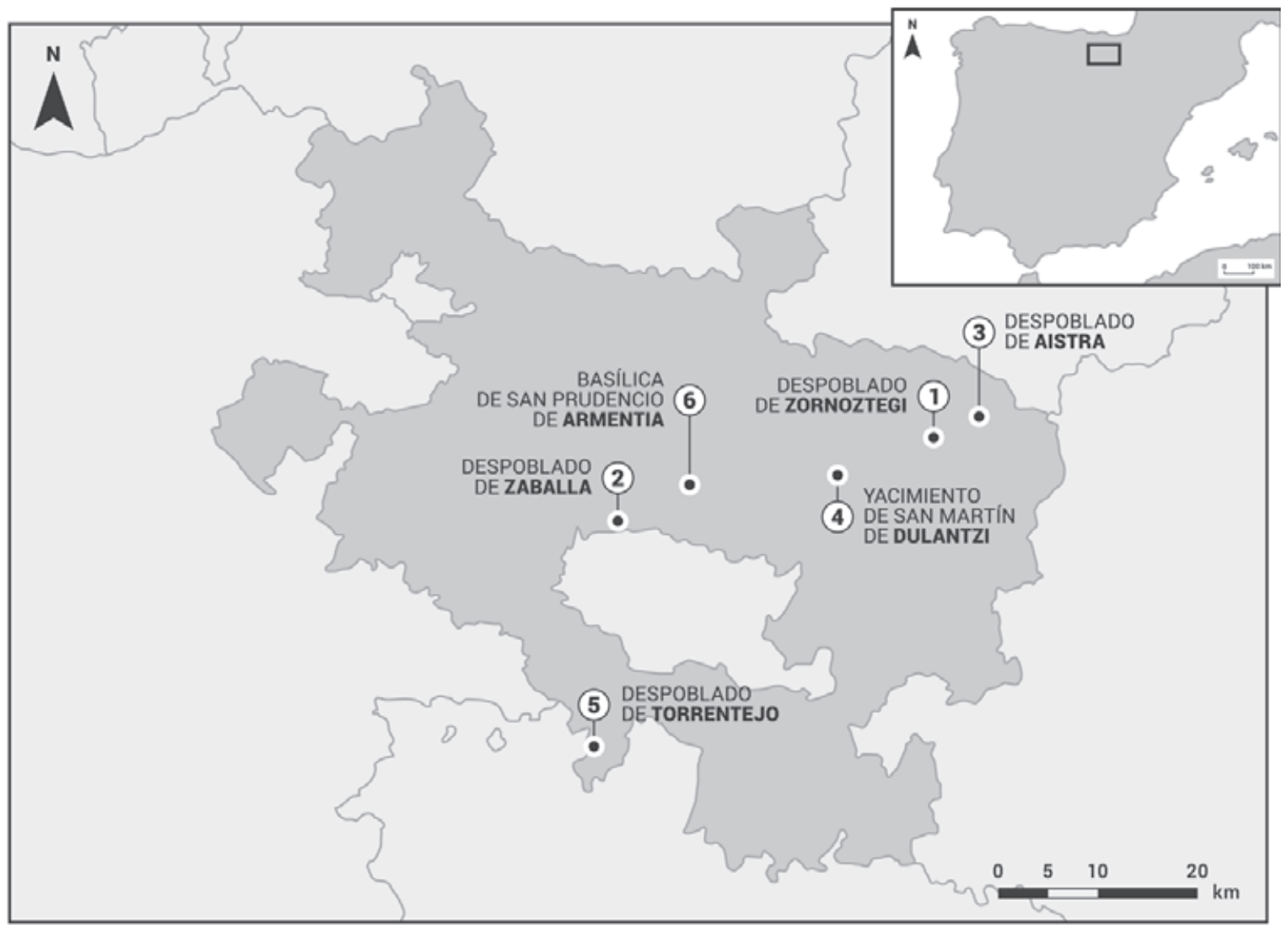

Figura 1. Mapa con el ámbito geográfico y los casos de estudio considerados en el artículo.

centrándonos en las fases plenomedievales de los edificios de culto, sus estructuras asociadas (cementerios, espacios de almacenaje o de habitación) y su relación con las unidades habitacionales y productivas del entorno. Pretendemos, así, responder a las siguientes preguntas: ¿es posible identificar de forma generalizada transformaciones de calado durante estos siglos? De ser así, ¿pueden ser asociadas a la parroquia?

Se trata, en definitiva, de valorar la potencialidad de la arqueología para analizar un fenómeno, el de la formación de la red parroquial, tradicionalmente estudiado desde la documentación escrita. Por ello, no se tendrán en cuenta aspectos del mismo que no puedan ser identificados materialmente.

\section{CASOS DE ESTUDIO}

En este apartado analizaremos seis yacimientos arqueológicos, describiendo sus secuencias de ocupación y poniendo el acento en la evolución constructiva de las iglesias. El objetivo es identificar los cambios que se produjeron durante los siglos XI-XIII tanto en la materialidad de los edificios de culto como en la relación de estos con el poblamiento circundante.

Hemos seleccionado estos casos de estudio por un doble motivo. Por un lado, se trata de yacimientos excavados en extensión y estudiados de forma transdisciplinar, aunque todavía alguno esté a la espera de ser publicado. Por otro, hacen referencia a contextos aldeanos y rurales de diversa naturaleza que remiten a puntos de partida y trayectoria diferentes, lo que enriquece el análisis comparativo. Hemos obviado deliberadamente los asentamientos de carácter urbano por considerar que la atracción que ejercieron hacia diferentes poderes complica la interpretación de los cambios acaecidos durante estos siglos. De hecho, en nuestra investigación arqueológica sobre la villa de Treviño (Burgos) concluíamos que su condición de centro organizador del territorio le otorgó un carácter multifocal que atrajo a 


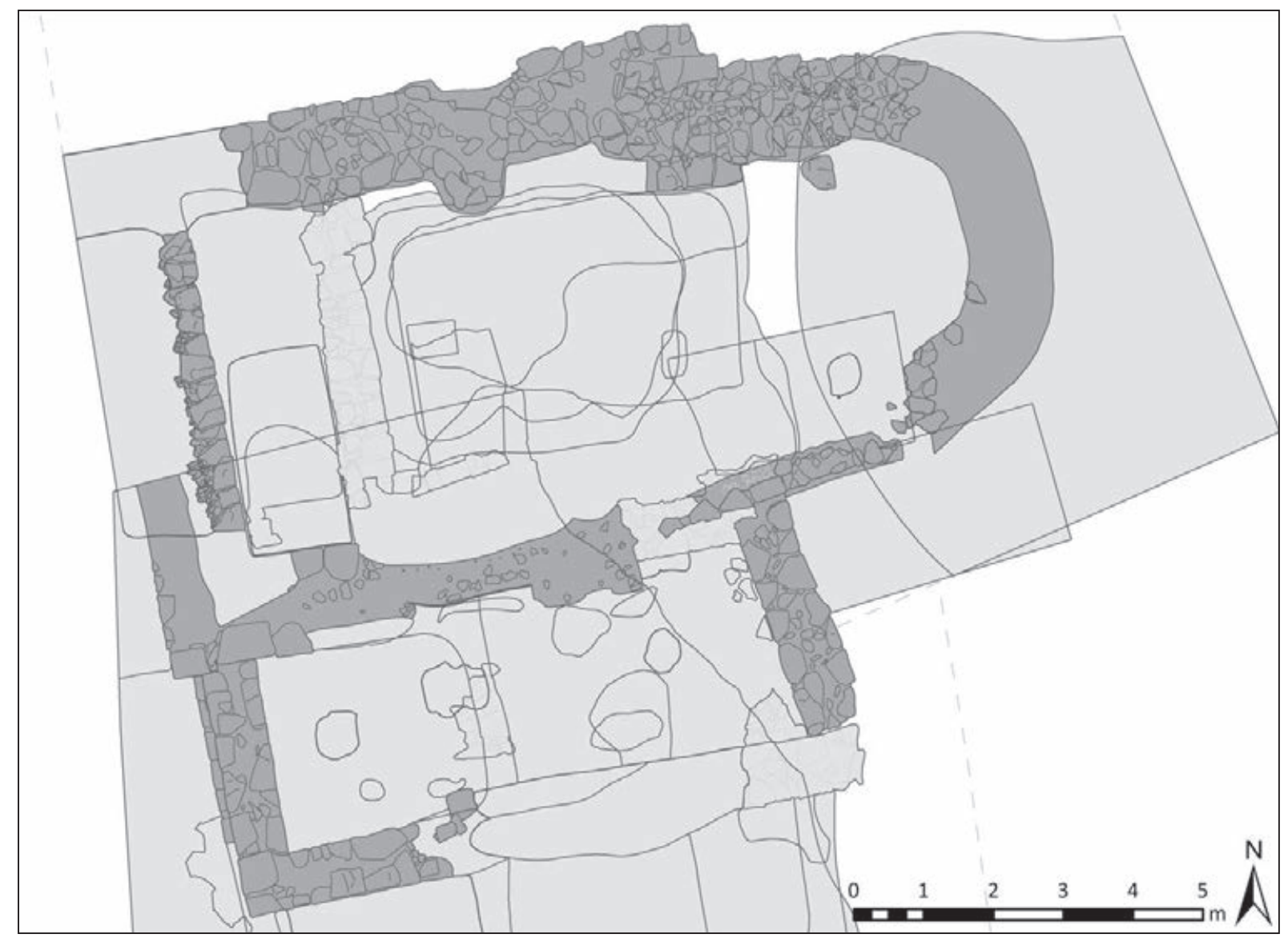

Figura 2. Zornoztegi. Planta de la iglesia y su pórtico meridional (fuente: Gipypac, UPV-EHU).

poderes de diversa naturaleza. Sugeríamos que la influencia de la parroquia, como instrumento de poder diocesano, había sido más limitada en esta villa que en el resto de aldeas estudiadas. La influencia de estos poderes debió de condicionar desde el principio el estatus de las iglesias de Treviño y su control efectivo por parte de la sede calagurritana, en especial mediante la figura del patronato (Alfaro 2016: 116-117).

\subsection{El despoblado de Zornoztegi (Salvatierra)}

El yacimiento de Zornoztegi se encuentra en el término municipal de Salvatierra, en la mitad oriental de la llanada alavesa. Ocupa casi 2 ha de extensión y está diferenciado en tres sectores: la cima del cerro ocupada por monte bajo, una plataforma elevada conocida con el nombre de Ubaide y la base de la colina formada por laderas poco pronunciadas. Fue excavado, afectando a $3.533 \mathrm{~m}^{2}$ de terreno, a lo largo de cinco campañas, entre 2005 y 2009, bajo la dirección de J. A. Quirós (Universidad del País Vasco UPV-EHU). Su secuencia ocupacional, exceptuando ciertos restos aislados de cronología calcolítica, se extiende entre el final de la Antigüedad (siglos IV-V) y el final de la Edad Media (siglo XIV-primer cuarto del XVI) (Quirós 2018).

Los periodos relevantes para nuestro estudio son el 4 y el 5. El periodo 4 (siglos VIII-XI) comprende la creación y desarrollo de la aldea de Zornoztegi. En este momento se identifican exclusivamente estructuras domésticas, de habitación y almacenaje, realizadas en materiales perecederos y localizadas en la plataforma Ubaide.

Durante el periodo 5 (siglos XII y XIII) se edifica una iglesia y su necrópolis asociada en la zona más elevada de Ubaide, así como algunas estructuras domésticas en la ladera norte de la colina. El templo dispuso de orientación canónica E-O, una sola nave, ábside semicircular, planta rectangular y pórtico al sur. Fue construido empleando mampuestos calizos de origen local 


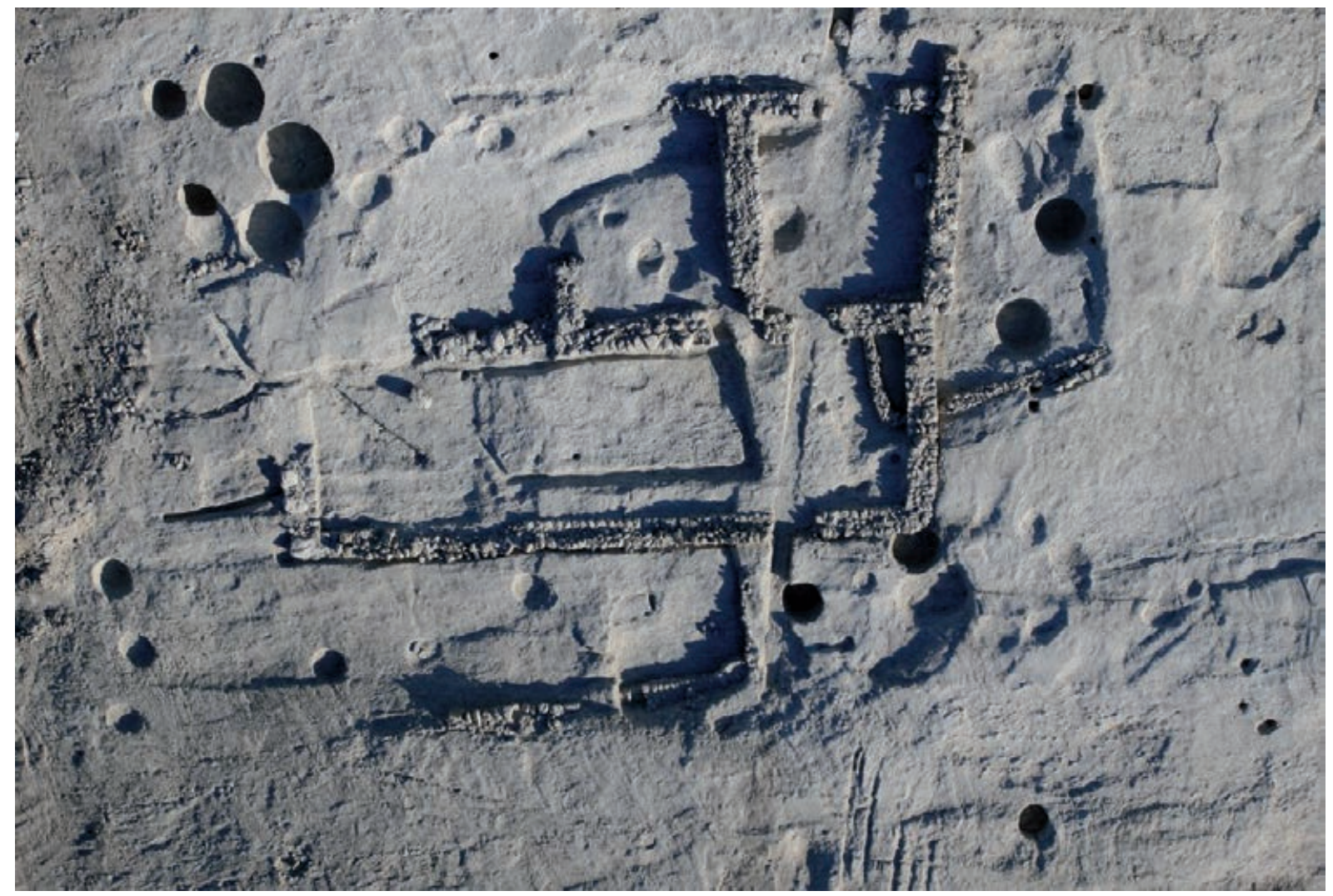

Figura 3. Zaballa. Fotografía aérea de la iglesia y su pórtico sur (en la mitad inferior) (fuente: Gipypac, UPV-EHU).

para los muros y caliza paleocena exógena para los esquinales y vanos. El carbono-14 y la morfología de la cabecera fechan su construcción en la primera mitad del siglo XII.

Al sur del pórtico se sitúa el área cementerial. En ella se identificaron seis inhumaciones, de las que se excavaron tres, y un osario. Los tres enterramientos eran de fosa simple y tenían abundantes evidencias de reutilización. Gracias a su secuencia vertical, y pese a su escaso número, es posible verificar la presencia de varias fases en la necrópolis, que debió extenderse hasta el abandono de la aldea en el siglo XIV (Mendizabal 2013).

La edificación del templo produjo una redefinición funcional del espacio en Ubaide, que adquirió una novedosa finalidad litúrgico-funeraria, amortizando la anterior de carácter doméstico y que llevaba en uso desde el siglo X. Coincidiendo con estos cambios, el extremo meridional de la aldea dejó de emplearse con fines domésticos y se transformó en un espacio de producción agrícola, mientras que el hábitat se dispuso alrededor del nuevo templo (Alfaro 2018).

\subsection{EI despoblado de Zaballa (Nanclares de la Oca)}

El término de Zaballa se sitúa en el extremo suroccidental de la llanada alavesa y en el ángulo sudeste del municipio de Iruña de Oca. El yacimiento se divide en dos sectores principales: una plataforma situada al nordeste (área 6000) y el valle adyacente (áreas 3000, 4000 y 5000).

Dirigida por J. A. Quirós, la intervención arqueológica se llevó a cabo debido a la intención de construir el Centro Penitenciario Norte I en este término. Se realizó una primera valoración arqueológica en julio de 2007 y pasó a excavarse en extensión a lo largo del siguiente año.

En una superficie intervenida de $46.055 \mathrm{~m}^{2}$ se identificó una secuencia ocupacional que comenzaba en el siglo VI y se extendía ininterrumpidamente hasta el siglo XVI, tras lo cual se produjeron ciertas ocupaciones de carácter marginal y, finalmente, la construcción de un polvorín militar en el siglo XX (Quirós 2012).

Nos referiremos a los periodos 2, 3 y 4, al ser los únicos relevantes para nuestro trabajo. Durante el periodo 2 (siglos VIII-X) se levantaron, en la plataforma y parte del 
valle (áreas 6000 y 3000), las estructuras domésticas que conformaban la aldea. El periodo se divide en dos fases, diferenciadas en función de los caracteres constructivos de las edificaciones: materiales perecederos en la primera (hasta el siglo X), arquitectura mixta en la segunda.

En un periodo indeterminado del siglo $\mathrm{X}$ se produjeron las transformaciones que definen el periodo 3 (hasta la primera mitad del siglo XIII): edificación de una iglesia en el área 6000 que amortizó el espacio doméstico precedente; densificación de la ocupación doméstica en el área 3000; construcción de las primeras terrazas de cultivo (áreas 4000 y 5000).

El edificio de culto contó con una orientación NE$\mathrm{SO}$, nave única, acceso al sur, ábside recto no diferenciado, una necrópolis y diversos silos de almacenaje asociados. Está realizado en mampostería, aunque empleando piezas talladas de mayor calidad para vanos y accesos, como sugieren los fragmentos hallados en depósitos secundarios más tardíos. Se fecha en el siglo X gracias a la datación radiocarbónica de un carbón recuperado de la zanja de cimentación de uno de sus muros.

En una fase posterior se dotó de un pórtico en su acceso sur. Esta acción constructiva está datada en el siglo XII a partir del carbono-14 de una semilla hallada en una de sus zanjas de fundación.

Cinco son los silos que pueden ser asociados al templo con total seguridad, todos ellos en el exterior. Los dos más antiguos, contemporáneos a la construcción de la iglesia, no están agrupados y destacan por su gran diámetro ( $>2{ }^{\prime} 5 \mathrm{~m}$ ), que sobrepasa ampliamente el de los silos de carácter doméstico del periodo anterior (promedio, en adelante $x^{\prime},=1,54 \mathrm{~m}$. Los tres silos restantes tienen un diámetro más reducido $\left(x^{\prime}=1,43 \mathrm{~m}\right)$ y son más tardíos (siglos XI-XIII).

Del cementerio de la iglesia de Zaballa se han podido recuperar 19 enterramientos, todos ellos en fosa simple excepto una tumba de lajas. Se emplazaba al norte, una ubicación poco común, y más si tenemos en cuenta que ni al este ni al sur se ha identificado ninguna inhumación a pesar de que eran espacios vacíos. Con todo, su relación con el templo está fuera de toda duda al mantener su misma orientación NE-SO y porque la única datación radiocarbónica realizada en una de las tumbas es coincidente con el periodo 3 .

Durante el periodo 4 (segunda mitad del siglo XIIImediados del XV) se produjo una reforma del complejo eclesial, la construcción de nuevos edificios adosados al norte y una proliferación de elementos de carácter habitacional en el área, que llevará, ya en la Edad Moderna (periodo 5) a su reutilización como estructura doméstica.

\subsection{El despoblado de Aistra (Zalduondo)}

El despoblado de Aistra se emplaza en el extremo nororiental de la llanada alavesa, al noroeste de la villa de Zalduondo y a los pies de los montes de Altzania. La intervención arqueológica de mayor calado corresponde al proyecto desarrollado entre 2006-2009 y dirigido por J. A. Quirós y A. Reynolds (University College London). En una extensión total de $2.744 \mathrm{~m}^{2}$ se definió una ocupación ininterrumpida desde el siglo VI hasta el siglo XIV (Reynolds y Quirós 2010), en la que destacaremos para nuestro trabajo los periodos 2, 3 y 4 .

En el periodo 2 (siglo VIII-primera mitad siglo X) comienza a emplearse un espacio próximo a la aldea, creada en el siglo VI, como espacio cementerial exento, no asociado a ningún edificio de culto. La campaña de 2009 sacó a la luz 54 sepulturas de esta necrópolis, organizadas en hiladas y alineadas E-O. Ninguna de ellas tenía ajuar y disponían de una tipología variada que incluía tumbas de fosa simple (40\%), de lajas (33\%) y de murete $(27 \%)$. Nunca se superponían, por lo que suponemos que se señalizaban de algún modo. Siete de estos enterramientos mostraban además evidencias de reutilización, aunque nunca con más de dos individuos (Mendizabal 2011: 413, 416-419).

El evento más destacable del periodo 3 (segunda mitad del siglo X-siglo XII) fue la construcción de una iglesia y de una nueva necrópolis a su alrededor durante la décima centuria. Se erigieron sobre un lugar aparentemente periférico de la aldea, vacío hasta ese momento. De forma paralela, se produjo el abandono de parte de las estructuras domésticas del periodo anterior.

Esta iglesia sobrevive hoy en día como ermita con la advocación de San Julián y Santa Basilisa. Tanto la tipología del ventanal monolítico orientado al este (García Camino 2002: 175-181), como la excavación de los cimientos del muro norte en 2006 (Reynolds y Quirós 2010: 38, 39) coinciden en que fue erigida a mediados del siglo $\mathrm{X}$.

Los restos conservados del siglo $\mathrm{X}$ aportan pocos datos sobre las características de la iglesia primitiva: cabecera recta y una única nave. Fue construida con bloques nuevos de cantera de arenisca albiense que se asemejan a sillares desde el exterior, pero que son en realidad lajas gruesas entre las que se dispuso un núcleo compuesto de mampuestos y argamasa. El empleo de esta litología alóctona de difícil talla y la presencia del vano monolítico reflejan la presencia exclusiva de canteros en la construcción del edificio.

La necrópolis que se establece en el periodo 3 alrededor de la iglesia ha sido atestiguada en diversas 


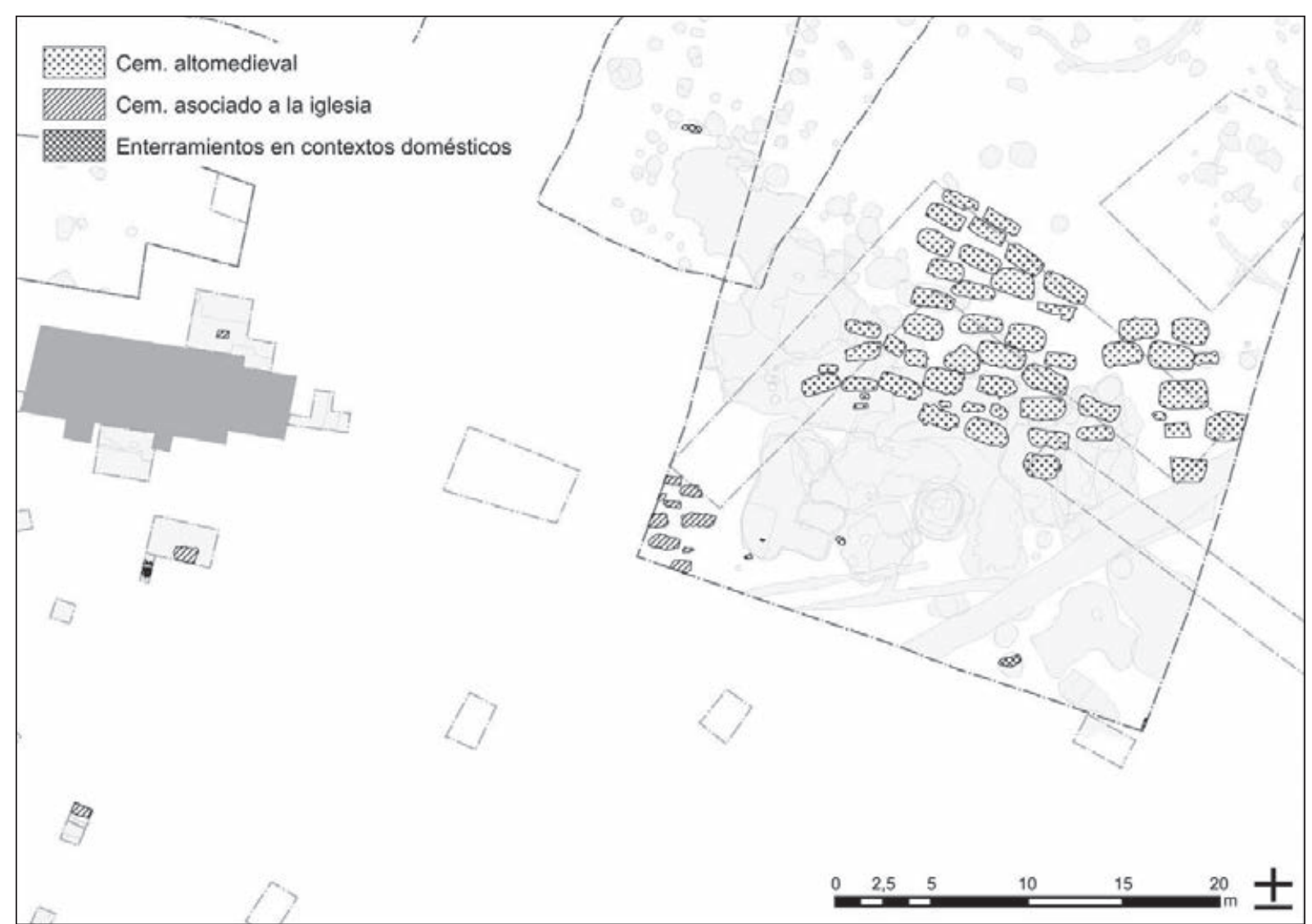

Figura 4. Aistra. Planta con todos los enterramientos identificados en las campañas 2006-2009 y la iglesia del siglo X (a la izquierda) (fuente: Gipypac, UPV-EHU).

campañas de excavación llevadas a cabo desde los 80 . Ya en 1982 se identificaron 27 tumbas con un claro predominio de las realizadas mediante lajas respecto a las de fosa simple (25-2) (García Retes 1987: 457-459). En campañas más recientes se excavaron seis individuos más dispuestos en una fosa de forma ordenada, aunque sin ningún elemento de separación entre ellos (GarcíaCollado 2011: 91-92).

Es importante precisar que la creación del cementerio asociado al templo no supuso el abandono de la necrópolis altomedieval de forma inmediata. Parece que ambos coexistieron a lo largo del siglo $\mathrm{X}$, quizá incluso más allá (García-Collado 2011: 67-69).

Más adelante, ya en el periodo 4 (siglos XI-XV), tuvo lugar una reforma de la iglesia, posiblemente en el siglo XII, aunque no hay ningún indicador cronológico que le asocie una cronología absoluta. Se presupone que fue realizada en esta centuria porque cuenta con elementos, como los canecillos, típicos del estilo románico.
La reforma, en cualquier caso, fue llevada a cabo cuando la iglesia primitiva se hallaba en buena medida arruinada, y supuso la reconstrucción de la cabecera y la ampliación de la nave en anchura. La obra fue dirigida por albañiles, como refleja el hecho de que se reutilizaran bloques de la fase anterior y se dispusieran con múltiples engatillados e irregularidades. No obstante, para algunos elementos puntuales como los canecillos, y quizá la cornisa, es evidente que se solicitó la colaboración de canteros.

\subsection{El yacimiento de San Martín de Dulantzi (Alegría-Dulantzi)}

Se localiza en la villa de Alegría-Dulantzi, en plena llanada alavesa y a medio camino entre Vitoria-Gasteiz y Salvatierra. En concreto, se ubica en el espacio que ocupaba la desaparecida aldea de Dulantzi, al norte del casco histórico de la villa y al otro lado del río Alegría. 
Los hallazgos relativos a la aldea de Dulantzi salieron a la luz en dos fases, la primera durante los años 2009-2010 y la segunda en 2014, ambas dirigidas por los arqueólogos M. Loza y J. Niso, de la empresa Iterbide SC.

La secuencia ocupacional del yacimiento se dividió en ocho fases que abarcan un amplio lapso entre el segundo milenio a.C. y el siglo XX (Loza y Niso 2016, Alfaro et al. 2017: 249-250). Las más significativas para nuestro trabajo son las cuatro fases medievales (4-7).

La fase 4 (segunda mitad del siglo VI-finales VII) se inicia con la construcción de una iglesia de grandes dimensiones y un cementerio asociado sobre el espacio doméstico, y quizá funerario, anterior. El templo tuvo una orientación canónica, ábside diferenciado, recto por el exterior y semicircular por el interior, y tres naves. Contaba, asimismo, con un baptisterio de planta rectangular imbricado al muro sur de la nave y una estancia parcialmente conservada al sur de la cabecera. Todos sus muros fueron elaborados con una misma técnica constructiva a base de lajas, mampuestos careados y elementos reaprovechados de época romana trabados con argamasa. Su fecha de construcción, años centrales del siglo VI, viene determinada a partir de las relaciones estratigráficas, el carbono-14 y los materiales cerámicos.

En esta fase el cementerio tiene un carácter exclusivo. Acogía en el interior de la iglesia solo a individuos destacados, como demuestran los análisis antropológicos, isotópicos y, en algunos casos, los materiales con los que fueron enterrados.

Durante la fase 5 (finales del siglo VII-siglo X) esta necrópolis dejó de ser un espacio funerario privilegiado y pasó a serlo de toda la comunidad aldeana, inhumándose en el exterior de la iglesia y con una gran variedad tipológica en las tumbas, que además ya no tienen ajuares.

La fase 6 (segunda mitad del siglo X-siglo XI) se caracteriza por el cambio de función del espacio interior de la iglesia, que comienza a ser empleado para el almacenamiento de cereal. Así, se abrieron, tanto en la nave como en el ábside, al menos 35 silos de grandes capacidades (volumen estimado: $x^{\prime}=1019 l$ ). Se desconoce el número total al quedar buena parte de la planta del templo fuera de los límites de la excavación. Como los silos se cortan entre sí, y aunque se extienden por todo el espacio disponible, sabemos que nunca debieron estar abiertos más que unos pocos a la vez, por lo que es perfectamente razonable que el templo mantuviera su función litúrgica. Hay que precisar que durante esta fase tanto el baptisterio como el cementerio exterior siguieron en uso.

A finales del siglo XI o comienzos del siglo XII, ya en la fase 7 (hasta el siglo XIV), se procedió al completo desmantelamiento de la primitiva iglesia, después de más de cinco siglos de actividad, y a la construcción unas décadas después de un nuevo templo más pequeño, bajo la advocación de San Martín, con su necrópolis aneja.

Esta iglesia estaba orientada E-O, dispuso de un ábside semicircular y, probablemente, de una única nave, planta rectangular y reducidas dimensiones. La única hilada conservada en alzado revela que se levantó con mampuestos trabajados, con al menos sus caras de contacto y cara vista regularizadas. Se disponían en hiladas horizontales y en una organización núcleo interno/caras exteriores en la que el núcleo se ejecutaba mediante material local sin trabajar y argamasa. El material empleado fue exclusivamente caliza local, aunque es más que probable que se utilizaran litologías alóctonas para vanos y quizá esquinales.

Llama la atención su emplazamiento. No solo no se aprovechó ningún paramento del templo anterior, sino que además levantaron el nuevo templo a sus pies, lejos de la zona de mayor consideración sacra, su ábside. En principio esto sugeriría que cuando comenzaron a construir San Martín la iglesia primitiva estaba ya arrasada, quedando únicamente en el lugar un recuerdo como espacio sagrado. Ello explicaría también el hiato de medio siglo entre ambas edificaciones.

\subsection{EI despoblado de Torrentejo (Labastida)}

La pequeña ermita de Santa Lucía es el único resto material visible que se conserva de la desaparecida aldea de Torrentejo. Se emplaza a orillas del Ebro y a un kilómetro al noroeste de la villa de Labastida. Entre 2014 y 2016 se llevaron a cabo tres campañas de excavación en el entorno del templo bajo la dirección de J. A. Quirós. Estas afectaron sobre todo al espacio inmediatamente al sur de la iglesia, aunque también se intervinieron varios sectores al norte y noroeste y se realizaron varias trincheras de valoración. El sondeo meridional, así como una lectura estratigráfica de alzados en el lienzo S, permitieron elaborar una secuencia ocupacional (Quirós 2015) de la que mencionaremos las fases 3 y 4 .

La fase 3 (siglos XI-XII) implicó la construcción de un edificio destacado y su posible iglesia asociada. 


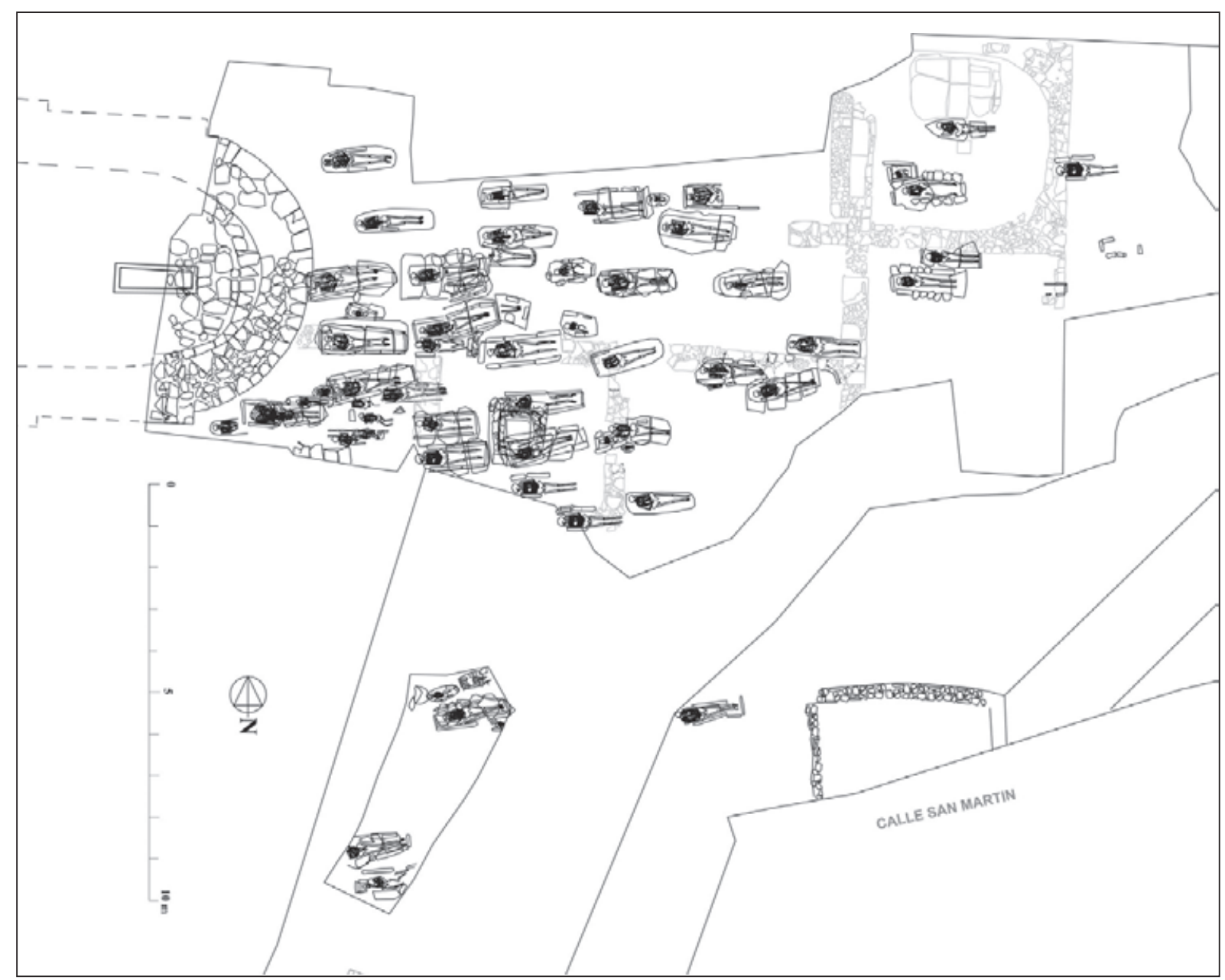

Figura 5. San Martín de Dulantzi. Planta con las dos iglesias y los enterramientos asociados a la segunda (fuente: Iterbide SC).

Esta segunda construcción ha sido interpretada como edificio de culto porque su muro de mampuestos de arenisca miocena orientado NE-SO fue cortado al levantar el templo del siglo XII, manteniéndose en uso hasta que levantaron la cabecera.

En un momento sin precisar del siglo XII, ya durante la fase 4, se levantó una nueva iglesia con ábside semicircular, presbiterio y una sola nave en dos momentos distintos, aunque próximos entre sí. En la primera etapa se edificó toda la cabecera y parte del extremo oriental de la nave, mientras que en la segunda se continuó la obra hacia el oeste. Esta última solo se ha identificado en el proceso de excavación, por lo que desconocemos si los sillarejos que la componen se emplearon solo para los cimientos o también para el resto de los alzados. Con todo, los paramentos de la primera etapa estaban elaborados con sillares de arenisca miocena dispuestos en hiladas horizontales y con talla diagonal de tallante a $45^{\circ}$. Salvo el amplio lapso del empleo de este útil (Sánchez Zufiaurre 2007: 328-341, Bessac 1986: 51, 104) no disponemos de argumentos materiales para certificar su cronología. Con todo, los historiadores del arte coinciden en considerarla del siglo XII (Cantera 1967: 198-199, Pérez García 1985: 363). No hay evidencias de que la iglesia contara con un espacio funerario asociado.

\subsection{La basílica de San Prudencio de Armentia}

Armentia es una pequeña localidad situada a escasos $3 \mathrm{~km}$ del centro de Vitoria-Gasteiz, a cuyo municipio pertenece. Más allá de su iglesia parroquial, la basílica de San Prudencio, nada recuerda al visitante su notable pasado medieval. De hecho, aquí se estableció la sede del obispado de Álava durante la Alta Edad 


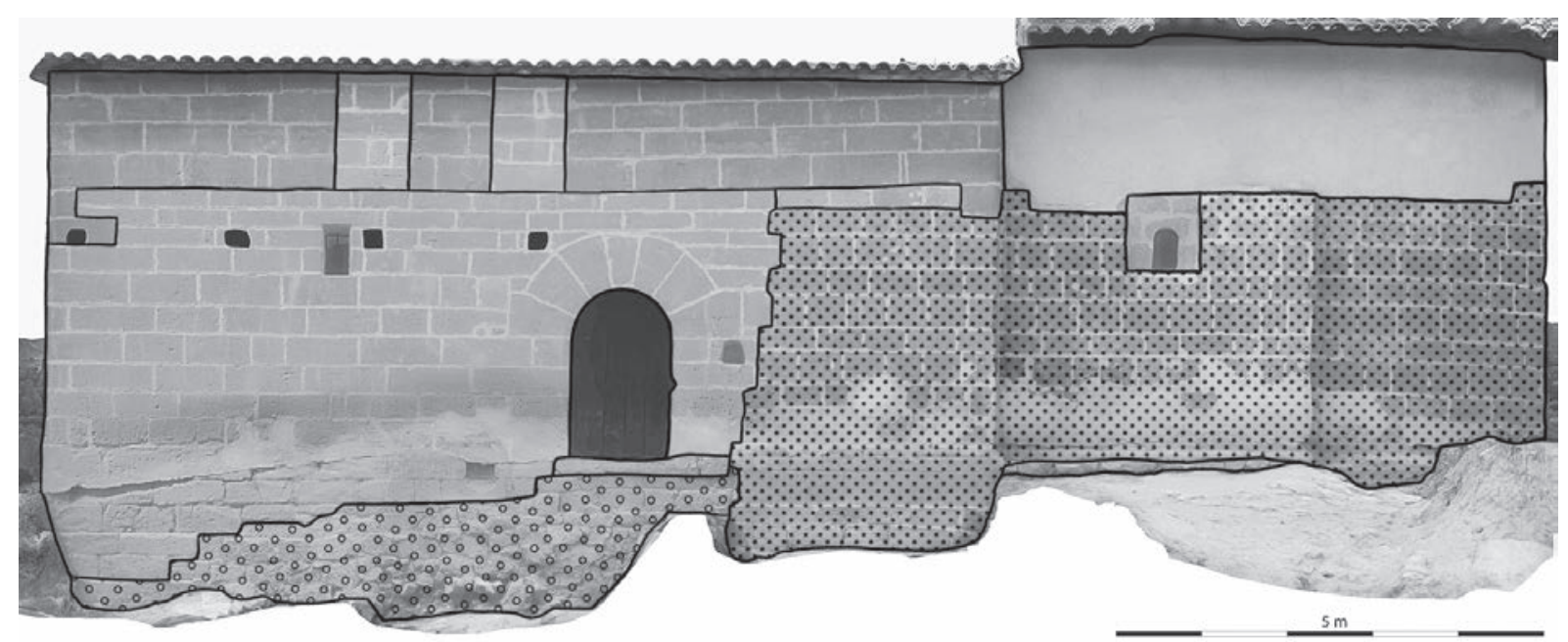

Figura 6. Torrentejo. Fases constructivas de la ermita. Se marcan con puntos los dos momentos de la fase 4 (fuente: Quirós 2015).

Media hasta que en 1087 o 1088 se convirtió en colegiata, estatus que mantendría hasta finales de la Edad Media (Portilla 1991: 218-219).

Bajo la dirección de A. Azkarate se llevó a cabo durante tres años (2003-2005) una intervención arqueológica, que supuso tanto la excavación de la zona circundante a la iglesia como la lectura estratigráfica de sus alzados. Su secuencia ocupacional se dividió en seis periodos y 16 fases, desde el siglo XI al XX (Azkarate et al. 2005), aunque solo nos centraremos en las seis primeras al ser las que se inscriben en la franja temporal de este estudio.

Sobre la amortización de las estructuras domésticas excavadas en la roca que conforman la fase 1 (ante quem siglo XI), se construyó en la fase 2 (siglo $\mathrm{XI})$ una primera iglesia, de la cual solo se ha identificado su esquina noroeste. Se emplearon sillares de caliza paleocena en sus esquinales y mampostería de calizas locales en el resto del muro. Estos exiguos restos no permiten reconocer su planta y dimensiones originales, aunque sí evidencian que mantenía una alineación NO-SE, diferente a la del edificio de culto actual.

Asociados a esta primera iglesia se identificaron varios agujeros de poste, cinco silos y un foso de más de $3 \mathrm{~m}$ de anchura que delimitaba presumiblemente el espacio eclesial. Los silos tenían una planta circular, sección piriforme, 0'83 $\mathrm{m}$ de profundidad máxima conservada y unos promedios en sus diámetros de $1^{\prime} 32 \mathrm{~m}$ en la parte superior, 1'44 $\mathrm{m}$ en la central y $1^{\prime} 17 \mathrm{~m}$ en la inferior. Cuatro de los silos estaban agrupados.
También se han asignado 17 enterramientos y dos fosas vacías a este momento. Sin embargo, no se puede establecer con rotundidad su contemporaneidad debido a la ausencia de relaciones físicas con el templo. Se ubican al este y al sur del mismo y todos ellos están realizados en fosa simple.

La fase 3 (siglo XII) corresponde a la primera fase constructiva de una nueva iglesia, que no fue una obra homogénea y respondió, de hecho, a varios cambios de diseño. Se trata de una iglesia de cruz latina realizada en sillería con acabado a tallante, cimborrio sobre el crucero, presbiterio y cabecera semicircular. Es, por tanto, una obra de cantería en la que participaron únicamente maestros especializados con destacables conocimientos técnicos.

Su cementerio asociado se extendió hacia el norte y sur de la nave, diversificándose las técnicas constructivas de los enterramientos debido a la presencia de rellenos antrópicos que impedían alcanzar la roca natural. De este momento son también varios restos de estructuras en materiales perecederos, así como un silo de almacenaje.

Durante las fases 4, 5 y 6 (siglo XII) continuó la edificación de la iglesia hacia el oeste, adosándose un pórtico al sur. Implicó igualmente una mayor actividad funeraria, extendiéndose la zona de inhumación hacia el espacio utilizado para habitación y almacenaje de la fase anterior. Estas estructuras acabaron amortizándose en la fase siguiente, cuando se construyó el cementerio al nordeste. La fase 5 se caracterizó además por la ampliación del crucero norte. En la fase 6 se levantó un cimborrio flanqueado en sus cuatro esquinas por torreones circulares. 


\section{DISCUSIÓN}

La exposición de las secuencias ocupacionales de estos seis yacimientos alaveses revela la presencia de transformaciones de diverso calado que ocurren, en todos los casos, en una horquilla cronológica precisa: el siglo XII. Estas alteraciones afectaron a la iglesia preexistente en Zaballa, Aistra, Armentia y Torrentejo, al templo y a su entorno inmediato en Dulantzi y a todo el espacio aldeano en Zornoztegi.

Parece que, más allá de sus diversas situaciones de partida, algo ocurrió a lo largo de esta centuria que dejó una impronta en el registro material. Sin embargo, ¿pueden estos cambios ser interpretados como evidencias materiales de la creación y extensión de la red parroquial sobre estas aldeas? Tratemos de responder a esta pregunta confrontando el registro de cada yacimiento agrupado en modelos definidos a partir de la situación preexistente.

\subsection{Aldea sin iglesia}

El despoblado de Zornoztegi caracteriza el primer modelo de análisis: una aldea de origen altomedieval que se dota de su primera iglesia en el siglo XII. Como se ha dicho, la construcción de dicho templo y su necrópolis asociada supuso la sacralización de un espacio doméstico previo, así como la reestructuración del caserío circundante. Pero ¿tenemos evidencias para asociar estas transformaciones con la red parroquial?

Hagamos hincapié sobre dos cuestiones. Por un lado, Santa María rompió de forma drástica con el ambiente técnico (el conjunto de saberes técnicos que desarrollaban las comunidades de tamaño pequeño y medio interactuando con el ambiente externo y cuyo rasgo más característico era la continuidad, v. Bianchi 1996: 53-54) imperante en la aldea desde el comienzo de la Edad Media. Inserto en la tradición constructiva local, se había caracterizado por estructuras domésticas sobre postes y semiexcavadas. La ruptura se infiere de la introducción del ciclo productivo de la piedra y la cal, la sofisticación de la técnica de mampostería, el empleo de materiales líticos alóctonos de gran calidad para elaborar vanos y elementos decorativos, el uso del tallante para la talla y el cierre oriental del templo mediante una cabecera semicircular.

Todo ello indica que, aunque la construcción del templo estuvo liderada por albañiles, contó con rasgos de la tradición especializada: participación de canteros, promotores con recursos, ciclo productivo de la piedra elaborado, división del trabajo, amplios conocimientos técnicos o empleo de piezas talladas nuevas de cantera (Bianchi 1996, Mannoni 1997, Quirós 2001).

Por otro lado, se produjo una reorganización del espacio aldeano, promoviendo una nueva zona litúrgica y funeraria en una posición central y elevada respecto al caserío. Ello supuso además la amortización de estructuras domésticas de prestigio anteriores, en uso desde el siglo X.

Este cambio en la función del espacio aldeano no resulta intrascendente. Antes de este momento y desde la Alta Edad Media, Zornoztegi habría dispuesto probablemente de un espacio funerario en el que enterrar a sus muertos. No obstante, en algún momento del siglo XII se decide olvidar este espacio ancestral (hasta el punto de que no hemos hallado ninguna prueba documental o arqueológica de su existencia) y sacralizar uno nuevo hasta entonces destinado a actividades profanas. Ello debió suponer un enorme cambio simbólico en el mapa mental de la comunidad: la referencia espacial básica de los siglos anteriores, la base de su pasado y de su origen fue sustituida y progresivamente olvidada, en lo que creemos fue un proceso paulatino que se alargó en el tiempo.

En definitiva, se reorganiza el espacio aldeano coincidiendo con la edificación de un templo y su necrópolis sobre un espacio privilegiado de la aldea. Aunque resulte complicado establecer qué sujetos sociales promovieron estas actividades, es obvia su capacidad de movilización de recursos e influencia en el seno de la aldea. No resulta descabellado sugerir, en este punto y atendiendo a lo expuesto, que se tratase de representantes del poder diocesano convergiendo y colaborando con la comunidad aldeana, en especial sus elites, en el contexto de extensión y consolidación de la red parroquial (Alfaro 2018).

\subsection{Aldea con iglesia propia}

Conviene precisar, antes que nada, que como iglesias propias entendemos, siguiendo la tradición historiográfica española y europea (proprietary churches, Eigenkirche), las ecclesiae y monasteria de los diplomas altomedievales. Se caracterizaron por su carácter familiar, con una organización variable y poco definida, y privado. Sus dueños, que pudieron ser laicos (familias nobiliarias o monarquía) o religiosos (monasterios u órdenes militares), las fundaban con tres tipos de 
intereses: espirituales, para lograr la salvación de sus almas, económicos, para cohesionar, aumentar y asegurar su patrimonio; $\mathrm{y}$ de prestigio y estatus, como instrumento de diferenciación social y de perpetuación de la memoria. Asimismo, las donaban, compraban y enajenaban como cualquier otra propiedad (Fernández Conde 2000: 276-277, Wood 2006: 445, Davies 2007: 215-216, Pérez 2012).

Dentro de este segundo modelo incluiremos los despoblados de Aistra y Zaballa, así como el yacimiento de San Martín de Dulantzi. Aunque cada uno cuente con sus peculiaridades, los tres tienen unos puntos de partida y siguen desarrollos evolutivos similares. Se trata de aldeas que dispusieron de iglesias propias al menos desde el siglo X y que, en torno al siglo XII, sufrieron alteraciones de diverso calado.

En el caso de Zaballa la condición de iglesia propia se justifica materialmente por la gran reorganización del espacio que acontece en la aldea coincidiendo con su construcción, que implica tanto la movilización de toda la población hacia el valle, como la sacralización del espacio central, quizá primigenio, de la aldea. Recordemos que estas transformaciones tuvieron lugar en Zornoztegi dos siglos después. En ambos casos lo vinculamos a la entrada en escena de poderes extralocales, aunque de diferente naturaleza: el obispado en Zornoztegi, una familia noble de influencia regional en Zaballa. La diferencia de interpretación entre ambos la fundamentamos en el conocimiento que, gracias a las fuentes escritas, tenemos tanto de la debilidad de las diócesis como de la proliferación de iglesias propias de carácter familiar a lo largo del siglo X (Quirós y Santos 2015, Alfaro et al. 2017: 266-267).

Ciertamente, la única actividad del registro material fechable en el siglo XII de la aldea de Zaballa, el añadido de un pórtico, tiene una entidad e importancia más limitada que en Zornoztegi. Sin embargo, no debemos desmerecer las implicaciones de esta nueva estructura. Hay que tener en cuenta que los pórticos otorgan cierto carácter comunitario al uso de las iglesias. Crean un espacio cubierto donde los habitantes de la aldea podían esperar a la celebración de los oficios y, por consiguiente, hablar, discutir y decidir sobre asuntos diversos (Bango 1975, Curiel 2009: 147). Todo ello en consonancia con lo que se espera de una iglesia parroquial, por lo que es posible que de la construcción de este elemento se infiera la presencia de la parroquia en la aldea.

Dicha interpretación estaría avalada además por la continuidad del cementerio al menos hasta el siglo XIII y por la mención de la iglesia de Zaballa entre las propiedades del obispo en la concordia de 1257, donde prelado y cabildo catedralicio se repartían las rentas de los templos pertenecientes a la diócesis de Calahorra (Rodríguez y Rodríguez de Lama 1989: 216-234).

Resulta plausible, además, que la construcción del pórtico estuviera acompañada de una reforma o ampliación de la antigua iglesia propia, en consonancia con lo que se conoce de otros templos alaveses erigidos antes del siglo XII (Sánchez Zufiaurre 2007). Sin embargo y dado que solo se han conservado los cimientos de la iglesia, es probable que las huellas de estas posibles modificaciones arquitectónicas sencillamente no hayan llegado hasta nosotros.

La naturaleza privada de la iglesia construida en Aistra en el siglo X se argumenta también a partir de los profundos cambios en la organización espacial de la aldea que generó y de la total ruptura de la obra eclesial con el ambiente técnico anterior. Ambos hechos nos orientan a promotores de ámbito supralocal con amplios recursos.

De hecho, las características constructivas de la iglesia primitiva de San Julián y Santa Basilisa (bloques nuevos de cantera, empleo de litologías alóctonas de difícil talla, puesta en obra ordenada y predecible, piezas decorativas, etc.) describen con claridad un sistema productivo de cantería liderado por maestros especializados.

Las transformaciones que paralelamente se desarrollaron en el espacio aldeano, sin embargo, son equiparables a las comentadas para Zaballa y, en otro contexto y cronología, para Zornoztegi. Aunque hay importantes diferencias a destacar: la iglesia se construyó en un lugar aparentemente periférico de la aldea, vacío hasta ese momento, y supuso el abandono de parte del espacio doméstico y funerario altomedieval.

Al igual que en Zaballa, en Aistra solo contamos con las modificaciones que sufrió el templo en el siglo XII para sugerir la presencia de la institución parroquial. La reforma de la iglesia en este momento evidencia un cambio claro en sus promotores y funcionalidad. Así, el primitivo templo se reconstruyó probablemente después de haberse arruinado casi del todo, quizá por la desidia de sus propietarios, que ya no contaban con los incentivos que habían llevado a aquellos promotores del siglo $\mathrm{X}$ a erigir una iglesia propia en esta aldea alavesa.

El sistema productivo mixto de la reforma, en el que se emplea sobre todo material reutilizado con una participación puntual de canteros, reflejaría una menor capacidad de movilización de recursos por parte de los promotores. Edificaron una iglesia funcional y 
bien ejecutada con una inversión mínima. De ello se infiere que fue probablemente la confluencia entre los representantes del poder episcopal y la comunidad aldeana, ya anunciada en el caso de Zornoztegi, la que se hizo con esta vieja iglesia arruinada y decidió reformarla para que cumpliera sus nuevas funciones como iglesia parroquial.

San Martín de Dulantzi difiere en tres destacables aspectos de los dos casos mencionados hasta ahora en este modelo de análisis. Primero, no hay continuidad física y espacial entre la iglesia propia y la que se edifica en el siglo XII. Segundo, el primer templo se construyó cuatro siglos antes de que podamos sugerir con una mínima seguridad su naturaleza privada. Tercero, la iglesia propia dispuso de un baptisterio que le otorgaba más competencias que en Zornoztegi o Zaballa. En cualquier caso, y a pesar de sus divergencias, mantiene en lo fundamental la misma evolución observada en estos dos casos de estudio.

La utilización a partir de la segunda mitad del siglo X del interior del templo para el almacenamiento de cereal es un indicador, a nuestro entender, de que ya se encontraba bajo control privado. Como ocurrió en Zaballa y Aistra, parece que elites de importancia y ámbito regional comenzaron a controlar una iglesia, en este caso una preexistente, con intereses espirituales y, claro está, terrenales.

Ello vincularía la apertura de las grandes estructuras de almacenaje en el interior con la percepción de rentas eclesiásticas, probablemente, y viendo su elevado número para los dos siglos posteriores, sobre un ámbito territorial mayor que en Zaballa.

Su condición de iglesia propia no implicó el cese de los servicios sacramentales que ofrecía a la comunidad, puesto que continuaron empleándose el baptisterio y el espacio circundante como lugar de enterramiento de la comunidad.

Estas competencias sobre la cura de almas, así como la centralidad referencial y simbólica que la iglesia debió tener para los habitantes de la aldea, debieron funcionar además como instrumentos para legitimar la autoridad de percibir sus diezmos (Alfaro et al. 2017).

A diferencia de los casos de Zaballa o Aistra, en este yacimiento la iglesia propia se desmanteló completamente a finales del siglo XI o comienzos del XII, después de más de cinco siglos de actividad, construyéndose el nuevo templo de San Martín sobre un depósito de nivelación unas décadas después.

Este hiato, en el que presumiblemente los habitantes de Dulantzi no dispusieron de un templo al que acudir para recibir sus sacramentos, subraya el carácter privado del mismo en su etapa anterior. Es cierto que había tenido competencias comunitarias, como la administración de sacramentos o la percepción de rentas eclesiásticas, pero fue ante todo una iglesia propia. Cuando los poderes que la habían instrumentalizado desaparecieron o dejaron de necesitarla, bien porque ya no era rentable, bien porque cambiaron las formas de representación del poder, la iglesia acabó arruinándose.

El lapso entre ruina y construcción recuerda al caso de San Julián y Santa Basilisa de Aistra, cuya reforma del siglo XII se ejecutó sobre las ruinas del templo anterior, aunque en Dulantzi ni siquiera aprovecharon alguno de los paramentos que todavía estaban en pie. Nivelaron el terreno y construyeron San Martín a los pies de la iglesia tardoantigua. Una tabula rasa que llama poderosamente la atención porque se obviaron, quizá al haber pasado suficiente tiempo para que fueran olvidados, los elementos en teoría más sagrados como la cabecera y su enterramiento privilegiado.

Todos estos indicadores aluden a un profundo cambio de promotores y funciones, probablemente con el escenario de la implantación de la red parroquial como telón de fondo. Suponemos que el estado en que se encontraba el viejo templo, además de su gran tamaño, poco apropiado para las modestas necesidades de una parroquia aldeana, hicieron desechar a los nuevos promotores la idea de una reconstrucción siquiera parcial.

\subsection{Aldea con iglesia episcopal}

Armentia representa un caso inédito en la muestra, al ser una antigua sede episcopal y constatarse documentalmente un precoz control por parte de la diócesis de Calahorra, tras el establecimiento efectivo del arcedianato de Álava en 1135 (Rodríguez y Rodríguez de Lama 1992: 178-179).

De la fase vinculada a priori con la sede del obispado de Álava contamos solo con estructuras domésticas de habitación. Llama la atención que no se hayan identificado ni la iglesia ni un espacio cementerial asociado. ¿Dónde estaba el templo episcopal? ¿Dónde se enterraban los habitantes de la aldea? Desde luego no en este lugar, ocupado en aquel momento por contextos domésticos.

Se desconoce además el momento exacto de construcción de la primera iglesia, pudiendo ser anterior al desmantelamiento del obispado en 1087-1088, así como la naturaleza de los promotores que la impulsaron. Después de todo, si la obra es anterior a esta fecha, 
debió de tratarse de la propia diócesis de Armentia; pero si es posterior no debe descartarse la participación de otro tipo de poderes en su construcción.

Tampoco sabemos con certeza si a su alrededor congregó un cementerio, ya que los enterramientos adscritos no disponen de relaciones estratigráficas que confirmen este punto. Con todo, los cuatro silos agrupados y contemporáneos a este templo sugieren la apropiación de rentas eclesiásticas ya desde el siglo XI.

La iglesia del siglo XII, por su parte, se caracteriza por sus grandes dimensiones, además de por su excelente factura, planta de cruz latina, ábside semicircular y cimborrio sobre el crucero (este tipo de planta es por sí mismo un rasgo de la excepcionalidad y significación de la iglesia de Armentia. Salvo Nuestra Señora de Estíbaliz, todas las iglesias conservadas de esta época en Álava tenían planta rectangular). Todas estas características nos remiten a una obra de canteros con destacados conocimientos técnicos, de elevados costes y con importantes promotores detrás. Es muy probable que haya que identificarla con el documento de 1135, donde se menciona la concesión a Armentia de las cuartas episcopales de veinte iglesias del entorno (Rodríguez y Rodríguez de Lama 1992: 178-179).

En definitiva, resulta factible que, debido al control episcopal directo del enclave de Armentia, ya desde el siglo XI su iglesia actuara a modo de parroquia. Al fin y al cabo, se percibían rentas eclesiásticas y era posiblemente un lugar de enterramiento y de administración de sacramentos para la comunidad.

Asimismo, la edificación del siglo XII hay que ponerla en relación con el esfuerzo del obispado de Calahorra, materializado en el documento de 1135, para reforzar la posición de Armentia como cabecera del arcedianato de Álava. Por ello, le fue entregado al arcediano una casa, heredades y las rentas (cuartas episcopales) de veinte iglesias próximas. El apoyo de Calahorra y las rentas obtenidas permitieron financiar los elevados costes del nuevo templo, contratando mano de obra especializada. Del cementerio asociado se infiere que, si la iglesia de Armentia no había dispuesto de funciones parroquiales desde el siglo XI, las desarrolló con seguridad a partir de este momento.

\subsection{Aldea con iglesia monasterial}

Conviene explicar en este punto que empleamos el término iglesia monasterial para aludir a las iglesias instaladas dentro del complejo de un monasterio sub regula, y no a las iglesias que eran propiedad de un monasterio.
El despoblado de Torrentejo es también singular, aunque por motivos diferentes a los de Armentia. Tanto la ausencia de un cementerio comunitario en su entorno, como que su iglesia no fuera mencionada en la referida concordia de 1257 (No obstante, esta ausencia pudo deberse a otras razones. Resulta llamativo que ni Labastida, ni otras poblaciones del oeste de la Rioja Alavesa que pertenecían al arcedianato de Nájera se citen en el documento. Por ello y dado que se desconocen los motivos que se esconden tras estas ausencias, sugerimos obrar con prudencia en este punto.), parecen sugerir que no desarrolló nunca un estatus parroquial.

De aceptar dicha interpretación surge una pregunta ineludible: ¿quién estuvo detrás de la iglesia del siglo XII, edificada con un sistema productivo de cantería por artesanos especializados y una elevada inversión?

Dado que un documento de 1075 menciona la donación de la iglesia de «Santa María de Torrencillo» por parte del rey Sancho IV de Pamplona a San Millán de la Cogolla, es probable que perteneciera a este monasterio. No obstante, este diploma está transcrito en el Becerro Galicano, redactado a finales del siglo XII, que consta con un encabezado en el que se hace referencia al monasterio de Santa María de Torrentejo (Becerro Galicano Digital [doc. 597]). Ello podría señalar la existencia de un complejo monasterial en este lugar para el siglo XII o su condición de decania sujeta a San Millán.

Torrentejo mantiene cuatro relevantes diferencias con el resto de casos de estudio. En primer lugar, es el único en el que no es posible vincular la reforma/construcción de la iglesia en el siglo XII con la parroquia. Obliga, por tanto, a cuestionar una relación directa tentadora, aunque reduccionista, entre ambos fenómenos.

Igualmente, a pesar de que los templos del siglo XI y del siglo XII son edificios distintos, no existe, como en Aistra o Dulantzi, un hiato más o menos destacado entre la destrucción y la reforma/construcción, sino que hay una aparente continuidad entre ambos. Quizá refleje la permanencia de su vínculo con poderes no diocesanos.

En tercer lugar, el edificio de culto del siglo XII es, junto al excepcional caso de Armentia, el único donde se infiere una participación exclusiva de la figura del cantero. Recordemos que en Zornoztegi, Aistra y Dulantzi fueron obras mixtas con una inversión más limitada.

Finalmente, el presbiterio de la iglesia del siglo XII llama la atención por sus dimensiones: 4'7 m entre sus paredes interiores norte y sur (medida A) y $4 \mathrm{~m}$ entre el arco toral, que separa el ábside del presbiterio, y el arco triunfal, que hace lo propio con el presbiterio y la nave 


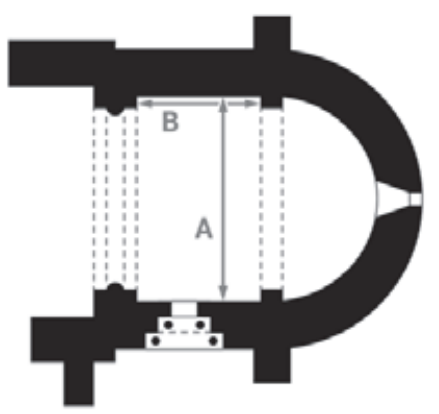

\begin{tabular}{|c|c|c|c|c|c|}
\hline LOCALIDAD & MUNICIPIO & ADVOCACIÓN & ESTATUS & $\begin{array}{c}\text { MEDIDA } \\
\text { A (m) }\end{array}$ & $\begin{array}{c}\text { MEDIDA } \\
\text { B (m) }\end{array}$ \\
\hline Acebedo & Valdegovia & San Juan Evangelista & Parroquia & 3,2 & - \\
\hline Alaitza & Iruraiz-Gauna & Nuestra Señora de la Asunción & Parroquia & 4,1 & 2,7 \\
\hline Alegría-Dulantzi & Alegría-Dulantzi & Nuestra Señora de Ayala & Ermita & 4,9 & 2,4 \\
\hline Argandoña & Vitoria-Gasteiz & Santa Columba & Parroquia & 4,6 & 2,0 \\
\hline Armentia & Vitoria-Gasteiz & San Prudencio & Parroquia & 6,4 & 4,2 \\
\hline Aturi & Arraia-Maeztu & La Soledad & Ermita & 3,3 & 1,0 \\
\hline Bellojín & Valdegovía & San Cornelio & Parroquia & 3,9 & 2,1 \\
\hline Berantevilla & Berantevilla & Santa María de Tobera & Ermita & 4,4 & 3,9 \\
\hline Elburgo & Elburgo & San Juan de Arrarain & Ermita & 6,6 & 2,4 \\
\hline Gazeo & Iruraiz-Gauna & San Martín de Tours & Parroquia & 4,0 & 2,5 \\
\hline Hueto Arriba & Vitoria-Gasteiz & La Natividad & Parroquia & 5,5 & 3,8 \\
\hline Karkamu & Valdegovía & San Juan Bautista & Ermita & 3,8 & 1,7 \\
\hline Kontrasta & Valle de Arana & Nuestra Sra. de Elizmendi & Ermita & 2,1 & 2,2 \\
\hline Labastida & Labastida & Santa Lucía & Ermita & 4,7 & 4,0 \\
\hline Markinez & Bernedo & San Juan Bautista & Ermita & 4,7 & 3,3 \\
\hline Nanclares de la Oca & Iruña Oca & La Asunción de Ntra. Sra. & Parroquia & 6,8 & - \\
\hline San Vicentejo & Treviño & La Concepción & Ermita & 5,6 & 1,8 \\
\hline Sobrón & Lantarón & San Martín de Lantarón & Ermita & 3,1 & 1,9 \\
\hline Trokoniz & Iruraiz-Gauna & San Vicente & Parroquia & 4,4 & - \\
\hline Ullíbarri-Arana & Valle de Arana & Andra Mari & Ermita & 3,6 & 1,9 \\
\hline Valluerca & Valdegovia & Santa María & Parroquia & 3,6 & 2,4 \\
\hline
\end{tabular}

Figura 7. Tabla con las dimensiones del presbiterio de aquellas iglesias de los siglos XII-XIII de Álava con ábside semicircular y planta publicada. 
(medida B). A modo de referencia, la referida iglesia de Zornoztegi, también del siglo XII y con cabecera semicircular, cuenta con un tamaño más reducido: 3'5 m en la medida A y 1'2 m en la B.

Podría plantearse, dada la probable condición monasterial de Santa María en el siglo XII, que este gran presbiterio respondiera a una mayor necesidad de espacio del clero regular, que habría atendido los oficios en este lugar, dejando la nave para una posible feligresía laica.

Si lo comparamos con los de otras iglesias de Álava y Treviño con ábsides semicirculares y datadas en los siglos XII-XIII (siempre con la debida cautela dadas las diferencias socioeconómicas entre sus diferentes regiones), vemos que destaca sobre el resto. Si bien su anchura (medida A) es convencional ( 4’4 m), con hasta seis iglesias (de una muestra de 20) con valores superiores, la longitud de su presbiterio (medida B) es la segunda más amplia y 1'5 $\mathrm{m}$ superior al promedio (2'5 m). Igualmente, el espacio útil del presbiterio es el tercero más grande $\left(11^{\prime} 7 \mathrm{~m}^{2}\right)$ con $20^{\prime} 9 \mathrm{~m}^{2}$.

A pesar de que efectivamente el de Santa María es un presbiterio de grandes dimensiones, no consideramos plausible explicar dicha circunstancia a través de su naturaleza monacal por dos razones: la ermita de Nuestra Señora de Elizmendi en Kontrasta, también de origen monasterial, contó con un presbiterio mucho más reducido (4' $6 \mathrm{~m}^{2}$ de área útil) y las iglesias que tienen presbiterios más grandes, la de Armentia y la de Hueto Arriba, parecen estar asociadas a otros poderes, diocesanos o locales-comunitarios.

\subsection{Valoración: diversidad de marcadores materiales}

En definitiva, parece que, salvo en el caso de Torrentejo, es posible relacionar las transformaciones materiales ocurridas durante el siglo XII con la extensión de la red parroquial. Llama la atención, sin embargo, la variedad de marcadores para tan solo seis casos de estudio, que refleja la complejidad del fenómeno y los diversos itinerarios que debieron seguirse en función de las situaciones de partida.

Entre estos marcadores materiales el más destacado es la presencia de un pórtico cubriendo el acceso principal a la iglesia. Que no haya sido identificado en iglesias propias o monasteriales, así como su presencia en las iglesias del siglo XII de Zornoztegi, Zaballa y Armentia parecen aludir a una naturaleza parroquial. También el hecho, ya comentado, de que este elemento otorgue un carácter comunitario al templo, al ofrecer un lugar a la comunidad para poder desarrollar diferentes actividades, refuerza esta idea.

La reforma arquitectónica de la iglesia siguiendo un modelo productivo mixto, en el que colaborasen canteros y albañiles, se emplea también como marcador de la parroquia, al reflejar promotores y funciones diferentes a los de las iglesias propias (Alfaro 2017). Por otra parte, una ruina total o parcial del templo, seguida de un hiato previo a su reconstrucción es, bajo nuestro punto de vista, un marcador aún más consistente. El caso de Dulantzi es significativo, más cuando hay una diferenciación física bien marcada entre el templo y el cementerio del siglo VI y los del siglo XII. Es probable que en Aistra hallemos un caso similar, aunque reconstruyendo la iglesia anterior.

Se han utilizado también otros marcadores materiales menos concluyentes que parecen asociarse igualmente a otro tipo de procesos y realidades, y que es necesario considerar en función del contexto y la cronología. Nos referimos a la reorganización del espacio aldeano o la presencia de caracteres constructivos que impliquen la ruptura con el ambiente técnico previo. Como hemos visto en los casos de Zornoztegi, Zaballa y Aistra, actúan más bien de indicadores de la introducción en el contexto aldeano de poderes extralocales, que pudieron ser familias propietarias de variada influencia, grandes cenobios o autoridades episcopales.

Para concluir, ni la función funeraria abierta a la comunidad, ni la apropiación de rentas eclesiásticas son marcadores fiables de este proceso, al menos para el caso alavés, ya que los hemos hallado indistintamente asociados a iglesias propias.

Así, la función funeraria se reconoce en Zaballa y Aistra desde el siglo X y en Dulantzi desde el siglo VI (aunque generalizada a toda la comunidad desde el siglo VIII). Los tres casos mantuvieron el espacio de enterramiento tras su conversión en parroquia en el siglo XII.

La historiografía ha tendido en este punto a poner el acento en las diferencias tipológicas entre enterramientos para discriminar cementerios de diferentes categorías. En este sentido, I. García Camino plantea para la cercana región de Vizcaya cómo los cementerios parroquiales, que fueron reemplazando a los altomedievales desde los siglos XI y XII, se caracterizan por una homogeneización de las prácticas funerarias. Asocia esta mayor uniformidad al triunfo de los planteamientos funerarios cristianos que niegan la personalidad del difunto y la individualidad de la tumba. Dichos cementerios se definían además por 
las sepulturas de lajas, la ausencia de ajuares y, fundamentalmente, la reutilización de tumbas (García Camino 2002: 250-252).

Esta misma dicotomía entre cementerios parroquiales y anteriores, con una mayor variedad tipológica de las sepulturas, fue identificada en el yacimiento guipuzcoano de Santa María de Zarautz. El paso entre uno y otro se habría producido también durante los siglos XI y XII (Ibáñez y Moraza 2006: 432).

Sin embargo, ya solo el caso de Aistra genera dos notables discordancias con este modelo: la temprana cronología y las reutilizaciones. Sobre la primera, I. García Camino menciona la extensión de este tipo de cementerios desde el siglo XI, pero la construcción de la iglesia de Aistra y su necrópolis datan del siglo X. Por otro lado, la reutilización de las sepulturas es para el arqueólogo vizcaíno la característica principal de los cementerios parroquiales y, en Aistra, aunque de forma minoritaria, la encontramos.

Quizá la solución a este aspecto radique en incidir no en el propio hecho de la reutilización, sino en su intensidad, como proponía E. Gutiérrez Cuenca en su tesis doctoral sobre las necrópolis de Cantabria en la Edad Media. El autor apuntaba que, mientras que esta práctica fue poco frecuente en los «cementerios altomedievales» (siglos VIII-XIII), el paso de un modelo de cementerio extensivo a uno intensivo multiplicó las reutilizaciones en los «cementerios bajomedievales/parroquiales» (siglos XIII-XV) (Gutiérrez Cuenca 2015: 640, 644).

Por su parte, los silos de almacenaje, que evidencian la apropiación de rentas eclesiásticas, tampoco son un marcador fiable para el reconocimiento de la parroquia. No solo porque se identifiquen en las iglesias propias de Zaballa o Dulantzi, sino también porque, salvo Armentia con su silo amortizado relativamente pronto en el siglo XII, ninguna de las interpretadas como parroquiales disponía de ellos.

De hecho, resulta significativo que apenas encontremos estas estructuras en contextos eclesiales a partir del siglo XII. Los casos de Zornoztegi, Zaballa, Dulantzi y Armentia parecen sugerir que, durante esta centuria, y a pesar de su uso más o menos generalizado en los siglos anteriores, el método de almacenaje del silo excavado en el subsuelo entró en declive. Es probable que de forma paralela se difundiera el uso de otro tipo de construcciones en alzado como graneros u hórreos, quizá conocidos con anterioridad y cuya identificación material es siempre más problemática.

En este sentido, los pocos silos asociados a iglesias identificados en Álava, apenas una veintena
(Alfaro et al. 2017: 267) parecen indicar que estas construcciones ya se empleaban antes del siglo XII. En esta dirección podrían interpretarse las estancias lignarias anejas a las iglesias del grupo 4 (siglo X-XII) que L. Sánchez Zufiaurre identificó, a partir de ménsulas en los muros $\mathrm{N}$ y $\mathrm{O}$, en su tesis doctoral sobre las iglesias prerrománicas de Álava (Sánchez Zufiaurre 2007: 291, 328).

\section{CONCLUSIONES}

A lo largo de estas páginas se ha dado respuesta a las dos preguntas planteadas en la introducción. Por un lado, es posible identificar transformaciones en el registro material de las aldeas alavesas dentro de una horquilla cronológica bastante específica: el siglo XII. Por otro, es razonable asociar dichas transformaciones con la implantación de la red parroquial en Álava.

No parece, eso sí, que la parroquia de los arqueólogos se corresponda plenamente con la de los historiadores. La diversidad de marcadores materiales reconocida, resultado de la propia variedad de situaciones preexistentes (aldea sin iglesia, aldea con iglesia propia, aldea con iglesia episcopal y aldea con iglesia monasterial), parece reflejar un proceso de establecimiento de la red parroquial más heterogéneo de lo que sugieren las fuentes escritas. ¿Se trató de un largo periodo de transición previo a las uniformes parroquias de la documentación? O, quizá, ¿debemos referirnos más bien a una implantación de las parroquias, en plural, para ilustrar la complejidad de una institución que adoptó rasgos diferenciados en función del momento, la geografía y la naturaleza de los poderes con que debía lidiar?

Todavía no contamos con evidencias suficientes para dar una respuesta concluyente, si es que la hay, a estas cuestiones. Quedan para investigaciones futuras. Baste este trabajo para reconocer el potencial de la praxis arqueológica en la comprensión del proceso de formación de la red parroquial. Como ya señaló E. Zadora-Rio, las contradicciones de los registros documental y arqueológico no son más que aparentes. Sus diferentes explicaciones ni son exclusivas, ni se pueden oponer como si perteneciesen a la misma escala (Zadora-Rio 2008: 265-266). Proponemos, en suma, una visión alternativa y complementaria a la de las fuentes escritas, una visión más de abajo hacia arriba, que aclara aspectos diferentes del universo empírico y centrada en las transformaciones de la identidad aldeana que se infieren de los cambios en el templo, el cementerio y los espacios domésticos. 


\section{Agradecimientos}

Este texto presenta algunas de las ideas desarrolladas en la tesis doctoral defendida por el autor en enero de 2016 en la Universidad del País Vasco UPV/EHU bajo el título La formación de la red parroquial en Álava y Treviño. Evidencias desde la arqueología (siglos XI-XIII).

Este trabajo ha sido realizado gracias a la ayuda para la especialización de personal investigador doctor 2017 del Vicerrectorado de Investigación de la Universidad del País Vasco UPV/EHU. El autor desea agradecer a Javier Niso y Miguel Loza (Iterbide SC) la cesión desinteresada de documentación e información sobre San Martín de Dulantzi, así como a Juan Antonio Quirós, Álvaro Carvajal, Rafael Varón (Universidad del País Vasco) y Javier Ordoño (ARKIKUS) sus aportaciones en la mejora del texto.

\section{BIBLIOGRAFÍA}

Alfaro, E. (2016): La formación de la red parroquial en Álava y Treviño. Evidencias desde la arqueología (siglos XI-XIII). Tesis doctoral, Universidad del País Vasco/Euskal Herriko Unibertsitatea. Inédita.

Alfaro, E. (2017): "La arquitectura eclesiástica en Álava y Treviño durante los siglos XII-XIII: promotores, constructores y significados en un momento de transición". Arqueología de la Arquitectura 14: e056, doi: <https://doi.org/10.3989/arq. arqt.2017.010>.

Alfaro, E. (2019): "Consideraciones en torno a Santa María de Zornoztegi: ¿una parroquia del siglo XII?", en J. A. Quirós (ed.), Arqueología de una comunidad campesina medieval: Zornoztegi (Álava): 441-452. Bilbao, Universidad del País Vasco.

Alfaro, E.; Loza, M.; Niso, J. y Solaun, J. L. (2017): "Iglesias, rentas y sistemas de almacenamiento en el País Vasco durante los siglos X y XI d. C.: el testimonio arqueológico de San Martín de Dulantzi (Alegría-Dulantzi, Álava)". Archivo Español de Arqueología 90: 247-270, doi: <https://doi. org/10.3989/aespa.090.017.011>.

Asenjo, M. (1999): Espacio y sociedad en la Soria medieval. Siglos XIII-XV. Soria, Diputación de Soria.

Azkarate, A.; De la Fuente Arana, A. y Lasagabaster, J. I. (2005): Plan Director de intervención para la restitución de los valores históricos y simbólicos de la Basílica de San Prudencio de Armentia y su entorno. Grupo de Investigación en
Arqueología de la Arquitectura de la Universidad del País Vasco. < http://www.arqueologiadelaarquitectura.com $>$ (descargado 12 de marzo de 2007).

Bango, I. G. (1975): “Atrio y pórtico en el Románico español: concepto y finalidad cívico-litúrgica”. Boletín del Seminario de Estudios de Arte y Arqueología 40-41: 175-188.

Becerro Galicano Digital [doc. 597]: "De monasterio Sancte Marie de Torrentelio, iuxta Iberum". Edición on line, Universidad del País Vasco. <http:// www.ehu.eus/galicano/id597> (consultado 13 de septiembre de 2018).

Bessac, J. C. (1986): L'outillage traditionnel du tailleur de pierre. De l'Antiquité à nos jours. Revue archéologique de Narbonnaise. Supplément 14. Paris, Editions du CNRS.

Bianchi, G. (1996): "Trasmissione dei saperi tecnici e analisi dei procedimenti costruttivi”. Archeologia dell'Architettura 1: 53-64.

Caballero, L. (2001): “Aportación a la arquitectura medieval española. Definición de un grupo de iglesias castellanas, riojanas y vascas", en Actas del V Congreso de Arqueología Medieval Española: 221-235. Valladolid (1999), Valladolid, Junta de Castilla y León.

Caballero, L. y Utrero, M. A. (2005): "Una aproximación a las técnicas constructivas de la Alta Edad Media en la Península Ibérica. Entre visigodos y omeyas". Arqueología de la Arquitectura 4: 169-192.

Calleja, M. (2000): La formación de la red parroquial de la Diócesis de Oviedo en la Edad Media. Oviedo, Real Instituto de Estudios Asturianos.

Cantera, J. (1967): "Labastida y Salinillas de Buradón", en E. Enciso, J. Cantera, F. Peralta y A. Peña (eds.), Catalógo Monumental de la Diócesis de Vitoria, Tomo I: Rioja alavesa: 189-250. Vitoria, Caja de Ahorros Municipal de Vitoria.

Curiel, I. (2009): La parroquia en el País Vasco-cantábrico durante la Baja Edad Media (c. 1350-1530). Organización eclesiástica, poder señorial, territorio y sociedad. Bilbao, Universidad del País Vasco.

Davies, W. (2007): Acts of Giving. Individual, Community, and Church in Tenth-century

Christian Spain. Oxford, Oxford University Press.

Etxezarraga, I. (2011): "Parroquia, hábitat y comunidad en Guipúzcoa. Una propuesta para el estudio de sus relaciones entre los siglos XIII y XV'. Domitia 12: 89-112.

Fernández Conde, F. J. (2000): La religiosidad medieval en España. Alta Edad Media (siglos VII-X). Oviedo, Trea. 
García Camino, I. (2002): Arqueología y poblamiento en Bizkaia, siglos VI-XII: la configuración de la sociedad feudal. Bilbao, Diputación Foral de Bizkaia.

García de Cortázar, J. A. (1988): La sociedad rural en la España medieval. Madrid, Siglo XXI.

García-Collado, M. I. (2011): Espacios cementeriales en la Alta Edad Media: Álava, siglos VIII-XI. Una lectura social. Memoria fin de máster, Universidad del País Vasco/Euskal Herriko Unibertsitatea. Inédita.

García Retes, E. (1987): “El camino de San Adrián (Guipúzcoa-Álava) en la Ruta Jacobea. Análisis documental y arqueológico". Estudios de Arqueología Alavesa 15: 355-497.

Gutiérrez Cuenca, E. (2015): Génesis y evolución del cementerio medieval en Cantabria. Tesis doctoral, Universidad de Cantabria. $<$ https://repositorio.unican.es/xmlui/handle/10902/7410?show=full $>$.

Ibáñez, A. y Moraza, A. (2006): "Evolución cronotipológica de las inhumaciones medievales en el Cantábrico Oriental: el caso de Santa María la Real de Zarautz (Gipuzkoa)". Munibe (Antropologia-Arkeologia) 57: 419-434.

Lauwers, M. (2005): "Paroisse, paroissiens et territoire. Remarques sur parochia dans les textes latins du Moyen Âge". Médiévales 49: 11-32.

Le Bras, G. (1975): "Historia de la Iglesia", en A. Fliche y V. Martín (eds.), La Iglesia medieval, vol. XII. Valencia, Edicep.

López Alsina, F. (1999): “Parroquias y diócesis: el obispado de Santiago de Compostela", en J. Á. García de Cortázar (ed.), Del Cantábrico al Duero. Trece estudios sobre organización social del espacio en los s. VIII al XIII: 263-312. Santander, Universidad de Cantabria.

López Alsina, F. (2006): “La reforma eclesiástica y la generalización de un modelo de parroquia actualizado", en Actas de la XXXII Semana de Estudios Medievales de Estella: 421-450. Estella (2005), Pamplona, Gobierno de Navarra.

Loza, M. y Niso, J. (2016): "La basílica tardoantigua de San Martín de Dulantzi (Alegría-Dulantzi, Álava)". Pyrenae 47.2: 95-129.

Mannoni, T. (1997): "Il problema complesso delle murature storiche in pietra. 1. Cultura materiale e cronotipologia". Archeologia dell'Architettura 2: 15-24.

Martí, R. (2006): "Del fundus a la parrochia. Transformaciones del poblamiento rural en Cataluña durante la transición medieval", en $\mathrm{Ph}$. Sénac (ed.), De la Tarraconaise à la Marche Supérieure d'al-Andalus
(IV-XI siècle). Les habitats ruraux: 145-166. Toulouse, FRAMESPA.

Mendizabal, A. (2011): "Estudio Antropológico y Patológico de Cementerios Altomedievales en el País Vasco. Los casos del despoblado de Aistra y el Castillo de Treviño". Munibe (Antropologia-Arkeologia) 62: 403-421.

Mendizabal, A. (2013): “Análisis del material antropológico de la necrópolis de Zornoztegi (Álava)”, en J. A. Quirós (ed.), Arqueología de una comunidad campesina medieval: Zornoztegi (Álava). Bilbao, Universidad del País Vasco, en prensa.

Pérez, M. (2012): "El control de lo sagrado como instrumento de poder: los monasterios particulares de la aristocracia altomedieval leonesa". Anuario de Estudios Medievales 42.2: 799-822.

Pérez García, J. M. (1985): La M. N. y M. L. villa de Labastida. Vitoria-Gasteiz, Ayuntamiento de Labastida.

Portilla, M. J. (1991): Una ruta europea por Álava a Compostela. Del paso de San Adrián al Ebro. Vitoria-Gasteiz, Diputación Foral de Álava.

Quirós, J. A. (2001): "La sillería en la arquitectura altomedieval en el Mediterráneo occidental", en Actas del V Congreso de Arqueología Medieval Española: 281-291. Valladolid (1999), Valladolid, Junta de Castilla y León.

Quirós, J. A. (2011): "Las iglesias altomedievales en el País Vasco. Del monumento al paisaje". Studia Historica. Historia Medieval 29: 175-205.

Quirós, J. A. (2012): Arqueología del campesinado medieval: la aldea de Zaballa. Bilbao, Universidad del País Vasco.

Quirós, J. A. (2015): Informe 2015 del proyecto arqueológico de Torrentejo, Labastida. Bibat, Museo de Arqueología, Registro General de Entrada 19 de 04/01/2016.

Quirós, J. A. (2018): Arqueología de una comunidad campesina medieval: Zornoztegi (Álava). Bilbao, Universidad del País Vasco, en prensa.

Quirós, J. A. y Santos, I. (2015): "Founding and Owning Churches in Early Medieval Álava (North Spain): The Creation, Transmission, and Monumentalization of Memory", en Sánchez-Pardo, J. C. y Shapland, M., Churches and Social Power in Early Medieval Europe. Integrating Archaeological and Historical Approaches: 35-68. Turnhout, Brepols.

Reynolds, A. y Quirós, J. A. (2010): Memoria final del proyecto arqueológico de Aistra (Zalduondo, Álava). Bibat, Museo de Arqueología, Registro General de Entrada 995 de 28/12/2010. 
Ripoll, G. y Velázquez, I. (1999): “Origen y desarrollo de las parrochiae en la Hispania de la Antigüedad Tardía", en P. Pergola (ed.), Alle origini della parrocchia rurale (IV-VIII sec). Atti della giornata temática dei Seminari di Archeologia Cristiana: 101165. Roma (1998), Città del Vaticano, Pontificio Istituto di Archeologia Cristiana.

Rodríguez y Rodríguez de Lama, I. (1989): Colección diplomática medieval de La Rioja. Tomo IV: documentos del siglo XIII. Logroño, Instituto de Estudios Riojanos.

Rodríguez y Rodríguez de Lama, I. (1992): Colección diplomática medieval de La Rioja. Tomo II. Documentos (923-1168), $2^{\mathrm{a}}$ edición revisada y aumentada. Logroño, Instituto de Estudios Riojanos.

Ruiz de la Peña, J. I. (1993): "Parroquias, concejos parroquiales y solidaridades vecinales en la Asturias medieval". Asturiensia Medievalia 7: 105-122.

Ruiz de la Peña, J. I. (2008): "La parroquia, célula de encuadramiento de la sociedad rural asturiana", en J. Á. Sesma y Laliena, C. (eds.), La pervivencia del concepto. Nuevas reflexiones sobre la ordenación social del espacio en la Edad Media: 197-217. Zaragoza, Gobierno de Aragón.

Sánchez Zufiaurre, L. (2007): Técnicas constructivas medievales. Nuevos documentos arqueológicos para el estudio de la Alta Edad Media en Álava. Bilbao, Gobierno Vasco.

To Figueras, Ll. (1991): "El marc de les comunitats pageses: villa i parròquia en les diòcesis de Girona $\mathrm{i}$ Elna (final del segle IX - principi del'XI)", en Catalunya i França meridional a l'entorn de l'any mil. Actes del Col·loqui Internacional Hug Capet: 212239. Barcelona (1987), Barcelona, Generalitat de Catalunya.

Utrero, M. A. (2006): Iglesias tardoantiguas y altomedievales en la Península Ibérica. Analisis arqueológico y sistemas de abovedamiento. Anejos del Archivo Español de Arqueología XL. Madrid, Consejo Superior de Investigaciones Científicas.

Villaginés, J. (1988): “El Fenomen parroquial en la societat del Vallès Oriental a l'alta Edat Mitjana (ss. XI i XII)". Acta historica et archaeologica mediaevalia IX: 125-142.

Wood, S. (2006): The Proprietary Church in the Medieval West. Oxford, Oxford University Press.

Zadora-Rio, E. (2008): "Conclusion generale", en Zadora-Rio, E. (ed.), Des paroisses de Touraine aux communes d'Indre-et-Loire. La formation des territoires. 34e supplément à la Revue Archéologique du Centre de la France. Paris, RACF. 
Martín-Seijo, M, y Vázquez Collazo, S. (2020): “Ad comburendum. El uso de la leña en el Castillo de Pambre (Palas de Rei, Lugo) durante los siglos XV-XVII", Spal 29.1: 321-341.

DOI: http://dx.doi.org/10.12795/spal.2020.i29.12

\title{
AD COMBURENDUM. EL USO DE LA LEÑA EN EL CASTILLO DE PAMBRE (PALAS DE REI, LUGO) DURANTE LOS SIGLOS XV-XVII
}

\section{AD COMBURENDUM. FIREWOOD USE IN THE PAMBRE CASTLE (PALAS DE REI, LUGO) DURING THE 15TH-17TH CENTURIES AD}

\author{
MARÍA MARTÍN-SEIJO \\ Responsable de la correspondencia \\ Grupo de Estudos para a Prehistoria do NO Ibérico-Arqueoloxía, Antigüidade e Territorio. GEPN-AAT (GI-1534). \\ Departamento de Historia. Universidade de Santiago de Compostela. Praza da Universidade 1. 15782. Santiago de Compostela, Spain \\ Correo-e: maria.martin.seijo@usc.es. (D) https://orcid.org/0000-0003-2924-7763 \\ Researcher ID: <https://publons.com/researcher/M-2214-2013> \\ SANTIAGO VÁZQUEZ COLLAZO \\ TOMOS Conservación-Restauración S.L. Rúa San Agustín, 28 - 4‥ 15001 - A Coruña \\ Correo-e: tomos@tomos.es. (D) https://orcid.org/0000-0002-3941-0731
}

Resumen: Se presentan los resultados del análisis antracológico, así como los datos dendrológicos y tafonómicos de varias muestras de carbón. Estas fueron recuperadas durante la intervención arqueológica desarrollada en el Castillo de Pambre (Palas de Rei, Lugo) en el año 2014, en relación con las tareas de rehabilitación del conjunto de edificaciones del castillo. Los datos obtenidos nos permiten definir el uso como combustible de los recursos leñosos que realizaron los ocupantes del castillo durante los siglos XV-XVII. Se documenta un predominio de la madera de roble (Quercus sp. caducifolio), seguida del avellano (Corylus avellana) junto con una gran diversidad de taxones, especialmente de árboles frutales, mientras que los taxones de matorral son poco significativos en el conjunto. Esto a pesar de coincidir con un período frío, la Pequeña Edad del Hielo, y de la importante deforestación registrada tanto en los datos paleoambientales como en la documentación.

Palabras clave: Antracología, madera, frutales, Pequeña Edad del Hielo, Edad Moderna, fortificaciones.

\begin{abstract}
This paper presents the results of charcoal analysis as well as dendrological and taphonomical attributes of charcoal samples. These were recovered during the archaeological survey in the Pambre Castle (Palas de Rei, Lugo) during 2014 and in relation to the rehabilitation activities in the group of buildings of the castle. The data obtained let us to define the use as firewood of wood resources performed by the inhabitants of the castle between $15^{\text {th }}$ to $17^{\text {th }}$ centuries AD. A predominance of oak (deciduous Quercus), followed by hazel wood (Corylus avellana) has been attested, besides a great taxa diversity, predominantly fruit trees whilst scrubland taxa are not significant in the assemblage. This even though it coincided with a cold period, the Little Ice Age, and the major deforestation registered in the paleoenvironmental proxies as well as in the written sources.
\end{abstract}

Keywords: Charcoal analysis, wood, fruit trees, Little Ice Age, Post-medieval, fortifications. 


\section{INTRODUCCIÓN}

Durante la Edad Moderna al igual que en la Edad Media (Le Goff 2002: 178, Pastoreau 2006, Fossier 2017), la madera continuó siendo la materia prima por excelencia. A pesar de que las plantas y las materias primas derivadas de estas cumplían múltiples finalidades como la obtención de alimento y forraje, combustible, y eran utilizadas en la construcción de estructuras y edificaciones, así como en la manufactura de todo tipo de artefactos incluyendo aquellos relacionados con el uso personal, herramientas, armas y medios de transporte, la aplicación de la antracología en este tipo de contextos de cronología reciente es muy puntual. Un hecho que es especialmente notorio en el análisis de muestras procedentes de contextos datados en el período de transición entre la Edad Media y la Edad Moderna. Este vacío en la investigación no solo afecta al noroeste peninsular (Martín-Seijo et al. 2010), sino que también es observable en el ámbito ibérico (Euba 2008, 2009, 2010, Cubero 2011, Ntinou et al. 2013, Mira et al. 2017) e incluso en el europeo (Zutter 2000, Leonardi 2002, Scipioni 2002, Ludemann et al. 2004, Burri 2010, Huntley 2010, Py y Durand 2010, Euba et al. 2011, Warren et al. 2012, Deforce et al. 2013, Knapp et al. 2015, Hazel et al. 2017, Burri 2018).

Los datos antracológicos de estas cronologías tardías proceden, de forma predominante, de estructuras relacionadas con la producción de carbón vegetal. Hasta el momento los únicos datos antracológicos para estas cronologías en el noroeste peninsular serían los del asentamiento rural de A Mourela (As Pontes, A Coruña). En este yacimiento se documentaron varios momentos de ocupación, y entre ellos uno datado entre los siglos XIII-XVII d.n.e.- (Martín-Seijo et al. 2009, 2010). Otros datos sobre los usos de la madera durante este período han sido obtenidos a partir del análisis xilológico de los objetos manufacturados preservados por anegamiento en el puerto de Pontevedra (Martín-Seijo et al. 2018). A nivel peninsular y en relación con el estudio de la madera, para este período también se han realizado análisis dendocronológicos, de dendroproveniencia y químicos en relación con pecios sumergidos (Traoré et al. 2017, Traoré 2018) o con maderas utilizadas en la construcción de edificios religiosos (Domínguez-Delmás et al. 2018).

A pesar de la escasez de estudios de carbones y maderas en contextos de esta cronología, los datos que pueden proporcionar este tipo de análisis arqueobotánicos pueden llegar a ser muy relevantes. La antracología permite completar y contrastar la información disponible en otros archivos medioambientales y proporciona datos relacionados con la vida cotidiana que son difíciles de rastrear a partir del estudio de las fuentes escritas. Este es el caso de la gestión de los recursos leñosos para la obtención de combustibles, y del aprovechamiento del bosque. Los estudios de la documentación escrita tanto de época medieval como de época moderna señalan una sobrerrepresentación en las fuentes documentales de aquellos árboles que eran objeto de un aprovechamiento directo, mientras que otros árboles y arbustos son invisibles en las fuentes, por no haber sido protegidos por la legislación o por no haber sido utilizados para pagar rentas (Carlé 1976, López-Sabatel 2009, Devia 2015). El estudio de muestras arqueobotánicas nos remite directamente a la importancia que el bosque tenía para estas comunidades y los esfuerzos destinados a proteger los árboles y las formaciones forestales (Carlé 1976), en un momento de fuerte deforestación (Guitián Rivera 2001), relacionado con la apertura de campos de cultivo pero también con la obtención de combustible destinado al abastecimiento de madera, leña y carbón de las ciudades (Armas Castro 1992, Franco-Rubio 2009, Estrella y Asla 2010), así como más tarde a la producción de hierro (González-Pérez 1994) y al aprovisionamiento de madera para la industria naval (Gomes y Gomes 2016). Por otra parte, el estudio de muestras arqueobotánicas de estas cronologías también es relevante porque coincide con un período de inestabilidad climática (1300-1850) conocido como la Pequeña Edad del Hielo (Fagan 2008) y que es considerado uno de los períodos más fríos del Holoceno reciente (Oliva et al. 2018).

El primer objetivo de este trabajo ha sido intentar aproximarnos a la cotidianeidad de las comunidades pasadas a partir de uno de los residuos más habituales generados por las actividades cotidianas: los carbones. Los carbones nos permiten aproximarnos a la vida diaria en el castillo, fundamentalmente y por los contextos en los que han sido recuperadas las muestras, al tipo de leña utilizada para el procesado de alimentos o para la iluminación y la calefacción de las estancias. La caracterización de la leña consumida incluirá no solo la identificación taxonómica sino también el registro de aspectos dendrológicos y tafonómicos que permitan completar datos como el tipo de leña, la existencia o no de almacenaje, etc. La leña nos permite conectar también esta actividad desarrollada intramuros con el exterior, con el bosque, la orla boscosa u otras formaciones vegetales en las que se producía el aprovisionamiento de dichos combustibles. Incluso y por la existencia de fuentes históricas para este período, podríamos 
plantearnos identificar quiénes fueron los encargados del aprovisionamiento de la leña y cómo era el acceso a este tipo de recursos leñosos. El segundo objetivo será obtener información paleoambiental a partir de los recursos leñosos explotados por estas comunidades, lo que nos permitirá completar los datos antracológicos y polínicos disponibles hasta el momento. Esta aproximación es cualitativa y su interpretación paleoambiental se encuentra limitada por las propias características del conjunto arqueobotánico; no obstante, sí se pueden identificar las especies arbóreas y arbustivas existentes en el entorno del castillo y utilizadas como leña.

\section{CONTEXTO ARQUEOLÓGICO, HISTÓRICO Y AMBIENTAL}

El Castillo de Pambre se encuentra localizado en el suroeste de la provincia de Lugo, Concello de Palas de Rei, parroquia de San Pedro de Pambre (fig. 1). La Fortaleza de Pambre es uno de los mejores ejemplos de la arquitectura militar de la Edad Media en Galicia (fig. 2). Su construcción se remonta a los años finales del siglo XIV o inicios del siglo XV y está atribuida a Gonzalo Ozores de Ulloa (Pardo de Guevara et al. 2011-2012, Rouco 2017). Lope Sánchez de Ulloa construyó el primer recinto y lo enriqueció, y su nieto Sancho Sánchez de Ulloa realizó el segundo y el reacondicionamiento palaciego en el interior del primero (Pardo de Guevara et al. 2011-2012, Rouco 2017). Estas dos fases constructivas son visibles en la propia estructura de la fortificación, con una torre del homenaje y dos recintos que la rodean, aunque no parecen observarse grandes diferencias arquitectónicas y probablemente la diferencia cronológica entre ambas fue escasa (Pardo de Guevara et al. 2011-2012). En el interior de uno de los recintos queda englobada una capilla románica datada en el siglo XI y posteriormente remodelada. Cuando la fortaleza se destina a usos agrícolas, hacia el siglo XVI, se construyen toda una serie de edificaciones con diferentes técnicas constructivas y materiales (Rouco 2017). El conjunto palaciego funciona como residencia habitual de Inés de Castro y de su hijo Sancho de Ulloa durante el s. XV, pasando a ser la residencia habitual de los Ulloa (Rouco 2007). Esta función decae tras la muerte de Sancho en 1505, momento a partir del que el castillo servirá como núcleo de una extensa explotación económica (Rouco 2017).

Este recinto fortificado ocupa un pequeño promontorio rocoso situado a $430 \mathrm{~m}$ s.n.m., a la orilla del río Pambre, que le sirve de defensa natural rodeándolo en sus caras norte y oeste. Actualmente este yacimiento se encuentra rodeado de áreas de pasto, formaciones de matorral en las zonas más elevadas situadas al norte y bosques de ribera a lo largo del río. En el entorno inmediato se han identificado varios ejemplares de roble (Quercus robur, Q. petraea) y castaño (Castanea sativa). En zonas próximas se localizan plantaciones forestales de pinos y eucaliptos. El Castillo de Pambre se encuentra en el piso colino de la región eurosiberiana, donde actualmente las formaciones arboladas más características serían los bosques mixtos planocaducifolios, con el roble (Quercus robur, $Q$. petraea, $Q$. pyrenaica) como especie predominante, acompañado de abedules (Betula alba, B. pendula), fresnos (Fraxinus excelsior), álamos (Populus tremula) o arces (Acer pseudoplatanus, A. platanoides) entre otros, y también pueden estar presentes plantas perennes como el acebo (Ilex aquifolium), el alcornoque (Quercus suber), la encina (Quercus ilex, Quercus rotundifolia) o el laurel (Laurus nobilis) (Costa et al. 2001, Amigo et al. 2017). La principal característica de estas formaciones es la gran riqueza de especies arbóreas y arbustivas acompañantes: Castanea sativa, Frangula alnus, Prunus avium, P. padus, Crataegus monogyna, Corylus avellana, Juniperus commnunis, etc. (Costa et al. 2001). Los matorrales de sustitución de estas formaciones están formados fundamentalmente por especies de la familia de las Ericaceae y de las Fabaceae (Ulex sp., Genista sp.) (Amigo et al. 2017). Las formaciones riparias de la región eurosiberiana están formadas por alisos (Alnus glutinosa), álamos temblones (Populus tremula), fresnos (Fraxinus excelsior), laureles (Laurus nobilis), abedules (Betula pendula) o diversos tipos de sauces (Salix spp.) (Costa et al. 2001).

Gran parte de la ocupación del castillo coincide con la Pequeña Edad del Hielo (1300-1850), un período frío en el que se han distinguido diferentes fases y cuyas evidencias han sido documentadas tanto en el registro paleoambiental del noroeste (Martínez-Cortizas et al. 1999, Desprat et al. 2003) como en las fuentes históricas (Fernández-Cortizo 2016). Para el período que nos interesa en relación con la ocupación del Castillo de Pambre, entre el 1300 y el 1480 se documenta un enfriamiento creciente con oscilaciones climáticas moderadas, entre 1480 y 1570 se dan unas condiciones más templadas, seguidas posteriormente de un enfriamiento gradual entre 1570 y 1620 , llegando al período más frío conocido como el Mínimo de Maunder entre los años 1620 y 1715 , con temperaturas aproximadamente $2^{\circ} \mathrm{C}$ por debajo de las actuales 


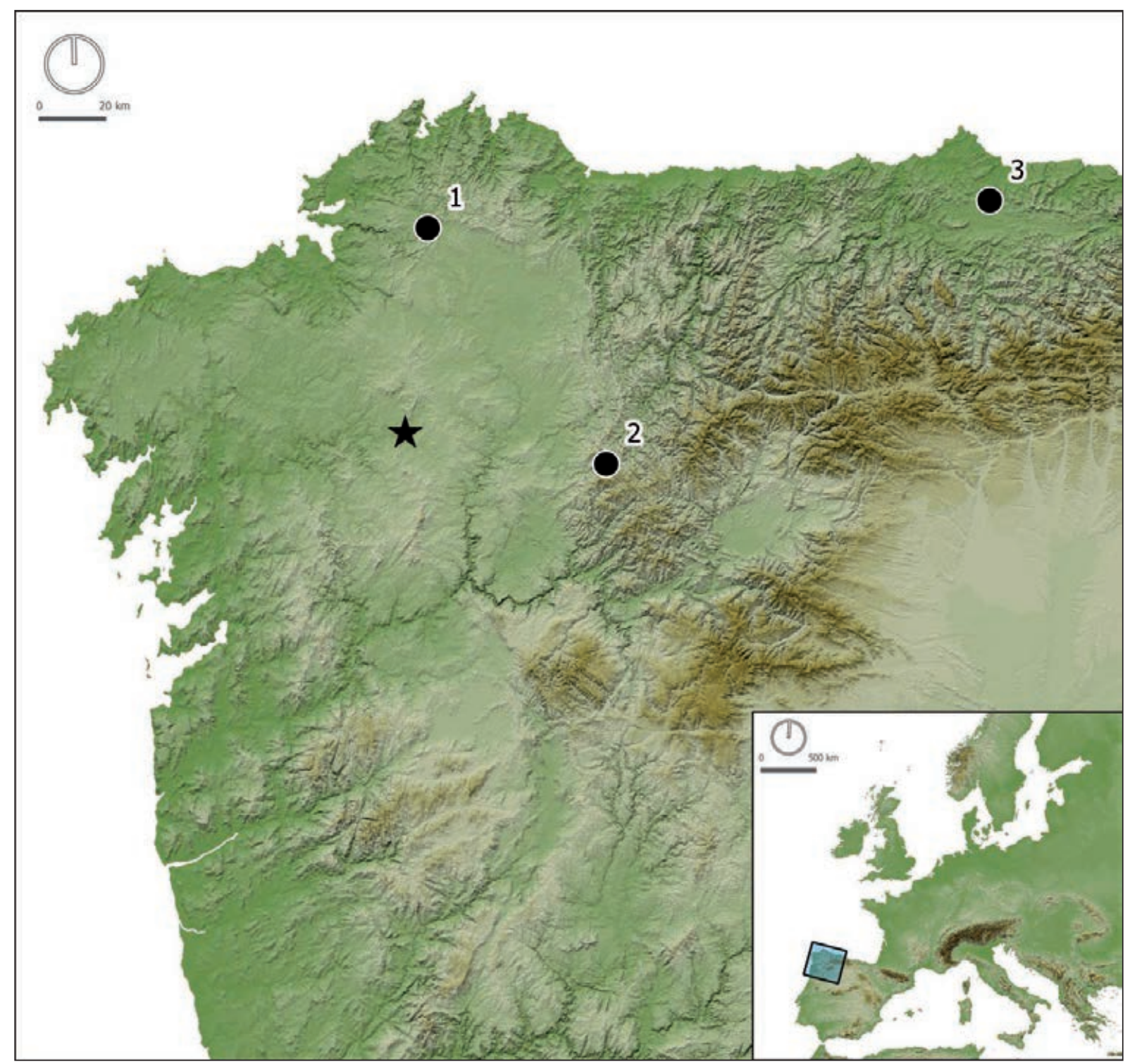

Figura 1. Localización del Castillo de Pambre (Palas de Rei, Lugo) en el noroeste peninsular (estrella), y otros yacimientos citados en el texto: 1) A Mourela, 2) Cova Eirós y 3) Peñaferruz (mapa elaborado por Emilio Abad Vidal).

(Oliva et al. 2018). A partir de los análisis dendroclimáticos, los períodos que concentran una mayor cantidad de oscilaciones se producirían en los intervalos comprendidos entre el 1400 y c 1600 y las temperaturas alcanzarían sus valores más bajos en el 1500 (Manrique y Fernández Cancio 2000). En el noroeste de Iberia los registros documentados en las turberas y en los depósitos marinos señalan el año 1700 como el momento en el que se alcanzan los episodios más fríos de la Pequeña Edad del Hielo (Martínez-Cortizas et al. 1999, Desprat et al. 2003).

\section{MATERIAL Y MÉTODOS}

Han sido analizados 806 fragmentos de carbón recuperados de tres muestras de sedimento, que fueron recogidas, cribadas y triadas para la realización de análisis zooarqueológicos en la Universidad de León. El volumen inicial de las muestras recogidas en campo fue de entre 7,8 y 11,31 litros, de los que se cribó aproximadamente la mitad, recuperándose carbón en todas ellas (tab. 1).

Todas las muestras fueron recogidas en un perfil del área de excavación situada frente a la puerta de la torre 


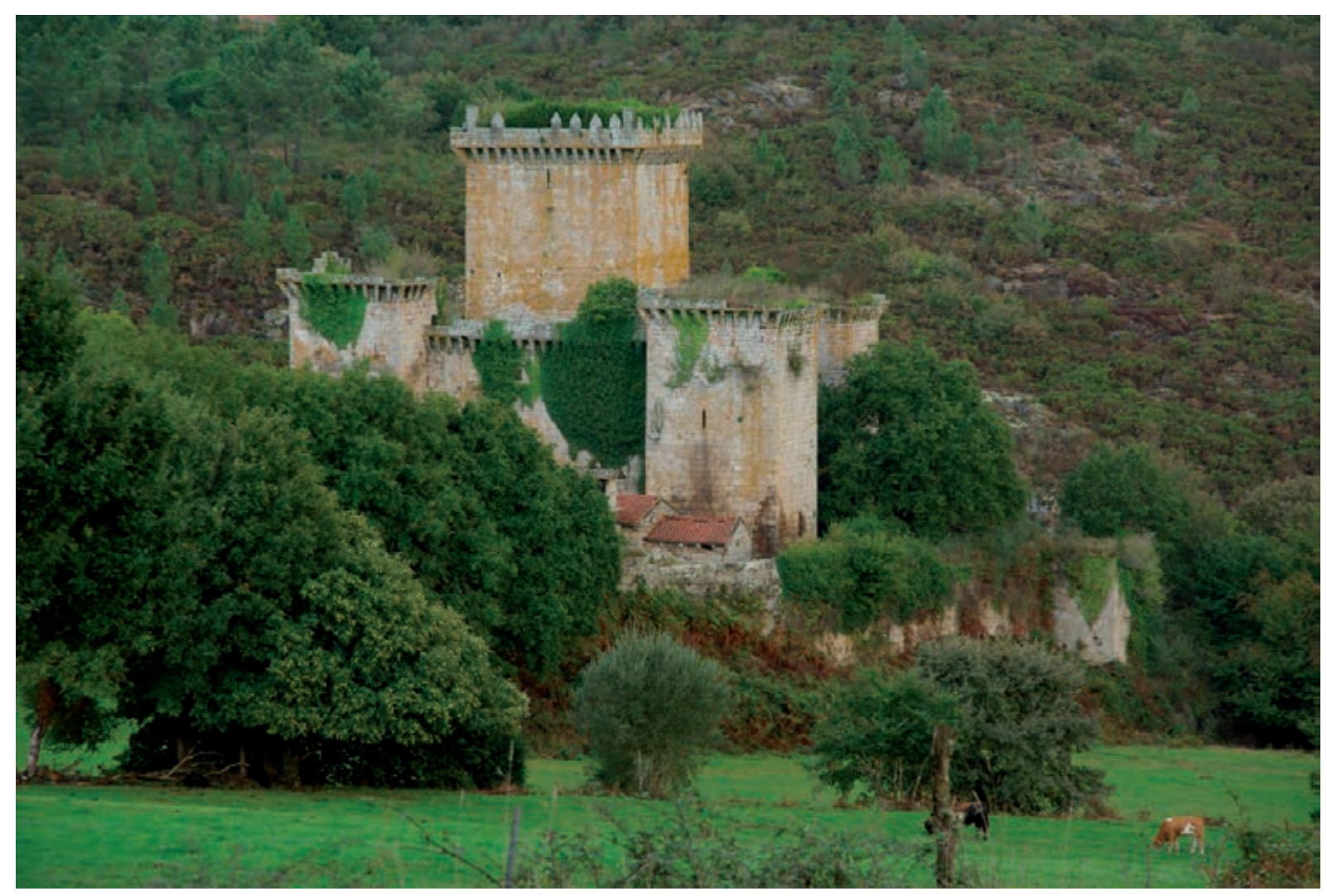

Figura 2. Vista del Castillo de Pambre desde el sur (fotografía: Santiago Vázquez Collazo).

Tabla 1. Resumen de los datos de las tres muestras analizadas.

\begin{tabular}{|c|c|c|c|}
\hline Código & Volumen inicial (1) & Volumen cribado (1) & Peso carbón (gr) \\
\hline M-0 & 7,90 & 3,05 & 91,80 \\
\hline M-1 & 7,80 & 3,06 & 34,64 \\
\hline M-2 & 11,31 & 4,76 & 22,60 \\
\hline
\end{tabular}

Las muestras están depositadas en el Laboratorio de Arqueobotánica del GEPN-AAT en la Universidade de Santiago de Compostela.

de homenaje del castillo de Pambre (fig. 3). La torre estaba situada en la zona central del recinto y su puerta, situada en la fachada norte, era elevada y se localizaba en la primera planta (Rouco 2017). Los carbones estaban relacionados con un depósito interpretado como basurero y están datados a partir de los materiales asociados, fundamentalmente cerámica y monedas, entre los siglos XV-XVI, pudiendo llegar incluso a inicios del siglo XVII.

Durante el estudio microscópico de las muestras de carbón, cada uno de los fragmentos fue identificado taxonómicamente siguiendo el procedimiento habitual (Cartwright 2015). Las muestras fueron observadas en un microscopio Olympus CX-40 con objetivos de $2 \mathrm{x}, 4 \mathrm{x}, 10 \mathrm{x}, 20 \mathrm{x}$ y $40 \mathrm{x}$ aumentos y sus características anatómicas, comparadas con bibliografía especializada (Schweingruber 1990, Gale y Cutler 2000, Hather 2000). Las fotografías fueron realizadas con una lupa binocular Olympus SZX7.

En paralelo al análisis antracológico se registraron también atributos dendrológicos y tafonómicos, con el objetivo de poder complementar los datos obtenidos de la identificación taxonómica. Se ha documentado la curvatura del anillo de crecimiento, una característica cualitativa que nos proporciona un valor relativo sobre el calibre de la madera consumida y la disposición 


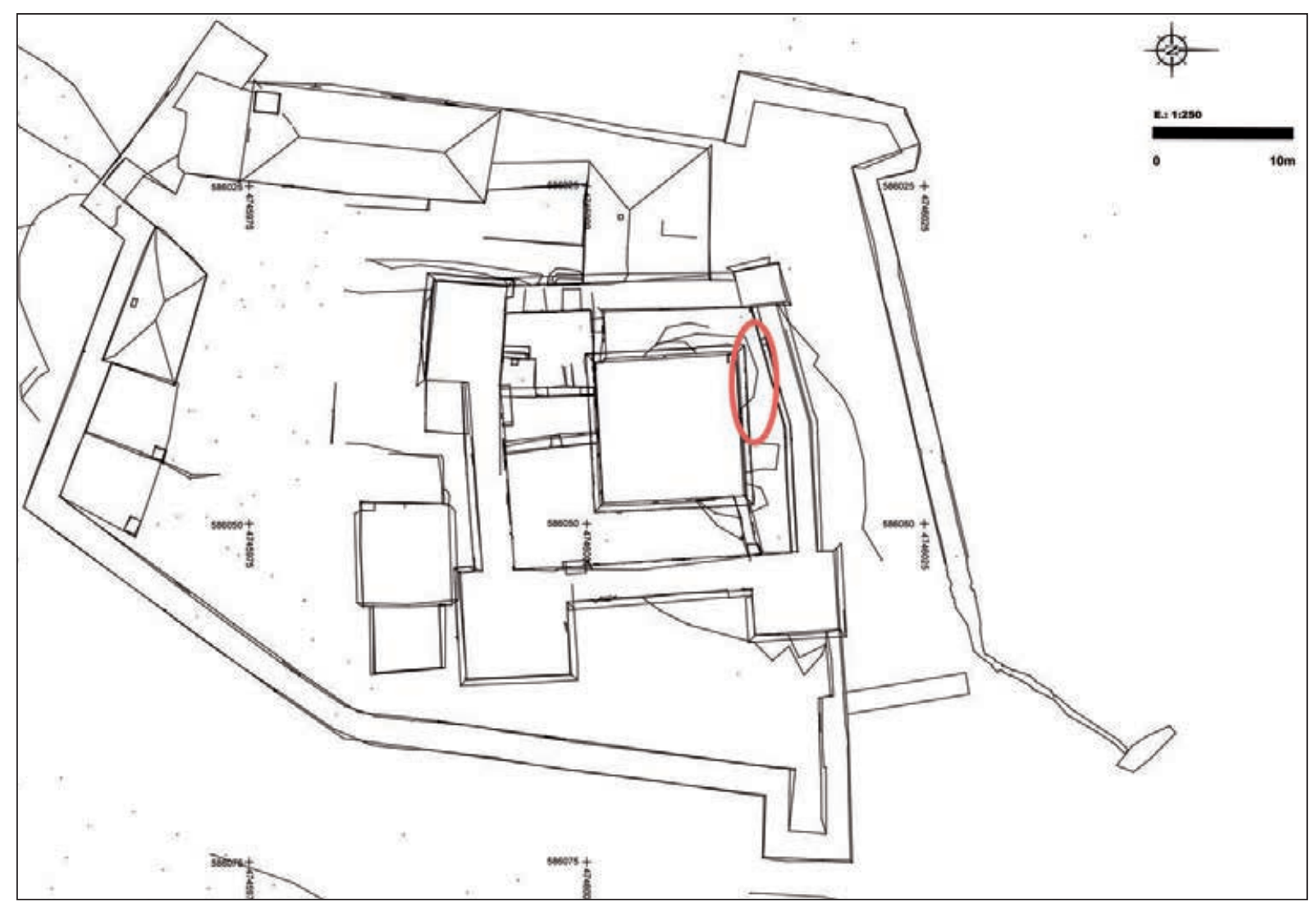

Figura 3. Plano del castillo de Pambre y en rojo, procedencia de las muestras analizadas.

del fragmento en el tronco. La curvatura del anillo indica si la madera procede de la parte central o exterior del tronco, si se trata de un tronco de calibre medio o grande, o de una pequeña rama (Carrión 2006, Marguerie y Hunot 2007) (fig. 4).

Se han registrado también alteraciones anatómicas relacionadas con las condiciones de vida de la planta, como la existencia de variaciones del ritmo normal de crecimiento. Esta es identificada por la supresión del crecimiento del leño final en los anillos anuales, conocida como narrow rings, y puede estar relacionada con la existencia de prácticas de poda, o con períodos desfavorables para el crecimiento de la planta (Schweingruber 2007, Schweingruber y Börner 2018). El ataque de microorganismos a plantas leñosas desencadena mecanismos de defensa destinados a detener su avance en el interior del árbol, en un proceso conocido como CODIT- Compartmentalization of Decay in Trees (fig. 5c) (Shigo y Marx 1977, Shigo 1979, Schweingruber y Börner 2018). Se puede documentar también la existencia de tejido cicatricial en el leño, una reacción a la existencia de algún tipo de herida en el cambium, cuyo origen puede ser muy diverso y difícil de establecer debido a la fragmentación de carbones estudiados habitualmente en las muestras antracológicas (Schweingruber 2007, Schweingruber y Börner 2018). Finalmente, se han registrado también otras evidencias relacionadas con la degradación biológica de la madera (Hickin 1963), como la presencia de hifas de hongos o galerías de insectos xilófagos (Carrión 2006, Marguerie y Hunot 2007, Moskal-del-Hoyo et al. 2010, Fohrer et al. 2017, Toriti 2018).

Se registraron también alteraciones relacionadas con el proceso de combustión, como la presencia de grietas y la vitrificación. Las grietas (radiales, tangenciales o arbitrarias) son habituales en las maderas y carbones arqueológicos (fig. 5a); su presencia está muy condicionada por la propia estructura anatómica de cada especie: afecta principalmente a aquellas maderas que presentan una importante densidad de radios o a aquellas que presentan radios multiseriados, y se localizan normalmente en las zonas más alejadas del duramen (Théry-Parisot y Henry 2012). La vitrificación es un tipo de alteración que hace que los carbones 


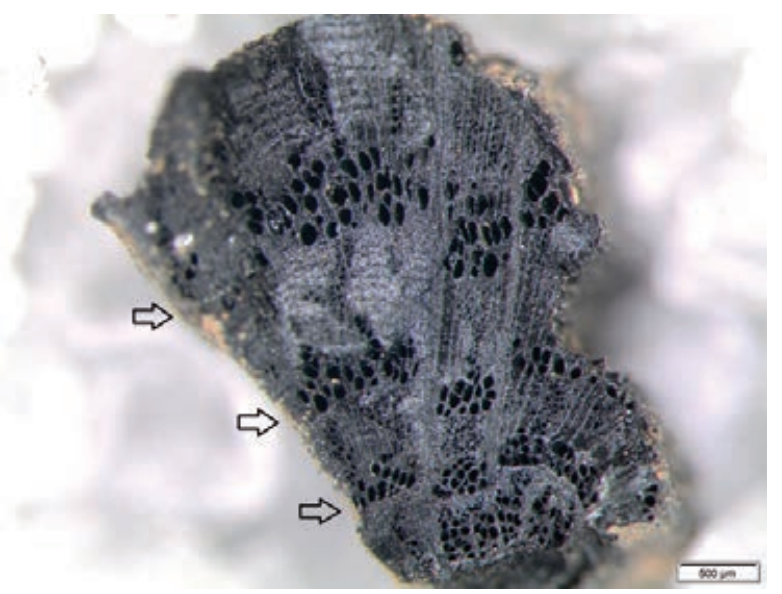

a

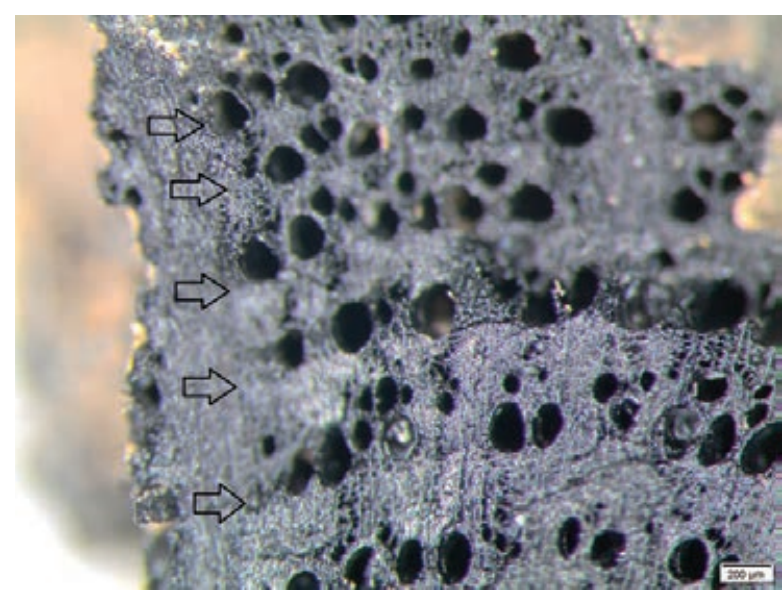

b

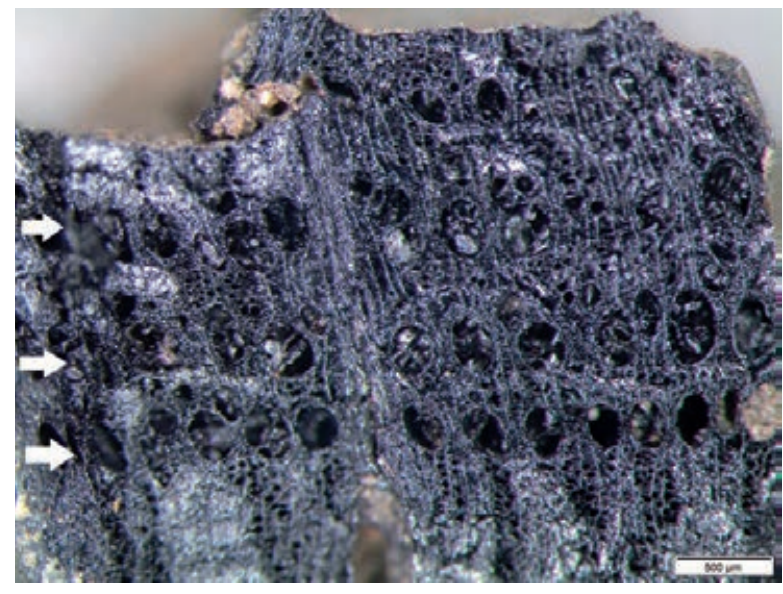

c

Figura 4. Curvatura del anillo de crecimiento en tres fragmentos de Quercus sp. caducifolio de Pambre: a) curvatura fuerte, b) moderada y c) débil.

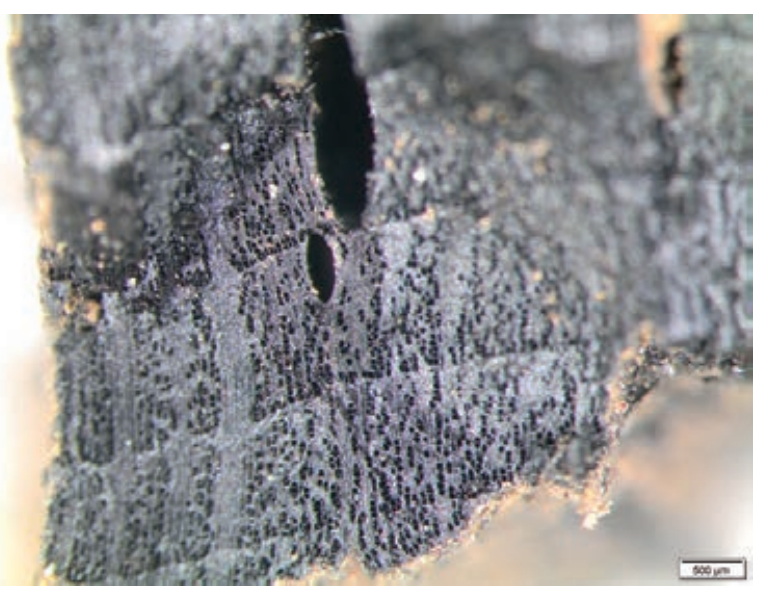

a

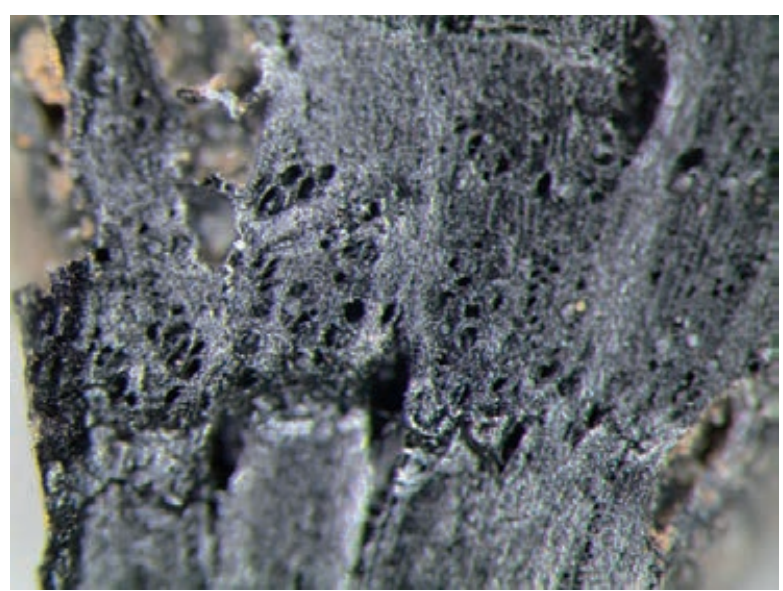

b

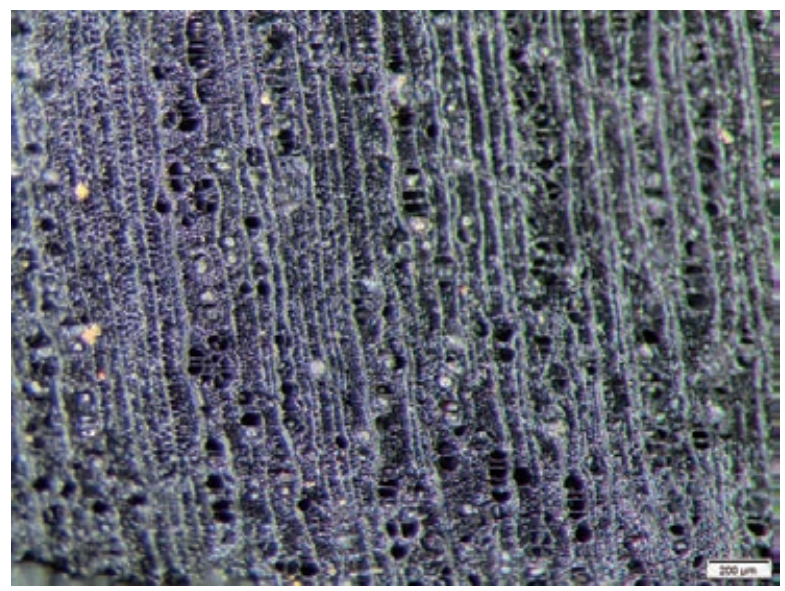

c

Figura 5. Alteraciones relacionadas con el proceso de combustión: a) grietas radiales en Corylus avellana, b) grietas radiales y vitrificación de los tejidos en Quercus sp. Caducifolio. Alteraciones relacionadas con la vida de la planta: c) presencia de compartimentalización en Corylus avellana. 
Tabla 2. Resumen de los resultados antracológicos obtenidos en tres muestras recuperadas en el castillo de Pambre.

\begin{tabular}{|c|c|c|c|c|c|}
\hline Formación & Taxones & M-0 & M-1 & M-2 & Total \\
\hline \multirow{11}{*}{ Bosque mixto } & Quercus sp. caducifolio & 68 & 134 & 283 & 485 \\
\hline & Corylus avellana & 10 & 44 & 46 & 100 \\
\hline & Castanea sativa & 2 & 13 & 25 & 40 \\
\hline & Prunus sp. & 3 & 3 & 25 & 31 \\
\hline & Rosaceae/Maloideae & 2 & 7 & 10 & 19 \\
\hline & Quercus/Castanea & - & 6 & 3 & 9 \\
\hline & Juglans regia & - & - & 7 & 7 \\
\hline & Quercus sp. perennifolio & 3 & - & - & 3 \\
\hline & Quercus sp. & - & 1 & 1 & 2 \\
\hline & Fraxinus sp. & - & 1 & 1 & 2 \\
\hline & Frangula alnus & - & 1 & - & 1 \\
\hline \multirow{2}{*}{ Bosque de ribera } & Salix/Populus & 1 & 2 & 6 & 9 \\
\hline & Sambucus sp. & 1 & - & 一 & 1 \\
\hline \multirow{4}{*}{ Matorral } & Fabaceae & 5 & 10 & 21 & 36 \\
\hline & Erica sp. & 3 & 9 & 18 & 30 \\
\hline & Juniperus sp. & - & 1 & - & 1 \\
\hline & Erica arborea/australis & - & - & 1 & 1 \\
\hline \multirow[t]{2}{*}{ Otros } & Corteza & 1 & 2 & 21 & 24 \\
\hline & Total & 100 & 238 & 468 & 806 \\
\hline
\end{tabular}

presenten un aspecto vítreo (fig. 5b), provocado por la fusión de los diferentes elementos anatómicos de la madera, que homogeneizan su estructura, pudiendo llegar incluso a provocar la fusión total de los tejidos y a impedir la identificación anatómica por la pérdida de características como puntuaciones, perforaciones, engrosamientos espiralados, células de parénquima, etc. (Théry-Parisot 2001, McParland et al. 2010). El registro de la presencia de grietas radiales y de vitrificación en los carbones puede proporcionar información sobre las condiciones de combustión de la madera e incluso sobre el estado de esta de forma previa a la combustión.

La fragmentación es uno de los efectos de la combustión y su intensidad es diferente en función de las características anatómicas de la madera, pero también puede estar relacionada con procesos deposicionales y postdeposicionales (Lancelotti et al. 2010). Cada fragmento analizado fue medido en su lado más largo, con el objetivo de registrar el índice de fragmentación y para realizar una valoración de los procesos de formación del contexto arqueológico en el que se localizan. Los grados de fragmentación establecidos son de 0,3-1 $\mathrm{cm}$ muestra muy fragmentada, de más de 1 a $3 \mathrm{~cm}$ fragmentada, de más de 3 a 10 moderadamente fragmentada y de más de $10 \mathrm{~cm}$ poco fragmentada (Martín-Seijo 2013). Para registrar los procesos de movilización a los que se pueden ver sometidos los carbones registramos también el tipo de aristas que presentaban, estableciendo dos categorías: angulosas o redondeadas (Rodríguez-Ariza 1993, Martín-Seijo 2013).

\section{RESULTADOS}

El análisis antracológico ha permitido identificar 17 taxones arbóreos y arbustivos (tab. 2): Quercus sp. 


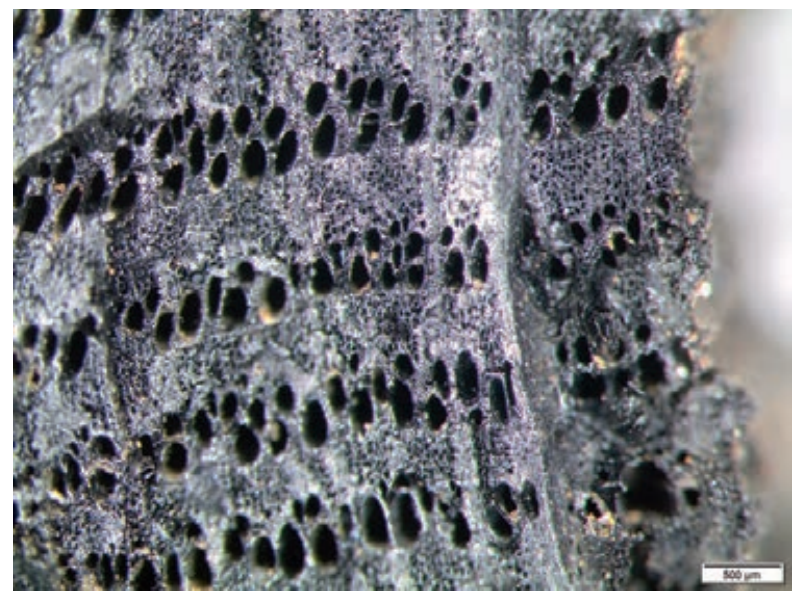

$\mathbf{a}$

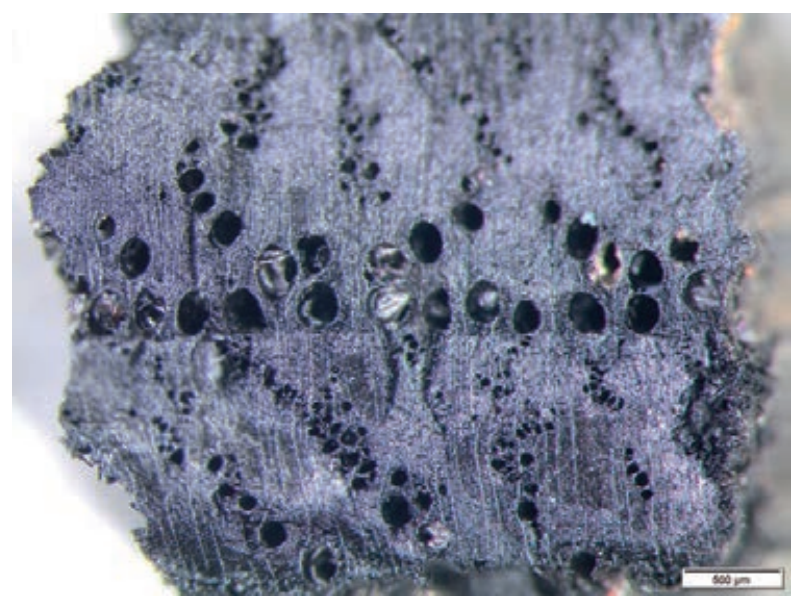

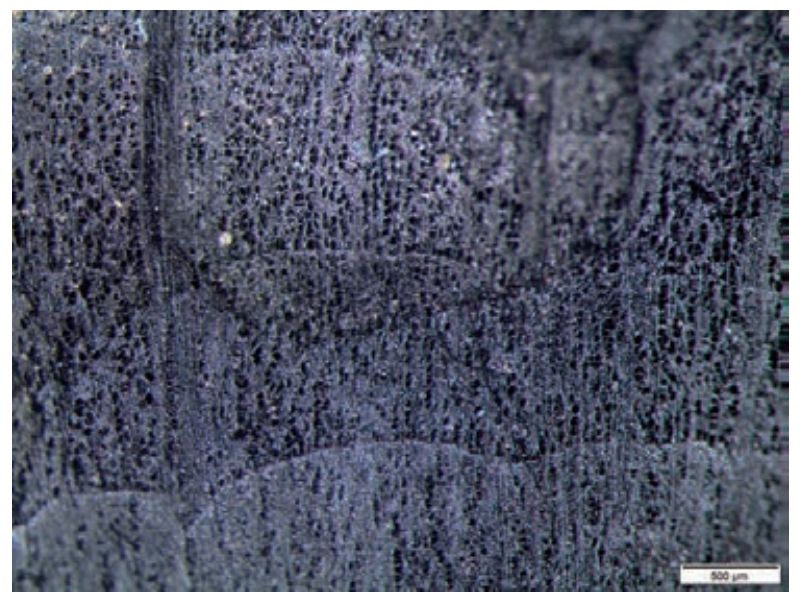

b

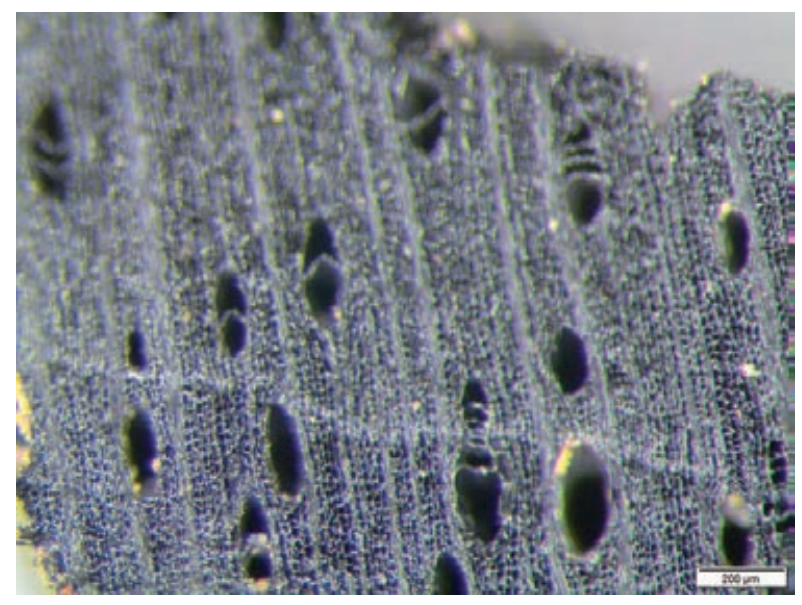

d

Fig. 6. Planos transversales de varios de los taxones identificados durante el análisis antracológico: a) Quercus sp. caducifolio, b) Corylus avellana, c) Castanea sativa, d) Juglans regia.

caducifolio, Corylus avellana, Castanea sativa, Fabaceae, Erica sp., Prunus sp., Rosaceae/Maloideae, Salix/Populus, Quercus/Castanea, Fraxinus sp., Quercus sp., Quercus sp. perennifolio, Sambucus sp., Frangula alnus, Juniperus sp., Juglans regia y Erica arborea/australis. Se han identificado también algunos fragmentos de corteza que no ha sido posible asignar a ningún taxón.

Los datos dendrológicos nos han permitido caracterizar los recursos leñosos consumidos más allá de la identificación taxonómica. En el $80,8 \%$ de los fragmentos pudo ser registrado el tipo de curvatura, predominando en el conjunto los fragmentos con curvatura moderada, seguida de aquellos con curvatura fuerte (tab. 3). En los taxones consumidos más habitualmente como Quercus sp. caducifolio, Corylus avellana,
Castanea sativa o Prunus sp. hay un claro predominio de los fragmentos de curvatura moderada, mientras que en taxones arbustivos como Fabaceae y Erica sp. hay un predominio de los fragmentos con curvatura fuerte (tab. 3).

La parte de la planta pudo ser identificada a partir de sus características morfológicas y anatómicas en 47 fragmentos, el 5,9\% de los casos (tab. 4). En 4 de los carbones las ramas conservaban la médula y la corteza, por lo que pudo ser recontada la edad en el momento de la muerte, 2 anillos anuales en un fragmento de Rosaceae/Maloideae y en dos fragmentos de Quercus sp. caducifolio, y 3 anillos anuales en un fragmento de Quercus sp. caducifolio.

En el conjunto de la muestra se han identificado diferentes tipos de alteraciones anatómicas o 
Tabla 3. Datos cualitativos de la curvatura en el anillo de los diferentes taxones identificados en Pambre: F: fuerte, F-M: fuerte-moderada, M: moderada, M-D: moderada-débil, D: débil, I: indeterminado.

\begin{tabular}{|c|c|c|c|c|c|c|}
\hline Taxones/Curvatura & $\mathrm{F}$ & F-M & M & M-D & $\mathrm{D}$ & I \\
\hline Quercus sp. caducifolio & 55 & 5 & 226 & 44 & 40 & 115 \\
\hline Corylus avellana & 13 & - & 80 & - & 2 & 5 \\
\hline Castanea sativa & 3 & - & 25 & 4 & 5 & 3 \\
\hline Fabaceae & 28 & 1 & 6 & - & & 1 \\
\hline Prunus sp. & 2 & - & 18 & 2 & 7 & 2 \\
\hline Erica sp. & 20 & - & 5 & - & - & 3 \\
\hline Rosaceae/Maloideae & 4 & - & - & - & 1 & 14 \\
\hline Quercus/Castanea & 3 & - & 2 & - & - & 4 \\
\hline Salix/Populus & 2 & - & 3 & - & 1 & 3 \\
\hline Juglans regia & - & - & 2 & - & 5 & - \\
\hline Quercus sp. perennifolio & - & - & 1 & - & - & 2 \\
\hline Fraxinus sp. & - & - & 2 & - & - & \\
\hline Quercus sp. & - & - & & - & 1 & 1 \\
\hline Frangula alnus & - & - & 1 & - & - & - \\
\hline Sambucus sp. & - & - & 1 & - & - & - \\
\hline Juniperus sp. & - & - & - & - & - & 1 \\
\hline Erica arborea/australis & - & - & - & - & - & 1 \\
\hline Total & 130 & 6 & 372 & 50 & 62 & 155 \\
\hline
\end{tabular}

morfológicas (tab. 5). Se han registrado alteraciones del ritmo de crecimiento (narrow rings) en el 5,6\% de los fragmentos de Quercus sp. caducifolio, cicatrices en el 26,3\% de los fragmentos de Rosaceae/Maloideae, y compartimentalización en el 16\% de Corylus avellana y 11,1\% de Salix/Populus. La presencia de evidencias de madera degradada es muy puntual y afecta solo a algunos fragmentos de Quercus sp. caducifolio, Corylus avellana y corteza. Las alteraciones más frecuentes son aquellas relacionadas con el proceso de combustión como la vitrificación $(25,5 \%)$ y las grietas radiales $(23,7 \%)$, afectando en mayor proporción a taxones como Fabaceae o Erica sp. La presencia de fragmentos con aristas redondeadas que se podrían relacionar con procesos de movilización es muy puntual y afecta solo al 3\% de los fragmentos analizados.

El tamaño de los fragmentos analizados oscila entre 0,2 y $2 \mathrm{~cm}$ (tab. 6). Predominan los fragmentos con tamaños comprendidos entre 0,5 y $1 \mathrm{~cm}$, seguidos de aquellos con tamaños de 0,2 a 0,5 cm. La muestra está muy fragmentada.

\section{DISCUSIÓN}

Los datos obtenidos a partir del análisis antracológico en el castillo de Pambre proporcionan información sobre la leña consumida por sus ocupantes entre los siglos XV y XVII. Establecer el uso de esta leña es complejo, no obstante, al estar asociados estos carbones a restos óseos y a ictiofauna, podemos plantear la posibilidad de que estuvieran relacionados con el procesado de alimentos; aunque no podemos descartar completamente que hubieran sido utilizados para la iluminación y calefacción de alguna de las estancias del palacio o de alguna de las construcciones del recinto fortificado, y que fueran posteriormente mezclados con residuos de comida. 
Tabla 4. Parte de la planta identificada: LI: leño indeterminado; RA: rama; N: nudo, C: corteza.

\begin{tabular}{|c|c|c|c|c|}
\hline Taxones/Parte de la planta & LI & RA & $\mathrm{N}$ & $\mathrm{C}$ \\
\hline Quercus sp. caducifolio & 470 & 11 & 4 & - \\
\hline Corylus avellana & 99 & - & 1 & - \\
\hline Castanea sativa & 40 & - & - & - \\
\hline Fabaceae & 30 & 6 & - & - \\
\hline Prunus sp. & 40 & - & - & - \\
\hline Erica sp. & 23 & 4 & 3 & - \\
\hline Rosaceae/Maloideae & 18 & 1 & - & - \\
\hline Quercus/Castanea & 9 & - & - & - \\
\hline Salix/Populus & 9 & - & - & - \\
\hline Juglans regia & 7 & - & - & - \\
\hline Quercus sp. perennifolio & 3 & - & - & - \\
\hline Fraxinus sp. & 2 & - & - & - \\
\hline Quercus sp. & 2 & - & - & - \\
\hline Frangula alnus & 1 & - & - & - \\
\hline Sambucus sp. & 1 & - & - & - \\
\hline Juniperus sp. & 1 & - & - & - \\
\hline Erica arborea/australis & 1 & - & - & - \\
\hline Indeterminado & - & - & - & 24 \\
\hline Total & 755 & 22 & 8 & 24 \\
\hline
\end{tabular}

La escasa presencia de carbones con aristas redondeadas en la muestra estudiada indicaría que no se vieron afectados por procesos de movilización más que de forma puntual, a pesar de que el tamaño de los fragmentos analizados indica que la muestra se encontraba muy fragmentada.

La identificación de 17 taxones en el conjunto de las muestras analizadas indica una explotación diversificada del entorno para la obtención de leña, no solo por la variedad taxonómica sino por las diferentes formaciones vegetales en las que estas comunidades se aprovisionaban de leña. El bosque mixto de planocaducifolios era la formación arbórea en la que obtenían la mayor parte del combustible y la mayor variedad de taxones: Quercus sp. caducifolio, Quercus sp., Castanea sativa, Fraxinus sp., Juglans regia y Quercus sp. perennifolio. También se explotaban probablemente las áreas de claro existentes en su interior o su orla arbustiva, tal y como indica la presencia de Corylus avellana, Prunus sp., Rosaceae/Maloideae y Frangula alnus. Las formaciones de ribera (Salix/Populus, Sambucus sp.) y las de matorral (Fabaceae, Erica sp., Erica arborea/australis y Juniperus sp.) fueron también utilizadas.

No se documenta el consumo de leña afectada por degradación biológica, solo se ha identificado la presencia esporádica de la acción de insectos xilófagos sobre Corylus avellana. Este hecho podría indicar que no existía una recolección de madera muerta o un almacenaje de la leña durante largos períodos, o que, si este se producía, se realizaba en condiciones que no favorecían la degradación de la madera. Las condiciones que favorecen el crecimiento de microorganismos son una elevada humedad de aproximadamente el 40-80\%, temperaturas de entre $1-50^{\circ} \mathrm{C}$ y nivel de $\mathrm{pH}$ alrededor de 6 (Blanchette 2000, Schmidt 2006). 
Tabla 5. Alteraciones relacionadas con la vida de la planta. AC: anillos estrechos relacionados con alteraciones de crecimiento, CI: cicatrices, CO: compartimentalización; HI: hifas, XI: galerías de xilófagos, GR: grietas radiales, GT: grietas tangenciales, VT: vitrificación, ER: erosión.

\begin{tabular}{|c|c|c|c|c|c|c|c|c|c|}
\hline Taxones/Parte de la planta & $\mathrm{AC}$ & CI & $\mathrm{CO}$ & HI & XI & VT & GR & GT & ER \\
\hline Quercus sp. caducifolio & 27 & - & - & 2 & - & 146 & 121 & - & 5 \\
\hline Corylus avellana & - & - & 16 & - & 2 & 10 & 17 & - & 7 \\
\hline Castanea sativa & - & - & - & - & - & 3 & 1 & - & 1 \\
\hline Fabaceae & - & - & - & - & - & 19 & 24 & - & \\
\hline Prunus sp. & - & - & - & - & - & 6 & 3 & - & 2 \\
\hline Erica sp. & - & - & - & - & - & 13 & 19 & 1 & 1 \\
\hline Rosaceae/Maloideae & - & 5 & - & - & - & 4 & - & - & 2 \\
\hline Quercus/Castanea & - & - & - & - & - & - & 2 & - & - \\
\hline Salix/Populus & - & - & 1 & - & - & - & - & - & 1 \\
\hline Juglans regia & - & - & - & - & - & 1 & 1 & - & 2 \\
\hline Quercus sp. perennifolio & - & - & - & - & - & 1 & 1 & - & 1 \\
\hline Fraxinus sp. & - & - & - & - & - & - & - & - & - \\
\hline Quercus sp. & - & - & - & - & - & - & - & - & 一 \\
\hline Frangula alnus & - & - & - & - & - & - & - & - & - \\
\hline Sambucus sp. & - & - & - & - & - & 1 & - & - & 一 \\
\hline Juniperus sp. & - & - & - & - & - & - & - & - & 1 \\
\hline Erica arborea/australis & - & - & - & - & - & 1 & 1 & - & - \\
\hline Indeterminado & - & - & - & 1 & - & 1 & 1 & - & 1 \\
\hline Total & 27 & 5 & 17 & 3 & 2 & 206 & 191 & 1 & 24 \\
\hline
\end{tabular}

El registro de las alteraciones que registran las condiciones de vida de las plantas aporta datos significativos en el caso de Quercus sp. caducifolio, Rosaceae/ Maloideae, Corylus avellana y Salix/Populus. En el primer caso, se documenta en un pequeño porcentaje de fragmentos la supresión del crecimiento del anillo anual durante el leño final, que podría relacionarse con la existencia de prácticas de poda como el trasmocho, el desmocho o la entresaca, relativamente habituales en esta época para mejorar la productividad de determinadas especies (Aragón-Ruano 2001, 2009), aunque no sería descartable que también que se asociaran a períodos de estrés hídrico o condiciones de crecimiento desfavorables (Schweingruber 2007, Schweingruber y Börner 2018). Teniendo en cuenta la limitación de esta evidencia, y la sucesión de períodos fríos durante la Pequeña Edad del Hielo, no podemos descartar ninguna de estas posibilidades, aunque sí es significativo que esta alteración solo se documente sobre Quercus sp. caducifolio. Este hecho podría apuntar a la existencia de poda sobre este árbol.

Por otra parte, la presencia de cicatrices sobre Rosaceae/Maloideae en un porcentaje elevado podría indicar que un individuo, o individuos de este grupo de árboles se vio afectado por algún factor que dañó el cambium: incendio, acción biológica o antrópica (Schweingruber 2007, Schweingruber y Börner 2018). Finalmente, la presencia de compartimentalización en fragmentos de Corylus avellana y Salix/Populus podría indicar que existían en el entorno del sitio un individuo o individuos de estos taxones que estaba afectado por algún tipo de microorganismos. 
Tabla 6. Tamaño de los fragmentos de carbón analizados

\begin{tabular}{|c|c|c|c|c|}
\hline Taxones/Tamaño (cm) & $0,2-0,5$ & $>0,5-1$ & $>1-1,5$ & $>1,5-2$ \\
\hline Quercus sp. caducifolio & 168 & 279 & 35 & 3 \\
\hline Corylus avellana & 31 & 58 & 7 & 4 \\
\hline Castanea sativa & 16 & 19 & 4 & 1 \\
\hline Fabaceae & 11 & 21 & 3 & 1 \\
\hline Prunus sp. & 13 & 15 & 3 & - \\
\hline Erica sp. & 16 & 9 & 5 & - \\
\hline Rosaceae/Maloideae & 8 & 10 & - & 1 \\
\hline Quercus/Castanea & 7 & 2 & - & - \\
\hline Salix/Populus & 5 & 4 & - & - \\
\hline Juglans regia & 3 & 3 & 1 & - \\
\hline Quercus sp. perennifolio & - & 3 & - & - \\
\hline Fraxinus sp. & 2 & - & - & - \\
\hline Quercus sp. & 1 & 1 & - & - \\
\hline Frangula alnus & 1 & - & - & - \\
\hline Sambucus sp. & & - & 1 & - \\
\hline Juniperus sp. & 1 & - & - & - \\
\hline Erica arborea/australis & 1 & - & - & - \\
\hline Indeterminado & 8 & 16 & 1 & - \\
\hline Total & 292 & 440 & 60 & 10 \\
\hline
\end{tabular}

Con respecto a los taxones identificados como combustible, destaca en primer lugar el predominio de la madera obtenida de árboles y arbustos, frente a la escasa importancia que tienen en el conjunto los taxones arbustivos asociados a las formaciones de matorral (Fabaceae, Erica sp., Erica arborea/australis, Juniperus sp.). En general predomina la leña de calibre medio a pequeño, tanto en los taxones predominantes (Quercus sp. caducifolio, Corylus avellana, Castanea sativa, Prunus sp.) como en aquellos menos frecuentes y de porte arbustivo (Fabaceae, Erica spp.). Se ha identificado el uso de ramas de Quercus sp. caducifolio, Fabaceae, Erica sp. y Rosaceae/Maloideae, en algún caso de solo 2-3 años. La presencia de curl wood ha permitido identificar también la presencia de nudos, pequeños brotes durmientes de las ramas, también en fragmentos de Quercus sp. caducifolio, Corylus avellana y Erica sp. El uso predominante de leña obtenida de ramas podría estar relacionada con las restricciones existentes desde época bajomedieval destinadas a proteger a los árboles y el bosque (Carlé 1976), o con el uso como combustible de madera obtenida durante la poda o a partir del desmoche, el trasmoche o el clareo.

Las alteraciones relacionadas con el proceso de combustión, como la vitrificación y las grietas radiales, afectan especialmente a taxones como Fabaceae o Erica spp. Ambos taxones son proclives a presentar este tipo de alteraciones quizá por su comportamiento durante la combustión, en el caso de Erica spp. las grietas son cortas y numerosas, y podrían estar relacionadas con el consumo de leña que conserva un cierto grado de humedad como han propuesto a partir de experimentos sobre coníferas Théry-Parisot y Henry (2012). Este dato nos permitiría plantear que las arbustivas pudieron haber sido consumidas en verde o húmedas, lo que indicaría un aprovisionamiento próximo al momento de 
uso como combustible, sin almacenaje previo que permitiera esa pérdida de humedad. Las fuentes señalan la presencia de tojales y codesales lindantes a las tierras de cultivo y que entre otros usos también eran aprovechados para forraje y para el abono de la tierra (Ríos Rodríguez 1997), y puede que se privilegiara este uso frente a su consumo como combustibles debido a la poca importancia que tienen en el conjunto estos taxones.

Es significativa también la importancia, tanto a nivel porcentual como por ubicuidad, de las muestras de taxones frutales silvestres y cultivados, tanto aquellos de porte arbóreo como los de porte arbustivo (Corylus avellana, Castanea sativa, Prunus sp., Rosaceae/Maloideae, Sambucus sp. y Juglans regia). A pesar de que algunas de estas especies pueden aparecer asociadas a los bosques mixtos de planocaducifolios (Corylus avellana, Sambucus sp.), hay otros que podemos agrupar dentro de la categoría de árboles fuera del bosque, tanto por su vinculación a prácticas de arboricultura como a su relevancia económica para estas comunidades: Castanea sativa, Prunus sp., Rosaceae/Maloideae y Juglans regia. Los árboles fuera del bosque serían aquellos que crecen próximos a las áreas de habitación y fuera de las masas boscosas. Este término es un neologismo que se define en relación al bosque y por defecto, agrupando a los árboles localizados en tierras que no pertenecen a la categoría de bosques o tierras forestales, ni a otras áreas boscosas, que pueden ser espontáneas o plantadas, generalmente cultivadas y conservadas (Bellefontaine et al. 2002: 2, Kleinn 2002: 74, 2000: 4). Se encuentran en tierras agrícolas, con construcciones, en los márgenes de los ríos o arroyos dentro del paisaje agrícola, o en tierras naturales en las que la cobertura arbórea es tan escasa que la vegetación no cumple con la definición de bosque (Kleinn 2002: 74). Esta categoría de clasificación es especialmente interesante para este momento en el que las fuentes distinguen entre lo culto y lo inculto, estando el bosque -silvae, montae, pascuae - en esta última categoría, mientras que este otro tipo de formaciones forestales eran manejadas y cultivadas como los soutos, las devesas, los pomares, los avellanales, etc. (Ríos Rodríguez 1997).

El castaño (Castanea sativa) es junto con la vid uno de los principales cultivos en los terrenos baldíos desde la Edad Media (López-Sabatel 2009). La expansión a gran escala de Castanea está documentada en diversos análisis polínicos del noroeste peninsular desde la Edad Media (Santos et al. 2000, López-Sáez et al. 2003), en una tendencia que tiene paralelos en otras áreas europeas (Conedera et al. 2004). El castaño estaba integrado en las tierras cultivadas, mezclado con todo tipo de cultivos, apareciendo referencias a este árbol en la documentación, con una presencia predominante en el paisaje agrario (Ríos Rodríguez 1997). Las castañas constituían un aporte nutritivo básico y el castaño era incluso objeto de sucesión testamentaria, su madera se utilizaba para la construcción de aperos, muebles domésticos y trabajos artesanales, y su leña se consumía en los hogares, hornos y cocinas (López-Sabatel 2009). De hecho, ciertos pagos en especie referidos en las fuentes documentales se refieren directamente a tareas de los foreros relacionadas con la arboricultura, como la poda y el injerto del castaño (López-Sabatel 2011).

Frente al castaño y a otros árboles frutales como nogales, higueras, manzanos, perales, cerezos, etc., el roble tiene en las referencias documentales una importancia secundaria (López-Sabatel 2009) a pesar de ser el combustible predominante en todo tipo de asentamientos durante la época medieval y moderna (tab. 6). La presencia de madera de frutales, si tenemos además en cuenta el calibre de la leña consumida, que sería de mediano a pequeño calibre, podría estar relacionada con el aprovechamiento de los residuos de poda como combustible. En el caso de determinados taxones, como los manzanos y los perales (Rosaceae/Maloideae) o los cerezos (Prunus sp.), probablemente procedían de árboles y arbustos situados en el entorno inmediato al lugar de habitación (cortiñas), ya que sus frutos no podían ser almacenados y tenían que ser consumidos de forma casi inmediata (López-Sabatel 2009). La presencia de madera de Prunus sp. es también relevante. A pesar de que no es excesivamente significativa a nivel porcentual, es un taxon que suele aparecer de forma recurrente en el registro antracológico asociado a contextos de cronología medieval y moderna en el norte peninsular (Allué 2003, Teira et al. 2011, Ruiz-Alonso et al. 2012). También se han documentado de forma recurrente conjuntos de semillas de Prunus avium/cerasus en contextos de época medieval del noroeste peninsular (Teira 2013, 2015; Peña-Chocarro et al. 2019).

Con respecto a la pregunta de quién realizó el aprovisionamiento de la leña consumida en el interior del castillo de Pambre, las fuentes textuales nos indican que las prestaciones en trabajo derivadas de la expresión de señoría, que incluían la recolección de leña en el monte, además de otras tareas agrícolas o exigencias de trabajos sobre infraestructuras, y que eran habituales desde el siglo $\mathrm{X}$ y hasta la segunda mitad del siglo XIII, fueron cada vez menos frecuentes, y a mediados del siglo XIV prácticamente no se encuentra referencia a las mismas (López-Sabatel 2011). La ausencia de 
Tabla 7. Comparación de los datos antracológicos obtenidos en contextos medievales y modernos del noroeste ibérico.

\begin{tabular}{|c|c|c|c|c|c|c|c|c|}
\hline & \multicolumn{2}{|c|}{ Cova Eirós } & \multicolumn{2}{|c|}{ Peñaferruz } & \multicolumn{2}{|c|}{ Pambre } & \multicolumn{2}{|c|}{ Mourela } \\
\hline Tipo de sitio & \multicolumn{2}{|c|}{ Cueva } & \multicolumn{2}{|c|}{ Castillo } & \multicolumn{2}{|c|}{ Castillo } & \multicolumn{2}{|c|}{ Rural } \\
\hline Cronología & \multicolumn{2}{|c|}{ s. X-XI } & \multicolumn{2}{|c|}{ s. IX-XIII } & \multicolumn{2}{|c|}{ s. XV-XVII } & \multicolumn{2}{|c|}{ s. XIV-XVII } \\
\hline Taxones & $\mathrm{N}^{\mathrm{o}}$ & $\%$ & $\mathrm{~N}^{\mathrm{o}}$ & $\%$ & $\mathrm{~N}^{\mathrm{o}}$ & $\%$ & $\mathrm{~N}^{\mathrm{o}}$ & $\%$ \\
\hline Quercus sp. caducifolio & 15 & 14,2 & 181 & 60,0 & 485 & 60,2 & 887 & 76,9 \\
\hline Corylus avellana & 2 & 1,9 & 26 & 8,6 & 100 & 12,5 & - & - \\
\hline Castanea sativa (y cf.) & 3 & 2,8 & 13 & 4,3 & 40 & 5,0 & - & - \\
\hline Fabaceae (y cf.) & 4 & 3,8 & 17 & 5,6 & 36 & 4,5 & 23 & 2,0 \\
\hline Prunus sp. & 1 & 0,9 & 2 & 0,7 & 31 & 3,8 & - & - \\
\hline Erica sp. (y cf.) & - & - & - & - & 30 & 3,7 & 220 & 19,1 \\
\hline Rosaceae/Maloideae (y cf.) & 15 & 14,2 & 10 & 3,3 & 19 & 2,4 & 18 & 1,5 \\
\hline Salix/Populus & 29 & 27,6 & - & - & 9 & 1,1 & - & - \\
\hline Quercus/Castanea & - & - & - & - & 9 & 1,1 & - & - \\
\hline Juglans regia & - & - & - & - & 7 & 0,9 & - & - \\
\hline Quercus sp. perennifolio & - & - & 1 & 0,3 & 3 & 0,4 & - & - \\
\hline Fraxinus sp. (y cf.) & 6 & 5,7 & - & - & 2 & 0,2 & - & - \\
\hline Quercus sp. & - & - & - & - & 2 & 0,2 & - & - \\
\hline Sambucus sp. & - & - & 1 & 0,3 & 1 & 0,1 & - & - \\
\hline Frangula alnus & - & - & - & - & 1 & 0,1 & - & - \\
\hline Juniperus sp. & - & - & - & - & 1 & 0,1 & - & - \\
\hline Erica arborea/australis & - & - & - & - & 1 & 0,1 & - & - \\
\hline Ulmus sp. & 7 & 6,6 & 1 & 0,3 & - & - & - & - \\
\hline Arbutus unedo & 1 & 0,9 & 3 & 1,0 & - & - & - & - \\
\hline Betula sp. & 22 & 20,9 & 1 & 0,3 & - & - & 2 & 0,2 \\
\hline Fagus sylvatica & - & - & 14 & 4,6 & - & - & - & - \\
\hline Laurus nobilis & - & - & 1 & 0,3 & - & - & - & - \\
\hline Ilex aquifolium & - & - & - & - & - & - & 4 & 0,3 \\
\hline Corteza & - & - & - & - & 24 & 3,0 & - & - \\
\hline Indeterminable & - & - & 11 & 3,6 & - & - & - & - \\
\hline Total & 105 & 100 & 302 & 100 & 806 & 100 & 1154 & 100 \\
\hline
\end{tabular}

galerías de insectos xilófagos indicaría que la leña probablemente no era almacenada durante mucho tiempo, mientras que el predominio de la madera de mediano y pequeño calibre obtenida del bosque de robles, así como de los árboles fuera del bosque, podría estar relacionado con las restricciones destinadas a proteger el bosque y determinados árboles (Carlé 1976), así como con el aprovechamiento de los restos de la poda como 
leña. La escasa importancia de la leña obtenida de las especies de matorral sí podría indicar que no se aprovisionan en los espacios comunales de monte más que de forma puntual, o que los matorrales eran utilizados de forma prioritaria para la obtención de forraje para el ganado y abono para los campos de cultivo (Ríos Rodríguez 1997).

La legislación proteccionista sobre bosques y árboles (Carlé 1976), así como el retroceso del bosque, que es acusado en este momento tal y como está documentado en diferentes secuencias palinológicas del noroeste peninsular (Martínez-Cortizas et al. 2000, Santos et al. 2000, Desprat et al. 2003, López-Sáez et al. 2003, Martínez-Cortizas et al. 2005, López-Merino et al. 2014, Silva-Sánchez et al. 2014), puede ser el motivo de que haya una gran diversificación en el aprovisionamiento, incluyendo árboles frutales, y una preferencia por leña de mediano a pequeño calibre, obtenido probablemente de ramas de mediano y pequeño tamaño, frente a la preferencia por madera de gran calibre que implicaría abatir árboles. El uso de las ramas, incluyendo en algunos casos la posibilidad de la existencia de prácticas como el desmoche, el trasmoche o el clareo, permitiría asegurar una renovación cíclica de los recursos, o el aprovechamiento de los residuos de la poda en el caso de los frutales. El uso preferente de leña de pequeño calibre tendría probablemente implicaciones en lo que respecta a la organización y estacionalidad de este aprovisionamiento, así como incluso respecto al tipo de herramientas utilizadas, fundamentalmente podones frente al uso de hachas.

Si comparamos los datos obtenidos en Pambre con otros contextos de época medieval y moderna del noroeste peninsular, podemos observar cómo durante todo este período parece existir una preferencia por la madera obtenida a partir del roble y otras especies caducifolias de Quercus y cómo la importancia de lo que podemos clasificar como árboles fuera del bosque se mantiene durante todo el período (tab. 7). El uso de la madera de Castanea como leña se documenta tanto en la ocupación en cueva de Cova Eirós (Teira et al. 2011) como en el castillo de Curiel en Peñaferruz (Allué 2003). A pesar de que en este último contexto también se documenta una cierta variabilidad taxonómica, la diversidad de taxones documentada en Pambre destaca sobre el conjunto. Esto puede estar condicionado por diferentes factores, por una parte con la propia organización de la recolección de la leña, pero por otra parte tampoco sería descartable que el tipo de contexto en el que las muestras fueron recuperadas, que acumularía combustiones realizadas durante un período de tiempo indeterminado, haya contribuido a esta diversidad. Las diferencias son acusadas cuando comparamos los datos de Pambre con los de A Mourela (Martín-Seijo et al. 2009, 2010), un asentamiento rural relacionado con una explotación pastoril de un área de monte. Esta diferencia nos llevaría a plantear la posibilidad de que existiera un acceso diferencial a los recursos forestales en uno y otro caso, más allá de aquellas diferencias que puedan derivar de los recursos disponibles en el entorno de cada asentamiento y del carácter permanente o temporal de la ocupación. Estas diferencias entre ambos podrían indicar que en el castillo existía un acceso a un mayor número de formaciones arbóreas y arbustivas en las que podía ser recolectada leña, frente a A Mourela donde únicamente se documenta el consumo de leña del bosque de caducifolios, fundamentalmente roble, y de especies de matorral.

\section{CONCLUSIONES}

El análisis antracológico de las muestras de carbón recuperadas en Pambre nos ha permitido obtener información directa sobre el tipo de leña utilizado en este castillo entre los siglos XV y XVII. Este análisis contribuye a aumentar el conocimiento que hasta el momento teníamos sobre el uso de los recursos vegetales durante el final de la Edad Media y el inicio de la Edad Moderna, tanto a partir del registro arqueobotánico como a partir de las fuentes escritas. Estos resultados son especialmente significativos porque los únicos datos de estas cronologías provenían de un asentamiento rural relacionado con actividades pastoriles, mientras que en el caso de Pambre los carbones analizados son probablemente los residuos de la leña quemada para procesar alimentos, o para la calefacción e iluminación de las estancias.

Los resultados obtenidos permiten documentar un aprovechamiento de los recursos leñosos mucho más complejo que lo registrado en las fuentes, y que lo documentado en otros sitios arqueológicos con cronologías similares. Se documenta una gran diversidad taxonómica en la que la mayor parte de la leña fue probablemente obtenida de las formaciones de planocaducifolios y de los árboles fuera del bosque, mientras que la importancia de las especies obtenidas en las formaciones de matorral es poco significativa. La principal madera consumida como leña es el roble (Quercus sp. caducifolio), seguido del avellano (Corylus avellana) y del castaño (Castanea sativa). En todos los casos predomina la madera de pequeño a mediano calibre 
obtenida a partir de especies que producen frutos comestibles, lo que podría estar indicando un aprovechamiento de los residuos de la poda. No se documentan evidencias de consumo de leña muerta o de almacenaje en condiciones favorables para el ataque de microorganismos. La presencia de grietas cortas y numerosas en algunos de los fragmentos de carbón podría apuntar incluso al consumo de madera verde o húmeda. El escaso peso que en el conjunto tienen taxones como Fabaceae o Erica spp. podría estar indicando que probablemente estas plantas se están utilizando con otros fines.

\section{Agradecimientos}

La investigación realizada por María Martín-Seijo ha sido financiada por una beca postdoctoral Plan I2C mod. B con el proyecto "MATERIAL-Materiality and Material Culture: Wood and Other Plant-based Materials in Archaeological Contexts". La intervención arqueológica realizada en el castillo de Pambre fue dirigida por Santiago Vázquez Collazo y financiada por la Secretaría Xeral para o Turismo de la Consellería de Presidencia de la Xunta de Galicia. Los autores quieren expresar su agradecimiento a Carlos Fernández Rodríguez de la Universidad de León, que se encargó de la recogida y procesado de las muestras. El análisis antracológico se llevó a cabo en el Laboratorio de Arqueobotánica del Grupo de Estudos do Noroeste Ibérico-Arqueología, Antigüidade e Territorio (GEPN-AAT) de la Universidade de Santiago de Compostela.

\section{BIBLIOGRAFÍA}

Allué, E. (2003): “Antracología”, en J.A. Gutiérrez (ed.). Peñaferruz (Gijón): el castillo de Curiel y su territorio: 375-381. Gijón, Ayuntamiento de Gijón/ Vtp Editorial.

Amigo, J.; Rodríguez-Guitián, M.A.; Honrado, J.J.P. y Alves, P. (2017): "The Lowlands and Midlands of Northwestern Atlantic Iberia", en J. Loidi (ed.), The Vegetation of the Iberian Peninsula: 191-250. Berlín, Springer. doi: <https://doi.org/10.1007/978-3319-54784-8>.

Aragón-Ruano, Á. (2001): "El bosque guipuzcoano en la Edad Moderna: aprovechamiento, ordenamiento legal y conflictividad". Munibe. Suplemento 14: $1-285$.

Aragón-Ruano, Á. (2009): "Una longeva técnica forestal: los trasmochos o desmochos guiados en
Guipúzcoa durante la Edad Moderna". Espacio, Tiempo y Forma, Serie IV, Historia Moderna 22: 73-105. doi: <https://doi.org/10.5944/etfiv.22.2009.1609>.

Armas Castro, J. (1992): Pontevedra en los siglos XII a XV. Configuración y desarrollo de una villa marinera en la Galicia medieval, Pontevedra. A Coruña, Fundación Barrié de la Maza.

Bellefontaine, R.; Petit, S.; Pain-Orcet, M.; Deleporte, Ph. y Bertault; J.-G. (2002): Los árboles fuera del bosque. Hacia una mejor consideración. Guía FAO Conservación 35. Roma, FAO.

Blanchette, R.A. (2000): "A review of microbial deterioration found in archaeological wood from different environments". International Biodeterioration \& Biodegradation 46 (3): 189-204.

Burri, S. (2010): "Le problème de la mobilité des artisans, pasteurs et usagers de l'incultum en basseProvence centrale (XIIe-XVIe siècle)". Migrations et mobilités au Moyen Âge. Histoire ancienne et médiévale 104: 131-136.

Burri, S. (2018): "Chapter 8: Ancient forest and oldgrowth forest from the perspective of medieval and modern written sources. The case of the 'Bois de la Sainte-Baume' (France, AD late 13th to early 19th centuries)", en S. Paradis-Grenouillet, S. Burri y Ch. Aspe (eds.), Into the woods. Overlapping perspectives on the history of ancient forests: 99-110. Versailles Cedex, Quae.

Carlé, M. C. (1976): "El bosque en la Edad Media (Asturias-León-Castilla)". Cuadernos de Historia de España 59: 297-375.

Carrión, Y. (2005): La vegetación mediterránea y atlántica de la península Ibérica. Nuevas secuencias antracológicas. Servicio de Investigación Prehistórica, 104. Valencia, Diputación Provincial de Valencia.

Cartwright, C.R. (2015): “The principles, procedures and pitfalls in identifying archaeological and historical wood samples". Annals of Botany 116 (1): 1-13. doi: 10.1093/aob/mcv056

Conedera, M.; Krebs, P.; Tinner, W.; Pradella, M. y Torriani, D. (2004): "The cultivation of Castanea sativa (Mill.) in Europe, from its origin to its diffusion on a continental scale". Vegetation History and Archaeobotany 13 (3): 161-179.

Costa, M.; Morla, C. y Saínz, H. (2001): Los bosques ibéricos. Una interpretación geobotánica. Barcelona, Editorial Planeta.

Cubero, C. (2011): "Woody plant resources in the medieval site of l'Esquerda (Roda de Ter, Barcelona, Spain)". Saguntum Extra 11: 171-172. 
Deforce, K.; Boeren, I.; Adriaenssens, S.; Bastiaens, J.; De Keersmaeker, L.; Haneca, K.; Tys, D. y Vandekerkhove, K. (2013): "Selective woodland exploitation for charcoal production. A detailed analysis of charcoal kiln remains (ca. 1300-1900 AD) from Zoersel (northern Belgium)". Journal of Archaeological Science 40 (1): 681-689. doi: <https://doi. org/10.1016/j.jas.2012.07.009>.

Desprat, S.; Goñi, M.F. y Loutre, M.F. (2003): “Revealing climatic variability of the last three millennia in northwestern Iberia using pollen influx data". Earth and Planetary Science Letters 213: 63-78. doi: $10.1016 / \mathrm{S} 0012-821 \mathrm{X}(03) 00292-9$

Devia, C. (2015). "El bosque medieval y el derecho de resistencia de los dominados". Cuadernos Medievales (18): 39-51.

Domínguez-Delmás, M.; van Daalen, S.; AlejanoMonge, R. y Wazny, T. (2018): “Timber resources, transport and woodworking techniques in post-medieval Andalusia (Spain): Insights from dendroarchaeological research on historic roof structures". Journal of Archaeological Science 95: 64-75. doi: $<$ https://doi.org/10.1016/j.jas.2018.05.002>.

Estrella, J. R. y Asla, A. (2010): "El aprovisionamiento de leña en las ciudades de la Baja Edad Media Hispánica”. Estudios de Historia de España 12 (1): 185-200.

Euba, I. (2008): Análisis antracológico de estructuras altimontanas en el Valle de La Vansa-Sierra del Cadi (Alt Urgell) y en el Valle del Matriu (Andorra): explotación de recursos forestales del Neolitico a la época moderna. Tesis doctoral, Universitat Rovira i Virgili, Tarragona. Inédita.

Euba, I. (2009): "La vegetación leñosa y el uso de la madera en tres valles de los Pirineos orientales desde el Neolítico hasta época moderna: análisis antracológico, dendrológico y tafonómico". Pyrenae 40 (2): 7-35.

Euba, I. (2010): "L'exploitation des ressources végétales dans les Pyrénées Orientales durant l'Holocène: analyse anthracologique des structures d'élevage, de fours et de charbonnières dans l'Alt Urgell (Chaîne du Cadí) et la Vallée du Madriu (Andorre)". Quaternaire 21 (3): 305-316. doi: <https:// doi.org/10.4000/quaternaire.5646>.

Euba, I.; Allée, P.; Rouaud, R. y Paradis-Grenouiller, S. (2011): "Metallurgy and forest landscapes from the Gallo-Roman to the Modern Period in Périgord-Limousin (France)". SAGVNTVM Extra 11: 197-198.

Fagan, B. (2008): La pequeña Edad del Hielo. Cómo el clima afectó a la historia de Europa 1300-1850. Barcelona, Gedisa.
Fernández-Cortizo, C. (2016): "La pequeña edad de hielo en Galicia: estado de la cuestión y estudio histórico". Obradoiro de Historia Moderna 25: 9-39.

Fohrer, F.; Toriti, M. y Durand, A. (2017): “Analyse des vermoulures pour la détermination de quelques espèces d'insectes xylophages de la famille des Ptinidae (Coleoptera)". Bulletin de la Société Entomologique de France 122 (2): 133-142.

Fossier, R. (2017): Gente de la Edad Media. Madrid, Ed. Taurus.

Franco-Rubio, G. (2009): "La vivienda en el Antiguo Régimen: de espacio habitable a espacio social". Chronica Nova 35: 63-103.

Gale, R. y Cutler, D. (2000): Plants in Archaeology. Identification manual of vegetative plant materials used in Europe and the southern Mediterranean to c. 1500. Kew, Westbury and Royal Botanic Gardens.

Gomes, R.V. y Gomes, M.V. (2016): A Gestão dos Recursos Florestais Portugueses na Construção $\mathrm{Na}$ val da Idade Moderna. Lisboa, Pórtico.

González-Pérez, C. (1994): A producción tradicional do ferro en Galicia: as grandes ferrerías da provincia de Lugo. Lugo, Servicio de Publicacións-Deputación Provincial de Lugo.

Guitián Rivera, L. (2001): "La destrucción histórica del bosque en Galicia". SEMATA, Ciencias Socials e Humanidades 13: 105-166.

Hather, J.G. (2000): The Identification of the Northern European Woods. A guide for archaeologists and conservators. London, Archetype Publications.

Hazell, Z.; Crosby, V.; Oakey, M. y Marshall, P. (2017): "Archaeological investigation and charcoal analysis of charcoal burning platforms, Barbon, Cumbria, UK". Quaternary International 458: 178-199. doi: $<$ https://doi.org/10.1016/j.quaint.2017.05.025>.

Hickin, N.E. (1963): The insect factor in wood decay. London, Hutchinson \& Co. Ltd.

Huntley, J. (2010): Northern England: A review of wood and charcoal recovered from archaeological excavations in northern England. Londres, English Heritage.

Kleinn, C. (2002): “¿Árboles fuera del bosque?”. Revista Forestal Centroamericana 37: 74.

Knapp, H.; Nelle, O.; y Kirleis, W. (2015): "Charcoal usage in medieval and modern times in the Harz Mountains Area, Central Germany: Wood selection and fast overexploitation of the woodlands". Quaternary International 366: 51-69. doi: <https://doi. org/10.1016/j.quaint.2015.01.053>. 
Lancelotti, C.; Madella, M.; Ajithprasad, P. y Petrie, C.A. (2010): "Temperature, compression and fragmentation: an experimental analysis to assess the impact of taphonomic processes on charcoal preservation". Archaeological and Anthropological Sciences 2 (4): 307-320. doi: <https://doi.org/10.1007/ s12520-010-0046-8>.

Le Goff, J. (2002): La civilización del Occidente medieval. Barcelona, Paidós.

Leonardi, G. (2002): "Le indagini sulle carbonaie di Vobbia, Castello della Pietra: un'esperienza didattica dell'Università di Genova'. Archeologia Postmedievale 6: 145-154.

López-Merino, L.; Cortizas, A. M.; Reher, G. S.; López-Sáez, J. A.; Mighall, T. M. y Bindler, R. (2014): "Reconstructing the impact of human activities in a NW Iberian Roman mining landscape for the last 2500 years". Journal of Archaeological Science 50: 208-218. doi: <https://doi.org/10.1016/j. jas.2014.07.016>.

López-Sabatel, J. A. (2009): "Uso y transformación en espacio agrario del monte y del estrato arbóreo en la Ribeira Sacra durante los siglos XIV y XV". Cuadernos de Estudios Gallegos, 56 (122): 213-233.

López Sabatel, J. A. (2011): "Rentas y exigencias feudales en la tierra de Lemos durante la Baja Edad Media (siglos XIV y XV)". Anuario de Estudios Medievales 41(1): 211-234.

López-Sáez, J.A.; Parcero, C.; Lima, E.; López, P.; Criado, F.; Macías, R.; Martínez-Cortizas, A. y Franco, S. (2003): "Paleopaisajes concretos: polen, suelos y arqueología del yacimiento de As Pontes (Abadín, Lugo)". Trabajos de Prehistoria 60 (1): 139-151.

Ludemann, T.; Michiels, H. G. y Nölken, W. (2004): "Spatial patterns of past wood exploitation, natural wood supply and growth conditions: indications of natural tree species distribution by anthracological studies of charcoal-burning remains". European Journal of Forest Research 123 (4): 283-292. doi: <https://doi.org/10.1007/s10342004-0049-z>

Manrique, E. y Fernández-Cancio, A. (2000): "Extreme climatic events in dendroclimatic reconstructions from Spain". Climatic Change 44: 123-138. doi: <https://doi.org/10.1023/A:1005458018568>.

Marguerie, D. y Hunot, J.Y. (2007): “Charcoal analysis and dendrology: data from archaeological sites in north-western France". Journal of Archaeological Science 34 (9): 1417-1433. doi: <https://doi. org/10.1016/j.jas.2006.10.032>.
Martín-Seijo, M. (2013): A xestión do bosque e do monte dende a Idade do Ferro a época romana no noroeste da península Ibérica: consumo de combustibles e produción de manufacturas en madeira. Tesis Doctoral, Universidad de Santiago de Compostela. Inédita.

Martín-Seijo, M.; Alles, M.J. y Abad, E. (2009): “Análise dos carbóns arqueolóxicos", en A. Bonilla y R. Fábregas (eds.), Círculo de engaños: Excavación del cromlech de A Mourela (As Pontes de García Rodríguez, A Coruña): 163-175. Santiago de Compostela, Andavira.

Martín-Seijo, M.; Antolín, F.; Alonso, N.; Fábregas, R. y Bonilla, A. (2010): "Prácticas agrícolas y gestión del combustible en el monte gallego entre los siglos VII y XVII. El caso de A Mourela (As Pontes, A Coruña)", en A. M. S. Bettencourt, M. I.C. Alves y S. Monteiro-Rodrigues (eds.), Variações paleoambientais e evolução antrópica no Quaternário do Ocidente peninsular: 159-170. Braga, APEQ \& CITCEM.

Martín-Seijo, M.; Sartal Lorenzo, M.; Kaal, J. y TeiraBrión, A. (2018): “A Multi-Disciplinary Study of Woodcrafts and Plant Remains that Reveals the History of Pontevedra's Harbour (Northwest Iberia) Between the 13th and 19th Centuries AD". Environmental Archaeology doi: <https://doi.org/10.1 080/14614103.2018.1522782>.

Martínez-Cortizas, A.; Fábregas Valcarce, R. y Franco Maside, S. (2000): "Evolución del paisaje y actividad humana en el área de Monte Penide (Redondela, Pontevedra): Una aproximación metodológica". Trabajos de Prehistoria 57 (1): 173-184.

Martínez-Cortizas, A.; Mighall, T.; Pontevedra Pombal, X.; Novoa Muñoz, J.C.; Peiteado Varela, E. y Piñeiro, R. (2005): "Linking changes in atmospheric dust deposition, vegetation change and human activities in northwest Spain during the last 5300 years". The Holocene 15 (5): 698-706. doi: $<$ https://doi.org/10.1191/0959683605hl834rp>.

Martínez-Cortizas, A.; Pontevedra-Pombal, X.; García-Rodeja, E.; Novoa-Múñoz, J.C. y Shotyk, W. (1999): "Mercury in a Spanish peat bog: archive of climate change and atmospheric metal deposition". Science 284: 939-942. doi: <https://doi. org/10.1126/science.284.5416.939>.

McParland, L.C.; Collinson, M.E.; Scott, A.C.; Campbell, G. y Veal, R. (2010): "Is vitrification in charcoal a result of high temperature burning of wood?". Journal of Archaeological Science 37: 2679-2687. $<$ https://doi.org/10.1016/j.jas.2010.06.006>. 
Mira, J. A.; Carrión, Y. C.; Morales-Pérez, J. V. y Ortega, J. R. (2017): "Nuevas aportaciones sobre el aprovechamiento faunístico y vegetal en el Castell de Castalla (Alicante, España) durante los siglos XI-XV". Arqueología y Territorio Medieval 24: 291-330.

Moskal-del Hoyo, M.; Wachowiak, M. y Blanchette, R.A. (2010): "Preservation of fungi in archaeological charcoal". Journal of Archaeological Science 37 (9): 2106-2116. doi: <https://doi.org/10.1016/j. jas.2010.02.007>.

Ntinou, M.; Badal, E.; Carrión, Y.; Fueyo, J. L.M.; Carrión, R. F. y Mira, J. P. (2013): "Wood use in a medieval village: the contribution of wood charcoal analysis to the history of land use during the 13th and 14th centuries a. d. at Pobla d'Ifach, Calp, Alicante, Spain". Vegetation History and Archaeobotany 22 (2): 115-128. doi: <https://doi.org/10.1007/ s00334-012-0349-z>.

Oliva, M.; Ruiz-Fernández, J.; Barriendos, M.; Benito, G.; Cuadrat, J. M.; Domínguez-Castro, F.; GarcíaRuiz, J.M.; Giralt, S.; Gómez-Ortiz, A.; Hernández, A.; López-Costas, O.; López-Moreno, J.I.; LópezSáez, J.A.; Martínez-Cortizas, A.; Moreno, A.; Prohom, M.; Saz, M.A.; Serrano, E.; Tejedor, E.; Trigo, R.; Valero-Garcés, B. y Vicente-Serrano, S.M. (2018): "The Little Ice Age in Iberian mountains". Earth-Science Reviews 177: 175-208. doi: <https:// doi.org/10.1016/j.earscirev.2017.11.010>.

Pardo de Guevara y Valdés, E.; Otero Piñeyro Maseda, P. S. y García González-Ledo, X. A. (2012): “La huella de los primeros Ulloa en las torres y fortalezas de la "terra" de Ulloa". Castillos de España 164-165-166: 59-67.

Pastoreau, M. (2006): Una historia simbólica de la Edad Media occidental. Buenos Aires, Ed. Katz.

Peña-Chocarro, L.; Pérez-Jordà, G.; Alonso, N.; Antolín, F.; Teira-Brión, A.; Tereso, J. P.; Montes Moya, E.; Reyes, D. L. (2019): "Roman and medieval crops in the Iberian Peninsula: a first overview of seeds and fruits from archaeological sites". Quaternary International 499-A: 49-66. doi: <https://doi. org/10.1016/j.quaint.2017.09.037>.

Py, V. y Durand, A. (2010): "Évolution des écosystèmes et des pratiques agrosylvopastorales et minière pour la production de bois de feu dans le haut Champsaur et la haute Durance (France) de l'âge du Bronze ancien au XVIe siècle", en Archéologie de l'espace montagnard: confrontation d'expériences européennes, Archéologie de la montagne européenne, Actes de la table ronde internationale de
Gap: 283-292. Gap (2008), Paris, Ed. Errance, col. BiAMA 4

Ríos Rodríguez, M. L. (1997): “Transformación agraria. Los terrenos de monte y la economía campesina (s. XII-XIV)", en M.P. de Torres Luna, R.C. Lois González y P. Saavedra (coord.), Semata: Ciencias sociais e humanidades. Espacios Rurais e Sociedades Campesiñas 9: 145-172.

Rodríguez-Ariza, M.O. (1993): “Los procesos de formación y transformación del registro arqueológico en los estudios antracológicos", en F. Burillo (ed.), Procesos postdeposicionales. Arqueología Espacial 16-17: 371-390.

Rouco, J. (2017): "Las funciones de una fortaleza bajomedieval: el caso de Pambre". Cuadernos de Estudios Gallegos 64 (130): 167-197.

Ruiz-Alonso, M.; Azkarate, A.; Solaun, J. L. y Zapata, L. (2012): "Exploitation of fuelwood in Gasteiz (Basque country, northern Iberia) during the Middle Ages (7001200 AD). Wood and charcoal evidence for human and natural history". Saguntum Extra 13: 227-236.

Santos, L.; Vidal, J.R. y Jalut, G. (2000): "History of vegetation during the Holocene in the Courel and Queixa Sierras, Galicia, northwest Iberian peninsula". Journal of Quaternary Science 15 (6): 621-632. doi: <https:// onlinelibrary.wiley.com/doi/abs/10.1002/1099$1417 \% 28200009 \% 2915 \% 3 \mathrm{~A} 6 \% 3 \mathrm{C} 621 \% 3 \mathrm{~A} \% 3 \mathrm{~A}$ AID-JQS524\%3E3.0.CO\%3B2-L>.

Schweingruber, F.H. (1990): Anatomy of European Woods. An atlas for the identification of European trees, shrubs and dwarf shrubs. Stuttgart, Paul Haupt.

Schweingruber, F.H. (2007): Wood Structure and Environment. Berlín-Heidelberg, Springer Verlag.

Schweingruber, F.H. y Börner A. (2018): The Plant Stem: A Microscopic Aspect. Berlín-Heidelberg, Springer Verlag.

Schmidt, O. (2006): Wood and tree fungi. Berlín-Heidelberg, Springer Verlag.

Scipioni S. (2002): "Dati antracologici da due pratiche attuali: la produzione del carbone vegetale nelle alte valli Scrivia e Trebbia (Appennino Ligure)". Archeologia Postmedievale 6: 49-65.

Shigo, A.L. (1979): Tree decay an expanded concept. Agriculture Information Bulletin 419: 1-72.

Shigo, A.L. y Marx, H.G. (1977): Compartmentalization of decay in trees. Agriculture Information Bulletin 405: 1-73.

Silva-Sánchez, N.; Martínez Cortizas, A. y López-Merino, L. (2014): "Linking forest cover, soil erosion and mire hydrology to late-Holocene human 
activity and climate in NW Spain". The Holocene 24 (6): 714-725.

Teira, A. (2013): “Dentro y fuera del bosque. La gestión del Prunus avium/cerasus en época romana y medieval en el NW ibérico". ArkeoGazte 3: 99-115.

Teira, A. (2015): "Cultivos e froiteiras na Idade Media en Galicia. O conxunto carpolóxico da escavación do Banco de España (Santiago de Compostela)". Gallaecia: Revista de Arqueoloxía e Antigüidade 34: 209-226.

Teira, A.M.; Martín-Seijo, M.; De Lombera-Hermida, A.; Fábregas, R. y Rodríguez-Álvarez, X.P. (2011): "Archaeobotanical analysis in sedimentation deposits of Roman and Medieval pits in caves of NW Iberia. Cova do Xato and Cova Eirós (Lugo, Galicia, Spain).”. Saguntum Extra 11: 163-164.

Théry-Parisot, I. (2001): Économie des combustibles au Paléolithique: Expérimentation, taphonomie, anthracologie. París, CNRS.

Théry-Parisot, I. y Henry, A. (2012): "Seasoned or green? Radial cracks analysis as a method for identifying the use of green wood as fuel in archaeological charcoal". Journal of Archaeological Science 39: 381-388. doi: <https://doi.org/10.1016/j. jas.2011.09.024>.

Tolksdorf, J. F.; Elburg, R.; Schröder, F.; Knapp, H.; Herbig, C.; Westphal, T.; Schneider, B.; Fülling, A. y Hemker, C. (2015): "Forest exploitation for charcoal production and timber since the
12 th century in an intact medieval mining site in the Niederpöbel Valley (Erzgebirge, Eastern Germany)". Journal of Archaeological Science: Reports 4: 487-500. doi: <https://doi.org/10.1016/j. jasrep.2015.10.018>.

Toriti, M. (2018): Les bois ouvragés durant l'Antiquité et le Moyen Âge en Gaule: approches interdisciplinaires depuis la coupe du bois jusqu'à la conservation du patrimoine ligneux. Tesis doctoral, Université du Maine. Inédita.

Traoré, M. (2018): Potential biomarkers of provenance of the wood from iberian typology shipwrecks (15th to 17th centuries). Tesis doctoral, Universidade de Santiago de Compostela. Inédita.

Traoré, M.; Kaal, J. y Cortizas, A. M. (2017): "Potential of pyrolysis-GC-MS molecular fingerprint as a proxy of Modern Age Iberian shipwreck wood preservation". Journal of Analytical and Applied Pyrolysis 126: 1-13. doi: <https://doi. org/10.1016/j.jaap.2017.07.003>.

Warren, G.; McDermott, C.; O’Donnell, L. y Sands, R. (2012): "Recent excavations of charcoal production platforms in the Glendalough valley, Co. Wicklow". Journal of Irish Archaeology 21: 85-112.

Zutter, C. (2000): "Wood and plant-use in 17th-19th century Iceland: archaeobotanical analysis of Reykholt, Western Iceland". Environmental Archaeology 5 (1): 73-82. doi: <https://doi.org/10.1179/ env.2000.5.1.73>. 

Recensiones 

Montero, S. y García Cardiel, J. (coords.): Santuarios oraculares, ritos y prácticas adivinatorias en la Hispania Antigua. Serie Investigación 23. Ediciones Complutense, Madrid, 2019. ISBN 978-84-669-3604-0. 401 pp.

La obra colectiva Santuarios oraculares, ritos y prácticas adivinatorias en la Hispania Antigua es el resultado de un proyecto de investigación $\mathrm{I}+\mathrm{D}+\mathrm{i}$ del mismo nombre, desarrollado desde 2017 en la Universidad Complutense de Madrid bajo la dirección del Prof. Santiago Montero Herrero, máximo especialista español en adivinación, oráculos y el papel que estos ritos y prácticas desempeñan en la religión y la sociedad romanas, tema al que ha dedicado una gran parte de su producción científica. Él es uno de los coordinadores del libro, lo que supone un aval para su contenido, y en esta ocasión se le une el Dr. Jorge García Cardiel, de la Universidad Autónoma de Madrid, especialista en ideología, imaginario e identidad de los pueblos prerromanos de Iberia. El libro recoge las intervenciones realizadas en un seminario celebrado en la Universidad Complutense en diciembre de 2017, a las que se han añadido aportaciones de otros especialistas en las religiones antiguas de Hispania. En total son trece estudios más el prólogo (9-19) que sirve como presentación y declaración de intenciones. Aunque en él los coordinadores exponen un breve estado de la cuestión, lo que plantean es sobre todo un concepto de la adivinación como construcción cultural, uno de los medios desarrollados por los antiguos para comprender el mundo. Por lo tanto resulta un elemento fundamental de su racionalidad, con importantes implicaciones políticas desde el momento en que la voluntad de los dioses directamente comunicada a los hombres puede tanto legitimar las decisiones del poder, como cuestionarlas. Los pueblos hispanos de la Antigüedad no escapaban a este fenómeno. Sin embargo sus prácticas oraculares y adivinatorias han sido, hasta la fecha, escasamente estudiadas, limitándose a cuestiones muy puntuales y sin un tratamiento global. Esta carencia es la que tratan de paliar los impulsores del proyecto de investigación, quienes han seleccionado autores y temas del libro en función de los intereses del mismo.

El resultado es de una heterogeneidad asumida: más que de una visión de conjunto, se trata de un conjunto de visiones que a modo de mosaico componen una imagen amplia del fenómeno oracular en Hispania, incluyendo técnicas de adivinación "regladas", otras referidas a formas de consulta de la voluntad divina, presagios y prodigios más o menos espontáneos, en diferentes regiones y ámbitos culturales de la península ibérica y por extensión, del mundo mediterráneo y europeo. A pesar de ello y aunque no de manera explícita, se reconoce cierta organización de los contenidos en tres apartados: los primeros estudios están dedicados a los pueblos célticos tanto en la etapa previa como posterior a la conquista romana; les siguen los ámbitos ibérico y fenicio-púnico, y en tercer lugar se abordan las prácticas adivinatorias de la Hispania romana, con un capítulo final centrado en su transformación durante la etapa tardoantigua y cristiana que en cierto modo sirve de epílogo. La extensión de estas "secciones" es desigual en función de la información disponible y los casos estudiados. Puesto que cada trabajo cuenta con su propia bibliografía, muy abundante y actualizada en todos los casos, el libro se cierra únicamente con un índice común de citas de autores clásicos que resulta útil, aunque se echan de menos otros, por ejemplo de epígrafes o de nombres, que hubieran facilitado la consulta.

El bloque dedicado a oráculos y adivinación en la Hispania céltica comprende cinco textos. El de M. Almagro-Gorbea, "Sacra saxa y ritos populares de adivinación en la Hispania prerromana" (21-52), exhaustivamente documentado con una amplia variedad de ejemplos aunque demasiado dependiente de suposiciones y extrapolaciones, plantea una continuidad de claro trasfondo esencialista entre ritos de adivinación relacionados con las piedras -sacrificios sobre o ante rocas, guijarros que se arrojan a un determinado lugar de la piedra sagrada, amontonamientos deliberados de piedras con connotaciones funerarias- $y$ ritos populares contemporáneos en sociedades tradicionales, sobre todo de Galicia y Portugal. El fondo común serían creencias animistas remontables a la Prehistoria, en un "dios-piedra" del que se pretende propiciación mediante los sacrificios, además de adivinar su voluntad. El estudio de M. V. García Quintela, "Sacrificio y adivinación en el área galaico-lusitana de Iberia" (53-86), propone una arqueología del sacrificio elaborada a partir de inscripciones, imágenes de las que realiza un acertado análisis iconológico, lugares de culto excavados y textos. Esto resulta muy interesante desde el punto de vista metodológico, aunque no siempre es fácil determinar la relación directa con la adivinación propiamente dicha de algunas de las prácticas descritas. F. J. Fernández Nieto, con una metodología comparatista y etnográfica similar a la empleada 
por Almagro-Gorbea, analiza en "Plynteria celtica. La ceremonia lustral de San Beturián" (87-110) presuntas pervivencias pre- / protohistóricas en un rito propiciatorio popular contemporáneo que se celebra en la comarca de Sobrarbe (Huesca), relacionado con el agua de una fuente sagrada, que pretende atraer la lluvia en tiempos de sequía. En él identifica de manera muy convincente elementos de origen celta, pero también griegos, en particular el empleo de la piel de bóvido y el arca o cofre que contiene un cuerpo humano o sus restos. La unión entre estos elementos, en los ritos antiguos y modernos, es el gesto de cubrir el arca con la piel de buey antes de sumergirla en el agua, lo que debe atraer la lluvia fecundante. Insiste en la misma senda el trabajo de P. R. Moya-Maleno "Prácticas adivinatorias y creencias oraculares en la Hispania Céltica: aportaciones etnoarqueológicas" (111-152), planteado como una recopilación general de prácticas oraculares y adivinatorias propias de la Europa céltica: sacrificios, predicciones según el calendario, combates entre animales, plantas de diverso tipo y saxa sacra como formas de augurio; aves y otros animales y plantas como fuente de agüeros inesperados. Se ocupa además de las visiones y sueños, tanto espontáneos como provocados, y dedica un último apartado, muy breve por falta de información, a los oficiantes e intérpretes. Estos datos se extrapolan a los pueblos peninsulares ante la falta de documentación directa sobre los mismos, reconocida por el autor y ante la cual solicita una cautela que no siempre parece aplicarse en el texto. Por último, J. C. Olivares Pedreño recurre en "Algunas precisiones sobre los rituales de sacrificio y adivinación en la céltica hispana" (153-182) a la documentación arqueológica, para realizar un exhaustivo estudio de los sacrificios humanos y su relación con la guerra, tanto en sentido oracular como propiciatorio y en calidad de ofrenda tras la victoria. La última parte muestra otras prácticas como la observación de aves, los sacrificios animales y los sueños, descritas por los autores latinos de forma sospechosamente parecida a los equivalentes romanos, sugiere Olivares que como medio de "suavizarlas" para sus lectores.

Con los matices propios de cada tema y de los planteamientos de sus autores, estos cinco estudios se sustentan en una idea base común: la unidad cultural (y por tanto también religiosa) de los pueblos célticos hispanos y extrahispanos. Igualmente tropiezan con un mismo inconveniente: la escasez de fuentes explícitas. Los autores, en su mayoría especialistas procedentes del campo de la Historia Antigua, juegan sobre todo con textos de escritores grecolatinos que casi siempre presentan estas prácticas como muestras de la barbarie y primitivismo de las comunidades conquistadas por Roma, pero estos testimonios son muy pocos, y menos aún los específicos de Hispania. El resultado es que los mismos pasajes de Estrabón, Livio, Tácito o san Martín de Dumio salen a relucir una y otra vez, no siempre interpretados en el mismo sentido. Utilizando el método comparativo y recurriendo a los paralelos etnográficos, testimonios de prácticas como los sacrificios humanos vinculados a augurios bélicos o la consulta oracular a piedras sagradas, constatados en diferentes áreas de Europa y la cuenca mediterránea desde la Prehistoria hasta la época romana, se extrapolan a la Hispania antigua aunque no haya constancia directa de los mismos en territorio hispano. El resultado en conjunto es coherente, brillante en ocasiones, pero en otras también desprende cierta sensación de construcción artificial. Los capítulos más sólidos acaban siendo los que más recurren a los datos arqueológicos, de los que los autores hacen en su conjunto un uso relativamente limitado y que son los que proporcionan una información vinculada de forma más directa a las comunidades que pretenden analizar.

A partir del trabajo de J. García Cardiel, “Agentes locales y prácticas oraculares durante la conquista romana de Hispania: el caso de las comunidades ibéricas" (183-218), entramos en una breve sección que incluiría también el texto de R. Barroso Romero, "Nuevas señales divinas para tiempos de cambio. La función simbólica de la palmera en el prodigio de Munda" (233-252), aunque en el libro no se presenten estos dos estudios de manera consecutiva. En ambos casos el interés se extiende al área ibero-púnica de la Península, aunque sin abandonar por completo la tradición céltica, y en ambos la documentación arqueológica, en particular iconográfica, desempeña un papel de gran importancia. El primer autor repasa las imágenes ibéricas interpretables como prodigia de origen divino, las referencias en diversos exvotos ibéricos al mandato directo de los dioses y su frecuente relación con la diosa púnica Tanit-Caelestis, así como los santuarios oraculares de origen fenicio con especial interés por el de Hércules Gaditano. Destacan sus interpretaciones críticas de un fragmento de Estrabón alusivo a sacrificios humanos de carácter oracular en Lusitania (Str. 3.3.6), que el resto de los investigadores hasta ahora reseñados acepta como una de sus fuentes fundamentales. En cuanto al trabajo de Barroso, parte de un prodigio acaecido en vísperas de la batalla de Munda, el nacimiento milagroso de una palmera en la roca, que tuvo una intensa utilización política por parte de Roma. Sin embargo se retrotrae a los orígenes orientales de la palmera y los significados 
simbólicos asociados a la misma, evidenciados en diversas imágenes de la Iberia púnica que el autor considera escasas y vinculadas sobre todo a ambientes funerarios; una opinión discutible, en vista del frecuente uso de la palma y la palmeta como motivos decorativos con valor simbólico en contextos religiosos y cultuales de la península ibérica. La impresión final es que el prodigium de Munda en sí mismo es poco más que un punto de partida -ni siquiera se incluye la narración completa- para el desarrollo del auténtico tema. Ambos trabajos destacan el enorme poder simbólico de los "discursos adivinatorios" y su intensa utilización política durante el proceso de la conquista romana de Hispania, en favor de los intereses de una y otra parte.

Los seis estudios restantes se refieren básicamente al desarrollo de técnicas adivinatorias / oraculares romanas en Hispania, aunque en ocasiones se implanten sobre o se relacionen con otras similares de las diferentes tradiciones locales, ya explicadas en los trabajos anteriores. S. Perea Yébenes se ocupa en "Omina mortis para Decimus Laelius, legado de Pompeyo en Hispania (año 76)" (219-232) de los augurios nefastos, típicamente romanos, recibidos por este personaje durante la Guerra Sertoriana, contexto a su vez de otros prodigios como el protagonizado por el propio Sertorio y la cierva oracular, que se menciona también en capítulos anteriores. El peso del estudio recae en el análisis de una serie de textos, que narran la derrota de una legión pompeyana al mando del citado legado sin mencionar ningún elemento premonitorio. Este sería añadido $a$ posteriori quizás por Livio, para justificar una derrota aplastante excusando al Senado y al general en jefe, Pompeyo. S. Montero Herrero retoma uno de sus temas favoritos en "Aruspicina y arúspices en la Hispania romana" (253-292), tratando tanto los testimonios prerromanos de sacrificio animal con análisis de las vísceras, fundamentalmente púnicos e ibéricos, como los propiamente romanos. Se refiere a arúspices públicos y privados, a su probable origen local y a su regulación en la legislación colonial y municipal, comentando los dos únicos epígrafes hispanos que mencionan arúspices y la dificultad para interpretar con exactitud las referencias a los mismos en la literatura tardía cristiana. El exhaustivo análisis de los textos, y el esfuerzo del autor por evitar tanto los tópicos como la reiteración de temas ya tratados en el libro, incrementan el interés de este capítulo. El artículo de J. M. Abascal Palazón "Los testimonios epigráficos de auguracula y augures en las ciudades de la Hispania romana" (293-304), muy breve, constituye una útil recopilación de las inscripciones hispanas referidas expresamente a augures, depurándola de textos mal interpretados donde la abreviatura AVG. se refiere al culto imperial, pero no entra en el análisis de las mismas.

D. Serrano Ordozgoiti, autor de "Sueños e incubatio en la epigrafía hispana: las fórmulas ex visu y ex iussu" (305-342), se ocupa de un tema tan sugestivo como la comunicación directa entre los dioses y los devotos mediante visiones y sueños, espontáneos o deliberadamente buscados con la práctica de la incubatio. Se trata sobre todo de una recopilación inicial de datos que incluye tablas, porcentajes básicos y la descripción pormenorizada de unos pocos casos particularmente llamativos. En cambio no llega a un estudio de conjunto de las fórmulas epigráficas, de su significado, de los posibles vínculos con prácticas rituales comunes, o del carácter de los dioses implicados. El tono del texto evidencia a un investigador joven, que probablemente tendrá ocasión en estudios futuros de profundizar en cuestiones que aquí resultan un tanto confusas, en especial la distinción ente sueños / visiones con fines terapéuticos, augurios de futuro y reclamaciones de exvotos y monumentos por parte de dioses y difuntos insatisfechos. Igualmente deberá argumentar mejor la diferencia entre una incubatio "mediterránea" y otra "indígena", más allá del lugar de hallazgo del testimonio. El tema de este trabajo está directamente relacionado con el del siguiente, "La adivinación en los cultos egipcios: testimonios de incubatio en la Hispania romana", de A. González Romero (343-368). En este caso el interés del autor se restringe a los cultos de origen egipcio, en el mundo romano en general e hispano en particular, y su relación con la práctica del sueño oracular / adivinatorio, sea o no con fines terapéuticos; una cuestión -la del carácter sanador de Isis y Serapis y su actuación a través del sueño- en la que los investigadores no parecen haber alcanzado un acuerdo, como González Romero pone de relieve. Es interesante que insista en el escepticismo de la mayoría de los autores romanos acerca del carácter oracular de los sueños, un aspecto que el artículo anterior no menciona y que daría claves interesantes sobre el ambiente (social, cultural, etc.) que rodea esta forma de adivinación. El respeto del autor por sus predecesores en la investigación, evidente en la proliferación de citas textuales y la manera de referirse a ellos sistemáticamente como "profesores" (lo sean o no), no debe disuadirle de esta vocación crítica.

Como cierre de la obra, el capítulo de D. M. Escámez de Vera, "Evolución de la adivinación en la Hispania cristiana" (369-394), funciona como un epílogo acerca de continuidades y pervivencias. Destacan 
especialmente dos cuestiones. Por un lado, el cristianismo aplica a las prácticas adivinatorias romanas (y a toda la religión pagana en conjunto) los mismos argumentos denigratorios -reforzados por su atribución al demonio- que la religión oficial romana aplicaba tanto a la adivinación privada fuera de los cauces oficiales como a las religiones heterodoxas, cristianismo incluido. Este último asume ahora el papel de religión oficial que marca las pautas de lo correcto. Por otro, más que de supervivencia habría que hablar de una hibridación, donde acaba por hacerse difícil diferenciar entre rituales de diversos orígenes e incluso algunos de nueva creación, practicados por un bajo clero escasamente formado que conecta así fácilmente con sus feligreses de extracción más popular.

Habría sido deseable un mayor esfuerzo en las tareas de edición. Aunque el aspecto general es cuidado, las ilustraciones, muy reducidas y en blanco y negro, se ven oscurecidas por el tono crema del papel resultando a veces poco clarificadoras. Respetando el estilo particular de cada autor, revisarlo más a fondo de manera conjunta evitaría errores de puntuación, párrafos un tanto confusos (por ejemplo el segundo de la página 158) o repetitivos (como el segundo de la página 353), y hubiera permitido ajustar el texto a las nuevas recomendaciones de la RAE acerca de la acentuación de pronombres y adverbios, o las relativas al uso de las mayúsculas y minúsculas en nombres geográficos como el de nuestra península ibérica. Más grave resulta que se hayan dejado pasar algunas erratas como la producida en la página 324, donde al comenzar el estudio de las inscripciones que utilizan la fórmula ex iussu se utiliza por error ex visu, que es precisamente la que ha terminado de analizarse. En la página 358, nota 8 se restituye una inscripción dedicada a Serapis e Isis en Carthago Nova, añadiéndole una línea que no está en la publicación original que cita el autor y que además es contradictoria con la cronología propuesta. Las crecientes dificultades, sobre todo burocráticas y económicas pero también de plazos, que los investigadores sufrimos a la hora de publicar resultados se encuentran sin duda detrás de pequeños fallos como los comentados. Pese a todo, nos encontramos ante una obra muy estimable en conjunto que viene a cubrir, aunque sea en un aspecto muy concreto, un evidente vacío en la investigación sobre la religiosidad hispanorromana, poco abordada de manera global en los últimos tiempos.

Mercedes Oria Segura, Universidad de Sevilla, Departamento de Prehistoria y Arqueología c/ Doña María de Padilla s $/ \mathrm{n}^{\circ}$ 41004-Sevilla (España) Correo-e: oria@us.es D https://orcid.org/0000-0002-9017-7752, Researcher ID: <https://publons.com/ researcher/L-7862-2017>. 
Victor S. Gonçalves y Ana Catarina Sousa. Casas Novas, numa curva do Sorraia (no $6^{\circ}$ milénio a.n.e. e a seguir). Estudos \& Memorias 11, Centro de Arqueologia da Universidade de Lisboa. Faculdade de Letras da Universidade da Lisboa, 2018, ISBN 978-989-99146-6-7, 279p.

Las problemáticas asociadas al proceso de neolitización están siendo tratadas de manera muy extensa en la bibliografía de los últimos años, tanto en la península ibérica como en Europa en general. En ese sentido, el territorio portugués no ha quedado al margen de esta dinámica, produciendo un gran número de artículos en publicaciones indexadas, en congresos y de monografías arqueológicas. Esta última modalidad es digna de apreciar, pues cada vez se prodigan menos en el panorama general.

Esta monografía representa un jalón más en un largo camino iniciado ya hace casi 50 años por Jean Guilaine y Octavio da Veiga Ferreira (1970). Esos primeros datos, si bien representaron un antes y un después para analizar el proceso de neolitización en Portugal, se basaban en materiales con escaso o nulo contexto arqueológico. Por suerte y gracias a una gran labor de los neolitistas portugueses, esa dinámica ha cambiado, y mucho.

Los coordinadores de este trabajo, V.S. Gonçalves y A.C. Sousa, vienen de un largo currículo que les ha enfrentado sobre todo con contextos calcolíticos, aunque han excavado y publicado numerosos contextos anteriores, y también posteriores. En este caso, la excavación de Casas Novas se integra dentro de un ambicioso proyecto, ANSOR, de prospecciones e intervenciones en la cuenca del río Sorraia. Este tuvo un primer periodo de vigencia a inicios de la década de los 80 del siglo XX, para tener una mayor intensidad entre 2008 hasta 2015. Dos trabajos preliminares fueron recientemente publicados, uno sobre los materiales descontextualizados (Gonçalves 2009) y otro sobre los resultados preliminares de las dos campañas realizadas en el yacimiento (Gonçalves y Sousa 2015).

La presente obra está estructura en grandes bloques temáticos que organizan de manera adecuada la información presentada. Se inicia con dos capítulos de contexto de la localización del yacimiento y su contexto geomorfológico. Este es un aspecto crucial para entender el problema que tienen numerosos yacimientos de la región, incluido Casas Novas, respecto a la no conservación de materiales orgánicos o, al menos, a su mala conservación. Un segundo bloque se orienta hacia las problemáticas y estrategias de intervención del yacimiento. Uno de los puntos más interesantes es la realización de prospección geofísica (ante la dificultad de elegir las zonas de sondeo por la gran extensión donde afloraba material arqueológico). Esta técnica, poco utilizada en yacimientos del primer Neolítico, permitió documentar numerosas anomalías que, inicialmente, fueron interpretadas como estructuras de combustión y como posibles cabañas. Los sondeos arqueológicos posteriores permitieron determinar que, en efecto, los hogares estaban presentes, mientras que las cabañas eran en realidad zonas con sedimentos endurecidos alrededor de los primeros. Se completa el bloque con una explicación no muy extensa sobre el desarrollo general de las dos campañas arqueológicas de 2010 y de 2011.

Esta relativa falta de detalle se compensa totalmente a partir del tercer bloque, donde se analizan, por campañas, los diferentes niveles y estructuras documentados en cada sondeo. El aparejo gráfico que acompaña el capítulo, sobre todo aquel referido a las fotografías, es de una alta calidad y son muy representativas de un contexto geomorfológico particular del que no tenemos ejemplos en el lado oriental de la península. En cambio, algunas de las plantas y secciones de sondeos no lo son tanto y podrían haber sido obviadas o fusionadas para conseguir un menor número de figuras.

Se concluye este bloque con dos capítulos sobre las fases del yacimiento, donde se resumen la tipología de las estructuras (estructuras de combustión, fosas de deyección y posibles estructuras positivas con bloques) y los materiales. Por su parte, la lectura del uso-relación entre niveles queda algo más diluida al no presentarse proyecciones de material en asociación a secciones con estructuras o en plantas, para determinar zonas de uso o intensidad de ocupación.

El bloque 4 es uno de los más extensos de la monografía, con cerca de 80 páginas dedicadas al estudio tradicional y pormenorizado de los materiales arqueológicos, básicamente la industria lítica y la cerámica. Ambos conjuntos son de gran interés, aunque la colección del yacimiento es relativamente reducida (sobre todo la cerámica).

Acerca de la industria lítica, se considera que el sílex es exógeno al territorio inmediato y/o próximo, 
factor que deberá certificarse con el futuro trabajo de caracterización petrológica del conjunto de Casas Novas. La mayor parte del material carece de córtex, lo que hace proponer a los autores que este llegaría ya en núcleos configurados. Aparte de este primer paso de la cadena operativa, el resto de acciones técnicas sí parecen producirse en Casas Novas a partir del gran número de núcleos, restos de talla, tabletas de avivamiento, crestas, etc. La contextualización general de los conjuntos de transición mesolítico/neolítico es muy completa y se recurre a ella constantemente para ir comparando el conjunto analizado con el de otros yacimientos del centro y sur de Portugal. Sobre la industria retocada, realizada mayoritariamente sobre lámina, la colección es relativamente numerosa y predominan por su significación los geométricos (trapecios sobre todo), entre los que están ausentes los triángulos. Esta industria puede verse representada en todas sus categorías en quince figuras.

Aunque mucho menor en cuanto a cantidad, también es interesante el conjunto de elementos macrolíticos de Casas Novas, realizados sobre granito y sobre rocas metamórficas. En este se documentaría partes activas y pasivas de molinos y preformas de hachas/ azuelas.

El estudio cerámico es igualmente completo. La colección no es demasiado extensa y, tal como sucede en otros yacimientos al aire libre de hábitat estricto, se encuentra muy fragmentada; ello ha impedido profundizar tanto en la morfología y tamaño de los recipientes como en sus composiciones decorativas. En ese sentido es interesante resaltar el alto porcentaje de fragmentos decorados, casi la mitad del registro (cerca de 100 fragmentos), lo que contrasta con otras colecciones peninsulares. La mayor parte del conjunto cuenta con cerámicas impresas (cardial, boquique, impresiones diversas), aunque el grupo de decoraciones incisas es también relevante, mientras que la almagra y las composiciones mixtas son anecdóticas. El conjunto es bastante heterogéneo en cuanto a sus técnicas decorativas, por lo que sería interesante haber presentado la localización espacial del material y su relación con los niveles, estructuras y muestras datadas. Sin embargo, se considera como una unidad asociada a la ocupación más antigua del yacimiento $\mathrm{y}$, en ese marco, se incide de manera profunda y actualizada en la contextualización de este conjunto cerámico en el marco del proceso de neolitización de Portugal, enmarcándolo en las últimas teorías del oeste Mediterráneo. Además de la importancia de restos cardiales, se incide bastante en la presencia de decoraciones de punto-y-raya (boquique) y su combinación puntual con la técnica cardial, así como en su contextualización. Según los autores, a partir de ciertos paralelismos con dataciones, esta combinación sería un indicador de la antigüedad del registro de Casas Novas. Sin embargo, la presencia muy importante de otro tipo de decoraciones impresas (instrumento, uña, etc.), incisiones y acanalados dan la imagen de un registro más reciente, tal y como se puede advertir en numerosos yacimientos portugueses.

Hay que destacar de este bloque que la documentación gráfica es de muy buena calidad (sobre todo la fotográfica) y está representada en un número abundante.

El bloque 5 es uno de los puntos que despiertan mayor interés de esta monografía, puesto que cuatro hechos han sido referidos frecuentemente en este trabajo: la antigüedad del yacimiento, la mala conservación de la materia orgánica en el mismo, la naturaleza arenosa del contexto y la presencia de puntuales perturbaciones estratigráficas (trabajos agrarios, raíces, etc.).

Para Casas Novas se obtuvo un total de ocho dataciones radiocarbónicas de muestras tomadas en la campaña de 2011. En la anterior se documentó un tramo arqueológico más rico y representativo, pero los restos orgánicos estaban muy alterados (pulverizados). Las muestras (carbones, que no pudieron ser determinados a nivel taxonómico) estaban asociadas a estructuras de combustión, aunque no necesariamente en su interior como se desprende de la explicación de los resultados radiocarbónicos obtenidos. La numeración correlativa del laboratorio Beta Analytic permite deducir que fueron enviadas cuatro muestras en dos tandas diferentes. En la primera se obtuvieron dataciones del Neolítico final, Edad del Bronce y Edad del Hierro. En la segunda, nuevamente resultados del Bronce y el Hierro y, por fin, del Neolítico antiguo (procedente de una fosa que está contextualizada con cerámicas incisas y a la almagra). Esta datación proporcionó un resultado relativamente elevado en el contexto de Portugal (Vale Pincel aparte) y la neolitización peninsular, aunque queda bien enmarcada en el grupo de fechas más antiguas sobre muestras de vida corta del complejo impresso-cardial (Mas d'Is, Guixeres de Vilobí). El resto de dataciones son de difícil adscripción debido a la falta de material del Neolítico final, Bronce o Hierro en Casas Novas.

La escasez de restos orgánicos para su datación es un problema en cualquier yacimiento y más cuando se trata de determinar el inicio de las primeras fases del Neolítico. En estos casos, donde se prioriza la datación de muestras domésticas de vida corta (tal 
como también se avisa en esta obra), los resultados pueden ser problemáticos o incluso controvertidos. En el caso que nos ocupa, la asociación de la fecha neolítica con un conjunto material que podríamos considerar tardío dentro del Neolítico antiguo (cerámicas con incisiones, acanalados y almagra) puede ser un problema para asociarla con el registro cardial. Sin embargo, a falta de más y mejor material datable es natural su uso y asociación. Su punto más favorable en el marco de este debate es, sin duda, la relativa abundancia (a escala de Portugal) de restos cardiales, que lo diferencia de otros yacimientos con fechas antiguas (p.ej. Vale Pincel, Soares et al. 2016). El problema de conservación de los biomateriales por culpa del medio arenoso es algo insalvable y que dificulta una mejor calidad de dataciones en algunos territorios peninsulares. Es un hecho lamentable puesto que no existen muchos yacimientos al aire libre como $\mathrm{Ca}$ sas Novas, donde se hayan excavado más de $400 \mathrm{~m}^{2}$ y donde se articule un nivel de ocupación y estructuras negativas asociadas.

Después de hacer una correlación con los yacimientos más antiguos de Portugal del Neolítico antiguo, se hace lo mismo, de manera más resumida, con las otras "ocupaciones" detectadas por las dataciones, el Neolítico final y las edades del Bronce y del Hierro. Ello se realiza mediante una adecuada y homogénea cartografía y los escasos materiales asociados a estos momentos. Quizá no sería necesaria esta parte del trabajo puesto que no existen estructuras ni estratigrafía asociadas a estas fases, solamente dataciones de las que no se puede determinar el origen, más allá de un problema tafonómico.

El bloque seis es un pequeño capítulo donde se resumen los resultados de manera relativamente escueta pero completa y donde se incluyen, también de manera breve, los resultados de los estudios específicos que se presentan en un bloque posterior. Quizá, la inclusión de esos informes en un apartado anterior y un resumen final donde se utilizaran más datos ya presentados, hubiese proporcionado mayores herramientas al lector para interpretar los resultados generales de la excavación.

Por último, la obra presenta cuatro estudios anexos a modo de apéndices, que de manera tangencial y/o puntual ya han sido expuestos durante los bloques anteriores pero que, en nuestra opinión, podrían haber sido más integrados en las discusiones generales del yacimiento y la cultura material, puesto que presentan datos interesantes y útiles. El estudio traceológico (por J. F. Gibaja) detectó el uso generalizado de los geométricos como proyectiles (tanto en forma de filo transversal como de modo apuntado) y el de las láminas para el trabajo sobre plantas no leñosas. No se pudo definir si estas podrían corresponder al corte de cereal, factor que sería interesante para compensar de manera indirecta la falta de restos carpológicos. El estudio arqueométrico de la cerámica (realizado por N. Inácio) identificó el uso de la chamota (tan significada con las producciones cardiales) solamente en dos de las muestras, en un fragmento con cordón y en uno con una lengüeta y, en general, el uso de arcillas locales y regionales para la fabricación de las cerámicas de Casas Novas. Por su parte, la pasta blanca que rellenaba la impresión de un fragmento cerámico del yacimiento era básicamente hueso (estudio realizado por C.P. Odriozola), algo que la asemeja con una tradición arraigada al sur del río Tajo. Sin embargo, los ejemplos disponibles a los que compararse son de un amplio abanico cronológico (Neolítico hasta Edad del Bronce), por lo que es difícil determinar la importancia de esta tradición. Por último, el estudio realizado sobre las improntas vegetales en los fragmentos de barro cocido (estudio de H.P. Stika) ha permitido identificar la existencia de restos de trigo y cebada, que junto con los elementos de molienda y la posibilidad que algunas láminas hubiesen sido utilizadas para la siega, demostraría que la agricultura estaba perfectamente asentada desde los primeros momentos del Neolítico.

Esta monografía es el resultado de un buen trabajo de campo no exento, ni mucho menos, de dificultades, y de un intenso trabajo posterior de análisis de restos y de estructuras y niveles arqueológicos. Presenta una magnífica calidad de registro fotográfico (tanto de campo como de cultura material) y no se escatiman las plantas y las secciones. A su vez, las referencias y los paralelos están hechos a partir de trabajos clásicos y también recientes. Todo ello hecho por parte de un grupo muy dinámico que trabaja en diferentes yacimientos y cronologías de la prehistoria holocena y en un escenario mayor, el portugués, de gran producción en las últimas décadas.

F. XAVIER OMS ARIAS

SERP, Seminari d'Estudis i Recerques Prehistòriques Secció de Prehistòria i Arqueologia Universitat de Barcelona Correo-e: oms@ub.edu (D) https://orcid.org/0000-0002-1642-548X Researcher ID: <https://publons.com/ researcher/E-5156-2015>. 


\section{REFERENCIAS}

Gonçalves, V. S. (2009): “Um sítio do Neolítico antiguo no vale do Sorraia: Casas Novas (Coruche). Uma primeira noticia". Revista Portuguesa de Arqueologia 12.2: 5-30.

Gonçalves, V. S. y Sousa, A. C. (2015): “O sitio do neolítico antigo de Casas Novas (Coruche). Leituras preliminares", en V.S. Gonçalves, M. Diniz y A.C. Sousa (eds.), Actas del 5. ${ }^{\circ}$ Congresso do
Neolítico Peninsular: 236-255. Lisboa (2011), Lisboa, UNIARQ.

Guilaine, J. y Ferreira, O. V. (1970): “Le Néolithique ancien au Portugal". Bulletin de la Société Préhistorique Française 67.1: 304-322.

Soares, J.; Mazzuco, N. y Clemente-Conte, I. (2016): "The first farming communities in the Southwest European Coast: a traceological approach to the lithic assemblage of Vale Pincel I". Journal of Anthropological Archaeology 41: 246-262. 
Información editorial 



\section{NORMAS DE PUBLICACIÓN}

SPAL. Revista de Prehistoria y Arqueología de la Universidad de Sevilla es una revista de periodicidad anual que se edita en marzo de cada año. Los trabajos recibidos son evaluados por revisores, alguno de los cuales podrá ser elegido de entre los propuestos por el/la autor/a.

1. Secciones. Todos los trabajos y textos recibidos deben ser inéditos y no estar pendientes de su publicación total o parcial en otro medio.

a) Cartas al director: extensión máxima de 1.500 palabras. Serán sometidas a revisión.

b) Artículos: trabajos originales de investigación con un máximo en torno a 15.000 palabras (incluidos figuras y tablas). Serán sometidos a la revisión de al menos dos evaluadores. Los trabajos que presentan solo avances de proyectos de investigación y temas novedosos o significativos, dispondrán de un máximo en torno a 7.500 palabras (incluidos figuras y tablas) Serán sometidos a la revisión de al menos dos evaluadores.

c) Recensiones: un máximo de 3.000 palabras (incluidas figuras y tablas). Consistirán en evaluaciones críticas de los trabajos reseñados y exposición de principales novedades de eventos científicos.

En todos los trabajos hay que considerar que figuras y tablas ocupan un espacio equivalente a un máximo de aproximadamente 400 palabras por página (figura o tabla a dos columnas).

2. Idioma de publicación. Se aceptan publicaciones en español, francés, inglés, italiano, portugués y alemán.

3. Envío de los trabajos. Los originales deberán estar ajustados a las normas de Spal, serán remitidos a la redacción de la revista: spal@us.es, Departamento de Prehistoria y Arqueología, Universidad de Sevilla, Doña María de Padilla s/n. 41004-Sevilla (España). Así mismo, deberán aportarse los siguientes formularios disponibles en la web de la revista http://www.editorial.us.es/spal lista de comprobación, carta de presentación y declaración responsable.

3.1. Soporte papel. Dos copias en A4 y mínimo de $80 \mathrm{~g}$ con márgenes de $2,5 \mathrm{~cm}$ e interlineado doble a un color (preferentemente negro). Párrafos: justificados, sin sangría y sin espaciados específicos. Paginación arábiga en cada página en el ángulo inferior derecho. Tipos: Times New Roman, 12 puntos. Figuras y tablas: podrán ir a color pero debe tenerse en cuenta que la edición en papel será en blanco y negro, mientras la separata digital (en formato PDF) sí se reproduce en color. Perfectamente etiquetadas en referencia al texto (figura 1 a $\mathrm{n}$ o, tabla 1 a $\mathrm{n}$ ㅇ, etc.).

3.2. Soporte informático. Una única copia que reúna todos los archivos (CD-Rom, DVD o soporte de almacenamiento de uso convencional). Figuras y tablas. Deben remitirse perfectamente etiquetados en referencia al texto (fig. 1 a no, tabla 1 a no, etc.). Podrán ir a color pero debe tenerse en cuenta que la edición en papel será en blanco y negro, mientras la separata digital sí se reproduce en color. Imágenes: de calidad, con una resolución mínima de 300ppp., a tamaño final de la revista, teniendo en cuenta que la máxima anchura será de $160 \mathrm{~mm}$, altura en proporción (imágenes horizontales) o bien $215 \mathrm{~mm}$ de máxima altura, anchura en proporción. Para el caso de imágenes a una columna la anchura será de 77,5 mm, altura en proporción. Es conveniente indicar a qué tamaño deberían ir, indicando una o dos columnas: ejemplo, cuando se haga la referencia en el texto, además de poner el número, añadir 1 columna o 2 columnas, o 1c o 2c. Programas y formato para edición del texto Word o compatible. Programas y formato para edición de tablas: Word, Excel o compatible. Programas y formato para edición de fotografías: PDF, Tiff, JPG. Programas y formato para edición de dibujos: Illustrator (.ai), CorelDraw (.cdr), EPS (.eps), PDF (.pdf), PowerPoint (.ppt). Etiquetas: Perfectamente etiquetados en referencia al texto (fig. 1 a no, tabla 1 a no, etc.). No distinguir entre figuras y láminas. Todos los objetos gráficos, ya sean imágenes o dibujos, llevarán una misma numeración. Las tablas se consideran diferenciadas con su propia numeración.

4. Recepción de originales. Se realizarán exclusivamente a partir de la plataforma Open Journal System de Spal (https://revistascientificas.us.es/index.php/spal). La redacción de Spal acusará recibo de recepción de originales consignando la fecha de recepción en un plazo máximo de 15 días.

5. Sistema de arbitraje: Los originales serán evaluados por dos expertos en la materia. Siempre que sea posible, se incluirán en el proceso revisor especialistas en el área no pertenecientes a la Universidad de Sevilla. Asimismo se ofrece la posibilidad a los autores de sugerir dos posibles evaluadores. La respuesta razonada de los revisores será comunicada al autor en un plazo no superior a tres meses desde la fecha de recepción del artículo. 
6. Normas de imprenta para autores: contenido, estructura y estilo. La versión más pormenorizada está disponible en la página web de Spal (http://editorial.us.es/es/spal/normas-publicacion).

6.1 Portada: a) Título del trabajo. Debe ser breve: se recomienda emplear menos de 15 palabras, evitando palabras y expresiones vacías, debe reflejar el tema central del trabajo, incorporando referencias explícitas sobre área geográfica, etapas culturales o cronológicas y evitando términos equívocos o ambiguos por generales. Se recomienda emplear descriptores extraídos de tesauros de la especialidad. Deberá evitarse el empleo de abreviaturas, acrónimos, símbolos y fórmulas en el título. b) Traducción del título. Si el trabajo está redactado en castellano, deberá ir (al igual que el resumen y las palabras claves) en inglés o en alguno de los idiomas aceptados por Spal.

6.2. Nombre de los autores. Nombres y apellidos, filiación profesional, dirección postal, correo-e, responsable de la correspondencia y teléfono y Fax.

6.3. Apoyos recibidos para la realización del estudio. Este apartado incluye también becas, equipos, grupos de investigación o recursos financieros.

6.4. Segunda página. a) Resumen. En el mismo idioma que el texto principal del trabajo. La extensión del resumen será de un máximo de 200 palabras en artículos, 100 en notas y 75 en comunicaciones breves o revisiones. En cuanto a la estructura, se recomienda una estructura similar a la del trabajo: Introducción, material/objeto de estudio, métodos y técnicas, resultados y conclusiones. Traducción del resumen. En el caso que el idioma original del trabajo sea el castellano se realizará una traducción al inglés, en el caso de que sea este idioma el empleado en el documento, se hará un resumen en castellano. El resumen será necesario en todas las secciones de la revista. b) Palabras claves. Un mínimo de 5 y un máximo de 7 . Deben evitarse las frases, se recomienda utilizar tesauro o lista de encabezamientos de materias autorizada. Traducción de las palabras clave. En el caso que el idioma original del trabajo sea el castellano se realizará una traducción al inglés, en el caso de que sea este idioma el empleado en el documento, se hará un resumen en castellano.

6.5. Texto. Tercera página y siguientes. La extensión máxima de las colaboraciones no excederá por lo general los siguientes límites: en Artículos 15.000 palabras (incluidas las ilustraciones), en la sección Noticiario 7.500 palabras (incluidas las ilustraciones), en las Reseñas 3.000 palabras (incluidas las ilustraciones) y en las Cartas al Director 1.500 palabras.

6.5.1. Estructura. Se recomienda estructurar el trabajo siguiendo el siguiente esquema: introducción (justificación del trabajo), objeto de estudio (materiales, yacimiento, segmento cronocultural, etc.), métodos y técnicas, resultados, discusión y conclusiones. En cualquier caso, de no seguirse la citada estructura será exigible una exposición ordenada y lógica del texto.

Para detalles sobre datos referidos a yacimientos, materiales, métodos y técnicas y resultados, consultar el manual de estilo de Spal.

6.5.2. Apartados y subapartados. Se numerarán siempre con numeración arábiga, hasta un máximo de 4 dígitos (ej. 1.1.1.1.).

6.5.3. Unidades de medida, símbolos y nomenclaturas. Sistema Internacional de unidades o normalizadas por el Sistema Internacional de Medidas y nomenclatura convencional de cada disciplina.

6.5.4. Citas textuales (vid. hoja de estilo).

6.5.5. Citas bibliográficas en el texto. Se empleará el sistema de autor (en minúscula)-año. Ejemplos: PeIlicer 1989; Bandera y Ferrer 2002; Blázquez et al. 2002.

6.5.6. Citas: a) de otro autor: Según Pellicer (1989: 150). b) Cita de textos clásicos. Se usarán las abreviaturas de los léxicos de Liddell-Scott-Jones, de P. G. W. Glare, de Lewis \& Short y de S. W. H. Lampe. Ejs.: A. Ch. 350-355; Pl. Ap. 34a; Th. 6.17.4.; Apul. Met. 11.10.6; Ov. Ars 3.635; Verg. Aen. 5.539. Para textos en inglés o francés se aceptará el sistema habitual en cada idioma. Se podrán utilizar fechas de la Hégira, del calendario gregoriano o preferiblemente ambas a la vez (en este caso separadas por una barra, sin h. ni d.C.), pero respetando el mismo sistema a lo largo del trabajo.

6.5.7. Notas. El uso de notas se considera excepcional. En los casos en los que sea imprescindible se incorporarán al pie de página sin contener ningún tipo de referencia bibliográfica.

6.5.8. Agradecimientos. Se incorporará entre el final del texto y antes de la bibliografía. Detalles en Hoja de estilo. 
6.6. Bibliografía. Se expondrá siguiendo un orden alfabético y de año de publicación (comenzando por el más antiguo) y siguiendo el estilo expresado en los siguientes tipos y modelos:

6.6.1. Autores:

a) Un autor, p. ej. Pellicer Catalán, M. (1983).

b) Dos o más autores, p. ej. Pellicer, M.; Escacena, J.L. y Bendala, M. (1983).

c) Mismo/s autor/es con obras diferentes en el mismo año o diferente.

c1. Años diferentes, p. ej.: Pellicer, M.; Escacena, J.L. y Bendala, M. (1983a); Pellicer, M.; Escacena, J.L. y Bendala, M. (1983b).

c2. Varias citas de primer autor igual y más de tres autores diferentes: Márquez J.E.; Jiménez, V. y Suárez, J. (2011a), Márquez, J.E.; Suárez, J.; Jiménez, V. y Mata, E. (2011b).

6.6.2. Tipos de referencias

a) Monografía, p. ej. Carriazo, J. de M. (1973): Tartesos y El Carambolo. Madrid, Ministerio de Educación y Ciencia.

b) Capítulos en monografías

b1. Versión impresa, p. ej. Pellicer, M. (1989): “El Bronce Reciente y los inicios del Hierro en Andalucía Occidental”, en M.E. Aubet (coord.), Tartessos. Arqueología Protohistórica del Bajo Guadalquivir, pp. 147-187. Sabadell, Ausa.

b2. Versión electrónica. Además de los datos convencionales, datos URL (Uniform Resource Locator), fecha de la publicación, Fecha de revisión (si existe), Fecha de la consulta entre corchetes $[\mathrm{dd} / \mathrm{mm} / \mathrm{aaa}]$.

c) Artículos de revistas

c1. Versión impresa. Título de la revista en cursiva: paginación (ej. Spal, Saguntum, Trabajos de Prehistoria, Zephyrus), p. ej. Aubet, M.E. (2009): “Una sepultura de incineración del Túmulo E de Setefilla". Spal 18: 85-92.

c2. Versión electrónica. Además de los datos convencionales: fecha de la publicación, fecha de revisión (si existe), fecha de la consulta entre corchetes [ ], disponible en dirección www, incluir el código doi (Digital Object Identifier), p. ej.: Cortés-Sánchez, M. [et al.] (2008): “Palaeoenvironmental and cultural dynamics of the coast of Málaga (Andalusia, Spain) during the Upper Pleistocene and Early Holocene". Quaternary Science Reviews, DOI: http://doi. org/10.1016/j.quascirev.2008.03.01.

d) Ponencias y comunicaciones a congresos. Indicar además el lugar y año de celebración del evento. P.ej. Arteaga, O; Schülz, H.D. y Roos, A.M. (1995): “El problema del 'Lacus Ligustinus'. Investigaciones geoarqueológicas en torno a las marismas del Bajo Guadalquivir", en Tartessos. 25 años después 1968-1993. Actas del Congreso Conmemorativo del V Symposium Internacional de Prehistoria Peninsular (Cádiz, 1993): 99-135. Cádiz, Ayuntamiento de Jerez de la Frontera.

e) Otros. No podrán incluirse en los listados bibliográficos Trabajos en preparación o no aceptados. No podrán incluirse en los listados bibliográficos.

Para una versión más pormenorizada y otros casos (Ley, patentes, informes científico-técnicos, tesis, documentos etc. consúltese hoja de estilo en web de la revista.

6.7. Figuras, Tablas y Anexos. Serán numeradas de 1 a n, usando numeración arábiga, mientras en el texto se abreviará su cita (fig. 1 a n y tab. 1 a n). Ambas serán adaptadas al tamaño de caja de la revista (22,5 x $16,5 \mathrm{~cm}$ ) o en su proporción a una columna y deberán disponer de la suficiente calidad.

7. Reglas ortográficas de carácter general. Para trabajos en castellano sólo se aceptarán en las formas aceptadas por la Real Academia Española en su Ortografía de la Lengua Española en la versión vigente (cf. Hoja de Estilo disponible en la web de la revista).

8. Pruebas de imprenta. Se remitirá al menos una prueba de imprenta al autor o autor responsable de la correspondencia que deberá remitir las sugerencias de cambios antes de 10 días.

9. Separatas. Los autores recibirán un ejemplar en formato papel de la revista Spal y un archivo en formato PDF como separata de su aportación. 



\section{NAAT Revista de Prehistoria y Arqueología \\ BOLETÍN PARA SUSCRIPCIÓN - PEDIDOS - INTERCAMBIOS*}

Peticionario:

Razón social / institución:.

CIF/NIF:

Dirección:

Localidad Provincia País .....

Correo-e: Tf: Fax:

Intercambio con la publicación periódica (sujeto a aprobación por el Consejo de Redacción de Spal). Suscripción de un número anual: $30 €$.

Adquisición**:

- Colección completa: 28 números (750€)

- Números sueltos (30€ por volumen):

\begin{tabular}{|l|l|l|}
\hline Cantidad & Número de la revista Spal & Año \\
\hline & & \\
\hline & & \\
\hline
\end{tabular}

\section{Forma de pago}

$\square$ Transferencia bancaria a la cuenta con Código internacional cuenta bancaria (IBAN) IBAN ES13 0049258876291425 0450. Código de identificación bancario (BIC): BSCHESMM Editorial Universidad de Sevilla c/. Porvenir, 27. E41003-Sevilla

Cheque nominal a la Editorial Universidad de Sevilla

$\square$ Reembolso* (sólo para España)

$\square$ Giro postal

\section{Contacto}

Secretaría de Spal: c/ Doña María de Padilla, s/n. 41004-Sevilla (España), tf.: (34) 954551417, fax: (34) 954559920, web: http://www.editorial.us.es/spal, correo-e: spal@us.es

Editorial Universidad de Sevilla: c/ Porvenir, 27. 41013-Sevilla (España), tf.: (34) 954487447 y (34) 954487451, fax: (34) 954487443, web: http://www.editorial.us.es, correo-e: eus4@us.es

Fecha:

\footnotetext{
* Formulario disponible en la dirección web de Spal: http://www.editorial.us.es/spal
}

** Gastos de envío correrán a cargo del peticionario. 


\section{S PAL}

REVISTA DE PREHISTORIA Y ARQUEOLOGÍA

[Número: 29.1] [2020] [Sevilla (España)] [294 páginas]

[ISSN: 1133-4525] [ISSN-e: 2255-3924] [DOI: http://dx.doi.org/10.12795/spal.2020.i29_1]

\section{ÍNDICE}

Editorial / Editorial

\section{Artículos}

Monumentalidad funeraria del Bronce en el sur de la península ibérica: la necrópolis de La Orden-Seminario (Huelva) / Funerary monumentality of the Bronze Age in the south of the Iberian Peninsula: the necropolis of La Orden-El Seminario (Huelva)

José Antonio Linares-Catela

La cronología fundacional de la Malaka fenicia: investigaciones en el solar del rectorado de la Universidad de Málaga / The founding chronology of the Phoenician Malaka: research on the site of the Rectory of the University of Málaga ........

José Suárez Padilla / Joan Ramon Torres / Bartolomé Mora Serrano / Leticia Salvago Soto / Cristina Chacón Mohedano

Uma lucerna grega arcaica da necrópole do Olival do Senhor dos Mártires (Alcácer do Sal, Portugal) / An archaic Greek lamp from the necropolis of Olival do Senhor dos Mártires (Alcácer do Sal, Portugal) Francisco B. Gomes

Cerro Macareno (La Rinconada, Sevilla): nuevos datos sobre su secuencia de ocupación y rasgos / Cerro Macareno (La Rinconada, Sevilla): new data on its occupation sequence and its constructive features constructivos.

Francisco José García Fernández

Ânforas da Idade do Ferro e de tradição pré-romana do Porto do Sabugueiro (Muge, Portugal) / Iron Age and pre-roman tradition amphorae from Porto do Sabugueiro (Muge, Portugal)

Elisa de Sousa / João Pimenta / Inês Silva / Henrique Mendes / Ana Margarida Arruda / Alberto Dorado-Alejos

Hacia una reinterpretación de la secuencia de ocupación del Yacimiento de a Cidadela (A Coruña) / Towards a reinterpretation of the archaeological sequence of the site of A Cidadela (A Coruña, Spain)

José Carlos Sánchez-Pardo/ Rebeca Blanco-Rotea / José Manuel Costa-García / Jorge Sanjurjo-Sánchez / Victor Barrientos-Rodríguez / Francisco Alonso-Toucido

La gestión del agua en la ciudad romana de Lacipo (Casares, Málaga)/ The water management in the Roman city of Lacipo (Casares, Málaga). María del Mar Castro García

Arquitectura pública de Santa Criz de Eslava (Navarra, conventvs caesaravgvstanvs) en época altoimperial: el criptopórtico del foro y su almacén anexo / Public architecture in Santa Criz de Eslava (Navarra, conventus caesaravgvstanvs) in Early Imperial period: the Forum cryptoporticus and the store building Rosario Cebrián Fernández / Javier Andreu Pintado / Luis Romero Novella / Rosario Mateo Pérez / Inmaculada Delage González

Consideraciones sobre la arquitectura doméstica urbana de Hispania en el siglo II d.C. / Considerations on the domestic architecture of hispania in the second century ad.......... Diego Romero Vera

Asturica (Astorga, León) y Albocela (Villalazán, Zamora) entre la Antigüedad y la Edad Media: análisis comparativo de sus territorios / Asturica (Astorga, León) and Albocela (Villalazán, Zamora) between Antiquity and the Middle Ages: a comparative analysis of their territories Pilar Diarte-Blasco / Enrique Ariño Gil / Marta Pérez-Polo

Iglesia, cementerio y aldea en Álava durante el siglo XII. ¿Evidencias materiales de la implantación parroquial? / Church, cemetery and village IN 12TH century Álava (Spain). Material evidence of the establishment of the Catholic parish? Egoitz Alfaro Suescun

Ad comburendum. El uso de la leña en el Castillo de Pambre (Palas de Rei, Lugo) durante los siglos XV-XVII / Ad comburendum. Firewood use in the Pambre Castle (Palas de Rei, Lugo) during the 15 th-17th centuries $A D$ María Martín-Seijo / Santiago Vázquez Collazo

\section{Recensiones}

Montero, S. y García Cardiel, J. (coords.): Santuarios oraculares, ritos y prácticas adivinatorias en la Hispania Antigua. Serie Investigación 23. Ediciones Complutense, Madrid 2019. ISBN 978-84-669-3604-0. 401 pp, ils. B/N Mercedes Oria Segura

Victor S. Gonçalves y Ana Catarina Sousa. 2018. Casas Novas, numa curva do Sorraia (no $6^{\circ}$ milénio a.n.e. e a seguir). Estudos \& Memorias 11, Centro de Arqueologia da Universidade de Lisboa. Faculdade de Letras da Universidade da Lisboa, 279p.

F. Xavier 0ms Arias

\section{Información editorial}

Normas de publicación
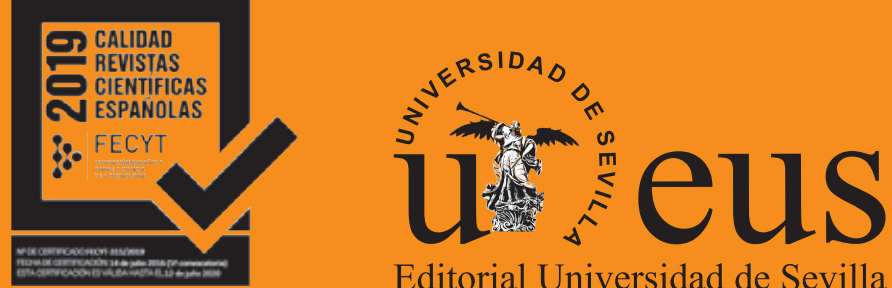

Editorial Universidad de Sevilla 